


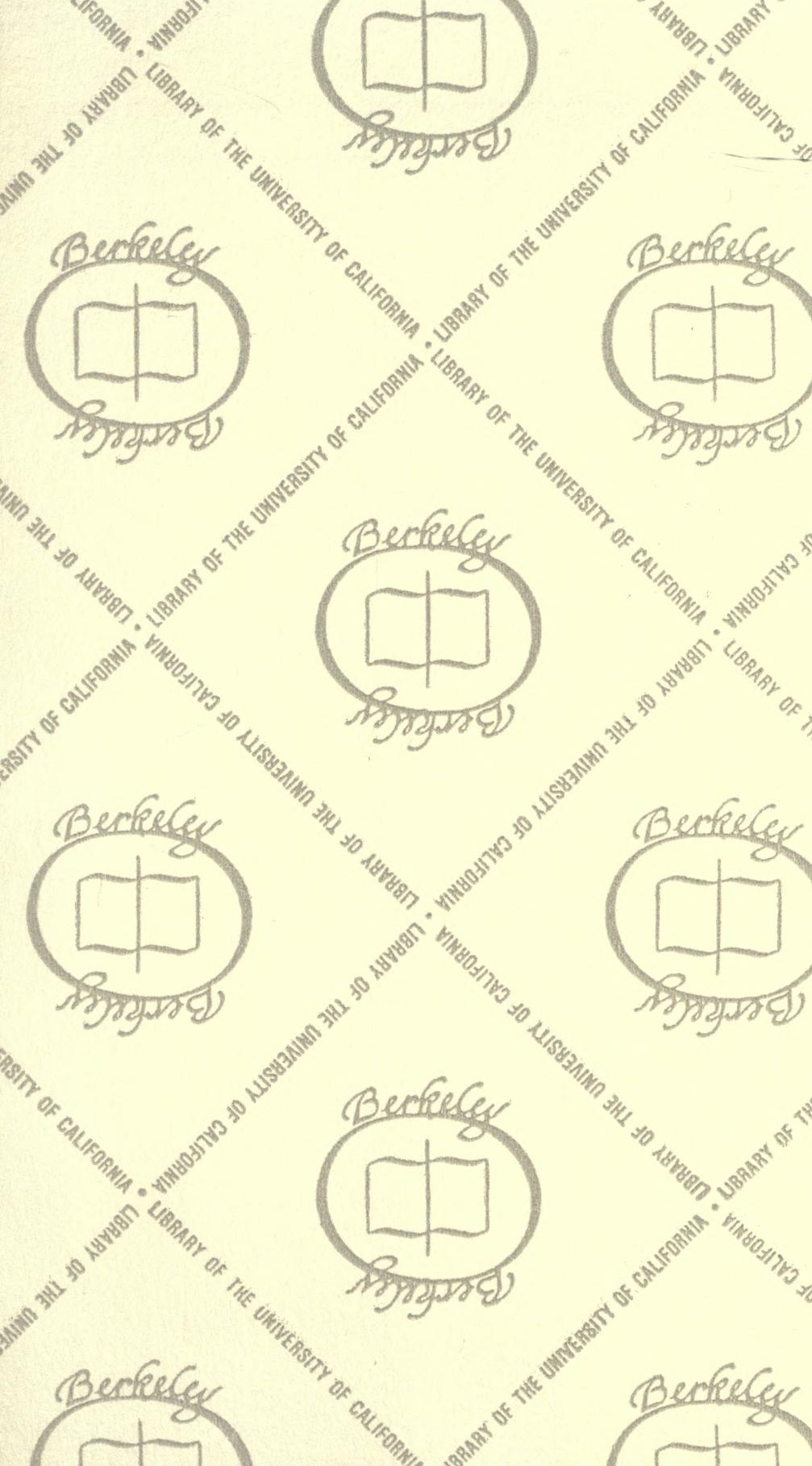




SYNOPSIS FILICUM;

or,

A SYNOPSIS OF ALL KNOWN FERNS. 



\section{SYNOPSIS FILIOUM; \\ or, \\ A SYNOPSIS OF ALL KNOWN FERNS,}

INCLUDING THE

OSMUNDACE开, SCHIZEACE正, MARATTIACE

OPHIOGLOSSACEA

(CHIEFLY DERIVED FROM THE KEW HERBARIUM).

ACCOMPANIED BY FIGURES

REPRESENTING THE ESSENTIAL CHARACTERS OF EACH GENUS.

BY THE LATR

SIR WILLIAM JACKSON HOOKER, K.H.,

D.C.L., F.R.S., A.S., AND L.S.,

DIRECTOR OF THE ROYAL GARDENS OF KEW,

AND

JOHN GILBERT BAKER, F.L.S., ASSISTANT CURATOR OF THE KEW HERBARIUM.

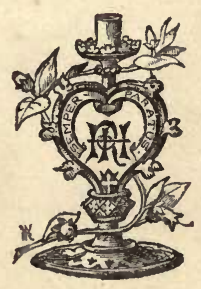

L O NDON:

ROBERT HARDWICKE, 192, PICCADILLY.

1868. 


\title{
Q1K523 $\mathrm{H} 64$ BIOLOGY LIBRARY \\ G
}

C'RY.AGRICULTURE DEFE.

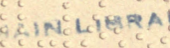

\author{
WYMAN AND SONS, \\ ORIENTAL, CLASSICAL, AND GENERAL PRINTERS, \\ GREAT QUEEN STREET, LONDON, w.c.
}




\section{EDITOR'S PREFACE.}

WHILsT the sheet which terminates at page 48 was passing through the press, Sir W. Hooker's long career of botanical authorship was somewhat unexpectedly terminated by his death. This is not the place to enlarge upon the services which in many different ways he reguciered to botanaicai science, or to do more than allude to the regret which will be felt by many who had waited for this long-planned work, that he was nct spare tio to complete it. I need only say that having been honoured by Dr. Hooker with the request that I should carry it out, and having been entrusted by him with the manuscript notes prepared by his father, and the copy of the "Species Filicum" annotated in contemplation of this work, and having had full access to the specimens from which the descriptions in the "Species Filicum" were made, I have done my best to carry out this "Synopsis" to a conclusion in strict accordance with the original plan.

The principal collection which we have received at Kew since the original preface was written is a beautiful series of the ferns of New Granada, gathered by MM. Lindig and Triana, for which we have to thank the authorities of the Paris Museum. This contained a considerable number of new species, which were described by Professor Mettenius, whose loss in the prime of life we have also had to deplore since the work was commenced. For other novelties we have also to thank Lady Barkly, Dr. Thwaites, and Mrs. Lyell. Partly in consequence of these additions, we have been obliged to extend the work to ten parts instead of nine, as was planned originally. The total number of species admitted and described is 2,235 .

A paper by myself, containing a summary of the leading features of fern-geography, based upon this work, will appear in the part for 1868 (vol. xxvi. part i.) of the "Transactions of the Linnean Society."

J. G. BAKER.

KEw, February, 1868. 



\section{PREFACE.}

THE Author, having recently completed his "Spgcies Filicum," * now offers to the public a "Synopsis of all known Ferns," vhich" contazns, besidecs brief diagnoses of the species described more in detaî in tbat wcrk, together with their geographical distribution as far as yet asseertaried, such radditiots and corrections as have come to his knowledge, together with an account of the Sub-Orders Osuundacee, Schizeacee, Marattiacee, and OphioGLOSSACEE. He does not, however, propose to include the Lycopodiacece, Salviniacece, Marsileacea, Isoetaceec, and Equisetacece, which differ much from these, and it may be said from each other, and which have of late engaged the study of several able monographers. He further intends to depart from the scope of the "Spectes Filicum" in another point, which requires a few words of explanation.

In the Introduction to the "Species Filicum," the Author stated that he had included in that work a considerable number of imperfectly described species, of which he had seen neither speeimens nor figures, solely because they had been proposed by authors of reputation. These he now thinks it desirable to omit. No doubt many are described under different names; of others there is no prospect of anything further being known; and of all the characters are so vague, or imperfect, or prolix, that it is impossible to define them by brief diagnostic characters, such as alone are suited to the pages of a Synopsis.

After upwards of half a century, more or less continuously passed in the study of Ferns in the richest Herbarium of that Order in the world (his own), and latterly with the aid of the finest in cultivation (that of the Royal Gardens of $\mathrm{Kew}) ; \uparrow$ and after the devotion of fully half that number

* In 5 vols. $8 \mathrm{vo}$, with 300 plates representing upwards of 500 species.

+ The formation of this fine collection is mainly due to the exertions and ability of Mr. John Smith, who for forty-three years held an important position among the officers of the Royal Gardens. His knowledge of Ferns, and his writings upon them, justly entitle him to rank among the most distinguished Pteridologists of the present day. 
of years to the preparation and publication of the "Species Filicum" and other works on the same subject, the Author feels satisfied that these doubtful and imperfectly described species form the greatest obstacle to any satisfactory advance in descriptive Pteridology. * He may, indeed, point with satisfaction to the fact, that before he undertook his work their number was many times greater than that still cumbering the volumes. But there is little satisfaction in the reflection that for the identification of a great majority the Author is indebted more to some happy accident, to the possession of cupiouis and varying suites of specimens, or to circumstances toninected with sistory or locality of the species, than to their published descrintions or to scientific evidence.

There have been "twa fruitful sources of these "bad species":-the first, the idea that geographical limits must limit the dispersion of species; the second, that any single characteristic, however minute, if only either constant or prevalent in a given area, is of specific value. Such arbitrary conclusions have led to the well-known Osmunda regalis receiving different names in many different countries, and to the forms of our Aspidium (Polystichum) aculeatum having even more names in our own country, and still others in exotic regions. The errors arising from the first are corrected as rapidly as botanical and geographical discoveries advance together; but it is not so with those due to the second source, for the difficulty of limiting these variable species is so great, that it often becomes impossible to frame such diagnoses as shall include all the varieties of one species, and exclude the varieties of another closely allied species. In all these cases we must trust to time and experience to test our conclusions; and such difficulties should teach us to look with indulgence on the views of those who differ in opinion from ourselves.

The same remarks apply to the genera as to the species of Ferns; the former having been, in the Author's opinion, unnecessarily multiplied. It

* In connection with Fern history, Mr. Thomas Moore undertook the publication of an extremely useful work under the title of "Index Filicum," to consist of a Synopsis, with characters of the genera, and an enumeration of the species of Ferns, with synonyms, references, \&c. \&c., accompanied by excellent outline figures of the genera. It is compiled with great industry and ability, and enumerates in an alphabetical arrangement of the genera, from Acrophorus to Goniophlebium inclusive, 1,730 species of true Ferns. The list of synonyms, both of genera and species, shows at a glance how much Pteridologists have been at variance on these points. The species enumerated in our "Species Filicum" amount to 2,401; according to Mr. Moore, the number of known Ferns would be 2,782. 
is the case here as with other scientific systems : those are the best characters which lead to a knowledge of the object sought for in the nearest and clearest way, keeping in view also as much as possible its natural affinities. The difficulties certainly are greater in the cryptogams than among the flowering plants, because their characters are fewer, and the forms of their organs more variable as regards size and shape.

In regard to the genera, the publisher has judiciously desired that nine plates should be devoted to their illustration. They are all drawn from nature by the talented Mr. Fitch, F.L.S., and on the same plan as the plates of Ferns in Hooker and Arnott's late editions of the "British Flora."

References are given to the volumes and pages of the "Species Filicum" for fuller characters of the genera and species, as well as for figures, more precise localities, and more copious observations; and it is hoped that the present volume will form a useful vade-mecum for the travelling botanist and the cultivator of Ferns, and for ready consultation in the Herbarium.

The Author cannot close these introductory remarks without expressing his acknowledgments to numerous friends and correspondents for their valuable communications of specimens (often accompanied by notes) from various parts of the world. Many of these are recorded under their habitats (or localities) in his former work ; and a repetition of them would be out of place in this. But space must still be found for the names of those persons to whom we are indebted for the discovery of any new species, or any new or interesting locality in connection with the geographical distribution of plants.

The commencement of the Author's formation of a Fern-Herbarium dates as far back as 1811, with the correspondence of the illustrious Swartz, only four years after the publication of his invaluable "Synopsis Filicum ;" a model for future works of the kind. It is, however, from comparatively new and distant regions, which have been within the last balf century so extensively explored by our men of science, that the most important collections liave been derived, and to these botanists and travellers he is anxious thus to express his obligations :-

From the East Indies, including the Malay Peninsula and Islands :From Wallich, Buchanan, Hamilton, Hooker fil. and Thomson, Gideon Thomson, Beddome, Lady Dalhousie, Anderson, Falconer, Jamieson, Edgeworth, Sir Frederick Adam Jacquemont, Blume, Miquel, De Vriese, Teijsmann, Sir William Norris, Thomas Lobb, Cuming, Wallace, Low, 
Hindes, Barber, Parish, Teschemacher, Motley, Millett, Wight, Stocks, Helfer, McIvor.

Ceylon:-General and Mrs. Walker, Gardner, Thwaites, Emerson.

Pacific Islands:- Forster, Menzies, Chamisso, Beechey, Brackenridge, Seemann, Vieillard and Deplanche and Lenormand (from N. Caledonia), Hillebrand, Rev. T. Powell, Milne and MacGillivray (in Denham's voyage), Sinclair, Bidwill, Harvey, Labillardiere, Macrae, Nightingale, Barclay, Lay and Collie, Diell, Bennett, Douglas.

Africa, East and West, including the principal Islands in the Atlantic, and on the east side, such as Madagascar, Mauritius, Bourbon, Seychelles, Johanna, \&c. :-Pappe and Rawson, Ecklon, Zeyher, Burke, Harvey, Admiral Sir Fred. Grey, Telfair, Sir Henry and Lady Barkly, Bojer, Ayres, Bouton, Carmichael, Kirk, Meller, Livingstone, Speke and Grant, Mann, Barter (in Baikie's exped.), the two Vogels, Webb, Lowe, Lyall, Forbes, Petit-Thouars, Mund, Krauss, Saltzmann, Schimper, Miller, Browne, Col. Blagrave, Gerrard, Villette, Atherstone, Sanderson, Sutherland, Melliss, Haughton, Gueinzius, Plant, Ansell, Curror, Hutton, Bowie, Alexander Prior, Swinburne Ward (Seychelles).

China, Japan, and Formosa :-Brackenridge, Alexander, Hance, Vachell, Oldham, Wilford, Champion, Urquhart, Loraine, Ringgold and Rogers, C. Wright, Hodgson, Babington, Swinhoe, Taite.

South America, from Mexico to the extreme south of that continent, including the West Indian Islands :-Swartz, Bancroft, Bertero, Poeppig, Richard, Bridges, King, Jameson, Mathews, Skinner, Gardner, Sellow, Tweedie, Galeotti, Imray, Hostmann, Linden, Martius, C. Wright, Chamisso, Lockhart, Schiede and Deppe, Moricand, Guilding, Wiles, Parker, Sir Hercules Robinson, Beyrich, Shach, Distin, Schomburgk, Appun, Raddi, Macfadyen, Purdie, Boog, Salzmann, Hartweg, Wm. Lobb, Miers, Ruiz and Pavon, Goudot, Humboldt, Blanchet, Burchell, Darwin, I.e Prieur, Tweedie, Vautier, Spruce, Consul Glennie, Swainson, Funck, Wilson, Liebmann, L'Herminier, Claussen, Hindes, Jürgensen, MacLean, Alexander Prior, Moritz, Andrieux, Fendler, Schlim, Heward, Otto, Holton, Jervisse, Sir Charles Bunbury, Philippi, Cuming, Lechler, March, Germain, Hayes, Salvin and Godman, Cruickshanks.

North America, United States, Canada, and British Columbia, to the extreme Arctic shores and Islands :- Pursh, Douglas, T. Drunmond, Bourgeau, Torrey, Short, Asa Gray, Peters, Menzies, Franklin, Parry, Ross (uncle and nephew), Richardson, and various officers of all the Government Arctic expeditions, Iyyall, Booth, Scouler, Tolmie, Macoun, 
Mrs. Percival, Eaton, Bigelow, Nuttall, Greene, Chapman, Bridges, Geyer, Goldie.

Australia and New Zealand:-Brown, Müller (including his own collections and those of the various Government explorations in Australia), Hill, Sieber, C. Moore, Allan and Richard Cunningham, Gunn, Lawrence, Archer, Backhouse, Harvey, Bynoe, Fraser, Js. Drummond, Heward, Simmons, Beckler, Colenso, Dieffenbach, Edgerley, Sinclair, Lyall, Raoul, Haast, Bidwill, Travers, Maling, Hector and Buchanan, Miss Nelson, Mrs. Jones, Bolton, Menzies, Stephenson, Jolliffe, Munro, Robertson.

Many of the above explorers have sent collections from other countries they have visited, besides those under which their names stand; and it should be observed that this list does not include the names of numerous travellers who have rendered themselves useful by disposing of their collections to botanists.

Royal Gardens, KEW,

April, 1865. 


\section{LIST OF ABBREVIATIONS OF WORDS OF FREQUENT OCEURRENCE IN THE FOLLOWING PAGES.}

\section{BOTANICAL TERMS.}

Caud. $=$ caudex, from which arises the frond or stipes.

$S t .=$ stipes, or stipites, which support the frond.

$F r .=$ frond, or fronds.

Pinnl.= pinnule, or pinnules.

Invol. = involucre, by many botanista called indusium.

Recept. $=$ receptacle, that which bears the sori or capsules; prominent in most Cyathece; elongated and columnar, or even bristle-shaped, in Hymenophyllum and Trichomanes.

Caps. = capsule, or capsules.

Segm.= segment, segments, or lobes : often used indifferently ; but a segment generally indicates a deeper or more elongated lobe.

Prim. = primary, or first division of a compoundly pinnate or pinnatifid frond ; thus prim. div., or prim. pinna or pinnl.

Second.= secondary ; the second principal division, or pinna, of a frond.

$F t .=$ foot, or feet.

MEASURES OF LENGTH.

In. =inch, or inches.

lin. $=$ line, $\frac{1}{12}$ of an inch.

l. =long ; thus, 1 in. $1 ., 1 \mathrm{ft}$. 1 .

$w$. $b r$. = wide or broad; thus, 1 line w. or $1 \mathrm{in.} \mathrm{br}$.

AUTHOR' NAMES AND THEIR WORKS.

$W_{.}=$Willd $_{.}=$Willdenow. Thus, $W . S p .=$ Willdenow's Species Plantarum.

$S w .=$ Swartz; generally, unless when other wise mentioned, referring to his Synopsis Filicum.

Schk. $=$ Schkuhr, as Schk. F. = Schkuhr's Filices.

Kze. in Schk. = Kunze, in Schk. Fil. Suppl.

$H k$. $S p .=$ Hooker, Species Filicum.

$H k$. et $G r . F .=$ Hooker and Greville's Tcones Filicum.

$H k$. Ic. $=$ Hooker, Icones Plantarum.

Hk. Cent. F. = Hooker's Century of Ferns, which corresponds with vol. 10 of Icones Plantarum.

$H$ H. $F . E x .=H o o k e r ' s$ Filices Exoticæ.

Hk. G. $P .=$ Hooker's Garden Ferns.

Hk. $2 d$. Cent. $F_{0}=$ Hooker's $2 \mathrm{~d}$. Century of Ferns.

Hab. = habitat, or locality, indicating the native country of the species.

Names of countries are so commonly abbreviated in descriptive Botany, that they scarcely need explauation : $N . A m_{0}=$ North America, $S . A m_{0}=$ South America, \&c. \&c. Malay $a=$ Malay Islands and Archipelago. "India" generally implies the British possessions of the mainland, exclusive of $N$. Ind. = North India, chiefly comprising the Himalayan range, and exclusive of the Indian islands. $M e x_{0}=$ Mexico. Pacif.$=$ Islands of the the the Pacific, unless otherwise expressed, \&c. \&c. 
TABLE of the Arrangements of the Orders and Genera of the TRUE FERNS IN the Following pages, with References to the Numbering of each Genus, and to the Figures of the Genera on the Plates.

Ord. FILICES. GEN. 1-75. TAB. I.-IX.

Sub Ord. I. Gleicheniace $A$. Gen. $1{ }^{*}$ Platyzoma. Tab. I. f. 1. GEN. 2. Gleichenia. TAB. I. f. 2.

Sub-Ord. II. POLYPODIACEA. Gen. 3-61. Tab. I. f. 3-12, and TAB. II.-VIII. f. 61 .

A. Involucrate. Gen. 3-47. Sori furnished with an involucre, Alsophila excepted. TAB. I. f. 3-12. TAB. II.-V. f. 43-47.

Tribe I. Cyathes. Gen. 3. Thyrsopteris. Tab. I. f. 3. Gen. 4. Cyathea. Tab. I. f. 4. Gen. 5. Hemitelia. Tab. I. f. 5. Gen. 6. Alsophila. TAB. I. f. 6. Gen. 7. Diacalpe. TAB. I. f. 7. GeN. 8. Matonia. TAB. I. f. 8.

Tribe II. Dicksonief. Gen. 9. Onoclea. Tab. I. f. 9. Gen. 10. Hypoderris. TAB I. f. 10. GEN. 11. Woodsia. TAB. I. f. 11. Gen. 12. Sphæropteris. TAB. I. f. 12. Gen. 13. Dicksonia. TAB. II. f. 13. Gen. 14. Deparia. TAB. II. f. 14.

Tribe III. Hymenophyllez. Gen. 15. Loxsoma. Tab. II. f. 15 . Gen. 16. Hymenophyllum. TAB. II. f. 16. GEN. 17. Trichomanes. TAB. II. f. 17.

Tribe IV. Davaluief. Gen. 18. Davallia. Tab. II. f. 18. Gen. 19. Cystopteris. TAB. II. f. 19.

Tribe V. Lindsayee. Gen. 20. Lindsaya. Tab. II. f. 20. Gen. 20 bis, Dictyoxiphipium. TAB. II. f. 20, b. c.

Tribe VI. Pteridex. Gen. 21. Adiantum. Tab. II. f. 21. Gen. 22. Ochropteris. TAB. II. f. 22. Gen. 23. Lonchitis. TAB. II. f. 23. Gen. 24. Hypolepis. TAB. II. f. 24 . Gen. 25. Cheilanthes. TAB. III. f. 25. Gen. 26. Cassebeera. TAB. III. f. 26. Gen. 27. Onychium. TAB. III. f. 27. Gen. 28. Llavea. TAB. III. f. 28. Gen. 29. Cryptogramme. Tab. III. f. 29. Gen. 30. Pellæa. Tab. III. f. 30. Gen. 31. Pteris. Tab. III. f. 31. GEN. 32. Ceratopteris. TAB. III. f. 32. GEN. 33. Lomaria. T'AB. III. f. 33.

* The numbering which precedes each genus corresponds with the number of the genus in the following pages; and it may be observed that the same numbering corresponds with the respective compartments on the plates, the compartments bearing the same numeral as that of the genus. 
Tribe VII. Blechnese. Gen. 34. Blechnum. Tab. IV. f. 34. Gen. 35. Sadleria. TAB. IV. f. 35. GeN. 36. Woodwardia. TAB. IV. f. 36. GeN. 37. Doodia. TAB. IV. f. 37.

Tribe VIII. Aspleniez. Gen. 38. Asplenium. Tab. IV. f. 38. Gen. 39. Allantodia. TAB. IV. f. 39. GeN. 40. Actiniopteris. Tab. IV. f. 40.

Tribe IX. Scolopendriex. Gen. 41. Scolopendrium. TAB. IV. f. 41.

Tribe X. Aspidies. Gen. 42. Didymochlæna. Tab. IV. f. 42 . Gen. 43. Aspidium (including Sagenia). TAB. V. f. 43. GEN. 44. Nephrodium: TAB. V. f. 44. GEN. 45 . Nephrolepis. TAB. V. f. 45. GEN. 46. Oleandra. TAB. V. f. 46 . Gen. 47. Fadyenia. TAв. V. f. 47.

B. Exinvolucrate. Sori destitute of involucre. Gen. 48-61. TAB. V. f. 48, TAB. VI.-VIII. f. 49-61.

Tribe XI. Polypodiee. Gen. 48. Polypodium. Tab. V. f. 48.

Tribe XII. Grammitidee. Gen. 49. Jamesonia. Tab. VI. f. 49. Gen. 50. Nothochlæna. TAB. VI. f. 50. GEN. 51. Mouogramme. TAB. VI. f. 51. GEN. 52. Gymnogramme. TAB. VI. f. 52. GEN. 53. Brainea. Tab. VI. f. 53. Gen. 54. Meniscium. Tab. VI. f. 54. Gen. 55. Antrophyum. TAB. VI. f. 55. GeN. 56. Vittaria. TAB. VI. f. 56. Gen. 57. Tænitis. Tar. VI. f. 57. Gen. 58. Drymoglossum. TAd. VI. f. 58. Gen. 59. Hemionitis. TAв. VI. f. 59.

Tribe XIII. Acrostichees. Gen. 60. Acrostichum. Tab. VII. and Tab. VIII. f. 60. GEN. 61. Platycerium. Tab. VIII. f. 61.

Sub-Ord. III. OSMUNDACEA. Gen. 62. Osmunda. Tab. VIII. f. 62. GEN. 63. Todea. TAB. VIII. f. 63.

SUb-ORd. IV. SCHIZ EACE Æ. GeN. 64. Schizæa. TAB. VIII. f. 64. Gen. 65. Anemia. Tab. VIII. f. 65. Gen. 66. Mohria. Tab. VIII. f. 66. GEN. 67. Trochopteris. TAB. VIII. f. 67. Gen. 68. Lygodium. 'TAB. IX. f. 68 .

SUb-Ord. V. MARATTIACE Æ. Gen. 69. Angiopteris. TAB. IX. f. 69. GEN. 70. Marattia. TAB. IX. f. 70. GEN. 71. Danæa. TAB. IX. f. 71. Gen. 72. Kaulfussia. TAB. IX. f. 72.

Sub-Ord. VI. OPHIOGLOSSACE E. Gen. 73. Ophioglossum. Tab. IX. f. 73. GEN. 74. Helminthostachys. TAB. IX. f. 74. GEN. 75. Botrychium. TAB. IX, f. 75 . 


\section{Ord, FILICES. Ferns.}

Capsules (sporangia) 1-celled, usually membranaceous and dorsal, or marginal, encircled by a complete or incomplete, jointed, elastic ring, collected in clusters (sori) of a definite but varied form, with or without a covering (involucre, often called indusium); or panicled or even spicate, rarely laxly scattered; or the capsules have the ring obsolete, or none, or the ring is confined to the apex of the capsule, where it forms a longitudinally striated crown, bursting vertically ; or the capsules are sunk in a many-celled, Heshy or corky receptacle of varied forms, opening by pores or clefts on the upper surface. Spores minute, various in form. -Vernation generally circinate, rarely erect. Gen. 1-75. 'TAB. I.-IX. Fig. 1-75.

\section{Sub-Ord. I. GLEICHENIACEA, Br.}

Sori dorsal, of few (2-10) capsules. Capsules opening vertically, surrounded by a broad, transverse, complete ring. Invol. 0.-Caud. mostly creeping. St. often dichotomous. Fronds rigid, generally large and dichotomously branched, frequently bearing axillary buds. Vernation circinate. (GeN. 1, 2.) Ta B. I. f. 1, 2.

\section{Gen. 1. Platyzoma, $\mathrm{Br}$.}

Sori of few sessile caps. (" mixed with a pulverulent substance," $\mathrm{Br}$.), arising from the apex of simple veinlets, and concealed by the singularly revolute margins of the pinnæ.-Caudex creeping, beautifully sericeo-paleaceous. Stipites tufted. -Fronds 8 in. to $1 \mathrm{ft}$. l., pinnated, with small, coriaceous, cucullate pinnoe, scarcely 1 line 1. TAB. I. f. 1.

1. P. microphyllum, Br.-Hk. Sp. 1.p. 2.

Hab. Trop. and subtrop. Australia.-A genus too nearly allied to Gleichenia.

\section{Gen. 2. Gleichenia, Sm.}

Sori of few (2-4 rarely $\tilde{5}$-10) sessile caps., situated on a lower exterior veinlet. -Caud. mostly creeping. Fr. rarely unbranched, generally dichotomously divided, often proliferous from the axils of the forks; pinnæ deeply pinnatifid, with the segments small and concave, suborbicular, or pectinate with elongated labes. TA B. I. f. 2.

$\$$ Eugleichenia. Sori solitary at the apex of a veinlet on the superior base of a lobe; lobes of the pinnoe small, suborbicular. Sp. 1-6.

1. G. (Eugl.) moniliformis, Moore ; caud. slender, substipitiform, erect,branched; st. tufted, 3-4 in. l. ; fr. coriaceous, 8-12 in. l., 3 in. br., linear, deeply pinnatifid ; lobes numerous, broad, concave beneath; sori solitary, mixed witli ferruginous hairs.-Stromatopteris, Mett. in Ann. Sc. N. 1861, p. 84.t.3.

Hab. New Caledonia, Vieillard, n. 1571. - A very remarkable species, but scarcely differing from the present genus.

2. G. (Eugl.) polypodioides, Sm.; lobes of the pinnoe ovate, glancous beneath; caps. $3-4$, sunk in a cavity forming a flat-topped sorus. $-S c h k . F . t .149 ; H k . S p .1$. p. 3. G. glauca, $S w$. (non Hk. Sp. 1.p.4).

Hab. S. Afr.; Cape Colony (north to Angola, Welwitsch).

3. G. (Eugl.) circinata, Sw.; lobes of the pinnoe ovate or subrotund (most so when fertile), more or less glaucous beneath, the margins slightly recurved; caps. 3-4, superficial, branches and rachis glabrous, or more or less clothed with chaffy pubescence.-G. microphylla, Br. Hk. Sp. 1. p. 3. G. Speluncæ, Br. Hk. Sp. 1. p. 2.t.1. B.; Guill.Ic. Pl. Austr.t.12. G. semivestita, Lab.Sert.N. Cal.t.11; Hk. Sp. 1. p. 3.t.2. A (rachises and young fr. very paleaceo-pubescent).

Hab. Australia, Tasmania, N. Zeal., N. Caledonia, Malacca. 
4. G. (Eugl.) rupestris, Br.; glabrous, lobes of the pinno rounded or obtusely subquadrangular, coriaceous, the margins thickened and recurved, subglaucous beneath; sori of 3-4 caps., superficial.-Hk. Sp. 1.p. 2.t.1. B.

Hab. Port Jackson and N. W. Austral., Mueller.-Too near, I fear, to G. circinata.

5. G. (Eugl.) Boryi, Kze.; small; fr. subelliptical, 4 in. l. by 3 in. br., bipinnate; prim. pinnes 4, subopposite, ultimate pair constituting a fork; terminal pinnl. elongate; lobes of the ultimate pinnoe very small, $\frac{1}{4} \mathrm{in} .1$., suborbicular-concave, glaucous beneath ; sori of few caps., mixed with copious ferruginous wool. Kze. in Scllk.t. 70.f. 1 .

Hab. Bourbon, Bory.

6. G. dicarpa, Br.; lobes of the pinnoe orbicular, subhemispherical, very fornicate ; caps. about 2 , concealed within the almost slipper-shaped lobes, and mixed with ferruginous paleaceous hairs, which often extend to the rachis.-Hk. $S p .1$. $p$. 3. t. 1. C. and $F$. Ex.t. 40.- $\boldsymbol{\beta}$ alpina; generally smaller and more compact, rachis and young shoots ferruginous, with paleaceous wool. G. alpina, $\mathrm{Br}$. $H k$. et Gr. F.t. 58 ; Hook. Sp. 1. p. 2. G. hecistophylla, A. Cunn. Hk. Sp. 1.p. 4. t. 2. B. G. Vulcanica, $\overline{B l}$. Hk. Sp. 1.p. 4 .

Hab. Australia and Tasmania, frequent. Isle of Pines, Denham. N. Cal., Vieillard. - $\beta$. High mountains, Tasmania, N. Zealand, Malay Isles (G. Vulcanica, Bl.).

§ Mertensia. Sori near the middle of, or at the forking of, the veinlets, the ultimate pinnce pectinate; segm. linear or oblong, rarely subovate, much longer than in the preceding section. St. forked, or, from the development of an axillary bud, proliferous and pinnated; pinnoe very long and pinnated; pinnl. deeply pinnatifid. Sp. 7-21.

\section{* Stipes forked, branched, and copiously bipinnate. Sp. 7.}

7. G. (Mert.) longissima, Bl.; large, often many ft. long; st. stout, forked ; branches very long, bearing numerous close-placed pinnoe 4-6-8 in. 1., 1-2 in. br., deeply pinnatifid to the rachis ; the segm. linear, acuminated, or oblong, paler or more or less glaucous beneath, glabrous, or (especially when found at great elevations) densely ferrugineo-tomentose, and very paleaceous on the st. rachis and young shoots; caps. 3-5, often mixed with hairs.-Hk.Sp. 1. p. 4. G. glauca, Hk. Sp. 1. p. 4. t. 3. B., not Sw. M. glabra, Brack. G. gigantea, Wall. in $H k$. Sp. 1. p. 5. t. 3. A. G. excelsa, J. Sm. Hk.Sp.1.p.5.t.4.B. G. Bancroftii, $H k$. Sp. 1.p. 5.t. 4. A. M. pinnata, Kze.- . arachnoides, frond cobwebby. G. arachnoides, Mett. in Ann. Bot. L. Bat.1.p. 47. G. bullata, Moore.

Hab. China and Japan, common, and mostly very glaucous beneath ; Bengal, Malay Islands and Peninsula, Sandwich Isles, W. Indies, N. Grenada, Mexico, and Guatemala. - $\beta$ Borneo, elev. 7,000 ft., Low. Java, Blume, De Vriese.-My copious specimens from the above localities quite satisfy me that the supposed species enumerated are trifling modifications of one and the same.

** Fr. dichotomous (rarely simple); pinnatifid; in other words, the leafy or frondose portion is not confined to the forked apices, but is decurrent upon the branched portion of the st. Sp. 8-21.

8. G. (Mert.) flabellata, Br.; fr. very proliferous; branches dichotomously flabelliform, submembranaceous ; pinnce ascending, a span and more 1., 1-2 in. br., lanceolate, subcaudato-acuminate, closely pectinato-pinnatifid; segm. linear, suberecto-patent.-Hk. Sp. 1.p. 6. Hk. F. Ex.t. 71.

.Hab. N. to S. Australia and Tasmania; N. Zealand; N. Cal., Vieillard.

9. G. (Mert.) tenera, Br.; "fr. dichotomous, proliferous ; branches lanceolate pinnatifid; pinnoe (segm.) linear, entire, divaricated, slightly hairy ; rachis scaly, caps. 3-5, inserted, sessile," Br.-Hk. Sp. 1. p. 6.

Hab. Tasmania.-What I suppose to be this, is probably a small and young form of $G$. flabellala with shorter and more spreading segm., and is slightly and partially villous and scaly. 
10. G. (Mert.) Cunninghami, Hew.; st. and costoe beneath hairy and deciduously scaly ; fr. often proliferous, coriaccous ; branches dichotomously flabelliform, glaucous beneath, and hairy; pinno linear-lanceolate, acuminate, often falcate, $4-6$ in. $1 ., \frac{1}{2}-1$ in. br. ; segm. linear, acute ; caps. $2-4$ in a sorus. $-H k . S p .1$. p.6.t.6.B. Hk. fil. N. Zeal.2.t. 71 .

\section{Hab. N. Zealand.}

11. G. (Mert.) umbraculifera, Moore; st. and rachis deciduously tomentose and subpaleaceous ; fr. often proliferous, flaccido-coriaceous ; branches dichotomously flabelliform, scarcely glaucous beneath ; pinnoe 4-6 in. 1., 1 in. br., lanceolate, subcaudato-acuminate, pectinato-pinnatifid; lobes narrow-linear; sori of $3-5$ caps. -Mertensia, Kze. in Linn. 18. p. 114.

Hab. S. Africa.-Perbaps too near G. Cunninghami of N. Zealand.

12. G. (Mert.) pedalis, Klfs.; st. and rachis with deciduous, chaffy scales ; fr. often proliferous ; branches dichotomously flabelliform, subcoriaceous, yellowgreen when dry ; pinnœ linear-lanceolate, spreading or recurved, $4-6$ in. $1 ., \frac{1}{2}-\frac{3}{4}$ in. br., deeply pinnatifid, oblong-ovate, subglaucous beneath, horizontal, the margins scarcely recurved; sori of 2-4 caps.-Hk. Sp. 1.p. 6. f. 8. B.

Hab. Chili, as far south as Valdivia; Juan Fernandez, Bertero.

13. G. (Mert.) cryptocarpa, Hk.; glabrous ; fr. proliferous, coriaceous, deep yellow or yellow-brown when dry; branches dichotomously flabelliform; pinnce broad-lanceolate, suberect and compact, 4-5 in. l., 1 in. br., pectinato-pinnatifid; segm. narrow-linear, strongly veined, the margins singularly revolute, concealing the suri ; caps. $1-4$ in a sorus.-Hk. Sp. 1.p. 7. t. 6. A.

Hab. S. Chili and Chiloe; Falkland Islands.

14. G. (Mert.) quadripartita, Hk. ; fr. coriaceous, black when dry, rufousbrown beneath, and there deciduously chaffy on the costæ, not proliferous, only once forked ; each branch flabelliformly dichotomous ; pinne lanceolate, acuminate, falcately curved, pectinato-pinnatifid, 4-6 in. 1., 1-1 $\frac{1}{2}$ in. br. ; lobes narrowlinear, subfalcate, sharply acute, the margins a little recurved; caps. 1-3 in a sorus.-Mertensia, Poir. G. acutifolia, Hk. Sp. 1.p. 7.t. 8. A.

Hab. Straits of Magellan, Port Famine.-Very dark coloured, quite black above when dry, red-brown beneath, remarkable in not being proliferous. This and the three preceding species have a strong family resemblance, and a very compact habit; yet each seems to be uniform in its respective characters.

15. G. (Mert.) revoluta, H. B. K. ; st. and rachis paleaceous, especially beneath ; fr. repeatedly dichotomous, rarely proliferous, rigid, subcoriaceous (gemmo often foliaceous) ; pinno linear-acuminate, 5-7 in. 1., $\frac{1}{2}-\frac{3}{4}$ in. br., deeply pinnatifid, much and laxly divaricated and falcate; lobes ovate, horizontal, obtuse with the margin recurved, subglaucous beneath; caps. 2-4.-Hk.Sp.1.p.7.t.7. A. M. pruinata, Mart. (Kze.). M. subflabellata, Brack. (Moore).

Hab. Andes of Quito, alt. 9-10,000 ft., Humboldt. Brazil (Klotzsch in Herb. Nostr.). Brackenvidge? Summit of the Blue Mountains, Jamaica, Purdie.-My authentic specimen of $M$. subflabellata, Brack., is more glabrous, and has slenderer and less divaricating pinnæ than true revoluta.

16. G. (Mert.) simplex, Hk. ; st. subpaleaceous, undivided ; fr. simple, linearlanceolate, pectinato-pinnatifid, acuminate at the apex, or, if undeveloped there, sericeo-paleaceous (rarely, in that state, with circinate heads), 6-14 in. 1., $\frac{1}{2}-1$ in. or. ; lowest segm. free, all obliquely patent, from a broad base linear-oblong, glausous beneath ; caps. 2-4, mixed with rufous hairs.-Hk. Ic. Pl. 1.t. 92. Sp. p. 7.

Hab. Andes of Quito and Peru.

17. G. (Mert.) pubescens, H. B. K. ; st. and rachises often paleaceous or woolly ; iranches of the fr. repeatedly dichotomous, subcoriaceous, leafy; pinnoe 5 in. to 
2 ft. l., 1-2 in. br., pectinato-pinnatifid, clothed with cobwebby, deciduous pubescence, generally ferruginous beneath; segm. sureading, linear, obtuse or retuse ; caps. 2-5, often concealed among the puhescence.-Hk. Sp. 1.p. 8. M. immersa, Klf. Hk. et Grev. Ic. F.t. 15 (excellent). Gl. tomentosa, Sw. Hk.Sp. 1.p.13. $-\beta$ more or less glabrous. M. furcata, $S w$. G. Mathewsii, Hk. Sp. p. 9. t. 7. B. M. farinosa, Klf. Hk. Sp. p. 9. - $\mathrm{\gamma}$ longipinnata; pinno 2 ft. 1., 3 in. wide. G. longipinnata, Hk. Sp. 1.p.9. M. grandis, Fée, in Hb. nostr.

Hab. Tropical America abundant; very variable in the more or less decurrent lobes of the frond, and in the presence or absence of tomentum and scales.

18. G. (Mert.) Owhyhensis, Hk. ; st. above much compressed, and winged with 2 elevated ciliated lateral lines; fronds subcoriaceous, 3-4 times or more dichotomous, leafy ; pinnce lanceolate, acuminate, a span to $1 \mathrm{ft} .1 ., 2-2 \frac{1}{2}$ in. w. ; segm. linear, horizontal, tapering and acute, cobwebby on the costa and veins beneath ; caps. 2-4.-Hk. Sp. 1.p. 9. Mert. Hawaiensis, Brack. Fil. U. S. Expl. Exp.p. 295.

Hab. Owhyhee. Macrae, Brackenvidge.

19. G. (Mert.) flagellaris, Spr.; branches of the fr. glabrous, repeatedly dichotomous, copiously foliaceous, glabrous, often glaucous beneath, subcoriaceo-membranaceous; pinnoe erecto-patent or divaricating, extremely variable, broad- or narrow- or linear-lanceolate, $5-6$ in. to a ft. and more 1. ; segm. $\frac{1}{2}-2$ in. and more 1 , linear, sometimes ferrugineo-tomentose at the base beneath ; caps. 2-4.-Hk. Sp. 1. p. 10. Mertensia, Bory. G. lævigata, $W$. Hk. Sp. 1. p. 10 G. bifurcata, $B l$. Hk. Sp. 1. p. 11. Mert. plumæformis, Pr. Epim. p. 24. t. 15 (very good). G. bracteata, Bl. in Hb. Hook. (axillary gemmoe pectinato-bracteated; branches of the fr. contracted).

Hab. Mauritius and Bourbon, Madagascar; Java and Malay Islands abundant ; Fiji, Milne.-The Malayan form of this is very large and rigid, yet the ramification and the copious foliaceous branches are the same as in the Mauritian and Madagascar form.

20. G. (Mert.) hirta, Bl. ; "fr. chartaceous when dry, opaque, green above, beneath cæruleo-pruinate (very glaucous on the rachises and costæ), together with the (small) gemmoe densely paleaceous with ferruginous, lanceolate scales, paler at the margin and ciliated, at length bare on the costæ, many times dichotomous; branches adscendenti-flabellate; prim. ones 1 in. 1., nudate ; second. ones $1 \frac{1}{2}$ in. l., subnudate; tertiary ones subelongate; ult. ones (or pinnce) 7-9 in. l., standing at an angle of $30^{\circ}$, linear, gradually attenuated, deeply pinnatifid ; lobes 8 in. 1., $1 \frac{1}{2}$ in. br. (oblong-) linear, obtuse, slightly curved, the margin revolute, the sides entire, the apex denticulate; veins lax, slender ; sori between the costa and the margin, of 3-5 caps." Mett.-Hk. Sp. 1.p. 11. Mett. in Miq. Ann. Mus. Bot. L. Bat. 1.p. 48.

Hab. Malay Islands, Reinwardt, Sir W. Norris. - It is but recently that I bave received specimens of this from Sir W. Norris, but unfortunately all sterile ones.

21. G. (Mert.) vestita, Bl.; " $f r$. chartaceous or subcoriaceous, dark opaquegreen above, pruinose beneath, ferruginously fimbriato-paleaceous on the rachises, costoe, and gemmoe, many times dichotomous ; inf. branches 1-2 in. 1., subdivergent; ult. ones (or pinnoe) 6-8 in. l., all deeply pinnatifid ; segm. approximate, patent, 4-5 lines l., $2 \frac{1}{2}$ lines br., oblong or ovato-oblong, rather obtuse or shortly apiculate, entire; gemmœ pinnatifidly bracteated ; veins lax, evident beneath, prominent above; caps.5, large," Mett.-Hk.Sp.1.p.10. Mett.in. Miq. Ann. Mus.Bot.L.Bat.p. 48.

Hab. Malay Islands, Blume, Van Hasselt. - I possess authentic specimens of this from Blume, quite glaucous beneath; those from Gedé (Van Hasselt) are not at all glaucous. Blume notices its close affinity with $G$. laeviguta, which we unite with $G$. flagellaris. It is a stouter-growing plant, with broader and shorter segments. Mettenius, with equal justice, says it is almost to be looked upon as a large form of $G$. vevoluta (n. 15), with large and less ciliated chaffy scales and more distinct veins.

§§ Stipes zigzag, branched; branches bearing from 1-3 pairs of forked divaricating pinno; segments never decurrent. Sp. 22. 
22. G. (Mert.) pectinata, Pr. (character given in the section).-G. glaucescens, H. B. K. Hk. Sp. 1. p. 11. Mertensia Hermanni, Hk. et Gr. Ic. F. t. 14 (excl. synonyms). Mertensia nervosa, Klfs. Gleichenia, IIk. Sp. 1.p. 12. t. 5. A.

Hab. Tropical S. America, common.-- $\beta$. Brazil.-The only species of this section, and not to be confounded with any other. Glabrous or pubescent beneath, very frequently glaucous. Sori of 8-10 capsules. $M$. nervosa, Klfs., is merely a young form of this.

\$ 4. Stipes zigzag, repeatedly di-or trichotomous, the ultimate branches bearing a pair of forked pinnae: a distinct pair of pinno also arises from the base of the forked branches (not of the frond). Segments never decurrent. Sp. 23.

23. G. (Mert.) dichotoma, Willd. (character given in the section).-Hk. Sp. 1. p. 12. G. Hermanni, Br. (not Hk. \& Gr.). Besides the many synonyms given in Sp. Fil. l. c., I may add M. pteridifolia, Pr. Epim. p. 23.t. 14 (a terminal fork only); M. rufinervis, Mart. Hk. Sp. 1.p. 11. G. Klotzschii, Hk. Sp. 1. p. 13. t. 5. B. M. revoluta, $K l$. Hb. nostr. (not of H. B. K.). M. crassifolia, Pr. Epim. p. 23. t. 13. G. ferruginea, Bl. (not Desv.). Hk. Sp. 1.p. 10. Mett. in Miq. Ann. Mus. Bot. L.Bat. 1.p.50. M. enarginata, Brack. Fil. U. S. Expl. Exp.p. 297.t. 42 (very ferrugineo-tomentose beneath, and with the segments often emarginate; as they are in the glabrous var. of $G$. dichotoma).

Hab. Tropical and subtropical regions, almost universal, in the New and in the Old Worlds ; Pacific Islands, and as far north as Japan.-As $G$. pectinata is a solitary species of its section, so is $G$. dichotoma of the present one. Besides being most extensively geographically distributed, it is very variable in the size of the pinnæ and in the shape of the segments, and in being more or less glabrous or densely tomentose beneath, green or glaucous, and very variable in the texture of the frond : but the pairs of accessory pinnæ at the base of a fork are invariably present. There are also abnormal or aberrant forms. Among them I have specimens with lobes of the pinnæ free (pinnules), and more or less deeply pinnatifid, from Penang and Java. I have others from Java, wbich Mettenius (Ann. Mus. Bot. L. Bat.) calls var. alternans, in which the primary divisions of the stipes are scarcely dichotomous, but alternate, "frondes inæqualiter dichotomæ."-In regard to size, some of the pinnæ are $1-1 \frac{1}{2} \mathrm{ft} .1$., and some are 6 in. br. Occasionally, the lowest pair of lobes is much elongated, reflected, and pinnatifid.

\section{Sub-ORd. II. POLYPODIACEA.}

Sori dorsal or marginal, subglobose, of many capsules, with or without an involucre, usually pedicellate, more or less completely surrounded with a jointed vertical and elastic ring, and bursting transversely (except in Hymenophyllex). TRIBE I.-XIII. GEN. 3-61. TA B. I. f. 3-12, and TA B. I.-VIII. f. 13-61, inclusive.

A. Involucrate. Sori furnished with an involucre (except in Alsophila). Tribe I-VIII. Gen. 3-47.

\section{'Tribe I. Cyatheas.}

Sori dorsal, globose, often at or near the forking of a vein. Caps. numerous, often very compact, sessile or stalked, generally on an elevated receptacle, often mixed with hairs, obovate, usually with a broad, vertical, or suboblique elastic ring. Invol. (wanting in Alsophila) inferior, including the sorus, lateral and resembling a scale on the under side of the sorus, or cup-shaped, often, when young, enveloping the sorus, eventually opening at the summit, or breaking down, with a more or less regular margin.-Caud. very generally arborescent. Tropical or subtropical. Gen. 3-8.

\section{Gen. 3. Thyrsopteris, Kze.}

Sori globose, marginal, collected into a panicle distinct from the sterile pinnæ. Caps. sessile, on a globose receptacle. Invol. inferior, cup-shaped, the mouth entire. - Fronds decompound, sterile portions bipinnate with lanceolate, incised pinnules; fertile ones 3-pinnate, of which cach pinnule bccomes a raceme of stalked involucres. TAB. 1. f. 3 . 
1. T. elegans, Kze., in Schk. Fï. Suppl. p. 3.t. 1. Hk. S'p. 1.p. 65.

Hab. Juan Fernandez, Bertero.-A solitary and very rare Fern. I remove this genus to the Tribe Cyathece, to which, I think, it has a closer affinity than to Dicksoniece.

\section{Gen. 4. Cratinea, $S m$.}

Sori on a vein, or in the axil of the forking of a vein. Recept. elevated, globose, or elongated. Invol. globose, inferior, covering the whole sorus, afterwards breaking at the summit and forming a more or less persistent cup, even or irregular at the margin.-Arborescent, tropical or subtropical. St. often aculeated. Fronds simple or pinnate, or decompoundly pinnate. TAB. I. f. 4.

\section{* Fronds undivided. Sp. 1.}

1. C. sinuata, Hk. \& Gr. ; caud. slender, erect, $2-4 \mathrm{ft}$. 1. ; fr. simple, 2-3 ft. 1., $1-2 \frac{1}{2}$ in. w., elongato-lanceolate, sinuated at the margin, acuminate, tapering into a short stipes at the base.-Hk.Sp. 1.p.15; and Gard.F.t.21. Thw. En. Pl. Cey. p. 396.

Hab. Wooded mountains, Ceylon, rare ; most abundant in the Singhe-rajah Forest.If not among the smallest, certainly among the most elegant and graceful of cyatheaceous plants, and the only one we know with quite simple fronds. A native only of Ceylon.

\section{* Fronds pinnate. Sp. 2, 3.}

2. C. Brunonis, Wall.; fr. large, pinnate, glossy ; pinnoe 8-14 in. 1., oblonglanceolate, finely acuminate.-Hk. Sp.p. $15 ;$ Gen. F.t. 2.

Hab. Malay Islands, frequent.-Caudex unknown to me.

3. C. Hookeri, Thw.; small but arborescent ; caud. $1 \frac{1}{2}$ in. thick ; st. short, black, muricated at the base and subpaleaceous; fr. coriaceo-membranaceous, 2-3 ft. 1., 4-5 in. w., elongato-lanceolate, acuminate, pinnate, pinnatifid at the apex; pinnoe from a broad base auricled on both sides, sublinear-lanceolate, acuminate, subsessile, coarsely dentato-pinnatifid, more or less entire towards the apex; veins pinnated; sori dorsal on the veins or in the lower axils; invol. breaking into irregular lobes.-Thw. En. Pl. Cey. p. 396.

Hab. Forest of Singhe Rajab, Ceylon, Thwaites, C.P. 3722.-A very distinct and peculiar species.

\section{*** Fronds decompoundly pinnate.* Sp. 4-55.}

\section{+ Species of tropical America. Sp. 4-24.}

4. C. arborea, Sm. ; unarmed or copiously prickly, often strongly so at the base of the st.; st. and rachis pale brown, or dark purple, or black ; fr. ample, bipinnate; sccond. pinno 5-8 in. l., sessile, oblong-lanceolate, deeply pinnatifid or again pinnate; lobes or pinnl. oblong, subfalcate, serrated, paler beneath; invol. chartaceous, pale or dark brown, exactly cup-shaped in maturity, with a beautifully even margin.-IIk. Sp. 1.p. 17.-Var. pallida; st., rachis, and invol. pale-coloured. C. elegans, Hew. C. Grevilliana, Mart. Hk. Sp. 1.p. 22. C. minor, Eat.

Hab. W. Ind. Islands ; most abundant in Jamaica, both varieties. Brazil, Polll.I have again examined with great care the two states of this plant, and am only the more confirmed in my opinion that they constitute but one species.

* The three preceding species are readily enough distinguished by the undivided or simply pinnated structure of the frond, combined with other peculiarities: but it is far otherwise with those which follow, whose fronds are more compoundly divided, which present a much greater similarity one with another, and of which, on account of their frequently gigantic size, we rarely receive other than mere fragments, telling nothing of their arborescent trunks or caudices, and rarely of their stipites, which often present useful characters. I am unable to offer any better sections or subdivisions than according to the countries they inhabit. 
5. C. serra, W. ; st. thicker than one's finger, more or less muricated (as well as the rachis), densely paleaceous with large whitish scales $1-1 \frac{1}{2}$ in. 1.; fr. bipinnate ; pinnl. lanceolate, deeply pinnatifid, 6-8 in. l., lanceolate, acuminate, deeply pinnatifid ; lobes linear-oblong, acute, serrated, falcate, glabrous ; rachis and costoe slightly hairy; sori generally covering the whole of the lobes; invol. very thin and membranaceous, at length forming a shallow cup, entire or more or less torn at the margin.-Hk. $S p$. 1.p. 17. t. 9. A. C. bicrenata, Liebm.

Hab. W. Indies, Brazil, Mexico. Guatemala?, Salvin \& Godwood (not at all muricated).

6. C. insignis, Eat.; st. very paleaceous at the base with long, glossy, subulate scales; fr. ample, coriaceous, glabrous, dark-green, glaucous beneath, all the rachises and costoe beneath muricated; prim. pinnoe $3 \mathrm{ft}$. 1. ; second. ones 7-8 in. $1 ., \frac{1}{2}-\frac{3}{4}$ in. w., elongato-oblong, finely acuminated, sessile, pinnatifid nearly to the costa ; lobes oblong-falcate, obtuse, quite entire, the margin slightly reflexed; sori copious ; invol. firm-membranaceous, cinnabar-brown, sub-pruinose (with a glaucous tint), often breaking down into 4 subequal valves.-Eat. in Fil. Wright, et Fendl. p. 215.

Hab. Jamaica, on St. Catharine's Peak; elev. 5,000 ft., Wilson, n. 716. Cuba, Wright, n. 1064. Mountain forests, Vera Cruz, Salvin.-A fine species, quite free from scales, except in the stoutest portion of the stipes I possess, where there are traces of long subulate glossy dark-brown ones, free from hairs; fronds glaucous beneath, and with very peculiar involucres.

7. C. Imrayana, Hk.; st. and rachis pale or dark-brown, sparsely tuberculatoasperous, beneath and on the costæ and costules more or less copiously clothed with ferruginous down and scurfy with small, laciniated, often bullate scales; fr. subcoriaceous, bipinnate; pinnl. lanceolate, acuminate, serrate, deeply pinnatifid; lobes oblong or linear-subfalcate, generally nearly entire ; sori near the costa ; invol. globose, membranaceous, fragile, breaking down very irregularly.IIk. Sp. 1. p. 18. t. 9. B. (excl. var. ß.). "C. Tussacii, Desv.," Kze. in H. nostr. - $\beta$. subnudata; main rachis with the scales deciduous. C. muricata $W$.? Griseb.?

Hab. West Indian Islands. Caracas.-C. muricata is a species of Willdenow, founded on the most unsatisfactory figure of Plumier. The generally copious scurfy scales on the underside of the frond are mainly characteristic of our $C$. Imrayana. It appears to be a high mountain species, gathered on the Blue Mountain Peak in Jamaica; alt. 5,000 ft.

8. C. balanocarpa, Eat.; "st. sparsely aculeated at the base and paleaceous with brown, narrow scales ; fr. glabrous, ample, bipinnate;" pinno 12-15 in. 1., 2 in. br., oblong, acuminate ; pinnl. very numerous, $2-2 \frac{1}{2}$ in. $1 ., 2 \frac{1}{2}$ lines w., linearoblong, obtuse crenato-lobate in their lower half, with a distinct, rounded auricle at the inferior base, the superior half of the pinnl., or less, entire ; sori, one corresponding to each lobe of the pinnl.; invol. mamillæform, subcoriaceous with a circular opening at the apex from which the capsules soon protrude.-Eat. Fil. Wright, et Fendl. p. 215.

Hab. Cuba, C. Wright, n. 1063. - A most distinct and well-marked species, admirably distinguished by Mr. Eaton, $l$. $c$.

9. C. cuspidata, Kze.; "fr. bipinnate ; pinnl. alternate, subsessile, divergent, oblong, cuspidate, $4 \frac{1}{2}-6$ in. 1 . by $1 \frac{1}{2}$ in. w., unequal at the base, deeply pinnatifid," having beneath a few deciduous whitish scales; lobes linear-falcate, the lower fertile portion a little contracted, crenulate at the apex, and acute; sori costal ; invol. cinnamon-brown, firm, bursting very irregularly, "stipes hairy at the base."-Hk. Sp. 1. p. 19.t. 12. A.

Hab. Peru, Poeppig.-My fragments received from Dr. Kunze in many respects resemble some of the forms of $C$. arborea; but the involucres are very different.

10. C. divergens, Kze.; base of the stout st. muricated, furfuraceo-tomentose 
and scaly (on the upper side) with firm, intensely black, lanceolate, very longpointed scales having a pale margin ; fr. large, glabrous, bipinnate, petiolate; pinnl. firm-coriaceous, 4-6 in. 1., 1-1 $\frac{1}{2}$ in. w., from a broad base oblong, acuminate, deeply pinnatifid; lobes rather distant, oblong-falcate, acute, subserrated ; sori costal, numerous ; invol. membranaceous, fragile, soon breaking in a very irregular manner.-Hk. Sp. 1. p. 19.t. 11. A.

Hab. Peru, Ecuador, alt. 11,000 ft., Spruce, n. 5367. N. Grenada, Schlim, n. 480. "Caud. arboreous, $40 \mathrm{ft}$. high, $1 \mathrm{ft}$. in diam. Fr. $7 \mathrm{ft}$. long, including the stipes. Pinnæ 12 on each side, excluding the few minute terminal ones." Spruce.

11. C. gracilis, Griseb.; st. strongly muricated at the base; $f r$. bipinnate, glabrous ; prim. and second. pinnoe long-petioled, deltoideo-acuminate, the latter $3-4$ in. $1 ., 1-1 \frac{1}{2}$ in. w. at the base, deeply pinnatifid ; lobes oblong, obtuse, sorrated, sori copious, generally confined to the superior half of the lobes; invol. darkbrown, bursting into somewhat regular valves or lobes to near the cup-like base. -Griseb. Fl. B. W. Ind.p. 704.

Hab. Jamaica, Wilson, Purdie. Antioquia, Jervise.-Allied, as Dr. Grisebach says, to $C$. divergens, but very distinct. A peculiar fecture is given to this plant by the unusual length of the petioles, generally $2-2 \frac{1}{2}$ in. 1 ., and by the pinnules being truncated at the base. Next to this species, Griesebach, l. c., places "C. tenera, Hook.," as a W. Indian Fern, by which he probably intends Alsopllila tenera, of J. Smith, which I have placed among "species dubiæ," in Sp. Fil. p. 49. But the original specimens are very imperfect; and, unless better known to Dr. Griesebach than to me, I should doubt the correctness of its being identical with Hemitelia multiflora, Br. ; the latter, I believe, is a very dubious plant.

12. C. Mettenii, Karst. "caud. arborescent bald (not clothed with the bases of old leaves), squamose above; st. brunneo-squarrose at the base, unarmed; $f r$. lanceolate, $6 \mathrm{ft}$. and more long, 3-4 ft. w., ovate-lanceolate, acute, bipinnate ; pinnl. 2 in. l., from a broad base lanceolate, deeply pinnatifid, deciduous ; costee and veins on both sides squamoso-pilose; lobes falcate, oblong, obtuse, obsoletely serrated, glaucous beneath; veins generally forked, soriferous at the fork; invol. globose, breaking open irregularly."-Karst. Fl. Columb. 1. p. 113. t. 56.

Hab. Andes of Bogota, alt. 14,200 ft., Karsten. Tarapota, Eastern Peru, Spruce, n. 4723.-Mr. Spruce's fronds entirely correspond with the beautiful figure and the description of Karsten. The stipes is castaneous, and very smooth; the scales at its base are unilateral, very large, and point upwards, glossy black, as if varnished, and have a ferruginous margin.

13. C. squamipes, Karst.; st. strongly aculeate, thick as a child's wrist below, and there clothed with long narrow castaneous scales; rachis and costce more or less muricated and downy ; fr. 10-12 ft. l., bipinnate; pinnoe 12-14 in. 1.; pinnl. 2-3 in. 1., hairy on the veins beneath, 5 lines w., linear-oblong, shortacuminated; sori copious, close to the costule; invol. pale, membranaceous, globose, opening at the apex by a circular but rather irregular mouth.-Karst. $F l_{\text {. }}$ Columb. t. $99 \& 100,3 b$.

Hab. Mountain of Merida, Columbia, alt. 6-9,000 ft., Karsten. Tarapota, E. Peru, Spruce, n. 4729.

14. C. incana, Karst.; "caud. arborescent, densely scaly ; st. scaly only below, and tomentose with linear scales; pinnce and pinnl. linear-lanceolate, deciduous; lobes oblong, falcate, subacute, fertile ones nearly entire, sterile ones slightly serrated, with the veins generally forked, soriferous at the fork; invol. pilose, membranaceous, irregularly opening at the apex."-Karst. Fl. Columb.t. 37.

Hab. Andes of Bogota, alt. 15,000 ft., Karsten.-Beautiful as is the figure, and laboured as is the descriptive portion of the text, there is such an absence of allusion to allied species (except slightly to "C. straminea, Karst.," and to C. Schanschin of Martius), that I dare not express any opinion on its validity.

15. C. frondosa, Karst.; "caud. lofty, unarmed, squamose with lincar-subulate 
scales, acuminate, frondose at the summit; $f r$. ovato-lanceolate, $12-14 \mathrm{ft} .1$. hy $6 \mathrm{ft}$. w.; pinnl. 4-5 in. l., from a broad base lanceolate; lobes oblong, margins recurved, penniveined; weins forked, their branches clavato-incrassate at the apex, terminating near the margin, and as well on the prim. and sccond. costoe pilose and squamose; sori near the costule at the furcature of the veins; invol. globose, glabrous, opening irregularly at the summit; recept. globose, entire, pilose."-Karst. Fl. Columb. 1. t. 74.

Hab. Andes of Bogota, alt. 14,400 ft., Karsten.-A pparently allied to C. arborec, var. pallida, and to $C$. Schanschin; but, unfortunately, no essentially distinguishing features are pointed out.

16. C. equestris, Kze.; "fr. vast, eoriaceous, bipinnate; pinno long-petiolate, lanceolate; pinnl. remote, alternate, petiolate, confluent into an acuminated apex of the pinna, lower ones divaricato-reflexed, middle ones divergent, superior ones patent, all oblong-lanceolate, pinnatifid, unequal at the base, acuminated; lobes falcato-oblong, rather obtuse, serrulate, lower ones soriferous ; sori near the costule irregular; costce and petioles hairy above ; partial rachises at the base sparingly aculeolate, beneath towards the base hairy."-Kze. in Schk. Suppl. t. 76. HK. Sp. 1.p. 19.

Hab. Peru, Poeppig. - The author compares this with our $C$. divergens; but his figure, and a pinna I possess from the author, show a greater resemblance to Hemitelia Guiarensis, Hk. It is, however, a true Cyathea. This was quite unknown to me at the time I published the Sp. Fil. I have since received a pinna from the late Professor Kunze. It is 5 in. 1., nearly $1 \frac{1}{2}$ in. br., oblong-acuminated, quite glabrous ; segments very closeplaced, 7 lines 1 . by 3.4 br., quite plane.

17. C. Beyrichiana, Pr.; st. aculeate and at the base clothed with long, brown, chaffy hairs; fr. ample, subcoriaceous, bipinnate; rachises and costa more or less downy; prim. pinnce $1 \frac{1}{2} \mathrm{ft}$. 1. ; pinnl. $3-3 \frac{1}{2}$ in. 1., sessile, oblong, acuminated, deeply, nearly to the costa, pinnatifid ; lobes linear-oblong, subfalcate, the margins obscurely serrate, recurved; sori rather copious and close to the costule, not extending to the margin; invol. dark-brown, firm, and persistent, lax, often splitting at the back and spreading or bifid, to all appearance covering the whole sorus in an early stage.-Hk. Sp. 1. p. 21. and 1 e. Pl.t.623. Amplicosmia, Moore.

Hab. Brazil.-I scarcely think it correct to refer this to the Amplicosmia section of IIemitelia, as Mr. Moore has done ; but, indeed, both the genera and species of Cyatheaceous ferns present great difficulties in the way of accurate determination. Beyrich looked upon this Fern as an Alsophila; but that it cannot be.

18. C. vestita, Mart.; "fr. bipinnate; st. and rachis shortly and sharply aculeated; partial rachis and veins with rusty hairs; pinnl. pubescenti-villous beneath, linear-acuminate, deeply pinnatifid, the lobes falcato-lanceolate, acute, crenulate with 6-10 sori in each."-Mart. 1c. Pl. Cr. p. 75.t.52. C. Delgadii, Pohl. (Moore).

Hab. Brazil, Martius, Pohl., Gardner, n. 1907 (Moore).-There seem to be no tangible eharacters to mark this species, if such it be.

19. C. hirtula, Mart. ; "fr. bipinnate; st. sharply aculeate and the rachis villous with brownish hairs and sparingly paleaceous; pinnl. slightly pubescenti-hirsute on both sides, linear, acute, pinnatifid ; the lobes ovato-lanceolate, rather obtuse, subcrenulate or entire; sori in each segment few and basal." -Mart. l. $c ., p .76$. t. 53. $H k$. Sp. p. 20. ‥

Hab. Brazil, Martius. Guiaua, R. Schomburgk, n. 1124a (according to Kunze and Moore).-Unknown to me.

20. C. Schanschin, Mart; "fr. bipinnate; st. and rachis sharply aculeated, and, as well as the rachis and veins, strigoso-villous; pinnl. downy, linear, cuspidatoacuminate, pinnatifid; lobes linear-oblong, obliquely rotundate, subcrenulate ; 
sori 6-10 in each segment."-Mart. l. c., p. 77.t.54. Hk. Sp. 1. p.20. C. oligocarpa, Kze.

Hab. Brazil, Venezuela, Peru, Mexico, Guatemala, Salvin \& Godman, n. 358 ? and 14 ?.-Martius has well represented in his plate the copious, glossy, ferruginous scales which clothe the nascent frond (t. 54, f. 1), of which the author takes no notice in his diagnosis. In the absence of these on our copious specimens, named and unnamed, I could not refer to any essential distinguishing character. Among our thus autheuticated specimens are Fendler's, $n .54$, and Sellow, from Herb. Reg. Bras.-Such good figures as those of Martius must not be thought light of ; but even they require to be accompanied by good diagnoses, and, unless they are specially well-marked species, with some notice also of the affinities.

21. C. Sprucei, Hk. ; caud. $15 \mathrm{ft}$. high ; st. stout, furfuraceous brown, $1 \mathrm{ft}$. l., bearing "long, slender, exceedingly fragile aculei," mixed with strong black spines 1-3 lines 1., with a broad dilated base; base of the st. clothed with very long, silky or woolly, deciduous, crinite, pale scales, which have a dark line down the centre; $f r .5 \mathrm{ft}$. l., lanceolate, bipinnate, glabrous or only slightly pubescent on the costæ, subrigido-coriaceous; prim. pinnoe 1-2 ft. 1., oblong, acuminate; pinnl. approximate, horizontal, 2 in. l., subsessile, narrow-oblong, deeply pinnatifid ; lobes narrow, ovate, acute, the margins slightly recurved, entire ; sori very copious ; invol. fragile, breaking into irregular lobes.

Hab. Ecuador, Montaña di Canelos, and Tungaragua, alt. 4,000-6,500 ft. ; and Chimborazo, alt. 3,000-4,000 ft., Spruce, n. 5744.-This I at first took for C. Schanschin, but the stipes (a portion of a tree-Fern too much neglected by plant-collectors in general) is quite different.

22. C. Mexicana, Schlecht.; unarmed; rachis and costa above pubescentiscabrous ; fr. bipinnate ; pinnl. lanceolate, acuminate, 3-4 in. l., pinnatifid, glabrous; lobes oblong, slightly falcate, rather obtuse, serrated; sori chiefly at the lower half of the lobe, on the back of a simple vein or at the forking of a divided vein ; invol. very thin and membranaceous, fragile, and soon obliterated. —Schlecht. in Linn. 5. p. 616. Hk. Sp. 1. p. 15. C. denudans, Kze. and C. hexagona, Fée (Moore).

Hab. Mexico.- I find this species to have the sorus sometimes on the back of a single vein, and sometimes on the fork of a vein, so that there is no reason to separate this species, as some authors have done, from the great mass of Cyathece which have bi-tripinnate fronds, with which, too, it is naturally allied. Presl. gives a figure of the venation (Tent. Pterid. t. 1. f. 8), but only represents the simple form, with dorsal sori.

23. C. Gardneri, Hk.; fr. bipinnate; st. and main rachis nearly glabrous ; pinnl. gradually and at the apex much acuminated, pinnatifid; lobes oblong, erecto-patent, obtuse, falcate, serrated, villous beneath, especially on the costa and veins, lowest inferior one adnato-decurrent; sori covering the whole underside of the lobe ; invol. almost globose, pale-brown, opaque, with a dark mammillate apex, at length bursting with a small aperture at the top.- $H k . S p \cdot p .21$. t. 10. A. (where, for Tab. X. A. read Tab. X. B.).

Hab. Brasil, Gardner.-A species of peculiar aspect, and remarkable for the adnate and subdecurrent base of the pinnules. The involucres seem also to be unusually persistent.

24. C. cbenina, Karst.; st. paleaceous below with large, lanceolate, glossy, firm, acuminated scales, dark in the centre, and slightly asperous (scarcely aculeate) ebeneous-black, as well the principal rachises; fr. glabrous, 5-6 ft. 1 ., firm-membranaceous, bipinnate ; prim. pinnoe 12-14 in. 1.; pinnl. distant, all rather long-petiolate, 3 in. l., from a broad, oblong base, acuminate, pinnatifid, deeply so and subpinnate below ; lobes broad, obtuse, serrate; sori rather sparse; invol. with the cup breaking into unequal lobes.-Karst. Fl. Columb. p. 3. t. 2. and $t$. 100. f. 2. (caudex.)

Hab. Columbia, alt. 15,000 ft., Moritz, in 116 . Nustr.-A very well-marked species ; 
in its much-petiolated pinnules resembling some species of Hemitelia. Caudex $18 \mathrm{ft}$. high, very slender, denudate.

25. C. microphylla, Mett. ; caud. $4 \mathrm{ft}$. high ; st. and rachises very deciduously ferrugineo-tomentose; $f r$. 2-3 ft. long, oblong-ovate, acuminate, tripinnate ; prim. pinnoe sessile, broad-oblong, acuminate; second. ones similar to them but smaller, crowded ; pinnl. small, scarcely 2 lines l., ovato-oblong, deeply pinnatifid; lobes oblong, obtuse, single-veined, entire ; sorus solitary at the base of the veinlet; invol. globose, breaking irregularly into 3-4 portions.-Mett. in Lechl. F. Per.p. $23 ; H k$. 2 nd Cent. of Ferns, t. 99.

Hab. Andes of Peru and Ecuador, Lechler, Jameson, Spruce. - A remarkable and most distinct species, with very compound fronds, and the smallest pinnules of any species of the genus.

+† Species of tropical and subtropical Africa, including the adjacent islands, Madagascar, Mauritius, Bourbon, Seychelles, \&c. Sp. 26-34.

26. C. Drègei, Kze. ; unarmed, or only rough with small tubercles at the base of the st., and there paleaceous with rather large, lanceolate-subulate, glossy, ferruginous scales ; fr. bipinnate ; pinnl. sessile, 2-3 in. l., glabrous or a little arachnoid at the base beneath, narrow-oblong, acuminate, deeply pinnatifid; lobes oblong-ovate, subfalcate, obtuse, more or less serrated; invol. fragile, opening at the top and forming a cup with a small slightly irregular margin. $H k$. Sp. 1. p. 23. $t$. 10. B. and $t$. 17. A. (lobes more serrated). C. Burkei, Hk. $S p .1 . t$. 17. B. ; lobes of the pinnules rather broader.

Hab. S. E. Africa, Natal, Macalisberg, as far as the Zambesi ; Moramballa, alt. 3,000 ft., Livingstone, Kirk ("caudex $4 \mathrm{ft}$. high"). - The only Cyatlea, I believe, inhabiting South Africa, but not extending to the extreme south.

27. C. Manniana, Hk. ; caud. $30 \mathrm{ft} .1$. ; st. and rachises pale-brown, glossy, muricate, glabrous ; fr. subcoriaceous, glabrous, tripinnate ; prim. pinnce $2 \mathrm{ft}$. 1., 8 in. w. ; second. pinnoe $\frac{1}{2}$ in. w., sessile oblong, pinnatifid only towards the narrow acuminated apices ; pinnl. narrow-oblong, falcate, acute, serrated ; veins forked, not prominent; sori rather large, few, mostly on the lower half of the pinnl., and mixed with ovate, fringed scales; invol. lax, deep-cupshaped, but breaking down at the margin, and subpersistent.

Hab. Fernando Po and Cameroon Mountains, alt. 3-4,000 ft., G. Mann.-Quite different from any other tropical African Cyathea I am acquainted with.

28. C. Welwitschii, Hk. ; caud. 20-25 ft. 1. ; st. scarcely any (2-3 in. 1. in my specimens), as thick as a swan's quill, castaneous, paleaceous, with large, subulate, firm, glossy scales, tuberculato-muricate, as is the base of the rachis, the rest glabrous ; rachis also castaneous ; fr. $3 \mathrm{ft}$. and more l., subcoriaceous, very dark-green and slightly hairy above, paler and more villous with spreading hairs beneath, ovato-lanceolate, contracted below and there bearing numerous dwarfed pinnoe, bipinnate ; prim. pinn. 6 in. 1., 1 in. w., sessile, pinnatifid only at the short acuminate apex; pinnl. and lobes very patent, oblong and obtuse, subfalcate, strongly crenato-serrate ; veins prominent beneath, forked ; sori mostly near the base of the pinnl. at the forking, and near the costule; invol. shallowcupshaped (possibly imperfect), surrounding the whole base of the sorus; costoe on both sides densely and subferruginously villous.

Hab. W. Africa, Island of St. Thomas, in the Bight of Biafra, alt. 3-7,000 ft., Welwitsch, n. 66, G. Mann.-Remarkable for the contraction of the lower portion of the frond, formed by dwarfed pinnæ, which extend nearly to the base of the stipes: thus the fronds are subsessile.

29. C. Camerooniana, Hk. ; st. 1-2 ft. and more 1., paleaceous with appressed, subulate scales at the base, scarcely asperous, and, as well as the rachis (paleaceohirsute upwards only) rufo-castaneous ; $f r .4 \mathrm{ft}$. or more l., 14-16 in. w., subcoriaceo-membranaceous, bipinnate, quite glabrous, above dark green, paler 
beneath ; the costoe and costules paleaceo-hirsute on both sides ; pinnoe 6-8 in. 1. , sessile, oblong acuminate, pinnated, or very deeply pinnatifid nearly to the costa; pinnl. or lobes 7-8 lines 1., obtuse, subfalcate, serrato-dentate ; veins forked; sori at the fork ; invol. very thin, membranaceous, fugacious, leaving a shallow ragged cup, most permanent at the inferior side.

Hab. Cameroon Mountains, alt. 3-4,000 ft., G. Mann.-Habit. of $C$. Welwitschii, but not tubercled on the rachis, quite glabrous on the fronds, except on the costæ and costules; and the lower pinnæ are not dwarfed.

30. C. Angolensis, Welw ; "caud. 12-15 ft. l., 8 in. in diam. ; fr. 6-8 ft. 1." (probably including the $s t$., which in the specimens is $1 \frac{1}{2} \mathrm{ft}$. or more, castaneous, slightly muricato-tuberculate and fusco-paleaceous at the base, the rest smooth), bipinnate, glabrous, subcoriaceo-membranaceous, paler and subglaucous beneath; prim. pinnce $1 \frac{1}{2} \mathrm{ft}$. and more l., oblong-acuminate ; pinnl. 3 in. 1., sessile, oblong, pinnatifid nearly to the base, sometimes ferrugineo-tomentose in the axils, deeply and nearly to the rachis pinnatifid (subpinnate at the very base); lobes oblong, subfalcate, obtuse, the margin a little thickened, subserrate ; sori at the forking of the veins, chiefly on the lower half of the lobe and near the costule; invol. cupshaped, short, but broken down and sublobed at the margin.-Welw. Phys.Geogr. in Ann. Cons. Ultram. 1858, p. 358.

Hab. Benguilla, distr. Huilla, Trop. W. Afr., alt. 3,500-5,550 ft. ; very rare, Welwitsch, n. 186 and 83.-The sori are rather old, and the involucres do not probably represent their earlier form.

31. C. Kirkii, Hk, ; main rachis unarmed, and, as well as the second. ones, deciduously pubescent and paleaceo-crinite with subulate, often spreading, black scales, pale at the margin ; fr. firm-membranaceous, dark-green, a little pales. beneath, glabrous, hirsutulous on the costæ on both sides; prim. pinnce 22 in. 1 ., 8 in. w., oblong-acuminate ; pinnl. $\frac{1}{2}-\frac{3}{4}$ in. w., oblong, rather suddenly acuminate, deeply pinnatifid (almost pinnate); lobes or ult. pinnl. approximate, oblong, obtuse, slightly crenate; veins forked ; sori near the costule, and in my solitary specimen near the base of the lobe; invol. membranaceous, breaking down into irregular lobes, but with the largest lobe generally at the inferior base of the sorus, hence somewhat hemitelioid.

Hab. Johanna Island, alt. 2,000 ft., $D r$. Kirk.-Unwilling as I am to found a new species on a mere fragment, though perfect in itself, I am, on the other hand, very unwilling to leave unnoticed a tree-Fern from so little known a country as Johanua Island.

32. C. Sechellarum, Mett.; st. tuberculato-asperous, and, as well as the main rachis, ebeneous-purple; fr. subcoriaceous, glabrous, dark-green above, paler beneath ; prim. pinnce $1 \frac{1}{2}-2$ ft. 1., 8-9 in. w. ; pinnl. 6-8 lines w., oblong, acuminate, deeply pinnatifid; lobes linear-oblong, acute, falcate, serrated; vein.s distinct, forked; sori mostly in the lower half of the lobes, and near the costule invol. membranaceous, pateriform, persistent.-Mett. in Miq. Ann. Mus. Bot. L. Bat. 1.p. 58.

Hab. Seychelles, Pervillé, n. 365, bis, and 76a (ex Herb. Mus. Par. in Hb. Nostr. since received from Swinburne Ward, Esq. (No. 2).-My own specimens are from the same s'uurce as those described by Mettenius, who observes that the species has the habit of C. spinulosa, Wall. (from Tndia), but the frond is coriaceous, the rachis muricate, not spinulose, the invol. entire, persistent, not soon breaking down into fraginents.

33. C. excelsa, Sw.; unarmed ; fr. bipinnate, coriaceo-membranaceous ; prim. pinnce 2 ft. l., 6-8 in. w. ; pinnl. $3-4$ in. l., $\frac{1}{2}$ in. w., sessile, deeply pinnatifid, subpinnate at the base; lobes oblong, obliquely subacute, serrated, scaleless; vein once forked near the base ; sori in the fork near the costa ; invol. membranaceous, very glossy, fragile, bursting irregularly into lobes, rarely sub-2-valved.- $H k$. Sp. 1.p. 24.t. 12. B.

Hab. Bourbon and Miuuritius. 
34. C. canaliculata, W. ; unarmed or indistinctly tuberculate ; fr. glabrous, bipinnate ; prim. pinno 8-18 in. l., oblong, acuminate, bipinnate, pinnatifid at the apex; pinnl. sessile, 1-1 $\frac{1}{4}$ in. l., oblong, subacute, entire or serrated ; veins copious, twice or thrice forked ; sori copious near the costa ; invol. at first globose, then breaking down into 3-4 tolerably regular lobes ; st. and the stout main rachis brown or purple-black.-Hk. Sp. 1. p. 23. t. 11. B.- $\beta$ latifolia; larger pinnl. broader.-Sp. Fil. p. 24. $t$. 13. A.

Hab. Mauritius and Bourbon; Madagascar, Newton.-It is possible that this may have tripinnate fronds, but my numerous specimens are not large enongh to indicate if it be so. The species is very distinct, but varies much in the size of the pinnules.

+十 Species of India, including Ceylon and the Malay Peninsula and Islands. Sp. $35-45$.

35. C. spinulosa, Wall.; st. and main rachis strongly aculeated, often darkpurple; fr. glabrous, ample, subflaccid ; pinnl. oblong, acuminate; lobes acute, serrulate, small bullate scales on the costules beneath ; sori copious, close to the costules; invol. globose, very thin, membranaceous, fragile, soon breaking irregularly.-Wall. Cat. n. 178. Hk. Sp. 1. p. 25.t. 12. C.

Hab. Continent of India generally. Ousima, S. Japan, C. Wright, in Hb, Nostr.

36. C. crenulata, Bl. ; unarmed ; fr. bipinnate, subcoriaceous ; pinnl. oblong, lanceolate, short-acuminate, 2-3 in. l., dark, livid green, paler beneath, minutely chaffy at the costro ; lobes approximate, oblong, subacute, subfalcate, crenulatoserrate; sori close to the costa ; invol. membranaceous, pale or chestnut-brown, fragile, soon breaking into very irregular lobes.-Hk.Sp.1.p. 25. Mett. in Miq. Ann. Mus. Bot. L. Bat. 1. p. 56. C. excelsa, Kze.

Hab. Java.-This presents no very striking specific character. Mettenius, who gives a very full description, $l . c$. , remarks, "Indusio conditione et consistentia $a b$ speciebus antecedentibus diversa ; viz. C. Javanica, Korthalsii, hymenodes, Zollingeriana, orientalis, and Sechellarum."

37. C. Javanica, Bl. ; " arboreous, unarmed ; fr. bipinnate, subcoriaceous ; pinul. lanceolate, acuminate, deeply pinnatifid, bullato-squamulose at the base of the costa ; lobes linear-subfalcate, obtuso-crenulate or entire, plane ; sori 2-5, parallel to the costa ; second. rachis paleaceo-tomentose ; prim. one asperulous, with minute bristles."-Bl. En.p. 245. Hk. Sp. 1.p.26. Mett. in Miq. Ann. Mus. Bot. L. Bat. 1. p. 56.

Hab. Java, Sumatra.-Mettenius describes the involucres as rigidly membranaceous, but breaking down into a nearly plane circular base : this is true in some of my authentic specimens; in others it breaks into unequally-lobed cups. Notwithstanding the careful descriptions of Dr. Mettenius of the Malayan species of $C y a t h e a, I$ fear we have yet much to learn with regard to their limits.

38. C. integra, J. Sm. ; unarmed ; fr. firm-membranaceous, brownish-green, oaler beneath, glabrous; prim. pinnce ample, $1 \frac{1}{2} \mathrm{ft} .1$. ; pinnl. sessile or petiolate, 3-5 in. 1., from a subtruncated base oblong-acuminate, pinnatifid $\frac{1}{2}-\frac{2}{3}$ of the way io the costa; broad-oblong, subfalcate, acute, serrated ; sori in 2 series, intermediate jetween the costule and margin; invol. pale-membranaceous, breaking down into ' persistent, lobed cup.-Hk.Sp. 1.p. 26; and in Ic. Pl.7.t. 638. Mett. in Miq., . c., 1. p. 55.- $\beta$ petiolata, Hk. Ic. Pl. 7.t.638.f.2. C. petiolata, J. Sm.

Hab. A mboyna, and Philippine Islands.

39. C. Sarawakensis, Hk.; caud. $12 \mathrm{ft} .1$. ; gen. and part. rachises smooth and lossy ; fr. ample, glabrous, subcoriaceous, bipinnate ; prim. pinnce distant, petilate, 20 in. l. or more, 6 in. w., broad-oblong, pinnatifid only at the acuminated ıpices ; pinnl. numerous, approxiniate, horizontal, sessile, 4-6 lines wide, oblongicuminate, crenato-serrate, obliquely cuneate at the base; veins approximate, i-trifurcate; sori dorsal or, rarely in the axils of the veins, globose ; invol. a thin, 
fragile membrane, at first covering the whole sorus, breaking down into irregular lobes.

Hab. Sarawak, Borneo, Thos. Lobb, n. 166. - Apparently a very distinct species, which I only possess from the above locality.

40. C. assimilis, Hk. ; caud. $20 \mathrm{ft}$. high ; st. bright chestnut, slightly muricated and fringed on one side with long, ferruginous scales; $f r$ ample, coriaceo-membranaceous, bi-tripinnate ; prim. pinnoe nearly 1 ft. l., 3-4 in. w., broad-oblong acuminate, petiolate, glabrous ; pinnl. and prim. sup. pinnoe deeply, almost to the costa, pinnatifid (lowest inf. lobe always the smallest), from 4-5 lines l., oblong, very obtuse, subfalcate, coarsely toothed ; sup. rachis and underside of the coste, subsquamose; veins simple or once or twice forked; sori dorsal or, in the axis of the fork, subglobose ; invol. at first entire, very thin and filmy, breaking down into very irregular lobes.

Hab. Hills, Sarawak, Borneo, T. Lobb, n. 168.-This has much the general aspect of Alsophila squamulata (Gymnosphera, Bl.), but is more compound, and has the true involucre of a Cyathea.

41. C. Lobbiana, Hk. ; fr. ample, subcoriaceous, pinnate, pinnatifid at the acuminated apex, everywhere snooth, glabrous, and destitute of scales; pinne petiolate ; inferior ones (the largest of our specimens) 9-10 in. 1., 2-2 $\frac{1}{2}$ in. w., oblong, deeply acuminate nearly to the rachis, pinnatifid, or pinnate only at the very base; lowest inferior pinnl. always the smallest; lobes or pinnl. horizontal, spreading, obtuse, obscurely serrated ; super. pinnoe gradually smaller, obtuse, sessile; veins distinct, approximate, simple or forked ; sori globose, dorsal, or rarely in the axil of the veins, in 2 rows, one on each side the costule; invol. a very thin, delicate membrane, at first investing the whole sorus, at length deliquescent, as it were, at the summit, and breaking down irregularly.

Hab. Sarawak, Borneo, T. Lobb.-My largest pinnæ have a very close affinity with those of Alsophila alternans; but here is a most distinct though almost filmy involucre.

42. C. hymenodes, Mett.; glabrous; prim. rachis dark purple-brown, subasperous ; pinnl. 3 in. l., oblong, acuminate, sessile, subcoriaceous, dark lurid green on both sides; costoe beneath minutely and sparsely scaly; lobes very compact, so as to close the sinus, oblong-falcate, very obtuse, obscurely serrate; sori at the base of the lobes, few, close to the costule; "invol. membranaceous, fragile, soon breaking down and falling away."-Mett. in Miq. Ann. Mus. Bot. L. Bat. p. 57 .

Hab. Sumatra, Korthals. - My authentic specimen has the sori far advanced and imperfect. May it not rather be an Alsophila?

43. C. orientalis, Moore (name only); rachises scarcely punctato-muricate; fi: ample, coriaceous, black-green, paler beneath, glabrous, bi-tripinnate; prim. pinnce 2 ft. l.; pinnl. 3-4 in. l., 6-7 lines w., sessile, oblong-lanceolate, suddenly caudato acuminate (acumen serrated), deeply near to the costa pinnatifid; costoe beneat ferrugineo-furfuraceous; lobes linear-oblong, subfalcate, the margin serrated an recurved; sori copious, close to the costule which they quite conceal ; invol. dark brown, firm-membranaceous, persistent, cupshaped, subglobose, rich chestnut brown, the mouth a little contracted, perfectly orbicular and even at the edge.Mett. in Miq. Ann. Bot. L. Bat. 1. p. 38. C. arborea $\beta$ pallida, Hassk.

Hab. Java, Zippel, Zollinger, De Virese, n. 98, 118, 130.-It is no wonder that Hasskar was disposed to consider this a var. of $C$. arborea, of the W. Indies : the involucre form an equally perfect cup, which seems to persist in that state without ever becomin fragmentary.

44. C. arachnoidea, Hk. ; all the rachises dark-coloured and opaque, muricate with short, black, sharp spines, and clothed with rusty tomentum ; fr. tripinnatc firm-coriaceous, glabrous above, cobwebby beneath; second. pinnce $4-4 \frac{1}{2}$ in. 1 . $\frac{1}{2}$ in. w., oblong, pinnate, pinnatifid only near the narrow acuminated apex; pinn 
scarcely 3 lines l., from a broad base linear, acute, subfalcate ; veins sunk, inconspicuous; sori near the middle of the pinnl., occupying the whole space between the costule and the recurved margin; invol. thin-membranaceous, white and delicate, breaking into variously lobed and laciniated seginents.

Hab. Island of Ternate, De Vriese \& Teijsmann, n. 1141.-Judying from the solitary but very perfect specimen in my possession, this is a very distinct species.

45. C. Korthalsii, Mett. ; fr. bipinnate, subcoriaceo-membranaceous, dull green ; prim. pinnce $1 \mathrm{ft}$. l. ; pinnl. sessile, $2-2 \frac{1}{2}$ in. $1 ., \frac{1}{2}$ in. w., oblong, acuminate, sparingly bullato-paleaceous beneath; lobes narrow-oblong, obtuse, scarcely serrate, subfalcate; sori more or less copious, chiefly in the lower part of the lobe close to the costule; invol. firm-membranaceous, breaking firstly at the summit, at lengtl falling away in fragments.-Mett. in Miq. Ann. Mus. Bot. L. Bat. 1. p. 57.

Hab. Sumatra, Korthals; Java (ex Herb. Miquel.). - My named specimens from Sumatra have old fructifications: those from Java (without name) have the involucres exactly as described by Mettenius. Perhaps too near his Hemitelia (not Cyathea) crenulata.

+t Species of Australia, N. Zealand, and the Pacific Islands; these latter, of the N. Pacific, may be expected occasionally to extend to the Malay Archipelago and Peninsula. Sp. 46-55.

46. C. Lindsayana, Hk. ; main and second. rachises quite unarmed; fr. membranaceous, glabrous, except on the costce and costules which are subvillous and have many scattered, small, bullate scales ; prim. pinnce $2 \mathrm{ft}$. l., pinnate nearly to the apex ; pinnl. 3-4 in. l., oblong, acuminated, deeply pinnatifid ; lobes oblong, subfalcate, serrated; sori on the lower half of the lobes on the forking of the veins ; invol. globose, firm-membranaceous, brown, opening with a circular, rather small and jagged mouth.

Hab. N. E. Australia, Mr. Lindsay, Walt. Hill.-The first true Cyathea found in Australia. My specimens are very perfect as far as the primary pinnæ and fructificatious are concerned. It might pass for a membranaceous form of C. Juvanica; but the cupfurmed involucre is much more permanent.

47. C. medullaris, Sw. ; caud. lofty ; st. glaucous-black, and the rachises muricated with short, spinous tubercles; fr. ample, bi-tripinnate, coriaceous ; second. pinnce 5-6 in. l., $\frac{3}{4}-1$ in. br., deeply pinnatifid or again pinnate; pinnl. or segm. oblong or linear-oblong, obtuse, coarsely serrated in the sterile specimens, lobatopinnatifid in the fertile ones, with the margins revolute; sori one to each lobule of the pinnl. or lobe, intermediate between the subpaleaceous costule and the Inargin ; invol. firm, membranaceous, brown, soon breaking open irregularly at the apex with an irregular, often 2-lobed, margin (voung $f r$. densely-paleaceous, with soft, deciduous hairs).-Hk. Sp. 1. p. 27, and Gard. Ferns, $t .25$.

Hab. N. Zealand.-A Fern similar to this, but differing chiefly in the ultimate pinnules or lobes bearing sori, is found in Norfolk and other of the Pacific Islands, which may possibly prove distinct : this is the $C$. Mertensiana, Bong., and perhaps the C. extensa, Sw. \& Schk. Fil. p. 127.t. 132. In our dried native specimens of $C$. medullaris, the stipes and main rachises are often pale-brown.-See C. affinis, our $n .54$.

48. C. Cunninghami, Hk. f. ; caud. 12-15 ft. l. ; st. and main rachises stramineous and asperous; fr. subcoriaceous, but flaceid ("soft, withering on the trunk"), tripinnate; prim. pinno $1 \frac{1}{2}-2 \mathrm{ft}$. 1 .; second. ones $3-5$ in. $1 ., \frac{3}{4}-1$ in. w., oblong, acuminate, pinnatifid only at the apex ; lobes or ultimate pinnl. 4-6 in. l., linear, obtusf, pinnatifid some way down with great regularity ; lobules entire; veins forked; sori one to each lobe, rather nearer the costule than the margin; invol. at first entire, globose, very thin, afterwards breaking down very irregularly, often leaving a large patent lobe or scale on the underside, as in Hemitelia; costce and costules villous and sparingly narrow-paleaceous.-Hk. fil. in Ic. Pl. t. 985.

Hab. N. Zealand.-Perhaps too near C. medullaris. I possess it among Forster's plants from N. Zealand, as well as from Colenso and Allan Cunningham. It is well represented in the Icones plant. $l$. $c$. 
49. C. dealbata, Sw.; unarmed or slightly asperous ; rachises and costoe clothed with pale, ferruginous, deciduous tomentum ; $f r$. subcoriaceous, bi-tripinnate : pinnoe oblong, acuminate, pure white beneath from the presence of a deciduons powder, deeply pinnatifid or pinnate at the base; lobes oblong, acute, falcate, serrated ; sori copious, sometimes confined to the lower half of the lobes; invol. rather small, globose, nembranaceous, fragile, soon breaking down in an irregular manner, the hase often remaining an orbicular membrane-Hk.Sp. 1. p. 27. Rich. Fl. N. Teal.p. 77. t. 10. - $\beta$ subglaucous, but not white, beneath.

Hab. N. Zealand, where it seems generally to retain its pure white beneath. Penang, Sir W. Norris, sterile. Lord Howe's Island (along with var. $\beta$ ), Milne \& Mc Gilivray. -This latter island may be reckoned as in the $\mathrm{N}$. Zealand groupe.

50. C. Aneitense, Hk. ; unarmed ; main and second. rachises ebeneous, purpleblack, quite smooth ; fr. coriaceo-membranaceous ; prim. pinnoe 1-1 $\frac{1}{2}$ in. l., 4-5 in. w., sessile, or nearly so, oblong, shortly-acuminate, pinnatifid nearly to the rachis ; lobes rather distant, oblong, acute, subserrated ; veins forked ; sori copious intermediate between the costa and the margin ; invol. thin-membranaceous, persistent, soon breaking down, and generally opening at the back so as to form a large, lax, almost transparent, 2-lohed and ragged cup, often again irregularly lacerated ; ult. rachises and costoe villous, with narrow scales.

Hab. Isle of Aneiteum, N. Hebrides, Milne, McGilivray. Ternate, Herb. Hort. Calc. - This is quite new, and not known, apparently, to Brackenridge.

51. C. nigricans, Mett.; " $f r$. coriaceous, opaque, green above, paler beneath, bipinnatisecto-pinnatipartite ; rachis unarmed, purplish, glossy ; prim. pinnce suhovato-lanceolate; second. ones subsessile, elongato-oblong, acuminate, caudate at the apex and sharply serrated, subglabrous above, beneath squamulose at the costæ and costules, with imbricated, white, bullate, ciliated scales; lobes subdistinct, contiguous by the dilated base, elongato-oblong, subfalcate, attenuated at the apex, obtuse or nearly so, serrated; veins forked, rarely bifurcate; sori $3-6$ on each side the costule, the lowest ones distant from the costule, the rest near to it ; recept. hemispherical ; paraphyses few, filiform, curved, generally torulose, formed of cells tumid in the middle, the terminal cell subglobose, or more or less dilated."-Mett. in Miq. Ann. Mus. Bot. L. Bat. 1.p. 36.

Hab. " Ualan, of the Caroline Islands, Mertens."-Unknown to me.

52. C. leucolepis, Mett. ; unarmed, and hairy only on the costoe above ; fr. ample, firm-membranaceous, bipinnate, lurid-green, paler beneath ; prim. pinnce $1 \frac{1}{2}$ in. 1 . ; pinnl. sessile or subpetiolate, paleaceous, with whitish bullate scales on the costæ and costules beneath, 3-4 in. l., from a broad base $1 \mathrm{in.}$ w. (narrowest on the inferior side), oblong, suddenly acuminate, pinnatifid $\frac{3}{4}$ of the way to the costule ; lobes oblong, obtuse, subfalcate, subentire ; veins all forked at the middle, distant ; sori copious, rather distant, and forming a line on each side between the costule and the margin ; invol. rather firm-membranaceous, of the same luridgreen as the frond, long - persistent, then breaking away at the summit, and eventually forming irregular lobes.-Mett. in Miq. Ann. Mus. Bot. L. Bat. 1, l. c., p. 56. C. Brackenridgii, Mett., l c.

Hab. Samoan Islands, Powell. Fiji, Harvey, Powell, n. 20 ; Aneiteum and Saloman's groupe (Mettenius), Brackenridge?, Milne.-Caudex $6 \mathrm{ft}$. high, 2 in. in diam. (Powell). -This appears to be a good species, or it may be the $C$. affinis, Brack., if so, scarcely of Swartz.

53. C. Milnei, Hk. ; caud. 30 ft. l., 9 in. diam. ; fr. subcoriaceous, dark hlackish-green ahove, paler beneath; rachises palish-brown, asperous, woolly, as well as the under side of the pinnce, near their base, with copious, deciduous tomentum ; pinnoe $1 \frac{1}{2}-2 \mathrm{ft}$. l., 6-10 in. $\mathrm{w}$.; pinnl. elongato-oblong, deeply to the costules pinnatifid ; lobes oblong, falcate, subobtuse, crenato-serrate, the margins a little recurved; sor $i$ copious, moderately large, mostly situated at the base of the lobes, near the costule; invol. membranaceous, rather firm, long-persistent 
in a cup-like form, with very irregular margins, occupying most of the breadth of the lobes.

Hab. Sunday or Raoul Island (of the N. Zealand region), Milne \& McGilivray). I give this as a new species with considerable hesitation. It has the deciduous wool of C. dealbata (to which Mr. Moore is disposed to refer it), but the aspect rather of $C$. affinis, of which, however, it wants the decided prickles.

54. C. affinis, Sw.; st. and main rachis brown, strongly tuberculato-muricate ; fr. amply firm-coriaceous, probably subcarnose in a recent state; prim. pinnoe $1 \frac{1}{2}-2$ ft. l., 6-10 in. w. ; pinnl. sessile, $\frac{3}{4}-1 \frac{1}{4}$ in. br., oblong-lanceolate, deeply to the very costa pinnatifid, often towards the base again pinnate; segm. $\frac{1}{2}-\frac{3}{4}$ in 1 ., oblong, falcate, obtuse, entire ; the ultimate pinnl., and generally the most fertile, subpinnatifido-serrate; veins once or twice forked; sori copious, rather nearer the costule than the margin, compact to the apex; invol. membranaceous, fragile, hreaking down from the apex in a very irregular manner; costules beneath with few small deciduous scales.-Sw. Syn. Fil. p. 140 and 358 ; Brack. Fil. p 283.? Polypodium, Forst. C. extensa, Sio. Schk. Fil.t. 132. a-c. C. propinqua, Mett.?

Hab. "Pacific Isles," Forster. Fiji, Brackenridge, Milne, Seemann. Lord Howe's Island, Milne. Pitcairn's Island, Mathews, Cuming (involucres rather more membranaceous). Cape Otway Roughs, Victoria, Wilkinson, (Mueller).-I possess a specimen of this plant from Forster's Herbarium, but unnamed, and I believe it to be the true $C$. affinis Sw., possibly the same as $C$. medullaris of N. Zealand.

55. C. Vieillardii, Mett. ; " unarmed ; fr. subcoriaceous, dark-green above, densely hairy, rusty on the costce and rachises, bi-subtripinnate; prim. pinnoe $1 \mathrm{ft} .1$.; sccond. ones sessile, ovatu-oblong or lanceolate, deeply pinnatipartite, subpinnate at the base, acuminate and obtusely serrate at the apex; lobes oblong, obtuse or acute, obtusely serrate; sor $i$ at the forking of the veins, intermediate between the costule and the margin ; invol. membranaceous, gradually breaking down and disappearing (fatescens)."-Mett. Fil. N. Caled. Ann. Sc. Nat. Bot. 1861, p. 82.

Hab. Balade, N. Caledonia, Vieillard. "Near D. Cunninghami (Hk. f.), which differs in being muricated, the lobes sharply serrated, and in the sori being costular."-I have seen only a small specimen of this from M. Lenormand's collection.

\section{Gen. 5. Hemitelia, $B r$.}

Sori globose, dorsal upon a vein or veinlet. Recept. elevated. Invol. a scale situated on the underside of the sorus, varying in size, and shape, and texture, often indistinct, and often very deciduous.-Mostly tropical and arborescent, with the habit of Cyathea ; a connecting link, as it were, between the latter genus and Alsophila, consequently often difficult to recognize. Fronds ample, pinnate or decompound. Veins pinnated, simple or branched, free, or, the costal ones especially, more or less anastamosing. TAB. I. f. 5.

\section{$\S$ Euhemitelia. Costal veins anastomosing. TA B. I. f. 5. b. Sp. 1-5.}

\section{* Pinnate. Sp. 1-5.}

1. H. (Euhemit.) Karsteniana, Kl. ; st. muricated and scaly at the base ; scales white, dark-brown in the centre; fr. ample, coriaceo-membranaceous, pinnated; pinnoe sessile, a span to $1 \mathrm{ft}$. $1 ., 1 \frac{1}{2}-2 \frac{1}{2}$ in. w., from a truncated base, elliptical, short-acuminate, quite entire, or more or less lobed at the very margin; sori (when perfect) in two oblique lines, meeting towards the rachis, and forming a series of the letter $\mathrm{V}$ between each pair of costules.-Kl. Bot. Zeit. 12. p. 439; Mett. F. H. Lips. p. 111.t. 29. f. 1-4.

Hab. Caracas, Karsten, Fendler, n. 386 Funck, n. 769.

2. H. (Euhemit.) subincisa, Kze.; st. rough, but scarcely muricate ; $f r$ anıle, pinnate ; pinnce remote, subpetiolate, firm-membranaceous, from a cuneatotruncated base, oblong or elliptico-lanceolate, finely acuminate, 10-12 in. 1. by 1-2 in. br., the margin inciso-lobate; lobes $2-4$ lines l., with generally an acute 
apex pointing upwards; sori minute, in 2 irregular lines between each pair of costules.-Kze. in B. Zeit. 1844, p. 296 ; Mett. Fil. Lechl. p. 23.

Hab. Tropical America (Pacific side), Peru, Poeppig, n. 244 (pinnæ exactly lanceolate); Andes of Ecuador, Spruce, n. 5365 (pinnæ 2 in. br., elliptical, lanceolate, "caudex none"); Guatemala, Forest of Vera Paz, Salvin (pinnæ narrow, oblong, 1 in. w.).-This appears to be a very distinct species. My specimen under this name from Lechler (Peru, n. 2172), quite corresponds with my other specimens from Spruce and Salvin.

3. H. (Euhemit.) grandifolia, Spr. ; arborescent ; st. aculeated ; fr. ample, sub-

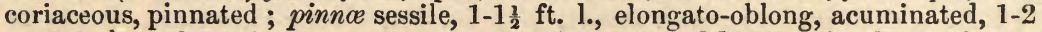
in. br., $\frac{1}{2}$ or $\frac{3}{4}$ of the way to the costa pinnatifid; lobes broad-oblong, obtuse, serrated at the apex, slightly falcate; sori on the free veins in a continued line, intermediate between the costule and the margin, often nearer the latter.- $H k$. Sp. p. 30. t. 14. A. Cnemidaria Kohautiana, $P r_{\text {. }}$ C. speciosa, $\operatorname{Pr}-\beta$ smaller pinnæ, sori submarginal. H. obtusa, Klfs.-Hk. Sp. 1.p. 29. t. 14. B.

Hab. W. Indies and N. Granada, Guiana ; abundant. Ecuador, Spmuce, n. 536.Best distinguished from $H$. horrida by the smaller size, obtuse lobes, and non-marginal sori. The anastomosing of the veins is very variable, present on some pinnæ, absent on others.

4. H. (Euhemit.) horrida, Br.; arborescent ; st. strongly aculeated, deciduously scaly, and often woolly near the base; $f r$. very large, $7-10 \mathrm{ft}$. 1., pinnate ; pinnoe sessile, 1-2 ft. l., broad oblong-lanceolate, deeply pinnatifid, lowest segm. sometimes free ; lobes 3 in. 1., oblong-lanceolate, acuminate, entire or lubatopinnatifid; veins pinnated, subfascicled; sori on the free veinlets, forming it continued line just within the margin.-Hk. Sp. 1. p. 30. t. 15, and Fil. Ex.t. 69 . H. horrida, et Hookeri, Auct. $-\beta$ Imrayana; veins less branched, arastomosing at the costa. H. Imrayana, Hk. Sp. 1.p. 33, and Ic. Pl.t. 669.

Hab. W. Indies, New Grenada. - $\boldsymbol{\beta}$ Dominica, Peru, Lechler, Spruce; Ecuador, Jameson.- I am satisfied that my $H$. Imrayana is only a small form of $H$. loorrida.

\section{** Bi-tripinnate. Sp. 5.}

5. H. (Euhemit.) petiolata, Hk. ; young fr. and base of the aculeated st. clothed with large, glossy, castaneous scales, pale at the edge ; fr. ample, bi-tripinnate, pinnatifid at the apex ; prim. pinnoe and pinnl. petiolated, ult. ones from a truncated and usually broad base, 2-6 in. 1., oblong-lanceolate, more or less acuminate, entire, or variously and more or less deeply pinnatifid, with rounded or broad-oblong lobes, entire or slightly lobulate; pinnl. with free venation, the deeply pinnatifid ones with the costal veins angularly anastomosing; sori forming a beautifully continuous border at the very margin, and following all the sinuosities of the lobes.-Hook. Sp. 1. p. 31.t. 16.

Hab. Istbmus of Panama, Sinclair, Fendler, n. 471 and 421, Seemann. Isle of Gorgone, Barclay.-This, in venation, is intermediate between the present and the following section (Amphicosmia).

$\S \S$ Amphicosmia. Veins all free. TAв. I. f. 5. a. Sp. 6-19.

$$
\text { * Pinnate. Sp. 6-9. }
$$

6. H. (Amphic.) speciosa, Hk.; caud. 20-24 ft. high ; young fr. clothed with glossy, castaneous scales which have a pale, very narrow fringe; st. tuberculato-submuricate ; $f r$. ample, pinnate, very long, pinnatifid at the extremity ; pinnoe firm, membranaceous, satiny, 8-12 in. $1 ., 1-1 \frac{1}{2}$ in. w., elongato-ensiform, acuminate, entire or merely sinuato-sublobate; veins all pinnated; veinlets free ; sori arranged in a sinuous continued chain or line just within the margin. - Hk. Sp. 1. p. 28. t. 13, and F. Ex.t. 66. Cyathea, H. J. K. (not Cnemidaria speciosa $\boldsymbol{P r}$, which is $H$. grandifolia, and, as I believe, Grisebach's $H$. speciosa). H. integrifol., $K l . K \approx e$. and others.

Hab. New Grenada, Schlim, n. 842 ; Fendler, n. 46.-German botanists do not scem 
agreed as to what is the true C. specios $\alpha$ of Humboldt. My specimens here characterized sufficiently accord with the description in Willd. \& H. B. K.

7. H. (Amphic.) Lindeni, Hk. ; fr. pinnate ; pinnoe distant, thin-membranaceous, opaque, green above, subpetiolate, 6-12 in. 1., 1-1 $\frac{1}{4}$ in. br., from a cuneatotruncate base, elongato-ensiform, finely acuminated, the margin pinnatifid or incised, with rather acute, regular short lobes about 2 lines 1., the apex directed upwards; veins all pinnate, the branches free; sori in 2-3 irregular lines or series at the margin.-Hk. Ic. Pl.t. 706.

Hab. Caraccas, Linden, n. 663.-Allied to H. speciosa, but much more freely and acutely lobed on the margins of the pinnæ, and with a very different arrangement of the sori.

8. H. (Amphic.) bella, Reichenb. f.; "st. aculeated at the base ;" fr. ample, subcoriaceous, glabrous, pinnated ; pinno distant, petiolate, $1-1 \frac{1}{2} \mathrm{ft} .1$., $1 \frac{1}{2}$ in. w., from a subcuneate base, elongato-oblong, obtusely acuminated, entire at the apex, the rest pinnatifid $\frac{1}{2}$ way to the costa, with very blunt, broad, ovate, spreading, subserrated lobes; veins copiously pinnated, all free; sori quite marginal, and forming a continuous single line, following the sinuosities of the lobes to the apex of the pinnæ.-Reichenbach, fil. in Mett. F. H. Lips. p. 110.

Hab. Caraccas (Mett.).-Doubtless allied to our $H$. speciosa and Lindeni, but very different in the coriaceous fronds and the deeply-lobed pinnatifid margins of the pinnæ. I only possess a garden specimen from Mettenius.

9. H. (Amphic.) apiculata, Hk. ; fr. glahrous, pinnate, pale-green, subcoriaceomembranaceous ; pinnce sessile, 10-12 in. 1., 1-1 $\frac{1}{2}$ in. br., elongato-oblong, finely acuminate, deeply (beyond the middle) pinnatifid ; lobes $\frac{3}{4}$ in. 1., oblong, subfalcate, aristato-acuminate, subserrate; sori small, forming a single line or series much nearer the margin than the costule; veins all pinnated and free.

Hab. Mexico, Jurgensen, n. 273.-My specimen of 5 pairs of pinnæ, partially fertile, has very much the appearance of $H$. (Euhemitelia) grandifolia; but the lobes are submucronate and pungent at the apex, and the veins are everywhere quite free.

\section{** Bi-tripinnate. Sp. 10-19.}

10. H. (Amphic.) Copensis, Br. ; caud. 12-14 ft. high ; st. unarmed, scaly at the base, and often bearing multifid anomalous pinnoe (which have been mistaken for some Trichomanes ); fr. ample, submembranaceous, bi-tripinnate ; prim.pinnoe petiolate, ovato-oblong; pinnl. subsessile, 2-3 in. 1., 6-8 lines w., oblong-acuminate, deeply pinnatifid, or again pinnate; lobes linear-oblong, acute, strongly serrated; veins simple, 1 to each serrature; sori frequently solitary at the base of the lobe or pinnl., rarely $3-4$, with a lax, deciduous scale at the base; costce and costules beneath with scattered, deciduous, bullate scales; recept. large, prominent.-Hk. Sp. 1. p. 36. Amphicosmia riparia, Gardn. in L. J. Bot. 1. t. 12 (excellent).

Hab. South Africa; Brazil; Java, Bl. in Hb. nostr.

\section{(Species of S. America. Sp. 11-15.)}

11. H. (Amphic.) platylepis, Hk. ; st. stout, unarmed, clothed at the base with very large, dark-brown, glossy scales, having a pale fringe at the margin; fr. ample, subcoriaceous, villous on both sides, tripinnate ; prim. pinnoe 12-14 in. 1.; second. ones $2-3$ in. l., $\frac{1}{2}$ in. w., again pinnated except at the very apex, oblongacuminate ; rachis very hairy, slightly winged; ult. pinnl. 3-4 lines long, oblong, the margins recurved, inciso-serrate; veins forked; sori copious, 1 to each lobe or serrature; invol. large, hemispherical, quite inferior. - Hk. 2nd Cent. $F$. t. 100.

Hab. Rio Nigro, Brazil, Spruce, n. 3127.

12. A. (Amphic.) calolepis, Hk. ; st. bright stramineous, tuberculated, the base clothed with copious, white, imbricated, satiny scales, 1 in. and more l., beluw 
subulate, with a brown line down the centre, nuch broader upwards ; $f r$. ample, membranaceous, bright-green, bipinnate, glabrous but mealy, with small, white, bullate scales on the costr and costules beneath ; prim. pinnoe $1 \frac{1}{2} \mathrm{ft}$. l., broad ovato-oblong; pinnl. approximate, $4-5$ in. $1 ., 1 \mathrm{in}$. w., deeply nearly to the costule pinnatifid ; lobes copious (lowest ones free), linear-oblong, obtuse, coarsely serrated ; veins all forked ; sori (far advanced) small, at the forking of the veins, mostly towards the costa, subtended by a broken invol., most conspicuous at the inferior side.--"Hemitelia," Eat.

Hab. Cuba, C. Wright, n. 950.-Allied to A. platylepis, but very distinct.

13. H. (Amphic.) Wilsoni, Hk.; caud. 12-14 feet high, rather slender; st. $2 \frac{1}{2} \mathrm{ft}$. l. ; rachises everywhere glabrous and smooth, stramineous-brown ; $f r$. $12 \mathrm{ft}$. l., $4 \frac{1}{2} \mathrm{ft}$. w., membranaceous, bright-green, glabrous, bipinnate ; prim. pinnce $1 \frac{1}{2} \mathrm{ft} .1 ., 4-5$ in. br., oblong, acuminate, deeply pinnatifid at the apex; pinnl. oblong-lanceolate, horizontal, acuminate, sessile and adnate, pinnatifid only in the middle (not deeply), regularly alternate; superior ones slightly decurrent; lobes of the pinnæ pinnatifid at the apex, quite entire, obtuse; veins fasciculatopinnate, free; sori small, forming a line equidistant between the costa and the margin ; invol. membranaceous, pale-brown, permanent, irregularly yet often 2-lobed, and these lobes often spreading. - "Hemitelia Sp." Wils. in Herb. nostr.

Hab. Mansfield, near Bath, Jamaica, alt. 1,000 ft., Wilson, n. 731.-A very peculiar and distinct species.

14. H. (Amphic.) Moricandiana, Kze. mst.; caud. "7-8 ft. high ;" rachises every where unarmed, dark-brown ; fr. ample, glabrous, subcoriaceous, bipinnate ; prim. pinnoe 12-14 in. and more l., 6 in. br., petiolate, pinnate, pinnatifid above ; pinnl. distant, sessile or subpetiolate, $3-4$ in. 1 ., from a truncated or obliquelycuneate base, oblong, acuminate, pinnatifid about half-way to the costa with triangular-ovate, obtuse, or acute, serrated lobes; super. pinnl. decurrent upon the rachis ; veins free ; sori copious, forming a single series, generally on the forking of a vein half-way between the margin and the costule; invol. a small scale at the base of the sorus.-Cyathea Moricandi, "Kze. Fil. Fl. Braz. ined."

Hab. Bahia, Bianchet, n. 3227 ; Brit. Guiana, Appun, n. 193.-This does not appear to be hitherto anywhere described ; yet, it is perhaps too near some of the many forms of H. Guianensis.

15. H. (Amphic.) Guianensis, Hk. ; st. muricate or aculeate ; fr. coriaceomembranaceous, bi-tripinnate, glabrous or (beneath especially) subhispido-hirsute; main rachises deciduously subulato-paleaceous; super. rachises distinctly winged; pinnl. sessile or petiolate, 3-5 in. or more l., $\frac{1}{2}-\frac{3}{4}$ in. br., oblong-lanceolate, ending in an entire more or less elongated acumen ; lobes ovate, obtuse, entire; veins forked ; sori few on each lobe in the forking of the veins, mostly nearer the costa than the margin ; invol. variable, rather lax, often 2-3-lobed (rarely ciliated), the base often extending round the sorus.-Hk.Sp. 1. p. 31, and Ic. Pl. 648. H. Hostmanni, Hk. Sp. p. 31, and Ic. Pl.t. 646 . H. Servitensis, Karst. Fl. Columb. t. 95.- $\beta$ Parkeri; sori more copious, extending higher up the lobes. H. Parkeri, Hk. Sp. 1. p. 32, and Ic. Pl.t. 643. Alsophila oblonga?, Kl. in Hb. Hook. (Schomb. n. 1125).

Hab. Guiana ; Para, Brazil, Spruce, n. 612 and 72 ?, and Tarapota, E. Peru, n. 4249, $4331,4323,4656,4712,4715$, and 4717 , and Ecuador, n. 5741 ?. - It is with reluctance, and only after an examination of more perfect specimens, than I before possessed, that I come to the conclusion that the above supposed species are slight varieties of one and the same. Spruce's very fine and copious specimens have very strong spines on the stipes, and very large, glossy, long-lanceolate scales, pale-coloured, but with a dark line down the centre. The species appears to abound in Guiana, Caraccas, and the whole valley of the Amazon, to Eastern Peru and Ecuador.

(Specics of Ceylon, Pacific, India. Sp. 16-19.)

16. H. (Amphic.) Walkcre, Hk.; st. unarmed or slightly muricated ; fr. ample, 
bi-tripinnate, thick, firm, very coriaceous ; prim. pinno $1 \frac{1}{2} \mathrm{ft}$. 1., second. pinnoe rather remote, $3-4$ in. l., deeply nearly to the costa pinnatifid, or again pinnate, oblong, narrow-acuminate; pinnl. or lobes oblong, very obtuse, entire or slightly crenate, often deciduously scaly on the costule beneatli; veins copious, sunk, forked once or twice ; sori occupying the lowest fork close to the costules; invol. large, hemispherical, inferior, at first covering the lower half of the sorus, then more or less reflexed, and often 2-lobed.-Cynthea, $H k$. Sp, 1. p. 24, and $I c . P l$. t. 647 ; Thw. En. Pl. Ceyl.p. 396. Amphicosmia, Moore. Alsophila comosa $\beta$, HK. Sp. 1. p. 53. not $\alpha .-\beta$ tripinnata; ult. pinnl. larger, lobulato-serrate.

Hab. Ceylon, to an alt. of 6,000 ft.-Our excellent friend Thwaites remarks that its indusium "is very variable, sometimes hardly to be detected ;" and, indeed, while this is in press, he sends me specimens, some of which night be referred to Hemitelia, some to Alsophila, while others have the involucres nearly of Cyathea.

17. H. (Amplic.) denticulata, Hk.; fr. ample, submembranaceous, bi-tripinnate, glabrous ; prim. pinnoe 14-15 in. l., 4-6 in. br., petiolate, dilated, and smaller at the base of insertion on the main rachis, pinnate, pinnatifid at the acuminated apex ; pinnl. $2-3$ in. l., $\frac{1}{2}$ in. br., oblong, acuminate, pinnatifid about $\frac{1}{2}$ way to the costa, subsessile ; lobes broad ovato-oblong, denticulato-serrate ; veins pinnate, simple or forked, rather distant, about 4 on each side; sori sinall, on the back of the simple veins, or in the axil of the forked veins, nearer the margin than the costule.

Hab. Elizabeth Island, S. Pacific, Cuming., n. 1360.-Readily distinguished in this group by the membranaceous but firm texture of the fronds, the distant veins, and the denticulato-serrated margins of the lobes.

18. H. (Amphic.) Smithii, Hk. ; " arboreous, unarmed ; st. below densely crinite, with rigid, elongated, serrulated scales; rachis and costa below sparsely pilose, with lax, rufous, deciduous scales above, strigoso-villous ; $f r$. bipinnate; prim. pinnce linear-elongate, acute, subfalcate, serrated or crenate, very glabrous, the costules beneath paleaceous or pilose or glabrous; sori on the forking of the veins ; invol. hemispherical."-Cyathea, Hk.f. Fl. N. Zeal. 2.p. 8. t. 72.

Hab. N. Zealand, Ralfs.

19. H. (Amplic.) Junghuniana, Mett.; "unarmed ; fr. chartaceous or membranaceous, above deep-green, subglossy, paler beneath, at the costæ sparingly clothed with minute, flattish, adpressed, broadly-ovate, pale, ferruginous, deciduous scales; fr. bipinnatisecto-pinnatipartite ; prim. segm. 2 ft. l., 6 in. w., subsessile, elongatoacuminate ; second. ones $4 \frac{1}{2}$ in. $1 ., 8-10$ lines w., elongato-oblong, crenulato-incised or serrulate at the apex ; veins manifest, lax, 6-9 on each side, forked at the base ; sori in the fork close to the costule, sometimes apart ; invol. squamiform, minute ; recept. depresso-globose, here and there hifid ; paraphyses minute, partly piliform, partly subulate."-Mett. in Miq. Ann. Mus. Bot.L. Bat. 1.p. 55. Alsophila, Kze. A. lunulata, $B l$., and Hemitelia Javanica, $\operatorname{Pr}$. ( $f$. Mett. $)$. Amphicosmia, Moore.

Hab. Java, Blume, in Hb.nostr. ; Sumatra ; Antinanarivo, Madagascar?, Meller.My specimens from Madagascar, if belonging to this species, are less coriaceous, and of a paler, but livid, green colour, than those from the Malay Islands. Specimens named iu my Herbarium, from Blume and Miquel, are no doubt the true plant; but I possess other specimens which I am disposed to consider the same species, under different names.

\section{Gen. 6. Alsophila, $B r$.}

Sori globose, dorsal, on a vein or in the forking of a vein. Recept. mostly elevated, frequently villous. Invol. O.-Arborescent, chiefly tropical, Ferns, with the general habit of Cyathea and Hemitelia, but destitute of invol. Veins simple or forked, free. Tि. I. f. 6.

* (Species of S. America. Sp. 1-37.)

Pinnate or bipinnate, pinnl. entire or pinnatifid. Sp. 1-6. 
1. A. blechnoides, Hk. ; fr. pinnate ; pinnce coriaceo-membranaceous, glossy, 6-12 in. l., lanceolate, suddenly acuminate and serrate at the apex; sori (mixed with copious long hairs) scattered in very irregular lines near the costa, sometimes extending towards the margin.-Hk.Sp.1.p. 35. Metaxya, Pr. Polypod, Sw. P. Parkeri, Hk. \& Gr. Ic. F. t. 232.

Hab. W. Ind. and Trop. America-Remarkable for the large nearly entire pinnæ.

2. A. phegopteroides, Hk. ; caud. $3 \mathrm{ft}$. 1. ; st. unarmed, short, 3-4 in. l., clothed with large lanceolate, glossy, black scales having a pale margin; $f r .1 \frac{1}{2}-2 \mathrm{ft}$. 1 , subcoriaceous, black-green above, paler beneath, villous on both sides, especially beneath, with long spreading hairs, broad-lanceolate, acuminate, pinnatifid at the apex, lowest ones reflexed ; pinnce sessile, 3-4 in. l., 8-9 lines w., oblong, shortly and bluntly acuminated, deeply nearly to the costa pinnatifid; lobes oblong, very obtuse, entire, the margin a little recurved; veins forked; sori at the fork, in a line between the costule and the margin ; rachis and costce beneatl sliaggy with whitish hairs, mixed with brownish, narrow scales.

Hab. Tarapota, E. Peru, Spruce, n. 4020.-A very peculiar species from the shortness of the stipes, the simply pinnato-pinnatifid frond (resembling some Lastrea or Phegopteris), and the hairy clothing, brown and shaggy beneath.

3. A. paleolata, Mart.; " fr. bipinnato-partite, on both sides, but especially beneath, pubescent; veins and veinlets beneath densely clothed with ovate, white scales; st. and rachis aculeate; common and partial rachi, and veins strigillose above; pinnoe linear-oblong, shortly acuminated ; pinnl. linear, shortly acuminated, pinnatifid, the apex serrated ; segm. linear-oblong, subfalcate, toothed in the upper margin; the ult. ones confluent, so as to form serrated pinnæ; sori 4-8, in the lower part of the segm., arrangerl in 2 rows."-Mart. Crypt. Bras. t. 43. Hk.Sp.1.p.44. Als. Sellowiana, Kl. Cyathea, Pr. Hk.Sp. 1.p.23. A. ferox, $\gamma$ H H.Sp. 1.p. 41 .

Hab. Brazil ; N. Granada ; Peru, Lechler, n. 2190 ; Spruce, n. 4322.-Very faithfully represented by Martius, and equally faithfully described; but in my specirrens the scales (paleolæ) are tawny and copious only on the immature fronds.

4. A. Tonitis, Hk.; fr. ample, coriaceo-membranaceous, bipinnate; pinnl. distant, 3-5 in. 1., lanceolate, acuminate, glabrous, subentire, petioled ; petiole articulated on the rachis; sori in a single series, equidistant between the costa and the margin, mixed with long, copious hairs.-Hk. Sp. 1. p. 35. A. excelsa, Mart. Cr. Braz. t. 27 and 37. Trichopteris, Pr.

Hab. Brazil.

5. A. elegans, Mart. ; st. aculeated ; fr. bipinnate, carnoso-coriaceous ; pinnl.

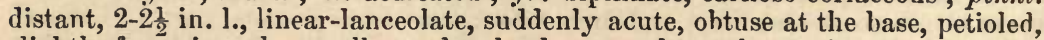
slightly ferruginously woolly and subpaleaceous beneath ; sori in 2 or 3 series, forming an unequal, broad, and more or less interrupted series nearer the costa than the margin.-Mert. Pl. Cr. Bras. p. 63 and 38. Hk. Sp. 1.p. 36.

Hab. Brazil ; apparently rare.

6. A. marginalis, Kl. ; fr. ample, subcoriaceous, glabrous, bipinnate; prim. pinne 12-14 in. l., $4 \frac{1}{2}$ in. w., pinnated, pinnatifid at the apex, oblong, acuminate; pinnl. approximate, truncated at the base, quite sessile, oblong, subfalcato-obtuse, entire, subsinuate at the margin ; sori in a single line, forming a flexnose continuous series a little within the margin; prim. rachis very paleaceous. $-K l$. in Linn. 18. p. 542.

Hab. Brit. Guiana, R. Schomburgk, n. 1129.-A well-marked and very distinct species. * Bi-tripinnate or decompound. Sp. 6-63.

7. A. Micrsii, 1Ik.; rachis aculeate; fr. firm-membranaceous, bipinnate, glabrous; prin. pinnce $2 \mathrm{ft}$. or more l., pinnated to the very apex; pinnl. 
remote, petiolate, 5-6 in. 1., 5-6 lines w., spreading, linear-lanceolate, subflexuose, finely acuminate, subirregularly pinnatifid about half-way to the costa; lobes ovate, entire; veins pinnated; veinlets simple or rarely forked; sori rather copious, occupying the lower portion of the lobes half-way between the costule and the margin ; recept. very hairy, very slightly elevated. $-H k$. Sp. 1. $p .38$.

Hab. Organ Mountains, Brazil.

8. A. procera, Klf.; st. aculeated and paleaceous below with very large and exceedingly glossy, dark brown scales; fr. submenbranaceous, bipinnate, glabrous, pinnatifid at the apex; prim. pinnoe $1 \mathrm{ft}$. l. or more, the rachis winged above; pinnl. 2-3 in. l., from a truncated sessile base 4.5 lines w., oblongacuminate or obtuse, pinnatifid half-way down to the costa; costce and costules beneath bullato-squamulose; lobes short subrotundate, often acute, mostly entire ; vcins simple; sori small on all the lobes, between the costule and the margin.Mart. Cr. Bras. p. 64. t. 40 (very good). Hk. Sp. 1.p.38. A. Hookeriana, $K l$. Hk. Sp. 1. p. 39. A. armigera, Kze. Hk. Sp. 1. p. 39.

Hab. Trop. America, frequent ; Brazil, Spruce, n. 2115 ; Venezuela, Fendler, n. 344 and 491 ; E. Peru, Spruce, n. 4715.

9. A. Schiedeana, Pr. ; "fr. ample submembranaceous, bipinnato-pinnatifid ; pinno and pinnl. alternate, remote, subsessile, the latter lanceolate, unequal at the base, shortly acuminate, deeply pinnatifid; segm. oblong, falcate, sinuatocrenate, subdilatate and obtuse at the apex; sori arranged between the costule and the nargin, small, somewhat apart; costoe and costules sparingly fuscopaleaceous; part. and univ. rachises sulcated, fusco-tomentose above, bereath aculeolate ; st. aculeate ; raud. arboreous." -Kze. in Linn. 13. p. 149. Hk. Sp. 1. p. 48. Polypod. Sclilecht.; an Als. pungens, Klf.?

Hab. Mexico, Schiede, Liebmann, in Hb. nostr.; B. Guiana, Rd. Schomburgk ("Als. pungens," $K l$. in Hb. nostr.) ; Amazon, Spruce, n. 2115. - Very near A. procera, but more deeply pinnatifid, and with blunter lobes.

10. A. armata, Pr.; "fr. bipinnato-partite; st. aculeate; rachises of the pinna aculeato-nodulose on both sides, together with the veins above hirsute; pinnce and pinnl. linear-lanceolate, acuminate, beneath hairy and paleolate, subfalcate, rather obtuse, crenate ; sori 12-20 on the lobes."-Mart. Cr. Bras. p. 73. t. 49 (A. Swartziana). Hook. Sp. 1.p. 40. Polypod. Sw.

Hab. S. America and W. Indies.-My numerous specimens sufficiently accord with Martius's figure; but neither that nor his description exhibits any marked feature by which it can be distinguished from some of its allies.

11. A. Gardneri, Hk.; aculeate; everywhere clothed with brownish woolly hairs ; pinnl. lanceolate, acuminate, sessile, deeply pinnatifid nearly to the costa, paleaceous with numerous small, bullate scales beneath; lobes oblong, very ohtuse, entire, covered with sori even to the acuminated apices of the pinnules.HIk. Sp. 1. p. 41.- $\beta$ less hairy. Cyathea nigrescens, Kl. in Hb. nostr.

Hab. Brazil ; Caraccas, Birshell.-Very hairy ; but my specimens are unsatisfactory. It has some affinity with $A$. Poeppigii, and perhaps with $A$. plagiopteris : too hairy for A. armata. - It must be confessed the aculeated S. American Alsophila are in a state of great confusion.

12. A. aspera, Br.; st. and rachis strongly aculeated, main (sometimes strongly aculeated too) and partial raclis above strigillose, slightly scaly beneath and on the costa, the rest glabrous, often glossy; fr. bipinnate, coriaceous; pinnl. shortly petiolate, oblong with an acuminated point; pinnatifid $\frac{1}{2}$ or $\frac{2}{3}$ of the way to the costa; lobes oblong-ovate, often rather acutely serrulate; costa and simple or forked veins of the same colour and texture as the frond, bearing small, deciduous, bullate scales beneath; sori very deciduous, intermediate between the costa and margin ; reccpt. elevated, with few hairs.-IIk. and Gr. Ic. F. t.213-215. 
Sp. 1. p. 39. t. 19. B. Cyathea muricata, Sieb. Klf.? Als. nitens., J. Sm. (fide Griseb.). A. gibbosa, $\dot{K} l$. (Moore).

Hab. W. Indies ; Cuba, $C$. Wright, with large, glossy, lanceolate scales at the base of the stipes, 1 in. or more 1.-I fear different authors have different species in view under the name of $A l s$. aspera and muricata. See remarks in Sp. Fil. $(l . c$.$) , and consult the$ W. Indian Alsophiloe in Grisebach, the species of which I cannot match with my specimens. It is necessary for an author, therefore, to be very cautious in quoting synonyms and localities. A reference to good figures is better than to the most laboured descriptions, often made from imperfect specimens.

13. A. ferox, Pr.; more or less hirsute, especially on the veins; rachis and st. sharply aculeated; fr. bipinnate; pinnl. sessile, broadly lanceolate, narrow-acuminate, deeply-pinnatifid almost to the costa; lobes linear-oblong, falcate, serrate, having small bullate scales beneath ; veins forked ; sori copious, but not wholly covering the lobes.-Hk. Sp. 1. p. 41. A. armata, Mart. Cr. Bras. p. 72.t. 48, and Mett. Polyp. aculeatum, Rad. Fil. Bras. t. 41. Alsoph. Klf.

Hab. Brazil, Guiana ; Amazon, Spruce, 11. 614.--Bordering too closely on more than one other supposed species of this group. Satisfactorily represented in the figures above quoted, if the species be truly distinct.

14. A. leucolepis, Mart.; "st. aculeate; fr. bipinnato-partite, slightly strigilloso-hirsute on the veins and veinlets above, beneath paleaceous with long and small white scales; part. rachis unarmed; pinnoe linear-acuminate, pinnatifid; lobes small, linear-lanceolate, subfalcate, sinuato-dentate; sori on all the lobes 10-12."-Mart. Cr. Bras. p. 70. t. 46. Hk. Sp. 1. p. 41.

Hab. Brazil, Martius, Gardner, n. 5329 and 5331 ; Venezuela, Fendler, n. 53 (young state).- Some of my specimens (which I am disposed to refer to $A$. atrovirens, $\mathrm{Pr}$., A. compta, Mart.) are very little removed from A. leucolepis, judging fron the figure, $l$. $c$.

15. A. infesta, Kze.; "fr. bipinnate; pinnl. unequal at the base, pinnatifid, acuminate; lobes oblong-falcate, rather obtuse; sori uniseriate, approaching the margin; rachis puberulous, furrowed and paleaceous; st. chaffy above, aculeate below." -Kze. Pl. Cr. Poepp. p. 98. Hk. Sp. 1.p.42. A. ph̆alerata, Mart. Cr. Bras.p. 67.t. 42. Hk. Sp. 1.p. 42. C. Caracasana, Kl.

Hab. S. America and W. I. Islands ; Para, Spruce, n. 22 ; Peru, Lechler, Spruce, n. 5724 ; Venezuela, Fendler, n. 56.-On many of my specimens, bearing this name, the upper portion of the rachis of the primary pinnæ is distinctly winged.

16. A. atrovirens, Pr. " $f r$. compound; pinnce pinnate, subpetiolate; pinnl. sessile, broadly lanceolate, coarsely and pinnatifidly dentato-serrate; sori scattered, arising from an hemispherical recept.; st. with short spines. (Arborescent ?)." - Poly pod. atro-virens, Langsd. et Fisch. p. 12.t. 14. Hk. Sp. 1. p. 46. Als. senilis, Kl. in Hb. nostr. Als. compta, Mart. Cr. Bras. p. 66. $t .41$.

Hab. S. America, Brazil to Mexico.

17. A. elongata, Hk.; sharply aculeated, glabrous, except on the rachis above ; fr. bipinnate; prim. pinnoe 2-3 ft. l., 8 in. w.; pinnl. 6 in. and more l., lanceolate, much elongated, pinnatifid nearly to the rachis, terminating in a long, narrow, serrated, caudate acumen; lobes 5-6 lines l., remote, linear, rather acute, rigid, much falcated, the margins recurved, serrated; veins twice or thrice forked from near the base; sori numerous, covering the entire segments except at the apex ; bullate scales none, or quickly deciduous ; recept. very hairy.- $H k$. Sp. 1. p. 43.

Hab. Columbia, Hartweg, n. 1528 ; Central America, Rarclay, Seemann.-Since first I published this, I have received specimens from other collectors, identically the same with our plant, and to one of which Mr. J. Smith had given the name of $A l s$. Tumacensis. 
18. A. Poeppigii, Hk.; "glabrous except the rachis above; pinnoe closely pinnated; pinnl. elongated, sessile, oblong-lanceolate, much and suddenly acuminated, pinnatifid nearly to the costa; lobes thick and coriaceous, crowded, narrow-oblong, falcate, very obtuse, densely clothed with sori to the very apex; the margins slightly reflexed; bullate scales none; copious hairs among the capsules." $-H k$. Sp. 1. p. 43. A. villosa, Kze. not Pr.

Hab. Peru, Poeppig, Ruiz et Pav. in Herb. nostr.-This appears to me quite distinct from the true Als. villosa, Kze. (which is the Chnoophora Humboldtii, $K l f$.), and more allied to our Als. Gardneri.

19. A. villosa, Pr. ; st. short, $1 \mathrm{ft}$. or more long, unarmed or only beset with small, elevated, tubercular points, at the base densely clothed with ferruginous, subulate, glossy scales $1 \frac{1}{2}$ in. l. ; fr. coriaceous, bi-subtripinnate, glabrous above, with a copious, lax, deciduous tomentum on both sides in the young state; pinnl. 1-3 in. l., oblong-lanceolate, gradually but obtusely acuminate, more or less deeply pinnatifid; lobes oblong, obtuse, entire or coarsely serrated; veins pinnated; veinlets forked ; sori occupying nearly the whole space between the costule and the margin; capsules mixed with copious hairs.-Hk.Sp. 1.p.44. Cyathea, H. B. K. Nov. Gen. 1.p. 24-7. t. 670. A. rigidula, Mart. Cr. Bras. t. 5̌1. A. Humboldtii, $K l$. Chnoophora, $K l f s$.

Hab. Tropical America; New Granada, Brazil ; Venezuela, Fendler, n. 47 and 492 ; S. Chili, Cuming, Capt. King.-Well figured by $H . B . K$. and by Martius.

20. A. plagiopteris, Mart. ; "fr. bipinnato-partite; st. aculeate; partial rachis and veins downy above; scales on the veins few and deciduous; pinnoe linearoblong, acuminate; pinnl. linear, much acuminated and pinnatifid; lobes between the rather broad sinuses lanceolate, falcate, toothed at the apex; the fertile ones nearly entire, the sterile serrated; in each pinnl. the lowest and shortest lobe is obliquely adnate with the rachis; sori upon all the segments 8-10."-Mart. Cr. Bras. p. 73. t. 50. Hk. Sp. 1. p. 44.

Hab. S. Brazil.-Moore alludes to its affinity with bis A. axillaris, Polypod. axillare, Rad. Fil. Bras. t. 41, which is A. hirta, Klf., and which my specimens very much resemble.

21. A. hirta, Klf. ; " fr. trifido-tripartite ; slightly hairy on both sides, more so beneath and there minutely scaly; st. and underside of the rachis aculeate, and, as well as the partial rachis rough with hairs; pinnoe linear-oblong, shortly acuminate, deeply pinnatifid; lobes broad-lanceolate, inciso-semipinnatifid, ult. ones obliquely ovate, acutely serrated above; sori in each segment 8-16."-Mart. ('r. Bras. p. 69. t. 44. Hk. Sp. 1.p. 45. (A. hirsuta). Polyp. arillare, Rad. Fil. Bras. p. 2. t. 41.

\section{Hab. Brazil.}

22. A. nigra, Mart. ; st. rather slender, aculeated and as well as the principal rachises ebony-black; $f r$. deep green, submembranaceous, sparsely hairy on the costro and costules, rarely with a few deciduous siales beneath; prim. pinnoe

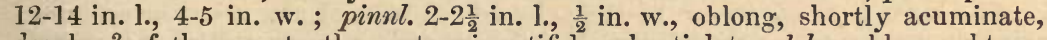
deeply $\frac{2}{3}$ of the way to the costa pinnatifid, subpetiolate; lobes oblong, obtuse, crenato-serrate; veins simple or forked; sori intermediate between the costule and the margin.-Mart. Cr. Bras. p. 71.t. 47. Hk. Sp. 1.p. 45.

Hab. Rio Negro, Brazil.-It were to be wished that many other S. American Alsophilae were as readily distinguished as this.

23. A. radens, Klf.; "caud. 3 ft. high, 3 in. diam. ; st. $2-3$ ft. 1., clothed with ovate, acuminated, pale brown scales, below together with the ramifications aculeate, above more densely paleaceo-subvillous ; fr. membranaceous, lanceolato-ovate, bipinnatisect; prim. segm. at length deciduous, $1 \frac{1}{2} \mathrm{ft}$. l., 
elongato-oblong, acuminate, second. ones 2-3 in. 1., not articulated, petiolulate, on both sides, and, more thickly at the costr hispido-pilose, from a truncated or on the inferior side cuneate base (the superior rounded), linear-lanceolate, pinnati-partite; segm. oblong, the anterior side rotundato-obtuse, denticulate; second. veins of the segm. forked, soriferous at the fork, or, simple and soriferous and the sori dorsal; upper ones sterile; sori between the costule and the margin, 4-6 on each side the costule ; recept. with copious hairs (paraphyses), scarcely longer than the capsules," Mett.-Hk. Sp. 1.p.46. Mett. F. H. Lips. p. 109 .

Hab. Brazil.-I only possess a garden (but authentic) specimen of this from Professor Mettenius.

24. A. pycnocarpa, Kze.; " fr. coriaceous, with elevated forked veins, ovate, bipinnate; prim. pinnoe petiolate, approximate at the base and apex of the frond, obliquely lanceolate; st. articulated and incrassated at its base; pinnl. subsessile, divergent from a broader base, subcuneately oblongo-lanceolate, crenate or incised at the base, obtuse at the apex; subfalcate, entire ; costa albo-squamose beneath; sori approximate, subcontiguous; rachises angulate, flexuose, aculeolate at their base; partial ones margined towards the apex and as well the aculeolate st. albido-paleaceous; caud. short."-Kze. in Schk. Fil. Suppl. 1.p. 208. t.86. Hk. Sp. 1.p. 46.

Hab. Peru.-A very peculiar-looking species, judging from the figure, for I have never seen a specimen.

25. A. microphylla, Kl.; "fr. $1 \frac{1}{2} \mathrm{ft}$. 1., bipinnate ; rachis semiterette, convex on the back, plane upwards, adpressedly hirsute ; pinnoe 4-8 in. l., lanceolate, patent, thin ; pinnl. 9-15 lines l. by 4 lines w., pinnatifid, remote, oblong, rather obtuse, sessile, glabrous above, subhirsute at the rachis beneath, especially below the middle, clothed at the costa with distant, ovate, acuminate, aureous scales; lobes oblong, subfalcate, obtuse ; veinlets simple; sori small, whitish, inserted on the middle of the back of the veins, globose ; recept. minute, glabrous.' -Kl. in Linn. 18. p. 541. A. squamata, $K l$. (fide Moore).

Hab. Caracas, Moritz, n. 110 ; Funck \& Schlim, n. 976, 978, and 998.

26. A. Salvinii, Hk. ; principal rachises $\frac{3}{4}$ in. thick, glossy-ebeneous black, slightly rough to the touch, scarcely to the eye ; fr. firm, subcoriaceous, glabrous, dark green, pale beneath, tripinnate, $3 \mathrm{ft}$. and more l., ovato-lanceolate, acuminate; second pinnce 4-5 in. l., oblong-acuminate, again pinnate with closeplaced shortly petiolate pinnl., $\frac{3}{4}$ in. l., subliastato-lanceolate, acute, or obtuse, pinnatifid, serrated at the apex, lowest pair of lobules frequently rounded and free (separate from the rest); veins pinnated; sori in a series nearer the costa than the margin ; recept. often 2-lobed and shortly stipitate.

Hab. Chilasco, Guatemala, Salvin \& Godman.-A very distinct and peculiar species.

27. A. Godmani, Hk.; rachises asperous, stramineous ; fr. bipinnate, membranaceous, full green and more or less hairy on both sides with sparse, white, longish hairs ; prim. pinnce 16-18 in. l., 4-6 in. w., oblong, much acuminate; pinnl. approximate, sessile, $2 \frac{1}{2}-3$ in. 1., 5-6 lines wide, narrow-oblong, horizontal, deeply to the costa pinnatifid, almost pinnate ; lobes very compact and crowded, so that the space between them can scarcely be seen except when held between the eye and the light, pinnatifid about half-way down to the costa with small, acute, ovate lobules, upper ones rarely toothed; veins one to each lobule, once or twice forked, the lowest lobule (exactly square), only one veinlet on each side soriferous ; sori small, of few caps., receptacles hairy ; principal rachises and costoe stramineous, pubescent and villous, and partially paleaceous with sinall ciliated scales.

Hab. Coban, Guatemala, Salvin \& Godman.-A very elegant and very distinct species, 
especially in the small, very close-spaced and strongly pinnatifid lobes, of which the lowest pairs are exactly square, adnate on two sides with the costa and costule.

23. A.? sagittifolia, Hk. ; unarmed?; fr. hard-coriaceous, bipinnate, glabrous ; prim. pinnce 8-9 in. 1., $1 \frac{1}{2}$ in. w., petiolate ; pinnl. 1 in. 1., 2-3 lines w., all free to the apex, shortly petiolate, oblony, acute, crenato-serrate, sagittate at the base, the lobcs obtuse, the margin recurved; veins indistinct; sori (far advanced) often mixed with paleaceous scales, copious on the forking of the veins, nearer the costule than the margin; recept. often 2-lobed.

Hab. Trinidad? (possibly the opposite coast of Venezuela), Cruger.-A very peculiar species, and I regret my specimens are but imperfect.

29. A. melanopus, Hk. ; "caud. 3-15 ft. high, $1 \mathrm{ft}$. diam., unarmed, ramentaceous" (Spruce) ; st. $3 \mathrm{ft} .1 ., 1$ in. thick, intense ebony-black (as well as the prim. rachises), slightly tuberculate and at the base paleaceous with very long, narrow scales ; fr. coriaceo-membranaceous, glabrous ; prim. pinnce $5 \mathrm{ft}$. $1 ., 12$ pairs $3 \mathrm{ft}$., or nearly so l., $1 \mathrm{ft}$. w. in the broadest part ; pinnl. 6 in.1., 12-14 linesw., distinctly petiolate, from a broad base oblong, rather suddenly tapering into a serrated acumen, deeply pinnatifid to nearly the costa ; lobes oblong, falcate, 3 lines wide, obtuse, entire ; veins distinct, all forked, sori at the forking of each vein, much nearer the costule than to the margin ; costoe and costules quite free from scales and mostly quite glabrous. - ? $\beta$ caudex slender, subflexuose, $3 \mathrm{ft}$. high ; pinnl. sessile ; lobes narrower and more acute.

Hab. In woods, Chimborazo, alt. 3,000 ft., Spruce, n. 5742.- $\beta$ Montana de Canelos, Spruce.-Habit and size of the pinnules very much as in Cyathea divergens (p. 17), but clearly an Alsophila, with intensely ebeneous prim. and second. rachises. I an doubtful about my var. $\beta$, which may prove a distinct species.

30. A. Chimborazensis, Hk.; " caud. $15 \mathrm{ft}$. high, 4 in. diam., aculeate (Spruce); st. very stout, 3-4 ft. 1., furfuraceo-pubescent, dirty brown, aculeated with very sharp, strong spines, and paleaceous with large, dark, brown, glossy scales ;" fr. 9-10 ft. l., ovato-lanceolate, subcoriaceous ("subscandent amongst neighbouring branches"); prim. pinnee $2 \frac{1}{2} \mathrm{ft} .1$., by $1 \mathrm{ft}$. w. ; pinnl. rather distant, distinctly petiolate, 1-1 $\frac{1}{4}$ in. w., horizontal, from a broad base oblong, acuminate, deeply pinnatifid near to the costa ; lobes oblong, obtuse, sulbfalcate, entire, the margins a little recurved; veins conspicuous, forked near the base; sori at the forks and close to the costule; main rachis thicker than a man's thumb, and as well as the sccond. ones aculeate, having a dirty aspect from a clothing of furfuraceopubescence.

Hab. Chimborazo, alt. 3,000-4,000 ft., Spruce, n. 5743.-This has still more the aspect of Cyathea divergens than our Als. melanopus; but here, again, the sori are clearly those of Alsophila. It is, however, the much more strongly aculeated of the two.

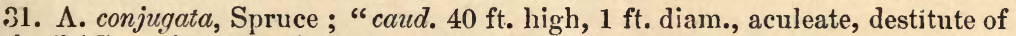
scales" (Spruce); st. $3 \mathrm{ft}$. l., 1 in. and more thick, prickly with slort, stout, not very sharp spines; fr. $9 \mathrm{ft}$. l., ovato-lancenlate, coriaceous ; prim: pinnoe 23 pairs, "all exactly opposite, save at the very apex," 2-3 ft. 1. ; pinnl. alternate, quite sessile, 4-5 in. l., 6-7 in. w., pinnatifid nearly to the costa ; lobes linear, from a broad base, acute, crenato-serrate at the slightly recurved margin; sori rather small, close to the costule, one to each serrature; rachises (all) and costce and costules rusty-pubescent and hairy.-Spruce, mst. in Hb. nostr.

Hab. Chimborazo, alt. 3,000-4,000 ft., Spruce, n. 4745.-Very remarkable for the exactly opposite prim. pinnæ : the second. ones are alternate.

32. A. Sprucei, Hk.; "caud. none, reduced to a subglobose rlizome" (Spruce) ; st. $4 \mathrm{ft}$. l., stout, strongly aculeate at the base, clothed with ferruginous scales of two kinds, long, very slenider, dense, hinir-like ones, and others large and lanceolate ; fr. subcoriaceous, glabrous, $4 \mathrm{ft}$. 1.; prim. pinnce 12-14 in. 1.; pinnl. 
$2 \frac{1}{2}-3$ in. $1 ., \frac{1}{2}$ in. w., oblong-acuminate, deeply nearly to the costa pinnatifid; lobes oblong, falcate, acute, entire, margins slightly reflexed ; sori copious, occupying the space between the costule and the margin ; rachises and costce beneath free from scales or pubescence.

Hab. Chimborazo, alt. 2,500 ft., Spruce, n. 5740.— “A pretty Fern when growing." Spruce.

33. A. aterrima, Hk.; st. castaneous, copiously aculeate, and at the base shaggy with very long ( $1 \frac{1}{2} \mathrm{in}$.), dense, ferruginous, flexuose scales and fine hairs; $f r$. ample, thick, carnoso-coriaceous; black above, a little paler and chocolate-coloured beneath, villous above; rachis shaggy; costce and costules, especially beneath, clothed with deciduous, tawny, lanose hair; prim. pinnce $1 \mathrm{ft}$. and more 1., pinnl. 2-21 in. l., 4 lines w., deeply to the costa pinnatifid; lobes oblong, very obtuse, entire ; sori chiefly on the lower half of the lobes (about 6), close to the costa, ferruginous.

Hab. Near Tarapota, E. Peru, Spruce, n. 4713.-The blackest-looking species, when dry, I am acquainted with, and of a very firm and coriaceous texture.

34. A. pruinata, Klf.; unarmed; st. densely lanigerous at the base; fr. coriaceous, glaucous, bi-tripinnate ; prim. pinnoe petiolate, 12-18 in. l., ovato-lanceolate ; pinnl. 3-4 in. l., 1 in. w. ; petiolulate, from a broad base oblongacuminate, deeply pinnatifid, or again pinnate; lobes or ult. pinnl. $\frac{1}{2}$ in. l., lanceolate, very acute, deeply or pinnatifidly and sharply serrated ; sori solitary, near the costule, one to each lobule or serrature; costce and costules beneath often very hairy, and hairs mixed with the capsules on a small recept.- Hk. Sp. 1. $p$. 47. Poloyp. griseum, Schk. Fil. $t$. 25. Trichosorus glaucescens, densus et frigidus, Liebm. Lophosorus, Pr.

Hab. Tropical America and W. Ind., extending as far south as Chili ; Juan Fernandez.

35. A. frigida, Karst.; " caud. not lofty ; st. and rachises clothed sparingly with deciduous tomentum and, especially at the base, muricated; fr. ovato-lanceolate, tripinnate, coriaceous; prim. and second. pinnoe from a broad base gradually narrower and acuminated; pinnl. $\frac{1}{2}$ in. l., oblong, more or less adnate at the base, densely squamose beneath, pinnatifid ; the lobes falcate, obtuse, crenate, separated by a very narrow, acute sinus, penniveined; the margin revolute; veins simple or forked, the lower ones on the middle of the back or in the fork soriferous ; recept. semiglobose, pilose."-Karst. Fl. Columb. t. 30.

Hab. Andes of Bogota, alt. 15,300 ft., Karsten.

36. A. Mexicana, Mart.; " $f r$. tripinnatifido-partite, sparingly hirsute on both sides; st. and rachis rough with hairs and furnished with scales varying in size; pinnce linear-oblong, acute ; pinnl. linear-acuminate, deeply pinnatifid; ultimate lobes obliquely and broadly ovate, entire or emarginato-bidentate; sori on each lobe near the rachis 2-8."-Mart. Cr. Bras.p. 70.t.45. Hk.Sp. 1. p. 47.

Hab. Mexico.

37. A. myosuroides, Liebm.; "caud. 10-16 ft. 1., 3-4 in. diam.; fr. ample; pinno patulous, petiolate, elongato-lanceol. $1 \frac{1}{2}-2 \mathrm{ft}$. 1 . ; pinnl. divergent, $3-3 \frac{1}{2}$ in. 1., $\frac{1}{2}$ in. w., elongato-lanceolate, long-acuminate, acute, deeply pinnatifid ; lobes from a dilated base linear-lanceolate, falcate, rather obtuse, crenulato-falcate ; margins a little revolute, the sinuses angled; the apex of the pinnl. contracted, $\frac{1}{2}-1$ in. 1., 1-2 lines w., crenated; costa on both sides appresso-pilose; sori numerous on each lobe, at length confluent; st. $1 \mathrm{ft}$. l., $1 \mathrm{in}$. thick, aculeolate with straight prickles."-Liebm. F. Mex. p. 134 .

Hab. Mexico, on mountains, alt. 2,400 ft., Liebmann.- The author seems to allude to an affinity with Als. armata, Pr. I possess copious specimens from Dr. Liebmann gathered 
in Mexico, and from the Copenhagen Garden, where it is cultivated ; but, save in the caudate apices of the pinnules, it possesses scarcely any distinguishing characters.

I may here mention, of S. American "Alsophilae," A. tenera, J. Sm., from St. Vincents, alluded to at p. 18 of this vol. under $C$.gracilis, Gris.; a fine-looking species from Tarapota, E. Peru, Spruce, n. 472, with very long, dense, subulato-crinite scales ; an Alsophila from Porto Alegre, S. Brazil, Mr.Fox, n. 247, of which the two lowest lobes of the pinnule are singularly reflexed upon the rachis ; a Guatemala species from Messrs. Salvin \& Godman, "n. 1 ;" a Cuban species, C. Wright, n. 1053, with oblong, falcate lobes, an inch long; and other Cuban species from the same collector, Nos. 1833, 1834, and 1834a. These, however, and some other dubious species, I dare not attempt to characterize.

\section{* Species of the Pacific 1sles, Australia, and N. Zealand. Sp. 38-47.}

38. A. Samoensis, Brack.; "arborescent, unarmed; st. and common rachis fulvo-tomentose above; $f r$. glabrous, nearly membranaceous, bipinnate; pinnl. elongato-lanceolate, scarcely acuminate, pinnatifid ; lobes oblong, obtuse, subfalcate, serrated; part. rachises and costa and veins (which are slender, forked, setose above) beneath bullato-squamose; sori few, infra-axillary, nearer the costa than the margin ; reccpt. columnar, with a lacerated scale beneath, and hairs among the capsules."-Brack. Fil. p. 287.t. 40.f. 1 .

Hab. Samoan Isles, Brackenridge; Louisiade Archipelago, McGillivray.-I have seen no authentic specimen of this ; but some of my specimens from the Louisiade sufficiently accord with the description and figure above quoted.

39. A. decurrens, Hk. ; unarmed ; fr. membranaceous, bipinnate above, the rest tripinnate, sparsely villous with long, white hairs on both sides, chiefly on the costules and veins, the former scurfy with small bullato-acuminated scales; prim. pinnoe 1-1 $\frac{1}{2} \mathrm{ft} .1 ., 6$ in w., oblong-acuminate; second. pinnoe $2-3 \mathrm{in}$. 1., oblong-

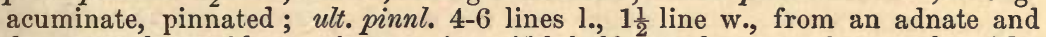
decurrent base oblong, obtuse, pinnatifid half-way down to the costule; lobes ovate, acute, entire or with 1 or 2 teeth ; sori 1 to each lobe of few lax capsules. - Hk. Sp. 1. p. 51 .

Hab. Pacific Islands ; Aneiteum, Samoan Islands; N. Caledonia (Vieillard).-A species not likely to be confounded with any other.

40. A. truncata, Brack. ; main and second. rachises dark purple, glossy, sharply muricate, deciduously furfuraceo-tomentose, as well as the costæ and costules beneath ; fr. tripinnate, firm, coriaceous, bright green above, paler beneath ; prim. pinnoe 10-16 in. 1., 4-5 in. w., oblong, acuminate ; second. ones $2 \cdot 3$ in. $1 ., \frac{1}{4}-\frac{1}{2}$ in. w., oblong, sessile, pinnated to the very short pinnatifid acumination; ult. pinnl. very small, rather distant, from a truncated shortly petiolated free base, linearoblong, acute, the margin recurved, sinuato-lobate ; costule thick and prominent, bullato-squamulose ; veins forked, almost from the base ; sori small, dark orange, lax, near the costule.-Brack. Fil. p. 288.

Hab. Fiji and Samoan Islands, Brackenridge; Ngau, Milne.-A very distinct and peculiar species.

41. A. Novoe Caledoniae, Mett. ; main and second. rachises rufo-fuscous, muricate and, as well as the costre beneath hirsuto-tomentose, and very minutely paleaceous; $f r$. coriaceous, dark blackish green above, glossy as if varnished (beneath in our specimen wholly covered with fructification), tripinnate; prim. pinnoe $1 \frac{1}{2}$ ft. 1., 6 in. w. ; second. ones sessile, linear-oblong, 4-5 lines w., pinnated, except the acuminated serrated apex; ult. pinnl. rather distant $2-2 \frac{1}{2}$ lines l., less than 1 line w., linear-oblong, obtuse, sessile, and slightly decurrent at the base, the margins recurved subcrenulate; sori copious, occupying the space between the costule and the margin.-Mett. Fil. $N$. Caled. n. 100.

Hab. N. Caledonia, Vieillard, n. 1633.-Mettenius compares this with A. truncata, Brack. ; no doubt its nearest affinity, but it is truly distinct 
42. A. Tahitensis, Brack.; " $f r$. bipinnate; pinnl. small, sessile, glabrous, oblong-lanceolate, deeply pinnatifid; lobes oblong-obtuse, crenulate; general rachis flexuose and, as well as the partial ones, rufo-tomentose; costa bullatosquamose beneath ; veins simple or forked; sori near the costule with a semicalyciform involucre, lacerated at the inner base; recept. subglobose, with no hairs among the capsules."-Brack. Fil.p. 288. t. 40.f.1.

Hab. Tahiti, Brackenridge.-Unknown to me. Lobes of pinnules 2 in. 1., scarce!y 1 in. w. An Hemitelia, $\S$ Amphicosmia?

43. A. Macarthurii, Hk.; st. jointed upon the caud.; main and second. rachises all dark ebeneous purple, deciduously pulverulent, mucronato-spinulose; $f r$. firm, cartilagineo-chartaceous, dark green above, subglaucous beneath, glabrous or nearly so and scaleless, tripinnate; prim. pinnee $1 \frac{1}{2}-2 \mathrm{ft}$. $1 ., 8 \mathrm{in}$. w., oblonglanceolate, acuminate; sccond. pinnoe oblong-acuminate, sessile, pinnatifid only at the apex; costoe beneath pubescenti-asperous; ult. pinnl. and lobes linearoblong, acute, the margins slightly recurved, spinuloso-serrate; sori copious, close to the costa ; recept. small, not hairy.

Hab. Woods near Sydney, Sir Wm. McArthur ; Hastings and Marlony Rivers, Beckler ; Illawara, Shepperd; Mt. Lindsay (caud. $20-25$ ft. 1., 9 in. w.). "Whip-stick Fern" of the colonists. - Allied to $A$. australis, but assuredly distinct.

44. A. australis, $\mathrm{Br}$.; st. with very long, firm, subulate scales, $1 \frac{1}{2} \mathrm{ft}$. 1 ., and as well as the main rachises muricato-asperous, stramineous ; $f r$. ample, coriaceo-submembranaceous, subglaucous beneath, more or less villous on the costæ and costule above, and very minutely bullato-paleaceous beneath, often quite naked; prim. pinnos $1 \frac{1}{2}$ ft. l., 6-10. in. w. ; pinnl. $3-4$ in. $1 ., \frac{1}{2}-\frac{3}{4}$ in. w., oblong, acuminate, deeply pinnatifid, or, towards the base even pinnate ; ult. pinnl. or lobes oblong, acute, serrated, subfalcate; sori copious, rather small, intermediate between the costule and the margin; recept. villous.-HK. Sp. 1. p. 50.t. 19. A.

Hab. Tasmania and Australia, especially in the South ; Hastings and Clarence Rivers, Beckler ; Louisiade Archip., McGillivray, n. 456.

45. A. Colensoi, Hk. f. ; unarmed, caud. small, to 4-5 ft. l. ; st. short, densely clothed with very long, white, silvery, subulate scales, 1 in. 1 ., and with copious lesser dark brown ones on the rest of the stipes, rachises, and costce, mixed with small bullate scales ; $f r$. submembranaceous, subhirsute, 2-4 in. l., 10-12 in. or more w. ; prim. pinnoe 12-14 in. l., oblong, acuminate ; pinnl. 2 in. l., 4-5 in. w., rather distant, deeply nearly to the costa pinnatifid; lobes 2-3 lines l., ovatooblong, strongly serrated; veins all simple; sori small, nearer the costule than the margin.-Hk.f. Fl. N. Zeal. 2. p. 8. t. 73.

Hab. New Zealand, Northern Island, Colenso; Otago, Sinclair.

46. A. excelsa, Br.; st. and main rachises muricated ; fr. ample, coriaceous, dark green above, paler beneath, when young more or less ferrugineo-tomentose beneath, mixed with copious, small, bullate scales on the costro and costules; prim. pinn. $1 \frac{1}{2}-2 \mathrm{ft}$. 1., 6-10 in. w.; pinnl. numerous, approximate, oblong-lanceolate, acuminated, deeply to the costule pinnatifid, often quite pinnate; lobes or ult. pinnl. $\frac{1-3}{4}-\frac{3}{4}$. l., oblong or linear-oblong, acute or obtuse, falcate, the margins subrecurved, serrated; veins once or twice or more forked; sori copious near the costules.-Hk. Sp. 1.p. 49.t. 18. A. A. Cooperi, Veitch's Cat.

Hab. Norfolk Island ; Illawara, C. Moore, and Hastings River, Australia, Beckler; Mount Lindsay, Walter Hill. - Said to have a trunk 60-80 ft. 1. The segments of the sterile fronds are larger and broader than the more coriaceous fertile ones, and of a paler green. It appears to be a larger and stouter-growing plant than $A$. australis. A plant, in every respect resembling the $A$. excelsa, has been sent living to Mr. Veitch, and has been cultivated in gardens under the name of $A$. Coopcri, in compliment to Sir Daniel Cooper. 
47. A. lunulata, Br.? Brack.; st. and main rachises mucronato-asperous, pale brown ; fr. ample, coriaceous, dark blackish-green, glabrous or very slightly villous and bullato-squamulose on the costules beneath; bi-subtripinnate; prim. pinnce $1 \frac{1}{2}-2$ ft. $1 ., 6-9$ in. w. ; pinnl. oblong, subcaudato-acuminate, deeply to the rachis pinnatifid; lobes united or lower ones free; lobes or ult. pinnt. closely placed, 4 lines 1., 1-1 $\frac{1}{4}$ line w., oblong or linear-oblong, when fertile falcate, acute, the margins reflexed and obscurely serrated in the upper half; veins forked below the middle; sori copious, deep brown, nearer the costule than the margin.-Hk. Sp. Fil. 1. p. 51. Brack. Fil. 1. p. 286. t. 39 (excellent). Polypod. Forst. Cyathea Mertensiana, Bong. in Hb. Nostr. an Hemitelia crenulata, Mett. (who quotes Alsophila extensa, Bl., not Br.)? An etiam Hemitelia Junghuniana, Mett., Alsophila, Bl., Als. intermedia, Metten.?

Hab. "Pacific Islands," Forster ; Samoan and Fiji Islands, Brackenridge; Isle of Bonin, N. Caledonia, Aneiteum, Alckillivray; Java?, Blume. Brackenridge gives N. Zealand; but I have never seen it from that country. This has much the habit of our Cyathea affinis; but there is no trace of involucre. I think it is quite likely to be the Polyp. lunulatum of Forster, and we have now happily a faithful figure given by Brackeuridge.

\section{*** Species of India, Ceylon, Malaya. Sp. 48-63.}

48. A. alternans, Hk.; rachis much thicker than a swan's quill, glabrous, smooth, tawny-brown; fr. ample, subcoriaceous, glabrous, subtripinnate; prim. pinnce short-petiolate, very remote, 10-14 in. 1., 2-3 in. w., oblong, acuminate, deeply pinnatifid, pinnated near the hase; lobes or pinnl. 1-1 $\frac{1}{2}$ in. 1., oblong, acute, subfalcate, entire or serrate, all horizontal, the extremity of the frond suddenly pinnated with oblong, undivided, sessile pinnl., serrated at the margin; veins approximate, once or twice forked, sori subbiseriate on each pinnl. or lohe, subglobose compact, mixed with rather copious jointed hairs.-Polypod. Wall. Hemitelia? HI. Sp. F. 1.p.29. Ic. Pl.t. 622 (omittingf. 3).

Hab. Penang, Wallich, Sir W. Norris.-In the figure above quoted, a depression formed by the sorus on the lobe was mistaken by the artist for an involucre.

49. A. ? Celebica, Mett. ; "fr. tripinnate, coriaceous, glauco-sericeous beneath ; pinnl. linear-lanceolate, acuminate; second. pinnl. linear-subfalcate, rather obtuse, crenulate at the apex, truncate and sessile at the base; common rachis furfuraceous, sparingly and slightly aculeated."--Mett. in Miq. Ann. Mus. Bot. Lugd. 1.p. 26. Cyathea? Bl. Hk. Sp. 1.p. 26.

Hab. Celebes and Ternate, Blume.-A sterile fragment of this (and but little more seems to be known) I owe to Dr. Blume. Its characters, such as they are, depend on the adventitious clothing : the racti sis muricated and furfuraceous; the costa beneath is shortly villous and furfuraceous ; and the general frond beneath is "glauco-sericeous."

50. A. comosa, Hk.; unarmed; st. paleaceous with long linear-subulate scales, pale brown, as well as the rachises, which are tawny-villous on the upper side; fr. herbaceous, yellow-green, glabrous, and scaleless; prim. pinnce 14-16 in. 1., 6-8 in w.; pinnil. oblong-acuminate, from a rather broad and truncated sessile or shortly petioled base serrated $\frac{2}{3}$ of the way to the costule, pinnatifid with very narrow sinuses; lobes close-placed, oblong-serrated; veins rarely forked, sori orange-colour, rather distant, between the costule and the margin, nearer the latter, receptacle small, very slightly elevated.- Hk. Sp. 1. p. 53. $t_{\text {。 }}$ 20. A. (excl. var. $\beta)$.

Hab. Sylhet and Sincapore.

51. A. contaminans, Wall. ; st. and rachides "paleaceous at the base," purplishbrown, glossy, aculeate with short prickles tipped with a gland; $f r$. ample, coriaceous, glabrous, black-green above (when dry), glaucous beneath; prima 
pinnce $2 \mathrm{ft}$. and more l., oblong-ovate, acuminate; pinnl. sessile, $4-5$ in. $1 ., \frac{1}{2}$ to nearly 1 in. w., deeply, near to the costule, pinnatifid, linear-oblong, subfalcate, entire, the fertile ones often more contracted with margins (when dry) revolute, obscurely crenate; veins once or twice forked; sori nearer the costule than the margin; a minute shallow-lobed and cut membrane surrounds the hase of the receptacle after the capsules are fallen.- $H k$. Sp. 1.p.52.18. B. Mett. in Miq. 1. p. 54 (Alsoph.). Chnoophora glauca, Bl. A. Brunoniana, Wall. Hk. Sp.1. p. อิ3.

Hab. Java and Malay Islands; Sylhet; Cachar, near Assam, Hk. \& Thoms.-Some of my specimens exhibit in a perfect state of the sori a thin membranous? covering, which breaks away from the top and gradually disappears. A. Brunoniana is probably identical with this, but scarcely known, except from the caudex and withered fronds allucled to in Sp. Fil. $l$. $c$.

52. A. crinita, Hk.; st. and main rachis stramineous, brown, hispidopaleaceous and strongly muricate; spines short, tipped with a black gland; fr. subcoriaceo-membranaceous ; rachises pilose above, beneath and on the costæ densely paleaceo-crinite; scales so.netimes short and minute, generally elongate and adpressed; prim. pinnce $2 \mathrm{ft}$. 1., $10 \mathrm{in.} \mathrm{w.} \mathrm{;} \mathrm{pinnl.} \mathrm{oblong,} \mathrm{acuminate,} \mathrm{sessile,}$ pinnatifid nearly to the costuli; lobes narrow-oblong, subobtuse, falcate, the inargins recurved, serrated; costce and veins often pilose; veins forked; sori covering the whole underside of the lobes, mixed with ciliated scales.-HK. Sp. Fil. 1. p. 54, and Ic. Fil.t.671. Bedd. Fil.p. 20.t. 59.

Hab. Ceylon, Nilghiris (Beddome) ; Java, De Vriese (excessively shaggy when young, with very long, fulvous, paleaceous hairs).-A very shaggy-looking species from the copious hairs and scales. Mettenius unites it with A. tomentosa, a species of Blume; but if what I receive under that name be the true plant, it is a very different species, the $A$. lepifera of J. Smith, our A. tomentosa.

53. A. tomentosa, Hk.; scarcely anywhere hairy or villous; st. and main rachises palish brown, strongly muricated with short spines tipped with a black gland; fr. coriaceous, blackish-green above, beneath in all my specimens copiously cobwebby with small white subtomentose ragged scales, which fill up all the interstices of the copious sori, which together cover the whole surface of the frond in all my specimens (the rest as in $A$. crinita).- Hk. Sp. 1.p.55. Mett. in Miq. Ann. Mus. Bot. 1.p. 53. Chnoophora, Bl. Als. lepifera, J. S'm. \& HK. Sp. 1. c. p. 54 .

Hab. Java; S. Comarines, Cuming; Formosa, Wilford.

54. A. caudata, J. Sm.; unarmed ; fr. glabrons, firm, subcoriaceo-membranaceous; pinnl. sessile, oblongo-lanceolate, broadest at the base, the apex is suddenly contracted into a long, narrow-serrated, tail-like acumen ; the lobes oblong, a little falcate, rather obtuse, serrated ; veins simple or forked; bullate scales none; sori close to the costule on the lower half of the lobes.-Hk. Sp. 1. p. 52. t. 20. B.

Hab. Luzon, Cuming.-A very dubious species, having sorne affinity with contaminans and, as J. Smith thinks, with lunulata.

55. A. ramispina, Hk.; st. subasperous, ebeneous (as well as the rachises and costce), a little paleaceous at the base and there bearing 3-5 subsecund, black spines $1 \frac{1}{2}$ in. 1., with numerous sharp divaricating branches ; fr. subcoriaceomembranaceous, dark green above, paler beneath, where the costa is quite scurfy with small brown bullato-paleaceous scales; prim. pinnoe $1 \mathrm{ft}$. and more 1, oblong, pinnatifid at the apex; pinnl. $2 \frac{1}{2}-3$ in. $1 ., \frac{1}{2}$ in. w., oblong, subpetiolate, obtusely acuminate, pinnatifid $\frac{2}{3}$ of the way to the costules; lobes oval-oblong, obtuse, serrated towards the apex; veins mostly simple (in the fertile pinnules); sori small, of few capsules, chiefly on the lower veins, and near the costule, which is very minutely bullato-squamulose ; recept. minute. 
Hab. Sarawak, Borneo; alt. 2,700, T. Lobb.-Its nearest affinity is perhaps with A. squamulata, from which the fronds differ in colour and texture; and it is remarkable for the large and curiously branched spines at the bases of the stipes.

56. A. podophylla, Hk. ; st. generally sharply mucronato-aculeate and, as well as the main rachises, purple-brown ; $f r$. subcoriaceo-membranaceous; prim. pinnce $1 \frac{1}{2}-2 \mathrm{ft}$. and more long, pinnatifid at the apex; pinnl. extremely variable in size and shape, petiolate, $4-8$ in. $1 ., \frac{1}{2}-1$ in. w., from a truncate, or subhastate, or cordate base sword-shaped, acuminate, entire, or serrated only towards the apex, or slightly lobed, or more or less pinnatifid, rarely deeply pinnatifid and even pinnate towards the base; veins pinnated; veinlets often united in the more entire pinnules towards the margin, bearing a sorus near their base, and consequently parallel with the primary vein.-Hk. K. Gard. Misc. 8. p. 334, and in 2nd Cent. of Ferns, $t$. 66.

Hab. Chusan; Hong-Kong, frequent. Variable as is this handsome species, I cannot but consider it quite distinct from $A$. glabra of $\mathrm{Bl}$.

57. A. squamulata. J. Sm. ; st. paleaceous, at the base tuberculato-asperous, and, as well as the rachises, dark, ebeneous-purple, subulato-squanulose ; $f r$. singularly firm and coriaceous, rich brown when dry ; prim. pinnce $1 \frac{1}{2} \mathrm{ft}$. 1., 6-8 ill. w., stipitate; pinnl. rather distant, all petiolate (petiole often 2 lines 1.), oblongacuminate, pinnatifid rather less than half-way to the thickened costule; lobes ovato or rotundato-serrated; costule with a few deciduous bullate scales; sori few, close to the costule.-Hk. Sp. 1.p. 51. Mett. in Miq. Ann. Mus. Bot. Lugd. Bat. 1.p. 52.? An Gymnosphæra squamul. Bl.?

Hab. Malacca, Mt. Ophir, Griffith, Cuming.-The fragment I possess of this plant from Java is, I think, only Als. glabta. Ours is, I believe, only from Mt. Ophir.

58. A. glabra, Hk.; st. asperous, paleaceous at the base, and, as well as the main rachises, purple-ebeneous, polished ; fr. subcoriaceo-membranaceous ; prim. pinnce $1 \frac{1}{2}-2$ and more ft. l., deeply pinnatifid at the apex; pinnl., upper ones sessile, lower ones petiolate, from a truncated base, oblong-acuminate, 3-6 in. 1., 5-9 l. w., pinnatifid, $\frac{1}{4}-\frac{1}{2}$ way to the costule, rarely more ; lobes triangular or rounded, rarely ovate, serrated; vcins pinnated, veinlets all simple ; sori on most of the lobes, generally arranged in the shape of a $\mathrm{V}$ inverted, not extending to the apex of the lobe.-Hk. Sp. 1. p. 51. Bedd. Fil. p. 20. t. 60 (very good). Als. gigantea, $H k$. 1. c. p. 53 .

Hab. Java and Malay Islands, generally (Moulmein, n. 3. Parish); China and throughout India; Ceylon.

59. A. latebrosa, Hk. ; st. aculeate at the base, muricated upwards, dark mahogany-brown in colour ; prim. pinnce oblong-acuminate, 12-24 in. l., 6-8 in. br.; pinnl. lanceolate-acuminate, $3-4$ in. $1 ., \frac{1}{2}$ in. br., cut down nearly to the rachis into numerous linear-oblong, blunt, slightly-toothed lobes on each side; texture herbaceous, upper surface dark-green, naked, lower surface naked, or slightly hairy and scaly; veins all once forked; sori elevated, conspicuous, occupying often the lower two-thirds of the segment.-Hk. Sp. 1.p.37. Bedd. Fil.p. 19. t. 58. Polypodium, Wall. Hemitelia, Mett. in Miq. 1.p. 54.

Hab. Common almost throughout India proper and the Malay Islands, Formosa, \&c.-There are plenty of scales amongst the fructifications, but none, I think, that can constitute a Hemiteloid involucre.

60. A. lurida, Hk.; st. smooth; rachis slightly scabrous and scaly below, densely tomentose and scaly ahove ; fr. broadly lanceolate; prim. pinnoe $1 \mathrm{ft} .1$.; pinnl. more than 2 in. $1 ., \frac{1}{2}$ in. br., cut down to the rachis into numerous linearoblong nearly entire segments ; texture subcoriaceous, upper surface dark-green, naked, lower densely scaly on the rachis and costr. -Chnoophora, Bl. Mctt. in Miq. Anv. Mus. Bot. I. Bat. 1. p. 53 . 
Hab. Java, Bl. in Herb. nostr. (but sterile), and Celebes.-I possess what I consider quite another plant, with membranaceous fronds, and quite free from scales beneath, except a few minute, widely scattered bullate ones, from Dr. Miquel, under the name, from Java, and what I believe to be the same also, but quite destitute of bullate scales, from Mr. Parish, Moulmein ; both in too imperfect a state to merit further notice.

61. A. crenulata, Mett.; "fr. bipinnate (or 3-pinnatifid) submembranaceous, beneath bullato-squamulose on the costæ ; pinnl. lanceolate, acuminate, deeply pinnatifid; segm. linear-oblong, obtuse, serrulate; sori (1-4) near the base of the costules ; rachises tomentose above, asperulous beneath ; caud. arboreous." Bl. En. Fil. Jav. p. 246, under Als. extensa, excl. Syn. (Mett.).

Hab. Java, Blume in Hb. nostr.-Some Indian Alsophila, in my Herbarium, I am unable to refer to any known species, nor are the specimens sufficiently perfect to justify me in describing them.

62. A. tristis, Bl.; st. as thick as a goose-quill, 2 ft. l. and more, dark purple, glossy, and as well as the main rachis (of the same colour) tuberculato-asperous; $f r$. subcoriaceous, blackish-brown when dry, ovato-lanceolate, $\delta \mathrm{ft}$. l. and more, tripinnate ; prim. pinno distant (3-4 in. apart below), $1 \mathrm{ft}$. 1., often $4 \mathrm{in.}$ w., ovato-lanceolate, much acuminated ; secund. pinno 2-3 in. l., oblong-acuminate ; ultimate pinnl. sessile, 3-5 lines l., oblong-obtuse, inciso-pinnatifid about half-way to the costule ; upper portion of the main rachis, the secund. rachises, and costa especially beneath, furfuraceo-hirsute; veins pinnated in the ultimate pinnules ; sori large, one to each lobule ; capsules, when young, apparently agglutinated, closepressed ; receptacle elevated. Alsophila tristis, $B l$. in $H b$, nostr. Cystopteris, Metten. in Hb. nostr,

Hab. Java, Blume, Millett, De Vriese.-A very remarkable Fern, with much of the general aspect of Diacalpe. I find no trace of an involucre; yet Mettenius has referred it to Cystopteris. I possess from Blume apparently a pinnule of another Java Fern, somewhat allied to this, under the name of Alsophila tenuisecta, which also I cannot find described : the fragment is 4 in. 1 . and $1 \frac{8}{4}$ in. w., bipinnate, dark olive-brown ; ultimate segm. 2 lines 1., oblong-obtuse, sessile, pinnatifido-serrate, laxly villous, as is the pale rachis ; veins pinnated ; one small sorus on the superior basal vein, of few capsules. It is probably a Phegopteris.

63. A. subglandulosa, Hance; st. densely clothed at the base with long flaccid linear light-brown scales; fr. ample, tripinnate ; lower pinnce $1 \mathrm{ft} .1$. ; pinnules lanceolate pinnatifid, the lower segments cut down nearly to the rachis, ciliated at the edge with glandular hairs; the lateral veins once forked; prim. and secund. rachises densely clothed with small linear dark-coloured scales, texture herbaceous ; sori copious.

Hab. Island of Formosa, gathered by the late Mr. Oldham. Our specimens have the fronds about $2 \mathrm{ft}$. 1 . by $1 \mathrm{ft}$, br.

\section{**** (Species of Tropical Africa. Sp. 64, 65.)}

64. A. Attiapica, Welw, msc., Hk. ; caud. 3-6 ft. 1., 2-3 in. w., knotted with large tubercles, the cicatrices of the fallen stipites; st, thick as a goose-quill, a span and more long, asperous with small tubercles, nearly smooth on the main rachis, purplish on the upper side; fronds firm-membranaceous, dark green, $4 \mathrm{ft}$. and more 1., broad-lanceolate, quite glabrous, except on the costre and costules, which are hairy on both sides, pinnated; pinnoe 8-10 in. 1., subsessile, oblongacuminate, pinnated below, the rest deeply pinnatifid with lobes $\frac{3}{4}$ in. l., oblongsublanceolate, scarcely falcate, acute, more or less coarsely serrated; veins forked; sori at the forks, copious, rather nearer the costule than the margin, orbicular compact.-A. Currori, Hk., Met.

Hab. Tropical Africa, S. of the Line, Dr. Curror ; Angola, Golungo alto, alt. 1,000$2,400 \mathrm{ft}$., Welwitsch, n. 116 and $116^{2}$.-A very peculiar and well-marked species. 
65. A. obtusiloba, Hk. ; st. thicker than a swan's-quill, short, scarcely 4 in. 1 , tuberculato-muricate, dark glossy purple like the rachis, which is nearly smooth and quite glabrous; fr. firm-membranaceous, black-green, scarcely paler beneath, $4 \mathrm{ft}$. and more long, pinnated, everywhere glabrous except on the costæ above, pinnated; pinno 9-10 in. 1. (3-4 of the lowest pair much dwarfed), shortly petioled, oblong, subacuminate, deeply pinnatifid nearly to the costæ below, less deeply upward; lobes 5-7 lines 1., broad-oblong, scarcely falcate, quite entire, very obtuse ; veins rather distant, forked, sori at the fork, copious, small, prominent, nearer the costa than the margin.

Hab. Sierra del Crystal, Trop. Africa, Mann.-Equally distinct as a species with the preceding. Somewhat allied to this, I possess a specimen of an Alsophila? (sterile), from Johanna Island, E. Trop. Afr., gathered by Dr. Kirk: the pinnoe are all petiolate, 3 in. 1., oblong, shortly acuminate, deeply pinnatifid, especially towards the base, the lobes rotundato-obscurely serrated, lowest inferior one generally free, glabrous ; costce subpubescent and, as well as the forked veins, with scattered bullate scales beneath ; rachis black-purple, below the apex winged between the superior pinnæ.

\section{Gen. 7. Diacalpe, $B l$.}

Sori globose, the receptacle small, scarcely elevated. Invol. inferior, globose, hard-membranaceous, entire, at length bursting very irregularly at the summit. Caps. numerous, nearly sessile; ring broad.-Tab. I. f. 7.

\section{D. aspidioides, Bl. Hk. Sp. 1. p. 59. D. pseudo-Cœnopteris, Kze.?}

Hab. Malay Islands ; Sylhet and Assam; Ceylon.-Fr. tripinnate, submembranaceous, often deciduously crinite ; pinnl. oblong-cuneate, lobed and more or less decurrent. This genus seems more appropriately placed with the Cyathece than with the Dicksoniece. The fronds much resemble those of Davallia nodosa.-What is D. Madagascariensis, Fée, Gen. Fil. p. 339.?

\section{Gen. 8. Matonia, $B r$.}

Recept. of the sori expanded into a firm-membranaceous, umbrella-shaped, obscurely 6-lobed, stipitate invol., which covers and encloses 6 large sessile caps. Not arborescent. Veins forked, free, except those around the sori, which are closely reticulated. Tав. I. f. 8.

1. M. pectinata, Br. in Wall. Pl. As. Rar. 1.t.16. Hk. Sp. 5. p. 286.

Hab. Summit of Mt. Ophir, Malacca.-One of the rarest and handsomest Ferns. Fr. ample, fan-shaped, $1 \frac{1}{2}-2 \mathrm{ft}$. w., hard-coriaceous, each portion subscorpioideo-pinnate on one (the superior) side. Pinnl. consequently all secund pectinato-pinnatifid.

\section{Tribe II. Dicksoniez (excluding Hymenophylleæ).}

Sori globose, situated on the back or apex of a vein. Invol. inferior subglobose, free, sometimes covering the whole sorus, closed, at length bursting irregularly; more frequently cup-shaped, entire or with 2 lips.-Caudex rarely arborescent. Venation free or anastomosing. GEN. 9-14.

\section{Gen. 9. Onoclea, L. Sw., Mett., Hk.}

Sori dorsal, globose, on the veins of the changed and contracted pinnæ of the fertile fr. and quite concealed by their revolute margins. Invol. very thin, delicate-membranaceous, hemispherical or half-cupshaped, originating from the inferior side of the sorus, or wanting.-Caud. erect or creeping. Fr. stipitate dimorphous, pinnate or pinnatifid, with free or anastomosing veins. Large herbaceous Ferns of cold or temperate climates. TA B I. f. 9. 
\$ Euonoclea. Frert. fr. bipinnate; pinnl. recurvato-globose; invol. a globose pellicle, bursting at the summit. Veins of the fertile fr. copiously anastomosing.

1. O. sensibilis, L.-Hk. Sp. Fil. 4. p. 160.

Hab. N. Am., U. St., from Florida to Canada; N. Asia, Amur, Japan, and Manchuria.

\$ Struthiopteris, $W . H k$. G. Fil.t. 69.-Sp. 2. 3. Fert. fr. pinnate; pinnce torulose or flattish. Veins all free pinnated; invol. subhemispherical, very fugacious.

2. O. Germanica, W.; fr. broad-lanceolate, long-attenuated at the base ; fert. pinnoe short, much contracted, linear-terete, torulose, lobed and torn at the margin ; invol. cup-shaped, very fragile and soon obsolete.-Hk. Sp. 4. p. 161.

Hab. N. Europe, Scandinavia to Austria ; N. Asia, Manchuria to Altai ; N. America, Canada to Pennsylvania.

3. O. orientalis, Hk. ; fr. ovato-oblong, not attenuated at the base ; fert. ones oblong (often $2 \mathrm{ft}$. l.) contracted; pinna linear-oblong, flattened 2-edged, the broad refracted margins covering the whole back, dark purple-brown, glossy, at length spreading, torn at the margin, inv. 0. ?-Hk. 2 nd Cent. of F. t. 4. Sp. 4. p. 161.

Hab. Sikkim, alt. 12,000 ft. ; Assam; Hakodadi, Japan.-I think Mettenius has done well in uniting Onoclea and Struthiopteris; and also in placing the genus near Woodsia, on account of the involucre (when present) having its origin beneath the sorus.

\section{Gen. 10. Hypoderis, $B r$.}

Sori subglobose in lines or series parallel with the second. veins. Invol. calyciform, thin-membranaceous, fimbriated at the margin.-Frond simple, subcordatohastate, costate, pinnatedly veined, membranaceous; veins alternato-flexuose. Veinlets copiously anastomosing. TAB. I. f. 10.

1. H. Brownii, J. Sm.-Hk. Sp. p. 57. Ic. Pl.t. 675, 676; and in Gard. $F$. t. 24. Woodsia, Mett.

Hab. Trinidad.-Fr. 10-12 in. 1., often hastately 3-lobed.

\section{Gen. 11. Woodsia, Br.}

Sori globose. Invol. inferior, soft-membranaceous, from the first calyciform or more or less globose, and sometimes enclosing the sorus, at length opening at the top, the margin or mouth irregular lobed or fringed.-Small herbaceous Ferns of cold or temperate climates, much tufted: the stipes often jointed and separating at the joint. ТАв. I. f. 11.

§ Euwoodsia.-Invol. smaller than the sorus, but fringed with hairs which extend beyond it. Tав. I. f. 11. Sp. 1-3.

1. W. Ilvensis, Br.; slightly hairy above, st., rachis, costules, and veins below crinite, with copious, rufous, chaffy scales; fr. broad-lanceolate ; pinno oblong, obtuse, broader at the base, sessile, deeply pinnatifid with many oblong, obscurely crenated lobes.-Hk. Sp. 1.p. 63, and Brit. F. t. 8.

Hab. Arctic regions and high mountains in the temperate zone, Europe, Asia, and America.

2. W. hyperborea, Br.; glabrous, or with the st., rachis, and costoe beneath slightly hairy, mixed with a few scattered scales; fr. linear-lanceolate, pinnated; pinnoe cordato-ovate, pinnatifid with few (5-7) broadly-obovate, entire lobes; the inf. lobes distant.-IIk. Sp. 1.p. 64, and Brit. F. t. 7.

Hab. Similar in its distribution to the preceding. 
3. W. glabella, Br. ; quite glabrous ; fr. linear, tapering a little below, pinnated; pinna very remote towards the short st., all of them deltoid, very obtuse, cut into few (3-7) short-rounded or subcuneate, entire lobes.-Br. Hk. Sp. 1 . p. 64, and in Fl. B. Am.2. $t .237$.

Hab. America, from the hills of New York northward to the Arctic regions ; Arakamtchechene Island, Behring's Straits ; Norway, Tyrol, Carinthia.-Possibly a glabrous form of W. hyperborea; and there is a subglabrous Arctic American plant which closely resembles $W$. Ilvensis.

4. W. lanosa, Hk. ; fr. oblong pinnated, quite shaggy with most copious, soft, long ferruginous hairs, mixed with very narrow, long, chaffy subulate scales; pinnce subcordate, dentate or lobato-dentate, scarcely pinnatifid (the rest as in W. hyperborea).

Hab. N. India; Mountains of Kamaoun; alt. 11-12,000', Strachey and Winterbottom; Sikkim, alt. 14-16,000', Hooker, fil.-Specimens from 3 different localities are very uniform in the indument; still, if $W$. glabella should prove a glabrous state of $W$. hyperborea, this may prove a var. in the opposite extreme, sericeo-tomentose in a very high degree.

\section{§§ Physematium. Involucre larger than the sorus, not ciliated. Sp. 5-14.}

5. W. mollis, J. Sm. ; fr. lanceolate pinnate, generally densely clothed, especially beneath, with soft jointed hairs, scarcely attenuated below; pinnoe sessile, from a broader base, oblong, obtuse, pinnatifid; lobes approximate, oval or subrotund, entire or crenate; sori marginal ; invol. opening with jagged, circular mouth.-Hk. Sp. 1. p. 60. Physematium, Kze. An. Pter. t. 27. W. fragilis, Liebm.

Hab. Mexico ; Guatemala, Salvin \& Godman, n. 123. Andes of Peru and Quito, Jameson, McLean.-Our now copious specimens quite resemble Kunze's figure ; but the involucres are rarely so perfect as he figures them.

6. W. Guatemalensis, Hk. ; fr. a span to $1 \frac{1}{2} \mathrm{ft}$. l., lanceolate, firm-membranaceous, much attenuated at the base with the lower pinnæ remote, glabrous or villous; pinno from a broad base oblong, very obtuse, pinnatifid; ultimate lobes oval, slightly crenato-serrate ; sori copious, submarginal ; invol whitish, pale, globose, opening irregularly at the summit and very permanent in that form.-Hk. Sp. 1. p.61.t.21. A.

Hab. Guatemala (Salvin \& Godman), Mexico (Liebmann, Schafiner). - What is W. Cumingiana, Kze., Hk. Sp. 1. p. 61, supposed to be from Chili?

7. W. Caucasica, J. Sm.; fr. lanceolate, a span long, glanduloso-hirsute on the rachises and costce, firm-membranaceous, bipinnate; prim. pinnoe sessile, nearly opposite, lanceolate, broadest at the base, acuminato-pinnatifid or again pinnate; lobes or ult. pinnl. ohlong, acute, serrate; sori large, 2 on each lobe or pinnule, one on each side near the margin ; invol. globose, membranaceous, lax, at first apparently entire with a central depression, at length opening with a contracted, depressed, irregular and somewhat 2-lobed mouth.-Hk. $S p$. 1. p. 62 . Hymenocystis, C.A. Meyer.

Hab. Rare ; rocky places in the Caucasus, alt. 1,000-6,000 ft.

8. W. elongata, Hk.; glanduloso-pilose, especially above ; fr. a span to $1 \mathrm{ft} .1$., oblong, pinnated; pinnoe rather distant, alternate, sessile, from a broadish base, oblong obtuse, pinnatifid not more than half-way down; lobes short, rounded inciso-dentate, each bearing a sorus (rarely more) on the lower anterior veinlet, near the sinus; invol. lax, very membranaceous, globose, soon bursting with an irregular opening at the apex.-H.$S p$. 1.p.62.t.21. C.

Hab. N. W. India, alt. 10,000 ft. ; Edgeworth, Strachey, \& Thomson. 
9. W. polystichioides, Eat. ; fr. a span long, subcoriaceo-membranaceous, opaque, lanceolato-pinnate, sparsely subulato-squamulose; pinno patent, approximate, sessile, 6-8 in. l., lanceolate, acute, cuneato-truncate at the base, acutely auricled at the superior base, entire or obsoletely crenate at the apex, indistinctly costate, veins immersed, simple or forked; sori marginal in a distinct line or series ; invol. globose, of 4-5 concave, ciliated, incurved scales, strongly ciliated. $-H k$. 2nd Cent. of $F$. t. 2.- 3 . Veitchii ; fr. very villous. Hk. Gard. F.t. 32. ff. 1. 2. 4.6.$\gamma$. sinuata; pinnæ broader, more obtuse, lobato-pinnatifid. Hk. I. c. t. 32. $f .3$.

Hab. $a$. and $\beta$. Japan, Eaton \& Wilford.- $\gamma$. Manchuria, $a$. Ta-lien-kwan, Yellow Sea, China, Birnie.

10. W. Manchuriensis, Hk. ; fr. 6-8 in. l., thin, membranaceous, oblonglanceolate, acuminate, pinnated ; pinnce sessile, 1 in. or more l, rather remote, oblong-obtuse, pinnatifid ; lobes oblique, patent, ovate, obtuse, entire or slightly sinuate, unisorous; veins pinnated in each lobe, lower superior vein soriferous; invol. globose, thin, membranaceous, at length opening with a toothed edge to the contracted mouth.-Hk. 2nd Cent. of $F . t .98$.

Hab. Manchuria, Wilford.

11. W. Burgessiana, Gerr. mst. ; fr. 6 in. l., 2 in. w., lanceolate, glandulosepubescent, membranaceous, flaccid, pinnated; pinnoe sessile, from a broad truncated base, oblong, pinnatifid; lobes broad, subtruncated, toothed at the apex ; sori small, rather sparse, submarginal ; invol. thin, membranaceous, depressedhemispherical, sublobate (apparently from the long capsules within), opening irregularly at the apex, persistent, at length breaking down into a very irregular margin.

Hab. Tugela R., Natal, Gerrurd, McKen.

12. W. obtusa, Hk. ; fr. 6-10 in. l., broad-lanceolate, glabrous or minutely glanduloso-pilose, firm membranaceous, pinnate or bipinn.; prim. pinnce remote, subopposite, slightly petiolate, deltoideo-ovate, attenuated, obtuse, deeply pinnatifid, or the lower half again pinnate; lobes or pinnl. oval-oblong, toothed or inciso-lobulate; sori submarginal, one to each lobe or lobule; invol. very thin and fragile, soon breaking down into irregular or laciniated lobes.-Hk. Sp. 1. p. 63, and Gard. F. t. 43.-W. Perriniana, Hk. \& Gr. Ic. Fil. t. 68.- - . Lyallii; pinnl. and lobes smaller, bright green. $-\gamma$. andina; smaller and more coriaceous.

Hab. N. Mexico; U. States, to the Rocky Mountains. $\beta$. Brit. N. W. Am., Lyall. $\gamma$. S. Am., especially on the Andes. - I am a little doubtful about some of the S. Am. specimens, which I refer here, and which are smaller and more robust, and rarely, if at all, bipinnate; especially a "W. crenata and W. canescens," of Mandon, from Bolivia, alt. 2,700-3,800 mètres, "Cistopteris vestita, Pr.," from Brazil, and an unnamed plant from Venezuela, Funck \& Schlim, n. 981 :- the peculiarities may, however, arise from great elevation or other circumstances.

13. W. incisa, Gill. ; fr. broad-lanceolate, minutely glanduloso-pilose pinnated ; pinnce approximate, subopposite, sessile, oblong, obtusely attenuated, deeply pinnatifid, or sometimes again pinnate; lobes or pinnl. pinnatifidly lobed and toothed or incised, with obtuse teeth; sorus solitary on each lobule near the sinus; invol. glabrous, very thin and fragile, soon breaking down into spreading lobes.-Hk. \& Gr. Ic. F. t. 191. Hk. Sp. F. 1. p. 63. Physematium, Kze. Cheilanthes crenata, Kze. Hk. Sp. F. 2. p. 86.

Hab. Argentine Republic, Mendoza, San Luis Cordova, and Villavincenzia.

14. W. Peruviana, Hk. ; fr. oblong-lanceolate, piloso-glandulose, bipinnate ; prim. pinnce nearly opposite, remote, sessile, ovato-acuminate ; pinnl. opposite or rarely alternate, oblong, obtuse, sessile and decurrent, so that the rachis is winged, somewhat pinnatifid with shallow bicuspidate lobes; sorus solitary in 
each lobe, subglohose, at first entire, soon bursting with an irregular mouth and breaking down into lobes and segments; st. and main rachis glabrous.IIh. Sp. 1. p. 61.f.21. B.

Hab. Andes of Peru.-Perhaps too near some of the Andine forms of $W$. obtusa.

\section{Gen. 12. Spharopteris, Wall.}

Sori globose, on the back of a vein or veinlet. Recept. large. Invol. inferion globose, coriaceous, stipitate, at first enclosing the whole sorus, at length bursting vertically into 2 spreading lobes or lips. Tав. I. f. 12.

1. S. barbata, Wall. Pl. Asiat. Rar. 1. t. 18. Hk. Sp. 1. p. 58. Peranema, Don.

Hab. Nepal, Sikhim, Khasya (Hk. $f$. and Thoms.), Western Ghats of Nilghiri, Beddome.-Fr. 2-3 ft. 1., tripinnate. Pinnl. oblong, deeply pinnatifid.

\section{Gen. 13. Dicksonia, L'Hérit.}

Sori placed at the apex of a vein, intra-marginal. Invol. inferior, subglobose, enriaceous or membranaceous, cup-shaped and entire, or more or less distinctly 2-valved.-About half the species are arborescent, with large decompound coriaceous fronds; the others have creeping rhizomes, and, with two exceptions, are at least fullybipinnate. They principally inhabit Tropical America and Polynesia; but one species reaches as far north as Canada, and several others are scattered throughout the southern parts of the Temperate Zone. Veins in all free. TAB. II. f. 13.

$\$$ Cibotium, Kaulf.-Involucre distinctly 2-valved, the outer value coriaceous, distinct from the substance of the frond. Sp. 1-5.

1. D. (Cibotium) glauca, Smith ; arborescent ; fr. bipinnate, ovate-lanceolate, 12-18 in. 1., 6-9 in. br. ; pinnl. linear-acuminate, cut quite down to the rachis in the lower part; lobes linear-oblong, subfalcate ; texture subcoriaceous ; surface naked on both sides, glaucous beneath; veins prominent; lateral veins of the segments once or twice forked; sori 2 to 12 to a lobe, inner valve oblong, narrower than the outer.-Hk. Sp. Fil. 1.p. 82.t.29. A.

Hab. Oahu, Sandwich Islands, discovered by Menzies eighty years ago.

2. D. (Cibotium) Barometz, Link ; arborescent ; fr. bipinnate ; lower pinnoe ovate-lanceolate, 1-2 ft. l., 6-12 in. br. ; pinnl. linear-acuminate, cut down within a short distance of the rachis above, and sometimes quite down to it at the base; segm. linear-oblong, acute, subfalcate ; texture subcoriaceous ; upper surface naked, shining, lower glaucous, sometimes furfu raceous; veins prominent ; lateral veins of the segments rarely forked; sori 2 to 12 to a lobe, the valves nearly equal, transversely oblong.-C. glaucescens, Hk. Sp. Fil. 1. p. 82. C. Assamicum, Hk. Sp. Fil. 1.p. 83. t. 29. B.

Hab. Assam, S. China, Malayan Peninsula and Islands.

3. D. (Cibotium) Menziesii; arborescent ; fr. bipinnate ; lower pinnoe 12-18 in. 1., 6-9 br. ; pinnl. linear-acuminate, cut down usually not more than half-way to the rachis ; lobes rounded, blunt; texture subcoriaceous ; surface naked on both sides, not glaucous beneath; veins prominent; lateral veins of the segments simple or forked ; sori 2 to 8 , rows with a broad space between them; inner valve narrower than the outer, oblong. - $H k$. Sp. Fil. 1. p. 84.t. 29. C.

Hab. Oahu and Honolulu, Sandwich Islands. 
4. D. (Cibotium) Chamissoi ; arborescent ; fr. bipinnate ; lower pinnoe ovatelanceolate, 12-18 in. 1., 6-9 in. br. ; pinnl. linear-acuminate, cut down to the rachis below; segm. oblong, bluntish, scarcely falcate; texture coriaceous; under surface not glaucous, sometimes furfuraceous; veins immersed; lateral veins of the segments usually once forked; sori 2 to 12 to a lobe ; valves unequal, outer one larger, suborbicular, inner one oblong.-Hk. Sp. Fil. 1. p. 83.

Hab. Oahu, Sandwich Islands.

5. D. (Cibotium) Schiedei ; arborescent ; fr. bipinnate, ovate-lanceolate, 12-18 in. 1., 6-9 in. br.; pinnl. linear, much acurninated, cut down nearly or quite to the rachis; lobes narrow, linear, acute, subfalcate; texture subcoriaceous ; upper surface shining, dark-green, under side glaucous or arachnoid; veins not prominent; lateral veins of the segments usually once forked; sori 2 to 12 to a lobe, the valves short, hemispherical, nearly equal.-Hk. Sp. Fil. 1.p. 84.t. 30. A.

Hab. Mexico and Guatemala.-All the five species appear to resemble one another very closely. The caudex of this is said by Galeotti to attain a height of from 10-15 ft.

$\$ \$$ Eudicksonia. Involucre distinctly 2-valved, the outer valve formed by the apex of a segment. Sp. 6-17.

6. D. arborescens, L'Hérit.; arborescent ; fr. bipinnate ; lower pinnce 12-18 in. l., 6-9 in. br.; pinnl. linear, cut down nearly or quite to the rachis ; segm. $\frac{1}{2}$ in. l., $\frac{1}{4}$ in. br., oblong; rachises tomentose throughout, the main one densely clothed at the base with linear ferruginous scales; texture very coriaceous; fertile pinnl. often conspicuously contracted; sori 2 to 6 to a lobe, large, globose; valves transversely oblong, nearly equal.-Hk. Sp. Fil. 1. p. 66. t. 22. A.

Hab. St. Helena, near the summit of Diana's Peak ; caudex about $10 \mathrm{ft}$. high.

7. D. antarctica, Labill. ; arborescent ; fr. bipinnate ; lower pinnce 12-18 in. l., 6 in. br. ; pinnl. linear-acuminate, cut down to the rachis except at the apex; segm. linear, acute, pinnatifid sometimes nearly to the rachis, $\frac{1}{4}-\frac{1}{2}$ in. 1 , $\frac{1}{8}$ in. br. ; rachises naked or tomentose; texture coriaceous; upper surface naked, under naked or more or less hairy, not glaucous ; fertile pinnl. slightly contracted; sori 2 to 12 to a lobe, $\frac{1}{2}$ a line across; valves suborbicular._Hk. Sp. Fil. 1. p. 66. D. fibrosa, Colenso, Hk. Sp. Fil. 1. p. 68. t. 33. B. D. lanata, Colenso, Hk. Sp. Fil. 1. p. 69. t. 33. C.

Hab. E. Australia, Van Diemen's Land, New Zealand, and New Caledonia.-Trunk attaining $30-35 \mathrm{ft}$. ; $f r .2-3$ yrds. $1 ., 2-2 \frac{1}{2} \mathrm{ft}$. across ; stems densely clothed at the base with silky yellowish-brown fibres; segm. often so narrow that the two rows of sori are quite contiguous.

8. D. chrysotricha, Moore ; arborescent ; fr. bipinnate ; lower pinnoe 12-18 in. 1. 6-9 in. br. ; pinnl. linear, quite cut down to the rachis except towards the apex; segm. linear-oblong, deeply toothed, $\frac{1}{2}$ in. 1., 2 lines br., bluntish; main rachis clothed with a thick coat of shining yellowish-brown hairs at the base ; rachis of the pinne and pinnules asperous and rather thickly tomentose; texture coriaceous ; fertile pinnl. slightly contracted; sori 2 to 6 to a lobe, $\frac{1}{2}$ a line across ; valves suborbicular.-Balantium chrysotrichum, Hassk. Cibotium speciosum, Blume. D. Blumei, Mett. D. magnificum, De Vriese.

Hab. Java, ascending to $11,000 \mathrm{ft}$.-Probably this is D. Javanica, Blume (Hk. Sp. Fil. 1. p. 78), and if so, this is the oldest name.

9. D. Sellowiana, Hk. ; arborescent ; fr. 6-8 ft. 1., 2-3 ft. br., lanceolate, bipinnate ; lower pinnce 12-18 in. l., 6-9 in. br. ; pinnl. linear, quite cut down to the rachis in the lower part; segm. $\frac{1}{2}$ in. 1 ., less than $\frac{1}{4}$ in. br., linear-oblong, acute, 
subfalcate ; main rachis usually smooth above, densely tomentose and subasperous below ; texture coriaceous ; fertile pinnl. slightly contracted; sori 2 to 6 to a lobe, $\frac{1}{2}$ a line across; valves suborbicular.-Hk. Sp. Fil. 1.p.67.t.22. B. B. Kalstenianum, Klotzsch.

Hab. Tropical America, from Guatemala southward to Brazil and Peru.-Caudex 15-30 ft. high, $1 \mathrm{ft}$. thick ; "stipes $\frac{1}{2}-2 \mathrm{ft}$. 1., so densely clad with long fulvous hairs, changing to brown or blackish, as to precisely resemble the thighs of the howling monkey."-Spruce.

10. D. squarrosa, Swartz ; arborescent ; fr. bipinuate ; lower pinnoe 12-18 in. 1 ., 6-9 in. br. ; pinnl. of the barren frond linear-acuminate, cut down within a short distance of the rachis above, quite to it below ; segm. $\frac{1}{2}$ in. l., $\frac{1}{4}$ in. br., with close mucronate teeth reaching about half-way down ; rachis rough with raised points, densely clothed below with long, shining, light-brown hairs; second. rachis also dark-brown and asperous; texture coriaceous ; fertile pinnl. much contracted, cut down nearly to the rachis; sori 2 to 12 to a lobe, $\frac{1}{2}-\frac{3}{4}$ line across ; valves suborbicular.-Hk. Sp. Fil. 1. p. 68.

Hab. New Zealand ; Richmond River, N. S. Wales, C. Moore (D. Youngice, C. Moore, MSS.). - "Trunk attaining 10-12 ft., slender, never more than 4 in. in diameter" (C. Moore). Fronds about 1 yrd. l., $\frac{1}{2}$ yrd. across.

11. D. Berteroana, Hk. ; arborescent ; fr. bipinnate; lower pinnoe $1 \mathrm{ft}$. l., about 6 in. br.; pinnl. of the barren frond linear-acuminate, cut down to the rachis except at the very apex; segm. $\frac{1}{2}-\frac{3}{4}$ in. l., $\frac{1}{4}$ in. br., subfalcate, nearly entire or broadly and bluntly toothed; texture coriaceous; rachis nearly naked, slightly asperous; fertile segm. consisting only of 2 to 8 stipitate sori with hardly any connecting membrane ; valves of the invol. suborbicular, nearly equal.--Hk. Sp. Fil. 1. p. 67. t. 23. A. D. thyrsopteroides, Mett.

Hab. Juan Fernandez, Samoa, Fiji, and New Caledonia.-Trunk attaining a height of $15 \mathrm{ft}$. This and the five preceding form a well-marked natural group, to which J. Smith restricts the name Dicksonia; but the present is very distinct by the character of the fertile frond, connecting the others with Thyrsopteris; but here sometimes there are barren and fertile segments in the same pinnule.

12. D. Culcita, L'Hérit.; roots from a thick rhizome, densely clothed with shining ferruginous hairs ; fr. 12-18 in. $1 ., 1 \mathrm{ft}$. br., tripinnate ; lower pinnl. deltoid, their divisions ovate, cut down to the rachis in the lower part, with oblongrhomboidal unequal-sided deeply-toothed segments, which are cuneate at the base on the lower, truncate on the upper side; texture subcoriaceous; rachises nearly naked; both surfaces naked; fertile fr. so much contracted that there is very little membrane between the sori, which are 1 line across, with reniform subequal valves.-Hk. Sp. Fil. 1.p.70. Balantium, Kaulf., J. Sm.

Hab. Madeira and the Azores; so abundant that the dense woolly covering of the rhizome has now become an article of commerce.

13. D. coniifolia, Hk.; fr. tripinnate ; lower pinnce 12-18 in. l., 12 in. br.; lower divisions of the pinnl. deltoid-acuminate, their segments cut down nearly to the rachis, with ovate-rhomboidal, bluntish, deeply-toothed lobes ; texture herbaceous; upper surface naked, lower and the rachises slightly hairy; sori 2 to 8 to a lobe, a line across ; valves equal, reniform, several times broader than deep. -Hk. Sp. Fil. 1. p. 70. t. 24. A. D. Martiana, Klot. Hk. Sp. Fil. 1. p. 70. t. 24. B.

Hab. Jamaica and Columbia, southward to Brazil.-A much more divided plant than any of the preceding, with sharply-cut acute ultimate segments, not more than $\frac{1}{4}-\frac{8}{8} \mathrm{in} .1$,, $\frac{1}{8}$ in. br.

14. D. dubia, Gaud. ; fr. tri-quadripinnate ; lower pinnce 1-2 ft. 1., $1 \mathrm{ft}$. br. ; 
lower divisions of the pinnl. deltoid-acuminate, their segments cut down to the rachis, except at the very apex, with ovate-rhomboidal, acute, sharply- and deeply-toothed lobes; texture coriaceous; upper surface naked, lower naked or somewhat hairy; sori 2 to 12 to a lobe, minute, orbicular ; the outer valve large, cucullate, the inner one inconspicuous.-Hk. Sp. Fil. 1. p. 71. t. 24. C. D, straminea, Labill., Hk. Sp. Fil. 1. p. 71. D. Torreyana, Brack.t. 38.f. 2.

Hab. S. Australia, Van Diemen's Land, New Caledonia, Aneiteum, Fiji group and ather Polynesian islands.-Nearest to $D$. coniifolia, but easily distinguishable by its coriaceous texture, minute sori, and very narrow and sharp ultimate segments.

15. D. Plumieri, Hk.; fr. hipinnate ; lower pinnoe 12-18 in. 1., 6-9 in. br.; lower pinnl. lanceolate-triangular, 6-8 ill. 1., 2-3 in. br., cut down at the lower part to the rachis, with linear-acuminate broadly-toothed segments; upper pinnl. linear only, slightly lobed; rachis and surface quite naked; texture herbaceous ; lateral veins of the segments simple or once or twice forked; sori 2 to 20 to a segment ; invol. small, membranaceous, suborbicular, deeply 2-valved, the outer valve at length cucullate.-Hk. Sp. Fil. 1. 72. D. Lindeni, Hk.Sp. Fil. 1. 72. t. 25. B. Davallia adiantoides, Swartz, Grisebach. Cibotium, Presl.

Hab. West Indian Islands and Columbia.-At first the involuere is that of a Davallia rather than a Dicksonia, but the outer valve is ultimately hooded. Adiantoides is the oldest specific name, but there is already a $D$. adiantoides, H. B. K.

16. D. sorbifolia, Smith ; fr. bipinnate ; lower pinnoe about $1 \mathrm{ft} .1 ., 3-4$ in. br. ; pinnl. slightly stalked, linear, truncate or cordate at the base, undivided, with small sharp serrations towards the apex ; rachis naked or slightly hairy; texture subcoriaceous; lateral veins of the segments usually once forked; sori very numerous to a pinnule; invol. subglobose, membranaceous; outer valve cucullate. -Hk. Sp. Fil. 1. p.72.t.25. A.

Hab. Moluccas and Isle of Henimae, Hindostan.

17. D. abrupta, Bory ; fr. simply pinnate, 12-18 in. 1., 4-6 in. br.; pinnce sessile, lanceolate, hardly toothed, the lower about 3 in. $1 ., 1$ in. br., the two halves rather unequal, the base of the upper one truncate, that of the lower slightly auriculate; rachis naked; texture coriaceous ; veins close, fine, inconspicuous ; fortile pinnoe narrow, acuminate; sori numerous, placed along both edges; outer valve reniform, nearly a line broad, inner smaller, suborbicular.-Hk. Sp. Fil. 1. p. 72 . Nephrolepis, Mett. Leptopleuria, Presl.

Hab. Bourbon.-Very like Nephrotepis davallioides in habit and general appearance.

§§ Patania, Prest. Dennstædia, Bernh., Moore. - Involucre cup-shaped, not at all or only very indistinctly 2-valved. Sp. 18-29.

\section{* Fronds ample; lower pinnce 9-24 in. in length. Sp. 18-25.}

18. D. adiantoides, H, B. K.; rhizome creeping; fr. bipinnate; lower pinnce 12.24 in. 1., 6-12 in. br.; pinnl. linear, cut down in the lower part nearly to the rachis ; the segm. oblong-rhomboidal, blunt, with 2 to 4 bluntish lobes in each side, which do not reach half-way to the rachis; texture herbaceous, under surface and rachises finely hairy; sor $i 2$ to 8 to a segment, placed at the base of the sinuses, about $\frac{1}{2}$ line across; invol. cup-shaped.-Hk. Sp. Fit. 1. p. 75. $t$. 26. B. D. erosa, Hk. Sp. Fil. 1. p. 75. D. obtusa, Moritz. D. consanguinea, Klotzsch. D. dissecta, Grisebach, nou Hooker.

Hab. Tropical Ameriea, from the West Indies southward to Brazil.-Fronds often $12 \mathrm{ft}$. 1. ; segments of the lower pinnules $\frac{8}{4}-1$ in. $1 ., \frac{1}{2}$ in. br. D. Sprucei, Moore, seems closely allied to this; but our specimens are very imperfect. 
19. D. cicutaria, Swartz ; rhizome creeping ; fr. bipinnate ; lower pinnoe 12-18 in. l., 6 in. br. ; pinnl. linear-acuminate, cut down in the lower part nearly or quite to the rachis; segm. oblong-deltoid, deeply inciso-pinnatifid; texture herbaceous; under surface and rachises naked or finely hairy; sori 2 to 12 to a segment, placed at the base of the sinuses, about $\frac{1}{2}$ line across ; invol. cup-shaped. -Hk. Sp. Fil. 1. p. 76. non Grisebach. D. tenera, Presl. D. ordinata, Kaulf. Hk. Sp. Fil. 1.p.75. D. cornuta, Kaulf. Hk. Sp. Fil. 1.p. 76.

Hab. Tropical America, from Mexico and the West Indies southward to Rio Janeiro and Peru.- Segments of the lower pinnules about 1 in. $1 ., \frac{1}{2}$ in. br. Closely allied to the preceding, from which it differs by its sharper and more divided segments : these two are bipinnate only, all the other ample-fronded Dennstedice being tripinnate.

20. D. apiiffolia, Swartz; fr. tripinnate ; lower pinnoe 12-18 in. 1.,6-9 in. br. ; pinnl. linear, quite cut down to the rachis throughout; lower segm. deltoid or oblongrhomboidal, cut down very nearly to the rachis in the lower half, with deeplyand sharply-toothed lobes; texture herbaceous; rachis and both surfaces naked or nearly so, shining; sori 2 to 12 to a segment, placed at the bottom of the sinuses of the lobes; invol. subglobose, cup-shaped, $\frac{1}{3}$ line acrose. $-H k$. Sp. Fil. 1. p. 77.t. 26. C.

Hab. Andes of Ecuador and Peru.-A fully tripinnate plant with shining bright-green subrigid fronds, the lowest segments 1 in. l., $\frac{1}{2}$ in. br. According to Grisebach, this is the $D$. cicutaria of Swartz; but I have not seen West Indian specimens. Sitolobium samoense of Brackenridge, tab. 38, is described as closely allied to this species.

21. D. rubiginosa, Kaulf. ; fr. tripinnate ; lower pinnoe 12-18 in. 1., 6-9 in. br. ; pinnl. linear, quite cut down to the rachis throughout; lower segm. deltoid or oblong-rhomboidal, deeply inciso.pinnatifid; texture herbaceous; rachis and under surface finely tomentose; sori 2 to 12 to a segment, placed at the base of the sinuses ; invol. cup-shaped, subglobose, $\frac{1}{3}$ line across. - Hk. Sp. Fil. 1. p. 79. t. 27. A. D. dissecta, Hk. Sp. Fil. 1. p. 77. $\beta$. D. anthriscifolia, Kaulf.; segm. larger and more divided; rachis and under surface nearly naked.- $H k$. Sp. Fil. 1.p. 79. t. 27. B.

Hab. Tropical America, from Mexico and the West Indies southward to Brazil and Peru (both varieties), Bourbon and Mauritius.-A less elegant plant than D. apiifolia, duller in colour, and with the under surface more or less hairy. Rachises slightly asperous ; lower segments $\frac{1}{2}-1$ in. 1 .

22. D. flaccida, Swartz ; fr. tripinnate ; lower pinnoe 9-15 in. 1., 6 in. br.; pinnl. lanceolate, quite cut down to the rachis throughout; lower segm. ovaterhomboidal, bluntish, cut down nearly to the rachis three or four times on each side, and the lobes again toothed; texture herbaceous; rachises densely tomentose ; sori 2 to 8 to a segment, placed at the base of the sinuses; invol. subglobose, cup-shaped, $\frac{1}{4}$ line across.-Hk. Sp. Fil. 1. p. 77.

Hab. Aneiteum and New Hebrides, Milne.-Perhaps not distinct from D. rubigino a, with which it quite corresponds in the size and division of the froud, but the habit is more rigid, and the rachises are densely tomentose throughout. The Cocos Island plant is D. rubiginosa.

23. D. Moluccana, Blume ; fr. tripinnate ; lower pinnoe 12-18 in. 1., 6-9 in br.; pinnl. linear-lanceolate, quite cut down to the rachis throughout; lower segm. oblong-rhomboidal, cut down to the rachis in the lower part, with blunt, oblongdeltoid lobes; texture subcoriaceous; main and second. rachises prickly; sori 2 to 12 to a segment; invol. subglobose, $\frac{1}{4}$ line across.-Hk. Sp. Fil. 1.p. 78.

Hab. Java.-Resembling D. rubiginosa in habit, but more coriaceous in texture, and the stems thickly furnished with strong hooked prickles. Lower segments $\frac{3}{4}-1$ in. l., $\frac{1}{2}$ in. br. D. scandens of Blume, also from Java, which is probably D. Zippeliana, Kunze, 
is said to differ from this by its more flaccid fronds, and in the larger teeth of the segments ; and a plant (probably the same) was gathered in Tahiti by the American expedition under Captain Wilkes. (See Brackenridge, p. 275.)

24. D. davallioides, R. Brown ; fr. tripinnate ; lower pinnoe 6-9 in. 1., 3-4 in. br.; pinnl. linear-acuminate, cut quite down to the rachis ; segm. oblong-rhomboidal, deeply inciso-pinnatifid ; rachis shining, not prickly, glabrous or nearly so ; texture herbaceous, under surface slightly hairy; sori 2 to 8 to a segment, placed at the base of the sinuses; invol. subglobose, cup-shaped, $\frac{1}{4}$ of a line across. -Hk. Sp. Fil. 1.p. 71. D. nitidula, Kunze, Mett. Fíl. Lips. t. 28.

Hab. Australia, both temperate and tropical. - Habit of growth lax, and texture of the frond thinner than in any of the other species. Fronds $2-4 \mathrm{ft}$. 1 . ; lower segments under $\frac{1}{2}$ in. 1., 2-3 lines br., and finely cut. The Philippine Island D. cuneata (Hk. Sp. Fil. 1. p. 80 . t. 28. C.) seems to be a form of this with broader segments than usual.

25. D. Smithii, Hk. ; fr. tripinnate ; lower pinnoe 9-12 in. 1., 3-4 in. br. ; pinnl. linear-acuminate, cut down to the rachis throughout, with rather distant, narrow, acute segments ; lower segm. $\frac{1}{2}$ in. l., 2 lines br.; rachises slightly inciso-pinnatifid; and under surface densely tomentoso-glandular; texture subcoriaceous ; sori 2 to 8 to a segment; invol. subglobose, cup-shaped, $\frac{1}{4}$ line across.-Hk. Sp. Fil. 1. p. 80.t. 28. $\mathrm{D}$.

Hab. Philippine Islands, Cuming.-Rachises similar to those of D. flaccida, but pin. nules narrower and segments much smaller and less divided.

\section{** Entire frond not more than 12-18 in. long. Sp. 26-29.}

26. D. obtusifolia, Willd. ; rhizome creeping; fr. 12-18 in. $1 ., 9$ in. br. at the widest part, simply pinnate only, oblong-lanceolate ; pinnoe linear, 4-5 in. 1. , 1 in. br., cut in the lower part $\frac{3}{4}$ down to the rachis into oblong-quadrangular blunt lobes, with 2 or 3 shallow blunt teeth on each side ; texture membranaceous; rachises tomentose; sori 2 to 6 to a pinnule; invol. subglobose, cupshaped, nearly $\frac{1}{2}$ lin. across.-D. Pavoni, Hk. Sp. Fil. 1. p. 74. t. 26. A.

Hab. Andes of Peru, Barclay.-This coincides with $D$. adiantoides in the shape of the lobes, but is simply pinnate only, so that a single large pinna of adiantoides equals in size and division the whole frond here.

27. D. scabra, Wall.; fr. 9-15 in. 1., 6-9 in. br., deltoid or lanceolate, bipinnate ; lower pinnoe 4-8 in. l., lanceolate ; pinnl. quite distinct, 1-1 $\frac{1}{2}$ in. 1., $\frac{1}{2}$ in. br., the lower ones cut down nearly to the rachis into numerous pinnatifid oblong deltoid segments on both sides; texture herbaceous or subcoriaceous; rachis and under surface more or less hairy; sori 2 to 6 to the lower segments; invol. cup-shaped, subglobose, $\frac{1}{4}$ line across.-Hk. Sp. Fil. 1. p. 80.t. 27. B. D. deltoidea, Hk. Sp. Fil. 1.p. 80.t. 27. A. Sitolobium strigosum, J. Sm.

Hab. India, from the Himalayas to Ceylon, Malayan Peninsula.-Stipe sometimes $1 \mathrm{ft}$. l., asperous, very hairy below; rhizome wide-creeping.

28. D. punctiloba, Hk.; fr. 12-18 in. 1., 6-9 in. br., lanceolate, bipinnate ; lower pinno lanceolate, 4-6 in. l., cut quite down to the rachis except at the top ; pinnl. ovate-rhomboidal, about $\frac{1}{2}$ in. $1 ., \frac{1}{4}$ in. br., deeply pinnatifid ; texture thinly herbaceous; rachis and under surface more or less glanduloso-pilose ; sori 2 to 12 to a pinnule, placed at the base of the sinuses ; invol. subglobose, cup-shaped, $\frac{1}{4}$ line across. - Hk. Sp. Fil. 1. p. 79.

Hab. Temperate N. America, from Canada southward to Carolina and Tennessee.

29. D. appendiculata, Wallich ; fr.12-18 in. 1., 6 in. br., lanceolate, bipinnate ; lower pinno linear-lanceolate, $3-4$ in. l., cut down quite to the rachis unless at 
the apex; pinnl. linear-oblong, $\frac{1}{2}$ in. 1., little more than 2 lines br., pinnatifid within a short distance of the rachis into numerous linear lobes; texture herbaceous ; rachis and under surface glanduloso-pilose; sori 2 to 16 to a pinnule, placed at the base of the sinuses ; invol. cup-shaped, globose, $\frac{1}{4}$ line across. $-H k$. Sp. Fil. 1. p. 79. t. 27. C.

Hab. Nepaul and Kumaon.-This and the preceding resemble in habit Athyrium filix-famina. Species 13 to 29, except 17, fall under the genus Sitolobium of J. Smith, and have creeping rhizomes.

\section{Gen. 14. Deparia. Hook. \& Grev.}

Sori protruded from the margin of the frond, or even stipitate. Invol. shallowly-cupshaped, membranaceous, not 2-valved. - Three very rare tropical species with broad, ample leafy segments, which differ from Dennstædia mainly by thcir extramarginal sori. Veins anastomosing in one of the species (Cionidium, Moore).

1. D. prolifera, Hk. ; fr. once fully pinnate ; lower pinnoe about 6-9 in. 1., 1-1 $\frac{1}{2}$ in. br., pinnatifid down throughout within a short distance of the rachis; lobes oblong, slightly toothed, with often a space equalling their breadth between them ; lateral veins of the lobes all simple ; texture herbaceous ; sori 4 to 12 to a lobe, extra-marginal, sessile or stipitate-Hk. Sp. Fil.1.p. 85 ; Fil. Exot. t. 82. D. Macraei, H. \& G. Ic. Fil. t.154.

Hab. Sandwich Islands.

2. D. concinna; fr. once fully pinnate; lower pinnoe more than $1 \mathrm{ft}$. l., nearly 2 in. br., cut down to the rachis in the lower part, but becoming nearly entire towards the apex ; lobes blunt, entire, broadly oblong-rhomboidal, unequal-sided and decurrent downwards; lateral veins of the lobes once or twice branched; texture subcoriaceous; sori 2 to 6 to a lobe, placed round the outer edge.Davallia concinna, Presl. Hk. Sp. Fil. 1.p. 74. Deparia Matthewsii, Hk. Sp. Fil. 1. p. 75. t. 30. B.

Hab. Peru, gathered by Matthews and Spruce.-This resembles closely Dicksonia adiantoides in habit. It bas the lower part of the sori included within the margin, and is placed by Moore in Dennstcedia.

3. D. Moorei, Hk. ; fr. 12-18 in. 1., 6-9 in. br., cordate-deltoid in general outline, pinnate below, pinnatifid only above ; lower pinnoe 6-9 in. 1., 4-6 in. br., cut down to the rachis below into deeply-pinnatifid broadly-toothed lobes; veins anastomosing ; texture thinly herbaceous ; sori copious, extra-marginal or stipitate.-Hk. Exot. Ferns, t. 28. Cionidium, T. Moore. Trichocarpa, J. Smith.

Hab. New Caledonia, gathered by $C$. Moore and Lenormand.-A much smaller plant than the others, with thin, broad, leafy fronds and anastomosing venation.

\section{Tribe III. Hymenophylles (including Loxsoma).}

Sori terminal or marginal from the apex of a vein. Recept. elongated, often filiform and long, and exserted more or less, especially below clothed with sessile orbicular imbricated subpeltate compressed capsules, surrounded by a complete transverse ring, opening vertically. Invol. inferior, various in shape, generally of the same texture as the frond. Small often epiphytal Ferns, herbaceo-membranaceous, more or less laxly cellular, variously costate and veined. Caudex frequently long-creeping, and filiform. (In Loxsoma the oblique ring of the subpedicellate capsule is incomplete; the fronds are coriaceous.) GEN. 15-17. 


\section{Gen. 15. Loxsoma, $B r$.}

Sori marginal, in the sinus of the teeth or lobes, terminating a vein, declined. Invol. suburceolate, coriaceous, the mouth truncated, entire. Recept. elongated, much exserted, clothed to the apex with stipitate caps. (mixed with jointed hairs), which have a short broad incomplete oblique ring, opening vertically. Caudex long, stout, creeping, paleaceous. Fr. long-stipitate, coriaceous, decompound, glaucous beneath. Veins simple or forked. Tав. II. f. 15.

\section{L. Cunninghami, Br. Sp.p. 86. Gard. F.t. 31.}

Hab. N. Zealand; Northern Island.-Fr. 1-1 $\frac{1}{2} \mathrm{ft}$. high. A remarkable Fern, with the babit of a coriaceous Dicksonia; the fructification rather of Trichomanes, but with a very short and oblique ring to the capsule.

\section{Gen. 16. Hymenoph yLuU.}

Sori marginal, more or less sunk in the frond or exserted, terminating a costa or vein. Invol. inferior, more or less deeply 2-lipped or 2-valved, of nearly the same texture as the frond, toothed, or fringed, or entire. Recept. elongated, columnar, exserted or included. Caps. mostly orbicular, depressed, attached by the centre, furnished with a broad transverse ring, opening irregularly at the apex. Small, sometimes very minute Ferns, of tropical and temperate climates, frequenting trunks of trees and damp rocks, the fronds delicately membranaceous in texture, often of a lurid or olivaceous green, simple or compound, costate or with simple or branched (never anastomosing) veins. † TAB. II. f. 16. Sp. 1-5.

* Fronds glabrous, simple or slightly lobed, or once or twice dichotomous.

1. H. cruentum, Cav.; st. slender, naked, 3-6 in. l. ; fr. ovate-lanceolate, slightly sinuated, 3-5 in. l., 1-1 $\frac{1}{2}$ in. br. below; the veins simple, prominent, branching from the costa to the margin at regular intervals, erecto-patent; sori 6-12 on each side, placed at the apex of the sinuations, the cuneate base sunk in the frond, the lips divided about half-way down, free, entire.-Hk. Sp. Fil. 1. p. 87. t. 31. A. Hymenoglossum, Presl.

Hab. Chili, especially in the province of Valdivia.-Quite peculiar in its habit of growth.

2. H. parvifolium, Baker ; st. not more than 1 line 1.; fr. very minute, 2-3 lines l., 1 line br., linear-oblong, simple or cleft at the apex, sometimes half-way

+ The principal, or at any rate the most copious, recent writer on Trichomanes and Hymenophyllum is the late Dr. Van den Bosch, whose magnum opus, the "Hymenophyllaceæ Javanicæ," contains engravings of many of the species, which, in point of beauty and delicacy of execution, have rarely been equalled. But his views, and their practical carrying out with regard to the limitation of genera and species, were the very opposite of those of Sir William Hooker, as may be judgel from the fact that in his Synopsis and Supplement, 450 so-called species are given, and that out of what are here considered two genera, be makes twenty-four. Upon this point Sir William Hooker wrote : "This genus and the following one have had their species multiplied to an extent with which I cannot at all concur. The late learned Dr. Van den Bosch, in his widely-scattered publications, has no doubt described many new species, which it has not been in my power to identify ; but baving been favoured with his opinion on a large portion of my collection, I regret to be compelled to join with my friend Dr. Grisebach in the opinion expressed in his 'Flora of the British West-Indian Islands,' that many of the species are not well founded." 
down, furnished only with a central costa and a few faint irregular free spurious venules, the margin not thickened; sori solitary, terminal, the cuneate base sunk in the frond, divided about halfway down; valves rounded, entire.-Baker, in Linn. Procecd. inedit. cum icone.

Hab. Moulmeine, Rev. C. S. Parish.-The smallest and simplest species of the genus, rivalling in minuteness Trichomanes Barklianum and Vitiense.

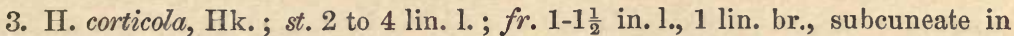
circumscription, two or three times dichotomously divided; segm. linear-oblong, emarginate, with only a single central costa in each ; sori solitary, terminal, the cuneate base sunk in the frond, the semi-orbicular lips free--Hk. in Thwaites Enum. Pl. Ceyl. p. 397.

Hab. Ceylon, on trees, Gardner, Thwaites.-Very like H. marginatum in habit, but thinner in substance, darker in colour, the pagina nearly flat, and the margin not thickened.

4. H. marginatum, Hk. \& Gr. ; st. 2-4 lin. 1. ; fr. linear, once or twice forked, about 1 in. l., 1 lin. br., furnished with a central costa; texture firm; margin bounded by a thickened line, the apex emarginate; sori terminal, solitary, suborbicular, divided down nearly to the base, with convex entire valves. $-H k . \& G r$. Ic. Fil.t. 34. Hk. Sp. 1. p. 87. Pachyloma, V. D. B.

Hab. Port Jackson, Australia, rare.-Substance of the frond undulated.

5. H. asplenioides, Sw. ; st. 1-2 in. 1., slender ; fr. 2-4 in. 1., by $\frac{1}{2}-1$ in. br., pendulous, oblong in general outline, pinnatifid to within a short distance of the rachis; lower lobes rhomboidal-cuneate, cleft on both sides or one only; upper lobes simple, linear-oblong; sori 1-4, terminal on the segments of the lobes; invol. orbicular, free, cleft nearly to the base.-Hk. Sp. 1.p.87. Ic. Pl. t. 957.

Hab. Tropical America, from Cuba and Mexico southward to Brazil.-Easily recognizable by its peculiar habit of growth.

\section{* Fronds glabrous, one to four times pinnatifid.--Sp. 6-30.}

6. H. abruptum, Hk.; st. about $\frac{1}{4}$ in. 1 , very slender ; fr. $\frac{1}{2}-1$ in. $1 ., \frac{1}{4}-\frac{1}{2}$ in. br., oblong, pinnatifid to within a short distance of the main rachis; pinnoe linear, erecto-patent, about $\frac{1}{4}$ in. $1 ., 1$ lin. br., sometimes dichotomously forked, only a central midrib in each division; sori 1 or 2 to a frond, terminal on the apex or upper segments; invol. not divided more than halfway down, the base cuneate, the valves rounded; recept. occasionally protruded.-Hk. Sp. 1. p. 88. t. 31. B. H. brevifions, Kunze.

Hab. Jamaica, Cuba, Guatemala, Venezuela, and Brazil.-Allied to H. rarum, but the main rachis has a broader wing below, and the pinnæ are at most simply forked.

7. H. mnioides, Baker; st. not more than $\frac{1}{2}$ in. 1., very slender ; fr. 1-2 in. 1 ., $\frac{1}{4}$ in. br., linear, once pinnatifid; rachis winged throughout; the segm. all quite simple, linear, the lower ones slightly imbricated, erecto-patent, 2 lin. 1 ., $\frac{1}{2}$ lin. br, the upper ones pressed close to the rachis and much imbricated; sori solitary on three or four of the upper segments, large compared with the size of the plant, divided about halfway down, the base campanulate; valves more than half a circle, large, membranaceous.

Hab. New Caledonia, Pic du Mont Mu, Deplanche.-A minute moss-like plant, with the habit of Mnium undulatum or serratum, but dark-brown in colour. It is allied to the preceding and the following, but whilst the segments are quite simple, the main rachis is scarcely winged below. 
8. H. rarum, R. Br. ; st. very slender, 1-3 in. l. ; fr. flaccid, pendent, 2-6 in. 1. by 1-2 in. br., linear-oblong or oblong, bipiunatifid, the main rachis winged throughout; pinnoe simple, linear, or forked or pinnatifid, with two or three deeply-cut segments on each side, which are $\frac{1}{4}-\frac{1}{2}$ in. $1 ., 1$ lin. br.; sori large, terminal on the segments of the upper pinnæ, often 1 lin. br., divided halfway down or more, the base cuneate, the valves rounded.-Hk. Sp. 1. p. 101. H. semibivalve, $H k$. \& $G r$. Ic. Fil. $t$. 33. H. Natalense and tabulare, $V . D . B$.

Hab. New Zealand, Auckland Isles, Van Diemen's Land, Mauritius, Natal, and Cape Colony.-A plant from Cliloe, gathered by Cuming, must probably be referred here ; and in the specimens to which I bave access I cannot distinguish the Japanese $H$. Wrightii, V. D. B., and the Fuegian H. Darwinii, V. D. B. The New Zealand H. imbricatum of Colenso differs by having the rachis much shortened, scarcely more than $1 \mathrm{in} .1$., and the pinnæ imbricated and slightly crisped. This and the two preceding differ from the species that follow next by their much broader segments.

9. H. capillaceum, Roxb.; st. about 1 in. l., slender ; fr. 2-4 in. l., by 1 in. or more br., oblong, pinnate, with distant segments ; main rachis free throughout; lower pinnoe alternate, about $\frac{1}{2}$ in. distant from one another, broadly rhomboidal, cut down to the rachis in the lower part but winged above ; segm. $\frac{1}{4}$ in. $1 ., 1$ lin. br., simple or once forked ; sori 2-6 to each pinna, terminal on the lateral segments ; invol. divided down nearly to the base; the valves orbicular, strongly toothed.-Hk. Sp. 1. p. 109. t. 38. B.

Hab. Confined to the island of St. Helena, where it has been long known.-Much resembling in habit a slender form of $H$. Tunbridgense.

10. H. gracile, Bory; st. 2-3 in. 1., slender, wiry ; fr. 2-6 in. 1., 1-2 in. br., lanceolate or oblong-acuminate, tripinnatifid ; main rachis nearly wingless throughout; pinnoe distant, 1-3 in. l., broadly rhomboidal, erecto-patent, cut down within a very short distance of the rachis; pinnl. sometimes simple, sometimes again pinnatifid, with simple or forked narrowly linear divisions; sori large, 2-4 to a pinna, terminal or axillary on the lateral segments; invol. not divided more than halfway down; valves rounded.-Hk. Sp. Fil.1.p. 110. Hk. \& Gr. Ic. Fil. t. 198.

Hab. Bourbon and Mauritius.-The Van Diemen's Land H. Gunnii, V. D. B, is either the same plant or very near it; and a plant from Chiloe, gathered by Cuming, is probably the same. Intermediate in habit between the preceding and $H$. polyanthos.

11. H. exsertum, Wall.; st. 1-2 in. 1., slender ; fr. 2-6 in. 1., 1-2 in. br., lanceolate-oblong, bipinnatifid; main raclis winged above or throughout, more or less densely clothed with deciduous ferruginous hairs; lower pinnoe rhomboidal, lanceolate-acuminate, divided more than halfway down to the rachis into simple or forked linear pinnules, slightly hairy on the principal veins; sori 2-8 to a pinna, terminal or axillary on the segments on both sides; invol. divided down nearly to the base ; valves oblong, bluntly denticulate at the apex.-Hk. Sp. 1 . p. 109. t. 38. A. H. macroglossum, $V . D . B$.

Hab. Hills throughout India, from the Himalayas southward to Ceylon.-See remarks under $H$. scabrum. It is recognizable also by the large lanceolate pinnæ, which have the central half entire.

12. H. axillare, Swartz; st. 1-2 in. 1., very slender ; fr. $3-8$ in. $1 ., \frac{1}{2}-1$ in. br., flaccid, pendent, linear-oblong, tripinnatifid ; main rachis winged throughout or above only; lower pinno varying from under $\frac{1}{2} \mathrm{in}$. l., with simple segments, to $1 \frac{1}{2}$ in. l., divided down nearly to the rachis, with pinnatifid pinnules with several segments; ult. segm. not more than 1 lin. 1.; sori $2-12$ to a pinna, terminal on the lateral segments; invol. divided more than half way down; valves rounded, entire.-Hk. Sp. 1.p. 111. Hk. \& Gr. Ic. Fil.t.124. H. apicale, V. D. B. Griseb. 
Hab. West Indian Islands and Venezuela.-Both this and $H$. myriocarpum are sometimes slightly crisped.

13. H. reniforme, Hk. ; st. very slender, naked, 2-3 in. 1. ; fr. 3-6 in. 1., 1 in. or less br., flaccid, pendent, linear-oblong, fully bipinnate; main rachis wingless throughout; pinnce usually under 1 in. 1 , divided quite down to the rachis; pinnl. simple or forked, or slightly pinnatifid; the ultimate segm. very narrowly linear; sori 2-6 to a pinna, at least twice as broad as the lobes; invol. divided down nearly to the base; valves rounded and denticulate.-Hk.Sp. 1. $p .110$. t. 38. C.

Hab. Andes of Ecuador and Peru.-Allied to H. axillare and crispum in habit, but readily distinguishable by its truly bipinnate frond and very narrow segments. The specific name applies here to the shape of the involucre, not, as in Trichomanes, to that of the frond.

14. H. crispum, H. B. K.; st. very slender, 1-2 in. l., wingless ; fr. 3-6 in. l., $1 \mathrm{in}$. or less br., flaccid, pendent, linear-oblong, tripannatifid ; main rachis only slightly or hardly at all winged above; pinnoe 1 in. l. or less, rhomboidal-oblong, beautifully and delicately undulato-crisped throughout, divided down nearly to the costa into pinnl., which are again pinnatifid; sori numerous, very small, placed at the apex of the segments ; invol. rather wider than the lobes, rounded, crisped at the edge.-Hk. Sp.1.p.106. H. amœnum, Sturm.

Hab. Tropical America, from Mexico and Cuba southward to Peru and Brazil.Closely allied to $H$. axillare in habit, but distinguished by its crisped fronds.

15. H. undulatum, Swartz; st. 1-2 in. 1., very slender; fr. 3-6 in. 1., scarcely more than 1 in. br., flaccid, pendent, ovate or linear-oblong, tripinnatifid ; main rachis winged; pinnce undulato-crisped, oblong-rhomboidal, divided down to a narrow central portion; pinnl. crowded, the lower ones a little pinnatifid; sori 2-6 to a pinna ; invol. divided down nearly to the base ; valves rounded, slightly crisped towards the margin, but not denticulate.-Hk.Sp.1.p.105. Ic. Pl.964.

Hab. Mexico, Jamaica, Peru.-Both this species and H. crispum bave the segments so much crisped that they bear the appearance of being toothed like a Leptocionium. This and the three preceding resemble one another in their small tender narrow flaccid fronds.

16. H. myriocarpum, Hk.; st. 2-3 in. l., erect, slightly winged above ; fr. 3-12 in. 1., 2-3 in. br., flaccid, pendent, ovate-lanceolate, tripinnatifid; rachis furnished with a narrow wing throughout; lower pinnoe 1-3 in. 1., lanceolate-rhomboidal, divided down nearly to the rachis on both sides into several pinnl., which are again pinnatifid with numerous membranous linear segments, not more than 1 lin. 1 . ; sori very numerous, terminal and lateral on the segments on both sides; invol. divided down to the base; valves ovate or rounded, entire or sinuated at the apex.-Hk:Sp. 1. p. 106.t. 57. D.

Hab. Mexico, southward to the Andes of Peru.-Closely allied to $H$. axillare, but rather stronger in habit, and the fronds broader below. Connects the four preceding species with $H$. polyanthos.

17. H. microsorum, V. D. B. ; st. 1-2 in. 1., slender, naked ; fr. $2-3$ in. 1., about $1 \mathrm{in.}$ br., flaccid, oblong-lanceolate, tripinnatifid; main rachis naked, furnished with a narrow wing nearly or quite to the base ; lower pinnoe oblong-rhomboidal, about 1 in. 1., erecto-patent, divided down to a narrowly-winged rachis into several pinnl., the lower of which are obversely triangular in shape and flabellately cut; sori $2-12$, terminal on the segments of both sides of the upper pinnæ, very small; invol. divided more than halfway down; the valves rounded, entire. 
Hab. Gathered by Dr. Hooker in the Sikkim Himalayas, at an elevation of $11,000 \mathrm{ft}$., and determined by Van den Bosch from his specimens.-Intermediate in habit between $H$. exsertum and polyanthos.

18. H. polyanthos, Swartz; st. 2-3 in. 1., slender, wingless ; fr. 2-8 in. 1., 1-3 in. br., ovate-oblong, tripinnatifid ; main rachis usually only narrowly winged above; lower pinnoe triangular-Thomboidal, divided down to a narrow centre into several pinnl. on each side, the lowest of which are cuneate or rhomboidal,

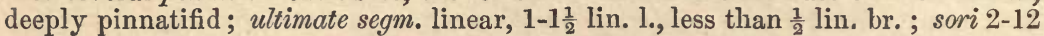
to a pinna, terminal or axillary on the segments on both sides; invol. small, divided down nearly to the base; valves ovate or rounded, entire or slightly denticulate.-Hk. Sp. 1. p. 107. H. protrusum, Hk. Sp. 1. p. 104. t. 37. B.

Hab. Widely diffused throughout the Tropics, and extending a little beyond them both north and south; America, from Cuba and Jamaica southward to Brazil, S. Chili, and Juan Fernandez; Asia, Nepaul and Sikkim to Ceylon, Tsus Sima, Malayan Peninsula, Java, and New Zealand; West Tropical Africa, Mauritius and Madagascar. This includes nearly, or quite, thirty of the species defined by Vau den Bosch.-It is a plant of slender flaccid habit, as compared with species 19 to 28, with the segments sometimes decurved, and when dry slightly crisped. The New Zealand $H$. villosum of Colenso has the stipes and rachis very slightly hairy. The Malayan H. Blumeanum, Spr., has narrower and more elongated fronds than in the type, and pinnæ sometimes simply pinnatifid only.

19. H. Andinum, V. D. B. ; st. 3-6 in. l., slender ; fr. 6-12 in. l., 1-2 in. br., flaccid, oblong, tripinnatifid; main rachis narrowly winged above; pinnoe distant, the lower oblong-rhomboidal, divided down to a narrow centre, with 2-3 pairs of pinnl. which are flabellately or laterally cut into a few linear segm.; sori 2-12 to a pinna, terminal or axillary on the segments on both sides; invol. divided more than halfway down; valves rounded, with a blunt point, entire.

Hab. Andes of Ecuador, Jameson.-Closely allied to $H$. polyanthos, but elongated and flaccid in habit, with fewer, more distant and less divided segments.

20. H. badium, Hk. \& Gr.; st. 2-3 in. l., slender, winged above; fr. 4-12 in. 1., 2-3 in. br., oblong or ovate-lanceolate, acuminate, tripinnatifid; main rachis broadly winged throughout; lower pinnoe lanceolate-rhomboidal, divided down to a broadly winged rachis into several pinnl. in each side, the lowest of which are a few times deeply incised, ultimate divisions broadly linear; sori $2-12$ to a pinna, terminal and axillary on the segments on both sides; invol. nearly 1 lin. br., divided down nearly to the base ; valves rounded, nearly twice as broad as deep, the outer edge denticulate.-Hk. Sp. 1. p. 102. Hk. \&. Gr. Ic. Fil.t. 76.

Hab. Malayan Peninsula, Sir W. Norris; East Indies (probably Nepaul), Dr. Wallich.

21. H. Javanicum, Spreng.; st. 2-4 in. l., erect, margined above with a broad crisped wing; fr. 4-8 in. l., 3-4 in. br., triangular, tripinnatifid; main rachis bordered throughout with a broad crisped wing; lower pinnoe $1 \frac{1}{2}-2 \mathrm{in}$. $\mathrm{l}_{\text {e, trian- }}$ gular-rhomboidal, erecto-patent, divided down to a narrow crisped centre into several plane or slightly crisped pinnl. on both sides, the lower of which are several times deeply pinnatifid; sori 6-20 to a pinna, terminal and axillary on the segments on both sides; invol. about as broad as the segments, divided down nearly to the base; valves orbicular, entire or denticulate-Hk. Sp. 1. p. 106. H. fimbriatum, J. Sm. Hk. Sp. 1. p. 102. t. 36. C. H. flexuosum, Cunning. Hk. Sp. 1.p. 105. Ic. Pl.t. 962. H. crispatum, Wall. Hk. \& Gr. Ic. Fil.t. 77. H. dxdaleum, Blume. H. micranthum, V. D. B. $-\beta, H$. atrovirens, Colenso ; segm. of the frond nearly plane; invol. smaller and narrower. H. Tasmanicum, $V . D . B$. 
Hab. India, from Nepaul and Sikkim to Ceylon, the Malayan Peninsula, the Philip. pines, New Zealand, and Australia. H. erosum of Blume, and $H$. Reinwardii, V. D. B., also belong here.

22. H. demissum, Swartz ; st. 4-6 in. 1., erect, firm, wingless ; fr. 4-12 in. 1. 3.4 in. br., ovate-triangular, 3-4 times pinnatifid; rachis only slightly winged above ; lower pinna $2-3$ in. 1., triangular-rhomboidal, divided down very nearly to the rachis into numerous pinnls. on both sides, which are again divided down nearly into the rachis into pinnatifid segm.; ult. lobes 1-2 lin. l., $\frac{1}{2}$ lin. br.; sori very numerous (20-30) to a pinna, terminal and axillary on the segments on both sides; invol. divided down nearly to the base; valves ovate, entire, or denticulate.-Hk. Sp. 1.p. 109. H. productum, Kunze.

Hab. New Zealand, Fiji, Java, the Philippines, and adjacent Polynesian Islands.-A larger and stronger plant than $H$. polyanthos, with which Sir W. Hooker was disposed to join it, with ample glossy deeply-cut fronds and very numerous involucres.

23. H. caudiculatum, Mart. ; st. 4-6 in. l., wiry, broadly winged above ; fr. 6-12 in. 1., 2-3 in. br., ovate-acuminate, tripinnatifid; main rachis furnished throughout with a broad slightly crisped wing; lower pinnoe rhomboidal-lanceolate, erecto-patent, often 2 in. l., divided down to a broad central rachis, the lower pinnl. again pinnatifid, the upper forked or simple, broadly linear; sori 2-12 to a pinna, placed at the apex of the segments on both sides; invol. very large ( $\frac{1}{8}$ in. br.), divided down nearly to the base ; valves twice as broad as deep, and bluntly toothed.-Hk. Sp. 1. p. 102.- $\beta, H$. caudatum, V.D. B. ; wing of the main and also of the second. rachis considerably crisped and undulated.

Hab. Brazil, Peru, and Chili.-Wing of the main rachis often 2 lines wide. H. Francavillei, V.D. B., from Martinique, apparently belongs here.

24. H. recurvum, Gaud. ; st. 2-4 in. 1., winged above ; fr. 4-12 in. 1., 2-3 in. br., flaccid, pendent, oblong-acuminate, tripinnatifid; main rachis narrowly winged throughout ; pinnoe flaccid, erecto-patent, distant, elongated, divided down nearly to the rachis into long simple or forked or slightly compound pinnls.; ult. segm. $\frac{1}{4}-\frac{3}{8}$ in. $1 ., \frac{1}{2}$ in. br., sori $2-6$ to a pinna, generally axillary ; invol. divided about halfway down; valves rounded, slightly forked.-Hk. Sp. 1. p. 109. t. 37. C.

Hab. Sandwich Islands, frequent.

25. H. flabellatum, Labill. ; st. 2-4 in. 1., firm, erect ; fr. 4-12 in. 1., 2-4 in. br., ovate-acuminate, tripinnatifid, somewhat glossy and flaccid; main rachis winged above; lower pinnoe 1-2 in. l., broadly rhomboidal-acuminate, erecto-patent, divided down to a broadly winged rachis into several cuneate-based pinnls., which are furnished on both sides with several linear segm.; sori 6-20 to a pinna, terminal on the lateral segments; invol. divided more than halfway down; valves rounded, entire.-Hk. Sp. 1. p. 111. H. nitens, Br. Hk. \& Gr. Ic. Fil. 197.

Hab. Australia, New Zealand, Lord Auckland Isles.-Very variable in the compactness, size, and degree of elongation of the fronds. H. Hookeri, Bory and V. D. B., is a small form with narrower involucres than in the type. A plant from Sumatra must probably be referred to this species.

26. H. scabrum, A. Rich.; st. 2-4 in. 1., strong, wiry, ciliated ; fr. 6-15 in. 1., 2-5 in. br., ovate-acuminate, tripinnatifid; main rachis winged above, thickly ciliated with long brown bristly hairs ; lower pinnae 2-3 in. I., erecto-patent, oblongrhomboidal acuminate, divided down nearly to the rachis into several pinnl. on both sides, which are again pinnatifid with compound lower and simple linear upper segm.; sori 6-20 to a pinna, terminal on the lateral segments on both 
sides ; invol. small, divided down nearly to the base, denticulate at the apex.Hk. Sp. Fil. 1, p. 110. Sphrrocionium glanduliferum, Presl.

Hab. New Zealand. - By their hairy rachis, this species and H. exsertum form a link between the glabrous and truly hirsute species.

27. H. dilatatum, Swartz; st. 2-4 in. 1., erect, wiry, slightly winged above ; fr. 6-12 in. 1., 4-6 in. br., ovate-lanceolate, tripinnatifid ; main rachis winged throughout, the wing quite flat; lower pinnoe rhomboidal-lanceolate, divided down nearly to the rachis, the lower pinnl. again pinnatifid; sori 2-12 to a pinna, terminal or axillary on the segments on both sides, divided about halfway down; valves rounded, entire, clusters often exserted.-Hk. Sp. 1. p. 104. Hk. \& Gr. Ic. Fil. t. 60. H. formosum, Bracken. H. Junghuhnii \& eximium, $V . D . B$.

Hab. New Zealand, Java, Tahiti, Samoa, Aneiteum, Fiji and other Polynesian Islands. - Closely allied to $H$. fuciforme, but different in the involucre.

28. H. fuciforme, Swartz ; st. strong, erect, 4-8 in. 1., narrowly winged above ; fr. 12-24 in. l., 4-6 in. br., triangular-lanceolate, tripinnatifid; main rachis winged throughout; lower pinno rhomboidal-lanceolate, cut down nearly to the rachis into numerous distant pinnl. on both sides, the lowest of which are triangular in outline and again pinnatifid, with 2-3 forked lower segm.; sori numerous, very small, placed principally in the axils of the segments; valves divided down nearly to the base, rounded, entire ; recept. and even the cluster of capsules often exserted.-Hk. Sp. 1.p. 103.t. 36. D.

Hab. South Chili and Juan Fernandez.

29. H. pulcherrimum, Colenso ; st. 3-4 in. 1., wiry, erect, winged down to the base ; fr. 6-12 in. 1., 4-6 in. br., ovate-triangular, 3- or 4 pinnatifid ; main rachis slightly winged throughout; lower pinnoe 2-3 in. 1., lasceolate-rhomboidal, the secondary rachis flexuose, slightly waved, the pinnæ with several distant pinnl. on both sides, the segm. of which are again pinnatifid with cuneate flabellately pinnatifid lower divisions; sori numerous, axillary and terminal on the segments on both sides; invol. orbicular, divided down nearly to the base ; valves entire.-Hk. Sp. 1.p. 105.t. 37. A. Hk. fil. Fl. N. Z. 232.t. 74.

Hab. New Zealand.-Species 20 to 29 much resemble one another in habit, and all have ample tripinnatifid firm glossy fronds, with comparatively broad erecto-patent segments.

30. H. Zollingerianum, Kunze ; st. 2-4 in. 1., wiry, deciduously hairy ; fr. 4-8 in. $1 ., 1 \frac{1}{2}-2$ in. br., lanceolate-acuminate, with a flaccid apex, tripinnatifid; pinnce rather distant, the lower ones ovate-rhomboidal, cut down to a rather broad centre; pinnl. close, the lower ones again deeply pinnatifid; main rachis narrowly winged and often slightly hairy, a single central vein in each segment, the lower part of which is conspicuously winged on both sides; sori 2 to 8 to a pinnule, large, terminal or axillary; invol. divided about halfway down, the moutl roundish, entire.- $V . D . B$. Hymen. Jav. $t .50$.

Hab. Java.-By its deciduously hairy rachis, this approaches the next section. The habit is something like that of $H$. polyanthos, with an elongated flaccid apex, and the curiously winged veins are very peculiar.

*** Fronds more or less ciliated and hairy upon the surface.-Sp. 31-51.

31. H. Borneense, Hk. MSS.; st. about 1 in. 1 , very slender ; $f r$ square or fan-shaped in general outline, $\frac{1}{2}-\frac{3}{4}$ in. $1 ., \frac{1}{2}$ in. br., divided down like a fan nearly 
to the base, the divisions linear, dichotomously branched; ult. segm. 1-3 lin. l., $\frac{1}{2}$ lin. br., the surface hairy, and the margin ciliated with branched rufous hairs; sori terminal, solitary, orbicular, the cuneate base sunk in the frond; valves ciliated.

Hab. Borneo, on hills near Sarawak, at an alt. of 2,700 ft., Lobb.-Peculiar in the group by resembling in habit the species of the Gonocormus section of Trichomanes.

32. H. hirsutum, Swartz ; st. 1-2 in. l., slender, naked or slightly winged and ciliated above; $f i$. linear-oblong, once pinnatifid, 2-6 in. l., about $\frac{1}{2}$ in. br., slender, flaccid, often pendulous, hairy over the surface; pinno short, close, erecto-patent, simple, linear-ohlong, or cuneato-flabellate, with 1 to 4 divisions; ult. segm. rather broad, closely ciliated; sori 1 to 4 on a pinna, terminal on the segments; invol. suborbicular, the cuneate base sunk in the frond; valves free, very hairy.-Hk. Sp. 1. p. 88. Hk. \& Gr. Ic. Fil. t. 84. H. venustum \& angustum, $V . D . B$. H. Raddianum, Muller.- $\beta$, H. latifrons, V. D. B. ; fr. larger and more dilated than in the type; segm. $\frac{1}{2}$ in. br.

Hab. Tropical America, from Cuba and Jamaica southward to the Organ Mountains in Brazil. $-H$. latifrons bears the same relation to the type that $H$. splendidum does to ciliatum.

33. H. Chiloense, Hk. ; st. 1-2 in. 1., not winged; fr. triangular or ovatelanceolate, bipinnatifid, 1-2 in. 1., $\frac{1}{2}-1$ in. br. below ; main rachis zigzag, ciliated, and broadly winged; lower pinnoe rhomboidal-oblong, with several rounded or linear pinni. on both sides, the margin regularly ciliated, with short strong hairs and the under surface of the frond slightly hairy ; sori placed singly at the base of the pinnæe on the upper side, divided about halfway down, the cuneate base free or sunk in the frond; valves semiorbicular, strongly ciliated.-Hk. Sp. 1. p. 90.t. 32. A. Leptocionium dicranotrichum, Presl.

Hab. S. Chili and island of Chiloe.-Placed by Presl and Van den Bosch in section 4 ; but its proper position is here.

34. H. ciliatum, Swartz; st. 1-2 in. 1., ciliated and decurrently winged above ; fr. oblong-acuninate, tripinnatifid, 2-6 in. $1 ., 1-2$ in. br. at the centre; main rachis broadly winged throughout and ciliated; lower pinnoe oblong or rhomboidal, with a broad central undivided portion, and numerous erecto-patent simple or forked ciliated linear segm. 2-3 lin. 1. ; sori 2 to 12 on a pinna, placed at the end of the lateral segments on both sides; invol. immersed, suborbicular; valves divided about halfway down, and conspicuously ciliated.-Hk. Sp. 1.p.88. Hk. \& Gr. Ic. Fil.t. 35. H. Plumieri, Hk. \& Gr. Ic. Fil. t. 123. H. Boryanum, Willd. Hk. Sp. 1. p. 89. t. 31. C.

Hab. Common in Tropical America, from Cuba and Mexico southward to Chili and South Brazil ; West Tropical Africa (Fernando Po, \&c.), and in the East in the Zambesi district and the islands (Mauritius, Madagascar, Bourbon, Seychelles, and Johanna Island).-The African plant, well known under the name of Boryanum, seems quite to coincide with the American ciliatum. It has also been gathered in New Zealand lately by Mr. Travers. Eleven species, admitted by Van den Bosch, do not appear materially different; viz. those already mentioned, and trapezoidale, Liebm. ; vestitum, Presl ; apterum, remotum, Surinamense, Presl ; commutatum, Presl ; Schiedianum, Presl, and splendidum. The latter is a magnificent form, with fronds $1 \mathrm{ft}$. l., pinnæ $\frac{1}{2}$ in. and rachis $\frac{1}{8}$ in. br., which occurs in Guatemala, Ecuador, and West Tropical Africa.

35. H. obtusum, Hk. \& Arn. ; st. 2 in. l., slender, ciliated ; fr. $2-4$ in. 1., 1-2 in. br., lanceolate or ovate-lanceolate, tripinnatifid; main rachis winged throughout; lower pinnoe lanceolate or triangular-rhomboidal, cleft nearly to the rachis into several linear simple or forked pinnl. on both sides, the surface and margin copiously clothed with pubescence; sori 2 to 6 to a pinna, terminal on the lateral 
segments ; invol. as broad as the segments, divided about halfway down; valves rounded, strongly ciliated.-Hk.Sp.1. p. 98.t. $33 . \mathrm{D}$.

Hab. Oahu, Sandwich Islands, and found recently in fine condition by Col. Blagrove, on Table Mountain, Cape of Good Hope.

36. H. aruginosum, Carm.; st. 1-2 in. 1., slender, tomentose ; fr. 2-3 in. 1., 1 in. or less br., lanceolate or ovate-acuminate, tripinnatifid; main rachis winged above; pinnoe often much imbricated, the lower ones flabellate or broadly rhomboidal in outline, divided down nearly to the rachis into simple or slightly pinnatifid linear segments, the surface and margin clothed copiously with pubescence; sori 2 to 12, terminal on the segments; invol. small, divided nearly down to the base; valves rounded and densely ciliated.-H. æruginosum, $\alpha, H \dot{k}$. Sp. 1.p. 93 .

Hab. Island of Tristan d'Acunha.-First gathered and described by Capt. Carmichael.

37. H. lanceolatum, Hk. \& Arn. ; st. 2-3 in. 1., slender, wiry, naked; fr. 3-6 in. l., 1-2 in. br., lanceolate or oblong tripinnatifid ; main rachis slender, wavy, flexuose, winged only at the very top ; lower pinnoe 1-2 in. l., rhomboidal-oblong, cut down nearly to the rachis into several simple or forked long linear segm. on both sides, hairs few, mostly confined to the nidrib and margin; sori 2 to 8 to a pinna, placed at the side or top of the lateral segments; invol. divided more than halfway down; valves rounded and copiously ciliated.-Hk. Sp. 1. p. 94 . t. 34 . B.

Hab. Islands of the Sandwich group.

38. H. Franklinianum, Colenso ; st. 1-3 in. 1., wiry, erect, tomentose ; fr. 3-8 in. l., $1 \frac{1}{2}-2$ in. br., ovate-lanceolate, tripinnatifid; main rachis slightly winged above; lower pinnoe spreadiug, divided down nearly to the rachis into numerous alternate pinnl., which are again deeply divided into broad linear segm., the surface and margin clothed copiously with tawny silky stellate pubescence; sori 2 to 12 to a pinna, terminal on the lateral segments ; invol. divided down nearly to the base; valves rounded and copiously ciliated.-H. æruginosum, $\beta, H \dot{k}$. Sp. 1.p. 93.t. 34. A. H. Berteroi, Hk. Sp. 1. p. 93. t. 33. C.

Hab. New Zealand, Chili, Chiloe, and Juan Fernandez.

39. H. hirtellum, $\mathrm{Sw}$; ; st. 1-4 in. 1., tomentose, not winged ; fr. ovate-acuminate, tripinnatifid, 3-6 in. 1., 2-3 in. br. ; main rachis only slightly winged above, tomentose ; lower pinnoe rhomboidal-lanceolate, with a narrow central undivided portion ; lower pinnl. pinnatifid, with long narrow linear ciliated segments ; sori 2 to 12 to a pinna, placed at the end of the lateral segments on both sides; invol. orbicular, sunk in the frond, divided about halfway down; valves strongly ciliated.-Hk. Sp. Fil. 1. p.90.t.31. D.

Hab. Mexico, Jamaica, and Guadeloupe.-Frond elastic in texture. This and the next four species closely resemble one another in the shape of the frond, and the extent to which it is divided.

40. H. elasticum, Bory ; st. $2-4$ in. 1., wiry, erect, naked or slightly tomentose; fr. 6-12 in. l., 2-4 in. br., ovate-acuminate, tripinnatifid; main rachis winged above, tomentose ; lower pinnoe rhomboidal-triangular, 1-3 in. l., divided down very nearly to the rachis into numerous alternate pinnl., which again are cleft very nearly to the rachis into long linear simple or forked segm.; texture firm but elastic, moderately hairy both over the surface and at the margin; sori very numerous, terminal on the lateral segments; invol. small, the base sunk in the frond; valves rounded, free, very hairy. $-H k . S p .1$. 93. Hk. \& Gr. Ic. Fil. $t .135$. 
Hab. Confined to the Mauritius and Bourbon, where it is abundant.-It is questionable whether this is distinct from the preceding.

41. H. Lindeni, Hk. ; st. 4-6 in. l., stout, erect, villose ; fr. often recurved, 6-12 in. 1., 4-6 in. br., ovate-acuminate, tripinnatifid ; main rachis villose, winged in the upper part; lower pinnoe 2-4 in. l., elongate-lanceolate, with numerous deeply-divided pinnl. on both sides, both surfaces hairy ; sori very numerous, terminal on the segments; valves short and broad, strongly ciliated.-Hk. Sp. 1.p. 94. t. 34. C. H. spectabile, Moritz.

Hab. Andes of Venezuela and Ecuador.

42. H. microcarpum, Desv. ; rhizome clothed with woolly yellow hairs ; st. 4-6 in. l., firm, tomentose, slightly winged above ; fr. ovate-triangular, tripinnatifid, 6-12 in. 1., 3-5 in. br.; main rachis furnished with a narrow wing throughout, and more or less tomentose, the frond slightly hairy, the margin subdenticulate and ciliated ; central pinnoe rhomboidal-oblong, with several pinnl. on each side, which are deeply cut into narrow linear segm.; sori 2 to 12 to a pinna, placed at the apex of the lateral segments of the upper pinnæ ; invol. ovate, free, divided down to the base; valves between toothed and ciliated.-H. Organense, Hk. Sp. 1. p. 90. t. 32. B. H. Beyrichianum, Kunze. Hk. Sp. 1.p. 91.

Hab. South America, Venezuela and Ecuador, southward to Peru and the South of Brazil.-H. Lindigii, Mert., and $H$. Ruizianum, Klotzsch, are allied to this species.

43. H. valvatum, Hk. \& Gr. ; st. 1-3 in. 1., naked or slightly winged above ; fr. ovate-triangular, acuminate, tripinnatifid, 4-6 in. l., $1 \frac{1}{2}-2 \frac{1}{2}$ in. br. below; main rachis winged throughout; pinnoe slightly hairy and ciliated, the lower ones triangular, with deeply pinnatifid pinnl.; ult. segm. linear, with the limb (not the margin) on each side of the midrib considerably waved and undulated; sori 12 to 20 to a pinna, terminal on the segments of the upper ones on both sides ; invol. ovate, divided down nearly to the base; valves glabrous or slightly ciliated. Hk. \& Gr. Ic. Fil. 219. Hk. Sp. 1. p. 90. H. pteropodum \& platylobum, $V . D . B$.

Hab. Nicaragua, Guadeloupe, Martinique, Andes of Columbia and Peru, ascending to $6,000 \mathrm{ft}$. - Of $H$. divaricatum and Orbignianum, placed by Van den Bosch near valvatum, I have not seen specimens.

44. H. Sprucei, Baker ; st. 1.2 in. l., slender, hairy ; fr. 3-6 in. 1., 1-2 in. br., lanceolate or oblong-acuminate, bipinnatifid ; rachis winged throughout, or only in the upper half, pilose, the frond furnished with scattered stellate hairs on the midrib and margin; lower pinnoe spreading, rhomboidal-lanceolate, cut down nearly to the rachis into simple or once forked linear erecto-patent pinnl., which are about $\frac{1}{8}$ in. l., and somewhat crisped or undulated as well as furnished with rather distant strong stellate hairs along the edge; sori 2 to 6 , terminal on the segments of the lateral pinnæ; invol. cut more than halfway down; valves rounded and ciliated with hairs like those of the segments.

Hab. Tarapota, E. Peru, Spruce.-This also, like $H$. Chiloense, might easily be taken for a serrated species. It resembles in habit the small forms of $H$. interruptum, but the frond is much thinner, and the hairs are confided to the ribs and edges.

45. H. interruptum, Kunze ; st. 1-2 in. 1., wiry, naked or slightly ciliated ; fr. pendent, varying from 6 in. to nearly a yard in length, 2-5 in. br., elongatolanceolate or oblong in general outline, bipinnatifid; rachis winged nearly throughout, and like the frond, more or less densely clothed with soft shining ferruginous hairs; lower pinnoe rhombuidal-lanceolate, cleft on both sides into simple or bifid lobes, which reach about halfway down to the rachis; sori 6 to 12 , 
terminal on the segments of both sides of the upper pinnæ; invol. divided more than halfway down; valves rounded and very hairy. $-H k$. Sp. 1. p. 92.t. 33. B. H. æquabile, Kunze.

Hab. Guadeloupe, and mainland of S. America, from Venezuela and New Granada southward to Peru.-Resembling $H$. sericeum in habit, but much thinner in texture, and the rachis winged.

46. H. sericeum, Sw.; st. 2-4 in. l., wiry, naked ; fr. pendent, 6-24 in. 1., 2-3 in. br., elongato-oblong, obtuse or acuminate, simply pinnatifid; rachis densely clothed with close tumentuin, free throughout ; pinnice 1-2 in. l., very numerous, opposite, rhomboidal-lanceolate, with a cuneate base and much-acuininated apex, sometimes only just crenated, sometimes pinnatifid more than half way d. wn to the rachis, the substance almost coriaceous and suft, with a dense cuating of tomentum; veins prominent, forked with nearly parallel branches, and often furnished with curious membranaceous wings or lamellæ; sori very numerous to a pinna, small, terminal on the apex of the pinnæ and lateral segments; valves rounded, shaggy, with strong reddish-brown hairs. $-H k . S_{p}$. 1. p. 92.

Hab. Tropical America, from Cuba, Jamaica, and Mexico southward to Peru and Brazil. - A curious species, quite peculiar in habit and texture, which Van den Bosch divides into eight ; viz. sericeum, eriophorum, Cubense, Sturm, plumosum, Kaulf., Karstenianum, speciosum, asterothrix, Kunze, and tomentosum, Kunze.

47. H. Malingii, Metten., MSS. ; st. 1-3 in. l., slender, naked ; fr. pendent, 4-6 in. 1., 1-1 $\frac{1}{2}$ in br., linear-oblong, bi- or tripinnatifid ; main rachis densely clothed with close tomentum, free throughout ; pinnce $\frac{1}{2}-\frac{3}{4}$ in. l., oblong or ovato-rhomboidal, cut down to a rounded rachis ; pinnl. deeply flabellately and subpinnatifidly cut; ult. segm. linear-filiform, 1-3 lin. 1., the substance coriaceous and soft, with a dense coating of tomentum, a single vein only in each segment; sori 2 to 12 to a pinna, terminal on the segments; invol. divided about halfway down; valves denticulate at the apex, and shaggy like the frond.-Trichomanes Malingii, Hk. Gard. Ferns, t. 64 .

Hab. New Zealand.-The connection of this curious novelty is certainly with $H$. sericeum, from which it differs principally in the total absence of a connecting membrane between the veins of the pinnæ, which, in one form of the South American plant, is partially defivient.

48. H. lineare, Swartz; st. about 1 in. l., slender, villose ; fr. flaccid, pendulous, 3-8 in. 1., 1-2 in. br., linear, elongated, fully pinnate; rachis slender, wavy, villose, free throughout; pinnoe spreading, ovato-rhomboidal, deeply cut into simple or forked linear lobes, the surface and margin densely hairy ; sori 2 to 6 , terminal on the lateral segments; invol. about as broad as the segments; valves rounded, strongly ciliated.-H. elegans, $S p r$. Hk. Sp. 1. p. 91. H. trifidum, IIk. \& Gr. Ic. Fil. t. 196. H. pendulum, Bory.

Hab. Tropical America, from Jamaica and Mexico southward to Brazil and Peru, ascending on the Andes of Ecuador to 12,000 ft., and occurring also in the Mauritius, from which we have just received specimens from Dr. Meller.-This species is very flaccid in habit, and the long narrow fronds form densely interlaced masses on rocks and trees. Van den Bosch gives the three plants already named as distinct, and his procerum, tricho. phyllum, Crugeri, and Moritzianum are also included here.

49. H. elegantulum, V. D. B. ; st. 1-4 in. 1., slender, ciliated ; fr. flaccid, pendulous, 6-18 in. 1., 2-6 in. br., linear-oblong and pinnate, or broadly oblong and bipinnate; rachis wavy, villose, free throughout; lower pinnce in the bipinnate form often with several pairs of pinnules ; pinnl. 1-3 in. l., deeply pinnatifid principally on the upper side; ult. segm. 1-2 lin. l., 1 lin. br., the surface and margin densely hairy ; sori 6 to 12 , terminal on the lateral segments; invol. sunk 
in the frond; valves rounded, strongly ciliated.-H. pulchellum, Hk. Syn. 1. p. 91, in part.

Hab. Andes of Ecuador and Colunbia, ascending to 13,000 ft. - Closely allied to H. lineare in its manner of growth, but a much larger plant, with broader and shorter seginents. The original $H$. pulchellum appears to be a small state of sericeum. This and the preceding are the only simply pinnate hairy species with divided pinnæ.

50. H. Catherince, Hk., MSS. ; st. 1-2 in. 1., erect, wiry, slightly ciliated ; $f r$. $2-3$ in. 1., 1-1 $\frac{1}{2}$ in. br., oblong, fully bipinnate ; main rachis free throughout, slightly ciliated; lower pinnoe broadly rhomboidal, cleft down to the rachis ; the lower pinnl. several times forked, with very narrow linear ciliated segm. about 2 lin. 1. ; sori 6 or more to each pinna, terminal on the segments of the upper pinnæ on both sides, considerably broader than the segments, the cuneate base sunk in the frond; the ciliated valves divided about halfway down.

Hab. St. Catherine's Peak, Jamaica, at an elevation of 5,000 ft., Wilson; Guadeloupe, L'Herminier. - A small, neat, deeply-cut plant with inconspicuous hairs. The Guadeloupe plant was distributed by M. Fée as $H$. protrusum, Hook., which belongs to the glabrous section, and is a form of $H$. polyanthos.

51. H. Pastoensis, Hk., MSS. ; st. 4-6 in. l., stout, erect, densely villose ; $f r$. 6-12 in. l., 4-6 in. br., ovate-acuminate, fully bipinnate ; rachis strong, erect, densely clothed with ferruginous hairs; pinnce ovate-lanceolate, recurved ; lower pinnl. 1 in. or more 1., divided down nearly to the costa into very long narrow linear segments, hairy principally on the rachis and margin ; sori 12 to 20 , terminal on and broader than the segments ; invol. orbicular, free, deeply 2 -valved; the valves only ciliated.

Hab. Volcano of Pasto, Andes of N. Ecuador, Jameson. - This and the preceding (both new species) are interesting, as showing a much more divided type of form in the frond than was known previously in this section.

**** Leptocionium, Presl, V.D.B.; margin of the frond spinuloso-dentate. All the species are more or less compound. Sp. 52-71.

* Frond not crisped. Sp. 52-66.

52. H. Tunbridgense, Smith ; st. $\frac{1}{2}-1 \frac{1}{2}$ in. 1. ; fi . oblong-lanceolate, 1-3 in. 1 , $\frac{1}{2}-1$ in br., pinnate throughout; pinnoe distichous, flabellato-pinnatifid ; the lobes linear, 1-3 lin. 1., and, as well as the usually solitary axillary suborbicular compound invol., conspicuously spinuloso-serrated ; the rachis and upper part of the main stem winged.-Hk. Sp. 1. p. 95. Brit. Ferns, t. 43.- -, H. Wilsoni, Hk.Invol. entire; pinnoe with fewer lobes, pinnatifid on the upper side only. $-H k$. Sp. 1.p.96. Brit. Ferns, t. 44.

Hab. Regarding these two as British plants alone, we should pronounce them readily separable by the characters given, which are taken from our two indigenous plants ; but, looking abroad, we find them connected by every intermediate stage of gradation. Fourteen species admitted or proposed by Van den Bosch cannot be clearly separated. To our $\boldsymbol{a}$ belong his Tunbridgense (Britain, Normandy, Corsica, Tyrol, Italy); Dregeanum, Presl (S. Africa) ; minimum, Richd. (Auckland Islands) ; antarcticum, Pr. (N. S. Wales and V. D. Land); asperulum, Kunze (Chili); and Zeelandicum, V. D. B. (New Zealand). Some of the Cape specimens are bipinnate, and have the lower pinnæ fully 2 in. 1 . A plant from the Falkland Islands bas the pinnæ only once forked, or even simple : $\alpha$ grows also in the Mauritius, Madeira, the Azores, Jamaica, and Venezuela. To $\beta$ belong Wilsoni (Britain, Feroe, Norway); megachilum, Pr. (Brazil) ; unilaterale, Bory (Bourbon); Meyeri, Pr. (S. Africa) ; affine, Brack. (Fiji group); cupressiforme, Lab. (New Zealand and Australia); Menziesii (Falkland Islands, Staten Land, Cape Horn); and Mettenii (Chili) : and it grows also in Guatemala and the Peruvian Andes. 
53. H. Serra, Presl ; st. slender, wiry, 1-2 in. 1. ; fr. narrowly oblong-acuminate, pinnate, 3-4 in. l., about 1 in. br. ; pinnoe distichous, flabellato-pinnatifid, recurved; the ult. segm. 3-5 lin. 1., very narrow, conspicuously spinuloso-dentate ; sori placed 1 or 2 in the upper side near the base of the pinnæ; invol. divided two-thirds of the way down; valves oblong, entire, or slightly toothed.

Hab. Chiloe and Chili.-Very near the preceding, but the segments very narrow and remote, and almost confined to one side of the pinnæ.

54. H. tenerrimum, V. D. B. ; st. very slender, $\frac{1}{2}-\frac{3}{4}$ in. 1 , naked ; fr. 1-2 in. 1 , less than $\frac{1}{2}$ in. br., pinnate, only the very summit winged; pinnoe distant, very small and slender, simple or once or twice forked, vaguely undulato-dentate; sori 1 or 2 together, terminal ; invol. divided down nearly to the base; valves rounded and ciliated.-V.D.B. Suppl. p. 101.

Hab. Peru, Spruce, 4700 and 4702.-Much the most slender and diminutive species of the section.

55. H. Jamesoni, Hk. ; st. 1-2 in 1. ; fr. flaccid, linear, 3-9 in. 1., $\frac{1}{2}-\frac{3}{4}$ in. br. ; rachis only slightly winged towards the apex, fringed throughout with soft membranous spines; pinnce forked at the apex, and with only 1 or 2 linear segm. on each side ; invol. axillary, solitary ; valves obovate, conspicuously spinose.HK. Sp. 1. p.96. t. 35. A.

Hab. Andes of Columbia, Jameson.-Readily distinguishable by its long narrow frond and flaccid habit. The costa, like the rachis, is conspicuously fringed with membranous spines.

56. H. barbatum ; st. slender, erect, naked, 1 in. or less $1 . ; f r$. oblong-triangular, $1 \frac{1}{2}-2$ in. 1 ., about $\frac{3}{4}$ in. br., tripinnatifid; rachis winged throughout ; lower pinnoe rhomboidal-oblong, with a broad winged rachis and short broadly linear spinuloso-dentate segm.; sori terminal on the segments of the upper pinnæ; invol. suborbicular or broadly oblong; valves divided more than halfway down, and deeply spinulose-dentate.-Leptocionium barbatum, V.D. B. Suppl. $p .62$.

Hab. Tsus Sima, near Japan, Wilford, 846.-A stouter plant than H. Tunbridgense, with rachis winged throughout, broader segments, and terminal sori.

57. H. secundum, Hk. \& Gr. ; st. 1-3 lin. 1., wiry, naked ; fr. pinnate, linearoblong, 3-4 in. 1., 1 in. br. ; pinnoe recurved, flabellato-pinnatifid ; ult. segm. narrowly linear, spinuloso-dentate, usually falcato-secund ; sori usually solitary, placed on the upper side of the pinnæ near the base; invol. 2-valved about halfway down; valves oval-oblong, entire.-Hk. Sp. 1. p. 100. Hk. \& Gr. Ic. Fil. t. 133.

Hab. Staten-land and Cape Horn.-Near H. Tunbridgense, but a larger plant, with two or three times dichotomous flabellate pinnæ.

58. H. Simonsianum, Hk. ; st. slender, wiry, naked, 1-2 in. 1. ; fr. linearoblong, 2-3 in. 1., $\frac{3}{4}$ in. br., once pinnatifid down to a broadly-winged rachis ; segm. fan-shaped, with only shallow divisions directed from the apex towards the base; veins dichotomous, the margins spinuloso-dentate; sori 1 to 4 , terminal on the divisions of the upper pinnæ; invol. broadly oblong, divided nearly to the base ; valves spinuloso-dentate.-Hk. 2nd Cent. $t .13$.

Hab. Khasia Hills and Sikkim, Simons, Griffith, Dr. Hooker.-The least divided species of this section.

59. H. pectinatum, Cav. ; st. 2-4 in. 1., wiry, naked ; fr. oblong, pinnate, 3-6 in. $1 ., 1 \frac{1}{2}-2$ in. br. ; main rachis only winged towards the apex ; pinnoe with only 
a slight wing to the rachis on the lower, but deeply pinnatifid on the upper side, with long, narrow, parallel, siruple or slightly forked linear spinuluso-dentate segm. ; sori often 6 to 8 to a pinna, terminal on the lower segments of the upper side; invol. divided nearly to the base with ovate entire valves.-Hk. Sp. 1.p. 96. t. 34. D.

Hab. Chili and Chiloe. - A beautiful species, easily recognized by its peculiar pectinate pinnæ.

60. H. multifidum, Swartz; st. 2-4 in. l., wiry, naked; fr. broadly ovato-lanceolate, tripinnatifid, 2-6 in. 1., 1-5 in. br.; main rachis winged above, wingless below; the second. rachis bruadly winged throughout, wavy; pinnoe and pinnl. rhomboidal-lanceolate; ult. segm. linear, 2-3 lin. 1., conspicuously spinuloso-dentate ; sori 1 to 12 to a pinna, terminal on the lateral segments of the upper pinnæ on both sides; invol. obovate, tubular below ; valves divided not more than halfway down, entire; recept. sometimes exserted.-Hk. Sp. 1. p.98. Hk. \& Gr. Ic. Fil. t. 167. H. Feejeense, Brack. t. 37.f. 2.

Hab. New Zealand, and islands of the Pacific.-An elegant plant in the larger forms. In exposed situations the fronds are much drawn together, and the segments are recurved.

61. H. triangulare, Baker ; st. 2-4 in. 1., smooth, naked ; fr. ovate-triangular, tripinnatifid, 4-6 in. 1., 2-3 in. br. at the base ; main rachis winged above; the second. rachis broadly winged throughout; pinnce rhomboidal-lanceolate; lowest pinnl. deeply pinnatifid, with simple or forked conspicuously spinuloso-dentate linear segm., 2-3 lin. l. ; sori usually solitary, placed on the upper pinnæ at the base of the anterior pinnule at the outer side; invol. large, ovate, fully a line deep, divided about halfway down; valves nearly entire.

Hab. Fernando Po, Mann, 333.-Much resembling $H$. multifidum and bivalve in habit, but the segments are broader, and the sori are much larger and usually solitary. It is the only Leptocionium which has yet been found in Tropical Africa.

62. H. bivalve, Swartz ; st. 2-4 in. l., wiry, naked ; fr. ovate-triangular, tripinnatifid, 3-8 in. 1., 2-3 in. br.; main rachis slightly winged above; the second. rachis winged throughout; lower pinnoe triangular-acuminate; ult. segm. linear, 2-3 lin. 1., spinuloso-dentate ; sori very numerous, often 6 to 8 on a single pinnule ; invol. suborbicular, entire, divided down nearly to the base ; recept. always included.-Hk. Sp. Fil. 1. p. 98.t. 35. D. H. pyriforme, V.D.B.

Hab. New Zealand.-Best distinguished from $H$. multifidum by the shape of the involucre. The frond is broader below and the sori are more abundant.

63. H. Smithii, Hk. ; st. 1-2 in. l., wiry, naked or slightly tomentose ; fr. oblong-acuminate, 3-8 in. 1., 2-3 in. br., bipinnatitid; rachis winged above, ciliated below ; pinnoe oblong-triangular, with a winged rachis and simple or 1 to 4 times forked linear spinuloso-serrate segm.; sori 1 to 4 , terminal on the segments of the pinnæ on both sides; invol. oblong, small, divided about halfway down ; valves entire.-Hk. Sp. 1.p. 97. $t$. 35. B. L. serrulatum, Preslii, affine and holochilum, $V . D . B$.

Hab. Philippine Islands, Java, and Malayan Peninsula.-L. flaccidum, V. D. B., is a plant gathered by Drs. Hooker and Thomson in the Khasia Mountains, which resembles this in habit, but has a broad undulato-crispate wing to the main rachis and slightly crisped pinnæ. Probably it is a distinct species; but I have not seen the fruit.

64. H. fucoides, Swartz ; st. 2-4 in. 1., wiry, ciliated ; fr. oblong, tripinnatifid, 4-6 in. 1., $1 \frac{1}{2}-2$ in. br. ; main rachis winged above and ciliated; the second. rachis winged throughout; pinno rhomboidal-acuminate, with long narrow spinuloso- 
dentate entire or forked linear segm.; sori few in number, not more than 4 to a pinna, and usually confined to the segments of the upper side, sessile or slightly stalked, a line each way; valves divided more than two-thirds of the way down, roundish or oblong, spinuloso-dentate or entire.-Hk. Sp. 1. p. 100. Ic. Fil. t. 963. H. spinulosum, H. B. K. Hk. Sp. 1. p. 100. H. pedicellatum, Kunze. H. blepharodes, Pr. H. cristatum, Hk. \& Gr. Ic. Fil. 148. H. Peruvianum, Hk. \& Gr.t. 208.

Hab. Common in Tropical America, from Cuba and Mexico southward to Brazil, ascending in the Andes to 9,000 ft.-The six plants quoted as synonyms are considered as distinct by Van den Bosch. H. torquescens and aculeatum, V. D. B., must probably be placed here also; but I have not seen specimens.

65. H. Magellanicum, Willd.; st. erect, wiry, rigid, 2-4 in. l., naked or margined with an undulato-crispate wing on each side ; fr. oblong triangular, 3-6 in. 1., 2-3 in. br., tripinnatifid; rachis winged throughout; lower pinnoe broadly triangular, with pinnatifid pinnl., furnished with several linear spinuloso-dentate segm. on each side; sori 6 to 10, small, terminal on the segments of the upper pinnæ; invol. oblong, with 2 short toothed valves.-H. attenuatum, Hk. Sp. 1. p. 99 . t. 36. B. L. Magellanicum, V.D. B. H. Bibraianum, Sturm, in Flora 1853, p. 361 .

Hab. Chili, Chiloe, and Organ Mountains.-Rachis and stipe with an undulato-crispate wing, but the frond plane.

66. H. Bridgesii, Hk. ; st. 2-6 in. l., wiry, naked or tomentose ; fr. broadly ovate-triangular, tripinnate, 4-6 in. 1., 2-3 in. br. below ; main rachis only very slightly winged near the apex; pinnoe oblong-triangular, with the pinnl. of the lower ones pinnate quite to the rachis ; ult. segm. very narrowly linear, rigid, 1-2 lin. 1., erecto-patent; sori minute, often 6 to 8 to a pinna, placed 1 or 2 at the base of the pinnules; invol. divided about two-thirds of the way down, oblong, entire or very slightly toothed.-Hk. Sp. Fil. 1. p. 97. t. 35. C.

Hab. Chili and Chiloe.--The only species of this section that is fully tripinnate.

$$
\text { ** Frond crisped. Sp. 67-71. }
$$

67. H. tortuosum, Hk. \& Gr. ; st. 2-3 in. 1., erect, wiry, furnished with a narrow crisped sinuated wing on both sides ; fr. broadly ovate-triangular, tripinnatifis, $3-6$ in. 1., 2-3 in. br. below ; main rachis winged throughout ; lowest pinnoe broadly rhomboidal-triangular ; the segm. more or less crisped ; the ult. divisions 2-3 lin. l., line:ir, irregularly toothed and undulated at the margin ; sori sometimes 10 to 20 to a pinna, terminal on the ultimate segments, sessile; invol. broadly ovate, divided about halfway down; valves spinulose on the outer edge.-Hk. Sp. 1 . p. 99. Hk. \& Gr.Ic. Fil. t. 129.

Hab. Chili, Patagonia, and neighbouring islands. $-L$. seselifolium and $L$. dentatum, placed by Van den Bosch near H. tortuosum, I have not seen.

68. H. dichotomum, Cav.; st. 2-3 in. 1., naked or slightly margined with an undulato-crispate wing on hoth sides; $f r$. ovate-triangular, bi- or tripinnatifid, 4-6 in. 1., 2-3 in. br. ; main rachis winged like the stipe throughont ; lower pinnoe three times as long as broad; the segm. crisped, broadly linear, undulato-dentate at the margin ; sori numerous, placed in the axils of the segments ; invol. small, ovate; valves spinose on the back, divided about halfway down, nearly entire at the apex.-Hk. Sp. Fil. 1.p.98.t.36. A.

Hab. S. Chili and Juan Fernandez.-A closely allied plant grows in Peru (Lechler, 2563) with robust fronds $10 \mathrm{in.}$., a tomentose rachis, and the lower pinnæ with deeply 
pinnatifid pinnules more than $\frac{1}{2}$ in. 1 . Doubtless it is a distinct species ; but $I$ have not seen the fruit.

69. H. denticulatum, Sw. ; st. 1-2 in. 1., erect, naked ; fr. ovate-triangular, tripinnatifid, 2-3 in. 1., 1 in. or more br. at the base ; rachis margined throughout, with a slightly undulated wing: pinnoe slightly crisped, the lower ones rhomboidal, twice as broad as long, deeply cleft, with flabellate or pinnatifid linear segm.; sori usually single, placed at the axils on the upper side of the pinnæ, sometimes recurved; invol. ovate, divided about two-thirds of the way down, spinose on the back, with serrulated valves.-Hk.Sp.1.p.101. V.D.B.Hym. Jav. $t .29$.

Hab. Moulmein, at 7,000 ft., and Java.-A larger and less crisped and more compound plant than $H$. Neesii. It is beautifully figured, as are the other Javanese forms, byVan den Bosch.

70. H. Neesii, Hk. ; st. 1-2 in. 1., naked or slightly winged, with a crispate margin on both sides; fr. ovate, about 2 in. 1., $\frac{3}{4}-1$ in. br., tripinnatifid ; rachis winged throughout, the wing and pinnæ much crisped; pinno with distant narrow simple or 1-3 times deeply-forked deeply-toothed segm.; sori small, usually single, supra-axillary on the upper pinnæ; invol. subcylindrical below, divided more than halfway down, with 2 acute spinuloso-dentate valves.-Hk. Sp. 1. p.99.

Hab. Malayan Peninsula, Java, Borneo, Fiji, and Philippines.-It is quite an open question whether this should be considered a Trichomanes or Hymenophyllum. The Philippine plant is Leptocionium aculeatum of Van den Bosch Valves of the involucre spinose on the back. L. acanthoides and Braunii of Van den Bosch very closely approach this species.

71. H. sabinofolium, Baker ; st. 1-2 in. 1., naked or slightly winged ; fr. broadly ovate, triancular, deeply tripinnatifid, 1-2 in. 1., more than $1 \mathrm{in}$. br. below; rachis margined throughout with a wing which is thickly beset with aristate teeth; pinnce crisped, the lower ones flabellato-pinnatifid nearly down to the midrib; the ult. segm. very narrow, 2-3 lin. 1., and deeply cut up nearly to the midrib by numerous strong aristate teeth; sori solitary, supra-axillary, spinose on the back, divided ahout halfway down with ovate spinoso-serrated valves.

Hab. Salak, Java, Zollinger.-Allied to $H$. Neesii and aculeatum; but here the leafy part is so narrow, and so much cut up by the numerous strongly aristate teeth, that the ordinary appearance of a Hymenophyllum is quite lost, and a frond looks more like a miniature branch of Junipernes Sabina.

\section{Gen. 17. Trichomanes, Smith.}

Sori marginal, always terminating a vein, more or less sunk in the frond. Invol. monophyllous, tubular, closely corresponding with the frond in texture, the mouth truncated or winged, or slightly two-lipped. Recept. filiforin elongated, often considerably exserted beyond the mouth of the involucre, capsuliferous principally at the base. Caps. sessile, depressed, surrounded by an entire, broad, nearly transverse ring, bursting vertically.-The ferns of this genus agree with those of the last in habit of growth and delicacy of texture, the character furnished by the shape of the involucre dividing a very natural tribe into two nearly equal halves. T'he gengraphical range of the species is very similar, as is the range of variation in size and circumscription of frond. TAB. II. f. 17.

$\$$ Feea.-Sterile and fertile fr. different, the latter consisting of a narrow distichous spike. Sp. 1-4. 
1. T. elegans, Rudge ; caud. erect, tufted; sterile fr. 6-8 in. 1., 2 in. br., on st. 2-3in.l., pinnatifid nearly to the rachis, with finely-toothed linear-oblong segments, the veins anastomosing, the apex often rooting and proliferous ; fertile fr. 6-12 in. 1., about $\frac{1}{2}$ in. br., on st. $4-8$ in. 1 . ; sori piaced in close rows along both margins, the tube yuite sunk, the mouth not at all dilated.-Hk. Sp. 1. $p .114$. Gard. F.t.2. Hymenostachys diversifrons, Bory. Feea Boryi, $V . D . B$.

Hab. Tropical America, from Trinidad and Guatemala southward to Peru.

2. T. botryoides, Kaulf. ; caud. erect, tufted; sterile fr. 2-3 in. 1., 1 in. or rather more br., on very short st., pinnatifid to a slightly winged rachis, with linear-oblong deeply-toothed lobes, the apex rooting and copiously proliferous; veins free; fertile fr. on st. 1-2 in. 1., narrowly linear, the lower sori stalked, usually free, the upper connected at the base, and the apex of the frond foliaceous. - T. nanum, Bory. Hk. Sp. 1. p. 115.

Hab. Tropical America ; Guiana, Leprieur \& Appun; Panama, Seemann.-Quite intermediate in the character of the fertile frond between elegans and spicatum, and more delicate in texture than either.

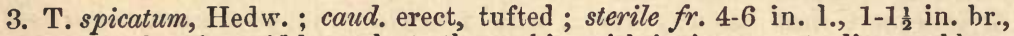
on st. 1-2 in. 1., pinnatifid nearly to the rachis, with inciso-crenate linear-oblong segments; veins free; the apex not rooting; fertile fr. composed of a rachis and two rows of sori, without any connecting membrane; tube obconico-cylindrical, firm in texture, mouth not dilated.-Hk. Sp. 1. p. 114. Gard. F. t. 60. Feea polypodina, Bory.

Hab. West-Indian Islands, frequent ; Panama, Guiana, and Ecuador.-Maschalosorus Mougeoti, V.D. B., is an abnormal state, with the sterile and fertile frond combined.

4. T. heterophyllum, H. B. K.; rhizome creeping, widely ferrugineo-villose; sterile fr. $2-4$ in. $1 ., 1-1 \frac{1}{2}$ in. br., on st. 1 in. or less l., pinnatifid to a narrowly winged rachis, with closely-placed imbricated sinuato-pinnatifid crisped oblong pinnæ; veins free; fertile fr. on villose wiry st. $6-8$ in. 1. , the frond 2-3 in. l., about $\frac{1}{2}$ in. br., subcoriaceuus in texture, linear-oblong, pinnatifid down to a broadly-winged rachis; the lobes oblong, pinnatifid about halfway to the midrib; sori 4-6 to each pinna, terminal on the upper ultimate segments; the tube quite sunk in the frond, the mouth not dilated.-T. Spruceana, Hk. Ic. Pl.t.981. Feea Humboldtii, $V$. D. B.

Hab. Tropical America ; Essiquibo, Schomburghk; N. Brazil, Spruce.-Connects in habit this dimorphous-fronded group with $T$. crispum.

\section{$\$ \S$ Eutrichomanes.f Sterile and fertile fronds uniform or nearly so. Sori not spiked.}

* Fronds entire or slightly lobed. Sp. 5-20. See also No. 60 \& 46.

+ Fronds without a distinct central midrib, but with veins radiating from the base as in a fan. Sp. 5-13.

\# This includes numerous genera of Presl and Van den Bosch, founded primarily on the texture of the frond (whether it is composed of one or more than one layer of cellules) ; secondarily, upon whether the mouth of the involucre is entire or two-lipped, and afterwards in the degree to which the frond is divided, and the character of the venation. 
5. T. reniforme, Forst. ; st. 4-8 in. 1., naked, wiry ; fr. orbicular, reniform, entire, with a deep sinus at the base, $2-4$ in. br.; spurious venules none; sori often encircling the whole of the outer margin ; recept. much exserted, stout, and covered with capsules.-Hk. Sp. 1. p. 115. Hk. \& Gr. Ic. Fil.t.31. Exot. Ferns, $t$. 2. Crepidomanes, Presl.

Hab. New Zealand.-This is the only species in which the frond has four layers of cellules, and the habit is quite peculiar.

6. T. lineolatum, Hk.; st. none or short, tomentose ; base of the fr. narrowed very gradually below; fr. $\frac{1}{2}-1$ in. $1 ., \frac{1}{2}$ in. br., suborbicular or obovatecuneate, nearly entire or subpalmate, or rather deeply pinnatifid, with linearoblong lobes, subopaque and prominently veined when dry ; spurious venules none ; sori few, subterminal ; invol. sunk in the frond, the mouth distinctly twolipped.-Hemiphlebium, $V . D . B$.

Hab. Cuba, Jamaica, and Merida.-Allied in habit to T. reptans and punctatum, but without spurious venules.

7. T. peltatum, Baker ; rhizome wiry, slender, wide-creeping, tomentose ; fr. quite sessile, attached to the rhizome near its centre or towards the base, suborbicular in general outline, $\frac{1}{2}-1$ in. each way, delicately membranaceous in texture, the margin undulated, not thickened, sometimes irregularly cleft rather deeply; veins close, regularly dichotomous at a small angle, with numerous interrupted spurious venules between them at the margin and towards the centre; sori 1 to 3 , scattered, firm in texture, the tube more or less exserted, with a very much dilated spreading slightly two-lipped mouth.-Baker in Linn. Proc. inedit. cum icone.

Hab. Samoa, Rev. T. Powell; New Caledonia, Vieillard, 2166.-A very curious novelty, quite peculiar in habit. "The different branches of the caudex," writes the discoverer, "run upwards, but so closely together, that the margins of the fronds overlap each other. The fronds all lie flat upon the tree, so that the whole fern bas much the appearance of a delicate foliaceous lichen or frondose Jungermannia."

8. T. membranaceum, L. ; fr. subsessile, membranaceous in texture, suborbicular in general outline, 2-3 in. br., more or less deeply cut from the circumference towards the centre, with broad rounded or narrow lobes, the margin fringed with a double series of peltate scales; spurious venules copious; invol. numerous, placed round the edge of the frond, the tube sunk, the mouth twolipped.-Hk. Sp. 1.t. 115. Exot. Flora, t. 76. Lecanium, V.D. B.

Hab. Tropical America, both the islands and continent.-Here, although the frond is so thin, there are two or three layers of cellules, and the curious peltate scales of the frond are unique. The habit is that of Padina pavonia amongst $A$ lgae or a broad-lobed Flustra.

9. 'T. cuspidatum, Willd.; fr. distinctly but very shortly stalked, about $\frac{1}{2}$ in. br., the outer edge rounded and more or less lobed, the base truncate or more or less cuneate; spurious veins distinct; invol. 1 to 6 , the tube sunk in the frond, the mouth dilated, but scarcely two-lipped.-Hk. $S^{y} p_{.}$1. $p .119$. Microgonium, V. D. B. T. Bojeri, Hk. Sp. 1.p. 116. Hk. \& Gr. Ic. Fil.t. 155.

Hab. Mauritius and Bourbon.

10. T. Motleyi, V. D. B. ; fr. copious, imbricated, sessile, about $\frac{1}{4}$ in. br., cordate-orbicular, nearly entire; spurious veins indistinct, the solitary exserted; sorus placed in a deep apical sinus, the mouth spreading and much dilated, but entire.

Hab. Borneo, discovered by Messrs. Barber and Motley; New Caledonia, Lenormand. 
11. T. Godmani, Hk. MSS. ; fr. tomentose, strong, $\frac{1}{4}-\frac{3}{4}$ in. $1 ., \frac{1}{4}-\frac{1}{2}$ in. br., suborbicular or obovate, the margin entire or slightly lobed; venation flabellate above, but the frond furnished with a distinct central costa through the lower half; spurious venules indistinct; sori 1 to 9 , the tube quite sunk in the frond, the mouth dilated, entire.

Hab. Guatemala, Salvin \& Godman; Panama, Hayes.-Similar to T. Motleyi in habit, but quite different in the fruit.

12. T. punctatum, Poiret ; fr. stalked or subsessile, $\frac{1}{4}-\frac{1}{2}$ in. br., suborbicular or obovate, undulated or slightly lobed at the margin; veins closely placed, with thick prominent spurious venules between them; sori 1 to 4 , placed on the outer edge of the frond, and more or less exserted, the mouth distinctly twolipped.-Hk. Sp. 1. p. 116 . Hk. \& Gr. Ic. Fil.t. 236. Hemiphlebium, V.D.B.

Hab. Tropical America, both the islands and mainland.

13. T. reptans, Swartz; st. $\frac{1}{4}$ in. 1. ; fr. $\frac{1}{4}-\frac{1}{2}$ in. br. each way, obovate-cuneate, often with short blunt lobes; veins close; spurious venules conspicuous; sori 1 to 4 , placed on the outer margin, tube partially or quite exserted, the mouth distinctly two-lipped.-Hk. Sp. 1.p. 116. Hk. \& Gr. Ic. Fil. t. 32. Hemiphlebium, $V . D . B$. T. sphenoides, Kunze in Schk. F.t. 88. fig. 2. in greater part.

Hab. Tropical America, both the islands and mainland.-There has been considerable confusion between this species and the preceding, which are very closely allied.

\section{H Fronds with a distinct central costa from apex to base. Sp. 14-20.}

14. T. Barklianum, Baker ; fr. very shortly stalked, 2-3 lin. 1., 1 lin. br., linear-oblong, entire, the margin undulated; veins pinnate; spurious venules none; sori solitary, terminal, the tube partially exserted, with a large dilated entire mouth. Baker in Linn. Proc. inedit. cum icone.

Hab. Tamari Cascade, Mauritius.-A very interesting novelty, the discovery of which we owe to Sir Henry Barkly, the Governor of Mauritius, and Lady Barkly.

15. T. Vitiense, Baker; fr. subsessile or very shortly stalked, oblong, entire or rarely bifid, 2-4 lin. 1., 1-2 lin. br., furnished with a midrib only ; lat. veins none; spurious venules none ; sori solitary, terminal, the tube partially exserted, the mouth entire, slightly dilated.-Baker in Linn. Proc. inedit. cum icone.

Hab. Fiji Islands, Milne.-This species rivals in minuteness Hymenophyllum parvifolium and the preceding. From this latter it is readily distinguishable by the absence of lateral veins, and the two are the only pinnate-veined species that are without spurious venules.

16. T. Neilgheriense, Beddome ; st. 1-2 lin. 1. ; fr. $\frac{1}{4}-\frac{1}{2}$ in. 1., 1-2 lin. br., oblonglanceolate, not lobed, but sometimes bifid at the apex; spurious venules numerous; sori 1 to 2 , the tube more or less sunk in the frond, the mouth exserted, with two large rounded lips.-Bedd. Fil. S. Ind. t. 6.

Hab. Western slopes of the Neilgherry range, S. Hindostan, discovered and figured by Captain Beddome.

17. T. Petersii, A. Gray ; st. 1-2 lin. 1.; fr. $\frac{1}{4}-\frac{1}{2}$ in. 1., 1-2 lin. br., varying in shape from linear to obovate-spathulate, crenate or slightly lobed; spurious venules few, short and often unconnected; sori solitary, terminal, the tube sunk in the frond, the mouth much dilated, but entire.-A. Gray, in Sill. Am. Journ., 1853, p. 326. Hk. Ic. Pl.t. 986 . Microgonium, $V . D . B$.

Hab. Near a waterfall in Winston co., Alabama, U. S. A. 
18. T. apodum, Hk. \& Gr.; rhizome strong, wide-creeping, tomentose, irregularly pinnate ; fr. subsessile, $\frac{1}{4}-\frac{1}{2}$ in. each way, orbicular-cordate, with broad deep lobes and scattered stellate tufts of ciliæ on the edge; second. veins distant and but little branched; sori solitary, terminal, quite exserted, the mouth dilated and distinctly two-lipped.-Hk. Sp. 1. p. 118. Hk.\& Gr. Ic. Fil. t. 117. Didymoglossum, $V . D$. B.

Hab. Tropical America, both the islands and mainland.

19. T. Henzaianum, Parish ; st. 1-2 lin. 1. ; fr. $\frac{1}{4-\frac{1}{2}}$ in. each way, thin in texture, orbicular or obovate-cuneate, bluntly lobed or slightly tending towards palmate; lat. veins rather distant; spurious venules copious; sori 1 to 6 , placed near the centre of the outer margin ; invol. sunk in the frond, the mouth distinctly two-lipped.-Parish in Hk. 2. Cent. Ferns, $t .1$.

Hab. On trees, Moulmein, Pegu, Henzai \& Parish.

20. T. muscoides, Swartz ; fr. shortly stalked, 1-3 in. l., $\frac{1}{4}-\frac{1}{2}$ in. br., varying in shape from linear-oblong to suborbicular, nearly entire or bluntly lobed, especially above; spurious venules faint but copious; sori 1 to 8 , terminal on the lobes, the tube sunk in the frond, the mouth free, dilated, but usually scarcely two-lipped.-Hk. Sp. 1.p. 117.

Hab. Tropical America, Asia, Polynesia, and Africa.-Sir W. Hooker was disposed to place bere eight species of Van den Bosch, authentically represented in his collection ; viz. muscoides, sublimbatum, cerugineum, erosum, Hookeri, Lenormandi, bimarginatum, and Kapplerianum. The first of these is considered by that author as a Hemiphlebium (mouth distinctly two-lipped), and the two next he separates from the other five by the character of "spurious venules free, joined together towards the margin." T. Schaffneri, Schlt., T. Pabstianum, C. Mull., and T. crispulum, V.D. B., are closely allied plants not represented by name in the Hookerian collection.

* Fronds entire below, palmate or digitate above.-Gonocormus, V.D.B. Sp. $21-30$.

21. T. parvulum, Poiret ; rhizome wide-creeping, interlaced ; st. 1 in. 1., wiry, slender, tomentose below; fr. $\frac{1}{4}-\frac{1}{2}$ in. each way, orbicular in general outline, cuneate or truncate at the base, flabellately cut about halfway down from the outer edge in the direction of the base into narrow irregular segments; veins close, prominent, so that the frond when dry appears channelled, dichotomous at a very small angle; spurious venules numerous; sori 4 to 6 , terminal on the central segments, the tube quite sunk in the frond, the mouth dilated at the sides.-Hk. Sp. p. 118. $t$. 39. A.

Hab. Japan, China, the Malaccas, Java, Polynesian Islands, Madagascar, and Johanna Island.

22. T. saxifragoides, Presl ; st. $\frac{1}{4}$ in. 1., slender, tomentose below ; fr. $2-3$ lin. each way, flabellato-suborbicular in general ontline, cut from the margin in the direction of the apex of the stipe into numerous linear-acute segments, the deepest divisions scarcely reaching halfway down ; veins close, prominent, irregular; sori 2 to 4 , the tube sunk in the frond, the mouth dilated, spreading, scarcely two-lipped.

Hab. Java, New Ireland, Fiji and Philippine Islands.-Very near T. parvulum, from which it differs by its smaller and less deeply cut fronds, and the dilated mouth of the involucre. Van den Bosch assigns to T. minutum, Blume, proliferous stipes; but I cannot distinguish from this his specimens thus marked in the Hookerian collection.

23. T. Mannii, Hk. MSS.; rhizome wide-creeping; st. $\frac{1}{2}-1$ in. l., slender, tomentose below; fr. $\frac{i}{2}-1$ in. each way, suborbicular in general outline, deeply 
flabellately divided into narrow dichotomous linear segments; spurious venules few ; sori 4 to 8 , terminal on the central lobes, the mouth much dilated and spreading, but not two-lipped.

Hab. Fernando Po, G. Mann.-Closely allied to T. parvulum, but a larger and more deeply divided plant, with a broad plaited wing all round the mouth of the involucre.

24. T. proliferum, Blume; rhizome wide-creeping, densely interlaced; st. 1-2 in. l., slender, bearing 1 to 3 deeply divided fronds, which were not more than 1 in. br. either way, varying from ovate-lanceolate to roundish in general outline; segm. narrow, dichotomously branched, divided down nearly to the central rachis; veins numerous, irregular; sori 4 to 12 , terminal, the tube quite sunk, the mouth obscurely two-lipped.-Hk. Sp. 1. p. 118. t. 39. B. T. palmatum, Presl.

Hab. Java, Philippine Islands, Ceylon, and western slope of the Neilgherries.-Usually easily recognizable by its peculiar proliferous habit, but the fronds are very variable in outline, and sometimes closely resemble the deeply-divided forms of section 3. T. diffusum, Blume, and T. T'eysmanni, V. D. B., are closely allied Javan plants, which I have not seen. A plant collected by Barter at Sierra Leone is probably this species; but it is in a young state, and does not show the proliferous ramification. This species is cut more deeply than the three preceding, and the segments are narrower.

25. T. flabellatum, Bory (non V.D. B.) ; st. 1 in. l., slender ; fr. $\frac{1}{2}$ in. br., flabellate-orbicular, the principal divisions reaching more than halfway down from the circumference to the summit of the stipe, the ultimate divisions short, the segments close together, broadly linear, obtuse, not toothed or ciliated; spurious venules none; sori 2 to 4 , terminal on the central segments; invol. turbinate, the mouth distinctly two-lipped, denticulate.-Hymenophyllum flabellatum, V.D.B.

Hab. Bourbon.-Our description is taken from specimens referred to the plant of Bory, on Dr. Van den Bosch's authority. Bory's plant came from the Falkland Islands, and he did not know the fruit. Dr. Van den Bosch considers this a Hymenophyllum, and uses the name for a plant we have placed under $T$. digitatum. There is an allied T. Thouarsianum, Presl, from Bourbon, which we have not seen.

26. T. Powellii, Baker; rhizome wide-creeping, tomentose; $f r$. quite sessile, $\frac{1}{8}$ in. br., $\frac{1}{2}-1$ in. l., simple or once or twice deeply forked, dark brown in colour, a single central costa only in each segment, the texture rather thickly membranaceous, the membrane on each side of the midrib slightly undulated, but the margin neither ciliated nor toothed; sori 1 to 4, terminal on the segments, nearly or quite sunk; invol. obconico-tubular, the mouth wide-spreading, two-lipped, naked, not toothed.

Hab. Samoa, Rev. T. Powell.-Allied to T. digitatum, but readily distinguishable by the characters given.

27. T. digitatum, Swartz; st. very slender, naked, $\frac{1}{2}$ in. 1. ; fr. 1-2 in. l., $\frac{1}{2}-1 \mathrm{in}$. br., irregular in general outline, divided down nearly to the base or a broadly-winged rachis into long broad!y linear dichotomous ciliated segments, with only a central costa in each ; sori 2 to 6 , terminal on the segments; invol. cupshaped, quite sunk, the mouth broadly dilated, slightly two-lipped.-Hk. Sp. 1 . p. 119. T. lancenm, Bory. Hk. \& Gr.Ic. Fil.t. 33. T. flabellatum \& nitidulum, V.D.B.- $\beta, T$. palmatifidum, C. Muller; fr. ciliated more strongly and densely, and not on the edge only, but also on the costa and margin of the invol.

Hab. Mauritius, Bourbon, Java, and Polynesian Islands.-This is given as a Cape plant, on Dr. Brown's authority, and there is a scrap from E. India from amongst Mr. Griffith's plants in Herb. Hooker. The Polynesian is generally more branched than the African plant, and in the latter the ciliæ are sometimes scarcely visible. 
28. T. calvescens, V. D. B. ; st. 1-2 in 1., filiform, naked; fr. about $\frac{1}{2}$ in. each way, inversely triangular or rhomboidal in general outline, flabellately divided down nearly to the rachis into slightly dichotomous denticulate broadly linear segm., with only a central costa in each ; sori 2 to 4 terminal on the central segments; invol. turbinate or obconical, sunk in the frond, with a free, broad dilated deeply and irregularly toothed naked two-lipped mouth.- $V . D . B$. Suppl. 2. p. 115.

Hab. N. S. Wales, Major Vicary.-This also would be quite as suitably ranked under Hymenophyllum in the section Leptocionium as bere.

29. T. Lyallii, Hk. MSS. ; st. 1-2 in. l., slender, filiform ; fr. $\frac{3}{4}-2$ in. each way, suborbicular in general outline, flabellately divided down very nearly to the base into dichotomously-branched narrowly linear ciliated and minutely denticulate segments; sori 3 or 4 , terminal on the segments; invol. obconical, quite sunk in the tube, the mouth ciliated, not dilated.-Hymenophyllum, Hk. fil. Fl. N.Z. 2-16.

Hab. Trees, south-west coast of the middle island, New Zealand, Dr. Lyall.-Quite intermediate between the typical Hymenophylla and Trichomanes in the shape of its involucre, the breadth of the orifice of which nearly equals the depth of the tube.

30. T. nanum, V.D. B. ; rhizome slender, wide-creeping ; st. very short ; fr. not more than $\frac{1}{2}$ in. each way, cuneate below, the outer margin rounded, central portion not more than $\frac{1}{2}$ in. broad, divisions simple or once branched; ult. segm. $1 \frac{1}{2}-2$ lin. 1 . by $\frac{1}{4}$ lin. br. ; texture thick but not rigid, surface somewhat undulated, margin bounded by a thickened line ; a central vein only in each segment; sori 1 to 2 to a frond, sub-terminal, tube turbinate, not at all exserted, the mouth dilated, undulated in irregular plications.- V.D. B. 2. Suppl. p. 122. Crepidomanes, $V . D . B$.

Hab. Assam, Griffith.-Closely resembling $T$. intramarginale in texture, but quite different in size, \&c., and in division agreeing best with this section.

\section{** Fronds more or less deeply pinnatifid, but not truly pinnate. Sp. 31-57.}

\section{+ Main rachis distinctly winged throughout. Sp. 31-47.}

31. T. pusillum, Swartz; rhizome wide-creeping, tomentose; fr. nearly sessile, $2-3$ in. 1., $\frac{1}{2}-1$ in. br., oblong or obovate, cuneate-attenuate below, once deeply pinnatifid down to a broadly-winged rachis; lobes linear or oblong, toothed or deeply pinnatifid, texture membranaceous; a central costa in each pinna, with numerous erecto-patent secondary veins and spurious venules; sori 1 to 4 , round the apex of the frond, tube exserted, mouth with two large rounded lobes.-Hk. Sp. 1. p. 117. T. quercifolium, Hk. \& Gr. Ic. Fil. t. 115. Hemiphlebium, $V . D . B$. T. Robinsoni, Hk. MSS.

Hab. Tropical South America, from Mexico and the West Indies southward to Brazil and Peru. Kranz-kop, Natal, Rotinson; Moulmein, Rev. C. S. Parish.

32. T. Krausii, IIk. \& Gr.; rhizome wide-creeping, tomentose ; fr. sessile or nearly so, 1-3 in. l., $\frac{1}{2}$ in. br., oblong, attenuate or cuneate at the base, once deeply pinnatifid down to a broadly-winged rachis; lobes linear-oblong, nearly entire, or toothed or sinuato-pinnatifid, texture membranaceous; a central costa in each pinna, with distant pinnate secondary veins passing gradually into spurious venules; sori 1 to 6 , on the apex of the frond, tube more or less exserted, mouth with two large rounded lips.-IIk. Sp. 1. p. 120. Hk. \& Gr. Ic. Fil. t. 149. Hemiphlelium, $V . D . B .-\beta$, crispatum; pinnoe deeply lobed or pinnatifid, broadly and conspicuously crisped, their secondary veins more numerous and divaricated than in the type, sometimes again branched. 
Hab. West Indian islands and Mexico southward to Brazil and Peru; $\beta$, Andes of Ecuador, Spruce, No. 5354.- - Very near the preceding, but the undivided portion of the frond is broader, and the central costa more clearly marked.

33. T. Kirkii, Hk. MSS.; st. slender, 1 in. 1., winged above ; tr. 1-2 in. l., 1 in. br., subquadrate or rhomboidal in general outline, cut down to a narrowlywinged rachis; segm. 1-2 in. 1., erecto-patent, linear, crenulate at the margin, with a considerable space between them; a central costa and numerous short oblique veins and manifest spurious venules in each segment; sori 2 to 12, the tube sunk in the frond, the mouth spreading, slightly two-lipped.

Hab. Johanna Island, West Africa, Dr. Kirk, Sir F. Grey.-Allied to the two preceding, rom which it differs by its long narrow little-divided pinnæ and winged involucre.

34. T. sinuosum, Rich.; rhizome wide-creeping, sinuous, rather strong; st. varying from hardly any to 2 in. 1. ; fr. $2-9$ in. $1 ., 1-1 \frac{1}{2}$ in. br., linear-lanceolate, very gradually decurrent below, pinnatifid down to a broadly-winged rachis; colour bright green, texture delicately membranaceous; lobes oblong, obtuse, crenate at the margin; a central costa in each, with 2 to 4 pairs of erecto-patent branches; spurious venules none, the margin ciliated; sori 2 to 4 to each lobe, the tube sunk, the mouth dilated, slightly two-lipped ; recept. much exserted.Hk. Sp. 1. p. 120. Hk. \& Gr. Ic. Fil.t. 13. T. incisum, Kaulf. Hk. Sp.1.p. 121.

Hab. Tropical America, from Mexico and Cuba southward to Peru and Brazil.

35. T. pinnatifidum, V. D. B. ; st. slender, 1-2 in. 1., winged above ; fr. 2-4 in. 1., 1-1 $\frac{1}{2}$ in. br., ovate-lanceolate in general outline, cut down to within a short distance of the rachis; segm. linear, erecto-patent, the lower $1 \mathrm{in.}$., with deep rounded lobes; substance thin; central veins of the segments with 2 to 6 pairs of lateral veins; spurious venules none, the margin ciliated; sori 1 to 3 , placed principally near the base of the segments on the upper side, the tube quite sunk, the mouth broadly dilated, two-lipped.- V. D. B. Suppl.2. p. 118.

Hab. Jamaica.-Closely allied to $T$. sinuosum, but different in outline, and much more deeply divided.

36. T. Bancroftii, Hk. \& Gr. ; st. 1-2 in. 1., broadly winged down to the very base ; fr. 3-6 in. 1., 1 in. br., ovate-oblong, pinnatifid down to a broadly-winged rachis, texture subcoriaceous; segm. oblong, blunt, crenate, either imbricated or with a small space between them; lat. veins of the segments branched; spurious venules none; sori 2 to 6 to a pinna, the tube sunk, the mouth rather dilated, but entire ; recept. long, filiform.-Hk. Sp. 1. p. 123. Hk. \& Gr. Ic. Fil. t. 204. Hk. Gard. Ferns, t. 56. T. coriaceum \& holopterum, Kunze.

Hab. Tropical America, from the West Indian islands southward to Brazil and Peru.]

37. T. macilentum, V. D. B. ; rhizome creeping, wiry ; st. 2-6 in. 1., wiry, winged above; fr. 2-6 in. 1., 1-2 in. br., lanceolate or ovate-lanceolate, divided down within a short distance of the rachis; segm.oblong or linear-oblong, nearly entire or divided more than halfway down into narrow linear lobes, texture subcoriaceous; veins thick; spurious venules none; sori 2 to 6 to a segment, the tube sunk, the mouth slightly two-lipped; recept. long, filiform.- $V . D . B .1$ st Suppl. p. 12.

Hab. Trinidad, Demerara, and northern provinces of Brazil.-Near T. Bancroftii, but distinguishable by its more divided fronds and creeping rhizome.

38. T. superbum, V. D. B. ; rhizome strong, wide-creeping ; st. 2-5 in. 1., strong, winged nearly down to the base ; fr. 4-9 in. 1., 2-4 in. br., broadly ovate, pinnatifid down to a narrowly-winged rachis, the substance subcoriaceous; lower pinnce lanceolate, divided more than halfway down to the rachis, with oblong 
crenate lobes; main and secondary midribs tomentose; lat. veins numerous; spurious venules none; sori 2 to 6 to each lobe ; invol. sunk, the mouth scarcely dilated; recept. long, filiform.-V. D. B. Suppl. 2. p. 119.

Hab. Trinidad and British Guiana.-This and the two preceding are very closely allied.

39. T. Kaulfussii, Hk. \& Gr. ; rhizome wide-creeping, strong, tomentose; st. 2-4 in. l., strong, compressed, winged above; fr. 4-12 in. l., $1 \frac{1}{2}-2$ in. br., ovatelanceolate-acuminate, once pinnatifid down to a broadly-winged rachis; segm. linear-oblong, rounded or acute, toothed, the largest 1 in. l., $\frac{1}{4} \mathrm{in.}$ br.; main rachis densely and the surface slightly hairy; lat. veins of the segments 1 to 4 times forked; spurious venules none; sori 2 to 12 to a pinna, tube more or less exserted, mouth with two lateral projections; recept. long, filiform. $-H k . S p .1 . p .122$. T. lucens, Hk. \& Gr. Ic. Fil. t. 10 (non Swartz).

Hab. West Indian islands, Guiana, and N. Brazil.

40. T. alatum, Swartz ; st. tufted, 2-4 in. 1., winged above ; fr. $3-12$ in. 1., 1-4 in. br., lanceolate or ovate-lanceolate, bi-tripinnatifid; main rachis winged throughout; pinnce lanceolate acute, cut more than halfway down to the rachis; lobes often again sharply toothed; texture delicately membranaceous; rachis rather hairy; ult. segm. with several lateral veins; spurious venules none; sori 2 to 12 to a pinna, terminal on the segments, the tube sunk, the mouth spreading but scarcely two-lipped; recept. long, filiform.-Hk. Sp. 1. p. 123. Hk. \& Gr. Ic. Fil.t. 21. T. attenuatum, Hk. Sp. 1. p. 122.t. 39. C. T. ptilodes, lineare, \& delicatum, $V . D . B$.

Hab. West Indies, Venezuela, and Ecuador.-Very variable in robustness and hairiness. The large state is a very beautiful plant.

41. T. bicorne, Hk. ; rhizome strong, scarcely creeping ; st. 1-2 in. l., winged

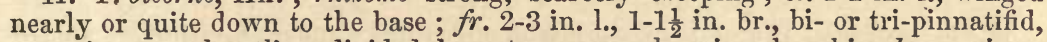
ovate in general outline, divided down to a narrowly-winged rachis; lower pinnoe ovate-triangular, cut down to a broadly-winged rachis, the lobes again deeply divided ; ult. segm. linear; substance subcoriaceous ; a central costa only in each segment; sori 2 to 4 to a pinna; invol. tubular, quite sunk in the frond, the mouth dilated into two lateral projections.-Hk. Ic. Pl.t.982.

Hab. North of Brazil, Spruce.-This and the two preceding resemble one another closely in delicacy of texture, but differ in the extent to which the frond is divided.

42. T. intramarginale, Hk. \& Gr.; rhizome slender, wide-creeping, tomentose ; st. very short ; fr. 1-2 in. 1., $\frac{1}{4}-\frac{1}{2}$ in. br., oblong-rhomboidal, bipinnatifid, tapering gradually below, central portion 1 lin. br.; segm. few, erecto-patent, linear, simple or forked; substance subcoriaceous, opaque, somewhat crisped when dry ; a central costa only in each segment, but the margin thickened; sori 1 to 4 to a frond, terminal or axillary on the upper segments, tube sunk, mouth not dilated. -Hk. \&. Gr. Ic. Fil.t. 211. Hk. Sp. 1. p. 120. Crepidomanes, V. D. B.

Hab. Ceylon, rediscovered recently by $\mathrm{Mr}$. Thwaites. - This resembles in texture the next species and No. 31 .

43. T. latemarginale, Eaton; rhizome slender, wide-creeping, tomentose; st. none or scarcely any ; fr. about $\frac{1}{2}$ in. l., $\frac{1}{4}$ in. br., suborbicular or oblong-rhomboidal, pinnatifid; main rachis with a wing about 1 lin. br. ; segm. linear, close, simple, or once forked; substance membranaceous, surface naked; a central cost $\alpha$ only in each segment, but the margin thickened; sori 1 to 3 , terminal on the upper segments, tube sunk, mouth dilated, two-lipped.-Eaton, Fil. Chin. \& Japan, $p .3$. 
Hab. Hongkong, C. Wright.-We owe the discovery of this species to the United States North Pacific Exploring Expedition of 1853-6, under Capts. Ringgold and Rodgers.

44. T. humile, Forster ; rhizome creeping, deeply intermatted ; st. $\frac{1}{4}-\frac{1}{2}$ in. 1 ., slender, winged above ; fr. 1-2 in. 1., $\frac{1}{2}$ in. br., bipinnatifid, lanceolate-oblong in general outline, cut down to a narrowly-winged rachis; segm. pinnatifid, with simple or once-forked linear lobes ; substance membranaceous, surface and margin naked ; a central costa only in each segment ; no spurious venules ; sori solitary, on the upper side of the pinnæ, tube more or less exserted, the mouth spreading,

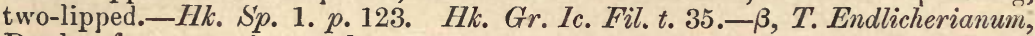
Presl ; fr. more elongated; segm. narrower and less branched. T. erectum, Brackenridge.

Hab. Java, New Zealand, and Pacific Islands.-T. aureum, V. D. B., differs from the type by its longer and broader slightly-crisped segments.

45. T. brachypus, Kunze ; rhizome long, wiry, wide-creeping, more or less tomentose ; fr. 1-2 in. apart, nearly sessile, 3-6 in. 1., 1-1 $\frac{1}{2} \mathrm{in.} \mathrm{br.,} \mathrm{once} \mathrm{pinnatifid,}$ cut down to a broadly-winged rachis ; lower pinnoe oblong, blunt, $\frac{1}{2}-1$ in. $1 ., \frac{1}{4}-\frac{1}{2}$ br., varying from nearly entire to cut down to a broadly-winged rachis with linear lobes ; texture membranaceous ; surface nearly naked or ferrugineo-tomentose, especially on the veins; veins prominent; lat. veins of the pinnæ parallel and erecto-patent; 110 spurious venules; sori 1 to 12 to a pinna, placed at the edge of the lower half on both sides, tube long, cylindrical, stalked, mouth scarcely spreading.-Hk. Sp. 1.p. 121. 'T. Ankersii, Parker, in Hk. Gr. Ic. Fal.t. 201. $-\beta, T$. Tanaicum, Hk. ; fr. 6-9 in. l., linear, undivided ; sori in long rows on both sides.

Hab. Tropical America, from the West Indian Islands southward to Peru and the South of Brazil.-A very distinct plant, which corresponds to the genus Lacostea of Van den Bosch, who makes nine species.

46. T. pallidum, Blume ; rhizome wide-creeping, slender, tomentose ; st. 1-3

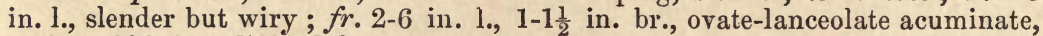
bipinnatifid, just divided down to a narrowly-winged rachis; lower pinnoe ovaterhomboidal, divided more than halfway down, and the lobes again slightly cut; substance subcoriaceous, both surfaces, when dry, often decidedly coated with white, always more or less clothed with strong light-brown hairs; veins broad and few ; sori 1 to 4 to a pinna, axillary on the segments on both sides, the tube nearly sunk, the mouth dilated, but scarcely two-lipped.-Hk. Sp. 1. $p .139$. T. glauco-fuscum, Hk. Sp. 1. p. 128. t. 40. A. T. album, Blume, Hk. Sp. 1. p. 129.

Hab. Malayan Peninsula, Ceylon, Java, Sumatra, and Pacific Islands.-This corresponds to the genus Craspedoneuron of V an den Bosch, who makes four species. The pallid hue of the dry frond is very peculiar, and the coating of hairiness is sometimes very prominent, but is sometimes nearly deciduous.

47. T. serratulum, Baker ; rhizome slender, wide-creeping ; st. slender, naked, about $\frac{1}{4}$ in. l. ; fr. under $\frac{1}{2}$ in. 1., about $\frac{1}{4}$ in. br., oblong or subrhomboidal in general outline, pinnatifid down to a narrowly-winged rachis ; segm. erecto-patent, in 2-6 pairs, linear, simple or forked, $\frac{1}{4}$ in. l., under $\frac{1}{2}$ lin. br., toothed at the margin, texture membranaceous ; a central costa only in each segment; spurious venules none; sori 1 to 2 , terminal on the upper segments, the tube exserted or even stipitate, the mouth slightly two-lipped, deeply ciliated with sharp linear teeth.

Hab. On trees, Lobong Peak, Borneo.-Resembling T. calvescens, Lyallii, and denticulatum in its toothed segments, but different in other respects, and a very distinct species. 


\section{H Main rachis hardly, if at all, winged in the lower part. Sp. 48-57.}

48. T. Filicula, Bory ; rhizome wide-creeping, tomentose, rather slender ; st. 1-2

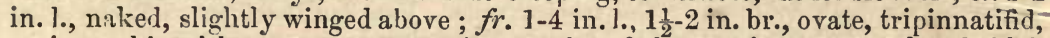
main rachis with a very narrow wing or free below; pinnce ovate-rhomboidal, pinnatifid down to a narrowly-winged rachis; the lower pinnl. again deeply pinnatifid; ultimate segm. linear; texture firm, membranaceous; a central costa in each segment, spurious venules none or indistinct; sori 1 to 4 to a pinna, axillary or terminal on the segments; tube sunk or somewhat exserted, the mouth very distinctly two-lipped, the lips subtriangular with a rounded apex.Hk. Syn. 1.p. 124. Didymoglossum, Desv.- $\beta$, T. late-alatum, V. D. B.; ultimate segments very narrow and acute, wing of rachis somewhat crisped, spurious venules distinct. $-V . D . B$. Suppl. 1.p. 54. D. plicatum, V.D.B.

Hab. Mauritius, Bourbon, Madagascar, Natal, Cape Colony, and Fernando Po; Nepaul, Assam, Japan, N. Hindostan, Ceylon, Java, Borneo, and Polynesian Islands. Very like T. pyxidiferum in habit, and principally distinguishable by the distinctly twolipped involucre. It was formerly supposed that one of them was confined to the New, the other to the Old World; but T. pyxidiferum has now been found abundantly in Asia, A frica, and the Polynesian Islands ; and I cannot distinguish from this, though labelled pyxidiferum on high authority, a Mexican plant from Liebmann. Here are included numerous species of Van den Bosch; amongst which are his Didymoglossum Draytonianum, euphlebium, Griffithii, racemulosum, insigne, capillatum, and dilatatum.

49. T. pyxidiferum, L. ; rhizome wide-creeping, tomentose, rather slender; st. 1-2 in. l., naked, winged above ; fr. 1-6 in. 1., 1-1 $\frac{1}{2}$ in. br., ovate-oblong, tripinnatifid, main rachis with a very narrow wing ; pinnoe ovate-rhomboidal. pinnatifid down to a narrowly-winged rachis, with the lower pinnl. again deeply pinnatifid; ultimate segm. linear, often emarginate at the apex; texture membranaceous; a central cosia in each segment; spurious venules none or indistinct; sori 1 to 4 to a pinna, axillary, tube more or less winged, mouth broadly dilated but scarcely two-lipped; recept. filiform, exserted.-Hk. Sp. 1.p. 124. Hk. \& Gr. Ic. Fil. t. 206. $-\beta, T$. emarginatum, Presl ; more divided, the segments of the pinnules numerous and crowded. T. cavifolium, C. Muller.- - , $T$. olivaceum, Kunze; segments broader, less divided, wing of rachis somewhat crisped, spurious venules distinct.

Hab. Tropical America, from Mexico and the West Indies southward to Brazil and Peru ; Bourbon, Cape of Good Hope, Angola, Fernando Po, Hindostan as far north as Khasia, Moulmein, Borneo, and New Caledonia. - Our a corresponds to numerous species of Van den Bosch, including his hymenophylloides, Lechleri, Brasiliense, Borbonicum, Milnei, Vieillardi, eximium, and Schmidtianum.

50. 'T. radicans, Swartz; rhizome wiry, wide-creeping, tomentose ; st. strong, wiry, ascending, 2-6 in. l., naked or nearly so, sometimes the upper part winged; fr. 4-12 in. 1., 2-6 in. br., tripinnatifid, main rachis very narrowly winged, often free, except near the apex; lower pinnoe 1-4 in. 1., ovate-rhomboidal, cut down to a narrowly-winged rachis; pinnl. again deeply pinnatifid, ovate-rhomboidal, with deeply toothed lower segm.; texture membranaceous but firm; a single vein only carried into each ultimate segment; sori lateral, 1 to 4 to a pinnule, the tube small, subcoriaceous, more or less decidedly exserted, the mouth very slightly two-lipped; recept. slender, elongated.-HK. Syn. 1.p. 125, non Hk. \&. Gr. Ic. Fil. t. 218. Hk. Brit. Ferns, t. 42. T. speciosum, Willd.-13, T. Kunzeanum, Hk. ; fr. 12-18 in. 1., subcoriaceous, main and secondary rachises hardly at all winged; pinnoe distant stalked, pinnules deeply pinnatifid, the lowest lobes again pinnatifid, the segments very long and narrow.-Hk. Syn. 1. p. 127. t. 39. D. T. Antillarum, V.D.B. T. umbrosum, Wall. $-\gamma, T$. Luschnatianum, Presl; fr. lanceolate acuminate, quite sessile.-Hymenophyllum rupestre, Raddi. 
Hab. Europe-Ireland, Wales, Spain ; Africa-Canaries, Madeira, island of St. Thomas, Fernando Po, Angola, 3 ohanna Island; Asia-Japan and Northern Hindostan, Polynesian Islands; America, from Alabama, Mexico, and the West Indian islands southward to Rio Janeiro.-A very widely-diffused and variable plant. The two striking varieties mentioned are both confined to the tropical zone. Van den Bosch refers T. scandens, Linn., to our $\beta$, but the plant of the Linnæan Herbarium is our species 69.

51. T. auriculatum, Blume; rhizome strong, wide-creeping, tomentose ; fr. nearly sessile, 6-12 in. 1., $1 \frac{1}{2}-2$ in. br., bipinnatifid, rachis wiry, very slightly winged throughout or above only; pinnoe shortly stalked, ovate-rhomboidal, obliquely cuneate at the base, irregularly pinnatifid halfway down or more, the lowest anterior lobe often considerably prolonged beyond the others; texture subcoriaceous ; venation close, flabellate; sori $2-12$ to a pinna, the tube nearly or quite exserted, the mouth truncate. Hk. Syn. 1. p. 133. T. dissectum, J.Sm. $H k$. Syn. 1.p. 140. Cephalomanes, $V . D . B$.

Hab. Japan, Formosa, N. Hindostan, Philippines, Java, and Guiana.-Placed by Van den Bosch in the same genus as T. Javanicum, on account of the agreement in venation.

52. T. denticulatum, Baker ; rhizome slender, wide-creeping ; st. slender, naked, $\frac{1}{4}-\frac{1}{2}$ in. $1 . ;$ fr. $1-1 \frac{1}{2}$ in. l., $\frac{3}{2}$ in. br., ovate or oblong, bipinnatifid, main rachis winged above, free below ; pinnoe pinnatifid down to a narrowly-winged rachis ; ultimate segm. linear, serrated, about $\frac{1}{8}$ in. $1 ., \frac{1}{2}$ lin. br. ; texture membranaceous; a costa only in each segment; sori 1 to a pinna, terminal on the lowest segment on the upper side, tube exserted, mouth with two bluntly triangular lips.

Hab. Borneo, discovered by the late Mr. Motley.-An interesting plant, combining the habit of $H$. Tunbridgense with the fruit of a Didymoglossum.

53. T. venosum, R. Br.; rhizome slender, wide-creeping; st. 1-2 in. 1., very slender, naked; fr. 2-5 in. 1., 1-1 $\frac{1}{2}$ in. br., and pinnatifid, the main rachis free in the lower half, broadly winged above; lower pinnoe about 1 in. 1., varying from linear and nearly simple to lanceolate deeply pinnatifid below; texture membranaceous; costa wavy, with numerous alternate once or twice dichotomous secondary veins ; surface naked, shining; sori only 1 to a pinna, axillary on the upper margin, tube immersed, much dilated, slightly two-lipped.-Hk. Sp. 1. $p$. 132. Hk. \& Gr. Ic. Fil.t. 78. Phlebiophyllum, V.D. B.

Hab. Australia and New Zealand.-A very distinct species.

54. T. crispum, L. ; rhizome short or somewhat elongated, strong, tomentose ; fr. scattered or tufted; st. 2-6 in. l., strong, wiry, tomentose ; fr. 4-12 in. l., $1 \frac{1}{2}-2$ in. br., lanceolate, fully pinnate or pinnatifid nearly to the rachis ; lower pinnce $\frac{3}{4}-1$ in, l., 2 lin. br., oblong, obtuse, spreading or even deflexed; texture membranaceous and the pinnæ often incurved and crisped; rachis more or less elothed with reddish-brown hairs, the surface hairy, especially beneath, and the margin ciliated; lateral veins of the pinnæ usually once dichotomous; sori 1 to 3 , placed round the apex of the pinnæ, tube quite sunk, mouth two-lipped; recept. long, exserted.-Hk. Syn. 1.p. 130. Hk. \& Gr. Ic. Fil.t. 12.

Hab. Tropical America, from Cuba and Mexico southward to Peru and Brazil, and recently gathered in West Tropical Africa (banks of the Nun and Niger) by Barter ald Mann.-Apparently we include here all the simply pinnatifid section of Achornanes of Van den Bosch, who enumerates eighteen species. The principal variation is in the vestiture of the froud and elongation of the rootstock, so that the fronds are either tufted or scattered. The extremes of the series in the former respect are $T$. pellucens, Kunze, which is nearly naked, and T. Marlinsii, Presl, and T. Plumula, Presl, in which tl.e rachis is densely clothed with long rust-coloured hairs, and the fronds also thickly coated, especially beneath.

55. T. cr initum, Swa! tz; st. tufted, 1-3 in. 1. , slender, villose ; fr. 2-8 in. $l_{\iota_{2}}$ 
$\frac{1}{2}-\frac{3}{4}$ in. br., ovate-lanceolate or linear-oblong, bipinnatifid ; pinnce reaching down very nearly to the rachis, the lower ones ovate-oblong, cut about half way down into broadly linear segments; substance membranaceous, the surface slightly hairy, margin ciliated; veins slender, the lateral vins of the pinnæo usually once branched ; sori 1 to 2 to a pinna, terminal, tube sunk, mouth ciliated, spreading, but scarcely two-lipped.-Hk. Sp. 1. p. 131.

Hab. West Indian Islands and Andes of Ecuador.-This constitutes the genus Ragatelus of Presl.

56. T. lucens, Swartz; caud. scarcely creeping; st. tufted, 2-4 in. 1., stout, densely clothed with long, fine, ferruginous hairs; fr. 6-18 in. 1., 2-4 in. br., oblong-lanceolate, fully pinnate ; pinnoe very close, often imbricated, transversely crisped, pinnatifid about halfway down to the costa, the lower ones linearacuminate, 1-2 in. l., $\frac{1}{4}-\frac{3}{8}$ in. br. ; substance delicately membranaceous ; rachis densely tomentose; costa and veins also rufo-villose; sori as many as 20 to a pinna, occupying the greater part of both edges, tube quite sunk, mouth with two lateral projections. $-H k$. Sp. 1. $p_{0} 139 . t .41$. A. T. splendidum, V.D.B.

Hab. Tropical America, from Guatemala and Jamaica southward to Peru.

57. T. Lambertianum, Hk. ; caud. scarcely creeping, tomentose ; st. stout, 4-5 in. l., densely clothed with long, fine, reddish-brown hairs ; $f r .6-12$ in. l., not more than 1 in. br., linear-oblong, acuminate, pinnate ; pinnce densely crowded, imbricated, subsecund, oblong, obtuse, cut more than halfway down to the rachis ; pinnl. again pinnatifid with linear-oblong segm.; substance thin, but the frond much crisped, and especially the rachis, densely tomentose; sori 4 to 12 to a pinna, the tube quite sunk, the mouth with two lateral projections.-Hk. Syn. 1. $p .139 . t .41$. B.

Hab. Peru,-A singular plant, with very closely-crowded pinnæ and segnents, the alliance of which is evidently with $T$. lucens.

**** Main rachis of the frond quite free or only very slightly winged towards the apex. Sp. 58-77.

\section{+ Fronds simply pinnate, pinnules not divided. Sp. 58-60.}

58. T. ccespitosum, Hk.; rhizome wide-creeping, densely interlaced ; fr. sessile or nearly so, 1-2 in. l., $\frac{1}{4}$ in. br., simply pinnate; pinnce concave, linear-oblong, entire, about $\frac{1}{4}$ in. l. by $\frac{1}{2}$ lin. br., the under surface, or solitary costa only, clothed with strong brown hairs; texture rather rigid ; sori 1 only to a pinna, terminal, the tube obovate-cuneate, quite immersed, the mouth spreading, with two rounded lips.-Hk. Syn:1.p. 132.t. 40. B. Serpyllopsis, V.D. B.

Hab. S. Chili, Cape Horn, and Falkland Islands.-A very distinct plant, placed by Van den Bosch in a genus by itself near Leptocionium.

59. T. Javanicum, Blume; caud. tufted, with numerous strong wiry roots ; st. 1-4 in. l, wiry, erect, naked or villose ; fr. 2-8 in. 1., 1-2 in. br., ovate-lanceolate, acuminate, once fully pinnate; lower pinnoe often 1 in. l., $\frac{1}{4}$ in. br., oblong, obtuse or acute, obliquely cuneate at the base, finely toothed; texture subcoriaceous ; veins numerous, close, central costa not clearly marked or continuous to the apex; sori 1 to 4, placed in the axils of linear segments on the upper side of the pinnæ, tube free, the mouth broadly dilated but not twolipped; recept. much exserted.-Hk. Sp. 1. p. 130. Hk. \& Gr. Ic. Fil. t. 240. Cephalomanes, V.D.B.

Hab. Tropical Hindostan, Malayan Peninsula, Borneo, Java, Polynesian Islands, and 
Madagascar.-This corresponds to the first section of the genus Cephalomanes of Van den Bosch, who makes nine species.

60. T. pinnatum, Swartz; caud. erect, tufted; st. strong, wiry, erect, naked, or slightly hairy, 3-12 in. 1.; fr. simply pinnate in the typical state, 4-18 in. l., 3-12 in. br., the apex often rooting and proliferous; pinnoe in 2 to 10 opposite or alternate pairs, and a terminal one, 2-6 in. 1. , $\frac{1}{4}$ to $\frac{3}{4}$ in br., linear-obtuse or acute, sharply and finely toothed, the upper edge usually free from the stem at the base, the under one attached and often furnished with a broad decurrent wing; texture subcoriaceous; central costa thick; lateral veins fine and very close, simple or forked, sometimes anastomosing; sori placed all round the pinnæ; invol. small, tubular, exserted or stipitate, the mouth slightly dilated; recept. long, filiform, exserted.-T. floribundum, $H . B . K . H_{.} . S p .1 . p .129$. $H k$. \& Gr. Ic. Fil.t. 9.- - , T. Vittaria, D. C. ; fr. 6-18 in. l., about 1 in br., linear-lanceolate, entire.-Hk. in Lond. Journ. Bot. 1. p. 117.t. 5.

Hab. Tropical America, from Mexico and Jamaica southward to Brazil and Peru. This corresponds to the genus Neurophyllum of Presl, Neuromanes of Van den Bosch. The latter makes five species, of which $N$. abruptum is distinguished from the other four by the absence of spurious venules connecting the veins on each side of the central costa. It is figured in Hk. G. F. t. 8, and is T. Hostmannianum, Klotzch. Some of Dr. Burchell's specimens show the simple and pinnate-fronded forms from the same root.

+ Fronds decompound, slender, flaccid, ultimate segments very narrowly linear or filiform. Sp. 61-68.

61. T. tenue, Brack. ; st. 1-2 in. 1., slender, naked; fr. 2-3 in. 1., 1-1 $\frac{1}{2}$ in. br., ovate-lanceolate, tripinnatifid, main rachis very narrowly winged in the upper half; pinnce cut down to a narrowly-winged rachis; pinnl. again pinnatifid, with a few long, narrow, distant, erecto-patent linear segm.; both surfaces naked, a central costa only in each segment; sori 1 to 4 to a pinna, tube exserted, the mouth widely dilated, naked, two-lipped.-Brack. t. 36. f. 2.

Hab. Tahiti.-This and the next are not so flaccid in habit as the rest of the group, and have distinctly two-lipped involucres.

62. T. brevipes, Baker ; rhizome tomentose, with numerous short-branched rootlets; st. very short; fr. $2-3$ in. $1 ., 1-1 \frac{1}{2}$ in. br., ovate-deltoid, fully pinnate, or rachis very slightly winged at the apex; pinnoe spreading, ovate, cut down to a very narrowly-winged rachis; lowest pinnl. again deeply pinnatifid, with narrow linear segm., 1 lin. $1 ., \frac{1}{4}$ lin. br.; texture membranaceous, a single costa only in each segment; sori 2 to 8 to a pinna, axillary, tube more or less exserted, mouth with two large rounded lips.-Didymoglossum brevipes, Presl, Hym. p. 23. 'T. melanorhizon, Hk. Syn. 1.p. 140. Ic. Pl. t. 705.

Hab. Leyte, Philippine Islands, Cuming, No. 316.-Distinguished from the preceding by its more numerous pinnules, each furnished with several comparatively short narrow linear segments on both sides.

63. T. Smithii, Hk. ; st. tufted, 1-2 in. 1., slender, erect, naked ; fr. 4-8 in. l., 1-1 $\frac{1}{2}$ in. br., flaccid, lanceolate-oblong, tripinnatifid, main rachis only slightly winged towards the apex; pinno cut down to a narrowly-winged rachis, the divisions usually simple, occasionally forked, long, linear ( $\frac{1}{4}$ lin. br., $\frac{1}{4}-\frac{1}{2}$ in. l.); texture membranaceous, a central costa in each segment, the cells several times broader than deep, separated from one another by continuous oblique vein-like lines; sori to 4 to a pinna, axillary, the tube narrowly winged, the mouth with two lateral projections.-Hk. Sp. Fil. 1. p. 138. Hk. Ic. t.704. Habrodictyon Cumingii, Presl, Hym. t. 7.

Hab. Philippine Islands.-Resembling T. tenerum and caudatum in habit, but the venation is quite unique and very peculiar. 
64. T. caudatum, Brack.; rhizome creeping; st. 1-2 in. 1., naked ; fr. 3-12 in. 1., 1-3 in. br., lanceolate, tripinnatifid, main rachis only very sligtly winged above; lower pinna ovate-rhomboidal, erecto-patent, pinnatifid down to a narrowly-winged rachis ; pinnl. again pinnatifid ; ultimate segm. about 1 lin. 1 ., $\frac{1}{4}$ lin. br. ; texture membranaceous, surface naked, a central costa only in each segment; sori 1 to 8 to a pinna, tube exserted, mouth spreading, not two-lipped. -Brackenvidge, $t$. 36. fig. 5.

Hab. Fiji Islands, Tahiti, and N. S. Wales. - Very near T. tenerum, but stronger in habit, darker in colour, the erecto-patent pinnæ broader and more divided.

65. 'T. tenerum, Sprengel ; rlizome creeping, tomentose, very slender ; st. 1-2

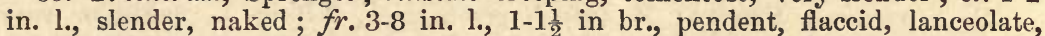
tripinnatifid, the main rachis only very slightly winged towards the apex; pinnoe distant, flaccid, cut down to a narrowly-winged rachis, with distant

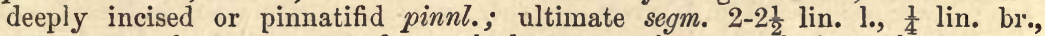
texture membranaceous, surface naked; a central costa only in each segment; sori 1 to 4 to a pinna, tube more or less exserted, mouth spreading, but not lipped.-T. angustatum, Carm. Hk. Sp. 1.p. 141. Hk. \& Gr. Ic. Fil.t. 166.

Hab. Tropical America, from Mexico southward to Peru and Brazil and island of Tristan d'Acunba.

66. T. exsectum, Kunze ; rhizome wide-creeping, slender, tomentose ; st. slender, naked, 1-3 in. l. ; fr. 6-12 in. 1., 1-2 in. br., pendent, flaccid, lanceolate, tripinnatifid, the main rachis narrowly winged in the upper half; pinnoe distant, flaccid, the upper ones often 3-4 in. l., the lower ones ovate or lanceolate, divided down to a narrowly-winged rachis, with a few deeply toothed or pinnatifid pinnl.; texture membranaceous, surface naked; a central costa only in each segment; sori 1 to 4 to a pinna, tube sunk, the mouth truncate.-Hk. Syn. Fil. 1.p. 141.

Hab. S. Chili, Chiloe, and Juan Fernandez.-A much larger plant than T. tenerum, with less divided pinnæ and broader and more distant segments.

67. T. Colensoi, Hk. fil.; rhizome slender, naked, wide-creeping; st. about 1 in. 1., slender, naked ; fr. 2-4 in. 1., $\frac{1}{2}-1$ in br., oblong-lanceolate, acuminate, fully pinnate; pinnoe distant, ovate or lanceolate-rhomboidal, stalked, and cut nearly or quite down to a slender rachis; segm. linear-acute, very narrow; substance flaccid, a central costa only in each segment; sori solitary, supraaxillary, the tube stipitate, the mouth scarcely dilated; recept. very long and slender.-Hk. 2. Cent. Ferns, t. 79.

Hab. New Zealand, discovered by the Rev. W. Colenso.

68. T. trichoideum, Sw. ; rhizome creeping, slender ; st. 1-2 in. 1., very slender, naked ; fr. 4-8 in. 1., 1-2 in. br., pendent, Haccid, lanceolate, tripinnatifid, main rachis only very slightly winged at the apex; pinnoe flaccid, 1-2 in. 1., the rachis only winged above; pinnl. deeply cut with distant linear-filiform segm. 1-2 lin. 1., $\frac{1}{4}-\frac{1}{6}$ lin. br. ; texture membranaceous, a central costa only in each segment; sori 1 to 4 to a pinna, the tube exserted, sometimes stalked, the mouth spreading, not two-lipped.-Hk.Sp. 1.p. 141. Hk. \& Gr. Ic. Fil.t. 199.

Hab. West Indian Islands and Mexico southward to Ecuador and Brazil.-Apparently this is the T. capillaceum of Linnæus.

†十 Fronds decompound, main rachis rigid, ultimate segments subcoriaceous, except in No. 69. Sp. 69-78.

69. 'T. scandens, Linn. Herb. ; rhizome wiry, wide-creeping; st. strong, erect, 
naked, 2-4 in. 1. ; fr. 6-18 in. 1., 3-6 in. br., fully pinnate, or the rachis very slightly winged above, ovate-acuminate in general outline, the rachis hairy ; lower pinnce ovate-lanceolate, nearly pinnate, 2-4 in. 1.; pinnl. divided down to a narrow wing and segm. again pinnatifid about halfway down, margins fineiy hairy ; substance finely membranaceous, several fine veins in each ultimate segment; sori 1 to 4 to a pinnule, tube quite sunk, mouth slightly spreading with two lateral projections. - Hk. Sp. 1. p. 140. T. macroclados, Kunze. T. Lindeni, Presl.

Hab. Cuba and Jamaica.-Differs from all the following species by its membranaceous segments.

70. T. rigidum, Swartz; st. tufted, erect, wiry, 2-8 in. 1., naked or very slightly winged above; fr. 2-8 in. l., 2-6 in. br., deltoid or ovate-acuminate, trior quadri-pinnatifid, the main rachis usually only slightly winged towards the top ; lower pinnoe 2-3 in. 1., erecto-patent, ovate or lanceolate-rhomboidal, cut down to a rachis which is very narrowly winged throughout or free below; pinnl. deeply pinnatifid, with deeply toothed or even pinnatifid linear lobes; texture subcoriaceous, colour dark-green, nearly black when dry, nearly naked, often slightly crisped; sori 2 to 12 to a pinnule, small, axillary, the tube more or less exserted, the mouth slightly dilated.-Hk. Sp. Fil. 1. p. 133. Beddome, Fil. Ind. t. 8. Sturm, Brasil. t. 18. f. 12. T. strictum, Hk. \& Gr. Ic. Fil. t. 122. $-\beta$, T. elongatum, Cunning.; fr. deltoid, segments broader, pinnæ and pinnules often imbricated; invol. slightly two-lipped.-Hk. Sp. 1. p. 134. Ic. Pl.t. 701.

Hab. Tropical America, Cuba, and Mexico southward to Peru and Rio Janeiro ; Polynesian Islands, New Zealand, Japan, Malayan Peninsula, S. China, S. Hindostan, Ceylon, Mascaren Isles, Natal, Cape Colony, Angola, Fernando Po.-Here belong numerous species of Van den Bosch, including Mandioccanum, obscurum, Dregei, Boivini, achillecefolium, tamarisciforme, flavo-fuscescens, pumilum, dentatum, and longicollum.

71. T. meifolium, Bory; st. tufted, 4-6 in. 1., strong, erect, more or less fibrillose, and the tuft densely so at the crown ; fr. 9-18 in. 1., 4-8 in. br., ovate, quadri-pinnatifid, the main rachis only slightly winged towards the apex; lower

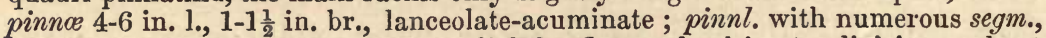
which are again cut down into slightly flattened ultimate divisions, about 1 lin. 1.; texture subrigid, surface naked, a single costa only in each segment; sori 2 to 12 to a pinnule, small, the involucre short, turbinate.-Hk. Sp. 1. p. 137. T. apiifolium, Presl. T. Bauerianum, Endl. T. exaltatum, Brack.$\beta, T$. polyanthos, Hk.; sori larger ; invol. $\frac{1}{8}$ in. deep, 1 lin. br., cupshaped, twolipped.-Hk. Sp. 1.p. 138. Ic. Pl.t. 703.

Hab. Philippine Islands, Java, Polynesian Islands, and Norfolk Island.-This resembles T. maximum in general outline, but the habit is more graceful, the texture more delicate, and the involucres are much smaller and shorter, verging upon those of Hymenophyllum.

72. T. maximum, Blume ; rhizome stout, creeping ; st. strong, erect, 3-6 in. l. ; fr. 12-18 in. 1., 6-9 in. br., ovate, quadripinnatifid ; pinnœe erecto-patent, ovatelanceolate, the largest 4-6 in. 1., 2 in. br. ; pinnl. lanceolate-deltoid, 1 in. or more l., cut down to the rachis into segm., which are again deeply pinnatifid; ultimate segm. $1 \frac{1}{2}-2$ lin. 1., slightly flattened, texture subrigid, surface naked, dark-green ; a central costa only in each segment; sori 2 to 8 to a pinnule; invol. cylindrical, the mouth dilated, but not two-lipped.-Hk. Sp. 1. p. 137. T. anceps, $\beta, H k$. Sp. 1. p. 135, t. 40. C. 3. T. intermedium, $V$. D. B.

Hab. Java, Borneo, and Polynesian Islands.-A larger plant than T. rigidum, with more divided pinnæ and narrower segments.

73. T. Prieurii, Kunze ; st. stout, tufted (sometimes 2 lin. thick below), 4-8 in. l., naked or slightly tomentose, sometimes the upper part winged; fr. 
12-18 in. 1., 6-12 in. br., broadly ovate, tri- or quadri-pinnatifid; main rachis very narrowly winged throughout or above only; lower pinnoe 4-6 in. l., ovate-rhomboidal, cut down to a narrowly-winged rachis; pinnl. again deeply pinnatifid, with rather distant, long, linear, sharply-toothed or pinnatifid segm.; texture subcoriaceous (three layers of cells), colour dark-green, nearly black when dry, surface a little hairy ; veins close, often more than one in the ultimate segments ; sori 2 to 12 to a pinnule, small, axillary, often recurved, tube free, much dilated, not two-lipped.-T. anceps, $a, H k$. Syn. 1. p. 135. t. 40. C. (non Wallich). T. Leprieurii, Hk. Gard. Ferns, t.11. Davalliopsis, V.D.B.

Hab. West Indian Islands southward to Peru and Brazil. $-T$. Weddellii, elegans, and opacum, V. D. B., apparently must be referred here.

74. T. giganteum, Bory ; rhizome wide-creeping, tomentose ; st. 4-6 in. 1., strong, erect ; fr. 12-18 in. l., 6-9 in. br., ovate, quadri-pinnatifid ; main rachis hardly at all winged above ; lower pinnoe ovate-lanceolate, 6-8 in.1., cut down to the rachis ; pinnl. 1 in. 1 ., cut down very nearly to the rachis, the divisions again deeply pinnatifid; ultimate segm. linear, distinctly flattened, 1 lin. 1., $\frac{1}{d}$ lin. br., surface dark-green, naked, shining, texture between rigid and membranaceous; a central vein only in each segment; sori 2 to 20 to a pinnule, axillary; tube more or less exserted, mouth rather dilated, not two-lipped.-Hk. Sp. 1.p. 137. Ic. Pl.t.702. T. elatum, V. D. B.

Hab. Mauritius, Bourbon, Joanna Island, Malayan Archipelago and Fiji group.-A handsome plant, distinctly quadri-pinnatifid, the most ample and divided species of the genus, nearest T. meifolium, but neither so rigid or coriaceous, and with shorter ultimate segments.

75. T. Sprucei, Baker ; st. nearly tufted, 1-3 in. 1., wiry, erect, naked, slightly winged above ; fr. $3-4$ in. $1 ., 1 \frac{1}{2}-2$ in. br., erect, ovate-deltoid, acuminate, tripinnatifid; main rachis very narrowly winged throughout; pinnce erectopatent, cut down to a very narrowly-winged rachis; lower pinnl. deeply pinnatifid, with forked or even pinnatifid lower segm.; ultimate segm. flat, linear, $1 \frac{1}{2}-2$ lin. 1., texture sub-membranaceous, surface naked, dark olive-green when dry, a single vein only in each segment, cellules large; sori 2 to 12 to a pinna, tube small, nearly free, mouth slightly spreading.

Hab. North of Brazil, Spruce, 1399 and 2838.-A more deeply divided plant than T. gemmatum, with a subdeltoid outline, more numerous sori, less rigid habit, and distinctly flattened segments.

76. T. gemmatum, J Smith; rhizome strong, wiry, tomentose, beset with numerous long black wiry fibres; st. 1-3 in. l., naked, wiry, winged above ; fr. 2-6 in. 1., 1-2 in. br., erect, subrigid, ovate-oblong, bipinnatifid; main rachis narrowly winged; pinnoe erecto-patent, cut down to a narrowly-winged rachis; lower pinnl. deeply forked with subrigid, linear-filiform segm. $1 \frac{1}{2}-2$ lin. 1 ., cellules large; sori 1 to 8 to a pinna, minute, axillary, the tube turbinate, stalked, the mouth nearly truncate.-T. cellulosum, Sturm, Hk. 2nd Cent. Ferns, t. 63. T. filiforme, Sturm. 'T. longisetum, Brack. 'T. Asæ-Grayi, V.D.B. 'T. fœeniculaceum, Hk. Sp. 1. p. 135. (in part).

Hab. Venezuela, north of Brazil, Polynesian Islands, Java, Philippines, and Malayan Peninsula.

77. T. longisetum, Bory ; rhizome strong, wiry, tomentose ; st. 1-4 in. 1., erect, wiry, tomentose, not at all winged ; $f r .3-8$ in. l., 1-2 in. br., erect, subrigid, lanceolate or ovate-lanceolate; main rachis quite free; pinnoe spreading or erecto-patent, 1-1 $\frac{1}{2}$ in. 1 ., cut down to the rachis; pinnl. cut down into numerous filiform capillary segm. 1 $\frac{1}{2}-2$ lin. 1 ., colour dark-brown or blackish; a central costa only in the segments, not visible except under a high magnifying power; 
sori 1 to 6 , minute, axillary, the tube stalked, the mouth truncate. $-V . D . B$. Hym. Jav. t. 21. T. Pluma, Hk. Ic. Pl. t. 997.

Hab. Borneo, Java, Samoa, Bourbon.-A very singular plant, with the segments spreading in all directions, and not at all flattened. T. Pluma of Hooker appears to be a long narrow form of this species, in habit singularly resembling a bottle-brush.

78. T. foeniculaceum, Bory ; st. nearly tufted, erect, wiry, 2-4 in. 1., naked or tomentose ; fr. 4-8 in. 1., 1 $\frac{1}{2}-3$ in. br., erect, rigid, ovate-lanceolate ; main rachis naked or slightly winged above; lower pinnoe spreading or erecto-patent, 1-1 $\frac{1}{2}$ in. l., cut down-quite or very nearly to the rachis; pinnl. regularly pinnatifid,

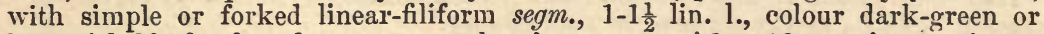
brownish-black when dry, texture subcoriaceous; sori 2 to 12 to a pinna, minute, axillary, the mouth rather spreading but not two-lipped.-Hk. $S p$. 1. $p .135$. (in part).

Hab. Mauritius, Bourbon, Borneo, and Rockingham Bay, Australia (T. setilobum, F. Mueller, MSS.).--Intermediate between rigidum and longisetum, the segments rather flattened.

\section{Tribe 4. Davaluiese.}

Sori marginal or submarginal, roundish, covered by a reniform or suborbicular squamiform involucre, which is open at the apex, fastened broadly at the base, and open or free at the sides. GEN. 18-19.

\section{Gen. 18. Davaluia, Smith.}

Sori intra- or submarginal, globose or elongated either laterally or vertically. Invol. terminal on the veins, various in shape, united or free at the sides, the apex always free. Caps. stalked. A large genus, which has its head-quarters in the Tropics of the Old World. Fronds various in size and division, herbaceous or coriaceous; veins always free; rhizome usually wide-creeping and scaly. There are four principal types in the shape of the involucre (see plate), of which Microlepia connects Eudavallia with Dicksonia and Odontoloma with Lindsaya. TAB. II. f. 18.

§ Humata, Cav. Invol. ample, coriaceous, suborbicular or reniform, attached by a broad base, the apex and sides free.-Sp. 1-11. Fronds in all coriaceous, usually deltoid, 3 to 6 inches long, more or less distinctly dimorphous, the barren ones hardly more than once pinnatifid. All plants of the Malayan islands, one reaching the Himalayas and the Mauritius. Sp. 12 is an anomalous simply pinnate S. American plant, which seems best placed here.

\section{* Barren fronds entire. Sp. 1-2.}

1. D. (Hum.) heterophylla, Smith ; rhizome wide-creeping, scaly ; fr. shortly stalked, 3-6 in. 1., 1 in. br, glabrous ; texture coriaceous, the sterile one ovatelanceolate, entire or slightly lobed at the base, the fertile one narrower, deeply sinuato-pinnatifid; sori 2 to 10 to a lobe.-Hk. Sp. 1. p. 152. Fil. Ex.t. 27. Hk. \& Gr. Ic. Fil. t. 230.

Hab. Malayan Peninsula and Polynesian Islands.

2. D. (Hum.) angustata, Wallich ; rhizome wide-creeping, scaly ; fr. subsessile or shortly stalked, 3-8 in. 1., $\frac{1}{4}-\frac{5}{8}$ in. br., linear, slightly and irregularly crenate at the margin, sometimes once forked ; texture coriaceous, both surfaces naked ; sori in a row along the edges.-Hk. Sp. 1.p. 152. Hk. \& Gr. Ic. Fil, t. 231.

Hab. Malayan Peninsula and Islands. 


\section{** Barren fronds pinnatifid. Sp. 3-11.}

3. D. (Hum.) parallela, Wallich ; rhizome creeping, scaly ; st. 2-4 in. l., erect,

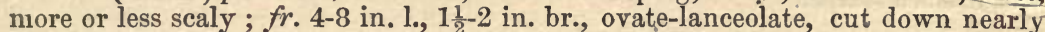
or quite to the rachis into long parallel linear-oblong entire bluntish or acute lobes, the lowest pair sometimes auricled ; texture coriaceous ; sori oblique, in two rows in the lobes, occupying the greater part of the space between the costa and margin.-Hk. Sp. 1. p. 153.t. 42. A. Pteroneuron, Fée.

Hab. Malayan Peninsula and Polynesian Islands.-Habit and size of Polypodium vulgare. Rachis sometimes densely scaly.

4. D. (Hum.) pectinata, Smith ; rhizome creeping, scaly ; st. 2-4 in. l., erect, more or less scaly ; fr. 4-8 in. l., 2-3 in. br., ovate-lanceolate, cut down nearly or quite to the main rachis into long parallel linear-oblong, entire or incisopinnatifid pinnoe, the lowest pair deeply pinnatifid on the lower side, with lobes sometimes $\frac{1}{2}$ in. l. ; texture coriaceous ; sori obliquely placed in two submarginal rows.-Hk.Sp. 1. p. 153. Hk. \& Gr. Ic. Fil. t. 139.

Hab. Tropical Polgnesian Islands. - Quite similar to the preceding in size and texture.

5. D. (Hum.) sessilifolia, Blume; rhizome very long, wide-creeping, densely clothed with rigid filiform scales; $f r$. subsessile, $2-4$ in. $1 ., 1-1 \frac{1}{2}$ in. br., ovatelanceolate, cut down nearly to the rachis into parallel linear-oblong, entire or sinuated lobes, the lower side of the lower one sometimes deeply pinnatifid; texture subcoriaceous; sori in two rows in the lobes, occupying the greater part of the space between the costa and margin.-Hk. Sp. 1. p. 154.- $\beta, H$. polypodioides, Brack. $t .32$; fr. stalked (st. 1-2 in. 1.), rather larger and more acute.

Hab. Java, Celebes, and Fiji Islands.-Examples gathered by Milne in Fiji quite connect the plant figured by Brackenridge with Blume's specimens.

6. D. (Hum.) pedata, Smith ; rhizome wide-creeping, scaly ; st. $\dot{2}-4$ in. 1 , rather scaly ; fr. $2-4$ in. $1 ., 1 \frac{1}{2}-2$ in. br. at the base, deltoid in general outline, cut down nearly to the rachis; upper segm. linear-oblong, acute, erecto-patent, inciso-dentate, the lower pair broader, deeply inciso-pinnatifid, especially on the lower side; texture coriaceous; sori placed in rows on the teeth on both sides of the lobes.-Hk. Sp.1. p.54. t. 45. A. Gard. Ferns, t. 7.

Hab. Hindostan, from 2,000 ft. in Khasia southward to Ceylon, Hongkong, Malayan Peninsula, Java, Borneo, Queensland, Mascaren Isles.

7. D. (Hum.) alpina, Blume ; rhizome creeping, scaly ; st. 2-4 in. 1.; fr. 2-3 in.1., 1-1 $\frac{1}{2}$ in. br., deltoid in general outline, upper segments of barren frond slightly dentate, blunt at the apex of the fertile frond, distant, deeply and sharply toothed, the lower ones cut nearly to the rachis with sharply-toothed lobes; texture coriaceous, lower part of rachis winged narrowly; sori placed in the teeth on both sides.-Hk. Sp. 1. p. 154. D. Belangeri, Bory. H. serrata, Brack.

Hab. Mergui and Ledong, Java, Borneo, and Polynesian Islands. - Very near $D$. pedata, but smaller and rather more deeply cut. We have not seen the Javanese D. longula, Kunze (Bot. Zeit. 1848, p. 215), which is said to be very closely allied to this.

8. D. (Hum.) pusilla, Metten.; rhizome creeping, scaly ; st. 1 in. or less l.; fr. 1-1 $\frac{1}{2}$ in. $1 ., \frac{1}{2}-\frac{3}{4}$ in. br., cordato-deltoid in outline, cut down to a narrowly-winged rachis; upper segm. linear-oblong, cuneate at the base, deeply inciso-dentate, lower pair broader, deeply inciso-pinnatifid on the lower side, teeth very acute; 
texture coriaceous; veins prominent; sori small, placed at the base of the small teetl.-Mett. Fil. Nov. Cal. No. 73.

Hab. Aneiteum and New Caledonia.-Near D. alpina, but the teeth of the fertile fronds much sharper.

9. D. (Hum.) vestita, Blume; rhizome wide-creeping, densely scaly ; st. 3-4 in. 1., rather scaly below; fr. 4-8 in. l., 3-4 in. br., deltoid in outline; all, except the upper pinna, cut down to a narrowly-winged rachis; barren frond with the segm. of all, except the lower pinnx, blunt, scarcely toothed; lobes of the fertile pinnæ narrower, sharper toothed; of the lower ones deeply so; texture coriaceous ; sori placed on the teeth of the segments.-Hk. Sp. 1. p. 156.t. 41. C. D. bipinnatifida, Blume, Hk. l. c.

Hab. Java and Ceylon.

10. D. (Hum.) Cumingii, Hk. ; rhizome creeping, scaly ; st. $3-4$ in. l., both it and the rachis rather scaly ; sterile fr. about 1 in. each way, deltoid-cordate, cut down nearly to the rachis; upper pinnoe blunt, slightly toothed, the lower pair deeply pinnatifid below ; texture coriaceous ; fertile fr. 4-5 in. 1., 3 in. br., the same shape, but much more divided; lowest pinnl. deeply pinnatifid with sharply toothed lobes; sori placed in the teeth of the segments.-Hk. Sp.1. p.155. t. 45. B.

Hab. Philippine Islands.

11. D. (Hum.) botrychioides, Brack. ; rhizome wide-creeping, scaly ; st. 3-5 in. 1., scaly below ; fr. 6-8 in. $1 ., 3-5$ in. br., deltoid in general outline, decidedly dimorphous, the barren ones with a narrowly-winged rachis; lowest pinnoe cut down nearly to the rachis, with deep bluntly-toothed'segments; fertile pinnoe muclı more finely divided; pinnl. of the lower pinnæ cut down to a narrow rachis with narrow sharply-toothed segments almost covered with sori.-Brack. t. 32. fig. 1 .

Hab. Aneiteum and Fiji Islands.

12. D. (Hum.) Imrayana, Hk. ; rhizome wide-creeping, paleaceous; st. 4-8 in. 1., erect, brown or black, naked, polished ; fr. 6-12 in. 1., 4-6 in. br., ovate, once pinnate; pinnoe 7 to 15 , the largest about 3 in. $1 ., 1$ in. br., lanceolate, with broad blunt teeth, somewhat unequal-sided and obliquely truncate at the base below ; texture herbaceous, both surfaces naked; sori placed in the teeth at a short distance from the margin; invol. rounded, broader than deep, attached by the base only. -Hk. Sp. 1. p. 171.t. 49. A.

Hab. Dominica, Guadeloupe, and Guiana.

$\$ §$ Leucostegia. Invol. attached as in Humata, but smaller, narrower, and thinner. Sp. 13-24. Pinnules uniform on the lower and upper side. Fronds various in size and texture, with one exception tri- or quadripinnatifid or pinnate, mostly inhabiting Polynesia and tropical Asia, several extending to the Himalayas, some to New Zealand, but none either to Africa or America. Acrophorus of Moore includes this and Odontoloma.

13. D. (Leucos.) Parishii, Hk. MSS.; rhizome creeping, scarcely scaly ; st. slender, 3-4 in. I. ; fr. flaccid, 6-9 in. l., 4-6 in. br., deltoid, cut down to the rachis below, but not above; lower pinnoe distant, the lowest pair broadest and most deeply cut on the lower side; lowest pinnl. reaching down nearly to the rachis, toothed more than halfway down, with oblong blunt crenate lobes; texture membranous; sori few, marginal in the crenations.

Hab. Limestone rocks, Moulmein, Rev. C. S. Parish.-A very distinct species. 
14. D. (Leucos.) membranulosa, Wallich ; rhizome stout, wide-creeping, densely clothed with lanceolate pale-brown scales; st. $2-3$ in. 1. ; fr. $6-9$ in. 1., 2-3 in br., lanceolate, once fully pinnate, but the main rachis slightly winged above; lower pinnoe lanceolate, 2-3 in. 1., $\frac{1}{2}$-in. br., eut down to a narrowly-winged rachis into numerous sharply-toothed oblong segments; texture thinly herbaceous; sori 2 to 8 to a segment, obliquely placed between the costa and margin.- $-H k$. Sp. 1 . p. 159.t.53. A.

Hab. Himalayas of Nepaul, Kumaon, and Bootan.

15. D. (Leucos.) immersa, Wallich ; rhizome hypogæous, wide-creeping, stout, fibrillose ; st. 4-8 in. l., strong, erect ; fr. 12-18 in. l., 6-9 in. br., deltoid, tripinnate; lowest pinnl. lanceolate-deltoid, $2-3$ in. $1 ., 1$ in. br., with broad segm., which are obliquely truncate at the base below, and roundly lobed, with the lobes again crenate above; texture herbaceous ; sori large (1 lin. br.), 1 to 6 to a segment, oblique,-Hk. Sp. 1. p. 156. Fil. Ex. t.79. Cyst. dimidiata, Dec.

Hab. Hindostan, ascending on the Himalayas to 6.8,000 ft., Malayan Peninsula and Java.-By its subdimidiate segments this connects Leucostegia with Odontoloma; it is also peculiar in having the rhizome developed beneath the surface of the soil.

16. D. (Leucos.) multidentata, Hk. MSS. ; rhizome stout, wide-creeping, scaly; st. 4-6 in. l., stout, clothed below with large ovate-lanceolate pale-brown scales; fr. 2-3 ft. l., $1 \mathrm{ft}$. br., ovate-deltoid, bipinnate; pinnl. of the lower pinnoe 2-3 in. 1., 1 in. br., deltoid-lanceolate, acuminate, cut down to a narrow rachis with deeply inciso-pinnatifid ovate-oblong lower segm.; texture herbaceous; sori 2 to 12 to a segment, placed at the base of its teeth on the upper side of the central vein.-Aspidium multidentatum, Wall. Cat. 346. Acro. Thomsoni, Moore.

Hab. Himalayas of Nepaul, Sikkim (5-7,000 ft.), Assam, \&c.

17. D. (Leucos.) pulchra, Don; rhizome thick, creeping, densely clothed with lanceolate bright-brown scales; st. 2-6 in. l., erect, scaly below ; fr. 6-9 in. 1 ., 2-4 in. br., lanceolate-deltoid, tri- or quadripinnate; lower pinnl. deltoid, their lobes cut down to the rachis into very narrowly linear sharp-pointed segments; texture subcoriaceous; sori copious, broader than the segments, placed at the ultimate forks.-Hk. Sp. 1. p. 160 .

Hab. Himalayas of Khasia and Sikkim, up to $11-12,000 \mathrm{ft}$.-An elegant plant, with all the copious divisions very narrow.

18. D. (Leucos.) falcinella, Presl; rhizome creeping, thickly clothed with purplish-black rigid hairs ; st. 2-3 in. l., erect ; fr. 4-6 in. l., 3-4 in. br., deltoid, tri- or quadripinnatifid; main rachis slightly winged; lowest pinnoe unequalsided, deltoid; pinnl. oblong, cut down nearly to the rachis with segments which are again deeply toothed, ultimate divisions of the fertile frond falcate mucronate, of the barren frond rather broader and not so sharp; texture subcoriaceous; sori 2 to 6 to a lobe, placed at the base of the teeth. $-H k . S p .1$. p. 159.

Hab. Philippine Islands. - This would perhaps be better placed amongst the deltoid Eudavallice, with which it agrees in habit.

19. D. (Leucos.) Novae Zelandiae, Colenso; rhizome creeping, clothed with filiform scales; st. 4-8 in. l., firm, erect; fr. 12-18 in. 1., 4-8 in. br., deltoid, tripinnate; lower pinnl. deltoid-lanceolate, cut down to the rachis, except towards the apex, into narrow deeply pinnatifid acute segments; texture subcoriaceous; sori numerous, placed on the teeth of the segments.-Hk. Sp. 1 . p. 158. t. 51. B. Gard. Ferns, t. 51. Acrophol us hispidus, Moore. 
Hab. New Zealand.-Allied to D.pulchra, but much larger in size, with broader more divided segments.

20. D. (Leucos.) choerophylla, Wallich ; rhizome wide-creeping, clothed with broad obtuse adpressed scales; st. 4-6 in. l., naked ; fr. 9-15 in. 1., 4-8 in. br., lanceolate-deltoid, tri- or quadripinnatifid ; lowest pinnl. 1-2 in. l., 1 in. br., cut down to a narrowly-winged rachis into deeply pinnatifid segm., ultimate lobes narrow and acute in the fertile, rather broader in the barren frond; texture thinly herbaceous, rather flaccid; sori copious, placed at the base of the teeth of the segments, which they about equal in breadth.-Hk. Sp. Fil. 1. p. 157.t.51. A. Cystopteris squamata, Dec., Hk. Sp. Fil. 1. p. 201.

Hab. North of India, ascending in the Himalayas to 9-10,000 ft., Cashmere, Neilgherries, Ceylon, Malayan Peninsula.

21. D. (Leucos.) parvula, Wallich ; rhizome wide-creeping, scaly ; st. 1-2 in. 1., or fr. subsessile, $\frac{1}{2}-\frac{3}{4}$ in. 1 . by $\frac{1}{2}$ in. br., deltoid in outline, bi- or tripinnate, with all the divisions of the frond almost filiform and the ultimate segm. sharp at the point; texture coriaceous; sori placed at the sinuses of the ultimate forks ; invol. broader than the segments.-Hk. Sp. 1.p. 160. Hk. \& Gr. Ic. Fil. 138.

Hab. Singapore and Borneo.-Placed by Mettenius in Humata, with which it quite agrees in habit.

22. D. (Leucos.) affinis, Hk.; rhizome thick, densely clothed with sharppointed ferruginous scales; st. 4-9 in. l., erect, strong; fr. 12-24 in. 1., 6-12 in. br., deltoid-lanceolate, tri- or quadripinnate; lower pinnl. with oblong rhomboidal lobes, the segm. of which are deeply and finely inciso-pinnatifid with sharp teeth; texture herbaceous; sori 2 to 6 to a segment, small, placed at the base of the teeth. - Hk. Sp. 1. p. 158. t. 52. B.

Hab. Neilgherries, Ceylon, Java, and Polynesian Islands, frequent.-Lowest pinnules often 2 in. $1 ., 1$ in. br. Very like $D$. choerophylla in texture and cutting, but much larger.

23. D. (Leucos.) nodosa, Hk. ; fr. tufted ; st. 12-24 in. l., strong, erect, scaly below ; fr. 2-4 ft. 1., broadly ovate, quadripinnate ; lower pinnce 12-18 in. 1., 6-9 in. br.; lower pinnl. lanceolate, 4-6 in. 1., 2 in. br., the segm. cut down to the rachis with distant, small, rather bluntly-toothed oblong-deltoid lobes ; texture herbaceous; sori small, 1 to 4 to a lobe, placed between the costa and margin. -Hk. Sp. 1.p. 157. Kew Gard. Misc. 9. t. 10. Acrophorus, Presl.

Hab. North Hindostan, ascending in Sikkim to 7-10,000 ft., Malayan Peninsula, Java. -Fronds like those of an Alsophila, but habit not arborescent. It is the original Acrophorus of Presl.

24. D. (Leucos.) trichomanoides, Hk. ; st. 6-9 in. 1., erect, strong ; fr. 9-18 in. 1., 6-9 in. br., supra-decompound; pinnl. of the lower pinnæ 2-3 in. l., 1 in. br., deltoid, their segments cut down to the rachis, and the lobes again cut down into linear-filiform ultimate divisions, about $\frac{1}{2}$ lin. 1 .; texture thinly herbaceous; sori placed at the dilated apices of the ultimate divisions; invol. oblong.-Hk. 2 nd Cent. Ferns, t. 64. D. ferulacea, Moore.

Hab. Fiji Islands; gathered by Mr. Milne.

\$§ Odontoloma. Invol. as in Leucostegia, but with a tendency to become confluent, and the pinnules pellucido-herbaceous in texture and dimidiate (resembling a quarter of a circle) in shape. Sp. 25-30. A small natural group very near the dimidiate Lindsayo. All but one are inhabitants of $S$. E. Asia and Polynesia, one being S. American and one Mauritian. 


\section{* Fronds not branched. Sp. 25-27.}

25. D. (Odont.) hymenophylloides, Baker ; rhizome wide-creeping, slender, scandent, paleaceous ; fr. subsessile, simply pinnate, 4-6 in. l., about $\frac{3}{4}$ in. br. ; pinnoe $1 \frac{1}{2}-2$ lin. deep, cut down into narrow simple or forked linear segments to a nearly straight rachis ; texture thinly herbaceous, both surfaces naked; sori subrotund. -Lindsæa, Blume, Enum. Fìl. Jav. p. 218.

Hab. Java. - This agrees with 0 . triquetra, except that the main rachis is not branched.

26. D. (Odont.) pulchella, Hk.; rhizome slender, wide-creeping, and much branched ; st. slender, wiry, erect, naked, 2-3 in. 1. ; fr. 4-12 in. 1., $\frac{1}{2}-\frac{3}{4}$ in. br. ; pinno slightly stalked, about $\frac{1}{4}$ in. across, $\frac{1}{8}$ in. deep, the lower margin more or less curved upwards, oblique at the base, the upper cut into 2 to 4 blunt lobes; texture herbaceous, rachis and both surfaces naked; sori small, placed in the lobes at a short distance from the edge ; veins sometimes anastomosing at the apex, and then their sori become confluent.-Hk. Sp. 1. p. 177.t. 548, Synaphlebium Pickeringii, Brack. p. 223. t. 50.

Hab. Philippine Islands, Fiji, and Samoa.-The original Philippine 0. pulchella quite corresponds with Dr. Seemann's smaller specimens of the Feejean plant.

27. D. (Odont.) repens, Desv. ; rhizome wide-creeping, paleaceous, climbing ; fr. simply pinnate, 8-18 in. 1., $\frac{1}{2}-1 \frac{1}{2}$ in. br.; pinnce $\frac{1}{4}-\frac{1}{2}$ in. 1., about half as broad as deep, the lower line slightly curved, oblique at the base, the upper rounded, nearly entire or crenately lobed; texture pellucido-herbaceous ; sori marginal, large, about as broad as deep, often confluent in the not crenated form.-D. Boryana, Presl, Hk. Sp. 1. p. 175. D. hemiptera, Bory, Hk. Sp. 1. p. 176.

Hab. Assam, Neilgherries, Ceylon, Java, Sumatra, Polynesian Islands, and Mauritius. -Very variable in size. Quite doubtful between Odontoloma and Lindsaya, and perhaps not distinct from $L$. oblongifolia.

\section{** Fronds more or less branched. Sp. 28-30.}

28. D. (Odont.) Parkeri, Hk. ; rhizome slender, creeping ; st. flexuose, wiry, naked, 2-6 in. l. ; fr. simple or branched, with one or two pairs of lateral pinnæ; the main fr. 4-6 in. 1., about $\frac{3}{4}$ in. br. ; pinnl. a quarter of a circle, about $\frac{3}{8}$ in. br., $\frac{1}{4}$ in. deep, the outer edge slightly crenate ; texture herbaceous, both surfaces naked; sori small, submarginal; invol. rather broader than deep.-Hk. Sp. 1. p. 176.t. 53 .

Hab. British Guiana.-Like 0. pulchella, but the rachis branched.

29. D. (Odont.) triquetra, Baker ; rhizome creeping, fibrillose ; st. strong, erect, 4-6 in. 1. ; fr. with 2 to 7 pairs of pinnæ and a terminal one ; lateral pinnoe spreading with subrigid rachises, 3-4 in. $1 ., \frac{1}{2}-\frac{3}{4}$ in. br. ; pinnl. cut down on the upper side into narrow simple or forked linear segments to a nearly straight flattened leafy rachis ; texture pellucido-herbaceous, both surfaces naked; sori small, terminal on the segments; invol. suborbicular. - Lindsaya triquetra, Metten. O. tenuifolia, Brack. non J. Sm.

Hab. Java, Zollinger, 3714.-Gathered in Samoa by the American Expedition under Captain Wilkes; and beautiful specimens have recently been forwarded from the same group by the Rev. T. Powell.

30. D. (Odont.) Blumeana, Hk. ; rhizome creeping ; st. strong, erect, 4-6 in. 1. ; fr. 8-12 in. 1., 6-8 in. br., bipinnate ; pinnoe rigid, erecto-patent, 4-6 in. 1., $\frac{1}{2}$ in. 
br. ; pinnl. thinly herbaceous, cut down on the upper side into very slender filiform simple or forked segments to a recurved filiform rachis; sori small, nearly terminal on the dilated apices of the segments; invol. suborbicular.-Hk. Sp. 1 . p. 177. t. 54. Lindsaya tenuifolia, Blume.

Hab. Java and Philippine Islands. - A very distinct and beautiful species, easily recognizable by its slender filiform segments.

§§§ Eudavallia. Invol. coriaceous, semicylindrical or half-cupshaped, attached at the sides as well as the base. Sp. 31-48.

+ Prosaptia, Presl. Habit of Lomaria Spicant. Invol. quite homogeneous with the texture of the frond. Sp. 31-32.

31. D. (Prosap.) Emersoni, Hk. \& Gr. ; fr. tufted, sessile, 6-12 in. l., nearly $1 \mathrm{in}$. br. at the widest part, linear-lanceolate, cut more than halfway down to the rachis into numerous linear-oblong, or at the lower part triangular, lobes; texture coriaceous; sori 1 to 6 , placed round the edge of the lobes.-Hk. Sp. 1. p. 161. Hk. \& Gr. Ic. Fil. t. 105.

Hab. Madras, Ceylon, Penang, Java, Borneo, and Philippine Islands.

32. D. (Prosap.) contigua, Swartz; fr. tufted, sessile or nearly so, 12-18 in. l., 1-1 $\frac{1}{2}$ in. br., linear-lanceolate, cut down nearly or quite to the rachis into numerous linear-acuminate or bluntish slightly-toothed lobes; texture coriaceous; sori 2 to 8 to a lobe, placed in the teeth on their upper part.-Hk.Sp.1.p.161. Hk. \& Gr. Ic. Fil. t. 141. D. Preslii, Hk. Sp. 1.p. 161.

Hab. Ceylon, Java, and Polynesian Islands.

+t Scyphularia, Fée. Fronds once pinnate. Segments few, linear, 4-6 in. l., $\frac{1}{2}-\frac{3}{4}$ in. br., nearly entire. Sp. 33-34.

33. D. (Scyph.) triphylla, Hk.; rhizome stout, creeping, densely fibrillose ; st. erect, strong, 2-4 in. l. ; fr. ternate, the central segment the largest, 4-6 in. l., $\frac{1}{2}-\frac{3}{4}$ in. br., linear, scarcely toothed, cuneate at the base ; texture coriaceous ; sori placed in close rows along the margin, edge to edge; invol. semicylindrical.Hk. Sp. 1.p. 162.t. 46. A.

Hab. Singapore; discovered by Mr. Cuming.-Veins more prominent than in the next, of which it may be a reduced form.

34. D. (Scyph.) pentaphylla, Blume; rhizome creeping, stout, densely fibrillose; st. erect, strong, 2-4 in. 1.; fr. with a terminal segment and 2 to 3 pairs of lateral pinnæ ; terminal segment of fertile frond linear, 4-6 in. l., $\frac{1}{2}$ in. br., of the barren frond broader and shorter; lateral pinnce similar, sessile or slightly stalked, lowest pair sometimes with one or a pair of similar smaller pinni. at the base; texture coriaceous ; sori in rows along the slightly-toothed margin ; invol. semicylindrical.-Hk.Sp. 1.p. 163. D. pycnocarpa, Brack. t. 35.

Hab. Java and Polynesian Islands.

+十 Fronds ample, deltoid, tri- or quadripinnatifid, coriaceous in texture. Sp. 35-48. A well-marked group, all of the species of which closely resemble one another. It has its head-quarters in Polynesia and S. E. Asia, and is entirely absent from the New World.

35. D. Lobbiana, Moore ; fr. 12-18 in. 1., 6-9 in. br., lanceolate-deltoid, bi- or tripinnatifid ; main rachis slightly winged above ; lower pinnoe 4-6 in. 1., 2 in. br., lanceolate-deltoid, acuminate, cut down to the rachis in the lower part into linear- or deltoid-oblong blunt segm., only the lowest of which are toothed deeply; 
sori copious, placed obliquely in two long rows in the pinnules near the edge; invol. broader than deep.-Moore, Ind. Fil. p. 296.

Hab. Borneo; discovered by Mr. Thos. Lobb.-A very distinct species, with the involucre resembling in shape that of Humata, but not free at the sides.

36. D. micans, Metten.; rhizome stout, wide-creeping, densely clothed with large lanceolate-acuminate silvery-brown scales ; st. 1-2 in. l., erect ; fr. 6-8 in. 1., 2-3 in. br., lanceolate, bi- or tripinnatifid ; lower pinnoe 1-1 $\frac{1}{2}$ in. $1 ., \frac{1}{2}$ in. br., lanceolate, spreading from the rachis at a right angle, cut down to the rachis at the base into oblong-rhomboidal deeply-toothed pinnules; texture subcoriaceous ; sori 1 to 4 to a pinnule, large, suborbicular ( $\frac{1}{2}$ lin. br.), placed at the base of the teeth at some distance from the margin.

Hab. Bootan, Griffith, 2790.

37. D. Moorei, Hk. ; rhizome creeping, fibrillose ; st. erect, strong, 4-8 in. 1.; fr. 4-6 in. 1., 3-4 in. br., bi- or tripinnatifid ; main rachis slightly winged above ; lowest pinnl. cut down nearly to the rachis below, the lobes oblong, bluntly toothed ; texture coriaceous; sori 4 to 6 to a lobe, placed in the teeth at a little distance from the edge; invol. half-cupshaped.-Hk. 2 d Cent. Ferns, t. 53.

Hab. New Caledonia, discovered by Mr. C. Moore.

38. D. decurrens, Hk. ; rhizome stout, creeping, densely fibrillose ; st. 4-6 in. l., stout, erect ; fr. 1-2 ft. l., 9-15 in. br., deltoid, tripinnatifid; main rachis hardly at all winged at the apex; pinnl. of the lower pinnæ lanceolate-acuminate, 3-4 in. 1., about 1 in. br., cut down throughout within a short distance of the rachis, with broadly-toothed linear-oblong segm.; texture subcoriaceous; veins uniform; sori falling short of the margin; invol. half-cupshaped.-Hk. Sp. Fil. 1.p.167.t.44. B.

Hab. Philippine Islands.-Resembles $D$. divaricata in the shape and position of the sori, but the fromd less divided.

39. D. solida, Swartz ; rhizome stout, densely clothed with adpressed scales or fibres ; st. strong, erect, 4-6 in. 1.; fr. 1-2 ft. 1., 12-15 in. br., deltoid, tripinnatifid ; apex with a moderately broad undivided centre; segm. ovate-rhomboidal, deeply toothed, narrower and sharper in fertile frond; veins uniform; texture coriaceous; sori nearly or quite marginal ; invol. semicylindrical.-Hk. Sp. 1. p. 164. t. 42. Fil. Exot. t. 57.- $\beta, D$. caudata, Cav.; pinnules more divided with narrower segments. Hk.Sp. 1.p. 164. D. Lindleyi, Hk. Sp. 1.p. 163. t. 48. B.

Hab. Malayan Peninsula, Java, and Polynesian Islands.-The reported station in New Zealand appears to be a mistake. D. stenomera, Kunze, from Java, which I have not seen, is said to differ from $D$. solida by its smaller size, obtuse or rounded pinnules, cuneate-oblong segments, and urceolate involucres. D. ornata, Wall., is a large handsome form, with broad slightly-cut segments.

40. D. elegans, Swartz; rhizome stout, creeping, densely clothed with woolly fibres ; st. firm, erect, 4-8 in. 1.; fr. 1-2 ft. 1., 9-1.5 in. br., deltoid, tripinnatifid; main rachis slightly winged towards the apex; pinnl. of the lower pinnæ 2-3 in. 1., 1 in. br., deltoid-lanceolate, cut down quite to the rachis in the lower part, with oblong-deltoid segm., which are slightly toothed and obliquely truncate at the base on the lower side; texture coriaceous ; venation close, prominent, irregular ; sori several to a segment, marginal, but the sharp teeth projecting beyond them at the edges; invol. half-cupshaped.-Hk. Sp. 1. p. 164.- $\beta, D$. elata, Swartz; $f r$. larger and less coriaceous; segm. narrower, more deeply and sharply cut.Hk.Sp. 1. p. 166. t. 55. A. D. Vogelii, Hk. Sp. 1. p.168.t.59. B.

Hab. Ceylon, Malayan Peninsula, China, Java, Borneo, Polynesian Islands, Tropical 
Australia, Madagascar, Angola, Fernando Po, Johanna Island.-Very near D. solida. Both vary much in division, but they are universally regarded as distinct. The best character for this seems to be the presence of numerous intermediate spurious venules between the veins proper, as in various species of Trichomanes. D. coniifolia is quite intermediate between D. elata and the type. D. patens, Swz. (Hk. Sp. Fil. 1. p. 167), must probably also be referred here, and $D$. flaccida, J. Smith, is a tender finely-cut form.

41. D. epiphylla, Blume, not Forster ; rhizome thick, fibrillose ; st. 4-6 in. l., erect, firm ; fr. 12-15 in. 1., 6-9 in. br., deltoid-lanceolate, tripinnatifid; main rachis hardly at all winged; pinnl. of the lowest pinnæ lanceolate, $1 \frac{1}{2}$ in. $1 ., \frac{1}{2}$ in. br. ; segm. narrow, mucronate, sharply toothed ; texture coriaceous ; veins not immersed, one or two carried into each tooth ; sori small, submarginal, half-cupshaped, with the sharp mucro of the tooth extending beyond them.-D. elegans, $\beta$, pulchra, Hk. Sp. 1.p. 165. t. 43. A. D. corniculata, Moore, Ind. Fï. 2. p. 292.

Hab. Java and Malayan Peninsula.-Still more coriaceous than D. elegans, with more finely-divided segments, very small sori, and sharp teeth protruded considerably beyond them.

42. D. divaricata, Blume; rhizome creeping, stout, clothed with linear ferruginous scales ; st. firm, erect, 6-12 in. l.; fr. 2-3 ft. l., tripinnatifid; lower pinnoe often 12 in. l., by 6 in. br.; segm. deltoid, cut down to the rachis in the lower part, with linear-oblong sharply-toothed lobes ; texture coriaceous ; veins uniform, not conspicuous; sori half-cupshaped, placed obliquely as regards the central veins in the teeth at some distance from the edge.-Hk. $S p .1 . p .167$. D. polyantha, Hk. Sp. 1. p. 168. t. 59. A.

Hab. Khasya and Mishmee, N. India, Malayan Peninsula, Hongkong, and Java.Best distinguished from solida and elegans by the position of the sori.

43. D. Mauritiana, Hk. ; rhizome stout, wide-creeping, densely fibrillose ; st. 6-8 in. l., stout, erect; fr. 1-2 ft. 1., 12-15 in. br., deltoid, quadripinnatifid; main rachis very slightly winged above; ultimate pinnl. $3-4$ in. $1 ., 2$ in. br., lanceolate-deltoid, cut down to the rachis in the lower part, with deeply incisopinnatifid lobes; texture coriaceous ; sori copious, marginal, placed in the teeth of the ultimate segments ; invol. semicylindrical.-Hk. Sp. 1. p. 164. t. 55. B.

Hab. Mauritius.-Sir William Hooker was latterly disposed to consider this an extreme form of $D$. solida.

44. D. Griffithiana, Hk. ; rhizome stout, clothed densely with pale-brown or

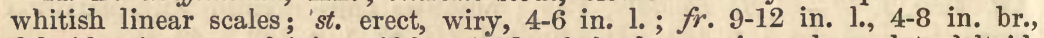
deltoid, tri- or quadripinnatifid; pinnl. of the lower pinnæ lanceolate-deltoid, $2-3$ in. $1 ., 1$ in. or more br.; lower segm. toothed on the barren frond, cut down nearly to the rachis in the fertile one; texture coriaceous; sori very large ( 1 lin. br.), cupshaped, submarginal or marginal, with the teeth projecting beyond them.-Hk. Sp. 1. p. 168. t. 49. B.

Hab. Himalayas of Khasya, Assam, Bootan, \&c., Malayan Peninsula and China (Amoy, Chusan, Formosa).-Distinguishable from all the other species of the group by its large broadly-cupshaped sori.

45. D. pyxidata, Cav.; rhizome stout, creeping, densely clothed with palebrown linear scales; st. strong, erect, 4-6 in. 1.; fr. 9-18 in. 1., 6-9 in. br., deltoid, tri- or quadripinnatifid; pinnl. of the lower pinnæ lanceolate, 2-3 in. l., 1 in. br., with deltoid or oblong segm., the lowest of which are cut down nearly to the rachis; texture coriaceous ; sori deeply half-cupshaped in the teeth, with a broad space outside them, which projects like a horn beyond them.- $H k$. Sp. Fil. 1. p. 170.t. 55. C.

Hab. New South Wales.-Very near $D$. canariensis in habit and texture, but some. what more finely cut and veined. 
46. D. Canariensis, Smith ; rhizome stout, creeping, densely clothed with palebrown linear scales; st. strong, erect, 4-6 in. l.; fr. 12-18 in. 1., 9-12 in. br., deltoid, quadripinnatifid ; pinnl. of the lower pinnæ lanceolate-deltoid, 2-3 in. l., more than 1 in. br., with ovate-rhomboidal deeply inciso-pinnatifid segm.; texture coriaceous; sori occupying a whole ultimate division or with a horn beyond them; invol. half-cupshaped.-Hk. Sp. 1.p. 169. t. 56. A.

Hab. Spain, Portugal, N. Africa, the Canaries, and Madeira.

47. D. bullata, Wallich ; rhizome creeping, stout, densely clothed with lightbrown or whitish fibrillose scales; st. strong, erect, 3-4 in. l. ; fr. 8-12 in. l., 4-8 in. br., deltoid, quadripinnatifid ; pinnl. of the lower pinnæ lanceolate, 2-3 in. l., 1 in. br., with deeply inciso-pinnatifid oblong-rhomboidal segm.; texture coriaceous; sori deeply half-cupshaped, occupying the greater part of the tooth in which they are placed, marginal, with usually a horn on the outside.- $H k$. $S p$. Fil. 1.p. 169. t. 50. B.

Hab. Hindostan, ascending in the north to $3-4,000 \mathrm{ft}$., Japan, Java, and Malayan Peninsula.- Very near $D$. Canariensis and pyxidata, but smaller, and somewhat thinner in texture, and the scales of the rhizome different.

48. D. nitidula, Kunze ; rhizome stout, creeping, fibrillose ; st. 6-8 in. 1., firm, but rather slender; fr. 12-24 in.1., 9-15 in. br., deltoid, quadripinnatifid; pinnl. of the lower pinnæ deltoid, cut down to the rachis into rather distant deltoid segm., the lobes of which are again deeply pinnatifid; texture between herbaceous and coriaceous; sori half-cupshaped, two-horned, occupying the whole of the end of the ultimate teeth.-Hk. Sp. Fil. 1. p. 165. t. 44. A.

Hab. Natal, Dr. Pappe; and fine specimens have recently been gathered by Dr. Welwitsch in Angola at 1-2,000 ft. Frond rather flaccid, rachises slender and flexuose.

49. D. Fijiensis, Hk. ; rhizome creeping, stout, densely fibrillose ; st. 6-9 in. 1., erect, strong ; fr. 12-18 in. 1., 6-12 in. br., deltoid, quadripinnatifid ; pinnl. of the lower pinnæ deltoid-lanceolate, the lobes of the segment cut down nearly to the rachis into narrow linear divisions, $\frac{1}{8}-\frac{1}{4}$ in. 1 . ; texture coriaceous ; sori halfcylindrical, terminal on the dilated apices of the segments, sometimes with a slight wing, but no liorn.-Hk. $S p$. 1. p. 166. $t$. 55. D.

Hab. Fiji Islands, plentiful. - The most finely-divided species of the series.

$\$ \$ \$ \$$ Microlepia. Invol. membranaceous, shallowly half-cupshaped, attached at the sides as well as the base. Sp. 50-65. Fronds very various in size, texture, and cutting. This sub-genus has its head-quarters in S. E. Asia and Polynesia. Four species are American and one African. Differing also from Humata, Eudavallia, and Leucostegia, in having the stems, except in D. ciliata, continuous with the caudex, and consequently falling under a different primary division (Desmobrya) of J. Smith's classification.

50. D. (Micro.) Hookeriana, Wallich ; rhizome creeping, both it and the lower part of stem pubescent-fibrillose ; st. stout, erect, 4-6 in. 1. ; fr. 12-18 in. 1., 6-8 in. br., simply pinnate; largest pinnos 4 in. 1., $\frac{1}{2}$ in. br., linear-acrimiuate, truncate and auricled at the base above, slightly undulated below, and tootheu towards the point; texture subcoriaceous; rachis and veins beneath villose ; sori in continuous rows along the edges; invol. small, about as broad as deep.- $H k$. Sp. 1.p. 172. t. 47 . B.

Hab. Sylhet, Kamoun, and Assam, Hongkong.

51. D. (Micro.) Saccoloma, Spreng. ; rhizome wide-creeping, often climbing ; fr. 4-6 ft. 1., simply pinnate; lower pinnce $1 \mathrm{ft}$. l., rather over 1 in. br., linearacuminate, sharply but not deeply toothed towards the point, undulated 
below ; texture subcoriaceous, but thin; sori in long continuous rows along the edges; invol. thin, twice as broad as deep.-Hk. Sp. 1. p. 171. Saccoloma elegans, Kaulf., J. Smith.

Hab. Tropical America, from Guatemala and W. Indies southward to Rio Janeiro.

52. D. (Micro.) pinnata, Cav.; rhizome creeping, fibrillose ; st. strong, erect, 6-12 in. l. ; fr. 9-15 in. 1., 4-8 in. br., with distant linear slightly toothed pinnoe 6 in. l., $\frac{1}{4}-\frac{3}{8}$ in. br.; texture coriaceous ; sori one to each tooth, small, submarginal.-Hk. Sp. 1. p. 173.t. 60.f.1. and 4. D. serrata, Blume.- $\beta, D$. gracilis, Blume ; lower pinnce cut down nearly to the rachis into narrow, linear, oblong lobes.-D. Luzonica, Hk. Sp. 1. p. 174.t. 60.f. 2. 3. and 5.

Hab. Malayan Peninsula, Java, and Polynesian Islands.-This and the two preceding are very distinct species, easily distinguishable from the rest by their simply pinnate habit and long narrow pinnæ.

53. D. (Micro.) Wilfordii, Baker ; rhizome creeping ; st.4-6 in. 1., slender, naked, flexuose ; fr. 6-9 in. l., 2-3 in. br. ; lanceolate, tripinnatifid; lower pinnce deltoid, stalked, about 1 in. l., $\frac{1}{2}$ in. br., cut down to the rachis below with broadly ovate-rhomboidal sharply toothed pinnules; texture herbaceous; rachis and both surfaces naked; sori 2 to 6 to a pinnule, apical in the teeth.-D. rhomboidea, Hk. 2nd Cent. t. 48. not Wallich. Microlepia Wilfordii, Moore.

Hab. Japan ; gathered both by Messrs. Wilford and Oldham.-This and the next, it will be seen, are very diminutive compared with all the species that follow.

54. D. (Micro.) pilosella, Hk. ; rhizome creeping, slender, pubescent; st. slender, erect, 3-4 in. 1., pubescent ; fr. 6-9 in. 1., 2 in. br., lanceolate, tripinnatifid; lower pinnoe deltoid-lanceolate, about 1 in. l., cut down to a broadlywinged rachis with oblong, rather sharply toothed, lobes; texture herbaceous ; rachises and both surfaces softly hairy; sori 2 to 6 to a pinnule, marginal in the teeth.-Hk. 2nd Cent. t. 96.

Hab. Japan and Tsus Sima; gathered by Messrs. Wilford and Oldham.

55. D. (Micro.) ciliata, Hk.; rhizome creeping, covered with soft brown hairs ; st. 3-4 in. 1., firm, erect, pubescent ; fr. 12-18 in. l., 6-9 in. br., ovatelanceolate, tripinnatifid; pinnoe spreading, lanceolate, the central ones the largest, 3-5 in. l., $1 \frac{1}{2}$ in. br., cut down to a broadly-winged rachis, with oblong pinnl. cut about halfway down with falcate, mucronate teeth; texture thinly herbaceous, flaccid; rachises and under surface softly hairy; sori 2 to 12 to a pinnule, very small, placed near the centre of the teeth near the base.-Hk. Sp. Fil. 1. p. 184. t. 60. A. Leucostegia hirsuta, J. Smith.

Hab. Philippine Islands.

56. D. (Micro.) villosa, Wallich ; rhizome strong, creeping, villose ; st. 1-2 ft. 1., erect, strong ; fr. 18-24 in. 1., 9-15 in. br., once pinnate ; pinnce 4-8 in. l., about 1 in. br., linear, cut down about halfway to the rachis, or less, into bluntish oblong lobes, the base above parallel with the stem, that of the lower side obliquely truncate; texture subcoriaceous; rachises densely villose and under surface also hairy; sori 2 to 8 to a lobe, submarginal.-Hk. Sp. 1.p. 172. $t .48$. A. D. calvescens, Wallich. Hk. Sp. 1.p. 172.t. 48. B.

Hab. Ceylon, and flank of the Himalayas, Japan, China.

57. D. (Micro.) strigosa, Swartz; rhizome stout, creeping, pubescent ; st. erect, strong, 6-12 in. 1., both it and the rachis pubescent throughout ; $f r .1-3 \mathrm{ft} .1$., 6-12 in. br., lanceolate, bipinnatifid ; lower pinnoe 4-8 in. 1., $\frac{3}{4-1}$ in. br., linearlanceolate, much acuminate, cut down to the rachis with unequal-sided, broadly 
and rather bluntly toothed, oblong, rhomboidal pinnl.; texture subcoriaceous; veins beneath prominently raised and, like the rachises, more or less hairy; sori 2 to 12 to a pinnule, small, placed at the base of the sinuses.-D. Khasiyana, Hk. Sp. 1. p. 173. t. 47. A. and 57. A.- $\beta$ D. rhomboidea, Wall. ; similar to $\alpha$ in texture and hairiness, but rather larger in all its parts, lower pinnl. lanceclatedeltoid, $1 \frac{1}{2}$ in. 1., cut down nearly to the rachis into oblong lobes.-D. polypodioides $\gamma$ and $\delta, H k$. Sp. Fil. 1.p. 182.

Hab. North of India, ascending in the Himalayas to 3-5,000 ft., Ceylon, Japan, Malayan Peninsula and Isles, S. E. China, Sandwich and Fiji. Islands.-This is very similar to the last in habit, but is at least bipinnatifid.

58. D. (Micro.) platyphylla, Don. ; rhizome creeping, stout, scaly ; st. 2-3 ft. 1., firm, erect ; fr. 3-4 ft. l., tripinnatifid ; lower pinnce 12-15 in. 1., 6-9 in. br., lanceolate, with distant linear lanceolate pinnl., which are cut nearly to the rachis below into broad bluntish, toothed, oblong-deltoid lobes ; texture subcoriaceous, both surfaces naked; sori 2 to 12 to a segment, placed one in each tooth a short distance from the edge, about a line across.-D. Ionchitidea, Wall. Hk. Sp. 1. p. 173. t. 46. B. Exot. F.t. 19.

Hab. Throughout Hindostan from Ceylon to the Himalayas.

59. D. (Micro.) urophylla, Hk. ; st. strong, erect, $2-3 \mathrm{ft} .1$. ; fr. 2-3 ft. 1., tripinnatifid ; lower pinnoe 9-12 in. l., 6-8 in. br., lanceolate with distant lanceolate lower pinnl., which are cut down to the rachis below into ovate-deltoid, acuminate, unequal-sided, broadly-toothed lobes; texture coriaceous, both surfaces naked; sori submarginal, one to each of the lower sinuses of the lobes.-Hk. Fil. Exot. t. 19. note.

Hab. Bootan, Griffith.

60. D. (Micro.) Thwaitesii, Baker ; rhizome creeping, tomentose ; st. 6-12 in. 1., erect, naked ; fr.2-3 ft. l., lanceolate-deltoid, tripinnatifid; lower pinnce 9-12 in. l., 3-4 in. br., lanceolate; pinnl. lanceolate-acuminate, cut down nearly or quite to the rachis into blunt slightly crenated oblong lobes; rachis and both surfaces slightly hairy, the upper bright-green, shining; texture subcoriaceous; sori small, submarginal, 2 to 12 to a segment.-D. proxima, Thwaites Enum. Pl. Zeyl. p. 238. non Blume.

Hab. Ceylon.-This comes nearest to urophylla, but the segments are shorter and blunter and the sori are smaller. An authenticated specimen of Blume's plant is probably $D$. hirta.

61. D. (Micro.) inoequalis, Kunze ; rhizome creeping; st. stout, 2-3 ft. 1.; fr. 2-3 ft. l., 12-18 in. br.; ovate-lanceolate, quadripinnatifid ; lower pinnoe 9-12 in. 1., 4-8 in. br., with lancelate pinnl. 3-5 in. l., 1-2 in. br.; lower segm. cut down nearly to the rachis with oblong toothed lower lobes; texture herbaceous, both surfaces naked; sori 2 to 12 to a segment, small, placed in the teeth at a short distance from the margin.-Hk. $S p$. 1. p. 180. excl. var. $\gamma . t .57 . \mathrm{B}$.

Hab. Tropical America from Jamaica and Guadeloupe, southward to Peru and Rio Janeiro, Aneiteum, and Philippine Islands.-The var. nigrescens, Kunze, is a large form which turns nearly black when dried. A plant from Burchell, No. 3549, marked by Professor Mettenius Saccoloma Brasiliensis, Mett. (Davallia, Hook.), has the lower pinnules only cut down to the rachis at the very base.

62. D. (Micro.) campyleura, Kunze ; st. strong, erect, about 1 foot high ; fr. 2-3 ft. 1., 9-18 in. br., deltoid, quadripinnatifid; lower pinnoe lanceolate, 9-12 in. 1., 4-6 in. br., the segm. of the pinnules cut down to the rachis into broadlytoothed, oblong lobes in the lower part; texture subcoriaceous, both surfaces naked; sori 1 to 6 in a lobe, placed in the teeth, small, submarginal.- $-\mathrm{D}$. inæqualis, $\gamma$ minor, Hk. Sp. Fil. 1. p. 180.t. 58. A. 
Hab. Polynesian Islands. $-M$. papillosa of Brackenridge seems to belong here. D. Amboynensis, Hk. Sp. 1. p. 178. t. 56. C., is apparently a reduced form of this, with only the lowest pinnules cut down to the rachis.

63. D. (Micro.) Denhami, Hk. ; rhizome creeping; st. 4-8 in. l., slender, erect; fr. 12-24 in. l., 6-12 in. br., ovate, quadripinnatifid; pinnl. of the lower pinnæ lanceolate, $1 \frac{1}{2}-3$ in. $1 ., 1$ in. br., cut down to the rachis into oblong toothed segm., the lower ones $\frac{1}{4}$ in. $1 ., \frac{1}{8}$ in. br. ; texture herbaceous, both surfaces naked; sori numerous, very small, terminal in the teeth; invol. half-cupshaped. -Hk. 2nd Cent.t.47; Brack. p. 236.

Hab. Fiji and Samoa.-Near D. campyleura, but much more finely cut and thinner in texture.

64. D. (Micro.) hirta, Kaulf. ; st. strong, 12-24 in. l.; fr. 3-6 ft. 1., 12-24 in. br., deltoid, tri- or quadripinnatifid ; lower pinnæ 6-12 in. 1., 3-4 in. br., ovatelanceolate; pinnl. lanceolate, cut down to the rachis into oblong broadly-toothed lobes; texture coriaceous; rachis and especially the under surface pubescent; veins beneath prominently raised; sori 2 to 20 to a segment, placed one or more together at the base of the teeth.-Hk. $S^{y}$. 1. p. 181. I). proxima, Blume?

Hab. North of India, Ceylon, Malayan and Polynesian Islands.-This has the stature and habit of $D$. Speluncee combined with the coriaceous texture and prominent venation of $D$. strigosa.

65. D. (Micro.) Spelunce, Baker ; st. strong, 12-18 in. l. ; fr. 3-6 ft. 1., 12-24 in. br., deltoid, tri- or quadripinnatifid ; lower pinnce 6-12 in. 1., 3-4 in. br., ovate-lanceolate; pinnl. lanceolate, cut down to the rachis below into oblong deeply-toothed lobes; texture herbaceous; rachis and under surface hairy; veins beneath neither prominent nor rigid; sori 2 to 20 to a segment, placed one or more together at the base of the lobes.-Polyp., $L$. D. polypodioides, $\alpha$ and $\beta$, $H k$. $S p$. 1. p. 181. D. Jamaicensis, Hk. Sp. 1. p. 183. D. trichosticha, Hk. Sp. 1.p. 183. D. Madagascariensis, Kunze.

Hab. Hindostan, ascending in the Himalayas to 1-7,000 ft., S. E. China, Ceylon, and Polynesian Islands, southward to Norfolk Island, and Queensland, Madagascar, Bourbon, West Tropical Africa, and Macalisberg mountains, west of Natal. West Indian Islands, southward to Brazil.-This is much more tender in texture than $D$. strigosa and hirta, so much so, that the pinnæ are liable to shrivel up when the plant is gathered in a hot country. It resembles Dicksonia rubiginosa considerably in general appearance, and has a wide geographical range.

\$§\$§\$ Loxoscaphe, Moore. Invol. forming a compressed suborbicular or cupshaped pouch at the side of the segments, which is open only at the top. All decompound with linear ultimate segments. Sp. 66-69. A very natural group, allied in habit to Darea, but quite different in the fructification.

66. D. (Lox.) concinna, Schrad. ; st. tufted, 3-4 in. 1., erect, naked ; fr. 6-9 in. 1., 2-3 in. br., oblong-acuminate, bipinnate; lower pinnoe erecto-patent, $1 \frac{1}{2}-2$ in. $1 ., \frac{1}{2}$ in. br., with simple or forked branches equalling the rachis in breadth, $2-3$ lin. 1., $\frac{1}{2}$ lin. br.; texture stoutly herbaceous, surfaces naked; sori half-cupshaped, 1 lin. br., sunk in the dilated apices of the segments.-Hk. Sp. 1 . p. 193. D. Schimperi, Hk. Sp. 1.p. 193.t. 50. B. D. thecifera, H. B.K. Hk. Sp. Fil. 1. p. 189. D. Lindeni, Hk. Sp. 1. p. 193. t. 56. B.

Hab. Andes of Colombia and Ecuador, Brazil, Cape Colony, Natal, Bourbon, Abyssinia, Angola, and Fernando Po.

67. D. (Lox.) gibberosa, Swartz ; st. tufted, 6-12 in. l., erect, naked ; fr. 12-18 in. 1., 6-9 in. br., lanceolate-deltoid, quadripinnatifid; pinnl. of lower pinno lanceolate-deltoid, 2-3 in. $1 ., 1$ in. br.; segm. cut down to the rachis with 
linear or forked ultimate divisions, 1-2 lin. l., equalling the rachis in breadth; texture stoutly herbaceous, surfaces naked; sori terminal in the ultimate divisions or with a horn beyond; invol. half-cupshaped, $\frac{1}{2}$ lin. across. $-H k$. $S p$. 1. $p .192$.

Hab. Polynesian Islands.-Like D. concinna in habit, several times multiplied.

68. D. (Lox.) nigrescens, Hk. ; st. 6-9 in. 1., stout, erect, paleaceous below ; fr. 12-24 in. l., 9-15 in. br., ovate-lanceolate, quadripinnatifid; lower pinnoe 4-8 in. l., $1 \frac{1}{2}-2$ in. br., lanceolate, acuminate; pinnl. deltoid, unequal-sided, cut down to the rachis throughout; segm., especially on the upper side, deeply, inciso-

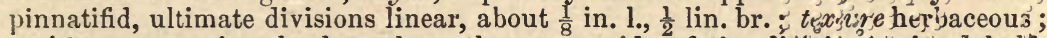
sori 2 to 6 to a pinnule, lateral on the upper side of the divisions cupshaped.-Hk. 2 nd Cent. Ferns, $t .93$.

Hab. Fernando Po, at an elevation of $3,000 \mathrm{ft} ., G$. Mann.-Nearest $\mathcal{Z}$. gübberosa, but the pinnules shorter and more divided, with flatter segments and pubescent rachises.

69. D. (Lox.) foeniculacea, Hk ; st. erect, firm, 6-8 in. 1. ; fr. 9-18 in. 1., 6-12 in. br., lanceolate-deltoid, quadripinnate; lower pinnl. lanceolate-acuminate, 2-3 in. l., 1 in. br.; segm. cut down to the rachis into simple or forked linear filiform ultimate divisions, 1-2 lin. l., equalling the rachis in breadth; texture herbaceous ; sori 2-6 to a segment, lateral, deeply half-cupshaped, under $\frac{1}{2}$ lin. br. -Hk. 2nd Cent. Ferns, $t .54$.

Hab. Fiji group ; gathered by Mr. Milne.-A very distinct and finely-cut species. Habit of $D$. trichomanoides, but sori quite different.

§\$§§\$§ Stenoloma, Fée. Invol. as in Loxoscaphe, but terminal on the segments. Sp. 70-79. Fronds very various in size, but the ultimate segments always cuneate, growing gradually wider from the base to the apex. Scattered throughout the tropics. Odontosoria, J. Smith. This goes with Microlepia into J. Simith's Desmobrya.

\section{* Fronds 6-18 in. l., not climbing.}

70. D. (Steno.) Goudotiana, Kunze; rhizome creeping, slender, fibrillose; st. not more than 1 in. 1 . ; fr. 4-6 in. l., $\frac{1}{4-\frac{1}{2}}$ in. br., linear-oblong; main rachis not branched; largest pinnoe deltoid, $\frac{1}{2}$ in. l., more than $\frac{1}{4}$ in. br., cut down to a slender subfiliform rachis into simple or forked linear-cuneate thinly herbaceous segments; sori terminal, suborbicular, 1 to each segment. $-H k$. Sp. 1. p. 189. $t$. 50. C., 2 Cent. t. 23.

Hab. Madagascar.

71. D. (Steno.) bifida, Kaulf.; rhizome short; st. 4-8 in. 1., wiry, naked, flexuose ; fr. 4-8 in. 1., 2-4 in. br., ovate-deltoid, quadripinnatifid; pinnoe flaceid, $2-4$ in. 1., lanceolate-deltoid, the lower pinnl. cut down to a filiform rachis, with deeply-cut pinnatifid or flabellate segm., ultimate divisions linear-cuneate, thinly herbaceous, $1 \frac{1}{2}-2 \frac{1}{2}$ lin. 1 ., less than $\frac{1}{2}$ lin. br. at the point ; sori small, terminal, suborbicular.-Hk.Sp. 1. p. 188. Hk. \& Gr. Ic. t. 238.

Hab. Minas Geraes and Organ Mountains, Brazil.

72. D. (Steno.) scoparia, Hk. MSS.; rhizome strong, creeping; st. strong, erect, 6-12 in. l. ; fr. 6-9 in. 1., 4-6 in. br., deltoid, tri- or quadripinnatifid ; pinnoe lanceolate, erecto-patent; pinnl. again pinnatifid with forked or pinnatifid lower segm., ultimate divisions subcoriaceous, linear-cuneate, $\frac{1}{4}$ in. l., $\frac{1}{2}$ lin. br. at the point; sori small, suborbicular, often not occupying the whole apex of the segment. - Lindsaya, Mett. Fil. N. Caled. p. 64. 
Hab. New Caledonia, Fieillard, No. 1550.- Very near D. clavata, but the pinnæ and segments are rather stouter and more rigid in texture.

73. D. (Steno.) clavata, Swartz; rhizome stout, creeping, densely villose; st. strong, erect, 6-9 in. 1. ; fr. 6-9 in. 1., 3-4 in. br., ovate-lanceolate, tri- or quadripinnatifid; pinnoe distant, with distant pinnl., the latter cut down to a filiform rachis; segm. again pinnatifid, ultimate divisions herbaceous in texture, linearcuneate, $\frac{1}{4}-\frac{3}{8}$ in. l., $\frac{1}{2}$ lin. br. at the top ; sori terminal, suborbicular or reniform, sometimes confluent.-Hk. $S p .1 . p .187$.

Hab. Węst Indian Tslands.

74. D.'(Steño.) 'tènuifolia, Swartz; rhizome stout, creeping, densely fibrillose ; sta sirong; exect polished, naked, dark-brown, 6-12 in. l. ; fr. 12-18 in. 1., 6-9 in. bri; sotate; quadripinastifid ; lower pinnoe ovate-lanceolate, 4-6 in. 1., 2-3 in. br. ; pinnl. lanceolate, their segments cut down to the rachis below with toothed cuneate lobes, 1-1 $\frac{1}{2}$ lin. across at the apex; texture subcoriaceous, both surfaces naked, the upper shining; sori terminal, usually solitary, often rather broader than deep.-Hk. Sp. Fil. 1. p. 186.- $\beta$, D. Chineasis, Smith ; fr. smaller ; segm. broader; sori 1 to 4 in a lobe.-Hk. Sp. 1. $p .187$.

Hab. Common in tropical Asia and Polynesia, ascending northward to Japan, and $5,000 \mathrm{ft}$. in the Himalayas, Madagascar, Bourbon, and Mauritius.

\section{** Fronds several feet long, usually climbing.}

75. D. (Steno.) uncinella, Kunze ; st. 6-8 ft. l., wide-climbing, flexuose, prickly; fr. tripinnate; lower pinnoe 1-2 ft. 1., with a long unbranched terminal segment and a few lateral ones, the lowest of which are also long and flexuose; segm. $\frac{1}{4}$ in. br. and deep, obliquely truncate below, blunt at the point, broadly and bluntly lobed above; veins not prominent; texture thick, subcoriaceous; sori small, cupshaped, marginal.-Kunze in Schk. Suppl. 2.p. 96.t. 140.

Hab. Cuba and Porto Rico.

76. D. (Steno.) aculeata, Swartz; rhizome creeping, stout, fibrillose ; st. (including rachis) 4-6 ft. l., strong, scandent, spinoso-flexuose; fr. tripinnatifid; lower pinnoe 12-18 in. l., 4-6 in. br., ovate-lanceolate ; pinnl. lanceolate, 2-3 in. l., 1 in. br. ; segm. $\frac{1}{4}$ in. br., cuneate, deeply 2 to 4 lobed, lobes with 2 or 4 veins; texture herbaceous; veins prominent beneath, once or twice flabellately forked; sori small, cupshaped, terminal.-Hk. Sp. 1.p. 191. t. 54. B.

Hab. West Indian Islands, common.

77. D. (Steno.) Melleri, Hk. MSS.; st. wide-creeping, scandent, not prickly ; fr. quadripinnatifid ; pinnl. of lower pinnæ 2-3 in. $1 ., 1 \frac{1}{2}$ in. br., ovate; segm. 1 in. $1 ., \frac{3}{4}$ in. br., cut down to the rachis below, lobes $\frac{1}{4}-\frac{8}{8}$ in. br., cuneate at the base, both deeply toothed and shallowly crenate; texture herbaceous; veins not prominent ; sori small, marginal, shallow, usually cupshaped, sometimes but not always as broad as the lobe in which they are placed, sometimes two confluent.

Hab. Madagascar; gathered by Meller and Lyall.-Intermediate between $D$. aculeata and Lindsaya retusa, and according to our definitions, with as good a right to be placed in one genus as the other.

78. D. (Steno.) fumarioides, Swartz; habit of D. aculeata and the stem and rachises similarly prickly, but segm. smaller and more deeply cut, the lobes but slightly broader at the apex than the base, usually only one-veined ; sori cupshaped, as broad as the segment.-Hk. Sp. 1.p. 191.

Hab. West Indian Islands. 
79. D. (Steno.) Schlechtendahlii, Presl ; fr. 2-3 ft. 1., 1-2 ft. br. ; main rachis strong, straight, naked; lower pinnce 9-12 in. 1., 4-6 in. br., ovate-lanceolate, spreading or deflexed, with a zigzag rachis; pinnl. 2-3 in. 1., about 1 in. br., cut down to a narrowly-winged strong rachis; segm. cut down to a centre which equals in breadth the narrow linear forked or flabellate ultimate divisions ; texture herbaceous; sori small, terminal, suborbicular.-Hk. Sp. 1.p.189. t. 54. C.

Hab. Mexico and Guatemala, ascending to 3,500 feet.

\section{Gen. 19. Cystopteris, Bernh.}

Sori globose, placed on the back of the veins. Invol. membranaceous, suborbicular, inserted by its broad base under the sorus, which at the beginning it covers like a hood.-Fronds small, two or three times divided, thin in texture, veins free. Allied to Woodsia and Microlepia, and exceptional amongst the ferns in its geography, having its head-quarters in the Temperate Zones of both hemispheres. TАB. II. f. 19.

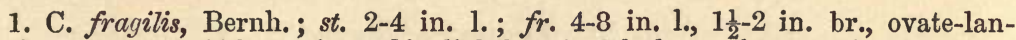
ceolate, tripinnatifid ; main rachis slightly winged above; largest pinnoe 1-1 $\frac{1}{2}$ in. l., $\frac{1}{2}-\frac{3}{4}$ in. br., lanceolate-deltoid ; pinnl. oblong-rhomboidal, cut down to a broad central space into bluntly- or sharply-toothed lobes; texture herbaceous ; sori 2 to 12 to a pinnule. Hk. Sp. 1.p.197. Brit. Ferns, t. 23.

Hab. Europe and Asia, everywhere from Iceland to Kamschatka, from the Arctic regions to Madeira, and the Himalayas, where it ascends to $15,000 \mathrm{ft}$. ; mountains of Abyssinia and Fernando Po; South Africa; Van Diemen's Land, New Zealand, Sandwich Islands; Temperate N. and S. America, and mountains in the intermediate Tropical Zone. C. Tasmanica, Sandwicensis, and Douglasii, do not appear to be safely separable.

2. C. alpina, Desv. ; st. 2-4 in. 1. ; fr. 4-8 in. 1., 1-2 in. br., oblong-lanceolate, tripinnatifid ; main rachis more or less winged above; largest pinnce deltoid, lanceolate, 1-1 $\frac{1}{2}$ in. $1 ., \frac{1}{2}-\frac{3}{4}$ in. br.; pinnl. ovate-rhomboidal, cut down to the rachis below into slightly toothed segm.; texture herbaceous; sori small, 2 to 12 to a pinnule.-Hk. Sp. 1.p. 199. Brit. Ferns, t. 24. Aspid. Taygetense, Bory and Chaub.

Hab. Mountains of Europe from Sweden to Greece and Spain, and Asia Minor.-In England naturalized on a wall at Low Leyton, Essex. A more tender and usually more finely-divided plant than the last, but often difficult to distinguish.

3. C. bulbifera, Bernh. ; st. 4-6 in. 1. ; fr. 6-12 in. 1., 3-4 in. br. at the widest part, ovate-lanceolate, often much elongated upwards, bi- or tripinnatifid ; lower pinnl. lanceolate or ovate-lanceolate, 2-3 in. 1., 1 in. br.; segm. linear-oblong, cut down to the rachis below, very slightly toothed; sori 2 to 12 to a pinnule, usually in two rows, one in each segment.-Hk. Sp. 1. p. 199. C. atomaria, Presl.

Hab. N. America from Canada southward to Virginia and N. Carolina. - A very distinct plant, which takes its name from the large fleshy bulblets which are formed in the axils of the upper pinnæ. These often fall to the ground and become new plants, which, Prof. Eaton says, are about two years in coming to maturity.

4. C. sudetica, A. Br. \& Milde ; rhizome wide-creeping; st. slender, 6-9 in. 1.; fr. 6-8 in. each way, deltoid, tri- or quadripinnatifid ; lowest pinnl. deltoidlanceolate, 1-1 $\frac{1}{2}$ in. 1., less than $\frac{1}{2}$ in. br.; lower segm. $\frac{1}{4}$ in. 1., 2 lin. br., ovaterhomboidal, deeply toothed; texture herbaceous; sori much larger than in C. montana, only 2 to 6 to the lower segments.-Nov. Act.vol. 26. P. 2. p. 554 . t. 44. 
Hab. Silesia, Sudetes of Moravia, and the Carpathians.-This species combines the habit of $C$. montana with the texture of $C$. fragilis.

5. C. montana, Link ; rhizome wide-creeping ; st. slender, erect, 6-9 in. 1. ; fr. about 6 in. each way, deltoid, quadripinnatifid ; lowest pinnl. deltoid-lanceolate, $1-1 \frac{1}{2}$ in. $1 ., \frac{1}{2}-\frac{3}{4}$ in. br. ; segm. cut down to the rachis below, the lobes oblong, 2 lin. 1., 1 lin. br., deeply and sharply toothed; texture thinly herbaceous; sori small, 18 to 24 to the lower segments.-Hk. Sp. 1. p. 200. Brit. Ferns, t. 25.

Hab. Mountains of Scandinavia, Scotland (very rare), and Central Europe; Kamschatka, east side of the Rocky Mountains, N. America.

\section{Tribe 5. LINDSAYEA.}

Sori placed in a line at or very near the edge of the frond, covered with an involucre, the inner valve of which is membranaceous, the outer (obsolete in Dictyoxiphium) formed of the margin of the frond. GEN. 20-20*.

\section{Gen. 20. Lindosaya, Dryand.}

Sori marginal or submarginal, placed at the apex of and uniting two or more veins. Invol. double, opening outwardly, the inner valve membranaceous, the outer formed of the more or less changed (scarcely changed in Diellia and some other species) margin of the frond. A moderately extensive genus, only a few species of which pass outside the tropics, most, but not all, the species of which have one-sided pellucido-herbaceous or coriaceous pinnce, approximating in shape to a quarter of a circle. TA B. II. f. 20.

§ Eulindsaya. Pinnce unilateral, veins free. Sp. 1-25. A well-marked section, which has its head-quarters in Tropical America, Asia, and Polynesia, but reaches the Mauritius, Japan, and Australia, with the habit of Adiantum, with fronds often pellucid.

\section{† Main rachis unbranched. Sp. 1-12.}

1. L. linearis, Swartz; rhizome wiry, creeping; st. wiry, flexuose, black, shining, 4-8 in. 1. ; fr. 6-12 in. 1., $\frac{1}{2}$ in. br., simply pinnate ; pinnoe 3 lin. l., 2 lin. deep, the upper edge very slightly toothed, the lower ones with often a considerable space between thein ; texture thickly pellucido-herbaceous; sori in a continuous line along the upper edge. $-H k . S p .1 . p .206$.

Hab. Australia, Van Diemen's Land, New Caledonia, and New Zealand.Pinnules often distinctly flabellate in shape, readily curling up when dry. It has much the smallest pinnæ of the unbranched group.

2. L. falciformis, Hk.; rhizome short-creeping ; st. very short, close together ; fr. 3-4 in. 1., $\frac{1}{2}-\frac{3}{4}$ in. br., simply pinnate; pinnce 4 lin. 1., $\frac{1}{8}$ in. deep, distinctly falcate towards the outside, both margins entire, close together, but not imbricated ; texture pellucido-herbaceous ; the costal vein parallel with the lower edge at a short distance from it; sori in a continuous marginal line.- $H k . S p .1$. p. 208. $t$. 64. B.

Hab. British Guiana; gathered by Sir R. Schomburgk.-A very doubtful plant, perhaps young, unbranched $L$. trapeziformis.

3. L. adiantoides, J. Sm.; st. nearly tufted, black, polished, wiry, 1-2 in. 1. ; fr. 4-6 in. 1., about 1 in. br., simply pinnate ; pinnoe $\frac{1}{2}$ in. l., $\frac{1}{4}$ in. deep, the upper imbricated, the lower edge straight or slightly curved, the upper rounded and broadly lobed about one-third of the way down ; texture pellucido-herbaceous ; sori marginal in the lobes.-Hk. Sp. 1. p. 204. $t .61 . \mathrm{C}$. 
Hab. S. Camarines, Malay Archipelago; gathered by Cuming.-Much resembling small unbranched forms of $L$. nitens, but recognizable by its simple venation.

4. L. ovata, J. Sm.; rhizome short-creeping ; st. 2-3 in. 1., wiry, flexuose, black; fr. 4-6 in. 1., $\frac{3}{4}$ in. br., simply pinnate; pinna 4 lin. l., 2 lin. deep, not imbricated, the lower ones with their own breadth between them, horizontally oblong, the point very blunt, the lower side obliquely truncate at the base, the upper slightly auricled ; texture subcoriaceous ; sori in a continuous marginal line.-Hk. Sp. 1.p. 205. t. 64. A.

Hab. Same station as $L$. adiantoides; gathered also by Cuming.

5. L. concinna, J. Sm. ; rhizome short-creeping; st. $2-4$ in. 1., wiry, erect; fr. 6-12 in. l., $\frac{3}{4}$ in. br., simply pinnate; pinnoe 4 lin. l., 2 lin. deep, very blunt on the outer edge, the upper edge very slightly crenate, the upper ones close together, but scarcely imbricated; texture pellucido-herbaceous; sori in a continuous or slightly interrupted line along the upper edge. $-H k$. Sp. 1. p. 205. t. 61. B.

Hab. Philippine Islands and Borneo.

6. L. Seemanni, J. Sm.; rhizome short-creeping ; st. wiry, flexuose, 3-6 in. 1. ; fr. 6-12 in. l., about 1 in. br., simply pinnate ; largest pinnos $\frac{1}{2}-\frac{3}{4}$ in. $1 ., \frac{1}{4}$ in. deep, the same shape as those of $\boldsymbol{L}$. cultrata, but the teeth, especially the lower one, deeper and the texture thinner.-J. Smith in Bot. Herald, p. 239.

Hab. Bay of Choce, Panama, discovered by Dr. Seemann.-Perbaps an American form of $L$. cultrata.

7. I. cultrata, Swartz ; rhizome short-creeping ; st. wiry, flexuose, 3-6 in. 1. ; fr. 6-12 in. 1. , about 1 in. br., simply pinnate; largest pinno $\frac{1}{2}-\frac{3}{4}$ in. $1 ., \frac{1}{4} \mathrm{in}$. deep, not imbricated, the lower margin straight or slightly curved, usually upwards, the upper edge slightly lobed, so that the continuity of the line of the fructification is broken, sometimes nearly entire, lower pinnæ stalked ; texture coriaceo-membranaceous.-Hk. Sp. 1. p. 203. Hk. \& Gr. Ic. t. 144. Hk. Fil. Exot. t. 67. L. Lobbiana, Hk. $S p .1$. p. 205. t. 62. C. L. gracilis, Blume, Hk. E. C.- $\beta$, japonica; fr. 2-3 in. l.; pinnoe nearly triangular, with the point at the base, upper edge nearly entire.

$\mathrm{Hab}$. North of India, ascending in the Himalayas to 4,000 ft. ; Neilgherries, Malayan Peninsula and Islands, Bourbon ; and gathered lately by Mr. Hill in Queensland, by Dr. Meller in Madagasear. $\beta$ is a remarkable variety discovered by Mr. Oldham in Japan.

8. L. botrychioides, St. Hil.; st. 4-6 in. 1., wiry, erect, polished, dark chesnutbrown ; fr. 9-12 in. 1., 1-1 $\frac{1}{2}$ in. br., simply pinnate ; pinnoe $\frac{1}{2}$ in. each way, with only the inner third of the lower half cut away, the lower line more or less decurved, the upper line broadly rounded, scarcely lobed, and the outer margin broad and blunt ; texture herbaceous ; rachis naked, polished ; sori in a continuous line round the upper and outer edge and the inner half of the lower one, the outer valve projecting beyond the inner.

Hab. Brazil. Burchell, 4402.-Probably this is only an unbranched form of $L$. flabellulata, which, however, is not known to occur in the New World. Our description is taken entirely from Burchell's specimens named by Mettenius.

9. L. dubia, Spreng. ; rhizome short-creeping; st. close together, wiry, 3-6 in. 1. ; fr. $4-8$ in. $1 ., 1 \frac{1}{2}-2$ in. br., simply pinnate; pinnoe $\frac{3}{4}-1$ in. 1 ., not more than $\frac{1}{8}$ in. br., the upper edge crenated towards the gradually narrowing point, even the upper ones with usually $\frac{1}{4}-\frac{1}{2}$ in. between them, often not truly dimidiate, but with the costa becoming central towards the point; texture pellucido-herbaceous; line of the sori not interrupted till it reaches the crenations of the outer third of the upper margin.-Hk. $s p$. 1. p. 209. t. 64. C. 
Hab. Venezuela, Guiana, and valley of Amazon.-A very distinct species and interesting as showing a transition from Eulindsaya to Isoloma.

10. L. pectinata, Blume; rhizome stout, wide-creeping, scandent, paleaceous ; st. erect, very short ; fr. $12-18$ in. $1 ., 1-2$ in. br., simply pinnate ; pinno $\frac{1}{2}-\frac{3}{4}$ in. 1. , $\frac{1}{4}$ in. deep, the lower line nearly straight, the upper margin round, slightly crenate, the point not very blunt, close together, but not imbricated; texture pellucido-herbaceous; sori in an interrupted line along the upper edge.-Hk.Sp. 1. p. 287. I. oblongifolia, Reinw. Hk. Sp. 1.p. 206.t.61. D.

Hab. Assam and Malayan Peninsula and Islands.-Habit of Odontoloma repens, which see. L. Calomelanos, Kunze, from Java, is said to be closely allied.

11. L. scandens, Hk. ; rhizome stout, wide-creeping, scandent, paleaceous ; fr. 9-12 in. l., 1 $\frac{1}{2}-1 \frac{3}{4}$ in. br., simply pinnate ; pinnoe $\frac{3}{4}$ in. $1 ., \frac{1}{2}$ in. br., the lower line slightly decurved, the upper rounded, entire, the point broadly rounded, placed in a long row close together, but not imbricated; texture pellucido-herbaceous ; costa marginal; sori in a continuous marginal line.-Hk. Sp. 1. p. 205. t. 63. B.

Hab. Malayan Peninsula and Philippine Islands; gathered by Sir W. Norris, Lady Dalhousie, and Mr. Cuming.- Said to be sometimes bipinnate, but very doubtfully distinct from $L$. pectinata. The two may readily be known from the rest of the group by the stout scandent rhizome.

12. L. Lapeyrousii, Baker ; st. tufted, very short ; fr. $9-15$ in. 1. , about $1 \frac{1}{2}$ in. br. at the widest part, not branched; pinnoe very numerous, about $\frac{3}{4}$ in. l., with 4-8 spathulate-cuneate secund segments cut down to a narrow rachis; texture herbaceous, both surfaces naked; sori subterminal on the segments; invol. shallow, nearly as broad as the segments, which measure a line or more across at the apex.-Davallia, Hk. 2nd Cent. $t .56$.

Hab. Vanekolla and Fiji ; gathered by Messrs. C. Moore and Milne.-Readily distinguishable from all the preceding by the pinnæ being cut down to the rachis into narrow linear-cuneate segments.

+十 Main rachis more or less branched when the plant attains its full development. Sp. 13-25.

13. L. filiformis, Hk.; st. slender, wiry, very flexuose, brownish-black, polished, 2-4 in. 1. ; fr. 4-6 in. l., with a long simply pinnate apex, and below several pairs of short, spreading, flexuose branches ; pinnl. 2 lin. br., 1 lin. deep, the lower line curved upwards or downwards, the upper nearly entire, placed near together but not imbricated, obliquely truncate on the side towards the rachis; texture pellucido-herbaceous; sori in a continuons line along the upper edge.-Hk. Sp. 1. p. 212. t. 63. D.

Hab. British Guiana; gathered by Sir R. Schomburgk.-The smallest and most slender of the branched species.

14. L. Catherince, Hk.; rhizome short-creeping; st. slender, erect, wiry, polished, 6-9 in. 1.; fr. 6-9 in. l., with a pinnate summit, and below several spreading branches, the lowest of which are sometimes again branched at the base; pinnl. $\frac{1}{2}$ in. l., $\frac{1}{4}$ in. deep, cut down nearly to the costa into two or three cleft obversely triangular lobes; texture thinly pellucido-herbaceous; sori not quite as broad as the lobes, the outer valve considerably broader than the inner, and finely toothed.- $H k$. Sp. 1. p. 212, t. 65. B.

Hab. St. Catherine's, Brazil ; gathered by Captain Beechey. - The most divided plant in the pinnules of the branched, as $L$. Lapeyrousii is of the unbranched group.

15. L. virescens, Swartz; rhizome short-creeping ; st. 6-9 in. 1., slender, flexuose, polished, dark-coloured ; fr. 6-9 in. 1., 4-6 in. br., deltoid in general outiine, with 
a simply pinnate point, and several pairs of erecto-patent branches, some of which are again a little branched below; pinnl. 4 lin. br., 3 lin. deep, nearly entire or once or twice cleft from the upper margin, placed close together, but not imbricated; texture thickly pellucido-herbaceous ; sor $i$ in a continuous line except when interrupted by the lobes.-L. Gardneri, Hk. Sp. 1. p. 213.t. 65. B.

Hab. Organ Mountains, Brazil ; gathered by Burchell and Gardner.-Allied in habit to $L$. fabellulata, but the pinnules are smaller and more divided.

16. L. flabellulata, Dry.; rhizome short-creeping; st. wiry, erect, brownishblack, polished, 4-12 in. 1. ; fr. 6-12 in. 1., simple or with one or several pairs of lateral branches; pinnl. $\frac{1}{4}-\frac{1}{2}$ in. 1., about $\frac{1}{4}$ in. deep, the lower line nearly straight or decurved, the upper rounded, entire, or lobed, the point broadly rounded; texture pellucido-herbaceous ; rachis naked; venation flabellate; sori in a continuous line except when interrupted by the lobes.-Hk. Sp. 1. p. 211.t.63. C. Hk. \& Gr. Ic. 75 .

Hab. N. Hindostan, S. E. China, Malayan Peninsula and Islands, Ceylon, N. Australia. - Very variable in the size of the pinnæ and in ramification. Var. gigantea of Hooker is an abnormal state, with some of the pinnæ of the central rachis 1-2 in. 1., and lengthened out to a narrow point. L. tenera, Dryander, Hk. Sp. 1. p. 211. (L. striata, Blume), only differs by its thinner texture. In this and the preceding the lower pinnæ are often nearly as deep as broad.

17. L. trapeziformis, Dry.; rhizome short-creeping ; st. strong, erect, 6-12 in. 1.; fr. 6-15 in. l., with a long entire point and 1 to 4 pairs of rather rigidly erectopatent branches, which are often 6-12 in. 1. ; pinnoe $\frac{3}{4}-1 \frac{1}{2}$ in. $1 ., \frac{1}{4}-\frac{1}{2}$ in. deep, the lower line nearly straight or curved upwards or downwards, the upper rounded, entire, closely placed, but scarcely imbricated ; texture pellucido-herbaceous ; sori in a continuous line round the upper margin.-1Kk. Sp.1.p. 214. L. quadrangularis, Raddi, Hk. Sp. 1. p. 214. L. horizontinalis, Hk. Sp. 1. p. 214.t. 62. B. L. arcuata, Kunze, Hk. Sp. 1. p. 215. L. caudata, Hk. Ic. Pl. t. 958. Sp. 1. $p$. $215:-\beta, L$. las'a, Kunze, upper margin broadly lobed, so that the line of the fruit is more or less interrupted. L. Klotzschiana, Moritz. $-\gamma, L$. falcata, Willd. ; fr. not branched; pinnce often very large. L. Leprieurii, Hk. Sp. 1. p. 208.t.62.D.

Hab. Tropical America, from Cuba and Guatemala southward to Rio Janeiro ; Ceylon, Malayan Peninsula and Islands. $-L$. caudata is a large handsome Ceylonese form, with more branches than usual ; $L$. arcuata, a form with long narrow falcate pinnules; and L. L'Herminieri, Fée, a plant from Guadeloupe, with the pinnules broadest at the outer edge and the upper margin concave.

18. L. Borneensis, Hk. MSS. ; rhizome short-creeping, paleaceous; st. strong, erect, polished, 9-15 in. l. ; fr. 12-18 in. l., 9-12 in. br., with a long unbranched apex, and 6 to 9. erecto-patent branches on each side, which are 6-9 in. 1.; pinnl. 3-4 lin. l., 1 $\frac{1}{2}-2$ lin. deep, closely placed or even imbricated, quite entire, the outer edge blunt; texture pellucido-herbaceous; veins prominent; sori in a continuous marginal line.

Hab. Forests of Borneo ; gathered by Messrs. Lobb and Barber. - This comes very near $L$. Guianensis in habit, but the sori are quite marginal.

19. L. Guianensis, Dry.; rhizome short-creeping ; st. 6-12 in. 1., rigid, erect, polished; fr. 1-2 ft. l., with an entire point and 1 to 6 pairs of lateral erecto-patent branches, 6-9 in. 1., which are sometimes again branched; pinnl. $\frac{1}{2}$ in. $1 ., \frac{1}{4}$ in. br., not lobed and the outer edge bluntly rounded, closely placed and sometimes imbricated; texture subcoriaceous; veins prominent beneath; sori in a continuous line, with the outer valve produced, but altered in texture- $-H k$. Sp. 1. p. 172. t. 62. A.

Hab. Tropical America from Jamaica southward to Rio Janeiro. - This is inter- 
mediate between trapeziformis and stricta, and is sometimes distinguishable from the former only with difficulty.

20. L. stricta, Dry.; rhizome short-creeping, fibrillose ; st. rigid, erect, 12-24 in. l., polished, often chesnut-brown ; fr. simply pinnate, 12-24 in. $1 ., \frac{1}{2}$ in. br., or with 1 or 2 pairs of erect rigid lateral branches; pinnl. $\frac{1}{4}$ in. br., less deep, the lower line often considerably decurved, the upper rounded, nearly entire, closely placed but imbricated; colour bright-green, but texture coriaceous; sori in a continuous line round the upper edge.-Hk. Sp. 1.p.216. L. elegans, Hk. Ic. Pl. t. 98. (an unbranched form).

Hab. Tropical America from Mexico and the West Indian Islands southward to Rio Janeiro.-The plant well deserves its name. The pinnules and stems are so rigid, that specimens can be only made to adhere to paper with great difficulty. It is occasionally even tripinnatifid.

21. L. rigida, J. Sm.; rhizome wide-creeping; st. 4-6 in. 1., rigid, erect, prickly towards the base; fr. with a long unbranched central point and 1 to 4 pairs of flexuose lateral branches, $4-8$ in. 1 . ; pinnl. $3-4$ lin. br., 2 lin. deep, the lower edge often falcate, the upper 3 or 4 times bluntly, not deeply lobed, placed close together but not imbricated; texture very thick and coriaceous ; veins prominent; sori in a marginal line on the lobes.-Hk. Sp. 1. p. 217.t.63. A.

Hab. Malayan Peninsula, on Mount Ophir.-Much resembling L. stricta, but the texture is thicker, the veins more conspicuous, and the upper margin of the pinnules is conspicuously crenate. The colour of the mature frond is sepia-brown, and the pale veins stand out from the groundwork in relief.

22. L. Kirkii, Hk. MSS. ; st. 1-2 ft. 1., stout, suberect ; fr. 1-2 ft. 1., 6-9 in. br., with a long unbranched point and numerous (6-9) erecto-patent branches on each side, 6-9 in. 1.; pinnl. about $\frac{1}{2}$ in. br., $\frac{1}{4}$ in. deep, much decurved at the base, the outer edge rounded, the upper crenate, that nearest the rachis frequently overlapping it, and the pinnules placed so close that one overlaps the base of the next above it; texture thinly herbaceous; veins prominently channelled; sori numerous round the upper edge, not more than twice as broad as deep, protruded from the margin, terminating only one or two of the veins.

Hab. Seychelles |Islands ; gathered by M. Bouton, Dr. Kirk, and R. W. Rawson, Esq.-A very distinct and handsome species. The veins occasionally anastomose.

23. L. pendula, Klotzsch ; rhizome wide-creeping, densely clothed with dark chesuut-brown fibrils; st. erect, 6-9 in. l., naked except below, polished ; fr. 9-12 in. 1., 3-4 in. br., oblong in general outline, the main rachis without pinnæ except above the branches, which are $1 \frac{1}{2}-2$ in. 1., and spread from the stem at right angles, or even curved slightly downwards ; pinnl. nearly 2 lin. br., hardly over 1 lin. deep, almost obversely triangular in shape, placed close together, but not imbricated, those of the upper side of the branches often deflexed and pendulous; texture subcoriaceous; sori in a continuous line along the upper edge of the pinnæ. -Hk. Sp. 1.p. 213.

Hab. British Guiana; gathered by Schomburgk, and again recently by Appun.

24. L. Sprucei, Hk. MSS. ; rhizome short-creeping ; st. erect, wiry, 6-15 in. 1. ; fr. 3-6 in. l., about $1 \frac{1}{2}$ in. br., ovate, bi- or tripinnatifid, branches $\frac{3}{4}-1$ in. l., rigid, filiform, spreading or decurved towards the point ; pinnl. about 1 lin. deep, flabellate, cut down to the rachis into narrow linear mucronate segments, $\frac{1}{2}-1$ lin. 1 ., those of the upper side of the branches often deflexed and pendulous ; texture coriaceous; fertile segm. broader at the apex ( $\frac{3}{2}$ lin. br.) ; sori not quite occupying the whole point.

Hab. San Carlos, on the Rio Negro, N. Brazil, Spruce, 2988.-A very curious plant, 
resembling $L$. pendula in its subsecund fertile pinnules, but with the ultimate divisions so narrow, that the sorus is usually as deep as broad; so that we place the plant here rather from analogy than because it fulfils the technical character of the genus.

25. L. ? Parishii, Baker ; rhizome slender, wiry, wide-creeping ; fr. $1 \mathrm{ft} .1 ., 3-4$ in. br., tripinnatifid, the rachis flexuose, and rooting at its extremity; pinnoe 15 to 20 on each side, 1-2 in. l., flexuose, spreading from the stem at about a right angle ; pinnl. oblong, blunt, the largest about 4 lin. l., 2 lin. br., cut down to a narrow flattened rachis into 3 or $4 \mathrm{segm}$. on each side, which are rather broader at the point than below, placed only on the lower side of the main rachis of the pinnæ, except one at its base, and often, but not always, a few towards its extremity ; texture herbaceous ; fruit unknown.

Hab. Banks of Packchang river, the southern boundary of the province of Tenasserim, Rev. C. S. Parish.-The fruit is quite unknown, but I was unwilling to leave this very curious fern unnoticed. In habit it comes nearest $L$. Sprucei; but the pinnules here are larger and different in texture, and confined principally to the under side of the rachis. The general aspect is very like that of a large leaf of a bipinnate Acacia, but with compound and subsecund leaflets.

§§ Isoloma, J. Smith. Pinnoe equilateral; veins free. Sp. 26-35. This section in habit and texture resembles Pteris rather than Adiantum, and the cuneate species approximate very closely to Stenoloma.

\section{* Fronds simple. Sp. 26-27.}

26. L. (Iso.) reniformis, Dry. ; st. wiry, flexuose, 4-6 in. l., black, polished ; fr. $2-2 \frac{1}{2}$ in. across, orbicular-reniform, with a deep basal sinus ; texture coriaceomembranaceous, not pellucid; sori continuous all round the edge, except in the sinus.-Hk. Sp. 1. p. 203.

Hab. Guiana and the Amazon valley.

27. L. (Iso.) sagittata, Dry. ; st. wiry, flexuose, 4-6 in. 1., black, polished ; fr. sagittate-acuminate, with a deep basal sinus, 2-4 in. across, sometimes lobed; texture as in the preceding, and the sori similarly continuous.-Hk. Sp. 1. p. 203. Hk. \& Gr. Ic.t. 87.

Hab. Guadeloupe and French Guiana.

\section{** Fronds simply pinnate, with linear pinnce. Sp. 28-30.}

28. L. (Iso.) Walkera, Hk. ; rhizome creeping, paleaceous ; st. wiry, erect, black, polished, 6-12 in. 1.; fr. 6-12 in. 1., 2-4 in. br., simply pinnate ; pinnoe $1 \frac{1}{2}-2$ in. l., $\frac{1}{4}$ in. br., entire, equilateral, erecto-patent, with several times their breadth between them; texture coriaceous ; rachis naked, shining, brownish-black ; sori in a continuous line along both edges.-Hk. $S p$. 1. p. 209.t.69. A.

Hab. Ceylon and island of Banca, east of Sumatra.

29. L. (Iso.) divergens, Wall. ; rhizome creeping, wiry, fibrillose ; st. wiry, erect, black, polished, 4-6 in. l. ; fr. 6-12 in. $1 ., 1 \frac{1}{2}-2$ in. br., simply pinnate ; pinno $\frac{3}{4}-1$ in. 1., 2-3 lin. br., obliquely truncate at the base below, auricled at the base above, the margin entire, the point bluntish ; texture coriaceous ; rachis naked and polished; sori in a continuous line along both edges.-Hk. Sp. 1. p. 210. Hk. \& Gr. Ic. t. 226.

Hab. Malayan Peninsula and Borneo.-Here the pinnæ are placed close together, and spread from the rachis at a right angle.

30. L. (Iso.) lanuginosa, Wall. ; rhizome stout, creeping, clothed with fibrillose 
scales ; st. stout, erect, 4-6 in. 1.; fr. 12-24 in. 1., 3-4 in. br., simply pinnate ; pinnoe $1 \frac{1}{2}-2$ in. $1 ., \frac{1}{4}-\frac{1}{2}$ in. br., linear, entire or very slightly toothed towards the point, which is acute in the fertile, bluntly rounded in the barren frond ; texture coriaceous ; rachis pubescent; sori in a continuous line along both edges.-Hk. Sp. 1. $p .210$. t. 69. B.

Hab. Malayan Peninsula, southward to Tropical Australia, Mauritius, and gathered by the Livingstone Expedition at the mouth of the Kongone river.-This has quite the habit of Nephrolepis acuta, and similar white cretaceous dots on the upper side of the very deciduous pinnæ.

\section{*** Fronds bi- or tripinnatifid, ultimate divisions cuneate. Sp. 31-36.}

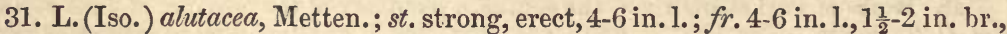
bipinnatifid, lower branches wiry, flexuose, 2-3 in. 1., erecto-patent, furnished with 6 to 8 stalked obversely-triangular pinnl., which are about 3 lin. br., 4 lin. deep, 2 - to 3 -lobed, and the lobes again crenate at the apex ; texture coriaceous ; venation flabellate; sori in a line across the point of the pinnules.-Metten. Fil. Nov. Cal. p. 63.

Hab. New Caledonia ; gathered by M. Deplanche.

32. L. (Iso.) trichomanoides, Dry.; rhizome creeping, fibrillose ; st. 4-6 in. 1., slender, wiry, polished, chesnut-brown ; fr. 4-9 in. 1., 2-3 in. br., ovate-oblong, bipinnatifid; pinno 2-3 in. 1., lanceolate, erecto-patent, cut down quite to the rachis below into cuneate pinnl., which are again broadly lobed on the upper edge ; texture herbaceous ; venation obscure, flabellate ; sori in a continuous marginal line.-Hk. Sp. 1. p. 218.- $\beta, L$. Lessonii, Bory ; simply pinnate, with broadly-lobed linear-lanceolate pinno.-Hk. Sp. 1. p. 217.

Hab. New Zealand, Van Diemen's Land, and N. S. Wales; gathered also lately in Fiji by Mr. Cairns.

33. L. (Iso.) microphylla, Swartz ; rhizome creeping, fibrillose ; st. flexuose, wiry, 3-6 in. 1. ; fr. 6-18 in. 1., 2-4 in. br., bi- or tripinnatifid ; primary pinnce distant, flexuose, 1-4 in. 1. ; pinnl. entire, or cut down to the rachis into several obversely triangular lobes, which when fertile are often not more than 1 lin. br.; texture herbaceous; venation flabellate; sori in a continuous marginal line.-Hk. Sp. 1 . p. 218. Hk. \& Gr.t. 194.

Hab. New Zealand and Temperate Australia.

34. L. (Iso.) elongata, Lab. ; rhizome stout, creeping, densely fibrillose ; st. 6-9 in. l., stout, erect, naked, chesnut-brown, polished ; fr. 12-18 in. 1., 6-9 in. br., ovate-deltoid, tripinnatifid ; lower pinnl. lanceolate-acuminate, $2-3$ in. $1 ., \frac{3}{4}$ in. br., cut down nearly to the rachis, but only slightly above into lobes which are broader at the apex than the base, and sometimes quite obversely triangular; texture coriaceous; veins prominently raised on the under side; sori occupying nearly or quite the whole margin of the lobes.-Hk. Sp. 1. p. 213.

Hab. New Hebrides, New Caledonia, Isle of Pines.

35. L. (Iso.) retusa, Metten. ; st. strong, erect, not prickly or climbing ; fr. tripinnatifid; lower pinnoe 12-15 in. l., 6-8 in. br. ; pinnl. lanceolate-deltoid, the lower segm. the same shape, 1-1 $\frac{1}{2}$ in. $1 ., \frac{1}{2} \cdot \frac{3}{4}$ in. br., cut down to the rachis below, the lobes 2-3 lin. br., cuneate ; texture herbaceous ; sori narrow, marginal, occupying the whole breadth of the lobes.-Davallia, Cav. Hk. Sp. 1. p. 188. t. 52. A.

Hab. Philippine Islands, Amboyna, Solomon's Isles, New Caledonia. - This species and No. 31 in particular in texture and habit approximate to Stenoloma very closely. 
§§ Synaphlebium, J. Smith. Pinnce unilateral; veins more or less anastomosing. Sp. 36-38. Habit and texture of Eulindsaya, from which it differs only by its anastomosing veins.

36. L. (Syn.) media, R. Br. ; st. 6-12 in. l., wiry, flexuose, shining, pale ; fr. 6-12 in. 1., deltoid in general outline, bi- or tripinnate; pinnoe 3-4 lin. 1., 2-3 lin. deep, the lower line nearly straight, the upper one rounded; texture subcoriaceous ; veins flabellate, free or anastomosing ; sori in a continuous marginal line. -Hk. Sp. 1.p. 112. Ic. Pl. t. 957.

Hab. Tropical Australia and adjacent islands.-Habit of $L$. flabellulata, but thicker in texture, and different in venation. The tertiary divisions, when present, are very short.

37. L. (Syn.) nitens, Blume ; rhizome short-creeping ; st. 6-9 in. 1., firm, erect ; fr. simple or with a long unbranched apex, and 1 to 6 pairs of erecto-patent branches, 3-6 in. l. ; pinnl. about $\frac{1}{2}$ in. 1. , $\frac{1}{4}$ in. br., the lower decurved principally at the base, the outer margin rounded, the upper three or four times broadly not deeply lobed, close placed, but not imbricated; texture thinly pellucido-herbaceous; veins anastomosing in the upper half of the lobes; sori marginal in the lobes, the inner valve of the invol. narrow and membranous, the edge of the frond produced beyond it and scarcely altered.-L. recurvata, $W$ all. L. propinqua and L. obtusa, Hk. Sp. 1. p. 222-4. t. 68. A. 66. B. and 70. A. Syn. pulchrum, Brack. p. 223.

Hab. Neilgherries and Ceylon (up to 5,000 ft.), westward to Queensland and the Polynesian Islands.-Much resembling $L$. davallioides in size and general appearance, but the pinnules are deeper and not so much lobed, and the nervation and position of the fruit differ. L. intermedia (Hk. t. 67. B.) appears to be a curious state of this species, in which the pinnule shows a strong tendency towards the equilateral type of form. Only the basal balf of the lower moiety of the pagina is deficient, and the fruit is continued round the edge of the rest. S. pulchrum of Brackenridge is a small simple unbranched form.

38. L. (Syn.) davallioides, Blume ; rhizome short-creeping ; st. 6-12 in. 1., firm, erect; $f r$. with a long central point and 2 or 3 pairs of erecto-patent curved branches, 4-8 in. 1. ; pinnoe 4-6 lin. 1., 2-3 lin. br., the lower margin straight or slightly curved, the upper with 4 to 6 regular rounded but not deep lobes, placed close together but not imbricated ; texture pellucido-herbaceous ; veins anastomosing at the base of the lobes ; sori marginal in the lobes.-Hk. Sp. 1. p. 224. t. 68. A. Davallia Kunzeana, Hk. Sp. 1. p. 177.

Hab. Malayan peninsula and islands.

$\S \S \S \S$ Schizoloma, Gaud. Pinna equilateral; veins more or less anastomosing. Sp. 39-48. Fronds entire or simply pinnate, not pellucid.

* Fruit in a continuous line along both margins. Sp. 39-44.

39. L. (Schiz.) cordata, Gaud. ; rhizome short-creeping ; st. 3-6 in. 1., slender, erect, wiry ; barren frond $2-3$ in. $1 ., 1-1 \frac{1}{2}$ in. br., cordate-oblong, quite entire, fertile one 3-6 in. 1., linear, entire or forked ; texture coriaceous ; sori in a continuous marginal line.-Hk. $S p$. 1. p. 219.t.66. A.

Hab. Malayan peninsula, rare.

40. L. (Schiz.) Gueriniana, Gaud. ; rhizome creeping, paleaceous ; st. 4-6 in. 1. ; fr. 6-9 in. l., oblong-lanceolate, simply pinnate; pinnoe $\frac{1}{2}-\frac{3}{4}$ in. 1 , ovate or oblong, nearly entire, horizontal or falcate, slightly auricled at the base on the upper edge ; texture subcoriaceous; sori in a continuous line along both margins. $-H k . S p .1 . p .221$. 
Hab. Malayan islands.-There is no specimen of this in the Hookerian Herbarium. The pinnæ are said to be very deciduous.

41. L. (Schiz.) ensifolia, Swartz ; rhizome creeping, stout, paleaceous ; st. 6-9 in. l., wiry, flexuose ; fr. 6-12 in. l., 3-4 in. br., with a linear-lanceolate simple or pinnatifid point, simply pinnate below ; pinnoe usually in numerous pairs, all stalked, $1 \frac{1}{2}-6$ in. l., $\frac{1}{4}-1$ in. br., varying from linear-acuminate to lanceolate in shape, only the sterile ones, which are broader than the others, a little toothed; texture herbaceous ; veins copiously anastomosing; sori in a continuous marginal line.-Hk. Sp. 1. p. 220. Gard. F.t. 62. Hk. \& Gr. t. 3. S. Agatii, Brack. t. 30. L. Griffithiana, Hk. Sp. 1.p.219.t. 68. B. L. pentaphylla, Hk. Sp. 1. p. 219.t.67. A.

Hab. Hongkong, and 4,000 ft. in the Himalayas, southward to Queensland, and eastward to the Polynesian Islands, Mauritius, Madagascar, Natal, Cape Colony, and Guinea coast. - This has quite the general habit of Pleris cretica, and is very variable in size and the number of pinnæ. L. Griffithiana is an unbranched form.

42. L. (Schiz.) macrophylla, Kaulf. ; st.12-18 in. l., strong, erect, polished ; fr. about 12 in. l., with an entire ovate undivided apex, about 6 in. $1 ., 2$ in. br.; pinnoe about as long but rather narrower, ovate-lanceolate, oblique at the base, decurrent on a short petiole, not toothed; texture between herbaceous and coriaceous; sori in continuous submarginal lines. - Hk. Sp. 1.p. 220.

Hab. Brazil and Guiana.-The inner valve of the involucre is a membranous line, and the edge of the frond is produced beyond the line of the sorus, and cannot be said to be altered in texture.

43. L. (Schiz.) Fraseri, Hk. ; rhizome slender, creeping, fibrillose; st. 2-3 in. 1., slender, erect; fr. 9-12 in. 1., 1 in. br., simply pinnate ; pinnoe in distant pairs, the largest $\frac{1}{2}-\frac{3}{4}$ in. $1 ., \frac{1}{4}-\frac{3}{8}$ in. br., cordate-ovate, toothed above and sometimes deeply lobed at the base, the upper ones almost as broad as long; texture thinly herbaceous; sori in a continuous marginal line.-Hk. Sp. 1.p.221.t.70. B.

Hab. Queensland.-It is not at all unlikely that this is a small delicate variety of L. heterophylla.

44. L. (Schiz.) heterophylla, Dry. ; rhizome short-creeping ; st. 4-8 in. 1., firm, naked, erect; fr. 6-12 in. l., 3-6 in. br., lanceolate or oblong-deltoid, varying from simply pinnate, with large linear-lanceolate entire pinno, to bipinnate, with erecto-patent branches, 3-4 in. 1., with oblong lanceolate blunt pinnl. $\frac{1}{2}-1$ in. 1., $\frac{1}{4}$ in. br.; texture herbaceous; sori in continuous marginal lines.Hk. Sp. 1. p. 223.

Hab. Neilgherries, Ceylon, Hongkong, Malayan peninsula and islands.-The pinnæe or pinnules of the barren frond are slightly toothed. $L$. cuneata, Willd., is this species from the Mauritius.

* Diellia, Brack. Sori not quite marginal, transversely oblong or linear, the outer valve of the involucre membranaceous, similar in shape to the sorus, but the frond on the other side usually produced beyond them and not altered in texture. Sp. 45-48.

45. L. (Diellia) pumila, Hk. MSS. (non Klotzsch) ; st. tufted, 1-2 in. 1., wiry, blackish, polished; fr. 4-9 in. 1., $\frac{3}{4-1}$ in. br., simply pinnate ; pinnoe 4-6 lin.1., $1 \frac{1}{2}-2$ lin. br., ovate-rhomboidal, rounded at the point, slightly undulated, auricled at the base on the upper side; texture subcoriaceous; veins immersed; sori transversely oblong, submarginal.-Diellia pumila, Brack.p. 219.

Hab. Sandwich Islands. - A very distinct plant, with the habit of a large form of Asplenium Trichomanes. 
46. L. (Diellia) erecta, Hk. MSS. ; st. 6-9 in. l., strong, erect, polished, chesnutbrown ; fr. 9-12 in. l., 3-4 in. br., lanceolate, simply pinnate ; pinnoe 1-2 in. 1., $\frac{1}{4}-\frac{3}{8} \mathrm{in}, \mathrm{br}$, linear-lanceolate, slightly undulated at the margin, the upper half rather the broadest and auricled at the base, the lower ones shorter and broader; texture herbaceous ; sori 2 to 3 times as long as broad, falling short of the margin. -Diellia erecta, Brack. t. 31.f. 2.

Hab. Sandwich Islands.

47. L. (Diellia) falcata, Hk. MSS.; st. 3-4 in. 1., strong, erect, densely paleaceous ; fr. 12-18 in. 1., 2-4 in. br., lanceolate, simply pinnate; pinnce 1-2 in. l., $\frac{1}{4}-\frac{3}{8}$ in. br., linear-lanceolate, falcate, acuminate, slightly undulated at the margin, the upper half rather broadest and auricled at the base, the lower ones very short and blunt; texture herbaceous; sori marginal, transversely oblong.Diellia falcata, Brack. t. 31. f. 1 .

Hab. Sandwich Islands.-Distinguished from $D$. erecta by its short paleaceous stem and marginal sori.

48. L. (Diellia) Michleriana, Eaton ; st. slender, elongated, slightly paleaceous; fr. 12-15 in. l., ovate-lanceolate in general outline, pinnate below with pinnce 3-5 in. 1., 1 in. br., the upper half linear, undulated at the margin; texture papyraceo-herbaceous; veins forming hexagonal areolæ with free included veinlets; sori nearly marginal, transversely oblong or linear, the outer valve of the involucre the same shape as the sorus, but the margin of the frond produced beyond it and unaltered.-Eaton, Fil. Wright \&. Fendl. p. 213.

Hab. Cataract of Truando, New Granada, Schott, No. 8.-A very curious plant, with the venation of Dictyoxiphium, but quite different in the fruit, which agrees very well with that of the three species for which Diellia was proposed as a genus.

\section{Gen. 20*. Dictroxiphium, Hook.}

Sori marginal, continuous. Invol. like that of Lindsaya, but the outer valve obsolete.-A single species with anastomosing areolar venation and free included veinlets. TАB. 2. f. 20. B. erroneously represents the inner instead of the outer valve of the involucre as suppressed.

1. D. Panamense, Hk.; fr. tufted, sessile, 2-3 ft. l., the barren one 2-3 in., the fertile $\frac{1}{2}-1$ in. br., narrowed from the middle gradually downwards, quite entire; texture subcoriaceous, the midrib strong and prominent; sori in a continuous marginal line.-Hk. Sp. 1. $p .224$.

Hab. Tropical America, from Guatemala to New Granada.-When the involucre is rolled over the sorus, the latter appears to be placed on the upper surface of the frond.

\section{Tribe 6. Pteride}

Sori marginal, oblong or linear. Invol. of the same shape as the sorus, formed of a more or less changed and reflexed portion of the frond, opening inwardly. GEN. 21-33.

\section{Gen. 21. Adrantum, $L$.}

Sori marginal, varying in shape from globose to linear, usually numerous and distinct, sometimes confluent and continuous. Invol. the same shape as the sorus, formed of the reflexed margin of the fronds bearing the capsules on its under side. A large genus, which has its head-quarters in Tropical America, most of the species of which are recognizable from all other Ferns but the typical Lindsayæ 
by the texture and one-sidedness of their segments. One group has flabellato-cuneate segments, but still without any distinct midrib, whilst a few species have equilateral segments, and approach in habit $\mathrm{Pteris}$ and Schizoloma. The veins only anastomose in four species out of sixty. 'T'AB. II. f. 21.

\section{§ Euadiantum. Veins not anastomosing. $†$ Sp. 1-57. \\ * Frond simple.-Sp. 1-2.}

1. A. reniforme, L. ; st. tufted, polished, chesnut-brown, 4-6 in. l. ; fr. orbicular-reniform, $1 \frac{1}{2}-2 \frac{1}{2}$ in. across, with usually a broad open sinus; texture subcoriaceous; sori all round the edge, $1 \frac{1}{2}-3$ lin. br.-Hk. Sp. 2.p. 2.t.71. A. Fil. Exot. 't. 8.- $\beta, A$. asarifolium, Willd. ; st. stronger, $6-12$ in. l.; fr. 2-4 in. br., thicker in texture, with a deep narrow sinus, the basal lobes sometimes even overlapping.-Hk. Sp. 2. p. 2.t. 71. B. Fil. Exot.t.11.

Hab. $\alpha$, Madeira and Teneriffe; $\beta$, Mauritius and Bourbon.

2. A. Parishï, Hk. ; st. tufted, slender, naked, dark-brown, polished, $\frac{1}{4}-\frac{1}{2}$ in. 1. ; fr. $\frac{1}{2}-1$ in. each way, suborbicular, slightly undulated, cuneate at the base; texture papyraceo-herbaceous ; veins not prominent; sori few, placed in crenations of the frond, $\frac{1}{8}$ in. br.-Hk.Sp.2.p.237. v.3.t.142. A. Fil. Exot.t.51.

Hab. Moulmein, Malayan Peninsula ; discovered by the Rev. C. S. Parish.

** Radicantes-group. - Frond essentially simply pinnate, the rachis often elongated and taking root at the apex. Sp. 3-6.

3. A. lunulatum, Burm. ; st. 4-6 in. l., tufted, wiry, naked, polished, dark chesnut-brown ; fr. 6-12 in. l., 2-3 in. br., simply pinnate, often elongated and rooting at the extremity; pinna $\frac{3}{4}-1 \frac{1}{2}$ in. br., $\frac{1}{2}-1$ in. deep, subdimidiate, the lower edge nearly in a line or oblique with the petiole, the upper edge rounded and, like the bluntly-rounded sides, usually more or less lobed; petioles of the lower ones spreading, $\frac{1}{4}-\frac{1}{2}$ in. 1. ; texture papyraceo-herbaceous, the rachis and both surfaces naked; sori in continuous lines along the edge.-Hk. Sp. 2. p. 11. $H k$. \& Gr. t. 104. A. dolabriforme, Hk. Ic. Pl.t. 191. A. deflectens, Mart. Hk. Sp. 2. p. 12. - $\beta, A$. tremulum, Kunze; whole plant more slender, the pinnules smaller and more membranaceous.-A. filiforme, Gardn. Hk.Ic.Pl.t. 503. Sp. 2. p. 15.

Hab. Hongkong, Cochin China, Himalayas (4,000 ft.), southward to Polynesian Islands and Tropical Australia, Madagascar, Zambesi Land, Angola, Guinea, Cape Verde Islands, Tropical America, from Mexico southward to the Organ Mountains.An easily-recognizable and widely-diffused species. The two varieties are evidently connected together by gradual intermediate stages. When the upper edge of the pinnæ is much lobed, the sori appear transversely oblong, but in some of the specimens the line is quite continuous. A. Philippense, Linn., adopted from Petiver, though described by Linnæus as simple, is figured by Petiver as pinnate, and is doubtless this species.

4. A. Cantoniense, Hance; st. slender, naked, polished, blackish, 2-3 in. 1.; fr. 4-6 in. l., $\frac{3}{4}$ in. br., simply pinnate with a terminal pinna, or prolonged and rooting at the extremity; pinnoe in 3 to 5 distant opposite pairs, $\frac{1}{2}$ in. br., $\frac{1}{4}-\frac{3}{8}$ in. deep, suborbicular, nearly entire or slightly lobed, shortly stalked; texture pellucido-herbaceous; rachis and surfaces naked; sori few round the outer edge, not contiguous, roundish or transversely oblong.

+ Except casually in A. macrophyllum, lucidum, and perhaps some other species. 
Hab. Ramparts of Canton, Hance, 7542.-This much resembles A. tremulum; but the petioles are shorter, and the lower pinnæ opposite and round, not dimidiate.

5. A. caudatum, Linn.; st. $2-4$ in. 1., tufted, wiry, spreading, dark chesnutbrown, tomentose; fr. 6-12 in. l., simply pinnate, often elongated and rooting at the extremity ; pinnce $\frac{1}{2}-\frac{3}{4}$ in. l., $\frac{1}{4}$ in. deep, dimidiate, nearly sessile, the lower line straight and horizontal, the upper rounded, more or less cut, often deeply and repeatedly, the point usually blunt, the lower ones slightly stalked; texture coriaceous, the veins prominent, the rachis and both surfaces of the frond villose ; sori roundish or transversely oblong on the edge of the lobes.-Hk.Sp. 2. p. 13 . Ex. Fl.t. 104.- $\beta, A$. rhizophorum, Swartz; pinnoe and rachis nearly or quite glabrous.-A. Edgeworthii, $H k$. $S p$. 2. p. 14. t. 81. B.

Hab. Arabia Felix, Himalayas (3,000 ft.), and Hongkong, southward to Ceylon and Java, Madagascar, Mauritius, Zambesi Land, Angola, banks of the Niger, and Cape Verde Islands.-A. soboliferum, Wallich (Hk. Sp. v. 2. t. 74. A.), appears to be a form of this with winged petioles and stipes. A similar form of A. lunulatum has been gathered by Drs. Kirk and Welwitsch in South Africa.

6. A. calcareum, Gard.; st. slender, filiform, 2-3 in. 1., polished, blackish, naked; fr. 4-6 in. l., or prolonged and rooting at the extremity; pinnoe $\frac{1}{4}-\frac{1}{2}$ in. br., $\frac{1}{4}$ in. deep, varying in shape from a quarter to nearly half a circle, lobed from the circumference towards the centre 2 or 3 times half the way down, and the main lobes again cleft less deeply; texture thinly herbaceous; rachis and both surfaces naked; sori roundish or transversely oblong, placed in small depressions at the apex of the lobes.-Hk. Sp. 2. p. 15. Ic. Pl. t. 467.

Hab. Province of Goyaz, Brazil ; gathered by Mr. Gardner.-A more tender plant than $A$. caudatum, which is not known in America, but not clearly distinct. A. v/lizophytum, Schrad., also from Brazil, is closely allied, or may be the same.

*** Polysorous group.-Fronds once or more pinnate, the fruit in numerous roundish or oblong or transversely reniform marginal patches. Sp. 7-31.

+ Ultimate segments not dimidiate, but having two more or less distinctly opposite rows of sori. Sp. $7-12$.

7. A. Kaulfussii, Kunze; st. 4-9 in. 1., wiry, erect, naked, polished, blackish ; fr. 6-12 in. l., 3-4 in. br., with a large terminal lohe and 1 to 12 alternate pinnoe on each side, the lowest $2-3$ in. $1 ., \frac{1}{2}-1$ in. br., cordate and auricled broadly at the base above, roundly cut away on the lower side, slightly stalked, and those of the barren frond slightly toothed ; texture coriaceous ; rachis pubescent ; sori in interrupted marginal lines.-Hk. Sp. 2. p. 7. Hk. \& Gr.t. 190.

Hab. Mexico and West Indies, southward to Brazil and Peru.-This and the next are the only species of the group with a clearly-defined midrib.

8. A. obliquum, Willd.; st. 3-6 in. 1., erect, wiry, polished, blackish, slightly pubescent ; fr. 6-12 in. l., 2-4 in. br., with a terminal lube and 3 to 12 pairs of alternate pinnoe, the lowest 1-2 in. $1 ., \frac{1}{2}-\frac{3}{4}$ in. br., costate nearly to the apex, the upper half the largest, rounded at the base, the lower half obliquely truncate at the base, shortly stalked, those of the barren frond slightly toothed; texture coriaceous; rachis pubescent; sori in numerous interiupted marginal patches 1-2 lin. br.-Hk. Sp. 2. p. 8.t.79. A.

Hab. West Indian Islands, Columbia, and Guiana.-Very doubtfully distinct from A. Kaulfussii. The characters relied upon are the thicker texture of this, its more continuous sori, and the absence of a glaucous tinge on the under side of the leaves. Grisebach refers the obscure $A$. denticulatum, Swartz, to this species. 
9. A. Galeottianum, Hk.; st. 3-4 in. 1., naked, erect, dark chesnut-brown, wiry, polished ; fr. 6-9 in. 1., simply pinnate, or branched at the base ; pinnoe in numerous opposite pairs, $\frac{3}{4}$ in. each way, suborbicular, nearly entire, slightly stalked; texture coriaceous; veins very close and fine but prominent; sori obversely reniform, about 1 lin. across, placed in shallow sinuses all round the frond.-Hk.Sp. 2. p. 10.t. 80. B.

Hab. Mexico, province of Oaxcaca, at an elevation of 3,000 ft., Galeotti, 6561.-A very distinct species, easily recognized by its large round equal-sided pinnules. The venation is very clearly marked on the under side of the frond, but is quite fabellate, and there is no central rib which is stronger than the others.

10. A. Peruvianum, Klotzsch ; st. 6-9 in. 1., strong, erect, nearly black, polished, naked ; fr. simply pinnate, or with 1-3 branches at the base, or even with some of the latter again slightly branched; pinnules 2 in. or more br., $1 \frac{1}{2}$ in. deep, unequally ovate, cuneate at the base, sometimes with an acuminated point, finely toothed and lobed round the upper and outer edge, the lowest on stalks $\frac{1}{2}-\frac{3}{4}$ in. l. ; texture papyraceo-herbaceous; rachis and both surfaces naked; sori in interrupted patches round the sides of the pinnules.Hk. Sp. 2. p. 35. t. 81. C.

Hab. Peru; gathered by Mathews, and lately again by Spruce.-A very fine and well-marked species, which the size and shape of its pinnules will readily distinguish in the group.

11. A. subcordatnm, Swartz; st. 6-12 in. 1., strong, erect, blackish, naked, polished ; fr. 1-2 ft. l., $1 \mathrm{ft}$. br., deltoid, tripinnate ; lower pinnae deltoid, $1 \mathrm{ft}$. l., 6-9 in. br. ; segm. about 2 in. $1 ., 1$ in. br., ovate-acuminate, equal at the base, or the lower side obliquely truncate, slightly lobed, on stalks $\frac{1}{4}-\frac{1}{2}$ in. l. ; texture papyraceo-herbaceous; rachis and both sides naked; sori in roundish or transversely oblong patches along both sides. $-H k$. $S p$. 2. $p$. 34. A. betulinum, Kaulf.

Hab. Guiana and Brazil.-This resembles in general habit A. trapeziforme, but differs in the shape of the pinnules, which are equilateral or slightly oblique at the base on the lower side.

12. A. intermedium, Swartz; st. 6-12 in. l., erect, strong, polished, but somewhat tomentose; $f r$. with a terminal pinna 6-9 in. $1 ., 2-3$ in. br., and 1 to 3 small spreading lateral ones on each side ; pinnl. 1-1 $\frac{1}{2}$ in. l., $\frac{1}{4}-\frac{1}{2}$ in. br., unequal-sided, but not dimidiate, the lower half being the smallest, about the inner third being cut off, the point bluntish or acute, the inner edge nearly parallel with the stem, the upper nearly straight, scarcely toothed; texture subcoriaceous; rachis tomentose ; sori in interrupted marginal patches, 1-2 lin. across, placed round the upper edge and outer two-thirds of the lower one.Hk. Sp. 2. p. 25. A. fovearum, Raddi. . A. triangulatum, Kaulf.

Hab. Tropical America, from Mexico and the West Indies southward to Peru and Rio Janeiro.-A widely-diffused and well-known species, distinguished from $A$. tetraphyllum by the outer edge being often brought down so as to be parallel with the upper edge, so that we have two opposite rows of sori instead of one at an acute angle with the other.

+† Ultimate segments dimidiate, the stems naked and polished. Sp. 13-20.

13. A. Shepherdi, Hk.; st. 3-4 in. 1., naked, polished, blackish ; fr. 6-12 in. 1., simply pinnate; pinnoe $\frac{3}{4}$ in. $\mathrm{br}$, $\frac{1}{4}-\frac{3}{8}$ deep, dimidiate, the lower line nearly straight, the upper rounded and, like the two bluntly rounded sides, broadly lobed, quite sessile and usually reflexed, so that the pinnules of the opposite sides of the rachis are brought face to face, the inner quarter of the blade being imbricated over the stem; texture subcoriaceous; rachis and both surfaces naked; 
sori numerous, obversely reniform, as deep as broad, placed in distinct hollows round the outer edge.-Hk. $S p .2 . p .9 . t$. 73. B.

Hab. Mexico, gathered originally by Mr. Bates in 1834; and fine specimens have been received lately from Morelia from Mr. Glennie.-In the texture of the frond and form of the sori this curious plant closely resembles A. Galeottianum, but the stem is quite simple, so far as we know, the form of the pinnules quite different, and the habit is very peculiar.

14. A. sinuosum, Gard: ; st. 4-8 in. 1., erect, naked, polished, nearly black ; fr. with a long terminal central pinna, 2-3 in. br., and 1 or 2 pairs of erectopatent branches at the base ; pinnl. $1 \frac{1}{2}$-in. br., $\frac{1}{2}-\frac{3}{4}$ in. deep, the lower line obliquely decurved, the upper irregularly rounded and deeply lobed, the lobes again crenate, the lower ones on stalks $\frac{1}{4}-\frac{1}{2}$ in. 1.; texture papyraceo-herbaceous; rachis and surfaces naked; sori obreniform, placed in rounded sinuses of the crenations of the lobes.-Hk. Sp. 2. p. 35. Ic. Pl. t. 504.

Hab. Brazil, Gardner, 3552, Burchell, 6752 ; and a similar plant has been gathered by Prof. Jameson near Guyaquil.-This resembles most $A$. Capillus-veneris in the segments. They come generally about halfway between the flabellato-cuneate and truly dimidiate types of form, so that its position may be said to be about midway between that species and $A$. trapeziforme.

15. A. diaphanum, Blume ; st. 4-8 in. 1., slender, erect, blackish, polished ; fr. 4-8 in. 1., 1 in. br., simply pinnate or with 1 to 3 branches at the base, which are sometimes nearly as large as the terminal one ; pinnl. $\frac{1}{2}$ in. br., $\frac{1}{4}$ in. deep, the lower line rather decurved, the upper nearly parallel with it, crenate like the blunt outer edge; texture thin; rachis naked, surfaces nearly so; sori obversely reniform, numerous, but not contiguous, placed in the sinuses of the upper and outer edge.-Hk. $S p$. 2. $p .11 . t$. 80. C. A. affine, $H k . S p .2 . p .32$. non Willd. A. setulosum, J. Sm.

Hab. S. E. China, Aneiteum, Java, Fiji, New Caledonia, Norfolk Island, N. Zealand, N.S. Wales.-This is nearest the next species, but is much less branched, and the pinnules are thinner in texture. In habit it shows an approximation towards the pedate group. It is not unlikely that $A$. erectum, Kunze (Bot. Zeit. 1848, p. 211), is the same.

16. A. affine, Willd.; st. 6-9 in. 1., erect, polished, blackish, glossy ; fr. with a terminal central pinna 4-6 in. 1., 1-1 $\frac{1}{2}$ in. br., and several smaller erecto-patent lateral ones, the lowest of which are again branched; pinnl. $\frac{1}{2}-\frac{3}{4} \mathrm{in} .1 ., \frac{1}{4}$ in. deep, dimidiate, the lower edge straight, the upper nearly parallel with it, crenate like the oblique or bluntly rounded outer edge; texture subcoriaceous; rachis and surfaces quite naked, the latter very glaucous; sori numerous, roundish, placed in small hollows round the upper and outer edge.-A. Cunninghami, Hk. Sp. 2. p. 52. t. 86. A. (not A. affine, Hk., which is A. diaphanum, Blume).

Hab. New Zealand.-A somewhat variable plant in branching and the size of the segments, but not likely to be confused with any other, especially as it is known only in New Zealand.

17. A. nigrescens, Fée ; st. 6-12 in. 1., strong, erect, naked, blackish, polished ; fr. 6-9 in. 1., 4-6 in. br., with a terminal pinna and several lateral ones on each side, the lowest of which are again branched; segm. about $\frac{1}{2}$ in. $1 ., \frac{1}{4}$ in. br., dimidiate, the upper and lower margins nearly parallel, the point bluntly rounded, the upper and outer edges finely toothed; texture coriaceous; rachis nearly naked, polished, surfaces naked; sori in transversely oblong patches along the upper edge. - Fée, Icon.t. 11. f. 2.

Hab. Guadeloupe, L'Herminier.-Probably this should be regarded as a subglabrous state of $A$.cristatum. From all the species placed near, it may be known by its coriaceous and much smaller segments. 
18. A. trapeziforme, L. ; st. 6-12 in. 1., firm, erect, naked, polished, blackish ; fr. with a central pinna 4-8. in. 1., 2-3 in. br., and 2 to 4 large spreading ones on each side, the lowest of which are often branched again; segm. $1 \frac{1}{2}-2$ in. 1 ., $\frac{1}{2}-\frac{3}{4}$ in. br., dimidiate, the sides nearly parallel, the outer edge oblique, both it and the upper one bluntly, not deeply lobed, the lowest on stalks $\frac{1}{4}-\frac{1}{2}$ in. 1 . ; texture papyraceo-herbaceous; rachis and both surfaces naked; sori numerous, contiguous, transversely oblong, placed round the upper and outer edge.- $H k$. $S p .2$. p. 33. Hk. \& Gr.t. 93.-, , A. pentadactylon, L. \& F.; lower margin of the segments somewhat decurved obliquely from the petiole. $-\gamma, A$. cultratum, J. Sm. ; outer edge of the segment bluntly rounded.-Hk. Sp. 2. p. 34 .

Hab. Tropical America, from Mexico and the West Indies southward to Brazil.-A well-known plant, readily distinguished from its neighbours by its ample trapezoid segments. A. Catherince of the gardens appears not to differ materially.

19. A. polyphyllum, Willd.; st. 12-18 in. l., strong, erect, blackish, polished, rather scabrous; fr. 2-3 ft. 1., 12-18 in. br., the upper part simply pinnate; lower pinnce sometimes $1 \mathrm{ft}$. l., 6 in. br., with a long terminal and numerous erecto-patent lateral pinnules; segm. $\frac{3}{4}-1$ in. $1 ., \frac{1}{4}$ in. deep, dimidiate, the upper and lower edge nearly parallel, the point bluntly rounded, the upper edge sharply but not deeply toothed; texture coriaceous, veins prominent; rachis and surfaces naked; sori in numerous suborbicular patches placed in hollows in lobes along the upper edge.-Hk. Sp. 2. p. 49. A. cardiochlæna, Kunze, Hk. Sp. 2. p. 50. t. 83. A. A. Matthewsianum, Hk. Sp. 2. p. 35. t. 84. A. A. macrocladum, Klotzsch, Hk. Sp. 2. p. 49. t. 83. B.

Hab. Columbia and Peru.-A large copiously-branched plant, with very numerous (sometimes fifty to a pinna) closely-placed subsessile segments. $A$. tomentosum, Klotzsch (A. Klotzschianum, Hk.), and A. urophyllum, Hk., seem forms of this with slightlypubescent rachises.

20. A. glaucescens, Klotzsch ; st. 6-9 in. 1., slender, erect, naked, polished ; $f r .1 \mathrm{ft}$. each way, with a terminal pinna and several loosely-spreading ones on each side; pinnl. $\frac{3}{4}-1$ in. l., $\frac{1}{4}-\frac{3}{8}$ in. deep, dimidiate, the lower border nearly straight, the upper nearly parallel with it, almost entire, the outer margin bluntly rounded, the lowest on short stalks; texture papyraceo-herbaceous; rachises naked, under surface glaucous; sori in numerous patches, 1-1 $\frac{1}{2}$ lin. br., with a space between them, placed round the upper and outer edge.Hk. Sp. 2. p. 26.

Hab. Ecuador, Guiana, and north of Brazil.-Perhaps this also is not distinct from A. polyphyllum, but it is less copiously branched, and the segments are fewer and thinner in texture.

*** Ultimate segments dimidiate, the stems pubescent. Sp. 21-31.,

21. A. Henslovianum, Hk. fil. ; st.6-12 in. l., erect, dark chesnut-brown, naked, glossy ; fr. 12-18 in. l., 6-9 in. br., ovate tripinnate, furnished witl numerous distant pinnoe on each side, the upper of which are simple, but the lowest slightly branched ; segm. $\frac{1}{2}-\frac{3}{4}$ in. br., $\frac{1}{4}-\frac{3}{8}$ in. deep, dimidiate, the lower line nearly straight, the upper rather ruunded, a good deal lobed, the point bluntly rounded ; texture papyraceo-herbaceous; rachis and under surface hairy; sori obversely reniform, placed in the hollows of the lobes of the upper and outer edge.-IIk. Sp. 2. p. 43. A. sessilifolium, Hk.p. 44. A. Reichenbachii, Moritz.

Hab. Columbia, Peru, Galapagos group.--This is well-marked amongst its neighbours by the shape of its segments, the inner edge of which is often imbricated over the rachis, as in $A$. Shepherdi and concinnum, and by the reniform sori which encircle a very distinct hollow.

22. A. cristatum, L. ; st. 6-12 in. 1., strong, erect, tomentose ; fr. $1 \frac{1}{2}-3 \mathrm{ft} .1$., 
9-12 in. br., with a terminal central pinna 6-9 in. l., 1-1 $\frac{1}{2}$ in. br., and numerous rather distant lateral ones on each side, the lowest of which are sometimes again branched; segm. $\frac{1}{2}-\frac{3}{4}$ in. $1 ., \frac{1}{4}-\frac{3}{8}$ in. br., dimidiate, the lower line nearly straight, the upper nearly parallel or rounded, the point blunt, texture coriaceous; rachis tomentose; sori in several oblong or linear patches round the upper and outer edge.-Hk. Sp. 2. p. 46. A. Kunzeanum, Klotzsch. Hk. Sp. 2. p. 47.

Hab. West Indies and Venezuela. - This species and the two next are distinguished from their neighbours by their smaller and more rigid segments. They bear the same relation to $A$. tetraphyllum that Lindsaya stricta bears to $L$. Guianensis and trapeziformis.

23. A. obtusum, Desv. ; st. 6-12 in. l., wiry, erect, polished, blackish, slightly tomentose ; fr. with a terminal and several pairs of erecto-patent lateral pinno ; pinnl. $\frac{1}{4}-\frac{3}{3}$ in. br., $1 \frac{1}{2}-2$ lin. deep, subdimidiate, the lower line nearly straight, without sori, the upper bluntly rounded, nearly entire, placed close, and the lower slightly stalked; texture coriaceous, venation flabellate; rachis often densely tomentose; sori in numerous close transversely oblong patches round the upper and outer edge.-Hk. Sp. 2. p. 19. Hk. \& Gr.t. 188.-, , A. Kunzei, Miquel; pinnules larger, sumetimes $\frac{1}{2}-\frac{3}{4}$ in. br., $\frac{1}{4}$ in. deep.

Hab. West Indian Islands and Panama southward to Peru and Rio Janeiro.-This comes very near in habit and texture to $A$. cristatum, from which it may be best known by its closer, more numerous, and shorter sori. A plant gathered by Barter in the Niger Expedition appears to agree with the copious American specimens.

24. A. hirtum, Klotzsch ; st. 6-9 in. 1., wiry, erect, polished, dark chesnutbrown, tomentose; $f r$. with a terminal and several pairs of erecto-patent lateral pinnoe; pinnl. $\frac{1}{4}-\frac{1}{2}$ in. br., $1 \frac{1}{2}-2$ lin. deep, dimidiate, the lower line straight and barren, the upper bluntly rounded, finely toothed, placed close, and the lower slightly stalked; texture subcoriaceous; venation fine, prominent, under surface slightly and rachis very tomentose; sori transversely oblong, placed in small lobes of the upper and outer margin.-Hk. Sp. 2. p. 20.t. 82. A.

Hab. Tropical America, from Panama and Guiana southward to Peru and Brazil.This is more closely and regularly branched than the two preceding, with the segments longer in proportion to their breadth, and the sori very close, small, and numerous. A. gracile, Fée, which I have not seen, seems near this.

25. A. formosum, R. Br. ; st. $12-18$ in. l., strong, erect, scabrous ; fr. 18-24 in. $1 ., 12-18$ in. br., tri- or even quadripinnate ; lower pinnœ 12-15 in. 1., 6-9 in. br., deltoid ; pinnl. deltoid ; ult. segm. $\frac{1}{4}-\frac{3}{8}$ in. br., $1 \frac{1}{2}-2$ lin. deep, dimidiate, the lower edge straight, the upper rather rounded and deeply lobed, the outer also oblique and lobed, the lower ones distinctly stalked; texture subcoriaceous ; rachis glossy, scabrous; sori numerous, between obreniform and transversely oblong, placed at the edge of the lobes along the upper and outer margin.- $-H_{k} . S p .2$. p. 51.t. 86. B.

Hab. Temperate Australia and New Zealand.-This has pinnules as small but not nearly so thick and rigid as in the three preceding. It comes from a different part of the world, and the ample compound pinnæ will at once distinguish it from all its allies.

26. A. Cubense, Hk. ; st. 4-6 in. 1., polished, blackish, naked, erect; fr. 6-9

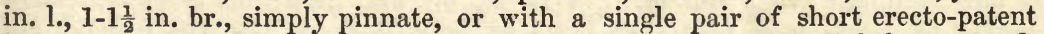
branches ; pinnl. $\frac{3}{4}$ in. br., $\frac{3}{8}$ in. deep, unilateral, the lower line slightly recurved, the upper rounded and broadly lobed, the outer edge blunt, lowest short-stalked; texture pellucido-herbaceous ; rachis slightly pubescent; sori in shallow hollows

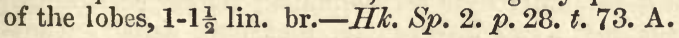

Hab. Jamaica and Cuba. - This species is marked by the simple or slightly-branched stem and character of the sori, which are not more than five or six in number, and placed in the centre of distinct hollows along the upper and outer edge. 
27. A. fulvum, Raoul ; st. 6-9 in. 1., strong, erect, polished, dark chesnut-brown, rough below, with strong hairs ; fr. 9-12 in. 1., 6-8 in. br., deltoid in general outline, with a terminal pinna $4-6$ in. l., about $1 \frac{1}{2}$ in. hr., and several erecto-patent branches, the lower of which are branched again; pinnl. about $\frac{3}{4}$ in. $1 ., \frac{1}{4}$ in. deep, dimidiate, the lower edge nearly straight, the upper almost parallel, with sharplytoothed lobes like the oblique outer edge ; texture papyraceo-herbaceous ; rachis glossy, but scabrous and rather hairy; sori large, numerous, obversely reniform, placed in small depressions round the upper and outer edge.-Hk. Sp. 2. p. 52 . t. 85. A.

Hab. New Zealand, Norfolk Island, N. S. Wales, and Fiji.-Very variable in the shape of its pinnules. It is much less compound than $A$. formosum, and the pinnules are larger.

28. A. pulchellum, Blume ; st. 6-12 in. 1., erect, naked, polished, nearly black ; fr. a foot or more each way, with a terminal central pinna $6-9$ in. $1 ., 1 \frac{1}{2}$ in. br., and a few large spreading lateral ones on each side, the lower ones branched again with 2 to 4 erecto-patent branches ; segm. $\frac{1}{2}-\frac{3}{4}$ in. $1 ., \frac{1}{4}-\frac{3}{3}$ in. deep, dimidiate, the lower line upcurved, the upper nearly straight, slightly toothed ; texture coriaceous ; rachis tomentose ; sori small, numerous, roundish, placed on the upper edge.-Hk. Sp. 2:p. 38. A. Lobbianum, Hk. Sp. 2. p. 51.t. 86. C.

Hab. Java, and gathered also by Milne in Aneiteum.-This comes very near $A$. fulvum in the shape, size, and texture of the segments, but is a larger plant with a more hairy rachis.

29. A. crenatum, Willd.; st. 6-9 in. 1., polished, blackish, naked or nearly so ; fr. with a terminal central pinna 6-9 in. l., and several large erecto-patent lateral ones on each side, the lowest of which are branched again; segm. $\frac{1}{2}-\frac{3}{4}$ in. $1 ., \frac{1}{4}$ in. deep, dimidiate, the lower line upcurved, the upper nearly straight, slightly crenate; texture subcoriaceous ; rachis slightly tomentose; sori numerous, round, placed on the upper and sometimes the outer edge.-A. Wilesianum, Hk. Sp. 2. p. 50 . t. 83. C.

Hab. Mexico and West Indian Islands.-This also comes very near A. tetraphyllum, but the rachis is only very slightly tomentose, and the main stem is glossy and polished, and the segments are perhaps more papyraceous in texture. A. politum, H. B. K., is referred here by Sprengel.

30. A. pectinatum, Kunze ; st. $1 \frac{1}{2}-2 \mathrm{ft}$. 1., strong, erect, nearly black, scabrous ; fr. 3-6 ft. 1., 2-3 ft. br., tri- or quadripinnate ; lower pinnoe 12-18 in. 1., 6-9 in. br., their lower branches with a long terminal pinnule and several erecto-patent lateral ones, the lowest of which are sometimes branched again ; segm. $\frac{1}{2}$ in. br., less than $\frac{1}{4}$ in. deep, dimidiate, the lower line straight, the upper slightly rounded, the point not very blunt; rachis tomentose ; surfaces naked; sori suborbicular, numerous, placed round the upper and outer edge.

Hab. Brazil, Burchell, No. 7416 ; Eastern Peru, Spruce, 4781.-A very fine plant, which size and babit at once clearly characterize. A. velutinum and Lindeni, described by $\mathrm{Mr}$. Moore in Gard. Chron. 1866, p. 777, seem to be allied to this species.

31. A. tetraphyllum, Willd.; st. 6-12 in. 1., strong, erect, tomentose ; fr. with

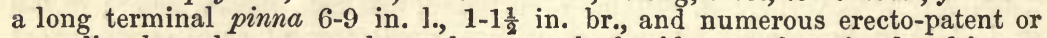
spreading lateral ones nearly as large on both sides, so that the frond is not unfrequently half a yard long by nearly as much broad; segm. $\frac{1}{2}-\frac{3}{4}$ in. br., $\frac{1}{4}$ in. deep, subdimidiate, the lower line straight or somewhat decurved, the upper nearly parallel, finely toothed, the outer edge very oblique; texture coriaceous ; rachis and under surface tomentose ; sori interrupted, marginal, usually transversely oblong or transversely reniform, placed round the upper and outer edge.-A. prionophyllum, $H . B . K$. Hk. Sp. 2. p. 21. A. fructuosum, $S p r$. Hk. 2. p. 24. 
Hab. Tropical America, from Mexico and the West Indies southward to Brazil ; gathered also in West Tropical Africa by Barter, Vogel, and Mann.-I am not prepared to point out any good character by which $A$. Cayennense, Willd., and A. Brasitiense, Raddi, may be distinguished from this widely-diffused and variable species.

**** Oligosorous group.-Frond once or more pinnate, the fruit in continuous or slightly interrupted marginal lines. Sp. 32-40.

+ Segments with a line of fruit on both sides, therefore not dimidiate. Sp. 32-36.

32. A. lucidum, Swartz; st. 6-9 in. 1., strong, erect, scabrous, tomentose ; fr. 9-15 in. 1., 4-8 in. br., simply pinnate, with a large terminal pinna and 6 to 10 lateral ones on each side, or the lowest very slightly branched, $3-4$ in. $1 ., \frac{1}{2}-1$ in. br., nearly equal-sided, but obliquely truncate at the base below, lanceolateacuminate, slightly serrated towards the point; texture coriaceous; rachis densely tomentose; veins free or anastomosing casually towards the edge, midrib distinct; sori in a continuous row along each side.-Hk. Sp. 2. p. 4. t. 79. C.

Hab. West Indian Islands and Panama southward to Brazil.-This comes so near the polysorous $A$. obliquum in everything but the fruit, that Dr. Grisebach unites them. A. platyphyllum, Swartz, is a little-known plant allied to this species.

33. A: Phyllitidis, J. Smith; st. strong, erect, naked, nearly black, polished, 6-12 in. 1. ; fr. 6-12 in. 1., 3-6 in. br., simply pinnate, with a large terminal lobe, and 1 to 6 pinnce on each side, or the lower pair again branched below ; pinnce 3-4 in. l., $\frac{3}{4}-1 \frac{1}{2}$ in. br., ovate or lanceolate-acuminate, very nearly entire, narrowed or rather rounded and stalked at the base ; texture coriaceous ; sori in a continuous line along both margins.-Hk. Sp. 2. p.5.t.72. B.

Hab. Guiana and Eastern Peru; gathered by Schomburgk, Spruce, and Appun.-This comes very near $A$. lucidum, but the pinnæ are fewer in number and broader, and the texture is thicker, and the venation consequently less distinct. They are the only polysorous species with a distinct midrib, and the shape of the pinnæ also characterizes them clearly.

34. A. macrophyllum, Swartz ; st. 6-12 in. 1., strong, erect, polished, naked, nearly black; fr, 9-15 in. 1., 4-8 in. br., simply pinnate (4 to 6 pairs of pinno); lower ones of the barren frond 3-4 in. 1., 2 in. br., ovate, so broad at the base that the opposite ones frequently overlap, the margin rather deeply lobed, fertile ones narrower ; texture membranaceo-herbaceous ; sori in long continuous or slightly interrupted marginal lines.-Hk. Sp. 2. p. 3. Hk. \& Gr. Ic. t. 132 . Hk. $F$. Ex. $t .55$.

Hab. Mexico and West Indian Islands southward to Brazil and Ecuador.-Occasionally this fine and well-known species becomes bipinnate in the lower part. The young fronds are often beautifully tinged with red. Its large equal-sided sessile pinnæ mark it clearly.

35. A. Seemanni, Hk. ; st. 6-9 in. l., erect, blackish, polished ; fr. 6-12 in. 1., simply pinnate or the lower branches compound; pinnl. $3-4$ in. l., $1 \frac{1}{2}-2$ in. br., ovate-acuminate, but rather unequal-sided, the barren ones finely serrated, one side usually cordate at the base, the other obliquely truncate, petioles of the lowest nearly an inch long; texture subcoriaceous; veins prominent and the under surface glaucous ; rachis naked, polished; sori in long continuous marginal lines. $-H k$. Sp. 2. p. 5. t. 81. A.

Hab. Veraguas and Guatemala ; gathered by Dr. Seemann and Messrs. Salvin and Godman. -This also is a very fine plant. It comes very near the polysorous $A$. Peruvianum in habit, but is less branched. The pinnæ are larger even than those of A. macrophyllum, and have black polished stalks often an inch long.

36. A. deltoideum, Swartz; st. densely tufted, 3-4 in. 1., wiry, erect, polished, 
naked, dark chesnut-brown ; fr. 4-6 in. l., $\frac{3}{4}$ in. br., with a terminal lobe and numerous subopposite pairs of pinno, the lower ones distant, distinctly stalked, $\frac{1}{2}$ in. $1 ., \frac{1}{4}-\frac{3}{8}$ in. br., hastate-deltoid, cordate or cuneate at the base ; texture pellucido-herbaceous; venation flabellate; sori in interrupted lines along the sides of the pinnæ, not reaching the rounded apex.-Hk.Sp.2. p. 9.

Hab. West Indian Islands. - Stem casually once branched below. A very clearlymarked species. The pinnæ resemble an ivy-leaf in miniature, but there is no clearlydefined central midrib.

t+ Segments dimidiate, with the line of fruit absent altogether from the lower margin. Sp. 37-40.

37. A. villosum, Linn.; st. 9-12 in. 1., strong, erect, blackish, polished, tomentose ; fr. with a terninal central and several erecto-patent pinnoe on each

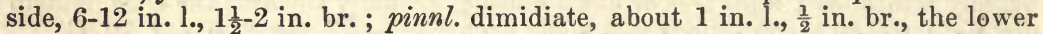
line nearly straight, the upper nearly parallel with it, but considerably larger, slightly toothed and the outer edge auricled at the base; texture coriaceous; rachises tomentose, both surfaces naked; sori in a continuous line round the upper and outer edge.-Hk. Sp. 2. p. 18. A. falcatum, Sw. S. F. p. 19.

Hab. West Indies and Panama southward to Brazil.-Easily recognizable by having the line of fructification continued all along the upper and then usually down the oblique outer edge. A. oblique-truncatum, Fée, seems to be the ordinary form of this species.

38. A. pulverulentum, L. ; st. 6-12 in. 1., strong, erect, blackish, tomentose ; fr. with a terminal pinna and several spreading lateral ones on each side, which are $4-8$ in. l., 1 in. br.; pinnl. $\frac{1}{2}$ in. l., $1 \frac{1}{2}-2$ lin. deep, dimidiate, the lower line nearly straight, the upper one nearly parallel, both it and the outer edge finely toothed; texture subcoriaceous; rachises tomentose, surfaces naked; sori in a continuous line along the lower two-thirds of the upper edge.-Hk. $S p .2$. p. 17.

Hab. West Indies southward to Brazil.-Here the line of fruit does not usually extend beyond the inner half or two-thirds of the upper margin.

39. A. incisum, Presl ; st. 4-6 in. 1., wiry, polished, naked, nearly black ; fr. 6-12 in. 1., 3-4 in. br., simply pinnate or with one or two pairs of short spreading branches at the base ; pinnoe 1-2 in. 1., $\frac{1}{4}-\frac{1}{2}$ in. deep, subdimidiate, the lower line often considerably curved upwards and toothed in its outer half, the upper one also more or less falcate and not deeply lobed; texture subcoriaceous; rachis nearly naked ; sori in a continuous marginal line on the edge of the lower twothirds of the upper margin.-Hk. Sp. 2. p. 16. A. alarconianum, Gaud.

Hab. West of Mexico and Columbia, Galapagos Island. - Very near A. pulverulentum, with which it quite agrees in the fruit. The frond is less branched, and the pinnules are larger and more toothed.

40. A. microphyllum, Kaulf. ; st. 6-9 in. 1., strong, erect, tomentose ; fr. with a terminal pinna 6-9 in. l., and several erecto-patent lateral ones on each side, the lowest of which are branched again ; segm. $\frac{1}{2}-\frac{3}{4}$ in. l., $\frac{1}{4}$ in. br., unequal-sided, with a midrib, the lower at first at a right angle with the stem and afterwards decidedly upcurved, the upper nearly entire, upcurved, so that the segment is falcate and narrowed to an acute point; texture coriaceous ; rachis tomentose or nearly naked; sori in a few elongated patches along the upper edge.-Hk. Sp. 2. p. 47.

Hab. West Indies, rare.-Very doubtfully distinct from A. pulverulentum. In habit and general appearance they are identical, but this has the line of fructification slightly interrupted. Grisebach suggests that this is probably A. pyramidale, Willd. 
***** Capillus-Veneris group. Fronds at least bipinnate, segments flabellatocuneate, with the petiole near the centre, sori obversely reniform. Sp. 41-51.

41. A. Capillus-Veneris, L. ; st. suberect, rather slender, 4-9 in. 1., polished, blackish, naked ; $f r$. with a short terminal and numerous erecto-patent lateral branches on each side, the lowest slightly branched again; segm. $\frac{1}{2}-1$ in. br., the base cuneate, the outer edge rounded, deeply lobed from the circumference in the direction of the centre, and the lobes again bluntly crenated, lowest petioles $\frac{1}{4}$ in. 1.; texture pellucido-herbaceous; rachis and both surfaces naked; sori roundish or obreniform, placed in roundish sinuses of the crenations.-Hk. $S p .2$. p. 36. Brit. F. t. 41. A. pseudo-capillus, F'é, Icon.t. 12.f. 1.

Hab. Europe, from S. W. Britain, Jura, and Tyrol, to Greece, Sicily, and Portugal. Africa : Abyssinia, Western Islands, Niger Valley, Angola, Cape Colony, Natal, Zanbesi Land, Mascaren Isles, Barbary States. Asia : Caucasus, Ural, Syria, Persia, Arabia, Himalayas (up to 6,000 ft.), Bombay, S. E. China and Japan, Polynesian Islands. America : Florida southward to Venezuela and Amazon Valley.-A. CapillusJunonis, Ruprecht, has the base of the pinnules somewhat rounded instead of cuneate, and a very deeply-lobed variety is figured by Hooker Sp. Fil. 2. t. 74. B.

42. A. Aithiopicum, L. ; st. 6-9 in. 1., rather slender, erect, dark chesnut-brown, polished, naked ; fr. 12-18 in. l., 6-9 in. br., deltoid in general outline, tri- or quadripinnate; lower pinnl. 3-4 in. l., 2-3 in. br., deltoid ; ultimate segm. $\frac{1}{4}-\frac{1}{2}$ in. across, $\frac{1}{4}$ in. deep, suborbicular, straight or subcuneate or rounded at the base, the upper part broadly, not deeply lobed; texture thinly pellucido-herbaceous ; rachis and surfaces naked; sori in several roundish or transversely oblong patches in rounded hollows of the outer edge.-Hk. Sp. 2. p. 37.t. 77. A. A. assimile, $S w$. Hk. $S p$. Fïl. 12. p. 37. A. emarginatum, Bory, Hk. Sp. 2. p. 39. t. 75. A.

Hab. Spain ; Africa-Cameroon Mountains at 7,000 ft., Natal, Cape Colony, Abyssinia, Zambesi Land, Bourbon and Madagascar ; Neilgherries, New Zealand, Temperate and Tropical Australia ; America, from Texas and California southward to Valparaiso and Monte Video.-Very like A.Capillus-Veneris in general habit, but the segments are more tender, smaller, broader at the base, and not so deeply lobed. A. Chilense, Kaulf., A.glanduliferum, Kunze, A. dilatatum, Nuttall, A. scabrum, Kunze, and A. sulphureum, Kaulf., appear to be forms of this with the segments hairy or more or less dusted over with white or yellow ceraceous dust beneath.

43. A. excisum, Kunze ; st. 2-3 in. l., wiry, chesnut-brown, naked, densely tufted ; fr. 6-12 in. l., 3-4 in. br., with numerous flexuose short branches on each side, the lowest of which are slightly branched again ; segm. 2-3 lin. br., broadly cuneate at the base, the upper edge rounded and bluntly lobed; texture thin; rachis naked, polished; sori 2 to 4, large for the size of the plant, obversely reniform, placed in distinct hollows on the lobes.-Hk. $S p .2 . p .41$.

Hab. Chili.-Perhaps this also should be considered a variety of Athiopicum, but it is smaller and more slender, and in habit resembles $A$. concinnum, the lateral branches of the pinnæ being but little developed.

44. A. concinnum, H. B. K. ; st. 4-8 in. 1., polished, blackish, naked ; fr. 12-18 in. l., 6-9 in. br., ovate-deltoid, tripinnate; pinnoe numerous, spreading, flexuose, the lowest $4=6$ in. 1., 2-3 in. br. ; segm. $\frac{1}{4}-\frac{3}{8}$ in. across, broadly cuneate at the base, the upper edge irregularly rounded, deeply lobed and the lobes again crenate, the lowest segment of each pinna and pinnule large, sessile, adpressed to the main rachis; texture papyraceo-herbaceous; rachis naked, glossy; sori numerous, obversely reniform, placed in distinct hollows of the outer edge.Hk. Sp. 2. p. 42.- $\dot{\beta}$, subscandens ; fr. 4-5 ft. l., subscandent.

Hab. Tropical America, from Mexico to the West Indies, southrard to Peru and Brazil. $-\beta$ is a plant collected by Spruce at the foot of Mount Chimborazo (No. 5706), 
which seems strikingly different from the normal form in habit, but resembles it closely in other respects. In the shape and size of the pinnules this species is not strikingly different from A. Capillus-Veneris, but is pinnately branched very regularly and copiously, and even when the pinnæ are furnished with long pinnules, there is an almost sessile single segment at the base adpressed to the main rachis.

45. A. colpodes, Moore; st. 4-6 in. 1. ; slender, glossy, dark chesnut-brown, polished, slightly fibrillose ; fr. 9-12 in. 1., 4-6 in. br., deltoid in general outline, tripinnate; lower pinnoe spreading at right angles from the rachis, 2-3 in. l., $1 \frac{1}{2}$ in. br., only slightly branched below; ultimate segm. about $\frac{1}{2}$ in. $1 ., \frac{1}{4}$ in. br., the lower line often straight for some distance, the upper irregularly rounded, lobed, and toothed, all nearly or quite sessile; texture pellucido-herbaceous; rachises and both surfaces naked ; sori placed in distinct teeth of the outer edge, the invol. obversely reniform.-Gardn. Chron. 1865.

Hab. Ecuador and Peru. - This has much of the regularly-pinnate habit of A. concinnum, with which it also agrees in its nearly sessile segments, which in shape resemble more nearly those of $A$. Athiopicum, showing, however, more of a tendency to the truncato-dimidiate type of form.

46. A. tenerum, Swartz; st. $1 \mathrm{ft}$. high, erect, naked, glossy ; fr.1-3 ft. 1., 9-18 in. br., deltoid, tri- or quadripinnate; segin. $\frac{1}{2}-\frac{3}{4}$ in. br., cuneate or tending towards rhomboidal-dimidiate in shape, the upper edge rounded or somewhat angular, broadly and often rather deeply lobed, all stalked; texture very thin ; rachis naked and glossy, surfaces naked; sori placed in numerous roundish or transversely oblong patches in the lobes of upper half.-Hk. $S p .2 . p .45$.

Hab. Mexico and West Indian Islands southward to Juan Fernandez and Peru.Resembling A. Capillus-Veneris, but a larger and more branched plant, the segments smaller, more delicate, and less lobed, easily falling from the apex of the petiole when dry. The ramification is much more straggling and confused than in A. concinnum, and the lower segments have stalks half as long as themselves. A. Farteyense, Moore, appears to be an abnormal form of this species of garden origin.

47. A. cuneatum, Langs. \& Fisch. ; st. 6-9 in. 1., slender, erect, blackish, naked, polished ; fr. 9-18 in. 1., 6-9 in. br., deltoid, tri- or quadripinnate ; lower pinnoe 4-6 in. 1., 2-3 in. br. ; segm. numerous, $\frac{1}{4}-\frac{3}{8}$ in.-br., cuneate at the base, the upper edge deeply lobed; texture thin; rachis naked; sori 4 to 6 , obversely reniform, placed in distinct hollows in the lobes of the outer edge.-Hk. Sp. 2. $p .39$. HT. \& Gr.t. 30.

Hab. Brazil.-This also comes near Ethiopicum, but is a larger and more branched plant, with numerous pinnæ, pinnules, and segments, the latter usually distinctly cuneate in the lower half.

48. A. glaucophyllum, Hk. ; st. 6-9 in. 1., blackish, glossy, erect, naked ; fr. 12-24 in. l., 9-15 in. br., deltoid, quadripinnate ; lower pinnce 6-9 in. 1., 3-6 in. br., deltoid, erecto-patent; segm. $\frac{1}{4}$ in. br., cuneate at the base, the upper edge irregularly rounded, more or less lobed ; texture papyraceo-herbaceous; rachises glossy; veins prominent, under side glaucous; sori 4 to 6 , obversely reniform, placed in distinct hollows in the apex of the lobes of the upper edge.-Hk. Sp. 2 . p. 40. Cent. 61 .

Hab. Mexico and Guatemala.-Very near A. cuneatum. The principal difference is in the more rigid texture and more prominent venation, and this is only known in North, the other in South America.

49. A. fragile, Swartz; st. tufted, very short, polished, glabrous, blackish ; fr. 6-12 in. 1., 3-6 in. br., with numerous pinnæ, the lowest of which are branched again; segm. articulated at the base, very deciduous, $\frac{1}{4}$ in. br., cuneate in the lower half, the upper edge rounded, broadly lobed; texture papyraceoherbaceous; rachis naked; sori obversely reniform, 2 to 4 , placed in distinct 
hollows in the lobes of the upper edge.-Hk. Sp. 2.p.41. Ic. Pl.t.965. A. parvifolium, Fée.

Hab. West Indian Islands. - The segments are so deciduous that they have entirely fallen from nearly all the specimens in the Hookerian Herbarium, so that nothing remains but a dense tuft of rigid stems with numerous slender glossy branches. In shape the segments most resemble those of cuneatum, but they are smaller and less lobed.

50. A. venustum, Don ; st. 6-9 in. l., slender, erect, wiry, naked, polished ; fr. 6-12 in. 1., 4-8 in. br., deltoid, tri- or quadripinnate ; pinnoe erecto-patent, the lower ones deltoid; segm. $\frac{1}{4}$ in. across, cuneate at the base, the upper edge irregularly rounded, sometimes broadly lobed, finely toothed; texture subcoriaceous ; rachis naked; sori 1 to 3 , large, roundish, placed in distinct hollows of the upper edge.-Hk. Sp. 2. p. 40.t.96. B. A. microphyllum, Roxb.

Hab. Afghanistan and Himalayas up to 7-8,000 ft. - The more rigid texture, the small numerous scarcely lobed segments and few large sori, will clearly distinguish this from the preceding.

51. A. monochlamys, Eaton ; st. 6-9 in. 1., wiry, erect, glossy, dark chesnutbrown, naked ; fr. 6-12 in. l., 4-6 in. br., ovate-deltoid, tripinnate ; pinnce rather distant, rigid, erecto-patent; segm. $\frac{1}{4}$ in. br., cuneate at the base, the upper edge rounded, slightly toothed; texture coriaceous ; rachis naked; sori single or very rarely two, placed in a decided hollow of the upper edge.-Hk. 2nd Cent. F. t. 50 . A. Veitchii, Hance, Ann. Sc. Nat. Ser. 4. v. 15.p. 238.

Hab. Discovered by the American Exploring Expedition under Capts. Ringgold and Rogers in Japan, and since gathered there by Mr. J. G. Veitch and by Mr. Wilford in Tsus-Sima.-It comes near $\boldsymbol{A}$. venustum, but seems to be truly distinct.

****** Scandentes group. Stems scandent, several feet long, tri- or quadripinnate. Sp. 52-53.

52. A. digitatum, Presl ; st. 12-18 in. 1., erect, blackish, glossy, nearly naked; fr. 2-3 ft. l., $1 \mathrm{ft}$. br., furnished with numerous distant spreading or erectopatent branches, which grow gradually shorter upwards, the lowest of which are branched again, the pinnæ being $6-9$ in. $1 ., 3-4$ in. br.; segm. $\frac{3}{4}-1$ in. each way, varying from deflexed to cuneate at the base, the upper edge rounded, deeply cut from the circumference towards the centre, and the lobes again less deeply cut, the lower ones distinctly stalked ; texture papyraceo-herbaceous ; rachises naked, glossy ; sori in lines along the edge of the lobes all round, except the base.Hk. Sp. 2. p. 39. A. speciosum, Hk. Sp. 2. p. 45. t. 85. C.

Hab. Brazil, Peru, Bolivia, and Ecuador.

53. A. Feei, Moore ; st. 12-18 in. 1., strong, scandent, brownish-black, tomentose; $f r$. 1-2 ft. l., $1 \mathrm{ft}$. or more br., tripinnate, the main and secondary rachises zigzag, all the branches firm and spreading at a right angle; lower pinnoe 6-9 in. 1., 3-4 in. br.; pinnl. 1-2 in. 1., $\frac{1}{2}$ in. br., consisting of a terminal segment and several distant stalked suborbicular-cuneate lateral ones; texture subcoriaceous; rachises densely brown-tomentose ; sori marginal, roundish or transversely oblong, more than half a line deep.-A. flexuosum, Hk. 2nd Cent. t. 61 .

Hab. Mexico and Guatemala.

******* Pedatum group. Fronds not pinnately branched, but dichotomously forked, with numerous pinnoe springing from the upper side of each of the two branches. Sp. 54-56.

54. A. pedatum, Linn. ; st. 6-12 in. 1., polished, dark chesnut-brown, glabrous ; fr. dichotomous, with the main divisions flabellately branched; central pinnoe 
6-9 in. 1., 1-1 $\frac{1}{2}$ in br.; pinnl. $\frac{1}{2}-\frac{3}{4}$ in. 1., $\frac{1}{4}$ in. deep, dimidiate, broadest on the side nearest the stem, the upper and outer margin lobed, sometimes one-third down, the lowest on short slender stalks; texture pellucido-herbaceous ; rachises and surface naked; sori roundish or transversely oblong, 1-2 lin. br.-Hk. Sp. 2.p. 55 .

Hab. North Hindostan, ascending to 7-9,000 ft., Japan, Mantchuria, Unalaschka, and Canada southward to Virginia and California. - In this the main forks curve gracefully, and have from 4 to 6 brauches, each springing from the upper side, the central ones of which are most developed.

55. A. tetragonum, Schrad:; st. 6-12 in. l., polished, blackish, glabrous ; fr. dichotomous, with main divisions again once or twice forked; pinnoe 8-12 in. l., 2-3 in. br.; pinnl. $1 \frac{1}{4}-1 \frac{1}{2}$ in. l., $\frac{3}{8}-\frac{1}{2}$ in. deep, not truly dimidiate, but only the lower two-thirds of the under half cut away, the upper margin rounded and broadly lobed, with the lobes finely toothed and point often lengthened out; texture papyraceo-herbaceous ; rachis and surfaces naked ; sori linear or transversely oblong, placed round the upper edge, and sometimes also the outer third of the lower one.-Hk. Sp. 2. p. 28. A. curvatum, Kaulf. Hk. Sp. 2. p. 29. t. 84. C.

Hab. Brazil.-Dasily recognizable from the preceding by the difference in the branching and by the pinnules not being quite unilateral. A. Lindscea, Cav., A. humile, Kunze, and $\boldsymbol{A}$. angustatum, Kaulf., are little-known pedate plants.

56. A. patens, Willd. ; st. 6-9 in. l., erect, dark chesnut-brown, polished, but slightly tomentose; $f r$. dichotomously branched, and the branches once or twice branched again ; central pinnoe 6-9 in. 1., $1 \frac{1}{2}$ in. br. ; pinnl. $\frac{1}{2}-\frac{3}{4}$ in. l., $\frac{1}{4}$ in. deep, dimidiate, the two sides nearly parallel, the upper one broadly and bluntly lobed, and the outer blunt and lobed also ; texture papyraceo-herbaceous; rachises slightly tomentose, under surface slightly hairy ; sori placed round the upper and outer edge, obversely reniform, and placed in distinct small rounded hollows. Hk. Sp. 2. p. 29. t. 87. A.

Hab. Mexico, southward to Ecuador and Galapagos Islands.-The large horny suborbicular involucres, sometimes $\frac{1}{8}$ in. br. and nearly as deep, distinguish this readily from the other plants of the group.

57. A. hispidulum, Swartz; st. 6-15 in. 1., strong, erect, polished, dark chesnut-brown, scabrous ; fr. dichotomous, with the main divisions flabellately branched ; central pinnae 6-9 in. l., $\frac{1}{2}-1$ in. br. ; pinnl. $\frac{3}{8}-\frac{3}{4}$ in. $1 ., 2-4$ lin. hr., dimidiate, subrhomboidal, rather broader on the side nearest the stem, the outer edge bluntly rounded or oblique, upper and outer margin finely toothed, lower ones slightly stalked; texture subcoriaceous; rachises and both surfaces hispid; sori roundish, numerous, contiguous round the upper and outer edge.-Hk.Sp.2. p. 31. A. pubescens, Schk.

Hab. Asia-Neilgherries and Ceylon eastward to Fiji, southward to N. S. Wales and New Zealand ; Africa-Bourbon, Mauritius, Zambesi Land, banks of the Niger.-Easily distinguished from the other species by its densely pubescent segments and rachises.

58. A. flabellulatum, Linn. ; st. erect, strong, polished, blackish, naked ; fr. dichotomously branched and the branches once or twice branched again; central pinnoe 4-8 in. l., $\frac{3}{4}$ in. br.; pinnl. about 4 lin. br., 3 lin. deep, dimidiate, the lower edge nearly straight, the upper rounded, the outer blunt, both entire or slightly toothed ; texture coriaceons, rachises and surfaces naked; sori in several transversely oblong patches round the upper and outer edge. $-H k$. Sp. 2. p. 30. A. amœnum, Hk. \& Gr.t. 103.

Hab. Hindostan from the Himalayas to Ceylon, Japan, S. China, Malayan Peninsula and Islands. - The pinnules are larger and broader than those of $\boldsymbol{A}$. hispidulum, and only the rachis is finely pubescent. 


\section{\$ Hewardia, J. Smith.-Veins anastomosing. Sp. 59-62.}

59. A. (Hew.) Hewardia, Kunze ; st. 6-9 in. 1., erect, blackish, glossy, naked; fr. simply pinnate or bipinnate, with a terminal pinna and 2 to 4 lateral ones on each side, the lowest pair of branches sometimes with 2 to 4 pinnules each; pinnl. 3-4 in. 1., $\frac{3}{4}-1$ in. br., nearly equal-sided except at the base, ovate-lanceolate, very nearly entire ; texture papyraceo-herbaceous ; rachis polished, naked ; veins copiously anastomosing, midrib distinct, blackish; sori in continuous lines along both edges.-Hk. Sp. 2. p. 7. Hewardia adiantoides, J. Smith.

Hab. Guiana. - The texture of the frond is thinner than in the next species, and the veins are more distinct and copiously and conspicuously reticulated.

60. A. (Hew.) dolosum, Kunze; st. 6-12 in. l., erect, polished, blackish, slightly hairy ; fr. 9-12 in. l., 6-12 in. br., simply pinnate, with a large terminal pinna and 2 to 6 subsessile lateral ones on each side, which are 4-6 in. 1., 1-2 in. br., ovate or ovate-lanceolate, acuminate, nearly entire; texture subcoriaceous; rachis hairy, veins inconspicuous and only uniting towards the edge, midrib hlack, distinct; sori in continuous lines along both edges.-Hk. $S p$. 2. p. 6. t.79. B. A. Wilsoni, Hk. Sp. 2. p. 6. t.72. A.

Hab. Jamaica, Guatemala, Panama, Granada, Guiana, and Brazil._-Scarcely deserving a place in Hewardia, and, except in venation, the resemblance of the plant is altogether to $A$. lucidum and Phyllitidis.

61. A. (Hew.) olivaceum, Baker ; st. 6-9 in. 1., erect, glossy, blackish, naked ; fr. about $1 \mathrm{ft}$. each way, with a terminal central pinna and one nearly equalling it on each side; pinnoe with a large terminal pinnule and several stalked lateral ones on each side, which are 4-5 in. l., about $\frac{3}{4}$ in. br., lanceolate-acuminate, equal-sided, but obliquely truncate at the base below, broadly lobed throughout; texture papyraceo-herbaceous, the rachis slightly tomentose; veins conspicuous and copiously anastomosing, the midrib distinct, black, glossy; sori in linear patches $\frac{1}{4}$ in. br. in the lobes on each side.

Hab. British Guiana, Appun, No. 646.-This resembles A. Hewardia in texture and venation, differing in the branching and sori.

62. A. (Hew.) Leprieurii, Hk. ; st. 6-9 in. 1., erect, naked, blackish, glossy ; fr. 9-15 in. 1., 6-9 in. br., deltoid tripinnate, with a terminal pinna 6-9 in. $1 ., 2$ in. br., and 2 or 3 branches on each side, the lowest of which are branched again ; pinnl. 1-1 $\frac{1}{2}$ in. l., $\frac{1}{2}-\frac{3}{4}$ in br., subdimidiate, the lower line curved so that the inner part of the lower half is cut away, the upper edge rounded, the point bluntish or acuminate; texture papyraceo-herbaceous ; rachis tomentose; veins anastomosing but not copiously, no distinct midrib; sori in linear patches $\frac{1}{8}-\frac{1}{4}$ in. across on the broad lobes of the upper edge and outer part of the lower edge.-Hk. Sp. 2. p. 31.t.82. B.

Hab. Guiana ; gathered by Leprieur, Schomburgk, and Appun. - Easily distinguished from the other three by the subdimidiate pinnules without any distinctly-defined midrib.

\section{Gen. 22. Ochropteris, J. Sm.}

Sori marginal, transversely oblong, occupying the apices of the lobes of the segments. Invol. the same shape as the sorus, formed of the reflexed margin of the frond, with which it coincides in texture and covering the sorus. $A$ single Mauritian species with free veins, and the texture and habit of an ample decompound Davallia. TA. II. f. 22.

1. 0. pallens, J.Smith; st. 2 ft. l., pale straw-coloured, naked; fr. about the same length, about $1 \mathrm{ft}$. br., deltoid, quadripinnatifid; lower pinnl. 3-4 in. 1., 
2 in. br., their segm. cut down to the rachis below, with oblong toothed lower lobes; texture coriaceous.-Hk. Sp. 2. p. 54.t. 77. B.

Hab. Mauritius.

Gen. 23. Lonchitis, Linn.

Sori marginal, placed in the sinuses of the frond, more or less distinctly reniform but often considerably elongated. Invol. the same shape as the sorus and covering it, membranous in texture, formed from the reflexed margin. TАв. II. f. 23. United by Mettenius with Pteris, from which it differs only by the position of the sori.

1. L. pubescens, Willd.; st. 1-2 ft. 1., strong, erect, densely clothed with woolly pubescence; fr. 2-4 ft. 1., deltoid, tripinnatifid, cut down to the rachis except towards the apex; lower pinnoe sometimes 12-18 in. 1., 9-12 in. br.; pinnl. lanceolate, cut down nearly to the rachis below, with blunt, oblong, sinuated segm.; rachis and under surface, especially the midrib, tomentose; veins copiously anastomosing into irregular hexagonal areolæ; sori placed round the main sinuses of the pinnules and in two or three of the hollows of the segments on each side.-Hk. Sp. 2. p. 56.- -, L. glabra, Bory ; fr. thinner in texture and less hairy.-Hk. Sp. 2. p. 57. L. Natalensis, Hk. Sp. 2. p. 57. t. 89. B.

Hab. Mauritius, Bourbon, Johanna Island, Seychelles, Natal, Cape Colony, and in West Tropical Africa on the Cameroon Mountains and the islands of Fernando Po and St. Thomas. - I cannot point out any character by which the South American plant, gathered in the Caraccas by Linden ( $L$. Lindeniana, Hook.), may be distinguished ; and that from Madagascar (L. Madagascariensis, Hook.) only differs by baving the lower segments of the pinnules distinctly separated, or even stalked, bluntly rounded at the point, and scarcely at all lobed. The venation is identical in all the forms. L. aurita, L., taken up from Plumier, is no doubt this, figured with a muricated stem by mistake.

2. L. occidentalis, Baker ; st. 1-2 ft. l., strong, erect, naked ; fr. 2-4 ft. 1., deltoid, tripinnatifid, cut down to the rachis except very near the apex; lower pinnce 12-18 in. 1., 9 in. br., lanceolate-deltoid; pinnl. lanceolate, cut down below about three-quarters of the way to the rachis into blunt oblong lobes; rachis and both surfaces naked; main veins forked at a broad angle towards the apex, but only anastomosing rarely, and the lowest vein from the midribs of the lobes sometimes meeting so as to form a costal arch; sori reniform, placed in the sinuses at the base or along the margin of the ultimate lobes.

Hab. Gathered by Dr. Welwitsch in Angola (No. 132), by Barter at Fernando Po, and by Gustave Mann, at an elevation of $4,000 \mathrm{ft}$., on the Cameroon Mountains. The naked surfaces and rachis and only casually anastomosing venation will distinguish this clearly from the preceding, and the lateral sinuses of the lobes in which the sori are placed are not nearly so distinct, and in the lower lobes of the pinnule there is often no sorus at the base.

\section{Ger. 24. Hypolepis, Bernh.}

Sori marginal, placed usually in the sinuses of the frond, small, subglobose, uniform, distinct. Invol. the same shape as the sorus and covering it, membranous in texture, formed out of the reflexed margin. This genus seems only. intelligible as distinct when restricted to those species which have equal roundish sori placed in the sinuses of the ultimate divisions of the frond. In this sense it is employed here, which excludes several plants placed under it in the Species Filicum. TАB. II. f. 24. 
§ Euhypolepis. Rhizome wide-creeping, fronds ample, tri-or quadripinnatifid. Sp. $1-10$.

1. H. tenuifolia, Bernh.; rhizome wide-creeping, puberulous ; st. 1 ft. l., strong, erect, slightly asperous, naked or pubescent; fr. 4-5 ft. l., quadripinnatifid; lower pinnce ovate-acuminate, 12-18 in. 1., 6-9 in. br. ; pinnl. lan-

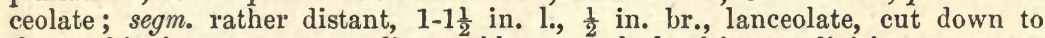
the rachis into numerous linear-oblong toothed ultimate divisions; texture herbaceous; rachises tomentose, the costa and sometimes the surface beneath slightly hairy and glandular; sori 2 to 6 to an ultimate division, placed at the sinuses of the teeth.-Hk. Sp. 2. p.60.t.89. C. and 90. A. H. dicksonioides, $H k$. Sp. l. c. H. pallida, Hk. Sp. 2. p. 64 .

Hab. Java, Polynesian Islands, New Zealand, Australia, Norfolk Island.-Closely allied to this are a number of Javan forms, deseribed as species by Blume and Kunze, for which I cannot give distinctive characteristics ; viz., $C$. setiger a, alpina, resinifera, polypodioides, javanica, and pallida of the former, sudis and stenophylla of the latter author. For an account of these, reference may be made to Blume's "Flora," Hooker's "Species Filicum," and the volume of the "Linnæa" for 1848 . H. resistens and amaurorachis of Kunze are referred by Mettenius to Polypodium rugulosum.

2. H. distans, Hk. ; st. 6 in. high, slender, flexuose, chesnut-brown, naked, slightly asperous; $f r$, about $1 \mathrm{ft}$. l., 4-5 in. br., ovate-lanceolate, bipinnate; pinnce spreading at right angles with the rachis, distant, especially the lower ones, lanceolate, 2-3 in. l., $\frac{1}{2}$ in. br.; pinnl. oblong, the lower ones approaching to deltoid, cut about halfway down; texture herbaceous; rachis scabrous but not tomentose; sori small, 2 to 4 to a pinnule, placed in the lower sinuses. $-H k$. Sp. 2. p. 70.t. 95. C.

\section{Hab. New Zealand.-Habit of a slender form of Athyrium filix-femina.}

3. H. anthriscifolia, Presl ; st. 1-2 ft. l., strong, erect, straw-coloured, naked but rather rough, with small raised points ; fr. ample, quadripinnatifid; lower pinnce deltoid-lanceolate, $1 \mathrm{ft}$. or more l., 4-6 in. br.; pinnl. lanceolate, rather distantly placed, the segm. cut down to the rachis into small oblong deeply pinnatifid ultimate divisions 2 lin. l., $\frac{1}{2}$ lin. br.; texture thinly herbaceous; rachis and under surface slightly hairy; sori 2 or 4 to each of the ultimate divisions, placed in the lower sinuses.-Hk. Sp. 2. p. 66. t. 95. A.

Hab. Bourbon, Mauritius, Cape Colony, Fernando Po.-The fronds are said by Bojer, who called it Adiantum elatum, to be from 10 to 18 feet in length. H. elata, Presl, and $H$. aspera, Presl, appear to be forms of this species. This is generally a more flaccid and more finely-cut plant than $H$. repens and tenuifolia; but some of the Fernando Po specimens have the rachis brown and very rough.

4. H. repens, Presl ; st. 1-2 ft. l., strong, erect, naked or puberulous, strawcoloured, more or less densely prickly; fr. $3-4 \mathrm{ft}$. l., quadripinnatifid; lower pinno 1-2 ft. l., 6-12 in. br, ovate-acuminate; pinnl. about 6 in. $1 ., 1 \frac{1}{2}-2$ in. br., lanceolate; segm. oblong-lanceolate, blunt, cut down nearly to the rachis into numerous bluntish lobes; texture herbaceous; rachises like the main stem; sori 2 to 6 to a segm., placed at the sinuses. $-H k$. Sp. 2. p. 64. t.90. C. - $\beta$, inermis, Hk. ; st. and rachis not at all prickly.

Hab. Tropical America, from the West Indies southward to Brazil and Peru.

5. H. nigrescens, Hk.; st. 12-18 in. l:, strong, erect, glabrous, rather thickly armed with strong prickles; fr. ample, quadripinnatifid; pinnoe numerous, spreading from the main rachis at right angles, the lowest $1 \mathrm{ft}$. l., 6 in. br.;

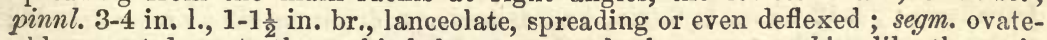
oblong, cut down to the rachis below; texture herbaceous ; rachises like the main 
stem; under surface nearly naked; sori small, placed at the bise of the sinuses. Hk. Sp. 2. p. 66. t. 90. C.

Hab. Jamaica, Martinique, Venezuela, and banks of the Amazon.-Cuming's Philippine plant, referred bere in "Species Filicum," is Dicksonia Moluccanc.

6. H. hostilis, Presl ; st. 1-2 ft. 1., erect, tomentose, scabrous ; fr. ample, quadripinnatifid; lower pinnce 6-12 in. l., 4-6 in. br., ovate-lanceolate; pinnl. lanceolate; segm. $\frac{1}{2}-\frac{3}{4}$ in. $1 . ; \frac{1}{4}$ in. br., cut down nearly to the rachis throughout into numerous linear-oblong tootheil ultimate divisions; texture thinly herbaceous; rachises tomentose; sori very small, placed against the sinuses of the ultimate divisions.-Hk. Sp. 2. p. 69.

Hab. Jamaica, Cocos Island, and Peru.-A more delicate plant than $H$. repens, with fmaller and more deeply divided ultimate lobes, in which respect, as well as in general habit, it very closely resembles the South African $H$. anthriscifolia.

7. H. Purdieana, Hk. ; st. 6-9 in. l., erect, strong, bright-brown, scabrous ; fr. 9-12 in. 1., . 3-4 in. br., lanceolate, tripinnatifid; largest pinnoe 2 in. $1 ., 1$ in. br., lanceolate-deltuid, cut down below to a narrowly-winged rachis, into numerous linear-oblong deeply crenato-pinnatifid pinnules; texture herbaceous ; rachis scabrous and densely clothed with brown filiform scales; costa also paleaceous; sori nearly a line across, roundish, placed against the sinuses of the pinnules.-.Hk. Sp. 2. p. 69. t. 91. B.

Hab. New Granada ; gathered by Mr. Purdie.-I give this and the six preceding species with great doubt as to how far they are distinct from one another, and with a suspicion that some of them at least, like other plants which have been placed in IIypo. lepis, will prove not really distinct from Polypodium rugulosum. With regard to the present one, for instance, Dr. Grisebach writes (Elora Brit. West Indies, p. 67), "Not to be distinguished from $P$. rugulosum but by the specially transformed involucral appendages, and probably passing into that widely-ranging species." Sir W. Hooker has expressed the same doubt with regard to $H$. distans; and reference may be made also, in connection with the same point, to Dr. Hooker's remarks in the Floras of New Zealand and Tasmania.

8. 11. parallelogramma, Hk. ; st. $2-4 \mathrm{ft}$. 1., strong, scabrous and prickly, but scarcely pubescent; fr. 10-20 ft. l., deltoid ; pinnoe 1-3 ft. l., ovate-lanceolate; pinnl. 6-9 in. l., not much over 1 in. br.s linear-lanceolate, with numerous linearoblong segm. about 9 liu. l., 3 lin. br., which are sinuato-dentate and have about their own breadth between them; texture subcoriaceous ; rachises like the stipes; sori sometimes 12 to a serm., placed at the sinuses.-Hk. Sp. 2. p. 65. t. 98. A. Clieilanthes scabra, Karst. C. Radula, Kunze.

Hab. Tropical America, from Guatemala southward to Brazil and Peru.-The segments are much larger than in any of the preceding, more coriaceous in texture, with the sides parallel for some distance and the point blunt, the veins beneath prominent.

9. H. millefolium, Hk. ; rhizome stout, wide-creeping ; st. about 6 in. 1 ., erect, pale-brown, glossy, scarcely scabrous; fr. $1 \mathrm{ft}$. or more l., 4-6 in. br., ovatetriangular, quadripinnatifid ; lower pinnce erecto-patent, 4-6 in. 1., 1-2 in. br.; pinnl. ovate-deltoid, their segm. cut down nearly to the rachis into several small sharply-toothed lobes; texture herbaceous, under surface of the frond slightly hairy; rachises of the pinnæ winged; sori small, roundish, placed in the lower sinuses.-Hk. Sp. 2. p. 68. t. 95. B.

Hab. New Zealand.-A much smaller plant than $H$. tenuifolia, with the ultimate segments more frequei, tly and sharply toothed.

10. H. Bergiana, Hk. ; st. tufted, 2 ft. ]., strong, erect, dark chesnut-brown, tomentose ; fr. 12-18 in. l., 6-9 in. br., deltoid, quadripinnatifid; pinnoe deltoid; pinnl. ovate-deltoid ; segm, ovate, $\frac{1}{2}-\frac{3}{4}$ in. $1 ., \frac{1}{4}-\frac{8}{8}$ in. br., cut down to the rachis 
into oblong blunt-toothed ultimate divisions ; texture thinly herbaceous; rachis rigid, zizgag, dark-brown, tomentose, and the under surface of the frond hairy ; swi very small, placed in the sides of the lobes of the segments or ultimate divisions.-Hk. $S p .2 . p .67$.

Hab. Cape Colony, Kaffraria, Natal, and Zambesi Land.--A well-marked plant.

\section{$\$ \oint$ Aspidotis, Nuttall. Fronds small, densely tufied. Sp. 11.}

11. H. (Aspid.) Californica, Hk. ; st. densely tufted, about 6 in. 1., strong, erect, brown, glossy ; fr. about 3 in. each way, deltoid, quadripinnatifid; lower pinnce deltoid, the pinnl. of the lower side much larger than the others, cut down to the rachis into numerous segm., which are again very sharply cut liearly to the centre; texture subcoriaceous; rachises naked, glossy, dark-brown; sori roundish, 2 to 6 to a segm., placed at the base of the sinuses.-Hk. Sp. 2. p. 71 . t. 88. A.

Hab. California.-This has quite the habit of the more finely-divided coriaceous species of Eucheilanthes (C. tenuifolia, \&c.).

\section{Gen. 25. Chemlantues, Swartz.}

Sori terminal or nearly so on the veins, at first small, subglobose, afterwards more or less confluent. Invol. formed from the changed reflexed marrin, roundish and distinct, or more or less confluent, but not quite continuous. TAls. III. f. 25. A considerable genus, with many species extending beyond the tropics, the fronds mostly under a foot long, often under six inches, tri-or quadripinnatifid, subcoriaeeous in texture. Veins free in all the spccies. Adiantopsis diffirs from Hypolepis in habit and the position of the sori, and Eucheilanthes from Pellæa and Pteris, by its more or less interrupted involucres. It is very difficult to draw the line between Cheilanthes and Nothochlona, which is the corresponding non-indusiate genus.

$\S$ Adiantopsis, F'ée. Involucres distinct, roundish, confined to the apex of a single veinlet. Sp. 1-13.

1. C. (Adiant.) monticola, Gardn.; st. densely tufted, under 1 in. 1., naked, wiry, polished, blackish ; fr. $3-4$ ilr. 1., $\frac{1}{2}$ in. br., linear-lanceolate, simply pinnate; pinnce $\frac{1}{4}-\frac{3}{8}$ in. l., $\frac{1}{8} \mathrm{in}$. br., oblong, obtuse, auricled at the base on the upper side ; texture herbaceous; rachis naked; sori small, numerous, roundish. -Gard. in Hk. Ie. Pl. t. 477. Hypolepis Gardneri, Hk. Sp. 2. p. 74. t. 92. B.

Hab. Brazil, province of Goyaz ; discovered by Mr. Gardner.-The only simply pinnate species of the subgenus.

2. C. (Adiant.) pteroides, Swz. ; st. 6-12 in. l., strong, erect, polished, dark chesnut-brown, naked ; fr. 12-18 in. l., 6-9 in. br., deltoid, tripinnate, upper part simply pinnate, lower with several opposite pairs of wiry erecto-patent branches growing gradually larger downwards, the lowest often again branched; segm. $\frac{1}{2}-\frac{3}{4}$ in. l., $\frac{1}{4}-\frac{3}{8}$ in. br., oblong, entire, broadly rounded at both ends, sessile; texture subcoriaceous ; rachis polished, naked, both surfaces naked; sori small, roundish, distinct but contiguous.-Hk. Sp. 2.p.80.t.101. A.

Hab. Cape Colony, on moûntains from 1-3,000 ft., and found also in Java.-Closely resembles in habit some of the Platyloma.

3. C. (Adiant.) regularis, Mett.; st. 6-9 in. l., densely clothed with ferruginous hairs ; fr. 6-8 in. 1., lanceolate-oblong, bipinnate; pinnoe spreading from the rachis at right angles, the lowest 2 in. 1., oblong-obtuse ; pinnl. 4-5 lin. 1., stalked, oblong-rhomboidal, cuneate at the base below, truncate or auricled. 
above, slightly crenate ; texture subcoriaceous; rachis pubescent like the stipe ; sori roundish, placed at intervals round the edge of the pinnules.-Adiantum, Kunze.

Hab. Brazil ; gathered by Beyrich and Bongard.-We have not seen this, and our description is an abstract of that of Prof. Mettenius.

4. C. (Adiant.) paupercula, Mett. ; st. tufted, wiry, slender, erect, 4-6 in. l., dark chesnnt-brown, glossy, naked; fr. 4-6 in. l., 3-4 in. br., triangularacuminate in general outline, simply pinnate half or one-third of the way down, with 2 to 4 erecto-patent pinnoe on each side of the lower half; pinnl. 3 lin. l., $1 \frac{1}{2}$ lin. br., oblong, scarcely toothed; texture subcoriaceous; rachis like the stipe ; sori 1 to 3 to a segment, small, roundish.-Hypolepis, Hk. Sp. 2. p. 73.t. 88. C.

Hab. Cuba ; gathered by Linden and Wright.

5. C. (Adiant.) radiaia, R. Br. ; st. tufted, 12-18 in. 1., strong, erect, wiry, glossy, blackish, polished; pinnoe 6 to 9 , all radiating from a common centre like the spokes of a wheel, with a whorl of bract-like segments at the axis, the longest 6.9 in. $1 ., \frac{3}{4}-1$ in. br. ; pinnl. numerous, close, $\frac{1}{2}$ in. l., 1-1 $\frac{1}{2}$ lin. br., unequal-sided, truncate at the base below, auricled at the base above; texture subcoriaceous; rachis glossy, naked; sori small, very numerous, placed along both margins of the entire pinnules.-Hypolepis radiata, Hk. Sp. 2. $p .72$. t. 91. A.

Hab. Tropical America, from the West Indies and Mexico southward to Peru and Rio Janeiro.

6. C. (Adiant.) Capensis, Swz. ; st. tufted, erect, 4-6 in. l., naked, dark chesnut-brown ; fr. 4-6 in. 1., 3-4 in. br., ovate-deltoid, bipinnatifid ; lower pinnoe much the largest; pinnl. on the lower side larger than the others, ovate, bluntish, 1 in. l., $\frac{1}{2}$ in. br., cut down below to a narrowly-winged rachis into oblong blunt nearly entire segm. 3 4 l. lin., 2 lin. br.; texture herbaceous ; rachis polished, chesnut-brown; under surface naked, bright-green ; sori small, placed all round the edge of the segments; invol. ciliated.-Hypolepis, Hk. Sp. 2. p. 72. t. 77. C.

Hab. Cape Colony.-This and the next differ from all the others by their more herbaceous texture.

7. C. (Adiant.) Kirkii, Hk. ; st. densely tufted, 6-9 in. l., erect, chesnutbrown, polished, naked, but fibrillose towards the base; fr. 4-6 in. each way, deltoid, bipinnatifid, the upper pairs of pinnoe narrowly decurrent, the lower pair much the largest and the pinnl. of the lower side much larger than those of the upper, 1-1 $\frac{1}{2}$ in. 1., lanceolate-oblong, acuminate, cut down nearly to the rachis into several linear-oblong segm., with about their own breadth between them ; texture herbaceous ; rachis dark chesnut-brown, both surfaces nearly naked; sori numerous, small, roundish, marginal, contiguous but not confluent. -Hk. 2nd Cent. F. t. 81.

Hab. Gathered by Dr. Kirk in Zambesi Land on rocks in the Moramballa Mountains at an elevation of from 2-3,500 ft., and by Dr. Welwitsch in Angola.- This has entirely the habit and other characters of Pelloca geraniifolia, but the fructification is that of this section of Cheilanthes.

8. C. (Adiant.) pedata, A. Br. ; st. tufted, 6-12 in. l., wiry, erect, naked, dark chesnut-brown, glossy ; fr. about 6 in. each way, ternately divided, the central portion triangular-acuminate, with numerous linear-lanceolate pinnl., growing gradually larger downwards, the lateral portions lanceolate, with the lowest

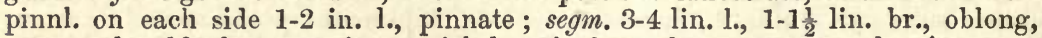
narrowed suddenly to a point, auricled at the base above; texture subcoriaceous; rachis dark-coloured and polished like the stipe; sori numerous, placed round 
both edges of the segments, small, roundish.-Hypolepis, Hk. Sp. 2. p. 73, t. 92 . A.

Hab. Jamaica; discovered by Mr. Purdie.

9. C. (Adiant.) dichotoma, Swartz; st. densely tufted, slender, 4-6 in. 1., polished, naked, dark chesnut-brown ; fr. 12-18 in. l., 4-6 in. br., oblong, tri- or quadripinnate, the main rachis very slender, zigzag, the secondary ones the same, spreading at right angles; pinnoe 2-3 in. 1., deltoid; pinnl. lanceolateoblong, cut down to the rachis into a few ternately-divided roundish or oblong segm. or even again slightly branched at the base; ult. divisions $\frac{1}{8}$ in. each way ; rachis niaked and polished, both surfaces naked; sori small, roundish, marginal, distinct.-Hk. Sp. 2. p. 104. t. 102. B.

Hab. Quito, Brazil, and Uraguay.-Very different from all the others in manner of growth, \&c.

10. C. (Adiant.) Seemanni, Hk. ; st. tufted, 3-6 in. l., strong, wiry, erect, dark chesnut-brown, fibrillose below ; fr. 4-9 in. 1., 2-3 in. br., ovate-lanceolate, tripinnatifid; pinnoe in numerous nearly opposite pairs, the lowest $1 \frac{1}{2}-2$ in. 1 ., $\frac{3}{4}$ in. br., lanceolate; the pinnl. ohlong-lanceolate, cut down to the rachis below ; texture subcoriaceous; rachis and both surfaces nearly naked; sori roundish, 1 to 4 to the segments, lateral, not confluent; invol. pale-brown.-Hk. Sp. Fil. 2. p. 85. t. 97. A.

Hab. Sierra Madre, N.W. Mexico ; discovered by Dr. Seemann.-This may be a form of C. microphylla, from which it differs only in its distinct involucres.

11. C. (Adiant.) Schimperi, Hk.; st. tufted, 3-6 in. l., erect, wiry, naked, chesnut-brown, glossy ; fr. 3-4 in. l., nearly as broad, deltoid, quadripinnatifid; lower pinnce much the largest; pinnl. lanceolate-deltoid, ult. divisions linear, acute, entire or toothed, 2 lin. l., less than $\frac{1}{2}$ lin. br.; texture subcoriaceous; rachis glossy, naked; sori numerous, small, placed along both margins of the ult. divisions.-Hk. Sp. 2. p. 70.

Hab. Abyssinia ; discovered by Schimper.-Habit of Hypolepis Californica and Cheilanthes tenuifolia.

12. C. (Adiant.) incisa, Kunze ; st. 1-2 in. l., erect, polished, naked, darkbrown; fr. 2 in. 1., 1 in. br., ovate-deltoid, tripinnatifid ; lower pinnes 1 in. 1. , cut down to the rachis into several oblong pinnl.; segm. narrow, linear, sharppointed ; texture subcoriaceous ; sori few, distant, marginal, roundish or transversely oblong.-Mett. Cheil. No. 65. t. 3. f. 28-31.

Hab. South of Brazil, fide Mettenius.-There is no specimen of this in the Hookerian Herbarium, but it is carefully figured and described by Prof. Mettenius, and seems a very distinct plant.

13. C. (Adiant.) chlorophylla, Swz.; rhizome stout, paleaceous ; st. contiguous, 12-18 in. l., strong, erect, polished, naked, dark chesnut-brown ; fr. 12-18 in. 1., 4-8 in. br., ovate-lanceolate tripinnatifid; pinnce $3-5$ in. $1 ., \frac{3}{4}$ to $1 \frac{1}{2}$ in. br., distant, lanceolate; pinnl. lanceolate, cut down to the rachis into numerous entire linear-oblong segm.; texture herbaceous; rachis like the stipe; sori numerous, small, roundish, placed on both edges.-Hypolepis spectabilis, Link, Hk. Sp. 2. p. 73. t. 88. B.

Hab. South America, from New Granada southward to Monte Video. 
\$\$ Eucheilanthes. Involucres more or less confluent, fronds not powdered beneath, segments larger and flatter than in Physapteris. Sp. 14-35.

\section{* Stipe scaly throughout, or more or less tomentose. Sp. 14-24.}

14. C. micropteris, Swartz; st. densely cæspitose, wiry, erect, tomentose, densely clothed with fibrillose light-brown scales at the base ; fr. 3-4 in. 1., 2-3 lin. br., simply pinnate ; pinnce 1-1 $\frac{1}{2}$ lin. br., ovate or roundish, crenate at the base, deeply lobed, the outer surface convex, pubescent; texture subcoriaceous ; rachis wiry, tomentose like the stipe; sori roundish, 3 to 5 to each pinna. - Hk. Sp. 2. p. 76.

Hab. Tropical America, from Ecuador southward to Peru and the Argentine territory. -The extreme forms of this and $C$. Matthewsii look very different; but upon view of the set of the Hookerian specimens, it seems doubtful whether they are really distinct.

15. C. Matthewsii, Kunze ; rhizome stout, creeping, densely clothed with linear-lanceolate dark-brown scales; st. numerous, almost tufted, strong, erect, wiry, densely pubeseent; fr. 4-12 in. 1., 1-2 in. br., linear-lanceolate, bi- or tripinnatifid ; pinnoe $\frac{1}{2}-1$ in. 1. , numerous, deltoid, much upcurled and incurved, cut down to the rachis below into linear-oblong, crenate or pinnatifid pinnl.; rachis stout, rigid, densely tomentose; texture subcoriaceous ; sori numerous; invol. roundish, slightly confluent.-Hk. Sp. 2. p.91. C. fasciculata, Goldm.

Hab. Andes of Bolivia and Peru.-C. pruinata, Kaulf., appears to be the oldest name, but the plant is not at all pruinate. The pinnules have the margins so much incurved, that it gives them the beaded habit of those of Eugleichenia.

16. C. fragrans, Webb \& Berth. (non Swartz) ; st. cæspitose, wiry, 1-3 in. 1., densely clothed with reddish-brown linear scales; fr. $2-3$ in. 1., about 1 in. br., ovate-acuminate, bi- or tripinnatifid; pinnce opposite, $\frac{1}{2}-\frac{3}{4}$ in. $1 ., \frac{1}{4}-\frac{3}{8}$ in. br., deltoid, cut down to the rachis below into several sinuato-pinnatitid linearoblong lobes; texture subcoriaceous; rachis polished but slightly scaly, both surfaces green and naked; sori small, copious ; invol. light-brown, membranous, toothed.-Hk. Sp. 2. p. 81. Polypodium fragrans, Linn. Mant. C. odora and suaveolens, Swartz. C. maderensis, Lowe.

Hab. South of France, Spain, Italy, Greece, Turkey, Canaries, Madeira, Algeria, Syria, Afghanistan, and N. W. Himalayas at $5,000 \mathrm{ft}$. ; and I cannot point out any good distinctive character for the South Anjerican C. andina (Hk. Sp. 2. p. 115), gathered by Mr. Maclean on the Peruvian Andes. Mettenius retains $C$. maderensis as distinct from the common S. European form.

17. C. arabica, Decaisne ; st. tufted, 1-3 in. 1., wiry, erect, dark chesnutbrown, fibrillose and tomentose ; fr. $2-3$ in. $1 ., 1-1 \frac{1}{2}$ in. bi., lanceolate-deltoid, bior tripinnatifid ; pinnæe opposite, the lowest $\frac{1}{2}-\frac{3}{4}$ in. l., cut down to the rachis into numerous linear-oblong segm., or slightly again branched at the base; texture subcoriaceous ; rachis chesnut-brown, fibrillose, upper surface naked, lower slightly hairy; sori copious.-Kunze, Linnoea, 23.p. 207. Mett. Cheil. p. 50.

Hab. Abyssinia, Schimper, 1431.-C. coriacea, Dec. (Hk. Sp. 2. p. 109), from Arabia, appears to be either this or very closely allied. This cornes very near $C$. pulchella, but is smaller in size, with a distinctly tomentose stipe and rachis. The ultimate segments are longer and narrower, and the involucre more continuous than in $C$. fragrans.

18. C. vestita, Swartz (non Hook.) ; st. tufted, 2-4 in. 1., wiry, polished,

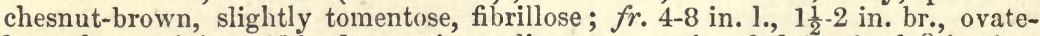
lanceolate, tripinnatifid; lower pinnce distant, opposite, $\frac{1}{2}-\frac{3}{4}$ in. $1 ., \frac{1}{4}-\frac{3}{8}$ in. br. lanceolate-deltoid, cut down to the rachis into several oblong pinnl. on each side the largest of which are quite $\frac{1}{4}$ in. $1 ., \frac{1}{8}$ in. br., cut down nearly or quite to the 
rachis below ; texture subcoriaceous, upper surface nearly naked, lower only slightly hairy, not densely matted; rachis thinly tomentose ; sori copious. Gray, Manial, p. 592.

Hab. Delaware and Penusylvania southward to New Carolina.-This is not described in the "Species Filicum," the $C$. vestita there given being our $C$. lanuginosa. We owe the unravelling of the synonymy to Prof. Eaton, who has ascertained, through the intervention of M. Naudin, that this is the Nephrodium lanosum of Michaux's Herbarium.

19. C. pilosa, Goldm. ; st. tufted, 2-4 in. l., flexuose, dark chesnut-brown, pilose, brittle ; fr. $6-12$ in. l., $1 \frac{1}{2}-2$ in. br., linear-oblong, tripinnatifid ; lower pinnce distant, $\frac{3}{4}-1$ in. l., deltoid, cut down to the rachis below into oblong pinnl., 3-4 lin. 1., 2 lin. br., deeply lobato-pimnatifid; texture herbaceous; rachises and both surfaces glandulose-pilose; sori copious, slightly confluent.C. MacLeanii, Hk. Sp. 2. p.93.t. 110. B.

Hab. Andes of Peru.-This comes nearest the true $C$. vestita, but is very flaccid in habit, larger, and more hairy.

20. C. microphylla, Swartz; rhizome slightly creeping; st. 2-6 in. 1., wiry, flexuose, polished, dark chesnut-brown, tomentose below when young; $f \dot{r}$. 3-9 in. 1., 2-3 in. br., ovate-lanceolate, bi- or tripinnatifid; pinnce in numerous nearly opposite pairs, the lowest 1-2 in. l., $\frac{1}{2}-\frac{3}{4}$ in. br., lanceolate or tending towards deltoid ; pinnl. linear-oblong, entire or subdeltoid, and cut down to the rachis below ; texture subcoriaceous; rachis usually naked ; both surfaces green and glabrous; sori roundish or elongated; invol. narrow, pale.-Hk.Sp.2. p.84. t. 98. A. C. elongata, Willd. Hk.l. c. p. 86. C. pygmæa, Klotzch, Hk. l. c. p. 88.- $\beta, C$. pubescens, H. B. K.; rachis tomentose, both surfaces of the frond

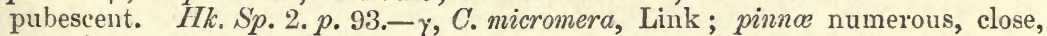
spreading, pinnules ovate-oblong, entire or nearly so ; invol. subcontinuous. C. aspidioides, $F^{\top} e .-\delta, C$. Moritziana, Kunze; whole plant larger; pinnl. often $\frac{1}{2}$ in. l., cut down nearly to the rachis for the lower two-thirds into oblong segm. - Hk. Sp. 2. p. 85.t. 99. B.

Hab. Tropical America, from Mexico and the West Indies southward to Peru.-A very variable plant, and it is to be feared that $C$. Tweediana, Hook., C. obtusuta, Presl, and C. cucullans, Fée, must also rank here.

21. C. Mysurensis, Wallich ; st. dense'y tufted, very short, wiry, dark chesnutbrown, polished, fibrillose below when young; fr. $3-12$ in. I., $1 \frac{1}{2}-3$ in. br., ovate-lanceolate, tripinnatifid ; pinnce numerous, the lowest opposite, $\frac{3}{4}-1 \frac{1}{2}$ in. 1 ., lanceolate-deltoid, cut down to the rachis into numerous linear-oblong incisopinnatifid pinnl.; texture herbaceous when young, subcoriaceous when mature; rachis polished, chesnut-brown, slightly fibrillose, both surfaces naked; sori small, roundish, distinct or slightly confluent.-Hk. Sp. 2. p. 94.t. 100. A. C. Chusana, Hk. Sp. 2. p. 95. t. 106. B.

Hab. Abundant in Tropical Hindostan, but not known in the Himalayas. Found also in Ceylon, West China, and at Canton and Chusan, and gathered lately by Mr. Oldham in Japan.- It resembles C. microphylla very closely, but the stipe is shorter and more scaly.

22. C. fragitis, Hk.; st. densely tufted, not more than 1-2 in. 1., strong, erect, tomentose and fibrillose; fr. 6-12 in. 1., 2-4 in. br., ovate-lanceolate, bipinnatifid; pinnse numerous, alternate, the lowest 1-2 in. apart, 1-2 in. 1., $\frac{1}{2}$ in. br., oblong-lanceolate, cut down to the rachis below into numerous linearoblong, blunt, sinuato-crenated lobes ; texture herbaceous ; rachises bright-brown, tomentose, both surfaces green and naked except the midrib beneath; sori small, roundish or subcontinuous ; invol. pale-brown, membranaceous.- $H k$. Fil, Exot. $t .96$. 
Hab. Limestone rocks near Moulmein, Malayan Peninsula; discovered by the Rev. C. S. Parish.-A larger plant than $C$. Mysurensis, but very doubtfully distinct.-From the Ceylonese C. $\operatorname{lax} a$, Moore, it differs mainly by its tomentose rachis.

23. C. liirta, Swartz; st. tufted, 2-4 in. l., strong, erect, densely coated with spreading bright reddish-brown woolly hairs ; fr. 4-12 in. l., 2-5 in. br., ovatelanceolate, tripinnatifid; pinnoe opposite, spreading from the main rachis at right angles, lanceolate, 1-3 in. 1 ., cut down to the rachis into numerous oblong pinnl. which are scarcely more than $\frac{1}{4}$ in. 1 ., and again inciso-pinnatifid; texture subcoriaceous; rachis and both surfaces more or less tomentose; margin of the segm. much incurved; sori copious. $-H k$. Sp. 2. p. 92. t. 101. B. - $\beta, C$. parviloba, Swz. ; rachis and surfaces less tomentose ; pinnoe shorter, with the segm. and apex slightly divided and convolute.-Hk.Sp.l. c.

Hab. Cape Colony north ward on the east to Natal, on the west to Angola.-There is a specimen from Java from Dr. Blume in the Hookerian Herbarium, and Mr. Moore gives it as Chinese. Our $\alpha$ varies much in size and hairiness, and includes three species of Fée; viz., his Cheilanthes olivacea (a large form, with the margin of the segm. less incurved) and his Myriopteris contracta and intermedia. It might as suitably be placed in Physapteris as here. C. glandulosa, Pappe and Rawson, is said to be closely allied.

24. C. viscosa, Kaulf. ; st. tufted, 4-6 in. 1., strong, erect, wiry, dark chesnutbrown, polished, pubescent ; fr. 4-6 in. each way, deltoid, tri- or quadripinnatifid; pinnce in pairs, the lowest much the largest; pinnl. of the lower side larger than the others, sometimes $1 \frac{1}{2}-2$ in. l., lanceolate, with narrow linearoblong segm., which are again cut down to the rachis into small beaded ultimate divisions; texture herbaceous in the barren frond, subcoriaceous in the fertile one when mature; rachises pubescent, like the stipe, both surfaces pilose ; sori more or less confluent.-Hk. Sp. 2. p. 105. t. 93. B.

Hab. New Mexico southward to Venezueli.-Easily distinguished from its allies by the deltoid outline of the frond. C. leucopoda, Link, is an allied Mexican plant, said to have a straw-coloured stipe and smaller fronds, and C.tenuis, Presl, another allied Mexican plant which I have not seen. From Allosorus hirsutus, Presl, this differs by its hairy stipes and rachis and Cheilanthoid involucre.

\section{** Stipe not hairy and slightly scaly only towards the base. Sp. 25-35.}

25. C. hispanica, Metten.; st. cæspitose, wiry, naked, dark chesnut-brown, polished, 2-3 in. l., with a dense tuft of wiry linear-filiform dark chesnut-brown

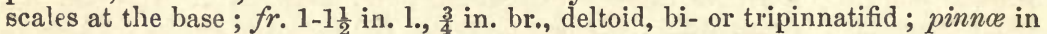
opposite pairs, the lowest the largest, oblong or again branched on the lower side; segm. roundish-oblong, crenate ; texture coriaceous ; rachis polished, upper surface green, naked, under brown, tomentose; sori small, copious.-Metten. Cheil. p. 30 .

Hab. Rocks on the banks of the Mondego, near Coimbra, Portugal, Welwitsch; Spain, fide Mettenius.

26. C. pulchella, Bory; st. densely tufted, 3-9 in. l., strong, erect, dark chesnut-brown, polished, slightly fibrillose below ; fr. 3-12 in. 1., 2-4 in. br., ovate-lanceolate or deltoid, tripinnate; lower pinnoe opposite, subdeltoid, 2-3 in. 1., 1-1 $\frac{1}{2}$ in. br.; pinnl. lanceolate, cut down to the rachis into numerous linear-oblong segm.; texture subcoriaceous; rachis and both surfaces naked; sori copious. - Hk. Sp. 2. p. 109. t. 94. A.

Hab. Madeira and the Canaries.-The Abyssinian plant placed here in "Species Filicum" is C. coriacea.

27. C. varians, Hk.; st. densely tufted, 2-6 in. 1., chesnut-brown, polished but rather slender and brittle, fibrillose below ; fr. $6-9$ in. $1 ., 1 \frac{1}{2}-2$ in. br., lan- 
ceolate, bipinnatifid ; pinnce in numerous pairs, the lower ones opposite, often $1 \frac{1}{2}-2$ in. apart, 1-1 $\frac{1}{2}$ in. 1 ., $\frac{3}{4}$ in. br., deltoid acuminate, cut down to the raehis in the lower part into oblong or linear-oblong entire or slightly toothed lobes; texture herbaceous; rachis like the stipe, both surfaces naked; sori copious, continuous; invol. narrow, membranaceous.-Hk. Sp. 2. p. 89. t. 93. A. C. Malaccensis, Fée.

Hab. Himalayas, ascending to 2-3,000 ft., Malnyan Peninsula, Luzon, S. China.

28. C. subvillosa, Hk.; st. densely tufted, 2-4 in. 1., polished, naked, bright chesnut-brown, rather brittle, clothed with lanceolate acuminate scales below; fr. 6-12 in. 1., 2-3 in. br., ovate-lanceolate, tripinuatifid; pinno in numerous pairs, the lower ones distant, $1 \frac{1}{2}$ in. l., more than $1 \mathrm{in.}$ br., deltoid ; pinnl. on the lower side the largest, sometimes 1 in. l., oblong-lanceolate, cut down to the rachis below into oblong lobes; texture herbaceous; rachis bright chesnutbrown, slightly pubescent, upper surface naked, lower villose, especially on the costa; sori copious; invol. greenish.-Hk. Sp. 2. p. 87. t. 98. B.

Hab. Pabur Valley and Simla, Himalayas; gathered by Mr. Edgeworth.-This species and $C$. Dalhousice differ from all the rest of the subgenus in their broader segments and more herbaceous texture, in which they agree with Adiantopsis Capensis and Kirkii.

29. C. Dalhousia, Hk. ; st. densely tufted, 3.6 in. 1., wiry, polished, dark chesnut-brown, when young clothed with linear scales ; fr. 6-12 in. l., 3-4 in. br., ovate-lanceolate or subdeltoid, tripinnatifid; pinnce in numerous opposite pairs,

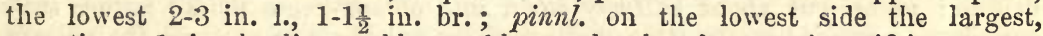
sometimes 1 in. J., linear-oblong, blunt, deeply sinuato-pinnatifid; texture herbaceous; rachis and costa naked and glossy like the stipe, both surfaces naked; sori numerous, roundish, small.-Hk. Sp. 2. $p .80$.

Hab. North of Hindostan, ascending in the Himalayas to $10,000 \mathrm{ft}$. - This occasionally shows a tendency to become farinose beneath. The involucres, though often erowded, are very slightly confluent.

30. C. allosuroides, Metten.; st. tufted, densely fibrillose at the base, 2-3 in. 1., wiry, erect, chesnut-brown, polished ; fr. $4-6$ in. l., 2 in. br., ovate-lanceolate, bipinnatifid ; pinnce alternate, about 1 in. $1 ., \frac{1}{2} \mathrm{in}$. br., lanceolate, cut down to the rachis into several ovate-acute pinnl., which are cuneate at the base and slightly lobed below; texture subcoriaceous; rachis like the stipe, slightly hairy above when young, glabrous when mature; invol. narrow, greenish, nearly continuous.-Mett. Cheil.p. 32.

Hab. Mexico.-Our description is taken from specimens gathered by Schafferer. It comes nearest $C$. Sieberi in habit, but is less rigid, and the involucre is more continuous.

31. C. Sieberi, Kunze; st. densely tufted, 3-6 in. l., strong, wiry, polished,

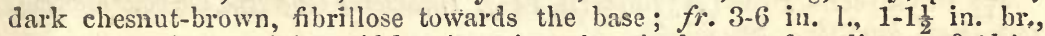
oblong-acuminate, tripinnatifid ; pinnoe in pairs, the lowest often distant, $\frac{3}{4}-1 \frac{1}{2}$ in. l., $\frac{3}{3}-\frac{1}{2}$ in. bro, deltoid, with several opposite oblong.deltoid pimnl., which are cut down to the rachis in the lower part; texture subcoriaceous; rachis wiry, naked, polished, both surfaces naked; invol. small, narrow, pale-brown, roundish and separate, or combined.-Hk. Sp.2. p. 83, t.97. B. C. Preissiana, Kunze. Hk. Sp. 2. p. 83 .

Hab. Australia, Now Zealand, New Caledonia, Isle of Pines.-Species 31 to 35 form a group of very closely allied plants.

32. C. bullata, Kunze; st. densely tufted, 4-8 in. l., dark chesnut-brown, polished, wiry, slightly tomentose below, and clothed with lanceolate scales; $f i$. 6.9 in. l., 2-3 in. br., ovate-lanceolate, tripinnatifid ; pinnee in numerous opposite pairs, the lower ones $1-\frac{1}{2}$ in. apart, $1 \frac{1}{2}$ in. $1 ., \frac{3}{4}-1$ in. br., lancelate or subm 
deltoid; pinnl. of the lower side the largest, cut down nearly to the rachis into numerous linear-oblong segm.; texture subcoriaceous; rachis like the stipe, upper surface naked, lower glandular; sori copious; invol. pale-brown.- $H k$. Sp. 2. p. 88. t. 96. A.

Hab. Neilgherry Hills, S. Hindostan.-Very near C. Sieberi, of which it is not unlikely only a larger and more robust variety, and both have a close connection with $C . m u l$ tifida.

33. C. multifida, Swartz; st. tufted, 3-9 in. 1., strong, erect, dark chesnutbrown, polished, slightly scaly towards the base; fr. 3-12 in. 1., 2-8 in. br., ovate-lanceolate or deltoid, tri- or quadripinuatifid; lower pinnl. opposite, remote, erecto-patent, deltoid, 2-6 in. l.; ult. divisions linear-oblong, deeply lobed and the margin in the fertile plant nuch recurved ; texture subcoriaceous ; rachis dark chesnut-brown, naked and polished, both surfaces naked; sor $i$ terminal on the lobes, small, roundish, slightly confluent; invol. membranaceous. -Hk. Sp. 2. p. 90.t.100. B. Gard. F.t. 39 .

Hab. Cape Colony northward to Zambesi Land and St. Helena, and sent also from Java by Dr. Blume.-Dr. Kirk's tropical specimens are larger and more compound than those from furtber south, but appear to be the same plant.

34. C. Wrightii, Hk.; st. 2-4 in. l., strong, wiry, chesnut-brown, polished, finely fibrillose below when young; fr. 2-3 in. l., 1-1 $\frac{1}{2}$ in. br., ovate-lanceolate, tripinnatifid ; pinnoe in several opposite pairs, the lowest about 1 in. $1 ., \frac{1}{2}$ in. br., deltoid; pinnl. cut about halfway down into oblong-acute lobes; texture subeoriaceous; rachis like the stipe, both surfaces naked; sori copious, the inargin of the fertile fronds much incurved.- $H k . S p .2 . p .87 . t .90$. A.

Hab. Gathered by Mr. Wright in 1849 in an expedition from Texas to New Mexico, U.S. A. - In habit it comes very near the small forms of $C$. tenuifolia, but the involucres are less confluent.

35. C. tenuifolia, Swartz; st. not tufted, 4-8 in. 1., wiry, flexuose, naked, dark chesnut-brown, polished, slightly fibrillose towards the base; fr. 4-8 in. l., 3-4 in. br., deltoid, tripinnatifid; pinnce in numerous opposite pairs, the lowest 2-4 in. 1., 1-2 in. br., deltoid; pinnl. on the lowest side the largest, the lowest 1 in. l., cut down to the rachis into oblong entire or sinuato-pinnatifid segm.; texture subcoriaceous; rachis polished like the stipe, both surfaces green and naked; sori roundish or subcontinuous; invol. narrow, brownish, more or less toothed.-Hk. Sp. 2. p. 82.t.87. C.

Hab. Himalayas (sub-tropical region), Madras, Ceylon, Malayan Peninsula apd Islands, S. E. China, Polynesian Islands, New Zealand, Australia, and southward to Van Diemen's Land.

$\$ \S \S$ Physapteris, Presl (Myriopteris, Fée). Involucres confluent, ultimate segments very small, beadlike. Sp. 36-48.

36. C. flexuosa, Kunze; st. about 2 in. l., erect, wiry, dark chesnut-brown, naked, polished; fr. 2-3 in. 1., rather more than 1 in. br., ovate-lanceolate, bipinnate; pinnoe numerous, close, spreading at right angles from the rachis, with 8-10 small beadlike nearly sessile pinnl. on each side, which are hardly more than $\frac{1}{2}$ lin. each way and rolled up like a ball; rachis rigid, chesnutbrown, glandular ; texture coriaceous ; sori hidden.-Hk. Sp. Fil.p. 104.

Hab. Brazil.-Our description is taken from Brazilian specimens gathered by Lindberg, which are marked by Mettenius as Kunze's var. minor. The typical plant is described as tri- or quadripinnate.

ふ7. C. induta, Kunze ; st. 3-6 in. 1:, naked, polished, chesnut-brown, clothed thinly with linear-lanceolate scales when young; fr. 3.6 in. $1 ., 1 \frac{1}{2}-2$ in. br., 
ovate-lanceolate, tripinnatifid ; lower pinnoe rather remote, deltoid; pinnl. $\frac{1}{2}-\frac{3}{4}$ in. 1., cut down to the rachis into oblong lobed segm.; rachis polished like the stipe, but more or less tomentose; texture subcoriaceous, upper surface naked, very convex in the mature fertile frond, under surface tomentose like the rachis; sori marginal.-Hk. Sp. 2. p. 92.t. 102. A.

Hab. Cape Colony ; discovered by M. Drège.-It resembles C. lanuginosa and Szovitzii in size and general appearance, but is uaked on the upper surface, and not at all matted beneath.

38. C. lanuginosa, Nuttall ; st. densely tufted, erect, wiry, polished, dark chesnut-brown, thinly clothed with spreading woolly hairs; fr. 4-8 in. l., 1-1 $\frac{1}{2}$ in. br., ovate-lanceolate, bipinnatifid; pinnce in opposite pairs, the lower ones deltoid; pinnl. linear-oblong, contiguuus, cut duwn to the rachis into numerous small roundish or oblong segm.; rachis tomentose; texture subcoriaceous ; upper surface grass-green, slightly tomentose ; lower surface densely matted with a coat of pale-brown woolly tomentum, the margin of the segm. much incurved; sori copious, marginal.-C. lanosa, Moore. C. vestita, Hk. Sp. 2.p.99. C. gracilis, Riehl.

Hab. Illinois and Wisconsin westward and southward to the Rocky Mountains, California, and New Mexico.

39. C. Szovitzii, Fisch. \& Meyer; st. densely tufted, erect, wiry, polished, chesnut-brown, thinly coated with spreading woolly hairs, mixed with linear

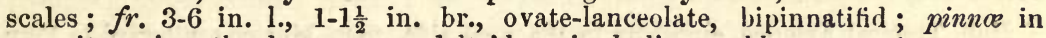
opposite pairs, the lower ones deltoid; pinnl. linear-oblong, contiguuus, cut down to the rachis below into sinall roundish beaded segm.; rachis scaly and tomentose like the stipe; texture subcoriaceous, upper surface green, slightly tomentose, lower surface densely matted with a coat of pale-brown woolly hairs, the margin of the segm. much incurved; sori copious, marginal.-Hk. Sp. 2 . p. 98.t.98. C. fimbriata, Visiani.

Hab. Asia Minor and Persia southward to N. Hindostan, ascending in the Himalayas to $8,500 \mathrm{ft}$., Italy and Daluatia.-Very near $C$. lanuginosa, from which it only differs by having distinct scales mixed with the tomentum upon the stipes and rachis. Notholana persica, Bory, is apparently this species.

40. C. gracillima, Eaton; st. densely tufted, 2-6. in. 1., wiry, slender, dark chesnut-brown, polished, only slightly scaly towards the base ; fr. $3-4$ in. l., 1 in. br., narrowly ovate-lanceolate, bi- or tripinnatifid; lower pinnce opposite, lanceolate-deltoid, about $\frac{1}{2}$ in. l., $\frac{1}{4}$ in. br., cut down to the rachis into several linear-oblong segm. on each side, the largest of which are $\frac{1}{8} \mathrm{in} .1$. , and the lowest again slightly divided; texture subcoriaceous; rachis slightly fibrillose, upper surface naked, the lower densely matted with pale-brown woolly tomentum, the margin of the segm. much incurved; sori copious, marginal.-Eaton in Report Mex. Bound. Survey, vol. 2. p. 234. C. Féei, Moore.

Hab. British Columbia, Oregon, California, Missouri, New Mexico, Guatemala.-A much less hairy and less divided plant than $C$. lanuginosa, with larger and less distinctly beaded segments.

41. C. Fendleri, Hk. ; st. scattered, 2-4 in. 1., wiry, chesnut-brown, polished,

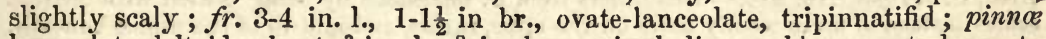
lanceolate-deltoid, about $\frac{3}{4} \mathrm{in.} \mathrm{l}$, $\frac{3}{8} \mathrm{in.} \mathrm{br.;} \mathrm{pinnl.} \mathrm{linear-oblong,} \mathrm{cut} \mathrm{down} \mathrm{to}$ the rachis into numerous small oblong beaded segm.; rachis densely clothed above with lanceolate acuminate entire scales, which are bright reddish-brown in the centre, silvery-white towards the edge; upper surface quite naked, under surface scaly only, not matted; texture subcoriaceous, margin much incurved; sori copious, marginal.-Hk. Sp. 2. p. 103.t. 107. B.

Hab. Rocky Mountains southward to California and New Mexico. 
42. C. Lindheimeri, Hk.; st. scattered, 3-6 in. 1., wiry, dark chesnut-brown, polished, thinly clothed with linear-lanceolate scales, scarcely tomentose; $f r$.

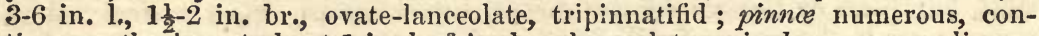
tiguous, the lowest about 1 in. $1 ., \frac{8}{8} \mathrm{in.} \mathrm{br.,} \mathrm{lanceolate;} \mathrm{pinnl.} \mathrm{numerous,} \mathrm{linear-}$ oblong; ult. segm. numerous, minute, roundish; rachis densely scaly alove ; upper surface woolly, the lower densely matted with wool and ovate-acuminate bright reddish-brown scales, margin of the segments much incurved; sori copious, marginal.-Hk. Sp. 2. p. 101.t. 107. A.

Hab. Texas and New Mexico.-This quite agrees with $C$. myriophylla in habit and texture, differing only in its wide-creeping rhizome and stipes without woolly tomentum.

43. C. myriophylla, Desv.; st. densely tufted, 3-6 in. 1., strong, wiry, erect,

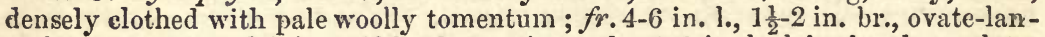
ceolate, tri- or quadripinnatifid ; lover pinnee about 1 in. l., $\frac{1}{2}$ in. br., lanceolatedeltoid, eut down to the rachis into numerous linear-oblong pinnl. on both sides, which are again slightly branched at the base; ult. segm. very small, roundish, beadlike; texture subcoriaceous; rachis clothed with tomentum like the stipe and also with distinct lanceolate-acuminate entire scales; upper surface green and pilose, lower densely matted and scaly, the margin of the segments much incurved; sori copious, marginal.-Hk. Sp. 2. p. 100.t. 105. A.- $\beta$, C. elegans, Desv.; ult. segm. obovate-pyriform, usually tapering into a distinct stalk. $-H k$. Sp. t. 105. B. C. paleacea, Mart. \& Gal. M. marsupianthes, Fée.

Hab. Tropical America, especially in the west side, from Mexico southward to Peru and Chili, and discovered lately by Capt. Beddome in the Neilgherries. Of $M$. cheiloglyphus and rufa of Fée, both Mexican plants gathered by Schaffner, I have not seen specimens.

44. C. scariosa, Kaulf.; st. densely tufted, not more than 1-2 in. 1., densely coated with large lanceolate whitish-brown scales; fr. $6-8$ in. $1 ., 1$ in. br., narrowly ovate-lanceolate, bipinnate; pinnoe numerous, contiguous, linearoblong, $\frac{1}{2}-\frac{3}{4}$ in. 1. , cut down to the rachis into numerous linear-oblong pinnl.; rachis and both surfaces densely coated with lanceolate-acuminate scales, which are about 2 lin. l., $\frac{1}{2}$ lin. br., bright-brown in the centre, silvery-white towards the ciliated and villuus margin; edge of the segments much incurved.- $I I k$. $S p$. 2. p. 99. t. 10\%. A.

Hab. Andes of Peru, and said to have been also gathered in Mexico.-The only species of the group with a dense coating of large scales.

45. C. Eatoni, Baker ; st. tufted, 3-6 in. l., wiry, erect, densely clothed with pale-brown linear-subulate scales; fr. 3-8 in. 1., $1 \frac{1}{2}-2$ in. br., ovate-lanceolate, tripinnatifid; lower pinn. distant, alternate or opposite, deltoid ; pinnl. linearoblong, pinnatifid; rachis rigid, covered with scales like the stipe, which also cover thickly the midrib of the pinur beneath; texture coriaceous; upper surface densely clothed with white woolly tomentum, lower also densely matted, the margin of the segments incurved.-C. tomentosa, IIk.Sp.2. p.96. (in part), $t$. 109. A. non Link.

Hab. Gathered in an expedition from Western Texas to El Paso, New Mexico, October 1849, $C$. Wright, No. 816. - This differs from $C$. tomentosa by being coated with distinct scales instead of mere woolly hairs on the stipe, rachis, and midrib of the pinnæ beneath, and by being matted with tomentum on the upper surface. Gordon's Colorado plant is perbaps the same, but is more slender and less distinctly scaly. We are indebted to Prof. Eaton for the elucidation of the United States species of the genus.

46. C. tomentosa, Link ; st. tufted, 4-6 in. l., strong, erect, densely matted with pale-brown woolly tomentum; fr. 6-12 in. 1., 2-3 in. br., ovate-lanceolate,

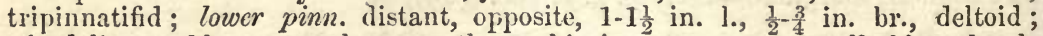
pinnl. linear-oblong, cut down to the rachis into numerous small oblong bead- 
like segm.; texture subcoriaceous; rachis densely woolly like the stipe ; upper surface grey-green, pubescent, lower densely matted, the margin of the segm. incurved; invol. pale, membranaceous.-C. Bradburii, Hk. Sp. 2. p. 97. t. 109. B. and C. tomentosa, $H k$. (in part).

Hab. North Carolina and Tenessee southward to Mexico.-The American botanists have the authority of Prof. Kunze for referring the common Physapteris of the Southern States to $C$. comentosa. There is a specimen, said to be from Jamaica, from Mr. A. B. Lambert, in the Hookerian Herbarium. The Afghanistan plant mentioned in "Species Filicum" is C. Szovitzii.

47. C. lendigera, Swartz; st. 3-12 in. l., strong, erect, polished, chesnutbrown, clothed with copious rusty-brown tomentum ; fr. 4-12 in. 1., 2-4 in. br., lanceolate, tri- or quadripinnatifid; pinnce numerous, the lowest opposite, erecto-patent, 2-3 in. l., $\frac{1}{2}-\frac{3}{4}$ in. br., lanceolate; pinnl. numerous, linear-oblong, cut down to the rachis into numerous distinct convex small segm. $\frac{1}{2}$ lin. or less each way; rachis densely tomentose; texture subcoriaceous; upper surface naked, lower villose; sori subcontinuous ; invol. membranaceous, whitish.- $H k$. Sp. 2. p. 95. t. 104. B.- $\beta, C$. minor, Mart. \& Gal.; hairs of the rachis less copious and more chaffy.-Hk. l. c. t. 106. A.

Hab. Mexico (ascending to 9-11,000 ft.), southward to the Andes of New Granada and Ecuador.-C. frigida of Linden and Moore we have not seen.

48. C. speciosissima, A. Br.; st. 3-6 in. 1., stout, erect, densely clothed with large (1-1 $\frac{1}{2}$ in. l., $\frac{1}{6}-\frac{1}{4}$ in. br.) linear-lanceolate ferruginous scales; fr. $12-24 \mathrm{in}$. 1., 4-6 in. br., ovate-lanceolate, tripinnate ; pinnce numerous, contiguous, 2-3 in.1., $\frac{3}{4}$ in. br., spreading, lanceolate; pinnl. numerous, close, linear-oblong, cut down to the rachis into numerous small beaded segm.; texture subcoriaceous; rachis densely paleaceous below like the stipe, the upper part of the rachis of the pinnre densely clothed with long rusty woolly hairs; upper surface nearly naked, under side tomentose; sori not quite marginal, the edge of the segments much incurved, membranaceous and toothed at the border so as to form a subconfluent involucre.-Hk. Sp. Fil. 2. p. 103. Plecosorus mexicanus, Fée.

Hab. Mexico (ascending to 12,000 ft.) and Guatemala.-The genus Plecosorus of Fée is characterized by distinctly intramarginal sori.

$§ \S \S \S$ Aleuritopteris, Fée. Involucres more or less confluent, fronds coated beneath with white or yellow powder. Sp. 49-53.

49. C. rufa, Desv.; st. tufted, 1-2 in. 1., densely clothed with rusty-brown woolly tomentum; fr. 6-9 in. 1., 2-3 in. br., ovate-lanceolate, bipinnatifid; pinnce opposite, the lower ones with 1-2 in. between them, oblong; pinnl.-on the lower side the largest, $\frac{1}{4}-\frac{1}{2}$ in. l., linear-oblong, sinuato-dentate; texture herbaceous; raclis densely tomentose like the stipe; upper surface tomentose, under surface more or less coated with white powder; sori copious, marginal, roundish, small; invol. brown, ciliated.-Hk. Sp. 2. p. 79. t. 99. $\Lambda$.

Hab. North of Hindostan, ascending to $4,000 \mathrm{ft}$. - The only tomentose plant of the group.

50. C. aurantiaca, Moore; st. tufted, 1-2 in. 1., chesnut-brown, polished, fibrillose below ; fr. 4-8 in. l., 2-3 in. br., bipinnate; pinnce opposite, the lower ones spreading, lanceolate, $1-1 \frac{1}{2}$ in. $1 ., \frac{1}{2}-\frac{3}{4}$ in. br., cut down nearly to the rachis into numerous linear-oblong entire or slightly crenated pinnl.; rachis and upper surface naked, lower densely coated with bright orange meal ; texture herbaceous; sori maginal, copious.-Allosorus, Presl. Pteris, Cav. C. ochracea, Hk. Sp. 2.p. 114. Ic. Pl.t.904.

Hab. Mexico. 
51. C. Welwitschii, Hk. MSS. ; st. densely tufted, 4-6 in. 1., wiry, naked, dark chesnut-brown, polished ; fr. 6-12 in. 1., 2-3 in. br., lanceolate, bipinnatifid; pinnoe with $1 \frac{1}{2}-2$ in. between the lowest, in opposite pairs, the lowest deltoid, $1 \frac{1}{2}$ in. $1 ., 1$ in. br., cut down to the rachis below into long linear-oblong sinuatodentate pinnl.; texture subcoriaceous ; lower surface densely coated with brightyellow meal, the costre and rachis polished like the stipe; sori numerous, small, subcontinuous, marginal.

Hab. Angola, frequent, 2,400-3,800 ft., Dr. Welwitsch, 148 \& 198.-This comes near C. aurantiaca, but is much more lengthened out in the stipe and frond.

52. C. argentea, Hk.; st. densely tufted, 3-6 in. 1., wiry, polished, dark chesnut-brown, clothed at the base with linear scales when young ; fr. $3-4$ in. 1 ., 2 in. br., deltoid, bi- or tripinnatifid, upper part not cut down to the rachis; lower pinnoe much the largest, cut down nearly to the rachis; lowest pinnl. sometimes $\frac{1}{2}$ in. 1., sinuato-pinnatifid; rachis and costa polished like the stipe ; upper surface naked, green, lower thickly covered with white ceraceous powder; sori numerous, very small, brownish, united at the base, marginal.Hk. Sp. 2. p. 97.- -, C. chrysophylla, Hk. Sp. 2. p. 113 ; pinnl. more nearly equal, in numerous opposite pairs, the frond narrower and longer, densely coated with yellow, not white, powder on the undet side.

Hab. $\boldsymbol{\alpha}$, Siberia, from the Altai to Kamschatka, Japan, China, Malayan Peninsula, and Khasya ; $\beta$, Khasya, ascending to $5,500 \mathrm{ft}$. - There is a wide range of forms, as may be well seen in the large quarto figure in Fil. Exot. t. 95, in the shape of the frond and thickness and colour of the ceraceous coating.

53. C. farinosa, Kaulf. ; st. densely tufted, 3-6 in. 1., wiry, polished, dark chesnut-brown, clothed with linear scales when young; fr. 3-12 in. 1., 3-6 in. br., lanceolate or deltoid, bi-tripinnatifid; pinnoe in numerous opposite pairs, the lower ones often much the largest, with the lowest pinnules longer than the others (1-2 in. 1.) and deeply sinuato-pinnatifid, most of the others with a broad entire central space; texture subcoriaceous ; rachis and costa naked and polished like the stipe ; under surface densely coated with pure white powder; sori small, brown, placed in a continuous line along the edges.-Hk. Sp. 2. p.77. Hk. \& Gr. Ic. 134. Bot. Mag. t. 4765 .

Hab. Africa-Cameroon Mountains, Angola, Zambesi Land, Bourbon, Abyssinia. Asia-Arabia, Himalayas (up to 7,000 ft.), Bombay, Neilgherries, Ceylon, Malayan Peninsula, Java, Philippine Islands. America-Mexico (up to 8,000 ft.), Guatemala, New Granada. - Very variable in size. The coriaceous coating is occasionally thin, and sometimes yellowish. M. Fée makes two species; one, A. farinosa, with more distinct, the other, A. dealbata, with more confluent sori.

\section{Gen. 26. Cassebeera, Kaulf.}

Sori terminal on the veins, subglobose or oblong, not reacling beyond the branches of a single vein. Invol. inserted distinctly within the margin and separate from it, of the same shape as the sorus and pressed down upon it. TAв. III. f. 26. Three local Brazilian species.

1. C. triphylla, Kaulf. ; st. slender, wiry, 2-3 in. l., naked, blackish, polished ; fr. digitate, $\frac{3}{4}$ in. each way, formed of 3 to 5 nearly equal linear-oblong segments; texture coriaceous; both surfaces naked; sori in close rows along the margin of the segments.-Hk. Sp. 2. p. 118.

Hab. S. Brazil and Monte Video.

2. C. pinnata, Kaulf. ; st. 6-12 in. 1., stout, erect, polished, dark-brown, naked; fr. about 6 in. each way, simply pinnate with crenate linear-oblong 
pinno 2-3 in. 1., $\frac{1}{4}-\frac{3}{8}$ in. br. when flat, or somewhat compound below, the margins of the segments much incurved in the mature plant; texture coriaceous, both surfaces naked; sori in close rows along the margins.-Hk. Sp. 2. p. 119.

Hab. South Brazil.-C. petiolata (F€́, Mem. p. 30.t. 12), which we have not seen, is perhaps a small form of this species.

3. C. gleichenioides, Gardn. ; st. 6 in. l., stout, erect, naked, polished ; fr. 6-9 in. 1., bipinnate, with stalked linéar pinnce 1-2 in. 1., cut down to the rachis into numerous quadrangular pinnl. 1 lin. br., which are incurved and rolled over the rachis, sometimes the lower branches again branclied; texture coriaceous; sori occupying the whole margin of the segments on which they are placed.-Hk. Sp. 2. p. 119. Ic. Pl.t. 507 .

Hab. Diamond district, Brazil, Gardner, 5295.-A very distinct and peculiar plant, with the habit of Eugleichenia.

\section{Gen. 27. Onychium, Kaulf.}

Sori placed upon a continuous linear receptacle, which connects the apices of several veins. Invol. parallel with the margin of the segments, linear, opposite, pressed down over the sori, the edge nearly or quite reaching the midrib. TAв. III. f. 27. United by Mettenius with Pteris, from which the four closely allied species differ rather in the cutting of the frond and the smallness and narrowness of the ultimate segments than essentially in fructification.

1. O. melanolepis, Decaisne ; st. tufted, 4-6 in. 1., slender, naked, strawcoloured ; fr. 3-4 in. 1., 2 in. br., ovate, quadripinnatifid ; lower pinnce 1-1 $\frac{1}{2}$ in. 1. deltoid; pinnl. deltoid, distant; ult. divisions linear-oblong when barren, not more than 1-1 $\frac{1}{2}$ lin. 1.; texture thinly herbaceous, both surfaces naked; invol. pale, membranaceous.-Hk. Sp. 2. p. 124. Ic. Pl. t. 902.

Hab. Persia and Abyssinia.

2. O. strictum, Kunze ; st. tufted, slender, 6-12 in. l., naked, polished, strawcoloured; fr. 6-9 in. 1., 3-4 in. br., ovate, quadripinnatifid; pinnce deltoid; pinnl. with a few distant segm., which are very narrow and acute, entire or once or twice cleft at the apex or slightly again branched; ult. divisions sharppointed and very narrow; texture herbaceous; rachis and both surfaces naked, the fertile segments larger than the others; invol. often considerably shorter than the segments on which they are placed, pale, membranaceous. - Hk. Sp. 2. p. 123. 2nd Cent. t. 32.

Hab. Cuba ; gathered by Linden and Wright.

3. O. auratum, Kaulf.; st. 6-12 in. 1., stout, erect, naked, straw-coloured or pale-brown ; fr. $1 \mathrm{ft}$. or more 1., $6 \mathrm{in.} \mathrm{br.,} \mathrm{ovate,} \mathrm{quadripinnatifid} \mathrm{;} \mathrm{lower} \mathrm{pinnoe}$ 4-6 in. l., subdeltoid, erecto-patent; pinnl. and segm. numerous, usually deltoid ; ult. divisions of the sterile frond often obovate-cuneate, trifid at the apex, not more than 1 lin. $1 ., \frac{1}{3}-\frac{1}{4}$ lin. br. when entire, coriaceous in texture, of the fertile frond podlike, $\frac{1}{2}-1$ in. $1 ., \frac{1}{8}$ in. br.; rachis and both surfaces naked, the membranous involucres and copious sori a rich golden-yellow.-Hk. Sp. 2. p. 121. $H k$. \& Gr.t. 121.

Hab. Himalayas, ascending 5,000 ft., and Malayan Peninsula and Islands.

4. O. japonicum, Kunze ; st. 6-12 in. 1., stout, erect, naked, straw-coloured or pale-brown ; fr. $1 \mathrm{ft}$. or more l., $6 \mathrm{in.} \mathrm{br.,} \mathrm{ovate,} \mathrm{quadripinnatifid;} \mathrm{lower} \mathrm{pinno}$ 4-6 in. l., lanceolate-deltoid; pinnl. and segm. numerous, usually deltoid, the copious linear-mucrunate ult. divisions $1 \frac{1}{2}-2$ lin. 1 ., nearly uniform in the barren 
and fertile frond ; texture herbaceous or, when mature, subcoriaceous; rachis and both surfaces naked; invol. pale, membranaceous; sori brown.-Hk. Sp. 2. p. 122. O. lucidum, Spreng. Hk. Sp. 2.p. 121.

Hab. Japan, China, North of India (ascending in Sikkim to 9-10,000 ft.), Java.-The plant conmon in Japan does not differ from the ordinary Himalayan form. O. Capense, Kunze, seems to be this reported from South Africa by mistake.

\section{Gen. 28. Llavea, Lagas.}

Sori linear, occupying the whole length of the changed pod-like segments of the upper part of the frond. Invol. the same shape, rolled over and quite concealing them. 'ТА

1. L. cordifolia, Lagasca; st. 1 ft. l., strong, erect, naked, straw-coloured, fibrillose towards the base; fr. 1-2 ft. l., 6-12 in. br., tripinnate, the lower part sterile with stalked ovate segm. $1 \frac{1}{2}-2$ in. l., $\frac{1}{2}-\frac{3}{4}$ in. br., the fertile segments of the upper part pod-like, $1 \frac{1}{2}-3$ in. 1 .; texture subcoriaceous; both surfaces naked; veins prominent.-IHk. Sp. 2. p. 125. Ic. Pl.t. 387-8. Ceratodactylis, J. Sin. Mett.

Hab. Mexico, ascending to $7,500 \mathrm{ft}$.

\section{Gen. 29.-Cryptogramme, $R$. Br.}

Sterile and fertile fronds usually different from tho same root; sori terminal on the veins, at first separate, subglobose, afterwards confluent, the continuous invol. formed of the changed margin of the frond, rolled over them till full maturity. TAB. III. f. 29. This and Llavea differ from Pellæa $\$$ Allosorus rather in the dimorphic fronds than in anything else.

1. C. crispa, R. Br.; st. tufted, straw-coloured, polished, brownish, and slightly scaly towards the base; fr. $2-4$ in. $1 ., 1 \frac{1}{2}-2$ in. br., oblong, tri- or quadripinnatifid; ult. segm. of the barren frond obovate-cuneate, deeply pinnatifid, those of the fertile frond pod-shaped, $\frac{1}{4}-\frac{3}{8}$ in. 1.; texture thickly herbaceous, both surfaces naked.- $\beta, C$. Brunoniana, Wall.; habit of $\alpha$, but the fertile segments oblong, about 3 lin. 1., 1 lin. br., with the invol. spreading in the mature plant and a space left free from fruit in the centre.-Hk. \& Gr.t. 153.$\gamma, C$. acrostichoides, R. Br.; habit larger and stronger, barren segments thicker in texture and more prominently veined and not so deeply cut, the fertile ones $\frac{3}{8}$ in. or even $\frac{1}{2}$ in. $1 ., 1$ lin. br., the invol. spreading when mature. $-H k$. $\& G$. t. 29. Hk. $s_{p}^{2} .2 \cdot p .130$.

Hab. $\alpha$, Arctic Europe to Lake Baikal, Mount Olympus in Bithynia, Etruria and Sierra Nevada ; $\beta$, Himalayas, at 10-15,000 ft.; $\gamma, N$. W. America, from Sitka and the Arctic regions south ward to Lake Superior, Oregon, and California.

\section{Genus 30. Pellak. Link. Hooker.}

Sori intramarginal, terminal on the veins, at first dotlike or decurrent on the veins, but soon running into a line. Invol. formed of the more or less changed edre of the frond, quite continuous, sometimes very narrow. Allied to Clieilanthes in habit of growth and geographical distribution, differing by the continuous involucre. Veins free in all the species except the last two. 'TA B. III. f. 30. 
$\S$ Cheiloplecton, Fee extens. Texture herbaceous or subcoriaceous, and veins clearly visible, the involucre broad, and in most of the species rolled over the sorus till full maturity. Sp. 1-11.

\section{* Fronds lanceolate or ovate-lanceolate. Sp. 1-4.}

1. P. auriculata, Link ; st. tufted, 2-3 in. 1., flaccid, bright chesnut-brown, slightly scaly ; $f r .3-9$ in. l., 1-1 1 in. br., linear-lanceolate, with 12 to 18 rather distant pinnoe on each side, which are slightly stalked and broader in the barren than in the fertile frend, and vary in shape from lanceolate-oblong and entire, to auricled at one or both sides at the base, or cut down nearly to the rachis in the lower part into oblong lobes; texture herbaceous; rachis and both surfaces naked; invol. similar in colour and texture to the frond, broad and much wrinkled.-Hk. Sp. 2. p. 140. Hk. \& Gr. Ic. t. 116.

\section{Hab. Cape Colony.}

2. P. Breweri, Eaton; st. tufted, densely fibrillose at the base, $2-3$ in. 1., wiry, polished, chesnut-brown, nearly naked; fr. 2-3 in. 1 ., under 1 in. br., linearoblong, simply pinnate; pinnae opposite, 6 to 8 on each side, the upper ones ovate, undivided, sessile, the lower ones cleft down the centre nearly to the base into two unequal halves, of which the lowest is the smallest, each the same shape as the upper pinnæ, and not toothed or further divided, the largest half about $\frac{1}{2}$ in. $1 ., \frac{1}{4}$ in. br. ; texture thick, but scarcely coriaceous; rachis naked, polished like the stipe; both surfaces pale-green, naked; sori in continuous marginal lines ; invol. broad, pale, membranous.-Eaton, Proc. Am. Ac. Art. \& Sc. vol. 6. p. 555 .

Hab. California ; gathered by Messrs. Brewer and Hillebrand.-Very near $\boldsymbol{P}$. auriculata, but the cutting of the pinnæ is different, and also the venation.

3. P. Seemanni, Hk. ; st. tufted, 1-2 in. 1., slender, wiry, naked, slightly scaly at the base ; fr. 3-4 in. 1., 1-2 in. br., deltoid-oblong, bipinnatifid ; lower pinnoe not more than $1 \mathrm{in}$. 1., lanceolate-deltoid, cut down to the rachis below into a few broad oblong blunt slightly-lobed pinnl.; rachis and both surfaces naked; texture. herbaceous, but the venation scarcely visible; invol. narrow, membranous. Hk. Sp. 2. p. 141. t. 117. B.

Hab. Mazatlan, Mexico ; gathered by Dr. Seemann.-Very like $P$. auriculata in habit, differing by its finer venation and narrower involucre.

4. P. gracilis, Hk.; st. scattered, slender, 2-3 in. 1., naked, straw-coloured or pale-brown, polished ; fr. 2-4 in. l., 1-2 in. br., ovate, bi- or tripinnatifid ; pinnce lanceolate-deltoid, 1:2 in. 1., cut down to the rachis; lower pinnt. sometimes again slightly divided; ult. segm. of the barren frond obovate, slightly crenate, of the fertile one linear-oblong, terminal one much larger than the others; texture thinly herbaceous and flaccid; rachis and both surfaces naked; veins visible; invol. broad, continuous, membranous.-Hk. Sp. 2. p. 138. t. 133. B.

Hab. Canada to Wisconsin, rare; Himalayas of Tibet and N. India at 9-10,000 ft.This has been confounded with Cryptogramme crispa, but is not tufteds and is much more delicate in texture.

\section{** Frond deltoid. Sp. 5-11.}

5. P. pilosa, Hk.; st. 6-9 in. 1., strong, wiry, brownish-black, more or less clothed with small linear scales throughout; barren and fertibe fr. different, the former deltoid, $1 \frac{1}{2}$ in. each way, cut down to within $\frac{1}{4} \mathrm{in}$. of the rachis ; lowest pinno much the largest, deeply lobed, with the lobes again broadly crenate on the under side, the lower surface densely pilose, and the midrib scaly like the stipe; 
fertile fr. larger and quite cut down to the rachis, with narrower, larger, and more deeply-divided pinnæ; texture subcoriaceous; invol. membranous, incurved. -Hk. Sp.2.p. 132.t.114. B.

Hab. Bourbon.

6. P. columbina, Hk. ; barren fr. with slender, wiry, naked, polished, brownishblack stems 6 in. l., the frond not much over 1 in. each way, deltoid, cut down to a broadly-winged rachis into two lobes on each side, the lowest of which is much the largest and again deeply lobed and sinuated on the lower side; fertile $f r$. on longer and stronger stems, 2-3 in. each way, cut down nearly to the rachis into about four lobes on each side, the upper of which are linear and entire, the lowest again deeply lobed below with a compound lower and simple upper linear segments; texture subcoriaceous, both surfaces naked; veins inconspicuous ; sori soon hiding the narrow spreading membranous invol.-P. lomariacea, $\beta, H k$. Sp. 2. p. 133. t. 112. - $\beta$, vestita; st. shorter, clothed throughout with brown fibrillose scales.

Hab. Brazil, summit of the Organ Mountains ; gathered by Mr. Garduer.-The alliance of this seems to be with $P$. pilosa and geraniaefolia. The barren fronds in size and cutting much resemble those of the former.

7. P. geranicefolia, Fée; st. 6-9 in. 1., naked, erect, wiry, brownish-black, polished, slightly scaly towards the base; $f r .2-4$ in. each way, deltoid, cut down nearly to the rachis into 3 or 4 pinnoe on each side, of which the lowest pair is much the largest, with the pinnl. on the lower side much larger than the others and deeply lobed with linear-oblong segm.; rachis and costa dark-coloured and polished like the stipe; texture herbaceous, lateral veins once forked; sori in broad marginal lines.-Hk. Sp. 2. p. 132. Ic. Pl.t.915.

Hab. Tropical America, from Guatemala southward to Brazil and Peru ; Polynesian Islands from New Caledonia northward to the Neilgherries, N. China, and Subtropical A ustralia, Mascaren Isles, Zambesi Land, Angola, and Cape Colony.-This and the two preceding agree in habit with Pteris pedata and Cheilanthes Kirkii. From the former their simple veins furnish the readiest mark of distinction. The plant from Australia, sent by Dr. Mueller, gathered at Rockhampton by Messrs. Thozet and Dallachy, is not unlikely distinct. It has fronds not more than 1 in. each way, resembling closely in cutting and texture the barren fronds of the preceding.

8. P. Tamburii, Hk. ; st. 6-9 in. l., erect, naked, chesnut-brown, polished; $f r$ about 6 in. each way, deltoid, with three principal pinnoe, the terminal one cut down neitrly to the rachis into several broad, opposite, lanceolate lobes, of which the upper ones are entire and the lower ones larger and sinuated; lateral pinnoe with the lobes on the upper side nearly entire, but those on the lower side prolonged and again deeply lobed, the largest entire divisions about 1 in. deep, $\frac{1}{2}$ in. br. at the base; texture subcoriaceous; rachis polished, brown like the stipe; under surface thinly coated with white farina; invol. brownish, continuous but regularly crenated along the outer edge.-Hk. Sp. 2. p. 134. t. 129. $\Lambda$.

Hab. Tambur Valley, East Nepaul; gathered by Dr. Hooker.-A very distinct species.

9. P. deltoidea, Baker; st. tufted, $1 \frac{1}{2}-2$ in. l., erect, wiry, dark chesnut-brown, naked, polished; fr. $1 \frac{1}{2}-2$ in. each way, deltoid, bipinnate; lower pinnoe much the largest, lanceolate-deltoid; lowest pinnl. cut down to the rachis below into oblong lobes; ult. segm. oblong, or obovate obtuse, about 2 lin. l., 1 lin. br.; texture herbaceous or, when mature, subcoriaceous; rachis and both surfaces naked; veins immersed; sori in continuous lines; invol. membranous, crenate. -Cheil., Kunze, Hk.Sp. 2. p. 107.

Hab. Cape Colony, Burchell, 2033. Namaqua Land ; gathered by Drége, and latterly by the Rev. Mr. Whiteliend. 
10. P. Skinneri, Hk.; st. 6-9 in. l., stout, erect, straw-colour or pale-brown, naked or slightly fibrillose ; fr. 6-12 in. l., 4-8 in. br., deltoid, tripinnatifid; lower pinnoe deltoid; lowest pinnl. 1-2 in. 1., 1 in. br., deltoid-acuminate, cut down nearly to the rachis into broad oblong acuminate lobes; rachis slightly tomentose, both surfaces naked; texture scarcely coriaceous ; veins fine, inconspicuous; invol. narrow, membranous.-Hk. Sp. 2. p. 141.t.118. B.

Hab. Guatemala ; discovered by Mr. Skinner'; and much finer specimens have recently been gathered by Messrs. Salvin and Godman.

11. P. rigida, Hk.; st. 4-6 in. l., stout, erect, dark chesnut-brown, naked or slightly scaly ; fr. 4-9 in. l., 3-6 in. br., deltoid, bi- or tripinnate; lowest pinnce the largest, erect, patent, 3-4 in. l., subdeltoid; pinnl. of the lower side larger than the others; ult. segm. linear-oblong, obtuse, decurrent at the base, $\frac{1}{4-\frac{1}{2}}$ in. 1 . in the barren frond, $1 \frac{1}{2}-2$ lin. br.; rachis naked or slightly scaly, both surfaces naked or slightly hairy; texture subcoriaceous; veins close and fine; sori in a continuous marginal line, the broad pale wrinkled invol. rolled down tightly over it.-Hk. Sp. 2. p. 144. Cheiloplecton, Fée.

Hab. Mexico, Guatemala, and said to have been also found by M. Nee in Peru.

$\S \S$ Allosorus, Presl. Texture coriaceous; the veins not perceptible; the ultimate segments of the frond at least twice as long as broad, often revolute at the margin; invol. broad, conspicuous. Sp. 12-32.

\section{* Frond not more than bipinnately cut. Sp. 12-21.}

12. P. (Allo.) ambigua, Baker ; st. 6-9 in. 1., wiry, erect, polished, dark chesnutbrown, naked ; fr. 4-6 in. l., 2-3 in. br., oblong, simply pinnate, or bipinnate at the base ; pinnoe $1 \frac{1}{2}-2$ in. l., 1 lin. br., linear, erecto-patent, flexuose ; texture subcoriaceous, brittle; rachis and both surfaces naked, margin incurved; invol. distinct from it, papyraceous, brown, continuous, mapped out into a series of roundish depressions, the two opposite edges interlacing by a marginal fringe, and sometimes concealing the dark-coloured polished midrib.-Cheil., Metten. Cheil.p.49. Synochlamys ambigua, Fée, 8. Mem.t. 20.

Hab. New Granada; discovered by M. Schlim in 1852.

13. P. (Allo.) atropurpurea, Link ; st. tufted, 3-4 in. 1., rigid, erect, more or less tomentose ; fr. 4-12 in. 1., 2-6 in. br., varying from lanceolate and simply pinnate to ovate-lanceolate, with deltoid pinnoe 2-3 in. l., with several pinnl. on each side, the latter nearly sessile, 1-2 in. l., at most $\frac{1}{4}$ in. br., entire or sharply auricled at one or both sides at the base; texture coriaceous; rachis tomentose like the stipe; both surfaces naked, except the costa beneath ; veins hidden; invol. formed of the slightly altered incurved edge of the pinnules, at length nearly hidden by the broad line of the fruit.-Hk. Sp. 2. p. 139.

Hab. N. America, from sub-arctic latitudes southward to Texas, the Rocky Mountains, and British Columbia ; and Prof. Eaton informs us it has also been gathered in the South of Mexico.

14. P. (Allo.) dura, Hk.; st. strong, erect, 6-12 in: l., naked, dark chesnutbrown, polished ; fr. 6-12 in. l., 2-4 in. br., linear-oblong and simply pinnate, or branched at the base with short deltoid pinnæ; segm. quite sessile, 1-1 $\frac{1}{2}$ in. 1,, $\frac{1}{8}-\frac{1}{4}$ in. br. ; texture coriaceous ; rachis naked or slightly pubescent; veins hidden; both surfaces pale-green, naked; sori broad, soon hiding the narrow membranous involucre. $-H k$. Sp. 2.p. 139. t. 113. A.

Hab. Mauritius, Madagascar, and discovered recently by Dr. Welwitsch in Angola at $3,800-5,500 \mathrm{ft}$.- This and $\boldsymbol{P}$. alropurpurea differ from all that follow by having the lower pinnæ pinnate. 
15. P. (Allo.) ternifolia, Fée; st. tufted, densely fibrillose at the base, $2-4$ in. 1 ,

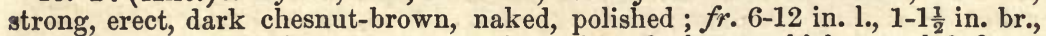
linear-lanceolate, with 6 to 12 opposite pairs of pinnæ, which are cleft down nearly to the base into three linear mucronate rigid segments with enrolled edges; texture coriaceous; rachis dark-coloured and polished like the stipe; both surfaces pale glaucous-green, naked; invol. formed out of the edge of the frond, rolled over the sori till they attain full maturity.-Hk. Sp. 2. p. 142. Fil. Exot. t. 15.

Hab. Tropical America, especially in the Andes, from Mexico southward to Peru and Chili ; Sandwich Islands.-Easily recognizable by its claw-like pinnæ.

16. P. (Allo.) mucronata, Eaton ; st. tufted, 2-4 in. 1., strong, erect, naked, dark-brown, polished ; fr. 3-6 in. 1., 1-3 in. br., deltoid, bipinnate ; pinnoe spreading or erecto-patent, rigid, 1 in. or more l., with several distant linear-oblong pinnl. on each side, about $\frac{1}{4}$ in. 1 ., with enrolled edges and a sharp mucronate point; rachis chesnut-brown, polished like the stipe ; texture coriaceous; both surfaces naked, pale glaucous-green ; invol. broad, coriaceous, rolled permanently over the sori.-A. mucronatus, Eaton in Sill. Journ. July 1856. P. Wrightiana, $H k$. $S p .2 . p .142$. t. 115. B. P. longimucronata, Hk. $S p .2 . p_{.}$143. t. 115. A.

Hab. California, New Mexico, and valley of the Rio Grande.

17. P. (Allo.) profusa, J. Sm. ; st. tufted, 2-3 in. 1., wiry, erect, blackish, polished, more or less fibrillose throughout ; fr. 3-4 in. 1., 1-1 $\frac{1}{2}$ in. br., oblonglanceolate, tripinnatifid; lower pinnoe opposite, lanceolate-deltoid, cut down to the rachis into several deltoid pinnl, the upper of which are ternately lobed, the lower cut down to the rachis below ; texture coriaceous ; rachis blackish, naked, polished; both surfaces green and naked; sori continuous ; invol. distinct and pale membranous.-Cheil., Kunze. Hk. Sp. 2.p. 108.

Hab. Namaqua Land and Cape Colony.-C. cornuta, from Zeyher and Drége, appears. to be safely referrible here ; but whether Ecklon's plant, described by Mettenius (Cheil. No. 33), be the same, is doubtful.

18. P. (Allo.) aspera, Baker ; st. densely tufted, 2-3 in. 1., wiry, blackish, more or less densely clothed with narrow seales and pale-brown tomentum ; fr. 4-6 in. l., about 1 in. br., narrowly ovate-lanceolate, bipinnate ; lower pinnoe distant, deltoid, $\frac{1}{2}-\frac{3}{4}$ in. $1 ., \frac{1}{4}$ in. or more br., cut down to the rachis into a few linear or ovateoblong nearly entire pinnl.; texture subcoriaceous ; rachis scaly and tomentose like the stipe; both surfaces pale-green and scabrous, with short white bristly hairs ; sori copious, marginal, confluent.-Cheil., Hk. Sp. 2. p. 111. t. 108. A.

Hab. New Mexico ; gathered by Mr. C. Wright.-Very like $P$. profusa in size and habit, but easily recognizable by its scabrous hairy surface.

19. P. (Allo.) Alabamensis, Baker ; st. subtufted, 2-4 in. 1., wiry, polished, blackish, fibrillose below, and at the base with copious fine woolly reddish-brown scales ; fr. 4-8 in. $1 ., 1 \frac{1}{2}-2$ in. br., ovate-lanceolate, bi- or tripinnatifid ; pinnoe numerous, the lower ones opposite, about $\frac{3}{4}$ in. $1 ., \frac{1}{4}$ in. br., lanceolate, cut down to the rachis into numerous linear-oblong segm., most of which are entire, but the lowest often again pinnatifid ; texture subcoriaceous ; rachis blackish, polished; both surfaces naked; sori continuous along both edges of the pinnules; invol. pale-green, membranous.-Cheil., Kunze. Hk. Sp. 2. p. 89. t. 103. B. Ex. F.t. 90 .

Hab. Alabama, Georgia, and Tenessee.

20. P. (Allo.) intramarginalis, J. Sm.; st. tufted, 3-6 in.'1., erect, dark chesnutbrown, polished, slightly fibrillose below ; fr. 6-12 in. $1 ., 2-4$ in. br., ovatelanceolate, bipinnatifid ; pinnoe opposite, lanceolate, 2-3 in. $1 ., 1$ in. br., cut down mearly to the rachis into long linear-oblong pinnl.; rachis polished like the stipe; 
both surfaces naked ; veins beneath prominent, the lateral ones forked ; sori copious, confluent, marginal ; invol. broad, membranaceous, fringed.-Cheil., Hk. Sp. 2. p. 112. - $\beta$, serratifolia ( $H k$. 2 d C Cent. t. 72); pinnules distinctly toothed. Pteris fallax, Mart. \& Galeotti.

\section{Hab. Mexico and Guatemala.}

21. P. (Allo.) ornithopus, Hk. ; st. tufted, 3-6 in. 1., rigid, ereet, polished, dark chesnut-brown, naked ; fr. 4-6 in. 1., 2-3 in. br., deltoid, bipinnatifid ; pinnoe rigid, spreading, $1-1 \frac{1}{2}$ in. 1 ., $\frac{1}{4}-\frac{3}{8}$ in. br., with numerous distantly-placed sessile pinnæ on each side, which are cut to the base into three linear mucronate segm., of which the central one is the largest, but is not more than $1 \frac{1}{2}-2$ lin. 1. ; rachis polished like the stipe; texture coriaceous; both surfaces naked, very pale glaucous-green ; invol. broad, coriaceous, crenate, rolled permanently over the sori.-Hk. Sp. 2. p. 144. t. 116. A.

Hab. California.-The pinnules here are clawed like the pinnæ of $P$. ternifolia.

* Frond at least tripinnatifid. Sp. 22-32.

22. P. (Allo.) nitidula, Baker; st. densely tufted, slender, dark eliesnut-brown, polished, $3-6$ in. l., fibrillose below ; fr. 3-4 in. 1., 1-1 $\frac{1}{2}$ in. br., bi-tripinnatifid ; pinnce opposite, the lower ones deltoid, cut down to the rachis into a few pinnl., the upper ones linear-oblong, entire, the lower ones again pinnatifid; rachis and both surfaces naked ; sori copious, confluent ; invol. broad, membranous, toothed. - Cheil., Hk. Sp. 2. p. 113. Ic. Pl. 10.t.912. Allosorus, Presl.

Hab. Himalayas, ascending to $6,000 \mathrm{ft}$.

23. P. (Allo.) densa, Hk.; st. tufted, 4-6 in. 1., slender but wiry, polished,

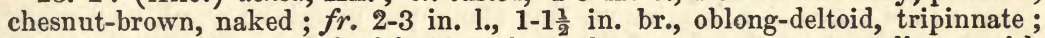
pinnoe and pinnl. crowded, deltoid or lanceolate; segm. numerous, linear, with enrolled edges, sessile or shortly stalked, sharp-pointed or mucronate, the terminal ones the largest, sometimes $\frac{1}{4}$ in. 1. ; texture coriaceous; rachis and both surfaces naked ; invol. broad, rigid, rolled permanently over the sori.-Hk. Sp. 2. p. 150. $t$. 125. B. Onychium, Brack.

Hab. Oregon, Washington territory, and California.

24. P. (Allo.) robusta, Hk. ; st. 1-2 in. l., ereci, wiry, bright-brown, naked, polished ; fr. 2-3 in. l., 1 in. or less br., oblong, obtuse, tripinnatifid ; pinnoe $\frac{1}{2}-\frac{3}{4}$ in. l., deltoid, cut down to the rachis into several pinnl. on each side, with a few thick linear-oblong simple or forked segm. not more than $1 \frac{1}{2}$ lin. l., $\frac{1}{2}$ lin. br.; texture subcoriaceous; rachis and both surfaces light-green, naked; sori in a continuous line along both edges; invol. similar in substance to the frond, and rolled over the fruit till full maturity.-Hk.Sp.2. p. 147.

Hab. Namaqua Land, S. Africa.-This and $\boldsymbol{P}$. densa are very like Cryptogramme crispas in size and habit, but the barren and fertile fronds are similar, the segments smaller and more crowded, and the involucre thicker in texture.

25. P. (Allo.) Boivini, Hk.; st. 4-8 in. 1., strong, erect, naked, dark-brown, polished ; fr. 6-9 in. 1., 4-6 in br., subdeltoid, bi- or tripinnate; pinnoe erectopatent or spreading, growing gradually smaller upwards, the lowest broadly lanceolate, simply pinnate, or oceasionally bipinnate; ult. segm. ovate, bluntish or acute, $\frac{3}{4}-1$ in. 1 ., $\frac{1}{4}-\frac{3}{8}$ in. br., shortly stalked, cordate or rounded at the base ; texture coriaceous ; rachis tomentose ; both surfaces naked; veins sunk in the frond; sori in a continuous line all round the segments; invol. membranous, nearly half a line broad.-Hk.Sp. 2. p. 147. t. 118. A. 
Hab. Madagascar, Mauritius, Macalisberg, Ceylon, Neilgherries (3-5,000 ft.).-This comes near $\boldsymbol{P}$. hastata in size and habit, but the segments are narrower, and the involucre is that of this section.

26. P. (Allo.) andromedoefolia, Fée ; st. 6-9 in. 1., strong, erect, pale-brown, naked, densely clothed at the base with linear subulate reddish-brown scales ; $f r$. 6-12 in. 1., 3-6 in. br., ovate, tri- or quadripinnate ; pinnoe rigid, erecto-patent, lanceolate-deltoid, the lowest with several linear oblong pinnl., the lower segm. of which are sometimes slightly branched; ult. divisions $1 \frac{1}{2}-2$ lin. l., linear-oblong, blunt with enrolled edges; texture coriaceous; rachis and both surfaces naked, the wrinkled invol. scarcely changed from the substance of the frond, and sometimes nearly meeting edge to edge.-Hk. $S p$. 2. p. 149.-,$C_{\text {. }}$. pubescens, Nutt. ; rachis and pinnules pubescent.

Hab. California, southward along the Andes to Chili ; Cape Colony.

27. P. (Allo.) pulchella, Fée ; st. densely tufted, 2-3 in. 1., wiry, erect, polished, dark chesnut-brown, naked ; fr. 3-6 in. 1., 1-3 in. br., oblong, tripinnate ; lower pinnoe deltoid; pinnl. lanceolate, the very deciduous ult. segm. oblong, blunt, scarcely more than $\frac{1}{8}$ in. 1 . by half as broad; rachis rigid and polished like the stipe ; texture coriaceous, both surfaces green, naked, the edges of the fertile segments much enrolled, and the broad invol. permanently rolled over the sori.Hk. Sp. 2. p. 150.

\section{Hab. Andes, from New Mexico southward to Peru.}

28. P. (Allo.) consobrina, Hk. ; st. strong, erect, 6-12 in. l., naked, dark-brown, polished ; fr. 6-12 in. l., 4-9 in. br., deltoid, tri- or quadripinnatifid; lowest pinnoe deltoid, with the pinnl. of the lower side larger than the others, these latter usually cut down into several lanceolate or deltoid pinnatifid segm.; simple ult. divisions linear-oblong, sometimes $\frac{1}{4}$ in. 1. ; texture coriaceous ; rachis and both surfaces naked; sori in a continuous line along the margins ; invol. moderately broad, membranous, the edge of the segments often enrolled.-Hk. Sp. 2. $p .145$. t. 117. A. P. Bojeri, Hk. Sp. 2. p. 146.t. 119. A. Cheil. Atherstonii, Hk. Sp. 2. p. 107.

Hab. Cape Colony, Kaffraria, Natal, Madagascar, and Cameroon Mountains.-P. Bojeri appears to be a slender form with a slightly fibrillose rachis. Mettenius refers here C. triangula, Kunze, but Drége's specimens are in part C. multifida.

29. P. (Allo.) angustifolia, Baker ; st. tufted, 6-12 in. 1., strong, erect, naked, dark chesnut-brown, polished ; fr. 6-12 in. 1., 3-6 in. br., deltoid-oblong, quadripinnatifid; pinnce 2-4 in. 1., lanceolate-deltoid; pinnl. often cut down to the rachis into numerous linear segm. with enrolled edges, the terminal ones much the largest ( $\frac{1}{2}$ in. or more 1.) ; rachis polished ; texture subcoriaceous, both surfaces pale-green, the upper slightly hairy; invol. broad, membranous, rolled over the sori.-Cheil., H. B. K. P. decomposita, Hk. Sp. 2. p. 151. t. 119. B. $-\beta, P$. cuneata, J. Sm. ; ultimate segments oblong-acute, $\frac{1}{4}$ in. l., $\frac{1}{8}$ in. br., cuneate at the base.-Cheilanthes cuneata, Link. Hk. Sp. 2. p. 107.

Hab. North of Mexico southward to Venezuela.-C. chœrophylla, Kunze, seems to be also a broad-leaved form of this.

30. P. (Allo.) glauca, J. Sm.; st. tufted, 4-8 in. l., strong, erect, polished, dark chesnut-brown, naked; fr. 3-4 in. each way, deltoid, quadripinnatifid; lowest pinnce much the largest and the pinnl. on the lower side larger than the others, lanceolate-deltoid, cut down to the rachis into segm. which are again cut down to the rachis below; ult. divisions about $\frac{1}{8}$ in. l., linear-oblong, with enrolled edges, more or less crenate ; texture coriaceous, upper surface green and naked, lower surface and the rachis tomentose; invol. coriaceous, rolled 
down over the sori.-Pteris, Cav. Swartz. Cheil., Mett. P. hirsuta, Hk. Sp. 2. p. 153.

Hab. Chili and Mexico.

31. P. (AHo.) marginata, Baker ; st. tufted, 3-9 in. 1., strong, erect, polished, chesnut-brown, naked, slightly fibrillose towards the base ; fr. 4-8 in. l., 3-6 in. br., subdeltoid, tri- or quadripinnatifid ; lower pinnoe usually much the largest; pinnl. on the lower larger than those of the upper side, the latter 1-2 in. l., lanceolate-deltoid ; ult. divisions linear-oblong with revolute edges, $1 \frac{1}{2}-2$ lin. l., $\frac{1}{2}$ lin. br. ; texture subcoriaceous ; rachises and both surfaces naked ; sori confluent. -Cheilanthes, Hk. Sp. 2. p. 105._ $\beta$, C. pyramidalis, Fée, 8. Mem. t. 25 ; fr. lanceolate; pinnce secund, with long (sometimes $\frac{1}{4} \mathrm{in}$.) pendent slightly compound pinnules.

Hab. Tropical America, from Mexico and Jamaica southward to Peru and the Argentine territory.-The finest examples in the Hookerian Herbarium are from Salvin and Godman's Guatemalan collections, with the lowest pinnules more than 2 in. $1 ., 1 \frac{1}{2}$ in. br. ; but usually it is much smaller. C. pyramidalis looks very different to the ordinary form, but appears connected with it by intermediate stages.

32. P. (Allo.) Barklyoe, Baker; st. 12-18 in. l., strong, erect, naked, darkbrown, polished ; $f r .1 \mathrm{ft}$. or more l., $9 \mathrm{in.}$ br., deltoid, quadripinnatifid ; lowest pinnoe 6-8 in. l., subdeltoid ; pinnl. on the lowest side the largest, with numerous segm. on each side, which are cut down to the rachis into numerous linear ult. divisions, 3 lin. I., 1 lin. br.; texture coriaceous; rachis and both surfaces naked; sori running along the opposite edges of the gradually narrowing segments, so that the broad pale-brown membranous invol. usually touch near the top.-Cheil. Barklyæ, Hk. MSS.

$\mathbf{H}_{\mathrm{ab}}$. Seychelles; sent by Lady Barkly and Dr. Kirk.-This comes nearest to the broad-leaved form of $P$. angustifolia, but is much larger in size.

$\S \S \S$ Platyloma, J. Smith. Texture coriaceous, the veins usually hidden, the ultimate segments broad and flat, the involucre so narrow that it is soon hidden by the fruit. Sp. 33-40.

33. P. (Platy.) Bridgesii, Hk.; st. 2-4 in. 1., wiry, erect, naked, bright chesnut-brown, polished; fr. 4-6 in. l., 1 in. or less br., linear, simply pinnate; pinnoe 6 to 8 on each side, sessile, oblong, entire, obtuse, rounded or cordate at the base; texture coriaceous; rachis naked and polished like the stipe, both surfaces naked, glaucous-green; veins hidden; sori in a broad marginal line with the much-wrinkled membranous edge of the frond protruding beyond it till full maturity.-Hk. Sp. 2. p.238. $t$. 142 . B.

Hab. California.

34. P. (Platy.) rotundifolia, Hk.; rhizome stout, creeping, scaly ; st. 6-12 in. l., stout, erect, more or less pubescent and clothed throughout with linear chaffy seales ; fr. 6-12 in. l., 1-1 $\frac{1}{2}$ in. br., linear, simply pinnate; pinnce 10 to. 20 on each side, short-stalked, oblong or roundish, entire, obtuse or mucronate at the point; texture coriaceous; rachis densely scaly and tomentose, both surfaces naked; veins beneath hidden; sori in a broad marginal line soon hiding the involucre.-Hk. Sp. 2. p.136. Fil. Ex.t. 48.

Hab. New Zealand and Norfolk Island.

35. P. (Platy.) falcata, Fée ; rhizome wide-creeping; st. 3-6 in, l., strong, erect, more or less pubescent and scaly ; fr. 6-18 in. 1., 1-2 in. br., linear-oblong, simply pinnate; pinnoe 10 to 20 on each side, nearly sessile, $\frac{1}{2}-1$ in. $1 ., \frac{1}{4}-\frac{1}{2}$ in. br., lanceolate or lanceolate-oblong, usually mucronate, often slightly falcate, 
cuneate or dilated and cordate at the base; texture coriaceous; rachis densely scaly and tomentose, both surfaces nearly naked; veins not visible; sori in broad marginal lines, soon hiding the narrow invol.-Hk. Sp. 2. p. 136.t. 11. B. (a small form).

Hab. Tropical Hindostan, Malayan Peninsula, Australia, Van Diemen's Land, New Zealand, Kermadec Isles. - P. seticaulis, Hook. ( $P$. alternifolia, Wallich), is a form with densely hirsute stipe and rachis and subhirsute papillose pinnæ.

36. P. (Platy.) paradaxa, Hk. ; st. 6-9 in. 1., strong, erect, dark-brown, naked or slightly tomentose; fr. 6-9 in. l., 4-6 in. br., oblong, simply pinnate; pinnoe 4 to 6 on each side, short-stalked, with a considerable space between them, $1 \frac{1}{2}-2$ in. $1 ., \frac{1}{2}-1$ in. br., lanceolate, entire, acute or bluntish, cordate or rounded at the base; texture coriaceous; veins hidden, midrib inconspicuous; rachis tomentose, both surfaces naked; sori in a marginal line often $\frac{1}{8}$ in. br., soon hiding the invol.-Hk. Sp. 2. p. 135.t. 111. A. Fil. Ex.t.21. Platyloma Brownii, $\mathcal{J}$. Sm.

Hab. Queensland and N. S. Wales.

37. P. (Platy.) Doniana, Hk. ; st. 4-8 in. 1., strong, erect, dark-brown, polished, slightly tomentose and clothed with linear scales towards the base; fr. 6-12 in. l., 2-4 in. br., oblong-lanceolate, simply pinnate or casually slightly branched towards the base ; pinnoe short-stalked, 6 to 15 on each side, $2-4$ in. l., $\frac{1}{2}-1$ in. br., lanceolate or ovate-lanceolate, entire or very slightly serrated towards the point, the base rounded or cordate; texture coriaceous; rachis slightly tomentose ; both surfaces naked, midrib nearly black in the lower part; sori in a narrow marginal line soon hiding the involucre.- $H k . S p .2 . p .137 . t$. 125.

Hab. Tropical Africa, the Niger country, Angola, and Zambesi Land.-This is very like $P$. paradoxa in size and habit, and is perhaps best distinguishable by the lower part of the midrib of the leaves being black and polished like the rachis.

38. P. (Platy.) hastata, Link ; st. 6-12 in. 1., wiry, erect, dark chesnut-brown, polished, naked; fr. 6-24 in. l., 6-12 in. br., oblong bi- or tripinnate; pinnce erecto-patent, varying from simply pinnate to copiously bipinnate; ult. divisions ovate or lanceolate, not toothed, 1-2 in. l., $\frac{1}{4}-\frac{1}{2}$ in. br., or nuore, sessile or very nearly so ; texture subcoriaceous; veins fine but plainly visible, once or twice forked; rachis and both surfaces naked; sori in a narrow continuous marginal line; invol. rather narrow, membranaceous, nearly or quite hidden when the fruit is mature.-Hk. Sp. 2. p. 145. Fil. Ex.t. 50.

Hab. Cape Colony northward to Natal, Zambesi Land, Mascaren Isles, Seychelles, and Angola.-There is a wide range in the size and branching of the frond and size and shape of the segments. Kunze makes three species, C. hastata, macrophylla, and hastofolia.

39. P. (Platy.) calomelanos, Link ; st. tufted, strong, erect, 4-6 in. 1., naked, dark-brown, polished, slightly fibrillose towards the base ; fr. 4-8 in. 1., 3-6 in. br., subdeltoid, bi- or tripinnate ; lower pinnoe rigid, spreading or erecto-patent, linear-oblong and simply pinnate or deltoid and bipinnate; ult. segm. on rigid black stalks, the lateral ones $\frac{1}{2}-\frac{3}{4}$ in. each way, varying in shape from cordateoblong-obtuse to hastate-triangular, about as broad as long, the two sides at the base often unequal; rachis shining, naked, blackish; texture coriaceous, both surfaces naked, glaucous-green; veins not perceptible; sori in a broad marginal line soon hiding the narrow membranous involucre.-Hk. Sp. 2. p.140. Bot. Mag.t. 4769.

Hab. Cape Colony, ascending to 4,000 ft., northward to Zambesi Land, Angola, and Natal ; Bourbon; Himalayas, ascending to $6,000 \mathrm{ft}$.

40. P. (Platy.) cordata, J. Smith ; st. 6-9 in. l., strong, erect, straw-coloured, polished, clothed below with small pale lanceolate scales when young; fr. $1 \mathrm{ft}$. 
or more 1., 4-6 in. br., lanceolate-deltoid ; pinnce lanceolate-deltoid, erecto-patent, with a straight rachis, the lower ones slightly branched at the base; segm. on short stalks, oblong or ovate, rounded or cordate at the base, $\frac{1}{2}-1$ in. 1. , half as broad, the point blunt; texture subcoriaceous; rachis pubescent and both surfaces slightly so; veins not visible; sori in broad marginal lines which soon hide the invol.-Hk. Sp. 2. p. 148. Allosorus, Hk. Bot. Mag. t. 4692.- $\beta, P$. flexuosa, Link; rachises zigzag, the pinnæ and pinnl. spreading at right angles or even deflexed.-Hk. Sp. 2. p. 148. Pteris, Hk. Ic. Pl. 2. t. 119.

Hab. Mexico and New Mexico southward along the Andes to Peru.-The two varieties'seem often very different in habit but, it is impossible to draw the line between them. Mr. J. Smith also admits as distinct Pteris sagittata, Cav., in which the segments are somewhat narrowed towards the point.

§\$\$ Holcochlæna, Baker. Texture and involucre of Platyloma, from which they differ only by the reticulated venation. Sp. 41-42.

41. P. (Holco.) Burkeana, Baker ; st. tufted, 4-6 in.1., naked, flexuose, polished, nearly black ; fr. $3-4$ in. 1., 2 in. br., with several pairs of simple, entire, short-

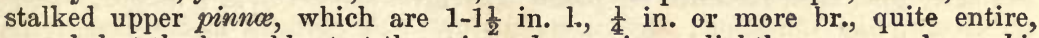
rounded at the base, blunt at the point; lower pinnoe slightly compound; rachis and both surfaces naked; costce black and polished in the lower part; texture coriaceous; veins copiously anastomosing; sori quite continuous round the margin of the pinnl., broad and ultimately hiding the reflexed involucre.Pteris, Hk. Sp. 2. p. 213. t. 126. B.

Hab. Macalisberg, Natal, S. Africa, discovered by Mr. Burke.

42. P. (Holco.) articulata, Baker; st. 6-12 in. l., strong, erect, naked, polished, dark chesnut-brown ; fr. 6-12 in. each way, subdeltoid, bi- or tripinnate; upper pinnoe stalked, simple, cordate-ovate, $1-1 \frac{1}{2}$ in. $1 ., \frac{1}{2}-\frac{3}{4} \mathrm{in.}$ br., the margin not toothed but sometimes undulated; lower pinnoc lanceolate-deltoid with several similar pinnl. $\frac{3}{2}$ in. or more apart, sometimes again compound below; texture coriaceous; rachis hairy; both surfaces naked; veins copiously reticulated ; sori continuous to the apex of the segments, ultimately concealing the reflexed involucre.-Pteris, Kaulf. Hk. Sp. 2. p. 214. t. 126. A.

Hab. Mauritius, Bourbon, and Madagascar.

\section{Gen. 31. Pteris, Linn.}

Sori marginal, linear, continuous, occupying a slender filiform receptacle in the axis of the involucre. Invol. the same shape as the sorus, usually membranous, at first quite covering it, at length more or less spreading. $A$ large cosmopolitan genus, including plants of almost every kind of division and venation. TAB. III. f. 31 .

§ Eupteris. Veins all free. Stems coespitose, involucre single. Sp. 1-39. TAB. III. f. 31. $a . b$.

\section{* Integrifolice. Lower pinnoe linear, undivided. Sp. 1-3.}

1. P. longifolia, L.; st. 6-12 in. l., stout, erect, pale, more or less clothed below with pale-brown linear scales; $f r .1-2 \mathrm{ft}$. 1., 4-9 in. br., oblong-lanceolate, attenuated below; pinnce sessile, often 20 to 30 on each side, 3-6 in. $1 ., \frac{1}{8}-\frac{3}{8}$ in. br., linear, entire, truncate or cordate or sometimes slightly auricled at the base ; texture subcoriaceous; rachis naked or slightly scaly below or throughout, both surfaces naked ; veins close and fine, usually once branched ; invol. membranous, yellowish-brown.-Hk. Sp. 2. p. 157. 
Hab. Tropical and warm temperate regions all round the world; Spain, Dalmatia, Sicily, Algiers, Abyssinia, Canaries, and Cape Verde Islands southward through Tropical Africa to Angola, Macalisberg, Mauritius, and Bourbon; Lebanon, Himalayas (up to 4,000 ft.), Chusan and Loo-choo southward to S. Australia ; West Indies, Mexico, and Venezuela.

2. P. moluccana, Blume ; st. strong, erect, naked, polished, dark-brown ; fr. 2-3 ft. l., oblong, simply pinnate; pinnce in numerous nearly opposite pairs, linear, cuneate at the base, spinuloso-serrated towards the point, the largest 12-18 in. l., $\frac{1}{2}-\frac{3}{4}$ in. br.; raclis naked, like the stipe, both surfaces bright-green and shining; texture subcoriaceous; veins conspicuous, fine, close (about 6 to aline), usually simple; invol. narrow, membranous.-Hk. Sp. 2. p. 158. $t$. 112. B.

Hab. Malayan Islands.-P. venusta, Kunze (Bot. Zeit. 6. p. 195), is said to be allied to this, but to have the pinnæ subauriculate at the base, and occasionally forked.

3. P. opaca, J. Sm.; st. strong, erect, pale, finely pubescent ; fr. $2-3 \mathrm{ft}$. 1. , oblong, simply pinnate; pinnoe in numerous opposite pairs, linear, cuneate at the base, quite entire towards the point, the largest about $1 \mathrm{ft} .1 ., \frac{1}{2}$ in. br. ; rachis pubescent, like the stipe; texture coriaceous, both surfaces naked except the midrib beneath; veins sunk in the frond and only visible as faint striations; invol. narrow, brownish.-Hk. Sp. 2. p. 159.t. 114. A. Pycnodoria, Presl.

Hab. Island of Samar, one of the Philippines, Cuming, 342.-A well-marked species, out of which Presl made a new genus upon a mistaken view of the involucre, which is that of typical Pteris.

** Furcatoe. Lower pinnce forked or slightly pinnate below, with a long linear entire point. Sp. 4-11.

4. P. cretica, L. ; st. 6-12 in. l., erect, wiry, naked, straw-coloured, or palebrown, polished; fr. 6-12 in. 1., 4-8 in. br. ; lateral pinnoe usually in 2 to 6 opposite sessile pairs, of which the upper one is sometimes a little decurrent, 3-6 in. 1., $\frac{1}{8}-\frac{3}{4}$ in. br., the sterile ones considerably the broadest and spinulososerrated, the lower pairs often cleft down nearly to the base into two or three linear pinnl.; rachis and both surfaces naked; texture coriaceous; veins fine, close, parallel, simple or once forked; invol. pale, membranous.-Hk. Sp. 2. $p .159 .-\beta, P$. stenophylla, ${ }^{\mathrm{S}} \mathrm{Hk}$. \& Gr. Ic. $t .130$; pinno 3 to 5 only, clustered at the apex of the stipe. P. digitata, Wallich. $-\gamma, P$. melanocaulon, Fée; stipe dark-coloured; veins sometimes scarcely visible.-P. scabripes, $W$ all.

Hab. Italy, Crete, Corsica, Abyssinia, Bourbon, Natal, Cape Colony, Ural, Caucasus, Arabia, Persia, Japan, Himalayas (up to 8-9,000 ft.), Neilgherries, Philippine Islands, Fiji and Sandwich Islands, Florida, Mexico, and Guatemala.-A variegated form (albolineata, Hort.) is figured in Bot. Mag. t. 5194. The Brazilian station given in Sp. Fil. is a mistake.

5. P. pellucida, Presl ; st. 1 ft. or more 1., erect, naked, straw-coloured or brown; fr. 12-18 in. l., ovate-lanceolate, simply pinnate; pinnoe usually in 3 to 6 sessile pairs, linear, entire or serrated towards the point, the upper ones slightly decurrent, the lower ones often 8 in. l., 1 in. br., usually all simple, but occasionally the lowest forked; rachis naked; texture coriaceous, both surfaces bright-green, often glossy; veins conspicuous, fine, close (about three to a line), simple or once forked; invol. membranous, brownish.-HK.Sp. 2. p. 161. t. 129. B. (a simple-fronded state).

Hab. Himalayas, Neilgherries, Ceylon, Malayan Peninsula, Philippines, Guinea Coast. -Different in the typical state from $P$. cretica, but not satisfactorily distinct. Pinnæ of the sterile frond not much broader than the others, scarcely toothed, but sometimes crisped at the edge. 
6. P. Hookeriana, Agardh ; st. 6-12 in. l., nalked, erect, pale; fr. 9-12 in. 1., 6-9 in. br., with a long, linear, entire terminal pinna, and two to six pairs of sessile opposite entire lateral ones, the largest of which is about 6 in. $1 ., \frac{3}{4}$ in. br., and the lowest of which is forked at the base on one or both sides; texture coriaceous ; rachis and both surfaces naked, opaque; veins nearly 1 lin. apart at the base, simple or once forked, conspicuous above, but searcely visible beneath ; invol. narrow, brownish.- $H k . S p .2 . p .165$.

Hab. Adam's Peak, Ceylon, at about 2,000 ft. - Regarded by Mr. Thwaites as a variety of $P$. cretica.

7. P. dactylina, Hk. ; st. 6-9 in. l., slender, wiry, naked, straw-coloured ; fr. consisting of 3 to 5 linear slightly serrated pinnce, 2-6 in. l., 1 $\frac{1}{2}-2$ lin. br., which issue from at or near the same point, sometimes the two outer ones from a little below the others; texture coriaceous, both surfaces naked; veins conspicuous, simple or forked, usually about 1 lin. distant from one another at the base ; invol. broad, pale.-Hk. Sp. 2. p. 160.t.130. A.

Hab. Nepaul, Sikkim, and Khasya, ascending to 9,000 ft.-In habit this comes near $P$. cretica $\beta$, but the venation is different.

8. P. umbrosa, R. Br. ; st. 12-18 in. 1., strong, erect, bright reddish-brown, scabrous ; fr. 12-24 in. l., 6-12 in br., with a terminal pinna and usually 6 to 9 lateral ones, all of which run down the stipe at the base so as to form a broad wing which reaches nearly or quite to the next node, the upper ones linear, 3-6 in. l., $\frac{1}{4}-\frac{1}{2}$ in. br., finely serrated in the sterile portions, the lower ones forked or with 2 or 4 erecto-patent linear pinnules; rachis and both surfaces naked ; texture coriaceous; veins fine but conspicuous, simple or once forked.Hk. Sp. 2. p. 162.t. 130. B.

Hab. Tropical and Temperate Australia. - A larger plant than $P$. cretica, with a conspicuously winged rachis and several compound pinnæ.

9. P. serrulata, L. fil. ; st. 6-9 in. l., erect, wiry, naked, pale or brownish ; fr. 9-18 in. l., 6-9 in. br., ovate, bipinnatifid, the main rachis margined with a wing which is $1 \frac{1}{2}-2$ lin. br. at the top, and grows gradually narrower downwards; pinno in six or more distant opposite pairs, the upper ones simple, often 4-6 in. 1., $\frac{1}{8}-\frac{1}{4}$ in. br., the lower ones with several long linear erecto-patent pinnules on each side, the edge of the barren ones spinuloso-serrulate; texture scarcely coriaceons ; rachis and both surfaces naked; veins clearly visible, simple or once forked, about 1 lin. apart at the base; invol. narrow, membranous.-Hk. Sp. 2. $p .167$.

Hab. A well-known plant in gardens, common in China, and received lately from Japan from Dr. Hance, and from Natal from R. W. Rawson, Esq.-P. luxuriosa, Kunze, a garden plant, supposed to be a native of Manilla, is said to differ by its longer and narrower frond, less branched and more equal lower pinnæ, and winged petioles.

10. P. crenata, Swartz ; st. 3-6 in. l., slender, erect, naked, straw-coloured ; fr. 6-12 in. l., 3-6 in. br., with a long terminal pinna and 2 to 4 pairs of lateral ones, those of the fertile frond slightly compound, the central portion 2-4 in. l., $\frac{1}{4}$ in or less br., entire, the upper ones of the sterile frond decurrent, the lower ones subdeltoid, cut down to the rachis below into 2 to 6 ovate-oblong sharply-toothed pinnules, which are often $\frac{3}{8}$ or even $\frac{1}{2}$ in. br.; texture subcoriaceous ; rachis and both surfaces naked; veins not very conspicuous, usually once or twice forked.-Hk. Sp. 2. p. 163. t. 127. A.

Hab. Hindostan, from the Himalayas to Ceylon, Chusan, and Loo-choo Islands southward to Tropical Australia, eastward to Samoa and Fiji.-This has the fertile fronds of the present, with barren ones more like those of the next group. 
11. P. distans, J. Sm.; st. about 6 in. l., slender, erect, naked, pale ; fr. about $1 \mathrm{ft}$. l., 4-6 in. br., terminated by a pinna with a long, narrow, sharply serrated linear apex, below which are 12 to 20 pairs of closely-placed short lobes $\frac{1}{2}$ in. or less 1 , $\frac{1}{8}$ in. br., the lower two-thirds of the frond with 6 to 9 opposite pairs of distantly-placed pinnæ with a long linear point, and at the base a few spreading pinnules; rachis scabrous; texture coriaceous ; veins conspicuous, simple or once-forked, about 1 lin. apart at the base ; the barren lobes sharply and finely spinuloso-serrated; invol. membranous.-Hk. Sp. 2. p. 169. t. 124. B.

Hab. Luzon, Philippine Islands; gathered by Mr. Cuming.

*** Pinnatoe. Lowest pinnoe simply pinnate. Sp. 12-18.

12. P. heteromorpha, Fée ; st. 6-12 in. l., naked, erect, pale ; fr. 12-18 in. l., 6-9 in. br., ovate-lanceolate, with the apex of the long terminal point entire, but the lower half sinuated and furnished with a few short linear lobes; pinno in several opposite pairs, the lowest of which are 3-4 in. apart, the upper ones entire or slightly compound at the base, the lowest pair cut down nearly to the rachis with several spreading linear pinnules on each side, 1 in. or more $1 ., \frac{3}{8}$ in. br. ; texture subcoriaceous ; rachis and both surfaces naked, the margins slightly crisped ; veins conspicuous, usually once forked, their bases about 1 lin. apart; invol. narrow, membranous. Hk. Sp. 2. p. 166.t. 127. B.

Hab. Philippine Islands ; gathered by Mr. Cuming.-This may be one of the aberrant forms of $P$. semipinnata, which it resembles in general habit.

13. P. Griffithii, Hk. ; st 6-8 in. l., slender, erect, wiry, naked, strawcoloured; fr. 6-8 in. l., 2-3 in. br., ovate-lanceolate, the terminal pinna linear, entire, about 2 in. l., $\frac{1}{8}$ in. br.; upper lateral ones simple, not more than $\frac{1}{4}$ in. apart, and the base decurrent down to the next, the lower ones lanceolate-deltoid, with a linear entire point and several short erecto-patent linear entire pinnl. on each side ; texture subcoriaceous ; rachis and both surfaces naked ; veins obscure, about $\frac{1}{8}$ in. apart at the base, usually once forked; invol. narrow, membranous.-Hk. Sp. 2. p. 170.t. 123. A.

Hab. Mishmee, N. Hindostan ; gathered by Griffith.

14. P. madagascarica, Ag. ; fr. ample, bipinnate; terminal pinna linear, the upper lateral ones small, linear, sessile, those next in order larger and stalked, the lower ones 2 in. apart at the base, deflexed, oblong-lanceolate, about 6 in. l., 4 in. br., with an entire terminal lobe and several stalked lateral pinnl. on each side, which are about 2 in. $1 ., 2$ lin. br., deeply serrated towards the point, and spreading from the scabrous rachis at right angles; texture coriaceous; veins conspicuous, about 1 lin. apart at the base and usually once forked near the base; invol. narrow, firm.-Hk.Sp.2.p. 171.t. 122. A. P. subserrata, Bojer.

Hab. Madagascar ; gathered by M. Bojer.

15. P. mutilata, Linn.; st. slender, erect, naked, polished, straw-coloured or bright-brown, those of the fertile frond the largest (9-12 in.) and strongest; fr. about 6 in. each way, deltoid, with a linear entire point, several entire pinnoe, but the lowest pair lanceolate-deltoid, 4-6 in. 1., 3-4 in. br., with several linear, erecto-patent pinnules on each side, the divisions of the barren frond shorter and broader than those of the fertile one, not serrated, but mucronate at the point, and furnished with a crisped white cartilaginous border; rachis and both surfaces naked and shining; veins about 1 lin. apart at the base, simple or once forked ; invol. narrow, membranous.-Hk. Sp. 2. p. 164. t. 131. A.

Hab. West-Indian Islands. - P. concinna, Howard, is a more compound form than usual. 
16. P. semipinnata, Linn.; st. 1 ft. or more 1., strong, erect, naked, bright chesnut-brown; fr. 12-18 in. 1., 6-9 in. br., ovate-lanceolate, the upper part cut down nearly to the rachis into numerous close entire linear lobes, the largest of which are $1 \frac{1}{2}-3$ n. l., $\frac{1}{4}-\frac{1}{2}$ in. br., the lower two-thirds with 6 or 8 pairs of opposite distantly-placed pinnoe, the largest of which are 3-6 in. 1., with a long linear entire point, and a broad entire wing on the upper side of the rachis, but the lower side with several linear pinnl. 1-2 in. l., $\frac{1}{4}$ in. br. ; texture scarcely coriaceous, barren segm. finely serrated; rachis and both surfaces naked; veins simple or once forked, $\frac{1}{8}$ in. apart at the base ; invol. membranous.-Hk. Sp. 2. p. 169. Gard. F.t. 59.-, , P.dispar, Kunze ; pinnoe more or less pinnate on the upper side also.

Hab. Himalayas (ascending to 3-4,000 ft.), to Ceylon, S. E. China, Japan, the Philippines, and Borneo.-The two forms look very different when typical, but are connected by intermediates.

17. P. paucinervata, Fée; st. about $1 \mathrm{ft}$. l., erect, naked, reddish-brown; fr. (in our specimen) with a terminal pinna and a single unbranched lateral one on each side, the former broadly lanceolate, 9 in. $1 ., 4$ in. br. below, cut down nearly to the rachis into linear oblong slightly falcate lobes, which are decurrent at the base and bluntly crenate towards the point, the largest 2 in. $1 ., \frac{1}{2}$ in. br. ; lat. pinnoe similar but smaller; rachis and both surfaces naked; texture subcoriaceous; veins fine, once or occasionally twice forked, the lower ones $\frac{1}{8}$ in. to 2 lin. apart at the base ; sori continued nearly to the apex of the lobes. $-H k$. Sp. 2. p. 194.

Hab. Mexico.-This and the next species have quite the habit of quadriaurita, but the venation seems to distinguish them.

18. P. litobrochioides, Klotzsch ; st. strong, erect, naked, bright chesnutbrown ; fr. $2 \mathrm{ft} .1 ., 18$ in. br., the terminal pinna $1 \mathrm{ft}$. or more l., $2-3$ in br., cut down within a short distance of the rachis into numerous spreading linear

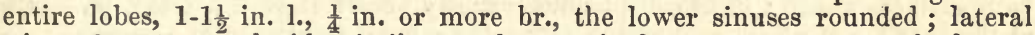
pinnoe 3 or 4 on each side, similar to the terminal one, erecto-patent, the lowest 3 to $4 \mathrm{in}$. distant at the base, all unbranched in our specimens; texture coriaceous; rachis and both surfaces naked; veins conspicuous, once forked, 1 lin. apart at the base; sori reaching nearly to the apex of the lobes.- $H k$. $S p$. 2. $p .178$.

Hab. Gathered by Sir R. Schomburgk in British Guiana, and Dr. Spruce in the Amazon Valley.

\section{**** Bipinnatce. Lowest pinnce at least bipinnatifid. Sp. 19-35.}

19. P. marattiaefolia, Hk. ; st. stout, erect, quadrangular, deeply sulcate, glossy, straw-coloured; fr. ample, bipinnate, the upper part simply pinnate, with several linear lobes which are slightly decurrent at the base, prominently serrated towards the point, the longest 4 in. 1., $\frac{1}{2}$ in. br. : lower pinnoe 6-12 in. l., pinnate, with numerous similar lobes on both sides a d again compound with smaller pinnl. on both sides at the base ; texture scarcely coriaceous; rachis and both surfaces naked; veins usually once forked, $\frac{1}{8}$ in. apart at the base ; sori not reaching to the apex of the lobes.-Hk. $S p$. 2. p. 177. $t$. 122. B. P. flexuosa, Mett. P. semiadnata, Philippi.

Hab. Chili and Chiloe. - A very distinct species, easily recognizable by its large distinct pinnules, of which only the lowest of the basal pinnæe are again compound.

20. P. Dalhousioe, Hk. ; st. strong, erect, about $1 \mathrm{ft}$. high, polished, naked, light-brown; fr. 2-3 ft. l., 12-18 in. br., tri- or quadripinnatifid; upper pinnoe linear, unbranched, decurrent down to the next pair, lower ones sometimes $1 \mathrm{ft}$. l., deltoid ; pinnl. with simple or occasionally with branched linear segm., 
the longest undivided ones 6 in. $1 ., \frac{1}{4}-\frac{3}{8}$ in. br., those of the pinnæ with usually about 1 in. between them, the margins very slightly serrated; texture subcoriaceous; rachis and both surfaces naked; veins fine, simple or once forked, about 3 to a line; invol. narrow, membranous. - Hk. Sp. 2. p. 170. t. 121. A.

Hab. Gathered at Penang by Lady Dalhousie, and in Java by Mr. Lobb.-Very different from any other species of the group. It is most like $P$. umbrosa, but much more compound.

21. P. irregularis, Kaulf.; st. 1-2 ft. 1., strong, angular, naked, polished, brownish ; fr. 12-24 in. l., often $1 \mathrm{ft}$. br.; main rachis with a wing throughout which is $\frac{3}{8}-\frac{1}{2}$ in. br. ; upper pinno linear, simple, lower ones 2-3 in. apart at the base, with several long, linear, erecto-patent pinnl. on each side, which are sometimes again slightly compound; longest simple segm. 3 or 4 in. 1. , $\frac{3}{8}-\frac{1}{2}$ in. br.; rachis and both surfaces naked; texture subcoriaceous; veins about 1 lin. apart at the base, usually once forked; invol. narrow, membranous. - Hk. Sp. 2. p. 173.

Hab. Sandwich Islands ; and a fragment of what is probably this species is in the Herbarium from Sumatra. This again is very distinct. It is more like $P$. Dalhousice than any other species, but the pinnules are regularly pinnate instead of mostly forked.

22. P. quadriaurita, Retz. ; st. 1-2 ft. l., strong, erect, naked or slightly scabrous, straw-coloured or brownish; fr. 6 in. to 2 or $3 \mathrm{ft} .1 ., 4 \mathrm{in}$. to $1 \mathrm{ft}$. or more br., with a terminal central pinna cut down nearly to the rachis into numerous close parallel linear-oblong lobes $\frac{1}{2}-1$ in. $1 ., 2-3$ lin. br., the barren ones entire or slightly serrated, and below this several similar pinnoe on both sides, which are 6-12 in. or more l., 1-2 in. br., the lowest 1-2 in. apart at the base, usually again compound, with one or two similar but smaller pinnl. branching from them at the base on the lower side; texture subcoriaceous; rachis and both surfaces naked; veins conspicuous, usually once forked, 1 lin. to $\frac{1}{8}$ in. apart at the base; sori often continuous along the whole margin of the segments.Hk. Sp. 2. p. 179. t. 134. B.

Hab. All round the world within the Tropics, and a little beyond them. West Tropical Africa-Angola, Natal, Zambesi Land, Madagascar. Hindostan (ascending in the Himalayas to $11,000 \mathrm{ft}$.), S. China and Japan southward to Ceylon and the Malayan and Polynesian Islands and Rockingham Bay in Trop. Australia. America, from Cuba and Mexico southward to Brazil. - Varies much, especially in size. P. asperula, J. Smith, is a form with the rachises and costæ furnished with slender spines; $P$. subquinata, Wallich and Agardh, an Indian form with fewer pinnæ than usual ; $P$. argyroea, Moore, a form with a more or less distinctly marked band of white down the centre of the frond; $P$. tricolor, Linden, the same, with a tinge of red added (see Bot.'Mag. t. 5183): and I cannot distinguish by any clear character the West-Indian P. Swartziana, A gardh, and $P$. felosma, J. Smith; the Brazilian P. sulcata, Link; the Malayan P. pyrophylla, Blume, and $P$. deltea, Agardh, and the South-African $P$. catoptera, Kunze. All our specimens of the Polyuesian plant have dark-brown naked stipes and rachis. Mr. Thwaites sends from Ceylon a series of remarkable abnormal forms passing down gradually into a plant with narrow linear pinnæ, the lowest with only two smaller similar pinnules on the lower side. Down to No. 28 the species are osely allied to this and one another.

23. P. longipinnula, Wallich ; st. erect, naked, 2-3 ft. l., yellowish-green; $f r$. 1-3 ft. 1., 12-18 in. br., the terminal pinna $1 \mathrm{ft}$. or more 1., 2-3 in. br., with numerous spreading, entire, blunt, linear lobes on each side, which are $1 \frac{1}{2}-2$ in. 1 ., and reach down nearly to the rachis at the base, the point caudate; lateral pinnce several on each side, similar to the terminal one, the lowest 2 in. apart, sometimes forked ; texture subcoriaceous ; rachis and both surfaces naked; veins once forked, $\frac{1}{8}$ in. apart at the base ; sori continued nearly to the apex of the segments. $-H k$. Sp. 2. p. 179, t. 134. A. 
Hab. Hindostan (ascending in the Himalayas to 2-4,000 ft.), Malayan Peninsula, Borneo, and Japan.-Very doubtfully distinct from the preceding.

24. P. excelsa, Gaud.; st. stout ( $\frac{1}{4}-\frac{3}{3}$ in. thick), erect, naked, glossy, pale-brown ; fr. 5-6 ft. 1. ; terminal pinna $1 \mathrm{ft}$. or more 1., 3 in. br., with numerous closelyplaced falcate linear lobes on each side, which are sometimes more than 2 in. 1., $\frac{1}{4}-\frac{3}{8}$ in. br., narrowly obliquely decurrent and slightly serrated on the barren part; lateral pinnoe several, similar to the terminal one, the lowest several inches apart at the base, sometimes bipartite; texture subcoriaceous ; rachis and both surfaces naked; veins once forked, $\frac{1}{8} \mathrm{in}$. apart at the base ; sori not reaching the apex of the segments.-Hk. Sp. 2. p. 183.t. 136.

Hab. Hindostan (ascending in the Himalayas to 7-8,000 ft.), Ava, Philippine and Sandwich Islands.-Like $P$. quadriaurita on a larger scale.

25. P. pungens, Willd.; st. 1 ft. or more 1., naked, distinctly prickly, glossy, pale or brownish; fr. 1-2 ft. 1., 12-18 in. br.; terminal pinna sometimes $1 \mathrm{ft}$. l., more than 2 in. br., with a long entire point and numerous close, parallel, linearoblong lobes, which extend down nearly to the rachis (1-1 $\frac{1}{2}$ in. $1 ., \frac{1}{4}$ in. br.), and are finely toothed towards the point when barren; pinnee several on each side, similar to the terminal one, the lowest $2-3$ in. below the next above it, once forked, with a smaller similar pinnule ; texture subcoriaceous ; rachis and both surfaces naked; voins conspicuous, once forked, $\frac{1}{8}$ in. distant at the base; sori not reaching the apex of the segments.-Hk. $S p$. 2. p. 182.

Hab. West-Indian Islands. - If the muricated stipe be not of a permanent character, this cannot be regarded as distinct from $P$. quadriaurita. Poppig's Peruvian plant, called $P$. edentula, Kunze, has a smooth stipe, and is normal quadriaurita.

26. P. scabra, Bory ; st. 1-2 ft. l., strong, erect, glossy, dark chesnut-brown ; fr. 2 ft. 1 . or more, $12-18$ in. br. ; terminal pinna 6-12 in. $1 ., 1 \frac{1}{2}-2$ in. br., made up of numerous linear erecto-patent lobes, which are often 1 in. l., $\frac{1}{4}$ in. br., cut down regularly within about $\frac{1}{8}$ in. of the rachis, and suddenly dilated to the wing within a short distance of the base; lateral pinnoe several in number on each side, similar to the terminal one, the lowest 2 in. apart at the base, with 1 or 2 similar smaller pinnl. on the lower side; texture very coriaceous; rachises rigid and glossy like the stipe; both surfaces naked; veins conspicuous on both sides, simple or once forked, 1 line apart at the base; sori narrow, continuous along nearly the whole length of the segment.-Hk. Sp. 2. p. 187.t.138. A.

Hab. Mauritius and Bourbon.-The texture is so coriaceous that the specinens can scarcely be fastened down on paper. Capt. Carmichael's Bourbon plant with a stramineous stipe, mentioned in "Species Filicum," is evidently P. flabellata. P. angusta of Bory seems to be a smaller form of this, which resembles $P$. quadriaurita in outline, but differs in texture.

27. P. paleacea, Roxb. ; st. 2-4 ft. 1., strong, erect, straw-coloured or reddishbrown, clothed throughout with large lanceolate brown scales, which fall off and leave it densely muricated with hard raised points; $f r .1 \mathrm{ft}$. or more each way ; terminal pinna 6-9 in. l., $1 \frac{1}{2}$ in. br., made up of numerous contiguous falcate linear lobes, which are 1 in. or more $1 ., 2$ lin. br., blunt at the point, and not at all serrated; pinnoe several in number on each side, similar to the terminal one, closely placed (not 1 in. apart at the base) and imbricated, the lowest with several large similar pinnl. from its under side; texture coriaceous ; rachises scaly and asperous like the stipe; veins faint, full $\frac{1}{8}$ in. apart at the base, usually once forked; sori extending along the whole length of the edge.-Hk. Sp. 2. $p .186$.

Hab. St. Hëlena, in the upper exposed part of Diana's Peak.

28. P. Novce-Caledonice, Hk. ; st. $1 \mathrm{ft}$. or more 1., erect, polished, naked, bright claret-brown ; fr. ample ; terminal pinna 6-9 in. $1 ., 1 \frac{1}{2}$ in. br., made up of numerous 
linear erecto-patent contiguous lobes, which are $\frac{3}{4}-1$ in. $1 ., \frac{1}{8}$ in. br., and serrated when barren; lateral pinnoe numerous, contiguous, similar to the terminal one, the lower ones much larger, deltoid, and again compound ; texture herbaceous ; rachises bright-coloured like the stipe, both surfaces naked; veins not conspicuous, simple or once forked, about 1 lin. apart at the base; sori absent from the upper part of the segm.; invol. membranous, conspicuous, $\frac{1}{2}$ lin. br.-Hk. Sp. 2. p. 189.

Hab. New Caledonia; discovered by Mr. C. Moore of Sydney, and since gathered by MM. Vieillard and Deplanche.-Mr. Moore says that the fronds are sometimes 10 feet in height. One of M. Deplanche's specimens shows the lower pinnæ, which measure nearly $1 \mathrm{ft} .1 ., 9$ in. br., and have five large pinnules on each side.

29. P. heterophylla, L. ; st. wiry, slender, erect, naked, straw-coloured ; $f r$. 6-12 in. l., 3-6 in. br., ovate-deltoid, tripinnate ; pinnce all, except two or three of the highest, compound, the lowest deltoid, with the pinnl. again pinnatifid; ult. segm. of the barren frond ovate, sharply and deeply toothed, cuneate and entire at the base, about $\frac{1}{2}$ in. $1 ., \frac{1}{4}$ in. br., of the fertile frond about $\frac{3}{8} \mathrm{in} .1 ., \frac{1}{8} \mathrm{in.}$ br., the tip sterile and toothed; texture herbaceous, both surfaces naked, bright-green; veins obscure ; invol. broad, pale, membranous.-Hk. Sp. 2. p. 166.

Hab. West-Indian Islands and Brazil.

30. P. gracilis, Fée ; st. 6-9 in. l., slender, erect, wiry, naked, polished, pale ; fr. 9-12 in. l., 6-9 in. br., deltoid, tri- or even quadripinnate ; only the very uppermost pinnoe simple, the lower ones hardly more than 1 in. apart, erecto-patent, with numerous closely-placed pinnl. on each side, the lower ones sometimes with the segm. again compound ; the ult. divisions linear, when simple not much over $\frac{1}{2}$ in. l., less than 1 lin. br., those of the barren frond sharply and deeply spinulososerrated ; texture herbaceous ; rachis and both surfaces naked ; veins about $\frac{1}{8}$ in. apart, simple or once forked; invol. pale, membranous. - Hk. Sp. 2. p. 172. t. 128. A. P. semidentata, Fée, Hk. l. c.

Hab. New Granada and South Brazil.-In some of the specimens with most of the veins simple they anastomose casually in the broader segments, so that it is probable that this is a free-veined form of $P$. leptophylla, with which in general habit it coincides.

31. P. laciniata, Willd.; st. $1 \mathrm{ft}$. or more l., stout, erect, very hairy ; fr. 2-4 ft. 1., 1-2 ft. br., deltoid, tripinnatifid, the upper part not cut down to the rachis, with oblong entire lobes $\frac{1}{2}-\frac{3}{4}$ in. $1 ., \frac{3}{8}$ in. br. ; lower pinnce 12-18 in. 1., 6-9 in. br., with numerous lanceolate pinnl. on each side, which are cut down to a broadlywinged rachis into lobes which are about $\frac{1}{2}$ in. $1 ., \frac{1}{4}$ in. br. ; texture herbaceous ; rachis and both surfaces hairy ; veins few, often $\frac{1}{4}$ in. apart at the base, usually once forked; sori lateral in the ultimate lobes, but not reaching the apex.Hk. Sp. 2. p. 176. t. 132. B. Lonchitis hirsuta, Linn.

Hab. Mexico and West Indies southward to Peru.-Though in technical character a Pteris, this is far more like the two species of Lonchitis in habit. Lonchitis Ghiesbreghtii of Linden (Pteris, J. Smith) is a less hairy form than asual.

32. P. arguta, Aiton; st. $1 \mathrm{ft}$. or more 1., strong, erect, naked, glossy, bright straw-coloured or reddish-brown ; fr. 1-3 ft. l., $1 \mathrm{ft}$. or more br. ; terminal pinna 6-9 in. 1., 1 $\frac{1}{2}-2$ in. br., made up of numerous contiguous erecto-patent linear lobes about 1 in. 1., 2 lin. br., which reach down nearly to the rachis, and are slightly toothed when barren ; pinnce several in number on each side, similar to the terminal one, the lowest forked or with one or two similar smaller pinnl. from the base on the lower side; texture herbaceous ; rachis and both surfaces naked ; veins once forked, about 1 lin. distant at the base ; sori nearly $\frac{1}{2}$ lin. br., not usually extending beyond the lower half of the lobes.-Hk.Sp. 2. p. 184.

Hab. Portugal, Azores, Madeira, Canaries. 
33. P. flabellata, Thunb. ; st. 1 ft. or more 1., strong, erect, naked, glossy, strawcoloured ; fr. 1-3 ft. l., $1 \mathrm{ft}$. or more br. ; terminal pinna 6-12 in. 1., 2-3 in. br., made up of numerous almost contiguous erecto-patent linear lobes 1-2 in. 1., 2-3 lin. br., which reach down nearly to the rachis, and are finely serrated when barren; pinnoe several on each side, similar to the terminal one, the lowest with 1 to 3 similar smaller pinnl. from the base on the lower side; texture herbaceous; rachis and both surfaces naked ; veins $\frac{1}{8}$ in. apart at the base, usually once forked; sori narrow, continuing along nearly the whole length of the segments. $-\beta, P$. Ascensionis, Swartz ; much smaller, the lower pinnæ sometimes with several small compound pinnules on both sides.-Hk. Sp. 2. p. 185.

Hab. Cape Colony northward to Bourbon, Abyssinia, and Fernando Po. - This comes very near $\boldsymbol{P}$. arguta. The best character is in the sori, which here are longer and narrower. The Ascension plant grows in a very exposed situation, and has more or less horizontal fronds with ascending or nearly vertical pinnæ.

34. P. tremula, R. Br. ; st. 1 ft. 1. or more, strong, erect, naked, polished, bright chesnut-brown ; fr. 2-4 ft. l., 6 in. to $2 \mathrm{ft}$. br., the apex with a few closely-placed linear entire lobes, which are decurrent obliquely at the base, the largest hardly more than 1 in. l., 1 lin. br. ; upper pinno simply pinnate, with numerous similar lobes on both sides, the largest about 6 il. 1., more than 1 in. br.; lower pinnoe often very compound, sometimes $1 \mathrm{ft}$. 1 . and bipinnate; texture herbaceous ; rachis and both surfaces naked; veins sunk, $\frac{1}{8}$ in. apart at the base, usually once forked; sori copious, sometimes filling up the whole segment except the midrib.-Hk.Sp. 2 . p. 174. t. 120. B. - $\beta, P$. Kingiana, Endl.; ult. segm. larger, sometimes $1 \frac{1}{2}$ in. 1 ., nearly $\frac{1}{4}$ in. br., without being toothed.-Hk. Sp. 2. p. 188.

Hab. Australia, Van Diemen's Land, and New Zealand.- $\beta$ was originally published from Norfolk Island, but some of the New Zealand specimens agree with it.

35. P. Chilensis, Desv. ; st. 6-12 in. l., erect, naked, pale or brownish ; fr. 1-2 ft.1., 9-18 in. br., deltoid, only the very uppermost lobes simple; upper pinnoe lanceolate, cut down nearly or quite to the rachis into short linear-oblong pinnl., which are finely serrated in the barren frond; lowest pinnos sometimes $1 \mathrm{ft}$. l., deltoid, with several bipinnatifid pinnl. on each side, the largest undivided segm. not more than $\frac{1}{2}$ in. $1 ., \frac{1}{8}$ in. br. ; texture herbaceous, or slightly coriaceous ; rachis and both surfaces naked; veins sunk, oblique, about 1 lin, apart at the base, usually once forked ; sori extending from the base to the apex of the segments.-Hk. Sp. 2. p. 175 . t. 120. A.

Hab. Chili and Juan Fernandez.-Agardh gives also Peru, and a plant gathered by Mann on the banks of the Gaboon river in West Tropical Africa I believe to be the same. It is near $P$. tremula, but the segments are broader and shorter, and in the barren frond finely toothed.

***** Tripartitæ. Lowest pinnoe much larger than the others, often nearly equalling the central portion of the frond. Sp. 36-39.

36. P. pellucens, Agardh ; st.1-2 ft. 1., erect, naked, straw-coloured ; terminal pinna about 6 in. $1 ., 1$ in. br., with numerous erecto-patent linear-oblong lobes on each side, which are cut down very nearly to the rachis, about $\frac{1}{2}$ in. $1 ., 2$ lin. br., bluntly toothed towards the point when barren; lateral pinnoe numerous on each side (often 20), not more than 1 in. apart, the longest simple one about 6 in. 1 ., the lowest large, compound, sometimes nearly as large as the central portion of the frond, $1 \mathrm{ft}$. l., 6 in. br.; texture herbaceous ; rachis and both surfaces naked ; veins not prominent, once forked, about $\frac{1}{8}$ in. apart at the base ; sori falling short of the apex of the segments.-Hk. Sp. 2. p. 191.

Hab. South flank of the Himalayas, and a similar plant, with more caudate pinnules, and segments not so close, and decurrent at the base, gathered by Mr. Cuming in the 
Philippine Islands. In some of the specimens, but not all, the costa of the pinnules is spinulose on the upper side.

37. P. deflexa, Link; st. $2 \mathrm{ft}$. or more 1., strong, erect, naked or slightly asperous below, straw-coloured or reddish-brown; fr. ample, $2-4 \mathrm{ft}$. 1. ; terminal pinna 6-9 in. l., about 1 in. br., with a long point and numerous linear-oblong lobes on each side, which are nearly cut down to the rachis, about $\frac{1}{2}$ in. l., $\frac{1}{4}$ in. br., the barren ones sharply spinuloso-serrated ; lateral pinnoe numerous, similar, the lower ones stalked, the lowest pair much larger than the others, often more than $1 \mathrm{ft}$. 1., 6-9 in. br., with numerous pinnate pinnl. on each side; rachises smooth ; texture coriaceous ; veins once forked, $\frac{1}{8}$ in. apart at the base ; sori reaching nearly to the apex of the segments.-Hk. Sp. 2. p. 190. P. stridens, Ag. Hk. Sp. 2. p. 192.

Hab. Tropical America, from the West Indies southward to Brazil and Peru. P. Gaudichaudii, Ag., is either this species or closely allied. In general aspect this species comes between quadriaurita and aquilina.

38. P. coriacea, Desv. ; st. 1-2 ft. l., erect, straw-coloured, asperous ; fr. $2 \mathrm{ft} .1$. or more, deltoid ; terminal pinna lanceolate, 6-9 in. 1. , $\frac{3}{4}$ in. br., with numerous linear-lanceolate falcate lobes on each side, which are $\frac{1}{2}-\frac{3}{4}$ in. $1 ., 1-1 \frac{1}{2}$ lin. br., sharply spinuloso-serrated when barren ; lateral pinnoe a dozen or more on each side, similar, the lower ones slightly compound below, the lowest pair nearly as large as the central portion of the frond ; pinnl. again bipinnate ; texture coriaceous; partial rachises densely muricated with small prickles, which also run along the midribs of the ultimate divisions beneath; veins usually once forked, about $\frac{1}{8}$ in. apart at the base ; sori reaching nearly to the apex of the segments. Hk. Sp. 2. p. 192. t. 124. A.- $\beta, P$. Jamesoni, Hk. ; lowest ultimate divisions 1 in. l., $\frac{1}{4}$ in. br., sometimes decurrent at the base ; texture very coriaceous ; rachis beneath scarcely muricated.-Hk. Sp. 2. p. 194. $t .193$.

Hab. Tropical America, from Venezuela along the Andes to Peru.-P. muricata, Hk., differs from $\beta$ principally by its lower pinnæ being conspicuously stalked at the base. This species much resembles $P$. deflexa in general appearance, but may be known readily by its muricated rachises. A muricated plant, gathered by Dr. Spruce in the Central Andes (Nos. 5707 and 5665), is probably distinct. The stipe is strong and distinctly prickly, and is marked in one of the numbers as 5, and in the other as 12 feet in length. One of the pinnæ is 2 feet long, the largest pinnule 10 inches, and the largest ultimate segment 1 inch long, 2 lines broad. The venation is fainter than in P. coriacea, and both surfaces are bright-green. What appears to be the same plant is in the Herbarium from New Granada from Linden and Lieut. Norton, and these latter are the $P$. coriacea $\beta$ of the Sp. Fil. p. 192.

39. P. brerisora, Baker; st. 2-4 ft. 1., strong, erect, quite smooth ; fr. with a central pinna 1-2 ft. 1., 6-9 in. br., and two opposite lateral ones which are nearly as large ; pinnl. 4-6 in. l., $\frac{1}{2}-\frac{3}{4}$ in. br., lanceolate acuminate, the lowest 1-2 in. apart ; segm. numerous, $\frac{1}{2}$ in. l., $\frac{1}{8}$ in. br., linear-oblong, blunt, very slightly toothed; texture herbaceous; rachis naked; sori in a continuous line along the border of each segment.-Hypolepis pteridioides, Hk. 2 nd Cent. t. 59.

Hab. Cameroon Mountains and Fernando Po, at an elevation of 4-7,000 ft. ; discovered by Mr. Mann.

§ Pæsia, St. Hilaire. Veins free, rhizome creeping, stems sub-distant, involucre more or less distinctly double. Ornithopteris, Agardh. Sp. 40-43. According to strict technical characters, this group of species, which differs from the rest of the genus also in habit of growth, has as good a claim to be placed in Lindsayæ as Pterideæ. Tав. III. f. $31, d$, e, f.

40. P. (Pæsia) aquilina, L.; rhizome stout, wide-creeping, subterraneous ; st. ft. or more l., strong, erect, naked, straw-coloured or pale-chesnut; fr. 2-4 ft. 
or more 1., 12-24 in. br., subdeltoid in general outline, only the uppermost pinnoe simple, those next in order lanceolate, cut down nearly or quite to the rachis into short triangular or linear pinnl, the lowest long-stalked, $1 \mathrm{ft}$. or more 1 ., with ample lanceolate pinnl, which are cut down to the rachis into numerous lanceolate segm., which are again fully pinnate; largest entire ult. divisions. 1 in. $1 ., 2$ lin. br.; texture subcoriaceous; rachis and both surfaces naked or pubescent ; veins close, conspicuous, often twice forked, involucre double or the inner one obsolete. $-\beta, P$. caudata, L. ; pinnl. sometimes linear and entire or with less crowded segm. than in $a$, and the terminal lobe linear entire, 1-2 in. 1 . $-\gamma, P$. esculenta, Forst. ; ult. divisions narrower and not contiguous, suddenly decurrent at the base, so that the bases are connected by a narrow lobe.-Hk. $S p$. 2. $p$. 196. P. arachnoidea, Kaulf.

Hab. All round the world both within the Tropics and in the North and South Temperate Zones, unless it be absent from South Temperate America, from which there are no specimens in the Herbarium. In Lapland it just passes within the Arctic circle, ascending in Scotland to 2,000 ft., in the Cameroon Mountains to 7,000 ft., in Abyssinia to 8,000 or $9,000 \mathrm{ft}$., in the Himalayas to about $8,000 \mathrm{ft}$; ; $\gamma$ inhabits principally New Zealand, Australia, the Polynesian Islands, and Tropical South America.-Dr, Spruce has seen it. in the Andes $14 \mathrm{ft}$. in height.

41. P. (Pæsia) viscosa, Baker ; rhizome wide-creeping, subscandent, densely clothed with dark-brown fibrillose scales; st. $1 \mathrm{ft}$. or more l., flexuose, darkbrown, glanduloso-villose ; fr. ample, decompound; upper pinnoe small, lanceolate, pinnatifid, the lower ones 1-2 ft. 1., 6-9 in. br., spreading, with numerous lanceolate pinnl. on each side, which are cut down into deeply lobed lanceolate-deltoid spreading segm., about $\frac{1}{2}$ in. 1., $\frac{1}{4}$ in. br.; texture scarcely coriaceous ; rachises very wavy, like both surfaces, densely clothed with brown viscid glands; invol. double, membranous, the inner one sometimes obsolete. Pæsia viscosa, St. Hilaire. P. scalaris, Moritz. Hk. Sp. 2. p. 200. t. 121. B. \& 3. $t$. 141. C.

Hab. Jamaica, Venezuela, and Peru.-Dr. Spruce's Peruvian specimens have the largest pinnules not more than $1 \frac{1}{2}$ in. $1 ., \frac{1}{2}$ in br., their segments cut down to the rachis into small oblong-cuneate lobes about $\frac{1}{2}$ lin. br. ; and with these a plant gathered by M. Deplanche in New Caledonia quite agrees.

42. P. (Pæsia) scaberula, Richard ; rhizome wide-creeping; st. 6-12 in. 1., strong, flexuose, bright reddish-brown, scabrous ; fr. 12-18 in. 1., 6-9 in. br., lanceolate or ovate-lanceolate, tri- or quadripinnatifid; lower pinnoe lanceolatedeltoid, 4-9 in. 1., cut down to the rachis into numerous lanceolate pinnl. on each side, which are again cut down into oblong toothed segm. 2-3 lin.1., 1 lin. br.; texture subcoriaceous; rachis flexuose and scabrous like the stipe, upper surface asperous ; sori copious, occupying when mature nearly the whole segment except the midrib.-Hk. Sp. 2. p. 174.t.93. A.

Hab. New Zealand.

43. P. (Pæsia) rugulosa, Labill. ; st. erect, strong, glossy, nearly smooth, pale-brown ; fr. ample, quadripinnatifid ; lower pinnoe 12-18 in. 1., 4-6 in. br.; pinnl. lanceolate, distant, spreading at right angles; lower segm. deltoid, cut down to the rachis into numerous oblong deeply toothed ult. divisions; texture herbaceous ; rachis rigid, zigzag, glossy, scarcely asperous, both surfaces of the frond naked; sori 1 lin. 1., placed along the sides of the ult. divisions.-Hypolepis, Hk. Sp. 2. p. 68.

Hab. Society Islands. - This is clearly a Pteris, not a Hypolepis; and both this and $P$. scaberula show occasionally a narrow membrane on the inner side of the receptacle, as in aquilina and viscosa. 
\$\$\$ Heterophlebium, Fée. Veins free below, anastomosing towards the nargin. S j. 44-45. TАB. III. f. 31. c.

44. P. (Hetero.) lomariacea, Kze.; st. 6-12 in. l., wiry, flexuose, dark chesnutbrown, naked; fr. deltoid, about 4 in. each way, with a terminal linear lobe and cut down below to a broadly-winged rachis into 2 or 4 pinnoe on each side, the lowest of which are much the largest and again deeply lobed on the lower side; primary and secondary lobes of the barren frond $\frac{1}{4}-\frac{3}{8} \mathrm{in.}$ br., of the fertile, longer, narrower, and more divided ; texture subcoriaceous, both surfaces naked; veins very inconspicuous, close, fine, anastomosing slightly towards the margin ; costoe dark-coloured and polished like the stipe; invol. rather broad, membranous, ultimately spreading.-Pellæa, Hk.Sp.2. p. 135.

Hab. Gathered by Sir R. Schomburgk and Appun in British Guiana, and by Messrs. Gardner and Lindberg in the South of Brazil. This resembles very closely $P$. palmata in habit, but the venation is quite different. The veins are very close, and nearly parallel, simple or once forked; and the branches of the same veins or of two contiguous ones occasionally join near the edge. The three plants brought together under this name in "Species Filicum" must be separated, one to be placed near Pellcea geraricefolia, and the other near $P$. palmata.

45. P. (Hetero.) grandifolia, Linn.; st. 6-12 in. 1., erect, naked, strawcoloured, clothed below with rusty woolly scales; fr. 1-2 ft. l., simply pinnate; pinno linear, erecto-patent, entire, sessile, or the lower ones stalked, the lower ones 6-12 iu. l., $\frac{3}{4}-1$ in. br. ; texture coriaceous ; rachis and both surfaces naked; veins fine, less than $\frac{1}{8}$ in. apart at the apex, anastomosing only in the outer third of the space between the rachis and edge; sori often continuous along the whole length of the pinnæ.-Hk. Sp. 2. p. 201.t. 113. $\mathrm{B}$.

Hab. Tropical America, from Mexico and the West Indies southward to Peru.-P. vittata, Schk., is a form with nearly free veins. Sir H. Barkly sends from Jamaica a form with the pinnæ curiously sinuated, and some of them branched.

\$\$\$ Campteria, Presl. Veins all free, except that those of the last divisions but one are more or less connected by arching veins at the very base. Sp. 46-50. TAB. III. f. 31. g.

46. P. (Camp.) biaurita, L. ; st. 1-2 ft. 1., strong, erect, naked, straw-coloured ; fr. with a terminal pinna 6-12 in. 1., $1 \frac{1}{2}-2$ in. br., cut down within from $\frac{1}{8} \cdot \frac{1}{4}$ in. of the rachis into numerous spreading linear-oblong lobes on each side, which are 1 in. or more l., $\frac{1}{4}$ in. or less br.; lateral pinno several on each side, similar to the terminal one, the lower ones 2 in. apart and usually once forked; texture subcoriaceous; rachis and both surfaces naked; veins prominent, those of the ult. segm. quite free, usually once forked, $\frac{1}{8}$ in. apart at the base, but the midrib of the segments connected by an arching vein which passes from base to base; sori continued to the apex.-HK. Sp. 2. p. 204.

Hab. West Tropical Africa, Mauritius, Bourbon, Hindostan (ascending in the Himalayas to 4,000 ft.), Ceylon, Java, S. China, Malayan Peninsula, and Tropical America from the West Indies southward to Brazil. - This differs only from $P$. quadriaurita in the pinnæ being less deeply pinnatifid, and the bases of the midribs of the segments being connected by an arching vein. This arch springs normally from the bases of the midribs, but sometimes begins and ends at points between them. It is sometimes triangular, but sometimes very low, and in what Agardh considers as $P$. nemoralis, Willd., we have the venation considered as characteristic of biaurita combined with the entirely free venation considered as characteristic of quadriaurita in one and the same frond, so that they must be regarded as very doubtfully distinct. ' $P$. Galeotti, Fée; $P$. amœena, Blume; $P$. atrovirens, Willd.; and $P$. armata, Presl, are apparently allied plants ; and C. Kleiniana, Presl, and C. Anamallayensis, Beddome, I cannot distinguish clearly. 
47. P. (Camp.) patens, Hk. ; st. 1 ft. or more l., erect, naked, glossy, chesnutbrown ; fr. ample, 3-4 ft. l., $2 \mathrm{ft}$. or more br.; terminal pinna 6-9 in. $1 ., 1 \frac{1}{2}-2$ in. br., with several narrow linear lobes on each side, which are widened suddenly on both sides within a short distance of the base, the barren ones slightly serrated ; lateral pinnoe numerous, similar but larger, sometimes 18 in. 1 ., 2 in. br., the lowest forked; texture scarcely coriaceous ; rachis and both surfaces naked ; veins oblique, not conspicuous, usually once-forked, 1 line apart at the base; sori continued nearly to the end of the segment.-Hk. Sp. 2. p. 120. A. P. decussata, $J$. $\$$ m .

Hab. Ceylon, Borneo, Philippines, Society Islands.-By looking on the upper surface towards the top of the frond, shallow costal arches may clearly be seen, so that Mr. Thwaites is doubtless quite correct in his suggestion of the identity of Litobrochia Gardneri, Fée, with our plant. The sudden widening of the base of the often nearly opposite lobes (which suggested J. Smith's name) is more conspicuous here than in any other of the quadriaurita series.

48. P. (Camp.) triplicata, Ag. ; st. strong, erect, smooth, naked ; fr. 1-2 ft. l., 9-12 in. br., the terminal pinna 6-9 in. $1 ., 1-1 \frac{1}{4}$ in. br., cut down within $\frac{1}{8}$ in. of the rachis into numerous spreading contiguous entire linear-oblong lobes, which are $\frac{3}{4}$ in. $1 ., \frac{1}{4}$ in. br., and blunt at the point; lateral pinnoe few and distant ( 4 to 6 on each side and the lowest 3 in. apart) with a stalk about 1 in. 1 ., an apex like the terminal pinna with a long entire caudate point and two smaller stalked spreading pinnl.; texture scarcely coriaceous; rachis and both surfaces naked; veins all free except the basal arch; sori continuous along the whole edge of the segments.-Hk. Sp. 2. p. 205.

Hab. Mozambique; gathered by Forbes, and said by Agardh to be also a plant of Madagascar.

49. P. (Camp.) Melleri, Baker ; st. 6-12 in. 1., firm, erect, naked, brownish ; fr. 18 in. l., 9 in. br., the terminal pinna 4 in. l., the upper two-thirds linear, the apex sharply toothed, the rest broadly undulated at the margin, the lower part with two linear lobes on each side; pinnoe numerous, the upper pair linear and sessile, 3 in. $1 ., \frac{1}{4}$ in. br., all the lower ones more or less compound, on petioles $\frac{1}{2}$ in. or more l., the point and often the pinnules linear entire ; lobes not reaching down to the rachis, linear, bluntish, deeply serrated, the longest about $\frac{1}{2}$ in. l., $\frac{1}{4}$ in. br., sometimes present on one side of the pinna or pinnule and not on the other; lowest pinna with 5 pinnules, which are again slightly compound at the base ; texture subcoriaceous; veins united only by costal arches, which are sometimes present, sometimes not when the pinnæ and pinnules are not pinnatifid; rachis and both surfaces naked.

Hab. Cascades of the Anevoca Valley, Madagascar. Dr. Meller.-This may be a very abnormal form of the preceding. We have a single specimen only.

50. P. (Camp.) Wallichiana, Agardh ; st. 5-6 ft. 1., strong, bright chesnutbrown, naked, glossy; fr. tripartite with lateral divisions again forked, the central one often $2 \mathrm{ft}$. l., $1 \mathrm{ft}$. br., with numerous lanceolate sessile opposite pinnl. on each side, the largest of which are 6 in. l., under 1 in. br., cut down within about $1 \mathrm{lin}$. of the rachis into numerous contiguous linear-oblong lobes, $\frac{3}{8}-\frac{1}{2}$ in. l., $\frac{1}{8}$ in. br., nearly entire when barren; lateral pinnoe nearly as large as the terminal one; texture herbaceous; rachis and both surfaces naked; veins not conspicuous, usually once forked near the base, 1 lin. apart ; sori continuous along nearly the whole length of the edge.-Hk. Sp. 2. $p .206$.

Hab. Himalayas (ascending to 8,000 ft.), Japan, and Philippine Islands.-Occasionally an areole may be seen at the base of the segments near the arch, and it may be doubted 
whether this be not a Campteroid form of $P$. tripartita, which it resembles closely in all respects except venation.

§§§§ Doryopteris, J. Smith. Fronds small, sagittate or subpedate, veins copiously anastomosing, without free included veinlets. Sp. 51-59.

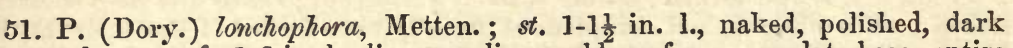
chesnut-brown; fr. 1-3 in. l., linear or linear-oblong from a cordate base, entire or furnished at the base with two short spreading lobes with rounded basal auricles, when undivided $\frac{1}{8}-\frac{1}{4}$ in. br. ; texture coriaceous; rachis and both surfaces naked; veins anastomosing, immersed; sori subcontinuous; invol. crisped, subscariose.-Mett. Cheil.p. 5. t. 3.

Hab. Rio Janeiro.

52. P. (Dory.) sagittifolia, Raddi; st. 4-6 in. 1., erect, naked, blackish, polished; fr. 4-6 in. 1. from the top of the stipe to the apex, $2-3$ in. br. opposite the former point, hastate-lanceolate or subtriangular, the basal lobes triangular acuminate, directed downwards, the margin entire ; texture coriaceous; both surfaces naked; midrib blackish like the stipe; veins inconspicuous, copiously anastomosing; sori continued all round the margin.-Ex.F.t. 39.$\beta, P$. hastata, Raddi; with two large lateral lobes spreading horizontally in addition to the deflexed basal ones.-Hk. Sp. 2. p. 207.

Hab. Venezuela southward to Brazil.

53. P. (Dory.) ludens, Wallich ; st. naked, or below pubescent, polished, nearly black, that of the barren frond $3-4$ in. 1.; barren fr. varying in shape from triangular with two slightly deflexed basal lobes to hastate, with two basal and two large spreading lateral lobes, the margin entire; fertile fr. with a stalk often $1 \mathrm{ft} .1$., 4-6 in. each way, cut down into five linear-lanceolate or lanceolate lobes, one erect, two spreading, and two deflexed, of which all, except the last, are sometimes again forked; texture coriaceous; costa polished like the stipe; veins hidden; sori continuous all round the margin.-Hk. Sp. 2. p. 210.

Hab. Malayan Peninsula and Philippine Islands.

54. P. (Dory.) ornithopus, Metten. ; st. 6-12 in. 1., strong, wiry, flexuose, polished, dark brownish-black, naked; barren fr. 3 in. deep, 4 in. br., palmately lobed, the central segment deep, triangular, the three lateral ones on each side not so deep and blunter ; fertile fr. cut down within $\frac{1}{2}$ in. of the base into seven entire linear lobes 2-3 in. l., $\frac{1}{4}$ in. br., the outer ones each with a smaller linear lobe at the base, each with a broad thick central costa ; texture very leathery; both surfaces naked; veins inconspicuous, anastomosing copiously; invol. broad, leathery.-P. lomariacea $\gamma, H k . S p . F i l . p .133$.

Hab. South of Brazil, Burchell, Gardner, and Lindberg.-This agrees with P. palmata in texture and venation, differing in having on the fertile frond several narrow segments like the claws of a bird radiating from an undivided centre.

55. P. (Dory.) palmata, Willd.; st. 1 ft. or more 1., erect, nearly naked, polished, chesnut-brown ; fr. 4-9 in. each way, the barren ones with a broad undivided centre and five or more triangular lobes, of which the terminal one is the largest, the lowest deflexed and the sinuses rounded; fertile fr. cut down to a broadly winged centre into linear lobes, of which the upper ones are entire and the lower ones again cut on the lower side, the longest entire ones 3-4 in. l., $\frac{1}{4}-\frac{3}{8} \mathrm{in} . \mathrm{br}$; texture thick and coriaceous; rachis and both surfaces naked; costoe black and polished; veins anastomosing copiously; sori continued to the apex of the segments.-Hk. Gard. F.t. 22. P. pedata, Hk. Syn. Fil. 2. p. 208. in part. P. collina, Raddi. Dory. euchlora, Klotzsch. D. nobilis, Hort. 
Hab. Tropical America, from West Indies and Columbia southward to Peru and Rio Janeiro; and there is a specimen from Wallich marked $P$. Mysurensis, Heyne, from Dindighul in Hindostan, in Herb. Hooker.

56. P. (Dory.) pedata, Linn. ; st. blackish, naked, polished, those of the barren fr. 3-4 in. 1.; barren fr. 1-2 in. each way, with an almost entire triangular apex, and a bluntly divided lateral lobe on each side ; fertile fr. 4-6 in. each way, cut down nearly to the rachis into several pinnoe on each side, of which the upper ones are linear and entire (1-1 $\frac{1}{2}$ in. $1 ., \frac{1}{4}-\frac{3}{8}$ in. br.), the lowest pair much larger than the others, and with several pinnules on the under side, the lowest of which are again pinnatifid; texture scarcely more than herbaceous; rachis and both surfaces naked; costce dark-coloured and polished; sori reaching to the point of the segments.-Hk. Ex. F.p. 34. Sp. 2. p. 208. in part.

Hab. Tropical America, from the West Indies southward to Brazil.

57. P. (Dory.) decipiens, Hk.; st. 6 in. 1., erect, naked, polished, nearly black; fr. 3-6 in. each way, nearly or quite cut down to the rachis above the lower pair of pinnæ; upper divisions entire, falcate ; the central ones deeply cut, the lower pair much larger than the others; lowest pinnl. $1 \frac{1}{2}-2$ in. l., cut down nearly to the rachis into 3-6 deep linear-oblong lobes; texture coriaceous, rachis and both surfaces naked; costoe black, polished; veins hidden, anastomosing copiously; sori reaching the tip of the segments.-Hk. Sp. 2. p. 209.

Hab. Sandwich Isles._-Precisely resembling Pellaea geraniifolia in size and outline, differing by its Pteroid sori and anastomosing venation.

58. P. (Dory.) Felicienno, F. Muell.; st. slender, smooth, 6 in. 1., stramineous ahove, ebeneous at the base; $f r$. cordate-deltoid in general outline, with a terminal lobe and 3 to 5 deeply pinnatifid lanceolate oblong pinnoe, the lowest pair distant from the others, slightly stalked, 3 in. l., the upper ones sessile or decurrent; lateral lobes of the pinnæ ovate or oblong crenulate; texture membranous; 'achis slender, naked, stramineous; veins reticulated.-F. Muell, Frag. 36. p. 124.

Hab. Rockingham Bay, Australia, Dallachy.-This we have not seen.

59. P. (Dory.) decora, Bracken.; st. 6-8 in. 1., erect, naked, dark chesnutbrown; fr. 3-4 in each way, with a narrow linear terminal lobe decurrent down to 2 or 3 pairs of similar lateral ones, and below these two pairs of compound pinnoe, the lowest cut down to the base into three principal divisions, each again pinnate, their lowest segm. nearly 2 in. l., less than 1 lin. br. ; texture coriaceous; rachis and both surfaces naked; veins quite hidden; sori reaching to the apex of the segments.-Hk. Sp.2.p.210. Brack. t. 13.

Hab. Sandwich Islands ; discovered by the American Exploring Expedition; and very fine specimens have since been gathered by Dr. Hillebrand.-Although the pagina is so narrow, the veins clearly anastomose.

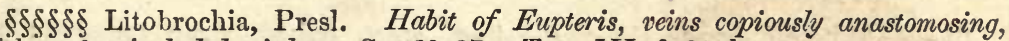
without free included veinlets. Sp. 60-87. ТАв. III. f. 31. h.

\section{* Integrifolice. Sp. 60-63.}

60. P. (Lito.) Vicillardi, Metten.; st. 6-12 in. l., erect, wiry, naked, chesnutbrown, that of the barren fr. shorter than that of the fertile one, both (in our specimens) with a long linear central lobe, which is 6 in. l., in the barren one 1 in., and in the fertile one $\frac{3}{8}$ in. br., quite entire, and two smaller lateral ones; texture coriaceous, both surfaces naked; veins anastomosing copiously ; sori continuous to the apex of the pinnæ.-Metten. Fil. Nov. Cal. p. 12. 
Hab. New Caledonia; discovered by M. Vieillard.-A very distinct species, the least divided of the subgenus.

61. P. (Lito.) lancecefolia, Agardh ; st. erect, naked, pale, glossy ; fr. simply pinnate, 12-18 in. 1., 6-9 in. br. ; pinnoe linear, entire, slightly stalked, 4-6 in. 1., $\frac{1}{2}$ in. br., erecto-patent, the lowest about 1 in. apart; texture subcoriaceous; rachis and both surfaces naked; veins copiously anastomosing ; sori very narrow ; falling short of the apex of the pinnæ.-Hk.Sp. 2. p. 212. P. alternifolia, Bojer.

Hab. Madagascar; discovered by M. Bojer.

62. P. (Lito.) splendens, Kaulf.; st. erect, naked, dull, slightly scabrous ; fr. ample, simply pinnate, with numerous pairs of nearly sessile linear pinnoe, the largest of which are $1 \mathrm{ft}$. l., more than $1 \mathrm{in}$. br., spinuloso-serrated towards the acuminate point; texture coriaceous ; rachis and both surfaces naked; veins conspicuous, copiously anastomosing; sori falling rather short of the apex of the pinnæ, ultimately hiding the narrow invol.-Hk. Sp. 2. p. 211.

Hab. Brazil.-P. chrysodioides and papyracea of Fée appear to be closely allied. Frond sometimes quite entire.

63. P. (Lito.) Mannii, Baker ; st. 3 ft. l., slender, flexuose, downy; fr. 12-18 in. 1., 6-9 in. br., the terminal pinna subhastate with two erecto-patent, broad-lanceolate lobes; lateral pinnoe in 5 to 7 nearly opposite pairs, $1 \frac{1}{2}-3$ in. apart, the lowest pair but one the largest, 6 in. 1 ., under 1 in. br., linear, the point acute, the margin only slightly sinuated, the base deeply cordate, and the upper side slightly auricled; texture herbaceous; rachis rather thickly clothed with fine spreading hairs, and both surfaces, especially the midrib, also hairy; veins fine, anastomosing copiously; sori continuous along the undulated edge nearly to the point.

Hab. Fernando Po ; discovered by Gustave Mann.

** Pinnatoe. Sp. 64-71.

64. P. (Lito.) laurea, Desv.; st. 1 ft. 1., erect, naked, polished, straw-coloured or pale bright-brown; fr. 12-18 in. $1 ., 9$ in. br., oblong, the terminal pinna linear, entire, deeply serrated towards the point, 6 in. or more l., $\frac{1}{4}-\frac{3}{8}$ in. br. ; lateral pinnoe numerous, 1-2 in. apart at the base, even the upper ones slightly compound, the lower ones branched, with a long entire point and one or two small stalked linear pinnl. on each side, which are occasionally again compound; texture subcoriaceous; rachis and both surfaces naked; veins $1-1 \frac{1}{2}$ lin. apart at the base, and the hases sometimes connected by a transverse veinlet, often twice branched before they reach the edge; invol. narrow, membranous. -Hk. Sp. 2. p. 166. P. triphylla, Agardh. Hk. Fil. 2. p. 171. t. 131. B.

Hab. Madagascar ; gathered originally by Dr. Lyall, and much finer specimens have been sent recently by Dr. Meller.

65. P. (Lito.) Currori, Hk.; st. stout, erect, naked, straw-coloured; fr. ample, several ft. 1., $2 \mathrm{ft}$. or more br., the terminal pinna subhastate, deeply lobed; lateral pinnoe numerous, the upper ones 4-6 in. 1., 1 in. br., the margin deeply and broadly sinuated, the lowest (in our specimens) in opposite sessile pairs 2-3 in. distant from the next pair, 16 in. $1 ., 5$ in. br., cut down within a very short distance of the rachis in the lower part into lanceolate sinuated lobes 3 in. deep, $\frac{3}{4}$ in. br.; texture scarcely more than herbaceous; rachis and both surfaces slightly hairy; veins fine, copiously anastomosing; sori in numerous patches, which are sometimes interrupted and very short.- $H k$. $S p .2$. $p .232$. t. 140.- $\beta, P$. Barteri; rachis hairy; costa beneath and whole under surface clothed with long, fine spreading hairs; veins stronger and more prominent. 
Hab. Discovered at or near Elephants' Bry, West Tropical Africa, by the late Dr. Curror, and fine specimens were procured on the mountains of Fernando Po at 3-500 ft., by Gustave Mann. - $\beta$, which is not unlikely a distinct species, was gathered on the Niger expedition by Barter, who describes the rhizome as creeping. This comes very near Lonchitis in texture, and the sori are often only reniform, and show a decided preference for the sinuses.

66. P. (Lito.) denticulata, Swartz; st. about 1 ft. l., slender, wiry, naked; fr. 12-24 in. l., 8-12 in. br.; upper pinnce simple, linear, 4-6 in. 1., $\frac{1}{2}-\frac{3}{4} \mathrm{in.} \mathrm{br.,}$ united at the base, finely spinuloso-serrated when barren, those next in order quite cut down to the rachis and forked, the lower ones often pinnatifid with several linear pinnnl., especially on the lower side; texture subcoriaceous ; veins fine, anastomosing copiously; rachis and both surfaces naked; sori not quite reaching the point of the pinnules.-Hk. Sp. 2. p. 215. Hk. \& Gr.t. 28.$\beta, P$. Brasiliensis, Raddi ; pinnoe broader, 6-9 in. 1., 1 in. br., more compound.Hk. Sp.2.p. 214.

Hab. Tropical America, from the West Indies southward to Brazil.-The typical form much resembles cretica in general aspect.

67. P. (Lito.) Hoenkeana, Presl ; st. 1-3 ft. l., pale, firm, naked ; fr. several ft. l., the upper part with numerous, simple, linear pinnoe on both sides, which are $6-9$ in. $1 ., 1-1 \frac{1}{2}$ in. br., a cuminate at the point, narrowed gradually towards the base, the lower ones slightly stalked and about 2 in. apart, the barren ones finely spinuloso-serrated, the lower pinnæ often $1 \mathrm{ft}$. or more 1., spreading with. numerous similar pinnl.; texture coriaceous; rachis and both surfaces naked; veins fine, clearly visible, anastomosing copiously; sori not quite reaching the point of the pinnules.-Hk. Sp. 2. p.213.

Hab. Tropical America, from Guatemala and New Granada southward to Peru.

68. P. (Lito.) pulchra, Schlecht.; st. strong, erect, naked, polished, strawcoloured; fr. ample, simply pinnate above, with numerous sessile linear, acuminate pinnce on each side, which are 4-6 in. 1., $\frac{1}{2}-\frac{3}{4}$ in. br., slightly serrated towards the point, lower pinnæ simply pinnate, $1 \mathrm{ft}$. or more $1 ., 6-9 \mathrm{in}$. br., nearly opposite, 1 in. or more apart; texture coriaceous; rachis and both surfaces naked; veins fine and numerous; sori not extending to the apex of the pinnules, ultimately concealing the invol.-Hk. Sp. 2. p. 213.

Hab. Mexico, ascending to 5,000 feet.

69. P. (Lito.) macroptera, Link; st. 1 ft. or more 1., erect, naked, polished, straw-coloured or brownish; fr. $2 \mathrm{ft}$. or more l., 12-18 in. br., cut down very nearly to the rachis in the upper part into numerous linear lobes, the lowest. of which are 6-9 in. $1 ., \frac{1}{2}$ in. br., with about 1 in. between them at the base, the point narrowed very gradually and very faintly toothed when barren; lat. pinnoe few, often a single pair only, like the terminal one, but smaller; texture papyraceo-herbaceous; rachis and both surfaces naked; veins fine but conspicuous ; sori not reaching the apex of the segments.

Hab. Brazil, Burchell, \&c.

70. P. (Lito.) vestita, Baker ; st. slender, erect, $1 \mathrm{ft}$. or more l., villose when young, straw-coloured or brownish ; fr. 18-24 in. l.; terminal pinna 12-15 in. l., $2 \frac{1}{2}$ in. br., cut down to a broadly-winged rachis into numerous lobes on both sides, the upper ones close, the lower ones $1 \frac{1}{4}$ in. l., $\frac{3}{8}$ in. br., falcate with a space. between them ; lateral pinnoe two on each side (in our specimens), spreading, like the terminal one but smaller, caudate at the point; main rachis and those of the pinnæ densely villose; both surfaces hairy; veins fine, anastomosing copiously; sori confined to the inner two-thirds of the segments; invol. consisting principally of a dense fringe of strong hairs.

Hab. Peru, Spruce, 4063.-Habit most like the next, but the pinnæ much larger and. fewer. 
71. P. (Lito.) Junghunhii, Baker ; st. firm, erect, polished, nearly strawcoloured; fr. $2 \mathrm{ft}$. 1., with numerous pinnce on each side, which are cut down two-thirds of the way to the rachis into linear-oblong falcate lobes $\frac{1}{4} \mathrm{in}$. br. at the base, the lowest (in our specimens) simple, 9 in. l., 1 in. br. ; texture subcoriaceous ; rachis and both surfaces naked ; veins fine, anastomosing principally in costal arches and in the space between the sinuses and midrib; sori reaching nearly to the point of the segments.-Campteria, Reinw.

Hab. Java, De Vriese.-Habit of quadriaurita, but texture firm, and pinnæ with an undivided central space more than $\frac{1}{4}$ in. br.

\section{*** Bipinnatce. Sp. 72-81.}

72. P. (Lito.) ciliaris, Eaton; st. about $1 \mathrm{ft} .1$. , naked, polished, straw-coloured or bright-brown ; fr. 9-12 in.1., 6-9 in. br., subdeltoid, tripinnate ; terminal pinna linear, 2 in. l., $\frac{1}{8}$ in. br., serrated when barren, uppermost pair simple, the next forked at the base, the lowest about 2 in. apart, deltoid, 2-3 in. each way; lowest pinnl. also deltoid, with two segm. on each side, the lowest forked, upper segm. decurrent ; texture herbaceous; rachis and both surfaces naked; veins fine, distant, anastomosing into irregular costal arches in the lower half of the segments; sori falling short of the point.-Eaton, Fil. Wright \& Fendl. p. 203.

Hab. Cuba, Wright, 868.

73. P. (Lito.) spinulifera, Schum.; st. $1 \mathrm{ft}$. ]., polished, more or less prickly ; fr. 1-2 ft. l. ; terminal pinna 6-9 in. 1., 2-3 in. br., cut down within a short distance of the rachis into numerous linear lobes $1-1 \frac{1}{2}$ in. $1 ., \frac{1}{4}-\frac{3}{8}$ in. br., which are slightly toothed when barren ; lateral pinnoe in numerous opposite pairs, the lowest sometimes $1 \mathrm{ft}$. 1., the lobes similar to those of the terminal one, the lowest pair forked, with a similar smaller pinnl. on the under side; both surfaces naked; rachis of the pinnl. beneath sometimes, but not always, furnished with a row of weak prickles ; texture herbaceous; veins fine and inconspicuous ; sori not reaching to the point of the segments.-Hk. Sp. 2. p. 221 .

Hab. Guinea Coast and Angola.-Habit of $P$. quadriaurita, but with prickly stems and anastomosing venation.

74. P. (Lito.) woodwardioides, Bory ; st. 6-12 in. 1., naked, erect, strawcoloured; fr. 12-18 in. 1.; terminal pinna 6-9 in. 1., 2 in. br., cut down to a broadly-winged rachis into numerous spreading linear lobes on both sides, the barren ones blunt and not toothed; lateral pinnoe in a few approximated pairs, the lowest as large as the terminal one, the lowest bipartite ; longest segm. $1 \frac{1}{2}$ in. $1 ., \frac{3}{8}$ in. br. ; texture thinly herbaceous ; rachis and both surfaces naked; veins fine, anastomosing principally in costal arches; sori falling rather short of the point of the segments.-Hk. Sp. 2. p. 220.

Hab. Mauritius. Habit of large quadriaurita, thinly herbaceous in texture. M. Fée has two Bourbon species of this group, $L$. borbonica and Montbrisonis, which I cannot separate by the descriptions alone. Is not $P$. pseudo-lonchitis, Bory, a Campteroid form of this species?

75. P. (Lito.) Milneana, Baker ; st. strong, erect, polished, yellowish-brown ; fr. 2-3 ft. l., with numerous pinnce on each side, cut down throughout nearly to the rachis into linear-oblong falcate lobes $\frac{1}{2}-\frac{3}{4}$ in. $1 ., 2$ lin. br., the lowest 6-9 in. l., 1-1 $\frac{1}{2}$ in. br., with a single similar but smaller pinnl. at the hase on the lower side; texture herbaceous; rachis and both surfaces naked; veins anastomosing copiously ; sori falling short of the subentire tips.-P. tripartita $\gamma, H k$. $S p$. 2. p. 226. t. 138. B.

Hab. Solomon Isles, Milne, 511 ; Fiji, Milne, Harvey, and a plant from Queensland with simple lower pinnæ from Mr. Hill is probably the same.-Habit of $P$. quadriaurita. 
76. P. (Lito.) decurrens, Presl ; st. 1 ft. l., strong, erect, naked, strawcoloured ; fr. $1 \frac{1}{2}-3 \mathrm{ft}$. l., 12-18 in. br., the terminal pinna $6-9$ in. $1 ., 1 \frac{1}{2}-2$ in. br., cut down to a broadly-winged rachis into numerous linear slightly toothed and slightly falcate lobes, 1-1 $\frac{1}{2}$ in. 1., $\frac{1}{4}$ in. br.; lateral pinnoe numerous, the upper ones narrowly decurrent at the base, the lower pair about $2 \mathrm{in}$. below the next, and bipartite; texture herbaceous; rachis and both surfaces hairy; veins fine, inconspicuous, anastomosing copiously; sori reaching nearly to the tip of the segments.-Hk. Sp. 2. p. 221.

Hab. South of Brazil.- Habit of quadriaurita, with decurrent upper pinnæ and both surfaces conspicuously hairy.

77. P. (Lito.) macilenta, Cunning. ; st. 6-12 in. 1., naked, straw-coloured, brownish and scabrous below; fr. 1-3 ft. 1. ; terminal pinna 4-8 in. 1., cut down nearly to the rachis into several deeply sinuated and toothed oblong lobes on each side; lat. pinnoe numerous, the upper ones 2 in. apart at the base, cut down quite to the rachis below into deeply lobed deltoid pinnl., the lower ones $1 \mathrm{ft}$. l. and very compound; texture thinly herbaceous; rachis naked, straw-coloured, slender, flexuose; veins fine, not anastomosing much except the costal arches; sori not reaching the point of the segments.-Hk. Sp. 2. p. 219.

Hab. New Zealand. - The largest ultimate segments not cut down to the rachis are about $1 \frac{1}{2}$ in. $1 ., \frac{8}{4}$ in. br. A well-marked species.

78. P. (Lito.) comans, Forst.; st. 1 ft. or more 1., naked, erect, glossy ; terminal pinna $1 \mathrm{ft}$, or more l., cut down nearly to the rachis into long linear lobes, which are sometimes 4 in. l., $\frac{1}{2}$ in. br., suddenly decurrent at the base, bluntly toothed when barren ; lateral pinnoe in a few opposite pairs, sometimes 18 in. 1., 6 in. br., the lowest sometimes slightly compound at the base; rachis and both surfaces naked; texture thinly herbaceous; veins fine, anastomosing copiously; sori falling short of the apex of the segments.- $H k$. Sp. 2. p. 219.$\beta, P$. Endlicheriana, Ag. ; fr. much larger; lobes smaller with sinuated margins ; lower pinnoe very compound, their pinnl. 6-9 in. l., deltoid, with numerous deeply pinnatifid lanceolate segm, on both sides.-Hk. l. c. Ic. Pl. t. 973.

Hab. Polynesian Islands, Juan Fernandez, Norfolk Island, New Zealand, Van Diemen's Land.-Though $\boldsymbol{P}$. comans and Endlicheriana are very different in the extreme states, they appear to be quite connected by intermediate stages. The Juan Fernandez plant (P. Berteroana, Ag.) corresponds very nearly with the former. The allied $P$. laevis, Metten., from New Caledonia, we do not possess.

79. P. (Lito.) aculeata, Swartz; st. $2 \mathrm{ft}$. 1. or more, smooth or rough with raised points, naked ; fr. ample; terminal pinna 6-12 in. l., cut down nearly to the rachis throughout into lobes $1 \frac{1}{2}-2$ in. 1 ., $\frac{1}{4}-\frac{3}{8}$ in. br., the point acuminate, sterile parts finely serrated; lateral pinnce numerous, upper ones simple, lower compound, sometimes 18 in. l., 9 in. br., with numerous pinnatifid pinnl. on both sides; rachis and surfaces naked; texture herbaceous; veins fine, anastomosing copiously; sori not reaching the points.-Hk. Sp. 2.p. 224.

Hab. West Indies and Mexico southward to Brazil and Peru.-P. propinqua, Ag., and $P$. polita, Link, appear to be forms of this, differing, the former by its more coriaceous texture, the latter by its less compound lower pinnæ. P. Beecheyana, Ag., agrees with the latter. L. Tussaci and grandis, Fée, are allied plants unknown to us.

80. P. (Lito.) leptophylla, Swartz; st. erect, firm, straw-coloured, 6-9 in. 1. ; fr. 9-12 in. each way, deltoid; a few of the upper pinnoe simple, the largest of these under 1 in. $1 ., \frac{1}{8}$ in. br., decurrent at the base, strongly spinuloso-serrated when barren, the central ones lanceolate pinnatifid with numerous similar pinnl. and caudate, the lowest deltoid, with pinnules often 2 in. l., and again pinnatifid; texturc herbaceous; rachis and both surfaces naked; veins fine, usually anasto- 
mosing once only between the midrib and margin; sori not reaching the tip of the segm. Hk. Sp. 2. p. 216. Gard. Ferns, t. 23.

Hab. Brazil.

81. P. (Lito.) incisa, Thunbg. ; st. stout, erect, polished, straw-coloured or bright-brown, sometimes slightly muricated towards the base ; fr. often several ft. 1., bi- or tripinnate, only the uppermost pinnoe simply pinnate with entire linear-oblong pinnl., those next in order with numerous pinnatifid pinnules 2-3 in. 1., about $\frac{3}{4}$ in. br., in opposite pairs, the lowest often quite close to the stem, reduced in size and their segments dilated, the lowest pinnæ often very large and compound; texture herbaceous or subcoriaceous; under surface often glaucous; veins free or more or less anastomosing; sori interrupted or continuous, often reaching the point of the segments. $-H k$. Sp.2. p. 230. P. Vespertilionis, Labill. P. sinuata, Brack. Hk. Sp. 2. p. 232. $\beta, P$. aurita, Blume; lowest pair of pinuules quite simple and closely adpressed to the stem at the base of the pinnæ.-Hk. Sp. 2. p. 231.

Hab. Tropical America from West Indies and Columbia southward to Chili, Juan Fernandez, and Brazil ; Polynesin; Himalayas, and Formosa, southward to New Zealand, Van Diemen's Land, and Ceylon; Mascaren Isles, Cape Colony, West Tropical Africa.-A very variable plant in size, cutting, texture, and venation. It is often scandent, with long spreading rigid branches, and is said to attain a length of 10 yards. In a form gathered by Capt. Carmichael in the island of Tristan d'Acunha, the veins do not anastomose at all; often there is only a single arch on each side of the costa at the base of a segment, and in specimens, otherwise quite similar, there is copious joining towards the edge. Sometimes the sori are confined to the sinuses, as in Lonchitis.

\section{**** Tripartitce. Sp. 82-87.}

82. P. (Lito.) tripartita, Swartz; st. $1 \mathrm{ft}$. or more 1., strong, erect, naked, polished, straw-coloured or brownish ; fr. tripartite, the central portion $2 \mathrm{ft}$. l. or more; terminal pinna 6-9 in. l., $\frac{1}{2}-1$ in. br., cut down nearly to the rachis into numerous closely-placed linear lobes on each side, which are very slightly toothed when barren; lateral pinnoe very numerous, closely placed, all unbranched; lateral divisions similar to the central one but smaller, sometimes forked again; rachis and both surfaces naked; texture usually herbaceous; veins fine, anastomosing principally in arches against the midrib; sori falling rather short of the point of the segments.-Hk. Sp. 2. p. 225. excl. $\beta$ and $\gamma$.

Hab. Polynesian and Malayan Islands from the Philippines sonthward to the Isle of Pines, Erromanga, Queensland; Malayan Peninsula, Ceylon, Sylhet, Seychelles, Mauritius, Bourbon, and West Tropical Africa.-P. heterophlebia, Kunze, Bot. Zeit. 6. p. 197, is probably a form of this with the veins usually only anastomosing once between the midrib and edge of the segments.

83. P. (Lito.) Luschnathiana, Baker; st. 2 ft. 1., strong, erect, naked, strawcoloured; $f r$. tripartite, with the three divisions nearly equal; terminal pinna 6-9 in. 1., $1 \frac{1}{2}$ in. br., cut down to a broadly-winged rachis, into numerous narrow falcate linear lobes with a broad sinus between them, which are finely spinuloso-serrated when barren; lateral pinnoe numerous, similar, the lowest 2 in. below the next, not forked; rachis and both surfaces naked; veins fine, scarcely anastomosing in the ultimate segments except in costal arches in the lower half; sori falling short of the point.-Campteria, Klotzsch.

Hab. Brazil, Luschnath.

84. P. (Lito.) podoplyylla, Swartz; st. $4 \mathrm{ft}$. 1. or more, $\frac{1}{2}-\frac{3}{4}$ in. thick at the hase, muricated below, straw-coloured, glossy ; fr. ample, ternately divided ; terminal pinna 6 in. 1 . or more, 1-1 $\frac{1}{2}$ in. br., cut down two-thirds of the way to the rachis into numerous linear-oblong falcate lobes, which are finely spinuloso- 
serrated when barren ; lateral pinnoe in numerous closely-placed nearly opposite pairs, 6-9 in. 1., 1-1 $\frac{1}{2}$ in. br., with numerous lobes similar to those of the terminal one ; lateral divisions of the $f r$. like the terminal one, but smaller ; texture thick, coriaceous, both surfaces and the glossy straw-coloured rachis naked, or nearly so; veins fine, inconspicuous; sori continuous, falling short of the apex of the segm.-Hk. Sp. 2. p. 227. Gard. F. t. 55. L. camptocarpa, Fée. Hk. Sp. 2. p. 229. $-\beta, P$. setifera, Fée; pinnoe smaller; segm. narrower and sharper.Hk. Sp. 2. p. 224.

Hab. Mexico and West Indies southward to the Andes of Ecuador.-In texture this is most like $\boldsymbol{P}$. deflexa and coriacea, with which it agrees in its tripartite habit. A plant from Java, sent by $D e$ Vriese without name, may be identical with $P$. setifera.

85. P. (Lito.) Kunzeana, Agardh ; st. 3 ft. 1., strong, erect, naked, polished, straw-coloured or reddish-brown, muricated below ; fr. ample ; terminal pinna $1 \mathrm{ft} . \mathrm{l} ., 3 \mathrm{in.}$ br., cut down two-thirds of the way to the rachis into numerous linear sharp-pointed falcate lobes, which are slightly spinuloso-serrated when barren ; lateral pinnoe in numerous nearly opposite pairs, the lower ones stalked, equalling or exceeding the terminal one in size and sinilarly pinnatipartite, the lowest pair large, deltoid, compound below, with smaller similar pinnl.; texture coriaceous; rachis and both surfaces naked; veins anastomosing copiously; sori falling short of the apex of the segm.-Hk. Sp. 2. p.221.t. 139.

Hab. Tropical America, from West Indies and Ecuador southward to Peru.-This is united by Dr, Grisebach with podophylla, but seems saisfactorily distinct. The pinnæ are very much larger, so that there is sometimes a space of fully $\frac{1}{2}$ in. between their sinuses and the rachis. I gather from one of Dr. Spruce's notes, that this also is tripartite in habit, and cannot from the descriptions and authenticated specimens distinguish $\boldsymbol{P}$. longibracteata, Ag., which has equally large pinnæ and segments.

86. P. (Lito.) elata, Agardh ; st. 2-3 ft. l., erect, naked, glossy, straw-coloured; fr. ample, tripartite; terminal pinna 12-18 in. l., cut down nearly or quite to the rachis into numerous linear lobes on both sides, which are $3-5$ in. 1. , $\frac{1}{2}$ in. or more br., spinuloso-serrated when barren; upper lat. pinnce 6 in. 1., not cut down to the rachis; lower ones equalling in size and cutting the terminal one, the lateral divisions of the frond deltoid, 2-3 ft. l. ; texture subcoriaceous ; rachis and both surfaces naked; veins fine, anastomosing copiously; sori falling short of the points of the segments. $-H k$. Sp. 2. p. 223.

Hab. Tropical America from Panama southward to Ecuador.

87. P. (Lito.) gigantea, Willd.; st. 2-3 ft. l., stout, erect, naked, polished ; fr. tripartite; terminal pinna $1 \mathrm{ft}$. l., 3 in. br., cut down to a broadly-winged rachis into numerous linear falcate lobes, which are a little bluntly toothed when barren; lat. pinnoe numerous, the largest often 18 in: 1., 4 in. br., the largest pinnl. nearly 2 in. l., more than $\frac{1}{2}$ in. br. ; lat. divisions $2 \mathrm{ft}$. l., deltoid ; texture subcoriaceous; rachis and both surfaces naked; veins fine, anastomosing copiously; sori falling short of the apex of the segments.-Hk. Sp. 2. p. 217. P. crassipes, $A g$. Hk. l. c.

Hab. West Indies and Columbia southward to Peru.

$\S \S \S \S \S \S \S$ Amphiblestra, Presl. Veins copiously anastomosing, with free included veinlets. Sp. 84. TA B. III. f. 31 . i.

88. P. (Amphi.) latifolia, H.B. K. ; fr. 1-2 ft. l., with a large terminal and a pair of lateral pinnoe, the former with an oblong-triangular sinuated acuminated apex and two spreading lanceolate lateral lobes, the lateral ones sometimes 1 ft. l., 2 in. br., nearly entire; texture herbaceous; principal veins nearly parallel, about 1 in. apart.-Hk. Sp.2. p. 233.

Hab. Venezuela; gathered first by Humboldt and Bonpland. 


\section{Gen. 32. Ceratopteris, Brong.}

Sori placed on two or three veins which run down the frond longitudinally, and are nearly parallel both with the edge and midrib. Caps. scattered on the receptacles, sessile, subglobose, with a ring which is either complete, or more or less partial or obsolete. Invol. formed of the reflexed margin of the frond, those of the two sides meeting against the midrib. $A$ very anomalous genus, regarded by some as a distinct suborder and placed by others in Polypodiex. TAB. III. f. 32 .

1. C. thalictroides, Brong.; st. tufted, thick, inflated, filled with large aircells ; $f r$. succulent in texture, the barren ones floating, simple or slightly divided when young, bi- or tripinnate, with narrow linear segm. when mature, fertile ones bi- or tripinnate; ult. segm. podlike.-Hk. Sp. 2. p. 236.

Hab. Throughout the Tropics in quiet waters; Mexico and W. Indies southward to Brazil ; Punjaub southward to Tropical Australia, Madagascar, Angola, West Tropical Africa.-Parkeria pteroides, Hk. Gr. Ic. t. 97, is the form without a ring to the capsule.

\section{Gen. 33. Lomarta, Willd.}

Sori linear, continuous, parallel with the midrib and occupying the whole or nearly the whole of the space between it and the edge. Invol. membranous, formed of the revolute edge of the frond. Fronds dimorphous, usually once pinnatifid or pinnate, rarely simple or bipinnate. Veins free, except casually in one species. A considerable genus, closely connected with Blechnum, most of the species of which resemble one another closely in habit and cutting, which has its head-quarters in the South Temperate Zone, with outliers all over the world. TAB. IV. f. 33.

$\S$ Eulomaria. Base of the stipe not suddenly dilated and glandular. Ring of capsule vertical. Sp. 1-33.

* Frond simple or central and lower pinnoe of the sterile frond more or less distinctly dilated and connected at the base. Sp. 1-20.

+ Fronds simple or pinnoe few. Sp. 1-2.

1. L. Patersoni, Spreng.; rhizome short-creeping ; st. 2-3 in. 1., wiry, erect, rather scaly below ; sterile fr. about $1 \mathrm{ft}$. l., under 1 in. br., broadest one-third of the distance from the top, narrowed very gradually downwards, the point acuminate, the margin cartilaginous and wavy; texture coriaceous, veins inconspicuous; fertile fr. as long but only $\frac{1}{8}$ in. br.; sori occupying the whole space between the midrib and margin.-Hk.Sp.3. p. 3. F. Ex.t. 49. L. Cumingiana, Hk. Sp. 3. t. 143. $-\beta$, L. elongata, Blume; both sterile and fertile fr. pinnatifid, $2 \mathrm{ft}$. l. or more, the former cut down nearly to the rachis into 6 to 9 pinnce on each side, which are often $6-9$ in. l., nearly 1 in. br., and suddenly decurrent at the base, the fertile pinnæ often numerous on each side, erecto-patent, 6 in. 1., $\frac{1}{8}$ in. br.-L. Colensoi, Hk. fil. L. punctata, Blume.

Hab. $\alpha$, S. Australia, Van Diemen's Land, and Philippines. $-\beta$, Neilgherries and Ceylon eastward and southward to Fiji and New Zealand.-The two supposed species were at first believed-Patersoni to be always simple, and elongata to be always pinnate ; but the Australian one has now been traced into a pinnate form, and the Polynesian into a simple form in the fertile state, and in each case I cannot find any character to distinguish these from the other supposed species. As in most of others, the fronds are occasionally in part sterile and in part fertile. The pinnæ are fewer and more distant from one another than in any of the species that follow, and their decurrent base is broader and more conspicuous. 
2. L. Viellardii, Baker; caudex stout, erect, woody ; st. 3-4 in. l., clothed below with large dark-brown lanceolate scales; sterile fr. $1 \mathrm{ft}$. or more 1., 1-3 in. br., varying in shape from linear and entire to oblong, with a long, linear, entire point and cut down within $\frac{1}{2}$ in. of the rachis into several pinnce on each side, which are $1 \frac{1}{2}-2$ in. $1 ., \frac{1}{2}$ in. br., furnished with a distinct wavy cartilaginous border and subdentate towards the apex; the base gradually narrowed into an undulated wing to the rachis, with sometimes a few distinct auriculate lobes ; texture coriaceous; veins fine, rather distant ; fertile fr. quite simple or pinnate, with several narrow distinct linear pinnoe on each side, which are 3-4 in. l., $\frac{1}{2}-\frac{3}{4}$ in. apart at the base.-Blechnum, Metten. Annales, series 4. vol. 15. p. 70.

Hab. New Caledonia, Vieillard, 48.

+† Attenuata group. Fronds ample, ovate; pinnoe numerous, 2 in. or more long. Sp. 3-10.

3. L. ciliata, Moore ; caudex a span high, $1 \frac{1}{2}$ in. thick; st. blackish, slightly scaly below ; $f r$. not numerous, 8-12 in. l., ovato-oblong, simply pinnate; barren pinnoe linear-oblong, the lower ones distant and narrowed below; the upper ones more approximate, adnato-decurrent, with a broad rounded auricle at the base on the lower side, bluntish, frequently emarginate or bifid, the margins lobed and spinuloso-ciliated; texture firm but thin; veins usually once forked; fertile pinnoe narrow, linear, decurrent, sometimes slightly pinnatifid; rachis dark-coloured like the stipe, slightly scaly below.-Moore, Gard. Chron. 1866. p. 290.

Hab. New Caledonia ; imported by Mr. Veitch.-This I have not seen, and rely entirely upon Mr. Moore for its characters. "Allied to $L$. gibba in the swollen decurrent bases of the pinnæ, but differing in its less numerous fronds, and in the much less crowded series of pinnæ as well as in their very apparent fringe of spinulose teeth."

4. L. gibba, Labill. ; caud. 2-3 ft. high ; st. short, strong, erect, densely clothed below with long, linear-subulate black scales; $f r .2-3 \mathrm{ft}$. l., 6 in. br., both barren and fertile with very numerous erecto-patent pinnoe on each side, those of the former 4-6 in. l., $\frac{1}{4}-\frac{3}{8}$ in. br., cut down nearly to the rachis, dilated and connected at the base, the lower ones growing shorter very gradually, the margin nearly entire; texture coriaceous; veins once forked, tine, subparallel; fertile pinnoe $4-6$ in. l., $\frac{1}{8}$ in. br., the sori occupving the whole space between the edge and midrib; rachis stout, the lower half fibrillose like the stipe.-Hk. Sp. 3. p.5.

Hab. New Caledonia, Aneiteum, Isle of Pines.-A large stout plant much resembling $L$. attenuata in the shape of the pinnæ and the gradual way in which they decrease downwards, but differing by its dark bristly scales, which extend considerably up the rachis. A specimen from Erromanga, from R. Brown's herbarium, has the sori not quite marginal.

5. L. discolor, Willd. ; caud. stout, ascending ; st. 3-6 in. l., strong, black, glossy, densely clothed at the base with long, dark, linear-subulate scales ; $f r$. 1-3 ft. l., the barren one 4-6 in. br., narrowed gradually at the base; pinnoe numerous, spreading, contiguous, linear, $2-3$ in. l., $\frac{3}{3}$ in. br., cut down very nearly to the rachis, narrowed suddenly towards the point, the margin wavy; texture coriaceous; veins prominent, close, subparallel ; fertile pinnce as numerous but narrower and shorter ; rachis naked, usually reddish-black in the fertile frond.-Hk. Sp. 3. p. 5 .

Hab. Australia, Van Diemen's Land, and New Zealand ; abundant.-Dr. Mueller sends a curious bipinnatifid form. "Very similar to $L$. attenuata, but usually larger, the fronds forming an elegant crown, red-brown below, the pinnules narrower, those of the fertile frond often leafy at the base." $-D r$. Hooker. 
6. L. attenuata, Willd.; caud. long, horizontal, stout, densely clothed at the apex with linear-subulate, bright-brown scales ; st. 4-6 in. l., erect, naked or slightly scaly below ; fr. 1-3 ft. l., 6-9 in. br., ovate, narrowed very gradually downwards ; barren pinnoe numerous, contiguous, spreading, linear, 3-4 in. l., $\frac{1}{2}-\frac{3}{4}$ in. br., narrowing gradually towards the point, which is sometimes bluntly serrated, dilated on both sides at the base; texture coriaceous; veins strong;

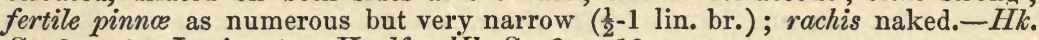
Sp. 3.p.6. L. gigantea, Kaulf. Hk. Sp. 3. $p .10$.

Hab. America from the West Indies and Guatemala southward to Brazil and Juan Fernandez ; Polynesian Islands, Norfolk Island, Mauritius, Bourbon, Fernando Po, and Cape Colony. $-L$. pteropus, Kunze, is evidently a form with the lower pinnæ confluent. Occasionally all the pinnæ are obliterated, and we have an entire lanceolate frond like that of $L$. Patersoni.

7. L. L'Herminieri, Bory ; caud. ultimately elongated, densely clothed with linear dark-brown scales; st.4-6 in. l., strong, erect, dark-brown, paleaceous ; barren $f r$. ovate-lanceolate, 9-15 in. l., 3-4 in. br. ; the pinnoe dilated at the base, slightly falcate, 2 in. or rather more l., $\frac{1}{2}$ in. br., the point bluntish, a few of the lower ones cut down suddenly into mere auricles; texture coriaceous; colour dark-green, both surfaces naked; veins not conspicuous; fertile pinnoe 2-3 in. 1., $\frac{1}{8}$ in. br., the lower ones $\frac{1}{2}-1$ in. apart at the base.-Hk. Sp. 3.p.9. Gard. Ferns, $t .40$.

Hab. America from the West Indies and Columbia southward to Chili.-A smaller plant than $L$. attenuata, narrowed more suddenly below, with shorter, broader, and blunter pinnæ.

8. L. divergens, Kunze ; caud. thick, creeping or suberect, densely scaly at the crown ; st. 6-12 in. 1., stout, erect, dark-coloured, naked ; fr. 2-3 ft. l., 9-12 in. br., oblong-lanceolate, abruptly terminated at the base; pinnoe very numerous on each side, spreading, those of the barren frond 4-6 in. 1., $\frac{1}{2}-\frac{3}{4}$ in. br., cut down very nearly to the base, the edges flat, entire, contiguous, the point acuminated; texture subcoriaceous ; veins obscure, subparallel, nearly $\frac{1}{8}$ in. apart at the base ; fertile pinnoe 4-6 in. l., $\frac{1}{8}$ in. br., often variously curved, dilated at the base, rachis naked.-L. Plumieri, Desv. Hk. Sp. 3. p. 7.

Hab. Tropical America from the West Indies and Columbia southward to Rio Janeiro and Peru.-In some of the forms the pinnæ are nearly equal at the base, in others few in number and conspicuously dilated. This and the next may be known from all the preceding by the abrupt termination of the frond in a downward direction, the lowest pair of pinnæ being usually not much shorter than the others.

9. L. vulcanica, Blume; caud. thick, erect or subprostrate, densely clothed at the crown with subulate blackish scales ; st. 4-6 in. l., pale, erect, paleaceous below ; fr. 6-18 in. 1., 3-6 in. br., the barren one ovate-lanceolate, not narrowed at the base or the lower pinnæ abbreviated; pinnce spreading, lanceolate, $2-4$ in. l., $\frac{1}{4} \cdot \frac{3}{8}$ in. br., the base slightly dilated, the point acute or bluntish, the lowest pair deflexed; texture coriaceous, the margin cartilaginous and undulated; veins fine and prominent beneath, the surface and margin often slightly hairy; fertile pinnoe linear, distant, dilated suddenly at the base, $2-4$ in. 1., $\frac{1}{8} \mathrm{in.} \mathrm{br.-Hk.} S p$. 3. p. 13. Ic. t. 969 . L. pilosa, Brack.

Hab. Java, Polynesian Islands, New Zealand, and Van Diemen's Land.

10. L. opaca, Baker; caud. ascending, clothed at the crown with numerous linear dark-brown scales; barren fr. ovate, narrowed very gradually below, 6-12 in. l., 4-6 in. br. ; pinnce numerous, close, spreading horizontally, linearoblong, 1-2 in. l., $\frac{1}{2}-\frac{3}{4}$ in. br., dilated and connected at the base, the margin undulato-dentate, and the apex bluntly rounded and emarginate; texture thick and. coriaceous; veins fine, at least twice branched, sometimes anastomosing 
before they reach the margin; rachis pubescent and the lower surface slightly so, colour deep-green ; fertile fr. with numerous distant, spreading, narrow, linear pinnæ.-Blechnum, Metten. Annales, 4 ser. part 15.p. 69.

Hab. Gathered by Milne in Aneiteum, and Vieillard in New Caledonia.-This is a very curious plant which $\mathrm{Sir}$ W. Hooker thought might be an abnormal form of $L$. attenuata, under which it is mentioned in Sp. Fil. It is only the New Caledonian examples which show the anastomosing venation, but Milne's plant is evidently the same. The apex of the frond is not cut down within a considerable distance of the rachis. Mettenius compares it in habit to $L$. nigra.

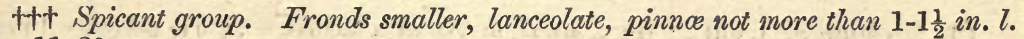
Sp. 11-20.

11. L. lanceolata, Spreng. ; caud. elongated and densely clothed with darkhrown linear scales; st. 4-6 in. 1., firm, erect, dark-brown, paleaceous ; fr. 6-12 in. $1 ., 2-4 \mathrm{in}$. lr., the barren ones lanceolate, narrowed very gradually below; pinnoe close, slightly falcate, $1-1 \frac{1}{2}$ in. $1 ., \frac{1}{4}-\frac{3}{8}$ in. br., gradually narrowed to a point or bluntish, slightly toothed, both surfaces naked; texture coriaceous, colour bright-green, the veins strong and prominent; fertile pinnoe linear, spreading or falcate, about $\frac{1}{8}$ in. apart at the base; rachis pale, naked.- $H k$. $I c$. t. 42.9. Sp. 3. p. 11 .

Hab. Australia, Van Diemen's Land, New Zealand, and Polynesian Islands.

12. L. blechnoides, Bory ; caud. creeping ; barren fr. short-stalked, lanceolate, about 6 in. 1., 1-1 $\frac{1}{2}$ in. br.; upper pinnoe $\frac{3}{4}$ in. $1 ., \frac{3}{8}$ in. br., dilated at the base, rather falcate, the point blunt, the lower ones narrowed gradually into mere auricles; texture coriaceous, veins not conspicuous ; fertile fr. $12-18$ in. $1 ., 3$ in. br. ; st. 6 in. l., strong, erect, dark chesnut-brown ; pinnoe $1 \frac{1}{2}-2$ in. $1 ., \frac{1}{8}$ in. br., dilated suddenly at the base, the upper ones $\frac{1}{4}-\frac{3}{8}$ in. apart, and the bases nearly or quite decurrent from one to another.-Hk. Sp. 3. p. 12.

Hab. Chili.-Probably this should be joined with $L$. lanceolata, from which it only differs by its larger fertile frond, with pinnæ widened suddenly at the base on both sides.

13. L. dura, Moore ; caud. erect, subarhorescent; st. 1 in. l., thick, erect, with ovate-lanceolate scales at the base; fr. $1 \mathrm{ft}$. or more 1 ., lanceolate, cut down to the rachis below; barren pinnoe, the lower ones dwarfed into rounded lobes, the middle ones oblong subfalcate, the upper ones narower and more acuminated ; fertile pinnoe shorter, crowded, broadish, very blunt, decurrent at the base above; texture coriaceous, veins forked; invol. transversely wrinkled, the margin fimbriated.-Moore, Gard. Chron. 1866, p. 290. L. rigida, J. Sm. Ferns Brit. \& For. p. 290.

Hab. Chatham Islands. - "Allied to $L$. lanceolata and blechnoides, but differing by its thick leathery texture when fresh, and in the entire somewhat cartilaginous margin. Fertile fronds remarkable for their stout densely-fruited very blunt crowded pinnæ and fringed indusia." -Moore, $l$. $c$.

14. L. aspera, Klotzsch ; caud. stout, ultimately elongated, clothed with linear chesnut-brown scales; st. scarcely any; barren fr. 6 in. $1 ., 2$ in. br., ovate-lanceolate, narrowed very gradually below ; pinnoe close, the largest $\frac{3}{4}$ in. 1. ,, $\frac{3}{8}$ in. br., slightly dilated at the base and auricled on the upper side, the point bluntish; texture coriaceous; veins inconspicuous; fertile fr. much smaller ( 3 in. 1., $\frac{3}{4}$ in. br.), on a longer stem ; pinnoe crowded, $\frac{1}{2}$ in. $1 ., \frac{1}{8}$ in. br., blunt, the invol. broad, and involute- $-H k$. Sp. 3. p. 14. t. 144.

Hab. Chili and Chiloe.-The fronds take root at the extremity and produce new plants. The habit of the barren frond is just that of $L$. lanceolata, but the fertile one is very different. 
15. L. onocleoides, Spreng. ; rhizome long, scandent, densely clothed with linear chesnut-brown scales; barren fr. on st. 3-4 in. 1., lanceolate, 12-18 in. 1., 1-2 in. br., narrowed very gradually below ; pinnoe 1 in. l. or less, $\frac{1}{4}-\frac{3}{8}$ in. br., lanceolate, dilated at the base, narrowed gradually towards the point; texture very coriaceous, the surface shining and the veins beneath prominently channelled; fertile fr. on st. 4-6 in. 1. ; pinno linear, 1-1 $\frac{1}{2}$ in. 1 ., central ones $\frac{1}{4}$ in. apart at the base; invol. broad, involute.-Hk. Sp. 3. p. 10. t. 146.

Hab. West Indies and Ecuador.-A more rigid plant than the four preceding, with a different caudex. The pinnæ recall those of attenuata, but are much shorter.

16. L. obtusata, Labill. ; caud. stout, suberect, clothed with dark-brown linear scales; st. 2-3 in. l., strong, erect, scaly below ; barren fr. linear-lanceolate, narrowed very gradually towards both ends; pinnoe close, erecto-patent, linear, slightly falcate, bluntish, $\frac{1}{2}$ in. $1 ., \frac{1}{8}$ in. br., the lower ones reduced down to mere auricles; texture coriaceous ; veins inconspicuous; fertile fr. rather longer and on longer stalks; pinnœ narrowly linear, falcate, $\frac{1}{4}$ in. apart, decurrent at the base.-Lab. Sert. t. 6.

Hab. New Caledonia.-Very like L. Spicant in general outline, but much more rigid, with an elongated caudex.

17. L. Spicant, Desv. ; rhizome stout, short-creeping; barren fr. on stalks 2-3 in. l., lanceolate, 6-9 in. 1., 1-1 $\frac{1}{2}$ in. br., narrowed gradually below ; pinnae linear, $\frac{1}{2}-\frac{3}{4}$ in. l., $\frac{1}{8}$ in. br., bluntish or mucronate, sl ${ }^{\circ} \mathrm{g}^{\prime}$ tlly dilated at the base ; texture herbaceous; veins inconspicuous; fertile fr. $\mathrm{o}^{\prime}$ te: $1 \mathrm{ft} . \mathrm{l} ., 2 \mathrm{in}$. br., on st. 6-9 in. 1., chesnut-coloured and polished ; narrowly linear pinnoe $\frac{1}{4}-\frac{3}{8}$ in. apart, dilated at the base, the line of fructification at first slightly intramarginal. Hk. Sp. 3. p. 14. Brit. F.t. 40.

Hab. Throughout Europe from the Arctic regions to Madeira and Crete, Caucasus, Kamtschatka, Japan, N. W. America.-In this and the next the fertile fronds are erect, and the barren ones more or less spreading. It seems probable that Blechnum doodioides, Hook. Sp. Fil. 3. p. 60.t. 153. which has not been refound, is a Doodioid form of this, analogous to the one which occurs in $L$. punctulata.

18. L. alpina, Spreng. ; rhizome slender, wide-creeping, clothed with lanceolate-ferruginous scales at the crown ; barren fr. 4-8 in. l., $\frac{1}{2}-\frac{3}{4}$ in. br., linearlanceolate, with spreading close-placed linear-oblong, obtuse pinnoe $\frac{1}{2}$ in. 1. , $\frac{1}{8}$ in. or rather more br. ; texture subcoriaceous ; rachis naked ; fertile fr. on st. 4-12 in. 1.; pinnoe narrower and more distant; invol. slightly intramarginal.-Hk. $S p .3$. p. 16. Fil. Exot. t. 32.

Hab. S. Brazil ; plentiful in Temperate S. America, New Zealand, Van Diemen's Land, Alps of S. Australia.-A smaller plant than $L$. Spicant, with a slender widecreeping rhizome, and the pinnæ, especially of the fertile frond, broader and shorter.

19. L. Banksii, Hk. fil.; caud. stout, woody, elongated, clothed upwards with lanceolate ferruginous scales; st. 3-4 in. 1., erect, dark-coloured, scaly below ; barren fr. lanceolate, 6-9 in. l., about 1 in. br. ; pinnce spreading, oblong, obtuse, $\frac{3}{8}-\frac{1}{2}$ in. l., $\frac{1}{4}$ in. br., close-placed, passing gradually downwards into a sinuated decurrent wing to the stem; fertile fr. smaller and more slender; pinnoe narrower and more distant; texture subcoriaceous; rachis naked.-Hk. Sp. 3. p. 17. Hk. fil. Fl. N.Z. t. 76 .

Hab. New Zealand.-Easily distinguisbed from all its allies by its oblong obtuse pinuæ, even the upper ones more than half as broad as long.

20. L. pumila, Raoul ; rhizome slender, creeping, clothed with bluntish ferruginous scales at the apex; barren fr. lanceolate, $3-4$ in. 1. , $\frac{1}{2}$ in. br. ; pinnoe spreading, linear-oblong, obtuse, crenated, $\frac{1}{4}$ in. $1 ., \frac{1}{8}$ in. br., the stem about 1 in. 1.; fertile fr. on st. 3-4 in. 1.; the pinno linear-oblong with a considerable space 
between them; texture herbaceous; veins inconspicuous; rachis naked.-Hk. Sp. 3.p. 18.

Hab. New Zealand.-Most like $L$. alpina, but much more delicate in texture, with the pinnæ distinctly crenated.

* Central and lower pinnoe of the sterile frond narrowed at the base and always distinctly separated from one another. Sp. 21-30.

21. L. punctulata, Kunze; caud. stout, densely paleaceous at the crown; st. 3-6 in. 1., strong, erect ; barren fr. oblong-lanceolate, 1-2 ft. 1., 4-6 in. br. ; pinnoe very numerous, contiguous, linear, subfalcate, $2-3$ in. l., $\frac{1}{4}-\frac{3}{3} \mathrm{in}$. br., rounded or cordate and auricled at the base, the lower ones deflexed and the lowest reduced down to auricles; texture coriaceous; veins inconspicuous ; fertile fr. similar, but the pinnæ often not more than $\frac{1}{8}$ in. br. ; invol. often more or less intramarginal; rachis stout, erect, straw-coloured, naked.-Hk. Sp. 3. p. 31.

Hab. S. Africa from Natal southward and Java.-This has sometimes the fruit of Lomaria and sometimes of Blechnum, but the most surprising abnormal form is the Scolopendrium Krebsii of Kunze (Bot. Mag. t. 4768), in which every pinna has a large number of parallel rows of fruit directed from the midrib towards the edge at an acute angle with the former, as is usual in the Aspleniece, and there is a form differing only from Blechnum in the line of fructification being interrupted, and thus agreeing with Doodia. It is the representative of $L$. attenuata in the pinnate-fronded series, and may be best known from procera by the lower pinnæ being gradually reduced down to auricles.

22. L. procera, Spreng.; caud. stout, woody, elongated, clothed with large ovate or lanceolate acuminate ferruginous sciles; st. 6-12 in. 1., stont, erect, scaly below; barren fr. ovate, 1-3 ft. l., 6-12 in. br. ; pinnce linear, 3-12 in. l., $\frac{1}{2}-1$ in. br., the lower ones stalked, the base rounded or even cordate, sometimes auricler, the point narrowed gradually, sometimes slightly toothed; texture coriaceuus; veins fine and parallel, midrib beneath more or less chaffy; fertile pinnce narrowly linear, distant, 4-6 in. l., $\frac{1}{4}$ in. br. ; rachis stout, erect, more or less scaly; invol. broad, membranaceous, ciliated, sometimes slightly intramarginal.- Hk. Sp. 3. p. 23. Ic. t. 127, 128. Gav.d. Ferrs, t. 53. L. Gilliesii, H. \& G. Ic. t. 207.

Hab. Mexico and W. Indies southward to Chili ; Malayan and Polynesian Islands, N. Zealand, S. Australia, Van Diemen's Land, and S. Africa.-Often the same frond is partially barren and partially fertile, aud there is a form that has the barren pinnæ slightly pinnatifid. We include here, from inability to separate them clearly, a large number of plants which have been regarded as distinct, ranging from $L$. daneacea, Kunze, which has only two or three pinnæ on each side nearly an inch broad, up to $L$. ornifolia, Presl (L. spectabilis, Liebm., L. tuberculata, J. Sm., and L. longifolia, Schlecht), which has fronds $3 \mathrm{ft}$. long with as many as forty pinnæ, the lower ones distinctly stalked and often furnished with glands like those of Plagiogyria at the base of the petiole. L. chilensis, Kaulf., L. Capensis, Willd., and Blechnum Lechleri, Mett., are similar large-growing forms; $L$. vestita, Blume, and $L$. squamulosa, Desv., have densely paleaceous rachises. Dr. Hooker, in the New Zealand Flora, defines four varieties, which keep their characters under cultivation.

23. L. caudata, Baker ; caud. elongated, densely clothed at the apex with lanceolate dark-brown scales; st. 2-3 in. l., strong, erect, scaly below; barren fr. $2 \mathrm{ft}$. l. or more, $4 \mathrm{in}$. br., gradually narrowed below and elongated and rooting at the apex ; pinnoe numerous, all quite distinct, narrowed suddenly to the midrib, but not stalked at the hase, the laryest at and a little below the centre of the stem, linear-oblong, $1 \frac{1}{2}-2$ in. 1. , $\frac{1}{2}$ in. hr., spreading horizontally, narrowed suddenly at the base, slightly auricled on the lower side, narrowed sudder.ly at the point; the lower ones blunt, passing gradually down into mere auricles; those above the centre of the stem growing gradually smaller and blunter to where it takes root; texture coriaceous; colour hright-green; vcins benealh 
prominent; rachis and midrib more or less chaffy; fertile fr. with narrow linear pinnæ 3-4 in. l.

Hab. Andes of Ecuador, Spruce, 5329.-Most like L. procera, of which it may be an abnormal form. Pinnæ at least $\frac{1}{2} \mathrm{in}$. distant at the base.

24. L. Boryana, Willd.; caud. stout, erect, 1-2 ft. high, woody, densely clothed with dark-coloured, firm linear-subulate scales ; st. stout, erect, 4-6 in. I. ; barren fr. ovate, 1-2 ft. l., 6-8 in. br.; pinnoe closo-placed, erecto-patent, lancéolate, narrowed gradually to the point, narrowed and sometimes auricled at the base, $3-6$ in. 1. , $\frac{1}{2}$ in. or rather nore br.; texture coriaceous; veins inconspicuous; fertile pinnoe narrow, linear, rather close; invol. brown, membranaceous, fimbriated, sometiınes slightly intramarginal.-L. Magellanica, Desv. Hk. sp. 2.p.27. Gard. Ferns, t.52.

Hab. W. Indies southward to Falkland Island́s and Straits of Magellan; Mauritius, Bourbon, Madagascar, Angola, and S. Africa.-Very near L. procera, but a stoutergrowing plant, with narrower and more spreading pinnæ. Perhaps the best distinction is in the scales, which here are very dense, long, and fibre-like. Usually the rachis is quite naked, but in a stout-growing form from Tristan d'Acunha (L. robusta, Carm.), it is densely scaly throughout.

25. L. acuta, Desv.; caud. stout, elongated, densely scaly at the crown; st. strong, erect, 4-6 in. l., dark-coloured, paleaceous below ; fr. stout, erect, ovate, 2-3 ft. l., $1 \mathrm{ft}$. br., with numerous pinnæ on each side, which are quite distinct and 1 in. or more distant at the base, linear, 4-6 in. l., nearly 1 in. br., entire at the edge, and narrowed gradually towards both ends; texture coriaceous ; veins inconspicuous, both surfaces naked ; fertile pinnoe 1 in. distant, narrowly linear, 4-6 in. 1.; rachis stout, erect, naked.-L. cuspidata, Kze. Hk. Sp. 3. p. 30. t. 151.

Hab. Peru and New Granada.-Most like L. procera, but the pinnæ are much more distantly placed and are gradually narrowed to a slightly adnate base from two thirds of the way down.

26. L. filiformis, Cunning. ; rhizome scandent, stout, paleaceous ; st. distant, 1-4 in. l.; sterile fr. ovate-lanceolate, 1-2 ft. l., 3-4 in. br.; pinnoe numerous, spreading, linear, 2-3 in. 1., $\frac{1}{2}$ in. br., distinctly stalked, narrowed gradually tuwards the point and regularly crenato-dentate throughout; $f r$. of the lower part of the caudex often much smaller, linear in general outline, 3-4 in. l., 1 in. br., with oblong obtuse sharply-tootled pinnæ; fertile fr. ovate, with numerous narrowly linear pinnæ 3.4 in. I.; rachis naked.-HK. Sp. 3. p. 33. Stenochlæna heteromorpha, J. Smith.

Hab. New Zealand and Fiji.-A very distinct species, easily recognizable by its trimorphic fronds. Species 21.26 in size and habit recall $3-10$, but are more distinctly pinnate.

27. L. Germainii, Hk. ; caud. elongated, clothed at the apex with lanceolate pale-brown scales; st. 1-2 in. l., erect, firm, scaly ; barren fr. 2-3 in. l., $\frac{3}{4}-1$ in. br., oblong-lanceolate, with imbricated spreading linear obtuse crenate pinnæ, the largest $\frac{3}{8}$ in. $1 ., \frac{1}{8}$ in. br., the lower ones distant and narrowing down gradually to mere auricles; texture stout, coriaceous; veins inconspicuous; fertile fr. on longer stalks, with pinnæe nearly as broad and close as the others; rachis naked.-Hk. Sp. 3. p. 32. t. 152 .

Hab. Chili ; gathered by M. Germain.-Most like $L$. alpina in size and habit, but the lower pinnæ distinctly separated. We have a garden specimen of what looks like the same, but is more slender and elongated, marked "L. crenulata, Moore, MSS. Japan, Veitch." 
28. L. nigra, Col.; caud. stout, clothed at the crown with linear scales; st. slender, erect, densely scaly, 2-3 in. 1. ; barren fr. 4-6 in. 1., 1-1 $\frac{1}{2}$ in. br., linearoblong, with a large bluntish sinuated point, cut down below to the rachis into numerous roundish-oblong sinuated pinno on each side, which are $\frac{1}{2}-\frac{3}{4}$ in. 1 ., $\frac{1}{4}-\frac{3}{8}$ in br., the lower ones quite distinct and a short distance from one another; texture herbaceous; colour dark-green ; veins fine; fertile fr. with longer stalks, the terminal pinna long, linear, the lateral ones linear, erecto-patent.- $H k . S p .3$. $t .35$. Ic. $t .960$.

Hab. New Zealand. A very distinct species of herbaceous texture, with the lower pinnæ quite distinct, but a large terminal portion of the frond lobed only.

29. L. fluviatilis, Spreng.; caud. 3-4 in..1., stout, clothed towards the crown with linear bright-brown scales ; st. 3-4 in. l., erect, densely scaly ; barren fr. linear, 6-18 in. 1., 1-2 in. br.; pinnoe oblong, obtuse, spreading, not decurrent, $\frac{1}{2}-\frac{3}{4}$ in. l., $\frac{1}{4}-\frac{3}{8}$ in. br., the upper ones nearly contiguous, the lower ones shorter and more distant; texture herbaceous; veins conspicuous; fertile pinno linear obtuse, $\frac{1}{2}-\frac{3}{4}$ in. 1., $\frac{1}{8}$ in. br., erecto-patent, the lower ones with more than their own length between their bases; rachis paleaceous throughout.-Hk. Sp. 2. p.34.

Hab. New Zealand, Van Diemen's Land, South Australia.-Easily recognizable from all the others by the shape of its pinnæ.

30. L. membranacea, Col.; caud. short, the scales linear, dark-brown ; st. very

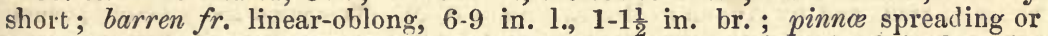
erecto-patent, linear-oblong, obtuse, crenated, the largest $\frac{3}{4}$ in. 1. , $\frac{1}{4}$ in. br., the lower ones quite distinct at the base, but contiguous, the lowest gradually reduced to mere auricles; texture coriaceous; veins often conspicuous ; fertile fir. on a st. several in. 1.; pinno subdistant, linear, erecto-patent; rachis naked.IIk. Sp. 3. p. 34. t. 145.

Hab. New Zealand.-Intermediate in habit between the last and L. lanceulata.

*** Sterite fronds bipinnatifid or bipinnate. Sp. 31-34.

31. L. diversifolia, Baker; caud. stout, oblique, densely clothed with linearsubulate dark-brown scales; sterile fr. ovate, 6-8 in. 1., 3-4 in. br., its stem stout, erect, 4-6 in. l., dark chesnut-brown, paleaceous below ; pinnoe linear, spreading liorizontally, the largest $1 \frac{1}{2}$ in. $1 ., \frac{3}{8}$ in. br., cut down throughout halfway to the rachis into ovate-mucronate lobes, not at all adnate at the base ; texture coriaceous, both surfaces naked; veins strong and prominent, the lateral ones in each of the lobes of the pinnæ usually once branched; fertile fr. on a st. $1 \mathrm{ft}$. l.; pinnoe distant, narrowly linear, 3-4 in. l.; rachis naked and dark chesnut-brown like the stipe.-Blechnum, Metten. Annales, 4 ser. vol. 15. p. 71.

Hab. New Caledonia, Vieillard, 1532.-By their bipinnatifid barren fronds, this and the next connect $L$. Fraseri with the rest of the genus, but the fertile frond is just that of a typical Lomaria.

32. L. Lenormandi, Baker ; st. 4-6 in. 1., strong, 'erect, densely clothed with long brown fibrillæ; sterile fr. oblong-lanceolate, 12-18 in. 1., 6-8 in. br., with numerous quite distinct linear pinnoe on each side, which are 3-4 in. 1., rather more than $\frac{1}{2}$ in. br., cut down very nearly to the rachis throughout into finelytoothed linear falcate pinnl., the lower ones growing shorter very gradually; texture herbaceous ; rachis fibrillose throughout; veinlets of the pinnules inconspicuous; fert. pinnoe very numerous, narrowly linear, quite entire, 2-3 in. 1., $\frac{1}{4}$ in. apart.

Hab. New Caledonia, Vieillard.-This is sent as B. contiguum, Mett., but this latter from the description is a simply pinnate plant near $L$. procera. Here the barren frond resembles that of $L$. Fraseri in cutting, but the rachis is fibrillose, not winged, whilst the fertile frond is not materially different from a large number of the foregoing. 
33. I. Fraseri, Cunning. ; caud. elongated, stout, suberect, densely clothed with linear dark-brown scales at the crown; st. 4-6 in. 1., strong, erect, scaly; fr. ovate-acuminate, bipinnatifid, 12-18 in. 1., 4-6 in. br.; pinnoe linear-lanceolate, the lower ones $2-3$ in. $1 ., \frac{1}{2}-\frac{3}{4}$ in. br., cut down very nearly to the rachis into linear-oblong mucronate slightly-tootled pinnl., their bases decurrent into a pinnatifid wing to the main rachis with triangular lobes; texture herbacenus; veins fine, the lateral ones of the pinnules usually once forked; fertile fr. similar in size and cutting.-Hk. Sp. 3.p. 40. Ic. Pl.t. 185.

Hab. New Zealand.-Very dissimilar in habit to all the other species, combining a frond like one of our common Lastrece with the fructification of a Lomaria.

34. L. volubilis, Hk.; fr. $20 \mathrm{ft}$. 1., scandent and twining; pinnoe distantly placed, deltoid-ovate, $1 \mathrm{ft}$. or more 1., by nearly as broad, with a terninal pinnl. and several opposite pairs, which are oblong, the largest $4-5$ in. 1., $1 \frac{1}{4}-1 \frac{1}{2}$ in. br., narrowed suddenly to a long acuminate point, the upper part slightly toothed and rounded at the base to a short petiole; texture subcoriaceous; veins fine, close-placed, usually simple; rachis and both surfaces naked; fertile pinnl. narrowly linear, 4-6 in. 1., 1 in. or more apart at the base, with a broad continuous invol. springing from the edge of the leafy rib not more than a line wide. -Hk. Sp.3. p. 39. t. 150.

Hab. Banks of the Rio Negro, Spruce, 1263 ; and since gathered by Dr. Spruce at Napes $(2,800)$, and by Appun in British Guiana (995). - This remarkable plant appears quite to agree in habit with Blechnum volubile, of which it is probable it will ultimately be shown to be an abnormal Lomarioid form.

\$ Plagiogyria, Kunze. Base of the stipe suddenly dilated, fleshy, triquetrous, furnished with large spongy glands. Capsules with an oblique ring. Sp. 3̃-39.

35. L. (Plag.) semicordata, Baker ; caud. short, erect; st. dilated at the base, winged below, erect, naked, 3-6 in. 1. ; fr. ovate-lanceolate, 1-2 ft. 1., 4-6 in. br. ; pinno numerous, spreading, linear, $3-4$ in. l., $\frac{1}{4}-\frac{3}{8}$ in. br., finely serrated throughout, the lower ones deflexed, the point narrowed gradually ; texture subcoriaceous; veins fine; fertile fr. similar, but the pinnæ more distant and narrowly linear ; rachis strong, erect, naked.-Lomaridium, Presl. L. biserrata, $M . \& L$. Hk. Sp. 3. p. 19.

Hab. Tropical America from Columbia to Peru.

36. L. (Plag.) adnata, Blume ; caud. short, stout; st. 6-18 in. 1., firm, erect, naked, dilated at the base ; fr. ovate-lanceolate, 12-18 in. 1., 4-6 in. br.; pinnoe linear, falcate, the largest 3 in. $1 ., \frac{3}{8} \mathrm{in.} \mathrm{br}$., the lowest equal to those next in order, the lower ones narrowed at the base below, $\frac{1}{2}$ in. apart, the point narrowed very gradually and finely toothed; texture subcoriaceous; veins conspicuous; fertile fr. similar, but the pinnoe more distant and narrowly linear; rachis naked, erect.-Hk. Sp. 3. p. 19. t. 147 .

Hab. Java and Khasia at 1-4,000 ft.-This and the preceding have the central pinnæ of the barren frond dilated, but the other three have them narrowed at the base and distinct from one another, as in species 21-30.

37. L. (Plag.) glauca, Blume ; st. 1 ft. 1., nakéd, erect ; fr. ovate, 12-24 in. 1., 6-9 in. br. ; pinnoe contiguous, erecto-patent, linear, $3-5$ in. $1 ., \frac{1}{2}$ in. or more br., narrowed gradually and sharply toothed towards the point, narrowed on both sides at the base; texture coriaceous; veins fine, subparallel, under surface glaucous; fertile fr. similar, but the pinnæ distant and narrowly linear; rachis stout, erect, naked.-Hk. Sp. 3. p. 22.

Hab. Java and Khasia at 6,000 ft. ; gathered by Drs. Hooker and Thouson.Readily distinguishable by the silvery whiteness of the under side of the frond. 
38. L. (Plag.) pycnophylla, Kunze; caud. stout, erect, woody; st. stout, erect, naked, 6-9 in. l. ; fr. ovate-lanceolate, 2-3 ft. l., 6-9 in. br.; pinnoe very numerous, linear, spreading, 4-6 in. l., $\frac{1}{2}$ in. br., contiguous, narrowed on both sides at the base, the point narrowed very gradually and finely toothed; texture coriaceous ; veins inconspicuous ; fertile fr. similar, but the pinnæ distant and narıowly linear; rachis strong, erect, naked.-Hk. Sp. 3. p. 21. t. 148.

Hab. Java, Malayan Peninsula, and N. Hindostan, ascending to $10,000 \mathrm{ft}$.-The pinnæ of both the barren and fertile fronds are often but not always furnished with a large gland at the base.

39. L. (Plag.) euphlebia, Kunze ; caud. stout, woody, elongated; st. 1 ft. or more l., naked, erect, triquetrous below ; fr. ovate-lanceolate, 1-2 ft. 1., 6-12 in. hr.; pinnoe 1 in. or more apart at the base, erecto-patent, linear, 4-6 in. 1., $\frac{1}{2}-\frac{3}{4}$ in. br., narrowed at the base on both sides and narrowed very gradually and toothed towards the point; texture subcoriaceous; veins prominent; fertile fr. similar, but the pinnæ more distant and narrowly linear ; rachis erect, naked.Hk. Sp. 3. p. 20. 2nd Cent. t. 89. L. articulata, F. Muell. Frag. 5. p. 174.

Hab. Japan and Tsus Sima; gathered lately by Messrs. Oldham and Wilford, by Dallachy at the source of the Mackay River, Australia, and N. Hindostan, ascending to 6,000 ft.-Pinnæ much less numerous and more distant than in $L$. pycnophylla, and venation not so fine.

\section{Tribe 7. Blechnede.}

Sori linear or oblong, dorsal, parallel with the midrib and edge of the segments, not close to the latter. Invol. the same shape as the sorus, superior, opening towards the midrib. GEN. 34-37.

\section{Gen. 34. Bleennum, $L$.}

Sori linear, continuous, or nearly so, parallel with and usually contiguous to the midrib. Invol. membranaceous, distinct from the edge of the frond. Fronds uniform or slightly dimorphous, generally pinnate or pinnatifid, in one species simple and in one bipinnate. Veins usually free. $A$ not large genus of closely resembling species, diffused widely throughout Tropical aad South Temperate regions. TAB. IV. f. 34 .

§ Eublechnum. Stem straight, frond not more than simply pinnate. Sp. 1-17.

* Frond usually simple. Sp. 1.

1. B. Lanceola, Swartz; rhizome slender, creeping, stoloniferous ; st. slender, erect, 2-4 in. l.; fr. lanceolate, undivided, 4-6 in. l., $\frac{3}{8}-\frac{1}{2}$ in. br., narrowed gradually from the centre in both directions, especially upwards; texture subcoriaceous; sori in a continuous line close to the midrib. $-\beta, B$. trifoliatum, Kaulf.; $f r$. furnished with 1 or 2 pairs of small oblong obtuse lateral pinnæ at the base of the large terminal one.-Hk. Sp. 3. p. 47. Ic. p. 970.

Hab. Tropical America from Panama southward to Brazil and Peru.-The littleknown B. plantagineum, Presl, is said to be like the type, but with a space between the line of fructification and midrib.

\section{* Frond pinnatifid. Sp. 2-6.}

2. B. asplenioides, Swartz; caud. ultimately elongated, clothed at the crown with small linear scales; st. none or short; fr. linear-lanceolate, narrowed at both ends, 6-8 in. l., $\frac{1}{2}-\frac{3}{4}$ in. br. ; pinno numerous, the central ones spreading, lanceolate-deltoid, $\frac{1}{4}-\frac{3}{8}$ in. $1 ., \frac{1}{8}$ in. br., the point aeute or blunt, all connected at the base, the lower ones dwindling in size very gradually; texture subcoriaceous; 
rachis and loth surfaces naked; veins inconspicuous; sori in a short line close to the midril, often on one side only.-Hk.Sp.3. p. 45. B. polypodioides, Kze. \& Mett. non Raddi.

Hab. Tropical America from Panama and N. Granada to Brazil and Peru.-A more slender and narrower plant than $B$. unilaterale, with even the lowest pinnæ connected and much less copious sori.

3. B. unilaterale, Willd.; caud. elongated, densely clothed at the crown with linear pale-brown scales ; st. slender, erect, 1-4 in. l., slightly scaly below ; fr. lanceolate, $6-12$ in. $1 ., 1 \frac{1}{2}-2$ in. br.; pinnoe numerous, spreading horizontally, linear, $\frac{3}{4}-1$ in. l., the central ones $\frac{1}{4}-\frac{3}{8}$ in. br., the point usually mucronate, the edge entire or nearly so, the lower part dilated to a broad base, the lower ones broader, blunter, and short; texture herbaceous, both surfaces and rachis naked or slightly hairy; veins inconspicuous; sori in a line close to the midrib.B. poly podioides, $R a d d i$. Hk. $S p$. 3. p. 45 .

Hab. Tropical America from Mexico and the W. Indies southward to Peru and S. Brazil.-This comes very near the small forms of $B$. occidentale, and we cannot, from the description alone, distinguish $B$. triangulare, Link.

4. B. cartilagineum, Swartz; caud. oblique, densely clothed at the crown with blackish fibrillose scales; st. strong, erect, 4-6 in. 1., scaly and muricated in the lower part; fr. ovate-oblong, 1-2 ft. 1., 6-9 in. br.; pinna numerous, erectopatent, linear, 4-6 in. 1., $\frac{1}{4}-\frac{1}{2}$ in. br., narrowed gradually towards the point, the margin finely toothed, dilated and connected at the base, the lower ones not conspicuously smaller than the others ; texture coriaceous ; rachis and both surfaces naked; veins fine; sori in a broad line close to the midrib.-Hk. Sp. 2. p. 43.

Hab. Temperate Australia. Very like $B$. nitidum, from which it is best distinguished by its muricated stipe.

5. B. nitidum, Presl ; st. stout, erect, naked, 3-4 in. 1. ; fr. oblong-lanceolate, $1 \mathrm{ft}$. or more l., 4-6 in. br.; pinnoe numerous, erecto-patent, subfalcate, linear, 3-4 in. 1., $\frac{1}{4}-\frac{3}{8}$ in. br., narrowed gradually towards the point, dilated and connected at the base, the edge undulato-dentate, the lower ones linear acute and not much smaller than the rest; texture coriaceous, both surfaces and rachis naked; veins fine; sori in a continuous line close to the midrib; invol. conspicuous. - Hk. Sp. 3. p. 44.t. 55.

Hab. S. Brazil, Philippines, Marianne Islands, Isle of Gaudalcomar and Mishmee, N. Hindostan.-Near $B$. brasiliense, but a smaller plant, terminating abruptly below, aud the involucre more conspicuous. In some of the specimens (var. contractum, Hook.) the pinnæ are contracted and the edge is much undulated. It seems probable that the B. vittatum, figured by Brackenridge from Fiji, is the same abuormal form, which in some of M. Vieillard's New Caledonian examples named by Mettenius, has completely Lomarioid sori.

6. B. brasiliense, Desv. ; caud. erect, stout, subarborescent, 1 ft. or more l., densely clothed at the crown with dark-brown fibrillose scales; st. short, stout, densely scaly ; fr. oblong-lanceolate, 2-3 ft. 1., $1 \mathrm{ft}$. or more br., narrowing downwards very gradually ; pinnoe close, erecto-patent, linear, 4-6 in. $1 ., \frac{1}{2}$ in. br., narrowed gradually towards the point, very finely toothed, connected at the base, the lower ones short and blunt; texture coriaceous, both surfaces naked; veins fine; rachis naked; sori in a continuous line close to the midrib; invol. narrow.-Hk. Sp. 3. p. 43. t. 157. B. Corcovadense, Raddi.

Hab. Brazil and Peru. 


\section{*** Fronds pinnate. Sp. 7-17.}

7. B. longifolium, H. B. K. ; rhizome slender, creeping; st. firm, erect, nearly naked, 6-12 in. l. ; fr. with a terminal pinna and 3-6 lateral ones on each side, which are $3-5$ in. l., $\frac{1}{2}$ in. hr., narrowed gradually towards the point, narrowed or even slightly stalked and then cordate at the base, the lower ones about $1 \mathrm{in}$. apart; texture coriaceous; rachis and both surfaces naked; veins inconspicuous; sori in broad lines close to the midrib. - Hk. Sp. 3. p. 49. t. 94. - $\beta, B$. fraxineum, Willd.; habit more robust; pinnoe 6-8 on a side, sometimes 1 in. br.-B. Schlimense, Fée.

Hab. Tropical America from Mexico and the West Indies southward to Brazil and Peru.-B. gracile, Kaulf., appears to differ from the type only by its rather more slender habit, and $B$. intermedium, Link, is more slender still, and may possibly belong to species 1. The veins occasionally form costal arches, as is the case also in $B$. unilaterale and australe.

8. B. Fendleri, Hk.; rhizome slender, wide-creeping; st. 9 in. l., slender, pale straw-coloured, slightly villose above ; $f r$. subdeltoid, 4-6 in. l., 3 in. br., with a linear terminal pinna and 3-4 pair of spreading subfalcate lateral ones, which are 2-3 in. $1 ., \frac{1}{4}$ in. or rather more br., with an acute point, the lower ones auricled at the base, quite adnate but not connected with one another; texture herbaceous ; rachis villose and both surfaces slightly so ; veins fine, forming a series of costal arches halfway up the pinnæ; sori in continuous lines close to the midrib, with a pale broad membranous slightly villose involucre.-Hk. Sp. 3. $p .48$. $t .158$.

Hab. Venezuela, Fendler, 116. Brazil, Burchell, 6460.-This has quite the general babit of the preceding, of which it is not unlikely a form with more slender habit and more anastomosing venation.

9. B. occidentale, Linn.; caud. stout, erect, clothed at the crown with lanceolate acuminate scales ; st. 6-12 in. l., erect, scaly below ; $f r$. ovate-acuminate, 9-18 in. 1., 4-8 in. br., with 12-24 linear pinnce on each side, which are 3-6 in. 1., $\frac{3}{8}-\frac{3}{4}$ in. br., narrowed gradually to a point, truncate or cordate or even auricled at the base, the lower ones often $1 \mathrm{in}$. apart, and the lowest pair deflexed and not much less than the rest; texture coriaceous; rachis and both surfaces naked or slightly pubescent; veins inconspicuous; sori in a broad continuous line close to the midrib. $-H k$. Sp. 3. p. 50.

Hab. America, common from Mexico and W. Indies southward to Chili and S. Brazil. -B. pectinatum, Hk. Ic. Pl. t. 95, is a form with narrow pinnæ dilated, and most of them connected, at the base, and $L$. campylotis, Kunze, a form with a distinct acute auricle at the base of the pinnæ on the upper side.

10. B. arcuatum, C. Gay; caud. stout, suberect, densely clothed at the crown with lanceolate acuminate dark-brown scales; st. 6-12 in. l., strong, erect, scaly

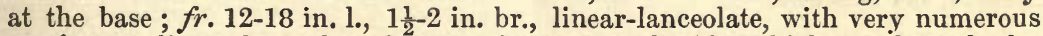
contiguous linear-lanceolate falcate pinnoe on each side, which are $\frac{3}{4}$ in. 1 ., by under $\frac{1}{4}$ in. br. below, gradually narrowed upwards, hastately auricled on the upper side, quite distinct at the base, but sometimes imbricated, gradually diminishing downwards to mere auricles; texture rigid and very coriaceous; rachis and both surfaces naked; veins immersed; sori in a continuous line close to the midrib.-Hk. Sp. 3. p. 59. B. acuminatum, Sturm, non Fée.

Hab. Chili and Chiloe.-A more rigid plant than the last, with a narrower frond narrowing gradually downwards.

11. B. hastatum, Kaulf. ; caud. short, stout, scaly ; st. erect, 4-6 in. l., nearly naked; fr. 12-18 in. 1., 2-4 in. br., lanceolate, with 20-40 pinnce on each side, the sterile ones $1-1 \frac{1}{2}$ in. $1 ., \frac{1}{4}-\frac{3}{8}$ in. br., lanceolate, falcate, narrowed gradually to 
a point, the lower side truncate and slightly auricled, the upper side cordate with a large hastate auricle, the lower ones broader and shorter ; texture coriaceous ; rachis and both surfaces naked or slightly pubescent; veins fine, the lateral ones often twice forked; fertile pinno narrower; sori midway between the midrib and edge, in a continuous or interrupted line.- $H k . S p .3 . p .57$.

Hab. Temperate S. America.-M. remotum, Presl, is a small pubescent form, and Tonitis sagittifera, Bory, a form with pinnatifid pinnæ. Very near $B$. australe, but the sori more interrupted and not so near the midrib.

12. B. australe, Linn. ; caud. stout, creeping, scaly ; st. erect, 4-6 in. 1. ; fr. 9-18 in. 1., 2-3 in. br., lanceolate, narrowed towards both ends ; pinnoe numerous, spreading, the sterile ones $1 \frac{1}{2}$ in. $1 ., \frac{1}{4}-\frac{3}{8}$ in. br., linear, narrowed to a sharp point, hastate-cordate or auricled at the base, especially on the upper side, quite distinct, the lower ones passing down into mere auricles; texture rigid and coriaceous; veins hidden; rachis and both surfaces naked; fertile pinnoe narrower; sori in a continuous or slightly interrupted line not quite contiguous to the midrib, sometimes reaching the edge.- $-H k . S p .3 . p .57$.

Hab. S. Africa, northward to Bourbon, Madagascar, and Natal.-This and the preceding may be known from all the others by having a space between the sori and midrib, which characterizes Presl's genus Mesothema.

13. B. lovigatum, Cav.; caud. stout, ascending, clothed at the crown with large lanceolate pale-brown scales; st. erect, 6-9 in. 1. , pale, naked or scaly below; barren fr. oblong-deltoid, 9-15 in. 1., 6-9 in. br., with a large lanceolate terminal pinna, and numerous spreading oblong-lanceolate lateral ones on each side, the largest of which are 3-4 in. 1., 1 in. br., narrowed suddenly to an acuminate point, the margin slightly serrated, quite distinct and cordate at the base ; texture coriaceous ; rachis and both surfaces naked, or the former slightly scaly; veins inconspicuous and nearly 1 lin. apart; fertile fr. smaller and the pinnæ narrower and more distant, the line of sori contiguous to the midrib, $\mathbf{1} \frac{1}{2}-2$ lin. br., with a large brown membranous invol.-Hk. Sp. 3. p. 56.

Hab. N. S. Wales.

14. B. serrulatum, Rich.; caud. elongated, stout, ascending ; st.6-12 in.1., strong, erect, smooth, nearly naked; $f r$. oblong-acuminate, 1-2 ft. l., 6-9 in. br., with 12-24 pairs of quite distinct articulated linear-oblong pinnce on each side, the largest of which are $4-5$ in. $1 ., \frac{1}{2}-\frac{3}{4} \mathrm{in}$. br., narrowed gradually towards the point and downwards to a narrow base, the margin finely incised; texture coriaceous; rachis rigid, naked; veins very fine and close, not conspicuous ; fertile pinnoe narrower; sori in a continuous line close to the midrib.-Hk. Sp. 3. p. 54 . B. striatum, Br. Hk. Sp. 3. p. 55. t. 159.

Hab. Florida, W. Indies, Guiana, and Brazil; Australia, New Caledonia, Borneo, Malacca, and Mishmee.

15. B. orientale, Linn. ; caud. stout, erect, clothed at the crown with fibrillose dark-brown scales ; st. 4-8 in. l., strong, erect, scaly below ; fr. 1-3 ft. 1., 6-12 in. br., ovate, with very numerous nearly contiguous linear pinnoe on each side, which are 4-8 in. l., $\frac{3}{8}-\frac{3}{4}$ in. br., narrowed to a long point, the bases quite distinct, the upper ones decurrent, a few of the lowest mere auricles; texture subcoriaceous; rachis and both surfaces naked; veins fine and close ; sori in a long continuous line close to the midrib.-Hk. Sp. 3. p. 52. F. Ex.t. 77.

Hab. Australia aud Polynesian Islands northward to S. China and the Himalayas.Presl places this with species 4, 5, 6, 14, and 17, in his genus Blechnopsis, characterized by having a cartilaginous border to the pinnæ which unites the tips of the veins.

16. B. melanopus, Hk.; st. erect, 6 in. l., naked, dark chesnut-brown ; fr. 
ovate-lanceolate, 8-9 in. 1., 3 in. br., with numerous contiguous linear falcate pinnoe on each side, which are 1-1 $\frac{1}{2}$ in. $1 ., \frac{1}{4}-\frac{3}{8}$ in. br., narrowed gradually towards the point, the edge entire, the upper ones adnate and dilated at the base, but those below the centre distinct, the lowest ones growing gradually shorter and blunter; texture coriaceous ; rachis and both surfaces naked; veins forming large arched areoles; sori in a continuous line near the midrib.- $H k$. Sp. 3. p. 64. t. 161. Blechnidium, Moore.

Hab. Khasia Hills, Bengal, Simons, 78.-Most like some of the forms of B.occidentale in habit, with the cuticle of the under side of the frond loose and wrinkled.

17. B. Finlaysonianum, Wall. ; caud. sliort; st. 1 ft. l., strong, erect, darkbrown, polished; fr. 3-4 ft. l., with a large terminal pinna and numerous erecto-patent lateral ones on each side, the largest 9-12 in. l., 1 in. or more br., narrowed gradually to a point and below to a narrow base, the margin entire, the lowest reduced to mere auricles; texture coriaceous, both surfaces naked; veins close, inconspicuous; sori in a continuous line close to the midrib.Hk. Sp. 3. p. 53. Hk. \& Gr. Ic. t. 225.

Hab. Malayan Peninsula and Borneo.-This is glossy, with the largest pinnæ in the genus, resembling in habit $B$. orientale, some of the large forms of which come very near it.

\section{§§ Salpichlæna, J. Sm. Stem twining, frond bipinnate. Sp. 18.}

18. B. (Salpi.) volubile, Kaulf. ; st. wide-climbing ; pinno in distant opposite pairs ; pinnl. usually 4-6 on each side, stalked, linear-lanceolate, 6-12 in. 1., $\frac{1}{2}-2$ in. br., with an undulated cartilaginous border; texture coriaceous; rachis and both surfaces naked; invol. broad, membranous, at first wrapped over the fruit, afterwards breaking up into short pieces.-Hk. Sp. 3. p. 63. Gard. $F$. t. 15. S. scandens, Presl. Peru.

Hab. Tropical America from the West Indies and Columbia southward to Brazil and

\section{Gen. 35. Sadleria, Kaulf.}

Sori in a continuous line close to the midrib on both sides, placed on an elevated receptacle. Invol. narrow, subcoriaceous, at first wrapped over the sorus, afterwards spreading. Veins forming a series of costal arches. Caudex 3-4 feet high, arborescent. ТАв. 4. f. 35.

1. S. cyatheoides, Kaulf.; st. strong, erect, 6-18 in. 1., naked except at the base, where it is densely clothed with long linear scales ; fr. 4-6 ft. 1., 9-18 in. br. ; pinnce 8-12 in. 1., $\frac{1}{2}-\frac{3}{4}$ in. br., cut down to the rachis into very numerous connected linear pinnl. $\frac{3}{8}-\frac{1}{2}$ in. 1., $\frac{1}{8}$ in. br., acute or bluntish ; texture coriaceous ; veins immersed and inconspicuous; rachis stout, naked.-Hk. Sp. 3. p. 65 . B. Kaulfussianum, Gaud. Atlas, $p$. 78.

Hab. Sandwich Islands and Sumatra.-A fine plant, which combines the habit of a small Cyathea with the fructification of a Blechnum. The original S. pallida, H. \& A., is a mere form with a paler rachis; but a plant thus named by Mettenius, gathered by Dr: Hillebrand, is less rigid in texture, with flatter, broader, and blunter pinnules, and quite conspicuous venation. Probably this is Brackenridge's pallida, which is said to have a somewhat paleaceous rachis; and we have also another plant from Dr. Hillebrand like the type in texture, but the largest pinnæ 21 in. $1 ., 3$ in. br., which agrees with Gaudichaud's figure of $B$. Souleytianum.

2. S. squarrosa, Gaud.; st.6-8 in. 1., erect, reddish-brown, scaly and asperous ; fr. 12-18 in. 1., 6 in. br.; pinnce in 12-18 pairs on each side, linear-lanceolate, 3-4 in. l., $\frac{1}{2}-\frac{3}{4}$ in. br., cut down to the rachis into quite distinct oblong 
subfalcate pinnl. $\frac{1}{4}-\frac{3}{8}$ in. $1 ., \frac{1}{4}$ in. br. ; texture coriaceous; veins immersed ; main rachis and that of the pinnæ densely clothed throughout with ovate-acuminate dark-brown scales.-Gaud. Voy. Bonit. Atlas, $t$. 2. Blechnum polystichoides, Brack. Fil. U.S. Exp.p. 135.

Hab. Sandwich Islands; gathered lately by Dr. Hillebrand.-Very different in habit from No. 1, and the rows of fruit are shorter and not quite close to the inconspicuous midrib.

\section{Gen. 36. Woodwardia, Sm.}

Sori linear or linear-oblong, sunk in cavities of the frond, placed in single rows parallel with and contiguous to the midribs of the pinnæ and pinnules. Invol. subcoriaceous, the same shape as the sorus, closing over the cavity like a lid. Veins forming always a series of costal arches, for the rest free or anastomosing. A small genus with fronds usually ample and bipinnatifid, which belts the world in the North Temperate Zone, extending very slightly within the Tropic. TA B. IV. f. 36 .

\$ Euwoodwardia. Fronds uniform, the veins forming at least one series of areolations between the sori and the margin. Sp. 1-2.

1. W. radicans, Smith ; st. strong, erect, naked, scaly at the base ; fr. 3-6 ft. 1., 12-18 in. br. ; pinnoe lanceolate, the lower ones often $1 \mathrm{ft}$. l., cut down below within a short distance of the rachis into finely-toothed lanceolate pinnl. 1-1 $\frac{1}{2}$ in.1., those of the under side the shortest; veins anastomosing once outside the line of fruit; gemmo few and large, placed at the base of the upper pinnæ.- $H k . S p .3$. p. 67 .

Hab. Madeira and the Canaries, Spain, Italy, Sicily, Northern India, Java, California, Mexico, and Guatemala.

2. W. orientalis, Swartz; st. erect, densely clothed at the base with large linear-lanceolate scales; fr. 4-8 ft. 1., 12-18 in. br. ; pinnoe lanceolate, sometimes more than $1 \mathrm{ft}$. l., cut down below nearly to the rachis into sinuated or pinnatifid pinnl., sometimes 4 in. l., those of the under side shorter and none at the base of the pinnæ; veins anastomosing copiously outside the sori, upper surface of the frond often producing copious gemmiferous buds.-Hk. Sp. 3. p. 68.

Hab. Japan southward to Formosa.-Probably this ought to be joined with the preceding.

\$ Anchistea, Presl. Fronds uniform, the veins all free between the sori and the margin. Sp. 3-4.

3. W. Virginica, Smith ; st. strong, erect, 12-18 in. 1. ; fr. oblong-lanceolate, 12-18 in. 1., 6-9 in. br.; pinnoe linear-lanceolate, 4-6 in. 1., $\frac{3}{4-1}$ in. br., cut down within 1 lin. or less of the rachis into linear-oblong lobes which are 2-3 lin. br. at the base, the lines of sori which margin the midrib of the pinnæ often reaching low down in the lower ones.-Hk. Sp. 3. p. 69.

Hab. United States from Vermont to Florida.

4. W. Japonica, Swartz ; st. 6-12 in. 1., erect, scaly below ; fr. broadly ovate, 12-18 in. 1., 9-12 in. br. ; pinnoe lanceolate, often 6 in. 1., 1-1 $\frac{1}{4}$ in. br., pinnatifid, with lobes $\frac{1}{4}-\frac{3}{8}$ in. br., which reach half or two-thirds of the distance down to the rachis, the lines of sori which margin the midrib of the pinnæ confined to the upper part of the upper ones.-Hk. Sp. 3. p. 69.

Hab. China and Japan. 
$§ \S \S$ Lorinseria, Presl. Fronds dimorphous, veins everywhere anastomosing. Sp. 5-6.

5. W. areolata, Moore ; sterile fr. with a slender st., 9-12 in. 1., 6-8 in. br., deltoid-ovate, with numerous oblong-lanceolate sinuated pinnce on each side, the lower ones 3-4 in. 1., $\frac{1}{2}-\frac{3}{4}$ in. br., reaching down to the rachis, which above has a broad wing; texture herbaceous, both surfaces naked; fertile fr. with an elongated, strong, erect, chesnut-brown, naked stem ; pinnoe 3-4 in. 1., narrowly linear, $\frac{1}{2}-1$ in. apart.-Hk. Sp. 3. p. 70. Gard. F.t.61. W. angustifolia, Sm.

Hab. United States, from Massachusetts to Florida.

6. W. Harlandii, Hk.; st. 6-18 in. l., erect, nearly naked ; barren fr. varying in shape from linear-lanceolate, undivided, to broadly ovate, with 1 or 2 spreading linear-lanceolate lobes $3-4$ in. l., $\frac{1}{2}-\frac{3}{4}$ in. br., reaching down to a broadly-winged rachis ; texture coriaceous, both surfaces naked ; fertile $f r$. with more numerous and narrower lobes, the lowest pair often quite free from the others; sori in broad lines close to the midrib of the lobes, with short lines branching from these in an erecto-patent direction.-Hk. Sp. 3.p. 70. Fil. Ex. t. 7.

Hab. Hong-Kong.

\section{Gen. 37. Doodra, R. Br.}

Sori oblong or slightly curved, superficial, placed in one or more rows parallel with and between the midribs and margins of the pinnæ. Invol. membranous, the same shape as the sorus. Veins forming one or two series of arches between the midrib and edge, on which the sori are placed. Fronds 6-18 in. l., pinnate or pinnatifid. A small genus, confined to the islands from Ceylon eastward to Fiji, New Zealand, and Australia. TAв. IV. f. 37.

\section{* Pinnatifid. Sp. 1-3.}

1. D. aspera, R. Br. ; st. 2-4 in. 1., erect, dark-coloured, asperous ; fr. 6-18 in. l., 2-4 in. br., oblong-lanceolate, with numerous spreading linear pinnoe on each side, which are 1-2 in. 1., $\frac{1}{4}$ in. br., the margin strongly serrated, the base dilated, the lower ones dwindling down gradually to mere auricles ; texture coriaceous; sori oblong, about their own length apart, in one or two rows, the innermost a short distance from the midrib.-Hk. $S p$. 3. $p .71$.

Hab. Temperate Australia.

2. D. blechnoides, Cunning. ; st. 3-4 in. 1., erect, slightly scabrous below ; fr. 15 in. l., 6 in. br., oblong-lanceolate, with numerous spreading linear pinnce on each side, the largest of which are 3 in. l., by rather more than $\frac{1}{4}$ in. br., the margin sharply serrated, the base dilated, the upper ones connected, the lower ones shorter and free, not dwindling down to auricles; texture coriaceous; sori oblong, in a rather irregular row contiguous to the midrib.-Hk. Sp. 3. $p .72$.

Hab. N. S. Wales.-Our description is taken from a wild specimen gathered by Mr. Fraser. The plaut cultivated under this name has the pinnæ reduced very gradually below, as in the last.

3. D. dives, Kunze ; st. 6-12 in. 1., slender, erect, smooth, clothed towards the base with dark-coloured linear scales; sterile fr. $1 \mathrm{ft}$. l., 3-5 in. br., oblonglanceolate, with numerous spreading linear-oblong pinnoe on each side, which are 2-3 in. l., $\frac{1}{2}$ in. br., the point blunt, the margin undulated and serrated, the base suddenly dilated, and all except the lowest connected ; texture coriaceous ; fertile fr. longer, with narrow linear pinnoe, the central ones 1 in. apart, connected by a 
broad decurrent wing to the rachis, the two or three lowest pairs free; sori linearoblong, in two irregular rows, nearer the midrib than the edge.-Hk.Sp. 3. p. 74 .

Hab. Ceylon.-Kunze's original Javan plant has the fertile pinnæ closer.

\section{** Pinnate in lower half. Sp. 4-5.}

4. D. media, R. Br.; st. 4-6 in. l., erect, smooth, usually nearly black ; fr. 12-18 in. l., $1 \frac{1}{2}-4 \mathrm{in}$. br., lanceolate, with numerous spreading linear pinnoe on each side, which are 1-2 in. $1 ., \frac{1}{4}-\frac{3}{8}$ in. br., acute or bluntish at the point, the margin toothed, the upper ones dilated and connected at the base, those below the middle free and cordate or even auricled on the upper side, the lower ones gradually diminishing; texture coriaceous or subcoriaceous; sori short, oblong, distant, in one or two rows, with a considerable space between the inner one and the midrib.-Hk. Sp. 3. p. 74.- $\beta$, D. connexa, Kunze; fr. larger, more herbaceous in texture; pinnoe sometimes 3 in. or more l.-Hk. Sp. 3.p. 75.

Hab. Polynesian Islands, Australia, and New Zealand.

5. D. caudata, R. Br.; st. 4-6 in. l., slender, smooth ; fr. 6-12 in.1., $1 \frac{1}{2}-2$ in. hr., lanceolate, with numerous spreading linear pinnoe on each side, which are often 1 in. or more l., the sterile ones oblong, blunt, sharply serrated, only the uppermost connected at the base, the frond often terminated by a long entire point; texture subcoriaceous; rachis slender, often pubescent; fertile pinnce narrower and shorter.-Hk. Sp. 3. p. 75 .

Hab. Australia, Van Diemen's Land, and New Zealand. - "Very closely allied to $D$. media, and probably a variety of it, but more flaccid, the fronds often prostrate, pinnate nearly to the top, fertile more distinct from the barren and longer."Dr. Hooker, Fl. N. Z. p. 370 . A curious form (D. linearis, J. Smith) from New Caledonia and Australia, has a long narrow linear frond, the upper part undivided, only the lower third sinuato-pinnatifid, with short rounded lobes, the lowest of which are distinct.

\section{Tribe 8. Aspleniez.}

Sori attached to the veins, oblique with regard to the costa or occasionally subparallel with it, linear or oblong. Invol. the same shape as the sorus, when single opening towards the midrib, sometimes double. Gen. 38-40.

\section{Gen. 38. Asplenium, Linn.}

Sori dorsal or submarginal, linear or oblong. Invol. similar in shape, straight, or occasionally curved, single or double, plane or tumid, bursting along the outer edge. The second in extent of our genera, including plants from all parts of the world where ferns grow, of every variety in size, texture, and cutting. Veins free in a large proportion of the species. Euasplenium is connected with Davalliex by Darea and Loxoscaphe, with Aspidieæ through Athyrium, with Pterideæ through Acropteris and Actiniopteris, and with Grammitideæ by Ceterach. TAB. IV. f. 38 .

\$ Thamnopteris, Presl. Veins connected at the apex by a transverse intramarginal line. Fronds undivided. Sp. 1-3. Neottopteris, J. Sm.

1. A. (Thamn.) Nidus, L. ; fr. 2-4 ft. 1., 3-8 in. br., lanceolate, acute or acuminate at the apex, tapering gradually below into a short stem, the edge entire, the midrib rounded on the back; texture coriaceous; veins fine and parallel, about $\frac{1}{2}$ lin. apart ; sor $i$ reaching about halfway towards the margin.Hk. Sp. 3. p. 77. Bot. Mag. t. 3101.- $\beta, A$. muscefolium, Mett. ; fr. larger, sometimes $6 \mathrm{ft}$. l., $1 \mathrm{ft}$. br., with sori extending nearly to the edge.-Hk. Sp. Fil. 
3. p. 78. - $\gamma$, A. Australasicum, Hk. ; midrib keeled on the back, often black.Hk. F. Ex. $t .88$.

Hab. Mauritius, Johanna Island, Seychelles, Himalayas, Japan, Bonin, and Chusan, westward to the Society Islands ; southward to New Caledonia, Queensland, Norfolk Island, and Isord Howe's Island. The Himalayan and Malayan A. Phyllitidis, Don, seems to differ from the type only by its smaller size. The sori in some of the specimens are quite as close as in any of the above. A. pachyphyllum and tceniosum, Kunze, we have not seen. A plant from Malacca and Java has the veins $\frac{1}{8}$ in. apart and much broader sori.

2. A. (Thamn.) Grevillei, Wall. ; fr. $12-18$ in. 1., 2-3 in. br., lanceolatespathulate, narrowed to an acute apex and suddenly below to a broad wing to the stipe, which grows very gradually narrower downwards, the margin entire ; texture coriaceous; midrib keeled below; veins nearly horizontal, those in the body of the fr. about $\frac{1}{2}$ lin. apart ; sori on most of them extending within a short distance of the edge.-Hk. Sp. 3. p. 80. Hk. \& Gr. Ic.t. 128.

Hab. Gathered in Tavoy by Dr. Wallich and Mishmee by Helfer.

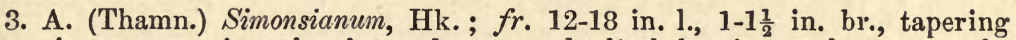
above into an acuminated point and very gradually below into a short stem, the margin nearly entire; midrib only rounded and prominent below ; texture coriaceous ; veins erecto-patent, about $\frac{1}{2}$ lin. apart ; sori copious, reaching from the midrib to within a short distance of the edge.-Hk. Sp. 3. p. 81. Ic. Pl. t. 925 .

Hab. Khasia and Unker Hills, Bengal, Simons, 232.-This and the preceding are two little-known plants, perhaps not really distinct from No. 1.

$\S \S$ Fuasplenium. Veins free, simple or branched; sori linear or linear-oblong, straight, discoidal. Sp.4-154. Fig. 38. a.

\section{* Fronds quite entire. Sp. 4-17. Phyllitis. J. Sm.}

4. A. ensiforme, Wall. ; st. tufted, 1-3 in. l., firm, erect, scaly below ; fr. 12-18 in. 1., $\frac{1}{2}-\frac{3}{4}$ in. br., much acuminated towards the point, edge nearly entire, lower part narrowed into the stem very gradually; texture coriaceous; veins immersed, inconspicuous, erecto-patent, usually once forked ; sori broad, reaching nearly to both midrib and margin.-Hk. Sp. 3. p. $90 . \quad H k . \&$ Gr. Ic. t. 71.

Hab. Himalayas (ascending to 10,000 ft.) to Ceylon; Moulmein.-The Mexican $A$. coriaceum, Fée, seems from the description to agree with this.

5. A. angustum, Swartz ; st. tufted, short, firm, greyish, erect ; fr. 1-2 ft. 1., 1-1 $\frac{1}{2}$ in. br., linear-lanceolate, the point much acuminated, the margin nearly entire, or the point a little serrated, the lower part narrowed very gradually to the stem from two-thirds of the way down; texture subcoriaceous; veins erectopatent, usually simple; sori rather distant, reaching from the midrib nearly to the edge.-Hk. Sp. 3. p. 89. A. loriforme, Hk. $1 c .926$.

Hab. Brazil and Guiana.

6. A. concolor, Hk. ; st. tufted, 1-2 in. l., firm, greenish, clothed with scales in the lower part; fr. 6-8 il. 1., 1 in. or more br., lanceolate, the point acute, the edge slightly crenato-serrate upwards, the lower part narrowed into the stem very gradually; texture herbaceous; veins usually simple; sori numerous, narrow, extending from the midrib to the edge.-Hk. $S p$. 3. p. 88. $t$. 164. A.

Hab. Java; and a very similar plant, but with a longer stem and frond, has been gathered on the Guinea coast by Messrs. Curror, Barter, and Mann. 
7. A. sinuatum, Beauv.; st. tufted, grooved in front, short, erect ; fr. lanceolate, 1-2 ft. 1., 1-2 $\frac{1}{2}$ in. br., narrowed to an acuminate apex and very gradually below, the margin sliyhtly undulated but not toothed; texture coriaceous ; veins 1 lin. apart, usually simple ; sori narrow, often on every vein, reaching from near the rachis nearly to the margin.-Hk. Sp. 3. p. 82. Fil. Ex. $t .61$.

Hab. Guinea Coast southward to Angola.-A. venosum, Hk., does not seem safely separable.

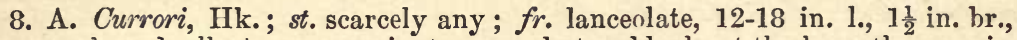
narrowed gradually to an acuminate apex, but suddenly at the base, the margin slightly undulated; texture subcoriaceous; veins fine, usually once branched, about $\frac{1}{8}$ in. apart; sori not reaching by a space either midrib or margin.-Hk. Sp. 3. p. 82.

Hab. Guinea Coast; gathered by Curror, Barter, and Mann.-Distinguished from the last by its more distant and usually branched veins and broader sori.

9. A. coriaceum, Baker ; st. tufted, 2-3 in. 1., firm, compressed, winged ; fr. 9-12 in. l., $1 \frac{1}{2}$ in. br., much acuminated at the apex, the edge very nearly entire, narrowed below gradually into the winged stem; texture very coriaceous ; veins oblique and curved, branched at the base and again at or above the middle, so that at the edge the veins that originate from one are $\frac{1}{4}-\frac{3}{8}$ in. apart ; sori distant, very oblique, generally $\frac{1}{2}$ in. 1 .

\section{Hab. Cameroon Mountains, G. Mann.}

10. A. squamulatum, Blume ; st. tufted, 2-4 in. l., strong, erect, scaly below ; fr. lanceolate, 12-18 in. 1., 2-3 in. br., narrowed to an acuminate apex and very gradually below into the stem, the margin entire ; texture very coriaceous ; veins inconspicuous, 1 lin. apart, usually simple ; sori reaching from near the midrib to $\frac{1}{4}-\frac{1}{2}$ in. of the margin; rachis stout, pale, the lower part furfuraceous.-Hk. Sp. 3. p. 82.

Hab. Java, Borneo, Philippines.-Habit of $A$. Nidus, but the veins falling short of the edge.

11. A. scolopendrioides, J. Sm.; st. short, erect, scaly ; fr. lanceolate, nearly $1 \mathrm{ft}$. l., $1 \frac{1}{4}-1 \frac{1}{2}$ in. br., narrowed suddenly above to a long caudate apex, very gradually into the stem below, the margin entire; texture subcoriaceous; veins oblique, usually simple, 1 lin. apart; sori reaching from the midrib to within $\frac{1}{4}$ in. of the margin ; invol. leaving a distinct elevated ridge on the frond when it separates. - Hk. Sp. 3. p. 84. Ic. Pl.t. 930.

Hab. Philippines, Cuming, 318. - A fragment from Borneo exhibits the same raised line where the involucre bursts, but the stem is much longer. Doubtfully distinct from Sp. 13, with which it corresponds in texture and venation.

12. A. Sundense, Blume; rhizome creeping, naked; st. short, erect, naked; fr. lanceolate, $12-18$ in. l., $1 \frac{1}{2}-3$ in. br., narrowed to an acute point and very gradually into the stem below, the margin obscurely toothed; texture coriaceous; veins simple, close, nearly horizontal, the copious sori often reaching from the midrib nearly to the edge.-Hk. Sp. 3. p. 85. A. vittæforme, J. Sm.

Hab. Java, Philippines, Fiji.-An authentic example of Brackenridge's A. amboinense agrees with this. If Willdenow's plant be the same, that name has priority. This belongs to the genus Micropodium of Mettenius, which includes the Aspleniece with the mode of growth of Eupolypodium (Eremobrya, J. Smith).

13. A. Fejeense, Brack.; rhizome wide-climbing ; st. 6 in. 1., scaly below ; fr. lanceolate, $18-24$ in. $1 ., 1 \frac{1}{2}-2$ in. br., caudate or acuminate, often proliferous at 
the apex, narrowed below to a subtruncate base, the margin nearly entire; texture subcoriaceous; veins oblique, occasionally branched, $\frac{1}{8}$ in. apart ; sori reaching from the midrib nearly to the edge.-Hk. Sp. 3. p. 87 .

Hab. Fiji, Samoa, and Aneiteum. Differs from the last by its more oblique and more distant veins and longer and scaly stems.

14. A. simplicifrons, F. Muell.; rhizome scaly; $f r$. subsessile, narrowed gradually towards both ends, $12-18$ in. $1 ., \frac{3}{4}-1$ in. br., the edge entire or very slightly undulated, the point acuminate; texture subcoriaceous; veins alınost horizontal, parallel, simple, or forked, 1 lin. apart; sori not touching by a space either edge or midrib.-Fragm. 5. p. 74.

Hab. Rockingham Bay, Australia_-Dallachy, Hill.

15. A. Grifithianum, Hk. ; st. tufted, short, erect ; fr. lanceolate, 6-9 in. 1., $\frac{3}{4}-1 \mathrm{in} . \mathrm{br}$., the point acuminate, narrowing below very gradually, the margin crenato-serrate ; texture subcoriaceous; veins distant, obscure, usually once forked; sori reaching from the midrib two-thirds of the way to the edge.- $H k$. Sp. 3. p. 87. t. 928.

Hab. Assam and Sikkim, ascending to 4,000 ft.-Recognizable at once in the group by its distinctly crenated margin. A plant from Penang, gathered by Mactier, agrees with this except that it has a slender stem 6-9 in. 1 .

16. A. Gautieri, Hk. ; st. tufted, 1-3 in. 1.; fr. oblong-lanceolate, 3-4 in. 1., $\frac{3}{4}-1 \mathrm{in}$. br., the point acute, the upper part slightly crenato-dentate, the base narrowed rather suddenly to a wing which narrows very gradually into the stem, sometimes with one or a pair of small oblong blunt lobes at the base; texture herbaceous; veins $\frac{1}{8}$ in. apart, usually once forked about the middle ; sori small, distant, not reaching either edge or midrib.-Hk.Sp. 3. p. 88.t. 184 .

Hab. Island of Nissobe, near Madagascar, Gautier.-The smallest and most delicate of the group.

17. A. serratum, Linn. ; st. short, stout, erect ; fr. $1 \frac{1}{2}-3 \mathrm{ft}$. 1., 2-3 in. br., acute at the apex, narrowed below gradually, the margin undulato-dentate or crenate, especially towards the apex ; texture coriaceous ; midrib prominent below ; veins about $\frac{1}{2}$ lin. apart; sori often on each, reaching about two-thirds of the distance to the edge.-Hk. Sp. 3.p. 81. F. Ex.t. 70.

Hab. West Indies and Guatemala, southwård to Society Islands, Peru, and S. Brazil. -We include three species of Fée,-his integrum, serratum, and crenulatum.

\section{** Fronds lobed or pinnatifid. Sp. 18-24.}

18. A. subhastatum, Hk.; st. tufted, 3-4 in. 1., firm, erect, naked ; fr.4-9 in. 1., $1 \frac{1}{2}$ in. br. at the base, lanceolate, with two short rounded lobes at the base, the apex acute, the margin entire, the base rounded suddenly into the petiole; texture coriaceous; veins immersed, inconspicuous, erecto-patent, distant, once or twice forked; sori not reaching either edge or midrib.-Hk. Sp. 3. p. 91. Ic. Pl.t. 929 .

Hab. Caraccas, and gathered lately in Peru by Dr. Spruce.-Basal lobes not always obvious. Veins casually anastomosing.

19. A. trilobum, Cav. ; st. tufted, scaly below, $2-3$ in. 1., firm, erect ; fr. 1-1 $\frac{1}{2}$ in. l., 1 in. br., rhomboidal, the apex acute, the base cuneate, entire, the margin undulato-crenate, or the lower part deeply lobed with broad inciso-crenate divisions; texture coriaceous; sori broad and short.-Hk. Sp. 3. p.90. 2nd Cent. F.t. 11 .

Hab. Chili and S. Brazil.-A. parvulum, Hk. Ic. t. 222, is a small undeveloped form. 
20. A. Hemionitis, Linn. ; st. tufied, naked, firm, dark-coloured, 4-8 in. 1. ; fr. 4-6 in. each way, hastate, with a triangular, acute terminal lobe and two large cordate, acute lateral ones, again bluntly or acutely lobed at the base, the basal sinus rounded, 1 in. or more deep, and the lobes on each side imbricated over one another and the petiole; texture herbaceous ; veins close, usually simple, with often a narrow line of fruit on each, the longest $1 \frac{1}{2}$ in. 1.-Hk. $S p$. 3. p. 91 . A. palmatum, Lam.

Hab. Spain, Portugal, Barbary States, Azores, Canaries, Madeira, and Cape Verde Islands.

21. A. attenuatum, R. Br.; st. tufted, 3-4 in. 1., firm, more or less scaly throughout; $f r$. linear-lanceolate, sometimes 1 ft. l., $\frac{1}{2}-\frac{3}{4}$ in. br., narrowed upwards very gradually, sometimes proliferous at the point, the margin toothed, the lower third also lobed; the lowest lobes, which are oblong or roundish, reaching down nearly or quite to the rachis; texture subcoriaceous; veins ascending, the midrib beneath hispid like the stem; sori reaching nearly to the edge.-Hk. Sp. 3. p. 92. Hk. \& Gr. Ic. t. 200. Ic. Pl.t. 914.

Hab. Queensland and N. S. Wales.

22. A. variabile, Hk.; rhizome wide-creeping ; fr. $3-6$ in. 1., $\frac{1}{2}$ in. br., lanceolate or oblong-lanceolate, the apex acuminate or bluntish, narrowed below very gradually into a short stem, the margin varying from crenate to rather deeply lobed, especially below; texture thinly herbaceous, both surfaces naked; veins often $\frac{1}{8}$ in. apart at the base, simple or once forked; sori falling short of the margin. $-H k$. Sp. 3. p. 93. t. 185.

Heb. Fernando Po, Barter, Mann.

23. A. pinnatifidum, Nutt. ; st. tufted, 2-4 in. 1., naked, polished, chesnutbrown; fr. 3-6 in. 1., 1 in. or more br. at the base, lanceolate-deltoid, with a long gradually narrowing point which is sinuated only, the lobes below this $\frac{1}{4}-\frac{1}{2}$ in. deep, the lowest ovate-oblong or subspathulate, $\frac{1}{2}$ in. deep by nearly as br., sinuated and reaching down nearly to the rachis ; texture herbaceous ; lowest lateral veins of the pinnæ often twice forked; sori copious.-Hk. Sp. 3. p. 91 . Ic. t. 927 .

Hab. Pennsylvania southward to Alabama.

24. A. alternans, Wall.; st. tufted, 1-2 in. l., clothed with linear scales; fr. 6-8 in. 1., 1-1 $\frac{1}{2}$ in. br., lanceolate-oblong, cut down into numerous bluntlyrounded lobes on each side, which reach very nearly down to the rachis, the lower growing smaller gradually and sometimes distinct; texture subcoriaceous, both surfaces an opaque greyish-green; veins free, subflabellate; sori copious. -Hk. Sp. 3. p. 92. A. Dalhousiæ, Hk. Ic. t. 105.

Hab. N. W. Himalayas, ascending to 6,000 ft., and gathered also by Schimper in Abyssinia. - This has entirely the habit and cutting of $A$. Ceterach.

\section{*** Fronds once pinnate. Sp. 25-103.}

+ Pinnoe $\frac{1}{4-\frac{1}{2}}$ in. l., blunt, in most of the species nearly as broad as long. Sp, 25-44.

A. Group of A. viride. Rachis green, slender. Sp. 25-34.

25. A. projectum, Kunze ; st. scattered, very slender ; fr. $2-3$ in. 1., 2 lin. br., procumbent, with 12 to 16 pinnoe on each side, in slightly-stalked pairs, the largest of which are not more than 1 lin. each way, roundish and nearly entire; texture membranaceous; rachis taking root and the apex gemmiferous; sori 1 to 2 to a pinna, oblique.-Hk. Sp. 3. p. 148.t. 181. A. 
Hab. Peru; gathered by by Poeppig.-Habit of Anagallis tenella, but much more slender.

26. A. viride, Huds.; st. densely tufted, 2-4 in. 1., naked, the lower part chesnut-brown ; fr. 4-6 in. l, $\frac{1}{2}$ in. br., with 12 to 20 subsessile pinnoe on each side, which are between ovate and rhomboidal in general outline, the upper edge narrowed suddenly at the base, the lower one obliquely truncate, the outer part deeply crenated; texture herbaceous; rachis green, naked; veins subflabellate; sori copious, linear-oblong, oblique.-Hk. Sp. 3. p. 144. Brit. F.t. 30.

Hab. Arctic Europe to the Pyrenees, Dalmatia, Sitcha, and the Himalayas (12,000 ft.) ; N. America, Rocky Mountains, British Columbia, New Brunswick.

27. A. Kraussii, Moore ; st. tufted, slender, green, $\frac{1}{2}$ in. $1 . ; f r .3-4$ in. $1 ., \frac{3}{8}$ in. br., linear, with about 12 pairs of sessile pinnce on each side, which are under $\frac{1}{4}$ in. each way, cuneato-flabellate or subrhomboidal in general outline, the upper and outer edge sharply toothed, the lower straight and entire; texture herbaceous; rachis green; veins flabellate; sori linear-oblong, 1-3 to a pinna, oblique.-Hk. Sp. 3. p. 147. t. 180. A.

Hab. Natal, Krauss, 25.-Very near $A$. viride, of which it may be a form, but the pinnæ are more dimidiate and more sharply toothed.

28. A. fragile, Presl ; st. tufted, 2-4 in. 1., slender, flexuose, green or brownish, sometimes gemmiferous; fr. 6-9 in. $1 ., \frac{3}{8}-\frac{1}{2}$ in. br., with 12 to 20 sessile pinnoe on each side, which are $\frac{1}{4}$ in. br., nearly as deep, subrhomboidal in outline, the upper and outer edge toothed, the former narrowed suddenly at the base, the lower edge entire, nearly straight from the base; texture herbaceous; rachis green, naked; veins pinnate; sori short oblique.-Hk. Sp. 3. p. 145. Ic. t. 932.

Hab. Along the Andes from Mexico and Peru.-A. rhomboideum, Brack., which grows also in the Sandwich Islands, has fronds 12-18 in. 1., with pinnæ not so dimidiate and often deeply lobed on the upper side near the base. This also comes very near A. viride in habit and texture.

29. A. Gilliesianum, Hk. ; st. tufted, very slender, 1-2 in. l., green ; fr. 4-8 in. 1., $\frac{1}{2}$ in. or rather more br., with 10 to 20 distant subsessile pinnoe on each side, which are $\frac{1}{4}-\frac{3}{8}$ in. br., $\frac{1}{4}$ in. deep, rhomboidal in general outline, the upper and outer edge deeply and sharply toothed, the lower truncate in a straight or decurved line; texture thinly herbaceous; veins fine and copious, subflabellate; sori irregular, not reaching the edge.-Hk. Sp. 3. p. 146. Hk. \& Gr. Ic. t. 63.

Hab. Andes of Peru and Bolivia.-This comes very near A. fragile, but is a moro slender plant, with the pinnæ sharply and irregularly cut.

30. A. vagans, Baker; st. tufted, 1-2 in. l., firm, naked, pale-green ; fr. 3-4 in. 1., $\frac{1}{2}-\frac{5}{8}$ in. br., wide-straggling, elongated and rooting at the apex, with 8-12 sessile pinnce on each side, which are $\frac{1}{4}$ in. br. by less deep, subrhomboidal in general outline, the upper and outer edge deeply crenated, the base narrowed suddenly, the lower edge straight and entire; texture coriaceous; rachis stout, compressed, and slightly winged upwards ; veins immersed ; sori $2-3$ to a pinna, short, linear-oblong, placed near the margin.

Hab. Island of St. Thomas, West Tropical Africa, G. Mann; Madagascar, Dr. Meller. -This seems a very distinct species, nearest flabellifolium in habit, but very different in size, texture, and shape of the pinnæ.

31. A. flabellifolium, Cav.; st. tufted, 3-6 in. 1., slender, green or chesnutbrown, flexuose; fr. procumbent, wide-straggling, elongated, and rooting at the apex, 6-12 in. l., $\frac{3}{4}-1$ in. br., with 10 to 15 sessile flabellate pinnoe on each side, which are $\frac{1}{4}-\frac{1}{2}$ in. each way, broadly lobed and the lobes sharply toothed, the 
base cut away in a curve on the lower side ; texture herbaceous ; veins flabellate ; sori oblique, irregular, copious.-Hk. Sp. 3. p. 146. Ex. Fil.t. 208.

Hab. Temperate Australia, Tasmania, and New Zealand.

32. A. Quitense, Hk.; st. slightly tufted, slender, green, 1 in. or less 1. ; fr. 2-3 in. l., $\frac{3}{4}$ in. br., with 6-12 conspicuously stalked horizontal pinnæ on each side, which are oblong-deltoidal in general outline, but half the lower side cut away, the rest broadly and bluntly lobed; texture herbaceous; rachis green, compressed and slightly winged; veins distant, pinnate ; sori $2-4$ to a pinna, principally on the upper side.-Hk. Sp. 3. p. 145. 2nd Cent. t. 20.

Hab. Andes of Ecuador, Jameson, 707 ; Spruce, 5334.-Recedes from A. viride by its more distant, more deeply lobed and distinctly stalked pinnæ.

33. A. Sandersoni, Hk.; st. tufted, 1-2 in. 1., green, slightly fibrillose ; fr. 6-9 in. $1 ., \frac{1}{2}-\frac{3}{4}$ in. br., linear, often gemmiferous at the apex, with 12 to 20 horizontal dimidiate pinnoe on each side, which are deeply crenate on the upper edge, and at the base narrowed suddenly into a winged petiole, the lower one nearly straight and quite entire; texture herbaceous; rachis green, flaccid; only the lowest side vein forked; sori 1-3, oblong.-Hk. Sp. 3. p. 147. t. 179.

Hab. Natal, Zambesi Land, and Johanna Island.-Nearest A. Quiterse, but the pinnæ quite dimidiate and the teeth of the upper side closer and vertical.

34. A. dentatum, Linn. ; st. tufted, 2-6 in. 1., slender, naked, polished, ebeneous below ; fertile fr. 2-3 in. 1., 1 in. br., with 6 to 8 pairs of stalked subopposite pinnoe, which are $\frac{1}{2}$ in. br., $\frac{3}{8}$ in. deep, oblong-rhomboidal, the lower side at the base truncate in a curve, the outer edge irregularly crenate ; sterile fr. smaller, on shorter stalks; texture herbaceous; rachis slender, naked, green; veins subflabellate; sori copious, in two parallel rows. $-H k$. $S p .3 . p .130$.

Hab. West Indies, Mexico, and Guatemala.-Pinnæ much further apart than in the rest of the group, the lower pair sometimes 1 in. from the others.

\section{B. Group of A. Trichomanes. Rachis wiry, chesnut-brown or blackish.} Sp. $35-44$.

35. A. pygmoeum, Hk. ; st. tufted, $\frac{1}{2}$ in. 1., slender, densely clothed with long horizontal fibrillose scales; fr. 1-1 $\frac{1}{2}$ in. 1 ., $\frac{1}{4}-\frac{3}{8}$ in. br., linear, with a pinnatifid point and 3 to 4 sessile pinnoe on each side, which are $\frac{1}{8}$ in. each way, oblong, rhomboidal, between cuneato-flabellate and dimidiate, the apex deeply crenated; texture herbaceous; rachis scaly like the stem; sori unknown.-Hk. Sp. 3 . p. 147. t. 180. B.

Hab. Madagascar, Dr. Lyall.

36. A. Heuffleri, Reichardt ; st. densely tufted, 2-3 in. 1., wiry; slender, polished, dark chesnut-brown ; fr. $1 \frac{1}{2}-2$ in. $1 ., \frac{1}{2}-\frac{3}{4}$ in. br., with 3 or 4 pairs of opposite distant pinnæ, the lowest of which is $\frac{1}{4}$ in. each way, rhomboidalcuneate, inciso-dentate, and sometimes deeply lobed, uniformly narrowed on both sides below to a distinct petiole ; texture herbaceous ; rachis naked, darkcoloured and polished like the stem; veins flabellate; sori irregular, linearoblong.-Verh. Zool. Bot. Ges. Wien. 1859. p. 95. $t .4$.

Hab. Tyrol, Heuffer.-Some of the German botanists have regarded this as a hybrid of Trichomanes and germanicum, between which it is quite intermediate.

37. A. Trichomanes, L. ; st. densely tufted, 1-4 in. l., naked, glossy, chesnutbrown, polished ; fr. 6-12 in. $1 ., \frac{1}{2}$ in. or rather more br., with 15-30 opposite pairs of sessile horizontal pinnce, which are $\frac{1}{4}-\frac{3}{8}$ in. br., $1 \frac{1}{2}-2$ lin. deep, the edge 
slightly crenate, the two sides unequal, the upper one the broadest, and narrowed suddenly at the base ; texture subcoriaceous ; veins pinnate, inconspicuous ; rachis polished like the stem ; sori linear-oblong, 3-6 on each side of the midrib.Hk. Sp. 3. p. 136. Brit. F. t. 29.

Hab. Temperate regions of the Old World, from Britain and the Azores eastward to Japan and the Himalayas, where it ascends to 6-8,000 ft. ; S. Africa ; South Australia, Van Diemen's Land, New Zealand, Sandwich Islands; N. America, and southward along the Andes to Peru.-The Madeiran A . anceps, Sol., and S. American A castaneum, Cham. \& Schl., seem to be luxuriant forins. The latter has the frond sometimes 18 in. and the pinnæ $\frac{1}{2}$ in. 1. : A densum, Brack., is a reduced alpine form from the Andes.

38. A. arcuatum, Liebm. ; st. tufted, very short, polished, blackish ; fr. arcuate, 6-9 in. l., $\frac{1}{2}$ in. br., linear, with 20-30 very close-placed horizontal subdimidiate sessile pinnoe on each side, which are $\frac{1}{4}$ in. or rather less br., $\frac{1}{8}$ in. deep, blunt at the point, the upper side slightly crenate, slightly auricled, and narrowed suddenly at the base, lower line entire, nearly straight or decurved in the lower ones; texture subcoriaceous; rachis black, and polished like the stem; veins pinnate; sori short, only 1 or 2 , parallel with the lower edge of the pinnæ.Hk. Sp. 3. p. 142. t. 189 .

Hab. Mexico.-Probably this ought to be joined with A. monanthemum.

39. A. extensum, Fée ; st. tufted, 4-6 in. 1., polished, blackish ; fr. 12-24 in. 1., $\frac{3}{4}-1$ in. br., with 20-40 sessile pinnæ on each side, which are $\frac{1}{2}$ in. $1 ., \frac{1}{4}-\frac{3}{8}$ in. deep, blunt and entire, the upper side rather the broadest, and often cordate, whilst the lower is merely rounded at the base ; texture coriaceous ; veins inconspicuous ; rachis polished like the stem, with 2 hairy lines running up it, sometimes bearing gemmæ, and throwing out branches from the axils of the pinnæ; sori linearoblong, 2 or 3 on each side of the midrib.-Hk. Sp. 3. p. 142.

Hab. Andes of Columbia and Peru.-A larger plant than A. Trichomanes, with pinnæ very blunt, sometimes nearly round.

40. A. Petrarchae, D. C. ; st. densely tufted, 1-2 in. 1., wiry, nearly black, densely glandular when young; fr. $2-3$ in. l., $\frac{1}{2}$ in. br., linear-lanceolate, with 6-10 horizontal sessile pinnæ on each side, which are $\frac{1}{4}$ in. l., rather less br., cordate-ovate, the point blunt, the edge sinuated or pinnatifid, the base unequal, slightly truncate on the lower side; texture subcoriaceous ; veins obliquely pinnate, ebeneous ; rachis and young fronds glandular ; sori oblong, very short, 4-6 on each side of the midrib.-Hk. Sp. 3. p. 138. Hk. \& Gr. Ic.t. 152. A. pilosum, Guss.

Hab. France, Spain, Italy. - Distinguished from A. Trichomanes by its glandulosity and more deeply-cut pinnæ.

41. A. monanthemum, Linn. ; st. densely tufted, 3-6 in. l., naked, polished, chesnut-brown ; fr. 12-18 in. 1., $\frac{3}{4}-1$ in. br., with 20-40 horizontal sessile subdimidiate pinna on each side, which are $\frac{3}{8}-\frac{1}{2}$ in. $1 ., \frac{1}{4}$ in. deep, the upper side crenate, suddenly narrowed at the base, often distinctly auricled, the lower more or less distinctly cut away in a straight or, in the lower pinnæ, decurved line ; texture subcoriaceous; veins flabellate; sori linear-oblong, usually 1 or 2 , parallel with the lower edge of the pinnæ.-Hk. Sp. 3. p. 140.

Hab. Madeira, Azores, Abyssinia, Cape Colony, Sandwich Islands and Mexico along the Andes to Chili.-A larger plant than $\mathbf{A}$. Trichomanes, with the sori typically one or two to a pinna ; but in some of the forms,-for instance, A. Galeottii, Fée, and A. Menziesii, Hk. \& Gr. Ic. t. 100,-more numerous.

42. A. normale, Don ; st. 4-6 in. 1., tufted, wiry, blackish, polished ; fr. 8-12 
in. $1 ., 1 \frac{1}{2}$ in. br., with very numerous close-placed pinnæ, the lower ones, which are $\frac{3}{4}$ in. l., $\frac{1}{4}$ in. br., deflexed, the point obtuse, the edge inciso-crenate, the upper side auricled and narrowed suddenly at the base, the lower truncate in a straight line; texture subcoriaceous; rachis glossy, nearly black; veins mostly once forked; sori in 2 unequal parallel rows.-A. multijugum, Wall. $H k$. $S p$. 3. p. 139. t. 188.

Hab. Himalayas to Ceylon.-A. opacum, Kunze, is a large form, with herbaceous pinnæ 1 in. l. Very doubtfully distinct from $A$. monanthemum, but constantly plurisorous.

43. A. subavenium, Hk. ; st. tufted, $2-3$ in. 1., wiry, blackish, densely fibrillose ; fr. 9-12 in. l., $1 \frac{1}{2}$ in. br., with very numerous close-placed horizontal pinnce on each side, which are $\frac{3}{4}-1$ in. l., $\frac{1}{4}-\frac{3}{8}$ in. br., blunt at the point, the edge slightly inciso-crenate, the upper side distinctly auricled, and narrowed suddenly at the base, the lower narrower below, but nearly equal upwards ; texture coriaceous ; veins faint, and a distinct midrib only in the lower part of the pinnæ; rachis densely fibrillose, especially below; sori $2-4$ on each side, oblique.-Hk. Sp. 3. p. 143. t. 181. B.

Hab. Penang, Mactier.-Bojer's Madagascar specimen, figured in "Species Filicum," seems to be an example of this, which differs from the rest of the group by its densely fibrillose rachis, and is not unlikely $A$. setosum, Desv.

44. A. ebeneum, Ait. ; st. tufted, 3.6 in. 1., chesnut-brown, polished, nearly naked ; fr. 12-18 in. 1., 2-3 in. br., linear-lanceolate, with 20-40 sessile horizontal or subfalcate pinnce on each side, which are 1 in. or more $1 ., \frac{1}{8}$ in. or rather more br., the point acute or bluntish, the edge inciso-serrate, but sometimes very faintly so, the base hastately auricled on one or both sides, often cordate ; texture herbaceous; veins fine and close, once or twice forked; rachis chesnut-brown and bright polished; sori often 10-12 on each side, oblong, short.-Hk. Sp. 3. p. 138.

Hab. Canada to the West Indies, and Ecuador ; Cape Colony.-A. ebenoides, Scott, of which a single root was found on the banks of the Schuykill above Philadelphia, looks most like this ; but the pinnæ are not cut down to the rachis, and the frond has an elongated point which is only sinuated with a single row of sori on each side. Probably, as suggested by Professor Eaton, this is A. Hendersoni of Houlston, figured by Lowe, vol. 5, t. 12. This species recedes from the Trichomanes group towards $A$. formosum.

\section{H Pinnoe 1 or 2, linear-cuneate. Sp. 45-46. Acropteris, Link.}

45. A. septentrionale, Hoffm. ; st. densely tufted, 3-4 in. l., slender, erect, naked, ebeneous towards the base; fr. simple or cleft from the apex into two or three cuneate divisions, $1-1 \frac{1}{2}$ in. l., 1 lin. br., with a few sharp lateral and terminal teeth ; texture coriaceous; veins forked, subparallel ; sori elongated, copious, often at last hiding the whole under surface.-Hk. Sp. 3. p. 174. Brit. F.t. 26.

Hab. Norway and Britain, to Spain, Italy, Siberia, and the Himalayas, Rocky Mountains and New Mexico.-This and the following connect Asplenium with Actiniopteris.

46. A. Seelosii, Siebold ; st. densely tufted, 1-2 in. l., slender, wiry, green, ebeneous below ; $f r \cdot \frac{1}{2}-\frac{3}{4}$ in. l., palmately cleft, usually into 3 nearly equal forks, which are about 1 lin. br., the edge slightly inciso-serrate ; texture coriaceous; upper surface pale-green, hairy ; veins obscure ; sori copious, when mature occupying the whole surface.-Hk. $S p$. 3. p. 175. 2nd Cent. $t .82$.

Hab. Tyrol and Carinthia. 
H+ Pinnoe numerous, linear or linear-oblong, usually ample, acute or acuminate. Sp. 47-103.

A. Group of A. salicifolium. Pinnce equal or nearly so on both sides at the base. Sp. $47-60$.

47. A. angustifolium, Mich. ; st. tufted, $1 \mathrm{ft}$. or more 1., erect, brownish, slightly scaly below ; fr. 18-24 in. l., 4-6 in. br., lanceolate-oblong, flaccid, with 20-30 subsessile horizontal pinnce on each side, the sterile ones the largest, 3-4 in. l., $\frac{1}{2}$ in. br., acuminate at the point, the edge obscurely crenate, the base rounded and equal on both sides; fertile pinnoe narrower and more distant; texture thinly herbaceous ; veins sometimes twice forked ; sori very close and regular, extending from the midrib nearly to the edge.-Hk. Sp. 3. p.115.

Hab. Canada, southward to the Southern United States.-A very distinct species.

48. A. multilineatum, Hk.; st. 6 in. 1., firm, erect, naked, greyish-green ; fr. 12-18 in. l., 6-8 in. br., oblong-lanceolate, with a long linear-lanceolate terminal pinna and 9-18 lateral ones on each side, which are 4-6 in. 1., $\frac{1}{2}-\frac{3}{4}$ in. br., the point acuminate, the edge faintly toothed, but the point more deeply, the base cuneato-truncate with a short petiole; texture herbaceous ; colour dark-green ; rachis naked; veins mostly simple, with sori on each reaching from the midrib to the edge. -Hk. Sp. 3. p. 102. A. distans, Brack.

Hab. Samoa and Fiji.-Characterized by its simple veins, which branch from the midrib at an angle of from 70 to 80 , and close regular rows of sori.

49. A. longissimum, Blume; st. tufted, 3-12 in. 1., strong, erect, blackish, nearly naked ; fr. 2-3 ft. 1., 4-6 in. br., lanceolate elongate, proliferous and rooting at the apex, with very numerous horizontal pinnoe on each side, which are 2-3 in. l., $\frac{1}{4}-\frac{3}{8}$ in. br., the point acuminated, the two sides nearly equal, with a distinct central midrib, the edge slightly toothed, the base on both sides often auricled; texture herbaceous ; rachis dark-coloured, strong, slightly villose ; veins forked, oblique; sori numerous, in 2 regular rows on each side the midrib and reaching nearly to the edge. $-H k$. Sp. 3. p. 149. $t .190$.

Hab. Java, Borneo, Malacca, Mauritius.

50. A. Wightianum, Wall. ; st. tufted, 6-9 in. 1., greenish, naked ; fr. 12-18 in. 1., 6-8 in. br., oblong-lanceolate, with 6-9 pinnae on each side, which are distinctly stalked, and the lowest 2 in. apart, $5-6$ in. $1 ., \frac{1}{2}-\frac{3}{4}$ in. br., the point acuminated, the edge irregularly crenate, the base gradually truncato-cuneate, equal on both sides ; texture coriaceous ; colour pale-green ; veins inconspicuous, distant, often forked; sori distant, falling short of the edge.-Hk.Sp. 3. p. 105. $t .167$. A. longipes, $F e ́ e, H k . S p .3 . p .106$.

Hab. Madras and Ceylon.

51. A. Sumatranum, Hk. ; st. 6-9 in. 1., firm, erect, grey, naked ; fr. 18 in. 1., 6 in. br., with a long narrow linear terminal pinna and 6 erecto-patent ones on each side, which are 6 in. l., $\frac{3}{4}$ in. br., the point acuminate, the lower part obscurely undulated, the upper part crenate, the base equally truncato-cuneate on both sides, decurrent so as to form a distinctly-marked wing to the rachis in the upper part ; texture very coriaceous ; veins very oblique, usually once forked ; sori long, reaching nearly from the midrib to the edge.-Hk. Sp. 3. p. 110 . $t .168$.

Hab. Sumatra, Teschemacher; Fiji, Daernel.

52. A. salignum, Blume; st. 4-6 in. l., slender, naked ; fr. 6 in. 1., about 6 in. 
br., ovate in general outline, with a long, linear, terminal pinna and 2-3 opposite pairs, which are $3-4$ in. $1 ., \frac{1}{2}-\frac{3}{4}$ in. br., with an acuminate point, the margin faintly crenated, the base cordate, the nodes thickened; texture coriaceous ; rachis and both surfaces naked; veins distant, obscure; sori falling short of the margin.-Hk. Sp. 3. p. 95. t. 165. A. diversifolium, Blume.

Hab. Java.-This and the two preceding agree in texture, but may be recognized by the base of the pinnæ.

53. A. alatum, H. B. K. ; st. 4-6 in. 1., rather slender, naked, the upper part winged, and the rachis furnished throughout with a distinct wing; fr. 1-1 $\frac{1}{2}$ ft. 1., 3-4 in. br., with 12-20 horizontal sessile pinnoe on each side, which are 1-1 $\frac{1}{2}$ in. $1 ., \frac{1}{2}-\frac{3}{4}$ in. br., bluntish at the point, the edge uniformly inciso-crenate, the base nearly equal on both sides, but the upper one slightly more dilated; texture herbaceous; veins usually once forked ; sori distant, not reaching either the midrib or edge. $-H k$. $S p$. 3. $p .121$.

Hab. West Indies and Columbia southward to Peru and S. Brazil.

54. A. Vieillardii, Mett. ; st. tufted, 4-6 in. l., firm, erect, nearly naked ; fr. 6-9 in. l., 6 in. br., with a large linear-lanceolate terminal pinna, lengthened out at the point and deeply serrated, and 3-4 pairs of erecto-patent similar lateral ones, which are 4 in. l., upwards of $\frac{1}{2}$ in. br., equally truncato-cuneate, and the lower ones slightly stalked at the base; texture herbaceous ; rachis firm, grey, naked; veins oblique, once or twice forked; sori distant, falling short of both edge and margin.-Mett. Annales, 4 ser. v. 15.p. 72.

Hab. New Caledonia, Vieillard, 1645-6.

55. A. salicifolium, Linn.; st. tufted, strong, naked, erect, 6-12 in. l. ; fr. 12-18 in. l., 6-9 in. br., oblong, with a terminal pinna and 4-10 distinctly stalked often horizontal ones on each side, which are 4.6 in. $1 ., \frac{3}{4}-1$ in. or more br., the point acuminate, the edge nearly entire or occasionally lobed below, the base equally truncato-cuneate on both sides; texture herbaceous; veins erecto-patent, rather close, once or twice forked; sori falling short both of the edge and midrib.Hk. Sp. 3. p. 112 .

Hab. West Indies and Panama southward to Rio Janeiro and Peru.-According to Mettenius, $A$. juglandifolium, Lam. (A. integerrimum, Spr.), is a distinct species, allied to this, with entire pinnæ; and $A$. neogranatense, Fée, a form of the same with few pinnæ, the terminal one elongated.

56. A. longicauda, Hk. ; st. 6-12 in. l., firm, erect, brownish, nearly naked ; fr. 12-18 in. 1., 6-9 in. br., with a large oblong-acuminate terminal pinna 6-8 in. 1., 1-1 $\frac{1}{2}$ in. br., which is often elongated and proliferous ; lateral pinnoe 3-9 on each side, similar in shape to the terminal one, but usually smaller, the margin obscurely undulated, the base nearly equal, and the lower ones slightly stalked ; texture herbaceous ; colour deep-green ; veins $\frac{1}{8}$ in. apart, simple or forked; sori broad and distant, not reaching either the edge or midrib.-Hk. 2nd Cent. F. t. 69.

Hab. Cameroon Mountains and Fernando Po. - In one of Dr. Curror's specimens the terminal pinna is a foot long, considerably sinuated upwards, and gemmiferous at the apex ; the lateral pinnæ are also often proliferous at the point.

57. A. emarginatum, Beauv. ; st. 6-12 in. 1., firm, erect, brownish, nearly naked ; fr. 12-18 in. l., 6-9 in. br., with a large lanceolate-oblong terminal pinna 6-8 in. l., 1-1 $\frac{1}{2}$ in. br., and 3-6 pairs of distant slightly-stalked lateral ones, the lowest of which are rather smaller than the terminal one, the apex of each 
emarginate, with a small bud in the open sinus, the edge slightly crenate, the base equal on both sides, rounded into a short stalk ; texture thinly herbaceous ; colour bright-green; veins usually forked ; sori irregular, close, reaching from the midrib nearly to the edge.-Hk. 2 nd Cent. F.t. 80.

Hab. Guinea coast and Angola.

58. A. virens, Presl ; st. 6-12 in. l., rather slender, greyish, naked ; fr. 9-12 in. l., 6-8 in. br., ovate, with a terminal pinna and 3-5 lateral ones on each side, which are $\frac{1}{2}-1 \frac{1}{2}$ in. apart at the base, the lowest only distinctly stalked, 3-4 in. $1 ., \frac{3}{4}-1$ in. br., the point acuminate, the margin deeply crenato-dentate, the base truncato-cuneate ; texture herbaceous; colour bright-green; rachis green, subflaccid, naked; veins distant; sori reaching from the midrib to the edge.Hk. Sp. 3. p. 101.

Hab. Gorgona Island and Guyaquil, West Tropical America. - Closely allied to A. salicifolium and oligophyllum.

59. A. vulcanicum, Blume ; st. 6-9 in. l., firm, erect, grey, naked ; fr. 1-2 ft. 1., 4-8 in. br., oblong-lanceolate, with a linear-terminal pinna, or gemmiferous at the apex, and 6-12 lateral ones on each side, the lower ones distinctly stalked, 4-6 in. 1., $\frac{3}{4}-1$ in. br., the point acuminated, the edge slightly crenatodentate, the base truncato-cuneate into a petiole sometimes $\frac{1}{2}$ in. 1. ; rachis naked; texture herbaceous or subcoriaceous; veins simple or forked; sori very regular and parallel, falling short of the edge ; invol. broad, pale.-Hk. $S p$. 3. p. 102. A. heterodon, Mett., Hk. Sp. 3.p. 107.

Hab. Java and Fiji.-The Ceylonese A. Walkerce, Hk. Sp. 3. p. 108. t. 163, does not seem to be safely separable; and Mr. Thwaites says that this last and $\boldsymbol{A}$. Wightianum pass into one another gradually. A. heterodon, Blume, is said to differ by its stouter habit, broader pinnæ, and fewer sori.

60. A. oligophyllum, Kaulf. ; st. tufted, 6-12 in. 1., firm, erect, scaly below ; fr. 1-2 ft. l., 6-9 in. br., oblong, with a large terminal pinna and 3-8 erecto-

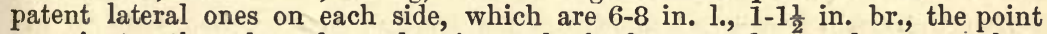
acuminate, the edge obscurely sinuated, the base nearly equal, narrowed or rounded on both sides into a short winged petiole, the upper ones decurrent on the rachis ; texture herbaceous ; veins faint, distant, usually once forked ; sori not reaching the edge by a considerable space.-Hk. Sp. 3. p. 107.

Hab. Columbia and Brazil ; and I cannot distinguish a plant gathered at Penang by Mactier.

B. Pinnce narrowed suddenly at the base on the upper side, the inner edge nearly parallel with the main rachis, the lower side obliquely truncate.Sp. 61-98.

a. Group of $A$. erectum. Texture of the frond herbaceous, the colour dark-green, the veins clearly visible. Sp. 61-75.

61. A. tenerum, Forst. ; st. tufted, firm, erect, greyish, naked, 4-6 in. 1. ; fr. 8-15 in. 1., 3-4 in. br., oblong-lanceolate, with 10-20 stalked horizontal pinnoe on each side, which are $1-1 \frac{1}{2}$ in. $1 ., \frac{1}{4}-\frac{3}{8}$ in. br., bluntly rounded at the point, the edge deeply toothed throughout, the two sides unequal, the upper one narrowed almost at a right angle, sometimes slightly auricled, the lower one very obliquely truncate, lower pinnæ deflexed; texture herbaceous; rachis compressed; veins usually simple; sori numerous, regular, parallel, not reaching either edge or midrib.-Hk. Sp. 3. p. 117. A. elongatum, Sw. Hk. l. c.

Hab. Ceylon and Malayan Peninsula and islands eastward to Samoa and Fiji, and gathered lately by Mann at Fernando Po.-A. Doreyi, Kze.; seems to be a form of this 
with pinnæ more narrowly pointed. This and the two next are distinguished from the rest of the group by their very close and regular sori.

62. A. lineatum, Swartz ; st. tufted, 6-9 in. 1., firm, erect, more or less scaly ; fr. 1-2 ft. l., 4-6 in. br., oblong-lanceolate, with 20-30 pinnae on each side, which are 3-4 in. 1. , about $\frac{1}{2}$ in. br., acuminate at the point, dentate throughout, all sessile or nearly so, the base cuneate, but the lower side narrower and more cut away than the upper; texture herbaceous; colour dark-green ; rachis brownish-grey, and slightly paleaceous; veins close, often forked; sori very regular, reaching from the midrib nearly to the edge.-Hk. $S p .3 . p .104$.

Hab. Mauritius and Bourbon.-A very puzzling plant, from the fact that it runs gradually into forms with the pinnæ again pinnate, which have either small narrow linearcuneate pinnules (Darea incequalis, Willd., and $D$. bifida, Kaulf.), or even these latter again deeply bifid or pinnatifid (D. bifida and violascens, Bory).

63. A. prionurus, J. Sm. ; st. tufted, 6-9 in. 1., firm, erect, slightly scaly below ; fr. 12-18 in. l., 6-9 in. br., oblong, with 9-18 pinnoe on each side, which are 4-6 in. 1., rather over $\frac{3}{2}$ in. br., very much acuminated at the point, deeply and regularly toothed throughout, the base rather unequal, more truncato-cuneate on the lower side, with a short distinct petiole on the lower ones ; texture herbaceous ; veins usually simple, with sori on each reaching nearly to the edge. -Hk. Sp. 3. p. 103.

Hab. Philippines, Cuming, 197.-Probably this should be united with A. lineatum.

64. A. erectum, Bory ; st. tufted, 2-4 in. 1., firm, nearly naked, grey or ebeneous ; fr. 6-18 in. l., $1 \frac{1}{2}-2$ in. br., narrowly lanceolate-oblong, with 12-20 horizontal pinnoe on each side, which are 1-1 $\frac{1}{2}$ in. $1 ., \frac{1}{4}-\frac{1}{2}$ in. br., bluntish or acute at the point, more or less deeply inciso-crenate throughout, the two sides unequal, the upper one at the base narrowed suddenly at about a right angle, the lower one obliquely truncate ; lower pinnæ often deflexed; texture herbaceous; rachis firm, greyish; veins simple or once forked; sori falling short of both edge and midrib.- $H k . S p .3 . p .127$.

Hab. Universally distributed throughout the Tropics; America, from Cuba to Rio Janeiro and Juan Fernandez ; Sandwich Islands, Indian and Malayan Peninsula, Ceylon, Cape Colony, Tristan d'Acunha northward to Bourbon, St. Helena, Ascension, and the Guinea coast. $-A$. harpeodes, Kunze, Hk. Sp. Fil. t. 178, is a large form with acuminate pinnæ; A. Fernandesianum, Kunze, a form from Juan Fernandez, with a more rigid rachis and subcoriaceous pinnæ; A. tenellum, Roxb. (A. reclinatum, Houlst., Hk. Fil. Exot. t. 72), a form with wide-spreading, dark-green fronds copiously proliferous at the apex ; $A$. Barteri, Hk. 2nd Cent. t. 75, a slender flaccid plant, also proliferous ; $A$. pteropus, Kaulf., and $A$. camptorachis, Kze., forms with the rachis compressed and slightly winged; and the pinnæ are sometimes more or less distinctly pinnatifid, as in the S. African A. lobatum and A. gracile of Pappe and Rawson, and the Polynesian A. Macraei, Hk. \& Gr. t. 217 . Kunze and Mettenius consider this to be the A. lunulatum of Swartz, which is an older name than erectum.

65. A. persicifolium, J. Sm. ; st. tufted, 6-9 in. 1., firm, erect, nearly naked ; fr. 18-24 in. l., 6-8 in. br., oblong-lanceolate, often gemmiferous at the apex, with 10-20 horizontal subsessile pinnoe on each side, which are 4-6 in. 1., $\frac{3}{4}-1$ in. br., acuminate at the point, the margin nearly entire or inciso-crenate, especially upwards, the two sides unequal, the upper one broader and less obliquely truncate than the lower one ; texture herbaceous; veins usually once-forked; sori distant, falling short of both midrib and edge.-Hk. Sp. 3. p. 109.

Hab. Neilgherries, Ceylon, Philippines and Solomon's Islands.-A. salicinum, J. Sm., is a form with narrow pinnæ 6 in. 1 ., $\frac{1}{2}$ in br., serrated throughout. A. Zenkerianum, Kze., is the oldest name with a description.

66. A. obtusifolium, L. ; st. almost tufted, 6-9 in. 1., firm, erect, dark-green, 
naked ; fr. 12-18 in. 1., 4-6 in. br., with 12-20 stalked horizontal pinnoe on each side, which are $2-3$ in. $1 ., \frac{1}{2}-\frac{3}{4}$ in. br., the point acute, the edge slightly undulato-crenate, the upper side with a distinct auricle at the base, and then narrowed suddenly, the lower side obliquely truncate; texture thinly herbaceous; colour deep-green ; rachis naked, green, compressed, flaccid ; veins fine, distant, usually once forked; sori distant, in 2 regular rows, falling short of the edge. -A. riparium, Liebm. Hk. Sp. 3. p. 119. t. 169.

Hab. Tropical America, from Mexico and the West Indies to S. Brazil.-A. obtusifolium; L., appears to be founded on a dwarfed form of this, with blunt and somewhat laciniated pinnæ.

67. A. fuliginosum, Hk. ; st. tufted, very short, densely clothed with blackish fibrillose scales ; fr. 6-12 in. 1., 2-3 in. br., with 12-24 broadly-adnate horizontal subfalcate pinnoe on each side, which are $1-1 \frac{1}{2}$ in. $1 ., \frac{3}{8}-\frac{1}{2}$ in. br., the point acute, the edge slightly toothed, the base a little narrowed on both sides in the lower ones, which are gradually reduced in size downwards; texture papyraceoherbaceous ; colour nearly black when dry ; rachis densely fibrillose throughout; veins usually once forked; sori in 2 regular rows near the point of the pinnæ. -Hk. Sp. 3. p. 120. 2nd Cent. F.t.3.

Hab. Borneo ; gathered by Mr. Low.-A very well-marked plant.

68. A. Borneense, Hk. ; st. 3-4 in. l., stout, greyish, arcuate, fibrillose ; fr. $3 \mathrm{ft} .1 ., 2 \frac{1}{2}$ in. br., with very numerous sessile pinnoe, the lower ones growing smaller very gradually, the central ones $1 \frac{1}{4}$ in. $1 ., \frac{1}{4}$ in. deep, the point bluntly rounded, the upper edge inciso-lobate, auricled inwards, and narrowed suddenly at the base, the rest and the outer part of the lower edge, which is very obliquely truncated at the base, distantly toothed; texture herbaceous ; rachis firm, nearly naked; veins subflabellate in the outer half of the pinnæ; sori few, almost in parallel rows.-Hk. Sp. 3. p. 135. t. 186.

Hab. Borneo, H. Low, Jr.-This comes near A. cultrifolium, but is a stronger plant, with blunter and more unequal-sided pinnæ dwindling downwards very gradually.

69. A. firmum, Kunze ; st. tufted, 4-8 in. 1., firm, erect, greyish, naked ; fr. 6-12 in. I., 3-4 in. br., sometimes proliferous at the apex, with 12-20 sessile horizontal pinnoe on each side, which are $1 \frac{1}{2}-2$ in. $1 ., \frac{1}{2}-\frac{5}{8} \mathrm{in}$. br., the point bluntish, the edge inciso-crenate, the upper one narrowed suddenly at the base, the lower one obliquely truncate; texture herbaceous; rachis firm, naked, slightly winged; veins distant, once forked; sori short, in 2 regular rows, falling short of both midrib and edge.-Hk. Sp. 3. p. 134.t. 174. A. abscissum, Auct.

Hab. Tropical America, from Cuba and Guatemala to Peru and S. Brazil,-Very doubtfully distinct from $A$. cultrifolium, from which it differs mainly by its shorter and blunter pinnæ.

70. A. cultrifolium, Linn. ; st. 4-6 in. 1., naked, greyish, firm ; fr. 6-12 in. 1., 4-6 in. br., deltoid-ovate, with a lobed terminal point and 6-10 pinnoe on each side, which are $3-4$ in. 1 ., $\frac{1}{2}-\frac{3}{4}$ in. br., the point acute, the edge broadly toothed, sometimes lobed below nearly or quite to the rachis, the base nearly at a right angle on the upper, but obliquely truncate on the lower side; texture herbaceous ; veins fine, distant, usually once forked; sori falling short both of the edge and midrib.-Hk. Sp. 3. p. 110. Diplazium, Kunze.

Hab. West Indies and Guatemala southward to Guyaquil._-The diplazioid character of the sori is sometimes clearly marked.

71. A. auriculatum, Swartz ; st. tufted, $-4-8$ in. 1., firm, erect, nearly naked ; fr. 12-18 in. 1., 4-6 in. br., lanceolate-oblong, with 10-20 stalked horizontal pinnoe on each side, which are $2-4$ in. $1 ., \frac{3}{4}-1$ in. br., lanceolate, often subfal- 
cate, the edge deeply crenate, the two sides unequal, the upper one with a cordate auricle, the lower one obliquely truncate; texture herbaceous; lower veins twice forked, oblique; sori distant, not reaching either the midrib or edge. -Hk. Sp. 3. p. 118. t. 171. A. falx, Desv.

Hab. Tropical America, from Mexico and the West Indies southward to Brazil and Peru.-This also comes very near A. cultrifolium in habit and texture. The best character is the distinctly cordate base of the upper half of the pinna.

72. A. Prionitis, Kunze ; st. tufted, 6-12 in. 1., strong, erect, greyish ; fr. 1-2 ft. 1., 6-9 in. br., with 8-12 stalked pinnce on each side, which are 4-6 in. l., 1-1 $\frac{1}{4}$ in. br., the point acute or acuminate, the edge sharply toothed throughout, the upper side narrowed suddenly, and the lower obliquely truncate at the base ; texture herbaceous; rachis strong, erect, naked; veins usually once forked; sori copious, linear, reaching nearly to the edge.-Hk. Sp. 3. p. 102.

Hab. Natal and Angola.-A stronger plant than species 68 to 71, with larger pinnæ.

73. A. anisophyllum, Kunze ; st. tufted, 6-12 in. 1., firm, erect, scaly below ; fr. 1-2 ft. 1., 6-9 in. br., oblong-lanceolate, with 10-16 subsessile almost horizontal pinnce on each side, which are 3-5 in. 1., $\frac{3}{4}-1$ in. br., acuminated at the point, crenate or crenato-dentate, the two sides unequal, the upper one narrowed suddenly but not auricled, the lower one obliquely truncate at the base ; texture herbaceous; veins usually once forked; sori distant, elliptical, not reaching more than halfway from the edge to the margin.- $H k$. $S p .3 . p .111$. t. 166.

Hab. Cape Colony, northward to Bourbon, Zambesi Land, and the Cameroon Mountains; Galapagos Isles, Brazil, and Cuba.-Allied to species 68 to 72 , and best recognized by its short regular sori, with large tumid involucres. A. sanguinolentum, Kze., Hk. Sp. 3. p. 114, is the American form of this species. The original plant of Kunze has nearly entire pinnæ. The Natal A. Boltoni, Hk. MSS. (figured Sp. Fil. t. 166), has them uniformly rather deeply inciso-crenate, and with this Mr. Randall puts $\boldsymbol{A}$. discolor of Pappe and Rawson as a more divided form.

74. A. Wrightii, Eaton ; st. 1 ft. 1., tufted, stout, scaly below ; fr. 18-24 in. 1., 6-9 in. br., ovate-oblong, the upper half of the rachis with a narrow wing, 12-20 pinnoe on each side, the lower ones 4-6 in. 1., $\frac{3}{4-1}$ in. br., lanceolate, subfalcate, the point acuminate, the upper part sharply and distantly toothed, the lower also cut down into roundish-spathulate lobes, which reach down nearly to the rachis, the base unequal, the lower side only obliquely truncate; texture herbaceous; veins dichotomously forked in each lobe; sori few, not reaching either midrib or edge.-Hk. Sp. 3. p. 114. $t .183$.

Hab. Japan ; gathered by Wright, and lately by Oldham.

b. Texture of the frond coriaceous or subcoriaceous, colour pale-green, veins comparatively obscure. Sp. 75-98.

$b^{*}$. Group of A. marinum. Sori nearly equal, in two regular pinnate rows on the two sides of the distinct midrib. Sp. 75-89.

75. A. rhizophorum, Linn.; st. tufted, firm, erect, 4-8 in. 1., naked, polished, chesnut-brown ; fr. 1-2 ft. 1., 4-6 in. br., elongated, and taking root at the apex; pinnoe 12-30 on each side, the lower ones spreading horizontally, subsessile, $1 \frac{1}{2}-2$ in. 1., about $\frac{1}{2}$ in. br., inciso-dentate throughout, the two sides unequal, the upper one auricled, and narrowed at about a right angle, the lower one obliquely cuneate ; texture herbaceous; veins usually once forked; sori not reaching either the edge or midrib.-Hk. Sp. 3. p. 122. t. 187. A.

Hab. Tropical America, from Mexico and W. Indies southward to Peru, and gathered also by Milne in the Solomon's Islands, S. Pacific. - This is exceedingly variable in cutting, and may be best recognized by its elongated proliferous rachis. We have 
described the form with simple pinnæ. A. cyrtopteron and fabellatum of Kunze have them deeply lobed and pinnatifid, especially in the lower half, whilst the plant called rhizophorum by Swartz is fully bipinnate, and $A$. rachirhizon, Raddi, and $A$. amabile, Líebm., have distinctly separated oblong-rhomboidal pinnules again deeply cut into narrow segments.

76. A. anisodontum, Presl ; st. tufted, firm, erect, grey, naked or slightly fibrillose ; fr. 12-18 in. 1., 4-6 in. br., with numerous horizontal or subfalcate sessile pinnce on each side, which are $2-3$ in. $1 ., \frac{1}{2}$ in. br., the point acuminate, the edge inciso-crenate, the base on the upper side auricled and narrowed rather obliquely, on the lower side obliquely truncate; texture subcoriaceous ; rachis firm, erect ; veins oblique, mostly once branched ; sori parallel, in 2 regular rows, reaching nearly from the midrib to the edge.-Hk. Sp. 3. p. 153.

Hab. Java and Philippines.

77. A. contiguum, Kaulf. ; st. tufted, 6-9 in. l., firm, erect, chesnut-brown, naked ; fr. 12-18 in. 1., 4-6 in. br., with 20-30 horizontal subfalcate pinnoe on each side, which are acuminated at the apex, the edge more or less sometimes deeply inciso-serrated and slightly lobed, the base narrowed suddenly, and sometimes auricled on the upper, obliquely truncate in a curve on the lower side; texture subcoriaceous; rachis firm, naked or slightly villose, chesnut-coloured; veins oblique, obscure ; sori close, copious, falling considerably short of the margin.-Hk. Sp. 3. p. 156.t. 194.

Hab. Sandwich Islands, Philippines, Neilgherries.-The alliance of this and the preceding is with $A$. falcatum, but the fronds are narrower, and the sori more uniform.

78. A. hirtum, Kaulf. ; st. tufted, 2-4 in. 1., strong, erect, brownish, deciduously fibrillose ; fr. 12-24 in. 1., 4-8 in. br., with very numerous horizontal pinnce on each side, which are 2-3 in. $1 ., \frac{1}{4}-\frac{3}{8}$ in. br., the point acuminated, the edge broadly not deeply toothed, the base on the upper side conspicuously auricled, on the lower side rather suddenly but obliquely narrowed; texture coriaceous; rachis dark-coloured, strong, more or less fibrillose ; veins oblique, inconspicuous ; sori in 2 regular rows, which fall considerably short of the edge.-Hk. Sp. 3. p. 149. t. 191.

Hab. Mauritius, Madagascar, Seychelles, Malayan Peninsula and Islands, Hong-Kong, the Philippines, Ladrones and Solomon Islands.-This has the simple veins and regular sori of $A$. lineatum and longissimum, but the pinnæ are unequal-sided. A. induratum, Hk. 2nd Cent. F. t. 61, from Fiji, seems to be only a small form of this with blunter pinnæ. A. pellucidum, Lam., is apparently this species ; and if so, that name (a very inappropriate one) is the oldest.

79. A. hastatum, Klotzsch ; st. tufted, 4-6 in. 1., firm, erect, greyish, scaly below ; fr. 6-12 in. 1., 3-4 in. br., oblong-lanceolate, with 8-12 horizontal subsessile pinnce on each side, which are $1 \frac{1}{2}-2$ in. l., about $\frac{1}{2}$ in. br., the point acuminate, the edge deeply crenato-dentate throughout, the two sides unequal, the upper one narrowed at nearly a right angle, the lower one very oblique ; texture subcoriaceous ; rachis compressed ; veins obscure, very oblique ; sori distant, falling short of both edge and midrib.-Hk. Sp. 3. p. 116. t. 172.

Hab. Columbia and Ecuador.-A. fragrans, Hk. Ic. t. 88, is a small Andine form with a winged rachis. This is very near $A$. firmum and auriculatum, but is thicker in texture. The Chinese A. crinicaule, Hance, is said to be like this, but to have a wingless rachis clothed like the stem with long lanceolate vinose scales with a filiform point.

8Q. A. enatum, Brack. ; st. tufted, 6-8 in. l., firm, erect, naked ; fr. about 1 ft. $1 ., 4-5$ in. br., with 9-15 pinnoe on each side, which are 2-3 in. $1 ., \frac{1}{2}-\frac{3}{4}$ in. br., the point acute, the upper part bluntly crenated, the two sides very unequal, the upper rounded or narrowed suddenly at the base, the lower 
obliquely truncate; texture subcoriaceous; rachis firm, compressed and winged above; central veins once forked; sori in 2 regular rows, falling short of the edge.-Hk. Sp. 3. p. 106.

Hab. Sandwich Islands.-Very near A. compressum, but less robust.

81. A. compressum, Swartz ; st. tufted, stout, erect, 6-8 in. 1., clothed with scales in the lower part; fr. 2-3 ft. 1., 8-12 in. br., lanceolate-oblong, with 10-20 sessile pinnoe on each side, which are 6-8 in. 1., 1 in. or more br., acute or bluntish at the point, the edge slightly crenato-dentate, the upper ones decurrent at the base upon the stout fleshy compressed rachis, the upper side narrowed suddenly at about a right angle, the lower one obliquely truncate; texture herbaceous ; veins distant, often twice forked; sori broad, distant, not reaching either the midrib or edge.-Hk. Sp. 3. p. 121. Fil. Exot.t. 76.

Hab. St. Helena.-Pinnæ often proliferous from the upper surface (A. frecundum, Kunze):

82. A. vomeriforme, Hk. ; st. 1 ft. l., naked, firm, erect ; fr. 18 in. $1 ., 6$ in. br., lanceolate, with about a dozen stalked horizontal pinnoe on each side, which are 3 in. l., 1 in. br., acute at the point, the edge nearly entire, the base cordate on the upper, slightly truncate or rounded on the lower side; texture subcoriaceous ; veins immersed, inconspicuous, oblique, often twice forked; sori long, but falling considerably short of the edge.-Hk. Sp. 3. p. 109. t. 162.

Hab. Peru, Matthews, 1851.-The alliance of this is with the two preceding, but the pinnæ are cordate on the upper, rounded on the lower side at the base.

83. A. macrosorum, Bert. ; st. tufted, 4-6 in. 1., scaly at the base, naked and polished and nearly black upwards ; fr. 6-12 in. 1., 3-4 in. br., cordate-acuminate, with a large terminal pinna, which is 4-6 in. $1 ., 1-1 \frac{1}{2}$ in. br., deeply crenate and cuneate at the base, and 2 or 3 pairs of similar lateral ones, which are slightly stalked, and the lowest subdeltoid ; texture subcoriaceous; rachis and midrib dark-coloured and polished like the stem ; veins distant ; sori broad, not reaching either the midrib or the edge.- $H k$. Sp. 3. p. 93.t. 176.

Hab. Juan Fernandez; gathered by Bertero and Philippi.

84. A. nitens, Swartz ; st. scattered, 6-9 in. 1., firm, erect, chesnut-brown, polished, naked; fr. $1 \frac{1}{2}-2$ ft. l., 6-9 in. br., with 12-20 ascending or subfalcate pinnoe on each side, which are 4-6 in. $1 ., \frac{1}{2}-1$ in. br., the point much acuminated, the edge finely toothed, the base broadly rounded on the upper, truncate in a curve on the lower side; texture subcoriaceous ; rachis naked, shining; veins oblique, often twice forked; sori in close regular rows, not extending more than halfway from the midrib to the edge.-Hk. Sp. 3. p. 157.t. 195.

Hab. Mauritius and Bourbon.-This and the two next, like species 76 and 77, resemble the falcatum group in habit and texture.

85. A. platybasis, Kunze ; st. scattered, 4-8 in. 1., strong, erect, channelled, the lower part scaly ; fr. 12-18 in. 1., 6-9 in. br., with 12-20 erecto-patent pinnoe on each side, which are 4-6 in. $1 ., \frac{3}{4}-1$ in. br., acuminated at the apex, the edge serrated, the two sides unequal, the upper one narrowed suddenly at the base, the lower one obliquely truncate ; rachis strong, erect, nearly naked ; veins close, oblique ; sori copious, touching the midrib, but falling short of the edge.A. falcatum var. $H k$. Sp. 3. p. 160. A. firmum, Fée, non Kunze.

Hab. St. Helena.-Differs from $A$. Serra mainly by its more copious sori.

86. A. Serra, Langs. \& Fisch. ; st. distant, 6-12 in. 1., firm, erect, chesnutcoloured, polished, the lower part scaly; fr. 2-4 ft. $1 ., 6-12$ in. br., with 12-20 
spreading pinnce on each side, which are 4-8 in. $1 ., \frac{3}{4}-1 \frac{1}{2}$ in. br., the point acuminate, the edge sharply inciso-serrate, the upper base rounded, the lower cuneate; texture coriaceous ; rachis strong, erect, brown, sometimes polished; veins very oblique; sori mostly in 2 parallel rows, close to the midrib.-Hk. Sp. 3 . p. 154.

Hab. Tropical America, from Cuba and Guatemala southward to Organ Mountains and Peru, and gathered also by Mann on the Cameroon Mountains and at Fernando Po.Var. Imrayanum, Hk., is a large form with the pinnæ often deeply lobed.

87. A. marinum, Linn. ; st. tufted, 3-6 in. 1., naked, except at the base, polished, chesnut-brown, the scales linear, nearly black; fr. 6-12 in. 1., 2-3 in. br., oblong-lanceolate, the apex pinnatifid ; pinnoe of the lower half quite distinct, spreading horizontally, 1 in. or more l., $\frac{1}{2}$ in. br., oblong or lanceolatedeltoid, the point acute or obtuse, the margin crenato-dentate, sometimes deeply sinuated, the base slightly truncate below, and often auricled above; texture subcoriaceous; veins usually once forked; sori broad, falling short of the edge. -Hk. Sp. 3. p. 95. Brit. F. t. 31 .

Hab. Coast of W. Europe, from the Orkneys to the Canaries and Azores; and there are specimens also in the Kew Herbarium from Nova Scotia, the island of St. Vincent, and S. Brazil.

88. A. obtusatum, Forst. ; st. tufted, 3-6 in. l., firm, greyish, densely clothed at the base with large, thin, grey, lanceolate scales; fr. 6-12 in. 1., 3-4 in. br., oblong or ovate-deltoid, with a terminal pinna not much larger than the others, and 2-6 pairs on each side, which are 1-2 in. $1 ., \frac{1}{2}-\frac{3}{4}$ in. br., obtuse at the point, the edge crenate, the base truncato-cuneate, especially on the lower side, and shortly stalked; texture cartilaginous ; rachis firm, broad, often compressed and channelled, both surfaces naked ; colour pale-green ; veins immersed and inconspicuous ; sori copious, broad, linear-oblong, falling short of the edge.- $H k$. $S p$. Fil. 3. p. 96. Fil. Ex. $t .46 .-\beta, A$. obliquum, Forst. ; fr. often more than $1 \mathrm{ft}$. 1., 6 in. br. ; pinnoe more numerous, often 4 in. l., 1 in. br., narrowed gradually to an acute point, with the lines of fruit $\frac{1}{2}-\frac{3}{4}$ in. 1 . and closer ; texture still cartilaginous. $-\gamma, A$. lucidum, Forst. ; fr. sometimes $2 \mathrm{ft}$. 1., with 15-20 pairs of pinnce on each side, which are more herbaceous in texture, darker green in colour, the

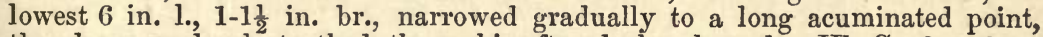
the edge more deeply toothed, the rachis often dark-coloured.-Hk. Sp. 3.p.99.

Hab. Peru and Chili, Polynesian Islands, and plentiful in New Zealand and Australia. -The three well-known plants here united appear to glide into one another by the most gradual intermediate stages of transition; and what complicates the matter still more is the occurrence of forms with the pinnæ pinnatifid or even fully pinnate, which cannot be separated clearly. Of these A. scleropium, Hombr. \& Jacq., is most like $\beta$ in texture, with the pinnæ regularly and closely toothed throughout to a depth of two lines or more; A. difforme, R. Br., has an ovate-deltoid frond of coriaceous texture, with pinnæ quite cut down to a narrow-winged rachis in the lower part into distinctly separated roundish or oblong sinuated pinnules; and A. Lyallii, Moore (A. lucidum, var. Lyallii, Hk. fil. Fl. N.Z. t. 77), has a herbaceous frond nearly 18 in. $1 ., 9$ in. br., with lanceolate deltoid lower pinnæ 6 in. l., 3 in. br. ; in the extreme form cut down into deeply-toothed pinnules, which are cuneate at the base and distinctly stalked.

89. A. gemmiferum, Schrad. ; st. tufted, 3-6 in. 1., firm, greyish, the base and lower part scaly ; fr. 1-2 ft. 1., 4-8 in. br., oblong, generally proliferous at the apex, with 6-12 erecto-patent distinctly-stalked pinne on each side, the lowest of which are 4-6 in. 1., $\frac{3}{4}-1$ in. br., narrowed gradually to an acute point; the edge crenato-dentate, the base truncato-cuneate; texture herbaceous or subcoriaceous ; rachis firm, naked, compressed below; veins immersed and inconspicuous ; sori copious, broad, falling short of both edge and midrib.-Hk. Sp. 3. p. 100 . 
Hab. Cape Colony, northward to Angola, Zambesi Land, Bourbon, Mauritius, and Madagascar.-Very near A. obtusatum, of which it may be an African form. Schlechtendahl referred it to Forster's lucidum. The pinnæ vary considerably in textnre, and here also there is a divided form (A. flexuosum, Schrad.) which has the pinnæ cut down into narrow lobes about balfway down to the rachis in the upper part, and sometimes quite down to it near the base.

$b^{* *}$. Group of $A$. falcatum. Sori and veins long, irregular, subflabellate, very oblique. Sp. 90-98.

90. A. auritum, Swartz ; st. tufted, 4-8 in. 1., firm, erect, grey, naked ; fr. 6-12 in. 1., 2-4 in. br., with 10-15 distinctly stalked horizontal pinnoe on each side, which are $2-3$ in. $1 ., \frac{1}{2}-\frac{3}{4}$ in. br., the point acute or bluntish, the edge sharply toothed or often lobed, especially on the upper side towards the base, which, if not lobed, is distinctly auricled and narrowed suddenly, whilst the lower edge at the base is obliquely truncate ; texture coriaceous ; rachis firm, erect, grey, naked ; veins close, oblique, inconspicuous; sori in 2 broad rather oblique rows. - $\beta, A$. macilentum, Kze. ; rachis broadly winged ; pinnoe blunt.- $\gamma, A$. rigidum, Sw.; pinnce deeply pinnatifid throughout.-Hk. Sp. 3. p. 179.

Hab. Common in Tropical America, from Cuba and Mexico to Peru and S. Brazil ; Neilgherries, Bourbon.

91. A. paleaceum, R. Br.; st. densely tufted, 1-3 in. l., spreading, densely scaly ; fr. 6-9 in. 1., $1 \frac{1}{2}-2$ in. br., sometimes rooting and proliferous at the apex, with 12-20 subsessile pinnoe on each side, which are 1 in. $1 ., \frac{2}{8}-\frac{1}{2}$ in. br., the point bluntish, the edge irregularly inciso-dentate, the upper base auricled and narrowed suddenly, the lower obliquely truncate, the lower ones stalked, and nearly as broad as long; texture subcoriaceous; rachis densely clothed throughout; veins flabellate, deep channelled, conspicuous on the upper surface ; sori linear, extending nearly to the edge.-Hk. Sp. 3. p. 162. t. 199.

Hab. Tropical Australia.-A very distinct species.

92. A. Hancei, Baker ; st. densely tufted, 3-4 in. l., erect, dark-brown, slightly fibrillose ; fr. 6-9 in. 1., $1 \frac{1}{2}$ in. br., with $9-15$ horizontal pinnæe on each side, which are $\frac{5}{8}-\frac{3}{4}$ in. l., $\frac{1}{4}-\frac{3}{8}$ in. br., the point bluntish, the edges irregularly inciso-crenate, the upper side narrowed suddenly, sometimes auricled at the base, the lower obliquely truncate; texture subcoriaceous ; rachis firm, slightly fibrillose, no distinct midrib; veins subflabellate; sori few, linear, very oblique.

Hab. S. E. China, Dr. Hance, Col. Dunlop.-Intermediate between A. paleaceum and planicaule.

93. A. erosum, Linn. ; st. tufted, 6-9 in. l., firm, erect, nearly naked ; fr. 6-12 in. $1 ., 4-8$ in. br., with 9-15 pinnoe on each side, which are $3-4$ in. $1 ., \frac{1}{2}-\frac{3}{4}$ in. br., the edge slightly lobed and crenato-dentate, the point acuminate, the two sides unequal, the upper one narrowed suddenly, the lower one obliquely truncate at the base; texture subcoriaceous ; rachis firm, erect, greyish; veins very oblique; sori falling short of the edge.-Hk. Sp. 3. p. 198.

Hab. West Indies.-Probably an American form of falcatum.

94. A. falcatum, Lam. ; st. tufted, 6-9 in. 1., firm, erect, greyish, nearly naked; fr. 6-18 in. l., 4-6 in. br., with 6-20 stalked nearly horizontal pinnoe on each side, which are 2-3 in. $1 ., \frac{1}{2}-1$ in. br., the point acuminated, the edges lobed often onethird of the way down, and the lobes sharply toothed, the two sides unequal, and the lower one at the base obliquely truncate; texture coriaceous ; rachis naked or slightly fibrillose; veins very oblique; sori in long irregular lines reaching nearly to the edge. $-H k$. Sp. 3. p. 160. 
Hab. Polynesian Islands, Australia, N. Zealand, Malaccas, Ceylon, Indian Peninsula, Mascaren Isles, Zambesi Land.

95. A. caudatum, Forst. ; st. tufted, 4-6 in. 1., firm, erect, densely clothed with fine brown fibrillose scales ; fr. 12-18 in. l., 4-8 in. br., with 20-30 pinnoe on each side, which are 3-4 in. $1 ., \frac{1}{2}-1$ in. br., the point acuminated, the edge deeply toothed, sometimes lobed more than halfway down to the rachis in the lower part, the two sides unequal, the upper auricled and narrowed suddenly, the lower very obliquely truncate at the base ; texture coriaceous ; rachis deciduously villose ; veins very oblique; sori subflabellate.-Hk. Sp. 3. p. 152.

Hab. Polynesian and Malayan Islands, Australia, Hindostan, Johanna Island, Angola. -Doubtfully distinct from $A$. falcatum. The best character is in the sori, which are more confined to the centre of the pinnæ, being often restricted to two parallel rows close to the rachis.

96. A. dimidiatum, Swz. ; st. tufted, 6-12 in. 1., blackish, slightly paleaceous, firm, erect ; fr. 6-15 in. 1., 4-6 in. br., with 6-9 opposite pairs of pinno, which are 2-3 in. 1., $\frac{3}{4}-1$ in. br., the point acuminated, especially the outer and upper edge sharply inciso-serrated, the latter rounded or cuneate at the base, the lower edge very obliquely truncate ; texture coriaceous ; rachis dark-coloured, firm, slightly scaly ; veins close, flabellate, and no distinct midrib ; sori radiant, narrow, long, linear.-Hk. Sp. 3.p. 159.

Hab. Tropical America, from Cuba to Peru ; Guinea Coast.-Resembles A. falcatum in sori and texture, but the pinnæ are broader below.

97. A. macrophyllum, Swartz; st. tufted, 6-12 in. l., stout, erect, brownish, nearly naked; fr. 6-18 in. l., 6-12 in. br., with 6-12 opposite pairs of stalked nearly horizontal pinno, which are 4-8 in. $1 ., 1-3$ in. br., the point acuminate, the edge sharply serrated, the two sides nearly equal, but the lower one narrowed rather more obliquely ; texture subcoriaceous ; rachis naked, firm, erect ; veins very oblique; sori in close long parallel lines reaching from the midrib nearly to the edge. $-H k$. Sp. 3. p. 158. $t$. 196-7.

Hab. Polynesia, Malayan Peninsula and Islands, Hong-Kong, Hindostan, Ceylon, Mauritius, Johanna Island.-Very near the preceding; indeed, all the species from 93 to 98 are very close to one another.

98. A. paradoxum, Blume ; st. firm, erect, grey, slightly scaly ; fr. 1-2 ft. 1., 6-9 in br., with a large oblong-rhomboidal terminal pinna, and 8-12 lateral ones on each side, the lowest of which are 5-6 in. l., 1-1 $\frac{1}{2}$ in. br., the point acuminate and slightly toothed, the two sides unequal, the upper one narrowed suddenly almost at a right angle, the lower obliquely cuneate ; texture coriaceous ; rachis firm, erect, compressed, rather scaly; veins obscure, very oblique, usually once forked; sori reaching nearly from the midrib to the edge. $-H k$. $S p$. 3. p. 98. A. zamioides, Hk. Sp. 3. p. 114. t. 170.

Hab. Java, Sumatra, and Penang.-This occurs sometimes with Scolopendrioid sori. (See Mett. Fil. Ind. 2. p. 234.)

99. A. obesum, Baker ; st. tufted, 4-8 in. 1., firm, erect, naked, dark chesnutbrown, polished ; $f r .6-9$ in. $1 ., 3$ in. br., with a deltoid terminal pinna $1 \frac{1}{4}-1 \frac{1}{2}$ in. each way, and 4-6 opposite pairs of sessile lateral ones, $1 \frac{1}{4}-1 \frac{1}{2}$ in. $1 ., \frac{1}{2}-\frac{3}{4}$ in. br., all entire or very slightly crenate, the upper ones acute, narrowed suddenly on the upper side at the base, obliquely truncate on the lower one; the lower ones blunt, as broad as long, nearly semicircular ; texture coriaceous; rachis polished like the stem, with a raised line on each side; no distinct midrih, the venation flabellate; sori large, linear-oblong, principally in two rows in the upper part of the pinna. 
Hab. Guatemala, Salvin \& Godman, 119.-Very different from the rest of the group in the shape of its pinnæ.

C. Group of $A$. resectum. Pinnoe with from half to the whole of the lower side cut away. Sp. 100-104.

100. A. formosum, Willd. ; st. tufted, very short, naked, polished, chesnutbrown; fr. 12-18 in. l., 1 in. br., with 20-30 sessile horizontal pinnoe on each side, which are $\frac{1}{2}$ in. 1 ., $1 \frac{1}{2}-2$ lin. deep, the upper edge deeply cut, the point rather obtuse, the lower edge truncate in a straight line, so that about half the lower side is cut away ; texture herbaceous ; colour bright-green ; veins obscure, simple or forked ; sori linear-oblong, short, oblique, placed 1 to 4 on each side of the midrib.-Hk. Sp. 3. p. 143. Fil. Ex.t. 16.

Hab. Tropical America, from Cuba and Mexico southward to Brazil and Peru; Ceylon and the Neilgherries, Angola and Congo.-By its wiry polished rachis this approaches the Trichomanes group.

101. A. pulchellum, Raddi ; st. tufted, 1-2 in. 1., slender, erect, naked, greenish ;

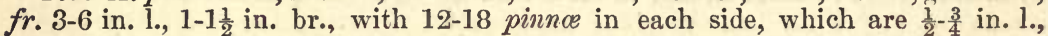
2-3 lin. br., bluntish at the point, almost dimidiate, the upper edge inciso-crenate, and narrowed suddenly at the base ; texture thinly herbaceous ; rachis slender, green, compressed ; veins distant, once forked ; sori linear, oblique, falling short of the edge, sometimes 1 or 2 almost parallel with the midrib on the lower side of it.-Hk. Sp. 3. p. 129.

Hab. Tropical America, from Columbia to Peru and Rio Janeiro.-A. Otites, Link, is a form with broad blunt scarcely-cut pinnæ. Intermediate between firmum and resectum.

102. A. resectum, Smith ; st. scattered, slender, naked, dark chesnut-brown, polished, or grey and opaque, 4-8 in. l. ; fr. 6-15 in. 1., 2-4 in. br., lanceolateoblong, with 10-30 subsessile horizontal pinnae on each side, which are 1-3 in. 1., $\frac{1}{4}-\frac{1}{2}$ in. br., in shape almost dimidiate, two-thirds of the lower side being entirely cut away, the point bluntish, all except the truncate part inciso-crenate, the upper half at the base narrowed nearly at a right angle; texture thinly herbaceous; rachis usually polished like the stem, sometimes green and opaque; veins once or twice forked; sori not reaching either the midrib or edge.- $H k$. Sp. 3.p. 130. Hk. \& Gr. Ic.t. 114.

Hab. Japan and Himalayas (ascending to 8,000 ft.) southward to Ceylon, Oahu, and Fiji ; Mauritius, Seychelles, Bourbon, Angola, and Guinea Coast. - Sometimes the lower side of the pinna is entirely cut away. A. serroforme, Mett., is a form with a straweoloured stem and abbreviated sori, and $A$. cristatum, Wall., a tall form with a strong. green stem and falcate deeply-toothed pinnæ, cut away for about one-third of the lower side only.

103. A. loetum, Swartz ; st. tufted, 4-6 in. 1., firm, erect, brownish, naked ; fr. 6-12 in. 1., 3 in. br., with 16-24 sessile pinnoe on each side, which are $1 \frac{1}{2}$ in. 1. , $\frac{1}{2}$ in. br., acute at the point, the edge irregularly inciso-crenate, the upper side narrowed suddenly at the base, the lower truncate in a broad curve; texture herbaceous; rachis naked, polished; veins fine, distant, the lower ones twice forked; sori in two unequal rows falling short of both edge and midrib.Hk. Sp. 3. p. 133. t. 173.

Hab. Tropical America, from Mexico and Cuba southward to the Amazon.-Probably this should be joined with the preceding, but the texture is usually firmer, and the pagina is more developed on the lower side of the midrib, as in the cristatum form just mentioned.

104. A. heterocarpum, Wall. ; st. scattered, 4-9 in. 1., firm, erect, chesnutbrown, polished; fr. $6-15$ in. $1 ., 1 \frac{1}{2}-2$ in. br., with very numerous close-placed dimidiate pinnoe on each side, which are $\frac{3}{4}-1$ in. br., $\frac{1}{4}$ in. deep, the lower edge 
quite entire, the upper broadest towards the base, where it is narrowed suddenly, deeply incised throughout; texture pellucido-herbaceous ; rachis glossy, chesnutbrown; sori 1 or rarely 2 together in the teeth.-Hk. Sp. 3. p. 132.t. 175.

Hab. Himalayas to Ceylon, Malayan Peninsula, S. E. China, Borneo.-A very wellmarked plant, resembling in babit a dimidiate Adiantum.

*** Pinnoe cut down at any rate in the lower part nearly or quite to the rachis. Sp. 105-113. See also 95.

105. A. planicaule, Wall.; st. tufted, 3-6 in.1., firm, erect, greyish, nearly naked ; fr. 6-12 in. 1., 2-3 in. br., with 12-20 stalked horizontal pinnce on each side, which are 1-1 $\frac{1}{2}$ in. $1 ., \frac{1}{4}-\frac{3}{3}$ in. br., the point acute, the edge lobed often halfway down or more and deeply inciso-serrated, the upper side narrowed and the lower one very obliquely truncate at the base; texture coriaceous; rachis firm, compressed, greyish ; veins very oblique; sori copious, reaching nearly to the edge. -Hk. Sp. 3. p. 163.t. 200. B.

Hab. Himalayas (ascending to 6,000 ft.), Neilgherries, Ceylon.

106. A. laciniatum, Don ; st. tufted, $4-8$ in. l., firm, erect, greyish, often scaly ; fr. 6-12 in. l., 2-3 in. br., with 12-20 stalked horizontal pinnoe on each side, which are $1 \frac{1}{2}-2$ in. $1 ., \frac{1}{2}-\frac{3}{4}$ in. br., the point acute, the edge cut down nearly or quite to the rachis in the lower part into stalked ovate-rhomboidal lobes, which are deeply toothed round the outer edge, the lower side very much truncated at the base; texture subcoriaceous; rachis firm, compressed, greyish; veins very oblique; sori falling short of the edge.-Hk. Sp. 3. p. 164.t.200. A.

Hab. Himalayas (temperate region) and Japan.-A more herbaceous and more deeplycut plant than the preceding, with which Mettenius unites it.

107. A. bissectum, Swartz ; st. tufted, 4-6 in. l., firm, erect, chesnut-brown, nearly naked; $f r .12-18$ in. $1 ., 4-6$ in. br., with 20-30 horizontal pinnæ on each side, which are 2-3 in. l., $\frac{1}{4}$ in. br., with a very long, narrow, deeply incisopinnatifid upper portion, the base on the upper side narrowed suddenly, on the lower obliquely truncate; texture subcoriaceous; rachis chesnut-brown and villose like the stem; sori almost all in two parallel rows close to the midrib.Hk. Sp. 3. p. 152.t. 192.

Hab. West Indies and Ecuador.-In texture this agrees with the falcatum group.

108. A. horridum, Kaulf.; st. strong, erect, brownish, fibrillose ; $f r .2-3 \mathrm{ft} .1$., 8-12 in. br., with very numerous spreading pinnoe on each side, which are 4-6 in. 1., $\frac{3}{4}$ in. br. at the base, narrowed gradually to an acuminated point, cut down throughout more than halfway to the rachis into nearly uniform rhomboidal lobes, cordate or broadly rounded at the base on the upper, truncate in a broad curve on the lower side ; texture subcoriaceous; rachis stout, clothed with reddishbrown woolly fibres; veins oblique, usually once forked; sori in two nearly parallel lines close to the midrib, and a few also on the disk of the lobes. $-H \dot{k}$. Sp. 3. p. 153.t. 193.

Hab. Sandwich Islands, Samoa, and Java. -A well-marked plant.

109. A. protensum, Schrad. ; st. tufted, 3-6 in. 1., erect, brownish, villose ; fr. 1-2 ft. l., 4-6 in. br., with 12-30 horizontal pinnce on each side, which are 2-3 in. l., $\frac{1}{2}$ in. br., the point acuminate, the edge sharply cut halfway down to the rachis, the two sides unequal at the base, the upper one auricled and narrowed suddenly, the lower one obliquely truncate in a curve; texture herbaceuus; rachis firm, erect, brownish, villose; veins inconspicuous; sori in 
two oblique rows, almost confined to the undivided part of the pinnæ.- $H k$. Sp. 3.p. 150.

Hab. Cape Colony to Natal, Mauritius, Abyssinia, and Fernando Po.

110. A. Hallii, Hk. ; st. tufted, 1-2 in. l., glossy, chesnut-brown ; fr. 6-12 in. 1., $1 \frac{1}{2}-2$ in. br., elongated and rooting at the point ; pinnoe numerous, horizontal, the lower ones deflexed, 1 in. $1 ., \frac{1}{4}-\frac{3}{8}$ in. br., the point bluntly rounded, the upper two-thirds cut only halfway down to the rib with linear erecto-patent teeth, but the lower third cut down nearly or quite to the centre; texture herbaceous; rachis polished like the stem; veins simple, oblique; sori in two rows.-Hk. Sp. 3. p. 202. 2nd Cent. F.t.30.

Hab. Ecuador and the Amazon Valley.-The alliance of this is with A. protensum, of which it may be an American form, and both closely resemble the very variable $A$. erectum in many points.

111. A. mucronatum, Presl ; st. tufted, slender, naked, polished, 1-2 in. l. ; fr. $1 \mathrm{ft}$. or more l., $1 \mathrm{in}$. or less br., very flaccid in habit, with very numerous pairs of deflexed sessile pinnæ, which are $\frac{1}{2}-\frac{3}{4}$ in. l., $\frac{1}{4}-\frac{3}{8}$ in. br., deeply pinnatifid on both sides, the lobes mucronate, in the lower part reaching down nearly to the rachis, the base on both sides cordate ; texture membranous; colour brightgreen; upper veins simple, distant; sori lineal-oblong, short.-Hk. Sp. 3. p. 128. Ic. Fil. t. 917.

Hab. Brazil.-A very delicate and well-marked plant.

112. A. bipartitum, Bory ; st. tufted, 3-6 in. l., firm, slender, greyish, naked ; fr. 6-8 in. l., 2-3 in. br., with about 10-15 conspicuously stalked pinnoe on each side, which are 1-1 $\frac{1}{2}$ in. $1 ., \frac{1}{2}-\frac{3}{4}$ in. br., bluntish at the point, cut down at the base on the upper side into one distinctly-stalked cuneate pinnl., sometimes into two or three, the outer edge inciso-crenate, the base on the lower side obliquely truncate; texture herbaceous; rachis compressed, winged upwards, naked; veins mostly simple; sori in two regular rows, which reach nearly to the edge. -Hk. Sp. 3. p. 178. t. 208.

Hab. Mascaren Isles. - This comes nearest some of the divided forms of auritum, but is less rigid.

115. A. pumilum, Sw. ; st. tufted, 3-4 in. l., erect, naked, polished, ebeneous below ; fr. 4-6 in. each way, deltoid, the upper part sinuated only, the lower cut down to the rachis into distinct pinnoe, of which the lowest pair is much the largest, the pinnl. on the lower side sometimes $2 \mathrm{in.}$ l., reaching down to a slightly-winged rachis, acuminate and deeply lobed; texture herbaceous; rachis green, flaccid, compressed; sori very oblique, the lower ones sometimes $\frac{3}{4}-1$ in. 1.-Hk. Sp. 3. p. 174.

Hab. W. Indies and Mexico to Columbia ; and a small tender form (A. tenerrimum, Hochst.) has been gathered by Schimper in Abyssinia, and Dr. Kirk in Zambesi Land.A very distinct species.

*\%** Fronds bi- to quadripinnate. Sp. 114-155. See also Sp. 64, 75, 88-90.

Group of A. cuneatum. Texture coriaceous. Ultimate divisions of the frond linear- or ovate-cuneate, often shining on the upper surface. Venation subflabellate. Sp. 114-132.

114. A. germanicum, Weiss; st. densely tufted, 2-4 in. 1., naked, slender, ebeneous; fr. 2-3 in. 1., $\frac{3}{4}-1$ in. br., lanceolate, cut down to the rachis into a few distant narrow flabellato-cuneate pinnce on each side, the lowest of which are again deeply cleft and also slightly inciso-serrate towards the point; texture 
coriaceous; veins obscure, subparallel ; sori linear, when mature covering the whole breadth, but falling short of the point of the pinnæ.-Hk. Sp. 3. p. 175 . Brit. F.t.27.

Hab. Scotland and Norway to Hungary and Dalmatia.-Intermediate between Rutamuraria and septentrionale.

115. A. Ruta-muraria, Linn.; st. tufted, $2-4$ in. l., slender, wiry, naked, ebeneous towards the base ; fr. 1-2 in. l., about 1 in. br., deltoid, cut down to the rachis into a few pinnice on each side, the lower ones again cut down into spathulato-cuneate pinnl., which are serrated round the outer edge; texture coriaceous; rachis firm, green, naked ; veins flabellate; sori copious.-Hk. $S p .3$. p. 176. Brit. F.t. 28.

Hab. Arctic Europe to Spain, Algiers, Cashmere, Tibet, and Siberia ; Cape Colony, United States,

116. A. Hookerianum, Col. ; st. tufted, 1-3 in. 1., slender, greenish, deciduously

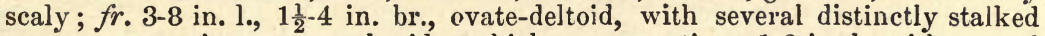
erecto-patent pinnæ on each side, which are sometimes 1-2 in. l., with several stalked pinnl. $\frac{1}{4}$ in. each way, the lower half cuneate, the upper rounded and crenate; texture herbaceous ; rachis greenish; veins subflabellate; sori 3-5 to a pinnl.-Hk. Sp. 3. p. 194. A. adiantoides, var. minus, Hk. Fil. Ic. Pl.t. 983.

Hab. New Zealand.-The pinnæ and pinnules in shape resemble those of Rutamuraria, but the petioles of the former are terete, not flattened, and the texture is thinner. A plant which resembles this (var. Mairii, Hk. fil.) has pinnate pinnules and Dareoid sori.

117. A. Magellanioum, Kaulf. ; st. tufted, 3-4 in. 1., wiry, naked, ebeneous below ; fr. 2-3 in. 1., 1-1 $\frac{1}{2}$ in. br., deltoid with several pinnoe on each side, the lower ones often $1 \mathrm{in} .1$. , $\frac{3}{4}$ in. br., cut down to the rachis into several distinct pinnl. on each side, which are again cut down below into cuneato-spathulate segm. 1-1 $\frac{1}{2}$ lin. br., which are slightly inciso-serrate round the outer edge; texture coriaceous; rachis green, naked, compressed; veins obscure, flabellate ; sori oblong, copious, at length covering the whole surface.-Hk. Sp. 3. p. 177 . $H k$. \& Gr. Ic.t. 180.

Hab. Temperate S. America.-Divisions like those of Ruta-muraria, but the frond more compound.

118. A. fissum, Kit. ; st. tufted, 2-6 in. 1., slender, naked, ebeneous below ; fr. 2-5 in. 1., 1-2 in. br., oblong-deltoid, with a few distant pinnoe on each side, with distinct flabellato-cuneate pinnl. which are again deeply pinnatifid; ult. segm. under $\frac{1}{2}$ lin. br. ; texture herbaceous; rachis green, naked, slender; veins solitary ; sori linear-oblong, when mature occupying the whole breadth of the segments.-Hk. Sp. 3. p. 177.

Hab. Seattered from Gothland to Turkey and Naples.-A well-marked species.

119. A. sepulchrale, Hk., MSS. ; st. densely tufted, 1-2 in. 1., firm, greenish, nearly naked, ebeneous below ; $f r .4-6$ in. $1 ., 1-1 \frac{1}{2}$ in. br., with several lanceolatedeltoid pinnce on each side, which are cut down to a compressed rachis into several ovate-rhomboidal pinnl. on each side, which are again deeply pinnatifid ; ult. segm. linear-cuneate; texture subcoriaceous; upper surface shining; rachis compressed, green, naked; veins and sori one to a segm.

Hab. Japan, Oldham, 83, 304, 462 ; China, Blakiston, Maingay, Robinson.-This comes nearest to $A$. varians, but the texture is thicker, and the segments are narrower.

120. A. montanum, Willd.; st. tufted, 2-3 in. 1., wiry, naked, ebeneous below ; 
fr. 2-3 in. l., 1 in. br., lanceolate-deltoid, with several pinnoe on each side, the lowest of which are distinctly stalked, deltoid, about $\frac{1}{2}$ in. each way, cut down to the rachis in the lower part into spathulato-cuneate pinnl., sharply serrated round the outer edge; texture coriaceous; rachis naked, green, compressed, winged upwards; veins obscure; sori short, copious.-Hk. Sp. 3. p. 177.

\section{Hab. United States.-Intermediate between Ruta-muraria and Adiantum-nigrum.}

121. A. Adiantum-nigrum, Linn. ; st. tufted, 6-9 in. 1., nearly naked, polished, chesnut-brown ; fr. 6-12 in. l., 4-6 in. br., sub-deltoid, with numerous pinnoe on each side, the lower ones deltoid, $2-3$ in. $1 ., 1 \frac{1}{2}-2$ in. br., cut down to a compressed winged rachis into numerous lanceolate-deltoid pinnl., truncate on the lower side, cut down nearly or quite to the rachis into oblong or spathulate segm., sharply toothed round the outer edge ; texture coriaceous ; rachis polished and chesnut-coloured below, upwards winged and compressed; veins obscure, oblique; sori copious, at last often occupying the whole under surface of the segm. $-\beta, A$. acutum, Bory; habit more graceful, fr. more finely cut ; ult. div. linear-spathulate with mucronate teeth. $-\gamma, A$. obtusum, Willd.; ult. segm. short, flabellato-cuneate, often $\frac{1}{8}$ in. br., habit more slender. A. Serpentini, Tausch. - $\delta$, A. Gaudichaudianum, Hk. ; texture very thick; pinnl. distant, lanceolate, with small distant oblong-spathulate ult. segm.-Hk. Sp. 3. p. 187. Brit. F. t. 33 .

Hab. Norway and Britain to the Cape Verdes, Azores, Canaries, Cameroon Mountains, Algiers, Abyssinia, Himalayas, and Siberia ; Cape Colony, Sandwich Islands. Reported also from Java, Virginia, Porto Rico, St. Helena, and Mascaren Isles.

122. A. solidum, Kunze ; st. tufted, 4-6 in. 1., dark chesnut-brown, naked, polished ; fr. oblong-deltoid, 6-12 in. 1., 4-6 in. br., with 8-12 pinnoe on each side, which decrease gradually upwards, the lowest lanceolate-deltoid, 4 in. l., 2 in. br., cut down to the rachis into several quite distinct deltoid pinnl., which are again cut down below to the rachis into sharply serrated rhomboidal segm.; texture subcoriaceous; rachis chesnut-brown and polished like the stem; veins flabellate, channelled; sori linear-oblong, when mature sometimes filling up nearly the whole width of the segments.-Hk. Sp. 3.p. 167.t.201.

Hab. Cape Colony; and a plant which appears to be the same has been gathered by Oldham in Japan.- Very near the preceding, with which it probably should be joined.

123. A. dissectum, Brack. ; st. 6-9 in. l., firm, erect, greyish, naked ; fr. 12-18 in. 1., 4-6 in. br., cut down to the rachis into numerous lanceolate-deltoid pinnoe

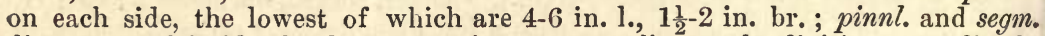
distant, subdeltoid, the latter cut into narrow linear ult. divisions, 1-2 lin. l., $\frac{1}{2}$ lin. br., acute or acutely toothed at the apex; texture subcoriaceous; rachis firm, greyish; veins one in each ult. division; sori usually solitary.-Brack. Fil. U.S. Expl. Exp.t. 24.

Hab. Sandwich Islands; gathered by Douglas and Brackenridge.

124. A. cuneatum, Lam.; st. tufted, 6-9 in. 1., firm, erect, naked ; fr. 6-15 in. l., 6-9 in. br., with numerous spreading pinnoe on each side, the lower ones 3-4 in. 1., 1-1 $\frac{1}{2}$ in. br., lanceolate-deltoid, cut down to the rachis into several distinct ovate-cuneate pinnl., which are inciso-dentate and cut down in the lower part nearly or quite to the rachis ; texture subcoriaceous ; rachis firm, greyish, nearly naked; veins fine, conspicuous on the upper surface; sori linear, subflabellate.-Hk. Sp. 3. p. 168.

Hab. Tropical America, West Indies to Brazil ; Polynesian Islands to Java and Hong-Kong ; Cape Colony to Mozambique, Johanna Island, and Seychelles. - A. splendens, Kze. Hk. Sp. 3. p. 168, does not seem to be safely separable.

125. A. furcatum, Thunb.; st. tufted, 4-8 in. 1., firm, erect, clothed with 
deciduous woolly hairs ; fr. 6-18 in. 1., 4-6 in. br., with 12-20 pinnæ on each side, which are lanceolate-deltoid in general outline, 2-3 in. $1 ., \frac{3}{4}-1$ in. hr., cut down throughout nearly or quite to the rachis into linear-cuneate pinnl., which are sharply serrated on the outer edge; texture coriaceous; rachis firm, erect, more or less fibrillose like the stem; veins deep-channelled, flabellate; sori linear, radiant.-Hk. Sp. 3. p. 165. A. præmorsum, $S w$.

Hab. Tropical America, from Mexico and the West Indies to Peru ; Polynesian Islands and Australia northward to Tsus-Sima and the Himalayas; Cape Colony to Mascaren Isles, Abyssinia, and the Canaries.-Distinguished from the preceding by its fibrillose rachis and longer and narrower divisions.

126. A. affine, Swartz; st. 6-12 in. 1., firm, erect, grey, nearly naked; fr. 12-18 in. 1., 6-12 in. br., with numerous pinnce on each side, the lower ones lanceolate-rhomboidal, cut down to the rachis into numerous distinct rhomboidal pinnl. 4-6 in. 1., 1 $1 \frac{1}{2}-2$ in. br., which are again inciso-serrate or deeply lobed; texture subcoriaceous; rachis firm, naked; veins subflabellate; sori copious, linear.-Hk. Sp. 3. p. 170.t.202. A. spathulinum, J. Sm. Hk. Sp. 3. p. 170 .

Hab. Mascaren Isles, Ceylon, Philippines, Borneo, Fiji, Sandwich Islands.-Very near $A$. cuneatum, but a more robust plant, with often 10-15 distinct pinnules to the lower pinnæ.

127. A. nitidum, Swz.; st. $1 \mathrm{ft} .1$., firm, erect, greyish, naked; fr. 2-3 ft. 1., $1 \mathrm{ft}$. br., with numerous lanceolate-deltoid pinnee on each side, the lowest of which are 6-9 in. 1., 2-3 in. br., cut down to the rachis into numerous stalked subdeltoid pinnl., which are again cut down to the rachis into broad flabellatocuneate segm., inciso-serrate round the outer edge; texture subcoriaceous ; rachis firm, grey, naked ; veins channelled, flabellate; sori short, radiant.-Hk. Sp. 3. p. 172.

Hab. North of India, Ceylon, Malayan Peninsula and Isles.-Very near the last, but a still larger plant, with ample shiuing rhomboidal acuminate pinnules, sometimes again pinnatifid.

128. A. laserpitiifolium, Lam. ; st. tufted, 6-12 in. l., firm, erect, greyish, naked ; fr. 2-4 ft. l., 6-18 in. br., with numerous pinnoe on each side, the lowest deltoid-lanceolate, 6-9 in. 1., 4-6 in. br., cut down to the rachis into numerous distinct pinnl., the lowest with rhomboidal-cuneate segm. again deeply pinnatifid ; texture herbaceous; rachis slender, naked; veins fine and deeply channelled; sori short, linear-oblong, irregular.-Hk. Sp. 3. p. 171.t. 203.

Hab. Polynesian Islands and N. Australia northward to Chusan and Assam; and gathered also by Gerrard in Natal.-Like the two preceding, closely allied to A.cuneatum.

129. A. nigritianum, Hk.; st. tufted, strong, erect, 4-6 in. l., nearly black and densely villose; $f r .12-18$ in. $1 ., 4-6$ in. br., with numerous horizontal or slightly deflexed pinnce on each side, which are 2-3 in. $1 ., \frac{1}{2}-\frac{5}{8} \mathrm{in}$. br., cut down to the rachis into numerous subdimidiate rhomboidal pinnl., the lower ones once deeply lobed and also inciso-crenate, the lowest imbricated over the main rachis ; texture subcoriaceous; rachis firm, erect; veins subflabellate; sori oblong.Hk. Sp. 3. p. 223. 2nd Cent. t. 44.

Hab. Prince's Island and St. Thomas, Guinea Coast ; gathered by Barter and Mann. -A very distinct species, of which our dried specimens are nearly black.

130. A. scandicinum, Kaulf. ; st. tufted, 6-9 in. 1., firm, erect, grey, naked; fr. 9-18 in. 1., 4-8 in. br., with numerous rather distant pinnoe on each side, the lower ones subdeltoid, $3-6$ in. 1., 1-1 $\frac{1}{2}$ in. br., cut down to the rachis into numerous stalked subdistant pinnl., which are again cut down into cuneato- 
flabellate segm., 1-2 lin. br., sharply toothed on the outer edge ; texture coriaceous ; rachis firm, grey, naked; veins subflabellate; sori oblong, usually one only to a segm.-Hk. Sp. 3. p. 183. t. 204.

Hab. Brazil and Ecuador.-Mettenius makes here two species ; one, A.divergens, Mett. (Burchell, 2374, 4671), a foot or more long, with pinnules toothed only; the other smaller (Burchell, 3508), with pinnatifid and flaccid decurved main rachis and pinnæ; but our figure is midway between them.

131. A. fragrans, Swartz ; st. tufted, 4-8 in. 1., firm, naked, erect, brownish below ; fr. 6-9 in. l., 3-4 in. br., subdeltoid, tripinnate, with numerous closeplaced deltoid pinnoe on each side, the lowest 3 in. $1 ., 1 \frac{1}{2}$ in. br. ; pinnl. lanceolate-deltoid; segm. subspathulate, 1 lin. br., dentate round the outer edge; texture subcoriaceous; rachis firm, naked; veins fine, obscure, one in each tooth of the segm.; sori copious, at last often covering the whole under surface of the segm.- $\beta, A$. foeniculaceum, H. B. K. ; ult. segm. narrowly linear.-Hk. Sp. 3. p. 181 .

Hab. Tropical America, from Mexico and the West Indies to Peru and Brazil.-The two varieties seem to be quite connected by gradual intermediate gradations.

132. A. Blakistoni, Baker ; st. tufted, 3-4 in. l., firm, erect, greenish, nearly naked ; fr. 4-5 in. 1., 3 in. br., ovate-deltoid, with numerous imbricated pinnoe, the lowest deltoid, 2 in. 1., 1-1 $\frac{1}{4}$ in. br. ; pinnl. lanceolate, cut down to the rachis into distant linear-cuneate sharply-toothed segm. ; texture subcoriaceous ; rachis firm, naked; veins obscure, one in each segment; sori copious.

Hab. Province of Szchuan, West China, Capt. Blakiston.-This comes nearest to some of the more finely divided forms of the preceding.

Group of $A$. lanceolatum. Texture herbaceous or slightly coriaceous. Venation pinnate. Fronds 4-8 in. long, lanceolate. Sp. 133-136.

133. A. fontanum, Bernh.; st. tufted, 2-4 in. 1., wiry, slender, naked, greenish ; fr. 3-6 in. 1., 1-1 $\frac{1}{2}$ in. br., oblong-lanceolate, with numerous pinnoe on each side, the lower ones short and reflexed, the central ones horizontal, $\frac{1}{2}-\frac{5}{8}$ in. l., $\frac{1}{4} \cdot \frac{3}{8}$ in. br., cut down to the rachis into several stalked pinnl. on each side, the lower ones oblong, deeply inciso-pinnatifid; texture herbaceous; rachis and upper surface bright-green; veins oblique; sori copious, covering nearly the whole under surface of the pinnl.-Hk. Sp. 3. p. 193. Brit. F. t. 34.$\beta, A$. Bourgai, Boiss ; pinne oblong, blunt, $\frac{3}{8}$ in. l., $\frac{1}{8}$ in. br., cut down about halfway to the rachis into oblong sharply-toothed lobes, most of them somewhat decurved.

Hab. England to Spain, Naples, and Greece ; Lycia ; Himalayas.-A. refractum, Moore (Nat. Brit. F.t. 35), only known in cultivation, comes very near var. $\beta$, but has a chesnut. coloured rachis, and larger, closer, and more distinctly reflexed pinnæ. A. exiguum, Beddome, from the Neilgherries, seems to be a less-divided form of this, with narrow fronds and an ebeneous rachis. A similar plant has been gathered in Mexico by $\mathrm{Mr}$. Glennie, and a long narrow-fronded form, but with broader and more divided pinnæ, in Japan by Mr. Wright.

134. A. varians, Hk. \& Gr. ; st. tufted, 1-3 in. l., slender, naked, greenish ; fr. 4-6 in. 1., 1 in. br., oblong-lanceolate, with 8-12 pinnoe on each side, the lower ones subdeltoid, $\frac{1}{2}-\frac{3}{4}$ in. $1 ., \frac{1}{4}-\frac{3}{8}$ in. br., cut down to the rachis into a few cuneatoflabellate pinnl., the lowest 2 lin. across, sharply toothed on the outer edge; texture herbaceous; rachis slender, naked, green; veins one carried into each tooth ; sori copious, when mature covering nearly the whole under surface of the pinnl.-Hk. Sp. 3. p. 192. Hk. \& Gr. Ic. t. 172.

Hab. Himalayas, Neilgherries, Ceylon, Cape Colony, Caffraria, Natal. 
135. A. incisum, Thunb. ; st. tufted, 1-3 in. l., polished, chesnut-brown ; fr. 6-12 in. 1., $]_{\frac{1}{2}}-2$ in. br., with numerous pinnoe on each side, the lower distant and blunt, the central ones lanceolate-deltoid, 1 in. $1 ., \frac{1}{2}$ in. br., cut down to the rachis into numerous ovate-rhomboidal pinnl., much truncated at the base on the lower side and deeply inciso-pinnatifid; texture thinly herbaceous; rachis. greenish above, compressed, flaccid; veins one to each tooth ; sori linear-oblong, one to each vein.-A. elegantulum, Hk. Sp. 3. p. 178. 2nd Cent. F. t. 28.

Hab. Japan (common), Tsus-Sima, Chusan, W. China.-Very near A. lanceolatum, but narrower in outline, and thinner in texture.

136. A. lanceolatum, Huds.; st. tufted, 3-4 in. 1., naked, glossy, chesnutcoloured ; fr. 6-9 in. l., 2-4 in. br., with numerous pinnoe on each side, the lower ones distant, 1-1 $\frac{1}{2}$ in. $1 ., \frac{1}{4}-\frac{3}{8}$ in. br., cut down to the rachis into numerous oblongrhomboidal pinnl., which are truncate on the lower side, sharply toothed and often broadly lobed below; texture herbaceous; rachis firm, erect, green or tinged with chesnut; veins fine; the lateral ones usually once forked; sori copious, when mature covering nearly the whole under surface.-Hk. Sp. 3 . p. 190. Brit. F.t. 32 .

Hab. South-west of Europe ; England to Greece, Algiers, Madeira, Azores, St. Helena. A. obovatum, Viv. (Hk. \& Gr. t. 147), is a less divided southern form with obovate pinnules.

Group of $A$. bulbifcrum. Venation pinnate. Fronds $1 \mathrm{ft}$. or more long. Ultimate divisions ample, herbaceous. Sp. 137-144.

137. A. angustatum, Presl ; st. 6-12 in. 1., naked, greyish or ebeneous below; fr. 6-12 in. 1., 4-6 in. br., with numerous pinnce on each side, the lower ones deltoid, $2-4$ in. 1., $1 \frac{1}{2}-2$ in. br., lobed and pinnatifid on the upper, cut down below into distinct inciso-crenate ovate-rhomboidal or spathulate pinnl. $\frac{1}{4}-\frac{3}{8}$ in. br. ; texture herbaceous; rachis naked, compressed and winged upwards; veins pinnate; sori linear, falling considerably short of the edge.-Mett. Aspl. 177. non Desv. \& Bl.

Hab. Brazil.-This is nearest A. adiantoides, but considerably less compound, with blunt sessile subspathulate pinnules.

138. A. adiantoides, Raddi ; st. tufted, 6-12 in. l., naked, grey, firm ; $f r$. 12-24 in. l., 8-15 in. br., deltoid, quadripinnate ; lower pinnoe distant, deltoid, 6-9 in. 1., 4-6 in. br., with numerous stalked deltoid pinnl. on each side; segm. deltoid, cut down nearly or quite to the rachis; ult. divisions cuneate-spathulate, deeply flabellately cut; texture herbaceous; rachis firm, naked; veins one to each ult. division; sori copious, linear. $-H k$. Sp. 3. p. 186.

Hab. Jamaica and Brazil.-Distinguished in the group by its distant long-stalked pinnæ and pinnules.

139. A. Wardii, Hk. ; st. 6.9 in. 1., erect, slender, polished, greyish, scaly towards the base; fr. 12-15 in. $1 ., 10$ in. br., deltoid, with numerous lanceolate pinnoe on each side, the lowest 5 in. $1 ., 1 \frac{1}{4}$ in. br., cut down to the rachis into numerous ovate-rhomboidal pinnl., which are $\frac{5}{8}$ in. $1 ., \frac{1}{4}$ in. br., the point blunt, the two sides unequal, the upper one auricled, the lower one obliquely truncate at the base, the edge very slightly crenate ; texture thinly herbaceous ; rachis slender, polished, greyish; veins conspicuous, the central lateral ones twice forked; sori in two regular oblique rows near the midrib.-Hk. Sp.3. p. 189. 2nd Cent. F. $t .33$.

Hab.-Island of Tsus-Sima, Wilford, 717.-A very distinct species.

140. A. pseudo-nitidum, Raddi ; st. 1 ft. l., polished, glossy, purplish-black; $2 \mathrm{E}$ 
fr. 12-18 in. 1., 6-9 in. br., ovate-deltoid, bipinnate, with 9-12 pinnoe on each side, the lower ones subdeltoid, 4-6 in. 1., 2 in. br.; lower pinnl. stalked, ovaterhomboidal, with the outer edge toothed and the base on the lower side truncate in a curve, sometimes lobed in the lower part; texture herbaceous; rachis firm, naked; veins rather close, once or twice forked; sori in two nearly regular rows.- $\beta$, crenatifolium, Hk. ; pinnoe cut down in the lower part into spathulate pinnl.-Hk. Sp. 3. p. 184. A. Lindeni, Hk. Sp. 3. p. 185. t. 209.

\section{Hab. Brazil, Venezuela, Ecuador.}

141. A. Jamesoni, Hk. ; st. 6-12 in. l., firm, erect, angular, the lower part clothed with large brown deciduous scales ; $f r .1-2 \mathrm{ft}$. or more 1., 9-12 in. br., with numerous pinnoe on each side, the lower ones 6-9 in. 1., 3-4 in. br., cut down to a broadly-winged rachis into deltoid pinnl, which are again deeply pinnatifid; ult. segm. oblong or spathulate; texture herbaceous; main rachis firm, compressed and winged upwards ; veins distant ; sori large, oblong, principally in two lines close to the midrib and nearly parallel with it.-Hk. Sp. 3. p. 184.t. 205.

Hab. Andes of Ecuador, Jameson, Spruce, 5627.

142. A. acuminatum, Hk. \& Arn. ; st. subtufted, 6-9 in. l., strong, erect, greyish, deciduously paleaceous ; $f r .1-2 \mathrm{ft} .1 ., 9-12$ in. br., with very numerous

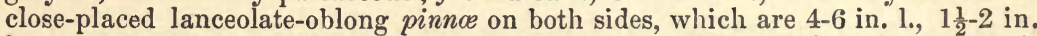
br., cut down to the rachis into numerous unequal-sided lanceolate pinnl., which are acuminate at the apex, with the edges sharply toothed or even lobed below, the lower base obliquely truncate; texture coriaceous; rachis strong, erect, greyish ; veins fine, close, deep-channelled; sori in two rows in the upper part of the pinnl., often diplazioid.-Hk. Sp. 3. p. 183. $t .206$.

Hab. Sandwich Islands.-Intermediate between A.bulbiferum and cuneatum.

143. A. squamosum, Linn.; st. stout, erect, 12-18 in. 1., clothed with large brown scales below ; fr. 3-6 ft. 1., 12-18 in. br., with numerous pinnce on each side, the lower ones 3-4 in. apart and horizontal, 6-9 in. 1., 4-6 in. br., cut down to a compressed and winged rachis into numerous stalked pinnl. on each side, which are ovate-rhomboidal, 2-3 in. 1., 1-1 $\frac{1}{2}$ in. br., the apex acuminated, the edge crenate, the base on the lower side truncate in a curve; texture rather thinly herbaceous; main rachis compressed and channelled; veins oblique, the lateral ones usually twice forked; sori few, principally near the midrib.HK. Sp. 3. p. 186. t. 210.

Hab. West Indies, Venezuela, and Ecuador.-Easily recognized by its large size and ample pinnules.

144. A. bulbiferum, Forst. ; st. tufted, 6-12 in. 1., firm, erect, greyish, scaly at the base ; fr. 1-2 ft. l., 8-12 in. br., oblong-deltoid, with numerous horizontal pinnoe on each side, which are often proliferous from the upper surface, the largest 4-8 in. l., $1 \frac{1}{2}-2$ in. br., cut down to a compressed winged rachis into numerous lanceolate-deltoid pinnl., which are again cut down into slightly-toothed linearoblong segm. $\frac{1}{4}-\frac{1}{2}$ in. l., 1 lin. br.; texture herbaceous ; rachis firm, sometimes pendulous ; veins fine, pinnate; sori oblong, when mature often filling the whole breadth of the segm.-Hk. Ic. $t .423 .-\beta, A$. laxum, R. Br.; habit more slender ; segm. narrow, so that the sori are often as if marginal. $-\gamma, A$. Fabianum, Homb. and Jacq. ; lower segm. deeply pinnatifid, with narrow divisions and submarginal sori.-Hk. Sp. Fil. 3. p. 196.

Hab. New Zealand, Australia, New Caledonia, Penang, Samoa, N. India, Mexico, Guatemala, Bourbon, Seychelles, Johanna Island, Natal.-A. Mertensianum, Kze., from Bonin, and $A$. Shuttleworthianum, Kze., are both apparently large quadripinnatifid forms of this with quite marginal sori. 
Group of A. cicutarium. Venation pinnate. Fronds various in size, texture thinly herbaceous, colour bright-green, ultimate divisions finely cut. Sp. 145-155.

145. A. triphyllum, Presl ; st. tufted, 1-2 in. l., slender, spreading ; fr. 6-9 in. 1., $\frac{1}{2}-\frac{3}{4}$ in. br., with numerous pinnoe on each side, cut down into 3 or 5 stalked linear or oblong-spathulate pinnl. $\frac{1}{8}$ in. 1. ; texture herbaceous; rachis slender, wide-rambling, often gemmiferous; veins one in each pinnl.; sori 1-2 on the disk of each.-A. herbaceum, Fée.- $\boldsymbol{\beta}, \boldsymbol{A}$. sessilifolium, Desv. ; rachis stronger ; pinnoe distant, with usually three spathulate pinnl., the terminal one $\frac{1}{8}$ in. br. A. imbricatum, Hk. \& Gr. $t$. 165. A. ternatum, Presl. $-\gamma$, compactum, Hk.; texture subcoriaceous; rachis firm, erect; pinnce close; pinnl. more numerous.; sori copious.-Hk. Sp. 3. p. 203.

Hab. Andes of Ecuador and Peru.-Pinnæ usually consisting of three, or at most of five, nearly equal divisions.

146. A. repens, Hk.; st. wide-scattered, very slender, very short; fr.1-2 in. 1 , $\frac{1}{2}$ in. br., ovate-lanceolate, bi- or tripinnatifid; pinnce horizontal, $3-4$ on each side, cut down to the rachis into broad cuneate pinnl., which are sharply toothed on the outer edge and sometimes deeply cleft; texture thinly herbaceous ; rachis naked; veins simple or forked in each pinnl.; sori oblong, solitary.-Hk. Sp. 3. p. 194. 2nd Cent. $t .31$.

Hab. Andes of Ecuador, Jameson and Spruce.

147. A. delicatulum, Presl ; st. tufted, 1-2 in. 1., slender, ebeneous ; fr. 3-4 in.1., 2-3 in. br., subdeltoid, tripinnate, with several deltoid pinnoe on each side, the lowest of which are 1 in. or more l., $\frac{3}{4}$ in. br. ; pinnl. deltoid ; ult. segm. linear, 1 lin. l., $\frac{1}{4}$ lin. br. ; texture thinly herbaceous; rachis compressed, flaccid; a vein to each segm.; sori few, scattered, short.-Hk. Sp. 3.p. 182. Ic. Pl.t.915.

Hab. Peru, Venezuela, N. Granada, Brazil.

148. A. divaricatum, Kunze ; st. tufted, very short ; fr. 4-6 in. 1 ., $1 \frac{1}{2}-2$ in. br., oblong-lanceolate, with numerous close-placed pinnoe on each side, which are $\frac{1}{2}-1$ in. l., $\frac{1}{4}$ in. br., cut down to the rachis into numerous pinnl. not more than 1 lin. br.; segm. linear-oblong, not toothed; texture membranaceous; rachis very slender, ebeneous; veins one to each segm.; sori solitary.-Hk. Sp. 3. p. 204 .

Hab. Chili and Peru.-Very doubtfully distinct from A. myriophyllum.

149. A. Gibertianum, Hk. ; st. tufted, very short, compressed ; fr. 6-8 in. 1., 1 in. br., caudate at thc apex, with numerous close-placed pinnce on each side, the largest $\frac{1}{2}$ in. l., $\frac{1}{4}$ in. br., ovate-rhomboidal, broadest on the upper side, cut down to the rachis into simple linear sharp-pointed or broader flabellately incised pinnl.; texture herbaceous; rachis green, much compressed and with a broad wing on each side all the way down; veins one to each segm.; sori one at the base of each segm.-Hk. Sp. 3. p. 199.'2nd Cent. t. 22.

Hab. Paraguay ; gathered by M. Gibert.-A stronger and more regular-growing plant than the rest of the group, with a very peculiar rachis.

150. A. Colensoi, Hk. fil.; st. tufted, 3-4 in. 1., firm, erect, clothed throughout with small scales; fr. 4-5 in. l., 2 in. br., with numerous rather rigid erectopatent pinnoe, the lower on stalks $\frac{1}{4}-\frac{1}{2}$ in. l.; lower pinnl. spreading, deeply incisopinnatifid, with linear segm.; texture herbaceous ; rachis slightly scaly; one vein to each segm.; sori oblong, solitary.-Ic. Pl.t.984.

Hab. New Zealand.-This is somewhat more rigid in texture than the rest of the group, but seems on the whole best placed here. 
151. A. Fadyeni, Hk. ; st. seattered, 3-4 in. 1., slender, scaly below ; fr. 6-8 in. l., 2 in. br., with several distant horizontal lanceolate pinnoe on each side, which are only lobed in the upper third, but cut down below into spathulate pinnl. 2 lin. 1., $\frac{1}{8}$ in. br.; texture herbaceous; rachis naked, flaccid; veins pinnate; sori few, small, linear-oblong.-Hk. Sp. 3. p. 192. 2nd Cent.t. 27.

Hab. Jamaica, McFadyen.-This is a feebler plant than the less cut forms of A. rhizophyllum, with fewer and more distant pinnæ and pinnules.

152. A. tenuifolium, Don ; st. tufted, 3-6 in. l., slender, naked, slightly ebeneous; fr. 6-12 in. 1., 3-5 in. br., oblong-lanceolate, with numerous pinnce on each side, the lower ones 2-3 in. l., $\frac{3}{4}$ in. br.; lower pinnl. subdeltoid, cut down to a narrowly-winged rachis into spathulate segm. $\frac{1}{8}$ in. br., sharply incised on the outer edge; texture thinly herbaceous; rachis green, naked, slender; veins solitary; sori 1 or 2 to each segm. placed on the disk.-Hk.Sp. 3. p. 193. 2nd Cent. F.t.29. A. concinnum, Wall.

Hab. Himalayas, Neilgherries, Ceylon, Malayan Peninsula.

153. A. rhizophyllum, Kunze ; st. tufted, $2-6$ in. 1., greyish, naked ; fr. 6-12 in. 1., $1 \frac{1}{2}-2$ in. br., cut down into numerous close-placed horizontal pinnoe on each side, the central ones 1 in. $1 ., \frac{1}{4}-\frac{3}{8}$ in. br., cut down throughout nearly to the centre into simple or forked erecto-patent pinnl., the lowest on the under side suppressed; texture herbaceous; rachis compressed, winged; veins one to each segm.; sori solitary, submarginal.-A. dubium, Brack. $\beta, A$. myriophyllum, Presl ; fr. broader; central pinnoe $1 \frac{1}{2}$ in. l., with lower pinnl. cut down into several simple or forked linear segm.-Hk. Sp. 3. p. 200.

Hab. Wisconsin, Florida, and W. Indies, to Peru, Sandwich Islands, and Fiji ; and gathered lately by Mr. Sanderson in Natal.-A. strictum, Brack. t. 23, differs from the typical plant by its stronger rachis, and pinnules of the upper half of the pinnæ linearfalcate and simple; $\boldsymbol{A}$. bifissum, Fée, is a slender form, with pinnatifid pinnules with distant linear segments ; and A. cladolepton, Fée, has cuneato-flabellate lower pinnules deeply 2- to 3-cleft at the apex.

154. A. rutaceum, Mett. ; st. tufted, 1-4 in. 1., naked, polished, chesnut-brown ; fr. 6-12 in. 1., 3-4 in. br., oblong-lanceolate, elongated and radicant at the apex ; pinnoe numerous, close-placed, horizontal, the central ones 1-1 $\frac{1}{2}$ in. $1 ., \frac{1}{4}-\frac{3}{8}$ in. br., cut down to the rachis into numerous rhomboidal pinnl. 2 lines each way; lowest segm. spathulate, stalked; texture thinly herbaceous; rachis polished and chesnut-brown like the stem; veins one to each segm.; sori solitary, central. -Hk.Sp.3.p. 203. 2nd Cent. F.t. 34.

Hab. Venezuela, New Granada, Ecuador, Galapagos Island--This differs from the preceding by its radicant habit and distinctly obovate-spathulate pinnules. It comés near A. rachirhizon, Raddi.

155. A. cicutarium, Swartz; st. tufted, $4-8$ in. 1. , firm, greenish, naked ; fr. 6-15 in. l., 4-6 in. br., with 10-15 horizontal pinnoe on each side, the lower ones 2-3 in. l., 1 in. br., cut down to the rachis into numerous ovate-rhomboidal pinnl., which are $\frac{3}{8}-\frac{1}{2}$ in. $1 ., \frac{1}{4}$ in. br., obliquely truncate on the lower side, and cut down to the rachis throughout into linear or oblong segm., the latter once or twice cleft at the apex; texture thinly herbaceous; colour bright-green; rachis compressed and often winged; sori principally in two rows along the pinnl.Hk. Sp. 3. p. 198. - $\beta, A$. Abyssinicum, Fée ; fr. flaccid; texture thin ; pinnl. and segm. fewer and broader.-Hk. Sp. 3. p. 191.

Hab. Tropical America, from Cuba and Mexico to Peru ; Abyssinia, Macalisberg, Guinea Coast. $-A$. montverdense, Hk. 2 nd Cent. t. 41 , appears to be a reduced form of this. 
$\S \S \S$ Darea, Juss. (Conopteris, Bory). Veins simple, ultimate divisions of the frond narrowly linear; sori linear or linear-oblong, marginal or submarginal. Sp. 156-177. See also Sp. 62, 144. Fig. 38. b. c.

* Fronds 6-9 in. l., lanceolate or subdeltoid. Sp. 156-164.

156. A. (Darea) Mannii, Hk. ; st. tufted, 1 in. or more l., slender, naked ; fr. 1-2 in. 1., 1 in. br., lanceolate-deltoid, the upper branches simple, the lower ones once or twice forked dichotomously; primary or secondary branches $\frac{1}{4}-\frac{1}{2}$ in. 1 ., not more than $\frac{1}{4}$ lin. br. ; texture thinly herbaceous, a single vein in each branch; sori oblong, solitary, marginal.-Hk. 2nd Cent. t. 60.

Hab. Cameroon Mountains and Fernando Po ; discovered by Gustave Mann, and gathered also lately in Zambesi Land by Dr. Kirk.

157. A. (Darea) brachypteron, Kunze ; st. tufted, 2-4 in. 1., wiry, naked ; fr. 4-6 in. 1., 1-1 $\frac{1}{2}$ in. br., with 12-24 horizontal pinnce on each side, of which from half to nearly the whole of the lower side is cut away, the largest $\frac{1}{2}-\frac{5}{8}$ in. l., cut down to the rachis into simple or forked linear pinnl. 1-1 $\frac{1}{2}$ lin. 1.; texture herbaceous ; rachis slender, naked; sori solitary, often quite marginal.-Hk. Fil. Ex. t. 14.

Hab. Madagascar, Natal, Angola, and Guinea Coast.

158. A. (Darea) Dregeanum, Kunze ; st. 2-4 in. l., grey, naked ; fr. 6-9 in. l., 2-3 in. br., flaccid and rooting at the point, with numerous flaccid pinnoe on each side, some of which have half the lower side cut away; the largest 1-1 $\frac{1}{4}$ in. 1. , cut down into simple or slightly-forked linear pinnl. $\frac{1}{4}-\frac{3}{8}$ in. 1.; texture herbaceous; rachis naked; sori solitary, submarginal.-Hk. Sp. 3. p. 214.

Hab. Natal.- Very doubtfully distinct from A. brachypteron, with which it is joined by Mettenius.

159. A. (Darea) obtusilobum, Hk. ; st. tufted, 2-4 in. l., naked, greenish ; fr. 6 in. l., 2 in. br., with 9-12 subdeltoid pinnoe on each side, of which only the inner third on the lower side is cut away, the largest 1 in. l., $\frac{3}{4}$ in. br. ; lowest pinnl. $\frac{3}{8}$ in. deep, flabellately cut into 3-5 linear lobes; texture herbaceous; rachis green, naked; veins one in each fork; sori submarginal.-Hk. Ic. t. 1000 .

Hab. Tanna and Aneiteum ; and a less-divided plant gathered by Dr. Seemann in Fiji is probably the same.-Closely allied to the two preceding.

160. A. (Darea) dichotomum, Hk. ; st. tufted, 1 in. l., firm, erect, greenish ; fr. 3-4 in. 1., 1-1 $\frac{1}{4}$ in. br., oblong, acute, tripinnate, with 8-12 pinnoe on each side, which are truncate on the lower side, cut down to a narrow compressed rachis, only the lower pinnl. again pinnatifid; ult. segm. $1 \frac{1}{2}-2$ lin. $1 ., \frac{1}{4}$ in. br.; texture herbaceous; main rachis compressed, greenish, naked; one vein to each segm.; sori solitary, linear, quite marginal.-Hk. Sp. 3. p.210. 2nd Cent. t. 39.

Hab. Borneo.

161. A. (Darea) bipinnatifidum, Brack.; st. tufted, 2-4 in. 1., naked, wiry, slender ; fr. 6-8 in. 1., 1-1 $\frac{1}{2}$ in. br., with 12-20 close-placed erecto-patent pinvice on each side, the largest $\frac{1}{2}-\frac{3}{4}$ in. $1 ., \frac{3}{8}$ in. br., cut down to the rachis into linear slightly-flattened pinnl., $\frac{1}{4}$ in. deep, the lowest again pinnatifid ; texture subcoriaceous; rachis firm, erect, naked; veins one in each segm.; sori small, solitary, marginal.-D. furcata, Brack. p. 170.

Hab. Fiji ; gathered by Brackenridge, Seemann, and Milne. 
162. A. (Darea) davallioides, Hk.; st. tufted, 3-4 in.1., firm, naked ; fr. 4-6 in. 1., 2-3 in. br., deltoid, quadripinnate, with 6-9 pinnoe on each side, the lowest much the largest, 2-3 in. l., 1-1 $\frac{1}{2}$ in. br., deltoid; pinnl. deltoid, with a broadly-winged rachis and lower segm. again pinnatifid, with curved divaricate lateral divisions, 1-1 $\frac{1}{2}$ lin. 1., $\frac{1}{2}$ lin. br. ; texture thick, coriaceous; colour bright-green ; rachis compressed; veins one to each division ; sori copious; quite lateral, oblong, often occupying the whole upper side of the ult. divisions.-Hk. Sp. 3. p. 212. 2nd Cent. F. t. 40. Humata dareoidea, Mett.

Hab. Japan, Tsus-Sima, Loo Choo, Hong-Kong, Formosa.-The species of all the group that comes nearest to Davallia.

163. A. (Darea) irregulare, Baker ; st. scattered, 2-4 in. l., naked, firm, erect, pale-green ; fr. 6-8 in. 1., 2-3 in. br., with numerous pinnoe on each side, the uppermost simple, $\frac{1}{4}-\frac{3}{8}$ in. l., linear-falcate, those next in order dichotomously forked, the lowest regularly pinnate, with a prolonged simple point and several distant pinnl. $\frac{1}{4}-\frac{3}{8}$ in. 1., $\frac{1}{2}$ lin. br.; texture subcoriaceous; rachis flaccid, naked, compressed; veins one to each pinnl. ; sori sometimes $\frac{1}{4}$ in. l., with very narrow involucres.

Hab. Sierra del Crystal, Guinea Coast, Mann, 1636.

164. A. (Darea) Richardi, Hk. fil. ; st. tufted, 3-6 in. 1., firm, erect, greenish, scaly throughout; fr. 5-6 in. l., 2 in. br., with 12 or more close-placed lanceolate erecto-patent pinnoe on each side, which are cut down to a winged rachis into numerous ovate-rhomboidal pinnt., which are again deeply pinnatifid with linear-mucronate segm. 1 lin. or less 1.; texture coriaceous; rachis firm, compressed ; one vein in each segm. ; sori oblong.-Hk. Sp. 3. p. 197. Ic. Pl.t. 977.

Hab. New Zealand.-This seems to be nearest some of the dwarf tripinnatifid forms of flaccidum.

\section{Fronds ample, 1-3 ft.l. Sp. 165-177.}

165. A. (Darea) flaccidum, Forst. ; st. tufted, 4-8 in. l., stout, greenish, naked ; fr. 1-3 ft. 1., 4-8 in. br., often pendent, with numerous close or distant lanceolate pinnoe, which are 4-8 in. l., $\frac{1}{2}-\frac{3}{4}$ in. br., sometimes rather rigid and recurved, sometimes quite flaccid and drooping like the main rachis, sometimes deeply pinnatifid but more often cut down to the thick rachis in oblique or subfalcate narrow linear lobes; texture thick, subcoriaceous; rachis naked, pale-green like the frond, compressed upwards; veins obscure, one in each lobe; sori in the divided form quite marginal.-Hk. Sp. 3. p. 205.

Hab. New Zealand, Australia, Van Diemen's Land ; and gathered lately also by Dr. Hillebrand in the Sandwich Islands, and Mr. Sanderson in Natal.-A very variable species.

166. A. (Darea) rutofolium, Kunze; st. tufted, 6-9 in. 1., compressed, greenish, naked; fr. 6-15 in. 1., 2-3 in. br., with 12-20 pinnoe on each side, the lowest subdeltoid, 2 in. or more l., cut down to the rachis into numerous erecto-patent distant pinnl. on each side, the lowest on the upper side again cut down into erecto-patent linear segm., the lowest on the under side suppressed; texture coriaceous; rachis compressed; colour pale-green ; sori small, marginal. -Hk. Sp. 3. p. 206. A. stans, Kze. A. prolongatum, Hk. Sp. 3. p. 205. 2nd Cent. t. 42 .

Hab. Cape Colony northward to Natal and Zambesi Land ; Himalayas, Ceylon, Japan, and Fiji.

167. A. (Darea) Borbonicum, Hk. ; st. tufted, 4-6 in. l., firm, erect, greyish ; fr. 6-15 in. 1., 3-4 in. br., with 12-20 distant erecto-patent pinnæe on each side, 
which are $1 \frac{1}{2}-2$ in. l., $\frac{1}{4}-\frac{3}{8}$ in. br., truncate at the base on the lower, side, regularly cut down throughout into distant, linear, curved pinnl. $\frac{1}{2}$ lin. br., the lowest on the upper side larger and again pinnatifid or palmate; texture coriaceous ; colour pale-green ; rachis thick, flaccid, compressed upwards; one vein and sorus to each segm., the latter marginal.-Hk. Sp. 3. p. 207.

Hab. Mauritius and Bourbon.-Very near the preceding.

168. A. (Darea) Belangeri, Kunze ; st. tufted, 4-8 in. l., firm, erect, greenish, naked; fr. 12-18 in. 1., 2-3 in. br., with numerous horizontal pinnoe on each side, 1-1 $\frac{1}{2}$ in. l., $\frac{3}{8}$ in. br., rounded at the point, truncate at the base on the lower side, regularly cut down throughout to a broadly-winged rachis into linear erecto-patent pinnl. $\frac{1}{2}$ lin. br., with their own breadth between them, the lowest usually once forked ; texture coriaceous ; colour pale-green ; rachis compressed; one vein and sorus to each segm., the latter marginal.-Hk. $S p .3 . p .209$. A. Veitchianum, Moore.

Hab. Malayan Peninsula, Java, Sumatra, Borneo.-A. Sampsoni, Hance, gathered by Mr. Sampson about 100 miles west of Canton, of which our only specimen has lanceolate fronds not more than 4 in. 1 ., under 1 in. br., and ovate-oblong pinnæ only cut down to the rachis at the base, is probably a reduced form. It has been suggested that this bears the same relation to tenerum that incequale does to lineatum, A. decorum, Kunze, being a connecting link.

169. A. (Darea) Thunbergii, Kunze; st. tufted, 3-4 in. l., firm, naked, greyish ; fr. 9-15 in. 1., 3.4 in. br., oblong-lanceolate, acuminate, with numerous pinnce on each side, the largest $2 \mathrm{in.}$ l., $1 \mathrm{in}$. br., bluntish at the point, truncate at the base on the lower side, regularly cut down throughout to a broadlywinged rachis into blunt pinnls. 1 line br., the lowest larger and often again pinnatifid; texture herbaceons; rachis compressed and flaccid upwards ; veins and sori one in each segm.-Hk. Sp. 3. p. 208.

Hab. Natal ; and a similar plant, with longer stems and narrower pinnæ and pinnules, was gathered by G. Mann at Fernando Po.- Habit of the two preceding, but texture different. Perhaps a Dareoid form of A. erectum.

170. A. (Darea) viviparum, Presl ; st. tufted, 6-9 in. 1., firm, erect, greenish, deciduously fibrillose ; fr. 1-2 ft. 1., 6-8 in. br., with numerous close-placed erecto-patent pinnoe on each side, which are $4-6$ in. $1 ., 1 \frac{1}{2}-2 \mathrm{in}$. br., cut down to a compressed rachis into numerous pinnatifid pinnl., the lower segm. of which are again forked; ult. divisions $\frac{1}{4}-\frac{3}{8}$ in. l., $\frac{1}{4}$ lin. br. ; texture herbaceous ; rachis firm, erect, often viviparous; one vein to each division; sori solitary, marginal. -Hk. Sp. Fil. 3. p. 215.

Hab. Mauritius and Bourbon.

171. A. (Darea) Novoe-Caledoniae, Hk. ; st. tufted, 6-12 in. l., firm, erect, naked ; fr. 9-12 in. 1., 6-9 in. br., subdeltoid, tripinnate; lower pinnee and pinnl. deltoid; segm. rigid, scarcely fiattened, $\frac{1}{2}$ in. or more 1., distantly placed and erecto-patent; texture coriaceous; rachis firm, erect; veins solitary in each segm. ; sori long, linear, marginal.-Hk. Sp. 3. p. 213. Ic. Pl.t. 911.

Hab. New Caledonia ; gathered by C. Moore, Vieillard, and Deplanche.

172. A. (Darea) dimorphum, Kunze; st. 6-12 in. 1., firm, erect, naked; fr. 2-3 ft.l., 12-15 in. br., ovate-deltoid, sterile and fertile ones different or combined; lower pinnoe ovate-deltoid, 6-8 in. l., 2 in. br.; sterile pinnl. ovate-rhomboidal, 1 in. or more 1., $\frac{1}{2}$ in. br., bluntly toothed and the base on the lower side obliquely truncate; fertile ones the same size, but cut down to the rachis into 
very narrow simple or forked linear pinnl.; texture herbaceous; rachis firm, erect; sori linear, solitary, marginal.-Hk. Sp. 3. p. 213. 2nd Cent. t. 37.

Hab. Norfolk Island.-Easily recognized by its dimorphous fronds.

173. A. (Darea) scandens, J. Sm.; st. scattered on a stout creeping rhizome, very short; fr. 1-2 ft. l., 6-12 in. br., with numerous horizontal pinnoe on each side, which are 4-6 in. 1., $1 \frac{1}{2}$ in. br., cut down to a distinctly winged rachis into numerous subdistant ovate-rhomboidal pinnl., which are cut down to the rachis throughout; lower segm. again pinnatifid; ult. divisions narrowly linear; texture thinly herbaceous; rachis firm, erect; one vein in each division; sori solitary, marginal.-Hk. Sp. 3. p. 216. 2nd Cent. t. 37.

Hab. New Guinea and the Philippines ; and a similar plant, with simply pinnate pinnæ and a stem about 1 in. l., from Fiji and Celebes.

174. A. (Darea) multifidum, Brack. ; st. stout, erect, grey, naked, slightly paleaceous, 12-18 in. l. ; fr. 2-3 ft. l., 12-18 in. br., subdeltoid, quadripinnatifid, with numerous pinnoe on each side, the lowest 6-9 in.1., 4 in. br.; pinnl. lanceolatedeltoid, truncate at the base on the lower side; segm. $\frac{1}{2}-\frac{3}{4}$ in. l., $\frac{1}{4}$ in. br., the lowest cut down nearly to the rachis below into close oblong-spathulate bluntly-toothed divisions, $\frac{1}{8}$ in. br.; textuve subcoriaceous ; rachis grey, firm, rather scaly; veins and sori one to each division, the latter very small, quite marginal.-Hk. Sp. 3. p. 212.

Hab. Tahiti, Society Isles, and Fiji.

175. A. (Darea) Poroellii, Baker ; st. naked, greyish, firm, erect; fr. $2-3 \mathrm{ft}$. 1., 12-18 in. br., subdeltoid, 5-pinnatifid, with numerous imbricated erecto-patent pinnoe on each side, the lowest 9-12 in l., 3-4 in. br.; pinnl. deltoid, 3 in.-l., $1 \frac{1}{2}$ in. br.; lower segm. deltoid, their lower divisions again pinnatifid; ult. divisions linear, $1 \frac{1}{2}-2$ lin. l., $\frac{1}{3}$ lin. br., all the divisions erecto-patent; texture herbaceous ; colour bright-green; rachis firm, compressed upwards; veins and sori solitary, the latter sinall (under 1 lin. l.), linear-oblong, submarginal.

Hab. Samoa, Rev. T. Powell.-This comes nearest to the preceding, but is considerably more divided.

176. A. (Darea) ferulaceum, Moore ; st. 6-12 in. l., firm, erect, naked, greyish ; fr. 1-2 ft. l., 9-12 in. br., ovate-deltoid, with several pinno decreasing gradually upwards, the lowest horizontal or deflexed, 6-9 in. 1., 3-5 in br.; pinnl. lanceolate-deltoid; segm. $\frac{3}{4}-1$ in. l., their divisions again pinnatifid; ult. lobes linear, blunt, 1 lin. l., $\frac{1}{4}$ lin. br. ; texture thinly herbaceous ; colour bright-green ; main rachis firm, naked; veins solitary; sori lateral, very small.- $H k . S p .3$. p. 216. 2nd Cent. t. 38 .

Hab. Andes of Ecuador and New Granada.

$\S \S \S$ Athyrium, Roth. Veins free, sori more or less curved, sometimes horseshoe-shaped. Sp. 177-199. Fig. 38. e.

\section{* Fronds deltoid. Sp. 177-180.}

177. A. (Athyr.) crenulatum, Fries ; st. 6-12 in. 1., scattered, firm, erect, naked, straw-coloured, clothed towards the base with large ovate dark-brown scales; fr. 9-15 in. each way, deltoid, tri- or quadripinnatifid, with 9-12 pinnoe

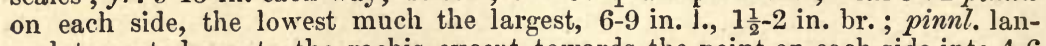
ceolate, cut down to the rachis except towards the point on each side into 4-6 blunt oblong segm. 2 lin. l., 1 lin. br., which are bluntly toothed; texture herbaceous; rachis straw-coloured; both surfaces hairy or nearly naked; sori 
2.6 to a segm., oblong, usually nearly straight, often double.-Hk. Sp. 3 . p. 226.

Hab. Scandinavia by way of Siberia to Japan.

178. A. (Athyr.) spinulosum, Baker; st. 6-12 in. l., scattered, firm, erect, naked, straw-coloured, more or less clothed throughout with lanceolate palebrown scales; fr. 9-12 in. each way, deltoid, tri- or quadripinnatifid, with 9-12 pinnoe on each side, the lowest much the largest, 6-9 in. $1 ., 2 \frac{1}{2}-3 \mathrm{in}$. br., ovatelanceolate; pinnl. lanceolate, cut down to the rachis on each side into 6-9 oblong-rhomboidal mucronate segm., 2 lin. l., 1 lin. br., which are sharply toothed; texture herbaceous; rachis firm, naked, or nearly so; sori $2-10$ to a segm., usually round and the invol. ovate, but occasionally oblong, and the invol. slightly curved.-Cystopteris spinulosa, Max. Fl. Amur. p. 340.

Hab. Amur-land, Maximowicz; Manchuria, Wilford, 1163 ; Korea, Wilford, 908.

179. A. (Athyr.) subtriangulare, Hk. MSS. ; st. 6-12 in. l., firm, erect, naked, clothed towards the base with lanceolate pale-brown scales; $f r .1 \mathrm{ft}$. each way, deltoid, quadripinnatifid, with 12-18 pinnoe on each side, the lowest much the largest, 6-9 in. l., 2 in. br., lanceolate; pinnl. lanceolate, cut down to the rachis on each side into 9-12 close elliptic-rhomboidal segm., 2 lin. l., 1 lin. br., which are inciso-serrated, sometimes halfway down; texture herbaceous; rachis firm, naked; sori 2-12 to a segm., roundish, but the lower invol. quite horseshoeshaped.-Athy. Hookerianum, Moore.

Hab. Sikkim, 10-12,000 ft. ; gathered by Dr. Hooker.-Pinnæ more numerous than in the preceding, the segments narrower, more abundantly but not so sharply toothed, the sori more copious, and the involucre different.

180. A. (Athyr.) medium, Hk. ; st. tufted, 4-6 in. 1., firm, erect, densely clothed throughout with crisped linear reddish-brown scales; fr. 6-9 in. l., 4-6 in. br., subdeltoid, tripinnate, with numerous spreading pinnoe on each side,

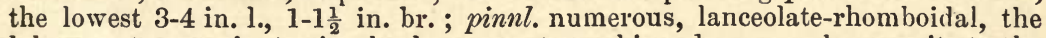
lobes ovate-acuminate, in the lower part reaching down nearly or quite to the rachis; texture herbaceous; rachis firm, erect, fibrillose; veins pinnate, conspicuous; sori copious, often 6-8 to a segm.; invol. roundish, reniform.-Hk. Sp. 3. p. 227. Ic. t. 43.

Hab. Tristan d'Acunha.-A well-marked species, which was placed by Carmichael in Aspidium.

\section{* Fronds lanceolate or ovate-lanceolate. Sp. 181-199.}

181. A. (Athyr.) cystopterioides, Hk.; st. 4-6 in. l., scattered, slender, pale,

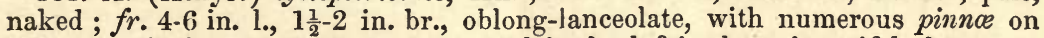
each side, the lower ones lanceolate, $1-1 \frac{1}{2}$ in. l., $\frac{1}{2}-\frac{3}{4}$ in. br., pinnatifid above, cut down to the rachis below into blunt ovate-rhomboidal pinnl., which are broadly lobed about halfway down to the midrib; texture herbaceous; both surfaces slightly hairy and glandular; sori 2-6 to a pinnl., placed near the base of the teeth; invol. hispid, lunulate.-Hk. Sp. 3. p. 220. Athyrium, Eaton.

Hab. Loo-Choo Islands. - A small plant with the habit of Cystopteris fragilis, and a slender wide-creeping rhizome.

182. A. (Athyr.) Hohenackerianum, Kunze ; st. tufted, 2-4 in. l., firm, erect, clothed throughout rather closely with linear-subulate scales; fr. 6-9 in. 1., $1 \frac{1}{2}-3$ in. br., ovate-lanceolate, with numerous lanceolate pinnoe on each side, which are cut down below nearly or quite to the rachis into ovate inciso-serrated pinnl.; texture herbaceous ; rachis naked or scaly below ; sori copious, oblong; invol. conspicuous, some distinctly curved.-Hk. Sp. 3.p. 220. 
Hab. Scinde, Peninsular India, Ceylon.-Habit of a small form of Filix-foemin, but with more sausage-like sori and a fibrillose stem.

183. A. (Athyr.) grammitoides, Hk.; st. subtufted, 3-4 in. l., firm, erect, copiously scaly; fr. 6-8 in. $1 ., 1 \frac{1}{2}-2$ in. br., lanceolate, with numerous lanceolate-falcate pinnoe on each side, which are $1-1 \frac{1}{2}$ in. $1 ., \frac{1}{4}-\frac{3}{8}$ in. br., the two sides unequal, the point bluntish, the edge irregularly inciso-crenate, the upper side distinctly auricled at the base ; texture herbaceous; rachis chaffy, winged upwards; veins pinnate; sori linear-oblong in two regular rows placed obliquely, the lower ones slightly curved, often diplazioid.- $H k$. Sp. 3. p. 228. Ic. t. 913 .

Hab. Peninsular India, Java, Philippines, Sandwich Islands.-The Indian plant is almost destitute of scales upon the stem and rachis.

184. A. (Athyr.) thelypteroides, Michx.; st. 1 ft. l., erect, polished, strawcoloured ; fr. 1-2 ft. l., 6-12 in. br., lanceolate, with numerous spreading pinnoe, the lower ones 4-6 in. l., 1 in. br., cut down to a broadly-winged rachis into numerous nearly entire elliptical spreading pinnl.; texture herbaceous; rachis sometimes slightly hairy; sori in close regular rows reaching nearly from the midrib to the edge, slightly curved, the lower ones often double.-Hk. $S p .3$. p. 229.

Hab. Canada, United States, Amur-land, Himalayas (ascending to 10,000 ft.), Penang. - Easily distinguished by its long sori in very regular rows.

185. A. (Athyr.) decurtatum, Link ; st. $1 \mathrm{ft}$. or more l., erect, straw-coloured above, deciduously scaly below ; fr. 2-3 ft. l., 9-12 in. br., with very numerous close-placed spreading pinnoe 4-6 in. l., 1 in. br., cut down nearly to the rachis throughout into blunt entire lobes with parallel sides, 2 lin. br.; texture herbaceous; both surfaces pubescent; veinlets simple, regularly pinnated ; sori oblong, falling short of both edge and midrib, the lower ones curved.- $H k$. Sp. 3 . p. 226.

Hab. Brazil, Lindberg, 620.-Very like the preceding in habit and cutting, but the sori much shorter.

186. A. (Athyr.) deparioides, Brack. ; st. 12-18 in. l., firm, erect, smooth, greyish ; fr. $3 \mathrm{ft}$. l., $1 \mathrm{ft}$. br., lanceolate, with numerous pinnoe on each side, the lower ones 6-8 in.l., 1 in. br., cut down nearly to the rachis throughout into rather distant oblong-obtuse pinnl., which are slightly inciso-crenate; texture subcoriaceous; rachis firm, naked, proliferous ; veins conspicuous, once pinnate in each pinnl., the veinlets simple, distant; sori oblong, one to each veinlet touching the edge, the lower ones very slightly curved.-Brack. p. 172.

Hab. Oahu ; and we have a single pinna of a plant from Sumatra, gathered by Teschemacher, with similar marginal sori, but with considerably broader pinnules not reaching more than two-thirds of the way down to the midrib.

187. A. (Athyr.) Skinneri, Baker ; st. 6-9 in. 1., erect, greyish, slightly scaly below ; fr. 9-15 in. 1., 6-9 in. br., ovate-lanceolate, with numerous pinnoe on each

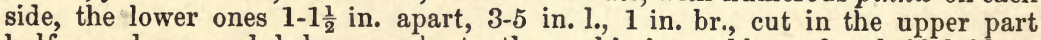
halfway down and below nearly to the rachis into oblong-rhomboidal blunt inciso-crenate pinnl., often $\frac{1}{4}$ in. br. ; texture herbaceous ; rachis naked, slender ; veinlets of the pinnl. sometimes forked; sori small, linear-oblong, 2 to 12 to a pinnl.-Athyrium, Moore.

Hab. Guatemala.-Perhaps this should be joined with the next, but the pinnæ and pinnules are much less deeply cut, and the latter so broad that they are slightly imbricated. 
188. A. (Athyr.) achilleoefolium, Liebm.; st. 6-9 in. I., erect, grey, scaly below ; fr. 12-18 in. 1., 6-9 in. br., ovate-lanceolate, with numerous pinnce on each side, the lower ones 1-1 $\frac{1}{2}$ in. apart, lanceolate-acuminate, 4-6 in. l., 1 in. br., cut throughout to a rachis $\frac{1}{8} \mathrm{in}$. br., into regular erecto-patent, oblong, bluntlytoothed pinnl. $\frac{1}{2}$ in. $1 ., \frac{1}{8}$ in. br.; texture herbaceous ; rachis naked, colour darkgreen ; veinlets of the pinnl. simple; sori oblong, often 1 to each lobe of the pinnules.-Hk. Sp. 3. p. 230.

Hab. Mexico. - Remarkable for the regularity of the broad wing of the midrib of its pinnæ.

189. A. (Athyr.) macrocarpum, Blume ; st. 6-9 in. l., firm, erect, strawcoloured, scaly below ; $f r$. 12-24 in. l., 6-9 in. br., ovate-lanceolate, with numerous pinnoe on each side, the lowest 3-6 in. 1., 1-1 $\frac{1}{2}$ in. br., lanceolate, cut down to the rachis into numerous oblong-rhomboidal pinnl., which are incisocrenate or pinnatifid; texture herbaceous; rachis naked; lateral veins of segm. forked ; sori copious, large ; invol. oblong-reniform, $\frac{3}{4-1}$ lin. br.-Hk. Sp. 3. p. 222. A. foliolosum, Wall. (in part). A. decipiens, fallax, and puncticaule, Mett.

Hab. Himalayas (up to 6,000 ft.), Ceylon, Java, and gathered lately by Dr. Maingay in the province of Shantung, N. China ; and the Japanese A. Goringianum, Mett., is probably the same plant with rather sharper teeth.-This has a general habit not unlike that of Nephrodium spinulosum, with the involucre so nearly reniform that Mr. Moore places it in Lastrea.

190. A. (Athyr.) nigripes, Blume ; st. tufted, 6-12 in. 1., straw-coloured, erect, scaly below ; fr. 12-24 in. l., 8-12 in. br., ovate-lanceolate, with numerous pinnoe on each side, the lowest lanceolate, 6-9 in. 1., $1 \frac{1}{2}-2$ in. br., cut down to the rachis into numerous elliptico-rhomboidal pinnl., which are broadly lobed about halfway down and the lobes slightly toothed; texture herbaceous; rachis naked, straw-coloured; lateral veins of the segm. forked; sori linear-oblong, often curved, 1-1 $\frac{1}{2}$ lin. 1 ., principally in two parallel rows close to the midrib of the pinnl.-A. gymnogrammoides, Klotzsch. Hk. Sp. 3. p. 227. A. costale, Blume, non Swartz.

Hab. Himalayas (ascending to $10,000 \mathrm{ft}$.), Neilgherries, Ceylon, Java, and Japan.Very like A. macrocarpum in general hatit, but quite different in fruit. A. solenopteris, Mett., is a form of this, with the pinnules more sharply toothed, and cut down in the lower part nearly or quite to the rachis ; and there is another plant (var. dissectum, Moore) with much smaller sori, and the habit of the more finely divided forms of Filixfomina.

191. A. (Athyr.) niponicum, Mett.; rhizome creeping, the scales lanceolate, reddish ; st. 6-12 in. l., glossy, stramineous ; fr. $1 \mathrm{ft}$. or more l., 6-8 in. br. ; pinnoe lanceolate, distinctly stalked, cut down nearly or quite to the rachis below into oblong-lanceolate unequal-sided pinnl., which vary from subentire to deeply pinnatifid; texture herbaceous; rachis and both sides naked, often tinged with purple; sori copious, the lower ones often quite horseshoe-shaped.-Mett. Fil. Ind. 2. p. 240.

Hab. Japan and China.

192. A. (Athyr.) Filix-foemina, Bernh.; st. tufted, 6-12 in. l., firm, erect, straw-coloured or brownish, scaly below ; fr. 1-3 ft. l., 6-12 in. br., oblong-lanceolate, with numerous pinno, the lower ones spreading, lanceolate, 3-6 in. J., 1-1 $\frac{1}{2}$ in. br., cut down to a compressed winged rachis into lanceolate or ovaterhomboidal pinnl., which are again deeply inciso-pinnatifid ; texture thinly herbaceous; rachis naked, slender; veins pinnate in the lobes; sori linear-oblong, the lower ones often curved.-Hk. Sp. 3. p. 217. Brit. F.t. 35 . 
Hab. Arctic Europe to Madeira, the Canaries, Algiers, Crete, Himalayas(10-12,000 ft.), Kamschatka, and Japan : Africa-Abyssinia, Natal, Cameroon Mountains (7,000 ft.): America-Sitka and Labrador to Cuba, Caraccas, and Venezuela. Of the common European forms A. Filix-fœemina is a large plant with narrow lanceolate deeply pinnatifid pinnules ; A. vhaticum, Roth, is smaller, with the pinnules broader, and not so deeply cut; A. molle, Roth, thinner in texture, with oblong rhomboidal pinnules $\frac{1}{4}$ in. broad; and A. latifolium, Bab. (non Presl), a form with the pinnules so broad that they are considerably imbricated. The N. American A. Martensi, Kunze, and A. Galeottii, Fée, do not seem safely separable. The E. Indian A. pectinatum, Wall., is very thin in texture, and has deeply-cut pinnules, with narrow spreading segments. A. tenuifrons, Wall., is like $A$. molle, but with the midrib of the pinnæ and pinnules beset with firm yellow spines or strigillæ; as is also the case with various Indian, Ceylonese, and Javan forms, with narrower, more slender, and more straggling pinnæ and pinnules,-as A. gracile, Don ; A. stramineum, J. Sm. ; A. tenellum, Wall. ; A. proliferum, Moore ; and the S. American A. Dombeyi, Desv. The Abyssinian A. Schimperi, Moug. and Fée, has a creeping rhizome, firmer texture, and a bright stramineous rachis. The Natal $A$. laxum, Pappe and Rawson, is like A. rhoticum, but firmer in texture. Plants from Vancouver's Island and the Rocky Mountains have round sori, with slightly-developed ovate involucres ; and a plant found by Mr. Stansfield in Yorkshire, very delicate in texture and bright-green in colour, with pinnules quite cut down to the rachis into linear-lanceolate segments, which are again deeply incised, produces involucres only very rarely, and is the Phegopteris plumosa of J. Smith (B. and F. Ferns, p. 269).

193. A. (Athyr.) oxyphyllum, Hk. ; st. firm, erect, 6-12 in. 1., straw-coloured, clothed at the base with large lanceolate-acuminate reddish-brown scales; $f r$. 1-2 ft. l., 6-12 in. br., lanceolate, with several distant pinnoe on each side, which are 4-8 in. l., 1-2 in. br. ; pinnl. lanceolate, sometimes auricled on the upper side, in the larger forms again pinnatifid, teeth mucronate ; texture subcoriaceous ; rachis firm, naked, straw-coloured; veins regularly pinnated; sori in two rows on the pinnæ or pinnl. midway between the midrib and edge; invol. oblongreniform.-Hk. Sp. 3. p. 221. A. drepanopteron, $A$. Br. Lastrea eburnea, J. Sm.

Hab. Himalayas (ascending to 7,000 ft.), Java, and Japan.-The midrib of the pinnæ on the upper side is often spinulose. This is as variable as A. Filix-formina in size and cutting, but the texture is rigid, and the involucre much more like that of Lastrea.

194. A. (Athyr.) aspidioides, Schlecht. ; st. tufted, 6-12 in. 1., stramineous, slender, naked, except at the base ; fr. 1-2 ft. l., 8-12 in. br., ovate-deltoid, tripinnatifid ; lower pinnoe 6-8 in. 1., lanceolate-deltoid ; pinnl. lanceolate, cut down below nearly to the rachis into inciso-pinnatifid ovate segm. 2 lin. br.; texture herbaceous; colour dark-green; both surfaces naked; rachis stramineous, slender ; sori copious, oblong, the lower ones curved.- $\beta, A$. scandicinum, Presl ; fr. larger and more finely cut; segm. deeply pinnatifid, with narrow linear divisions, the whole breadth of which the sori sometimes occupy.-A. multisectum, Brack. Hk.Sp. 3. p. 223.

Hab. Ecuador, Sandwich Isles, Neilgberries, Madagascar, Fernando Po, Cape Colony. -The extremes differ widely, but some of Dr. Spruce's American examples quite correspond with the Cape and E. Indian plant.

195. A. (Athyr.) brevisorum, Wall. ; st. 12-18 in. 1., erect, slender, naked, greyish ; fr. 2-3 ft. 1., 9-18 in. br.; lower pinnoe $1 \mathrm{ft}$. or more 1.; pinnl. lan-

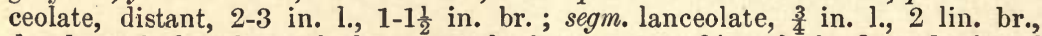
deeply and sharply toothed ; texture herbaceous; rachis naked; lateral veins of the segments forked; sori small, 6-12 to a segm., in two rows near the midrib, the lower ones curved, often double.-Hk. Sp. 3. p. 229.

Hab. Ava and Mishmee, and gathered lately in the Sandwich Islands by Dr. Hillebrand.-Like A. achillecefolium in cutting, but much larger and more compound.

196. A. (Athyr.) conchatum, Moore; st. 2 ft. or more l., stout, erect ; fr. 3-4 
ft. 1., 12-18 in. br.; lower pinno lanceolate, 9-12 in. 1., 2-3 in. br., with numerous lanceolate pinnl. on each side, which are cut down to a winged rachis into linear-oblong spreading inciso-crenate segm. $\frac{3}{4}-1$ in. l., $\frac{1}{4}$ in. br. ; texture herbaceous ; veins one to each tooth; sori short, oblong, in two oblique rows near the midrib; invol. brown, subcoriaceous, persistent.-Hk. Sp. 3. p. 231.

Hab. West Indies.-We include here four species of Fée-his Athyr. conchatum and Hypochlamys pectinata, Tussaci, and squamulosa. His genus Hypochlamys is characterized by having the suri on the lower side of the vein and the involucre opening towards it.

197. A. (Athyr.) fimbriatum, Hk.; st. $1 \mathrm{ft}$. or more 1., firm, erect, clothed below with dark-brown scales ; fr. 2-4 ft. 1., 12-18 in. br.; lower pinnoe 6-12 in. 1., 2-3 in. br.; pinnl. lanceolate; segm. subdeltoid, distinctly stalked, deeply and sharply inciso-pinnatifid, with mucronate teeth; texture herbaceous but firm ; rachis strong, naked; sori close, copious, broadly oblong ; invol. oblong or subreniform, convex.-Hk. Sp. 3. p. 234.

Hab. Himalayas, ascending to 8-9,000 ft.-Distinguished by its large compound habit, firm texture, and subreniform involucre.

198. A. (Athyr.) umbrosum, J. Sm.; st. $1 \mathrm{ft}$. or more 1., strong, erect, brownish, clothed below with dark scales; fr. 3-5 ft. 1., 12-18 in. br.; pinnoe ovate-lanceolate, 12-18 in. l., 3-6 in. br.; pinnl. lanceolate, close, cut down to the rachis into numerous unequal-sided elliptico-rhomboidal lobes, $\frac{3}{8}-\frac{1}{2}$ in. 1 ., 2 lin. br., which are deeply inciso-crenate; texture herbaceous ; colour brightgreen; veins pinnate; sori close, copious, oblong; invol. large, tumid, membranous.-Allantodia, R. Br. A. australe, Brack. Hk. Sp. 3. p. 232.

Hab. Madeira, Canaries, Azores, Guinea Coast, Himalayas (ascending to 6-8,000 ft.), to Ceylon, Java, Australia, Tasmania, and New Zealand.-I cannot point out any cbaracter to distinguish the Australian from the Madeiran plant. The Javan A. muricatum, Mett., has a muricated stem. This differs from the species retained in Allantodia by the involucre bursting not in the middle, but along the edge, as in the other species of Asplenium.

199. A. (Athyr.) woodwardioides, Baker; st. firm, erect, naked, dark chesnut-brown ; fr. 2-3 ft. l., 1 ft. or more br. ; lower pinnoe 6-9 in. 1., 3 in. br., pinnl. lanceolate, slightly stalked, $1 \frac{1}{2}$ in. l., $\frac{1}{2}$ in. br., cut down two-thirds of the way to the rachis into linear-oblong subfalcate finely-toothed lobes; texture herbaceous; rachis and both sides naked; veins pinnate in the lobes, with 4-5 veinlets on a side, the upper ones forked; sori oblong, confined to the lower lobes close to the midrib and not reaching more than halfway to the edge.Brachysorus, Presl. Allantodia sylvatica, Blume. Athyr. basilare, Fée. Dipl. brevisorum, J. Sm.

Hab. Philippines, Cuming, 153 ; Java, Blume.-Resembles in habit A. polypodioides.

§§§§ Diplazium, Swartz. Veins free, the sori and involucres extending to both sides of some of them. Sp. 200-263. Fig. 38. f.

\section{* Frond simple, entire or very nearly so. Sp. 200-202.}

200. A. (Dipl.) lanceum, Thunb. ; st. scattered, 4-6 in. l., slightly fibrillose ; fr. 6-9 in. l., $\frac{3}{4}-1$ in. br., attenuated gradually upwards and downwards, the edge entire or slightly undulated ; texture coriaceous ; veins pinnated, all reaching the edge ; sori linear, irregular, reaching nearly to the edge, but not to the midrib.-Hk. Sp. 3. p. 235. A. subsinuatum, Hk. \& Gr. Ic. t. 27. Triblemma, J. Smith.

Hab. Himalayas, Ceylon, China, and Japan. 
201. A. (Dipl.) subserratum, Blume ; st. scattered, 1-2 in. l., firm, erect ; fr. 12-18 in. $1 ., 1 \frac{1}{2}$ in. br., narrowed gradually towards each end, sometimes rounded at the base, the edge towards the point bluntly crenated; texture thinly herbaceous, satiny ; veins pinnated ; sori linear, reaching the midrib, but not the edge.- $H k$. $S p .3$. p. 236. $t$. 164. B.

\section{Hab. Java and Penang.}

202. A. (Dipl.) plantagineum, L. ; st. tufted, firm, erect, 6-9 in. 1. ; fr. 6-9 in. 1., 2-3 in. br., the point acuminate, the base rounded, the edge slightly undulatodentate upwards, sometimes lobed towards the base ; texture coriaceous ; veins pinnated ; sori slender, linear, sometimes nearly touching both edge and midrib. -Hk. Sp. 3. p. 237.

Hab. Mexico and W. Indies southward to Brazil.

\section{* Fronds linear-lanceolate, cut down to the rachis at the base. Sp. 203.}

203. A. (Dipl.) zeylanicum, Hk. ; st. scattered, 4-8 in. 1., firm, erect, scaly throughout ; fr. 6-12 in. l., 1-2 in. br., the point acuminated, the apex slightly lobed, the lower two-thirds more deeply so, and the base quite down to the rachis; lobes blunt, $\frac{1}{4}-\frac{1}{2}$ in. across ; texture herbaceous ; veins pinnate ; sori linear, 2-3 lin. 1.-Hk. Sp. 3. p. 237. 2nd Cent. t. 16.

Hab. Ceylon, Gardner, Thwaites.

\section{*** Fronds with the lower half or three-quarters pinnate. Sp. 204-235.}

\section{+ Pinnoe entire, or very slightly lobed. Sp. 204-217.}

204. A. (Dipl.) humile, Baker ; st. 6-8 in. l., firm, erect, dark-brown, and rather scaly at the base ; fr. 6-9 in. l., 4-5 in. br., ovate-deltoid, with numerous closeplaced pinnoe on each side, which are 2-3 in. l., $\frac{3}{8}$ in. br., the point much acuminate, the edge slightly inciso-serrated, the two sides rather unequal, the upper one slightly auricled, and both subcuneate at the base ; rachis naked, firm ; texture subcoriaceous ; veins fine, close, $4-5$ in a group ; sori beginning at the midrib, but not reaching the edge.-D. humile, Bojer.

Hab. Mauritius.-In habit not unlike A. cultrifolium, but different in texture and venation.

205. A. (Dipl.) pallidum, Blume ; st. 6-12 in. l., firm, erect, naked ; fr.1-2 ft. l., 6-12 in. br., with numerous horizontal pinnce on each side, the lower ones stalked, 1-1 $\frac{1}{2}$ in. apart, 3-6 in. l., $\frac{1}{2}-\frac{3}{4}$ in. br., linear-lanceolate, the apex acuminate, the base rounded, especially on the upper side, the edge often sharply toothed; texture subcoriaceous ; veins once or twice forked; sori in regular lines from the midrib very nearly to the edge.-Hk. $S p$. 3. $p .238$.

Hab. Philippines, and Malayan Peninsula and Isles.-A plant gathered by Cuming, herbaceous in texture, with very broad involucres, is perhaps distinct.

206. A. (Dipl.) porrectum, Wall. ; st. 1 ft. l., firm, erect, brownish ; fr. 9-18 in. l., 6-9 in. br., subdeltoid, with numerous horizontal pinnce on each side, the lower ones stalked, 3-4 in. l., $\frac{3}{4}$ in. br., the point rather blunt, the upper ones subentire, except that the base on both sides is distinctly auricled, the edge in the lower ones bluntly lobed, sometimes one-third to halfway down, the base narrowed suddenly ; texture subcoriaceous ; rachis naked; lateral veins simple or once forked ; sori in regular parallel rows extending from the midrib to the edge.- $H k$. Sp. 3. $p .250$.

Hab. Malayan Peninsula and Isles-This comes very near to the last in texture, and is probably $A$. crenato-serratum, Blume. 
207. A. (Dipl.) cultratum, Mett. ; st. tufted, 4-6 in. 1., grey, naked ; fr. 6-9 in. 1., 3-4 in. br., the apex pinnatifid, the lower two-thirds pinnate, with 3-5 pinnoe on each side, the lower ones distinctly stalked, 2 in. $1 ., \frac{3}{4}$ in. br., the point acute, rather falcate, the edge nearly entire, both sides narrowed suddenly, and the upper one auricled at the base ; texture subcoriaceous ; veins twice forked ; sori linear, slender, reaching the edge but not the midrib.-Hk. Sp. 3. p. 247.

Hab. Luzon, Cuming, 199.

208. A. (Dipl.) pinnatifido-pinnatum, Hk.; st. 6-12 in. l., firm, erect, naked ; fr. 9-12 in. 1., 6-9 in. br., with a deltoid apex deeply lobed below, and 3-4 pinnoe on each side, which are 3-4 in. 1., 1 in. br., the point acute, the edge sharply but not deeply toothed, the base cuneate on both sides ; texture coriaceous ; veins obscure, copiously pinnated ; sori irregular, beginning at the midrib, but falling far short of the edge.- $H k$. Sp. 3. p. 238.

Hab. Mishmee, Griffith.-In texture and dulness of colour this resembles the last species and A. Brackenridgii.

209. A. (Dipl.) Seemannii, Baker ; st. 6-12 in. l., firm, erect, dark-brown, naked; fr. $9-15$ in. 1., 4 in. br., lanceolate, with 12-20 pinnoe on each side, the lower ones horizontal, subsessile, 2 in. $1 ., \frac{1}{2}-\frac{5}{8}$ in. br., the point acute, the edge slightly lobed below, the base slightly cordate on both sides, the upper side auricled ; texture herbaceous ; veins dark-green, 2-3 to a group ; sori reaching from the midrib quite to the edge. Diplazium, Moore, Ind. Fil.p. 337.

Hab. Darien, Seemann. - This has the texture and pellucid venation of A. grandifolium, but the whole plant and pinıæ are much smaller, with veins only twice forked, and sori running up on the unbranched fork to the edge.

210. A. (Dipl.) bantamense, Baker ; st. 6-12 in. l., firm, erect, nearly naked ; fr. 9-18 in. l., with a large terminal pinna and 1 to 4 pairs of lateral ones, which are 6-8 in. $1 ., 1-1 \frac{1}{2}$ in. br., both ends narrowed, the edge very nearly entire ; texture coriaceous ; veins $3-5$ to a group ; sori slender, irregular, nearly touching both edge and midrib.-Diplazium, $B l$. A. fraxinifolium, Wall., Hk. Sp. 3. p. 240. 2nd Cent. t. 19.- $\beta, A$. alternifolium, Mett. ; pinnoe broader, rounded at the base; lower veins not reaching the edge.-Hk. Sp. 3. p. 239.

Hab. Himalayas, Hong-Kong, Malaccas, Borneo, Aneiteum.-Probably a free-veined form of $A$. lineolatum.

211. A. (Dipl.) Lechleri, Mett. ; st. 2-3 ft. 1., stout, erect, slightly scaly towards the base ; fr. $3 \mathrm{ft}$. l., with numerous pinnoe $1 \mathrm{ft}$. or more 1., $2 \frac{1}{2}-3 \mathrm{in}$. br., the point acuminate, the edge slightly toothed towards the point, the base rounded equally on both sides ; texture very coriaceous; rachis strong, erect ; veins simple, close, parallel ; sori beginning at the midrib, but falling short of the edge.- $H k$. $S p .3$. p. 244 (in part).

Hab. Peru, Lechler, 2269 ; Rio Negro, Spruce, 3832 ; Essequibo, Appun, 186.

212. A. (Dipl.) Callipteris, Baker ; st. 1 ft. or more 1., strong, erect, brownish ;

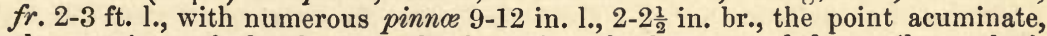
the margin toothed only towards the point, the base rounded equally on both sides, the lower ones stalked ; texture coriaceous ; colour bright-green ; veins 5-6 to a group ; sori beginning at the midrib, and reaching nearly to the edge.-Diplazium, Fée, Gen. Fìl. 214.

Hab. Cuba, Linden; Guadeloupe, L'Herminier; Tarapota, Peru, Spruce, 4760.-This rivals Lechleri in size and texture, differing totally in venation.

213. A. (Dipl.) grandifolium, Sw.; st. 1 ft. or more 1., firm, erect, naked or 
scaly below, ebeneous ; fr. 2-3 ft. 1., 9-12 in. br., the point pinnatifid, with 12-20 pinnoe on each side, the lower ones 2 in. or more apart, distinctly stalked, 4-6 in. 1., 1-1 $\frac{1}{2}$ in. br., the point acuminate, the edge slightly toothed, and sometimes broadly lobed below, the base equally rounded on both sides; texture thinly herbaceous ; colour deep-green ; rachis firm, erect, naked ; veins pinnated, pellucid, about 5 at the edge to a group; sori irregular, falling slightly short of both midrib and eảge.-Hk. Sp. 3. p. 241.

Hab. Cuba to Ecuador and Brazil, and we cannot distinguish a plant from the Ladrones gathered by Capt. Carnichael. - The sori are sometimes scarcely at all double, and then this comes near A. oligophyllum.

214. A. (Dipl.) flavescens, Mett. ; st. 1 ft. or more 1., firm, erect, brownish, nearly naked ; $f r .2-3 \mathrm{ft}$. 1., 9-18 in. br., with a large terminal and 10-15 lateral pinno, the lower ones sessile or slightly stalked, $4-8$ in. l., $1 \frac{1}{2}-2$ in. br., the point acuminate, the edge subentire or slightly toothed, the base narrowed or rounded equally on both sides; texture papyraceous or subcoriaceous; colour bright-green ; rachis firm, erect, naked ; veinlets dark-green, 3-4 in a group ; sori falling slightly short of both edge and margin.-A. juglandifolium, Hk. Sp. 3 . p. 242. Fil. Ex. t. 242 (not Lam.).

Hab. Cuba southward to Peru.-A larger and usually more coriaceous plant than the last, with a sub-arborescent caudex. A. Roemerianum, Kze., and A. crassidens, Fée, do not seem clearly separable. A. nicotiancefolium, Mett., differs by having the rachis and veins beneath coated with short ferruginous down.

215. A. (Dipl.) rhoifolivm, Mett. ; st. firm, erect, $1 \mathrm{ft}$. l., naked ; fr. $2-3 \mathrm{ft} .1$, 12-15 in. br., with a pinnatifid apex and 10-20 pinnoe on each side, the lowest on stalks $\frac{1}{8}$ in. l., the pinna 6-8 in. l., $\frac{3}{4}-1$ in. br., the apex acuminate, the edge subentire, the base on both sides rounded; texture subcoriaceous; rachis and both sides naked ; veins 5-6 in a cluster, the sori reaching nearly to the edge; invol. narrow, thin.-Mett. Aspl. p. 178.

Hab. New Granada.-A. Triance, Mett. Fil. N. G. p. 233, is said to differ from this by its opposite pinnæ with a cordate base and tonthed involucre. This has the texture of A. celtidifolium, but the pinnæ are more numerous and narrower, with the fruit prolonged almost to the edge.

216. A. (Dipl.) celtidifolium, Kunze ; st. strong, erect, $1 \mathrm{ft}$. or more l., brownish, paleaceous below ; $f r$. 2-4 ft. l., 9-18 in. br., with a pinnatifid apex and numerous pinnoe on each side, the lower ones distinctly stalked, $6-9$ in. $1 ., 1 \frac{1}{2}-2$ in. br., the point acuminate, the edge subentire or slightly toothed, sometimes with short blunt lobes $\frac{1}{8}$ in. deep, the base rounded or cordate on both sides ; texture subcoriaceous; rachis firm, often slightly fibrillose; veins pinnated, the same colour as the frond, 4-6 in a group; sori beginning at the midrib, but falling short of the edge.-Hk. Sp. 3. p. 240 .

Hab. Cuba and Columbia to Ecuador and Brazil.-D. crenulans, Fée, from Guadeloupe, is probably a form. Our specimen has coriaceous pinnæ bluntly lobed throughout to a depth of $\frac{1}{8}$ in., and 8-10 veins in a group. The Javan and Philippine A. Lobbianum (Hk. Sp. 3. p. 244 ; 2nd Cent. t. 17) agrees with this very nearly; and a specimen from Mettenius of $A$. neglectum, Karst., differs only by the pinnæ being subcuneate at the base.

217. A. (Dipl.) sylvaticum, Presl ; caud. decumbent ; st. 1 ft. l., firm, erect, brownish, naked, scaly at the base; fr. 1-2 ft. l., 4-8 in. br., ovate-lanceolate, with numerous spreading pinnoe, the largest $3-4$ in. l., $\frac{1}{2}-\frac{3}{4}$ in. br., the point acuminated, the edge broadly lobed to a depth of $\frac{1}{2}-1$ lin., and the base narrowed suddenly on both sides; texture thin, herbaceous; rachis firm, erect, naked; veins fine, pinnated in the lobes, $5-7$ to a group ; sori in long slender lines reaching nearly to the edge. $-H k$. Sp. 3. p. 248. (in part) Beddome, $t .161$. 
Hab. Mauritius, Fernando Po, Neilgherries, Ceylon, Malayan Peninsula, Java, Borneo, Samoa.-Of forms included here differing slightly from the type, the Malayau $A$. Prescottianum, Wall, has the pinnæ rather more deeply lobed towards the base in the lower part of the frond ; the Ceylonese A. elatum, Mett. (C. P. 1349), and a similar plant from the Sandwich Islands and Borneo, have them lobed throughout to a depth of $\frac{1}{4}$ in., the lobes subangular and toothed ; D. proliferum, Brack., from Tahiti, is said to have oblonglanceolate bluntly-serrated pinnæ, auricled on the upper and truncate on the lower side at the base; and we cannot separate clearly the American A. Ottonis and mutilum.

** Pinnoe more deeply lobed, generally from half to two-thirds of the way down to the rachis in the lower part. Sp. 218-235.

218. A. (Dipl.) Wichurce, Mett. ; rhizome firm, wide-creeping ; st. $\frac{1}{4-\frac{1}{2}}$ in. apart, 6-12 in. l., stramineous, slightly scaly at the base ; fr. 1 ft. or more 1. , 6-8 in. br., with numerous pinnoe on each side, the lower ones stalked, 3-4 in. l., $\frac{1}{2}-\frac{3}{4}$ in. br., the point acuminate, the edge toothed, sometimes lobed, auricled near the base on the upper side, obliquely truncate on the lower side ; texture herbaceous; veins pinnate in the lobes; sori not reaching the edge.-Mett. Fil. Ind.2. p. 237.

Hab. Japan.-Very near the next in size and cutting, but the rhizome decumbent and elongated.

219. A. (Dipl.) arboreum, Willd.; st. tufted, 6-9 in. 1., firm, erect, greyish, scaly below ; fr. 12-18 in. 1., 6-8 in. br., with numerous pinnoe on each side, the lower ones stalked, 3-4 in. l., $\frac{1}{2}-\frac{3}{4}$ in. br., the point acute or acuminate, the edge bluntly but not deeply lobed, except at the base on the upper side, where there is either a distinct auricle or a lobe, which sometimes reaches down to the rachis, the lower side narrower than the upper, and very obliquely truncate at the base; texture herbaceous; veins pinnate in the lobes; sori falling considerably short of the edge.-Hk. Sp. 3. p. 246. D. auriculatum, Kaulf.

Hab. West Indies and Venezuela.-Willdenow named this under a wrong impression as to the habit, which is not arboreous. It comes very near the next, but is less deeply lobed and more distinctly auriculate.

220. A. (Dipl.) Shepherdi, Spreng. ; st. tufted, 1 ft. 1., firm, erect, greenish, scaly below ; fr. 12-18 in. l., 6-9 in. br., with numerous pirnoe on each side, the lower ones stalked, 4-6 in. $1 ., 1-1 \frac{1}{2}$ in. br., the point acuminate, the edge lobed above, the lobes at the base sometimes reaching down to the rachis, $\frac{1}{4}$ in. br., and somewhat toothed ; texture herbaceous ; colour bright-green ; rachis rather slender, greenish, naked ; veins pinnate in the lubes ; sori long, linear, not reaching the edge.-A. striatum, Linn. Herb., Hk. Sp. 3. p. 245.- $\beta$, A. inoequilaterum, Mett.; texture firm, colour duller; pinnce much acuminated; the lobes deeper, more uniform and falcate, the two sides unequal, the lower one unequally truncate at the base. A. Schiedei, Mett. $-\gamma, A$. caracasanum, Willd.; habit slender ; texture herbaceous ; lobes deep, narrow, bluntly toothed ; sori in rows distant from the midrib, touching the edge. D. chlororachis, Kze.

Hab. Cuba and Mexico to Peru and S. Brazil.-The application of the name striatum, founded on two vague figures of Plumier, is so various, that it seems best to discontinue it. D. coarctatum, Link, from Brazil, differs only from our typical plant by its less deeply lobed pinnæ, the upper ones being subentire, with some of the sori reaching from the midrib nearly to the edge.

221. A. (Dipl.) semihastatum, Kze. ; st. 6-9 in. l., slender, naked, greenish ; fr. 6-9 in. l., 3-4 in. br., the apex pinnatifid, only the lower part pinnate ; most of the pinnoe simple, oblong, and auricled, the lowest stalked, and 1 in. below the next, 2 in. 1., 1 in. br., the point blunt, the edge toothed and cut down nearly or quite to the rachis into spathulate pinnl. ; texture herbaceous ; rachis slender, 
naked ; sori reaching from the midrib nearly to the edge.-A. cubense, $H K$. Sp. 3 . p. 253.t. 207.

Hab. Cuba, Wright, 1032-3.-This comes nearest A. arboreum, but is smaller and more delicate, with the lowest pinnules subdeltoid, and often reaching quite down to the rachis below on both sides.

222. A. (Dipl.) longifolium, Don ; st. 6-9 in. 1., slender, erect, scaly below ; fr. 12-18 in. 1., 4-6 in. br., the apex pinnatifid, below this 12-18 pairs of falcate pinno, the lower ones stalked, $2-3$ in. $1 ., \frac{3}{4}$ in. br., the point acuminate, the edge lobed, and the lobes sharply and finely serrated, the two sides unequal, the upper distinctly auricled, and the lower obliquely truncate at the base; texture herbaceous ; veins fine, 6 or more in a group; sori falling considerably short of the edge.-A. lobulosum, Wall., Hk. Sp. 3.p. 252.

Hab. Himalayas.

223. A. (Dipl.) Brackenridgii, Baker ; st. 6-9 in. l., firm, greyish, naked ; fr. 12-18 in. 1., 6-9 in. br., the apex pinnatifid, below this 6-9 pinnoe on each side, the lower ones 1-2 in. apart, and distinctly stalked, 4-5 in. l., nearly 1 in. br., the point acuminate, sharply serrated, the edge cut down one-third of the way to the rachis into blunt incised lobes $\frac{x}{4}$ in. br. ; texture subcoriaceous ; rachis firm, grey, naked; veins pinnate in the lobes; sori in long lines reaching to the edge.-D. bulbiferum, Brack.t. 18. N. extensum, J. Sm. (in part).

Hab. Philippines, Cuming, 333, 388 ; Fiji, Seemann, 825, Milne, 69, 306.-This differs from sylvaticum by its broader and distinctly stalked pinna of firm texture, which are often proliferous from the axils.

224. A. (Dipl.) tomentosum, Hk. (not Mett.) ; st. 6-9 in. l., firm, erect, grey, deciduously coated with fine short brown tomentum ; fr. 6-12 in. 1., 3-4 in. br., ovate-lanceolate, with numerous close-placed lanceolate pinno, the lower pair deflexed, those next in order horizontal, $2-3$ in. l., $\frac{1}{2}$ in. br., the point acute, the edge cut down regularly throughout into oblong-falcate lobes $\frac{1}{8}$ in. br., which reach one-half or two-thirds of the way down to the rachis, the base narrowed suddenly; texture subcoriaceous ; rachis finely tomentose ; both surfaces naked except the veins beneath; veins $3-4$ on each side in the lobes; sori linear, touching the edge but not the midrib.-HK. Sp. 3. p. 249.

Hab. Khasia and Malayan Peninsula and Isles.-In size and texture this corresponds with porrectum. It is the original $D$. tomentosum of Blume, according to an authentic specimen, but not the much more hairy A. tomentosum of Mettenius, which is our A. lasiopteris.

225. A. (Dipl.), Sprucei, Baker ; st. tufted, 6-9 in. l., dark-brown, firm, erect, nearly naked ; fr.9-15 in. l., 3 in. br., narrowly ovate-lanceolate, the apex pinnatifid, below this 15-20 pairs of spreading pinnoe 1-1 $\frac{1}{2}$ in. $1 ., \frac{1}{2}-\frac{3}{4}$ in. br., the point rather blunt, the edge lobed in the lower part halfway down to the rachis, the lobes 2-3 lin. br., inciso-crenate, the base narrowed suddenly on both sides; texture papyraceo-herbaceous ; colour very dark-green ; rachis angular, channelled and slightly winged; veins distantly pinnate, only $2-3$ simple veinlets on eacl side in the lower lobes; sori reaching from the midrib nearly to the edge.

Hab. Andes of Ecuador, Jameson, Spruce, 5346.-A well-marked plant, which from its colour and texture evidently grows in very damp places.

226. A. (Dipl.) japonicum, Thunb. ; rhizome slender, wide-creeping ; st. 6-12 in. l., straw-coloured or brownish, slightly scaly towards the base; fr. 9-15 in. 1., 4-6 in. br., ovate-lanceolate, with 8-10 rather distant pinnoe below the pinnatifid apex, the lower ones sessile, $3-4$ in. $1 ., \frac{3}{4}-1$ in. br., cut down in the lower parts two-thirds of the way to the rachis into close oblong slightly-toothed lobes 
$\frac{1}{4}$ in. br. ; texture herbaceous, both surfaces bright-green, nearly naked ; rachis slender, straw-coloured, nearly naked; veins about 6 on each side in the lower lobes, with sori on each reaching two-thirds of the way to the edge, the lowest $\frac{1}{8}$ in. 1.; invol. broad, brown, tumid.-A. Schkuhrii, Hk. Sp. 3. p. 251.- - , Oldhami; fr. smaller, lanceolate, 4-6 in. 1., 2-3 in. br.; rachis straw-coloured, polished, naked ; pinnoe 1-1 $\frac{1}{2}$ in. 1. , blunt ; lobes blunt, only 3 veins on a side in each. $-\gamma$, coreanum; $f r$. the same size as in $\beta$, but only the lower half pinnate, the rachis and stem rather chaffy and villose.

Hab. Japan, China, Formosa, Himalayas.-The Samoan and Fijian D. congruum, Brack. t. 18, comes very near to this. In a specimen from Mr. Powell, the substance is very thin, the rachis naked, the lobes $\frac{1}{2}$ in. deep, $\frac{1}{4}$ in. br., veinlets 5-6 on each side, most of them again forked; and a similar plant grows in the Sandwich Islands.

227. A. (Dipl.) Thwaitesii, A. Br. ; rhizome wide-creeping ; st. 6 in. 1., slender, green, densely clothed with strong white woolly hairs ; fr. $1 \mathrm{ft} .1 ., 4$ in. br., with 8-10 distant pinnoe beneath the pinnatifid apex, the largest 2 in. 1 ., $\frac{5}{8}$ in. br., cut down two-thirds of the way to the rachis in oblong crenulated lobes $\frac{1}{4} \mathrm{in}$. deep, 2 lin. across ; rachis flaccid, villose like the stem ; texture herbaceous ; colour palegreen, and both surfaces also villose; veins 4 on each side in a lobe, simple; sori reaching halfway to the edge, the lowest about a line long.-Hk. Sp. 3. $p_{0} 250$. 2nd Cent. t. 45.

\section{Hab. Ceylon.-Intermediate between the preceding and following.}

228. A. (Dipl.) lasiopteris, Mett. ; rhizome wide-creeping ; st. 6-9 in. 1., firm, erect, dark-coloured, villose; fr. 15-18 in. l., 6-8 in. br., with 8-10 pinnoe on each side below the pinnatifid apex, the largest $3-4$ in. l., 1-1 $\frac{1}{4}$ in. br., the lower lobes cut down nearly or quite to the rachis, $\frac{3}{3}-\frac{1}{2}$ in. deep, $\frac{3}{8}$ in. br., the point obtuse, the edge distinctly crenate ; texture herbaceous, the dark-coloured rachis and darkgreen frond villose on both sides ; veinlets 5-6 on each side, simple ; lower sori $\frac{1}{8}$ in. 1.-Diplazium, Kunze, Linncea, vol. 17. $p_{0} 568$. A. tomentosum, MLett. (non Hk.).

Hab. Canton, Java, and the Neilgherries, well figured by Beddome, t. 160.-This is the $D$. decussatum of English gardens ; but our original specimen from Wallich is A. japonicum. It comes near the two preceding, and the three are well marked by the character of the rhizome.

229. A. (Dipl.) speciosum, Mett. ; st. tufted, $1 \mathrm{ft}$. or more l., firm, erect, strawcoloured or brownish, nearly naked ; fr. 1-2 ft. 1., 8-12 in. br., with 10-20 pairs of pinnce below the pinnatifid apex, the lower ones often stalked, 4-6 in. 1., 1-1 $\frac{1}{4}$ in. br., the apex much acuminated, the edge lobed, the lobes reaching down twothirds of the way to the rachis or more, close, $\frac{1}{4}$ in. br., slightly toothed, the base truncate or slightly cuneate; texture herbaceous but firm; rachis erect, naked; veins pinnate in the lobes ; sori slender, reaching nearly to the edge.-Diplazium, Blume. A. acuminatum, Wall., Mett. (non $\boldsymbol{H}_{0} \&$ A.).

Hab. Malayan Peninsula and Philippines, Java, Hong-Kong.-This is nearest A sorzogonense, but the lobes are broader and not so deep, more herbaceous in texture, and distinctly toothed. A plant from Fiji comes very near this, but the pinnæ are fewer, thinner, the lower ones distinctly stalked, and the lobes broader ; and one from Richmond River, Australia, sent by Dr. Mueller, only differs by the lobes being rather broader and shallower. A specimen of Blume's plant from Miquel quite agrees with Wallich's examples of acuminatum.

230. A. (Dipl.) Welwitschii, Hk. MSS. ; st. $1 \mathrm{ft}$. or more 1., firm, erect, strawcoloured, naked ; fr. 18 in. l., 9 in. br., the lower pinnae 6-7 in. l., 1-1 $\frac{1}{2}$ in. br., the point acuminate, the edge slightly lobed above, cut down in the lower part half or two-thirds of the way to the rachis ; the lobes not quite contiguous, $\frac{3}{8} \mathrm{in.} \mathrm{br.,}$ nearly entire, the base sessile, truncate ; texture herbaceous ; veins distantly pin- 
nate in the lobes, with the lower veinlets branched; sori short, slender, distant from both edge and midrib.

Hab. Angola, Welwitsch, 100,-This comes nearest the preceding in habit, but the lobes are broader and the sori remarkably short.

231. A. (Dipl.) crenulatum, Baker ; caud. erect, subarborescent ; st. tufted, 12-18 in. 1., firm, erect, hardly at all scaly below, but slightly furfuraceous ; $f r$. 2-3 ft. 1., 9-15 in. br., with 15-20 pinnoe on each side below the pinnatifid apex, the largest $6-8$ in. $1 ., 1-1 \frac{1}{4}$ in br., the point acuminate, the edge cut down in the lower part half or two-thirds of the distance to the rachis ; lobes oblong, $\frac{1}{2}$ in. l., 4 lin. br., slightly toothed; texture herbaceous ; rachis firm, nearly naked ; veins 6-8 on a side in each lobe ; lowest sori $\frac{1}{8}$ in. 1.-D. crenulatum, Liebm. A. striatum, Mett. Aspl. p. 186. and Griseb. (non Hk.). A. dubium, Hk. (in part).

Hab. Cuba and Mexico to Brazil and Ecuador.-We take our description here from a plant grown at Kew, with which Liebman's specimens and the description of Mettenius quite correspond. In the typical plant the pinnæ are not more than pinnatifid, but in Grisebach's striatum $\beta$ and Liebman's $D$. amplum, the lower segments are distinctly separated, $1 \frac{1}{2}-2$ in. $1 ., \frac{1}{2}$ in. br., and broadly inciso-crenate, and the lower sori 2 lin. 1 . The W. Indian D. grammitoides, Fée, resembles this in habit, but the involucre is thin and very evanescent.

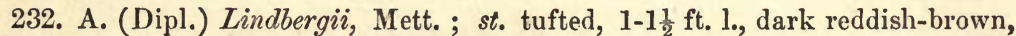
firm, erect, scaly at the base ; fr. 18-24 in. 1., 9-12 in. br., the apex pinnatifid, below this about 12 pinnoe on each side, the lowest $6-8$ in. 1., 1-1 $\frac{1}{4}$ in. br., the point acuminate, the edge cut about half way down into close subimbricated blunt incisocrenated lobes $\frac{1}{2}$ in. br.; texture herbaceous; rachis reddish-brown, naked; veins copiously pinnated, veinlets 6-8 on each side ; sori slender, confined to the inner half of the lobes, and not touching the midrib; invol. very narrow and tender, almost abortive.-Mett. Fil. Nov. Gran.p. 236.

Hab. Mexico to Brazil. - Not unlike the preceding in habit, but sori and involucre peculiar.

233. A. (Dipl.) sorzogonense, Presl ; st. tufted, 4-6 in. 1., densely fibrillose below ; fr. 1-2 ft. 1., 8-12 in. br., with numerous pinnoe on each side, the lower ones sessile, 4-6 in 1., 1 in. br., cut down regularly throughout two-thirds of the way down to the rachis into spreading blunt subentire lobes about 2 lin. br.; texture herbaceous ; rachis slightly fibrillose; veinlets of the lobes simple, with sori in regular rows reaching from the midrib to the edge.-Hk. Sp. 3.p.252. Hypochlamys, Fée.

Hab. Himalayas (to 8-10,000 ft.), Philippines, and Malaccas.-Nearest A. speciosum, but the lobes narrower and deeper, with parallel edges and a space between them. A plant from Borneo has a very fibrillose rachis, and the lobes of the lower pinnæ quite distinct, $1 \frac{1}{2}$ in. l., $\frac{1}{2}$ in. br.

234. A. (Dipl.) costale, Swartz; st. 1 ft. or more l., tufted, stout, erect ; fr. ample, the apex pinnatifid, with oblong entire lobes, the lower part copiously pinnate, with pinnae often $1 \mathrm{ft}$. I., $3 \mathrm{in.br}$., cut down half or two-thirds of the way down to the rachis into blunt slightly inciso-serrated lobes $\frac{3}{8}-\frac{1}{2} \mathrm{in.}$ br.; texture subcoriaceous ; veinlets of the lobes usually once forked, with broad copious sori which fall considerably short of the edge.- $\beta, A$. Desvauxii, Mett. ; lobes of the pinnæ acute, sometimes reaching down nearly to the rachis, 2 in. $1 ., 1$ in. br. -Hk. Sp. 3. p. 254.

Hab. West Indies southward to Peru.-This differs from all the preceding by its very large pinnæe and lobes. The extremes of the two forms look very different, but are connected by intermediate stages. D. apollinaris and Tussaci, Fée, are allied.

235. A. (Dipl.) Franconis, Mett. ; st. 1 ft. l., firm, tufted, erect, greyish, scaly below ; fr. 1-2 ft. l., 9-15 in. br., with numerous pinnoe on each side, the lower 
ones 6-8 in. l., much acuminated at the apex, cut down in the lower half into distinct pinnl. $1 \frac{1}{2}-2$ in. $1 ., \frac{1}{2}$ in. br., lanceolate, unequal-sided, falcate, the edge cut halfway down below into oblong sharply-toothed lobes, the lower side obliquely truncate; texture herbaceous but firm ; colour bright-green ; rachis naked ; lateral veins of the pinnl. pinnate in the lower lobes; sori in parallel rows in the pinnl., not reaching the edge.-Hk. Sp. 3. p. 261.

Hab. Mexico, Guatemala, and Ecuador. - The West Indian plant is larger (2-3 ft. I.) and more compound, with lower pinnæ 6-9 in. 1., 4-5 in. br., with numerous distinct stalked sub-distant lanceolate pinnl., cut down below into crenated oblong lobes nearly to the rachis.

**** Fronds copiously bipinnate. Sp. 236-259.

236. A. (Dipl.) deltoideum, Presl ; st. 6 in. l., slender, erect, ebeneous below, naked; fr. 1 ft. l., 9 in. br., deltoid, with a few distant pinnoe on each side, the lowest ovate-deltoid, 5 in. $1 ., 2-3$ in. br., cut down in the lower half into distinct stalked pinnl. 1-1 $\frac{1}{2}$ in. $1 ., \frac{1}{2}$ in. br., which are bluntly lobed below two-thirds of the way down; texture herbaceous; rachises naked, those of the pinnæe ebeneous ; veins pinnate in the lower lobes; sori reaching the edge.-Hk. Sp. 3. p. 256.

Hab. Luzon, Cuming, 29.-Caudex unknown.

237. A. (Dipl.) virescens, Mett. ; rhizome creeping; scales hlackish, lanceolatesubulate; st. 6 in. 1., straw-coloured; $f r .1 \mathrm{ft}$. l., deltoid, bipinnate below the middle; lower pinnce 8 in. l., 3 in. br., pinnate below the centre ; pinnl. $1 \frac{1}{2}$ in. l., $\frac{1}{2}$ in. br., the apex acuminate, the edge crenato-lobate, the base narrowed suddenly; rachis slender; texture thin ; colour pale-green; veins pinnate in the lower lobes, with 1-3 veinlets on each side; sori oblong, small, nearer to the midrib than the edge.-Hk. Sp. 3. p. 261.

Hab. Japan, Goring, Buerger.

238. A. (Dipl.) squamigerum, Mett.; st. 6 in. or more 1., straw-coloured, slender, with small scattered nearly black lanceolate scales throughout; $f r$.

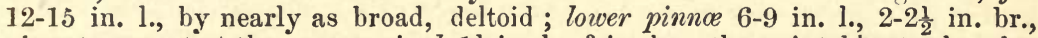
pinnate except at the apex ; pinnl. $1 \frac{1}{2}$ in. l., $\frac{3}{4}$ in. br., the point blunt, the edge broadly lobed, the lower lobes $\frac{1}{4}$ in. br., entire ; texture herbaceous ; rachis slender, stramineous, chaffy below; veins subflabellate, the lower veinlets of the lohes with one or two lateral curved furks on each side; sori linear, curved, falling far short of the edge, the lowest 2 lin. 1.-Mett. Fil. Ind. 2. p. 239.

Hab. Japan, Oldham, Siebold, Robinson.

239. A. (Dipl.) chinense, Baker ; st. 1 ft. l., slender, greyish, nearly naked; fr. 12-15 in. l., nearly as br., deltoid, bipinnate except at the very apex ; lower pinnce long-stalked, $3-5$ in. $1 ., 2-2 \frac{1}{2}$ in. br., with numerous close lanceolate pinnl. on each side, the lower ones $1-1 \frac{1}{2}$ in. $]$., $\frac{1}{2}-\frac{5}{8}$ in. br., the point acute, the edge cut down to a winged rachis below into deeply-toothed oblong segm. 4 lin. l., 2 lin. br.; texture herbaceous; rachis slender, naked, substramineous; veins pinnate, 4-5 lateral simple veinlets on each side in the lower segm.; sori linear, not reaching the edge.

Hab. Shanghai, China, Dr. Maingay, 475.

240. A. (Dipl.) nervosum, Mett. ; fr. ample, bipinnate ; lower pinnoe stalked, 12-18 in. 1., 6 in. br., lanceolate-acuminate; pinnl. close, patent, 3-4 in. l., $\frac{1}{2}-\frac{3}{4}$ in. br., lanceolate-oblong, obtuse or acuminate, only toothed, the base truncate; texture subcoriaceous; rachises densely scaly, the scales of the main one $\frac{1}{2}$ in. l., lingulate-acuminate, the edge subciliated; lower surface clothed with dense adpressed hairs; veinlets forked in the upper, subpinnate in the 
lower lobes; sori reaching from midrib more than halfway to the edge.-Mett. Fil. Nov. Gran. p. 235.

Hab. New Granada, Lindig, 293, 1015.-Distinguished by its vestiture and large scarcely-toothed pinnules.

241. A. (Dipl.) venulosum, Baker; caud. erect, subarborescent ; st. tufted, strong, $4 \mathrm{ft}$. l., the base clothed with linear dark-brown scales nearly 1 in. l.; fr. 4-5 ft. 1., 2-3 ft. br., with about 20 pairs of pinnoe, the lowest 12-18 in. 1., 4-6 in. br.; lower pinnl. 3 in. l., $\frac{1}{2}$ in. br., with their own breadth between them, the edge only slightly inciso-serrate; texture subcoriaceous; rachis and both sides naked ; veins very distinct, the upper ones of the pinnl. forked, the lower ones subpinnate; sori reaching from the midrib nearly to the edge.

Hab. Andes of Ecuador, Spruce, 5343.-This agrees with the preceding in its large subentire pinnules, differing in vestiture.

242. A. (Dipl.) cyatheafolium, Bory ; caud. erect, subarborescent ; st. firm, erect, dark-brown, nearly naked ; $f r$. 18-24 in. l, $12-18$ in. br.; lower pinnoe 9 in. $1 ., 3 \mathrm{in}$. br., cut down to the rachis in the lower two-thirds into numerous pinnl. on each side, the lower ones $1 \frac{1}{2}$ in. $1 ., \frac{1}{2}$ in. br., the upper ones incisocrenate, the lower ones cut down one-third of the distance to the rachis into oblong, falcate, sharply-toothed lobes; texture herbaceous ; rachis dark-brown, naked, like the stem; veins pinnate, with $3-4$ veinlets on each side in the lower lobes; sori falling considerably short of the edge.-D. caudatum, J. Sm. fide Mettenius.

Hab. Luzon, Cuming, 158, and, according to Mettenius, a plant also of Ualan and New Guinea.-A somewhat doubtful species, of which our description is taken from Cuming's specimens.

243. A. (Dipl.) Meyenianum, Mett.; fr. ample, tripinnatifid ; lower pinnoe lanceolate-oblong, 15 in. l., 9 in. br. ; lower pinnl. $4 \frac{1}{2}$ in. l., $1 \frac{1}{4}$ in. br., stalked, oblong-acuminate, cut down below into crenate oblong-obtuse segm., $\frac{1}{2}$ in. l., $\frac{1}{4}$ in. br., the lower ones subcordate at the base, the upper ones decurrent with a narrow wing; texture herbaceous, under surface glossy ; veins 4-5 on each side, the lower one branched; sori copious, reaching from the midrib nearly to the edge.-Mett. Aspl. p. 189.

Hab. Manila, Meyen.-Our single specimen of this is very imperfect, and our description is taken in part from Mettenius. The alliance of both this and the preceding is with polypodioides.

244. A. (Dipl.) polypodioides, Mett. ; caud. erect, subarborescent, densely clothed at the crown with long brown fibrillose scales 1 in. 1.; st. densely tufted, stout, green, $1 \mathrm{ft}$. or more l., rather densely muricated, not scaly, but slightly furfuraceous; $f r$. 3-4 ft. 1., $1 \frac{1}{2}-2 \mathrm{ft}$. br., with 8-9 pinnce on each side below the simple ones at the apex, the lower ones 4-5 in. apart, 9-12 in. 1., 6 in. br.; ; pinnl. numerous, spreading, $2-3$ in. $1 ., \frac{1}{2}-\frac{3}{4}$ in. br., cut down nearly to the rachis into linear-oblong slightly-toothed lobes; texture herbaceous; both surfaces naked; colour bright-green ; rachis green, stout, nearly naked; veinlets about 6 on each side in the lobes; sori falling distinctly short of the edge.Hk. Sp. 3. p. 257.

Hab. Himalayas (up to 8,000 ft.), Ceylon, Malayan Peninsula and Isles.-Our description is taken from the plant in cultivation at Kew, no doubt identical with the common Indian and Malayan species thus named, which is $\boldsymbol{A}$. frondosum, Wall. An authentic example of $D$. asperum, Blume, is rather more coriaceous in texture, with lower pinnæ 15 in. 1. ; even the secondary rachises asperous ; the lobes $\frac{1}{2}$ in. 1., with 8-10 veinlets on each side. D. ebenum, J. Sm., from the Philippines (Cuming, 159), has a slender naked ebeneous rachis and erecto-patent lobes, with only 4 distant veinlets in each; and we 
have closely allied plants from Queensland, Fiji, and the Seychelles, which need further investigation.

245. A. (Dipl.) Griffithii, Baker ; st. 1 ft. 1., naked, firm, erect; fr. 12-18 in. 1., nearly as broad; lower pinnce 9-12 in. l., 6 in. br., on stalks 1 in. l.; pinnl. numerous, the longest 3 in. l., $\frac{3}{4}$ in. br., cut down nearly to the rachis below ; lobes erecto-patent, $\frac{1}{2}$ in. deep, $\frac{1}{8}$ in. br., deeply toothed, not contiguous ; rachis smooth, flexuose, substramineous ; texture subcoriaceous, both surfaces naked; veins about 6 on a side in each lobe, with an oblong sorus on each, which is less than 1 lin. l., touches the costa and scarcely reaches halfway to the edge. -Diplazium, Moore Ind. Fil. p. 330.

Hab. Assam, Griffith.-This differs from the preceding mainly in the sori, and comes near $A$. woodwardioides.

246. A. (Dipl.) maximum, Don ; caud. erect; st. 2 ft. or more 1., firm, erect, scaly only at the base; $f r$. several ft. $1 ., 2-3 \mathrm{ft}$. br., with numerous pinnoe on each side, the lowest 9-18 in. l., 4-8 in. br., with numerous distinct subsessile pinnl. 2-4 in. l., $\frac{3}{4}$ in. br., the edge more or less lobed, sometimes halfway down; texture herbaceous; rachises and both sides nearly naked; veins pinnate in the lobes, 4-6 on a side ; sori medial, the lowest 2 lin. 1.-A. diversifolium, Wall., J. Sm. D. decurrens, Beddome, $t .220$.

Hab. N. India to Ceylon.-A common Indian plant, like A. sylvaticum in texture, a single lower pinna of this resembling a whole frond of that. We cannot in any way distinguish the New Caledonian A. sororium, Mett., of which the trunk is not known, from the less deeply lobed form of this, and have what appears to be the same from the Society Islands.

247. A. (Dipl.) melanochlamys, Hk. ; st. strong, erect, $2 \mathrm{ft}$. or more 1., smooth ; fr. 3-4 ft. l., $2 \mathrm{ft}$. br., with numerous pinnoe on each side, the lower ones 9-12 in. 1., 4-6 in br., with numerous distinct sessile pinnl. 2-3 in. 1., 1 in. br., cut down within a short distance of the rachis throughout into incisocrenate linear-oblong segm., $\frac{1}{4}$ in. br.; texture herbaceous but firm; colour

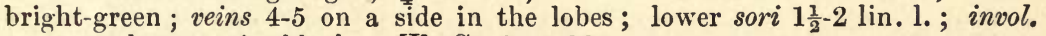
narrow, glossy, quite black.-Hk. Sp. 3. p. 260.

Hab. Lord Howe's Island, S. Pacific, Macgillivray, 702, Milne, 36. - Trunk unknown.

248. A. (Dipl.) vestitum, Presl ; st. stout, erect, brownish, tomentose throughout ; fr. 2-3 ft. 1., 9-18 in. br., with numerous pinnie on each side, the lower ones 9 in. $1 ., 4$ in. br., with numerous distinct subsessile pinnl., which are 2 in. 1., 1 in. br., blunt at the point, and bluntly-lobed to a depth of $\frac{1}{8}-\frac{1}{4}$ in., the base narrowed suddenly or even cordate; texture thinly herbaceous; rachis chaffy like the stem; veins pinnate in the lobes; veinlets 4-5 on each side; lower sori of the lobes $3-4$ lin. l., not reaching the edge.-Hk. Sp. 3. p. 260 . 2nd Cent.t. 46.

Hab. Philippines, Cuming, 336.-Trunk unknown. For the rest this resembles A. maximum, differing by its tomentose rachises.

249. A. (Dipl.) latifolium, Don ; caud. erect, subarborescent ; st. tufted, strong, erect, $1 \mathrm{ft}$. or more 1., livid, smooth, clothed towards the base with linear-crisped dark-brown scales; fr. 3-4 ft. 1., 12-18 in. br., subdeltoid, with about 12 pinnoe on each side, the largest $1 \mathrm{ft}$. $1 ., 4 \mathrm{in.} \mathrm{br.;} \mathrm{pinnl.} \mathrm{numerous,}$ the largest 2 in. $1 ., \frac{5}{8}$ in. br. at the base, the point acuminate, the edge slightly toothed, the base abruptly truncate on both sides; texture subcoriaceous ; rachis naked, livid ; veins about 6 in a group ; sori linear, the lowest often 2 lin. 1.A. dilatatum, Hk. Sp. 3. p. 258 (in part). 
Hab. Ceylon, Neilgherries, S. China, Philippines.-Here again we fall back upon the living collection at $\mathrm{Kew}$ for a description. Our plant is the $D$. diversifolium of J. Sinith, but scarcely of Wallich. Blume's original specimen of dilatatum, and a plant sent by Miquel as $A$. latifolium, Don, are like this in texture, but the pinnules are $1 \frac{1}{2}$ in. apurt, the lower oues distinctly stalked, 3 in. l., and bluntly lobed to a depth of $\frac{1}{8}$ in. below ; and we have similar examples from China, Java, and Moulmein.

250. A. (Dipl.) nigro-paleaceum, Baker; caudex decumbent; st. not tufted, suberect, $\frac{1}{2}$ in. thick, 12-18 in. 1. , greenish, deeply channelled in front, thickly clothed with lanceolate nearly black scales ; $f r$. 2-3 ft. l., nearly as br.; lower pinnoe 12-18 in. l., 6-8 in. br., with numerous spreading pinnl. 3-4 in. l., 1 in. br., cut down half or two-thirds to the rachis into inciso-crenate linear-oblong lobes, $\frac{1}{4}$ in. br.; texture thick, subcoriaceous ; colour bright-green ; rachis thick, naked, slightly zigzag, with a winged line on each side in front, the lower lobes imbricated over it; veins $6-8$ on each side, the lower ones forked; lower sori $\frac{1}{4}$ in. 1.-Diplazium, Kunze, Linn. 24, 270. D. Loddigesii, J. Sm.

Hab. St. Helena.-Our description is drawn up from the copious living specimens at Kew. Perhaps not distinct from $D$. arborescens, but a much stronger and more coriaceous plant, with a densely scaly stem.

251. A. (Dipl.) arborescens, Mett. ; caud. oblique ; st. 1-2 ft. l., strong, erect, smooth, nearly naked ; $f r .3-4 \mathrm{ft} .1 ., 2-3 \mathrm{ft}$. br., with numerous pinnoe, the lower ones 12-18 in. l., 4-6 in. br.; pinnl. 3 in. $1 ., \frac{5}{8}-\frac{3}{4}$ in. br., the point acuminate, the edge cut down two-thirds of the way to the rachis into nearly entire lobes $\frac{1}{4}$ in. deep, $\frac{1}{8}$ in. hr. ; rachis polished, stramineous ; texture herbaceous; veinlets $6-8$ on each side, mostly simple; lower sori $\frac{1}{8}$ in. 1. $-H k$. Sp. 3 . p. 256 (in part).

Hab. Mauritius, Bourbon, Polynesian Islands. - D. comorensis, Bojer, from Johanna Island, bas broader lobes, not cut more than halfway down to the rachis, 4-5 simple veinlets on each side, and lower sori $\frac{1}{4}$ in. 1 . There are two totally different modes of growth amongst these large compound species, and there is much to be done in studying the living plants before we can understand them clearly.

252. A. (Dipl.) melanocaulon, Baker; st. 1-2 ft. l., firm, erect, naked, ebeneous ; fr. 2-3 ft. 1., 9-18 in. br., with numerous pinno, the lower ones 6-12 in. l., 4-6 in. br.; pinnl. lanceolate, 2-3 in. l., $\frac{3}{4}$ in. br., cut down two-thirds of the way to the rachis into linear-oblong falcate inciso-crenate lobes, $\frac{1}{4}-\frac{3}{8}$ in. deep ; texture subcoriaceous; rachises slender, ebeneous like the stem ; veins pinnate in the lobes, 4-5 on each side ; sori short, oblong, not touching either midrib or edge. -Diplazium, Brack. p. 144.

Hab. Fiji and Aneiteum. -Apparently this agrees with arborescens in mode of growth. It differs by its more coriaceous texture, distant veins, ebeneous rachis, and short sori.

253. A. (Dipl.) Arnottii, Baker ; st. smooth, angular, brownish; fr. ample; lower pinnoe 9-12 in. l., 4-6 in. br.; pinnl. 3-4 in. l., 1 in. or more br.; cut down below to a distinctly winged rachis into deeply crenate, blunt, oblong lobes $\frac{3}{2}$ in. deep, $\frac{1}{4}$ in. br., with a space between them; texture herbaceous; rachis slender, naked; veinlets 5-6 on a side, nearly all branched, the lower ones subpinnate; sori copious, nearly all diplazioid and filling up when mature nearly the whole surface of the lobes.-Diplazium, Brack. p.144. A. diplazioides, Hk. \& Arn.

Hab. Sandwich Islands, frequent.-Caudex probably of $A$, arborescens.

254. A. (Dipl.) pulicosum, Hk. ; st. firm, erect, naked, straw-coloured; fr. $1 \frac{1}{2} 2 \mathrm{ft}$. 1., $1 \mathrm{ft}$. br., witl numerous pinnce on each side, the lower ones 6-8 in. 1 ,, 4 in. br.; lowest pinnl. 2 in. l., $\frac{3}{4}$ in. br., cut down nearly to the rachis into spreading, crenated linear-oblong lobes 2 lin. br.; texture coriaceous; colour 
pale-green; rachis firm, naked; veins 5 on each side in the lobes; sori in regular parallel rows not reaching more than halfway from the midrib to the edge; invol. rigid, nearly black.-Hk. Sp. 3. p. 262.

Hab. Ecuador, Jameson.-Caudex unknown.

255. A. (Dipl.) Klotzschii, Mett. ; caud. erect, subarborescent ; st. 1-2 ft. 1., strong, erect, dark-brown, and scaly below; fr. 3-5 ft. l., 9-18 in. br.; lower pinnce 6-9 in. 1., 3-4 in. br. ; lower pinnl. 2-3 in. l., $\frac{3}{4}$ in. br., cut down nearly to the rachis into blunt spreading slightly-toothed linear-oblong lobes 2 lin. br.; texture herbaceous; colour deep-green; rachis firm, naked; veins distant, pinnate, 4-6 on each side in the lobes ; sori linear-oblong, falling sliort of the edge; invol. tumid, brown, fimbriated.-Hk. Sp. 3. p. 263. Lotzea diplazioides, Klotzsch.

Hab. Columbia and Venezuela.

256. A. (Dipl.) flexuosum, Presl ; st. firm, naked, brownish ; fr. ample ; pinnoe with a very flexuose zigzag rachis and pinnl. deflexed and then curved upwards ; lower pinnoe 12-18 in. 1., 6-9 in. br.; pinnl. stalked, 3-5 in. 1., 1-2 in. br., the apex serrated only, the upper part lobed, the lower cut down nearly or quite to the rachis into blunt subentire oblong lobes $\frac{3}{8}$ in. br.; texture subcoriaceous; veinlets of the lobes forked, 7-8 on a side; sori long, linear, in regular rows not reaching the edge.-Hk. Sp. 3. p. 263.

Hab. Peru.-Caudex unknown.

257. A. (Dipl.) vastum, Mett. ; fr. ample, bipinnatifid ; lower pinnce $2 \mathrm{ft.}$ l., 7 in. br., ovate-lanceolate, acuminate ; pinnl. close, patent, $3 \frac{1}{2}$ in. l., 1 in. br., oblong-acuminate, cut down nearly or below quite to the rachis into toothed linear-oblong lobes; texture subcoriaceous; rachis stramineous, slightly downy upwards ; both sides quite naked; veins pinnate in the lobes, with 6-8 mostly simple veinlets on a side; sori reaching from the midrib to the base of the teeth.-Mett. Fil. Nov. Gran. p. 237.

Hab. New Granada, Lindig, 349.-Trunk unknown.

258. A. (Dipl.) hians, Kunze ; caud. erect ; st. $12-18$ in. l., tufted, slightly scaly ; fr. 3-4 ft. 1., 2-3 ft. br.; lower pinnoe $1 \mathrm{ft}$. or more 1., 4-6 in. br.; pinnl. numerous, lanceolate, $2-3$ in. 1 ., $\frac{1}{2}-\frac{3}{4}$ in. br., with blunt subentire lobes $1 \frac{1}{2}-2$ lin. br., reaching nearly down to the rachis ; texture herbaceous ; colour dark-green ; rachis and both sides naked; veinlets $3-4$ on each side; sori short, oblong, only the lower ones double ; invol. tumid.-Hk. Sp. 3. p. 233.

Hab. West Indies to Ecuador.-Grisebach unites this with A. umbrosum, J. Sm. It differs from the next by its narrower pinnæ and lobes, much shorter sori, and tumid involucre.

259. A. (Dipl.) radicans, Schk. ; caud. erect, subarborescent; st. 1-2 ft. 1., tufted, strong, erect, scaly below ; fr. 3-5 ft. l., 2-3 ft. br. ; lower pinnce 12-18 in. 1., 6-8 in. br.; pinnl. numerous, lanceolate, sessile, the upper ones entire, lower ones $3-4$ in. 1., $\frac{3}{4}-1$ in. br., with broad blunt lobes $\frac{1}{4}$ in. br., reaching $\frac{1}{2}$ or $\frac{2}{3}$ of the way down to the rachis ; texture herbaceous ; rachis naked or slightly pubescent; veins 4-6 on each side in a lobe ; lower sori sometimes $\frac{1}{4}$ in. 1.-A. dubium, Mett. Hk. Sp. 3. p. 261 (in part). $\beta, A$. expansum, Presl; rachis pubescent; pinnoe and lobes narrower; sori shorter.-Diplazium, Willd. D. umbrosum, Willd. D. Haenkeanum, Presl.

Hab. Tropical America, from Cuba and Columbia to Brazil and Peru.-The universally-distributed S. American large-growing tripinnatifid species. D. ambiguum, Raddi, is probably essentially the same, but the figure represents the pinnæ as only slightly lobed, with which Brazilian and Peruvian examples from Sellow and Spruce coincide. 


\section{Fronds fully tripinnate. Sp. 26C-263.}

260. A. (Dipl.) gracilescens, Mett.; st. straw-coloured, slender, but firm, naked, polished; fr. 3-4 ft. l., 2-3 ft. br., tripinnate; lower pinnce 12-18 in. l., 6 in. br.; lanceolate-acuminate; pinnl. close, short-stalked, 2-3 in. l., nearly 1 in. br., lanceolate-acuminate, with oblong unequal-sided pinnatifid segm.; texture herbaceous; rackis stramineous and both sides naked; two veinlets in the upper, four in the lower lobes; sori only one in each, except the lowest, 1 lin. 1.; invol. membranous. - Mett. Fil. Nov. Gran. p. 237. Diplazium, Moore.

Hab. Venezuela, Schlim, 69.

261. A. (Dipl.) Sandwichianum, Mett.; st. 2 ft. 1., firm, dark-brown, tomentose, furnished at the base with ovate-lanceolate scales, dark-brown in the centre, and a broad margin suddenly scariose; fr. 2-3 ft. 1., 1 $1 \frac{1}{2}-2 \mathrm{ft}$. br. ; lower pinnoe 9-15 in. $1 ., 6$ in. br., with numerous spreading pinnl. 3 in. l., 1 in. br., with distinct oblong segm. $\frac{1}{2}$ in. l., $\frac{1}{4}$ in. br., the lower ones cut down nearly to the rachis into blunt lobes ; texture herbaceous ; colour dark-green ; rachises brown and very tomentose, those of the pinnules distinctly winged; veins distant, pinnate ; sori copious, in regular rows not reaching the edge.-Hk. Sp. 3. p. 225. Athyrium, Presl. A. alienum, Mett. p. 169. A. fuscopubescens, Hk. Sp. 3.p. 264.

Hab. Sandwich Islands ; Peru, Lechler, Spruce, 4759, 5416a.--Spruce's specimens quite agree with those from Mr. Lambert, mentioned in "Species Filicum."

262. A. (Dipl.) Wilsoni, Baker ; st. slender, brownish, naked ; fr. 3-4 ft. l.,

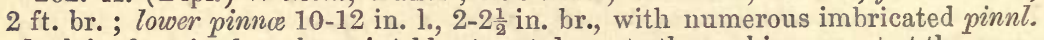
$1 \frac{1}{4}-1 \frac{1}{2}$ in. $1 ., \frac{1}{2}$ in. br., the point blunt, cut down to the rachis, except at the apex, into oblong-rhomboidal lobes, the lower ones $\frac{1}{4}$ in. $1 ., 1 \frac{1}{2} \cdot 2$ lin. br., broadly but not deeply lobed; texture herbaceous; both surfaces and rachis quite naked; colour deep-green; veins four on a side in the lower lobes, the lower ones forked; sori linear, 1 lin. l., rarely diplazioid ; invol. tumid.

Hab. Jamaica, Wilson, 929 ; March, 206, 377.-In habit and cutting this resembles the preceding closely.

263. A. (Dipl.) divisissimum, Baker; st. 1-2 ft. 1., firm, angular, polished, reddish-brown, shaggy below, with nearly black dense fibrillæ; $f r .3-4 \mathrm{ft} .1 ., 2 \mathrm{ft}$. br., with numerous pinno on each side, the lower ones $3-4$ in. apart, $1 \mathrm{ft}$. 1., 6 in. br., with very numerous close-placed lanceolate pinnl. 3 in. 1., $\frac{3}{4}$ in. br., cut down into very numerous oblong segm. $\frac{3}{8}$ in. I., 2 lin. br., which are again cut down to the rachis into obovate ult. divisions 1 lin. br.; texture herbaceous; rachis dark-coloured, naked; colour dark-green; two veinlets on each side in the lower ult. divisions; sori linear, sometimes 1 lin. l., only the lowest occasionally diplazioid.

Hab. Foot of M. Chimborazo, Spruce, 5695. - This comes nearest to the two preceding, but is much more compound. We have an incomplete specimen of a very similar plant from Celebes.

§§§§§\$ Anisogonium, Presl. Sori as in Diplazium, but veins anastomosing. Sp. 264-276. Callipteris, Bory. Fig. 38, g.

* Fronds simple or simply pinnate. Sp. 264-273.

264. A. (Aniso.) ternatum, Hk. ; st. slender, 3-6 in. 1. ; fr. ternate, with an oblong-lanceolate terminal pinna $3-4$ in. $1 ., 1 \frac{1}{2}$ in. $\mathrm{br}_{\text {, }}$, the point acuminate, the edge serrated, the base narrowed gradually, and a pair of similar smaller lateral 
ones; texture coriaceous; veins in pinnate groups, the outer upper vein of the group joining the others before they reach the edge, but the separate groups free from one another.-Hk. Sp. 3. p. 265.

Hab. Mexico, Liebmann.

265. A. (Aniso.) Kunzei, Mett. ; st. 6-15 in. 1., firm, erect, furfuraceous ; $f r$. varying in shape from spathulato-elliptical, 9 in. 1., 2 in. br., slightly lobed below, to $18 \mathrm{in.1.,6-9}$ in. br., the upper half deeply pinnatifid, with deltoid or lanceolate-acuminate lobes, the lower half with distant oblong-acuminate entire pinnce $3-4$ in. 1., 1 $1 \frac{1}{2}-2$ in. br. ; texture coriaceous ; veins in pinnated groups which unite very near the midrib, with slender lines of sori on each extending to the edge. - Hk. Sp. 3. p. 266.

Hab. Ecuador and Peru.

266. A. (Aniso.) cordifolium, Mett. ; st. 6-12 in. l., firm, erect, scaly below ; fr. 8-12 in. 1., 3-4 in. br., entire, cordate at the base, the point acuminate; texture coriaceous; veins in close groups of about four, anastomosing copiously in the outer half of the pagina; sori reaching from the midrib to the edge. $-\beta, D$. integrifolium, Blume; fr. 12-18 in. l., subdeltoid, with a large terminal and one or two pairs of smaller but similar spreading lateral pinna.-Hk. $S^{2} p .3$. p. 267. Ic.t. 936 .

Hab. Philippines and Malayan Peninsula and Isles.

267. A. (Aniso.) alismoefolium, Hk. ; st. 2-6 in. 1., firm, erect, scaly throughout; fr. varying in shape from simple, oblong-lanceolate, 6-9 in. 1., 2-3 in. br., the edges entire, the apex acuminate, to ternate or pinnate, with a large terminal and three pairs of lateral pinnce, each like the entire frond of the simple state; texture coriaceous; veins about three to a group in the inner half, but anastomosing copiously with hexagonal areolæ towards the edge.-Hk. Sp. 3. p. 267.

Hab. Luzon, Cuming, 116.

268. A. (Aniso.) lineolatum, Mett. ; st. 6-9 in. 1., firm, erect, grey, scaly below ; fr. occasionally simple, usually with a terminal pinna and 3-6 pairs of lateral ones, which are 6-12 in 1., 2 in. or more br., entire, often suddenly acuminate ; texture coriaceous; rachis naked; veins 4-8 to a cluster, uniting slightly towards the edge-Diplazium, $B l$. A. elegans, Mett. Hk. Sp. 3. p. 268. Ic. Pl.t. 939 .

Hab. Philippines and Malayan Peninsula and Islands.

269. A. (Aniso.) heterophlebium, Mett. MSS.; st. 1 ft. 1., grey, scaly throughout ; fr. 12-18 in. 1., 8-9 in. br., with 6-8 opposite pairs of pinnce below the pinnatifid apex; the lowest 2 in. or more apart, $3-4$ in. 1., 1-1 $\frac{1}{4}$ in. br., the edge undulated, the point acute, the base cordate on both sides; texture thinly herbaceous; colour dark-green; rachis villose and fibrillose throughout; both surfaces naked; veins pinnate, the groups joining one-third of the way from the midrib to the edge, and the veins of the same and different groups anastomosing ; sori not reaching the edge, copiously diplazioid."

Hab. Mishmee and Assam, Griffith.

270. A. (Aniso.) decussatum, Sw. ; st. 1-2 ft. l., strong, erect, often muricated ; fr. 2-4 ft. 1., with numerous pinnoe on each side, which are 6-12 in. 1., 1-2 in. br., often proliferous in the axils, the edge nearly entire or slightly lobed; texture herbaceous or subcoriaceous; veins in copiously pinnated groups, with a distinct barren vein in the centre, uniting one-third of the distance from the 
midrib to the edge, but only those of different groups joining one another; sori reaching nearly to the edge and copiously double. $-\beta, D$. robusta, Fée; pinnoe 12-18 in. l., deeply lobed in the upper part, in the lower cut down to the rachis into distinct pinnl. 2 in. l., $\frac{3}{4}$ in. br. $-H k . S p .3 . p .270$.

Hab. Polynesian and Malayan Islands, and sent lately by Dr. Ferd. Mueller from Queensland ; Mascaren Isles, Angola, and Guinea Coast.-The Assam station given in "Species Filicum" is a mistake.

271. A. (Aniso.) Chimborazense, Spruce, MSS.; st. 3 ft. 1., $\frac{3}{8}$ in. thick at the base, brown, angular, densely clothed below with large linear-lanceolate brown scales; $f r .6 \mathrm{ft}$. l., the apex pinnatifid, with lanceolate lobes towards the base of the pinnatifid portion 4-6 in. l., below this about 16 pairs of pinnoe, the lowest 15 in. l., $2 \frac{1}{2}$ in. br., the point suddenly acuminate, the edge slightly undulated, the base narrowed suddenly on both sides; texture thin but subcoriaceous; rachis strong, naked, brown; veins in groups of about six, not uniting till beyond half the way from the midrib to the rachis, the veins of the same and separate clusters anastomosing copiously beyond this; sori in slender lines reaching two-thirds of the way to the edge.

Hab. Foot of Chimborazo (alt. 3-4,000 ft.), Spruce, 5703.

272. A. (Aniso.) rivale, Spruce, MSS. ; st. 18 in. l., strong, erect, brownish, scaly towards the base; fr. $4-5 \mathrm{ft}$. l., the apex pinnatifid; below this about 15 pairs of pinnoe, the largest 8-9 in. l., 2 in. br., the point acuminate, the edge slightly repand, the base subcuneate on both sides; texture papyraceous, only the veins beneath slightly hairy; veins pinnate, with a distinct barren vein in the centre of each group and 6-8 lateral veinlets, all of which except the upper one or two unite with those of the next group, beginning to do so within $\frac{1}{4}$ in. of the costa ; sori linear, medial, rarely double.

Hab. Foot of Chimborazo (alt. 3-4,000 ft.), Spruce, 5700.

273. A. (Aniso.) stenocarpum, Mett.; fr. 5-8 ft. 1., $1 \frac{1}{2} \mathrm{ft}$. br.; pinnce numerous, close, the lower ones short-stalked, 9-10 in. l., 2 in. br., the point acuminate, sharply toothed, the edge broadly lobed to a depth of 1-3 lin., the base truncate; texture herbaceous; only the rachis and veins beneath slightly hairy ; main veins 3-4 lin. apart; veinlets $6-8$ on a side, the lower ones ceasing before they reach the edge, free or uniting with those of the next group, the upper ones free; sori reaching from the main vein more than halfway along the veinlets.-Mett. Fil. Nov. Gran.p. 232.

Hab. New Granada, Lindig and Triana.-The imperfectly-known A. chocoense, Triana, resembles this, but the under surface is clothed, especially on the veins, with ferruginous hairs, and the lower three or four veinlets of each group unite with those of the adjoining one.

\section{** Fronds bipinnate. Sp. 274-276.}

274. A. (Aniso.) esculentum, Presl ; caud. subarborescent, erect; st. 1-2 ft. l., strong, erect, tufted; fr. 4-6 ft. l., occasionally simply pinnate only, but usually bipinnate ; lower pinno 12-18 in. l., 6-8 in. br.; pinnl. $3-6$ in. 1., $\frac{3}{4}-1$ in. or more br., the point acuminate, the edge more or less deeply lobed, the base narrowed suddenly, often auricled; texture subcoriaceous; rachis often pubescent; veins fine, copiously pinnated, 6-10 on each side' in each lobe, with a distinct barren central midrib, the veinlets of the different clusters beginning to unite a short distance from the midrib, with lines of sori often on all the lateral veinlets. $-H k$. Sp. 3. p. 268. Digrammaria, Presl.

Hab. Himalayas to Ceylon, Hong-Kong, Formosa, Malayan Peninsula and Isles.D. serampurense, Spreng., is a pubescent simply pinnate form. 
275. A. (Aniso.) Smithianum, Baker ; caudex oblique, decumbent ; st. thick, 1 ft. l., slightly scaly below, furfuraceous throughout, and rather densely muricated ; fr. 18-24 in. 1., by nearly as broad, with 4-5 pinnate pinnce and 4-5 that are only pinnatifid below the point on each side, the lowest 3 in. apart, about 9 in. l., 4 in. br. ; pinnl. sessile, 2-3 in. l., $\frac{5}{8}-\frac{3}{4}$ in. br., the edge subentire, the point slightly toothed, acuminated, the base rounded on both sides ; texturo subcoriaceous ; both surfaces and rachis naked, the latter muricated in the lower part; veins in groups of $2-3$ on a side, the groups usually joining halfway across to the edge; sori often $\frac{1}{4}$ in. 1.-A. dilatatum, $J$. Srm. (non Blume).

Hab. Ceylon, Gardner, 1351.-Our description here is taken from the living cultivated plant. It differs from latifolium by its oblique caudex and anastomosing venation and asperous stipe.

276. A. (Aniso.) vitiense, Baker ; fr. ample ; lower pinnoe $1 \mathrm{ft} .1 ., 6$ in. br., with numerous close distinctly-stalked lanceolate pinnl. on each side, which are 2-3 in. 1., $\frac{3}{4}$ in. br., narrowed gradually from the truncate base to an acuminate point, and bluntly lobed about one-third of the way down to the midrib; texture herbaceous; rachis finely pubescent, both sides nearly naked; veins pinnate in the lobes with 6-9 veinlets on a side, the lowest of contiguous groups joining midway between the midrib and sinus; sori copious, medial; invol. membranous.

Hab. Fiji, Daernel ; communicated by Prof. Reichenbach.-This bears the same relation to $A$. decurrens that the preceding does to A. latifolium.

§\$§\$§ Hemidictyum, Presl. V Vins anastomosing towards the margin. Sori single. Fig. 38, h. Sp. 277-280.

277. A. (Hemi.) Ceterach, L. ; st. densely tufted, 1-3 in. 1., wiry, ebeneous, chaffy ; fr. 4-6 in. l., 1 in. or less br., cut down nearly or quite to the rachis into alternate, blunt subentire broadly-oblong or roundish lobes, $\frac{3}{8}-\frac{1}{2}$ in. 1 , $\frac{1}{4-3}$ in. br., with a rounded sinus between them; texture subcoriaceous; upper surface naked; lower densely coated with small pale reddish-brown ovate membranous scales; sori linear, oblique; invol. very rudimentary.-Brit. $F$. $t$. 36. Ceterach officinarum, Willd.- $\beta, C$. aureum, Link ; fr. 6-12 in. $1 ., 1 \frac{1}{2}-2$ in. br., lobes oblong, scales toothed.-Hk. Sp. 3. p. 273.

Hab. Britain and Gothland to Spain, Greece, Himalayas, and the Caucasus ; $\beta$, Canaries and Madeira.- The involucre is so very nearly absent, that this is placed by most authors in Grammitidece.

278. A. (Hemi.) Purdieanum, Hk.; st. 6-9 in. 1., clothed copiously with greyish-brown lanceolate-acuminate scales; fr. 6-9 in. each way, deltoid, cordate, with a terminal and $2-3$ pairs of opposite lateral pinnoe, the largest 4-5 in. 1., 1 $\frac{1}{2}-2$ in. br., acute at the point, narrowed at the base, the edge entire ; texture subcoriaceous; both surfaces naked; veins fine, the primary ones very oblique, anastomosing copiously halfway from the midrib to the edge, connected by a vague line within the margin; lower sori sometimes 1 in. l.-Hk. Sp. 3 . p. 273. Ic.t. 938 .

Hab. Discovered by Mr. Purdie in Venezuela (not Jamaica), and since gathered by Dr. Spruce in Peru.

279. A. (Hemi.) Finlaysonianum, Wall. ; st. 6-9 in. 1., green, subcompressed, nearly naked ; fr. 12-18 in. 1., 6-8 in. br., simply pinnate, with 2-6 opposite pairs of lateral pinnoe, the lower ones $4-8$ in. $1 ., 1 \frac{1}{2}-2$ in. br., the point very acuminate, the base narrowed very gradually on both sides to a distinct petiole, the edge entire, the two sides often unequal; texture coriaceous; veins subflabellate, very oblique, anastomosing . slightly towards the edge, sometimes bounded by an 
irregular intramarginal line; sori often $1 \frac{1}{2}-2$ in. 1.-Hk.Sp. 3. p.271. Ic. t.937. Asplenidictyon, J. Sm.

Hab. Himalayas and Malayan Peninsula.-This has the same close relation to A. macro* phyllum that elegans has to fraxinifolium.

280. A. (Hemi.) marginatum, Linn. ; st. $2-3$ ft. l., strong, erect, woody, sometimes $\frac{1}{2}$ in. thick at the base ; fro simply pinnate, $4-6 \mathrm{ft} .1 . ;$ pinnoe in several opposite pairs, the lowest 1-2 ft. 1., 3-4 in. br., the edge entire, the base often cordate; texture papyraceo-herbaceous; rachis naked, polished; veins anastomosing copiously in the outer third of the space between the midrib and edge, bounded by a distinct intramarginal line; sori long, linear, confined to the free veins.-Hk. Sp. 3. p.271. Fil. Ex.t. 63 .

Hab. Tropical America, from Cuba and Venezuela to Peru and Brazil.

\section{Gen. 39. Allantodia, Wall. (in part).}

Sori dorsal, linear-oblong, attached to the primary veins. Invol. the same shape as the sorus and quite enclosing it, bursting in an irregular line down to the centre. A single simply pinnate species with thin ample pinnce, differing from Asplenium in the dehiscence of the involucre. TАв. IV. f. 39.

1. A. Brunoniana, Wall. ; fr. often 2 ft. l., 1 ft. br. ; pinnoe $4-6$ in. 1., 1 in. br., entire; veins forked near the midrib, two rows of hexagonal areolæ occupying the outer half of the space between the midrib and the edge, bounded by an intramarginal line; spri confined to the anterior vein of the first fork. $-H k . S p$. 3. $p .275$.

Hab. Himalayas (up to 6,000 ft.), Ceylon, Java, Tahiti.-Asplen. javanicum, Blume, is the oldest name.

\section{Gen. 40. Actiniopteris, Link.}

Sori linear-elongated, submarginal. Invol. the same shape as the sorus, folded over it, placed one on each side of the narrow segments of the frond opening towards the midrib. A single species, at once recognizable by its flabellate habit, like a palni-tree (Chamoerops) in miniature, with fruit in character intermediate between Asplenieæ and Pterideæ. 'ТА в. IV. f. 40.

1. A. radiata, Link ; st. densely tufted, 2-6 in. 1. ; fr. like a fan, 1-1 $\frac{1}{2}$ in. deep, composed of numerous dichotomous segments which are rush-like in texture, not more than $\frac{1}{2}$ lin. br., the veins few and subparallel with the indistinct midrib, the segments of the fertile frond longer than those of the barren one.Ic. Fil. t. 975.- $\beta$, A. australis, link; segm. fewer, longer, subulate at the point. -Ic. Fil. t. 976. Hk. Sp. 3. p. 276.

Hab. Throughout India, especially in the Peninsula, Ava, Ceylon, Arabia, Upper Egypt, Abyssinia, Mascaren Isles, Zambesi-land, Macalisberg, Angola.

\section{Tribe 9. Scolopendriex.}

Sori as in Aspleniex, except that the involucres are arranged in pairs and open towards each other. GEN. 41.

\section{Gen. 41. Scolopendrium, Sm.}

\section{Characters of the tribe. TAB. IV. f. 41.}

\section{§ Euscolopendrium. Veins free or anastomosing only casually. Sp. 1-4.}

1. S. vulgare, Sm. ; st. 4-8 in. 1., fibrillose below ; fr. $6-18$ in. 1 ., $1 \frac{1}{2}-3$ in. br., ligulate-oblong, entire, the base cordate; texture subcoriaceous; veins in groups 
of 2-4, rarely anastomosing.-Hk. Sp.4.p.1. Brit. F. t. 37. S. Lindeni, $H k$. Ic. Pl.t. 488.

Hab. Britain and Gothland to Spain, Madeira, the Azores, the Caucasus and Japan ; United States and Mexiso, rare.-A very large number of curious varieties and monstrosities are in cultivation, of which the most remarkable has non-indusiate sori on the edge and upper surface of the frond and anastomosing venation.

2. S. Hemionitis, Sw.; st. 4-6 in. l., slender, slightly fibrillose ; fr. 4-6 in. 1., oblong-lanceolate, the base hastato-cordate, with short and rounded or prominent and almost acute lobes; texture thinner than in the last; sori shorter; veins more branched. $-H k$. $S p$. 4. p. 2.

Hab. Spain, S. France, Italy, and the Mediterranean Islands.

3. S. pinnatum, J. Sm. ; st. compressed, greyish ; fr. 2-4 ft. l., with an entire terminal pinna 4-6 in. 1., $1 \frac{1}{2}-2$ in. br., proliferous at the point and 1-6 pairs of similar lateral ones; texture subcoriaceous; veins usually once forked; sori oblique, $\frac{1}{2}-\frac{3}{4}$ in. 1., 1 lin. br.-Hk. Sp. 4. p. 2.

Hab. Philippines, Cuming, 187, 311. - S. longifolium, Presl (Micropodium, Mett.), gathered at Luzon by Haenke, has a simple undivided frond, and the limit between the edges of the contiguous involucres marked by a thin line, whilst in S. pinnatum it is an evident lamelliform crest. See Mett. Fil. Ind, 2. p. 233.

4. S. Durvillei, Bory ; rhizome firm, wide-scandent ; st. 2-3 in. 1., firm, erect, naked; $f r$. varying from simple lanceolate-oblong, 6 in. l., 1 in. br., the edge crenate, the base auricled (these alone fertile), to subdeltoid bipinnatifid, with several pinnce on each side, the lowest $1 \frac{1}{2}$ in. 1. , $\frac{3}{4}$ in. br., cut down nearly to the rachis into narrow toothed or pinnatifid lobes; texture subcoriaceous, both sides naked; veins of entire frond subparallel, simple or forked; sori reaching from the midrib two-thirds of the space to the edge without any raised line between them.-Kunze, Suppl. Schk.p.9. t. 5. Micropodium, Mett.

Hab. Ualan ; gathered first by Durville.

$\S \S$ Antigramme, Presl Frond with a distinct midrib, veins anastomosing towards the edge. Sp. 5-6.

5. S. (Anti.) Brasiliense, Kunze ; st. short, fibrillose ; fr. 6-12 in. 1., 1-1 $\frac{1}{2}$ in. br., subentire, tapering towards both ends; texture coriaceous; veins anastomosing about two-thirds of the distance from the midrib to the edge; sori linear, confined to the free veins.-Hk. Sp. 4. p. 3.

Hab. Brazil.-A. subsessilis, Fée, is a subsessile form, with a longer and narrower frond than usual.

6. S. (Anti.) plantagineum, Schrad.; st. 6-9 in. 1., firm, grey, naked; fr. 6-10 in. 1., 3-5 in. br., ovate, the base rounded or truncate or cordate, the edge entire ; texture coriaceous; veins anastomosing within about $\frac{1}{2}$ in. of the edge; forks of the free veins $\frac{1}{8}$ in. apart; sori confined to the free veins. - S. Douglasii, Hk. Sp. 4. p. 3. Asplenium, Hk. \& Gr. Ic. t. 150.

Hab. Brazil.

$\S \S \S$ Schaffneria, Feee. No distinct midrib, but the veins flabellate, uniting towards the edge. Sp. 7 .

7. S. (Schaff.) nigripes, Hk.; st. 1-2 in. 1., black, polished, naked, jointed at the apex; fr. obovate or roundish, $1-1 \frac{1}{2}$ in. br. ; texture thick, coriaceous; sori in 
irregularly linear or oblong patches.-Schaffneria, Fée. Asplenium, Hk. Kew Gard. Misc. 9. t. 9.

Hab. Mexico and Guatemala.

$\S \S \S \S$ Camptosorus, Link. Veins anastomosing near the midrib but free outwards. Sori usually in opposite pairs, but more or less divaricating. Sp. 8-9.

8. S. (Campt.) rhizophyllum, Hk.; st. 1-4 in. 1., naked, compressed, below chesnut-brown ; fr. 4-9 in. l., lanceolate, from an auricled cordate base, the point tapering out and often rooting ; texture coriaceous ; sori short, irregular, linearoblong.-Hk. Sp. 4. p. 4.

Hab. British America to the Southern United States.

9. S. (Campt.) sibiricum, Hk.; barren fr. ovate-acuminate, 1 in. $1 ., \frac{1}{4-\frac{3}{8}}$ in. br.; fertile fr. 6 in. or more l., $\frac{1}{4}$ in. br., the apex elongated and rooting, the base not auricled and narrowed gradually; st. 2-3 in. l., naked, green upwards, ebeneous below ; texture subcoriaceous; sori linear or oblong.-Hk. Sp. 4. p. 4. 2nd Cent.t. 35.

Hab. W. Siberia, Kamschatka, Tsus-Sima, Japan.

\section{Tribe 10. Aspidiea.}

Sori dorsal, subglobose, rarely elliptical. Involucre superior, similar in shape to the sorus, fixed either by the centre or a sinus. Gen. 42-47.

\section{Gen. 42. Didymochlana, Desv.}

Sori elliptical, terminal on a veinlet, but distinctly intramarginal. Invol. elliptical, emarginate at the base, attached to the linear receptacle, free all round the edge. TAB. 4. f. 42 .

1. D. lunulata, Desv. ; caud. erect, subarborescent ; $f r$. densely tufted, 4-6 ft. 1., bipinnate; pinnl. $\frac{3}{4}-1$ in. br., dimidiate, subquadrangular, entire or slightly sinuated; texture subcoriaceous; venation subflabellate; sori 2-6 to a pinnule. -Hk.Sp. 4. p. 5. G. F.t. 17. Aspid. truncatulum, Siv., Willd.

Hab. Tropical America, from Cuba and Guatemala to Peru and Brazil ; Fiji, Malayan Peninsula and Isles, Madagascar, Johanna Island, Natal, Fernando Po.-The pinnules in shape and texture correspond with those of the dimidiate Adiantece and Lindsayce.

2. D. polycarpa, Baker ; caud. erect ; st. tufted, short ; fr. 2-3 ft. 1., 12-18 in. br., simply pinnate; pinnoe close, very numerous, spreading, d windling down below to mere auricles, the largest 6-9 in. $1 ., \frac{1}{2}$ in. br., cut down halfway or more to the rachis into close linear-oblong lobes; rachis and lower surface villose; veins very close, pinnated, 12 or more on each side in a lobe ; sori small, close, ultimately confluent.-Aspid. Bl., Mett. Nephrodium javanicum, Hk. Sp. 4. p. 67. Fil. Ex. t. 61. Mesochlæna, R. Br. MSS. Sphærostephanos, J. Sm.

Hab. Malayan Peninsula and Islands. - Habit and venation of Eunephrodium, but the involucre in structure resembles the preceding. $M$. asplenioides, J. Smith, is a villose variety, with narrower pinnæ than usual, with short oblong-deltoid lobes.

\section{Gen. 43. Aspidium, $S w$. (in part), R. Br.}

Sori subglobose, dorsal or terminal on the veinlets. Invol. orbicular, fixed by the centre. A cosmopolitan genus, the species of which vary much in size, texture, cutting, and venation. ТА B. 5. f. 43 , 
Polystichum, Roth. Veins all free. Sp. 1-42. Texture more or less coriaceous in all except species 1, 4, 38, 39, and 41, and teeth usually awned.

\section{* Frond pinnatifid only. Sp. 1-2.}

1. A. (Polyst.) glandulosum, Hk. \& Gr. ; st. tufted, very short ; fr. 6-8 in. 1., 1-1 $\frac{1}{2}$ in. br., oblong-lanceolate, tapering to both ends, cut down nearly to the rachis above and quite below into bluntly sinuated linear-oblong lobes, emarginate on the upper, decurrent on the lower side at the base; texture herbaceous; rachis and both surfaces finely glanduloso-pilose; veins pinnate, the veinlets in groups of three; sori $2-8$ to a pinna, midway between the midrib and edge.-Hk.Sp.4.p.6. Hk. \& Gr.t. 140. (not Blume).

Hab. Cuba and Jamaica.

2. A. (Polyst.) Plaschnichianum, Kunze ; st. tufted, 3-4 in. 1., slender, fibrillose below ; fr. 4-6 in. 1., $\frac{1}{2}-\frac{3}{4}$ in. br., lanceolate, rooting at the point, subentire or slightly or deeply lobed at the base; texture coriaceous; both surfaces slightly fibrillose; lower veins in groups of four; sori copious, scattered.-Hk. Sp. 4. p. 7.t. 211.

Hab. Jamaica.-According to Grisebach, a less cut form of species 3.

* Fronds once pinnate, the lower pinnce entire or pinnatifid belowo. Sp. 3-17.

3. A. (Polyst.) rhizophyllum, Swz. ; st. tufted, 1-2 in. l., fibrillose, slender ; fr. 2-6 in. l., $\frac{3}{4}$ in br., with the long, narrow, upper half of the frond lengthened out and rooting, the lower half cut down to a flattened fibrillose rachis into oblong rhomboidal subentire lobes, $\frac{3}{8}-\frac{1}{2}$ in. br., $\frac{1}{4}$ in. deep ; texture subcoriaceous ; veins copiously pinnate in the lobes; sori scattered.-Hk.Sp. 4. p. 7. Hk. \& Gr. Ic.t. 59 .

Hab. Jamaica and Cuba.

4. A. (Polyst.) semicordatum, Sw. ; st. scattered, 6-12 in. l., fibrillose at the base ; fr. 2-3 ft. l., 8-i2 in. br., simply pinnate; pinnoe spreading, 4-6 in. l., $\frac{1}{2}-\frac{3}{4}$ in. br., nearly entire, acuminate, cordate or truncate at the base ; texture papyraceo-herbaceous or subcoriaceous, both sides naked and rachis nearly so ; veins pinnate, the lower ones ending short of the edge ; sori in 1-3 rows on each side, the inner one the most constant and regular, close to the midrib.- $H k$. $S p$. 4. p. 16. Cyclopeltis, J. Sm.

Hab. Tropical America, from Cuba and Panama to Brazil and Peru; Philippines, Amboyna, Malayan Peninsula and Isles.-This corresponds to the genus Hemicardium of Fée, who makes five species. A. Kingii, Hance (Ann. Sc. Nat. 4. ser. 18. p. 237), from the Caroline Isles, is said to have blunt repand pinnæ $1 \frac{1}{2}$ in. 1. , under $\frac{1}{2}$ in. br.; veins less branched, and fruit in a single line.

5. A. (Polyst.) munitum, Kaulf. ; st. tufted, 4-9 in. 1., strong, straw-coloured, densely clothed, especially below, with large glossy lanceolate scales; fr. 1-2 ft. 1., 4-8 in. br.; pinnoe close, 3-4 in. $1 ., \frac{3}{8}-\frac{1}{2}$ in. br., the apex acuminate, the edge finely spinuloso-serrated throughout, the upper side auricled and the lower obliquely truncate at the base; texture subcoriaceous; rachis generally scaly; veinlets fine, close; sori in two rows near the edge.-Hk. Sp. 4. p. 10.t. 219.

Hab. Western N. America, from Nootka to California.

6. A. (Polyst.) falcinellum, Swz.; st. tufted, 4-8 in. 1., densely olothed, especially below, with blackish-brown lanceolate scales ; fr. 12-18 in. 1., 4-6 in. br. ; central pinnoe with about their own space between them, 3 in. $1 ., \frac{1}{1}$ in. br., the 
point acute, the edge finely not spinosely serrated, the upper side bluntly auricled, the lower obliquely truncate at the base; texture very coriaceous; rachis usually scaly; veins inconspicuous; sori in two long rows. Hk.Sp.4. p. 10. Fil. Ex.t. 53 .

Hab. Madeira.-P. maderense, Johnst. (Ann. N. H. April, 1866), is said to be intermediate between this and $P$. angulare.

7. A. (Polyst.) acrostichoides, Swz.; st. 6-8 in. 1., densely clothed below with pale-brown lanceolate scales ; $f r .1 \frac{1}{2}-2 \mathrm{ft} .1 ., 3-5 \mathrm{in}$. br., the pinnoe of the lower half barren, 2-3 in. l., $\frac{1}{4}$ in. br., spinoso-serrated throughout, auricled at the base above, the pinnæ of the upper half fertile, much smaller; texture subcoriaceous; rachis straw-coloured, usually rather scaly ; veinlets in groups of four; sori occupying the whole under side of the fertile pinnæ.-Hk. Sp.4. p.9.

Hab. Canada to Florida and the Mississippi.-A. Schweinitzii, Beck, is a form with lobed pinnæ.

8. A. (Polyst.) lepidocaulon, Hk. ; st. tufted, 6-9 in. l., weak, densely clothed with large cordate brown scales ; fr. $1 \mathrm{ft}$. or more l., 4-6 in. br., sometimes elongated and radicant at the point ; pinnoe. $2-3$ in. l., $\frac{1}{2}-\frac{3}{4}$ in. br., lanceolatefalcate, not toothed, the two sides unequal, the upper ones with a triangular auricle at the base; texture subcoriaceous; rachis densely scaly like the stipe, lower surface with scattered scales; veins obscure, sometimes slightly connected; sori principally in two rows a short space from the midrib.-Hk. $S p .4$. p. 12. $t .217$.

Hab. Japan and Tsus-Sima.-Habit and texture of A. falcatum, but the veins only casually joined, and the rachis densely scaly.

9. A. (Polyst.) Lonchitis, Swz.; st. densely tufted, 1-4 in. 1., ebeneous and clothed with large lanceolate pale-brown scales at the base; fr. 12-18 in. l., 1-2 in. br., pinnate throughout; pinnoe $\frac{1}{2}-1$ in. $1 ., \frac{1}{4}-\frac{3}{8}$ in. br., ovate-rhomboidal, subfalcate, the two sides unequal, the point mucronate, the edge spinulososerrated, the upper side sharply auricled at the base, the lower obliquely truncate ; rachis nearly naked; texture coriaceous; sori usually in two rows.Hk.Sp.4.p.8. Brit. F.t.9.

Hab. Arctic Europe to Portugal, Naples, Greece, Himalayas, and Davuria ; Greenland, and mountains of the N. United States, and British America.

10. A. (Polyst.) mucronatum, Swz. ; st. tufted, 2-4 in. 1., stout, erect, densely clothed with large reddish-brown lanceolate scales; fr. $12-18$ in. $1 ., 1 \frac{1}{2}-2$ in. br., pinnate throughout; pinnoe very numerous, often imbricated, $\frac{3}{4}-1 \mathrm{in} . \mathrm{l}$., $\frac{1}{4}-\frac{3}{8}$ in. br., subrhomboidal, unequal-sided, the point mucronate, the edge subentire or slightly lobed, distinctly auricled at the base on the upper side; texture very coriaceous; rachis stiff and densely scaly; sori in a long row on each side the midrib. $-H k$. Sp. 4. p.9.t. 216.

Hab. West Indies.-Very like the preceding in appearance and texture.

11. A. (Polyst.) Lachenense, Hk.; st. densely tufted, 2-4 in. 1., stout, ebeneous, and clothed with large lanceolate scales below; fr. 4-8 in. l., $\frac{1}{2}-\frac{3}{4}$ in. br., pinnate throughout; pinnoe $\frac{1}{4}-\frac{3}{8}$ in. 1., 2-3 lin. br., ovate-deltoid, the two sides equal, the point bluntish, the edge spinoso-serrated, bluntly lobed below halfway down; texture coriaceous; rachis stramineous, fibrillose; sori often covering the whole under side of the pinnæ.-Hk. Sp. 4. p. 8. t. 212.

Hab. Sikkim, Himalayas (13-16,000 ft.); gathered by Drs. Hooker, Thomson, and Anderson.

12. A. (Polyst.) triangulum, Swz. ; st. tufted, 2-6 in. l., with large dark- 


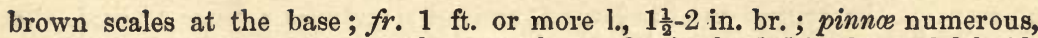
sessile, the lower ones distant, the central ones $\frac{3}{4}-1$ in. $1 ., \frac{3}{8}-\frac{5}{8}$ in. br., subdeltoid, but the lower side obliquely truncate, apex mucronate, edge subentire or slightly lobed with blunt or spinose teeth, one or both sides auricled at the base ; texture coriaceous ; rachis slightly scaly; veins flabellate; sori principally in two rows near the edge.-Hk. Sp. 4. p. 14 .

Hab. West Indies.- $P$. ilicifolium, Fée, appears to be a form with elongated fronds rooting at the point.

13. A. (Polyst.) auriculatum, Sw. ; st. tufted, 4-6 in. 1., scaly below or throughout ; fr. 12-18 in. l., 2-4 in. br.; pinnoe numerous, subsessile, usually close, 1-1 $\frac{1}{2}$ in. $1 ., \frac{3}{8}-\frac{1}{2}$ in. br., ovate-rhomboidal, falcate, the point acute, the edge spinoso-serrated, not lobed, the upper one with a prominent auricle, the lower one truncate in a horizontal line at the base; texture subcoriaceous; rachis stramineous, slightly scaly; lower veinlets in groups of three; sori in two rows. - $\beta, A$. marginatum, Wall. ; texture more coriaceous, upper edge of the pinnæ slightly lobed. $-\gamma, A$. lentum, Don; pinnoe cut into oblong mucronate lobes about halfway down to the rachis, the auricle sometimes quite. free.-A. ocellatum, Wall. Hk. Sp. 4. p. 11.

Hab. Throughout India and Ceylon, ascending in the Himalayas to 9,000 ft., Formosa. $-A$. obliquum, Don (ccespitosum, Wall.), agrees very nearly with $\alpha$. The typical plant looks distinct, but is connected by gradual intermediates with $\gamma$, which is barely distinguishable from $A$. lobatum.

14. A. (Polyst.) iticifolium, Don; st. densely tufted, 2-4 in. 1., slender, clothed with large scales throughout; fr. 6-9 in. 1., 1-2 in. br.; pinnoe subdeltoid or lanceolate, $\frac{x}{2}-1$ in. l., the apex mucronate, cut down below to the rachis into lanceolate or ovate-mucronate lobes; texture coriaceous; both surfaces naked; rachis slender, fibrillose; veins immersed; sori principally in two rows near the midrib.-A. stimulans, Kze. Hk. Sp. 4. p. 12. $t .214$.

Hab. N. India, ascending to $9,000 \mathrm{ft}$.-Quite doubtfully distinct from some of the forms of auriculatum and aculeatum.

15. A. (Polyst.) Thomsoni, Hk. ; st. tufted, 2-4 in. 1., slender, straw-coloured, fibrillose ; fr. 6-8 in. l., $\frac{3}{4-1}$ in. br., lanceolate-acuminate, narrowed gradually below, pinnate throughout; pinnoe $\frac{1}{2}$ in. l., $\frac{1}{4}$ in. br., ovate-deltoid, unequalsided, the lower side the smallest and obliquely truncate at the base, the edge pinnatifid halfway down or more, the lobes with sharp mucronate teeth; texture subcoriaceous; rachis naked or fibrillose; veins pinnate in the lower lobes ; sori mostly one to each lobe.-Hk. Sp. 4. p. 7. 2nd Cent.t. 25.

Hab. Himalayas, $7 \cdot 13,000 \mathrm{ft}$.

16. A. (Polyst.) viviparum, Fée ; st. tufted, 4-6 in. 1., with large lanceolate scales at the base, the lower ones nearly black in the centre; fr. 12-18 in. 1., 4-6 in. br. ; pinna numerous, nearly lanceolate, the central ones 2 in. $1 ., \frac{1}{2}-\frac{5}{8}$ in. br., the point mucronate, sometimes gemmiparous, the edge more or less deeply lobed, in the lower part sometimes quite down to the rachis, the upper side auricled, the lower obliquely truncate at the base ; texture very coriaceous; sori in two or four rows.-Hk. Sp. 4. p. 15.

Hab. West Indies. $-P$. heterolepis, Fée, is a form with long narrow pinnæ, the pinnules of the lower half distinct, the lowest slightly stalked. This may be the A. trapezioides of Swartz, with which Moore joins it.

17. A. (Polyst.) tridens, Hk. ; st. tufted, 2-4 in. 1., wiry, clothed with blackish lanceolate scales below ; fr. 6-9 in. l., 1-1 i in. br.; pinna numerous, close, $\frac{1}{2}-\frac{3}{4}$ in. l., $\frac{1}{4}-\frac{2}{8}$ in. br., deeply tripartite, all the three lobes linear-lanceolate, 
mucronate, the central one the largest, and all sometimes a little toothed, the base cuneate, nearly equal on both sides, the lower ones distinctly stalked; texture very coriaceous; veins obscure; sori in two close rows.p. 15.t. 215 .

Hab. Jamaica; gathered by Purdie and Wilson.-This and the preceding are both united by Grisebach with triangulum.

\section{*** Lower pinnce once pinnate. Sp. 18-29.}

18. A. (Polyst.) aculeatum, Sw.; st. tufted, 6-12 in. 1., more or less clothed with ovate-lanceolate and fibrillose pale brown-scales ; fr. 1-2 ft. 1., 8-12 in. br., ovate-lanceolate; lower pinnce close, lanceolate, 4-6 in. l., $\frac{1}{2}-\frac{3}{4}$ in. br.; pinnl. ovate-rhomboidal, unequal-sided, auricled on the upper side at the base; teeth aristate; texture subcoriaceous; rachis straw-coloured, more or less scaly; under surface slightly fibrillose; sori principally in two rows nearer the midrib than the edge.- $-a, A$. lobatum, Sw. ; texture coriaceous ; pinnl. confluent at the base. $-\beta, A$. aculeatum, Sw. ; texture less rigid ; pinnl. sessile, the lower ones free. $-\gamma, A$. angulare, Willd.; texture less rigid, lower pinnl. stalked, sometimes deeply pinnatifid.-Hk. Sp. 4. p. 18.

Hab. Throughout the world ; rare in the Arctic regions and Eastern N. America.A. squarrosum, Don (rufo-barbatum, Wall.) has the rachis densely clothed with reddishhrown fibrillose scales ; A. proliferum, Br., is a proliferous Australian form ; A. vestitum, Sw., bas the rachis densely clothed to the point both with reddish-brown fibrillose and large lanceolate dark-brown scales; $A$. biaristatum, Blume, has the frond narrowed suddenly uprards, and large rhomboidal pinnules, aristate principally at the point and auricle; the Cape $A$. luctuosum, Kunze, has the scales of the rachis fibrillose and nearly black; A. Tsus-Simense, Hk., is probably a slender form ; and A. ordinatum and Moritzianum, Kunze, and Polyp. muricatum, L., are luxuriant forms from S. America. We have non indusiate forms from New Zealand (Polyp. sylvaticum, Colenso), Britain (var. plumosum, Moore); and there is a wide range of forms in S. America included under Polyp. rigidum (Sp. Fil. 4. p. 246 ; Ic. Fil. t. 163), which correspond to the various forms of this species, differing only by the want of an involucre.

19. A. (Polyst.) pungens, Kaulf. ; rhizome stout, wide-creeping ; st. scattered, $1 \mathrm{ft}$. l., stramineous, scaly only below ; fr. 2-3 ft. l., 9-12 in. br.; lower pinnae 6-12 in. l., 1-2 in. br.; pinnl. ovate-rhomboidal, unequal-sided, often deeply pinnatifid, the teeth awned; texture subcoriaceous; both surfaces naked; sori principally in two rows nearer the midrib than the edge.-Schlecht. Adumb. p. 21, t. 10 .

Hab. Cape Colony and Natal.-Best distinguished from aculeatum by its creeping rhizome.

20. A. (Polyst.) mohrioides, Bory; st. tufted, 2-6 in. 1., stout, more or less densely clothed with lanceolate dark-brown scales; fr. 6-12 in. 1., 2-3 in. bl., with numerous dense, often imbricated, lanceolate pinnoe, which are cut down below into slightly-toothed oblong-rhomboidal pinnl.; teeth blunt or mucronate; texture coriaceous; both surfaces naked; rachis stout, compressed, scaly ; veins close, immersed; sori copious.-Hk. Sp. 4. p. 26.

Hab. Patagonia and the Cordilleras of Chili.-Like a stout reduced form of lobatum; but teeth in the typical specimens not at all spinulose; and a specimen from Bourbon quite agrees with the Patagonian plant.

21. A. (Polyst.) obtusum, Mett.; st. tufted, 4-6 in. 1., densely clothed with large, ovate-acuminate, bright-brown scales ; fr. $1 \mathrm{ft}$. or more 1., 4-6 in. br., lanceolate, with numerous distant linear-lanceolate pinno, the lower ones 3-4 in. 1., $\frac{3}{4}$ in. br.; pinnl. distinct, oblong-rhomboidal, the obscure teeth blunt or 
mucronate; texture subcoriaceous; surfaces naked; rachis densely fibrillose ; sori in two rows midway between edge and midrib.-Hk. Sp. 4. p. 24. $t .221$.

Hab. Luzon, Cuming, 234, Lobb.-Probably should be joined to aculeatum.

22. A. (Polyst.) californicum, Eaton ; st. 4-6 in. 1., straw-coloured, slightly scaly ; fr. 12-15 in. 1., 4 in. br., with numerous close-placed lanceolate pinnoe, the largest 2 in. l., $\frac{1}{2}$ in. br., the upper part with a broad, entire centre, the lower cut down nearly or quite to the rachis ; pinnl. ovate-deltoid, unequalsided, the teeth very mucronate ; texture coriaceous; rachis clothed throughout with small pale-brown scales; under surface fibrillose, especially on the midrib; sori almost confined to the outer half of the pinnoe.-Proc. Am. Ac. vol. 6. p. 555 .

Hab. California, Hillebrand.-Very near A. lobatum.

23. A. (Polyst.) Richardi, Hk.; st. tufted, 6-12 in. l., stout, erect, scaly throughout; fr. 9-18 in. 1., 6-9 in. br., ovate-deltoid, with numerous closeplaced lanceolate pinnoe $3-6$ in. $1 ., 1-1 \frac{1}{2}$ in. br., cut down below into distinct lanceolate sharply-toothed deeply-lobed pinnl.; texture coriaceous ; rachis slightly scaly; both surfaces nearly naked; veins immersed; sori in two rows midway between the midrib and edge.-Hk. Sp. 4. p. 23. $t .222$.

Hab. New Zealand and Fiji.-Differs from aculeatum by its more rigid texture, shorter teeth, and lower pinnæ not reduced.

24. A. (Polyst.) oculatum, Hk.; st. tufted, $1 \mathrm{ft}$. 1., firm, straw-coloured, clothed throughout with dark-brown lanceolate scales ; fr. $1 \mathrm{ft}$. or more 1., 4-6 in. br., ovate-deltoid, with numerous pinnoe on each side, the lower ones lanceolate-

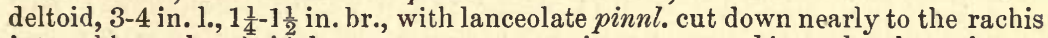
into oblong-rhomboidal segm.; texture coriaceous; rachis scaly throughout; lower surface furfuraceous; veins immersed; sori in two rows near the midrib. - Hk. Sp. 4. p. 24. t. 228.

Hab. New Zealand.- Very near the last, but the under surface downy, and segments shorter and blunter. Species 19-24 are all very near to 18.

25. A. (Polyst.) cystostegia, Hk. ; st. tufted, 2-4 in. 1., brown, shining, clothed with large lanceolate pale-brown scales; fr. 6-9 in. $1 ., 1 \frac{1}{2}-2$ in. br., oblonglanceolate; central pinnce close, ovate-deltoid, the lower ones distant and reduced; lower pinnl. oblong-lanceolate, deeply lobed, the teeth blunt; texture subcoriaceous; colour bright-green; surfaces naked; rachis densely clothed with linear pale-brown scales; sori in two rows in the lower pinnl.; invol. large, very convex. $-H k$. $S p$. 4. p. 26. $t .227$.

Hab. Mountains of N. Zealand.-A well-marked plant, scarcely more than herbaceous in texture.

26. A. (Polyst.) Prescottianum, Hk. ; st. tufted, 1-4 in. 1., clothed with large lanceolate pale-brown scales; fr. 12-18 in. 1., 2-3 in. br., narrowly ovatelanceolate, with numerous spreading pinnoe, 1-1 $\frac{1}{2}$ in. $1 ., \frac{1}{2}-\frac{5}{8}$ in. br., cut down to the rachis into several oblong-rhomboidal pinnl. with aristate teeth; texture subcoriaceous; rachis weak, stramineous, densely scaly throughout; veins immersed; sori filling up nearly the whole breadth between edge and midrib.Hk. Sp. 4. p. 22. t. 223.

Hab. N. India, ascending to $12,000 \mathrm{ft}$.-Distinguishable from the other Himalayan forms by its long narrow finely-cut flaccid frond.

27. A. (Polyst.) anomalum, Hk. \& Arn.; st. tufted, 1-2 ft. 1., stout, erect, 
densely clothed, especially below, with large lanceolate pale-brown scales; fr. 2-3 ft. l., $1 \mathrm{ft}$. or more br.; lower pinnae 6-9 in. 1., 2-3 in. br. ; pinnl. lanceolate, cut down in the lower part into oblong segm. ; teeth blunt or slightly mucronate ; texture subcoriaceous; rachis more or less scaly; both surfaces naked; veins obscure; sori placed near the sinuses of the pinnl.-Hk. Sp. 4. p. 27. Kew Gard. Misc. 8. $t$. 11.

Hab. Ceylon.-A very curious plant, perhaps an abnormal form of 18 . The sori are often upon the upper surface, and sometimes quite destitute of involucre.

28. A. (Polyst.) amabile, Blume ; st. scattered, 6-12 in. l., slender, polished, slightly scaly below ; $f r .1 \mathrm{ft}$. or more l., 6-9 in. br., with a lanceolate terminal pinna and 3-6 lateral ones on each side, which are 6-8 in. 1., 1-1 $\frac{1}{2}$ in. br., the lowest sometimes slightly compound at the base; segm. subrhomboidal, with at least half the lower side cut away, $\frac{1}{2}-\frac{3}{4}$ in. $1 ., \frac{1}{4}-\frac{3}{8} \mathrm{in.} \mathrm{br.,} \mathrm{the} \mathrm{upper} \mathrm{side} \mathrm{and}$ outer part of the lower lobed and sharply spinuloso-serrated ; texture subcoriaceous; rachis and both surfaces naked; lower veinlets in groups of $3-5$; sori submarginal.-Hk. Sp. 4. p. 25. t. 225.

Hab. Nepaul, Ceylon, Malaccas, Formosa, Japan.-This is nearest the simpler forms of aristatum, but has a long terminal pinna, with subuniform large rhomboidal segments.

29. A. (Polyst.) tripteron, Kunze ; st. 6-9 in. l., densely clothed at the base with large ovate dark-brown scales ; fr. 12-18 in. l., with a large terminal and two small spreading lateral pinnoe at the base of it, the former $2 \frac{1}{2}-3$ in. br., with very numerous spreading pinnl. on each side, $1 \frac{1}{2}$ in. $1 ., \frac{3}{8}-\frac{1}{2}$ in br., very unequal-sided, the point acute, the edge deeply inciso-pinnatifid, the lower lobes again toothed, the upper side abruptly narrowed and the lower obliquely truncate at the base; lat. pinnoe $3-5$ in. $1 ., 1 \frac{1}{2}-2$ in. br., with numerous similar pinnl.; texture herbaceous; rachis nearly naked, stramineous; sori principally in two rows midway between midrib and edge.-Hk. Sp. 4. p. 15 . 2nd Cent. t. 56.

Hab. Japan and Tsus-Sima.-A very distinct plant.

**** Lower pinnce more than once pinnate. Sp. 30-41.

30. A. (Polyst.) laserpitiifolium, Mett.; st. 4 in. l., stramineous, scaly at the base ; fr. 12-18 in. 1., 6-9 in. br., ovate-deltoid, tripinnate; lower pinnoe the largest, with pinnl. on the lower side prolonged, lanceolate, imbricated with small, distinct, bluntly, not deeply lobed segm.; texture subcoriaceous; colour light-green; both sides and rachis glabrous ; sori in two rows occupying nearly the whole space between the edge and midrib.-Mett. Fil. Ind. p. 227.t. 6. f. 2 .

Hab. Japan.-Differs from A. amabile by being more compound, with smaller, cuneate, oblong, less-toothed segments and larger sori.

31. A. (Polyst.) varium, Sw.; rhizome subrepent; st. 6-12 in. l., densely fibrillose below ; fr. 12-18 in. l., 9-12 in. br., lanceolate-deltoid ; lower pinnoe much the largest, subdeltoid, unequal-sided, 4-6 in. l., 3-4 in. br.; pinnl. lanceolate, imbricated, the lowest one on the under side much larger than the others; segm. oblong, blunt, faintly toothed, the teeth not awned; texture subcoriaceous; both surfaces naked; rachis slightly fibrillose ; sori principally in two rows near the midrib; invol. peltate or reniform.-Hk. $S p .4 . p_{0} .30$. t. 226. Lastrea, Hk. olim.

Hab. Japan, southward to Hong-Kong.-Habit intermediate between that of a Lastrea and typical Polystichum.

32. A. (Polyst.) capense, Willd.; st. scattered, 1-2 ft. l.., firm, erect, greyish, 
densely scaly below ; fr. 1-3 ft. 1., 12-18 in. br., subdeltoid ; lowest pinnoe the largest, 6-12 in. l., 3-4 in. br.; pinnl. and segm. lanceolate, the latter bluntly lobed, the teeth not mucronate ; texture very coriaceous; rachis strong, polished; both surfaces naked; veins immersed, pinnate; sori 1 lin. br., in two rows filling nearly the space between midrib and edge-Polyp. $L$. A. coriaceum, Sw. Hk. Sp. 4. p. 32.

Hab. America, from Cuba to Patagonia ; Polynesian Islands, New Zealand, and Australia ; Cape Colony, Natal, Mascaren Isles.

33. A. (Polyst.) flexum, Kunze ; rhizome stout, wide-creeping ; st. scattered, $1 \mathrm{ft}$. 1., deciduously scaly ; fr. 2-3 ft. l., 9-12 in. br. ; lower pinnoe lanceolatedeltoid, 6-9 in. 1., 4-6 in. br. ; pinnl. lanceolate-deltoid, cut down to the rachis below into oblong bluntly-lobed segm. $\frac{1}{2}$ in. $1 ., \frac{1}{4}-\frac{1}{2}$ in. br. ; texture coriaceous; teeth not awned; veins beneath prominent; under surface and rachises scaly; sori large, in two rows, occupying nearly the space between edge and midrib.A. Berteroanum, Colla. Hk. Sp. 4. p. 33. t. 229.

Hab. Juan Fernandez.-Closely allied to the preceding, from which it is distinguished by its furfuraceous rachis and under surface.

34. A. (Polyst.) Seemanni, Hk., ; st. stout, erect, the upper part naked; fr.

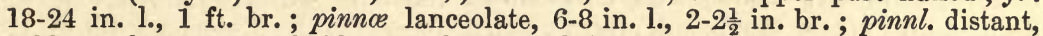
sublanceolate, unequal-sided, 1-1 $\frac{1}{2}$ in. l., $\frac{1}{4}-\frac{3}{8}$ in. br., bluntly lobed, the lower lobes reaching down nearly to the rachis; texture coriaceous; rachises and both surfaces nearly naked; midrib of the lobes prominent; sori $4-6$ in each.- $H k$. Sp. 4. p. 34. t. 230.

Hab. Panama, Seemann.-Very near the two preceding.

35. A. (Polyst.) ascendens, Hew. ; rhizome wide-climbing ; st. 1 ft. l., strawcoloured, polished, nearly naked ; fr. 2-3 ft. l., $1 \mathrm{ft}$. br., dimorphous; lower pinnoe of barren fr. subdeltoid, 6-9 in. 1., 3-4 in. br. ; pinnl. lanceolate-deltoid ; segm. stalked, ovate-rhomboidal, cut down to the rachis in the lower part and lobes acutely, not deeply toothed; texture coriaceous; rachis and both surfaces glossy, naked ; fertile segm. distant, $\frac{1}{2}$ in. l., $\frac{1}{8}$ in. br., the edge undulated; sori in two rows, which are close to the midrib and fill up the lobes.-Hk. $S p .4$. p. 32.t. 224.

Hab. Jamaica. - In habit this differs entirely from the other species, and coincides with Dicksonia coniifolia, of which Dr. Grisebach supposes it to be a dimorphic form.

36. A. (Polyst.) frondosum, Lowe; st. scattered, 1-2 ft. 1., strong, strawcoloured or pale-brown, polished, densely scaly below ; fr. 18-24 in. l., $1 \mathrm{ft}$. or more br., subdeltoid, the lower pinnce much the largest, 6-12 in. 1., 3-4 in. br., long-stalked; pinnl. lanceolate, erecto-patent; segm. very unequal-sided, pinnatifid, with rounded mucronate lobes, obliquely truncate at the base below; texture subcoriaceous; rachis glossy, stramineous ; both surfaces naked ; lateral veins of lobes often forked; sori large, copious, principally in two rows near the midrib.-Hk. Sp. 4. p. 31 .

Hab. Madeira, Zambesi-land, Natal.

37. A. (Polyst.) aristatum, Sw. ; rhizome creeping ; st. scattered, 12-18 in. 1., clothed, especially below, with linear or fibrillose scales; fr. 1-2 ft. l., 9-12 in. br., ovate-deltoid, tri- or quadripinnatifid ; lower pinnoe largest, 6-9 in. 1., 3-4 in. br., subdeltoid; lowest pinnl. much the largest, lanceolate-deltoid, 2-4 in. 1., with subdeltoid lower segm.; teeth copious, aristate; texture subcoriaceous, glossy ; both surfaces naked, rachis nearly so ; sori small, principally in two rows near the midrib; invol. sometimes reniform.- $\beta, A$. conii- 
folium, Wall. ; more finely divided ; segms. copiously toothed, with lower lobes distinct. $-\gamma, A$. Hamiltonii, Spr. ; texture more coriaceous ; lower pinnl. 3-4 in. l., with large ovate-deltoid slightly lobed segments.-Hk. Sp. 4. p. 27.

Hab. Japan and Himalayas to Ceylon, Norfolk Island, Fiji, Samoa, N. S. Wales, and Natal.-A. Cornu-Cervi, Don, is a deformed state of $\gamma$, which differs from capense principally by its aristate teeth, whilst the other varieties more resemble amabile and frondosum. Dr. Thwaites assigns to $\beta$ an erect caudex, and regards it as a good species. Arachniodes aspidioides, $\mathrm{Bl}$, is this, with the involucre fallen away.

38. A. (Polyst.) melanostictum, Kze. ; st. scaly below, 6-12 in. l., greyish ; fr. 18-24 in. l., 1 ft. br.; lower pinnoe 6-9 in. 1., 2-3 in. br.; pinnl. close, lanceolate, $1 \frac{1}{2}$ in. $1 ., \frac{1}{2}$ in. br., regularly cut down to the rachis into close, linear-oblong nearly entire slightly falcate segm.; texture herbaceous ; colour dark-green ; both surfaces and rachis nearly naked; sori 6-8 to a segm., placed in two rows filling up nearly the whole space between midrib and edge ; invol. peltate, black in the centre.-Hk. Sp.4. p. 34. t. 233. B.

Hab. Mexico.

39. A. (Polyst.) melanochlamys, Fée; st. tufted, 6-12 in. 1., erect, densely clothed, especially below, with dark-brown fibrillose scales; fr. 18-24 in. l., 9-12 in. br. ; pinnoe subdistant, erecto-patent, lanceolate, the lower ones 4-6 in. l., $1 \frac{1}{2}-2$ in. br. ; pinnl. distant, $\frac{3}{4}-1$ in. l., $\frac{1}{4}$ in. br., cut down to the rachis into close, oblong-falcate, entire lobes; texture herbaceous; colour dark-green; both surfaces naked ; rachises fibrillose; sori at the base of the lobes, principally in the lower ones; invol. peltate, black in the centre, the edge ciliated.-Hk. Sp. 4. p. 35. t. 233. A. Lastrea, Moore.

Hab. Cuba, Linden, 1865, Wright, 830.-This and the preceding have the habit of Lastrea, but peltate involucres.

40. A. (Polyst.) multifidum, Mett.; st. scattered, 6-12 in. 1., densely clothed with large, ovate, nearly black scales; $f r .18-24$ in. $1 ., 6-9$ in. br., ovatelanceolate; pinnoe close, spreading, the lower ones deflexed, 3-4 in. 1., $\frac{3}{4}-1$ in. br.; pinnl. subdeltoid, close, unequal-sided, with ovate or spathulate segm., the lower ones deeply pinnatifid, teeth not awned; texture subcoriaceous; rachises densely fibrillose ; sori small, scattered.-Hk. Sp. 4. p. 35.

Hab. Chili, Lechler, 3060.

41. A. (Polyst.) Sikkimense, Baker ; st. 12-18 in. l., stout, striated, with dark-brown ovate scales throughout; fr. 2-3 ft. l., 12-15 in. br., subdeltoid; pinnce close, lanceolate, spreading, the lowest 6-8 in. l., 2 in. br.; pinnl. close, lanceolate, unequal-sided, cut down nearly to the rachis into oblong deeply pinnatifid lobes with mucronate teeth; texture herbaceous; rachis slightly scaly; ; both sides naked; sori usually one on the base of each ult. lohe.-Polyst. Sikkimense, Beddome, F. Brit. Ind. t. 127. Neph. Thomsoni, Hk. MSS.

Hab. Mon-Lepcha, Nepaul, 10-11,000 ft., Dr. Thomson.

42. A. (Polyst.) foeniculaceum, Hk.; rhizome creeping; st. scattered, 6-12 in. l., densely clothed below with lanceolate reddish-brown scales; $f r .1-2 \mathrm{ft}$. l., 9-12 in. br., lanceolate-deltoid, 4-5-pinnatifid ; lower pinnoe 6-8 in. l., 3-4 in. br.; pinnl. subdeltoid, 2-3 in. l.; segm. close, cut down to the rachis, their lower divisions sometimes again pinnatifid; ult. divisions linear, 1 lin. 1., awned; texture subcoriaceous; surfaces glossy; rachis nearly naked; sori solitary. Hk. Sp. 4. p. 36. t. 237.

Hab. Sikkim, 7-10,000 ft., $H k$. fl. and Thomson, 274. 
§ Cyrtomium, Presl. Veins sometimes, but not invariably, uniting slightly towards the edge. Sp. 43-46.

43. A. (Cyrt.) abbreviatum, Schrad.; st. scattered, $1 \mathrm{ft}$. or more 1., glossy, smooth; fr. 1-2 ft. l., 6-9 in. br., simply pinnate; pinnoe 4-6 in. l., $\frac{3}{4} \mathrm{in} . \mathrm{br}$., linear-lanceolate acuminate, slightly stalked, the edge bluntly lobed; texture subcoriaceous; rachis and both surfaces nearly naked; sori in two irregular rows between the primary veins, $-H k$. $S p$. 4. p. 38. t. 234 .

Hab. W. Indies to S. Brazil.-A. Guianense, Klotzsch, is a form with free venation.

44. A. (Cyrt.) caducum, Wall. ; st. tufted, $1 \mathrm{ft}$. l., firm, erect, stramineous, scaly below ; fr. 1-2 ft. l., 6-9 in. br., simply pinnate, with numerous stalked subdistant lanceolate pinnce on each side, $4-6$ in. 1., 1-1 $\frac{1}{2}$ in. br., the apex acuminate, the edge subentire, or more or less deeply lobed, sometimes down to the rachis below; texture coriaceous; midrib below often fibrillose; veins in pinnate groups which are free or anastomose slightly towards the edge; sori large, in one or two rows on each side.-Hk. Sp. 4. p. 39. Hk. \& Gr. Ic. t. 171.

Hab. Himalayas, ascending to $7,000 \mathrm{ft}$.

45. A. (Cyrt.) juglandifolium, Kze. ; st. tufted, 1 ft. or more 1., clothed below with large ovate scales; $f r .2-3$ ft. 1., 9-12 in. br., simply pinnate; pinnoe in 2 to 12 pairs, linear-lanceolate, the lower ones stalked, $4-6$ in. 1 , , $\frac{3}{4}-1 \frac{1}{2}$ in. br., the apex acuminate, the edge entire or slightly toothed; texture coriaceous; both surfaces naked; veins close, pinnated, the lowest anterior branch free, the groups free or anastomosing towards the edge; sori copious, scattered.-Hk. Sp. 4. p. 38.

Hab. Mexico to Venezuela. - This corresponds to the genera Amblia and Phanerophlebia, Presl, the latter founded on a plant from which the involucre had fallen.

46. A. (Cyrt.) falcatum, Sw.; st. tufted, 6-12 in. l., densely clothed below with large dark scales; fr. 1-2 ft. l., 6-9 in. br., simply pinnate; pinnce numerous, the lower ones stalked, ovate-acuminate, falcate, 4-6 in. 1., 1-2 in. br., the edge entire or slightly undulated, the upper side narrowed suddenly, sometimes auricled, the lower rounded or obliquely truncate at the base; texture coriaceous; both surfaces naked, the upper one glossy; sori small,

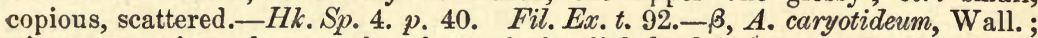
pinnce sometimes larger, sharply toothed, slightly lobed, sometimes auricled on both sides at the base; upper surface opaque.-Hk. Sp. 4. l.c. G. F.t. 13.

Hab. Japan, China, Himalayas (up to 8,000 ft.), Neilgherries, Sandwich Isles, Kaffraria, Natal.-It is impossible to separate our two varieties satisfactorily. The Japanese $C$. Fortunei, J. Sm., is like $\alpha$, but the pinnæ are narrower and opaque.

$\$ \$ \$$ Cyclodium, Presl. Veins pinnated, the opposite veinlets of contiguous groups joining. Sp. 47-49.

47. A. (Cyclo.) meniscioides, Willd.; st. 1-2 ft. 1., scaly below ; fr. 2-3 ft. 1., $1 \mathrm{ft}$. or more br., simply pinnated ; barren pinnce sessile, 6-9 in. 1 ., $1 \frac{1}{2}-2$ in. br., oblong-acuminate, nearly entire ; texture coriaceous, both surfaces naked ; fertile pinnoe much smaller; sori in two close rows between the primary veins.Hk. Sp. 4. p. 36. Hk. \& Gr. Ic. 121 .

Hab. West Indies to Brazil and Peru.

48. A. (Cyclo.) Hookeri, Baker; st. $1 \mathrm{ft}$. or more l., naked, erect; fr. 2-3 ft. 1., $1 \mathrm{ft}$. br.; pinnoe 6-8 in. $1 ., 1$ in. br., cut down to a broadly-winged rachis into nearly, close, spreading, entire, linear-oblong lobes $\frac{1}{8}$ in. br. ; texture herbaceous ; 
rachis naked, substramineous; veinlets slightly hairy, about 10 on a side, the lowest pairs uniting; sori nearer the edge than the midrib; invol. orbicular, membranous, redish in the centre, scariose in the outer half.-A. nephrodioides, Hk. Sp. 4. p. 42.t. 235. (non Klotzsch).

Hab. Malay Archipelago, Seemann.-This has entirely the habit and texture of an ordinary Eunephrodium, but the involucre is aspidioid.

§§§ Euaspidium. Veins anastomosing copiously. Sp. 49-55. A large number of species placed here in Sp. Fil. which have the involucres of Nephrodium are transferred to that genus. Aspidium, Schott.

49. A. plantagineum, Griseb. ; st. subtufted, 3-12 in. 1., often scaly throughout; fr. 6-12 in. 1., 2-4 in. br., oblong, narrowed rather suddenly at both ends, entire or slightly sinuated; texture papyraceo-herbaceous; both sides naked; midrib below sometimes rather scaly; primary veins distinct nearly to the edge, connected by irregular fine areolæ with free included veinlets; sori in two rows between each primary vein; invol. often abortive.-Hk. Sp. 4. p. 43. Polypodium, Jacq. Sw. A. sinuatum, Moore.

Hab. West Indies, southward to Brazil and Peru.-This belongs to the genus Bathmium of Fée, who makes three species, and Dryomenis and Melanopteris of J. Suith. Till lately it has always been placed in Polypodiece.

50. A. platanifolium, Mett.; st. 6-12 in. l., naked, glossy, ebeneous ; fr. 6-9 in. each way, never compound, cordate, palmately 3- or 5-lobed, terminal division subdeltoid, acuminate, lateral ones similar but smaller, basal ones sometimes blunt; texture papyraceo-herbaceous; midrib glossy like the stem; principal veins distinct to the edge, connected by copious small areolæ with free included veinlets; sori small, scattered, very abundant; invol. often absent.-A. angulatum, Hk. Sp. 4. p. 44. (not J. Sm.)

Hab. Malayan Islands.

51. A. angulatum, J. Sm. (not Hk.) ; st. 1-2 ft. l., glossy, ebeneous, scaly below ; fr. 1-2 ft. l., sometimes simple, usually with a large cordate-oblong entire terminal pinna and 1-2 lateral ones on each side, the lowest 6-12 in. l., 2-4 in. br., often forked at the base; texture papyraceo-herbaceous; midrib glossy, ebeneous; primary veins distinct to the edge; areoloe fine, copious, with free included veinlets; sori small, scattered, very abundant; invol. minute, fugacious.-Poly podium, Willd.

\section{Hab. Malayan Islands.}

52. A. trifoliatum, Swz. ; st. tufted, $1 \mathrm{ft}$. or more l., brownish, scaly only at the base; fr. 12-18 in. l., 6-12 in. br., with a large ovate-acuminate terminal pinna narrowed or forked at the base, and 1 or 2 lateral ones on each side, the lowest mostly forked; texture papyraceo-herbaceous; primary veins distinct to the edge; areoloe fine, copious, with free included veinlets; sori in rows near the main veins; invol. 1 lin. br., orbicular, peltate.-Hk. Sp. $4 . p .45$.

Hab. Tropical America, from Cuba and Mexico to Brazil and Peru.-A variable plant. A. heracleifolium, Willd., is a form with pinnæ pinnatifid on both sides at the base, and A. fimbriatum, Willd. (A. Plumieri, Presl), a large form, with more copious and more scattered sori, and a less distinctly peltate involucre.

53. A. repandum, Willd ; st. 1-2 ft. l., naked, greyish-brown; fr. $2 \mathrm{ft}$. or more 1., 12-18 in. br., the apex deeply pinnatifid, with linear-oblong, slightly sinuated lobes; below this 4-8 pinnoe on each side, 6-8 in. $1 ., 1 \frac{1}{4}-1 \frac{1}{2}$ in. br., acuminate at the point, narrowed below, the edge bluntly sinuated, the lowest stalked and forked ; texture subcoriaceous; main veins distinct to the edge ; areola copious, 
with free veinlets; sori in two distinct rows near the main vein ; invol. orbicular, peltate, $\frac{1}{2}$ lin. br.-Mett. Aspid. 226.

Hab. Philippines, Cuming, 340.-In habit this is near Sagenia pachyphylla and poly. morpha, but it differs from both by its distinctly peltate involucre.

54. A. calcareum, Presl ; st. tufted, naked, 4-6 in. 1. ; fr. $1 \mathrm{ft}$. or more 1. , 6-9 in. br., with 4-6 stalked distant pinnce on each side below the pinnatifid apex, the lowest deltoid, 6 in. l., 3-4 in. br, cut down to the rachis below into stalked lanceolate-acuminate deeply and blunt-lobed pinnl.; texture subcoriaceous; areolce not very abundant and mainly costular ; invol. orbicular.Hk. Sp. 4. p. 46.

Hab. Philippines, Cuming, 310.

55. A. membranaceum, Hk. ; st. tufted, about $1 \mathrm{ft} .1$., nearly naked, with a few spreading linear scales below ; fr. $] \frac{1}{2}-2 \mathrm{ft}$. $1 ., 1 \mathrm{ft}$. br.; lower pinnoe much the largest, subdeltoid, 6-8 in. l., 3-4 in. br. ; pinnl. on lowest side much larger than the others, with lanceolate-pinnatifid segm. with small oblong, sinuated lobes; texture thinly herbaceous; colour pale-green; veins anastomosing principally in costal arches; sori copious, principally marginal in the lobes.-Hk. Sp. 5. p. 105. A. giganteum, var. minor, $H k$. Sp. 4. p. 50 .

Hab. Ceylon, Java, Philippines, W. China, Formosa.-Our description is taken from living specimens sent by Dr. Thwaites. The involucre is truly peltate.

\section{Gen. 44. Nephrodium, Rich.}

Sori subglobose, dorsal or terminal on the veinlets. Invol. cordato-reniform, attached by the sinus. A cosmopolitan genus, the species of which vary widely in size, texture, cutting, and venation. $\downarrow$ 'TAB. V.f. 44.

\section{§ Lastrea, Presl. Veins all free. Sp. 1-153.}

* Fronds not cut down to the main rachis. Sp. 1-3.

1. N. decursivo-pinnatum, Baker; st. tufted, 3-4 in. 1., with linear scales throughout; fr. $1 \mathrm{ft}$. or more 1., 3-4 in. br. ; pinnoe linear, 1-2 in. 1., $\frac{1}{4}$ in. br., the edge more or less deeply pinnatifid, the bases connected by a broad lobed wing, the lower ones gradually reduced and sometimes distinct; texture herbaceous; rachis scaly; under side slightly hairy; lower veinlets subpinnate; sori copious, scattered ; invol. minnte, fugacious.-Polyp. Van Hall, Hk. Sp. 4. p. 231. 2nd Cent. t. 49. Aspid. Kze. L. decurrens, J.Sm.

Hab. Japan, China, Formosa.

2. N. (Last.) pedatum, Hk. ; st. tufted, 4-6 in. 1., glossy, ebeneous ; fr. 3-4 in. each way, cordate-deltoid, deeply pinnatifid; upper lobes broad, blunt, subentire, lower deeply lobed on the lower side; texture coriaceous; both sides

+ The character furnished by the shape of the involuere divides the original Aspidium into two unequal halves. The two genera thus obtained have a closely similar range of variation in cutting and venation, and it is by no means clearin which of the two several species should be placed. It is perhaps scarcely needful to warn the young student to bear constantly in mind that an Aspidium with an abortive or obliterated involucre is not distinguishable from a Desmobryoid Polypodium. The number of species which have been originally described as non-indusiate, in which a more or less (often very slightly) developed involucre has been afterwards found to exist, is very considerable, and no doubt more will be added to the list. 
naked; veins in pinnated groups, casually anastomosing; sori large, in rows near the main veins. $-H k$. Sp. 4. p. 84. Camptodium, Fee. Pachyderis, J. Sm.

Hab. West Indies.-Habit of Sagenia, with most but not all the sori terminal on free veinlets.

3. N. (Last.) Braunianum, Hk.; st. $1 \mathrm{ft}$. or more l., naked, ebeneous ; $f r$. 12-15 in. 1., 9 in. br., subdeltoid, cut down to a rachis with a broad lobed wing into pinnatifid pinnoe, of which the lowest pair is much the largest, with the pinnl. of the lower side much developed, the lowest 2-3 in. l., again deeply pinnatifid, with toothed oblong lobes $\frac{1}{4}$ in. br.; texture papyraceo-herbaceous ; rachis and under side pilose on the veins; veinlets of the ult. lobes forked; sori small, copious, terminal on the veins.-Hk. Sp. 4. $p .84$.

Hab. Columbia.-This also, like the last, has the general habit of Sagenia.

** Pinnoe entire or lobed less than one-third of the way down to the midrib. Sp. 4-13.

4. N. (Last.) pusillum, Baker; st. tufted, 4-12 in. l., stramineous, pubescent; fr. 3-12 in. l., 1 in. br., linear, proliferous from the axils of the upper pinnæ; pinnoe numerous, $\frac{1}{4}-\frac{1}{2}$ in. l., $\frac{1}{8}$ in. br., oblong, obtuse, the edge slightly crenate, the base truncate; texture subcoriaceous; rachis and under surface pubescent; veins simple or the lower ones forked ; sori medial ; invol. membranous, densely pilose.-Aspid. Mett. Fil. Nov. Gran. p. 216.

Hab. New Granada, Lindig, 92.

5. N. (Last.) semihastatum, Hk. ; st. tufted, 3-4 in. l., slender, villose ; fr. 6-8 in. $1 ., 1 \frac{1}{2}$ in. br., oblong-lanceolate ; pinnae close, $\frac{3}{4}$ in. l., $\frac{1}{4}$ in. br., blunt, the edge slightly sinuated, bluntly auricled at the base, the lower ones growing smaller gradually, lowest pair deflexed; texture papyraceo-herbaceous; rachis and under surface villose; upper veins forked, lower slightly pinnated; sori small, scattered.-Hk.Sp. 4. p. 87.

Hab. Peru, Poppig.

6. N. (Last.) decipiens, Hk. ; st. wiry, substramineous ; fr. 8-10 in. 1., 4-5 in. br., lanceolate-deltoid ; pinnoe spreading, 2.3 in. l., $\frac{3}{8}$ in. br., the edge very slightly and broadly toothed; lower pair stalked, about equalling the next; texture subcoriaceous; rachis slightly fibrillose; both surfaces naked; veins pinnated, inconspicuous; sori in two rows near the midrib.- $H k . S p .4 . p .86$. $t .243$.

Hab. China, Alexander.

7. N. (Last.) cuspidatum, Baker; st. $1 \mathrm{ft}$. or more 1., naked, densely scaly at the base ; $f r .2-3 \mathrm{ft}$. l., 8-12 in. br. ; pinnoe 4-6 in. l., $\frac{1}{2}$ in. br., the edge sharply inciso-serrated to depth of $\frac{1}{2}-1$ lin.; texture papyraceo-herbaceous or subcoriaceous; rachis and both sides naked; veins in pinnated groups with $3-4$ veinlets on a side; invol. fugacious.-Aspid. Mett. Polyp. elongatum, Wall. Hk. Sp. 4. p. 234.

Hab. N. India, Ceylon.-Specimens recently received show the involucre clearly.

8. N. (Last.) podophyllum, Hk.; st. tufted, $1 \mathrm{ft}$. l., naked upwards, scales at the base black and fibrillose; fr. 12-18 in. l., 8-12 in. br.; pinnoe 4-8 on each side, erecto-patent, 4-6 in. lo, $\frac{1}{2}-\frac{5}{8}$ in. br., the edge nearly entire or with shallow, broad, blunt lobes; texture subcoriaceous; rachis and both surfaces naked; veins pinnate in the lobes, with 2-4 veinlets on a side, with sometimes a sorus on each distant from the main vein.-Hk.Sp. 4. p. 87. 
Hab. Chusan and Hong-Kong.- This and the next differ from the rest of the group by having a distinct terminal pinna similar to the lateral ones. In the others the apex of the frond is pinnatifid.

9. N. (Last.) Sieboldii, Hk. ; caud. tufted, with large brown lanceolate scales ; st. 6-12 in. l., scaly below; fr. with an entire or slightly toothed lanceolate-

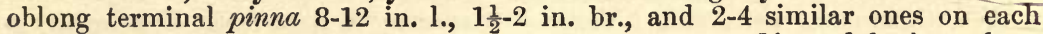
side, the lowest shortly stalked; texture coriaceous; rachis and both surfaces naked; veins in pinnated groups; sori large, copious, scattered.-Hk. Sp. 4. p. 87. Fil. Ex.t. 31. Pycnopteris, Moore.

Hab. Japan.-Pinnæ larger and fewer than in the last, and scales different.

10. N. (Last.) hirtipes, Hk. ; st. tufted, $1 \mathrm{ft}$. or more 1., densely clothed with long, blackish, fibrillose scales ; fr. 2-3 ft. l., 8-16 in. br.; pinna 4-8 in. l., $\frac{3}{4}-\frac{7}{8}$ in. br., with broad blunt lobes reaching from a quarter to a third down, lower ones not reduced; texture herbaceous ; rachises fibrillose like the stem ; both surfaces naked; veinlets $4-5$ on a side; sori medial.-Hk. Sp. 4. p. 115 . t. 249. A. atratum, Wall.

Hab. Himalayas (up to 6,000 ft.) to Ceylon, Malayan Peninsula and Isles.-This considerably resembles $N$. Filix-mas in general habit.

11. N. (Last.) subbiauritum, Hk. ; st. 4-6 in. 1., jointed about halfway down, firm, nearly naked; fr. 12-15 in. l., 4 in. br.; pinnce close, spreading, the longest 2 in. $1 ., \frac{1}{2}$ in. br., the edge with shallow, blunt lobes, those on both sides at the base larger than the others; texture herbaceous; rachis and under side pubescent; veins pinnate in the lobes, with 3-5 veinlets on a side ; sori terminal on the veinlets.-Hk. Sp. 4. p. 85.

Hab. Bourbon.-This comes nearest $N$. albopunctatum, and has similar white cretaceous dots above, and a jointed stem, so that it belongs to Arthropteris of J. Smith.

12. N. (Last.) punctulatum, Baker ; rhizome wide-creeping ; st. 6-9 in. 1., dark

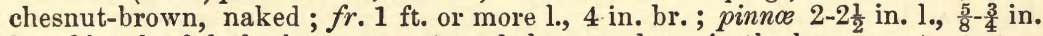
br., bluntly lobed about a quarter of the way down in the lower part; texture coriaceous; rachis and both surfaces naked, the upper marked with white cretaceous dots; veins in pinnated groups with $4-5$ veinlets on a side; sori terminating lateral veinlets; invol. distinctly stalked, persistent.

Hab. Cameroon Mountains (4,500 ft.), G. Mann.-This has very distinct white dots above, but the stem does not appear to be jointed.

13. N. (Last.) macrotis, Hk. ; st. tufted, 12-18 in. l., slender, pubescent ; fr. 18-24 in. 1., 8-10 in. br.; pinnoe 4-5 in. 1 ., $\frac{5}{8}-\frac{3}{4}$ in. br., cut about a quarter of the way down into blunt lobes, the apex acuminate, entire, the base with a large auricle $\left(\frac{1}{4}-\frac{1}{2}\right.$ in. 1.) on the upper side, all falcate, and the lower ones much deflexed; texture herbaceous; rachis and under side pubescent; veinlets 3-4 on each side; sori in rows near the main veins.-Hk. Sp. 4. p. 86. t. 242. B.

Hab. E. Peru, Spruce, 3979. - In habit this is most like N. refractum, but different in colour and clothing. The groups of veins join not unfrequently.

*** Pinnoe cut more than halfway down to the rachis into close, regular, entire, or nearly entire lobes. Sp. 14-73.

$+V$ einlets simple. Sp. 14-65. Involucre in many, but not all the species, thin and fugacious.

\section{A. Group of $N$. patens. Lower pinnoe hardly, if at all, reduced. Sp. 14-43.}

14. N. (Last.) subobliquatum, Baker; st. 12-18 in. l., firm, erect, naked ; fr. $1 \frac{1}{2}-2$ ft. 1., 6-10 in. br. ; pinnoe 3-5 in. $1 ., \frac{3}{4}-1$ in. br., unequal-sided below, the 
inner edge of the upper side parallel with the rachis, of the under side oblique, the margin cut about halfway down or at the base quite to the midrib into close hlunt lobes, the lower pinnæ distinctly stalked ; texture coriaceous; rachis and both surfaces naked; veinlets 4-6 on a side; sori medial ; invol. firm, naked.Polyp. Hk. Sp. 4. p. 240.

Hah. Guiana and the Amazon Valley. - Specimens recently received from Appun show the involucre clearly. It is not unlikely to be Willdenow's $A$. emarginatum.

15. N. (Last.) insigne, Baker; fr. 1 ft. l., 9 in. br.; pinnce opposite, subdistant, sessile, 5 in. l., $1 \frac{1}{2}$ in. br., cut down two-thirds of the way to the rachis into close, oblong, obtuse lobes, the lower ones deflexed ; texture thin, both sides naked; rachis smootll, stramineous ; veins $12-16$ on a side ; sori medial ; invol. minute, slightly hairy.-Aspid. Mett. Fil. Nov. Gran.p. 247.

Hab. New Granada, Triana.-Approaches $N$. brachyodon in babit.

16. N. (Last.) gracilescens, Hk. ; rhizome wide-creeping ; st. 6-9 in. l., slender, naked; fr. $1 \mathrm{ft}$. or more l., 6 in. br.; pinnoe 2-3 in. l., $\frac{3}{8}-\frac{1}{2}$ in. br., cut down within a short distance of the rachis into close, linear-oblong entire lobes $\frac{1}{8} \mathrm{in}$. br., the lowest pair deflexed ; rachis and both sides nearly naked ; veinlets 4-6 on a side; sori nearly terminal ; invol. naked.-Hk. $S p .4 . \quad p .93 .-\beta, N$. glanduligerum, Kze. (sub Aspid.) ; rachis hairy ; under surface slightly glandular ; invol. ciliated.

Hab. Java ; $\beta$, Japan, China, N. India.-Habit of $N$. Thelypteris, but a smaller plant, with veinlets always simple.

17. N. (Last.) chrysolobum, Fée; st. tufted, 4-6 in. 1., slender, villose, scaly below ; fr. 6-9 in. 1., 3-4 in. br. ; pinnoe $1 \frac{1}{2}-2$ in. 1 ., $\frac{5}{8}$ in. br., cut down nearly to the rachis into close, blunt, entire lobes $\frac{1}{8}$ in. br., the lowest pair deflexed and slightly stalked; texture herbaceous; rachis and under surface slightly villose and glandular; veinlets 6-8 on a side, with the sori near their apex.-Mett. Lips. p. 90.

Hab. Brazil and Columbia.-A. Schottianum, Kze., is a form with slightly toothed lobes. Most like N. falciculatum, but much smaller and less glandular.

18. N. (Last.) macrourum, Baker ; st. 1 ft. or more l., substramineous, nearly naked ; fr. 3-4 ft. 1., 18-24 in. br. ; pinnce 8-12 in. 1., $1 \frac{1}{4}$ in. br., cut down nearly to the rachis into subfalcate entire lobes 2 lin. br., with a space between them, the basal lohes enlarged and pinnatifid; texture herbaceous; rachis and under side finely villose ; veinlets $10-15$ on a side, the sori about midway between the edge and midrib.-Aspid. Kaulf. N. schizotis, Hk. Sp. 4. p. 107.

Hab. Brazil, Burchell, 752 ; E. Peru, Spruce, 4030 ; Caraccas, Birschell.-Doubtfully distinct from $N$. patens. The lobes are not so deep, and very falcate, and the lowest lobe on one or both sides is dilated and pinnatifid. Probably this is A. stipulare, Willd., but none of our specimens have the dilated lobes nearly so large as in Plumier's t. 23.

19. N. (Last.) patens, Desv.; rhizome oblique ; st. $1 \mathrm{ft}$. or more l., naked or slightly pubescent ; fr. 2-3 ft. 1., 8-12 in. br. ; pinnce 4-9 in. l., $\frac{1}{2}-\frac{3}{4}$ in. br., cut down about three-quarters of the space to the rachis into linear-oblong subfalcate lobes, the lowest lobes not diminished; texture herbaceous ; rachis and surfaces more or less villose; veinlets $6-12$ on a side; sori nearer the edge than the midrib; invol. persistent.-Hk.Sp. 4. p. 95.

Hab. Florida and Texas to Rio and Chili ; Polynesia, Japan, Zambesi-land, Angola, St. Helena. This has the general habit and soft herbaceous texture of molle, and it is not always easy to separate them. N. patens, J. Sm., is intermediate between the two, having an erect caudex, with the lowest pair of veins joining. A. albicaule, Fée, seems to belong here, and N. pilosulum (Hk. Sp. 4. p. 102) to be a more hairy form than usual. 
A. Brackenvidgii, Mett., from Polynesia, is said to differ by its reduced lower lobes, and the presence of a small black gland at the base of the midrib of the pinnæ.

20. N. (Last.) attenuatum, Baker ; st. 1 ft. or more l., firm, glossy, naked ; fr. 3-4 ft. l., 2 ft. br. ; pinnce 9-12 in. l., $\frac{3}{4}-\frac{7}{8}$ in. br., very acuminate at the point, the edge cut three-quarters of the way down into entire, spreading, blunt lobes 1 lin. br., the basal lobes much reduced, lower pinnæ slightly stalked; texture subcoriaceous; rachis naked; under surface glandular; veinlets 12-16 on a side ; sori in a close row near the midrib.-Lastrea, J. Sm. (not Brack.)

Hab. Philippines, Cuming, 327.-Habit of Didymochlcena polycarpa.

21. N. (Last.) abruptum, Baker; st. $1 \frac{1}{2} \mathrm{ft}$. l., angular, slightly villose above ; fr. 2-3 ft. l., $1 \mathrm{ft}$. or more br. ; pinnce 6-8 in. $1 ., 1$ in. br., cut down to a broadlywinged rachis into close, acute, falcate, entire lobes $\frac{1}{8}$ in. br., the basal lohes rather reduced, and the pinnæ on the upper side cut off in a slight curve; texture subcoriaceous, rigid; rachis and both surfaces nearly naked ; veinlets prominent, 12-16 on a side, with the sori near the apex.-Aspid. Kze. Mett. (non Blume).

Hab. Peru.-General habit and texture of $N$. invisum.

22. N. (Last.) invisum, Baker ; rhizome stout, wide-creeping, scaly ; st. 1-2 ft. 1., smooth ; fr. 3-4 ft. l., 1-2 ft. br.; pinnce 6-12 in. l., $\frac{1}{2}-\frac{3}{4}$ in. br., cut down nearly to the rachis into entire, linear-subfalcate lobes 1 lin. br., the basal ones the largest; texture subcoriaceous, rigid; rachis and under surface naked or finely villose; veinlets $10-15$ on a side, with the sori midway between the edge and midrib.-Polyp. Swz. N. macrourum and Serra, Hk. Sp. 4. p. 96-8.

Hab. Mexico and Cuba, southward to Brazil and Peru.-A larger and more rigid plant than $N$. patens, with narrower and more acute lobes, and closer and more prominent veinlets.

23. N. (Last.) immersum, Hk. ; st. tufted, 2 ft. l., or more, naked, sub-

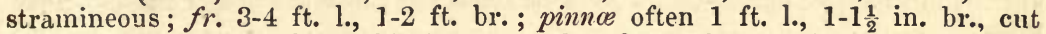
down very nearly to the rachis into spreading linear lobes 1 lin. br., with more than their own space between them; texture papyraceo-herbaceous; rachis and under surface naked or slightly pubescent and glandular; veinlets $10-20$ on a side ; sori submarginal, immersed so as to project on the upper surface; invol. subpeltate.-Hk. Sp. 4.p. 112.

Hab. Assam, Philippines, Malaccas.-Perhaps the shape of the involucre would justify our placing this in Aspidium, but in other respects it comes near the following four species. L. caudiculata, Presl, is said to differ from this by its medial sori.

24. N. (Last.) Spekei, Baker ; st. 1 ft. l., stramineous, slender, fibrillose ; fr. 18-24 in. l., 9-12 in. br.; pinnoe 4-6 in. l., 1 in. br., cut down very nearly to the rachis, entire, those of the fertile frond 1 lin. br., those of the barren frond wider ; texture papyraceo-herbaceous ; main rachis and that of the pinnæ slightly fibrillose; under side naked; veinlets $8-12$ on a side; sori midway between the edge and midrib; invol. subpeltate.

Hab. Johanna Island, Capt. Speke, Dr. Kirk; Angola, Welwitzsch. - This comes near the last, but the texture is thinner, the veinlets are fewer, and the sori medial, and not immersed. A plant from the Cameroon Mountains differs only by its more scaly rachises.

25. N. (Last.) crinibulbon, Hk. ; st. 9-12 in. l., tufted, slender, glandulosopilose, and fibrillose, especially below; st. $1 \mathrm{ft}$. l., 6 in. br.; pinnce spreading, 3 in. l., $\frac{5}{8}-\frac{3}{4}$ in. br., cut down very nearly to the rachis into linear-oblong entire lobes $\frac{1}{8}$ in. br. ; texture herbaceous; rachis fibrillose and viscose, and midrib heneath slightly so ; veinlets 5-6 on each side, with the sori nearly terminal.IIk. Sp. 4. p. 92 . t. 244 . 
Hab. Island of St. Thomas, W. Africa, G. Mann.-Very near N. Spekei, but smaller in size, the veinlets fewer, and the rachises densely fibrillose and glandular, and sori submarginal.

26. N. (Last.) ligulatum, Hk. ; st. grey, glossy, naked ; fr. 3-4 ft. 1., 12-18 in. br. ; pinnae 6-9 in. 1., 1 in. br., cut down very nearly to the rachis into linear, blunt, entire, erecto-patent lobes 1 lin. br., with more than their own space between them, lower ones slightly reduced; texture subcoriaceous; rachis and under side finely pubescent; veinlets $10-12$ on a side ; sori quite marginal.Hk. Sp. 4. p. 112.

Hab. Philippines, Cuming, 94, 343.-Allied to the three preceding.

27. N. (Last.) obliquatum, Baker ; rhizome creeping ; st. 8 in. 1., reddish, densely pubescent; fr. 1 ft. l., 6-8 in. br., ovate-acuminate; pinno lanceolate, cut down to a narrowly-winged rachis into close linear-oblong entire lobes; texture papyraceo-herbaceous; under surface and rachis densely villose ; veinlets 6-8 on a side, bearing the sori near the apex.-Aspid. Mett. Fil. Nov. Cal. p. 76.

Hab. New Caledonia, Vieillard, 1628.-Allied to species 23-27, but recognizable by its villose stems and frond.

28. N. (Last.) albo-punctatum, Desv. ; rhizome wide-creeping, scandent, scaly or naked; st. naked, greyish or ebeneous, jointed ; fr. 9-12 in. 1., 4-6 in. br.; pinnoe spreading, 2-3 in. 1., $\frac{1}{2}$ in. br., cut half down to the rachis or more into oblong, blunt, entire lobes; texture herbaceous ; rachis pubescent and under side slightly so; veins pinnate in the lobes, with $3-4$ veinlets on each side; sori terminal on the veinlets near the edge.-Hk. Sp. 4. p. 85. Fil. Ex. $t$. 89. Arthropteris, $\boldsymbol{J}$. Sm.

Hab. Guinea Coast, Angola, Mascaren Isles, Fiji.-The pinnæ have white cretaceous dots on the upper surface, as in Nephrolepis. N. Webbianum, Hk., from Amboyna, appears to be a form of this, with a glabrous rachis and pinnæ less deeply lobed than the type.

29. N. (Last.) calcaratum, Hk.; st. densely tufted, stramineous, villose above ; st. 1 ft. 1., 3-6 in. br.; pinnce spreading, 2-4 in. l., $\frac{3}{8}-\frac{3}{4}$ in. br., cut down two-thirds or more to the rachis into oblique, subfalcate, linear-oblong, acute or blunt lobes; colour dark-green; rachis villose; texture herbaceous or subcoriaceous; under side more or less villose; veinlets $3-6$ on each side; sor $i$ medial; invol. glabrous, persistent.-Hk. Sp. 4. p. 93. N. falcilobum, Hk. Sp. 4. p. 108.

Hab. N. India to Ceylon, Hong-Kong, Philippines, Malaccas.-A well-marked plant, with a considerable range of variation in cutting and texture. The lower pinnæ are sometimes but not usually reduced. $N$. falcilobum is a form with broader pinnæ and deeper and more spreading lobes than usual.

30. N. (Last.) viscosum, Baker; st. 6 in. or more l., firm, erect, reddish-brown, slightly scaly, finely villose; fr. 9-12 in. 1., 4-5 in. br., oblong-lanceolate; pinnae close, $2-3$ in. $1 ., \frac{3}{8}-\frac{1}{2}$ in. br., cut nearly to the rachis into close, spreading linear-oblong lobes under 1 lin. br.; texture herbaceous; colour dark-green; rachises villose ; under surface densely glandular; veinlets 5-6 on a side; sori medial.-Lastrea, $J$. Sm.

Hab. Malacca, Cuming, 401; Philippines and Borneo, T. Lobb.

31. N. (Last.) falciculatum, Desv. ; st. tufted, 6-12 in. l., clothed below with dark-brown linear scales; fr. 12-18 in. 1., 8-10 in. br., oblong-deltoid; pinnoe 4-5 in. l., 1 in. br., cut down very nearly to the rachis into linear-oblong entire falcate lobes $1 \frac{1}{2}-2$ lin. br., the lower ones not reduced; texture herbaceous; 
rachises slightly fibrillose, and both sides densely pubescent and glandular; veinlets 8-10 on a side; sori large, submarginal.-Hk. Sp. 4. p. 102.

Hab. Mexico to Brazil and Peru.

32. N. (Last.) vestitum, Baker ; st. 6-12 in. 1., stout, densely coated with woolly lanceolate scales ; fr. 1-2 ft. l., 6-10 in. br. ; pinnce 3-5 in. l., $\frac{3}{4}-1$ in. br., cut down to a narrowly-winged rachis into blunt, entire, falcate lobes 2 lin. br. ; texture herbaceous; rachis of the pinnæe densely clothed with broad furfuraceous scales; veinlets 6-8 on a side, the sori close to the midrib.-Polyp. Raddi. N. Raddianum, Hk. Sp. 4.p. 98. t. 245.

Hab. S. Brazil. - The Mauritian A. nitidum, Bory, is like this, except that the scales are narrower and finer, and with this a Brazilian plant, marked "A. squamigerum" by Mettenius, agrees.

33. N. (Lasi.) crinitum, Desv. ; st. 6-12 in. 1., stout, densely clothed with long, purplish-brown, fibrillose scales ; fr. 12-24 in. l., 8-12 in. br., ovate-deltoid ; pinnoe 4-6 in. l., 1 in. br., cut down nearly to the rachis into slightly falcate, linear-oblong lobes 2 lin. br. ; lower pinnce deflexed ; texture herbaceous ; rachis and midrib more or less fibrillose; veinlets $9-12$ on a side; sori medial.-Hk. Sp. 4. $p$. 111. (in part). A. sulcatum, $K l f$.

Hab. Mauritius and Bourbon.-This and the two preceding resemble one another closely in habit, texture, and shape of the lobes, and in all three the involucre is thin and fugacious. In $A$. pauciflorum, Kaulf, the scales are fewer, and not so distinctly subulate, but they do not seem clearly separable.

34. N. (Last.) Ctenitis, Baker ; st. more than $1 \mathrm{ft}$. 1., clothed throughout with black and ferruginous scales; fr. 2 ft. l., $1 \mathrm{ft}$. or more br. ; pinnoe 8-9 in. l., $1 \frac{1}{4}-1 \frac{1}{2}$ in. br., cut down nearly to the rachis into obtusely-toothed lobes, the lower ones with a space between them, the lower pinnæ stalked ; texture subcoriaceous; upper surface with scattered shart ferruginous hairs, lower with dark scales on the midrib; veinlets ahout 15 on a side; sori near the main veins; invol. persistent, glabrous.-Aspid. Kze. Mett. Asp. p. 91 .

Hab. Brazil.

35. N. (Last.) volleum, Baker ; st. 6 in. 1., densely clothed, especially at the base, with long linear scales; fr. $1 \frac{1}{2}-2$ ft. 1., 6-9 in. br. ; pinno $3-4$ in. 1. , $\frac{3}{4}-1$ in. br., cut down to the rachis into linear-oblong lobes $1 \frac{1}{2}-2$ lin. br.; texture herbaceous ; under side naked ; rachises densely clothed with long, pale, brightbrown fibrillose scales; veinlets $7-8$ on a side, the sori close to the midrib.Aspid. Willd. N. aureo-vestitum, Hk. Sp. 4. p. 101. t. 246.

Hab. West Indies. - This most resembles the three preceding, but the frond is narrower and more elongated, and the clothing of the rachis is quite peculiar.

36. N. (Last.) Caripense, Hk.; st. $1 \mathrm{ft}$. or more l., firm, clotherl principally at the base with long, dense, linear scales ; fr. $1 \frac{1}{2}-2 \mathrm{ft} .1 ., 8-12 \mathrm{in}$. br.; pinnce 4-6 in. l., 1 in. br., cut down to a broadly-winged rachis into close, blunt, entire lobes 2 lin. br., the lower lobes reduced and lower pinnæe slightly stalked; texture firm; rachis nearly and both sides quite naked; veinlets 12-15 on a side; sori medial; invol. small, fugacious. $-H k . S p .4 . p_{.99}$. N. Tarapotense, $11 k$. Sp. 4. p. 107.

Hab. Guatemala to Brazil and Peru.-A. alsoplitaceum of Kunze and Metienius is said to differ by its more rigid texture, and lobes not reaching more than half way down to the midrib, with 9-10 veinlets on a side.

37. N. (Last.) trichophorum, Baker ; rhizone creeping ; st. 6-9 in. 1., firm, pubescent upwards; $f i .12-18$ in. $1 ., 8-9$ il. br. ; pinnce 4-5 in. $1 ., \frac{3}{4}-\frac{7}{8}$ i. 1. br., $2 \mathrm{I}$ 
gradually narrowed from the base to the acuminate apex, all sessile, cut down very nearly to the rachis into erecto-patent, blunt, entire lobes 2 lin. br.; texture coriaceous ; rachis and veins beneath densely villose ; veinlets $6-8$ on a side ; sori marginal ; invol. large, persistent, villose.-Aspid. Fée, Fil. Ant.t. 23.

Hab. Guadeloupe, L'Herminier.-A. Capitainei and Germani, Fée, are very closely allied, but in both the veinlets are $9-10$ in number, and in the latter the caudex is said to be erect. A. asperulum, Fée, has narrower pinnæ and a decumbent caudex. All four are from the same island.

38. N. (Last.) triste, Hk.; st. $1 \mathrm{ft}$. or more 1., naked or slightly villose ; fr. 2-4 ft. 1., 8-18 in. br. ; pinnoe 4-9 in. l., 1-1 $\frac{1}{2}$ in. br., cut down two-thirds of the distance to the rachis into entire, bluntish or acute, subfalcate lobes 2-3 lin. br., the lower ones with a distinct stak and the lowest lobe narrowed out into a decurrent cuneate wing to it; texture subcoriaceous; rachis and veins beneath finely villose; veinlets $12-15$ on a side; sori medial ; invol. small, fugacious. Hk. Sp. 4. p. 104.

Hab. Columbia to Peru and Brazil.-Distinguished by its rigid texture and the distinct stalk of the lower pinnæ, the pagina of which is narrowed down gradually into it. A plint authenticated by Mettenius as $\boldsymbol{A}$. monostichum, Kze., seems to differ from this only by the sori being confined to one at each side of each lobe at the base.

3:. N. (Last.) tetragonum, Hk. ; st. tufted, $1 \mathrm{ft}$. or more l., finely pubescent ; fr. 1-2 ft. l., 8-12 in. br., oblong-deltoid ; pinnoe 4-6 in. 1., $\frac{3}{4-1}$ in. br., cut halfway down to the rachis or more into close entire lobes $1 \frac{1}{2}-2$ lin. br., the lower lobes gradually reduced and lower pinnæ distinctly stalked ; texture papyraceoherhaceous; rachis and veins beneath pubescent; veinlets $8-12$ on a side; sori medial ; invol. small, setose.-Hk. Sp. 4. p. 103.

Hab. Columbia to Peru and Brazil.-This agrees with the last in the character of the lower pinnæ, but the lobes are shorter and blunter, and the texture is more herbaceous. We cannot clearly distinguish $A$. lugubre, Mett., although favoured with an authentic specimen.

40. N. (Last.) crassifolium, Hk. ; st. tufted, 1 ft. or more l., glossy, slightly

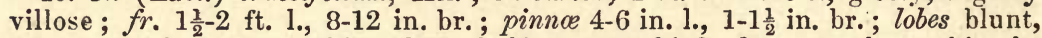
falcate, 2-3 lin. br., reaching from half to two-thirds down to the rachis, the lower ones distinctly stalked; texture subcoriaceous; both sides glossy, but the rachises finely villose; veinlets $10-12$ on a side, with the sori close to the midrib.Hk.Sp. 4. p. 114.

Hab. Philippines and Malaccas.-A closely-allied plant from Borneo (N. Motleyanum, Hk. MSS.) has the pinnæ not cut more than halfway down, with medial sori, with the groups of veinlets free in the fertile, but invariably anastomosing in the barren frond.

41. N. (Last.) echinatum, Baker; st. $1 \mathrm{ft}$. l., clothed with long, spreading, brown, lanceolate-subulate scales, scabrous when they fall; $f r .1 \mathrm{ft}$. l., 8-9 in. br., lanceolate-deltoid ; lowest pinnce stalked, 5 in. l., 7 lin. br., cut down to a narrowly-winged rachis into close, linear-oblong, entire lobes; texture coriaceous ; rachis scaly like the stem; under surface thinly pubescent and glandular; veinlets $7-8$ un a side; scri nearer the midrib than the edge.-Aspid. Mett. Fil. Ind. $p .230$.

Hab. Borneo, Korthals.-In this, as in the three preceding, the lowest veinlets sometimes joïn.

42. N. (Last.) Leprieurii, Ilk.; st. 1-2 ft. 1., grey, deciduously villose ; fr. 2-3

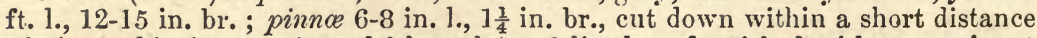
of the rachis into entire subfalcate lobes 2 lin. br., furnished with a prominent gland at the base, the lower ones sessile and lower lobes scarcely reduced; 
texture coriaceous ; rachis and under side finely villose ; veinlets prominent, about 12 on a side; sori medial ; invol. firm, villose.-Hk. Sp. 4. p. 106.

Hab. Guiana, Leprieur; Andes of N. E. Peru, Spruce.

43. N. (Last.) subfuscum, Baker ; st. $1 \mathrm{ft}$. or more 1., greyish, villose ; fr. 2-3 ft. $1 ., 1 \mathrm{ft}$. or more br.; pinnce 6-8 in. $1 ., 1$ in. or more br., cut down to a broadly-winged rachis into spreading, blunt, entire lobes 2 lin. br., with a large acute gland at the base, the lower ones sessile and lower lobes not reduced; texture herbaceous; rachis and under side finely villose; veinlets immersed, about 8 on a side ; sori medial; invol. small, fugacious.

Hab. Cayenne, Leprieur.

\section{B. Group of $N$. conterminum. Lower pinnce conspicuously reduced. Sp. 44-65.}

44. N. (Last.) sanctum, Baker ; st. densely tufted, slender, 2-3 in. 1., naked upwards ; fr. 6-9 in. 1., 1-2 in. br., lanceolate; pinnce distant, $\frac{1}{2}-1$ in. 1., $1 \frac{1}{2}-3$ lin. br., the point bluntish, the edge more or less deeply pinnatifid, the lobes sometimes close and linear-oblong, sometimes distinct, linear, or spathulate ; texture papyraceo-herbaceous; rachis naked; under side slightly glandular; veinlets simple; sori minute; invol. very fugacious.-Polyp. Sw. Hk. Sp. 4. p. 252.

Hab. West Indies and Guatemala.

45. N. (Last.) exiguum, Hk. ; st. tufted, 6-9 in. 1., slender, grey, naked ; fr. 8-10 in. l., $1 \frac{1}{2}-2$ in. br. ; pinnce 1 in. 1 ., $\frac{1}{4}-\frac{3}{8}$ in. br., blunt, cut down halfway to the rachis or more into close blunt lobes; texture papyraceo-herbaceous; rachis villose; veinlets obscure, $2-3$ on each side; sori near the midrib. $-H k$. Sp. 4. p. 92 .

Hab. Philippines, Cuming, 251, 272.-An obscure plant.

46. N. (Last.) canum, Baker ; st. densely tufted, 6-8 in. 1., slender, finely villose ; fr. 8-12 in. 1., 3-4 in. br. ; central pinnoe 2 in. $1 ., \frac{1}{2}$ in. br., gradually narrowed from the base to the point, cut down nearly to the rachis into close, slightly crenated lobes $\frac{1}{8}$ in. br.; lower pinnoe distant and dwindling down gradually; texture herbaceous; rachis slender, finely villose, and both sides slightly "so; veinlets $6-8$ on a side; sori submarginal; invol. thin, fugacious.Lastrea, $\boldsymbol{J}$. $S m$.

Hab. Himalayas.-Habit of $N$. molle, but a more slender plant, with gradually-reduced lower pinnæ and free veins. If it is Wallich's canum at all, it is so in part only, as some of the specimens clearly belong to $N$. molle.

47. N. (Last.) Beddomei, Baker ; rhizome slender, wide-creeping ; st. 6-9 in. 1., slender, glossy ; fr. 6-12 in. 1., 3-4 in. br., oblong-lanceolate; central pinnce the largest, $1 \frac{1}{2}-2$ in. $1 ., \frac{3}{8}$ in. br., cut down to the rachis into close, rather acute, entire lobes under 1 lin. br.; lower pinno distant and dwindling down very gradually; texture firm; veins beneath villose; veinlets $4-5$ on a side, the sori close to the incurved margin.-A. gracilescens, Thwaites (non Blume). L. gracilescens, Beddome, $t .110$.

Hab. Neilgherries, Ceylon (C. P. 1287), and Java.-This comes nearest the next species, but is smaller and more slender, with much fewer veins, and the texture is firmer.

48. N. (Last.) Noveboracense, Desv. ; rhizome slender, wide-creeping ; st. about $1 \mathrm{ft}$. l., slender, stramineous ; fr. 1-2 ft. 1., 4-6 in. br.; pinno spreading, 2-3 in. l., $\frac{1}{2}$ in. br., cut down very nearly to the rachis into linear-oblong lobes, 
those of the barren frond the broadest; lower pinnoe small, deflexed; veinlets rarely forked, $6-10$ on a side; texture herbaceous; rachis and both sides naked; sori soon confluent, in rows near the flat edge.-Hk. Sp. 4. p. 89.

Hab. Canada and United States.- Habit of $N$. Thelypteris, from which it may be known by its simple veins and reduced lower pinuæ.

49. N. (Last.) conterminum, Desv. ; st. densely tufted, 6-9 in. 1., naked or villose ; fr. 12-18 in. 1., 4-8 in. br., oblong-lanceolate ; central pinnoe the longest, $2-4$ in. $1 ., \frac{1}{2}$ in. br., cut down to the rachis into entire lobes about 1 lin. br., the lowest lobes often enlarged, the lower pinna decreasing gradually; texture herbaceous or subcoriaceous; rachis naked or pubescent; under surface often slightly villose and glandular; veinlets $6-8$ on a side; sori submarginal ; invol. minute, fugacious.- $H k . S p .4 . p .91$.

Hab. W. Indies and Mexico, southward to Brazil, Chili, and Bourbon.-This, which appears to be abundant throughout Central America, has the general habit of $N$. Thelypteris and Noveboracense, with an erect caudex. We cannot distinguish clearly $A$. oligocarpum, Kth., A. Funckii, Mett., and A. pilosulum, Klotzsch. Fée makes of this a genus Oochlamys, characterized by an involucre recedirg from that of typical Nephrodium towards Aspidium, and enumerates seven West-Indian species.

50. N. (Last.) Kaulfusii, Hk. ; st. tufted, 4-6 in. 1., slender, slightly pubescent ; fr. $1 \frac{1}{2}-2$ ft. 1., 6-8 in. br., oblong-lanceolate; pinnoe $3-4$ in. $1 ., \frac{1}{2}-\frac{5}{8}$ in. br., cut down nearly to the rachis into spreading, entire blunt lobes 2 lin. br., tha lower lobes not enlarged and lower pinnæ dwindling down gradually ; texture herbaceous or subcoriaceous; rackis and under surface finely pubescent; veinlets about 6 on a side; sori medial ; invol. fugacious.-Hk. Sp. 4. p. 97.

Hab. West Indies to Brazil. - This differs from the last by its broader lobes and medial sori. Both Mettenius and Grisebach unite it with oligocarpum.

51. N. (Last.) concinnum, Baker ; rhizome wide-creeping; st. 6-12 in. 1., naked or slightly pubescent; fr. 1-2 ft. l., 6-8 in. br., oblong-lanceolate; pinnce $3-4$ in. l., $\frac{3}{4}-1 \mathrm{in}$. br., ent down nearly to the rachis into spreading or falcate entire lobes $\frac{1}{8}$ in. br.; texture subcoriaceous ; rachis and under surface slightly villose; veinlets 6-8 on a side; sori submarginal; invol. minute, ciliated, fugacious.-Polyp. Willd.

Hab. Mexico to Chili.-This may be best known from the two preceding by its creeping rhizome. A. vivulorum, Link, is said to differ by its medial sori, and the presence of a gland at the base of the pinnæ beneath; and Pheg. adenochrysa, Fée, may be this without an involucre.

52. N. (Last.) Sprengelii, Hk.; st. 6-12 in. 1., stramineous, nakedor slightly pubescent; fr. $2-4$ ft. l., often 1 ft. br.; pinnce 6-8 in. l., 1 in. br., cut down nearly to the rachis into entire lobes $1-1 \frac{1}{2}$ lin. br., the lower ones with a gland at the base beneath; texture herbaceous or subcoriaceous; under surface naked or slightly villose and glandular; veinlets $8-12$ on a side; sori submarginal.$H k$. Sp. 4. p. 94 .

Hab. West Indies and Guatemala. - A much larger plant than $N$. conterminum, with a basal glund, and vearly twice as many veiulets.

53. N. (Last.) protixum, Baker ; st. 1-2 ft. 1., firm, glossy, substramineous, naked or nearly so ; fr. 2-4 ft. l., 8-12 in. br. ; pinnoe 4-8 in. 1., $\frac{3}{4}-1$ in. br., cut down nearly to the rachis into entire or bluntish, often falcate lobes $1-1 \frac{1}{2}$ lin. br., with a prominent gland at the base beneath, the lower ones gradually reduced; texture subcoriaceous; rachis and under side more or less villose ; veinlets prominent, 10-15 on a side; sori submarginal.-Aspid. Willd. N'. ochthodes, Hk. Sv. 4. n. 109. N. appendiculatum, Hk. l. c.- $\beta, N$. tylodes (Kze. 
sub Asp.); sori in a line close to the midrib; rachis and under side nearly naked; lower pinno reduced suddenly.

Hab. N. India to Ceylon, Mauritius, and Bourbon.-The Mascaren plant(A. stipulaceum, Mett.) has the lowest lobes sometinies dilated and pinnatifid, like those of $N$. macrour um. Dr. Thwaites regards tylodes and ochthodes as probably distinct species. The two are figured by Beddome, t. 106-7.

54. N. (Last.) limbatum, Desv. ; st. 4-6 in. 1., naked, glossy ; fr. 2-3 ft. l., 6-12 in. br. ; pinnce 3-6 in. $1 ., \frac{5}{8}-\frac{3}{4}$ in. br., with a gland at the base beneath, cut down very nearly to the rachis into slightly falcate, entire, linear-oblong lobes 1-1 $\frac{1}{2}$ lin. br.; texture papyraceo-herbaceous; raclis stramineous and both surfaces nearly naked; veinlets 6-10 on a side, the prominent persistent involucres protruding beyond the edge.-Hk. $S p$. 4. p. 94. Amauropelta, Kze.

Hab. West Indies. - Easily recognizable by the character of the involucre, on account of which Kunze made for it a new genus.

55. N. (Last.) resino-foetidum, Hk. ; st. 1-2 ft. l., naked, scaly below ; fr. 3-4 ft. l., 12-18 in. br. ; pinnce 6-9 in. l., 1 in. br., cut down nearly to the rachis into close, linear, acute, entire lobes $\frac{1}{8}$ in. br., with a space between them, furnished with a gland at the base, the lower ones reduced to mere auricles; texture coriaceous; rachis and nnder side naked or finely villose; veinlets $10-15$ on a side; sori submarginal; edge reflexed.-Hk. Sp. 4. p. 105. (in part).

Hab. Andes of Ecuador, Spruce; Bolivia, Mandon.-This is nearest $N$. Sprengelii, but is a larger and more rigid plant, with very numerous lobes and veinlets. It is said to have an unpleasant resinous scent when growing.

56. N. (Last.) Sprucei, Baker ; st. 1 ft. or more 1., nearly. naked ; fr. 2-3 ft. 1., 8-12 in. br. ; pinnce 4-6 in. l., 1 in. br., cut down nearly to the rachis into entire, spreading lobes 2 lin. br., with a considerable space between them, furnished with a gland at the base, the lower ones dwindling down gradually; texture papyraceo-herbaceous; rachis slightly villose; under side naked; veinlets 8-10 on a side; sori nearer the midrib than the edge ; invol. large, distinct.

Hab. Andes of Ecnador, Spruce.-Distinguished from the last by its more herbaceous texture, broader lobes, fewer veinlets, and medial sori.

57. N. (Last.) Bergianum, Baker; st. 6-12 in. 1., naked or finely villose; fr. 1 $\frac{1}{2}-2$ ft. 1., 6-10 in. br. ; pinnoe 3-5 in. l., $\frac{3}{4}$ in. br., cut down nearly to the rachis into close, entire lobes $\frac{1}{8}$ in. br. ; texture lerhaceous; rachis and under side more or less villose; veinlets 6-8 on a side; sori medial ; invol. small, fugacious.Polyp. Schlecht.

Hab. Cape Colony and Natal - Perhaps a variety of $N$. patens, but the lower pinnæ reduced gradually. A. Gueintzianum, Mett., differs by the presence of a gland at the base of the pinnæ beneath.

53. N. (Last.) tomentosum, Baker ; st. densely tufted, 3-4 in. l., finely villose ; fr. 1-2 ft. l., 6-10 in. br. ; pinnoe 3-5 in. l., $\frac{3}{4}-1$ in. br., with a gland at the base beneath, cut down nearly to the rachis into linear-oblong lobes, the lowest of which are often larger than the others; texture herbaceous ; lower pinnæe distant, and dwarfed down to mere auricles; rachis and under surface villose; veinlets 8-12 on a side; sori near'y terminal. - Polyp. Thouars. N. thelypteroides, Hk. Sp. 4.p. 95. (non Michx.).

Hab. Mauritius, Bourbon, Tristan d'Acunha.-This may be a luxuriant villose variety of conterminum.

53. N. (Last.) globuliferum, Hk. ; st. tufted, smootll, naked, glossy ; fr. $1 \frac{1}{2}-2$ ft. l., 1 ft. br.; pinnoe 4-6 in. 1., $\frac{3}{4}$ in. br., cut down to a broadly-winged rachis 
into close, distinctly-crenated lobes $1 \frac{1}{2}-2$ lin. br. ; texture subcoriaceous ; rachis and under surface not hairy, but densely coated with golden viscose glands; veinlets 6.8 on a side; sori marginal ; invol. persistent, gland-ciliated.- Hk. Sp. 4. p. 96.

\section{Hab. Sandwich Isles, Brackenridge, Hillebrand.}

60. N. (Last.) velatum, Hk. ; st. 3-4 in. l., densely clothed with large, ovate,

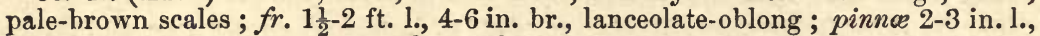
$\frac{1}{2}$ in. br., cut down nearly to the rachis into blunt, oblong, slightly-crenated lobes $\frac{1}{8}$ in. br.; texture subcoriaceous ; rachis densely scaly, like the stem ; veins 5-6 on a side ; sori marginal.-Hk. Sp. 4. p. 101. t. 247.

Hab. Cuba, Linden, 1901.-Well marked in the group by its very scaly rachis.

61. N. (Last.) palustre, Baker ; st. $1 \mathrm{ft}$. or more l., naked, stramineous ; fr. 2-3 ft. 1., 8-12 in. br. ; pinno close, erecto-patent, 4-6 in. l., $\frac{3}{4}$ in. br., cut down nearly to the raclis into linear-oblong, entire, slightly-falcate lobes $\frac{1}{8}$ in. br.; texture herbaceous; rachis and both sides quite naked ; veinlets 6-8 on a side; sorifilling up the greater part of the space between midrib and edge; invol. small, ciliated.-Aspid. Mett.

Hab. Brazil, Lindberg, 633.-In general habit most like $N$. montanum, but the lobes narrower, and veinlets simple.

62. N. (Last.) diplazioides, Hk. ; st. tufted, 6 in. or more 1., densely clothed with linear-spreading dark-brown scales ; fr. 2-3 ft. l., 8-12 in. br. ; pinnoe 4-6 in. $1 ., 1-1 \frac{1}{4}$ in. br., with a gland at the base beneath, cut down to a broadly-winged rachis into nearly entire, linear-oblong subfalcate lobes 2 lin. br. ; texture herbaceous ; rachis fibrillose, under side naked; veinlets 8-9 on a side; sori near the midrib; invol. small, setose.-Hk. Sp. 4. p. 99.

Hab. Columbia, Moritz, 408, Fendler, 159.-Distinguished by its herbaceous texture and broad lobes, not reaching much more than halfway down to the midrib.

63. N. (Last.) pachyrachis, Hk.; st. 6 in. or more l., nearly naked ; fr. $2-3$ ft. l., 8-12 in. br. ; pinnce 4-6 in. 1., $\frac{3}{4}-1$ in. br., with a gland at the base beneath, cut down to a broadly-winged rachis into spreading entire blunt lobes 2 lin. br.; lower pinnce dwindling down gradually to mere auricles; texture herbaceous, under side naked; veinlets $8-9$ on a side ; sori near the midrib ; invol. prominent, glandular.-Hk. Sp. 4. p. 100.

Hab. Venezuela, Moritz, 409, Fendler, 472.-Deeper cut than the last, and nearly naked, with a more prominent and persistent involucre. $A$. decrescens and cheilanthoides, Kze., are allied plants, with which we are not acquainted.

64. N. (Last.) lonchodes, Hk. ; rhizome creeping ; st. 12-18 in. l., glossy, naked ; fr. 1-2 ft. 1., 6-10 in. br. ; pinnce 4-5 in. l., $\frac{1}{2}-\frac{3}{4}$ in br., the lower ones with close entire lobes 2 lin. br., reaching two-thirds of the way down ; texture coriaceous; rachis and under surface finely pubescent; veinlets 4.5 on each side; sori about midway between the edge and margin.-Hk. Sp. 4. p. 99.

Hab. Cuba, Wright, 1007-8.

65. N. (Last.) deltoideum, Desv. ; st. tufted, 3-6 in. 1., densely clothed with deciduous linear scales; fr. 1-2 ft. 1., 4-8 in. br.; pinnoe of the lower third or quarter suddenly dwarfed, the larger ones $2-4$ in. 1., $\frac{3}{4}-1 \mathrm{in}$. br., cut two-thirds of the way down into close entire lobes 2 lin. br.; texture coriaceous ; rachis villose, under side nearly naked; veinlets prominent, 8-10 on a side ; sori nearer the edge than the midrib; invol. very fugacious.-Hk. Sp. 4. p. 103. Polyp.Sw.

Hab. West Indies.-Groups of veins not unfrequently slightly united. Easily recognizable by the abrupt dwarfing of the pinnæ below the centre of the frond. 


\section{+十 Vinlets forked. Sp. 66-73.}

66. N. (Last.) Thelypteris, Desv. ; rhizome slender, wide-creeping ; st. about $1 \mathrm{ft}$. l., slender, stramineous ; fr. 1-2 ft. l., 4-6 in. br.; pinnoe spreading, 2-3 in. l., $\frac{1}{2}$ in. br., cut down very nearly to the rachis into entire spreading linearoblong lobes, those of the barren frond the broadest; lover pinnoe equalling the others; upper veinlets simple, lower on es forked; textuve herbaceous ; rachis and both sides naked; sori small, not confluent, in rows near the recurved edge.-Brit. $F$. t. 13. - $\beta, N$. squamulosum, Hk.; rachis of the pinnæ slightly scaly.-Hk. $S p .4$. p. 88. Hemestheum, Neum.

Hab. Norway to Spain, Italy, Cashmere (5-6,000 ft.), and Amur-land ; Cape Colony, Natal, Angola, New Zealand; United States.

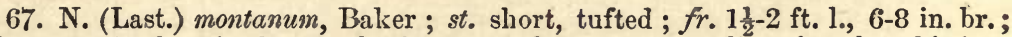
pinno 3-4 in. 1., 1 in. br. at the base, cut down to a broadly-winged rachis into close, blunt, oblong lobes; lower pinnæ distant, and gradually dwarfed down to mere auricles ; texture herbaceous ; rachis naked, or slightly scaly below, under surface glandular; lower veins forked; sori in rows near the edge.-Polyp. Vogler. N. Oreopteris, Desv.-Hk. Sp. 4. p. 90 ; Brit. F.t. 14. Hemestheum, Neum.

Hab. Lapland to Spain, Greece, and Georgia.

68. N. (Last.) apiciflorum, Hk. ; st. tufted, 6-12 in. 1., clothed throughout with linear spreading scales ; fr. 2-3 ft. l., 8-12 in. br.; pinnce close, lanceolate, the largest 4-6 in. l., $\frac{3}{4}-\frac{7}{8}$ in. br., cut down to the rachis into uniform, close, blunt, subentire lobes $\frac{1}{8}$ in. br. ; rachis more or less scaly ; texture herbaceous, under side naked ; sori 6-8 to a lobe, confined to the upper third ; invol. firm, prominent. -HK. Sp. 4. p. 112. t. 248.

Hab. N. India up to $9,000 \mathrm{ft}$.-Like $N$. Fitix-mas in general habit, but remarkable in the sori being restricted to the tip of the lobes.

69. N. (Last.) microsorum, Hk. ; st. $1 \mathrm{ft}$. or more l., fibrillose, especially below ; fr. $2 \mathrm{ft}$. l., $1 \mathrm{ft}$. br.; pinnoe 6 in. l., $1 \frac{1}{4}-1 \frac{1}{2}$ in. br., cut down to the rachis below into close, blunt, entire lobes $\frac{1}{4}$ in. br., lower ones not reduced ; texture herbaceous ; rachis fibrillose, those of the pinnæe and lobes villose, under surface naked ; veinlets 8-9 on a side, most of them forked; sori midway between the edge and midrib.Hk. Sp. 4. p. 106.

Hab. Foot of Mount Chimborazo, Spmuce.

70. N. (Last.) griseum, Baker ; st. firm, erect, grey, villose upwards ; fr. $1 \frac{1}{2} 2$ ft. 1., 8-9 in. br., oblong-lanceolate; pinnoe close, 3-4 in. l., $\frac{3}{4}-\frac{7}{8}$ in. br., narrowed gradually from the base to the apex, cut down nearly to the rachis into blunt, entire lobes 2 lin. br., with recurved edges; texture subcoriaceous ; rachis villose, and veins beneath slightly so ; veinlets about 10 on a side, mostly forked; sori small, submarginal ; invol. ciliated.

Hab. Cochin, S. Hindostan, Rev. Mr. Johnstone.

71. N. (Lașt.) sagenioides, Baker ; st. tufted, slender, 6-12 in. 1., dark chesnutbrown, scaly below ; fr. 12-24 in. 1., 6-12 in br., oblong-lanceolate ; pinnoe 3-6 in. l., 1 in. br., the lowest pair rather shorter than the others, and deflexed ; lobes cut down to a broadly-winged centre, linear-oblong, blunt, entire or slightly crenate; texture papyraceo-herbaceous; rachis polished, like the stem; veinlets $6-8$ on a side, the lower ones forked; sori in rows near the edge ; invol. fugacious. -Aspid. Mett. N. melanopus, Hk. Sp. 4. p. 110.

Hab. Malayan Peninsula and Isles, - A very distinct plant, resembling some of the 
Sagenice, not in general habit, but by its polished, dark-coloured stem, and by the sori being usually terminal on branch veins. A. zeylanicum, Fée, is probably this species.

72. N. (Last.) syrmaticum, Baker ; st. tufted, 1-2 ft. 1., naked, stramineous ;

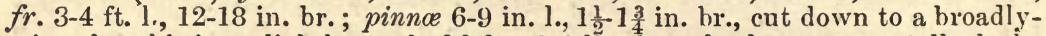
winged rachis into slightly-toothed lobes $2-3$ lin. br., the lower ones stalked, the lowest not much reduced; texture subcoriaceous; rachis and hoth surfaces naked; veinlets 12-15 on a side, nearly all forked; sori nearer the edge than the midrib. -Aspid. Willd. N. spectabile, Hk. Sp. 4. p. 115.

Hab. N. India to Ceylon, Philippines, and Malaccas.-There is a form with medial sori, and more distant and fewer (6-8) veinlets. This also bas the sori often terminal on the branch veinlets, and not unfrequently the groups join at the sinus. Willdenow supposed it to be a South American plant, doubtless by mistake.

73. N. (Last.) Filix-mas, Rich. ; st. tufted, 6 in. or more 1., more or less densely clothed with lanceolate scales; fr. 2-3 ft. l., 8-12 in. br. ; pinnoe lanceolate, 4-6 in. 1., $\frac{3}{4}-1 \frac{1}{4}$ in. br., cut down very nearly to the rachis into close, blunt, regular subentire lobes $1 \frac{1}{2}-2$ lin. br., lower ones rather shorter than the others; texture herbaceous; rachis more or less scaly, under surface naked; lower veinlets subpinnate; invol. large, convex.-Hk. Brit. F.t. 15.- $\beta, N$. affine (F.\& M. sub Aspid.); pinno not so blunt and with a space between them, narrower and the edge more or less deeply toothed.- $-\gamma, N$. elongatum, Hk. \& Gr. ; $f r$. sometimes $3-4 \mathrm{ft}$. l., $2 \mathrm{ft}$. br., subdeltoid, quadripinnatifid; lower pinnoe $1 \mathrm{ft}$. or more 1., 4-6 in. br.; pinnl. close, lanceolate, cut down nearly to the rachis into oblong crenated lobes; invol. $\frac{1}{3}-\frac{1}{2}$ lin. br.-Ic. Fil. t. 234.- $-\delta, N$. cochleatum, Don; sterile and fertile $f r$. different, the pinnl. of the former broad-leafy, the lower ones deeply lobed, those of the latter much contracted, the two rows of large sori with prominent convex invol. often 1 lin. br., occupying their whole surface.-Arthrobotrys, Wall. Hk. Sp. 4. p. 116. Dryopteris, Schott.

Hab. $\alpha$ and $\beta$ throughout Europe and Asia, from Lapland to Japan and the Malay Isles, ascending to the Himalayas to $15,000 \mathrm{ft}$.; Madeira, Sandwich Isles ; America, from Grcenland along the Rocky Mountains and Andes to Peru. $\gamma$, Azores, Madeira, Guinea Coast, Cape Colony, Mascaren Isles, Abyssinia, E. Indies, S. United States. $\delta$, Hindostan and Malaccas. - The extremes as described differ widely, but we cannot draw any clear line between them. A. Schimperianum, Canariense, Ludovicianum, and marginatum, none of them seem clearly separable from $\gamma$, which might be looked for in group 7 .

\section{**** Pinnoe cut nearly or quite down to the rachis into toothed or pinnatifid lobes. Sp. 74-87.}

74. N. (Last.) Preslii, Baker ; st. 6-9 in. 1., slender, deciduously fibrillose ; fr. 6-9 in. l., 4-5 in. br., lanceolate-deltoid ; upper pinnoe lanceolate, close, lowest pair deltoid, the upper pinnl. 2 lin. br., blunt, entire, the lower ones pinnatifid, with similar lobes and broad uncut centre; texture subcoriaceous; rachis fibrillose, both surfaces naked; sori about 6 to the lower lobes, dorsal on the veins, nearer the midrib than the edge.-L. propinqua, Presl \& J. Sm. (in part).

Hab. Philippines, Cuming, 255.-This agrees in cutting with the small forms of $N$. membranifolium, but the texture is thicker, and the sori are dorsal, not far from the base of the obscure veinlets.

75. N. (Last,) Goldieanum, Hk. ; st. tufted, $1 \mathrm{ft}$. l., clothed with large dark scales below ; fr. 2-3 ft. 1., $1 \mathrm{ft}$. or more br., ovate-deltoid ; lower pinnee 6-9 in. 1., 2 in. br., cut down nearly to the rachis into linear-lanceolate subfalcate, slightly-toothed lobes; rachis and both surfaces naked; texture herbaceous; veinlets obscure, forked; sor $i$ in rows near the midrib.-Hk. Sp. 4. p. 121 . Hk. \& Gr. Ic. t. 102.

Hab. Canada to Kentucky.-This comes nearest $N$. Filix-mas, which is not found in the Nor'hern United States. 
76. N. (Last.) marginale, Mich. ; st. tufted, 6-12 in. l., clothed principally at the base with large lanceolate concolorous scales; fr. 18-24 in. 1., 6-8 in. br., oblong-lanceolate, bipinnate ; pinnoe 3-4 in. 1., 1-1 $\frac{1}{2}$ in. br. ; pinnl. ovate-oblong, blunt, nearly entire; rachis and both sides nearly naked; texture herbaceous; lower veinlets of the pinnl. pinnate; sori marginal.-Hk.Sp.4. p. 122.

Hab. Canada and United States.-About midway between the typical form of Fitixmas and cristatum in general habit.

77. N. (Last.) lacerum, Baker; st. 4-8 in. 1., densely clothed below with large ovate-lanceolate scales; fr. 12-18 in. 1., 6-10 in. br., ovate-deltoid ; pinnoe 4-5 in. 1., $1 \frac{1}{2}-2$ in. br., lanceolate; upper pinnl. confluent, lowest free, lanceolate, acute, subfalcate, nearly entire, but the lower ones auricled on both sides of the base; texture subcoriaceous; rachises rather scaly; both sides naked; sori confined to the upper third of the frond, occupying nearly the whole of the contracted pinnl.; invol. $\frac{1}{2}$ lin. br.-Polyp. Thunb. Lastrea, Eaton.

Hab. Japan and Tsus-Sima.-Very near some of the Indian forms of Filix-mas, but admitted as distinct by Eaton and Mettenius.

78. N. (Last.) erythrosorum, Hk.; st. tufted, 6-9 in. 1., more or less densely clothed with long lanceolate and linear scales; fr. 12-18 in. 1., 8-12 in. br., ovate-lanceolate; pinno lanceolate, the lowest the largest, 5-6 in. $1 ., 1 \frac{1}{2} \mathrm{in.} \mathrm{br.,}$ cut quite down to the rachis below into oblong-bluntish pinnl. $2-3 \mathrm{in}$. br., the edge slightly, sometimes spinosely, toothed; texture firm but herbaceous; both sides naked; rachis slightly scaly; sori in rows of 6-9 to a pinnl. near the midrib ; invol. $\frac{1}{2}$ lin. br., flat, bright-red when young.-Hk. Sp. 4. p. 120. t. 253.

Hab. Japan and China. - Intermediate in appearance between Aspid. varium and N. Filix-mas.

79. N. (Last.) Floridanum, Hk.; st. 6 in. or more l., with a few ovate con-

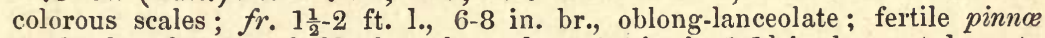
confined to the upper half, close, lanceolate, $3-4$ in. 1., 1-11 in. br., cut down to a narrowly-winged rachis into oblong, slightly crenated, blunt pinnl., with their own breadth between them and two rows of sori reaching from the midrib nearly to the edge; barren pinnoe broader, the lower ones rather reduced and subdeltoid, all not so deeply cut and the pinnl. close; texture herbaceous, both sides naked.-Hk. Fil. Ex.t. 99.

Hab. Louisiana and Florida.-Perhaps a form of $N$. cristatum, with which it agrees in its barren pinnæ, differing in its dimorphous fertile ones.

80. N. (Last.) cristatum, Mich. ; st. tufted, 6 in. or more 1., sparingly clothed with ovate concolorous scales; fr. 12-18 in. 1., 3-5 in. br., narowly oblonglanceolate; lower pinnoe deltoid, 2 in. $1 ., 1$ in. or more br., the lowest pair about equal to the next, cut down nearly, or quite, to the base below into broad, blunt, oblong, slightly pinnatifid pinnl.; teeth not aristate ; texture herbaceous; stramineous rachis and both sides nearly naked; invol. naked.-Hk. Sp. 4 . p. 121.- $\beta, N$. uliginosum (Newm. sub Lastrea); fr. broader ; pinnl. more acute and more deeply cut, teeth mucronate.-Brit. F.t. 17. A. spinuloso-cristatum, Lasch.

Hab. Scandinavia to N. Italy and Greece ; Hudson's Bay territory, Canada, United States.-Our $\beta$ is a connecting link between cristatum and spinulosum, the barren fronds resembling most the former, and the fertile ones the latter.

81. N. (Last.) Borneense, Hk.; rhizome stout, wide-creeping, densely fibrillose; st. 6 in. 1., firm, erect, brown, naked; fr. 12-18 in. l., 4-6 in. br., lanceolate ; pinnoe $2-3$ in. $1 ., \frac{3}{4}$ to 1 in. br., cut down to a broadly-winged rachis into linear-oblong deeply pinnatifid lobes ; texture subcoriaceous ; rachis and veins 
beneath finely villose ; veinlets about 6 on a side, with a sorus on each midway between midrib and edge; invol. coriaceous, persistent._Hk. Sp. 4. p. 111. 2nd Cent. t. 93.

Hab. Borneo.-Habit of $N$. flaccidum, but quite different in texture and mode of growth, in which it approximates towards Eudavallia, in which it is placed by J. Smitb.

82. N. (Last.) Salvini, Baker; st. tufted with a tuft of long brown linear scales at the base, and a few upwards, 6-9 in. 1.; fr. 12-18 in. 1., 3-4 in. br., lanceolate; pinnce close, lanceolate, $1 \frac{1}{2}-2$ in. $1 ., \frac{3}{4}$ in. br., cut down to the rachis below into imbricated oblong pinnl. with blunt lobes reaching about halfway down; texture herbaceous, firm; rachis and midrib of the pinnæ slightly scaly; veinlets forked; sori at the base of the lobes often 1 to each ; invol. naked, firm.

Hab. Guatemala, Salvin and Godman.-Most like N. faccidum in cutting, but quite different in other respects.

83. N. (Last.) flaccidum, Hk. ; st. tufted, $1 \mathrm{ft}$. or more l., slender, stramineous, naked; fr. 12-18 in. l., 6-8 in. br.; pinnoe 3-4 in. l., 1 in. br., cut down to a rachis with a narrow distinct wing into oblong lobes 2 lin. br. cut about halfway down; lower pinno distant, shorter than the others and deflexed; texture lerbaceous; the stramineous rachis and under side villose; veinlets forked or in the lower lobes subpinnate; sori about midway between the edge and midrib.Hk. Sp. 4. p. 133. t. 263.

Hab. Himalayas (up to 6,000 ft.) to Ceylon and Java.-General habit of some of the least-cut forms of $A$. Filix-faemina.

84. N. (Last.) Brunonianum, Hk. ; st. tufted, 4-6 in. 1., black, densely clothed with large dark-brown lanceolate scales; fr. 12-18 in. 1., 2-4 in. br., with numerous, close, subequal, oblong-lanceolate, blunt pinno, the lower ones reduced, the largest $1 \frac{1}{2}-2$ in. l., $\frac{3}{4}$ in. br., cut down nearly to the rachis into sharplytoothed blunt lobes $1 \frac{1}{2}-2$ lin. br.; texture herbaceous; rachises ebeneous and more or less clothed with long fibrillose scales; under surface naked; sori copious, about midway between the edge and midrib.-Hk. Sp. 4. p. 113. $t$. 251 .

Hab. Himalayas, 12-15,000 ft.

85. N. (Last.) barbigerum, Hk. ; st. tufted, 6-12 in. 1., densely clothed with large bright-brown scales and soft silky hairs; fr. 2-3 ft. 1., 6-12 in. br. ; pinnoe

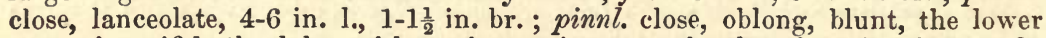
ones pinnatifid, the lobes with copious aristate teeth, the edge often incurved; texture herbaceous ; rachises clothed like the stem ; midrib beneath rather scaly; sori in rows close to the midrib of the pinnules.- $H k . S p .4 . p .113$.

Hab. Himalayas, 11-13,000 $\mathrm{ft}$.- This and the preceding are closely allied to one another, but not likely to be confused with anything else.

86. N. (Last.) setosum, Baker ; st. tufted, 4-6 in. 1., densely clothed with fibrillose scales; fr. 12-18 in. l., 6-9 in. br.; lowest pinnoe the largest, deltoid, 4-5 in. 1., 2-3 in. br. ; pinnl. lanceolate, $1 \frac{1}{2}-2$ in. 1., cut down to the rachis below into erecto-patent, entire, linear segm.; texture herbaceous; rachises densely fibrillose; both surfaces naked ; veinlets of the segments 5-6 on a side, the lower ones forked; sori in a line close to the midrib.-A. setosum, Blume! (non Swartz).

Hab. Java, Blume, Millett.

87. N. (Last.) Welwitzschii, Baker ; st. 6-12 in. 1., pubescent and fibrillose ; fr. $18 \mathrm{in.1.,} 1 \mathrm{ft}$. br. ; lower pinnce ovate-lanceolate, 6-8 in. 1., $2 \mathrm{in.}$ br., cut down nearly or quite to the rachis into linear-oblong pinnl. $\frac{1}{4}-\frac{3}{8} \mathrm{in}$. br., of which the 
central ones are the largest, and cut into close lobes more than halfway down to the rachis, but the upper and lower ones nearly entire; texture herbaceous; rachises finely fibrillose, under side opaque, and scattered over with short, stiff, shining hairs; veinlets forked or subpinnate in the lobes; sori in rows a short distance from the midvein of the latter ; invol. small, hairy.

Hab. Angola, Welwitzsch.-This seems a very distinct plant.

***** Group of $N$. spinulosum; caudex erect, fronds small or middle-sized, tri- or quadripinnatifid; involucres firm, persistent. Sp. 88-117. Lophodium, Newm.

\section{+ Fronds oblong-lanceolate or oblong-deltoid. Sp. 88-101.}

88. N. (Last.) viridescens, Baker; st. tufted, 12-18 in. l., naked, polished, brownish, glossy, with a few lanceolate scales near the base ; $f r .1 \frac{1}{2}-2 \mathrm{ft}$. $1 ., 1 \mathrm{ft}$. br.; lower pinnoe the largest; pinnl. oblong-lanceolate, pinnatifid, with broad, blunt lobes with a few sharp teeth, the lowest $2-3$ in. 1 , , and cut down nearly to the rachis ; texture herbaceous; colour bright green; rachis polished; both sides naked; sori in rows near the midribs of the pinnls.; invol. $\frac{1}{2}$ lin. br., naked.

Hab. Japan, Oldham, 89, 377.-A connecting link between this group and the last.

89. N. (Last.) fragrans, Rich.; st. densely tufted, very short, clothed with

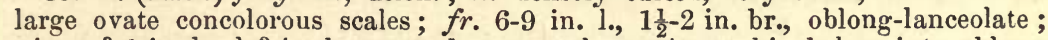
pinnce $\frac{3}{4}-1$ in. $1 ., \frac{1}{4}-\frac{3}{8}$ in. br., cut down nearly to the rachis below into oblong lobes, which are again toothed or pinnatifid; lower pinnæ reduced gradually; texture coriaceous; rachises densely scaly; veins subpinnate in the lower lobes of the pinnules, the lower part of which is often quite covered with the sori; invol. very large and membranous.-Hk. Sp. 4. p. 122. Hk. \&. Gr.t. 70.

Hab. Caucasus to Kamschatka, and Arctic America to Wisconsin.

90. N. (Last.) rigidum, Desv. ; st. tufted, 6 in. 1., densely clothed below with large lanceolate or ovate concolorous scales ; fr. 12-18 in. l., 4-6 in. br., oblonglanceolate; largest pinno 2-3 in. l., 1-1 $\frac{1}{2}$ in. br., the pinnl. of the lower half free, ovate-rhomboidal, cut down nearly to the rachis below; teeth mucronate; texture herbaceous ; rachises usually scaly ; under side slightly glandular ; veinlets subpinnate in the lower lobes of the pinnules; sori close to the midrib; invol. firm, prominent, fringed with glands.-Hk.Sp. 4. $p .160$. B. F.t. 16.

Hab. Britain to Spain, Greece, Syria, and Asia Minor ; California, N.W. Mexico.The S. Europeana nd American forms (A. pallidum, Link, and A. argutum, Kaulf.) have the lower pinnules often 1-1 $\frac{1}{2}$ in. 1., with the veins copiously pinnate in the lower lobes.

91. N. (Last.) spinulosum, Desv. ; st. tufted, about $1 \mathrm{ft} .1$., sparingly clothed with ovate concolorous scales; fr. 12-18 in. l., 6-8 in. br., oblong-lanceolate; lower pinnoe subdeltoid, $3-4$ in. $1 ., 1 \frac{1}{2}-2$ in. br., the lowest pair about equal to the next; pinnl. ovate-lanceolate, the largest about 1 in. $1 ., \frac{1}{2}$ in. br., cut down to the rachis below into close oblong lobes with copious aristate teeth; texture herbaceous; rachis stramineous, scarcely scaly; under surface not glandular; colour pale-green; invol. not gland-ciliated.-Hk. Bvit. F. t. 20.- $\beta, N$. dilatatum, Desv.; scales denser and narrower, dark-brown in the centre ; fr. ovatelanceolate or subdeltoid, larger and more deeply cut, the colour a darker and brighter green, the pinnoe closer, the under surface often finely glandular, the invol. gland-ciliated.-Hk.B.F.t.19.- -, N. remotum (A. Br. sub Aspid.) ; scales lanceolate, concolorous, extending to the rachis; fr. oblong-lanceolate, about $2 \mathrm{ft}$. l., 6 in. br.; pinnoe lanceolate, close; pinnl. ovate-oblong, only the lowest free, the largest about 1 in. $1 ., \frac{1}{2}$ in. br., cut halfway down to the rachis or more, spinulose teeth few ; under side and invol. not glandular.-Hk. Brit. $F$. t. 22. $-\delta, N$. Boottii ('Tucker., sub Aspid.); habit and scales of $\alpha$; pinnce distant, 
lanceolate; lowest pinnl. scarcely free, the largest ahout $\frac{1}{2}$ in. $1 ., \frac{1}{4}$ in. hr., cut froun one-third to halfway down to the rachis below.-L. collina, Newm.$\varepsilon$, lepidota, Moore; rachises chesnut-brown, scaly ; $f r$. subdeltoid ; lower pinna deltoid, 5-6 in. each way ; lowest pinnl. much the largest, often 3 in. l., 2 in. br., its segm. cut down to the rachis below and with lobes again deeply pinnatifid.Hk. Sp. 4. p. 127.

Hab. Arctic Europe and America southward to Madeira, the Mediterranean, W. Himalayas, and Carolina, and found also sparingly in Bourbon and Cape Colony.-A very variable plant. 'Var. $\gamma$ is the most distinct form, and from this a recedes in the direction of N. cristatum, and $\gamma$ towards Filix-mas. The common N. American form (A. intermedium, Muhl.) has an oblong-lanceolate frond and pale scales, but is generally larger and more finely cut than our typical plant. L. glandulosa, Newm., is most like $\beta$, but the scales are few and pale, and the frond is narrower, with the under side more distinctly glandular.

92. N. (Last.) Eatoni, Baker; st. 1 ft. 1., stramineous, clothed copiously with squarrose purplish fibrillose scales; fr. 12-18 in. l., 6-9 in. br., ovate-lanceolate; upper pinnoe lanceolate, lowest pair subdeltoid, 4-5 in. l., 2-3 in. br.; pinnl. lanceolate, close, cut down nearly or quite to the rachis into close, blunt, subentire, linear-oblong lobes; texture herbaceous; rachis stramineous and fibrillose like the stem; under side slightly villose and glandular; sori small, copious; invol. gland-ciliated.

Hab. Kakeah and Loo Choo Isles, E. Asia, C. Wright.-Habit and cutting of $N$. dilcstatum, from which it differs by its dense fine spreading hair-like scales and slightly villose rachises and under surface.

93. N. (Last.) mexicanum, Hk. ; st. tufted, 12-18 in. 1., stramineous, scaly towards the base ; fr. 1-2 ft. l., 6-12 in. br., ovate-lanceolate; pinnoe lanceolate, 3-6 in. $1 ., 1 \frac{1}{2}-2$ in. br., the divisions sometimes spathulate, not cut down quite to the rachis and nearly entire, but more usually the lower ones free, subdeltoid, and deeply pinnatifid; texture firm, herbaceous; colour pale-green; rachis and both surfaces naked; sori in rows about midway between the edge and midrib ; invol. naked, conspicuous.- $H k$. $S p$. 4. $p$. 138. $t$. 267. A. leptorachis, Kze.$\beta, A$. chorophylloides, Moritz. ; more compound, lower pinnæ sometimes 9-12 in. $1 ., 3-4$ in. br. ; pinnl. lanceolate, cut down nearly to the rachis into oblong crenated lobes.

Hab. West Indies and Mexico to Brazil and Ecuador.-The involucres are sometimes orbicular and peltate. There is a wide range in cutting between the extremes, $\beta$ resembling the larger forms of Filix-mas.

94. N. (Last.) sparsum, Don ; st. tufted, 6-12 in. 1., scaly only towards the base, stramineous and glossy upwards; fr. 1-2 ft. l., 8-12 in. br., ovate-lanceolate; lowest pinnce the largest, 4-6 in. l., $1 \frac{1}{2}-2$ in. br.; lowest pinnl. sometimes compound, the others lanceolate, unequal-sided, pinnatifid, with oblong, blunt lobes; texture firm, herbaceous; rachis naked or slightly scaly, both sides naked; colour pale-green; sori usually one to each lobe near the midrib; invol. naked, flat, 1 lin. br. - N. purpurascens, Hk. Sp. 4. p. 132.t. 262.

Hab. N. India to N. China, Ceylon, and Malay Isles; Mauritius.-This species resembles the last, and rivals it in range of size and cutting. Mettenius regards $A$. purpurascens, Blume, as distinct, characterized by being more rigid in texture, with divisions not so unequal-sided and the frond larger and more divided. L. deltoidea, Beddome, $t$. 248, from Ceylon, has subdeltoid fronds and pinnules $\frac{1}{4}-\frac{3}{8}$ in. br.

95. N. (Last.) undulatum, Baker; st. tufted, 6-12 in. 1., scaly towards the base, glossy, and stramineous upwards; $f r .1 \mathrm{ft}$. or more 1., $6-8$ in. br., ovatedeltoid, the main rachis very distinctly zigzag, the pinnoe deflexed and then curved upwards, imbricated, subdeltoid, the lowest pair the largest, 4-6 in. l., 
2-3 in. br. ; secondary and tertiary rachises also zigzag ; lower pinnl. subdeltoid ; segm. 2-3 lin. br., ovate-rhomboidal or pinnatifid ; both sides naked ; colour palegreen; sori large, 3-4 to the lower segm. near the midrib.-Aspid. Thwaites. Lastrea, Beddome, $t .271$.

Hab. Ceylon, C. P. 3858.-Perbaps not distinct from the last, with which it agrees, except in the peculiar zigzag rachises.

96. N. (Last.) deparioides, Hk.; st. 1 ft. or more l., firm, slightly scaly below ; fr. $1 \frac{1}{2}-2$ ft. l., 8-10 in. br., oblong-lanceolate ; lower pinnoe 4-6 in. l., 2 in. br., lanceolate, cut down to the rachis below into unequal-sided, stalked, deltoid pinnl. with broad, blunt subquadrangular lower lobes and prominent teeth; texture herbaceous; rachis and both surfaces naked; sori terminal in the teeth, which the convex involucres quite conceal.-Hk.Sp.4. p.139. Fil. Ex. t. 3. Diclosodon, Moore.

Hab. Ceylon and S. India.-Teeth very distinct and sori quite terminal, so the plant resembles Deparia, a character quite unique in the genus.

97. N. (Last.) Thwaitesii, Baker ; st. $1 \mathrm{ft}$. or more l., slender, stramineous, slightly scaly below; fr. 12-18 in. l., 6-8 in. br., lanceolate-deltoid; pinnoe lanceolate, 3-4 in. l., $1 \frac{1}{2}$ in. br.; pinnl. distant, subdeltoid, unequal-sided, slightly bluntly lobed below, obliquely truncate at the base on the lower side; colour pale-green ; texture herbaceous ; rachis and both sides quite naked ; sori small, quite marginal; invol. naked.-A. concinnum, Thwaites (non Mett.).

Hab. Ceylon.-Very like the last in outline, but quite different in fruit.

93. N. (Last.) sphoerocarpum, $\cdot$ Hk. ; st. 6 in. l., slender, stramineous, clothed below with a few lanceolate scales ; $f r .12-18$ in. 1., 6-8 in. br., ovate-lanceolate ; lower pinnoe 3-4 in.l., 2 in. br., lanceolate-deltoid; pinnl. lanceolate, cut down to the rachis below into small oblong toothed lobes; texture herbaceous; rachis stramineous, slightly scaly; both surfaces naked; sori mostly solitary at the base of the lobes; invol. large, reniform, membranous.-Hk. Sp. 4. $p .139$. Athyrium, Fée.

Hab. Mexico.-Thinner in texture than $N$. mexicanum, and the fruit different.

99. N. (Last.) athamanticum, Hk.; st. tufted, stout, stramineous, $1 \mathrm{ft} .1$. , clothed at the base with large concolorous linear scales ; fr. 1-2 ft. l., 6-9 in. br., oblong-lanceolate; pinnee imbricated, the lower ones 4-6 in. l., 2-3 in. br., the pinnl. cut down to the rachis below into blunt oblong-rhomboidal lobes; texture subcoriaceous; colour pale-green, the stramineous rachis and both sides naked; veinlets immersed, copiously pinnate in the lower lobes; sori close to the midrib; invol. large, persistent.-HK. Sp. 4. p. 125. t. 258.

Hab. Cape Colony to Natal and Angola.-Most like N. sparsum in texture, but more divided.

100. N. (Last.) incequale, Hk.; st. $1 \mathrm{ft}$. or more 1., with a dense tuft of reddish-brown lanceolate scales at the base and a few upwards; $f r .1-2 \mathrm{ft} .1$., 8-12 in. br., ovate-deltoid; lower pinnoe rather shorter and broader than the next, which are 6-8 in. 1., 2-3 in. br.; pinnl. lanceolate, cut down nearly to the rachis into oblong spinoso-serrated segm.; texture herbaceous; colour darkgreen; raclises and both surfaces nearly naked; sori in two rows near the midribs; invol. firm, naked.-Hk. Sp.4. p. 125.

Hab. Cape Colony and Natal.-Intermediate in habit between N. spinulosum and the large forms of Filix-mas.

101. N. (Last.) Falconeri, Hk. ; st. $1 \mathrm{ft}$. l., densely clothed throughout with

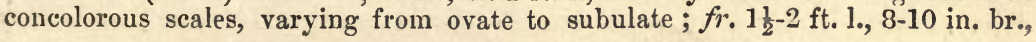


oblong-lanceolate; pinnce 4-5 in. l., $1 \frac{1}{2}-2$ in. br., largest pinnl. 1 in. l., $\frac{1}{4}$ in. br., cut down nearly to the rachis into oblong, blunt lobes with revolute edges; texture herbaceous; rachises densely fibrillose ; sori in rows close to the inidrib of the pinnl.-Hk. $S p$. 4. p. 123. $t .254$.

Hab. Cashmere, Falconer.-Seems a well-marked species, most like $N$. fragrans on a large scale.

\section{计 Fronds subdeltoid. Sp. 102-117.}

102. N. (Last.) stipitatum, Baker ; st. 8-9 in. 1., flexuose, densely scaly at the base ; fr. 3-4 in. each way, deltoid; pinnœ 6-9, the lowest $1 \frac{1}{2}$ in. 1. , unequalsided, ovate-lanceolate, cut down to a narrowly-winged rachis into oblong, obtuse lobes, the lowest subpinnate ; veinlets of the lobes 4-6 on a side, the lower ones forked; texture subcoriaceous; rachis and both sides naked; sori close to the midrib; invol. coriaceous, glabrous, persistent.-Aspid. Mett. p. 60.

Hab. Ladrones, Mertens. - With this we are not acquainted.

103. N. (Last.) hirtum, Hk. ; st. tufted, 4-8 in. 1., wiry, brown, densely fibrillose ; fr. 4-6 in. l., 3-4 in. br., subdeltoid ; lower pinnoe much the largest and lowest pinnl. larger than the others, which are $\frac{1}{2}-1$ in. $1 ., \frac{1}{4}-\frac{3}{8} \mathrm{in.}$ br., cut down to the rachis below into spathulate, usually entire, blunt lobes; texture herbaceous; colour bright-green; rachises fibrillose; under surface glandular ; veinlets pinnate in the lower lobes; sori small, distant from the midrib.- $H$ k. Sp. 4. p. 128. Cystopteris, Klotzch.

Hab. West Indies, and gathered also by Mr. Curror in West Tropical Africa.

104. N. (Last.) squamisetum, Hk. ; st. tufted, $1 \mathrm{ft}$. l., densely clothed with linear and upwards with fibrillose scales; fr. $1 \mathrm{ft}$. or more 1., 8-9 in. br., subdeltoid; lower pinnoe the largest, subdeltoid, 4-6 in. 1.; 2-3 in. br.; pinnl. lanceolate-deltoid, cut down to the rachis below into pinnatifid, blunt, oblongdeltoid lobes; texture firm, herbaceous; rachises fibrillose; both sides naked; sori in rows near the midrib.-Hk. Sp. 4. p. 140.t. 268.

Hab. Fernando Po (4000 ft.) G. Mann.-Most like sparsum and mexicanum in cutting and texture.

105. N. (Last.) chinense, Baker ; caud. decumbent; st. about 6 in. 1., slender, substramineous, clothed throughout with linear dark-brown scales; fr. 12-15 in. 1., 6-9 in. br., subdeltoid ; pinnoe few, the lowest much the largest, 5-6 in.1., 3-4 in. br. ; lowest pinnl. much longer than the others, which are lanceolate, with distinct, oblong-deltoid, deeply pinnatifid lower segm. ; texture herbaceous ; rachises naked or slightly scaly ; under surface almost naked; sori copious, $\frac{1}{3}$ lin. br., distant from the midrib.

Hab. N. China, Col. Urquhart; Korea, Wilford; Japan, Dickens.

106. N. (Last.) glabrum, Baker ; st. 6-9 in. l., naked, stramineous above, clothed towards the base with lanceolate concolorous scales; fr. $1 \mathrm{ft}$. or more l., 6-9 in. br. ; lowest pinnoe the largest, subdeltoid, 4-5 in. l., 2-3 in. br.; pinnl. close, lanceolate, cut down to the rachis below into small, oblong, pinnatifid segm. with mucronate teeth; texture herbaceous; rachis and both sides naked; sori copious, submarginal; invol. naked.-Lastrea, Brack.

Hab. Sandwich Islands.-Very near the preceding.

107. N. (Last.) tenuifolium, Hk.; st. about $1 \mathrm{ft}$. 1., slender, clothed throughout with small, grey, lanceolate scales; fr. 12-18 in. each way, deltoid; lower pinnoe much the largest, unequal-sided, deltoid; lowest pinnl. 3-4 in. l., 1-1 $\frac{1}{2}$ in. br., the rest lanceolate, cut down to the rachis below into oblong, bluntly-toothed lobes; texture herbaceous; rachises and midribs scaly and villose; both sides 
glandular and grey, with short stiff hairs; sori small, medial.-IIk. Sp. 4. p. 144.

\section{Hab. Fiji, Brackenridge, Milne.}

108. N. (Last.) edentulum, Baker ; st. stramineous ; fr. upwards of $1 \mathrm{ft} .1$. and nearly as br.; lower pinnce 5-6 in. l., more than 2 in. br., lanceolate-acuminate ; pinnl. distant, spreading, connected at the base, oblong, obtuse, $1 \frac{1}{4}$ in. l., with oblong, obtuse, entire lobes; texture thinly herbaceous; colour deep-green; under surface fibrillose on the midribs, the rest naked; veins 1 to each lobe; sori close to the midrib, 1 or 2 to a lobe ; invol. thin, glabrous, persistent.Aspid. Kze.

Hab. Java.-Our description is from Mettenius.

109. N. (Last.) cemulum, Baker; st. tufted, 1 ft. l. ; scales linear-lanceolate, concolorous, dense below; $f r$. lanceolate-deltoid, 12-18 in. l., 6-10 in. br., the lowest pinnoe much the largest; lowest pinnl. larger than the others, which are ovate-lanceolate, cut down to the rachis below into deeply pinnatifid lobes with aristate teeth ; texture herbaceous; rachis slightly scaly ; under surface glandular ; invol. not gland-ciliated. - Polyp. Sol. N. spinulosum $\gamma, H k$. Sp. 4. p. 127. Brit. F.t.20. N. Fænisecii, Lowe. L. recurva, Newm.

Hab. Britain, Madeira, Azores.-Smelling like hay when dried, the pinnæ and pinnules with the edge turned upwards in the growing plant.

110. N. (Last.) Karwinskyanum, Baker; st. 6-9 in. 1., slender, stramineous, with a few small concolorous scales; fr. 12-15 in. 1., 8-12 in. br., deltoid ; lower pinnoe much the largest, oblong-deltoid ; pinnl. close, lanceolate, 1-1 $\frac{1}{2}$ in. l., cut down below nearly to the rachis into oblong bluntly-toothed lobes; texture herbaceous; rachis slender, slightly scaly; under surface mealy, with fine glands; sori at the base of the lobes; invol. prominent, ciliated.-Aspid. Mett. p. 59 .

Hab. Mexico and Guatemala.-Differs from sphcerocarpum by its glandular fronds and deltoid outline.

111. N. (Last.) Napoleonis, Bory ; st. 6-12 in. l., densely scaly at the base, naked upwards ; fr. 12-18 in. 1., 8-12 in. br., subdeltoid; lower pinnce much the largest; pinnl. of the under side the longest, $\frac{1}{2} \mathrm{in}$. br., linear-lanceolate, close, cut down nearly to the rachis into slightly-toothed, broad, blunt lobes; texture subcoriaceous; rachis and both sides naked; sori close to the midrib; invol. naked.-Hk. Sp. 4. p. 123. t. 255.

Hab. St. Helena.

112. N. (Last.) Ascensionis, Hk. ; st. tufted, stout, densely clothed with darkbrown linear scales; fr. 8-12 in. l., 4-6 in. br., subdeltoid; pinnoe imbricated, the lower ones $3-4$ in. l., 2 in. br.; pinnl. linear-lanceolate, $\frac{1}{4}$ in. br., cut down to the rachis into subentire, oblong lobes ; texture subcoriaceous ; rachises scaly; sori one at the base of each lube.-Hk. Sp. 4. p. 124.t.257.

Hab. Island of Ascension.

113. N. (Last.) cognatum, Hk. ; st. tufted, stout, $1 \mathrm{ft}$. 1., densely clothed with large ovate scales ; fr. 2-3 ft. l., 12-18 in. br., ovate-deltoid ; pinnoe close, lanceolate, $6-9$ in. $1 ., 1 \frac{1}{2}$ in. br., the lowest pair broadest ; lobes oblong, bluntish, 3-4 lin. br., broadly toothed; texture subcoriaceous; rachises scaly ; sori in rows midway between the edge and midrib.-Hk. Sp. 4. p. 123. t. 256.

Hab. St. Helena. 
114. N. (Last.) rubiginosum, Hk.; st. $1 \mathrm{ft}$. l., densely clothed with large linear scales at the base, and upwards with spreading smaller ones; fr. 12-18 in. l., $1 \mathrm{ft}$. br., subdeltoid; pinno lanceolate, the lowest the largest, deltoid, 6-8 in. 1., 3-4 in. br.; pinnl. close, lanceolate, cut down to the rachis into slightly-toothed, oblong, blunt segm.; texture herbaceous, both sides naked; rachises fibrillose; sori close to the midrib.-Hk. Sp. 4. p. 143.

Hab. Sandwich Islands, Brackenridge.-The scales of the rachis are quite subulate, with alternate coloured and colourless cells. $N$. Figiense, Hk. 2nd Cent. t. 67, is probably distinct; the frond is larger and less deltoid, the rachises are less scaly, and the lower segments are pinnatifid, with small blunt lobes, with a sorus filling up more than half of them. It was gathered by Milne in Fiji.

115. N. (Last.) squamigerum, Hk. \& Arn. ; st. tufted, 1 ft. l., clothed throughout with lanceolate scales; fr. 12-18 in. 1., 6-9 in. br., ovate-deltoid; pinnce close, lanceolate, the lowest pair subdeltoid, 6-9 in. 1., 3-4 in. br. ; pinnl. lanceolate, close, more or less deeply pinnatifid, with broad blunt lobes; texture herbaceous; rachises and midribs of the pinnules beneath scaly; sori in rows near the midrib.-Hk. Sp. 4. p. 144. t. 280.

Hab. Sandwich Islands.-Unique in the group in the dense scaly clothing of its rachises.

116. N. (Last.) Bojeri, Baker ; st. 6-9 in. 1., naked, stramineous, the scales lanceolate, concolorous, confined to the base ; fr. $1 \frac{1}{2}-2 \mathrm{ft}$. l., nearly as br., deltoid ; pinnce imbricated, the lowest the largest, lanceolate, sometimes $1 \mathrm{ft} .1$., 4 in. br. ; pinnl. lanceolate, cut down to the rachis below into oblong-ligulate subentire lobes; texture herbaceous; rachis and both surfaces naked; veinlets forked; sori distant from the midrib; invol. firm, naked.-N. Boryanum, Hk. Sp. 4. p. 126.

Hab. Mauritius and Bourbon.-Mettenius has shown another quite different plant to be Willdenow's Boryanum. The alliance of this is $N$. Napoleonis, but the frond is more compound.

117. N. (Last.) odoratum, Baker ; st. 12-18 in. 1., stramineous, glossy, densely clothed at the base with a tuft of lanceolate bright-brown scales; fr. $918 \mathrm{in} .1$., deltoid; lowest pinnce much the largest, deltoid, 6-9 in. 1., 3-4 in. br. ; pinnl. lanceolate, often imbricated, with ovate or oblong pinnatifid segm. with blunt rounded lobes; texture herbaceous; colour pale-green; rachis and under side more or less pubescent; sori copious ; invol. large, pale, villose.-Aspid. Bory. N. hirsutum, Don. N. eriocarpum, Dec. Hk. Sp. 4. p. 141. Hypodematium, Kunze.

Hab. N. India (up to 7-8000 ft.), S. China, Malayan Peninsula, Mauritius, Cape Verdes.-A well-marked species, which specimens from Bojer show is A. odoratum of Willdenow.

*\%*\%* Rhizome wide-creeping. Fronds small or middle-sized, deltoid, tri- or quadripinnatifid. Sp. 118-125.

118. N. (Last.) pubescens, Desv. ; st, 6-18 in. 1., slender, deciduously villose ; fr. 6-18 in. l., deltoid ; lower pinno much the largest; pinnl. lanceolate ; lower segm. usually free, oblong-rhomboidal, unequal-sided; teeth mucronate; texture subcoriaceous; rachises often densely villose and under side more or less pubescent; colour pale-green; sori small, distant from the midrib.-Hk. Sp. 4. p. 146. Hk. \& Gr. Ic.t. 102 .

Hab. West Indies.-Veius sometimes anastomosing. Phegopteris Portoricensis, Fée, and Polyp. sericeum, Hk. Sp. 4. p. 258, are non-involucrate forms.

119. N. (Last.) Parishii, Hk.; st. 6-9 in. l., slender, naked, ebeneous ; fr. 6-8 
in. each way, deltoid, the lower pinnce much the largest; lower pinnl. larger than the others, which are oblong-lanceolate, acuminate, $1 \frac{1}{2}-2$ in. $1 ., \frac{1}{2}-\frac{3}{4}$ in. br., cut down nearly to the rachis into close, oblong lanceolate, crenated lobes; texture membranous; rachises and under surface pubescent; veinlets pinnate in the lobes; sori in rows not far from the midrib.-Hk. Sp. 4. p. 131.t. 260.

Hab. Moulmein, Rev. C. S. Parish.-Very different in texture from the rest of the group, and like species 71-2, approximating to some Sagenice in the sori being usually terminal on branch veins.

120. N. (Last.) subquinquefidum, Hk. ; st. $1 \mathrm{ft}$. or more l., brownish, firm, naked or villose upwards ; fr. 6-18 in. each way; lower pinnoe much the largest, with the pinnl. on the lower side much larger than the others, which are 1-3 in. 1., $\frac{3}{4}-1$ in. br., often cut down nearly to the rachis below into broad, oblong lobes; texture herbaceous ; colour dark-green ; rachis more or less villose ; sori medial.-Hk. Sp. 4. p. 130. N. Vogelii, Hk. 2nd Cent. t. 21. N. funestum, Hk. Sp. 4. p. 129. t. 259.- $\beta, N$. variabile, Hk. ; more compound ; lower pinnce sometimes $1 \mathrm{ft}$. l., quadripinnatifid, with lowest segm. 1 in. 1., $\frac{1}{2}$ in. br. $-H k . S p .4$. p. 140. L. pilosissima, $\boldsymbol{J}$. Sm.

Hab. West Indies to Brazil, island of Nissobè, Angola, Guinea Coast, Senegambia. -The extremes differ widely in cutting, but pass in to one another very gradually. $A$. acrocarpon, Fée, belongs here.

121. N. (Last.) subsericeum, Baker ; rhizome clothed with lanceolate, ferruginous scales; st. 7 in. 1.; fr. 8 in. l., deltoid, tripinnatifid; lowest pinnoe ovate-lanceolate, unequal-sided ; pinnl. ovate-rhomboidal, obtuse, cut down to a narrow wing into toothed or pinnatifid segm.; texture thin, flaccid; both sides slightly and the midrib above densely clothed with soft spreading hairs; sori 1 to each lobe.-Aspid. Mett. Fil. Nov. Cal. p. 74.

Hab. New Caledonia, Vieillard.

122. N. (Last.) decompositum, R. Br. ; rhizome wide-creeping ; st. 12-18 in. 1., scaly only at the base, firm, villose ; fr. 1-2 ft. l., $1 \mathrm{ft}$. or more br., ovate-lanceolate or deltoid ; lower pinnoe much the largest, deltoid, 4-9 in. 1., 2-4 in. br.; pinnl. lanceolate, more or less deeply pinnatifid; segm. unequal-sided, ovaterhomboidal, deeply pinnatifid, with toothed lobes; rachis and under side more or less villose; sori rather large, placed midway between the midrib and edge.$\beta, N$. glabellum, A. Cunn.; rlizome abbreviated ; $f r$. more finely cut, with more copious spinulose teeth, villose only on the rachis above, the surfaces glossy, and lobes not imbricated.-Hk. Sp. 4. p. 146.

Hab. Australia, Van Diemen's Land, and New Zealand to Tahiti and Fiji.-Very variable in size, texture, and cutting. Dr. Mueller sends a form with suppressed involucres. A. Shepherdi, Kze. (L. acuminata, Moore) is most like $\alpha$ in cutting, but the rhizome is abbreviated and the frond narrower.

123. N. (Last.) velutinum, Hk. fil. ; st. $1 \mathrm{ft}$. or more 1., bright-brown, villose upwards, scaly only at the base; fr. 12-18 in. l., by nearly as broad, deltoid; lower pinnce much the largest, deltoid; lowest pinnl. larger than the others, which are close, lanceolate, cut down to the rachis below into pinnatifid, oblong lobes; texture herbaceous ; rachises densely villose, and both sides softly pubescent; sori small, copious; invol. gland-ciliated.-Hk. Sp. 4. p. 145.

Hab. New Zealand.-Principally distinguished from the preceding by its more flaccid habit and densely villose surface and rachises. We have similar but not quite identical plants from Queensland and Fiji.

124. N. (Last.) recedens, Hk.; st. about $1 \mathrm{ft}$. 1., erect, villose, soft, clothed at the base with squarrose linear scales; fr. $1 \frac{1}{2}-2 \mathrm{ft}$. $1 ., 1 \mathrm{ft}$. or more br., deltoid ; 
lower pinnce much the largest, 6-12 in. 1., 3-6 in. br.; pinnl. of the lowest side the largest, often 6 in. 1., 2 in. br., with distinct, one-sided, lanceolate segm. with close slightly-toothed linear-oblong lobes; texture firm; rachises villose; under side nearly naked; sori small, 6-8 round the edge of the larger lobes.Hk. Sp. 4. p. 135̃. t. 265 .

Hab. Philippines, Neilgherries, and Ceylon.-In its mode of growth this agrees with the two preceding. Our description is taken from living specimens sent by Dr. Thwaites.

125. N. (Last.) Vieillardii, Baker ; st. strong, erect, slightly fibrillose towards the base; fr. 12-18 in. $1 ., 1$ ft. or more br., deltoid; lowest pinnoe 6-8 in. l., 3-5 in. br., the lowest pinnl. the largest, the others lanceolate, cut down nearly to the rachis at the base into entire or toothed linear-oblong lobes; texture subcoriaceous; rachis and both sides naked; sori small, medial.-Aspid. Mett. Fil. Nov. Cal. p. 75.

Hab. New Caledonia, Vieillard, 1604, 1610.-Largest uncut ultimate lobes 2 lin. br., 3 lin. deep, and texture like that of Polystichum.

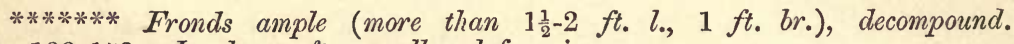
Sp. 126-153. Involucre often small and fugacious.

\section{+ Texture herbaceous. Sp. 126-146.}

126. N. (Last.) membranifolium, Presl; st. tufted, $1 \mathrm{ft}$. or more 1., rather slender, glossy, clothed with linear dark-brown scales towards the base; $f r$. 1-3 ft. 1., 9-18 in. br., deltoid ; lower pinnoe varying from simply pinnatifid, with broad blunt lobes, to $1 \mathrm{ft}$. 1 ., with similar pinnatifid pinnl., the centre usually uncut for a breadth of $\frac{1}{4}-\frac{1}{2}$ in., and the uncut bluntish or acute ult. divisions as broad; colour bright-green; texture papyraceo-herbaceous; rachis and both surfaces nearly naked ; sori copious, generally submarginal ; invol. flat, $\frac{1}{2}-\frac{3}{4}$ lin. br.-Hk. Sp. 4. p. 131. Polyp. Milnei, Hk. Sp. 4. p. 204.

Hab. N. India and Philippines to Samoa, New Caledonia, Ceylon, S. W. Australia, and Madagascar.- Habit of $N$. cicutarium, and similarly variable in size, but the veins only casually uniting. A. Gardnerianum, Mett., is doubtless the same, and P. Milnei is evidently a compound non-indusiate form. Probably it is A. sinuatum, Labill., but the figure represents the stem as too scaly and the involucre as orbicular.

127. N. (Last.) Milnei, Hk.; st. $1 \mathrm{ft}$. or more l., naked, polished, ebeneous ; fr. $1 \frac{1}{2}-2 \mathrm{ft}$. 1., $1 \mathrm{ft}$. or more br., subdeltoid ; lower pinnoe much the largest, 6-9 in. 1 , 4-5 in. br.; pinnl. close, lanceolate, cut down throughout to a narrowly-winged rachis into narrowly-oblong, crenated or pinnatifid lobes ; texture subcoriaceous ; rachises ebeneous; both surfaces naked; colour deep green ; veinlets immersed, the sori terminal on short lateral branches.-Hk. Sp. 4.p. 143. 2nd Cent. t. 62.

Hab. Fiji, Milne.-Somewhat doubtfully distinct from the preceding, but the texture is firmer and the stem ebeneous.

128. N. (Last.) splendens, Hk. ; st. 2-3 ft. 1., stout, polished, chesnut-brown or nearly black, deciduously scaly ; fr. $3-4 \mathrm{ft}$. 1., 1 $\frac{1}{2}-2 \mathrm{ft}$. br.; lower pinnoe often 1 ft. l., 2 in. br., close, lanceolate ; pinnl. lanceolate-oblong, unequal-sided, blunt, a broad central portion uncut; texture subcoriaceous; rachis naked, chesnut-brown; both sides naked; veinlets forked; sori in rows near the midrib. $-H k$. Sp. 4. p. 126.

Hab. Sikkim, Bootan, Malaccas. - In habit this comes nearest the large compound forms of Filix-mas, but the dark-coloured polished rachis will at once distinguish it.

129. N. (Last.) latifrons, Hk. ; caud. oblique ; st. about $1 \mathrm{ft}$. l., strong, densely clothed with deciduous scales; $f r .2-3 \mathrm{ft}$. l., subdeltoid; lower pinnce 
the largest, often $1 \mathrm{ft} .1 ., 6$ in. br. ; pinnl. $\frac{1}{2}$ in. br., close, lanceolate-acuminate, cut down about halfway to the rachis into blunt, entire lobes $\frac{1}{4}$ in. or more br.; texture herbaceous; under surface mealy, with fine glands; rachises slightly scaly; veinlets of the lobes simple; sori large; invol. $\frac{3}{4}$ lin. br.-Hk. Sp. 4 . p. 138.

Hab. Sandwich Isles.-This also has a habit not unlike that of the large forms of Filix-mas. Our description is taken from living plants sent by Dr. Hillebrand.

130. N. (Last.) ferrugineum, Baker ; st. 12-18 in. 1., densely clothed throughout with spreading broad ovate concolorous scales; fr. $2 \mathrm{ft}$. 1. or more, 12-18 in. br., 'subdeltoid, the main rachis flexuose and pinnoe spreading at a right angle, the lowest 6-9 in. 1., 3-5 in. br. ; pinnl. of the under side the largest, close, lanceolate, bluntish, cut down to the rachis into broad ovate segm. with close subentire lobes $\frac{1}{8}$ in. br.; rachises finely pubescent; both sides nearly naked; sori large, submarginal, $2-3$ in a lobe, confined to the upper half.Lastrea, Beddome, Fil. Ind. t. 100.

Hab. Neilgherries, Capt. Beddome.-This has altogether the habit and cutting of Spharopteris barbata.

131. N. (Last.) scabrosum, Baker ; st. $12-18$ in. l., slender, stramineous, furnished throughout with small, ovate, concolorous scales; $f r .1 \frac{1}{2}-2 \mathrm{ft}$. l., 12-18 in. br. ; lowest pinna deltoid, 6-9 in. 1., 3-5 in. br. ; pinnl. of the lower side the largest, with free lanceolate segm. $\frac{1}{2}-1$ in. 1 ., cut down nearly to the rachis into toothed ligulate lobes under 1 lin. br.; texture herbaceous ; rachises viscouspubescent, the hairs sometimes dense and ferruginous ; both sides nearly naked; sori small, usually 1 at the base of each ult. division; invol. small, fugacious.Aspid. Kze.

Hab. Neilgherries, Schmidt, McIvor, Sir F. Adam.-Polyp. nigrocarpum, Bedd. t. 169, is probably this. We have a closely allied plant from Sikkim and Moulmein with tufted fronds, larger and more delicate in texture, which will probably prove distinct.

132. N. (Last.) angustifrons, Baker ; rhizome wide-creeping; st. 1-2 ft. l., ebeneous, deciduously scaly; fr. 2 ft. 1., 6-8 in. br.; pinno distant, ereetopatent, flexuose, lanceolate, 4-6 in. 1., 2 in. br.; pinnl. distant, lanceolate, cut down to the rachis below into subquadrangular toothed lobes $\frac{1}{8}$ in. br. ; texture subcoriaceous; rachises and both sides naked; veinlets of the lobes forked; sori in rows close to the midribs of the pinnules.-Iastrea, Moore.

Hab. Nepaul, Wallich.-This seems a well-marked plant, perhaps nearest on the whole to $N$. sparsum.

133. N. (Last.) oppositum, Hk. ; st. 1 ft. or more - 1. , densely clathed with spreading, linear, dark-brown scales ; fr. $1 \frac{1}{2}-2$ ft. l., 12-18 in. br., subdeltoid ; lower pinnoe 6-9 in. 1., 3-4 in. br.; pinnl. close, linear-lanceolate, cut down nearly to the rachis into close, entire, slightly falcate, linear-oblong lobes $\frac{1}{8}$ in. br.; t texture herbaceous ; rachises scaly ; veinlets of the lobes simple ; sori small, submarginal ; invol. thin.-Hk. Sp. 4. p. 136.t. 266.

Hab. Mauritius and Bourbon.-This closely resembles the next in cutting, but the spreading scales of the rachis are $\frac{1}{4}$ in. 1 , and the sori are more regular and nearer the edge.

134. N. (Last.) intermedium, Baker ; st. 1-2 ft. l., stout, erect, densely clothed at the base with long bright-brown silky fibrils; fr. 2-3 ft. 1., 12-18 in. br., subdeltoid; lower pinno lanceolate, often $1 \mathrm{ft}$. 1., 4-5 in. br.; pinnl. close, lanceolate, with distinct, oblong-lanceolate segm. with ligulate subentire lobes about 1 lin. br.; texture herbaceous, firm; rachises slightly fibrillose like the stem; under surface naked or slightly scaly on the midribs; sori small, copious, 
nearer the midrib than the edge; invol. thin, fugacious.-Aspid. Blume! (non $M u h l$.) ; N. Blumei, Hk. (in part).

Hab. N. India to Ceylon, Philippines, Malaccas, and Japan.

125. N. (Last.) lepigerum, Baker ; st. 12-18 in. 1., angular, clothed only at the thase with long, linear-subulate scales; $f r .2-3 \mathrm{ft}$. 1 ., $1 \frac{1}{2}-2 \mathrm{ft}$. br. ; lower pinnce often $1 \mathrm{ft}$. l., 6 in. br.; lowest pinnl. much the largest, sometimes eompound, the others lanceolate, cut down to the rachis into broadly-toothed or entire, blunt, linear-oblong segm., the latter 2 lin. br.; rachises and costæ beneath rather densely clothed with linear scales; texture herbaceous, the rest of the surface naked; sori small, copious, nearer the edge than the midrib; invol. thin.

Hab. Isle of Bunin ; received from the Imperial Academy of St. Petersburg, and the U. S. Expedition of 1853-6.-Differs from the preceding by its larger lobes, distinct linear basal scales, and scaly under surface.

136. N. (Last.) obtusilobum, Baker; st. 1-2 ft. l., firm, erect, densely clothed with large, ovate, concolorous scales; $f r .3-4 \mathrm{ft}$. l., $1 \frac{1}{2}-2 \mathrm{ft}$. br.; lower pinnce often $1 \mathrm{ft}$. 1., 6 in. br.; pinnl. lanceolate, most of the segm. of the lower ones distinct, ovate-oblong, cut down to the rachis into oblong-rhomboidal entire lobes, the largest $\frac{1}{4}$ in. deep, $\frac{1}{8}$ in. br. ; texture herhaceous, turning blackish when dried; rachises slightly scaly, the upper ones, and especially the under surface, more or less glandular; lower veinlets of the entire lobes forked; sori medial.

Hah. Ceylon, Dr. Thwaites, C. P. 3142.-Most like $N$. intermedium in size and cutting, but the scales different, the under side very glandular, and the texture thinner.

137. N. (Last.) Boryanum, Baker (non Hk.) ; st. 2-3 ft. 1., stramineous or brownish, deciduously scaly ; $f r$. ample, $6-8 \mathrm{ft}$. $1 ., 2-3 \mathrm{ft}$. br.; lower pinnce 12-18 in. $1 ., 6$ in. br. ; pinni. lanceolate, $3-4$ in. l., cut down to a winged rachis into blunt, spreading, more or less toothed lobes 2-3 lin. br. ; texture herbaceous ; rachises and under side naked; veinlets simple or forked; sori in rows near the midrib.-N. divisum, $H k . S p .4 . p .133$.

Hab. Himalayas (up to 7,000 ft.), Madras, Moulmein, Java, Bourbon. See remarks under N. Bojeri.-This is a well-marked plant, and our Mascaren examples quite agree with those from India.

138. N. (Last.) catopteron, Hk.; st. 3-4 ft. l., pubescent ; fr. 4-6 ft. 1., 2-3 ft. br., lower pinnoe 12-18 in. l., oblong-lanceolate, with close lanceolate pinnl. or subdeltoid, with some of the pinnl. of the lower side compound; segm. oblong, bluntish, about $\frac{1}{2}$ in. l., $\frac{1}{4}$ in. br., more or less deeply pinnatifid ; texture herhaceous ; rachises and both surfaces villose ; veinlets forked ; sori copious; invol. firm.Hk. Sp. 4. p. 137. A. odoratum, Mett. (non Willd.)

Hab. Cape Colony to Natal, Mascaren Isles, and Guinea Coast. Specimens from Fernando Po are quite naked on both sides, and have a very distinctly marked wing to the rachis of the pinnules.

139. N. (Last.) setigerum, Baker ; rhizome creeping; st. 1-2 ft. l., naked upwards or scaly throughout; fr. 1-3 ft. 1.; lowest pinnoe the largest, often 8-12 in. l., 4-6 in. br. ; pinnl. close, linear-lanceolate, 1-3 in. l., $\frac{1}{4-\frac{1}{2}}$ in. br., cut down to the rachis into close pinnatifid lobes not more than 1 lin. br. in the broadest form ; texture herbaceous; main rachis straw-coloured, naked, or more or less fibrillose ; rachises of the pinnl. and under side finely villose; sori minute, copious, often 8-12 to a lobe; invol. very fugacious. - Cheilanthes, Blume.-N. tenericaule, Hk. Sp. 4. p. 142. t.269. Aspid. uliginosum, Kze. Mett.

Hab. Japan, China, and N. India to Ceylon and Malay, and Polynesia as far east as the Society Isles.-A common plant within its range, very variable in size and vesti- 
ture. It has received many names, of which Blume's is the oldest. Polypodium pallidum and nemorale, Brack. Hk. Sp. 4. p. 266, are apparently only the ordinary form, with suppressed or undeveloped involucres ; but Capt. Beddome considers $P$. ornatum, Wallich, as a distinct plant, distinguishable from this by its erect caudex and the constant absence of an involucre.

140. N. (Last.) subglandulosum, Baker ; st. $1 \mathrm{ft} .1$. , stout, polished, reddishbrown, deciduously scaly throughout; fr. 2-3 ft. l., $1 \mathrm{ft}$. br. ; lowest pinnoe

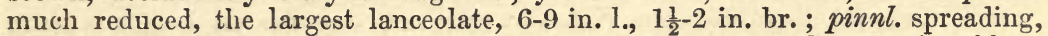
close, 1 in. 1. , $\frac{3}{8}$ in. br., cut down nearly to the rachis into close, entire, blunt lobes; texture herbaceous; rachises of the pinnæ and under side villose and the latter glandular; sori small, about 6 to the larger lobes, placed midway between the midrib and edge.-Aspidium, Mett.

Hab. Bourbon, Vieillard and Deplanche.-The alliance of this is close with the preceding.

141. N. (Last.) Grisebachii, Baker ; st. 2-3 ft. 1., densely elothed at the base with lanceolate scales 1 in. or more l., 1-1 $\frac{1}{2}$ lin. br., which leave distinct tubercles when they fall; fr. 3-4 ft. $1 ., 2 \mathrm{ft}$. or more br.; lower pinnoe often $1 \mathrm{ft}$. l., 6 in. br. ; pinnl. close, lanceolate, cut down nearly or quite to the rachis into oblong-toothed segm. $\frac{1}{4}$ in. br.; texture herbaceous; colour bright-green; rachis very slightly fibrillose and under side naked; sori small, copious, medial; invol. fugacious.-A. amplum, Griseb. (in part, not H.B.K.). N. amplum, HK. Sp. 4. p. 264.

Hab. Cuba, C. Wright, 1055.-This differs from the next principally in the scales.

142. N. (Last.) amplum, Baker ; st. 2-3 ft. 1., densely clothed at the base with an entangled mass of soft, bright, silky scales; fr. $3-4 \mathrm{ft}$. l., $2 \mathrm{ft}$. or more br.; lower pinnce often $1 \mathrm{ft}$. l., 6 in. br. ; pinnl. close, lanceolate, cut down nearly or quite to the rachis into oblong, crenated or pinnatifid lobes 2-3 lin. br.; texture herbaceous; rachises clothed with soft furfuraceous scales; under surface naked or slightly glandular, the rachis often scaly; sori copious, small, medial ; invol. very fugacious. - Aspid. H. B.K. Polyp. Sloanei, Kze. Hk. Sp. 4. p. 263. N. Palatanganum, Hk. Sp. 4. p. 260.

Hab. West Indies southward to Ecuador, and a plant from Pitcairn's Island is probably the same.-Asp. lutescens, Willd. (Plum. 34), is most likely this species.

143. N. (Last.) catocarpum, Hk. ; st. $1 \frac{1}{2}-2 \mathrm{ft}$. 1 ., densely clothed at the base

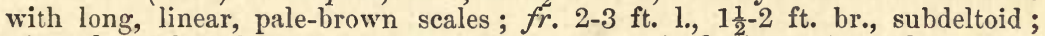
pinnce lanceolate-deltoid, 8-12 in. 1., 4-6 in. br.; pinnl. close, oblong-lanceolate, obtuse, $2-3$ in. l., $\frac{1}{2}-\frac{5}{8}$ in. br., cut down to the rachis below into close, blunt, nearly entire lobes $\frac{1}{8}$ in. br.; texture herbaceous; rachises slightly scaly ; under side naked; sori small, in rows midway between the edge and midrib.- $-H k$. $S p .4$. p. 259.

Hab. Venezuela.-A less compound plant than the last, with larger divisions and different scales.

144. N. (Last.) furcatum, Hk.; st. 2-3 ft. l., densely clothed with a mass of very narrow intertangled ferruginous scales; $f r .3-6 \mathrm{ft}$. $1 ., 2 \mathrm{ft}$. or more br.; lower pinno 12-18 in. l., 6-9 in. br., lanceolate or deltoid; pinnl. lanceolate; segm. oblong obtuse, cut down nearly to the rachis into close, entire lobes $1 \frac{1}{2}-2$ lin. br.; texture herbaceous; all the rachises densely clothed with small furfuraceous scales; costce beneath slightly scaly; sori copious, mèdial.- $H k$. Sp. 4. p. 36.

Hab. Columbia to Peru.-This has as large divisions as the last, but is much more compound and scaly, with the basal scales different. The Galapagos Polyp. paleaceum, Hk. Sp. 4. p. 261, probably belongs here. 
145. N. (Last.) villosum, Presl; st. tufted, 2-3 ft. or more 1., stout, usually villose and densely clothed with spreading scales ; $f r .4-6 \mathrm{ft}$. or more l., $2-3 \mathrm{ft}$. or more br.; pinnoe often $2 \mathrm{ft} .1 ., 1 \mathrm{ft}$. br.; pinnl. lanceolate, cut down to the rachis into close, oblong, pinnatifid segm.; largest entire lobes $\frac{3}{4}$ in. $1 ., \frac{1}{8}$ in. br. ; texture herbaceous; rachises densely villose and both sides also more or less pubescent; sori copious; invol. flat, $\frac{1}{2}$ lin. br., often suppressed.-Hk. Sp. 4. p. 134.t. 264.

Hab. West Indies southward to Peru and Chili.-A very fine plant, said to attain sometimes a height of $18 \mathrm{ft}$. The involucre is as often suppressed as developed. P. subincisum, Karstenianum, Berteroanum, and vestitum of the Species Filicum appear to be all villose forms of this without an involucre, and $P$. spectabile a subglabrous form. See Grisebach's West Indian Flora, p. 691.

146. N. arborescens, Baker ; caud. 10-12 ft. high; fr. ample; lower pinnce 12-18 in. 1., 6-8 in. br. ; pinnl. lanceolate, distinctly stalked, $3-4$ in. 1., 1-1 $\frac{1}{4}$ in. br., cut down to the rachis, except at the point, into lanceolate deeply pinnatifid segm. $\frac{3}{8}-\frac{1}{2}$ in. br., which are obliquely truncate on the lower side at the base; rachis slightly scaly; texture herbaceous; both surfaces naked; veinlets pinnate in the lobes of the segms.; sori small, medial ; invol. naked, firm, persistent, very distinctly reniform.

Hab. Samoa, Rev. T. Povell.

\section{†十 Texture coriaceous. Sp. 147-153.}

147. N. (Last.) Triance, Baker; st. smooth, stramineous or reddish ; fr. $1 \frac{1}{2}-2$ ft. 1., 9-10 in. br., broadly oblong, acuminate, tripinnatifid; pinnoe distant,

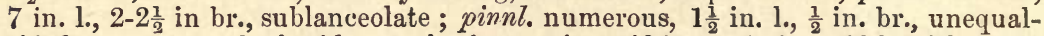
sided, cuneate on both sides at the base, pinnatifid or subpinnatifid, with close, oblong, usually entire lobes; texture subcoriaceous; rachis and both sides naked; ultimate veins simple, the lower ones on the upper side of the midrib falling short of the edge; sori dorsal or submarginal ; invol. large, membranous. -Aspid. Mett. Fil. Nov. Gran. p. 243.

Hab. New Granada, Triana.-Distinguished by the shape of its pinnules and lower veins not reaching the edge.

148. N. (Last.) acutum, Hk.; st. 2 ft. or more l., firm, smooth, polished; fr. 2 ft. or more 1., 12-18 in. br.; lower pinnce oblong-lanceolate, 6-9 in. 1., 3-4 in. br.; pinnl. linear-lanceolate, $\frac{1}{4}-\frac{3}{8}$ in. br., cut about one-third down to the rachis into blunt falcate lobes; texture subcoriaceous; rachis and both sides naked; sori copious, principally in rows close to the midrib.-Hk. Sp. 4. p. 147.t. 271.

Hab. Brazil and Peru.-In outline this comes nearest to $N$. furcatum, but it is quite naked, and more rigid in texture.

149. N. (Last.) platypus, Hk.; st. 1-3 ft. or more 1., smooth, glossy, with a dense tuft of bright-coloured scales at the base; fr. $1 \frac{1}{2}-2 \mathrm{ft} .1 ., 1 \mathrm{ft}$. and more br., deltoid; lower pinnce 6-9 in. l., 3-4 in. br.; pinnl. deltoid, obliquely truncate on the lower side at the base; lower segm. often free, $\frac{1}{4}-\frac{1}{2}$ in. br., ovateoblong; teeth mucronate; texture subcoriaceous; rachis and both sides naked and glossy; sori large, copious, in rows close to the midrib.-Hk. Sp. 4. p. 149.

Hab. Java, Moulmein, Khasia.-A doubtful plant, some of the specimens of which are very like some of the forms of Aspid. aristatum, but with a large, distinctly-reniform involucre.

150. N. (Last.) hispidum, Hk.; rhizome stout, creeping ; st. 12-18 in. 1., brown, densely clothed with squarrose, fibrillose, nearly black scales; fr. 12-18 in. 1., 8-12 in. br., subdeltoid; pinnoe lanceolate, the lowest deltoid ; lowest pinnl. larger than the others, which are lanceolate, with lanceolate segm. cut down 
to a winged rachis into small, oblong, or linear, sharply-toothed lobes; texture coriaceous; rachises fibrillose; both surfaces glossy; sori copious.-Hk. Sp. 4. p. 150.

Hab. New Zealand, Australia (very rare), Mauritius, Bouton.-A well-marked plant.

151. N. (Last.) denticulatum, Hk.; st. tufted, $1 \mathrm{ft}$. or more 1., densely clothed with linear scales at the base, naked above; fr. 1-2 ft. l., 8-12 in. br., deltoid; lower pinnoe much the largest; lowest pinnl. larger than the others, which are lanceolate or subdeltoid, with segm. which are again pinnate, with spathulate or subrhomboidal lobes with spinose teeth; texture coriaceous; rachis and both sides naked, glossy ; sori scattered, copious.-Hk. Sp. 4. p. 147. A. Klotzschii, Hk. 2nd Cent. t. 23.

Hab. W. Indies and Guatemala to S. Brazil.-There is a very rigid variety (A. dissectum, Fée) with linear, mucronate alternate divisions.

152. N. (Last.) davallioides, Baker ; rhizome stout, wide-creeping ; st. strong, $1 \frac{1}{2}-2 \mathrm{ft}$. l., brownish, naked, the dense fibrillose scales confined to the base ; fr. 3-4 ft. 1., $2 \mathrm{ft}$. or more br., deltoid; lower pinnoe often $1 \mathrm{ft}$. l. by nearly as broad ; pinnl. deltoid, with lanceolate or deltoid segm., the lobes of which are again deeply pinnatifid; all the divisions unequal-sided, the ultimate ones small, sublinear, mucronate; texture subcoriaceous ; rachis and both sides nearly naked ; sori small, copious; invol. firm, reniform.-Lastrea, Brack. p. 202.

Hab. Fiji, Tahiti, and Samoa.-The alliance of this is with the next species, but it is much more finely cut.

153. N. (Last.) effusum, Baker ; rhizome short-creeping; st. 2 ft. 1. or more, polished, slightly scaly below; fr. $3-4 \mathrm{ft}$. l., $2 \mathrm{ft}$. or more br., 4-5 pinnatifid; lower pinnce 12-18 in. l., often $1 \mathrm{ft}$. br.; pinnl. close, lanceolate, acuminate; segm. lanceolate or subdeltoid, unequal-sided, the lower ones cut down to the rachis into oblong, pinnatifid, bluntish lobes, often $\frac{1}{4}$ in. br.; texture subcoriaceous; rachises usually scaly; both sides pale-green, glossy, naked; sori copious, scattered ; invol. generally absent. - Polyp. divergens, Hk. Sp. 4. p. 265. N. amplissimum, Hk. Sp. 4. p. 145.-, , N. excultim, Hk. ; fr. often tripinnatifid only, the ult. divisions always broader and less deeply cut. $-H k$. Sp. 4. p. 149.

Hab. Cuba and Mexico to Brazil and Peru.-P. effisum .and excultum appear to be less, and $P$. divergens more divided forms of the same plant. $P$. dilatatum, Liebm. Hk. Sp. 4. p. 264, does not differ materially. N. macrostegium, Hk. Sp. 4. p. 148, is apparently a coriaceous variety, with firm, distinctly-developed reniform involucres. We have a single specimen of a plant from West Tropical Africa, gathered by Dr. Curror, which may be this species.

§ Eunephrodium. Lower veinlets of contiguous groups united. Sp. 154-196.

* Fronds ligulate, not cut down to the rachis unless at the very base. Sp. 154-158.

154. N. Cumingianum, J. Sm. ; st. tufted, slender, naked, 2-4 in. l. ; fr. 3-4 in. l., $\frac{1}{2}-\frac{3}{4}$ in. br., lanceolate-oblong, narrowed gradually at both ends, entire or slightly sinuated; texture subcoriaceous ; both surfaces naked; veins pinnate, in groups of $2-3$ on a side.-Hk. $S p$. 4. $p .6$.

\section{Hab. Panama.}

155. N. Skinneri, Hk. ; st. tufted, slender, villose, 2-3 in. 1. ; fr. 6-8 in. 1., $\frac{3}{4} .1$ in. br., lanceolate-acuminate, terminating abruptly below, with oblongfalcate subentire lobes reaching halfway down in the centre, and often quite to the rachis at the base; texture papyraceo-herbaceous; lower side, especially the 
midrib, villose ; veins in groups of 8-10 on a side, which are slightly united or quite free.-Hk. Sp. 4. p. 64. 2nd Cent. $t .25$.

Hab. Guatemala, Skinner; Andes of Ecuador, Spruce, 5293.

156. N. Wrightii, Hk.; rhizome creeping ; st. 4-6 in. 1., firm, erect, greyish; fr. 6-9 in. 1., 1-1 $\frac{1}{2}$ in. br., lanceolate-oblong, cut down nearly to the rachis above and quite below into close, oblong, entire, or auricled, spreading lobes $\frac{1}{8}-\frac{1}{4}$ in. br. ; texture coriaceous ; rachis and under surface villose; veinlets in groups of 10-18 on a side, sometimes forked; sori submarginal.-Hk. $S_{p} p .4 . p$. 64. t. 239.

Hab. Cuba, Wright, 824.

157. N. scolopendrioides, Hk. ; st. tufted, $2-4$ in. 1. , scaly ; fr. $1 \mathrm{ft}$. or more l., 1-2 in. br., oblong-lanceolate, the point acute, central lobes reaching nearly down to the rachis, oblong, nearly entire, close or with a space between them, lower ones quite free and gradually smaller; texture papyraceo-herbaceous; rachis and under side finely hairy; veinlets of the lobes forked or sometimes slightly pinnate and the groups joining; invol. very fugacious.-Hk. Sp. 4. $p .65$. Fil. Ex. t. 18. Polypod. L.

Hab. West Indies.-We include here Goniopt. strigosa, ferax, affinis, and domingensis of Fée.

158. N. incisum, Baker; st. tufted, 2-6 in. l., stramineous, scaly below ; fr. $1 \mathrm{ft}$. or more 1., $\frac{3}{4}-1 \frac{1}{2}$ in. br., linear-oblong, lobes triangular or lanceolate, often not reaching more than one-third down to the rachis, the frond narrowed very gradually below so as to form a scarcely cut wing to the stem; texture subcoriaceous; under surface finely villose; veins in simply pinnated groups of 6-12 on a side; invol. very fugacious.-Poly pod. Sw. N. stenopteris, Hk. Sp. 4. p. 65.

Hab. West Indies and New Granada.

** Fronds large, pinnate; rhizome wide-creeping. Sp. 159-176.

\section{+ Lower pinnoe hardly, if at all, reduced. Sp. 159-170.}

159. N. Otaria, Baker; st. 6-12 in. 1., substramineous; fr. $1 \mathrm{ft}$. or more l., with a linear-oblong terminal pinna 4-6 in. $1 ., 1-1 \frac{1}{2}$ in. br., the apex acuminate, the margin with finely serrated lanceolate lobes reaching $\frac{1}{4}-\frac{1}{3}$ of the way down, and 3-6 distant spreading similar lateral ones on each side, the lower ones stalked; texture thinly herbaceous; rachis and both surfaces naked; veins pinnate in each lobe, the groups united from about midway from the midrib to the edge; veinlets 6-8 on each side, with sometimes a sorus on each.-N. aristatum, Hk. Sp. 4. p. 62. t. 238. Anisocampium, Presl.

Hab. Philippines, Neilgherries, Ceylon.

160. N. distans, Hk.; st. 1 ft. or more l., firm, erect, brownish, slightly villose ; fr. $1 \frac{1}{2}-2 \mathrm{ft}$. l., 8-10 in. br. ; pinnoe spreading, $3-4$ in. $1 ., \frac{3}{4}$ in. br., very slightly lobed, the lower ones rather smaller than the others; texture papyraceoherbaceous; rachis and midrib beneath villose and veins slightly so; veins pinnate in the lobes, with 5-6 veinlets on a side ; rows of sori filling up nearly the whole space between the midrib and the next row; caps. naked.-Hk. Sp. 4 . p. 76 .

Hab. Madagascar, Boivin; Johanna Island, Dr. Kirk.-This in venation and pinnæ comes under Abacopteris, Fée; and Dr. Kirk's specimens show that it differs distinctly from $N$. glandulosum by its strong wide-creeping rhizome.

161. N. varians, Fée; st. $1 \mathrm{ft} .1$., smooth, with linear, blackish scales at the 
base ; fr. $1 \mathrm{ft}$. 1., 10 in. br., with 13-15 pinnoe on each side, the lower ones 5 in. 1., $\frac{5}{8}$ in. br., the point acuminate and toothed, the edge lower down bluntly lobed $\frac{1}{4}$ of the way to the rachis, the base subcuneate; rachis and both sides naked; veins pinnate in the lobes, with $3-4$ veinlets on a side; sori medial. - Fée, Fil. Ant. $t .24$.

Hab. Trinidad, Germain.

162. N. unitum, R. Br. (non Sieb.) ; st. 12-18 in. 1., brownish, naked ; fr. $2 \mathrm{ft}$. or more 1., 6-8 in. br. ; pinnoe 4-5 in. $1 ., \frac{1}{2}$ in. br., the edge cut from a third to halfway down into spreading, triangular, sharp-pointed lobes; lower pinnoe not dwindling down ; texture coriaceous ; veins pinnate in the broad lobes, with 6-8 veinlets on each side, with sori near the extremity principally in the lobes ; caps. naked.-Polyp. L. fide Mett. Aspid. Mett. Fil. Ind.p.230.—a, A. gongylodes, Schk. ; rachis and under side naked.- $\beta, A$. propinquum, $\mathbf{R} . \mathrm{Br} . ;$ rachis and under side villose.-Hk. Sp. 4. $p .79$.

Hab. Mexico and West Indies to Brazil and Peru ; Polynesian Isles ; Hong-Kong and Himalayas to Australia and New Zealand; Mascaren Isles, Natal, Cape Colony, Angola, Guinea Coast, Algiers.-We follow Mettenius in nomenclature, but the unitum of the Linnæan berbarium is Sieber's plant, our cucullatum.

163. N. sophoroides, Desv.; st. $1 \mathrm{ft}$. or more l., slender, substramineous, pubescent ; fr. 1-2 ft. l., 6-9 in. br. ; pinnoe spreading, 4-6 in. l., $\frac{1}{2}-\frac{3}{4}$ in. br., the apex acuininate, the edge cut about one-third of the way down into oblongtriangular subfalcate lobes; texture papyraceo-herbaceous; rachis and under surface finely villose; veins pinnate in groups, with 8-10 veinlets on a side, with sori distant from the midrib; caps. naked.-Polyp. Thunb. A. molle, Hk. Sp. 4. p. 68 (in part).

Hab. Japan to Hong-Kong and Formosa.-Very near the preceding in the shape of its pinnæ and lobes, but smaller and thinner in texture, and less rigid.

164. N. pteroides, J. Sm.; st. 1-2 ft. 1., slender, stramineous or greyish, slightly scaly below ; fr. 2-4 ft. 1., $1 \mathrm{ft}$. or more br. ; pinnce spreading, 4-8 in. l., $\frac{3}{4}$ in. br., the apex acuminate, the edge cut one-third or halfway down into oblong or subtriangular lobes; texture papyraceo-herbaceous; rachis and both sides nearly naked; veins pinnate in the lobes, with 8-10 veinlets on each side; sori quite marginal and confined to the lobes.-Polyp. Retz. N. terminans, Hk. Sp. 4. p. 73. (in part).

Hab. Himalayas, Neilgherries, Ceylon (Gardner, 1106), Malaccas, Philippines (Cuming, 48, 293), S. China, Queensland, Samoa.-This has, like the two preceding, oblong-triangular lobes $1 \frac{1}{2}-2$ lin. br., not reaching more than oue-third down, and differs from them by having the sori quite confined to the lobes.

165. N. extensum, Hk. ; st. 1-2 ft. l., naked or slightly pubescent, brownish ; fr. 2-4 ft. l., 12-18 in. br.; pinnoe 6-9 in. 1., $\frac{5}{8}-\frac{3}{4}$ in. br., cut about twothirds down to the rachis into linear-oblong lobes; lower pinnce scarcely shorter than the rest; texture papyraceo-herbaceous; under surface naked or slightly villose; veinlets $6-8$ on a side, often only the lowest pair united; sor $i$ in rows, nearly terminal in the veins, and not confined to the lobes.- $H k$. $S p$. 4. $p .72$. t. 240. A. (in part). Aspid. Bl.! A. conioneuron, Mett.

Hab. Ceylon (Gardner, 1362), N. India, Malaccas, Neilgherries (Beddome, t. 85), Philippines (Cuming, 391). - This is joined to the preceding by Mettenius. The texture is more herbaceous, and the lobes are much narrower and deeper, with a cousiderable space between them.

166. N. Serra, Desv. ; st. $1 \mathrm{ft}$. or more 1., firm, glossy, substramineous ; fr. 2-3 ft. 1., $1 \mathrm{ft}$. or more br.; pinnoe spreading, 6-12 in. 1., $\frac{1}{4}-\frac{1}{2} \mathrm{in.} \mathrm{br.,} \mathrm{cut} \mathrm{down}$ 20 
about halfway to the midrib into subtriangular, falcate, acute lobes, the lowest not smaller than the next pair; texture subcoriaceous; rachis and both surfaces naked; veins pinnate in the lobes, with 6-10 veinlets on a side; sori in rows apart from the midrib.-N. augescens, F'ée. Hk. Sp. 4. p. 79.

Hab. West Indies.-According to Grisebach, this is the Serra of Swartz. It is distinguished by its very narrow rigid pinnæ, with deep sharp lobes.

167. N. pallidivenium, Baker ; st. $1 \mathrm{ft}$. or more l., stramineous, naked or nearly so ; fr. 2-3 ft. l., 8-12 in. br. ; pinnoe 4-6 in. l., $\frac{3}{4}-1$ in. br., cut two-thirds of the way down to the rachis into linear-oblong, slightly falcate lobes; lower pinnoe not much smaller than the rest ; texture coriaceous; under surfaces naked or villose ; veinlets close, prominent, 12-16 on a side, the small sori in close rows about midway between the midrib and edge.-Polyp. Hk. Sp. 5. p. 8.

Hab. Guinea Coast, Vogel, Barter, Mann; and gathered in the Livingstone Expedition on the shores of Lake Nyassa.-Characterized in the group by its rigid texture, deep, close lobes, and very numerous veinlets.

168. N. dissectum, Desv. ; rhizome stout, wide-creeping; st. $1 \mathrm{ft}$. or more 1., stout, brownish, villose ; fr. $1 \frac{1}{2}-2 \mathrm{ft}$. 1., 8-12 in. br. ; pinnoe numerous, 4-5 in. 1 ., $\frac{1}{2}$ in. br., cut about one-third down into sharp, triangular, falcate lobes ; lower pinnoe distant and dwarfed; texture subcoriaceous; rachis and under surface villose; veins pinnate in the lobes, with 6-8 veinlets on a side; sori in rows close to the midrib; caps. setose.-Polyp. Forst. Asp. Mott. Fil. Ind. p. 232. A. attenuatum, $S$ w.

Hab. Common in the Polynesian Islands.-Very like $N$. cucullatum, from which it is distinguished by its setose capsules and lower pinnæ not dwarfed.

169. N. procurrens, Baker; st. 2 ft. l., villose above ; fr. 18 in. l., 10 in. br. ; pinnce 5-6 in. l., cut down to a narrow wing into oblong, obtuse lobes, the lowest not much shorter than the others and deflexed; rachis and both surfaces more or less villose ; texture herbaceous ; veinlets $5-6$ on a side, with sori midway between the midrib and edye.-Asp. Mett. Fil. Ind.p. 231.

Hab. Java.-Very like $N$. molle, but distinguished by its creeping rhizome.

170. N. longipes, Moore; st. 3-4 ft. l., livid ; fr. $3 \mathrm{ft} .1 ., 9-10$ in. br. ; pinnce 5-6 in. l., $\frac{3}{4}$ in. br., cut two-thirds of the way down into oblique, rather acute, oblong lobes, with a distinct sinus between them; textuve subcoriaceous; upper surface densely hairy on the veins, lower less so; veins 8-10 on a side; sori placed midway between the midrib and edge.-Aspid. Bl. Mett. Fil. Ind. p. 231.

Hab. Java.-With this we are not acquainted.

\section{** Lower pinnce conspicuously reduced. Sp. 171-176.}

171. N. cucullatum, Baker ; st. $1 \mathrm{ft}$. l., strong, erect, brownish, nearly naked ; fr. 18-24 in. 1., 8-12 in. br. ; pinnoe close, 4-6 in. l., $\frac{1}{2}$ in. br., cut down one-third of the way to the rachis into triangular, acute, subfalcate lobes; lower pinnoe dwindling down suddenly into mere auricles; texture coriaceous; rachis and lower surface densely pubescent; veins pinnate in the lobes, 8-10 veinlets on a side ; sori subterminal ; caps. naked.-Aspid. Bl. Mett. Fil. Ind.p. 232. N. unitum, Sieb. Hk. Sp. 4. p.81. (in part). N. canescens, Presl.

Hab. N. India, Ceylon, Malaccas, Mascaren Isles, Fiji.

172. N. Haenkeanum, Presl ; st. 1-2 ft. l., strong, erect, slightly pubescent; fr. 3-4 ft. 1., 12-15 in. br.; pinno 6-8 in. I., $\frac{3}{4}$ in br. ; cut from one-third to 
halfway down into acute subfalcate lobes; texture subcoriaceous; rachis and under surface finely pubescent; veinlets $10-12$ on a side; sori subterminal.A. multilineatum, Mett. Fil. Ind.p.232. (non Wall.)

Hab. Ceylon, Malaya, Fiji.-Much larger and less hairy than the last, with more numerous veins, and a very fugacious involucre. A plant sent from Mauritius by Lady Barkly as $N$. elatum, Bojer, is probably distinct. It has medial sori, 14-16 veinlets on a side and fronds sometimes 2 feet broad.

173. N. multijugum, Baker; st.1-2 ft. l., strong, erect, subglabrous; fr. 3-4 ft. 1., 12-15 in. br.; pinnoe 6-8 in. 1., $\frac{3}{4}-\frac{7}{8}$ in. br., cut two-thirds of the way down to the rachis into close, acute, subfalcate lobes $\frac{1}{8}$ in. br. ; texture subcoriaceous ; rachis and both sides nearly naked; veinlets $10-12$ on a side; sori near the midrib.-Aspidium, Wallich.

Hab. Malayan Peninsula.-This comes very near the last, but is nearly naked and more deeply cut, with the sori in a different position.

174. N. hirsutum, J. Sm. ; st. 1 ft. or more l., grev, villose ; fr. 3-4 ft. l., $1 \frac{1}{2} \mathrm{ft}$. br.; pinnoe very close and numerous, spreading, the largest $10 \mathrm{in}$. I., $\frac{3}{4}$ in. br., cut down halfway to the rachis into entire, linear-oblong, subfalcate lobes; the lower ones with a gland beneath at the base; texture subcoriaceous; rachis densely clothed with soft spreading hairs; under surface glandular; veins 6-8 on each side; sori medial.-Hk. Sp. 4. p. 70. t. 240. B. (not Don).

Hab. Philippines, Cuming, 82.- Habit of the two last, but the veins much fewer, sori medial, and lower pinnæ with a large gland at the base.

175. N. aridum, Baker; st. $1 \mathrm{ft}$. or more l., erect, naked ; fr. 3-4 ft.1., 12-18 in. br. ; pinnoe 6-9 in. l., $\frac{3}{4}-1$ in. br., cut about one-third of the way down into subtriangular sharp-pointed lobes; texture coriaceous; rachis and lower surface naked or slightly hairy; veinlets $8-10$ on a side; sori in rows about midway between the midrib and edge; caps. naked.-Aspid. Don Prod. Fl. Nep. p. 4. A. venulosum, Wall. A. obscurum, $B l$.

Hab. N. India, Philippines, Malayan Peninsula.-This differs from the three preceding by the under side being nearly or quite naked, and in the position of the sori. A.callosum, Bluine, quite agrees with this, except that there is a large prickle-like gland at the base of the pinnæ, and sometimes also of the veins.

176. N. venulosum, Hk.; st. $1 \frac{1}{2} \mathrm{ft} .1$., naked, greyish, sharply angled; fr. $4 \mathrm{ft} .1 ., 12-18 \mathrm{in} . \mathrm{br}$.; pinnoe numerous, the lowest short and very distant, the largest 8-9 in, l., 1 in. br., cut down halfway to the rachis into slightly-toothed oblong lobes; texture subcoriaceous; both surfaces naked; colour bright-green; veins about 9 on each side, conspicuous above, with a sorus on each midway to the edge.-Hk. Sp. 4. p.71.

Hab. Fernando Po.-A large plant, most like $N$. truncatum in habit and texture, but the rhizome creeping.

*** Fronds large, pinnate; caudex erect or suberect. Sp. 177-196.

+ Pinnce entire or slightly lobed, so that most of the veinlets unite. Sp. 177-184.

177. N. glandulosum, J. Sm.; st. tufted, $1 \mathrm{ft}$. or more 1., naked or slightly villose; fr. 1 foot or more l., 4-6 in. br., with 8.12 spreading pinnce on each side, those of the barren fr. the largest and closest, $2-3$ in. 1., $\frac{3}{4-1}$ in. br., the margin entire or slightly lobed, the base abruptly truncate and sometimes auricled; texture papyraceo-herbaceous; rachis and under surface naked or slightly villose, sometimes glandular; fertile pinnce contracted, the main veins not more than 1 lin. apart; veinlets $4-8$ on a side, with the sori close to the midrib.-Hk. Sp. 4. p. 76. Abacopteris, Fée. 
Hab. Assam, Philippines, and Malayan Isles.-This includes three species of Mettenius,-his glandulosum, asperum, and lineatum, which we cannot separate clearly.

178. N. amboinense, Presl ; st. tufted, 6-8 in. 1., greyish, nearly naked; fr. $2 \mathrm{ft}$. or more 1., 8-12 in. br.; pinnoe spreading, 3-4 in. l., $\frac{1}{2}-\frac{5}{8} \mathrm{in}$. br., cut about a quarter down into bluntish slightly falcate lobes; lower pinno shorter and deflexed; texture papyraceo-herbaceous ; rachis and under surface slightly pubescent; veins pinnate in the lobes, with 4-6 veinlets on a side; sori in rows close to the midrib; caps. naked.-Hk. Sp. 4. p. 75.

Hab. Philippines, Cuming, 83, 317 ; N. India, Malayan Isles ; Ceylon, Thwaites, 3390. - Very near $N$. molle, but more papyraceous in texture, and not so hairy or so deeply lobed.

179. N. Arbuscula, Desv. ; st. tufted, 4-8 in. l., naked or slightly pubescent; fr. 12-18 in. l., 6-8 in. br.; pinno close, numerous, 3-4 in. l., $\frac{2}{8}-\frac{1}{2}$ in. br., cut a quarter or less down into blunt lobes, several of the lower pairs short and distant; texture herbaceous ; rachis and lower side finely villose ; veinlets distant, 3-4 on a side; sori in close rows.-Hk. Sp. 4. p. 74. A. Hookeri, Wall. Hk. 2nd Cent. $t$. 22.

Hab. Mascaren Isles, Ceylon, Neilgherries, Amboyna, Philippines, Solomon Isles.

180. N. abortivum, J.Sm. ; st. tufted, 6-12 in. l., firm, erect, quite naked ; $f$. 1-2 ft. l., 6-8 in. br. ; central pinnø 3-4 in. $1 ., \frac{5}{8}-\frac{7}{8}$ in. br., cut about one-third of the way down into close, entire, truncate lobes $\frac{1}{8}$ in. br.; lower pinnce distant and reduced suddenly to mere auricles; texture firm, herbaceous; rachis and both sides quite naked; veinlets 6-8 on a side; sori medial.-Aspid. Blume. A. decurtatum, Kze.

Hab. Penang, Java, Ceylon.-Allied to glandulosum, but the pinnæ lobed, and the veins more distant.

181. N. refractum, Hk. ; st. tufted, 1 ft. l., naked, glossy ; fr. 12-18 in. l., 6-9 in. br. ; pinnoe growing gradually less from near the bottom to the top, the lower ones deflexed, $4-5$ in. $1 ., \frac{3}{4}$ in. br., the lowest pairs very much so, the lobes broad and blunt, reaching about a quarter of the way down to the midrib; texture herbaceous; colour bright-green; rachis and surfaces glabrous; veinlets 6-8 on a side ; sori medial; invol. minute, fugacious.-Hk. Sp. 4. p. 162. t. 252.

Hab. Brazil. - Well marked by its bright-green colour and peculiar habit. A Fern gathered in Trinidad by Aldridge, $N$. deflexum, J. Sm. MSS., bas similarly deflected lower pinnæ, but they are narrower, and the lobes reach halfway down to the midrib. It is not unlikely that this is Polyp. retroflexum, Linn., founded on Plumier's t. 68.

182. N. latipinna, Hk. MSS. ; st. tufted, 4-6 in. 1, slender, naked ; fr. 8-12 in. 1., 3-5 in. br., the upper half or third lanceolate, pinnatifid, with broad, oblong lobes ; below this several pinnoe on each side, the largest 2-3 in. l., $\frac{1}{2}-\frac{3}{4}$ in. br., cut about one-quarter of the way down into broad, oblong, subfalcate lobes; lower pinnoe much reduced and distant; texture papyraceo-herbaceous; rachis and both sides naked; veins pinnate in the lobes, with 3-5 distant veinlets on each side, with a sorus about the centre of each.-N. molle, $\beta$, Benth. Fl. Hong.p. 455.

Hab. Hong-Kong and Java.-Very doubtfully distinct from $N$. molle.

183. N. pennigerum, Hk. ; st. tufted, stout, 8-12 in. l., finely villose ; fr. 2-4 ft. 1., 12-18 in. br. ; pinnoe numerous, spreading, 6-9 in. l., 1-1 $\frac{1}{2}$ in. br., the apex acuminate, the edge cut about a quarter of the way down to the midrib into oblong falcate lobes, the lower pinnæ dwarfed and distant ; texture herbaceous or subcoriaceous; rachis and under surface finely villose; veinlets $6-9$ on a side ; sori medial ; caps. setose.-Hk. Sp. 4. p. 82. Aspid. pennigerum, Bl. (non Sw.). A. multilineatum, Wall. N. articulatum, Moore, J.Sm. A. megaphyllum, Mett.

Hab. Himalayas, Ceylon, Malaccas, Johanna Island, Angola, Guinea Coast. 
184. N. cyatheoides, Kaulf.; st. 1-2 ft. l., strong, naked, glossy, greyish ; fr. 2-3 ft.l., $1 \mathrm{ft}$. or more br. ; pinnce close, spreading, 4-6 in. l., $\frac{3}{4}-1$ in. br., the apex acuminate, the edge irregular, furnished with acute forward-pointing teeth to a depth of 1-2 lin., the lowest pair not shorter than the next; texture papyraceoherbaceous or subcoriaceous; rachis and both surfaces naked; veins in pinnatifid groups of 10-12 veinlets on a side, with often a sorus on each close to the main vein.-Hk. $S p$. 4. p. 76. t. 241. A.

Hab. Sandwich Islands and Sumatra.-Allied to $N$. ferox, but less deeply cut, and the stem not fibrillose.

\section{+t Pinnce cut from one-third to two-thirds down to the midrib. Sp. 185-196.}

185. N. asplenioides, Baker ; st. 6-9 in. 1., greyish, villose ; fr. 12-18 in. 1., 4-5 in. br., oblong, the lower half pinnate ; upper pinnoe close, oblong, entire, blunt, those next in order connected by a wing to the rachis and bluntly lobed, the longest 2-3 in. l., $\frac{1}{2}$ in. br., bluntly lobed one-third of the way to the midrib, the lowest distant and growing gradually shorter ; texture subcoriaceous ; rachis and under surface finely hairy ; veins pinnate in the lobes, with 6-8 veinlets on each side; sori minute, in rows near the midrib.-Polyp. Sw. N. sclerophyllum, Presl. Hk. Sp. 4. p. 65.

\section{Hab. West Indies.}

186. N. hispidulum, Baker; st. tufted, slender, 12-18 in. l., greyish, villose ; fr. 12-18 in. 1., 6 in. br.; pinnce distant, spreading, 3-4 in. 1., $\frac{1}{4}-\frac{8}{8}$ in. br., the apex acuminate, the edge cut about halfway down into oblong, slightly falcate lobes, the lower ones suddenly dwarfed down to mere auricles; rachis slender and under surface finely villose; veins pinnate in the lobes, with $3-4$ veinlets on each side, with a large sorus on each near the edge; caps. naked.-Asp. Decaisn. N. angustifolium, Presl. Hk. Sp. 4. p. 69.

Hab. Philippines and Malay Isles.-This is nearest $N$. Arbuscula, but the pinnæ are much narrower and more deeply lobed.

187. N. molle, Desv. ; st. tufted, $1 \mathrm{ft}$. or more 1., rather slender, deciduously hairy ; fr. 1-2 ft. 1., 8-12 in. br. ; pinnoe spreading, 4-6 in. 1., $\frac{3}{4}$ in. br., cut about halfway down to the midrib into scarcely falcate, blunt lobes, the lower pinnæ distant and rather shorter than the others; texture herbaceous; rachis and surfaces finely villose; veins pinnate in the lobes, with $6-8$ veinlets on a side; sori distant from the midrib; caps. naked.-Hk. Sp. 4.p.67. (in part).

Hab. Cuba and Mexico to Peru and Brazil ; Himalayas and Hong-Kong to New Zealand and N. S. Wales ; Mascaren Isles, Cape Colony, Guinea Coast, Azores, Cape Verdes, Madeira.-A variable plant. Of forms not safely separable A. violascens, Link, has an often rather bright-coloured purplish rachis ; the E. Indian P. molliusculum, Wall., and Mauritian $N$. Hilsenbergii, Presl, have the lobes deeper and narrower than in the type; the $\mathrm{S}$. American $N$. Jamesoni, Hk., is a less cut reduced form ; the Javan A. pilosiusculum, Mett., has setose capsules ; the Antillean A. pellitum, Willd., J. Sm., blunt pinnæ only $\frac{3}{8}$ in. br.; and the Philippine $N$. diversilobum, Presl, some of the lobes irregularly dilated and pinnatifid. There seems no reason to doubt this is the Linnæan Polyp. parasiticum; but the name molle is so thoroughly well established for the species, that it seems a pity to drop it.

188. N. heterocarpon, Moore ; st. tufted, 1-2 ft. l., slender, villose ; fr. 2-3 ft. 1., 8-12 in. br. ; pinnoe 5-6 in. l., $\frac{3}{4}$ in. br., cut down halfway or more to the rachis into linear-oblong subfalcate lobes; lower pinnoe abruptly dwarfed; texture herbaceous; rachis and under surface villose, and the latter glandular; veins pinnate in the lobes, with $8-10$ veinlets on a side; sori in rows close to the main vein ; caps. naked.-Aspid. Bl. Mett. Fil. Ind. p. 233. N. molle, Hk. Sp. 4.p. 67. (in part).

Hab. Hong-Kong and Malaccas.-Very near some of the forms of $N$. molle, but less 
hairy, and densely glandular beneath, with the lower pinnæ suddenly dwarfed. A.dimorphum, Kze., is said to differ from this by the presence of a gland at the base of the pinnæ.

189. N. stipellatum, Hk.; st. tufted, $1 \mathrm{ft} .1$. grey, naked; fr. $2 \mathrm{ft} .1 ., 8-10 \mathrm{in}$. br.; pinnoe 4-5 in. 1., $\frac{3}{4}$ in. br., the apex acuminate, the edge cut about one-third down into oblong-falcate lobes, the base with a large scale-like gland beneath the midrib; texture subcoriaceous; rachis and midrib beneath villose; veins pinnate in the lobes, with 6 veinlets on a side, with sori in rows near the main vein.-Hk. Sp. 4. p. 70 .

Hab. Java.-A more coriaceous plant than A. molle, with broader lobes, the under surface nearly naked. A. latebrrsum, Kze., is said to differ from this by being more deeply lobed, with the under surface glandular, and the basal gland bluntly tubercular, not scale-like.

190. N. crinipes, Hk. ; st.12-18 in. l., stout, erect, densely clothed with brown linear scales ; fr. 2-3 ft. l., 8-12 in. br. ; pinnoe horizontal, 4-6 in. 1., $\frac{1}{2}-\frac{3}{4}$ in. br., cut about halfway down into close linear-oblong lobes; rachis scaly in the lower part; texture herbaceous, both sides naked; veinlets $6-8$ on a side ; sori medial. -Hk. Sp. 4. p. 71.

Hab. Sikkim (subtropical region), Hk. fl. and Thomson; Malacca, Griffith.-Best distinguished from truncatum by its scaly stem and rachis.

191. N. venustum, J. Sm. ; st. tufted, 1 ft. or more l., naked, greyish, glossy ; fr. $2 \mathrm{ft}$. or more l., $1 \mathrm{ft}$. br.; pinno numerous, spreading, 6 in. $1 ., 1$ in. br., with blunt oblong lobes reaching halfway down; texture herbaceous; rachis and both surfaces naked, glossy ; veins about 8 on each side, with sori principally in the lobes close to the edge.-Hk. Sp. 4. p. 71 .

Hab. Jamaica.-About midway between molle and brachyodon. A Mexican specimen, sent by Professor Reichenbach as A. paludosum, Liebm., may be the same plant, but the veinlets are closer and more numerous (10-12 on a side).

192. N. ferox, Moore; st. 1-2 ft. l., strong, densely fibrillose, the hairs black and leaving the stem rough when they fall; fr. $3-4 \mathrm{ft}$. l., sometimes $2 \mathrm{ft}$. br. ; pinnoe rather close, spreading, 6-12 in. l., $\frac{3}{4}-1$ in. br., apex very acuminate, edge cut about a third down into lanceolate-falcate lobes; texture subcoriaceous; both surfaces glossy; veins in pinnated groups of 10-12 veinlets on a side, with often a sorus on each close to the main vein.-Hk. Sp. 4. $p$. 77. Phegopteris, Mett. Polyp. barbatum, Hk. Sp. 5. p. 11. Goniopt. Lobbiana, Fée.

Hab. Kumaon, Philippines, Java.-A well-marked species.

193. N. sagittcefolium, Moore ; st. 1-2 ft. l., tufted, stout, erect, villose ; fr. 3-4 ft. l., $1 \mathrm{ft}$. or more br. ; pinnoe numerous, spreading, 6-8 in. l., $\frac{3}{4}$ in. br., the apex acuminate, the edge cut from one-third to halfway down into oblong-falcate lobes, the lower pinnæ suddenly dwarfed and deflexed; texture subcoriaceous ; rachis and under surface densely villose; veins pinnate in the lobes, with 8-10 veinlets on a side, with a sorus midway on each; caps. setose.-Hk. Sp. 4. p. 78.

Hab. Java.

194. N. truncatum, Presl ; st. tufted, stout, erect, $2 \mathrm{ft} .1 .$, greyish, naked or slightly villose ; fr. 2-4 ft. 1., 12-18 in. br.; pinnoe 6-9 in. 1., 1 in. br., cut down one-third or more of the distance to the rachis into blunt, spreading, oblong lobes ; texture papyraceo-herbaceous ; lower pinnoe distant, small ; under surface nearly or quite naked; rachis slightly villose; veins pinnate in the lobes, with 6-8 veinlets on a side, with a sorus on each near the main vein.-Aspid. Mett. Fil. Ind. t. 234. N. abruptum, Presl. Hk. Sp. 4. p. 77. t. 241. B. N. Hudsonianum, Brack. N. eusorum, Thwaites. 
Hab. N. India to Ceylon, Malaccas, Australia, and Polynesian Isles.-A much larger and less herbaceous plant than A. molle, with close, blunt lobes, and the rachis and under surface nearly or quite naked. The Mauritian $N$. caudiculatum, Sieb., is either the same or closely allied. J. Smith distinguishes the Indian from the.Polynesian plant, calling the former abruptum, the latter truncatum.

195. N. brachyodon, Hk. ; st. tufted, 1-2 ft. l., grey ish, naked ; fr. 2-3 ft. l., 12-18 in. br. ; pinnoe 6-9 in. $1 ., 1 \frac{1}{2}-1 \frac{3}{4}$ in. br., cut from one-third to half the way down into blunt, oblong, slightly falcate lobes; lower pinnoe not much smaller than the others; texture coriaceous; rachis and both surfaces naked; veins pinnate in the lobes, with 10-15 veinlets on a side, with a sorus on each about midway between the midrib and edge; invol. small, fugacious.-Hk. $S p .4 . p .83$. Phegopteris Seemanni, J. Sm.

Hab. W. Indies and Panama southward to Peru and the Galapagos group; Malayan Peninsula and Isles.

196. N. Fendleri, Hk., st. tufted, 1-2 ft. l., greyish, naked; fr. 2-3 ft. l., 12-15 in. br. ; pinnoe 6-8 in. l., $1 \frac{1}{2}$ in. br., cut about a third of the way down into oblong blunt lobes; lower pinnoe not much smaller than the others ; texture coriaceous; rachis and both surfaces naked; veins pinnate in the lobes, with 10-12 veinlets on a side; sori marginal and almost confined to the lobes; invol. firm, persistent.-Hk. Sp. 4. p. 82.

Hab. Venezuela, Fendler, 372 ; Guiana, Appun, 1035.-Very like the last in texture and cutting.

$\S \S \S$ Pleocnemia, Presl. Lower veinlets of contiguous groups united, and those of the same group slightly so. Sp. 197-200.

197. N. (Pleo.) dissidens, Hk. ; st. 5 in. l., villose ; fr. 8 in. l., 4-5 in. br., oblong-lanceolate; pinnoe $2 \frac{1}{4}$ in. $1 ., \frac{3}{4}$ in. br., with oblong-acute lobes; texture thin and flaccid; rachis and frond pubescent; veins pinnate in the lobes, with 8-9 veinlets on a side, the lower ones forming costal arches ; sori 4-6 in each side near the margin of the lobes ; invol. small, ciliated.-Hk. $S p .4 . p .66$.

Hab. Porto Rico.-We have not seen this, and take the description from Mettenius.

198. N. (Pleo.) heterophyllum, Hk.; rhizome creeping; st. 2-4 in. l., densely villose; fr. 5-6 in. l., 1 in. br., simple, with blunt, oblong, slightly falcate lobes reaching a quarter of the distance to the midrib; texture coriaceous; both surfaces villose, especially the edge and midrib beneath; veins pinnate in the lobes, those of the sterile frond anastomosing towards the edge ; veinlets $5-6$ on each side, with a sorus on each.-Hk. Sp. 4. p.62. 2nd Cent. t. 20. Haplodictyum, Presl.

Hab. Philippines, Cuming, 322.

199. N. (Pleo.) excellens, Bl.; st. naked, greyish ; fr. ample, bipinnatifid; lower pinnoe $1 \mathrm{ft}$. 1., 3-4 in. br., cut down nearly to the rachis into entire, lanceolate lobes; texture subcoriaceous ; rachis and both surfaces nearly naked; veinlets of the lobes slightly pinnate and mostly forming costal arches; sori small, copious, principally in two irregular rows near the midrib of the lobes.Hk. Sp. 4. p. 63. Proferea, Presl.

Hab. Java, Blume.

200. N. (Pleo.) Leuzeanum, Hk. ; caud. subarborescent, densely scaly at the crown ; st. 2-3 ft. l., stout, striated ; fr. 4-6 ft. l., subdeltoid ; pinnoe 12-18 in. l., 6-8 in. br., simple, or the lowest with 2-3 large pinnated pinnl. from the lower side ; segm. 3-4 in.1., $\frac{3}{4}-1 \frac{1}{4}$ in. br., with oblong, subfalcate, entire, or sinuated lobes 
reaching down a broadly-winged rachis; veins pinnated in the lobes; sori copious, usually in close siugle rows in the lobes.-Hk. Sp. 4. p. 61.

Hab. N. India, Hong-Kong, Philippines, Malaccas, Fiji, Samoa.-A variable plant, of which Presl and others make several species. Sometimes the venation is quite free, and sometimes only the veinlets of contiguous groups are joined, and the lobes vary from as broad as deep, when they are blunt and entire, to four times as broad as deep, and deeply crenated. The involucre is very fugacious.

\$§§ Sagenia, Presl. Veins anastomosing copiously, usually with free included veinlets. Pinnoe and segments ample. Sp. 201-224.

* Sori copious, scattered irregularly. Sp. 201-212.

201. N. (Sagen.) Singaporianum, Baker ; rhizome creeping ; st. subtufted, those of the fertile fronds 6-12 in.1. ; fr. $1 \mathrm{ft}$. or more 1., 2-4 in. br., oblong, entire, acuminate at the apex, narrowed rather suddenly and then decurrent gradually at the base ; texture papyraceo-herbaceous or subcoriaceous ; primary veins distinct nearly to the edge; areoloe copious, with free included veinlets; sori numerous, close, 4-6 in a line between the main veins.-Asp. Wall. $H k$. Sp. 4. p. 42. Hk. \& Gr. Ic. t. 26. Podopeltis, Fée.

Hab. Malayan Peninsula and Isles.

202. N. (Sagen.) ternatum, Baker ; rhizome wide-creeping; st. 6-9 in. 1., slender, stramineous ; $f r$. sometimes simple, 8-10 in. 1., 2-3 in. br., oblong, entire, narrowed gradually to the apex and base, but more usually trifoliate, the lateral pinnce like the terminal one but smaller; texture papyraceo-herbaceous; main veins distinct nearly to the edge; areoloe copious, but rather large, with a few free veinlets; sori distant, in two distinct rows, and a few others between; invol. distinct, persistent.

Hab. Borneo, Lobb, Wallace, Motley.

203. N. (Sagen.) vastum, Baker ; rhizome creeping; st. scattered, narrowly winged, often nearly or quite to the hase ; $f r .2-4 \mathrm{ft}$. l., $1 \mathrm{ft}$. or more br., cut down to a broadly-winged rachis into entire linear-oblong pinnoe 6-12 in. 1., 1-2 in. br. ; texture papyraceo-herbaceous or subcoriaceous ; main veins distinct $\frac{3}{4}$ of the way to the edge, connected by copious areolæ with free included veinlets; sori small, scattered.-Aspidium, Blume. A. alatum, Wall. Hk. $S p$. 4. p. 47. Hk. \& Gr. Ic. t. 184.

Hab. Himalayas and Malayan Peninsula and Isles.

204. N. (Sagen.) melanocrulon, Baker ; rhizome ascending ; st. 1 ft. or more 1. , ebeneous, glossy, scaly at the base ; fr. 1-2 ft. 1., 9-15 in. br., ovate-deltoid, with a large, deeply pinnatifid, terminal pinna, and 1 to 4 lateral ones on each side, the central one deeply pinnatifid, with ovate-acuminate lobes, the lowest stalked, 6-12 in. $1 ., 4-6$ in. br., often again pinnate at the base; texture papyraceoherbaceous; rachis ebeneous; main veins reaching the edge, with numerous fine areolæ with free included veinlets between them; sori numerous, minute, scattered; invol. small, fimbriated, fugacious.-Aspid. Blume. Hk. Sp. 4. p. 53. (in part).

Hab. Philippines and Malayan Isles.

205. N. (Sagen.) subtriphyllum, Baker; rhizome creeping; st. $1 \mathrm{ft}$. or more 1 ., substramineous or brownish ; fr. 12-18 in. l., 8-12 in. br., subdeltoid, with a large, deeply pinnatifid apex with lanceolate lobes; below this 1 or 2 pinnoe on each side, the lowest stalked, distant, forked at the base or pinnatifid, the point lanceolate ; texture herbaceous ; main veins distinct to the edge ; areola fine, with 
copious free veins; sori rather large but scattered, confined to the connected veinlets.-Aspid. Hk. Sp. 4. p. 52.

Hab. Panama, Ecuador, Polynesia, China, Malaya, Ceylon, Mascaren Isles.

206. N. (Sagen.) latifolium, Baker ; st. 1-2 ft. l., glossy, naked, brownish ; fr. 2-3 ft. l., 12-24 in. br., the apex ample, deeply pinnatifid, with large, laneeolate, sinuated lobes, below this 3-4 pinnoe on each side, the lowest 9-18 in. l., deltoid, long-stalked, cut down below into distinct pinnatifid pinnl.; primary veins distinct to the edge; areoloe fine, close, with free included veinlets ; sori rather large but scattered, confined to the united veinlets; invol. thin, fugacious.Polypodium, Forst. A. Forsteri, Kze. \& Mett. (in part).

Hab. Panama, Ecuador, Polynesian Islands, Guinea Coast.-This agrees with the preceding in venation and the position of the sori, but is much larger and more compound. A. latifolium, Presl, Hk. Syn. 4. p. 51. is apiifolium.

207. N. (Sagen.) Lobbii, Baker ; st. 6 in. or more 1., naked, substramineous ; fr. about $1 \mathrm{ft}$. each way, subdeltoid, with an entire terminal pinna 4-6 in. l., $\frac{1}{2}-\frac{3}{4}$ in. br., tapering gradually from the middle to each end, and 2 similar lateral ones on each side, the lowest long-stalked and tripartite; texture subcoriaceous ; veins obscure, the primary ones close and very oblique; areoloe without free veinlets; sori copious, scattered.-Aspid. Hk. Sp. 4. p. 59. t. 232.

Hab. Borneo.

208. N. (Sagen.) semibipinnatum, Baker; st. $1 \mathrm{ft}$. or more 1., pale-brown, naked ; fr. 12-18 in. l., 6-9 in. br., with a linear-oblong terminal pinna 6-9 in. 1., 1 in. br., entire and narrowed towards both ends, and 4-6 smaller lateral ones on each side, the lowest 1 or 2 pairs tripartite ; texture papyraceo-herbaceous ; veins inconspicuous, the primary ones lost before they reach the edge, with fine, close areolæ between them, with free included veinlets; sori minute, scattered, confined to the connected veinlets.-Aspid. Hk. Sp. 4. p. 59. t. 231.

Hab. Penang and Borneo.

209. N. (Sagen.) Meyanthidis, Baker ; rhizome creeping ; st. 6-12 in. 1., naked, brownish; fr. 1-2 ft. l., $1 \mathrm{ft}$. or more br., with an acuminate, oblong-lanceolate,

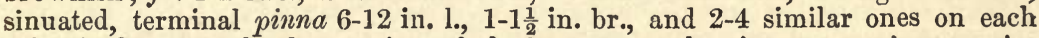
side, the lowest stalked, sometimes forked; texture subcoriaceous ; primary veins close, conspicuous, prolonged to the edge ; areoloe fine, with copious free veinlets ; sori small, scattered, all on the connected veinlets.-Asp. Presl. Hk. Sp.4.p.57.

Hab. Philippines, Solomon Islands, New Guinea.-In habit and texture this most resembles $N$. pachyphyllum, differing by its small irregular sori and pinnæ narrowed gradually to the base.

210. N. (Sagen.) irriguum, Baker ; st. tufted, 4-6 in. 1., greyish, finely villose ; fr. 6-9 in. l., 4-6 in. br., subdeltoid, with a large oblong terminal pinna with a pair of deep lanceolate lobes at the base, and below 1-2 pairs of slightly sinuated lateral pinnæ, the lowest forked at the base; texture papyraceo-herbaceous; main veins flexuose; areoloe fine, copious, with free included veinlets; sori small, scattered, often confluent; invol. small, fugacious.-Aspid. J. Sm. Mett. Fil. Ind. p. 239. Poly. menisciicarpon, Hk. Sp. 5. p. 86. (in part). Microsorium trifidum, Fée.

Hab. Philippines, Cuming, 31.-This may be a form of the next species, but the irregular confluent sori are peculiar. Sagenia heterocarpa, Beddome (Ferns Brit. Ind. t. 47), from Khasya, has similar sori, but agrees with typical polymorphum in general habit.

211. N. (Sagen.) polymorphum, Baker ; rhizome creeping; st. $1 \mathrm{ft}$, or more $1_{\text {, }}$ $2 \mathrm{P}$ 
naked, brownish ; fr. 2-4 ft. 1., 12-18 in. br., with a large, oblong, entire terminal pinna 6-12 in. 1., 1-2 in. br., and 2-6 similar lateral ones on each side, the lower ones often forked; texture subcoriaceous; principal veins distinct to the edge ; areola fine, close, with copious free veinlets ; sori small, scattered, abundant, all on the connected veinlets.-Asp. Wall. Hk. Sp.4. p. 54. A. grandifolium, Mett.

Hab. Himalayas (up to 4,000 ft.) to Ceylon, Malayan Peninsula and Isles.-There is a form with an ebeneous stipe.

212. N. (Sagen.) elatum, Baker ; st. 3-4 ft. l., stout, erect, dull-brown, scaly at the base ; $f r .3-3 \frac{1}{2} \mathrm{ft}$. l., the apex nearly $2 \mathrm{ft}$. 1., 5-partite, the central lobe 5 in. br. at the base, the lowest reaching nearly down to the rachis, below this 3-4 pinnce on each side, the lowest stalked, 18 in. 1., 4-5 in. br., narrowed towards both ends, slightly sinuated below; texture papyraceo-herbaceous; main veins distinct to the edge, $\frac{1}{2}-\frac{3}{4}$ in. apart; areoloe fine, copious, with free included veinlets ; sori close, large, copious, scattered irregularly, principally on the connected veinlets.

Hab. Foot of Mt. Chimborazo, Spruce, 5725.

* Sori large, confined to a distinct row on each side of the principal veins. Sp. 213-224.

213. N. (Sagen.) Pica, Baker ; st. 6-12 in. l., black, glossy ; fr. 1-2 ft. l., $1 \mathrm{ft}$. or more br., pedato-pinnatifid, or more usually pinnate, with 1 or 2 pairs of pinnee, which are 6-12 in. l., 2 in. or more br., the edge broadly undulated, the lowest sometimes with 1 or 2 large pinnl. on the lower side at the base; texture papyraceo-herbaceous ; main veins distinct to the edge ; areoloe copious, with free included veinlets; sori in two rows between the primary veins. Aspid. Desv. Hk. Sp. 4. p. 46. A. trifoliatum, Auct. (in part).

Hab. Mauritius and Bourbon.-Differs from A. trifoliatum by its ebeneous stems and cordate involucre. A. puberulum, Desv., is a slightly-pubescent form.

214. N. (Sagen.) Zollingerianum, Baker ; st. 9-12 in. 1., naked ; fr. 8-12 in. 1., 6-8 in. br., subdeltoid, the apex deeply pinnatifid, below this 3-4 pinnce on each side, the lowest 3-4 in. l., long-stalked, deltoid, cut down below into distinctly separated, deeply pinnatifid pinnl. with blunt linear-oblong lobes; texture subcoriaceous; veins beneath prominent, anastomosing principally in large costular arches; areoloe large, with free included veinlets, depressed so as to form a cavity, in which on the end of the free vein the large copious sori are placed.-Asp. Kze. A. immersum, Hk. Sp. 4. p. 58. Phlebigonium, Fée.

Hab. Java, Zollinger; and we have received copious specimens in Dr. Helfer's Tenasserim collections.

215. N. (Sagen.) variolosum, Baker ; rhizome creeping ; st. 1 ft. or more 1., naked, brownish ; fr.12-18 in. l., 8-12 in. br., subdeltoid, the apex deeply pinnatifid, with lanceolate, acuminate, entire or sinuated lobes; below this 1-3 pairs of lateral pinnoe, the lowest much the largest, sometimes cut down to the rachis at the base with a deeply pinnatifid pinnl.; texture papyraceo-herbaceous ; primary veins distinct; areoloe rather large, with free veinlets; sori large, in rows near the veins, terminating free veinlets.-Asp. Wall. Hk. Sp.4.p. 51 .

Hab. N. India and Malaya.-This has quite the habit and texture of N. subtriphyllum, differing in sori and venation.

216. N. (Sagen.) irregulare, Baker; st. $1 \mathrm{ft}$. or more 1., glossy, ebeneous ; fr. 2-3 ft. 1., 12-18 in. br., the apex deeply pinnatifid, with lanceolate-acuminate lobes, the lower ones sinuated, below this 3-5 pinnoe on each side, the lowest much 
the largest, 8-12 in. 1., 6-8 in. br., deeply pinnatifid above, pinnated at the base, lobes acute; texture papyraceo-herbaceous; rachis glossy like the stipe; main veins distinct to the edge; areoloe fine, with copious free included veinlets; sori in rows near the main veins, mainly or entirely on the connected veinlets.Aspid. Brack. p. 180.

Hab. Polynesian Islands.-Doubtfully distinct from $N$. latifolium, from which it differs by its more regular sori and ebeneous stem.

217. N. (Sagen.) decurrens, Baker ; rhizome creeping ; st. narrowly winged, often nearly or quite to the base; fr. $2-4 \mathrm{ft}$. $1 ., 1 \mathrm{ft}$. or more br., cut down to a winged rachis into 4-8 pairs of sinuated linear-oblong pinnce 6-12 in. 1., 1-2 in. br., the lowest sometimes forked ; texture subcoriaceous; principal veins distinct to the edge, connected by copious areolæ with free included veinlets; sori large, in two regular rows between the principal veins.-Aspid. Presl. A. pteropus, Kze. Hk. Sp. 4. p. 47.

Hab. N. India, Ceylon, Philippines, Malaccas, Formosa, Aneiteum, Fiji, Samoa.-Habit of $N$. vastum, from which it is well distinguished by the biserial sori. A dwarf form, with fronds under $1 \mathrm{ft}$. l., and the fertile ones much contracted, is figured from Ceylon by Capt. Beddome, t. 245.

218. N. (Sagen.) siifolium, Baker; st. $1 \mathrm{ft}$. or more 1., naked, brownish ; fr. $1 \mathrm{ft}$. or more 1., 6-8 in. br., with a broad, oblong, acuminate, terminal pinna, and 3-4 lateral ones on each side, the lowest stalked, 3-4 in. 1., 2 in. br., forked at the base, the margin rather deeply lobed; texture subcoriaceous; primary veins close, distinct to the edge ; areoloe fine, copious, with free included veinlets; sori large, copious, in two close rows, often confluent.-Polypod. Willd. Aspid. Mett. Fil. Ind. p. 237. A. Teysmannianum, Hk. Sp. 4. p. 41.t. 236. Polyp. menisciicarpon, Hk. Sp. 5. p. 86. (in part).

Hab. Philippines, Cuming, 4. Java and Sumatra.

219. N. (Sagen.) pachyphyllum, Baker ; st. 1 ft. or more 1., naked, brownish ; fr. 2-3 ft. l., 12-18 in. br., with an oblong-lanceolate, entire, or sinuated terminal pinna 6-12 in. 1., $\frac{3}{4}-1 \frac{1}{2}$ in. br., and 4-8 similar erecto-patent lateral ones on each side, the lower ones forked at the base ; texture subcoriaceous; primary veins straight and distinct nearly to the edge ; areoloe fine, with copious free included veinlets; sori large, in two regular rows.-Asp. Kze. Hk. $S p$. 4. p. 56. A. grande, J.Sm. Hk. Sp. 4. p. 55.

Hab. Philippines and Malay Isles, Solomon Isles, Fiji.

220. N. (Sagen.) Barteri, Baker ; st. $1 \mathrm{ft}$. or more 1., naked, substramineous ; fr. 2-3 ft. 1., 12-18 in. br., with an oblong, entire terminal pinna 9-12 in. l., 3-4 in. br., acuminate at the apex and narrowed gradually to the base, and 3-4 similar ones on each side, all simple, the lowest slightly stalked; texture papyraceo-herbaceous or subcoriaceous; main veins distinct to the edge, $\frac{1}{4}$ in. apart; areolce fine, copious, with free included veinlets; sori rather small, placed in two regular rows near the main veins; invol. minute, fugacious. Aspid. J. Sm. Ferns, B. \& F.p. 286.

Hab. Fernando Po, Barter and Mann.-Most like N. polymorphum in habit and texture.

221. N. (Sagen.) cicutarium, Baker ; st. $1 \mathrm{ft}$. or more l., brownish or ebeneous ; fr. 1-2 ft. l., subdeltoid, the apex deeply pinnated, with sinuated lanceolate lobes; below this 3-6 pinnee on each side, the lowest subdeltoid, deeply pinnatifid or pinnate below ; texture papyraceo-herbaceous or subcoriaceous ; main veins distinct to the edge; areoloe with few or no included free veinlets; sori rather large, in two rows near the main veins on connected or free veinlets, - 
Polyp. Linn. Aspid. Sw. Hk. Sp. 4. p. 48.-, N. apiifolium, Hk. \& Arn. ; larger and more compound ; lower pinnoe deltoid, $1 \mathrm{ft}$. or more 1.; rachis broadwinged above, often free below; sori sometimes immersed. - A. latifolium, Presl. Hk. Sp. 4. p. 51. A. dilaceratum, Kze.

Hab. Cuba and Mexico southward to Brazil and Peru, Polynesian and Malayan Islands, Himalayas (up to 4,000 ft.), Neilgherries, Ceylon, Mascaren Isles, Zambesi-land, Angola, Guinea Coast.-This includes all the Eusagenia (six species) of Moore's Index. The extremes differ in size very much, but all the forms appear to agree in sori and venation.

222. N. (Sagen.) Griffithii, Baker; st. 1-2 ft. 1., brownish, not glossy ; fr. 3-4 ft. l., with a large terminal pinna cut down nearly to the rachis in the lower part into lanceolate divisions, with deep lanceolate-acuminate lobes, below this several pinnæ on each side, the lowest deltoid, $1 \mathrm{ft}$. or more l., by nearly as broad, deeply pinnatifid above, pinnate below ; texture papyraceo-herbaceous; main veins distinct to the edge, with copious free included veinlets; sori rather large, in two rows, nearly all terminating free veinlets.

Hab. Burmah, Girffith.-This comes nearest the largest forms of the preceding, but the venation is closer, and it has copious free veins, and sori not on the connected veinlets.

223. N. (Sagen.) giganteum, Baker ; st. 1-2 ft. 1., glossy, chesnut-brown ; fr. 2-3 ft. l., 12-18 in. br., deeply pinnatifid at the apex, with lanceolate sinuated lobes; below this 4-6 pinnce on each side, the lowest much the largest, often $1 \mathrm{ft}$. l., pinnate at the base, with deeply pinnatifid pinnl. ; texture papyraceoherbaceous; rachis and both surfaces naked; veins anastomosing principally in costal arches; sori large, terminating free veins, principally in rows on the lobes on both sides the main veins.-Aspid. Blume. Hk. Sp. 4. p. 50.

Hab. Ceylon, Philippines, Malaya.-Resembles $N$. cicutarium in habit, but the texture is thicker, and the venation much less compound.

224. N. (Sagen.) macrophyllum, Baker ; st. tufted, 1-2 ft. l., dull brownish, scaly below ; fr. 2-3 ft. l., $1 \mathrm{ft}$. or more br., with a large terminal pinna, often forked at the base, and 4-8 lanceolate-oblong lateral ones on each side, 6-12 in.1., 1-3 in. br., entire or slightly lobed, the lowest pair forked at the base; texture papyraceo-herbaceous; rachis and both surfaces usually naked; primary veins continued nearly to the edge, with numerous fine areolæ with free included veinlets between them; sori in 2 rows between each primary vein.-Aspid. Swz. Hk. Sp. 4. p. 56.

Hab. Tropical America, from Cuba and Mexico to Brazil and Peru. - The Malayan A. Haenkei, Presl, is either a form of this or very near it.

\section{Gen. 45. NePhroleprs, Schott.}

Sori round, arising from the apex of the upper branch of a vein, generally near the edge. Invol. reniform or roundish. Veins in all free, the fronds simply pinnate, with the pinnoe articulated at the base and often very deciduous in the dried plant, with white cretaceous dots on the upper surface. Belts the world in the Tropics, passing a little beyond them both north and south. TA B. V. f. 46.

1. N. cordifolia, Baker ; caud. suberect or oblique, the wiry fibres often

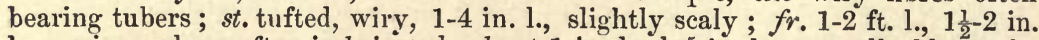
br.; pinnoe close, often imbricated, about 1 in. 1. , $\frac{1}{2}-\frac{5}{8}$ in. br., usually blunt, the edge entire or slightly crenate, the under side rounded or cordate, the upper distinctly auricled at the base; texture subcoriaceous ; rachis slightly scaly ; both sides nearly naked; sori in a row about midway between the midrib and edge ; invol. firm, distinctly reniform, oblique or opening towards the outer edge.- 
Polypod, Linn. N. tuberosa, Hk. Sp. 4. p. 151.- $\beta$, N. pectinata, Schott ; no tubers, stem and rachis naked, pinnoe less distinctly auricled at the base on the upper, obliquely truncate on the lower side.

Hab. Cuba and Mexico to Brazil and Peru ; Japan and N. India southward to Australia and New Zealand ; Mascaren Isles, Zambesi-land, Guinea Coast. $\beta$ restricted to the New World.-Distinguished from the two next by its narrower frond, close blunt pinnæ, and submedial sori. Here belong $N$. occidentalis, Kunze, N. imbricata, Kaulf., $N$. obtusifolia, Presl, and N. delicatula, Decaisne ; the lattèr a small delicate N. Indian form.

2. N. exaltata, Schott ; st. tufted, 4-6 in. l., firm, naked, or slightly scaly ; fr. 1-2 ft. or more l., 3-6 in. br.; pinnoe close, $1 \frac{1}{2}-3$ in. 1. , $\frac{1}{4}-\frac{1}{2}$ in. br., usually ate, the edge entire or slightly crenate, the upper side auricled, the lower rounded at the base ; texture subcoriaceous ; rachis and both sides nearly naked; sori submarginal ; invol. firm, distinctly reniform.-Hk. Sp. 4. p. 152.- $\beta, N$. hirsutula, Presl ; rachis densely and both surfaces more or less coated with ferruginous down.-Polyp. Forst.

Hab. Cuba, the Bahamas, and Mexico to Peru and Brazil ; Polyncsia ; N. India and Cbusan to Queensland and Ceylon; Mauritius, Angola, Zambesi-land, Guinea Coast.To this appear to belong $N$. volubilis, J. Sm., a straggling flexuose form, and the American A. pendulum, Raddi, and A. pilosum, L. and F., the former a large pendulous, and the latter a more delicate pilose plant. The typical form differs from the next species by its smaller size and firmer distinctly, reniform involucres; but in some of the forms which agree with this in babit, as the New World $A$. sesquipedale, Willd., $N$. valida, Kze., $N$. neglecta, Kze., and Old World $N$. biserrata, Schott, the involucre resembles that of N. acuta.

3. N. acuta, Presl ; st. tufted, 4-8 in. 1., firm, naked or slightly scaly ; fr. 2-4 ft. l., 8-12 in. br. ; pinnoe 4-8 in. l., $\frac{1}{2}-1$ in. br., acute, the edge entire or slightly crenate, the upper side auricled, the lower rounded at the base; texture subcoriaceous ; rachis and both sides nearly naked; sori submarginal ; invol. suborbicular, subpeltate.-Hk.Sp.4. $p .153 . \quad$ N. punctulata, Presl. N. ensifolia, Presl. N. splendens, Presl.

Hab. Cuba and Guatemala to Peru and Brazil ; Polynesia, Hong-Kong, and Loo Choo to Queensland; Mascaren Isles, Zambesi-land, Natal, Angola, Guinea Coast.-As will be seen, this is almost identical with the preceding in its distribution. There is also a ferrugineotomentose variety of this, which appears to be $N$. rufescens, Presl. N.platyotis, Kunze, is a form with the auricle sometimes $1 \mathrm{in} . \mathrm{l}$.

4. N. ramosa, Baker; st. very short, scattered, on a slender, wiry, widecreeping rhizome ; fr. 6-12 in. 1., 1-3 in. br. ; pinnoe $\frac{1}{2}-1 \frac{1}{2}$ in. 1., $\frac{1}{4} \frac{1}{2}$ in. br., slightly crenate, the upper edge auricled and truncate, parallel with the stem, the lower oblique; texture papyraceous; rachis and both sides slightly villose, the whole plant turning blackish when dried; invol. roundish, very fugacious.-Aspidium, Beauv. N. obliterata, Hk. Sp. 4. p. 154. N. trichomanoides, J. Sm.

Hab. West Tropical Africa, Johanna Island, Ceylon, Philippines, Malaccas, Australia, Samoa, Fiji. - Beauvois' is the oldest name, and he has given a characteristic figure in the Flore d'Oware. Polypodium? Beckleri, Hk. Sp. 4. p. 224, is this in a small barren state.

5. N. altescandens, Baker ; st. very short, distant, on a slender, wiry, widecreeping rhizome; fr. 6-12 in. l., 1-3 in. br.; pinnoe $\frac{1}{2}-1 \frac{1}{2}$ in. l., $\frac{1}{4}-\frac{1}{2}$ in. br., distinctly crenato-pinnatifid, the upper edge auricled and truncate, parallel with the stem, the lower oblique; texture papyraceous; rachis and both sides more or less villose, the plant keeping green when dried; invol. very fugacious.-Polyp. Colla, $H$ k. Sp. 4. p. 218. P. procurrens, Kze.

Hab. Juan Fernandez, Samoa, Queensland, N. S. Wales.-This differs from the preceding by its firmer texture, crenate pinnæ, and by not turning at all black when dried. 
Both have the stem usually jointed a short distance above the base, as in J. Smith's Arthropteris. N. tenuis, Moore, is a small form, and $N$. repens of Brackenridge apparently belongs in part to this, and in part to $N$. ramosa.

6. N. floccigera, Moore; st. furfuraceous ; fr. 2-3 ft. l., 8-12 in. br. ; pinnoe 4-6 in. l., $\frac{3}{8}-\frac{3}{4}$ in. br., the apex acuminate, the edge crenated to a depth of 1 lin., the base slightly unequal; texture subcoriaceous; rachis and under surface furfuraceous ; sori in the crenations; invol. firm, reniform.-Hk. $S p .4$. $p .155$.

Hab. Java and Celebes.-Resembles exaltata in habit, but the pinnæ are distinctly crenated, and the sori placed at the tip of the lobes.

7. N. davallioides, Kze. ; caud. short, stoloniferous ; st. tufted, $1 \mathrm{ft}$. or more 1., scaly towards the base ; $f r$. drooping, 2-3 ft. l., $1 \mathrm{ft}$. or more br.; lower pinnoe barren, $4-8$ in. l., $\frac{1}{2}-1$ in. br., the apex acuminate, the edge inciso-crenate to a depth of 1 lin. or less, fertile pinnæ narrower, the lobes deeper and bearing each a single sorus at the point; texture subcoriaceous; rachis furfuraceous, both sides nearly naked; invol. reniform.-Hk. Sp. 4.p. 155. Fil. Ex.t. 60.

Hab. Java.-Clearly distinguished by its pinnatifid fertile pinnæ, with the sori at the tip of the lobes. Ophioglossum acuminatum, Hout., is the oldest name.

\section{Gen. 46. Olenandra, Cav.}

Sori round, inserted in a row near the base or below the centre of the compact free veinlets. Invol. reniform. A small genus, almost restricted to the Tropics, distinguished from Nephrodium mainly by habit, with wide-creepinq scandent shoots, jointed stems, and entire lanceolate-elliptical fronds. TAB. V. f. 46.

1. O. neriiformis, Cav.; shoots woody, suberect, clothed with adpressed scales ; st. $\frac{1}{2}-1$ in. 1., with the joint below the middle; fr. 6-18 in. 1., $\frac{3}{4}-1 \frac{1}{2}$ in. br., scattered, or in opposite pairs, or often in terminal whorls, narrowed gradually towards both ends; texture generally subcoriaceous and both sides naked; sori in two rather irregular rows near the midrib; invol. oblique.-Hk. Sp. 4. p. 156. (in part). Fil. Ex.t. 58.

Hab. America-N. Granada and Guiana to Brazil and Peru ; Fiji, N. Guinea, Samoa, Aneiteum, N. India (up to $6,000 \mathrm{ft}$.), Philippines, Malaccas, Guinea Coast.-A variable plant, but we cannot distinguish clearly more than one species with firm suberect shoots. $O$. phyllarthron, Kze., is a form with small, rigid, sessile fronds ; $O$. micans, Kze.; $O$. hirta, Brack. ; O. mollis, Presl ; O. Trujulensis, Karst. ; O. hirtella, Miquel ; and o. pilosa, Hk., are S. American plants, with thinner and more or less pilose fronds, and with the sori often in an irregular wavy line not close to the midrib, as in 0 . articulata.

2. O. musafolia, Kunze; shoots firm, wide-climbing, clothed with adpressed scales, curving upwards to where it bears the fronds singly or in tufts of 2 to 5 , and then downwards ; st. $\frac{1}{2}-1$ in. 1 , jointed close to the base ; fr. 6-12 in. 1., 1-1 $\frac{1}{2}$ in. br., narrowed gradually towards both ends; texture subcoriaceous, naked or the midrib slightly pilose; sori in two irregular rows near the midrib; invol. oblique.-Mett. Fil. Ind. p. 240.

Hab. Ceylon and Malay Isles.-Well distinguished from the preceding by its different mode of growth. O. Moritzii, Kunze, is a form with more scattered fronds and subsquarrose scales.

3. O. articulata, Cav.; shoots firm, suberect, wide-climbing, clothed with linear-subulate adpressed scales; st. scattered, sometimes opposite but not whorled, 1-2 in. l., with the joint close to the base ; fr. 6-12 in. 1., 1 $\frac{1}{2}-2$ in. br. ; texture subcoriaceous; midrib beneath slightly scaly; sori in two irregular rows, often some distance from the midrib.-O. neriiformis, Hk. Sp. 4. p. 156. 
(in part). $-\beta$, O. Welwitzchii, Baker; shoots weaker, wide-trailing; scales linearsubulate, squarrose.

Hab. Natal, Mascaren Isles, Seychelles, Guinea Coast; $\beta$, Angola, Dr. Welwitzsch.The typical plant is about midway in mode of growth between species 1 and 4 ; $\beta$ has the trailing shoots and spreading scales of nodosa, but in other respects agrees with this.

4. O. nodosa, Presl ; shoots trailing horizontally, densely clothed with linearsubulate spreading scales; st. scattered, $2-6$ in. l., often ebeneous, articulated not far from the base ; fr. $6-12$ in. $1 ., 1 \frac{1}{2} \cdot 2 \frac{1}{2}$ in. br., the apex acuminate, the edge entire; texture subcoriaceous, both sides glossy; sori scattered, placed nearly all in the inner half of the frond; invol. $\frac{1}{3}$ lin. br. $-H k . S p .4 . p .157$.

Hab. West Indies and Guiana.-Distinguished from all the other species by its trailing shoots, satiny gloss, and copious irregularly-scattered sori.

5. O. Wallichii, Hk.; shoots trailing horizontally, the scales fibrillose, spreading, ferruginous; st. close or scattered, $\frac{1}{2}-2$ in. 1., jointed close to the base; fr. 6-12 in. l., $\frac{3}{4}-1 \frac{1}{2}$ in. br., the apex acuminate ; texture papyraceoherbaceous or subcoriaceous; rachis naked or scaly; both sides naked; sori in single rows close to the midrib ; invol. $\frac{1}{3}$ lin. br., ciliated, opening towards the edge.-Hk. Sp. 4. p. 158.

Hab. N. India, up to $7,000 \mathrm{ft}$.

6. O. Cumingii, J. Sm.; shoots trailing horizontally, clothed with adpressed linear scales; st. close or scattered, 2-3 in. 1., articulated near the base ; fr. 12-18 in. l., $1 \frac{1}{2}$ in. br., narrowed gradually towards both ends; texture herbaceous; rachis and both sides slightly pubescent; sori in two irregular rows near, but not close to, the midrib; invol. firm, oblique.-Hk. Sp. 4.p.155. O. chinensis, Hance.- $\beta$, O. Sibbaldi, Grev.; texture thinner; surfaces more hairy; sori in very irregular wavy lines not so near the midrib.-Ann. Nat. Hist. 2 ser. 1. p. 327.

Hab. Canton, Assam, Philippines, Neilgherries, and Malaya.-Var. longipes, Hk., from Moulmein, has stems 4-5 in l., articulated near the middle. $\beta$, Tahiti ; gathered by Sibbald and Bidwell. Probably this occurs in Tropical Australia, as there are specimens amongst Leichbardt's plants.

\section{Gen. 47. Fadyenia, Hook.}

Sori oblong, in two series near the midrib, terminating free veinlets. Invol. large, subreniform, attached by the centre, free all round the edge. $A$ single West Indian species. 'TA B. V. f. 47 .

1. F. prolifera, Hk.; fr. entire, dimorphous, the sterile ones $\frac{3}{4}-1$ in. br., elongated and rooting at the apex, the fertile one ligulate, narrowed below, 6-9 in. l., $\frac{1}{4} \cdot \frac{3}{8}$ in. br.; veins anastomosing copiously; texture subcoriaceous; sori filling up nearly the whole space between midrib and edge.-Hk. Sp. 4 . p. 160. Fil. Ex.t. 36 .

Hab. Cuba and Jamaica. 
B. Exinvolucratæ. Sori without an involucre. Tribes 11-13. Gev. 48-61.

\title{
Tribe 11. Polypodiez.
}

Sori on the back of the lobes, round or rarely oblong, not more than twice as long as broad. Gen. 48.

\author{
Gen. 48. Polypodum, $L$.
}

Characters of the Tribe.

The largest genus, including plants of two different modes of growth, each series including a number of species of each of the different kinds of venation and from all climates. TА в. V. f. 48.

* Desmobryoid series. Habit and mode of growth of Aspidiece, i.e. stems continuous with the caudex, and sori always medial on the veins. Phegopteris, Mett. Sp. 1-90. Fig. C.

\$ Euphegopteris. Venation of Lastrea, i.e. veins free. Sp. 1-55. T TB. 48.

\section{* Pinnae entive or lobed less than halfway down to the midrib. Sp. 1-7.}

1. P. (Pheg.) cordatum, Hk. ; st. very short, slender, stramineous, pubescent ; fr. 3-4 in. l., 1 in. br., oblong-lanceolate ; pinnoe oblong, entire, blunt, 2 lin. br., rounded at the base and stalked, the lower ones reduced ; texture subcoriaceous ; rachis and under side finely pubescent; veinlets of the pinnæ usually simple, with medial sori.-Hk. Sp. 4. p. 233.

Hab. Cuba.-Probably a free-veined form of $P$. reptans, with which Mettenius unites it.

2. P. (Pheg.) hastofolium, Sw. ; st. tufted, 1-2 in. 1., wiry, deciduously scaly ; fr. $6-9$ in. $1 ., 1 \frac{1}{2}-2$ in. br. ; pinnoe blunt, entire, $\frac{1}{8}$ in. br., with a sharp distinct auricle on both sides at the base, those of the lower half of the frond reduced gradually; texture subcoriaceous; rachis villose; under side nearly naked; veinlets forked, with the sori below the middle.-Hk. Sp. 4. p. 232.

Hab. West Indies.

3. P. (Pheg.) flavo-punctatum, Kaulf. ; st. $1 \frac{1}{2}-2 \mathrm{ft}$. 1., slightly scaly towards the base ; fr. 2-3 ft. or more 1., 12-18 in. br. ; pinnos 6-9 in. 1., 1-11 in. br., the apex acuminate, the edge crenate or inciso-dentate, the lower ones slightly stalked, 2 in. apart, the lowest not reduced; texture papyraceo-herbaceous ; rachis naked or slightly scaly, both sides naked; main veins only about 2 lin. apart, with 3-4 veinlets on each side, all except the upper ones uniting; sori medial.$\beta, P$. Prionitis, Kunze; pinno lobed from a quarter to a third of the way down to the midrib.-Hk.Sp.4. $p .239$.

Hab. W. Indies and Mexico to Peru and. Brazil.-Neph. Imrayanum, Hk. Sp. 4. p. 86. t. 242. A., is evidently the same plant, and I cannot see an involucre. The name is derived from minute pellucid yellow dots, which are scattered over the frond. It may be $P$. rotundifolium, Willd. (Plumier, t. 38 ).

4. P. (Pheg.) Sancta-Gabrieli, Hk. ; st. 18 in. l., firm, erect, brownish, glossy, scaly only at the base; $f r .2 \mathrm{ft}$. l., nearly $1 \mathrm{ft}$. br. ; pinnoe spreading, the lowest stalked, 5-6 in. $1 ., \frac{1}{2}-\frac{5}{8}$ in. br., the apex acuminate, the edge bluntly lobed to a depth of a line, the base on the upper side with a distinct rhomboidal auricle; texture herbaceous; rachis and both sides naked; veinlets 2-3 on a side; sori copious.-Hk. Sp. 4. p. 233. 
Hab. St. Gabriel, Amazon Valley, Spruce, 2153.-Very near the last, of which it may be a form.

5. P. (Pheg.) alleopterum, Kunze ; st. $1 \frac{1}{2} \mathrm{ft} .1$. ; fr. $1 \frac{1}{2} \mathrm{ft} .1 ., 1 \mathrm{ft}$. br., ovateoblong, slightly narrowed below ; pinnoe 6 in. l., $1 \frac{1}{2}$ in. br., the edge incisocrenate, with subfalcate acute or obtuse lobes, the base unequal, the lower pinnæ stalked; texture papyraceo-herbaceous; rachis and both sides naked; veinlets 2-5 on a side; sori large, close to the main veins.-Mett. Pheg. p. 19.

Hab. Columbia.

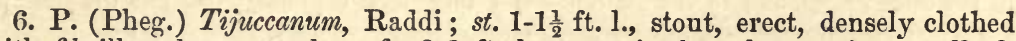
with fibrillose brown scales; fr. 2-3 ft. l., 12-18 in. br.; lower pinnce stalked, 6-9 in. $1 ., 1-1 \frac{1}{2}$ in. br., cut about halfway down to the rachis into blunt entire lobes $\frac{1}{4}$ in. br., lower ones not reduced; texture papyraceo-herbaceous; rachises sealy ; under side naked; veinlets 6-9 on a side, simple, with the sori below the middle.-Hk. Sp. 4. p. 239.

Hab. Guiana, Brazil, and Peru.

7. P. (Pheg.) Walkerce, Hk.; st. 12-18 in. 1., strong, erect, substramineous, deciduously scaly ; fr. 2-3 ft. 1., $1 \mathrm{ft}$. or more br.; lower pinno distinctly stalked, 6.12 in.1., 1 in. br., acuminate, the edge crenated or slightly or deeply lobed; texture coriaceous; rachis slightly scaly; under surface quite naked, glossy; veins immersed, in free pinnated groups, with $5-6$ very oblique veinlets on a side; the sori distant from the midrib of each.-Hk. $S p .4 . p .234 .-\beta, b i$ pinnatum; lower pinnoe $1 \mathrm{ft}$. 1 , with distinct unequal-sided pinnatifid pinnl. cuneate at the base.

Hab. Ceylon.-A doubtful plant; $\alpha$ is probably a form of Aspidium caducum, without an involucre; whilst $\beta$ comes near to $A$. aristatum $\gamma$, but is without spinose teeth. The various forms are figured by Capt. Beddome, t. 234.5.

** Pinnoe cut more than halfway down to the rachis into close, regular, subentire lobes. Sp. 8-24. Veinlets all simple except in 20-24.

8. P. (Pheg.) pauciflorum, Hk.; st. tufted, 6-8 in. l., firm, polished, brownish, naked ; fr. 8-10 in. 1., 4-5 in. br., lanceolate; lower pinnoe distinctly stalked, 2-3 in. l., $\frac{3}{4}$ in. br., cut halfway down or more into close, broad, blunt lobes, lowest not reduced; texture papyraceo-herbaceous; rachis and under side a little hairy; veinlets simple, $4-5$ on a side, with a few sori near their apex.-Hk. $S p .4$. p. 242.

Hab. Surinam, Hostmann, 64.

9. P. (Pheg.) deflexum, Baker; caud. erect, the scales ovate, dull-brown ; st. 2-3 in. l., slender, naked, stramineous ; fr. 8-12 in. 1., 2 in. br. ; pinnoe 1 in. l., $\frac{1}{4}$ in. br. ; lanceolate-acuminate, cut down to the rachis into pointed linearoblong lobes $\frac{3}{4}$ lin. br., the lower pinnæ deflexed, very distant and dwindling down gradually to mere auricles; texture herbaceous ; rachis naked, stramineous; both sides slightly hairy ; veins 4-6 on each side ; sori nearer the midrib than the edge.-Phegop. Mett. Fil. Nov. Gran. 241. Nephrodium, Presl.

Hab. New Granada, Lindig, 321.-Habit of N. Beddomei.

10. P. (Pheg.) obtusilobum, Desv. ; st. densely tufted, about $1 \mathrm{ft}$. 1., slender, nearly naked ; fr. $2 \mathrm{ft}$. or more 1., 8-10 in. br.; pinnoe 4-6 in. 1., $\frac{3}{4-7}$ in. br., narrowed gradually from the base to the point, cut down nearly to the rachis into entire slightly falcate lobes $\frac{1}{8}$ in. br.; lower pinnoe reduced gradually ; texture herbaceous ; rachises naked or slightly pubescent; veinlets 8-9 on a side; sori small, medial. 
Hab. Mauritius and Madagascar, Bojer ; Cameroon Mountains and Fernando Po, Mann. - Habit of Neph. conterminum.

11. P. (Pheg.) Sieberianum, Kaulf. ; st. 12-18 in. 1., firm, naked, stramineous ; fr. $1 \frac{1}{2}-2$ ft. l., 1 ft. or more br. ; pinnce 6-9 in. l., 2 in. or more br., cut down to a broadly-winged rachis into falcate entire lobes, $\frac{1}{4}-\frac{3}{8}$ in. br., lowest pair rather smaller and deflexed ; texture papyraceo-herbaceous or subcoriaceous; veinlets 8-9 on a side, with the sori about the centre.-Hk. Sp. 4. p. 235.

Hab. Mauritius and Bourbon.-Occasionally the lowest veinlets join those above them in the same group, and in the barren frond they fork copiously, and join towards the edge. Resembles most Neph. brachyodon.

12. P. (Pheg.) erubescens, Wall.; st. 2 ft. or more l., tetragonous, glossy, stramineous, naked ; fr. 3-4 ft. l., 1-2 ft. br.; lower pinnae sometimes $1 \mathrm{ft} .1$. , $1 \frac{1}{2}$ in. br., cut down nearly to the rachis into close acute or bluntish entire lobes 2 lin. br.; texture rigid, subcoriaceous; rachis and both sides naked; veinlets simple, often 20 on a side, the sori close to the raised midrib. $-\beta$, Amboynensis; lower pinnee on stalks 1 in. l. and narrowed conspicuously at the base; sori not close to the midrib.-Hk. Sp. 4. p. 236.

Hab. N. India (up to 2,000 ft.), Malayan Peninsula and Isles.-Habit of N. prolixum, but lower pinnæ not reduced.

13. P. (Pheg.) appendiculatum, Wall. ; st. tufted, about $1 \mathrm{ft} .1$. , deciduously villose ; fr. $1 \frac{1}{2}-2$ ft. l., 8-10 in. br., ovate-lanceolate ; pinnoe $3-5$ in. l., $\frac{3}{4}-\frac{7}{8}$ in. br., narrowed from the base to an acuminate point, cut down nearly to the rachis into linear-oblong falcate lobes $\frac{1}{8}$ in. br.; lower pinnoe with a small gland at the base, slightly reduced; texture herbaceous; rachis and lower surface villose ; veinlets 8-12 on a side; sori close to the midrib.-Wall. Cat. 349.

Hab. East Himalayas and Penang. - Intermediate between the preceding and following.

14. P. (Pheg.) auriculatum, Wall. ; st. tufted, $1 \frac{1}{2}-2 \mathrm{ft} .1$. , deciduously villose ; fr. 3-4 ft. 1., $1 \mathrm{ft}$. or more br. ; pinnoe 6-8 in. l., 1 in. br., cut down nearly to the rachis into close spreading entire blunt lobes $2-3$ lin. br. ; lower pinnoe reduced down to mere auricles, furnished with a prominent gland at the base beneath; texture herbaceous; rachis densely villose; under side nearly naked; veinlets simple, 10-12 on a side, bearing the sori about the middle.-HK. Sp. 4. p. 238.

Hab. Himalayas, up to $6,000 \mathrm{ft}$.

15. P. (Pheg.) Germanianum, Baker ; st. 6-9 in. 1., tufted, firm, erect, nearly naked ; fr. 2 ft. l., 1 ft. br. ; central pinnce 6 in. l., $1 \frac{1}{4}$ in. br., cut three-quarters of the way down to the rachis into linear-oblong blunt entire lobes 2 lin. br., with a space between them, the lower pinnæ sessile, much reduced; texture herbaceous; rachis and veins beneath slightly pubescent; veins pinnate in the lobes, with 8-10 veinlets on a side; sori medial.-Pheg. Fée, Mem. 11-12.t. 13.

Hab. Guadeloupe, L'Herminier. $-\boldsymbol{P}$. ctenoides, macrotheca, and hydrophila, Fée, are allied plants from the same island ; all of them closely resembling Gymnogramme daval. lioides in general habit, but the sori are roundish.

16. P. (Pheg.) rusticum, Baker ; st. tufted, 4-6 in. 1., strong, densely clothed

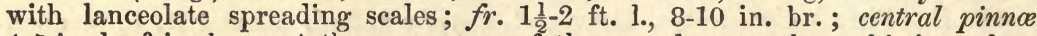
4-5 in. l., $\frac{3}{4}$ in. br., cut three-quarters of the way down to the rachis into close blunt entire lobes 2 lin. br. ; lower pinnoe distant and dwindling down very gradually ; texture herbaceous ; rachis scaly in the lower part, villose throughout like the costæ; veins pinnate in the lobes, with 6.8 simple veinlets on a side; sori medial.-Phegopteris, Fée, Mem. 11-12.t. 13. 
Hab. Guadeloupe, L'Herminier.-Habit not unlike that of the least-divided forms of N. Filix-mas.

17. P. (Pheg.) refulgens, Klotzsch; st. $1 \mathrm{ft} .1$., clothed with bright-brown scales

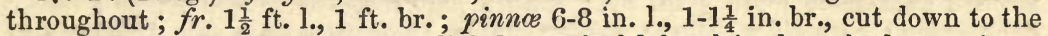
centre into close oblong obtuse slightly-toothed lobes $\frac{1}{4}$ in. br., the lower pinnæ stalked and rather narrowed at the base; texture herbaceous; rachis and main veins above densely downy, the veins beneath with yellowish glandular hairs and reddish setaceous scales; veinlets simple, 7-12 on each side ; sori medial. Phegop. Mett. Fil. Nov. Gran. p. 240.

Hab. Panama, Columbia, and Guiana.-Habit of Neph. caripense.

18. P. (Pheg.) rude, Kze.; st. $1 \frac{1}{2}-2 \mathrm{ft}$. 1., scaly towards the base, villose

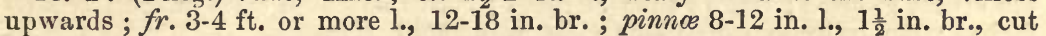
down nearly to the rachis into subfalcate entire lobes $\frac{1}{8}$ in. br., the lower pinnæ not reduced, but with a gland at the base and the lower lobes small; texture subcoriaceous; rachis conspicuously villose and under side less so; veinlets simple, 12-16 on a side ; sori submarginal.-Hk. Sp. 4. p. 243. Glaphyropteris, Presl.

Hab. Mexico to Peru.-Neph. piloso-hispidum, Hk. Sp. 4. p. 105, seems to belong here, and I cannot distinguish an involucre.

19. P. (Pheg.) decussatum, L. ; st. 2-3 ft. 1., stout, erect, scaly towards the base, polished upwards, sometimes slightly muricated ; $f r .3-4 \mathrm{ft}$. or more 1 .,

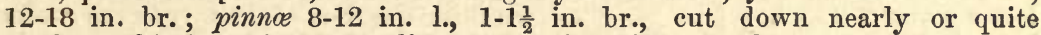
to the rachis into close spreading entire blunt lobes 1-1 $\frac{1}{2}$ lin. br., with a large subulate gland at the base beneath; texture subcoriaceous, rigid; rachis and both sides nearly naked; veinlets simple, close, 20 or more on a side; sori in rows near the midrib.-Hk. Sp. 4. p. 244. Glaphyropteris, Presl.

Hab. West Indies and Panama southward to Peru and Brazil.

20. P. (Pheg.) unisorum, Baker ; st. tufted, slender, 1 in. l., dark purplishbrown, clothed throughout with linear scales; fr. $2-3$ in. l., 1 in. br., oblonglanceolate; pinnoe horizontal, with a roundish terminal lobe $1 \frac{1}{2}-2$ lin. each way, and 1-2 smaller sessile ones on each side; texture coriaceous; rachis densely scaly like the stem; both sides naked; veins immersed, flabellate; one large sorus at the base of each lobe.

Hab. Mount Rauai, Sandwich Isles, Hillebrand.-A very curious and distinct little plant.

21. P. (Pheg.) platylobum, Baker ; st. 12-18 in. l., firm, erect, scaly towards the base, finely villose upwards ; $f r .2-3 \mathrm{ft}$. $1 ., 1 \mathrm{ft}$. or more br. ; central pinnoe 6-8 in. l., 1-1 $\frac{1}{4}$ in. br., cut down to the rachis in the lower part into blunt oblong nearly entire subfalcate lobes $\frac{1}{4}$ in. br. ; lower pinnoe slightly reduced; rachises densely villose; under surface nearly naked; texture herbaceous ; veinlets about 6 on a side, the lower ones forked; sori almost marginal.-P. rotundatum, Hk. Sp. 4. p. 238. (non Willd.)

Hab. Tarapota, N. E. Peru, Spruce, 4656.

22. P. (Pheg.) fibrillosum, Baker; st. $1 \mathrm{ft}$. or more 1., densely clothed throughout with spreading fibrillose scales; fr. $1 \frac{1}{2} \cdot 2 \mathrm{ft}$. $1 ., 1 \mathrm{ft}$. br.; lower pinnoe the largest, sessile, 6 in. $1 ., 1 \frac{1}{2}$ in. br., cut down within 1 lin. of the rachis into close, blunt, nearly entire falcate lobes 3-4 lin. br.; texture herbaceous ; rachis fibrillose and upwards villose; both sides nearly naked; veinlets forked, 6-8 on a side, with the sori close to the midrib.

Hab. Andes of N. E. Peru, Spruce, 4742. 
23. P. (Pheg.) macrophyllum, Hk. ; st. $\frac{1}{2}$ in. thick, $4 \mathrm{ft}$. 1., clothed with scattered lanceolate scales; $f r$. ample, 5-6 ft. 1., 2-3 ft. br. ; lowest pinnoe 16 in. $1 ., 2 \frac{1}{2}$ in. br., cut down to a broadly-winged rachis into close slightlytoothed subfalcate lobes $\frac{3}{8}$ in. br. ; texture papyraceo-herbaceous, firm ; colour dark-green; both sides naked ; veinlets simple, 12 or more on a side, bearing sori about the centre.-Hk. Sp. 4. p. 241.

Hab. Andes of N. E. Peru, Spruce, 4270.-This also has pellucid dots, and is a very fine plant.

24. P. (Pheg.) pteroideum, Klotzsch ; st. 2-4 ft. l., scaly at the base, naked and stramineous upwards ; fr. 3-6 ft. or more l., 2-3 ft. br. ; lower pinnoe 12-18 in. 1., 3-4 in. br. ; pinnl. linear, acute, entire, $\frac{1}{4}$ in. br., the lower ones deflexed, the lowest reduced; texture subcoriaceous; rachis and both sides naked; veinlets forked ; sori quite marginal.-Hk. Sp. 4. p. 255. t. 280.

Hab. Columbia and Ecuador.-Well distinguished from all the preceding by twothirds of the pinnules of the lower pinnæ being quite distinct. It attains a height of 15 feet.

*** Pinnoe cut nearly or quite down to the rachis into toothed or pinnatifid lobes. Sp. 25-30.

25. P. (Pheg.) Phegopteris, L. ; rhizome slender, wide-creeping ; st. 6-9 in. 1., slender, naked, except towards the base ; fr. 6-9 in. 1., 4-6 in. br., subdeltoid ; lower pinnoe 2-3 in. l., $\frac{1}{2}-\frac{3}{4}$ in. br., cut down three-quarters of the way to the rachis into close, blunt, entire or slightly toothed lobes, $1 \frac{1}{2}-2$ lin. br., the lowest pair deflexed; texture thinly herbaceous; under side slightly hairy ; veinlets $6-8$ on a side, the lower ones forked; sori nearer the edge than the midrib.- $H k . S p .4$. p. 245. B. F.t. 3 .

Hab. Lapland to Japan, Etruria, and Greece; Greenland, Iceland, and Russian America, south ward to the United States.

26. P. (Pheg.) distans, Don; st. $1 \frac{1}{2}-2$ ft. l., slender, glossy, stramineous or chesnut-brown; fr. $1 \frac{1}{2}-3 \mathrm{ft}$. $1 ., 8-12$ in. or more br.; lower pinno 6-8 in. l., $1 \frac{1}{2}$ in. br., cut down nearly or quite to the rashis into deeply pinnatifid pinnl. $\frac{1}{4}$ in. br., with blunt or acute toothed or subentire lobes, the base dilated ; texture herbaceous; rachis naked, glossy, straw-coloured or brown ; under side slightly hairy; veinlets slightly pinnate in the lower lobes, pellucid; sori scattered, copious.-P. paludosum, Blume. Hk.Sp. 4. p. 244.

Hab. N. India (up to $9-10,000 \mathrm{ft}$.) to Ceylon, Java.-A variable plant. P. Griffithii, Hk. Sp. 4. p. 236, appears to be a form with subentire lobes ; and N. microstegium, Hk. Sp. 4. p. 119. t. 250, a large form, with distinctly-pinnatifid lobes, and a stramineous rachis.

27. P. (Pheg.) obscurum, Hk.; st. tufted, 1 ft. l., black, glossy, naked ; fr. 12-18 in. 1., 8-10 in. br.; pinnoe not close, 4-5 in. 1., 1 in. br., cut three-quarters down to the rachis into close blunt lobes 2 lin. br., lowest pair the largest, those of the fertile frond contracted; rachis ebeneous; texture papyraceoherbaceous; veinlets fine, 6-8 on a side, the lower ones forked; sori copious, submarginal.-Hk. $S p$. 4. p. 237.

Hab. Philippines, Cuming, 302 ; Tavoy, Rev. C. S. Parish. - Very likely a noninvolucrate form of Neph. sagenioides.

28. P. (Plieg.) molle, Roxb. ; st. 1 ft. or more 1., stout, deciduously scaly ;

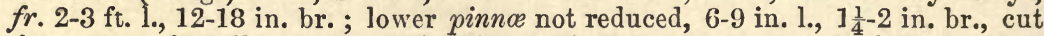
down to a broadly-winged rachis into oblong entire or crenated blunt lobes $\frac{1}{4}-\frac{3}{3}$ in. br. ; texture subcoriaceous ; rachis densely scaly; under surface finely 
villose all over ; veinlets forked ; sori small, copious, distant from the midrib.P. Dianæ, Hk. Sp. 4. p. 234.

Hab. St. Helena.

29. P. (Pheg.) caudatum, Kaulf.; st. 12-18 in. 1., firm, angular, brownish, slightly scaly ; fr. 2-3 ft. l., 12-15 in. br. ; pinnoe 6-9 in. 1., 1-2 in. br., cut down to a distinctly-winged rachis into oblong falcate distinctly-toothed lobes 2-3 lin. br., lower ones not reduced; texture herbaceous ; rachis more or less scaly ; both surfaces naked; veinlets simple, 1 to each tooth, 6-8 on a side; sori near the midrib.-Hk. Sp. 4. p. 241.

Hab. Cuba to Brazil.

30. P. (Pheg.) biseriale, Baker; st. 1-2 ft. 1., slightly scaly ; fr. $2-3 \mathrm{ft}$. 1., $1 \mathrm{ft}$. or more br. ; lower pinnoe the largest, 6-8 in. $1 ., 2-5 \mathrm{in}$. br., cut down to the rachis below into distinct oblong-lanceolate pinnl. 1-2 in. 1. , with the veinlets pinnate in the lower lobes; texture herbaceous; rachises villose and slightly scaly; lower side nearly naked; sori in pairs on the lower lobes.

Hab. Andes of Peru and Ecuador, Spruce.

**** Fronds small or middle-sided, tri-or quadripinnatifid. Sp. 31-43.

31. P. (Pheg.) hexagonopterum, Michx. ; rhizone wide-creeping ; st. 12-18 in. 1., slender, stramineous, naked, glossy ; fr. 8-12 in. 1., nearly as broad, deltoid; lower pinnoe 4-6 in. 1., the lowest pair deflexed, often 2 in. br., the pinnl. reaching down nearly to the rachis, those of the lower side 1-1 $\frac{1}{2}$ in. l., pinnatifid halfway down, with broad blunt lobes; texture thinly herbaceous; under side slightly villose; veinlets pinnate in the lobes; sori marginal.-Hk. Sp. 4. p. 245.

Hab. Canada, southward to Florida.-General habit of $P$. Phegopteris.

32. P. (Pheg.) Hasseltii, Blume; st. 9 in. 1., slightly scaly; fr. about $1 \mathrm{ft}$. each way, deltoid, quadripinnatifid; lowest pinnoe 6 in. $1 ., 3-5$ in. br. ; pinnl. stalked, ovate, the lowest much the largest, with ovate-oblong obtuse lobes, the lower ones deeply pinnatifid; texture coriaceous; rachis and both sides naked; veins pinnate in the lobes; sori medial.-Hk. Sp. 4. p. 217.

Hab. Java.

33. P. (Pheg.) rufescens, Blume ; rhizome short-creeping; st. 12-18 in. 1., firm, erect, naked ; fr. 12-18 in. 1., 9-12 in. br., subdeltoid ; lower pinnoe much the largest, deltoid, 6-8 in. l., 3-4 in. br.; pinnl. lanceolate, unequal-sided, bluntly lobed, the lowest nearly down to the rachis; texture subcoriaceous; rachis and both sides naked or slightly pubescent; veinlets pinnate in the lower lobes, 3-4 on a side; sori medial. - Hk. Sp. 4. p. 257.

Hab. Java, Ceylon, New Caledonia, Queensland.-P. Barterianum, Hk. Sp. 4. p. 254, from Fernando Po, is evidently the same.

34. P. (Pheg.) Dryopteris, L. ; rhizome slender, wide-creeping ; fr. 6-12 in. l., slender, stramineous, naked upwards, slightly scaly below; fr. 6-10 in. each way, deltoid; lower pinno much the largest; pinnl. lanceolate, only the lowest free, oblong, slightly crenate ; texture thinly herbaceous; rachis and both sides glabrous; sori submarginal.- $-H k$. Sp. 4. p. 250. B. F. t. 4.- $\beta, P$. Robertianum, Hoffm.; rhizome thicker, the whole plant more rigid and finely glandular.B. F.t. 5 .

Hab. Lapland to the Pyrenees, N. Italy, N. India (5-8,000 ft.), Manchuria, Japan ; America-Greenland and Sitka to the Rocky Mountains and Northern United States. 
$\beta$ has nearly as wide a range as the type in Europe, and occurs also in the United States.

35. P. (Pheg.) glanduliferum, Liebm.; st. tufted, 3-4 in. 1., slender, stramineous ; fr. 6-8 in. 1., 3-4 in. br., lanceolate-deltoid; lower pinnoe the largest, about 2 in. l., 1 in. br., cut down to the rachis below into distinct unequal-sided deeply-pinnatifid pinnl., with erecto-patent, linear-oblong, entire or slightlytoothed lobes; texture herbaceous; rachis and both sides finely glandular; veinlets immersed; sori 1 at the base of each lobe.-Hk. Sp. 4. p. 252.

Hab. Mexico, Liebmann.

36. P. (Pheg.) drepanum, Hk. ; st. tufted, 12-18 in. 1., with dark-coloured

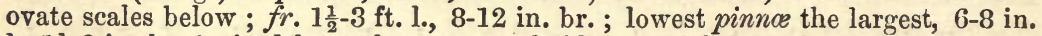
l., $1 \frac{1}{2}-2$ in. br. ; pinnl. lanceolate, unequal-sided, auricled on the upper, truncate on the lower side at the base, with a broad uncut centre and copious spinose teeth, the lowest stalked; texture coriaceous; veins distinct ; both sides nearly naked; sori medial.-Hk. Sp. 4. p. 249.

Hab. Madeira.-This and the two next have entirely the habit of Polystichum.

37. P. (Pheg.) platyphyllum, Hk. ; st. tufted, 12-18 in. 1., clothed towards the base with ovate scales ; fr. 1-2 ft. 1., 4-12 in. br. ; lower pinnoe the largest, 3-6 in. l., 1 $\frac{1}{2}-2$ in. br., with distinct close unequal-sided, subrhomboidal pinnl., very obliquely truncate on the lower side at the base, the upper side auricled, with the inner edge parallel with the stem, the central part uncut, the teeth spinose; texture subcoriaceous; rachises fibrillose; both sides nearly naked; venation subflabellate; sori small, principally in rows near the midrib.- $H k$. $S p$. 4. $p .248$.

Hab. Cuba and Guatemala to Brazil and Peru.

38. P. (Pheg.) rigidum, Hk. \& Gr. ; st. tufted, 6-18 in. 1., more or less scaly ; fr. 1-3 ft. 1., 4-18 in. br. ; pinnoe 2-9 in. l., $\frac{3}{4}-1 \frac{1}{4}$ in. br., with close unequal-sided subrhomboidal pinnl. with copious aristate teeth; texture coriaceous; rachises usually scaly; venation subflabellate; sori principally in rows near the midrib. -P. rigidum and pycnolepis, Hk. Sp. 4. p. 246.

Hab. Guatemala, along the Andes to Peru.-Very variable, the forms differing only by the want of an involucre from the forms of Aspid. aculeatum, to which it should probably be joined. There is a detailed account of the various forms in the "Species Filicum." We include here three species of Mettenius,-his rigida, cochleata, and pycnoleppis.

39. P. (Pheg.) Mannianum, Hk.; st. tufted, 6-9 in. l., glossy, stramineous, with scattered lanceolate scales ; fr. nearly $1 \mathrm{ft}$. l., 4-5 in. br., lanceolate; lowest pinnoe the largest, 2-3 in. $1 ., 1-1 \frac{1}{4}$ in. br., cut down to the rachis below into ovate-deltoid pinnl. with deep blunt entire lobes; texture herbaceous; rachis stramineous; under surface naked; veinlets pinnate in the lower lobes ; sori 2-8 to a pinnule.- $I K k$. Sp. 4. p. 253.

Hab. Fernando Po, G. Mann.-Habit of the less-divided forms of N. spinulosum.

40. P. (Pheg.) unidentatum, Hk. \& Arn. ; st. tufted, $1 \mathrm{ft}$. l., clothed with squarrose dark-brown linear scales towards the base ; $f r .2-3 \mathrm{ft}$. l., $1 \mathrm{ft}$. or more br., deltoid ; lower pinnoe the largest, deltoid, 6-9 in. l., 4-5 in. br. ; pinnl. lanceolate, the lower segm. distinct, ovate-oblong, deeply pinnatifid, with slightlytoothed lobes; texture herbaceous; rachis and both sides naked; ult. veinlets forked; sori submarginal.-Hk. Sp. 4. p. 267.

Hab. Sandwich Isles.-This also, which is now in cultivation at Kew, is like a Nephrodium of the Lophodium group. 
41. P. (Pheg.) Oldhami, Baker; st. tufted, 12-18 in. l., clothed at the base with long dense linear-subulate bright-brown scales, and throughout with small adpressed scales; fr. $1 \frac{1}{2}-2 \mathrm{ft}$. l., $1 \mathrm{ft}$. or more br., deltoid; lower pinnoe much the largest; pinnl. of the lower side 2-3 in. 1., with distinct lanceolate deeplypinnatifid segm.; largest ult. lobes $\frac{1}{4}$ in. $1 ., \frac{1}{8}$ in. br. ; texture herbaceous ; rachis densely furfuraceous like the stem; under side rather glossy; sori very denso and numerous, close to the midrib.

Hab. Formosa, Oldham.

42. P. (Pheg.) alpestre, Hoppe ; st. tufted, 4-6 in. 1., scaly below ; fr. 1-2 ft. l.,

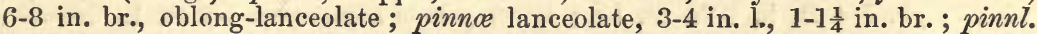
lanceolate, deeply pinnatifid, with toothed lobes; texture herbaceous; rachises and both sides nearly naked; veinlets pinnate in the lobes; sori small, 1-4 to each lobe-Brit. F. t. 6.- $-\beta, P$. flexile, Moore; habit more flaccid; pinnl. oblong, with fewer lobes and a broad uncut centre.-Hk. Sp. 4. p. 251. Pseudathyrium, Newm.

Hab. Lapland and Scotland to the Pyrenees, Alps, and Central Russia ; Sitka, Oregon, California.-Habit of Athyrium filix.foemina, which see.

43. P. (Pheg.) Bojeri, Hk. ; st. firm, erect, polished, stramineous ; fr. 2 ft. or more l., 12-18 in. br. ; lower pinnoe the largest, 6-10 in. 1., 2 in. or more br., lanceolate; pinnl. lanceolate, $\frac{1}{4}-\frac{1}{2} \mathrm{in}$. br., cut down nearly to the rachis below into close entire blunt lobes; texture herbaceous; rachis and under surface slightly pubescent ; veinlets of the lobes simple ; sori small, copious.-P. sessilifolium, Hk. Sp. 4. p. 251. P. ammifolium, Bojer (non Lam.).

Hab. Mauritius and Bourbon.

***** Fronds ample, decompound. Sp. 44-55.

44. P. (Pheg.) crinale, H. \& A.; st. tufted, stout, densely clothed with squarrose fibrillose scales; $f r .2-3 \mathrm{ft}$. $1 ., 1 \mathrm{ft}$. or more br.; pinnoe ovate-lanceolate or subdeltoid; pinnl. lanceolate, blunt, $1 \frac{1}{2}-2 \mathrm{in}$. l., with rounded blunt lobes $1 \frac{1}{2}-2$ lin. br., the lower ones reaching down to the midrib; texture coriaceous; rachises densely fibrillose; both surfaces naked; ultimate veinlets forked; sori (in our specimens) 1 to each lobe near the upper edge.-HK. Sp. 4. p. 266.

Hab. Sandwich Isles.

45. P. (Pheg.) asperulum, J. Sm.; st. firm, terete, brownish, pubescent ; fr. $1 \frac{1}{2}-2 \mathrm{ft}$. 1., $1 \mathrm{ft}$. or more br.; lower pinnoe 6-9 in. 1., 2-3 in. br.; pinnl. lanceolate, $\frac{1}{2}$ in. br., unequal-sided, cut down to the rachis below into oblongpinnatifid unequal-sided segm.; texture subcoriaceous; rachis and both surfaces villose; veinlets immersed; sori copious, one to each ult. lobe.-Hk. Sp. 4. p. 257.

Hab. Philippines, Cuming, 63.

46. P. (Pheg.) aquilinum, Thouars ; rhizome creeping; st. 1-2 ft. 1., stont, erect, brown, pubescent, densely scaly at the base ; fr. 2-4 ft. l., 12-18 in. br.; pinno much imbricated, the lowest 6-9 in. 1., 4-5 in. br.; pinnl. lanceolate or oblong-lanceolate, with linear-oblong, entire or sinuato-pinnatifid segm.; texture coriaceous ; rachis and under side villose; veins immersed ; sori minute, copious, the margins recurved.-Hk. Sp. 4. p. 270.

Hab. Tristan d'Acunha.-General habit of Pteris aquilina, and all the aspect of a plant grown in a very exposed situation.

47. P. (Pheg.) Hillebrandi, Hk.; st. 2 ft. or more 1., stout, clothed below 
with deciduous fibrillose scales ; fr. 3-4 ft. or more 1., 2-3 ft. br. ; lower pinnae 12-18 in. 1., with the pinnl. of the lower side the largest, sometimes again compound, with lanceolate deeply pinnatifid segm. 3-4 in. l., $\frac{3}{4}$ in. br.; ult. entire lobes $\frac{1}{4}$ in. br., blunt; texture papyraceo-herbaceous ; colour dark-green ; under surface sprinkled over with pellucid glands; veinlets of the lobes 6-8 on a side, mostly forked; sori large, submarginal.-Hk. Sp. 4. p. 254.

Hab. Sandwich Isles, Hillebrand, 42.-Most like N. latifrons in general habit.

48. P. (Pheg.) punctatum, Thunb.; rhizome firm, wide-creeping, villose; st. scattered, 1-2 ft. 1., firm, erect, stramineous, polished, naked or hairy, and viscid ; fr. 1-4 ft. 1., 6-24 in. br.; lower pinno sometimes 1-2 ft. 1., deltoid; pinnl. and segm. close, lanceolate; ult. lobes oblong, crenate or pinnatifid, with the edge often more or less reflexed; texture herbaceous; rachises naked or viscid ; under side slightly hairy; sori copious, marginal. $-\beta, P$. rugulosum, Labill. ; fr. less compound and more coriaceous ; rachis deep purplish-brown and densely viscid.-Hk. $S p .4$. $p .272$.

Hab. Columbia to Chili, Sandwich Isles, New Zealand, New Caledonia, Australia, Japan, Philippines, Malaccas; N. India to Ceylon, Bourbon, Tristan d'Acunha, St. Helena. -Very closely related to Euhypolepis, see page 130. Mettenius regards our two varieties as distinct species.

49. P. (Pheg.) prasinum, Baker ; st. 2 ft. or more 1., densely clothed below with long, squarrose, linear-subulate scales, naked and glossy upwards ; fr. 5-6 ft. l., $2 \mathrm{ft}$. or more br.; lower pinnoe often $1 \mathrm{ft}$. 1., 4-6 in. br. ; pinnl. distinct, lanceolate, cut halfway down to the rachis into close blunt lobes; texture herbaceous; colour bright-green; rachis slightly scaly, both sides naked; veinlets about 4 on a side in the lobes; sori close to the midrib.-P. punctatum, Spruce. Hk. Sp. 4. p. 262. (non Thunb.).

Hab. Andes of Peru and Ecuador.

50. P. (Pheg.) Sandvicense, Hk. \& Arn. ; st. 2 ft. l., stout, glossy, naked ; fr. 3-4 ft. or more l., $2 \mathrm{ft}$. or more br. ; lowest pinnoe 12-18 in. 1., 6-8 in. br. ; pinnl. lanceolate, spreading, 3-4 in. 1., $1 \frac{1}{2}$ in. br.; segm. with a space between them, ovate-lanceolate, truncate on the lower side, deeply pinnatifid, with erecto-patent linear-oblong entire or toothed lobes; rachis glossy, castaneous; both sides naked; veinlets forked; sori usually 1 near the base of each lobe.-Hk. Sp. 4. p. 267.

Hab. Sandwich and Society Isles.-The New Hebridean P. Aneitense, Hk. Sp. 4. p. 268, is apparently the same species.

51. P. (Pheg.) connexum, Kaulf. ; st. 3-4 ft. l., firm, naked ; fr. deltoid, tripinnatifid, 3-4 ft. or more 1., $2 \mathrm{ft}$. or more br.; lower pinno lanceolatedeltoid, 8-12 in. 1. ; pinnl. 3-4 in. $1 ., \frac{3}{4}$ in. br., cut down nearly to the rachis into oblong, entire or slightly crenate lobes $\frac{1}{4}$ in. br. ; texture herbaceous ; rachis and both sides naked; veinlets of the lobes 5-6 on a side, the lower ones often forked; sori medial.-Hk. Sp. 4. p. 261.

Hab. Brazil.

52. P. (Plieg.) splendidum, Kaulf. ; trunk subarborescent ; st. $2 \mathrm{ft}$. or more l., strong, glabrous, angular ; fr. 4-6 ft. or more 1., 2-3 ft. br.; lower pinnoe 12-18 in. 1., 6-8 in. br., with distinct lanceolate pinnl. with close, blunt, entire lobes $\frac{1}{4}$ in. br.; texture herbaceous ; rachis and midrib beneath slightly villose ; veinlets of the lobes simple, often obscure. $-\beta, P$. macropterum, Kaulf. ; pinno lanceolate, 6-9 in. 1., 2 in. br., with entire oblong-falcate lobes $\frac{1}{4}-\frac{3}{8}$ in. br., reaching down three-quarters of the way to the midrib.-Hk. Sp. 4. p. 258.

Hab. Brazil, frequent. 
53. P. (Pheg.) Vogelii, Hk.; st. $1 \frac{1}{2}-2 \mathrm{ft} .1$., naked, substramineous, with long linear scales at the base; $f$ r. ample, probably $4 \mathrm{ft}$. or more l., $2 \mathrm{ft}$. br.; lowest pinnoe $1 \mathrm{ft}$. l., the pinnl. of the lower side much the largest, and the lowest larger than the others, which are lanceolate, $4-5$ in. $1 ., 1 \frac{1}{2}$ in. br., cut down nearly to the rachis into oblong toothed lobes $\frac{3}{8}-\frac{1}{2}$ in. br.; texture subcoriaceous ; rachis naked; under side only slightly hairy on the main veins; veinlets of the Lobes forked; sori medial.-Hk. Sp. 4. p. 721. (in part).

Hab. Fernando Po, Vogel. - This comes near $P$. connexum, but the sori are larger, and the texture is thicker. The Cape Verde plant is a large form of N. Filix-mas. Gymnogramma subsimilis, Hk. Sp. 5. p. 142. t. 293, is apparently this species, with the sori not fully developed.

54. P. (Pheg.) nigritianum, Baker ; st. $1 \frac{1}{2}-2 \mathrm{ft}$. 1., naked, or upwards subvillose ; fr. 3-4 ft. l., $2 \mathrm{ft}$. or more br.; lower pinnoe $1 \mathrm{ft}$. l., the pinnl. of the lower side lanceolate, $4-8 \mathrm{in}$. $1 ., 1 \frac{1}{2}-2 \mathrm{in}$. br., cut down to the rachis below into distinct oblong unequal-sided segm. with deep close entire lobes; texture herbaceous; rachises of the pinnl. densely villose and under side less so; veinlets pinnate in the lower lobes; sori submarginal.

Hab. Gathered by Barter in the Niger Expedition, and by Mann at Fernando Po.

55. P. (Pheg.) Keraudrenianum, Gaud.; st. $\frac{1}{4}$ in. thick or more, stramineous or brownish, polished; fr. 12-15 ft. l., subscandent; pinnoe distant, the lower ones 1-3 ft. J., 6-15 in. br. ; pinnl. lanceolate, often deflexed, cut down nearly or quite to the rachis into lanceolate or linear-oblong entire or pinnatifid segm. ; texture herbaceous; rachises stramineous; both sides naked or the under one villose ; veinlets pellucid, forked; sori submarginal.-Hk. Sp. 4. $p .268$.

Hab. Sandwich Isles and Java.-P. procerum, Brack., is evidently a form of this, which varies much in cutting, and resembles $P$. distans on a large scale.

$\$ \oint$ Cyrtomiphlebium. Venation of Cyrtomium, $i . e$. , with the contiguous groups uniting irregularly. ТАв. 48. Fig. f. Sp. 56.

56. P. (Cyrt.) dubium, Hk.; st. tufted, $12-18$ in. l., densely clothed at the base with large firm scales, and upwards with smaller ones; $f r .2-3 \mathrm{ft}$. $1 ., 6-12$ in. br. ; lower pinnoe 3-6 in. $1 ., \frac{3}{4}-1 \frac{1}{2}$ in. br., unequal-sided, the apex acuminate, the edge finely toothed, the inner edge on the upper side nearly parallel with the stem, on the lower side oblique ; texture coriaceous ; rachis and both sides nearly naked; sori copious, roundish or oblong.-Hk. Sp. 5. p. 15.

Hab. Andes of Ecuador and Peru.-Exceedingly like some of the forms of Aspidium falcatum in habit and texture. The bipinnatifid plant placed here in "Species Filicum" appears to be a form of $P$. platyphyllum, with slightly anastomosing venation.

§§ Goniopteris, Presl. Venation of Eunephrodium, i.e., veins pinnate, with the lower veinlets of contiguous groups joining. Sp. 57-80. Tав. 48. f. e.

\section{* Pinnce entire or the edge slightly crenate. Sp. 57-64.}

57. P. (Goniopt.) simplicifolium, Hk.; st. tufted, strong, 2-4 in. l., villose upwards ; fr. 6-12 in. l., with a lanceolate-acuminate entire apex 1-1 $\frac{1}{2} \mathrm{in}$. br., and at the base 1-6 small blunt spreading entire distinct pinnoe; texture subcoriaceous; midrib beneath hispid, and the prominent veins slightly so ; main veins 2 lin. apart, all the veinlets joining; sori minute.-Hk. Sp. 5. p. 2. Nephrodium, Hk. 2nd Cent. t. 19. Abacopteris, Fée.

Hab. Philippines, Cuming, 315 ; Fiji, Seemann, 736.

58. P. (Goniopt.) debile, Baker ; st. slender, slightly hairy ; fr. 6-12 in. l., 
2 in. br., oblong-lanceolate ; pinnoe close, the central ones 1-1 $\frac{1}{4}$ in. 1., $\frac{1}{4}$ in. br., the point bluntish, the edge slightly crenate, the base truncate, with a distinct broad blunt auricle on the upper side, the lower ones gradually reduced; texture papyraceo-herbaceous; rachis villose and under side slightly so; veinlets 2-3 on a side; sori small, medial.-Phegop. Mett. Fil. Ind. p. 223.

Hab. Amboyna, Zippelius.

59. P. (Goniopt.) Borneense, Hk. ; st. 6 in. l., naked, slender, stramineous ; fr. 6-8 in. l., 3 in. br., with an acuminate terminal pinna 1 in. br., with shallow blunt lobes and 4 smaller pinnæ on each side $1 \frac{1}{2}$ in. $1 ., \frac{3}{4}$ in. br., truncate at the base and auricled on the upper side; texture subcoriaceous; rachis and both sides naked; veinlets fine, $4-5$ on a side; sori small, in two rows.-Hk. Sp. 5 . p. 11.

\section{Hab. Borneo, T. Lobb.}

60. P. (Goniopt.) diversifolium, Swz.; st. 1-2 ft. 1., tufted, slender, naked ; fr. 1-2 ft. 1., 6-9 in. br.; pinnoe 3-5 in. $1 ., \frac{3}{4}-1$ in. br., the apex acuminate, the lower ones narrowed at the base, the edge nearly entire ; texture subcoriaceous; rachis and both sides naked; veins fine, close, about 4 veinlets on a side, the rows of sori contiguous.-P. fraxinifolium, Jacq. Hk. Sp. 5. p. 4.

Hab. S. Brazil, Caraccas, Ecuador.

61. P. (Goniopt.) rubidum, Hk. ; st. firm, erect, glossy, naked, reddishbrown ; fr. 12-18 in. 1., $1 \mathrm{ft}$. or more br.; pinnoe numerous, the lowest stalked, 6-8 in. 1., $\frac{3}{4}-\frac{7}{8}$ in. br., the apex acuminate, the edge nearly entire ; texture subcoriaceous ; rachis and both sides naked; veinlets obscure, 8-10 on a side; sori close to the main veins. $-H k . S p .5 . p .12$.

Hab. Philippines, Cuming, 145.-Professor De Vriese sends from Borneo a more coriaceous plant that may be distinct.

62. P. (Goniopt.) poecilophlebium, Hk. ; st. 6-9 in. l., erect, slender, naked ; fr. about $1 \mathrm{ft}$. 1., nearly as broad, with a terminal pinna and 2-3 lateral ones on

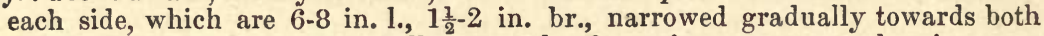
ends, slightly crenate, especially towards the point; texture subcoriaceous; rachis and both sides naked; main veins 2 lin. apart; veinlets fine, very oblique, 4-5 on a side; sori minute, medial.-Hk. Sp. 5. p. 14.

Hab. N. E. Australia and Queensland.

63. P. (Goniopt.) Kennedyi, F. Muell.; st. 3-4 ft. 1., nearly naked; pinnoe 6-12 in. l., $1 \frac{1}{2}-2$ in. br., sessile, acuminate, the lower part subentire, the upper slightly crenate; texture papyraceo-herbaceous; rachis and under surface slightly downy; veinlets 10-15 on a side; sori medial.-Meniscium, Muell. Frag. 4. p. 165.

Hab. Queensland.

64. P. (Goniopt.) meniscioides, Liebm.; st. 1-2 ft. 1., strong, erect, quite naked; fr. 2-4 ft. 1., 12-24 in. br., with a terminal pinna and 6-12 lateral ones on each side, the lowest stalked, 1 ft. $1 ., 1 \frac{1}{2}$ in. br., the apex acuminate, the edge nearly entire ; textuve rigid; rachis and both sides quite naked; veins prominent, the main ones $\frac{1}{8}$ in. apart; veinlets $15-20$ on a side ; sori in single or double rows between them.

Hab. Mexico.-Most like P. lineatum in texture, but less distinctly toothed. 


\section{** Pinnce pinnatifid or distinctly crenate. Sp. 65-80.}

65. P. (Goniopt.) urophyllum, Wall.; rhizome creeping; st. 2 ft. or more 1. , stout, erect; fr. 2-4 ft. or more l., 12-18 in. br., with a terminal pinna and usually several on each side, which are sometimes $1 \mathrm{ft}$. 1 . and more than $2 \mathrm{in}$. br., the edge entire or very slightly lobed, the apex acuminate, the base truncate or narrowed ; texture subcoriaceous ; rachis and both sides naked; veins prominent, the veinlets 15-20 on a side, with the sori in two close rows, or sometimes one row only.-Hk. Sp. 5. p. 9.

Hab. N. India to Ceylon, Malaccas, Chusan, Aneiteum, and Queensland.-Fée has three East-Indian species,-G. repanda, crenato-dentata, and Dalhousiana, which we have not seen. This resembles on the one hand Nephrodium glandulosum, and on the other Meniscium cuspidatum, and is very doubtfully distinct from the latter.

66. P. (Goniopt.) crenatum, Swz. ; st. 1-2 ft. 1., erect, naked or pubescent ; fr. 1-2 ft. l., $1 \mathrm{ft}$. or more br., with an oblong-lanceolate terminal pinna 6-8 in. l., $1 \frac{1}{2}-2$ in. br., the edge nearly entire or a little bluntly lobed, and 2-4 opposite pairs of similar lateral ones ; texture papyraceo-herbaceous ; veins fine, the main veins $1 \frac{1}{2}-2$ lin. apart, and veinlets $6-9$ on a side ; rachis and under side naked or finely villose; sori in rows near the main veins.-Hk. Sp. 4. p. 2.

Hab. Cuba and Mexico to Ecuador and Brazil.-G. Rivoirei, Fée, Fil. Ant. t. 18, appears to belong here.

67. P. (Goniopt.) Gheisbreghtii, Linden; st. 1 ft. or more 1., firm, erect, densely villose; fr. 12-18 in. 1., with a terminal pinna 6-9 in. l., 1 $\frac{1}{2}-2$ in. br., the edge slightly lobed, and 3-6 similar ones on each side; texture papyraceous; rachises and under surface densely villose, the upper surface slightly so; veinlets about 12 on a side, the sori in dense rows close to the main vein.-P. crenatum, Hk. Fil. Ex. t. 84. (not Sw.). Goniopt. mollis, Fée, Fil. Ant. t. 24.

Hab. Tabasco, S. Mexico, Linden, 1499.-We have a single specimen of a closely allied densely villose Goniopteris from Queensland from Mr. Hill, which is probably a new species.

68. P. (Goniopt.) faucium, Liebm. ; st. 1 ft. or more l., firm, erect, naked ; fr. 12-18 in. 1., $1 \mathrm{ft}$. or more br., with an oblong-lanceolate terminal pinna 6-8 in. l., $1 \frac{1}{2}$ in. br., pinnatifid about one-third of the way down, and several similar but narrower and less deeply lobed ones on each side; texture coriaceous; rachis and under surface naked; veins prominent, 9-12 on a side; sori in rows close to the main vein.

Hab. Mexico.

69. P. (Goniopt.) proliferum, Presl ; rhizome stout, creeping ; st. spreading, naked, 2-8 in. 1.; fr. 1-2 ft. 1. or more, 6-12 in. br., erect or decumbent, often elongated and rooting at the point and branched copiously from the axils; pinnoe 4-6 in. l., $\frac{1}{2}-\frac{3}{4}$ in. br., broadest at the base, truncate or cordate, the edge bluntly lobed more than 1 lin. deep, the point often blunt; texture subcoriaceous; rachis and under side naked or slightly pubescent; veinlets fine, $6-10$ on a side ; sori medial, oval, sometimes confluent.-Hk. Sp. 5. p. 13. Ampelopteris, Kze.

Hab. N. India to S. China, Philippines, New Caledonia, N. Australia, Angola, Zambesi-land, and South Africa.

70. P. (Goniopt.) arthrothrix, Hk.; st. erect, rather slender, densely villose ; fr. about $1 \mathrm{ft}$. l., 6-9 in. br.; lowest pinnoe the largest, distinctly stalked, 3-4 in. 1., $\frac{5}{8}-\frac{3}{4}$ in. br., the edge nearly entire or with slight blunt lobes, the base truncate ; texture herbaceous, rather thick; rachis and botle sides clothed with soft brown 
hairs ; veins fine; veinlets $3-4$ on each side, immersed; sori small, scattered.$H k . S p .5 . p .14$.

Hab. Madagascar, Bojer, Lyall.

71. P. (Goniopt.) lineatum, Coleb. ; st. 1-2 ft. 1., firm, naked, reddish ; fr. 2-3 ft. l., $1 \mathrm{ft}$. or more br. ; pinnoe numerous, 6-8 in. $1 ., \frac{1}{2}-\frac{3}{4}$ in. br., the apex acuminate, the edge with acute falcate lobes under 1 lin. deep; texture subcoriaceous or papyraceo-herbaceous; veinlets about 8 on a side; sori in rows close to the main veins. $-H k$. Sp. 5. p. 12. P. Penangianum, Hk. Sp. 5. p. 13.

Hab. N. India, Ceylon, Malaccas.

72. P. (Goniopt.) multilineatum, Wall.; st. firm, erect, naked, $2 \mathrm{ft}$. or more 1. ; fr. 3-4 ft. l., $1 \frac{1}{2}-2 \mathrm{ft}$. br. ; pinnae numerous, sometimes $1 \mathrm{ft} .1 ., 1 \frac{1}{4} \mathrm{in}$. br., the apex acuminate, the edge with falcate acute lobes reaching about 1 lin. deep ; texture coriaceous; rachis and both sides naked; veinlets prominent, 15-20 on a side; sori in two rows. $-H k . S p .5 . p .11$.

Hab. N. India, up to $3,000 \mathrm{ft}$. ; and we have what is probably the same from Fiji, gathered by Dr. Seemann.

73. P. (Goniopt.) stramineum, Baker; st. $1 \mathrm{ft} .1$., angular, stramineous, naked ; fr. 12-15 in. l., 8-10 in. br.; lower pinnoe 1 in. apart, 6-8 in. l., $\frac{3}{4}$ in. br., acuminate, the edge with broad blunt lobes reaching about a quarter down; texture subcoriaceous; stramineous rachis and both sides naked; veins in pinnated groups of 5-6 on a side, usually joining before they reach the edge ; sori near the midrib.-P. salicifolium, Hk. Sp.4.p. 242. (non Willd.).

Hab. Venezuela, Fendler, 474.

74. P. (Goniopt.) reptans, Swz.; st. tufted, slender, wiry, naked, 1-8 in. 1.; fr. spreading, or often decumbent and rooting, 4-12 in. l., 1-3 in. br. ; pinnoe $\frac{1}{2}-1 \frac{1}{2}$ in. $1 ., \frac{3}{8}-\frac{1}{2}$ in. br., blunt, varying from nearly entire to bluntly lobed one-third down, often auricled at the base, the lower ones stalked; texture herbaceous or subcoriaceous; rachis and under side naked or slightly hairy; veins in pinnate groups, 2-4 veinlets on a side. $-H k$. Sp. 5. p. 6.

Hab. West Indies and Guatemala to Brazil.-A very variable plant. In seedlings the veins are often simple or once forked, and quite free, $P$. reptans of authors is the loose straggling, and $P$. asplenioides the more erect larger form. $P$. asterothrix, Hk., is probably another form, with broad deeply-lobed pinnæ and 4.6 veinlets on a side, and a more villose rachis ; and G. gracilis, Moore, apparently also belongs here.

75. P. (Goniopt.) costatum, Hk. ; st. 1 ft. or more l., strong, brownish, glossy ; fr. 3-4 ft. l., $1 \mathrm{ft}$. or more br.; pinnoe very numerous, $8-10$ in. $1 ., 1 \frac{1}{4}-1 \frac{1}{2}$ in. br., cut down two-thirds of the way to the rachis into nearly entire bluntish lobes $1 \frac{1}{2}-2$ lin. br., with a space between them; texture subcoriaceous; rachis and both sides naked; veinlets prominent, $20-25$ on a side; sori close to the main vein.-Hk. Sp. 5. p. 7 .

Hab. Society Isles and Fiji.-G. longissima, Brack., Hk. l.c., from Tahiti, is probably a larger form of the same plant; but in our specimens from the author, which have pinnæ 18 in. l., the rachis is muricared. G. glandulifera, Brack., from Samoa, which we have not seen, appears to be closely allied ; and we have a similar plant from the New Hebrides from Mr. C. Moore.

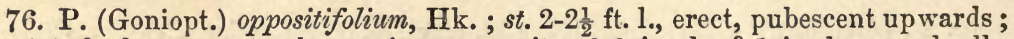
fr. 3-5 ft. 1., 12-18 in. br.; pinnce opposite, 6-9 in. l., $\frac{3}{4}-1$ in. br., gradually narrowed from the base to the acuminate apex, the edge cut into rather sharp falcate lobes 2 lin. br., $1 \frac{1}{2}$ lin. deep, lower pinnæ reduced ; texture subcoriaceous; 
rachis and veins beneath pubescent; main veins 2 lin. apart ; veinlets raised, 6-7 on a side; sori small, medial.-Hk. Sp. 5. p. 8.

Hab. Island of St. Thomas, W. Africa, Mann.

77. P. (Goniopt.) stegnogrammoides, Baker ; caud. subarborescent; st. $1 \frac{1}{2}-2 \mathrm{ft} .1$., firm, erect, pubescent upwards ; $f r .2-3 \mathrm{ft} .1 ., 1 \mathrm{ft}$. or more br.; pinnoe 6-9 in.1., $1 \frac{1}{2}$ in. br., the apex acuminate, the edge bluntly lobed about a quarter of the way down; texture subcoriaceous; rachis and veins beneath a little hairy; veinlets prominent, 8-9 on a side; sori in rows near the midrib.-P. sandvicense, $H k$. Sp. 5. p. 5. (not Sp. 4. p. 267). Stegnogramma, Brack.

Hab. Sandwich Isles.

78. P. (Goniopt.) pennigerum, Forst. ; st. tufted, 6-12 in. 1., glabrous, slightly scaly ; fr. $1 \frac{1}{2}-2$ ft. l., 8-12 in. br.; pinnoe $4-6$ in. $1 ., \frac{3}{4}-1$ in. br., cut about halfway down into blunt, falcate, slightly crenated lobes about 2 lin. br.; lower pinnoe gradually reduced; texture firm-herbaceous; rachis and both sides naked ; veinlets $6-8$ on a side; sori in rows near the midrib.-Hk. Sp. 5. p. 7. G. Forsteri, Moore.

Hab. New Zealand.-Very near $P$. tetragonum, from which it differs principally by the lower pinnæ being gradually reduced.

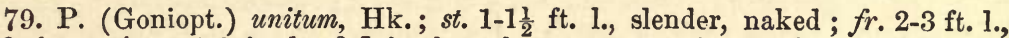
1 ft. br. ; pinnoe 4-6 in. 1., $\frac{3}{4}-\frac{7}{8}$ in. br., the apex acuminate, the edge bluntly lobed about a quarter of the way down, the base truncate; texture firmherbaceous; rachis and both sides naked; veinlets $5-6$ on a side; sori close to the main veins. $-H k . S p .5 . p .5$.

Hab. Natal, Cameroon Mountains.-Barely, if at all, distinguishable from some of the forms of $P$. tetragonum.

80. P. (Goniopt.) tetragonum, Sw.; st. erect, 1-2 ft. 1., naked or slightly villose; fr. 1-3 ft. l., $1 \mathrm{ft}$. or more br.; pinnce numerous, spreading, 6-8 in. l., $\frac{1}{2}-1$ in. br., the lowest narrowed at the base and sometimes stalked, cut from a quarter to halfway down into blunt lobes; texture thinly herbaceous; rachis and under side naked or slightly hairy; veinlets $6-10$ on a side; sori in rows near the midrib. $-\beta, P$. megalodus, Schk. ; pinnoe $1 \frac{1}{2}$ in. br., lobes $\frac{1}{4}$ in. br., subfalcate; veinlets $12-15$ on a side. $-H k . S p .5 . p .3$.

Hab. Cuba and Panama, southward to Brazil and Peru.-Judging from the figures quoted, this is $P$. androgynum of Lamarck ; and if so, that name has priority. It varies greatly in the breadth of the pinnæ and depth of the lobes. A full account of the forms will be found in Fée's Ferns of the Antilles; and our $\alpha$ apparently includes bis tenera, leptocladia, pyramidata, Féei, tetragona (five varieties), quadrangularis, Guadalupensis, and hastata. Our $\beta$ is placed by Mettenius in his latest publication in Aspidium.

$\$ \$ \S \S$ Dictyopteris, Presl. Venation of Sagenia, i.e., veins anastomosing. copiously. TА . 48. f. o. Sp. 81-90.

\section{* Sori biserial. Sp. 81-86.}

81. P. (Dicty.) Barberi, Hk. ; st. tufted, 6-12 in. l., slightly scaly at the base ; $f r$. palmately 5 -lobed or more usually pinnate, with a large terminal segment and 1-4 pairs of pinnæ, the upper ones oblong-lanceolate, 4-6 in. 1., 1 in. br., nearly entire, the lowest pair with a deep lanceolate lobe at the base on the lower side; texture subcoriaceous; both sides naked; areoloe rather large and regular, with copious free veinlets ; sori copious, principally in two rows near the main veins.-Hk. $S p .5 . p .100$.

Hab. Malay Peninsula and Isles. 
82. P. (Dicty.) megalocarpum, Hk.; fr. 2-3 ft. l., $1 \mathrm{ft}$. or more br., the upper part deeply pinnatifid, with lanceolate pinnatifid lobes, below this 6 pairs of distinct pinnoe, the lowest 6-9 in. I., 3 in. br, with entire blunt oblong lobes $\frac{1}{4}$ in. br., reaching more than halfway down ; texture subcoriaceous; under surface glossy; areola copious, without free veinlets ; sori large, in two distinct rows.HK. Sp. 5. p. 102.

Hab. Java, T. Lobb.-This has a good deal the general habit of difforme, but the ultimate lobes are longer and narrower, and the sori very different.

83. P. (Dicty.) ferrugineum, Baker ; st. $1 \frac{1}{2} \mathrm{ft}$. l., clothed densely below, and less so above, with ferruginous down and large lanceolate ferruginous scales; fr. 12-15 in. l., 8 in. br., the lowest pinnoe much the largest, deltoid, with distinct lanceolate pinnl., those of the lower side cut down to the rachis into oblong sinuated or pinnatifid lobes ; texture thinly herbaceous; under surface sprinkled with ferruginous hairs; areoloe confined to a single costal series without free veinlets; sori biserial.-Phegop. Mett. Fil. Ind. p. 224.

Hab. New Guinea, Zippelius.

84. P. (Dicty.) tenerifrons, Hk. ; rhizome creeping, fragile ; st. very slender, 8-12 in. 1. ; fr. 6-12 in. each way, deltoid, the upper part pinnatifid, below this 1-3 distinct pinna, the lowest much the largest, deltoid, the lowest side produced with deeply pinnatifid lanceolate lobes $2-3$ in. 1 .; texture very thin, colour bright-green ; areoloe copious, without free veinlets; sori in rows near the main veins.-Hk. Sp. 5. p. 104.

Hab. Moulmein, Parish, 92.

85. P. (Dicty.) macrodon, Reinw.; rhizome decumbent; st. $1 \mathrm{ft}$. or more 1., slightly scaly below ; fr. 2-3 ft. l., 12-18 in. br., the apex deeply pinnatifid, below this numerous lanceolate pinno, the lowest sometimes $1 \mathrm{ft}$. l., 6-8 in. br., cut down to a narrow wing on the rachis into pinnatifid, close, lanceolate pinnl.; texture thin ; both sides naked; areoloe copious, without free veinlets ; sori small, in rows near the main veins.-P. Cumingianum, Hk. Sp. 5. p. 103.

Hab. Philippines, Malaccas, Solomon Isles, Fiji.

86. P. (Dicty.) Cameroonianum, Hk. ; st. 4 ft. l., glossy ; fr. $3-4$ ft. l., 2 ft. br., the upper part pinnatifid, with deep lanceolate lobes; lower pinno deltoid, more than 1 ft. 1., 6-8 in. br., cut down below nearly to the rachis into pinnatifid lanceolate lobes ; texture herbaceous, both sides naked ; areoloe copious, with free veinlets ; sori in rows near the main veins.-Hk. Sp. 5. p. 104.

Hab. Cameroon Mountains, Mann, 1362.-It is by no means clear that this and the two preceding are distinct from one another, and from Neph. cicutarium.

** Sori copious, scattered irregularly. Sp. 87-90.

87. P. (Dicty.) Brongniartii, Bory ; fr. 2-3 ft. 1., 12-18 in. br., the apex pinnatifid, with deep, lanceolate, repand lobes; below this numerous distinct pinno, the lowest 6-9 in. l., lanceolate, cut three-quarters of the way down throughout into acute, subentire, lanceolate lobes $\frac{1}{2}-1 \frac{1}{2}$ in. 1., $\frac{1}{4}-\frac{3}{3}$ in. br.; texture subcoriaceous ; areoloe copious, with a few free veinlets; sori rather small and quite confined to the margin of the lobes.-Hk. Sp. 5. p. 103.

Hab. Malay Isles and Philippines.-Habit of $P$. difforme, but well distinguished by its marginal sori.

88. P. (Dicty.) difforme, Blume ; st. tufted, erect, $1 \mathrm{ft}$. or more 1., the Inwer part scaly ; fr. 3-4 ft. l., the upper pinnoe lanceolate, entire, or with broad blunt or falcate lobes reaching halfway or more down to the rachis, the lower ones 
often deltoid, with the lobes of the lower side prolonged, several inches long, and pinnatifid; texture subcoriaceous ; both sides naked; areolce copious, with a few free veinlets; sori scattered, very copious.-P. irregulare, Presl. Hk. Sp. 5. p. 106.

Hab. Malay Peninsula and Isles. $-P$. petrophyum, Blume, is said to differ by its longer ultimate lobes and copious free veinlets.

89. P. (Dicty.) sparsiflorim, Hk. ; rhizome thick, knotted ; st. 18 in. 1., scaly towards the base; fr. 2-3 ft. l., $1 \mathrm{ft}$. or more br.; pinnoe distant, 7-8 in. 1., $1 \frac{1}{2}-2$ in. br., the apex acuminate, the edge slightly repand, the base narrowed, the lower ones stalked; texture herbaceous; both sides naked; no distinct main veins; areoloe rather large, without free veinlets; sori small, scattered irregularly.-Hk.Sp. 5. p. 92 .

Hab. Sierra de Crystal and Old Calabar, West Tropical Africa, Mann.

90. P. (Dicty.) draconopterum, Hk.; rhizome woody, the scales lanceolate, dull-brown ; st. 2-3 ft. 1., firm, erect, scaly below ; fr. 3-4 ft. l., $2 \mathrm{ft}$. or more br., with a large oblong-acuminate terminal lobe, and several lateral ones on each side, which do not reach down to the rachis, the lowest sometimes $1 \frac{1}{2} \mathrm{ft}$. $1 ., 4 \mathrm{in}$. br., and forked; texture papyraeeous; both sides naked; main veins distinct to the edge, connected by distinct transverse veinlets with copious areolæ with free veinlets between; sori minute, copious, scattered, often confluent. $-H k . S p .5$. p. 86.

Hab. New Granada to Ecuador.

** Eremobryoid series. Stems articulated at the point of junction with the rhizome, and sori generally, but not always, terminal on the veins. Polypodium, Mett. Sp. 91-389.

§§§§§ Eupolypodium. Veins free. Sp. 91-224. Tав. 48. Fig. a, b.

* Fronds entire. Sp. 91-111.

+ Sori round. Sp. 91-103.

91. P. Sprucei, Hk. ; st. tufted, very short, clothed with soft spreading hairs ;

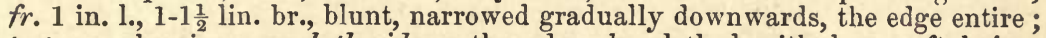
texture subcoriaceous; both sides rather densely clothed with long soft hairs; veins simple; sori few, round.-Hk.Sp. 4. p. 172. 2nd Cent.t. 10.

Hab. E. Peru, Spruce, 4746.

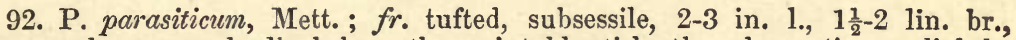
narrowed very gradually below, the point bluntish, the edge entire or slightly undulated; texture coriaceous; both sides when young rather thickly clothed with long soft hairs; veins immersed, forked; sori roundish, in two rows, ultimately confluent.-Hk. Sp. 4. p. 167.

Hab. Neilgherries and Ceylon.-Probably this is the Javan P. pilosinsculum, Hk. (Grammitis, Blume); and $G$.adspersa, Blume, which we have not seen, is apparently very near it.

93. P. Hookeri, Brack.; st. tufted, 1 in. or less 1., clothed with soft spreading hairs ; fr. $3-5$ in. 1., $\frac{1}{4}-\frac{3}{8}$ in. br., the point acute or bluntish, the edge entire, the lower part narrowed gradually; texture subcoriaceous; both sides thinly clothed with soft hairs; veins simple or forked; sori round, in long rows close to the midrib.-Hk. Sp.4. p.171. P. setigerum, Hk. \& Arn. (non Blıme).

Hab. Sandwich Isles, Fiji, Queensland, Philippines.-The Bourbon P. Beaumontii, Leperv., is evidently the same. An authentic example of $P$. conforme, Brack., does not 
differ essentially. P. subspathulatum, Brack., from the Society Isles, is said to have partially-immersed sori placed as near the edge as the midrib, and small subspathulate sterile fronds.

94. P. pseudo-grammitis, Gaud. ; rhizome wide-creeping ; fr. 4-6 in. 1., about 1 lin. br., the point bluntish, the lower part tapering gradually into the short stem, the edge slightly undulated; texture subcoriaceous; both sides naked; veins simple, immersed; sori large, subglobose, scattered, close to the midrib, but often projecting over the edge.-Hk. Sp. 4. p. 165.

Hab. Sandwich Islands.

95. P. ligulatum, Baker ; st. short, slender, naked, tufted ; fr. 5-6 in. $1 ., \frac{1}{8}$ in. br., ligulate, narrowed gradually towards both ends, the edge very slightly repand; texture subcoriaceous; both sides naked; veins forked; sori round, distant, close to the midrib.

Hab. Fiji, Brackenridge.-Like the preceding, but the texture thinner, the veins forked, and sori a space from the margin.

96. P. subevenosum, Baker ; st. tufted, very short, black, wiry ; fr. $3-4$ in. l., $\frac{1}{8}$ in. br., ligulate, the point bluntish, the lower part narrowed very gradually, the edge slightly repand; texture subcoriaceous; colour bright-green, the rachis black, slightly furfuraceous below ; veins simple, very short and indistinct; sori round, tending slightly towards oblong, in a long row on each side close to the midrib.

Hab. Penang, Mactier.-Like the last in general habit, but quite different in the veins.

97. P. jungermannioides, Klotzsch ; st. densely tufted, short, slender, ebeneous ; fr. 2-3 in. l., $1 \frac{1}{2}-2$ lin. br., ligulate, the point blunt, the lower part narrowed gradually and the edge slightly repand; texture subcoriaceous ; both sides thinly clothed with soft spreading hairs; veins forked; sori round, distant from one another in a line close to the midrib.-Hk. Sp. 4. p. 166.

Hab. Guatemala to Peru and Chili.

98. P. hirtellum, Bl.; rhizome short-creeping, scaly ; fr. 2-3 in. l., 2-3 lin. br., the point bluntish, the edge entire, the lower part tapering gradually into the short stem ; texture subcoriaceous ; both surfaces thinly clothed with long, soft, brown hairs; veins hidden; sori in two close rows nearer the midrib than the edge.-Hk. Sp. 4. p. 166.

Hab. Java.-P. lasiosorum, Hk., is probably a form of the same plant, with a smaller frond and longer stem.

99. P. hirtum, Hk.; st. tufted, 1-2 in. l., densely clothed with soft spreading hairs; fr. 4-5 in. l., $\frac{1}{4}-\frac{3}{8}$ in. br., narrowed gradually downwards, the point bluntish, the edge entire ; texture subcoriaceous, the surface, especially the edge and midrib, ciliated like the stem ; veins with one short fork near the base; sori round, in long rows close to the midrib.-Hk. Sp. 4. p.170.t.273. A. P. Reinwardtii, Mett.

Hab. Luzon, Cuming, 222 ; Java, Zollinger, 1791.-P. adspersum, Blume, judging from the figure, is like this, but quite naked.

100. P. setigerum, Blume; st. densely tufted, 2-3 in. l., densely clothed with long soft spreading ferruginous hairs; fr. 8-12 in. $1 ., \frac{5}{8}-\frac{3}{4}$ in. br., the point acute, the lower part narrowed rather suddenly, the edge entire ; texture subcoriaceous; both sides thinly clothed with long soft hairs like the stem; veins pinnate; sori round, in long rows close to the midrib.-Hk. Sp. 4. p. 171. 2 nd Cent. t. 41.

Hab. Java. 
101. P. zeylanicum, Mett.; rhizome strong, wide-creeping, clothed with broad grey scales; st. 1 in. or more l., clothed with soft spreading hairs; fr. 8-12 in. 1., $\frac{1}{4}-\frac{3}{8}$ in. br., the point acuminate, the base narrowed very gradually, the edge slightly undulated; texture coriaceous, both sides naked; veins forked, oblique; sori round, in long rows midway between the midrib and edge.-Hk.Sp. 4 . p. 169. $t .272 . \mathrm{B}$.

Hab. Ceylon.

102. P. samoense, Baker; st. tufted, 1 in. or less l., slender, brown, clothed with soft spreading brown hairs ; $f r .3-6$ in. l., 2-3 lin. br., the point bluntish, the edge nearly entire, the lower part narrowed very gradually; texture subcoriaceous; the rachis green, the surfaces very nearly naked; veins once or even twice forked; the sori small and sometimes on the point of both veinlets, forming an irregular wavy line near the edge.

Hab. Samoa, Powell, 111.

103. P. chrysolepis, Hk.; rhizome wide-creeping, densely clothed with reddishbrown squarrose scales; st. 1 in. or more apart, 1 in. or more l., scaly ; fr. 2-3 in. l., $\frac{1}{2}$ in. br., the point acute, the edge entire, the lower part narrowed very gradually; texture thick, coriaceous; both surfaces clothed with small, pale, ovate-acuminate deciduous scales attached by the centre of the disk; veins forked; sori large, round, in rows nearer the midrib than the edge.-Hk.Sp. 4 . p. 173. Ic. Pl.t. 721 .

Hab. Andes of Quito, Jameson, 37.--Scales like those of Lepicystis.

\section{† Sori oblong. Sp. 104-111. Grammitis, Auct.}

104. P. (Gram.) bisulcatum, Hk.; rhizome wide-creeping, scaly ; fr. resembling the stem of a rush, 6-9 in. l., less than 1 lin. thick, with 5 furrows, of which the two deepest bear the close prominent oval sori; veins invisible.-Hk. Sp. 4. p. 164. 2nd Cent. t. 98. Holcosorus pentagonus, Moore.

Hab. Borneo; discovered by Mr. T. Lobb.

105. P. (Gram.) gramineum, Sw. ; rhizome short-creeping, scaly; st. subtufted, slender, 1-2 in. l., finely villose; fr. 2-4 in. l., $\frac{1}{8}$ in. br., ligulate, narrowed rather suddenly into the stem, the edge entire; texture coriaceous; both sides nearly naked; veins oblique, forked; sori oval or oblong, placed nearly end to end, with a space between them, in two rows, which reach from the midrib nearly to the edge.-H H.Sp. 4. p. 165.

Hab. West Indies, Guiana.-The Javan G. ccespitosa, Blume, is said to differ by its immersed sori and setigerous capsules, and is considered a distinct species by Mettenius.

106. P. (Gram.) Poppigianum, Mett.; st. tufted, clothed at the base with lanceolate scales; fr. 1 in. l., $\frac{1}{4}$ in. br., lanceolate-spathulate, obtuse, entire ; texture coriaceous; both sides naked ; veins immersed, forked; sori oblong, close to the midrib.-Hk. Sp. 4. p. 168.

Hab. Cape Colony, Poppig, fide Mettenius.

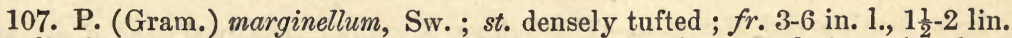
br., ligulate, blunt at the point, tapering gradually downwards into the short stem; texture coriaceous; both surfaces naked or slightly hairy, the frond margined with a distinct black line; veins oblique, simple; sori close, copious, oval or oblong, in rows nearer the midrib than the edge.-Hk. Sp. 4. p. 164.

Hab. West Indies and Guatemala to Guiana and Peru ; St. Helena, Cape Verdes. 
108. P. (Gram.) australe, Mett. ; rhizome creeping, forming a dense mass; fr. 1-6 in. l., 2-6 lin. br., the small ones spathulate, the larger ligulate, bluntish at the point, tapering gradually downwards into the short stem; texture coriaceous; st. and both sides naked or slightly ciliated, the edge not bordered; veins oblique, often forked; sori close, copious, oval or oblong, in rows nearer the midrib than the edge.-Hk. $S p .4$. $p .167$.

Hab. Southern extremity of America and adjacent islands; Tristan d'Acunha, New Zealand, Australia, as far north as Queensland and New Caledonia.

109. P. (Gram.) sessilifolium, Hk.; fr. tufted, 3-9 in. 1., 2-3 lin. br., narrowed gradually below the point, bluntish, the edge entire or slightly undulated; texture subcoriaceous; both sides naked; veins forked; sori oblong, placed end to end in two long rows close to the midrib.- $H k$. Sp. 4. p. 168. t. 272. A.

tive. Philippines and Malaya.

110. $1 \%(G)+23)$ freciatum, Mett. ; rhizome strong, wide-creeping, clothed with broad grej stsies; st. $1.2 \mathrm{in.} 1$, ximid deciduously ciliated ; fr. $1 \mathrm{ft}$. or more l., $\frac{1}{4}-\frac{3}{8}$ in. br., nareved gradually to wa both ends, the edge entire ; texture coriaceous, the surface naked, miuriw very prominent; veins immersed, forked; sori oblong, in two long rows end to end close to the midrib.-Hk. Sp. 4. p. 169.

Hab. Malaya.

111. P. (Gram.) Deplanchei, Baker; rhizome stout, densely coated with stiff spreading dark-brown fibrillose scales ; fr. sessile, 6-9 in. 1., $\frac{3}{8}-\frac{1}{2} \mathrm{in}$. br., narrowed gradually to both ends, the edge entire or with a few conspicuous blunt teeth about the middle; texture very coriaceous; both sides naked; veins oblique, once forked; sori oblong, oblique, immersed, in close rows in the upper half of the frond near the edge.

Hab. New Caledonia, Deplanche, 5 .

\section{** Fronds lobed or dichotomously forked. Sp. 112-114.}

112. P. flabellivenium, Baker ; rhizome wiry, slender, wide-creeping, hardly at all scaly ; st. 1-2 in. l., wiry, naked, very slender ; fr. $\frac{1}{4}-\frac{5}{8}$ in. 1. , nearly as br., roundish or broadly oblong, the edge very distinctly thickened, subentire or with a few shallow rounded lobes; texture thick and rigid; veins flabellate, three or four times dichotomously forked, distinctly visible when the frond is held up to the light, sometimes the ultimate forks uniting before they reach the broad thickened border ; sori distinctly immersed, 1-6 to a frond, all in the upper half, not far from the edge, on the back of the veins.

Hab. Borneo ; gathered by Signor Beccari, communicated by Mrs. Lyell.-A very distinct and interesting novelty; more like Drymoglossum rigidum in texture than anything else.

113. P. multifidum, Bory ; st. tufted, very short, slender, naked; fr. 2-3 in. 1., $1 \frac{1}{2}-2$ lin. br., entire or forked, tapering downwards gradually; texture coriaceous; both sides naked; veins immersed, simple, oblique; sori large, roundish, prominent, close, when mature projecting over the edge.-Hk. Sp. 4. p. 174.

Hab. Bourbon and Mauritius.-The forking is probably abnormal ; and if so, this should be placed next to $P$. parasiticum. Bojer's "Grammitis obtusa, Willd.," is evidently the same plant.

114. P. furcatum, Mett. ; st. densely tufted, short, naked ; fr. 3-4 in. 1., 1 lin. br., once or twice dichotomously forked, gradually attenuated below, the edge 
entire or subsinuated; texture subcoriaceous; sori oblong, distant, oblique, terminal on the principal veins.-Hk. Sp. 4. p. 174. Grammitis, Hk. \& Gr. t. 62 .

Hab. Guiana and the Amazon valley.

*** Fronds pinnatifid. Sp. 115-131.

+ Lobes not reaching more than halfway down to the rachis. Sp. 115-118.

115. P. barbatulum, Baker ; st. tufted, slender, $\frac{1}{4}-\frac{1}{2}$ in. 1., clothed with soft brown spreading hairs ; fr. 1-1 $\frac{1}{2}$ in. l., $\frac{1}{4}$ in. br., the edge entire or broadly lobed to a depth of $\frac{1}{2}$ line ; texture subcoriaceous ; both sides more or less densely clothed with long soft hairs; veins pinnate in the lobes ; sori medial, uniserial.P. ciliatum, Bojer, Hort. Maur. p. 416. (non Willd.).

Hab. Bourbon.

116. P. andinum, Hk. ; fr. tufted, subsessile, 4-6 in. 1., $\frac{1}{4}-\frac{3}{8}$ in. br., regularly bluntly lobed about a quarter or third of the way down, the point acute or bluntish, the lower part narrowed very gradually ; texture subcoriaceous ; both sides thinly clothed with soft spreading hairs; veins once forked; sori large, round, one to each lobe.-Hk. Sp. 4. p. 179. 2 nd Cent. $t$. 6.

Hab. Andes of Ecuador and Peru.-May possibly be $P$. crispatum, L. (Plum. t. 102. B.).

117. P. trichosorum, Hk.; rhizome creeping; st. 1-2 in. 1., slender, densely clothed with soft spreading hairs ; fr. 3-4 in. 1 ., $\frac{1}{2}-\frac{5}{8}$ in. br., the point bluntish, the edge crenato-sinuate to a depth of 1 lin., the lower part narrowed from the middle; texture coriaceous; both sides, and especially the edge, clothed with hairs, like those of the stem; veins in pinnated groups; sori in 2-3 rows on each side.-Hk. Sp. 4. p. 178. 2nd Cent. t. 12.

Hab. Andes of Quito, Jameson, 349.

118. P. trifurcatum, L. ; rhizome stout, creeping, densely clothed with linear scales; st. close, 3-5 in. 1., more or less villose, often bent ; fr. 6-9 in. 1., 1 in. or more br., with broad blunt entire lobes reacling from a third to halfway down; texture coriaceous; both sides nearly naked; veins in copiously pinnated groups, with the lower veinlets forked, sometimes anastomosing; sori copious, principally in two rows in each lobe, immersed. - P. comptoniæfolium, Desv. Hk. Sp. 4. p. 192. P. scolopendrioides, Hk. \&. Gr. p. 42.

Hab. West Indies to Peru.-The Linnæan name was founded on a forked form figured by Plumier.

**** Lobes reaching nearly down to the main raclis. Sp. 119-131.

119. P. serrulatum, Mett. ; rlizome wide-creeping, fibrillose ; st. tufted, short, slender, naked ; fr. 3-6 in. 1., 2-3 lin. br., the upper part, sometimes the whole, subentire, but more usually pectinato-pinnatifid, with rigid erecto-patent lobes; rachis subrigid, flexuose; texture coriaceous; both sides nearly naked; sori oblong, confluent.-Hk. Sp. 4. p. 174. Xiphopteris, Kaulf. Hk. Gard. F. t. 44.

Hab. West Indies and Mexico to Brazil, Peru, and Juan Fernandez; Sandwich Isles, Madagascar, Mauritius, Guinea Coast. $-X$. extensa, Fée, is a narrow elongated form; $X$. Jamesoni, Hk. 2nd Cent. t. 14, a form with a distinct uncut upper part, the lower two-thirds pectinato-pinnate, and the texture so rigid that the threadlike midrib remains after the pinnæ fall ; Grammitis myosuroides, Schk. (P. setosum, Mett. Hk. Sp. 4. p. 175), is apparently a form of this pinnatifid throughout; and P.? binerve, Hk. Sp. 4. t. 273. B, one of the curious abnormal conditions of Acrostichum sorbifolium. 
120. P. subpinnatifidum, Bl.; fr. tufted, subsessile, 4-6 in. 1., 2 lin. br., attenuated at the base, cut down nearly to the rachis into lobes, the upper edge of which is nearly straight and horizontal and the lower very oblique; texture subcoriaceous; both sides naked; veins forked, the upper branch bearing a solitary sorus in each lobe.-Hk. Sp.4. p. 177.

Hab. Java, Sandwich Isles.-Very like the next in habit and cutting, but the fertile lobes quite flat.

121. P. cucullatum, Nees.; st. densely tufted, very short, naked ; fr. 3-5 in. 1., 2-3 lin. br., flaccid, pinnatifid throughout; lobes linear-oblong, blunt, entire, $\frac{1}{2}-\frac{3}{4}$ lin. br., the fertile ones confined to the upper part, broader and with the edges upcurved so as to clasp the large solitary sorus; texture thick, subcoriaceous; rachis naked or ciliated; both sides naked.-Hk. Sp. 4. p. 176. Calymmodon, Presl.

Hab. Philippines, Malaya, Ceylon, Samoa, New Caledonia.

122. P. subdimidiatum, Baker ; st. densely tufted, very short, wiry, naked; fr. flaccid, 4-12 in. l., $\frac{2}{5}-\frac{1}{2}$ in. br., cut down nearly to the rachis into lobes nearly as broad as deep, which are irregular in shape, the upper edge crenate, cut away close against the rachis, the lower edge subdimidiate, entire, and very much decurrent ; texture subcoriaceous; colour pale-green; both sides naked; main vein not produced to the point of the pinnæ, with usually a short branch below and a large one above; sori large, 1-3 in the centre of the lobes.

Hab. Venezuela, Fendler, 207 ; Andes of Ecuador, Jameson, 2122 ; British Guiana, Appun, 1130.

123. P. organense, Mett. ; st. tufted, 1 in. or more 1., naked; fr. 6-8 in. 1., 3-4 lin. br., cut down about halfway to the rachis into close oblong entire blunt lobes, the lower part narrowed very gradually; texture subcoriaceous; both surfaces naked; sori oblong, one at the base of each lobe, ultimately confluent and forming two long rows close to the midrib.-Hk. Sp. 4. p. 177. Ic. Pl. t. 509.

Hab. Organ Mountains, Brazil, Gardner, 5913.

124. P. leucosorum, Bojer ; rhizome short-creeping, densely clothed with darkbrown fibrillose scales; st. 4-6 in. 1., rigid, dark-brown, glossy, fr. $1 \mathrm{ft}$. or more 1., $1 \frac{1}{2}-2$ in. br., cut down within a short distance of the rachis into blunt entire lanceolate lobes, those of the barren fr. broader and shorter; texture coriaceous ; both sides naked; veins obscure, mostly twice forked; sori large, prominent, in two rows, appearing when young as white chalky dots. - Hk. $S p .4 . p .198$. Ic. $t .942-3$.

Hab. Mauritius and Bourbon.

125. P. villosissimum, Hk. ; rhizome stout, creeping, densely scaly ; st. subtufted, 2-4 in. l., clothed with fine soft spreading hairs, sometimes geniculate; fr. 6-9 in. l., $\frac{3}{4}-1 \frac{1}{2}$ in. br., cut down within a short distance of the rachis into close entire lobes 2-3 lin. br., the lower ones reduced; texture coriaceous; rachis and under side densely clothed with long soft brown hairs; veinlets obscure, twice forked or subpinnate; sori in two rows near the midrib.-Hk.Sp.4. p. 197.

Hab. Sierra Leone and Fernando Po; gathered by Barter and Mann.

126. P. solidum, Mett. ; rhizome stout, the scales lanceolate, bright-ferruginous; st. 1 in. 1., firm, erect, naked; fr. 6-8 in. 1., $\frac{3}{4}$ in. br., cut down nearly to the rachis into close, distinctly toothed bluntish lobes $\frac{1}{8}$ in. br. ; texture 
coriaceous; both sides quite naked; veinlets forked; sori medial.-Hk. Sp. 4. p. 193.

Hab. Java, Zollinger, 165.

127. P. discolor, Hk. ; fr. tufted, subsessile, 4-6 in. 1., $\frac{1}{2}-\frac{3}{4}$ in. br., cut down within a short distance of the rachis into close, blunt, entire, linear-oblong lobes $1 \frac{1}{2}-2$ lin. br. ; texture coriaceous ; upper surface with small white dots, the lower clothed with white chalky meal; veins obscure; sori in rows of 3-4 on each side close to the edge.-Hk. Sp. 4. p. 189 . Ic. Pl.t. 4 .

Hab. British Guiana, Schomburgk, 1031.

128. P. crassifrons, Baker; rhizome stout, the scales spreading, fibrillose, dark-brown; st. tufted, firm, very short, densely clothed with short darkbrown hairs; $f r .5-6$ in. l., $\frac{1}{2}$ in. br., narrowed very gradually downwards, cut down nearly to the rachis into close entire blunt lobes 1 lin. br. ; texture very thick; under surface, especially the midrib, clothed with short brown tomentum; veins hidden; sori in close rows of 6-8 each, close to the edge of the lobes.

Hab. New Caledonia, Deplanche.-The alliance of this is with the preceding.

129. P. subserratum, Hk. ; rhizome creeping ; st.4-5 in. l., erect, rigid, slender, nearly black, clothed above with short stout black hairs; fr. 8 in. $1 ., 2$ in. br., cut down nearly to the rachis into close blunt entire lobes $\frac{1}{4} \mathrm{in}$. br.; texture papyraceo-herbaceous ; rachis black, erect, hispid, like the stem; both sides naked; veins close, black, distinct, once forked; sori not known.-Hk. Sp. 4. p. 202 .

Hab. Borneo ; gathered by Mr. Wallace.

130. P. Khasyanum, Hk.; st. tufted, very short, fringed with soft hairs; $f r$. $1 \mathrm{ft}$. or more l., $1 \frac{1}{2}$ in. br., flaccid, cut down within a short distance of the rachis into linear-oblong entire or slightly undulated blunt lobes $2-3$ lin. br.; texture thick, subcoriaceous ; rachis and both sides ciliated ; veinlets simple; sori sunk, in rows of 4-6 on each side the midrib.-Hk. Sp. 4. p. 191. 2nd Cent. t. 49.

Hab. Kbasya and Assam (3-4,000 ft.).

131. P. incequale, Fée; st. tufted, very short ; fr. 18 in. 1., 3-4 in. br., cut down within $\frac{1}{8}$ in. of the rachis throughout into linear-oblong bluntish or acute. subentire lobes, those of the lower part $1 \frac{1}{2}-2$ in. l., 2 lin. br., the lowest much reduced ; texture subcoriaceous; both sides naked; veins nearly all forked; sori nearer the edge than the midrib.-Fée, Fil. Ant.t. 12.

Hab. Guadeloupe.

\section{***** Fronds pinnate. Sp. 132-207.}

+ Pinnoe close, dilated and casually confuent at the base. Sp. 132-186.

A. Fronds half an inch or less broad.-Sp. 132-143.

132. P. moniliforme, Lag. ; rhizome stout, creeping, densely clothed with dullbrown linear or lanceolate scales ; st.1-3 in. l., erect, rigid, slightly villose ; $f r$. 6-9 in. $1 ., \frac{1}{4}$ in. br., cut down to the rachis into close entire rounded pinnos $\frac{1}{8}$ in. each way; texture very coriaceous; rachis black; both sides naked; veins hidden; sori 1-4 to each pinna.-Hk. $S p$. 4. p. 182. P. subcrenatum, Hk. Ic. $t$. 719. Jamesonia adnata, Kze.

Hab. Along the Andes from Mexico to Peru.-Distinguished in the group by its very rigid habit and short broad often decurved pinnæ. $P$. humile, Mett., appears to be a variety with the sori nearer the edge than usual. 
133. P. exiguum, Griseb.; st. tufted, thread-like, very short, naked; $f r$. pendulous, 6-24 in. 1., 2 lin. br.; pinnoe $\frac{1}{2}-1$ lin. l., $\frac{1}{2}$ lin. br., half-ovate, blunt, entire or with a single crenation on the upper side, distant, but the base broadly dilated on both sides; texture subcoriaceous; both sides naked; veins and sori 1 to each pinna, the former forked.-Griseb. Fl. Brit. W. Ind.p. 701.

Hab. Jamaica, Purdie.

134. P. trichomanoides, Swz.; st. densely tufted, short, clothed with soft spreading deciduous hairs ; fr. 3-6 in. l., 2-4lin. br., cut down to the rachis into close linear-oblong blunt pinnce under 1 lin. br.; rachis wiry, ebeneous; texture subcoriaceous, the surfaces naked or slightly clothed with soft hairs; veins and sori 1 in each pinna, the former forked, the latter near the base.-Hk. Sp. 4. $p$. 178. $-\beta, P$. truncicola, Klotzsch; lobes not reaching quite down to the rachis, soft hairs more copious.-Hk. Sp. 4. l. $c$.

Hab. Cuba to Brazil and Ecuador; Juan Fernandez, Ascension Island, Malacca, Sikkim.

135̃. P. flabelliforme, Lam.; st. tufted, short, fringed with long soft hairs; fr. flaccid, 4-12 in. l., $\frac{3}{8}-\frac{1}{2}$ in. br., cut down throughout nearly or quite to the rachis into entire or slightly crenate blunt pinno 1-1 $\frac{1}{2}$ lin. br., which are decurrent at the base; texture papyraceo-herbaceous; rachis and both sides naked or with a few long soft hairs; sori large, 1-3 to a pinna, terminal on the short simple veinlets.-HK. Sp. 4. p. 187 .

- Hab. Columbia to Peru. -Distinguished in the group by its flaccid habit, slender black filiform rachis, and few sori.

136. P. subtile, Kunze ; st. tufted, slender, very short ; fr. flaccid, 3-4 in. 1., 2-4 lin. br., ligulate, narrowed gradually towards both ends, cut down to the rachis throughout into close entire blunt pinnoe $\frac{1}{2}-\frac{3}{4}$ lin. br.; texture papyraceoherbaceous; rachis black, like both sides thinly clothed with long soft hairs ; sori 3-6 to a pinna, terminating the short veinlets.-Hk. Sp. 4. p. 187. t. 275. A.

Hab. Venezuela to Peru.-Lobes narrower and closer than in the last, and texture almost that of a thin Adiantum. P. subscabrum, Hk. Sp. 4. p. 183. t. 274. A. is apparently this ; but it is not the plant of Klotzsch.

137. P. delicatulum, M. \& G.; rhizome wide-creeping, slender ; st. tufted, wiry, 1-2 in. 1., densely clothed with long soft hairs ; fr. $4-6$ in. l., $\frac{1}{2}$ in. br., cut down to the rachis into close blunt entire pinno 1-1 $\frac{1}{2}$ lin. br., the lower ones broader and shorter; texture subcoriaceous; veinlets simple; both sides thinly clothed with long soft hairs; sori copious, subimmersed, 6-8 to a pinna.- $I I k$. Sp. 4. p. 184.

\section{Hab. Mexico to Ecuador.}

138. P. peruvianum, Desv.; rhizome creeping, fibrillose ; st. 1-2 in. l., slender, erect, clothed with soft spreading hairs ; fr. $3-4$ in. $1 ., \frac{1}{4}-\frac{3}{8}$ in. br., cut down to the rachis into oblong-triangular blunt entire pinnoe $\frac{1}{8}$ in. br.; texture subcoriaceous; both sides nearly naked; veinlets immersed, simple; sori rather large, 2-4 to a pinna.- $H k$. $S p$. 4. p. 186. P. anfractuosum, $K z e$.

Hab. Venezuela and Peru.-This comes very near the next species. P. monticola, Klotzsch, is probably a reduced form. It is described as cæspitose ; but in our specimen the rhizome is slender and greatly elongated, with the fronds $2-3$ in. distant from one another.

139. P. parvulum, Bory; rhizome stout, short-creeping, clothed with linear scales ; fr. 4-6 in. l., $\frac{1}{2}$ in. br., tapering gradually downwards into a very short 
stem, cut down to the rachis into entire erecto-patent pinnce 1 lin. br.; texture subcoriaceous ; rachis and both sides naked or deciduously hairy; veinlets immersed, simple ; sori 2-6 to a pinna, medial.-Hk. Sp. 4. p. 184.t. 274. B.

Hab. N. India (up to 8,500 ft.), Ceylon, Mascaren Isles, Zambesi-land.-The Javan plant, $P$. inconspicuum, Blume, is said to differ by its firmer texture and costular sori.

140. P. glandulosum, Hk.; st. tufted, very short ; fr. $2-4$ in. $1 ., \frac{1}{4}-\frac{3}{8}$ in. br., cut down nearly or quite to the rachis into close, rather deeply-toothed, decurrent oblong pinnoe, the lower ones gradually reduced; texture papyraceoherbaeeous; colour dull-green; both sides densely glandular but not hairy; veinlets simple; sori 1-3 to each pinna.-Hk. Sp. 4.p. 193. t. 276. A.

Hab. Ceylon.-Perhaps a form of $P$. parvulum, with which it agrees in general habit.

141. P. juboeforme, Kaulf.; st. tufted, slender, 1-2 in. l., wiry, naked ; fr. 6-12 in. l., $\frac{1}{2}$ in. br., cut down to the rachis into close, entire, decurrent blunt lobes 1 lin. br.; texture subcoriaceous; the black threadlike rachis and both sides naked ; veinlets simple; sori medial, 2-6 on a side, conspicuously immersed.Hk. Sp. 4. p. 186.

Hab. West Indies and Panama.

142. P. pilosissimum, M. \& G.; st. tufted, 1-2 in. 1., rigid, clothed with soft spreading hairs ; $f r$. 4-8 in. $1 ., \frac{1}{2}-\frac{3}{4}$ in. br., cut down nearly or quite to the rachis into close, blunt, entire lobes 1-1 $\frac{1}{2}$ lin. br., the lower ones growing gradually shorter and broader; texture coriaceous; rachis rigid, ebeneous; both sides naked or the lower one pilose; sori in rows of 4-5 on each side of the midrib of the pinnoe, distinctly immersed.-Hk. Sp. 4. p. 181.

Hab. Mexico to Ecuador and South Brazil.--The most rigid of the group except P. moniliforme.

143. P. lasiostipes, Mett.; st. tufted, very short, clothed with short stiff spreading blackish hairs; fr. $2-4$ in. $1 ., \frac{1}{2}$ in. br., cut down to the rachis into erecto-patent blunt entire pinnoe 1 lin. br.; texture subcoriaceous ; rachis beneath densely and the surface slightly hispid like the stem; veinlets simple, 4-6 on each side ; sori submarginal.-Mett. Fïl. Nov. Cal. p. 76.

Hab. New Caledonia, Vieillard, 1601-2.

\section{B. Fronds more than half an inch broad, flaccid, pendulous. Sp. 144-163.}

144. P. cultratum, Willd. ; st. tufted, short, slender, clothed with soft spreading brown hairs; fr. 6-18 in. l., $\frac{1}{2}-1$ in. br., cut down to the rachis into close horizontal or decurved blunt pinnoe $1 \frac{1}{2}-2$ lin. br. ; texture papyraceo-herbaceous ; the black threadlike rachis and both sides clothed with hairs like those of the stem ; veinlets simple, 4-6 on each side ; sori medial.- $\beta, P$. elasticum, Bory,smaller, Hk. Sp. 5. p. 190. P. senile, Fée.

Hab. Cuba and Guatemala to Brazil and Peru ; Mauritius, Fernando Po.

145. P. grammitidis, R. Br. ; st. tufted, 1-2 in. 1., wiry, naked ; fr. 4-12 in. 1., 2 in. or more br.; pinnoe erecto-patent, sometimes linear, blunt, usually $\frac{1}{4}-\frac{3}{8}$ in. br., more or less deeply pinnatifid, the base abruptly decurrent; texture coriaceous ; rachis and both surfaces naked; veinlets immersed, simple or forked; sori oblong, copious, usually 1 to each lobe at the base.-Hk. Sp. 4. p. 230 .

Hab. New Zealand and Van Diemen's Land.

146. P. sarmentosum, Brack.; st. subtufted, 1 in. or less l. ; fr. 3-6 in. 1., 1-2 in. br., the point caudate, cut down nearly to the rachis into erecto-patent blunt 
entire or slightly crenated pinnoe $\frac{1}{8}$ in. br., dilated at the base, the lower ones narrowed down gradually to a wing to the rachis; texture subcoriaceous; rachis and both sides naked or slightly villose ; veinlets oblique, simple or forked; sori few, scattered.-Hk. Sp. 4. p. 195.

Hab. Sandwich Isles and Sumatra.-Very near the next.

147. P. Adenophorus, Hk. \& Arn. ; fr. subsessile, flaccid, pendulous, 6-12 in. $1 ., \frac{3}{4}-1$ in. br., cut down nearly or quite to the rachis into acute slightly sinuated horizontal or even rather decurved pinnoe $\frac{1}{8} \mathrm{in}$. br., which are dilated at the base, the lower ones shorter and broader; texture subcoriaceous; rachis and both sides nearly naked; veinlets simple or forked; sori in rows close to the midrib.-Hk. Sp. 4. p. 195.

Hab. Sumatra, Sandwich Isles, Peru.-The alliance of this is with the two preceding.

148. P. obliquatum, Blume; st. tufted, 1 in. or more 1., rigid, naked or villose; fr. 8-12 in. $1 ., 1 \frac{1}{2}-2$ in. br., cut down to the rachis throughout into entire close subhorizontal linear pinnoe 1-1 $\frac{1}{2}$ lin. br., dilated at the base, the lower ones short and blunt; texture subcoriaceous; rachis naked or hispid; both sides naked; veinlets simple; sori sunk in a cavity, 4 to 6 on each side, the edge of the fertile pinnæ sometimes undulated.-Hk. Sp. 4. p. 190 (in part). Cryptosorus, Fée.

Hab. South India, Ceylon, Malaya, Philippines.-Forms the genus Coelopteris, A. Br., and with $P$. papillosum, Thylacopteris of Kunze.

149. P. repandulum, Mett. ; st. tufted, very short, naked ; fr. 4-6 in. 1., 1-1 $\frac{1}{2}$ in. br., cut down to the rachis throughout into erecto-patent blunt crenated pinnoe $\frac{1}{2}-\frac{3}{4}$ lin. br. ; texture subcoriaceous; rachis and both sides naked; veinlets simple; sori slightly immersed, filling nearly the whole space between the midrib and edge.-P. obliquatum, Hk. Sp. 4. p. 190 (in part). P. Thwaitesii, Beddome, Fil. Brit. Ind. t. 188.

Hab. Ceylon, Gardner, 1147, 1290 ; Thwaites, 3900.-A smaller and less coriaceous plant than the last, with the sori indistinctly immersed.

150. P. subsecundo-dissectum, Zolling. ; st. tufted, $\frac{1}{4}-\frac{1}{2}$ in. 1. ; fr. 4-8 in. $1 ., \frac{3}{4}-1$ in. br., cut down nearly to the rachis into numerous close subdimidiate oblong pinna, which are quite entire or only slightly toothed towards the point on the outer side, but cut down nearly to the rachis on the inner side into 4 to 6 oblong lobes; texture papyraceo-herbaceous; both sides clothed with soft spreading yellowish hairs ; veins abbreviated; sori close to the midrib.-Mett. Fil. Ind. 2. p. 220.

Hab. Java, Zollinger, 1578. - Characterized in the group by its subdimidiate pinnæ.

151. P. minutum, Blume; st. tufted, 2-3 in. 1., clothed with soft yellowish hairs ; fr. 4-6 in. 1., $\frac{5}{8}-\frac{3}{4}$ in. br. ; pinnoe 1-1 $\frac{1}{2}$ lin. br., close, erecto-patent, blunt, slightly crenated, the lower ones reduced; texture papyraceo-herbaceous; both sides clothed with soft yellowish hairs; veins simple, very short; sori 1 to 3 on each side, close to the midrib.-Hk. $S p .4 . p .188$.

Hab. Ceylon, Malay Isles, and Philippines.

152. P. subfalcatum, Blume; st. derısely tufted, under 1 in. 1., thinly clothed with soft spreading hairs ; fr. 6-9 in. l., 1-1 $\frac{1}{2}$ in. br. ; pinnoe close, spreading, rather sharply toothed from one-third to halfway down, decurrent at the base, the lower ones gradually reduced; texture papyraceo-herbaceous ; both sides slightly villose ; veinlets simple; sori in rows, 1 to each tooth.-Hk. Sp. 4. p. 193 (in part).

Hab. Malay Isles.-The Javan P. lividum, Mett., is said to differ by its firmer texture, shorter hairs, and immersed sori. 
153. P. decipiens, Hk. ; st. tufted, slender, wiry, short, naked or villose ; $f$. flaccid, pendent, $1 \mathrm{ft} .1 ., 2$ in. or more br. ; pinnoe 1-2 in. 1., distinct, entire, 1 lin. br., pinnatifid ; texture papyraceo-herbaceous; ebeneous rachis and both surfaces naked; veinlets 1 to each lobe; sori copious.-Hk. Sp. 4. p. 231. t. 279. B. P. pilipes, Mett. non $H k$.

Hab. West Indies to Peru.-The alliance of this is with the preceding species rather than with $P$. pilipes, which is much more coriaceous in texture, with an indistinct rachis.

154. P. subsessile, Baker ; st. scarcely any ; fr. 6-18 in. $1 ., 1 \frac{1}{2}-2$ in. br., the pinnoe distant, linear, bluntish, about 1 lin. br., entire or slightly crenate, dilated suddenly at the base so as to be almost or quite connected, the lower ones reduced to a mere zigzag wing to the rachis; texture papyraceo-herbaceous ; rachis black ; both sides naked or even glossy; veinlets simple; sori in 2 long rows.-P. pteropus, $H k$. Sp. 4. p. 192. t. 275 B. non Blume.

Hab. Columbia, Guiana, and Ecuador.

155. P. farinosum, Hk. ; st. 1 in. or less 1., wiry, flexuose ; fr. pendent, 4-5 in. $1 ., 1 \frac{1}{2}-2$ in. br. ; pinnee close, 1 in. or more l., $2-3$ lin. br., the point blunt, the edge obscurely undulated, the base dilated and then narrowed; texture subcoriaceous; both sides with white meal; voinlets immersed, forked; sori copious. Hk. Sp. 4. p. 223.2 . 2 d Cent. t. 47.

\section{Hab. Andes of Ecuador, Jameson.}

156. P. curvatum, Sw. ; rhizome stout, scaly ; st. 3-4 in. 1., naked, glossy, darkbrown ; fr. 12-18 in. 1., 2-3 in. br., pendent, cut down to the curved and flexuose rachis into close linear crenated pinnoe $1 \frac{1}{2}-2$ lin. br., which are decurrent at the base ; texture subcoriaceous; rachis finely pubescent; both sides naked ; veinlets obscure, 1- or 2-forked; sori bright-yellow, in 2 long rows.-Hk. Sp.4. p. 201. P. curvans, Mett.

Hab. Jamaica to Ecuador and Peru.-This has a good deal the appearance and texture of $P$. pectinatum, but is pendent and remarkably flexuose.

157. P. pendulum, Sw. ; caud. suberect, scaly ; fr. flaccid, pendulous, 6-12 in. or more l., 1-2 in. br., subsessile or short-stalked, cut down nearly or quite to the rachis into blunt entire pinno $1 \frac{1}{2}-2$ lin. br., which are dilated at the base, the lower part narrowed into a mere decurrent wing to the rachis ; texture subcoriaceous ; rachis naked or villose ; both sides naked ; veinlets forked ; sori slightly immersed, forming a row on each side close to the midrib.-Hk. Sp. 4. p. 194.

Hab. West Indies to Brazil and Peru.

158. P. suspensum, L. ; st. tufted, 4-8 in. 1., dark chesnut-brown, clothed with soft spreading hairs ; fr. $12-18$ in. $1 ., 1 \frac{1}{2}-3$ in. br., cut down to the rachis into horizontal entire acute or bluntish pinnce $1 \frac{1}{2}-3$ lin. br., dilated at the base, the lower ones not gradually reduced; texture papyraceo-herbaceous or subcoriaceous ; rachis and under side more or less clothed with ferruginous hairs ; veinlets forked ; sori in long rows close to the midrib.-Hk. Sp. 4. p. 196.

Hab. Mexico and Cuba to South Brazil and Ecuador. - This has often an erect stem, with a very decided curve at the top (Plum. t. 102). P. asplenifolium, L., is larger in size, densely clothed with long rough reddish hairs, the pinnæ broader, and the lower ones reduced. $P$. mollissimum, Fee, is like the type in habit, but very soft, with the veins simple, and the lower pinnæ much reduced.

159. P. melanopus, Gr. \& Hk. ; st. 3-4 in. l., slender, black, naked, bent so that the frond hangs down; fr. 7-8 in. 1., 2-3 in. br., cut down to the rachis into linear bluntish faintly crenated pinnoe $\frac{1}{8} \mathrm{in}$. br., the lower ones slightly reduced; texture 
subcoriaceous; rachis and both sides naked ; veinlets very distinct, once forked ; sori in 2 long rows. $-H k . S p .4 . p .200$.

Hab. Andes of Ecuador, Jameson. - This may be a form of the last, but the pinnæ are longer and closer.

160. P. celebicum, Blume; st. $3-5$ in. 1. , tufted, villose ; fr. 12-15 in. $1 ., 2$ in. br., eut down to the rachis throughout into close nearly horizontal entire bluntish pinnoe $1 \frac{1}{2}-2$ lin. br. ; texture coriaceous ; rachis ciliated, the rest nearly naked ; veinlets simple; sori deeply sunk, 8 to 12 in a row on each side the midrib.Hk. Sp. 4. p. 191.

Hab. Borneo and Celebes.

161. P. griseum, Liebm. ; rhizome stout, wide-creeping, scaly ; st. 4-6 in. 1., palebrown, polished, villose ; fr. flaccid, 1-2 ft. or more 1., 3-4 in. br., cut down to the rachis into entire acute or bluntish lanceolate pinnce $\frac{1}{4}-\frac{3}{8} \mathrm{in}$. br.; texture herbaceous ; rachis densely villose, and both sides finely puhescent; veins fine, close, 2 - or 3 -forked, the groups sometimes joining; sori in 2 long rows midway between the midrib and edge.-Hk. $S_{p} .4 . p .202$.

Hab. Mexico and Guatemala.

162. P. sublanosum, Hk. ; st. 4-6 in. l., firm, erect, greyish, villose throughout; fr. 12-15 in. l., 3 in. br. ; pinnoe close, alternate, $1 \frac{1}{2}$ in. l., $\frac{1}{4}-\frac{3}{8}$ in. br., bluntish, entire, dilated at the base, only the lowest, which are shorter and deflexed, quite free ; texture papyraceo-herbaceous; weak rachis and both sides villose; veinlets twice forked, very fine and inconspicuous; sori in medial rows.-Hk. Sp. 4 . p. 221.

Hab. Organ Mountains, Gardner, 122.

163. P. pilipes, Hk.; st. tufted, flexuose, 3-4 in. l., densely clothed with soft spreading hairs ; $f r$. pendent, $6-9$ in. $1 ., 2-4$ in. br., cut down nearly to the rachis into close linear lobes, which are often deeply pinnatifid; texture coriaceous; rachis and both sides naked; veinlets 1 to each lobe; sori copious.-Hk. Sp. 4. p. 230. Ic. t. 221 .

Hab. Peru, Matthews.

\section{Fronds more than half an inch broad, erect or suberect. Sp. 164-186.}

164. P. macrocarpum, Presl; rhizome stout, wide-creeping, densely clothed with lanceolate adpressed scales; st. 1-3 in. 1., wiry, often flexuose, deciduously scaly ; fr. 3-4 in. l., 1 in. or more br., lanceolate, cut down nearly to the rachis into blunt entire or obscurely toothed pinnoe $\frac{1}{8}$ in. br., dilated at the base, and with a rounded sinus between them; texture coriaceous; veins hidden, forked; upper surface naked, lower densely coated with scales; sori large, copious.-Hk. Sp. 4. p. 215. P. Tweedianum, $H k$. Ic. $t .86$.

Hab. Bolivia to Chili. - Habit and scales like those of $P$. incanums.

165. P. madrense, J. Sm.; rhizome stout, wide-creeping, densely clothed with minute scales; st. 2-4 in. l., firm, erect, naked or slightly scaly ; fr. 3-5 in. l., $\frac{1}{2}-2 \mathrm{in}$. br., cut down very nearly to the rachis into horizontal blunt entire pinnoe $\frac{1}{8}$ in. br., with a rounded sinus between them; texture coriaceous; ebeneous rachis and under side thinly coated with minute scales; veinlets 2 -forked, obscure; sori large, copious. - Hk. Sp. 4. p. 214.

Hab. Sierra Madre, N. W. Mexico, Seemann, 1941.-About midway between the last and $P$. pectinatum. 
166. P. rigescens, Bory ; rhizome stout, creeping, densely clothed with dullbrown linear scales; st. 1-3 in. lo, wiry or slightly villose, naked ; fr. 6-12 in. l., $\frac{3}{4}$ in. or more br., cut down to the rachis into close entire blunt linear-oblong pinnae $\frac{1}{8}$ in. br., the lower ones reduced ; rachis black, wiry ; both surfaces naked, the under one sometimes glaucous; veinlets hidden; sori in rows of 4 to 5 on each side. $-H k$. \& $G r . I c . t .216$.

Hab. Cuba to Chili and Brazil ; Bourbon, Fernando Po.-A plant from Dr. Spruce has a rigid rhizome $2 \mathrm{ft}$. 1., clothed with large ovate-lanceolate scales, and the fronds are quite sessile ; and another has fronds 18 in. 1., 2 in. br., with 6-9 sori in a row.

167. P. fuscatum, Blume; st. tufted, 1-3 in. l., densely clothed with soft spreading hairs ; $f r .3-6$ in. $1 ., \frac{2}{2}-1$ in. br., cut down nearly or quite to the rachis throughout into close entire obtuse pinnoe $\frac{1}{2}$ lin. br., the lower ones shorter and broader; texture subcoriaceous; rachis and both sides thinly clothed with soft hairs ; veins obscure, simple ; sori forming a close row on each side the midrib,' at last filling nearly the whole surface.-Hk. Sp.4. p. 181.

Hab. Java and Ceylon.

168. P. decorum, Brack.; rhizome creeping, densely clothed with linear scales; st. 1 in. or less l., rigid, naked; fr. 6-12 in. $1 ., \frac{1}{2}-1$ in. br., cut down nearly or quite to the rachis into entire linear blunt pinnoe about 1 lin. br., the lower ones growing gradually shorter and blunter; texture coriaceous; both sides naked, or the rachis hispid; weins obscure; sori immersed, in 2 rows of 4 to 6 each, filling up the whole space between the midrib and edge.-Hk. Sp. 4. p. 179.

Hab. Ceylon, Malaya, and Philippines to Tahiti and Sandwich Isles.-This is referred to $P$. nutans (Blume) by Mettenius, but the figure and description do not quite agree with it.

169. P. blechnoides, Hk.; rhizome stout, clothed with dense linear scales; st. 2-3 in. l., rigid, erect, naked ; fr. 8-12 in. $1 ., 1-1 \frac{1}{2}$ in. br., cut down very nearly to the rachis throughout; fertile pinnoe confined to the upper half of the frond, longer and narrower than the barren ones, which are bluntish, about $\frac{1}{8}$ in. br., growing gradually shorter and broader downwards; texture coriaceous; rachis and both sides naked; sori oblong, immersed, in rows near the midrib.-Hk.Sp. 4 . p. 180. Cryptosorus Seemanni, J. Sm.

Hab. Polynesian Islands and Queensland.

170. P. Lobbianum, Hk. ; rhizome short-creeping, stout, densely scaly ; fr. subsessile, $4-6$ in. l., $\frac{3}{4}-1 \frac{1}{4}$ in. br. ; pinnoe numerous, close, $\frac{1}{2}$ lin. br., the edge with distinct rounded crenations, lower ones gradually reduced; texture coriaceous ; rachis wiry, ebeneous; both sides quite naked; veinlets simple, indistinct, 1 to each lobe; sori immersed, small, copious. $-H k$. Sp. 4. p. 226. t. 278. B.

Hab. Borneo, T. Lobb. - This and the three last are the most rigid in texture of the group.

171. P. argyratum, Bory ; rhizome stout, the scales linear, ferruginous ; st. 2-3 in. 1 ., wiry, naked ; fr. $4-6$ in. $1 ., 1 \frac{1}{2}-2$ in. br., cut down to the rachis into close horizontal nearly entire pinnce $\frac{1}{8}$ in. br., narrowed gradually upwards; texture subcoriaceous; under surface coated when young with white meal, which disappears as the plant grows older, for the rest naked; veinlets immersed; sori marginal, 4 to 8 on each side.-Hk. Sp. 5. p. 198.

Hab. Bourbon and Mauritius.

172. P. Skinneri, Hk.; rhizome wide-creeping, clothed with broad pale adpressed scales ; st. 2 in. l., rigid, deciduously scaly ; fr. $6-9$ in. $1 ., 1 \frac{1}{2}-2$ in. br., cut down nearly or quite to the rachis into numerous close horizontal linear slightly crenated pinnoe not more than 1 lin. br., with a rounded sinus between them; 
texture subcoriaceous; rachis and under surface thinly clothed with minute ovate toothed scales; veinlets obscure, simple ; sori in 2 long rows. $-H k . S p .4 . p .276$. B.

Hab. Guatemala ; gathered by Mr. Skinner.

173. P. furfuraceum, Schlecht.; rhizome strong, densely clothed with brown woolly fibrils ; st. $3-4$ in. l., rigid, erect, scaly and villose ; fr. 12-18 in. l., 2-4 in. br., cut down to the rachis into linear acute or bluntish entire pinnoe 2 lin. br., dilated on both sides at the base; texture coriaceous; rachis and under side clothed with dense scales and soft spreading hairs; veinlets forked; sori in 2 long rows. - Hk. Sp. 4. p. 213.

Hab. Mexico.-Rigid habit and dense scales of Lepicystis, but the veins free.

174. P. papillosum, Blume; rhizome stout, wide-creeping, scaly; st. 4-6 in. l., erect, slender, rigid, naked; $f r .1 \mathrm{ft}$. or more l., 2 in. br., cut down to the rachis into close horizontal blunt entire or faintly crenated pinnoe 2-3 lin. br.; texture papyraceo-herbaceous; rachis and both surfaces naked; veins black, distinct, once forked; sori in rows near the edge, deeply immersed, the cavity prominent on the upper side.-Hk. Sp. 4. p. 198. 2nd Cent. $t .46$.

Hab. Java and Philippines, and, according to Mettenius, Japan.

175. P. radicale, Moritz; st. 6-8 in. 1., tufted, ebeneous, rigid, clothed with soft spreading hairs; fr. 8-12 in. 1., 2-3 in. br., cut down to the rachis into spreading entire blunt pinnoe $\frac{1}{8}$ in. br., dilated at the base, the lower ones not reduced ; texture coriaceous; both surfaces naked ; veinlets hidden ; sori large, in marginal rows.

Hab. S. Brazil, Gardner, 128 ; Venezuela, Fendler, 216.-Most like P. suspensum in cutting, but suberect, and the texture so rigid that the frond will scarcely adhere to paper.

176. P. pulchrum, M. \& G.; rhizome stout, shortly scaly ; st. subtufted, 3-4 in. l., rigid, erect, blackish, glossy ; fr. 12-18 in. l., 2-3 in. br., cut down into close horizontal entire blunt pinnoe 1-1 $\frac{1}{2}$ lin. br., dilated at the base ; texture papyraceo-herbaceous; rachis rigid, black, scaly throughout on the lower side; midrib black; veinlets obscure; sori small, in 2 long rows.-Hk. Sp. 4. p. 199.

Hab. Cuba and Mexico to Brazil.-Very near $P$. taxifolium, but a coarser plant, with less distinct venation.

177. P. taxifolium, L. ; rhizome stout, scaly ; st. subtufted, 2-4 in. l., erect, rigid, clothed with soft spreading hairs; $f r .6-12$ in, or more l., $1 \frac{1}{2}-3$ in. br., cut down to the rachis into close entire or slightly crenated blunt horizontal pinnoe $1 \frac{1}{2}-2$ lin. br., the lower ones distant and much reduced; texture papyraceoherbaceous or subcoriaceous; rachis naked or villose; both sides naked; veinlets simple, very distinct, with the sori terminal upon them.-P. Plumula, H. $B . K$. Hk. Sp. 4. p. 200.

Hab. Mexico and West Indies to Peru and South Brazil.-Well distinguished by its finely-cut pectinate habit and simple oblique usually distinctly-marked veinlets, with the sori terminal upon them. $\boldsymbol{P}$. ferrugineum (M. \& G.), Hk. Sp. 4. p. 182. and $\boldsymbol{P}$. apiculatum (Kze.), Hk. l.c. p. 185. both seem small forms of this, rather thicker in texture than usual. P. L'Herminieri, Fée, Fil. Ant. t. 12. belongs here.

178. P. recurvatum, Kaulf.; rhizome creeping, the scales ovate-lanceolate, bright-ferruginous ; st. 3-6 in. l., firm, erect ; fr. 1-3 ft. 1., 4-6 in. br., cut down to the rachis into close entire acuminate pinnae $\frac{1}{8}-\frac{1}{4}$ in. br., the lower ones quite distinct, not smaller than the others; texture subcoriaceous; rachis finely pubescent; veins obscure, forked; sori in a single medial line.-Mett. Polyp. p. 60 . 
Hab. Brazil, Burchell, 1977, 2020.-This comes near some of the forms of $\boldsymbol{P}$. pectinatum, but the scales are different, and the lower pinnæ not reduced.

179. P. pectinatum, L. ; rhizome stout, fibrillose ; st. rigid, erect, 2-6 in. 1., naked or finely villose; $f r .1-2 \mathrm{ft} .1 ., 2-6 \mathrm{in}$. br., cut down to the rachis into

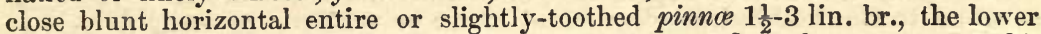
ones much reduced; texture papyraceo-herbaceous; colour deep-green ; rachis and both sides naked or finely villose; veinlets pellucid, once or twice forked;

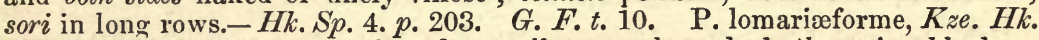
l. $c . \quad \beta, P$. Schkuhrii, Raddi; fr. smaller, nearly naked, the veins black.Hk. Sp. 4. p. 204.

Hab. Mexico and W. Indies to Peru and Brazil ; common.-Similar in habit to the two last, but larger, with the veinlets pellucid in the living, and consequently inconspicuous in the dried plant, usually twice forked, and producing the sorus from the tip of the lowest branch.

180. P. meridense, Klotzsch ; rhizome creeping, the scales fibrillose, darkbrown ; st. 3-6 in. l., wiry, black, scarcely at all villose ; fr. 6-9 in. l., 3 in. br., lanceolate, cut down to the rachis into close bluntish slightly crenate pinnoe 2 lin. br., which are dilated at the base, the lowest not reduced; texture coriaceous; rachis villose; both surfaces nearly naked; veins hidden, once forked; sori submarginal.-Klotzsch, Linn. 20.p.380. P. Spixianum, Mart.

Hab. Columbia, Moritz, 335, Lindig; Brazil, Burchell, 2268.

181. P. Abitaguce, Hk. ; rhizome clothed with linear bright-ferruginous scales ; st. 6-9 in. l., firm, erect, ebeneous, finely villose ; fr. $1 \mathrm{ft}$. or more 1. , $3-4$ in. br., cut down to the rachis into obscurely undulated subacute horizontal pinnoe $\frac{1}{4}$ in. br., dilated at the base, the lowest not reduced ; texture coriaceous ; rachis and both sides finely villose; veins immersed, once forked; sori in two rows midway between the edge and midrib.-Hk. Sp. 4. p. 206.

Hab. Andes of Ecuador, Spruce, 5281.-Very near the last, from which it differs by its finely-villose stem and surface and medial sori. The two are much more coriaceous than pectinatum, with the veins hidden, and lower pinnæ not reduced.

182. P. Moritzianum, Link; rhizome stout, creeping; scales lanceolate-subulate, ferruginous ; st. 4-6 in. l., naked, glossy, erect ; fr. erect, 12-18 in. l., 3-4 in. br., cut down nearly or quite to the rachis into close bluntish nearly horizontal obscurely undulated pinnce $\frac{1}{4}-\frac{3}{8}$ in. br. ; texture papyraceo-herbaceous; rachis and both surfaces naked; veinlets distinct, once forked; sori in two long rows.-Hk. Sp. 4. p. 202.

Hab. Venezuela, Moritz, 217, Fendler, Steetz.

183. P. ellipsoideum, Fée; rhizome stout, wide-creeping, the scales long, spreading, lanceolate-acuminate, dark-brown; st. $3-4$ in. l., slender, erect ; fr. 6-9 in. 1., $1 \frac{1}{2}-2$ in. br., cut down to the rachis into close spreading pinnce $1 \frac{1}{2}-2$ lin. br., which are slightly dilated at the base and then narrowed gradually to an acute point; texture thin; rachis and both sides finely villose; veinlets pellucid, the lower ones subpinnate; sori oblong, in a close row near the edge.

Hab. Mexico, Schaffner.

184. P. Martensii, Mett.; rhizome stout, wide-creeping, clothed with large bright-ferruginous lanceolate membranous scales; st. 1-2 in. l., firm, erect; fr. 8-12 in. $1 ., 3-4$ in. br., cut down to the rachis into numerous entire horizontal pinnce 2 lin. br., with their own breadth between them; texture papyraceoherbaceous; rachis and both sides finely villose; veins subpinnate; sori medial, 12 or more on each side. $-H k$. Sp. 4. p. 207. 
Hab. Mexico.-Judging from the description, $P$. Ehrenbergianum, Klotzsch, may be a form of this with broader pinnæ.

185. P. pellucidum, Kaulf.; rhizome stout, wide-creeping, densely scaly; st. 3-6 in. 1., rigid, erect, naked, glossy ; fr. 6-12 in. l., 3-5 in. br., cut down nearly or quite to the rachis into close blunt entire or subacute pinnoe $\frac{1}{4}-\frac{3}{8}$ in. br.; texture coriaceous; rachis and both sides naked; veinlets pellucid, subpinnate; sori large, prominent.-Hk. Sp. 4.p. 206. 2nd Cent. t. 44.

Hab. Sandwich Isles. - P. myriocarpum, Hk. Ic. t. 84 . is a form with pinnatifid pinnæ. Very like $P$. vulgare in habit, but the veins beautifully pellucid, distinct even in dried specimens.

186. P. vulgare, Linn. ; rhizome stout, the scales bright-ferruginous ; st. 2-4 in. l., firm, erect, stramineous ; fr. 6-12 in. l., 3-6 in. br., cut down nearly or quite to the rachis into close entire or slightly toothed usually blunt pinnae $\frac{1}{4}-\frac{1}{2}$ in. br.; texture herbaceous or subcoriaceous; both sides naked; veinlets pinnate; sori large, uniserial. Hk. Sp. 5. p. 205. Brit. F. t. 22.

Hab. Lapland, throughout Europe to the Azores, Madeira, Barbary States, Turkey in Asia, and Japan; Cape Colony. N. America-Sitka, southward to California and the north of Mexico.-P. australe, Fée, is a large southern form; $P$. cambricum, L., a form with often deeply pinnatifid pinnæ; and $P$. falcatum, Kellogg (P.glycyıthiza, Eaton), a Californian variety, with the pinnæ finely toothed, and narrowed very gradually to an acute point.

\section{H Most of the pinnoe distinctly separated at the base. Sp. 187-207.}

187. P. clavifer, Hk.; st. densely tufted, very short ; fr. 4-5 in. 1., $\frac{1}{2}$ in. br., pinnate throughout; pinnoe distant, linear-subulate, rigid, curved, the fertile ones dilated at the point, which bears a large solitary sorus and is tipped with a bristle; rachis rigid, ciliated with deciduous bristly hairs; texture coriaceous.Hk. Sp. 4. p. 176. Grammitis, Hk. 2nd Cent. t. 5.

Hab. Borneo, H. Low.-A very distinct plant, with the dilated apex of the pinnæ holding the solitary sorus like a spoon, thus falling under Calymmodon of Presl.

188. P. tenuifolium, H. B. K. ; rhizome stout, clothed with reddish-brown fibrillose scales; st. 2-3 in. l., slender, naked, erect; fr. 8-12 in. $1 ., 1 \frac{1}{2}-2$ in. br., cut down to the rachis into distant linear blunt entire or slightly crenated pinnce 1 lin. br.; texture papyraceo-herbaceous; rachis and both sides naked; veinlets simple or rarely forked; sori slightly immersed, in two rows of 6-10 each to a pinna.- $H k$. $S p$. 4. p. 192.

Hab. West Indies and Columbia.-Grisebach considers this $P$. Otites, Sw., but the plant of Linnæus is in part $P$. pectinatum.

189. P. venulosum, Blume; st. tufted, rigid, wiry, 1-3 in. 1., deciduously villose ; fr. 12-18 in.1., 1-1 $\frac{1}{2}$ in. br., cut down to the rachis throughout into close entire horizontal pinnae 1 lin. br.; texture subcoriaceous; colour dark-green; rachis villose; both sides naked; midrib and simple veinlets raised; sori copious, immersed.-Hk. Sp. 4. p. 223. Cryptosorus, Fée.

Hab. Malay Isles and Japan.-This and the preceding resemble $P$. pectinatum in habit, but the pinnæ are more distinctly separated.

190. P. heteromorphum, Hk. \& Gr.; st. tufted, slender, wiry, naked ; fr. very flaccid, pendent, simple or dichotomously forked or pinnate, with close irregular pinnl. 12-18 in. 1., $\frac{1}{4}-\frac{3}{8}$ in. br.; pinna close, obovate or oblong, $\frac{1}{4} \cdot \frac{3}{8}$ in. $1 ., 1 \frac{1}{2} \cdot 2$ lin. br., entire or pinnatlifid with short blunt lobes; texture papyraceo-herbaceous; rachis and both sides densely clothed with soft spreading hairs; veinlets of the 
pinnl. simple ; sori copious, 1-6 to a pinna.-Hk. Sp. 4. p. 229. Hk. \& Gr. Ic. $t .108$.

Hab. Mexico along the Andes to Ecuador.-Resembles $P$. trichomanoides in texture.

191. P. reclinatum, Brack.; st. subtufted, slender, very short, villose ; fr.

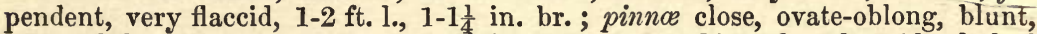
entire, $\frac{1}{4}-\frac{3}{8}$ in. br. ; texture papyraceo-herbaceous ; rachis and under side clothed with fine soft hairs; veinlets simple; sori $2-5$ in a row.-P. semiadnatum, Hk. Sp. 4. p. 222. (in part).

Hab. South Brazil, Gardner, 112; Brackenridge.

192. P. semiadnatum, Hk.; st. $4-6$ in. 1. , slender, flexuose, slightly villose ; fr. flaccid, pendent, 1-2 ft. l., $\frac{3}{4}-1 \frac{1}{4}$ in. br.; pinnce very numerous, close, oblong, $\frac{1}{2}-\frac{5}{8}$ in. l., 2 lin. br., blunt, distinctly crenated, the lower ones reduced and distant; texture subcoriaceous; rachis and under side with a few long soft hairs; veinlets forked; sori copious.-Hk. Sp. 4.p.222. (in part). $2 n d$ Cent.t. 48.

Hab. Andes of Ecuador, Jameson.

193. P. dependens, Baker; st. tufted, short, thread-like, clothed with soft spreading hairs ; $f r$.pendent, very flaccid, $2 \mathrm{ft}$. or more l., $\frac{3}{4}$ in. br.; pinnoe alternate, $\frac{1}{4}-\frac{3}{8}$ in. l., $\frac{1}{8}$ in. br., ovate-oblong, blunt, entire, the central ones on the same side $\frac{1}{4}$ in. apart; texture papyraceo-herbaceous; slender black rachis and both sides clothed with soft spreading hairs; veinlets simple; sori close to the midrib.

Hab. Andes of Ecuador, Spruce, 563. - Like the next species on a smaller scale.

194. P. alternifolium, Hk. ; st. very short, tufted, slender, flexuose, clothed with soft spreading hairs ; fr. pendent, very flaccid, 2-10 ft. l., 2 in. br.; pinnoe distinct, alternate, lanceolate, entire, 3-4 lin. br. at the base ; texture papyraceoherbaceous; slender rachis and both sides thinly clothed with soft spreading hairs ; midrib ebeneous, slender, flexuose; veinlets simple; sori copious. $-H k$. Sp. 4. p. 222. t. 277. A.

Hab. Andes of Ecuador.

195. P. sericeo-lanatum, Hk. ; st. 1-4 in. 1., slender, densely clothed with soft spreading grey hairs; fr. flaccid, pendent, 1-2 ft. l., $1 \frac{1}{2}-3$ in. br.; pinnce close, 3-1 $\frac{1}{2}$ in. 1., 2-3 lin. br., blunt, entire, spreading; texture thick; rachis and both sides densely matted with soft silky hairs; veins simple; sori in 2 long rows.Hk. Sp. 4. p. 221.

Hab. Andes of Columbia and Ecuador.-This and the five preceding in their flaccid pendent mode of growth correspond with the cultratum group.

196. P. firmum, Klotzsch; rhizome creeping, the scales large, linear, dullbrown ; st. 1-2 in. l., wiry, naked ; $f r$. loosely spreading, 8-12 in. l., 2 in. br. ; pinnoe distant, 1 in. $1 ., \frac{1}{8}$ in. br., blunt, upcurved, dilated at the base, the lower ones reduced; texture firm; rachis slender, black, wiry, clothed with short stiff black hairs; both sides nearly naked; midrib black; veins simple; sori in two long rows.-Hk. Sp. 4. $p .185$. (in part).

Hab. Guiana, Richard Schomburgk, 1170 ; New Granada, Lindig, 300.-Habit of $P$. pectinatum, but more rigid, and the pinnæ distinctly separated.

197. P. lanigerum, Eaton; st. tufted, 1-2 in. 1., densely clothed with soft spreading reddish-brown hairs ; $f r$. flaccid, pendent, 6-9 in. $1 ., 1 \frac{1}{2}-2$ in. br., cut down to the rachis into erecto-patent blunt entire pinnoe 2-3 lin. br., the lower ones reduced; texture herbaceous; both sides thinly coated with soft hairs; 
veinlets fine, simple; sori $6-9$ in a row, on each side near the midrib.-Hk, Sp. 4. p. 189.

- Hab. Venezuela, Fendler, 212. - Desvaux's plant thus named appears to be $P$. cultratum, from which this differs by its distinctly separated pinnæ, the largest more than an inch long, narrowed gradually from the base to the point.

198. P. sporadolepis, Kze.; rhizome stout, wide-creeping, clothed with grey adpressed scales ; st. 4-6 in. l., wiry, slightly scaly ; fr. 6-12 in. l., 2-3 in. br.; pinno horizontal, bluntish, entire or slightly crenate, 2-3 lin. br., narrowed towards both ends, the lowest not reduced; texture subcoriaceous; rachis wiry, nearly naked ; under side with minute scattered scales; veinlets obscure, forked; sori copious.-Hk. Sp. 4. p. 212.

Hab. Columbia and Ecuador.-This comes near the next species, but is more slender, with narrower distant pinnæ and an ebeneous rachis.

199. P. plebeium, Schlecht. ; rhizome stout, wide-creeping, clothed with small grey scales ; st. 4-8 in. l., strong, erect, castaneous, nearly naked ; fr. 6-12 in. l., 3-6 in. br., ovate-deltoid; cut down nearly or quite to the rachis into spreading entire or obscurely crenated pinnoe $\frac{1}{4}-\frac{3}{8}$ in. br., the lowest not reduced ; texture subcoriaceous; rachis and under side with small scattered scales; veins obscure ; sori copious.-Hk. Sp. 4. p. 213.

Hab. Mexico to Peru.-Intermediate, as are the following species, in general habit between pectinatum and vulgare.

200. P. Hartwegianum, Hk. ; rhizome stout, wide-creeping, the scales linear, dark-brown ; st. 4 in. l., erect, naked ; fr. 1 ft. l., $3 \frac{1}{2}$ in. br., cut down to the rachis into linear-lanceolate obscurely crenated pinnoe, $\frac{1}{4}-\frac{3}{8} \mathrm{in}$. br., dilated at the base, the lower ones distinct from the others, the lowest pair deflexed; texture papyraceo-herbaceous; rachis slender, villose; both sides slightly hairy; veinlets distinct, twice forked; sori bright-yellow, oval, in two long rows.-Hk. Sp. 4 . p. 207.-Ic.t. 380 .

\section{Hab. Mexico, Hartweg, 415.}

201. P. biauriculatum, Hk. ; st. 4-6 in. l, stout, erect, villose upwards ; fr. 12-18 in. 1., 4-6 in. br. ; pinnce horizontal, 2 in. 1., $\frac{1}{4}$ in. br., the edge entire, both sides distinctly auricled at the base; texture subcoriaceous; rachis and both surfaces densely pubescent; veins immersed, indistinct; sori filling up nearly the whole space between edge and midrib.- $H k$. Ic, $t .121$.

Hab. Peru, Matthews.-Placed by Moore in Goniophlebium.

202. P. puberulum, Schlecht. ; rhizome wide-creeping, scaly ; st. 6-8 in. l., firm, naked, polished ; fr. 12-18 in. 1., 6-8 in. br.; lower pinnoe 3 in. 1. , $\frac{1}{2}$ in. br., the edge irregularly crenate, the base distinctly auricled on both sides; texture papyraceo-herbaceous; rachis and veins beneath pubescent; veins in slightly pinnated groups, the main vein prominent; sori in rows nearer the edge than midrib. - Hk. Sp. 4. p. 220. (in part).

Hab. Mexico and Guatemala.-Very near the last, but the position of the sori different.

203. P. subpetiolatum, Hk. ; rhizome stout, wide-creeping, densely clothed with ferruginous lanceolate scales; st. 4-6 in. 1 ., firm, stramineous ; fr. $1 \mathrm{ft}$. or more 1 ., 6-8 in. br. ; pinnoe 3-4 in. l., $\frac{1}{2}$ in. br., the point bluntish, the edge inconspicuously crenate, the lower ones rounded at the base, subpetiolate; texture papyraceo-herbaceous; rachis and both sides finely villose; veins subpinnate; sori in rows nearer the midrib than the edge.-Hk. Sp. 4. p. 220. 
Hab. Mexico, Guatemala, and Cuba.-The Mexican P. subserratum, M. \& G., is probably the same, but in our specimens from Mettenius the fronds are much more elongated, and the pinnæ more numerous.

204. P. sororium, H. B. K. ; rhizome stout, wide-creeping, densely clothed with small pale-brown scales; st. 6-12 in. 1., firm, erect, naked ; fr. 1-2 ft. 1., 6-9 in. br.; lower pinnœ the largest, sessile, 4-6 in. 1., $\frac{1}{2}-\frac{3}{4}$ in. br., the apex acuminate, the edge entire or obscurely undulated; texture papyraceo-herbaceous ; rachis and both sides naked; veins fine, very distinct, pinnated; sori in distinct rows nearer the midrib than the edge.-Hk. Sp. 4. p. 219.

Hab. Cuba and Mexico southward to Peru.-According to Mettenius, Goniophlebium elatum, Fée, is a form of this with the veins sometimes united.

205. P. fraternum, C. \& S. ; rhizome wide-creeping, the scales ovate-acuminate, bright ferruginous ; st. 4-8 in. 1., firm, erect, naked ; fr. 12-18 in. 1., 6-9 in. br., lower pinnoe 1 in. apart, 4-5 in. l., narrowed at both ends, the edge obscurely crenated ; texture subcoriaceous; both sides naked; veins close, pinnate ; sori medial, uniserial, slightly immersed.-Mett. Pol. p. 63. P. Henchmanni, J. Sm.

Hab. Mexico.-Mettenius describes a closely allied $P$. harpophyllum, Zenk., from the Neilgherries, with which we are not acquainted. Goniophl. revertens, Fée, appears to be a form with the groups of veins sometimes joined.

206. P. legionarium, Baker; st. 6 in. or more 1., firm, erect, glossy, naked ; fr. $1 \frac{1}{2}-2 \mathrm{ft}$. l., $1 \mathrm{ft}$. or more br.; lower pinnoe the largest, sessile, 6-8 in. $1 ., \frac{1}{2}-\frac{3}{4}$ in. br., broadly crenate, the base rounded; texture herbaceous; both sides finely villose ; veinlets in pinnated groups of $2-3$ on a side; sori large, in long distinct rows nearer the midrib than the edge.-P. macrodon, Hk. $S p .4 . p .218$. (non Reinv.).

Hab. Guatemala, Saloin.

207. P. tenellum, Forst. ; rhizome wide-climbing, woody, scaly when young ; st. 2-3 in. l., firm, nearly naked, jointed near the base ; fr. pendent, 1-2 ft. or more 1., 2-4 in. br. ; pinnoe 2-3 in. l., $\frac{1}{2}$ in. br., narrowed to both ends, entire or obscurely crenated; texture papyraceo-herbaceous ; rachis and both sides naked; veins 2-3 forked; sori in rows near the edge.-Hk. Sp. 4.p.217. Arthropteris, J. Sm.

Hab. Australia, New Zealand, and adjacent islands.-A very distinct species.

$$
\text { ***** Fronds bipinnatifid or bipinnate. Sp. 208-219. }
$$

208. P. hymenophylloides, Kaulf.; rhizome fibrous, very slender ; st. 1 in. or less 1., densely tufted, very slender; fr. 2-4 in. l., $\frac{1}{4}-\frac{3}{8}$ in. br.; pinnoe close, usually dimidiate, cut down to a broadly-winged rachis into a few small oblong lobes; texture pellucido-herbaceous; rachis and both sides finely glandular; veinlets 1 to each lobe; sori terminal.-Hk. Sp. 4. p. 228. Adenophorus, Hk. \& Gr. 1c.t. 176.

Hab. Sandwich Isles and Sumatra.-A very distinct species, resembling a Hymeno. phyllum in habit and texture.

209. P. fallax, Schlecht; rhizome slender, wide-creeping, much-branched, clothed with fine brown tomentum ; st. distant, slender, $\frac{1}{2}-1$ in. l., nearly naked ; fr. 1-1 $\frac{1}{2}$ in. l., $\frac{1}{2}$ in. br., with a few distinct pinnoe on each side, the lowest the largest and deeply pinnatifid with linear lobes ; texture coriaceous ; under surface with minute scattered scales; sori large, prominent, often 1 only to a pinna.$H k$. Sp. 4. p. 215.

Hab. Mexico.-Fronds often more than an inch apart on a long thread-like rhizone. 
210. P. tenuisectum, Blume ; st. tufted, short, wiry, 1-2 in. l., clothed with soft spreading hairs ; fr. 6-9 in. $1 ., 1 \frac{1}{2}-2$ in. br. ; pinnoe close, 2 lin. br., cut down to a narrow rachis into linear very regular erecto-patent lobes; texture subcoriaceous; rachis erect, straight, villose; both sides naked; veinlets simple, immersed, 1 to each lobe ; sori much broader than the lobes, placed at their base. -Hk. Sp. 4. p. 227. (in part).

Hab. Java.

211. P. myriophyllum, Mett.; st. flexuose, wiry, 4-6 in. l., densely clothed with long soft spreading brown hairs; fr. flaccid, pendent, $1 \mathrm{ft} .1 ., 3 \mathrm{in}$. br.; pinnoe close, flexuose, $\frac{1}{4}$ in. br., cut down to a narrow rachis into linear-subulate lobes, the lower ones distant and shorter ; texture subcoriaceous ; rachis and under side slightly villose; veinlets simple, immersed, 1 to each lobe; sori broader than the lobes, placed at their base. P. tenuisectum, Hk. Sp. 4.p.227. (in part). 2nd Cent.t. 21.

Hab. Peru, Lechler, 2567.- Very near the last, but different in habit, with the lobes of the pinnæ twice as long and not nearly so close and regular.

212. P. achilleoefolium, Kaulf.; st. tufted, wiry, 1 in. or less 1., clothed with

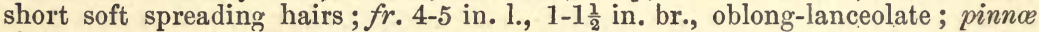
close, erecto-patent, deeply pinnatifid with linear lobes, lower pinnæ gradually reduced; texture coriaceous; rachis and under surface slightly villose; veinlets immersed, forked, 1 to each lobe ; sori copious.-Hk. Sp. 4. p. 225.

Hab. Ecuador and Brazil.

213. P. longisetosum, Hk.; st. 2-3 in. 1., slender, deciduously villose ; fr. flaccid, pendent, 6-8 in. 1., 2 in. br., oblong-lanceolate, the pinnoe close, erectopatent, linear, about 1 in. 1., 2 lin. br., deeply pinnatifid, with blunt rounded lobes, the base decurrent; texture papyraceo-herbaceous; both sides and rachis thinly clothed with long spreading hairs; veinlets simple, one to each lobe; sori copious.-Hk. Sp. 4. p. 225. t. 278. A.

Hab. Andes of Ecuador, Jameson, 97.

214. P. funiculum, Fée; rhizome wide-creeping, wiry, slender, naked ; st.

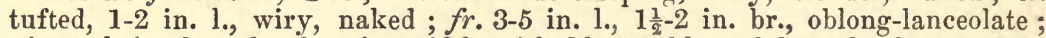
pinnoe $\frac{1}{8}$ in. br., deeply pinnatifid, with blunt oblong lobes, the lowest very small; texture papyraceo-herbaceous; rachis and both sides naked; veinlets simple, 1 to each lobe ; sori small, yellowish.-Hk. Sp. 4. p. 226.

Hab. Cuba, Linden, Wright.

215. P. gracile, Hk. ; st. 3-4 in. l., tufted, slender, wiry, naked ; fr. flaccid, pendent, 6-9 in. 1., $\frac{1}{2}-1$ in. br. ; pinnoe distinct, $\frac{1}{4}-\frac{1}{2}$ in. 1., 1 lin. or rather more br., deeply pinnatifid, with broad blunt lobes; texture subcoriaceous; rachis and both sides naked; veins immersed, obscure; sori 1 to each lobe.-Hk. Sp. 4. p. 224. Hk. \& Gr.t. 222.

Hab. Andes of Peru, Cruckshanks.

216. P. tamariscinum, Kaulf. ; rhizome stout, creeping, scaly ; st. $2-3$ in. 1.,

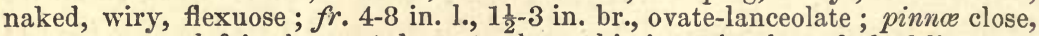
erecto-patent, $\frac{1}{4}-\frac{3}{8}$ in. br., cut down to the rachis into simple or forked linear or oblong lobes; texture subcoriaceous; both surfaces naked; veinlets 1 to each lobe; sori copious, placed near the apex of the lobes.-Hk. Sp. 4. p. 228. Adenophorus, Hk. \& Gr. Ic. $t .175$.

Hab. Sandwich Isles, Tahiti, Malay Isles.-A.tripinnatifidus, Gaud., is a form with 
forked or subpinnatifid lobes; P. Hillebrandii, Hk. Sp. 4. p. 228, is probably a luxuriant form of this species; the pinnæ are $3 \mathrm{in.}$ l., and the sori sometimes 2 to a lobe, and not quite terminal.

217. P. athyrioides, Hk. ; st. 2-3 in. 1., firm, wiry, slightly hairy ; fr. 8-12 in. l., 2 in. br. ; pinnce close, linear-lanceolate, $\frac{1}{4}$ in. br., cut] halfway down to the rachis into close oblong lobes; lower pinnæ reduced very gradually; texture subcoriaceous; rachis firm, slightly villose; both sides nearly naked; veinlets simple, 1 to each lobe ; sori oblong, copious.-Hk. Sp. 4. p. 224. t. 277.B.

Hab. Peru, Matthews, 1103.

218. P. murorum, Hk.; rhizome stout, wide-creeping, densely clothed with linear scales; st. 4-8 in. l., wiry, glossy, naked; fr. 4-8 in. 1., 2-3 in. br., ovate-lanceolate; pinnoe quite distinct, the lower ones varying from linear and nearly entire to lanceolate ( $\frac{3}{8}$ in. br.) and deeply pinnatifid ; texture coriaceous ; veins hidden; under surface thinly coated with scales; sori large, in two long rows.-Hk. Sp. 4. p. 216. Ic.t. 70.

Hab. Andes of Columbia and Ecuador.

219. P. microphyllinum, Mett.; st. 3-4 in. 1., slender, flexuose, naked; fr. pendent, 3-4 in. 1., $\frac{3}{4}-1$ in. br.; pinnce erecto-patent, flexuose, $\frac{1}{8}$ in. br., cut down to the rachis into close regular obovate lobes $\frac{1}{2}$ lin. br. ; texture subcoriaceous; rachis and under side slightly villose ; veinlets immersed, 1 to each lobe; sori 1 to each lobe.

Hab. Peru, Lechler.

\section{***** Fronds tri-quadripinnatifid. Sp. 220-224.}

220. P. millefolium, Blume; st. 1-3 in. 1., clothed with spreading ferruginous hairs ; fr. 8 in. l., $1 \frac{1}{2}$ in. br. ; pinnoe $\frac{3}{4}$ in. l., ovate-lanceolate, cut down to the rachis into linear-oblong or spathulate toothed or pinnatifid pinnl. $\frac{1}{4}$ in. 1 . ; texture firm, subcoriaceous ; under surface slightly hairy; veinlets simple or forked ; sori terminal.-Mett. Poly. p. 54.

Hab. Java, Zollinger, 1723, fide Mettenius.

221. P. onustum, Hk. ; rhizome stout, wide-creeping, densely clothed with grey adpressed scales ; st. 4-6 in. l., wiry, erect, naked or slightly scaly ; $f$. 6-12 in. 1., 3-5 in. br., ovate ; lower pinnce lanceolate or subdeltoid, cut down to a winged rachis into pinnatifid rhomboidal lobes; texture thick, coriaceous; under surface with scattered scales; sori large, prominent, often 1 to each lobe.Hk. Sp. 4. p. 216 . Ic. t. 749.

Hab. Andes of Columbia and Ecuador.

222. P. Friedrichsthalianum, Kze. ; rhizome stout, wide-creeping, clothed with grey adpressed scales; st. $3-4$ in. 1. , wiry, erect, deciduously scaly ; fr. flaccid, 12-18 in. l., 3-4 in. br.; pinnce very numerous, imbricated, deltoid, the largest 2 in. l., 1 in. br., cut down to the rachis into deeply pinnatifid blunt linear pinnl. with short blunt lobes; rachis and under side densely scaly; sori small, 1 to each lobe. $-H k$. Sp. 4. p. 217.

Hab. Mexico and Guatemala:

223. P. dareoforme, Hk.; rhizome stout, wide-creeping, clothed with dense linear pale-brown scales ; st. 6-9 in. 1., naked, glossy ; fr. 12-18 in. l., 8-12 in. br.,

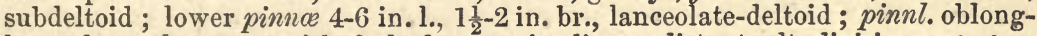
lanceolate, the segm. with forked or entire linear distant ult. divisions; texture 
herbaceous; rachis glossy, both sides naked; veins 1 to each division, not reaching the edge, but bearing the sori beneath the thickened apex.-Hk. Sp. 4 . p. 256. 2nd Cent. $t .24$.

Hab. Sikkim, Khasia, Moulmein.

224. P. subdigitatum, Blume; st. tufted, firm, $1 \mathrm{ft}$. or more 1., stramineous, naked or furfuraceous; $f r .2 \mathrm{ft}$. or more l., 12-18 in. br.; lower pinnoe the largest, 6-9 in. l., 3-4 in. br.; pinnl. lanceolate, often 2 in. 1., $\frac{3}{4}$ in. br., with close spreading ovate-lanceolate or rhomboidal segm., with blunt lobes or even again pinnate, obliquely truncate on the lower side; texture pellucido-herbaceous ; colour dark-green; veinlets 1 to each ult. lobe, not reaching the edge, and the copious sori terminal upon them.-P. davallioides, Mett. Hk. Sp. 4 . p. 256. Monachosorum, Kunze.

Hab. N. India (up to 7-8,000 ft.), Malay Peninsula and Isles.-A beautiful and wellmarked species.

§§§§§ Goniophlebium, Blume. Veins forming ample regular areole, each with a single distinct free included veinlet, the sori terminal on the latter, often in the costal areoloe only, but sometimes also in the second or even third row. TAB. 48. f. h. i. Sp. 225-263.

\section{* Under surface not at all or slightly scaly. Sp. 225-260.}

\section{+ Fronds simple. Sp. 225-228.}

225. P. (Gonioph.) vacciniifolium, F. \& L. ; rhizome slender, very widecreeping, densely clothed with grey or ferruginous fibrillose scales; fr. subsessile, dimorphous, entire, coriaceous, quite naked, the barren ones roundish or elliptical, obtuse, 1-2 in. l., $\frac{1}{4}-\frac{1}{2}$ in. br., the fertile ones linear or ligulate, with large uniserial sori.-Hk. Sp. 5. p. 35. Craspedaria, Link. Lopholepis, J. Sm.

Hab. Jamaica to Paraguay.

226. P. (Gonioph.) piloselloides, L. ; rhizome very wide-creeping, slender, scandent, clothed with squarrose fibrillose scales; fr. dimorphous, the barren ones oblong, entire, 1-3 in. l., $\frac{1}{2}-\frac{3}{4}$ in. br., the fertile ones narrower and longer, both on short ciliated stems; texture coriaceous; both sides naked or more or less scaly and hairy; sori large, uniserial, confined to the large costal areolæ.Hk. G. F.t. 18. - $\beta, P$. ciliatum, Willd. ; fertile fr. so narrow that the sori project beyond the edge. $-\gamma, P$. aurisetum, Raddi ; fr. small, sometimes nearly round, scaly, and especially the fertile ones on the back densely fulvo-villose. Hk. $S p$. 5. $p$. 33. Craspedaria, Fée. Lopholepis, J. Sm.

Hab. Common throughout Tropical America, including the West Indies.-Lopholepis, $J$. Sm., has the venation of Goniophlebium, with dimorphous fronds and a wide-trailing rhizome.

227. P. (Gonioph.) nummularium, Mett.; rhizome wide-creeping, slender, the scales linear-subulate, ferruginous; $f r$. distant, the barren ones suborbicular, $\frac{1}{2}-\frac{3}{4}$ in. l., nearly as broad, on short slender stems ; texture coriaceous; both sides naked; veins immersed, very obscure ; sterile $f r .3-4$ in. $1 ., \frac{1}{8}$ in. br., on stalks nearly as long.-Hk. Sp. 5. p. 39. Crypsinus, Presl.

Hab. Philippines, Cuming, 121.

228. P. (Gonioph.) glaucophyllum, Kze. ; rhizome firm, wide-creeping, deciduously scaly ; st. scattered, $2-6$ in. l., firm, erect, glossy ; fr. uniform, oblonglanccolate, entire, 4-10 in. 1., 1-2 in. br., the point acuminate, the base rounded ; texture coriaceous; both sides naked; main voins $1 \frac{1}{2}-2$ lines apart, with 4-6 
areolæ in a series between the midrib and edge, with one sorus in each.-Hk. $S p$. 4. $p .18$.

Hab. West Indies and Columbia to Ecuador; Guinea Coast. $-P$. semipinnatifidum, Mett., is a variety with larger sori, and the frond not at all glaucous, and sometimes deeply lobed.

\section{** Fronds pinnatifid. Sp. 229-231.}

229. P. (Gonioph.) Mattherosii, Mett.; st. 4-6 in. 1., clothed with deciduous soft spreading brown hairs ; fr. pendent, $6-18$ in. $1 ., 2-5$ in. br., cut down nearly to the rachis into numerous entire pinnoe 1-3 in. 1., 2-3 lin. br., with generally a broad rounded sinus hetween them; texture coriaceous; under surface elothed with hairs like those of the stem; veins obscure; areoloe and sori in a single series.-Hk. Sp. 5. p. 20.

Hab. Andes, from Columbia to Peru.-A well-marked species, characterized by its very pendulous habit and coriaceous texture.

230. P. (Gonioph.) niponicum, Mett. ; st. stramineous ; fr. 5 in. l., $1 \frac{1}{4}$ in. br., sublanceolate, cut down nearly to the rachis into about 20 pairs of spreading linear-oblong entire obtuse pinnoe, of which the lowest are free, slightly reduced and deflexed; texture papyraceous; both sides densely pubescent; areoloe in a single series; sori unknown.-Mett. Fil. Ind. 2. p. 222.

Hab. Japan, Siebold, Buerger.

231. P. (Gonioph.) amoenum, Wall.; rhizome stout, densely clothed with spreading fibrillose dull-brown scales; st. 6-12 in. 1 ., firm, erect, naked; fr. 1-2 ft. l., 6-12 in. br., cut down nearly to the rachis into numerous entire or slightlytoothed pinnoe 3-6 in. l., $\frac{1}{4-3}$ in. br., narrowed gradually from the base to an acute point, the lowest pair deflexed ; texture firm, herbaceous; both sides naked, or the rachis beneath rather scaly ; areoloe and sori in a single series.Hk.Sp. 5. p. 24.

Hab. N. India (up to $10,000 \mathrm{ft}$.) and Formosa.

$$
\text { *** Fronds pinnate. Sp. 232-260. }
$$

\section{A. Pinnoe close, dilated and casually confluent at the base. Sp. 232-244.}

232. P. (Gonioph.) trilobum, Cav. ; rhizome stout, the scales ovate-acuminate, reddish ; st. $4-6$ in. l., firm, erect, glossy ; fr, 6-12 in. l., subdeltoid, with a linear entire or slightly toothed terminal pinna, and 1-3 similar distant ones on each side, the lowest 3-4 in. $1 ., \frac{3}{8}-\frac{3}{4}$ in. br., sometimes forked ; texture subcoriaceous; rachis and both sides naked; sori and areoloe uniserial, the former oblong, quite immersed.-Hk. Sp. 5. p. 22.

Hab. Chili.

233. P. (Gonioph.) ensiforme, Thunb. ; rhizome stout, the scales linear, ferruginous, fimbriated; st. 4-6 in. l., stout, erect, naked ; fr. 6-12 in. l., 4-6 in. br., with a ligulate terminal pinna 3-4 in. 1 ., $\frac{1}{4}$ in. br., and several distant similar erecto-patent ones on each side, which are decurrent at the base; texture very thick; both sides naked; veins immersed; areoloe uniserial, the sori large, distinctly immersed.-Hk. Sp. 5. p. 23.

Hab. Cape Colony and Natal.

234. P. (Gonioph.) californicum, Kaulf. ; rhizome wide-creeping, the scales spreading, lanceolate, ferruginous ; st. $3-6$ in. l., firm, erect, naked ; $f r .6-9$ in. 1. , 3-5 in. br., oblong-deltoid, cut down nearly or quite to the rachis into entire or finely-toothed pinnce $1 \frac{1}{2}-2 \frac{1}{2}$ in. 1 ., $\frac{3}{8}-\frac{1}{2}$ in. br., lowest not reduced; texture papyraceo- 
herbaceous; groups of veins usually joining once; sori large, in single rows near the midrib.-Hk. Sp. 5. p. 18. (not Mett.).

Hab. California.- $P$. intermedium, H. \& A., is a form with the groups of veins uniting but rarely. This and the next are very like $P$. vulgare in general habit.

235. P. (Gonioph.) Scouleri, Hk. \& Gr. ; rhizome stout, wide-creeping, the scales lanceolate, spreading, dull-brown; st. 3-4 in. l., firm, erect, naked ; fr. 6-12 in. l., 4-8 in. br., cut down to the rachis into close blunt subentire pinno $\frac{1}{2}-\frac{3}{4}$ in. br. ; texture very coriaceous; both sides naked; groups of veins uniting once; sori very large, in a single row close to the midrib.-Hk. Sp. 5. p. 19. H. \& Gr.t. 56. P. pachyphyllum, Eaton.

Hab. Vancouver's Island, Oregon, British Columbia.-The specimens figured are very small compared with those of Professor Eaton.

236. P. (Gonioph.) patens, J. Sm.; rhizome stout, the scales fibrillose, brightferruginous, crisped; st. 2-4 in. l., firm, stramineous, naked ; fr. 6-12 in. 1., subdeltoid, with a linear entire terminal pinna and 3-4 similar ones on each side, which are 3-5 in. l., $\frac{3}{8}-\frac{1}{2}$ in. br., narrowed gradually from the base to the apex; texture subcoriaceous; both sides naked; areoloe and sori in a single series.Hk. Sp. 5. p. 23.

Hab. Panama, Seemann, 25.

237. P. (Gonioph.) transtucens, Kunze ; rhizome stout, the scales large, lanceolate, ferruginous ; st. 4-6 in. 1., firm, erect, glossy ; fr. 8-12 in. 1., 6-8 in. br., subdeltoid, with an irregularly crenated terminal pinna 3-4 in. $1 ., \frac{1}{2}-\frac{3}{4}$ in. br., and several close similar ones on each side which are sonietimes connected at the base; texture papyraceo-herbaceous; rachis and both sides naked; veins distinct, the areolæ in one principal row, with the sori some distance from the midrib.Hk. Sp. 5. p. 22.

Hab. Juan Fernandez.

238. P. (Gonioph.) lachnopus, Wall. ; rhizome wide-creeping, densely clothed with spreading black bristly scales; st. 2-4 in. l., slender, naked; fr. flaccid, 12-18 in. l., 3-4 in. br., cut down nearly or quite to the rachis into spreading slightly-toothed pinnoe $1 \frac{1}{2}-2$ in. 1. , $\frac{1}{4}$ in. br. ; texture papyraceo-herbaceous ; both sides naked or the rachis beneath slightly scaly; areoloe and sori in a single series.-Hk. Sp. 5. p. 25. 2nd Cent.t.52.

Hab. N. India, up to $11,000 \mathrm{ft}$.

239. P. (Gonioph.) pubescens, Hk. \& Gr.; rhizome wide-creeping, the scales lanceolate, spreading; st. 4-8 in. l., naked, stramineous ; fr. 6-12 in. 1., 3-4 in. $\mathrm{br}$., cut down to the rachis into numerous spreading nearly entire pinnce $1 \frac{1}{2}-2$ in. l., $\frac{3}{8}-\frac{1}{2}$ in. br., the lowest pair deflexed, rather reduced; texture subcoriaceous; rachis and under side slightly glandular and hairy; veins fine; areoloe and sori generally in a single series.-Hk. Sp. 5. p. 19. Hk. \& Gr.t. 182.

Hab. Andes of Peru.

240. P. (Gonioph.) plesiosorum, Kunze; rhizome stout, the scales ovate or lanceolate, dense, reddish ; st. 2-4 in. l., firm, erect, glossy ; fr. 6-12 in. l., 4-6 in. br., cut down to the rachis into close entire pinnoe $\frac{3}{8}-\frac{1}{2} \mathrm{in}$. br., narrowed gradually upwards, dilated slightly on both sides at the base ; texture herbaceous; areotoe usually in two rows, the prominent sori in a single row close to the midrib.-P. loriceum, Hk. $S p .5 . p .21$. (in part). P. rhodopleuron, gonatodes and colpodes, $K \approx e$.

Hab. Mexico to Venezuela.-Differs from P. loriceum by its shorter and broader frond, 
more herbaceous texture, and larger almost constantly uniserial sori. The Mexican $P$. appendiculatum, Klotzsch (Hk. Fil. Ex. t. 87), non Wallich, is apparently a form of this more delicate in texture, with the veins and rachis tinged with bright-red.

241. P. (Gonioph.) lasiopus, Klotzsch; rhizome stout, the scales dense, squarrose, ovate-acuminate, dark-brown; st. 4-6 in. 1., firm, erect, stramineous; fr. 8-12 in. 1., 4-5 in. br., cut down to the rachis into close bluntish entire pinnce $\frac{1}{2}$-in. br., slightly dilated at the base; texture herbaceous; both sides finely villose ; sori prominent, uniserial.-Hk. Sp. 5. p. 21.

Hab. Venezuela.-Very near the preceding.

242. P. (Gonioph.) Catharince, F. \& L. ; rhizome wide-creeping, the scales spreading, dark-brown, ovate-acuminate ; st. 4-6 in. 1., erect, naked, glossy ; fr. 6-12 in. l., 3-5 in. br., cut down to the rachis into close blunt spreading subentire pinnoe $1 \frac{1}{2}-3$ in. $1 ., \frac{1}{4}-\frac{1}{2}$ in. br., the lowest pair shorter and deflexed; texture subcoriaceous, colour dark-green; both sides naked; main veins $\frac{1}{8}$ in. apart, with generally two areolæe between the edge and midrib; sori large, in single rows close to the midrib.-Hk. Sp. 5. p. 20. (not J. Sm.).

Hab. Brazil.-P. Wageneri, Mett., from Columbia, is said to differ from this by its linear frond and very numerous pinnæ.

243. P. (Gonioph.) loriceum, L.; rhizome stout, wide-creeping, the scales black in the centre, with a scariose border ; st. 4-6 in. l., sometimes ebeneous; fr. 12-18 in. l., 4-6 in. br. ; pinnoe close, 2-3 in. l., $\frac{3}{8}-\frac{1}{2}$ in. br., subentire, sometimes falcate, dilated at the base on the upper side; texture subcoriaceous; rachis and both sides usually naked; veins very distinct, the areolæ generally in two distinct rows, with the small sori often in both. $-H k$. Sp. 5. p. 21.- $\beta$, $P$. latipes, L. \& F. t. 10 ; larger, as coriaceous but less rigid ; pinno much dilated on both sides at the base; veins less distinct; scales ovate, dense, dullbrown.-P. Catherinæ, J. Sm. (not $L . \& F$.) P. harpeodes and vacillans, Link (fide Moore).

Hab. Mexico and West Indies to Brazil and Chili.-From this we cannot distinguish clearly $P$. dasypleuron and Falcaria (Kze.) and latum (Raddi). P. pectinatum (J. Sm.) is smaller and more delicate, with close narrow acute pinnæ, densely fibrillose bright ferruginous scales and constantly uniserial sori. P. punctulatum, Hk. Ic. t. 720 (P. Calaguala, Fée), resembles this in its slender pectinate habit and uniserial sori, but is more rigid in texture.

244. P. (Gonioph.) eleutherophlebium, Mett.; rhizome creeping, the scales dense, ovate-lanceolate, brown ; st. 4 in. l.; fr. 7 in. $1 ., 4$ in. br., ovate-deltoid, cut down nearly to the rachis above, quite below, into linear-oblong obtuse crenate or irregularly pinnatifid pinnce 2 in. 1., $\frac{1}{4}$ in. br., with blunt rounded lobes ; texture coriaceous ; sori large, uniserial.-Mctt. Polyp. $p .75$.

Hab. Venezuela, Funck and Schlim, 1102.-We have not seen this, and are indebted to Mettenius for the description.

\section{B. Most of the pinnoe distinctly separated at the base. Sp. 245-260.}

245. P. (Gonioph.) chacapoyense, Hk. ; st. 6-8 in. l., firm, naked, reddish ; fr. $1 \mathrm{ft} .1$., 2-3 in. br., with a linear entire terminal piona $2-3 \mathrm{in.} 1 ., \frac{1}{4}$ in. br., and several smaller blunt close erecto-patent similar ones on each side ; texture subcoriaceous; rachis and under side slightly villose; areoloe and veins in a single row.-Hk. Sp. 5. p. 29. t. 281.

Hab. Peru, Mutthews, 3279.

246. P. (Gonioph.) surrucuchense, Hk. ; rhizome stout, densely clothed with spreading grey lanceolate scales; st. 6-12 in. l., firm, naked, glossy ; fr. 1-2 ft. 
1., 8-12 in. br. ; pinnoe numerous, erecto-patent, 4-6 in. 1., $\frac{1}{4}-\frac{3}{4}$ in. br., the edge entire, the base subcuneate; texture coriaceous; rachis and both sides naked; areolee and prominent sori in a single series.-Hk. Sp. 5. p. 30. Ic. t. 69.

Hab. West Indies to Ecuador.

247. P. (Gonioph.) plectolepis, Hk.; rhizome stout, the scales squarrose, lanceolate, ferruginous; st. 6-12 in. l., firm, stramineous, glossy ; $f$ r 1 1-2 ft. l., $1 \mathrm{ft}$. br. ; pinnoe numerous, spreading, 4-6 in. $1 ., \frac{1}{2}-\frac{5}{8}$ in. br., narrowed gradually from the base to the point, the edge distinctly crenate ; texture papyraceoherbaceous; rachis and both sides finely pubescent; areolee and sori in a single series.-Hk. Sp. 5. p. 30.

Hab. Mexico and Guatemala.

248. P. (Gonioph.) chnoodes, Spreng. ; rhizome stout, densely clothed with soft spreading dull-brown subulate scales ; st. 4-6 in. l., erect, slender, naked ; fr. drooping, 1-2 ft. 1., 4-9 in. br., cut down to the rachis into distinct entire falcate opposite pinnoe $2-4$ in. $1 ., \frac{1}{2}-\frac{3}{4}$ in. br., cordate at the base; texture papyraceo-herbaceous; rachis and both sides glandular and pubescent; areoloe and sori in 2-3 series.-P. dissimile, Hk. Sp. 5.p. 25.

Hab. West Indies and Venezuela.-The synonym of $P$. dissimile, Linn., is doubtful ; Schkuhr and Grisebach refer it to our P. sororium.

249. P. (Gonioph.) persicaefolium, Desv.; rhizome wide-creeping, the scales small, linear, dull-brown; st. 6-12 in. l., firm, naked, subebeneous ; $f r .2-3 \mathrm{ft}$. l., 8-12 in. br., decurved ; pinnce distant, 4-6 in. 1., $\frac{3}{4-1} \mathrm{in}$. br., the apex acuminate, the edge slightly toothed, the base narrowed gradually and the lower ones distinctly stalked ; texture subcoriaceous; rachis and both sides naked; areoloe in about 3 rows, the sori uniserial, distinctly immersed. P. cuspidatum, Blume. Hk.Sp. 5. p. 32.

Hab. Java. - Very near to $P$. subauriculatum, from which it may be best known by the pinnæ being narrowed at the base, and the lower ones distinctly stalked. P. grandidens, Kze., appears to be a more deeply toothed form.

250. P. (Gonioph.) puberulum, Baker; rhizome wide-creeping, the scales dense, subulate, reddish-brown ; fr. 18 in. $1 ., 7-8$ in. br. ; pinnce $3-4$ in. $1 ., \frac{1}{2}$ in. br., the edge deeply crenated, sometimes auricled at the base on the upper side, all sessile, the upper ones more or less adnate; texture herbaceous; rachis and both sides rather densely clothed with soft whitish hairs; areoles in 2-3 rows, the sori uniserial.-Gonioph. molle, Beddome, Fil. Brit. Ind. t. 206.

Hab. Burmah, Rev. C. S. Parish.

251. P. (Gonioph.) subauriculatum, Blume; rhizome wide-creeping, clothed with small dull-brown linear scales; st. 6-12 in. l., firm, erect, naked, glossy ; fr. 2-3 ft. 1., 8-12 in. br., oblong-lanceolate, decurved ; pinnce 4-6 in. 1., $\frac{1}{2}-1$ in. br., the edge entire or slightly toothed, sessile, the base rounded or even auricled; texture herbaceous or subcoriaceous; rachis and both sides naked; areoloe in 2-3 rows, the sori uniserial, distinctly immersed. $-H k . S p .5 . p .32$. P. argutum, Wall, Hk. l.c.

Hab. N. India (up to $8,000 \mathrm{ft}$.), Malaccas, Philippines, Fiji, Samoa, N. Caledonia, Queensland.-G. serratifolium, Brack., is a deeply-toothed herbaceous form, and $P$. Reinwardtii, Kunze, is crenate instead of dentate.

252. P. (Gonioph.) verrucosum, Wall. ; st. $1 \frac{1}{2}-2$ ft. l., firm, erect, terete, naked ; fr. 3-4 ft. l., $1 \mathrm{ft}$. br.; pinnce numerous, distant, 6-8 in. $1 ., \frac{1}{2}-\frac{3}{4}$ in. br., quite entire ; texture coriaceous; rachis and both sides naked or slightly hairy; areolce in 
several rows ; sori confined to the inner one, firm, immersed, so as to form very distinct papillæ on the upper side. $-H k . S p .5 . p .31 .-G . F . t .41$.

Hab. Philppines and Malaccas.-This and the two preceding form the genus Schellolepis of J. Smith.

253. P. (Gonioph.) Korthalsii, Mett. ; rhizome wide-creeping, the scales small, reddish-brown, subulate, ciliated ; st. 5-6 in. l., smooth, reddish-brown ; fr. 12-15 in. l., $1 \mathrm{ft}$. br. ; pinnoe lax, spreading, sessile, 5-7 in. $1 ., 1-1 \frac{1}{2}$ in. br., lanceolate-acuminate, the base cuneate, the edge slightly crenate; texture subcoriaceous; rachis and both sides quite naked; areoloe in 3-4 and the sori in 1-3 rows.-Mett. Fil. Ind. 2.p. 223.

Hab. Sumatra, Korthals.-Differs from the three preceding by its multiserial sori. $P$. Lampongense, Zoll., may be the same, but the pinnæ are said to be cordate or even subauriculate at the base.

254. P. (Gonioph.) attenuatum, H.B.K.; rhizome stout, the scales grey, ovate-acuminate, spreading; st. firm, erect, 6-12 in. l., glossy, naked; fr. 1-2 $\mathrm{ft}$. 1., often $1 \mathrm{ft}$. br., cut down to the rachis into numerous erecto-patent entire pinnoe 4-6 in. 1., $\frac{3}{8}-\frac{3}{4}$ in. br., which are dilated at the base ; texture subcoriaceous ; rachis and both sides naked; areoloe in 3 or 4 rows; sori slightly immersed in 1 or 2 rows.-Hk. Sp. 5. p. 24. (non $R . B r$.$) . P. xiphophoron and gladiatum,$ Kze.

Hab. West Indies to Brazil and Ecuador.-Very near the next, with which Grisebach unites it. The pinnæ are closer, narrower, and dilated, sometimes confluent at the base, and the sori mostly uniserial.

255. P. (Gonioph.) neriifolium, Schk.; rhizome stout, the scales grey, lanceolate, spreading; st. 6-12 in. l., firm, glossy; fr. 1-3 ft. l., $1 \mathrm{ft}$. or more br., with an entire or slightly sinuated terminal pinna 4-8 in. l., $\frac{1}{2}-1 \frac{1}{2}$ in. br., and numerous similar ones on each side, which are narrowed at the base, the lowest sometimes stalked; texture coriaceous; rachis and both sides naked; veins beneath prominent; areoloe in 2-6 rows between the midrib and edge, the immersed sori 1-3 serial.-Hk. Sp. 5. p. 28.

Hab. West Indies and Mexico to Brazil and Peru.-G. intermedium and acuminatum, Fée, Fil. Ant. t. 18-19, appear to belong here. Apparently this is P. brasiliense, Lam., and if so, that name has priority.

256. P. (Gonioph.) guatemalense, Hk.; st. 6-12 in. l., naked, stramineous ; fr. 2-3 ft. l., $1 \mathrm{ft}$. or more br., with an entire terminal pinna 6-8 in. $1 ., 1-1 \frac{1}{4}$ in. br., and several similar ones on each side, the upper ones narrowed but adnate at the base; texture subcoriaceous; rachis and both sides naked; areoloe in series of 3-4, the large uniserial sori in the first or second row.-Hk. $S p .5 . p .29$. Phlebodium inæquale, Moore.

Hab. Guatemala, Skinner.-In this there is occasionally a costal areole inside the one that contains the sorus, but the free veinlet which bears the latter is always simple.

257. P. (Gonioph.) cordatum, Kze.; rhizome stout, clothed with spreading linear scales; st. $1 \mathrm{ft}$. or more l., strong, quite naked; fr. $1 \frac{1}{2}-2 \mathrm{ft} .1 ., 8-10 \mathrm{in}$. br.; pinnoe in numerous opposite pairs, 4-5 in. 1., $\frac{3}{4}-1$ in. br., the edge entire, the point acute, the base very cordate; texture coriaceous; rachis and both sides naked ; areoloe irregular except the inner series; sori in 1-2 rows, immersed.Mett. Polyp. p. 85.

Hab. Peru.

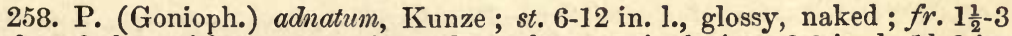
ft. $1 ., 1 \mathrm{ft}$. br., with an entire oblong-lanceolate terminal pinna 6-9 in. 1 ., $1 \frac{1}{2}-2$ in. 
br., and several similar lateral ones on each side, the upper ones broadly adnate to the rachis at the base; texture subcoriaceous; rachis and both sides naked; main veins $\frac{1}{8}$ in. apart; areolae and sori in rows of 4-6 between the midrib and edge.-Hk. Sp. 5. p. 27.

Hab. Guatemala to Guiana and Galapagos.-Differs from the next by its more herbaceous texture and adnate upper pinnæ. P. Richardi, Klotzsch, is a pubescent form.

259. P. (Gonioph.) fraxinifolium, Jacq. ; rhizome stout, clothed with deciduous, spreading, dark-brown, linear-subulate scales; st. 1-2 ft. l., firm, erect, naked; fr. 2-4 ft. 1., 12-18 in. br., with numerous distinct pinnoe on each side, which are 4-9 in. 1., 1-2 in. br., the apex acuminate, the edge entire, the base narrowed; texture subcoriaceous; both sides naked; main veins $\frac{1}{8}$ in. apart ; areoloe and sori in series of 6-8.-Hk. Sp. 5. p. 26.

Hab. Columbia to Brazil and Peru.-P. rhizocaulon, Willd., is a wide-scandent variety, thinner in texture than the ordinary form, and thus intermediate between it and the preceding. This includes several species of cultivators.

260. P. (Gonioph.) menisciifolium, L. \& F. ; st. 1-2 ft. l., firm, erect, naked ; fr. 2-3 ft. l., $1 \mathrm{ft}$. or more br., with an entire terminal pinna $6-9$ in. $1 ., 1 \frac{1}{2}-2$ in. br., and numerous similar ones on each side, all narrowed to the base; texture subcoriaceous; ractis and both sides naked; main veins $\frac{1}{8}$ in. apart; areoloe and sori in rows of about 4 , the latter immersed and prominent on the upper side.Hk. Sp. 5. p. 27.

Hab. Panama, Trinidad, Brazil.

** Under surface densely clothed with small scales. Lepicystis, J. Sm. Sp. 261-263.

261. P. (Gonioph.) incanum, Sw.; rhizome woody, wide-creeping, the scales small, dense, dull-brown, fibrillose ; st. 1-4 in. l., firm, erect, furfuraceous ; fr. 2-4 in. $1 ., 1-1 \frac{1}{2}$ in. br., cut down to the rachis into subdistant spreading entire blunt pinno 1-1 $\frac{1}{2}$ lin. br., dilated at the base; texture coriaceous; under side densely scaly ; veins united or frequently free; sori uniserial,-Hk. Sp. 5. p. 209. Р. Eckloni, Kze. Hk. l. c.

Hab. Ohio to Uraguay and Chili ; Cape Colony, Natal, Zambesi-land.

262. P. (Gonioph.) lepidopteris, Kze.; rhizome stout, wide-creeping, densely clothed with grey or reddish scales; st. 1-4 in. l., rigid, erect, densely scaly; fr. 6-18 in. l., $1 \frac{1}{2}-3$ in. br., cut down to the rachis into horizontal entire pinnoe 2-3 lin. br., the lower reduced very gradually; texture very thick; both sides clothed, the lower very thickly, with ferruginous or white hairs and scales; veins hidden; sori copious. - Hk. Sp. 4. p. 212.- $\beta, P$. sepultum, Kaulf.; fr. ovatelanceolate; lower pinnoe scarcely reduced. $-\gamma, P$. rufulum, Presl; scales of rhizome bright reddish-brown; pinnae $\frac{3}{8}$ in. br., blunt, much twisted.

Hab. Mexico to Galapagos, Peru, and Rio Janeiro.

263. P. (Gonioph.) squamatum, L.; rhizome stout, wide-creeping, clothed with adpressed lanceolate scales; st. 6-12 in. l., rigid, erect, scaly ; fr. 6-12 in. 1. , 2-4 in. br., cut down nearly or quite to the rachis into entire bluntish pinnoe 1-2 in. 1., 1 $\frac{1}{2}-3$ lin. br., with a considerable space between them, dilated and often united at the base; rachis and under surface densely coated with minute membranous ovate-acuminate squarrose scales; veinlets obscure; sori large, copious.-Hk. Sp. 4. p. 209.

Hab. West Indies and Mexico to Peru.-P. tridens, Kze., from the Galapagos, appears to be a luxuriant state of this with forked pinnæ. 
§§§§§§§ Phlebodium, R. Br. Veins forming ample regular areolo, each with two or more distinct free included veinlets, which bear the sori on their united points, the costal series of areoloe being always destitute of sori. TAB. 48. fig. g. Sp. 264-266.

264. P. (Phleb.) nigripes, Hk. ; rhizome stout, the scales black and rigid, with a deciduous membranous ferruginous edge; st. nearly 1 ft. l., firm, erect, slightly scaly; fr. $1 \mathrm{ft}$. $1 ., 6-7$ in br., cut down nearly or below quite to the rachis into pinnoe $\frac{1}{2}-\frac{5}{8}$ in. br., which are slightly crenate towards the bluntish point; texture subcoriaceous ; under surface furfuraceous ; sori in single rows on each side the midrib.-Hk. Sp. 5. p. 17.

Hab. Venezuela, Fèndler, 247.

265. P. (Phleb.) aureum, L. ; rhizome stout, wide-creeping, densely clothed with bright ferruginous linear-subulate soft scales; st. 1-2 ft. 1., stout, erect, naked, glossy ; fr. 3-5 ft. l., 9-18 in. br., with a long linear-lanceolate terminal lohe, and cut throughout within $\frac{1}{4}-\frac{3}{4}$ in. of the rachis into numerous horizontal entire or slightly undulated later:al pinnoe 4-9 in. 1., about 1 in. br., with a rounded sinus between; texture subcoriaceous; both sides naked, slightly glaucous; areoloe copious, both the fertile and barren ones with free veinlets; sori irregularly 1-3 serial. $-\beta, P$. areolatum, H. B. K. ; fr. smaller, more coriaceous, very glaucous, the lobes closer, the sori uniserial and barren areolæ with no free veinlets.-P. sporalocarpum, Willd.- $\gamma, P$. pulvinatum, Link ; like $\beta$ in sori and venation, but the frond hardly at all glaucous and the terminal lobe very small.- $H k$. Sp. 5. $p .16$.

Hab. Florida and Mexico southward to Brazil, and reported by Dr. Mueller from A ustralia.-C. trilobata, Fée, is a dwarf form with ouly three lobes. A plant from Spruce (Andes of Ecuador, 5240), agreeing with the small forms of this with uniserial sori in habit and texture, has the sori usually terminal on a free veinlet in the costal areolæ, as in typical Goniophlebium, but occasionally a short veinlet is carried from the centre of the one that bears the sorus to the next above it, which springs from the midrib, as in $P$. guatemalense, and as represented in the figure by Mettenius of $P$. pleurosor um, Kze. ; so that we have then a venation midway between that of Goniophlebium and Phleboctium proper.

266. P. (Phleb.) decumanum, Willd.; rhizome stout, the scales bright-ferruginous, soft ; st. 1-2 ft. l., stout, erect, glossy ; fr. 1-3 ft. 1., 1-2 ft. br., cut down nearly, or below quite, to the rachis into nearly entire ligulate-oblong pinnæ often $1 \mathrm{ft}$. l., 2-3 in. br.; texture papyraceous or subcoriaceous ; rachis and both sides naked; main veins parallel, 2 -3 lines apart, with two sets of areolæ about 6 deep between them, each containing a sorus terminating 2 or 3 free veinlets, $-H k$. Sp. 5. p. 17. C. dictyocallis, F'ée.

\section{Hab. New Granada and Guiana to Brazil and Peru.}

\$\$\$\$\$\$ Campyloneuron, Presl. Primary veins distinct from the midrib to the edge, connected by parallel straight or curved transverse veinlets, the areoloe similar, containing 2 or more sori, the free veinlets all directed towards the edge. ТАв. 48. f. j. Sp. 267-296.

\section{* Surfaces naked. Sp. 267-275. \\ + Fronds simple. Sp. 267-273.}

267. P. (Camp.) angustifolium, Sw.; rhizome stout, epigæous, clothed with deciduous brown lanceolate scules; fr. 12-18 in. l., $\frac{1}{4}$ in. br., quite entire, the point acute, the lower part narrowed very gradually into a generally short stem ; texture coriaceous; both sides naked, the edges often revolute ; veins immersed, often obscure; areolve and sori in 1-4 rows between the midrib and edge, the 
latter in 2 rows between the main veins. $-\beta, P$. ensifolium, Willd.; fr. very narrow, sessile, the areolæ and sori in 1 row between the edge and midrib.Hk. Sp. 5. p. 40.

Hab. Cuba and Mexico to Peru and Brazil.-Very variable. The broadest form ( $P$. amphostemon, Kze.) is about 1 in. br. with 4 rows of sori, whilst the narrowest $(P$. solutum, Klotzsch) has sometimes only uniserial areolæ with a single sorus in each, on a free veinlet, as in Goniophlebium.

268. P. (Camp.) lucidum, Beyr. ; rhizome short-creeping; st. short, firm, erect ; fr. 6-12 in. l., $\frac{1}{2}-\frac{3}{4}$ in. br., narrowed to both ends, the edge entire ; texture rigid ; both sides very glossy; veins immersed, hidden; areola in 2-3 irregular rows; the sori not copious and confined to the upper part of the frond.-Hk. Sp. 5. p. 41. P. nitidum, Fil. Ex.t. 12. (non Kaulf.).

Hab. Venezuela and Brazil.-Very near the last, with which Mettenius unites it.

269. P. (Camp.) sphenodes, Kze.; rhizome slender, wide-creeping, the linear scales spreading, soon falling; st. 4-6 in. 1., stramineous, glossy, wiry ; fr. 4-8 in. $1 ., 1 \frac{1}{2}-3$ in. br., the apex very cuspidate, the lower part narrowed gradually, the edge thickened and wavy; texture coriaceous; both sides naked; areoloe in rows of 6-8 between the midrib and edge, with 2 small distinct sori in each.Hk. Sp. 5. p. 42.t. 282.

Hab. Columbia and Ecuador.-This and the next are known from the other species by their more distinct stems.

270. P. (Camp.) coarctatum, Kunze; rhizome wide-creeping; st. 5 in. 1.; fr. $1 \mathrm{ft}$. l., 2-3 in. br., oblong, the point acuminate or cuspidate, the base narrowed gradually; texture coriaceous; both sides naked; areoloe in rows of 12-15 between the midrib and edge, with two sori in each.-Mett. Polyp. p. 84.

Hab. Peru, Poppig. - We have not seen this, and are indebted to Mettenius for the description.

271. P. (Camp.) lapathifolium, Lam.; rhizome woody, wide-creeping, the scales spreading, lanceolate, dark-brown ; st. 1-6 in. l., firm, erect ; fr. 6-18 in. 1., $\frac{3}{4}-1 \frac{1}{2}$ in. br., the apex acuminate, the lower part narrowed very gradually, the edge subentire; texture coriaceous ; main veins not distinct to the edge, with 3-5 areolæ between the midrib and edge, with one or two sori in each.-P. fasciale, Willd. Hk. Sp. 5. p. 41.

Hab. West Indies and Guatemala to Brazil and Ecuador.-The venation ranges between that of Campyloneuron and Goniophlebium, being sonetimes more like one, sometimes the other. C. minus and cubense, Fée, seem to belong here.

272. P. (Camp.) repens, L. ; rhizome slender but firm, wide-creeping, tortuous, the scales linear, deciduous; st. scattered, 1-5 in. l., firm ; fr. 6-18 in. 1., 1-3 in. br., entire or slightly sinuated, the point acute, the base narrowed very gradually ; texture papyraceous or subcoriaceous; both sides naked, opaque; main veins often wavy, distinct nearly or quite to the edge ; areolce in rows of 5-10 between the midrib and edge, with 2 sori in each.-Hk. Sp. 5. p. 39.

Hab. Mexico and W. Indies to Peru and Brazil.-Distinguished from the preceding by its regular areolation and sori, from the next, with which Grisebach unites it, by its thinner substance, less prominent veins and usually longer stem. $P$. nitidum, Kaulf., differs from this by its more rigid texture and glossy surfaces, and $P$. Lindigii, Mett., has paraphyses intermixed amongst the capsules and persistent lanceolate scales.

273. P. (Camp.) Phyllitidis, L.; rhizome stout, hypogæous, clothed with deciduous cordate brownish scales; st. scattered or subtufted, short, or sometimes none; fr. 1-3 ft. l., 1-4 in. br., the point acute, the lower part narrowed 
very gradually; the edge entire or slightly sinuated; texture rigid, very coriaceous; both sides naked, often with cretaceous dots above; main veins straight, very prominent, distinct to the edge; areoloe in rows of 6-12 between the midrib and edge, with usually 2 sori in each.-Hk. Sp. 5. p. 38.

Hab. Florida to S. Brazil, common.-C. latum, Moore, is a large broad-leaved variety with often 3 sori in the areolæ. P. nitidissimum, Mett., in the specimens we have seen has a very glossy frond, st. 5-6 in. 1., and lanceolate-acuminate scales.

\section{† Fronds pinnate. Sp. 274-5.}

274. P. (Camp.) decurrens, Raddi ; rhizome wiry, rather slender, the scales deciduous; st. 6-12 in. l., firm, naked; $f r$. usually with several erecto-patent pinnoe on each side, which are 8-12 in. $1 ., 1 \frac{1}{2}-2$ in. br., the point acuminate, the base narrowed, the edge nearly entire; texture subcoriaceous ; colour darkgreen ; both sides glossy; areole about 6 between the midrib and edge, with 2-3 sori in each.-Hk. Sp. 5. p. 42 .

Hab. Brazil and Peru.

275. P. (Camp.) Fendleri, Eaton; rhizome stout, densely clothed with large lanceolate greyish-brown scales; st. $1 \frac{1}{2}-2 \mathrm{ft}$. l., strong, naked, glossy ; fr. with several erecto-patent pinnoe on each side, which are 12-18 in. 1., 2-4 in. br., the point cuspidate, the base narrowed, the edge entire ; texture coriaceous; colour pale-green; both sides glossy ; veins raised, very distinct ; the areoloe in rows of 8-12 between midrib and edge, with 3-4 sori in each.-C. magnificum, Moore.

Hab. Venezuela, Fendler, 231, 410. New Granada, Lindig, 307, Triana.

** Under surface matted with woolly or cottony tomentum. Niphobolus, Auct. TAB. 48. fig. k. l. Sp. 276-296.

\section{+ Tomentum thin, adpressed. Sp. 276-284.}

276. P. (Niph.) confluens, R. Br.; rhizome filiform, wide-creeping, clothed with squarrose fibrillose ferruginous scales; st. $\frac{1}{4}-\frac{1}{2}$ in. 1. ; fr. dimorphous, the sterile ones orbicular or oblong, the fertile ones longer and narrower, about $1 \mathrm{in.}$ l., $\frac{1}{4} \mathrm{in}$. br., the edge quite entire ; texture coriaceous; upper surface naked, lower with dense glossy subferruginous tomentum ; veins quite hidden; sori immersed but prominent, sometimes covering the whole surface.-Hk. Sp. 5. p. 46.

Hab. Temperate E. A ustralia.-Probably a variety of $P$. serpens.

277. P. (Niph.) serpens, Forst. (non Sw.) ; rhizome wide-creeping, firm, clothed with linear-acuminate ferruginous scales; $s t . \frac{1}{2}-3$ in. 1 ., firm, erect; $f r$. dimorphous, the barren ones round or elliptical, the fertile ones longer and narrower, 4-6 in. l., $\frac{1}{2}-\frac{3}{4}$ in. br. ; texture coriaceous; upper surface scattered, lower densely coated with close whitish or subferruginous tomentum; veins quite hidden ; sori large, prominent, scattered, ultimately covering the whole of the upper part of the frond.-P. rupestre, $R . B r$. Hk. Sp. 5. p. 46. (in part). Hk. \& Gr.t. 44, 93.

Hab. Australia and New Zealand, eastward to the Society Islands.-Differs from P. glabrum, Mett., by its broader barren fronds and copious irregularly scattered sori.

278. P. (Niph.) adnascens, Sw. ; rhizome firm, but slender, the scales linear, deciduous ; st. $\frac{1}{4}-1$ in. l., firm, erect ; $f r$. dimorphous, the barren ones elliptical or spathulate, blunt, the fertile ones longer and narrower, 6-12 in. $1.1^{\frac{1}{4}-\frac{1}{2}}$ in. br.; texture coriaceous; upper surface naked, lower thinly coated with whitish tomentum in the barren but more densely in the fertile part beneath; veins hidden; sori small, bright-coloured, immersed, occupying the whole of the 
contracted upper part of the frond.-Hk. Sp. 5. p. 47. G.F.t.19. P. spissum, Bory, Hk. p. 48.

Hab. N. India and Chusan to Ceylon and Fiji; Mascaren Isles, Cameroon Mountains. $-N$. varium, Blume, is a large variety with the barren and fertile fronds similar, $\frac{1}{2} \cdot \frac{3}{4}$ in. br., and often nearly naked beneath, and $P$. Konigi, Bl., a small form with uniform narrow linear fronds.

279. P. (Niph.) acrostichoides, Forst. ; rhizome woody, wide-creeping, clothed with roundish adpressed scales, black in the centre; st.1-3 in. l., firm, erect; fr. 1-2 ft. l., $\frac{1}{2}-1$ in. br., ligulate, narrowed very gradually below ; texture very coriaceous; upper surface naked, lower clothed with thin dirty white tomentum; sori bright-coloured, not immersed, small, close, covering the whole of the upper part of the frond. $-H k$. Sp. 5. p. 44. (in part).

Hab. Ceylon, Malaccas, Philippines, New Hebrides, Queensland. - Distinguished from the last by its larger size, more rigid texture, and sori not buried in tomentum. M. Deplanche sends from the Loyalty Isles a form twice dichotomously forked.

280. P. (Niph.) Lingua, Sw. ; rhizome wide-creeping, clothed with spreading lanceolate ferruginous scales ; st. 3-6 in. l., firm, erect ; fr. uniform, 4-8 in. l,, 1-4 in. br., the apex often cuspidate, the base narrowed or rather rounded, the edge entire; texture coriaceous; upper surface naked, lower matted with close compact cottony subferruginous down; main veins distinct to the edge; sori rather large and prominent, in close rows of 4-6 each between them.-Hk. Sp. 5. p. 49.

Hab. N. India (up to 5,000 ft.) and Japan to Ceylon and the Malay Isles.-Well marked by its decided stem and comparatively short broad frond.

281. P. (Niph.) sphcerostichum, Mett. ; rhizome woody, wide-creeping, the scales ovate, acuminate, brown, crisped ; st. 2-3 in. l., firm, erect; fr. uniform, 4-5 in. l., 1 in. br, oblong-lanceolate, the apex acuminate, the base narrowed suddenly; texture coriaceous; under surfaee very thinly matted; main veins distinct to the edge; sori confluent, covering the whole under surface.-Mett. Polyp. p. 130.

Hab. Luzon, Cuming, 127.-Like the last in habit, but the sori multi- instead of uniserial between the transverse veinlets.

282. P. (Nipl..) tricuspe, Swz.; rhizome stout, the scales grey, lanceolate; st. 6-8 in. l., firm, erect ; $f r$. hastate, $2-4$ in. each way, the central lobe lanceolatedeltoid, the lateral ones spreading, distinctly auricled at the base; texture coriaceous; upper surface naked, lower densely matted; sori minute, in rows of 3-4 between the main veins, of 9-12 between the midrib and edge.-Hk. Sp. 5 . p. 44.

Hab. Japan and Korea.-The only species of the group of which the frond is not quite entire.

283. P. (Niph.) stigmosum, Sw.; rhizome short-creeping, the scales ferruginous, fibrillose ; st. subtufted, $1-6$ in. l., firm, erect ; fr. $1 \frac{1}{2}-2 \mathrm{ft} .1 ., 1-3$ in. br.; the apex acuminate, the lower part narrowed gradually, the edge entire; texture subcoriaceous ; upper surface glabrons, the lower coated with thin grey-ferruginous tomentum; main veins distinct to the edge; the sori in several rows between the transverse veinlets, very small, quite continuous, sometimes covering the whole frond except the very base.-P. costatum, Wall. Hk. Sp. 5. p.90. Apalophlebia, Presl.

Hab. N. India (up to 2,000 ft.), Malay Peninsula and Isles, New Guinea.-This and the next may be readily distinguished from the rest of the group by the much larger size of their fronds. The Himalayan plant ( $P$. costatum, Wall.) is less distinctly stalked 
than the type and narrowed more gradually below, and $P$. princeps, Mett., from New Guinea, has the scales divided at the point into 3-4 ciliæ, and is thinner in texture, with more adpressed tomentum, and more numerous sori and areolæ.

284. P. (Niph.) subfurfuraceum, Hk.; rhizome short-creeping, clothed with deciduous ferruginous fibrillose scales ; st. 4-6 in. l., firm, erect ; fr. $1 \frac{1}{2}-2$ ft. 1 ., 4-5 in. br., the apex acuminate, the lower part narrowed gradually, the edge entire ; texture coriaceous ; upper surface naked, lower with thin glaucous tomentum ; main veins distinct to the edge, connected by arched areolæ, with 1 or 2 irregular rows of 6 to 10 sori in each.- $H k . S p .5 . p .52$.

Hab. Mishmee and Bhootan, Givifith.

\section{+十 Tomentum thicker, more woolly, and looser. Sp. 285-296.}

285. P. (Niph.) nummulariofolium, Mett. ; rhizome slender, wide-creeping, filiform, clothed with bright-ferruginous fibrillose scales; st. erect, $\frac{1}{4}-1$ in. l., often scaly; $f r$. dimorphous, the barren ones roundish or elliptical, the fertile ones longer and narrower, $1 \frac{1}{2}-2$ in. $1 ., \frac{1}{4}-\frac{1}{2}$ in. br. ; texture subcoriaceous ; upper surface naked, lower densely coated with loose ferruginous woolly tomentum; main veins distinct, connected by 4 to 6 arched areolæ ; sori close, scattered, sometimes covering the whole surface.-Hk. Sp. 5. p. 54. Galeoglossa, Presl.

Hab. N. India (up to 2,000 ft.), Neilgherries, Philippines, Malaccas.-P. obovatum, Mett., is said to be like this, but to have the fertile fronds similar in shape to the barren ones, and both obovate-oblong.

286. P. (Niph.) floccigerum, Mett.; rhizome wide-creeping, the scales squarrose, lanceolate-acuminate, bright-ferruginous ; st. very short; fr. $6-12$ in. $1 ., \frac{1}{4}-\frac{1}{2}$ in. br., narrowed gradually to both ends, the edge entire; texture rigid, coriaceous; upper surface naked, lower densely matted with subferruginous tomentum ; veins hidden; sori immersed amongst the tomentum, covering the whole upper part of the frond.-Hk. Sp. 5.p.45. Antrophyum niphoboloides, Hk. Sp. 5 . p. 94 .

Hab. N. India, Philippines, Malaccas.-Most like N. porosum, but the frond much narrower and texture more rigid.

287. P. (Niph.) fissum, Baker ; rhizome stout, short-creeping, the scales dense, spreading, lanceolate, ferruginous ; st. none, or very short ; fr. $6-12$ in. $1 ., \frac{1}{2}-1 \frac{1}{2}$ in. br., narrowed very gradually to both ends, the edge entire; texture subcoriaceous ; upper surface naked, lower densely coated with soft woolly ferruginous tomentum ; veins hidden ; sori close, scattered, immersed amongst the tomentum. -Niphobolus, Bl. P. porosum, Wall. Hk. Sp. 5. p. 48.

Hab. Himalayas (5-6,000 ft.) to Ceylon and Java.-Characterized by its strapshaped subsessile fronds, very woolly beneath.

288. P. (Niph.) flocculosum, Don ; rhizome short, the scales linear-subulate, paleferruginous ; st. 4-6 in. l., firm, erect, cottony upwards ; fr. 6-18 in. $1 ., \frac{3}{4}-1 \frac{1}{2}$ in. br., narrowed very gradually to both ends ; texture coriaceous ; upper surface naked, lower densely matted with close glaucous or subferruginous tomentum; main veins distinct to the edge ; sori small, hright-coloured, in straight rows of 4 to 6 each between them.-P. detergibile, Hk. Sp. 5. p. 49.

Hab. N. India, ascending to $5,000 \mathrm{ft}$.

289. P. (Niph.) africanum, Mett.; rhizome stout, densely clothed with large grey ovate scales; fr. subsessile, 6-12 in. l., $\frac{1}{2}-1 \frac{1}{2} \mathrm{in}$. hr., narrowed gradually to both ends, the edge entire ; texture coriaceous ; upper surface naked, lower densely coated with close nearly white woolly tomentum; voins immersed; sori close, 
bright-coloured, spread over the whole upper part of the frond, sunk in the tomentum.-Hk. Sp.5.p.45. Gynosorium, Presl.

Hab. Kaffraria, Natal, Zambesi-land, Angola, Guinea Coast.-Very near the last, but smaller and subsessile.

290. P. (Niph.) albicans, Mett.; rhizome stout, clothed with rather large pale lanceolate scales ; st. 2-4 in. l., firm, erect, naked ; fr. 1-2 ft. l., 1-2 in. br., narrowed gradually towards both ends, the edge entire, revolute ; texture very coriaceous ; upper surface glabrous, lower densely clothed with ferruginous tomentum ; veins immersed, hidden, the main ones distinct to the edge ; sori in close rows of 3 to 4 each between them.-Hk.Sp.5.p.51.

Hab. Java.-This and the two next are the only densely-tomentose species that are rigid in texture.

291. P. (Niph.) distichocarpum, Mett.; st. 5 in. l., firm, erect ; barren fr. 10 in. l., $1 \frac{1}{2}-2$ in. br., linear-oblong, narrowed to both ends; fertile $f r .2 \mathrm{ft}$. $1 ., 1 \frac{1}{2}$ in. br., narrowed gradually from the middle to both ends; texture subcoriaceous ; upper surface nearly naked, lower tomentose; main veins 4 lines apart, with the sori in 2 rows between them, and 5 to 6 areolæ between the midrib and edge.Mett. Fil. Ind. 2. p. 231.

Hab. Sumatra, Korthals.-Most like the preceding, from which it may be known by its biserial sori.

292. P. (Niph.) americanum, Hk. ; rhizome very thick, clothed with large spreading grey lanceolate scales; st. strong, erect, 1-4 in. 1. ; fr. $1 \frac{1}{2}-2 \mathrm{ft}$. $1 ., \frac{1}{2}-\frac{3}{4}$ in. br., narrowed very gradually downwards, the edge reflexed; texture very coriaceous ; upper surface tomentose when young, naked, bright-green and pitted when mature, lower densely coated with loose dirty-white woolly tomentum; veins quite hidden; sori large, immersed, in single oblique rows of 4 between the midrib and edge.-Hk. Sp. 5. p. 54.

Hab. Andes of Ecuador, Jameson, Spruce.-Like the last in general habit, but the sori much larger and only uniserial between the main veins. The only American species of Niphobolus.

293. P. (Niph.) Gardneri, Mett.; rhizome short-creeping, clothed with rigid lanceolate black scales with a brown border; st. 3-4 in. l., firm, naked; fr. 12-18 in. l., 1-1 $\frac{1}{2}$ in. br., narrowed very gradually towards both ends, the edge entire ; texture coriaceous ; upper surface naked, lower densely matted with grey tomentum ; main veins straight ; the sori in close rows of about 4 each between them.Hk. Sp. 5. p. 51. Ex. F. t. 68.

Hab. Ceylon.-Very like $\boldsymbol{P}$. stigmosum in general habit, but the sori larger and the tomentum thicker.

294. P. (Niph.) penangianum, Hk. ; st. very short ; fr. 12-18 in. 1., 2-3 in. br., the point acute, the lower part narrowed very gradually, the edge obscurely undulated ; texture papyraceous ; upper surface naked, lower thinly clothed with fine silky tomentum; main veins very oblique, distinct to the edge, connected by nearly straight veinlets; the areoloe with 3 to 4 sori in each, the rows close together, confined to the upper part of the frond, and the mass falling distinctly short of the edge.-Hk. Sp.5.p.52 (not p.13). Polycampium, Presl.

\section{Hab. Penang, Lady Dalhousie.}

295. P. (Niph.) Boothii, Hk. ; st. 1 ft. or more 1., firm, erect, with lanceolate scales at the base ; $f r .1 \frac{1}{2}-2 \mathrm{ft} .1 ., 3-4$ in. br., narrowed gradually towards both ends, the edge entire ; texture coriaceous ; upper surface glabrous, lower with a 
thick coat of ferruginous tomentum; main veins distinct to the edge, connected by arched veinlets ; the areola containing 2 irregular rows of sori, with 6 to 12 in each.-Hk. $S p .5 . p .53$.

Hab. Bhootan, Griffith, Booth.

296. P. (Niph.) splendens, Hk. ; fr. subsessile, $1 \frac{1}{2}-3 \mathrm{ft} .1 ., 3-4$ in. br., the point cuspidate, the lower part narrowed very gradually, the edge entire ; texture subcoriaceous, upper surface with scattered cottony down, lower matted with ferruginous tomentum and fine silky dark-brown hairs; main veins straight to the edge, connected by nearly straight veinlets; the sor $i$ very fine and close, falling short of the edge.- $\dot{H} k . S p .5 . p .52$. Apalophlebia, Presl.

Hab. Philippines, Cuming, 331.

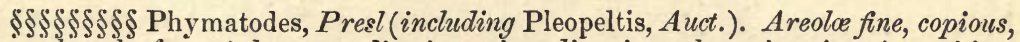
irregular, the free veinlets spreading in various directions, the sori various in position, generally on the back of united veinlets. Sp. 297-389. Tав. 43. fig. n.

* Fronds simple. Sp. 297-344.

† Main veins not distinct to the edge. Sp. 297-329.

A. Substance thick, all the veins obscure. Sp. 297-318.

A*. Under surface naked. Sp. 297-312.

297. P. (Phym.) subecostatum, Hk. ; rhizome creeping, matted with tomentum, the scales brown, fibrillose, squarrose ; fr. sessile, 4-8 in. l., $\frac{1}{2}$ in. br., narrowed gradually to both ends, the edge entire; texture thick, coriaceous; colour palegreen ; both sides naked; no main veins, areolæ obscure ; sori in single marginal rows. $-H k$. Sp. 5. p. 59. t. 273. A.

Hab. Borneo, Lobb.-Midrib upwards indistinct, and distinguished from all its allies by quite sessile fronds.

298. P. (Phym.) accedens, Blume ; rhizome threadlike, very wide-creeping, scarcely scaly; st. very short; fr. dimorphous, the sterile ones oblong, obtuse, the fertile ones longer and narrower, $2-4 \mathrm{in} .1 ., \frac{1}{4}-\frac{1}{2} \mathrm{in}$. br., the soriferous portion contracted ; texture coriaceous ; both sides naked ; veins hidden, no distinct main veins, areolæ irregular, with free veinlets; sori in single rows close to the midrib. -Hk. Sp. 5. p. 66.

Hab. Philippines, Malaya and Polynesian Islands.-Characterized by the sori being confined to the narrowed upper fertile part of the frond.

299. P. (Phym.) rostratum, Hk.; rhizome filiform, wide-creeping, the scales small, fibrillose ; st. 1-2 in. l., firm, naked ; fr. $2-4$ in. 1., $\frac{1}{2}-1$ in. br., narrowed gradually to both ends, the edge entire; texture coriaceous; both sides naked; veins immersed, no distinct main veins, areolæ fine, copious, with free veinlets; sori large, in single rows not far from the midrib.-Hk. Sp. 5. p. 66. $2 n d$ Cent. t. 53.

Hab. Khasia, Bhootan, and Mishmee; gathered by Griffith and Drs. Hooker and Thomson.

300. P. (Phym.) geminatum, Schrad.; rhizome stout, very wide-creeping, the young scales linear, ferruginous ; fr. subsessile, usually in distant pairs, uniform, entire, 3-6 in. 1., $\frac{1}{2}-1$ in. br., narrowed towards both ends, but the point often blunt; texture coriaceous; both sides naked; veins immersed, the main ones with copious fine areolæ between them; sori in a row midway between the midrib and 
edge, distinctly immersed, placed on the connected veinlets.-Hk. Sp. 5. p. 36. Anapeltis, J. Sim.

Hab. Brazil.-Near P. lycopodioides, but thicker in texture, and veins less distinct.

301. P. (Phym.) oodes, Kunze; rhizome slender, the scales small, fibrillose, yellowish ; st. distant, slender, naked, 3-4 in. 1 ; ; fr. $1 \frac{1}{2} 2 \frac{1}{2}$ in. l., 1-1 $\frac{1}{4}$ in. br., ovate, entire, the base rounded, hardly decurrent; texture coriaceous ; both sides naked; main veins distinct nearly to the edge, with fine areolæ and free veinlets; sori rather large, few, scattered.-Hk. Sp. 5. p. 71.

Hab. Philippines, Cuming, 58.

302. P. (Phym.) Schraderi, Mett. ; rhizome firm, short-creeping, the scales black, fibrillose ; fr. $3-5$ in. $1 ., \frac{1}{2}-\frac{3}{4}$ in. br., narrowed gradually upwards and below into a short stem or the base, the edge entire; texture subcoriaceous ; no main veins; areoloe fine, irregular, with free veinlets; sori large, in a single row on each side close to the midrib.-Hk. Sp. 5. p. 59.

Hab. Cape Colony and Natal.

303. P. (Phym.) Cunninghami, Hk. ; rhizome short-creeping, the scales large, lanceolate, dull-brown ; fr. 6-12 in. 1., $\frac{3}{3}-\frac{3}{4}$ in. br., the point acuminate, the edge entire, the widest part above halfway down, from which it is narrowed gradually to the base or a short stem ; texture coriaceous, not rigid ; surfaces naked ; areolice uniform, without free veinlets ; sori large, prominent, not immersed, roundish or oblong, in a row nearer the midrib than the edge.-Hk. Sp. 5. p. 58. P. attenuatum, Hk. Ic. t. 409. Dictymia lanceolata, J. Sm.

Hab. New Zealand and New Hebrides.

304. P. (Phym.) lineare, Thunb.; rhizome wide-creeping, woody, the scales lanceolate, dull-brown; st. varying from almost none to 1-2 in. l.; fr. 6-12 in. l., $\frac{1}{2}-2$ in. br., entire, narrowed gradually to both ends ; texture subcoriaceous ; both sides nearly naked; areoloe fine, with copious free veinlets; sori distinctly immersed, large, prominent, forming a single row nearer the midrib than the edge, when young covered with copious peltate scales.-Gard. F.t.14. Pleopeltis nuda, Hk. Ex. Fl. t. 63. - $\beta$, P. simplex, Sw. ; fr. larger, sometimes 2 in. br., 18 in. 1.; texture thinner, and veins more distinct. P. loriforme, Wall. Hk. Sp. 5. p. 57 . P. excavatum, Bory.

Hab. N. India (common, ascending to 10,000 ft.) and Japan to Ceylon and the Malay Islands, Mascaren Isles, Natal, Kaffraria, Angola, Fernando Po.

305. P. (Phym.) tenuilore, Kunze ; rhizome slender, woody, scandent ; fr. 9-18 in. l., $\frac{1}{4}-\frac{1}{2}$ in. br., the apex acuminate, the edge entire, the lower part narrowed very gradually into a short stem or the base ; texture rigid, coriaceous; both sides naked ; main veins none; areoloe hidden, fine, irregular, with free veinlets ; sori minute, copious, scattered, sometimes confluent, and especially so along the edge. -Hk. Sp. 5. p. 60. Diblemma, J. S'm.

Hab. Philippines, Cuming, 287, 332.-The only species of the group with small irregularly-scattered sori.

306. P. (Phym.) stenophyllum, Bl. ; rhizome moderately thick, wide-creeping, densely clothed with linear pale-brown scales; st. distant, 1 in. or more l., firm, erect ; fr. 4-9 in. l., $\frac{1}{4}-\frac{1}{2}$ in. br., entire, narrowed gradually to both ends ; texture very coriaceous; both sides naked ; veins hidden, immersed, no distinct main veins, and free veinlets few ; sori completely immersed, and very prominent on the upper side, forming a single row close to the edge. $-H k . S p .5 . p .65$.

Hab. Philippines and Malaccas. 
307. P. (Phym.) soridens, Hk. ; rhizome wide-creeping, the scales squarrose, linear, reddish ; st. 1-3 in. l., slender, naked ; fr. 4-12 in. 1., $\frac{1}{4}-\frac{1}{2}$ in. br., narrowed very gradually to both ends, the barren ones entire, the fertile ones repand; texture rigid, coriaceous; both sides glossy; areoloe fine, irregular, free veinlets rare ; sori 1 to each lobe, deeply immersed, and forming very distinct papillæ on the upper side.-Hk. Sp. 5. p. 61.t.283. B.

Hab. Borneo, Wallace, Lobb.

308. P. (Phym.) sinuosum, Wall.; rhizome forming a crust which enwraps the matrix, clothed with peltate scales, black in the middle and white round the edge, the stem arising from a conical protuberance, 1-2 in. l., firm, naked ; fr. dimorphous, the barren ones 3-6 in. l., $\frac{1}{2}-1$ in. br., the edge entire, the fertile ones longer, and the edge repand; texture coriaceous; both sides naked ; veins obscure ; sori large, immersed, round or oblong, marginal or submarginal.-Hk.Sp. 5. $p .61$. t. 274 .

Hab. Malaccas, Amboyna, New Hebrides, Solomon Isles.

309. P. (Phym.) longifolium, Mett.; rhizome woody, short-creeping, the scales linear, nearly black; fr. 1-2 ft. l., $\frac{1}{2}-1 \frac{1}{2}$ in. br., the apex acute, the edge entire, often revolute, the lower part narrowed very gradually into a short firm stem; texture coriaceous, the lower surface naked or subfurfuraceous; main veins none; areolo fine, hidden, with copious free veinlets ; sori oblong, quite immersed, placed end to end a space from one another in a line close to the edge, the caps. mixed with minute stalked peltate scales.-Hk. Sp. 5. p.60. 2nd Cent. t. 87. Fil. Ex. t. 20. Paragramma, Moore.

Hab. Malaccas and Philippines.

310. P. (Phym.) Brownii, Wickst.; rhizome woody, wide-creeping, the scales lanceolate, dull-brown; $f r$. scattered, $6-18$ in. $1 ., \frac{1}{4}-\frac{1}{2}$ in. br., ligulate, the point bluntish, the edge entire or slightly repand, the lower part narrowed very gradually to a base or short stem; texture very coriaceous, rigid ; areoloe uniform, without free veinlets ; sori large, prominent, oblong, immersed, in a single row end to end a space from one another midway between the midrib and edge.P. attenuatum, R. Br. Hk.Sp.5.p.58. G. F.t. 30 (not H.B.K.). Dictymia, J. Sm. $-\beta$, marginatum; sori quite marginal.

Hab. Australia, New Caledonia, Fiji ; $\beta$, New Caledonia and Isle of Pines.

311. P. (Phym.) superficiale, Blume; rhizome woody, wide-creeping, the scales lanceolate, spreading, brown, shining ; st. 4-6 in. 1., firm, naked, often curved ; fr. 6-12 in. 1., 1-2 in. br., narrowed gradually at both ends, the edge entire; texture subcoriaceous ; both sides naked ; areoloe fine, irregular, with free veinlets ; sori copious, scattered irregularly.-Hk. Sp. 5. p. 71 .

Hab. N. India (up to 5-6,000 ft.), Tsus-Sima, Hong-Kong, Malaccas.-Characterized in the group by its large, copious, irregularly-scattered sori.

312. P. (Phym.) Schomburghianum, Kze. ; rhizome $\frac{1}{2}-1$ in. thick, densely clothed with spreading lanceolate scales, with a broad scariose border; st. distant, 1-2 in. 1 ., firm, erect ; $f r .12-18$ in. $1 ., 1 \frac{1}{2}-3$ in. br., entire, narrowed at both ends ; texture coriaceous; both sides naked, the margin thickened, no distinct main veins ; areolce copious, fine, with free veinlets ; sori large, not immersed, in single rows not far from the midrib.-Hk. Sp. 5. p. 68.

Hab. Guiana and Amazon Valley. 


\section{$\mathrm{A}^{* *}$. Under surface matted or furfuraceous. Sp. 313-318.}

313. P. (Phym.) percussum, Cav. ; rhizome wiry, wide-creeping, the scales lanceolate, adpressed, deciduous ; st. 2-3 in. l., distant, firm, erect ; fr. 6-12 in. l., $\frac{3}{4}-1 \frac{1}{2}$ in. br., entire, narrowed gradually towards both ends ; texture very coriaceous, rigid; under side with fine scattered scales; areoloe fine, distinct, free veinlets few and short; sori round, distinctly immersed, forming a row midway between the midrib and edge.-Hk. Sp. 5. p. 56. Fil. Ex.t. 59.

Hab. Columbia to Peru and Brazil.

314. P. (Phym.) lanceolatum, Linn.; rhizome wiry, wide-creeping, the scales lanceolate, adpressed, bright-ferruginous ; st. distant, 1-3 in. 1., firm, erect ; fr. $3-9$ in. l., $\frac{1}{4}-\frac{3}{4}$ in. br., narrowed gradually to both ends ; texture coriaceous ; both sides, especially the under one, more or less thickly coated with fine peltate scales; veins inmersed, hidden; arcoloe without free veinlets ; sori large, uniserial, immersed, often reaching from the midrib to the edge.-P. lepidotum, $W i l l d$. Hk. Sp. 5. p. 56. Pleopeltis ensifolia, Hk. Ex. Fl.t. 62.

Hab. West Indies and Panama to Brazil, Araucania, and Juan Fernandez, Sandwich Isles, Neilgherries, Mascaren Isles, Zambesi-land, Cape Colony, St. Helena, Guinea Coast. -A well-marked plant, with a long list of synonyms. The most remarkable form is $P$. polylepis, Roem., in which the scales are so dense as to quite cover the under surface.

315. P. (Phym.) linearifolium, Hk. ; rhizome wide-creeping, densely clothed with secund fibrillose ferruginous scales ; fr. sessile, $3-4$ in. 1., 1-1 $\frac{1}{2}$ lin. br., blunt, ligulate, entire ; texture subcoriaceous ; upper surface slightly, lower densely coated with loose woolly tomentum; areola in 2 irregular rows, without main veins; sori in a single row on each side of the midrib.-Hk. Sp. 5. p. 53. 2nd Cent. $t .58$.

Hab. Tsus-Sima, Wilford, 862 ; Formosa, Oldham, 54 ; Peel Island, Korea, Oldham, 1048.

316. P. (Phym.) glabrum, Mett.; rhizome woody, wide-creeping, the scales linear, bright-ferruginous ; st. $\frac{1}{2}-1$ in. l., firm, wiry ; fr. nearly uniform, 4-6 in. l., $\frac{1}{4}-\frac{1}{2}$ in. br., ligulate, entire, the point bluntish, the base narrowed gradually ; texture very coriaceous ; under surface coated with thin dirty-white tomentum ; veins hidden ; sori marginal, confined to the upper part of the frond, soon confluent so as to form a ridge on both sides extending from the midrib to the edge.-P.rupestre, HK. Sp. 5. p. 46. (in part). P. acrostichoides, Sieb. (non Forst.).

Hab. East Australia, Norfolk Island, Lord Howe's Island, New Caledonia.-Very near the next species, but smaller in size, and the sori more confluent.

317. P. (Phym.) angustatum, Sw. ; rhizome stout, wide-creeping, clothed with whitish, linear, deciduous scales ; st. 2-4 in. l., strong, erect ; fr. 6-12 in. $1 ., \frac{1}{2}-1 \frac{1}{2}$ in. br., ligulate, entire ; texture very coriaceous ; upper surface naked, lower clothed with adpressed cottony subferruginous tomentum ; veins hidden ; sori large, prominent, in rows near the edge of the contracted upper part, and sometimes confluent.-Hk. Sp. 5. p. 44. G. F.t.20. Niphopsis, J. Sm.

Hab. North India to Tahiti and N. S. Wales.

318. P. (Phym.) samarense, Mett. ; rhizome firm, wide-creeping, clothed with deciduous spreading white linear scales ; st.1-4 in. l., firm, erect ; fr. 1-2 ft. l., $\frac{1}{2}-\frac{3}{4}$ in. br., quite entire ; texture coriaceous ; upper surface naked, lower densely coated with dirty-white or greyish-ferruginous tomentum; veins hidden; upper half of the frond contracted, the dense thick sori quite confluent, and occupying the whole surface.-Mett. Polyp. p. 123. 
Hab. Samar, Philippines, Cuming, 323 (in part).-This and the three preceding agree with Niphobolus in the coating of the under surface, but with Phymatodes in venation.

\section{B. Substance thinner, and veins distinct. Sp. 319-329.}

319. P. (Phym.) Swartzii, Baker; rhizome wide-creeping, slender, the scales linear, ferruginous; st. $\frac{1}{2}-1$ in. l., slender, naked; fr. nearly or quite uniform, 2-4 in. 1., $\frac{1}{8}-1$ in. br., narrowed gradually towards both ends, the edge entire or slighly lobed; texture subcoriactous; both sides naked; areoloe fine, copious, irregular; sori uniserial on free veinlets.-P. serpens, $S w$. $H k$. $S p$. 5. $p$. 35 . (non Forst.). Anapeltis, J. Sm.

Hab. West Indies and Cayenne.-P. runcinatum, Desv., is the sinuato-crenate form.

320. P. (Phym.) zosteraforme, Wall. ; rhizome wide-creeping, slender, scaleless; st. $\frac{1}{2}-1$ in. l., very slender ; fr. 4-6 in. l., 2 lin. br., the edge entire, the base narrowed gradually ; texture herbaceous; colour dark-green, both sides naked; veinlets distinct, no main veins; areoloe in $2-3$ irregular rows with no free veinlets; sori distant in rows close to the midrib.-Hk. Sp. 5. p. 64 .

Hab. Tenasserim, Wallich, 280 ; Moulmein, Parish, 191.

321. P. (Phym.) stigmaticum, Presl ; rhizome slender, wide-creeping, fibrillose ; fr. subsessile, uniform, 4-5 in. l., $\frac{1}{2}-\frac{3}{4}$ in. br., entire, narrowed gradually towards both ends; texture subcoriaceous; both sides naked; main veins not reaching to the edge ; areoloe fine, copious, with distinct free veinlets; sori uniserial, placed on the connected veinlets. - Hk. Sp. 5. p. 36. Anapeltis venosa, J. Sim.

Hab. Columbia.-Very near the next species, but the texture thinner, and free veinlets copious and distinct.

322. P. (Phym.) lycopodioides, L. ; rhizome wide-creeping, firm, the scales lanceolate-subulate, ferruginous; $f r$. distant, dimorphous, short-stalked or sessile, the barren ones $2-4$ in. $1 ., \frac{1}{2}-1$ in. br., entire, often blunt, narrowed gradually at the base, the fertile ones longer and narrower ; texture coriaceous ; both sides naked; areola in several rows, that containing the uniserial sori the largest, the free veinlets few and inconspicuous. $-\beta, P$. salicifolium, Willd.; fr. narrower, the sterile and fertile ones nearly or quite uniform.-Hk. Sp. 5. p. 34 .

Hab. Cuba and Mexico to Peru and South Brazil, Sandwich Isles, Java, Angola, Mauritius, Natal, Guinea Coast.-More rigid and coriaceous in texture than the rest of the group, but the veinlets raised and usually quite distinct.

323. P. (Phym.) fusco-punctatum, Hk.; rhizome woody, wide-creeping, the scales ovate, bright-brown ; fr. subsessile, 6-9 in. 1., the point acute, the base narrowed very gradually, the edge entire; texture subcoriaceous; both sides naked, with abundant fine dark-brown points; areoloe very distinct, with no main veins and a few included veinlets; sori large, uniserial, medial.- $H k . S p .5$. p. 69. t. 285. A.

Hab. Chimborazo, Spruce, 5734.

324. P. (Phym.) Mackenii, Baker ; rhizome epigæous, $\frac{1}{4}$ in. thick, very widecreeping, the scales lanceolate-acuminate, pale reddish-brown ; fr. distant, nearly sessile, $4-5$ in. 1., $\frac{5}{8}-\frac{3}{4}$ in. br., the point subacute, the edge entire, the base narrowed rather suddenly; texture subcoriaceous; both sides quite naked; areoloe in one large central row which contains the sori, and one of smaller ones on each side, with free veinlets; sori round, in a single row rather nearer the midrib than the edge.

Hab. Natal, McKen, 22.-Closely allied to the two following species, but firmer in texture, with a stouter rbizome, and the venation not nearly so complicated. 
325. P. (Phym.) Lindbergii, Mett. ; rhizome epigæous, very wide-creeping, the scales lanceolate, adpressed, bright-brown ; $f r$. distant, quite sessile, 6-8 in. l., 1-1 $\frac{1}{2}$ in. br., narrowed gradually to both ends, the edge entire; texture thinly herbaceous; colour bright-green; both sides finely pubescent; main veins distinct about halfway to the edge, only the outer areolæ wth free veinlets; sori round, in a single row nearer the midrib than the margin.

Hab. Brazil, Lindberg, 576. -Nearest the next, but the fronds quite sessile, and the sori smaller and round.

326. P. (Phym.) persicariafolium, Schrad.; rhizome epigæous, very widecreeping, the scales linear-subulate, bright-brown; fr. distant, 5-8 in. 1., 1-2 in. br., the edge entire, the point acute, the lower part narrowed gradually into a short stem; texture subcoriaceous; both sides naked; main veins distinct halfway to the edge, with fine areolæ between them, only the outer ones with free veinlets ; sori large, oblong, oblique, forming a single row on each side nearer the midrib than the edge.-Hk. Sp. 5. p. 55. Microgramme, Presl.

Hab. West Indies to Brazil and Ecuador.

327. P. (Phym.) normale, Don; rhizome woody, scandent, clothed with deciduous black fibrillose scales; st. 1-3 in. l., stramineous ; fr. 1-2 ft. 1., 1-2 in. br., entire, narrowed gradually to both ends; texture subcoriaceous; both sides naked; no distinct main veins, but the fine veinlets slightly raised, forming copious irregular areolæ with free included veinlets ; sori large, prominent, not immersed, in a row not far from the midrib.- $\beta, P$. longifrons, Wall.; fr. 2-3 ft. I. ; sori copious, scattered irregularly.-Hk. \& Gr. t. 65. Hk. Sp. 5. p. 70 .

Hab. N. India (up to 6,000 ft.), Malaya, S. China, Natal, and Caffraria.-Not always easy to distinguish from the large forms of $P$. lineare.

328. P. (Phym.) myriocarpum, Mett.; rhizome firm; st. very short; fr. 2-3 ft. l., 2-4 in. br., the apex acuminate, the base narrowed very gradually, the edge entire; texture papyraceous; both sides naked; distinct costal areolae reaching two-thirds of the space to the edge, and beyond these a small distinct row, including copious fine areolæ with free veinlets; sori very copious, minute, scattered irregularly.-Hk. Sp. 5. p. 68.

Hab. Philippines, Borneo, and Cochin-China.

329. P. (Phym.) linguoforme, Mett. ; rhizome stout, short-creeping ; fr. quite sessile, 8-18 in. l., $2 \frac{1}{2}-3$ in. br., tongue-shaped, narrowed from the centre to three-quarters of the way down, and then dilated again to the broadly-rounded base, the edge entire ; texture papyraceous ; both sides naked; veins very distinctly raised, the main ones irregular, the areolæ subquadrangnlar, with a single distinctly immersed sorus on free or joined veinlets in the centre of each.-Mett. Fil. Ind. p. 225.

Hab. Amboyna, P. B. Webb; Solomon Isles, J. G. Veitch.-Well marked by the peculiar shape of the frond and very distinct venation.

++ Main veins distinct nearly or quite to the edge. Pleuridium, Fée, J. Sm. Sp. 330-344.

330. P. (Phym.) lanceola, Mett. ; rlizome wide-creeping, the scales dense, ovate-acute, bright-ferruginous ; st. 1 in. 1 . ; fr. $3-5$ in. $1 ., \frac{1}{4}-\frac{1}{2}$ in. br., the apex acuminate, the edge entire, revolute, the base shortly narrowed; texture coriaceous; main veins distinct to the edge, with copious fine areolæ with free veinlets ; sori in a single row near the midrib.-Mett. Fil. Nov. Cal. p. 78.

Hab. New Caledonia, Vieillard, 1595. . 
331. P. (Phym.) rhynchophyllum, Hk.; rhizome firm, wide-creeping, with copious fibrillose bright-ferruginous scales; $f r$. dimorphous, the barren ones ovate, $1-1 \frac{1}{2}$ in. l., with stems about the same length, fertile ones 3-6 in. 1 ., $\frac{1}{2}-\frac{3}{4}$ in. br., narrowed very gradually upwards, the edge obscurely toothed, the stem 2-4 in. 1. ; texture coriaceous; both sides naked; main veins distinct to the edge, with copious fine areolæ between them with free included veinlets; sori uniserial, confined to the upper half of the fertile fronds.-Hk. Sp. 5. $p .65$. 2nd Cent. t. 55.

Hab. N. India (up to 4,000 ft.), and Moulmein (7,000 ft.).

332. P. (Phym.) Griffthianum, Hk. ; rlizome wide-creeping, the scales dense, linear, squarrose, dull-brown ; st. distant, 3-6 in. l., firm, erect ; fr. 6-8 in. l., $1 \frac{1}{2}-2$ in. br., the point acute, the edge repand, the base rounded or rather narrowed or auricled; texture coriaceous; main veins very distinct to the edge ; areoloe fine, hidden, with copious free veinlets; sori large, 1 between each main vein in a row near the midrib.-Hk. Sp. 5. p. 62. 2nd Cent.t.51.

Hab. N. India, up to 7,000 ft.

333. P. (Phym.) Melleri, Baker ; st. slender, naked, 1 in. or more 1.; fr. 2-3 in. 1., $\frac{1}{2}$ in. br., lanceolate, narrowed gradually from near the base to the point, the edge thickened, repand and wavy, the base rounded; texture subcoriaceous; surfaces naked; main veins wavy, distinct to the edge, with copious fine areolæ with free veinlets between them, and one sorus between each midway between the edge and midrib.

Hab. Madagascar, Dr. Meller.

334. P. (Phym.) triquetrum, Bl.; rhizome stout, woody, the scales dense, ovate, blunt, 1 lin. br., almost scariose ; st. distant, 4-8 in. l., firm, erect ; barren fr. 6-9 in. 1., 2-3 in. br., the apex acuminate, the edge entire, the fertile one rather longer and narrower; texture very coriaceous; both sides naked; main veins very distinct to the edge, the areolæ hidden; sori in two close rows between the main veins, 5-8 between the midrib and edge, not immersed.- $H k . S p .5$. p. 63.

Hab. Java.

335. P. (Phym.) rupestre, Blume (not $\mathrm{R} . \mathrm{Br}$.) ; rhizome woody, the scales squarrose, dull-brown, lineal-acuminate ; st. 4-8 in. l., firm, erect ; fr. 4-8 in. l., 1-1 $\frac{1}{2}$ in. br., the apex acuminate, the edge entire or obscurely repand; texture very coriaceous; both sides naked; main veins very distinct, the areolæ hidden ; sori in two rows between the main veins, 6-8 between the midrib and edge, not immersed.-P. saxatile, Mett. Hk. Sp. 5. p. 64.

Hab. Java and Philippines.-Very near the preceding.

336. P. (Phym.) ovatum, Wall.; rhizome wide-creeping, woody, the scales lanceolate, dull-brown, deciduous; st. 4-8 in. l., firm, erect, slightly scaly below ; fr. 6-12 in. 1., 2-3 in. br., the point acute, the edge entire, the lower part narrowed rather suddenly; texture firm-herbaceous; both sides naked; main veins distinct to the edge, with copious fine areolæ with free included veinlets in the interspaces; sori large, varying from irregularly 1 to 3 serial.- $H k$. Sp. 5. p. 64. Hk. \&. Gr. p. 41 .

Hab. Khasia, Sikhim, and Bhootan, up to 7,000 ft.

337. P. (Phym.) platyphyllum, Sw.; rhizome woody, the scales dense, long, subulate, nearly black ; st. 3-4 in. l., strong, erect ; fr. 12-18 in. l., 2-4 in. br., the poirit acute, the edge entire ; texture very thick and rigid ; both sides naked; 
main veins very distinct, the areolæ hidden; upper surface with close small dirty-white dots; sori much immer'sed, in single rows between the main veins, 8-9 between the midrib and edge.-P. crassinervium, Blume. H1k. Sp. 5. p. 63.

Hab. Java.

338. P. (Phym.) crassifolium, L. ; rhizome woody, short-creeping, the scales ovate-acuminate, dull-brown; st. 2-6 in. 1., strong, erect; fr. 1-3 ft. 1., 1-5 in. br., narrowed gradually to both ends, the edge entire; texture very coriaceous, the upper side with scattered small white dots; main veins very distinct, the intervening areolæ hidden; sori in single rows between the main veins, $2-9$ in a row between the midrib and edge.-Hk. Sp. 5. p. 62 .

Hab. West Indies and Mexico to Brazil and Peru, common.-Very variable in the breadth of the frond and compactness of the sori. $P$. anocarpum (Kze.) and $P$. vittaria (Mett.) are not more than $\frac{1}{2}-1$ in. br., with the sori in 2 to 4 rows; $P$. albo.punctatissimum, J. Sm., is a glaucous much-dotted form, with less distinctly-raised veins than usual.

339. P. (Phym.) membranaceum, Don ; rhizome stout, the scales ovate, spreading, membranous, lurid-green ; st. 1-4 in. l., firm, erect ; fr. 1-3 ft. 1., 2-6 in. hr., the edge entire or repand, both ends narrowed gradually; texture very thin, membranous; main veins distinct, with very copious fine areolæ with free veinlets between them; sori mostly in two rather irregular rows near the main veins. $-\beta, P$.grandifolium, Wall.; fr. larger ; sori more copious and scattered irregularly.-Hk. Sp. 5. p. 70.

Hab. N. India (up to 5-6,000 ft.) to Ceylon, common.

340. P. (Phym.) heterocarpum, Blume (non Mett.); rhizome firm, wide-creeping, the scales squarrose, linear, dull-brown ; st. $3-4$ in. l., firm, erect; fr. 1-2 ft. $1 ., 1 \frac{1}{2}-3$ in. br., entire, narrowed to both ends very gradually; texture firm; both sides naked; main veins distinct to the edge; areoloe copious, with free veinlets; sori in rows of 4 to 6 near the main veins.-P. Zollingerianum, $K_{z} e_{0}-$ ß, P. Zippellii, Blume ; sori smaller, scattered irregularly.-Hk. Sp. 5. p. 72.

Hab. N. India, Ceylon, Java, Borneo, Philippines. - Like the last in habit, but firmer in texture, and the two forms of each corresponding to one another.

341. P. (Phym.) irioides, Lam. ; rhizome stout, the scales dark-brown, ovate, obtuse ; $f r$. sessile or subsessile, 1-3 ft. l., 1-3 in. br., narrowed gradually to both ends, the edge entire ; texture subcoriaceous; both sides naked; main veins fine, but distinct to the edge, connected by cross veinlets larger than the others, with copious fine areolæ in the interspaces, including free veinlets; sor $i$ very small and copious, scattered irregularly.-Hk. Sp. s. p. 67. Fil. Ex. t. 4. Microsorium, Link.

Hab. N. India and Chusan to Fiji, Isle of Pines, and N. S. Wales, Mascaren Isles, Zambesi-land, Natal, Angola, Guinea Coast.

342. P. (Phym.) musafolium, Blume; rhizome woody, the scales ovate, dullbrown; fr. 1-3 ft. 1., 3-4 in. br., the point acute or bluntish, the lower part broadly winged to the very base ; texture coriaceous ; both sides naked; main veins very distinct, connected by distinct arched veinlets, with copious fine areolæ with free veinlets in the interspaces; sori small, very numerous, sometimes covering nearly the whole surface.-Hk. $S p .5 . p .68$.

Hab. Malay Isles._-Very near the last, but the veins more distinct.

343. P. (Phym.) hemionitideum, Wall.; rhizome woody, hypogrous ; st. 1-6 in. 1. , firm, erect; fr. 9-18 in. 1., 2-3 in. br., narrowed to.both ends, the edge 
entire; texture subcoriaceous; both sides naked; veins very distinct, the main ones branching and becoming lust before they quite reach the edge, including irregular rather large areolæ with a few free veinlets; sori in a very irregular row between each main vein, often confluent.-Hk. Sp. 5. p. 73. Colysis, Presl.

Hab. N. India (up to 6,000 ft.) and Neilgherries.

344. P. (Phym.) ensatum, Thunb.; rhizome firm, wide-creeping, the scales lanceolate, spreading, dull-brown; st. 6-12 in. l., erect, scaly below ; fr. 6-18 in. 1., $1 \frac{1}{2}-3$ in. br., narrowed to both ends; texture subcoriaceous; both sides naked; main veins distinct nearly to the edge, the areolæ fine, close, copious and free veinlets abundant; sori irregularly uniserial between the main veins, few, but often confluent.-Hk. Sp. 5. p. 72.

Hab. Japan and Tsus-Sima.

** Fronds varionsly lobed but not regularly pinnatifid or pinnate. Sp. 345-353.

\section{+ Fronds not in two halves. Sp. 345-350.}

345. P. (Phym.) crispatum, Hk. ; st. tufted, slender, 1-2 in. 1., clothed with soft spreading hairs ; fr. pendent, 6-18 in. l., $\frac{1}{2}-\frac{3}{4}$ in. br., ligulate, nearly entire or bluntly lobed a quarter or even halfway down to the midrib; texture subcoriaceous; both sides thinly clothed with soft hairs; veins in pinnated groups, the veinlets forked and uniting with those of the next group ; sori dorsal, 2-6 to each lobe, small, quite immersed.-Hk. Sp. 5. p. 1. Gryphotænium, J. Sm.

Hab. Panama, Seemann, 995.-Differs from Phymatodes by its regular pinnated veins, and from Goniophlebium by being without free veins, and by its dorsal sori.

346. P. (Phym.) Labrusca, Hk. ; caud. woody, the scales large, linear, darkbrown ; st. $4-8$ in. 1., firm, erect, scaly below ; fr. $3-4$ in. l., $2 \frac{1}{2}-3$ in. br., cordateovate, with a deep basal sinus, the edge sinuated; texture coriaceous; both sides naked; main veins distinct to the edge; areoloe fine, copious, distinct; sori small, copious, scattered irregularly.-Hk. Sp. 5. p. 73. t. 285. B.

Hab. Borneo, Lobb.-A very distinct species, with fronds like the leaves of Vitis Labrusca.

347. P. (Phym.) bifrons, Hk. ; rhizome woody, but rather slender, branched, tortuose, nearly naked ; barren fr. sessile, 3-4 in. 1., 1 in. br., elliptical, narrowed at both ends, with blunt lobes, which reach nearly halfway down; fertile fr. 4-6 in. 1., 2-4 lin. br., short-stalked, entire ; texture papyraceous ; both sides naked; a midrib to each lobe, with copious areolæ between, with free veinlets ; sori large, oblong, placed end to end in a row on each side close to the midrib.Hk.Sp. 5. p. 78. Fil. Ex.t. 52 .

Hab. Ecuador, Jameson, 789.

348. P. (Phym.) Spectrum, Kaulf.; rhizome woody, wide-creeping, the scales black, subulate, deciduous ; st. distant, $3-4$ in. 1 ., firm, erect, naked ; fr. 6-9 in. each way, cordate-hastate, the apex acuminate, the lateral lobes rounded or acute, the basal lobes deep, sometimes imbricated, the edge not toothed; texture firm; both sides naked; areolo fine, with copious free veinlets; sori small, copious, scattered irregularly.-Hk. Sp. 5. p. 74. Colysis, J. Sm.

Hab. Sandwich Isles and Sumatra.

349. P. (Phym.) hastatum, Thunb. ; rhizome firm, the scales linear, spreading, bright-ferruginous ; st. 2-4 in. l., firm, erect, glossy ; fr. 4-6 in. l., simple, lanceolate, $\frac{1}{2}-1 \frac{1}{2} \mathrm{in}$. br., or 3 -lobed, with the lateral lobes like the terminal one 
but smaller; texture coriaceous; both sides naked; main veins distinct to the edge, parallel, with copious fine areolæ between them, with free included veinlets; sori in a single row, nearer the midrib than the edge.-Hk. Sp. 5. p. 74.

Hab. Japan to Formosa.

350. P. (Phym.) pteropus, Blume ; rhizome wide-creeping, hypogæous, the emergent portions clothed with blackish lanceolate-subulate scales ; st. 4-6 in. l., sometimes scaly; $f r$. varying from oblong-lanceolate entire to ternate or pinnatifid, with a large terminal lobe 4-9 in. l., 1-2 in. br., and 2 smaller ones on each side; texture thin but firm ; colour dark-green; both sides naked; areolae fine, copious, the main veins not distinct to the edge ; sori small, scattered.P. tridactylon, Wall. Hk.Sp. 5. p. 75.

Hab. N. India to Ceylon, Malaccas, Philippines, Hong-Kong, Formosa._-Often grows under water.

+ Dipteris, Reinw. Fronds flabellate, in two halves, which are deeply lobed from the circumference in the direction of the base. Sp. 351-353.

351. P. (Dipt.) Dipteris, Blume; st. strong, 3-5 ft. l.; fr. 1-3 ft. l., and much broader, the main lobes reaching three-quarters of the way down, the edges sharply toothed; texture subcoriaceous; upper surface dark-green, lower very glaucous; main veins very prominent, dichotomously forked; areoloc copious; sori very minute, scattered irregularly, especially plentiful near the main veins, confluent, not gummy.-P. Horsfieldii, $R . \dot{B r} \cdot{ }^{\prime} k_{\text {. }} S_{p} .5 . p .99$. P: conjugatum, Kaulf. (not Lam.).

Hab. Malaccas and Polynesian Islands, as far east as Fiji.-This and the next are very distinct in habit from the rest of the genus.

352. P. (Dipt.) Wallichii, R. Br.; st. strong, 2-3 ft. 1. ; fr. 1.3 ft. 1. and much broader, the main lobes reaching three-quarters of the way down, the edges not toothed, the ultimate lobes acuminate; texture coriaceous; upper surface dark-green, lower dirty-white or subferruginous; main veins very prominent, dichotomously forked; areoloe copious; sori small, generally in distinct rows, not confluent but distributed equally over the surface, often gummy.Hk. Sp. 5. p. 99.

Hab. N. India, subtropical region.

353. P. (Dipt.) Lobbianum, Hk. ; st. 1 ft. or more 1. ; fr. 1 ft. l. and as broad, the main lobes reaching down to the base, 3 or 4 times dichotomously forked, the ultimate ones linear acuminate, entire; texture coriaceous; midrib only prominent; areoloe principally in one large costal series with 1 sorus in each.Hk. Sp. 5. p. 100.

Hab. Mount Ophir, Malayan Peninsula and Sarawak, Borneo, T. Lobb.-A very distinct plant, differing from the preceding by its very deep narrow lobes and few solitary sori.

*** Fronds deeply pinnatifid. Sp. 354-383.

$\dagger$ Fronds uniform, or the barren ones not drynarioid. Sp. 354-372.

354. P. (Phym.) leucosporum, Klotzsch ; rhizome woody, wide-creeping, the scales lanceolate, black in the centre, with a scariose border; st. 2-8 in. 1., firm, erect, furfuraceous ; fr. 4-8 in. 1., 2-3 in. br., the upper part bluntly sinuated, the lower cut more than halfway down into blunt lobes $\frac{1}{4}-\frac{3}{8}$ in. br. ; texture coriaceous; upper surface slightly, lower densely coated with minute furfuraceous scales; veins hidden; sori large, prominent, uniserial.-WK. Sp. 5. $p .76$.

Hab. Columbia.-Habit and scales of Lepicystis and P. lanceolatum. 
355. P. (Phym.) trifidum, Don ; rhizome stout, the scales linear, squarrose, bright-ferruginous ; st. $3-6$ in. l., firm, erect, glossy ; fr. 6-12 in. 1., 6-8 in. br., with a large linear terminal lobe and 1-5 similar ones on each side, which reach down within $\frac{1}{4}$ in. of the rachis and are 4-6 in. $1 ., \frac{1}{2}-1 \frac{1}{4}$ in. br., narrowed to the point, the edge entire or obscurely repand ; texture coriaceous ; both sides naked ; main veins distinct to the edge, with transverse veinlets and copious fine areolæ between them ; sori uniserial and 1 only between each main vein.-P. oxylobum, Wall. Hk. Sp. 5. p. 77.

Hab. N. India (up to 7,000 ft.) to Ceylon.

356. P. (Phym.) malacodon, Hk.; rhizome rather slender, the scales lanceolate-acuminate, brown or nearly black; st. 4-6 in. l., slender, glossy ; fr. 6-15 in. 1., 5-6 in. br., with a linear or linear-oblong subentire or repand and finely-toothed acuminate terminal lobe 3-4 in. 1., $\frac{1}{2}-\frac{3}{4}$ in. br., and 1-4 smaller lateral ones on each side, which are more or less confluent at the base; texture papyraceous or subcoriaceous; both sides naked; main veins fine but distinct, the areolæ fine and clearly visible, with copious free veinlets; sori in a single row on each side, nearer the midrib than the edge.-Hk. Sp. 5. p. 87. P. cyrtoloba, $J$. $S m$.

Hab. N. India, up to $12-13,000 \mathrm{ft}$.- Very near the last, but thinner in texture, the pinnæ deeper, and often finely toothed.

357. P. (Phym.) incurvatum, Blume; rhizome woody, the scales adpressed; fr. dimorphous, the barren ones 6-9 in. each way, deltoid, ternate or pinnatifid, with broad lanceolate-acuminate entire lobes, the stem firm, glossy, 6-9 in. 1.; fertile fr. larger, cut down nearly or below quite to the rachis into erecto-patent entire distant lobes 4-8 in. $1 ., \frac{1}{4}-\frac{3}{8}$ in. br., the lowest sometimes forked, the st. $1 \frac{1}{2}-2 \mathrm{ft}$. 1 . ; texture very coriaceous; both sides naked; main veins distinct to the edge; the uniserial sori quite immersed, and forming prominent papillæ on the upper surface.-Hk. $S p .5 . p .77$.

Hab. Malaccas,-Well distinguished by its very coriaceous usually ternate barren froud, with deltoid lobes.

358. P. (Phym.) angustum, Mett.; rhizome firm, the scales brown, linear, crisped ; st. $2-5$ in. l., firm, erect; fr. 6-9 in. each way, with a linear terminal lobe 4-6 in. l., $\frac{1}{4}-\frac{3}{8}$ in. br., and several similar erecto-patent lobes on each side, which reach down nearly or quite to the rachis and are dilated at the base; texture coriaceous; under surface furfuraceous, with minute scattered peltate scales; veins obscure; sori prominent, in a row on each side the midrib. $-H k$. Sp. 5. p. 76.

Hab. Mexico, Guatemala, W. Indies, S. Brazil.-The original Pleopeltis of Humboldt. The typical plant is sometimes subdigitate ; $P$. sectifrons, Kze. (Drynaria elastica, Fée), is a more fully pinnate form than usual ; and $D$. stenoloma, Fée, a form with the lobes only $\frac{1}{8}$ in. br.

359. P. (Phym.) insigne, Blume; rhizome slender, the scales linear, dullbrown ; st. 2-4 in. l., slender, erect, naked ; fr. 6-9 in. l., 4-6 in. br., with an entire lanceolate-acuminate terminal lobe $2-3$ in. 1. , $\frac{1}{2}$ in. or more br., and 2-4 similar ones on eacl side, which reach down within $\frac{1}{8} \mathrm{in}$. of the rachis and below them a long narrow decurrent wing to the stem; texture firm-herbaceous; both sides naked; veins fine, irregular, with free veinlets; sori small, scattered irregularly.-Hk. Sp. 5. p. 78.

Hab. Java, Philippines, and Malacca.

360. P. (Phym.) pustulatum, Forst.; rhizome woody, copiously branched, wide-scandent, the scales linear, dark-brown, squarrose; st. 1-3 in. 1. ; fr. 
varying in shape from entire, 3-9 in. $1 ., \frac{1}{4}-\frac{1}{2}$ in. br., narrowed to both ends, to 12-18 in. 1., 3-4 in. br., cut down to a broadly-winged rachis throughout into lanceolate lobes; texture papyraceous; both sides naked; areoloe rather large, irregular, with copious free veinlets; sori uniserial, submarginal, immersed.IIk. Sp. 5. p. 80.

Hab. New Zealand and Australia, both temperate and tropical.

361. P. (Phym.) Billardieri, R. Br.; rhizome woody, wide-creeping, the scales ovate-acuminate, adpressed, black in the centre, with a scariose border ; st. 4-8 in. l., firm, erect, glossy; fr. varying in shape from oblong-lanceolate, quite entire, to $18 \mathrm{in.} \mathrm{l.} \mathrm{and} \mathrm{half} \mathrm{as} \mathrm{broad,} \mathrm{deeply} \mathrm{pinnatifid,} \mathrm{with} \mathrm{lanceolate} \mathrm{or} \mathrm{linear}$ lobes; texture coriaceous; both sides naked; main veins irregular, with copious areolæ between them with free veinlets; sori large, uniserial, medial or submarginal, distinctly immersed.- $H k . S p .5 . p .82$.

Hab. New Zealand, S. Australia, Van Diemen's Land, and neighbouring islands.$P$. Vieillardii, Mett., from New Caledonia, is said to differ from this by its more numerous lobes, the lowest subpetiolate, and sori placed always in the second row of areolæ.

362. P. (Phym.) phymatodes, L.; rhizome wide-creeping, woody, the scales dark-brown, fibrillose ; st. 3-12 in. l., firm, erect, glossy; fr. varying from simple, oblong-lanceolate, to 2-3 ft. $1 ., 1 \mathrm{ft}$. br., cut down to a broadly-winged rachis into numerous entire acuminate lanceolate-oblong lobes 4-8 in. 1., 1-1 $\frac{1}{2}$ in. br. ; texture coriaceous; both sides naked; no distinct main veins; areolo fine, with copious free veinlets; sori large, more or less immersed, 1-2 serial or scattered.-Hk. Sp. 5. p. 82 .

Hab. Polynesian and Malayan Isles and N. Australia to Formosa and Loo Choo, TsusSima, Ceylon, Mascaren Isles, Natal, Zambesi-land, Angola, Guinea Coast.-P. maximum, Hk. (Drynaria, Brack.), from Tahiti, \&c., is probably a large simple form. It is curious that this very common Malayan species should be quite absent from Continental India. $P$. longipes, terminale, and peltideum of Link are garden varieties.

363. P. (Phym.) nigrescens, Blume ; rhizome stout, the scales ovate, adpressed ; st. 12-18 in. l., firm, erect, glossy ; fr. 2-3 ft. l., $1 \mathrm{ft}$. or more br., cut within $\frac{1}{4}-1$ in. of the rachis into usually numerous entire acuminate linear-oblong lobes 6-12 in. l., 1-2 in. br.; texture subcoriaceous; surfaces naked; colour darkgreen ; main veins distinct but wavy, the areolæ fine, copious, with free veinlets ; sori in a single row nearer the midrib than the edge, sunk in a deep cavity, which is prominent on the upper side.-Hk. Sp. 5. p. 81. Fil. Ex.t. 22.

Hab. N. India, Ceylon, Malaccas, Fiji, Samoa, Friendly Isles.-Differs from the last by its thinner texture, distinct veins, and more immersed sori.

364. P. (Pliym.) affine, Blume; rhizome woody, scaleless ; st. 12-18 in. 1., firm, glossy ; fr. 2-4 ft. l., $1 \mathrm{ft}$. or more br., cut down nearly to the rachis below, within $\frac{1}{2}$ in. above, into erecto-patent slightly repand much acuminated lobes 6-9 in. 1., about 1 in. br. ; texture papyraceous ; both sides naked; no distinct main veins; areoloe large, fine, with free veinlets; sori not immersed, in 2-3 irregular rows between the midrib and edge.-Hk. Sp. 5. p. 84.

Hab. Malaccas and Philippines.-Very near the last in habit and texture, but the sori different.

365. P. (Phym.) Powellii, Baker ; rhizome woody, scandent ; st. $1 \frac{1}{2}-2 \mathrm{ft} .1$., brownish, naked; fr. $2-3 \mathrm{ft}$. 1., $1 \mathrm{ft}$. or more br., cut down within $\frac{1}{4}$ in. of the rachis throughout into close acuminate entire lobes 5-6 in. 1., $\frac{5}{8}-\frac{3}{4}$ in. br. ; texture subcoriaceous ; surfaces naked; colour dark-green ; main veins not at all prominent, but distinct when held up to the light; areola rather large, with copious free veinlets; sori in a single row about midway between the edge and , not at all immersed. 
Hab. Samoa, Powell, 135.-Lobes narrower and more numerous than in $P$. nigrescens, the veins different, and sori not immersed.

366. P. (Phym.) dilatatum, Wall.; rhizome thick, woody, the scales large, ovate, dull-brown; st. $1 \mathrm{ft}$. or more l., with a narrow decurrent wing reaching nearly down to the base ; $f r .1 \frac{1}{2}-3 \mathrm{ft}$. l., $1 \mathrm{ft}$. or more br., cut down within $\frac{1}{4}-1$ in. of the rachis into acuminate entire erecto-patent lobes $4-8$ in. l., $\frac{1}{2}-1 \frac{1}{2}$ in. br.; texture papyraceous; both sides naked; main veins fine, wavy, falling rather short of the edge, with copious fine areolæ with free veinlets; sori small, copious, scattered irregularly, often confluent.-Hk. Sp. 5. p. 85.

Hab. N. India (up to 6,000 ft.), Malaccas, Samoa.-Habit of the two preceding, but the sori minute and scattered irregularly.

367. P. (Phym.) laciniatum, Blume ; rhizome wide-creeping, the scales lanceolate, ciliated, bright-ferruginous ; st. 6-12 in. l., firm, erect, glossy ; fr. 12-18 in. l., $1 \mathrm{ft}$. or more br., cut down throughout to a narrowly-winged rachis into lobes 6-9 in. 1., $\frac{1}{2}-\frac{5}{8}$ in. br., the point much acuminated, the edge slightly undulated, the lower ones deflexed ; texture subcoriaceous; both sides naked; main veins distinct to the edge ; areoloe fine, with copious free veinlets ; sori uniserial, immersed.-Hk. Sp. 5. p. 87.

Hab. Java.- $P$. violascens, Mett., is said to differ by its broader entire scales, coriaceous texture, immersed veins, and sori sunk in a deep pit.

368. P. (Phym.) alatum, Hk. ; rhizome woody, scaleless ; st. 12-18 in. 1., firm, erect; fr. $1 \frac{1}{2}-2$ ft. 1., 10-12 in. br., cut down nearly to the rachis below, within $\frac{1}{2}$ in. above, into numerous erecto-patent repand linear-oblong acuminate lobcs 6-8 in. 1., 1 in. or more br. ; texture papyraceo-herbaceous; both sides naked; main veins distinct to the edge, with copious fine areolæ with free veinlets; sori rather small, in rows of 3-4 near the main veins.-Hk. Sp. 5. p. 85.

Hab. Fiji, Brackenridge, Seemann.-Very like dilatatum in habit and texture, but the main veins straight, and the sori, though small, in 2 regular rows near them.

369. P. (Phym.) glaucum, Kze. ; rhizome stout, the scales long, dense, fibrillose, dark glossy-brown ; st. 6-12 in. l., firm, erect, glossy ; fr. 12-18 in. 1., 6-8 in. br., cut down throughout to a broadly-winged rachis into erecto-patent entire acuminate lobes $4-5$ in. $1 ., \frac{1}{2}-\frac{5}{8}$ in. br. ; texture very coriaceous; both sides naked ; no distinct main veins and areolæ quite hidden; sori forming single rows close to the midrib.-Hk. Sp. 5. p. 88.

Hab. Philippines.-Resembles some of the forms of $P$. aureum in texture and general habit.

370. P. (Phym.) lomarioides, Kunze; rhizome forming a thick wide-spreading crust, thickly clothed with small peltate scales, ferruginous in the centre, with a broad scariose border; st. 2-4 in. 1., firm, erect ; fr. 12-18 in. 1., 4-6 in. br., the barren one cut down within $\frac{1}{8}-\frac{1}{4}$ in. of the rachis into close horizontal oblong entire blunt lobes $\frac{3}{4}$ in. br. ; the fertile one cut nearly to the rachis throughout, with more numerous lobes, $\frac{1}{4}-\frac{3}{8}$ in. br.; texture coriaceous; surfaces naked; veins immersed, irregular; areoloe fine, with copious free veinlets; sori completely immersed, round or oblong, forming two close rows near the midrib. Hk. Sp. 5.p. 79.

Hab. Java, Borneo, Philippines,-Lecanopteris carnosa, Blume, appears to be an abnormal form of this, with the lobes intermediate in character between those of the typical barren and fertile frond, with large sori in very distinct marginal pits. Agrees with $P$. sinuosum in its very peculiar rhizome, the barren frond having quite the habit of a pinnatifid Lomaria.

371. P. (Phym.) ebcnipes, Hk.; rhizome stout, wide-creeping, the scales large, 
lanceolate, glossy, nearly black ; st. 6-9 in. l., naked, glossy ; fr. 6-18 in. 1., 8-12 in. br., cut down to a broadly-winged rachis into nearly entire acuminate lobes 4-6 in. 1., $\frac{3}{8}-1$ in. br., the lowest pair deflexed; main veins distinct to the edge ; areola fine, with copious free veinlets; sori in single rows near the midrib. -Hk. Sp. 5. p. 88.

Hab. N. India, up to $10,000 \mathrm{ft}$. - Resembles $P$. trifidum, but the pinnæ reach down deeper, and the main veins are closer and more distinct.

372. P. (Phym.) longissimum, Blume ; rhizome wide-creeping, the scales large, ovate, brown, adpressed ; st. 12-18 in. l., firm, glossy ; fr. 1-4 ft. 1., 6-12 in. br., cut down very nearly to the rachis into numerous erecto-patent acuminate linear subentire lobes $4-8$ in. $1 ., \frac{1}{4}-\frac{1}{2}$ in. br. ; texture coriaceous ; both sides naked; veins forming large distinct costular areolæ and beyond them smaller irregular ones, both with free veinlets; sori in close single rows near the midrib, forming distinct papillæ on the upper surface.-Hk. Sp. 5. p.89.

Hab. N. India, Neilgherries, Malaccas, Philippines, Formosa.-M. Deplanche sends from New Caledonia a plant that agrees with this, except that the sori are submarginal.

+1 Drynaria, Bory. Fronds with either a separate sterile frond or the base of the ordinary one pinnatifid like a sessile oak-leaf, brownish in colour and rigid in texture. Sp. 373-383.

\section{A. Sterile frond not separate. Sp. 373-375.}

373. P. (Dryn.) Heracleum, Kze.; rhizome stout, the scales long, silky, fibrillose, bright-brown ; fr. 3-6 ft. $1 ., 2 \mathrm{ft}$. or more br., the base with a cordate lobed wing 3-4 in. br., the upper part cut down to a broadly-winged rachis into entire acute lobes, which are often 12-18 in. 1., 3-4 in. br.; texture rigid ; both sides naked; main veins distinct to the edge, with 6-8 irregular quadrangular areolæ between the midrib and edge enclosing smaller ones with copious free veinlets; sori small, copious, scattered, slightly immersed.-Hk. Sp. 5. p.93. G. F.t. 1 .

\section{Hab. Java and Philippines.}

374. P. (Dryn.) Meyenianum, Schott.; rhizome very stout, the scales $\frac{1}{2}$ in. l., linear, crisped, bright-ferruginous ; fr. 2-3 ft. $1 ., 8-12$ in. br., the lower part cut down nearly to the rachis into erecto-patent linear-oblong blunt entire lobes 3-6 in. l., $\frac{1}{2}-1$ in. br., the upper part pinnate, with numerous close pinnæ 4-8 in. l., which consist only of a firm midrib, with a row of small round lobes on both sides, each with a sorus that covers it; texture of the barren lobes coriaceons, the main veins distinct, the copious areole with free veinlets.- $H k . S p .5$. p. 94. Aglaomorpha, Schott.

Hab. Philippines.

375. P. (Dryn.) conjugatum, Lam.; rhizome very thick, densely matted with long linear crisped bright-brown scales; $f r$. arranged in a circle, 2-4 ft. l., 12-18 in. br., the stem with a lobed wing $2-4$ in. br. on each side at the base, which is narrowed and more deeply lobed upwards, passing gradually into the frond, which is cut down nearly to the rachis throughout into entire erecto-patent

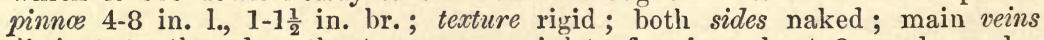
distinct to the edge, the transverse veinlets forming about 6 quadrangular areolæ between the midrib and edge; the sori in a single row close to the anterior main vein, sometimes confluent.-P. coronans, Wall. Hk. Sp. 5. p.95. Fil. Ex.t. 91.

Hab. N. India (subtropical region), Moulmein, Hong-Kong, Formosa. 


\section{B. Sterile frond distinct. Sp. 376-383.}

376. P. (Dryn.) Fortunei, Kunze; rhizome woody, the scales linear, bright

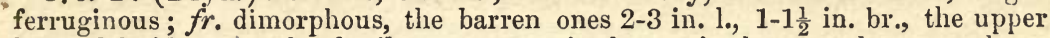
lobes deltoid-acute, the fertile ones 12-18 in. 1., 4-6 in. br., cut down nearly or quite to the rachis into lanceolate or oblong acute or bluntish entire erecto-patent lobes 2-4 in. 1., $\frac{3}{4}-1$ in. br. ; texture subcoriaceous; main veins distinct, 1-2 lin. apart, connected by prominent transverse veinlets, with a few faint ones in the intervals; sori in single rows of $3-4$ between the main veins. $-H k$. Sp. 5. p. 95.

Hab. South China, both the coast and interior.

377. P. (Dryn.) splendens, Hk.; rhizome woody, the scales grey, fibrillose, adpressed; fr. subsessile, 2-3 ft. $1 ., 1 \mathrm{ft}$. or more br., the lower part barren, cut down nearly or quite to the rachis into erecto-patent entire acute lobes 4-8 in. l., 1-2 in. br., the upper fertile pinnæ distant, ligulate, 4-8 in. 1., $\frac{1}{4-\frac{1}{2}}$ in. br. ; main veins distinct, with distinct transverse veinlets and copious intermediate ones and free veinlets; sori oblong or subquadrangular, filling up the whole of the fertile pinnæ except the midrib.-Hk. Sp. 5.p.96. Dryostachyum, J. Sm.

Hab. Philippines and Singapore.-D. pilosum, J. Sm., is a form with the fertile pinnæ slightly pubescent.

378. P. (Dryn.) Willdenovii, Bory ; rhizome thick, woody, the scales $\frac{1}{2}$ in. l., linear, crisped, bright ferruginous ; $f r$. dimorphous, the barren one 4-6 in. l., 3-4 in. br., the lobes short, rounded, blunt, the fertile one $1 \frac{1}{2}-2 \mathrm{ft} .1 ., 6-10 \mathrm{in}$. br., the upper lobes 4-5 in. 1., $\frac{1}{4}-\frac{1}{2}$ in. br., linear, acute, slightly repand, reaching down to the rachis, the lower ones shorter and blunt, with a narrow wing down the stem to the base; texture coriaceous; areoloe small, copious; sori slightly immersed, uniserial.-Hk. Sp. 5. p. 97.

Hab. Mauritius and Bourbon.

379. P. (Dryn.) propinquum, Wall. ; rhizome woody, wide-creeping, the scales linear, bright-ferruginous ; fr. dimorphous, the barren ones 4-9 in. 1., 3-4 in. br., cut half or three-quarters of the way down into bluntish or acute lobes, the fertile ones $1 \frac{1}{2}-3 \mathrm{ft}$. 1 ., often $1 \mathrm{ft}$. br., with a distinct stem, the lobes $4-6$ in. 1 ., $\frac{1}{2}-\frac{3}{4}$ in. br., reaching down nearly or quite to the rachis; texture subcoriaceous; areoloe copious, the free veinlets few and variously directed; sori in a row near the midrib, placed at the point of union of several veinlets.-Hk. $S p .5 . p .97 . \quad \mathbf{P}$. Wildenovii, H. G. F.t. 35. (non Bory).

Hab. N. India (up to 7,000 ft.), Java, and the West African islands.-The typical plant has more or less distinctly toothed fertile pinnæ, but in the Javan P. pleuridioides, Mett. ( $P$. Willdenovii, Blume, not Bory), they are quite entire.

380. P. (Dryn.) rivale, Mett. MSS.; rhizome stout, the scales dense, linear, bright-ferruginous ; fr. dimorphous, the barren ones 4-6 in. l., 2 in. br., cut down three-quarters of the way to the rachis into spreading blunt lobes, the fertile ones 1-2 ft. 1., 6-8 in. br., with a distinct stem, the blunt entire lobes 2-3 in. l., $\frac{1}{2}$ in. br., reaching down nearly or quite to the rachis ; texture of the fertile frond papyraceous; main veins not more than $\frac{1}{8}$ in. apart; areoloe fine, with copious free veinlets, all directed towards the edge, the close sori terminal on free veinlets in the costal series.

Hab. N. E. Himalayas.-Distinguished from the last by its much thinner texture, and venation like Goniophlebium. The veins of the fertile frond are scarcely at all raised, but are very distinct.

381. P. (Dryn.) quercifolium, L.; rhizome stout, the scales bright-brown, 
$\frac{1}{4}-\frac{1}{2}$ in. 1., lanceolate-acuminate, the base cordate; $f r$ dimorphous, the barren ones sessile, 3-12 in. l., 2-6 in. br., brown, rigid, bluntly lobed often halfway down, the fertile ones long-stalked, 2-3 ft. 1., $1 \mathrm{ft}$. or more br., cut down nearly to the rachis into entire erecto-patent lobes $6-9$ in. $1 ., \frac{1}{2}-1 \frac{1}{2}$ in. br. ; texture rigid; both sides naked; main veins distinct to the edge, with 4-6 quadrangular areolæ between them between the midrib and edge, enclosing each two large sori and copious lesser areolæ.-Hk. Sp. 5. p. 96.

Hab. N. India and S. China to Ceylon, Queensland, and Fiji.

382. P. (Dryn.) Linnoei, Bory ; rhizome stout, the scales 1-2 lin.1., broadly ovate, with a short acumen from a peltate base; $f r$. dimorphous, the barren ones sessile, brown, rigid, bluntly lobed; the fertile ones long-stalked, 2-3 ft. 1., 6-12 in. br., cut down nearly to the rachis into entire erecto-patent lanceolate lobes; texture rigid; both sides naked; nain veins distinct to the edge, with copious irregular areolce between them, with copious small scattered sori.-P. sparsisorum, $D$ esv.

Hab. Ceylon and Malaccas to Tropical Australia and Solomon Isles.-Differs from the last by its small scattered sori.

383. P. (Dryn.) rigidulum, Sw.; rhizome stout, wide-creeping, the scales fibrillose, dark glossy-brown ; fr. dimorphous, the barren one sessile, 6-9 in. l., 3-4 in. br., cut down $\frac{1}{3}-\frac{1}{2}$ way down to the rachis into blunt lobes, the fertile one 2-4 ft. l., 12-18 in. br., long-stalked, pinnate; pinnce 1 in. or more apart, narrowed or stalked at the base, 6.12 in. $1 ., \frac{1}{4}-\frac{3}{8}$ in. br., the point acuminate, the edge more or less deeply inciso-crenate; texture subcoriaceous; rachis and both sides naked; main veins not distinct to the edge; areolce copious, free veinlets few ; sori immersed in a single row halfway between the edge and midrib. $-P$. diversifolium, R. Br. Hk. Sp. 5. p. 98. G. F.t. 5 .

Hab. Malaccas to Queensland and Fiji.

**** Fronds pinnate. Sp. 384-389.

384. P. (Phym.) palmatum, Blume; rhizome stout, the scales large, lanceolate, full-brown ; st. 6-12 in. l., firm, erect, glossy ; fr. 6-18 in. 1., 8-12 in. br., with a linear or linear-oblong entire or slightly repand terminal lobe, and 1-6 similar ones on each side, which are 4-6 in. 1 ., $\frac{1}{2}-1 \frac{1}{2}$ in. br., narrowed or dilated, always slightly adnate at the base, those of the barren fr. the broadest; texture subcoriaceous; both sides naked; main veins distinct to the edge, the areolæ fine, hidden ; sori in a single row midway between the edge and midrib.- $H k$. $S p .5$. p. 89. Pleuridium, J. Smith. P. crenulatum, Mett.

Hab. Malaccas and Philippines.- $P$. angustatum, Blume (P. Lindleyanum, Wall.), and $\boldsymbol{P}$. palmatum, Blunie, appear to be varieties of one species, but the latter has only a very few pinnæ, which do not reach down to the rachis.

385. P. (Phym.) juglandifolium, Don ; rhizome stout, woody, the scales large, ovate, bright-ferruginous ; st. $1 \mathrm{ft}$. or more 1., firm, erect, glossy ; fr. $1 \frac{1}{2}-2 \mathrm{ft}$. 1., $1 \mathrm{ft}$. or more br. ; pinnce in pairs 1-2 in. apart, 4-8 in. 1., 1-1 $\frac{1}{2}$ in. br., the apex acuminate, the edge thickened and wavy, the base rounded; texture subcoriaceous; both sides naked; main veins distinct to the edge; areolo copious, hidden, with free veinlets; sori large, one between each main vein, forming a row nearer the midrib than the edge.-P. capitellatum, Wall. Hk. Sp. 5. p. 90. $-\beta, P$. tenuicauda, Hk. ; pinno narrower, very acuminate, narrowed at the base, and the lower ones often a little stalked.- $H k . l . c$.

Hab. N. India, up to $10,000 \mathrm{ft}$.-Pleopeltis Moulmeinensis, Beddome, Fil. Brit. Ind. t. 205, is either a form of this or very closely allied. 
386. P. (Phym.) Lehmanni, Mett.; rhizome woody, wide-creeping, the scales long, rigid, fibrillose, yellowish-brown; st. 6-9 in. 1., firm, erect, naked ; fr. 1-2 ft. 1., 8-10 in. br. ; pinno in distant pairs, 4-5 in. l., $\frac{1}{2}-\frac{3}{4}$ in. br., the apex acuminate, the edge entire or slightly repand, the base rounded; texture subcoriaceous; rachis and both sides naked; main veins distinct to the edge, with two rows of sori 3-4 deep between them.-Mett. Polyp. p. 117.

Hab. Burmah and Darjeeling, Griffith.

387. P. (Phym.) himalayense, Hk.; rhizome woody, wide-creeping, the scales linear, squarrose, bright-brown; st. $1 \mathrm{ft}$. or more l., firm, glossy ; fr. 1-2 ft. l., 8-12 in. br., the pinnæ in pairs $1-2$ in. apart, $4-8$ in. l., $1 \frac{1}{2}-2$ in. br., the point acuminate, the edge scariose, wavy, the base rounded or even cordate; texture subcoriaceous ; under surface finely pubescent ; main veins very distinct; areoloe fine, close, with copious free veinlets; sori in 1-2 rows of 3-4 each between the main veins.-Hk. Sp. 5. p. 91. P. venustum, Wall.

Hab. N. India, up to $7,500 \mathrm{ft}$. - Mettenius unites this with $P$. juglandifolium, but the pinnæ are much broader, with prominent veins and a distinct scariose wavy edge.

388. P. (Phym.) leiorhizon, Wall.; rhizome very thick, clothed with ovate adpressed peltate scales; st. 1-2 ft. 1., firm, erect; fr. 2-4 ft. 1., 1-2 ft. br.; pinnce narrowed at the base, the lower ones stalked, 6-12 in. l., $\frac{3}{4}-1 \frac{1}{2}$ in. br., the apex acuminate, the edge entire ; texture subcoriaceous, surfaces naked ; areoloe fine, uniform, with copious free veinlets; sori slightly immersed, in a row near the midrib on each side.-Hk. Sp. 5. p. 91. Fil. Ex. $t .25$.

Hab. N. India, up to $5-7,000 \mathrm{ft}$.

389. P. (Phym.) albo-squamatum, Blume; rhizome woody, the scales long (sometimes 1 in. 1.), dense, fibrillose, dark-brown; st. 6-12 in. l., firm, erect, glossy ; fr. sometimes simple, usually pinnate, 1-2 ft. 1., $1 \mathrm{ft}$. or more br., with several distant erecto-patent pinno on each side, which are 6-10 in. $1 ., \frac{1}{2}-\frac{3}{4} \mathrm{in}$. br., the apex much acuminated, the edge slightly repand towards the point, the base narrowed, the lower ones stalked; texture subcoriaceous; upper surface with small white dots at the edge or all over; main veins usually indistinct; sor $i$ in a single row midway between the midrib and edge.-Hk. Sp. 5. p.92. G. F.t. 47 .

Hab. Malay Isles and Philippines.-P. varians, Blume, is a form with narrow pinnæ and more distinct main veins.

\section{Tribe 12. Grammitides.}

Sori on the back of the lobes, more than twice as long as broad, usually linear. GEN. 49-59.

\section{Gen. 49. JaMesonia, Hk. \& Gr.}

Sori oblong, placed on the flabellate veins on the back of the pinnæ remote from the edge. $A$ single Andine species, placed by Mettenius in Gymnogramme. ТА . 6. $f .49$.

1. J. imbricata, H. \& G. ; rhizome woody, creeping, black, tortuose ; st. wiry, ebeneous, slender, 3-4 in. 1. ; fr. 6-18 in. 1., 2-3 lin. br., simply pinnate ; pinnoe close, roundish, often spreading horizontally, the edge much incurved; texture coriaceous; rachis and under surface slightly villose.-Ic. t. 178.- $\beta, J$. canescens, Kze., habit stouter, the long, silky, yellowish-brown hairs of the upper part of the frond often so dense that they quite hide the pinnæ.- $\gamma, \boldsymbol{J}$. verticalis, Kze.; st. $1 \mathrm{ft}$. 1., rigid, wiry ; fr. 6-9 in. $1 ., \frac{1}{2}$ in. br. ; pinnoe oblong-deltoid, 3 lin. 1 ., 
2 lin. br. ; tomentum of the rachis very short, and the pinnoe naked.-Hk. Sp. 5 . p. 105.

Hab. Andes, from New Granada southward to Peru.-Mettenius admits our three varieties as species, and also $J$. scalaris, Kze., and $J$. rotundifolia, Fée, the latter a robust plant, most like $\gamma$, but with closer and rounder pinnæ.

\section{Gen. 50. Nothochlena, $R$. Br.}

Sori marginal, at first oblong or roundish, soon confluent into a continuous marginal line, without a distinct involucre, but with the edge of the frond frequently inflexed. Veins free in all the species. A small widely-dispersed genus, differing from Cheilanthes only by the absence of a distinct involucre, and connected with it by gradual intermediate stages. ТА В. 6. f. 50 .

\section{§ Eunothochlæna. Fronds not farinose beneath. Sp. 1-16. \\ * Fronds densely matted beneath; stcms robust. Sp. 1-11.}

1. N. Rawsoni, Pappe; rhizome woody, wide-creeping, the scales dense, adpressed, linear, black in the centre and ferruginous towards the edge; st. 3-4 in. l., wiry, erect, naked, dark chesnut-brown ; fr. 6-9 in. $1 ., \frac{1}{2}$ in. br., simply pinnate; pinnoe in distant pairs, nearly as broad as long, deeply pinnatifid; texture subcoriaceous; upper surface pale-green, naked, lower densely matted with ferruginous tomentum; sori black, the edge not inflexed.-Hk. Sp. 5 . p. 110.

Hab. Namaqua-land, Rev. Mr. Whitehead.

2. N. sinuata, Kaulf.; rhizome very thick, densely clothed with linear bright ferruginous scales and bearing bulbs ; st. subtufted, 2-4 in. 1., firm, erect, chesnutbrown, matted ; fr. 1-2 ft. l., 1-2 in. br., simply pinnate ; pinnoe short-stalked, $\frac{1}{2}-1$ in. 1 ., $\frac{1}{4}-\frac{1}{2}$ in. br., ovate or oblong, varying from entire to deeply pinnatifid ; texture thick, coriaceous; upper surface green and slightly villose; lower surface and rachis densely coated with small linear ferruginous scales; edge slightly inflexed. -Hk. Sp. 5. p. 108. Bot. Mag. t. 4699.

Hab. New Mexico, along the Andes to Chili.

3. N. ferruginea, Hk. ; rhizome thick, bearing bulblike scaly buds, the scales very dense, fibrillose, dark-brown ; st. subtufted, 2-4 in. 1., wiry, erect, black, slightly matted; fr. 6-12 in. l., $\frac{1}{2}-1$ in. br., simply pinnate; pinnoe sessile, $\frac{1}{4}-\frac{1}{2}$ in. lo, ovate, deeply pinnatifid, with blunt lobes; texture coriaceous; upper surface pale-green, villose, lower densely matted with ferruginous or nearly white tomentum ; edge inflexed, slightly membranous; sori black. $-H k . S p .5 . p .108 .2 n d$ Cent. t. 52 .

Hab. West Indies and Mexico, along the Andes to Chili.-This and the two preceding may be distinguished from the rest of the group by having even the lower pinnæ pinnatifid only.

4. N. lanuginosa, Desv.; st. densely tufted, woolly, wiry, very short ; fr. 6-9 in. 1., 1-1 $\frac{1}{2}$ in. br., oblong-lanceolate, bipinnate; pinnoe close, lanceolate, the central ones the largest, with close, roundish or oblong, entire or 3-lobed pinnl.; texture herbaceous but thick; both sides, especially the lower one, coated with whitish or subferruginous tomentum ; rachis bright chesnut-brown, more or less woolly. $-H k . S p .5 . p .119$.

Hab. South Europe, from Spain to Syria, Greece, Madeira, Teneriffe, Cape Verde Isles, Algiers, Temperate and Tropical Australia.-Distinguished from the rest by its dense white woolly tomentum. 
5. N. Brackenridgii, Baker; rhizome thick, clothed with lanceolate ferruginous scales ; st. 3-4 in. l., chesnut-brown, glossy, nearly naked ; fr. 4-5 in. l., oblonglanceolate, tripinnatifid; lower pinnoe distant, stalked, oblong-deltoid, cut down to the rachis into oblong-deltoid pinnl. with rounded lobes; texture thick, coriaceous ; upper surface dark-green, nearly naked; lower and rachis densely clothed with small, linear, dark chesnut-brown scales.-N. sinuata, Brack.p. 19 (non Kaulf.).

Hab. Peru, Brackenridge.

6. N. incequalis, Kze.; rhizome stout, the scales long, dense, fibrillose, brightferruginous ; st. 3-6 in. l., firm, erect, naked, stout, ebeneous ; fr. 4-6 in. 1., 2-3 in. br., lanceolate or subdeltoid, tripinnatifid; upper pinnce lanceolate, lower deltoid, with blunt lanceolate pinnatifid pinnl. ; texture thick; both surfaces densely coated with ferruginous woolly tomentum; the rachis nearly naked.Hk. Sp. 5. p. 118.

Hab. Macalisberg, near Natal, Burke; Angola, Welwitzsch, 147, 197.-A larger plant than the last, almost as woolly, but the tomentum brown.

7. N. Aschenhorniana, Kze. ; st. tufted, 2-3 in. 1., wiry, ebeneous, densely scaly ; fr. 8-12 in. l., 2-3 in. br., oblong-lanceolate, tripinnatifid ; pinnoe lanceolate, 1-1 $\frac{1}{2}$ in. $1 ., \frac{3}{3}$ in. br., cut down to the rachis into linear-oblong crenate or pinnatifid pinnl.; texture subcoriaceous ; upper surface pale-green and slightly hispid, lower densely matted with linear, ciliated, bright-ferruginous scales, beneath which it is subfarinose; sori black, the edge not inflexed. $-H k$. Sp. 5. p. 117. t. 287. B.

Hab. Mexico.-This and the next three are very near to one another.

8. N. squamosa, Baker ; st. tufted, 1-4 in. 1., densely clothed with ovate-acuminate pale-brown scales; fr. $3-4$ in. $1 ., 1$ in. or more br., ovate-lanceolate, bipinnate ; pinnoe opposite, the lowest $\frac{1}{2}$ in. l., $\frac{1}{4}$ in. br., ovate, blunt, cut down to the rachis below into several linear-oblong pinnl.; texture thick, subcoriaceous ; rachis and under surface densely covered with ovate- or lanceolate-acuminate ciliated ferruginous scales; sori brownish, the edge subscariose.-Cheil. Hk. Sp. 2. p. 82. H. \& G.t. 151.

Hab. Mexico and Guatemala to Peru and the Argentine territory.-Probably this is $N$. peruviana, Desv., and if so, that name is the oldest. Mettenius distinguishes from this C. brachypus, Kze. (Nothochleena, J. Sm.), by its shorter stem, and the presence of long flaccid hairs as well as scales on the under surface.

9. N. Marantce, R. Br. ; rhizome woody, the scales dense, fibrillose, bright-fer-

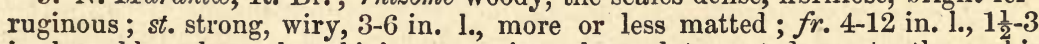
in. br., oblong-lanceolate, bipinnate; pinnoe lanceolate, cut down to the rachis into close, oblong, entire pinnl. 1 lin. br. ; texture thick, coriaceous ; upper surface pale-green, naked, lower and rachis densely coated with lanceolate, bright-ferruginous scales.-Hk. Sp. 5. p. 120.

Hab. Himalayas (up to $15,000 \mathrm{ft}$.), Syria, and Tauria, to Ardeche and Portugal ; Barbary States, Abyssinia, Azores, Madeira, Canaries, Cape Verde Isles.

10. N. Eckloniana, Kunze; rhizome woody, the scales lanceolate, dense, brightferruginous ; st. 3-6 in. l., strong, erect, scaly ; fr. 6-12 in. 1., 2-3 in. br., bitripinnatifid; upper pinnce close, the lower ones subdistant, deltoid ; pinnl. close, lanceolate, pinnatifid or pinnate, with short, oblong segm.; texture thick, coriaceous; upper surface pale-green, lower and rachis densely clothed with brightferruginous scales.-Hk. Sp. 5.p. 116.

Hab. Cape Colony and Natal.-Usually more divided than the last, but very doubtfully distinct. 
11. N. mollis, Kunze; rhizome woolly, very thick, the scales fibrillose, black ;

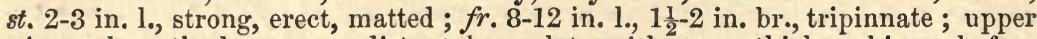
pinnoe close, the lower ones distant, lanceolate, with a very thick rachis, and often upcurled; the segm. small, roundish ; texture thick, rigid ; upper surface darkgreen, naked, lower and rachises woolly, with close thick short subferruginous tomentum.-Hk. Sp. 5. p. 120.

Hab. Chili and Andes of Guatemala.-A well-marked species, more rigid and robust than any of the preceding, with dense woolly tomentum beneath.

\section{* Fronds thinner in texture, and not so much matted; stems slender.} Sp. 12-19.

12. N. fragilis, Hk. ; st. 3-4 in. 1., very slender, wiry, naked, glossy, dark chesnut-brown ; fr. $1 \frac{1}{2}-3$ in. each way, deltoid ; lower pinnoe much the largest, deltoid, with the lowest pinnl. pinnate, with oblong pinnatifid segm. $\frac{1}{3}-\frac{1}{2}$ lin. br.; texture herbaceous; both surfaces rather densely coated with grey spreading hairs ; sori small, the edge slightly recurved.-Hk. Sp. 5. p. 114. $t .287$. A.

Hab. Arnhems-land, Tropical Australia, Dr. Mueller.

13. N. hirsuta, Desv.; st. tufted, 3-6 in. l., glossy, dark chesnut-brown, slightly villose ; fr. 6-8 in. l., $1 \frac{1}{2}-3$ in. br., lanceolate-oblong, tri- or quadripinnatifid ; lower pinnoe 1-1 $\frac{1}{2}$ in. apart, subdeltoid, with lanceolate pinnl. and oblong blunt entire or slightly-lobed segm. 1-2 lin. br.; texture herbaceous; rachis, and especially the under side, finely villose and glandular; sori brown.-Hk. $S p$. 5 . p. 116.

Hab. Hong-Kong and Polynesian Islands.-The Philippine N. densa, J. Sm., is probably a less-divided form. In habit this closely resembles Cheilanthes tenuifolia, to which N. nudiuscula, glabra, and semiglabra of Sp. Fil. must probably be referred.

14. N. distans, R. Br.; st. densely tufted, 1-3 in. 1., castaneous, wiry, clothed with ferruginous linear scales ; fr. $6-9$ in. l., $\frac{3}{4}-1$ in. br., bipinnate; lower pinnae distant, deltoid, cut down to the rachis into oblong obtuse entire or slightly-lobed pinnl.; texture subcoriaceous; upper surface pale-green and slightly villose, lower surface and rachis more or less densely coated with long linear ferruginous scales ; pinnoe often much curled together, and the edge incurved.-Hk. Sp. 5 . p. 114. 2nd Cent. t. 80.

Hab. Australia, New Zealand, New Caledonia.

15. N. hypoleuca, Kunze ; rhizome bulbiferous, the scales rigid, fibrillose, darkbrown ; st. tufted, slender, 2-4 in. l., dark chesnut-brown ; fr. 4-6 in. 1., $\frac{3}{4}-1$ in. br., bipinnatifid ; pinnoe $\frac{1}{2}-\frac{3}{4}$ in. I., $\frac{1}{4}-\frac{3}{8}$ in. br., ovate, cut down nearly or quite to the rachis below into blunt lobes ; texture subcoriaceous; upper surface nearly naked, pale-green, lower densely matted with white or slightly ferruginous tomentum ; edge slightly inflexed.-Hk. Sp. 5. p. 110.

Hab. Chili.-This is the most matted of any of the group, but the stem is almost or very nearly naked.

16. N. Pohliana, Kunze ; st. tufted, 3-4 in. l., slender, wiry, naked, ebeneous ;

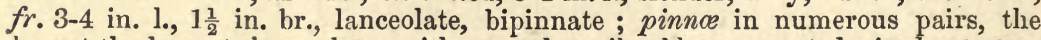
lowest the largest, lanceolate, with several sessile oblong crenated pinnl.; texture subcoriaceous; both surfaces, especially the lower one, with long silky hairs; rachis ebeneous; sori brown.-Hk. Sp. 5. p. 118.t. 286. B.

Hab. Brazil, Pohl, Gardner.

17. N. eriophora, Fée ; st. tufted, wiry, 3-4 in. 1., slender, dark chesnut-brown, more or less villose; fr. 2-3 in. each way, deltoid, with 3-4 blunt linear-oblong 
entire lobes on each side, the lowest pair much the largest, deeply pinnatifid on the lower side ; texture very thick ; under surface densely matted with yellowishbrown tomentum ; veinlets forked ; sori copious, marginal.-Polypodium, Hk. Sp. 4. p. 229. Ic. $t .991$.

Hab. South Brazil, Gardner, 2390.-A very distinct species, with the habit of Doryopteris.

18. N. Buchanani, Baker ; st. tufted, slender, villose, bright chesnut-brown, 3-4 in. l. ; fr. $1 \frac{1}{2}-2$ in. 1., 1-1 $\frac{1}{2}$ in. br., subdeltoid, with 2-3 pairs of distinct pinnce below the deeply-pinnatifid apex, the lowest much the largest, -cut down to the rachis at the base into oblong blunt repand pinnl., that on the lower side $\frac{1}{4}-\frac{3}{8}$ in. l.; texture herbaceous; rachis and both sides densely clothed with spreading whitish or ferruginous hairs ; sori copious, brownish, quite marginal.

Hab. Natal, Buchanan and McKen, 32.-This is very like the last in outline, but is more deeply divided, not so thick in texture, and though very hairy, yet not matted.

19. N. tenera, Gill. ; st. densely tufted, 4-6 in. 1., chesnut-brown, naked, glossy ; fr. 3-6 in. 1., 1 $\frac{1}{2}-2$ in. br., ovate, tripinnate ; pinnoe distant, the lower ones deltoid ; the pinnl. long-stalked, with blunt oblong segm. $\frac{1}{2}-1$ lin. br.; texture subcoriaceous ; rachises rigid; both surfaces naked; sori brown.-Hk. Sp. 5. p. 112. Bot. Mag. t. 3055 .

Hab. Chili and Andes of Bolivia.-Very doubtfully distinct from $N$. nivea, from which it differs only by being without white powder beneath.

\section{$\S \S$ Cincinalis, Desv. Fronds coated beneath with white or yellow powder. Sp. 20-27.}

20. N. (Cinc.) trichomanoides, R. Br. ; rhizome thick, bulbiferous, the scales black, fibrillose ; st. tufted, 2-4 in. l., firm, erect, chesnut-brown, slightly scaly ; fr. 6-12 in. l., $\frac{3}{4}-1 \frac{1}{2}$ in. br., simply pinnate ; pinnoe sessile, ovate-oblong, blunt, pinnatifid, with blunt lobes; texture subcoriaceous ; upper surface pale-green, nearly naked, lower clothed with white powder and fine ferruginous woolly hairs, the edge inflexed.-Hk. Sp. 5. p. 109.

Hab. Jamaica and Cuba.-Differs from all the following by being tomentose as well as farinose, and sometimes the powder is quite bidden beneath the tomentum.

21. N. (Cinc.) affinis, Hk.; st. tufted, 2-s in. 1., wiry, glossy, naked, nearly black ; fr. $4-5$ in. $1 ., \frac{3}{4}-\frac{7}{8}$ in. br., bipinnatifid ; pinnoe short-stalked, deltoid-oblong, $\frac{3}{8}$ in. l., $\frac{1}{4}$ in. br., deeply pinnatifid, with close entire lobes, the lower ones distant and dwindling down gradually ; texture subcoriaceous ; upper surface and ebeneous rachis naked, lower densely matted with sulphur-coloured meal; sori marginal, brownish.-Hk. Sp. 5. p. 109.

Hab. Mexico and Guatemala.-Our description is taken from a set of specimens gathered by Messrs. Salvin and Godman, and does not entirely agree with that of Mettenius. In habit our plant agrees with the preceding, but is perfectly without tomentum. Specimens from Cuba (C. Wright, 1075-6) are very similar, but are rather more slender, and the farina is pure-white.

22. N. (Cinc.) sulphurea, J. Sm. ; rhizome creeping, the scales dense, rigid, linear, nearly black ; st. tufted, 4-6 in. l., ebeneous, wiry, naked ; fr. 2-3 in. each way, deltoid ; upper pinnce simple, central ones lanceolate, cut down to the rachis at the base into oblong lobes; lowest pair with the lowest pinnl. much prolonged, $\frac{1}{2}$ in. or more l., pinnatifid or pinnate ; texture subcoriaceous ; upper surface naked, pale-green, lower coated with white or yellow powder, the ribs ebeneous; sori black.-Pteris, Cav. Cheil. pulveracea, Hk. Sp.2. p. 78. N. candida, Hk. Sp. 5. p. 111. 
Hab. California and New Mexico along the Andes.-We include here four species of Mettenius. His $C$. Borsigiana, Reich., has the pinnæ very close, and the lower pair much larger than the others, with the powder bright-yellow. From this $C$. cretacea seems to differ only by its white powder, and there are various intermediate stages. In $C$. candida and monostich $a$ the pinnæ are not so close and less unequal, the powder being white in the first and yellowish in the latter.

23. N. (Cinc.) flavens, Moore ; st. densely tufted, 4-8 in. 1., glossy, naked, chesnut-brown ; fr. 4-9 in. 1., 2-4 in. br., oblong-deltoid, tripinnate; pinnoe distant, the lower ones deltoid; the pinnl. stalked, with oblong segm. 1-1 $\frac{1}{2}$ lin. br.; texture subcoriaceous; rachises wiry, castaneous; upper surface naked, lower densely coated with bright-yellow powder ; sori brown, extending from the edge nearly to the midrib.-Gymnogramme, Hk. Sp. 5. p. 146. Fil. Ex.t. 47.

Hab. Central America.-Habit of the next, but the powder bright-yellow, and the sori in a broader band.

24. N. (Cinc.) nivea, Desv. ; st. densely tufted, 4-6 in. 1., chesnut-brown, naked,

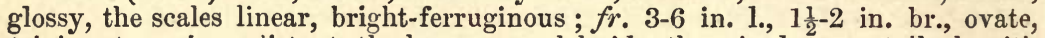
tripinnate ; pinn w distant, the lower ones deltoid; the pinnl. long-stalked, with blunt oblong or roundish terminal segm. 1-2 lin. 1., $\frac{1}{2}-1$ lin. br.; texture subcoriaceous ; rachises wiry, glossy, castaneous ; upper surface naked, pale-green, lower coated with pure-white powder ; sori brown. - Hk. Sp. 5. p. 111.

Hab. Andes, from Mexico to Peru.-N. Hookeri, Lowe, t. 13, is a form known only in cultivation, with close dilated segments and sessile pinnules.

25. N. (Cinc.) chilensis, Hk. ; st. tufted, 3-4 in. 1., stout, glossy, chesnut-brown, nearly naked ; fr. 3-4 in. l., 2 in. br., ovate, tripinnate; pinnce distant, the lower ones deltoid ; pinnl. sessile, deltoid ; the lower segm. linear-oblong, $\frac{1}{8}$ in. l., sometimes pinnatifid ; texture subcoriaceous ; rachises polished ; upper surface naked, pale-green, lower densely coated with white powder; sori brown.-Hk. Sp. 5 . p. 112. t. 286. A.

Hab. Juan Fernandez.-Probably this should be joined with the last.

26. N. (Cinc.) dealbata, Kunze ; st. densely tufted, 4-6 in. 1., slender, wiry, chesnut-brown, the scales linear, ferruginous ; fr. 3-4 in. each way, deltoid, tripinnate ; pinnoe distant, the lower deltoid ; the lowest pinnl. deltoid; lobes oblong, obtuse, 1 lin. or less l. by half as broad ; texture subcoriaceous; rachises slender, castaneous; upper surface naked, pale-green, lower coated with pure-white powder. -Hk. Sp. 5. p. 113.

Hab. Missouri.- Very near $N$. nivea, but more slender, with closer and more numerous pinnæ and smaller lobes.

27. N. (Cinc.) Fendleri, Kunze ; st. densely tufted, 2-3 in. 1., wiry, chesnutbrown, naked, the scales linear, bright-ferruginous ; fr. 2-3 in. each way, deltoid, tripinnate; all the rachises very zigzag; pinno, pinnl., and segm. all stalked, deltoid ; lobes close, oblong, blunt, not more than 1 lin. l. by half as broad; tcxture subcoriaceous; upper surface naked, lower with fine white powder.- $H k$. Sp. 5. p. 113.

Hab. New Mexico, Fendler, 1017a.-Very near the last, from which it differs principally by its very zigzag rachises.

\section{Gen. 51. Monogramme, Schk.}

Sori linear, close to the midrib on one or both sides. Small grass- or rush-like plants, the simplest in structure of all the Ferns. 


\section{§ Eumonogramme. Frond with a central vein only. Sp. 1 -7.}

1. M. darececarpa, Hk.; rhizome slender, wide-creeping; scales linear; fr. $\frac{3}{4}-1$ in. l., $\frac{1}{2}$ lin. br. upwards, narrowed gradually downwards into a short slender stem; texture subcoriaceous; sori sunk in a deep cleft on one side of the midrib, the wing which covers it reaching nearly to the edge.-Hk. Sp. 5. $p .121$. t. 287. A.

Hab. Labuan, Borneo, Barber.

2. M. graminea, Schk.; rhizome slender, wide-creeping, clothed with squarrose fibrillose brown scales; fr. 1-2 in. l., $\frac{1}{4}$ lin. br., flaccid, grass-like; the costa indistinct ; the sori in a line 2-3lin. l. near the apex, where the edges are incurved. M. linearis, $K l f . H k$. Sp. 5. p. 122.

Hab. Cape Colony, Mauritius, and Bourbon.

3. M. subfalcata, Hk.; rhizome slender, wide-creeping ; fr. 1 in. $1 ., \frac{1}{2}$ lin. br. towards the point, tapering gradually downwards into an indistinct stem; texture subcoriaceous; sori sunk in an unequal-sided longitudinal furrow, extending about $\frac{1}{2}$ in. from the apex.-Hk. Sp. 5. p. 122.t.219. A.

Hab. New Hebrides, C. Moore.

4. M. trichoidea, J. Sm.; rhizome very slender ; fr. 3-4 in. 1., densely cæspitose, threadlike, the fertile one dilated in two or three places for a space of $\frac{1}{4}$ in., and there bearing the sori in a longitudinal furrow, with a high raised edge on both sides.-Hk. Sp. 5. p. 123. Vaginularia, Fée.

Hab. Philippines, Cuming, 160.

5. M. rostrata, Hk. ; fr. densely cæspitose, 3-4 in. 1., 1 lin. br., tapering to the point and gradually downwards into an indistinct stem; texture coriaceous; the surface naked; the midrib very distinct; the sori quite sunk in a longitudinal furrow 1-2 in. 1.-Hk. Sp. 5. p. 122.t.287. B.

\section{Hab. Nicaragua, C. Wright.}

6. M. Junghuhnii, Hk.; rhizome slender ; fr. densely cæspitose, grass-like, flaccid, 6-12 in. 1., $\frac{1}{4-\frac{1}{2}}$ lin. br.; texture herbaceous ; sori deeply sunk in a furrow on one, or, according to Brackenridge, on both sides of the midrib.-Hk.Sp. 5 . p. 123. t. 289. B. Diclidopteris angustissima, Brack.

Hab. Ceylon, Java, Philippines, and Polynesian Islands.

7. M. graminoides, Baker ; fr. tufted, $\frac{3}{4}-1 \frac{1}{2}$ in. $1 ., \frac{1}{4}-\frac{1}{2}$ lin. br., simple or once dichotomously forked, narrowed below to an indistinct stem ; texture coriaceous ; midrib prominent; sorus linear-oblong, arising from the midrib near the dilated point; the edge scarcely incurved.-Grammitis, Sw. M. furcata, Desv., Hk. Sp. 5. p. 121. Cochlidium, Kaulf.

Hab. Jamaica, Brazil, St. Helena, and reported from Chili by C. Gay.

$\S \S$ Pleurogramme, Fée. Fronds with indistinct simple lateral veins in addition to the midrib. Sp. 8-9.

8. M. (Pleur.) seminuda, Baker ; fr. cæspitose, $4-8$ in. 1., $1 \frac{1}{2}-2$ lin. br., tapering downwards into an indistinct stem; texture coriaceous, rigid; veins simple, oblique, not reaching the edge; sori not sunk in a cavity, originating as 2 rows close to the midrib, which are ultimately confluent, covering the whole of the 
upper part of the frond, the edges of which are more or less inflex $\in$ d.-Blechnum, Willd. M. graminifolia, Hk. Sp. 5. p. 124.

Hab. West Indies and Guatemala to South Brazil.

9. M. (Pleur.) immersa, Fée ; fr. cæspitose, 2-3 in. $1 ., 1 \frac{1}{2}$ lin. br., tapering downwards into an indistinct stem; habit and veins of the preceding, but the sori sunk in a deep central longitudinal cavity, and in all our specimens confined to the central third of the triquetrous frond.-Hk. Sp. 5. $p .125$.

Hab. Cuba, Venezuela, and Guiana.-P. myrtillifolia, Fée, supposed to be from Mexico, has a subspathulate frond 7-8 lin. 1., with the short sorus in a depression near the point.

\section{Gen. 52. Gxmnogramme, Desv.}

Sori arising from the veins over the under surface of the frond, linear or linearoblong, simple or forked. A considerable genus, principally tropical, including plants of very various habit and venation. TAB. 6. f. 52.

Series 1. Habit and mode of growth of Aspidiece. Sori oblong or linearoblong, not forked. Sp. 1-13.

§ Leptogramme, J. Sm. Veins free. Differs from Euphegopteris only by its elongated sori. Sp. 1-11.

\section{* Frond bipinnatifid. Sp. 1-9.}

1. G. (Lept.) pilosa, Mart. \& Gal.; st. 3-4 in. 1., slender, villose, scaly at the base ; fr. 6-8 in. 1., $1 \frac{1}{2}-2$ in. br., lanceolate ; pinnce lanceolate, 1 in. 1. , $\frac{1}{2}$ in. br., the lower ones slightly bluntly lobed, the lowest scarcely reduced; texture herbaceous; rachis and both sides pilose; veins pinnate in the lobes, with 3 simple veinlets on a side; sori irregular. - Hk. Sp. 5. p. 141.

Hab. Mexico.-A doubtful plant; perhaps a small slender form of $G$. diplazioides, more hairy than usual.

2. G. (Lept.) asplenioides, Kaulf. ; caud. stout, suberect ; st. tufted, 2-6 in. 1., villose, and the lower part scaly ; fr. 6-12 in. 1., 3-4 in. br., bipinnatifid ; pinnoe $1 \frac{1}{2}-2$ in. l., $\frac{1}{4}-\frac{1}{2}$ in. br., horizontal, sessile, linear, varying from subentire to cut more than halfway down to the rachis in the lower part, the lowest lobe on the upper side produced and the lower side rather truncate; rachis and both sides slightly pubescent; texture firm-herbaceous; veinlets slightly pinnate in the lobes; sori oblong.-Hk. Sp. 5. p. 132.

Hab. Panama to Peru and S. Brazil.

3. G. (Lept.) Totta, Schlecht ; rhizome decumbent ; st. subtufted, 6-12 in. 1., slightly scaly below ; fr. 12-18 in. 1., 6-10 in. br., bipinnatifid; pinnoe lanceolate, 3-5 in. 1., $\frac{3}{4}-1$ in. br., with blunt entire lobes $1 \frac{1}{2}-2$ lin. br., which reach about halfway down; texture herbaceous; rachis and both sides finely villose; veinlets pinnate in the lobes, with $5-6$ veinlets on a side, with the linear-oblong sori medial.-Hk. Sp. 5. p. 138. G. Lowei, Hk. \& Gr. Ic. t. 138.

Hab. Cape Colony, Guinea Coast, Madeira, Azores, Abyssinia, Himalayas, Neilgherries, Ceylon, Java, Japan, Hong-Kong, Corea.

4. G. (Lept.) villosa, Link ; st. 6-9 in. 1., firm, stramineous, densely clothed with soft spreading greyish hairs; fr. 12-18 in. $1 ., 6-10$ in. br., bipinnatifid; pinnoe 3-5 in. 1., $\frac{3}{4}$ in. br., cut more than halfway down into subfalcate entire lobes 2 lin. br., the lower ones not reduced, narrowed at the base; texture 
herbaceous; rachis and both sides densely villose; veins pinnate in the lobes, with 8-10 simple veinlets on a side, the sori in the lower part of each.

Hab. Brazil.

5. G. (Lept.) polypodioides, Spreng.; rhizome creeping; st. 6-9 in. 1., firm, glossy, naked; $f r .1 \mathrm{ft} .1 ., 6-9$ in. br., bipinnatifid ; pinnce lanceolate, $3-5$ in. 1., $1 \mathrm{in}$. br., cut two-thirds of the way down into entire falcate lobes $\frac{1}{4} \mathrm{in}$. br., the lower ones not reduced and with an entire wing at the base; texture herbaceous ; rachis and both sides naked; veins pinnate in the lobes, with 8-10 simple veinlets on a side, with the linear-oblong sori down the centre of each.-Hk. Sp. 5 . p. 140.

\section{Hab. Brazil.}

6. G. (Lept.) diplazioides, Desv.; st. tufted, 3-4 in. l., glossy, scaly below ; fr. $1 \frac{1}{2}-2$ ft. $1 ., 6-8$ in. br., bipinnatifid ; central pinnce $3-4$ in. $1 ., \frac{3}{4}-\frac{7}{8}$ in. br., cut half to two-thirds of the way down into blunt entire lobes 2 lin. br., the lower pinnæ reduced gradually; texture herbaceous; rachis and both sides naked or slightly pilose ; veins pinnate in the lobes, witl 6-9 simple veinlets on a side, the sori oblong, often reaching nearly from the midrib to the edge.-G. Linkiana, Kze. Hk.Sp. 5. p.140. G. rupestris, Kze. Hk.l.c.

Hab. Mexico and West Indies to Peru and South Brazil,-Pheg. Duchassagniana, Fée Mem. 11-12. t. 14, must probably be efered here.

7. G. (Lept.) grandis, Baker ; st. tufted, $1 \frac{1}{2}-2$ ft. 1., strong, naked, scaly only at the very base ; fr. 3-4 ft. l., $1 \frac{1}{2}-2 \mathrm{ft}$. br., bipinnatifid; pinnoe $3-12$ in. l., $1 \frac{1}{2}$ in. br., cut three-quarters of the way down to the rachis into oblong falcate finely serrated lobes 3-4 lin. br.; lowest pinnce not reduced; texture subcoriaceous; rachis and both sides naked; veins pinnate in the lobes, with about 12 simple veinlets on a side; sori linear, close to the midrib.

Hab. Andes of Columbia, Holton 29, Linden 540 ; Ecuador, Spruce 5286.

8. G. (Lept.) gracilis, Heward ; st. $2-4$ in. 1., glossy, scaly ; fr. 2-4 ft. 1., $1 \mathrm{ft}$.

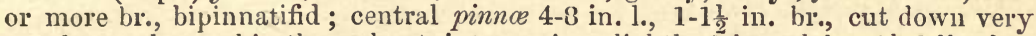
nearly to the rachis tbroughout into entire slightly falcate lobes $1 \frac{1}{2}-2$ lin. br., the lower pinnæ distant and divindling down very gradually; texture herbaceous or subcoriaceous; rachis and hoth sides naked; veins pinnate in the lobes, with 10-15 veinlets on a side; sori nearer the edge than the midrib.-Hk. Sp. 5 . p. 139. t. 292.- $\beta, G$. consimilis, Fée; fr. smaller; texture herbaceous; veinlets $6-8$ on a side.

Hab. Jamaica; $\beta$, Guadeloupe, L'Herminier.

9. G. (Lept.) aurita, Hk.; rhizome creeping; st. 1 ft. l., naked, glossy, chesnut-brown ; $f r .1 \frac{1}{2}-2 \mathrm{ft} .1 .$, 8-12 in. br., bipinnatifid or bipinnate; pinnoe in distant pairs, cut down nearly or quite to the rachis into lanceolate entire or crenate lobes, the lowest on one or both sides longer than the rest and pinnatifid; texture subcoriaceous; rackis glossy, castaneous; both sides naked; veinlets forked; sori oblong, sometimes produced on both forks.-Hk. Sp. 5. p. 141. 2nd Cent.t.74.

Hab. North India, up to 6,000 ft.-This has altogether the habit and texture of Polypodium distans.

$$
\text { ** Frond tripinnatifid. Sp. 10-11. }
$$

10. G. (Lept.) decurrenti-alata, Hk.; st. 18 in. 1., brown, weak, slightly scaly downwards ; fr. $18 \mathrm{in.}$ l., $1 \mathrm{ft}$. br., subdeltoid ; lower pinnce the largest, lanceolate, 6 in. l., 2 in. br., cut down to the rachis below into oblong bluntly lobed 
pinnl.; texture herbaceous; colour deep-green; rachis and both sides naked; veins pinnate in the lobes of the pinnl., with the suri near the main veins. $-H k$. Sp. 5. p. 142. t. 294.

Hab. Japan, Oldham, 374.

11. G. (Lept.) opaca, Spreng.; st. $1 \frac{1}{2}-2$ ft. l., strong, stramineous, glossy ; fr. several ft. l., often $2 \mathrm{ft}$. br. ; lower pinnce often $1 \mathrm{ft}$. 1., $6 \mathrm{in.} \mathrm{br.;} \mathrm{pinnl.} \mathrm{close,}$ lanceolate, cut down nearly to the rachis below into close oblong, slightlytoothed lobes; texture herbaceous; rachis and both sides naked; veinlets forked ; sori oblong, irregular, close to the midrib.-G. obtusata, Bl. Hk.Sp. 5. p. 143.

Hab. North India and Java.

$\S \S$ Digrammaria, Presl. Main veins and lower ones of the same group forming costular areoloe, as in Pleocnemia. Sp. 12.

12. G. (Digram.) ambigua, Hk.; st. slender, nearly naked; fr. $1 \frac{1}{2}-2 \mathrm{ft} .1$. , $1 \mathrm{ft}$. br., oblong-deltoid, bipinnatifid ; pinnoe lanceolate, 5-6 in. l., 1-1 $\frac{1}{2}$.in. br., the lower ones slightly stalked, cut halfway down to the rachis or more into linear-oblong lobes, the fertile ones contracted ; texture thinly herbaceous ; colour dark-green; rachis and both sides thinly clothed with long jointed hairs; veinlets of the lobes often forked, the lower ones forming costular areolæ; sori oblong, confluent when the veins fork. $-H k$. $S p$. 5. p. 150. Heterogonium aspidioides, Presl.

Hab. Philippines, Cuming, 154-321.

§§ Stegnogramme, Blume. Veinlets of contiguous groups uniting as in Eunephrodium and Goniopteris. Sp. 13.

13. G. (Steg.) aspidioides, Hk. (non Kaulf.) ; st. tufted, 6-9 in. l., deciduously villose; fr. 12-18 in. l., 6-10 in. br., oblong-lanceolate, simply pinnate ; pinnoe lanceolate, 3-5 in. 1., $\frac{3}{4}-1 \frac{1}{4}$ in. br., bluntly lobed a quarter or third of the way down to the midrib, truncate at the base; texture herbaceous; rachis and both sides more or less villose; veins pinnate in the lobes, with 6-9 veinlets on a side. -Hk. Sp. 5. p. 150. 2 nd Cent. t. 50.

Hab. Khasya, Ceylon, and Java.-The East Indian is less villose than the Malayan plant, with narrower pinnæ and fewer veins, and is S. asplenioides, J. Sm.

Series 2. Habit and mode of growth of Cheilanthes. Sori linear, usually forked. Sp. 14-57.

$\S \S \S \S$ Eugymnogramme. Veins free, under surface not powdery. Sp. 14-50. Fig. 52 a.

* Frond simple. Sp. 14-16.

14. G. reniformis, Mart.; st. densely tufted, 1-2 in. l., wiry, ebeneous ; fr. 1-1 $\frac{1}{2}$ in. each way, the outer edge round, faintly crenated ; texture coriaceous ; veins flabellate; sori simple, linear, at last forming a broad line parallel with the outer edge $\frac{1}{8}$ in. within it.-Hk. Sp. 5. p. 126. 2nd Cent.t. 9. Pterozonium, Fée.

\section{Hab. Brazil and Peru.}

15. G. marginata, Mett. ; fr. simple, ligulate-oblong, 8-16 in. 1 ., $\frac{3}{4}-1 \frac{1}{4}$ in. br., narrowed towards both ends, at the base gradually into a short stem, the edge slightly repand ; texture coriaceous; both sides naked ; veins prominent, usually forked; sori linear.-Hk. Sp. 5. p. 127.

Hab. New Caledonia, Vieillard, 1642.-A very distinct plant, with the habit of Thamnopteris. 
16. G. pumila, Spreng ; rhizome filiform ; fr. tufted, $1 \frac{1}{2}-2$ in. 1., palmately forked at the apex, the ultimate lobes narrow and acute, the blade narrowed below to an indistinct stem; texture subcoriaceous; upper surface dark-green and glossy ; veins flabellate ; sori linear, irregular.-Hk. $S p .5 . p .126$. Hecistopteris, $J$. Sm.

Hab. West Indies and Guatemala to the Amazon Valley.

* Frond simply pinnate. Sp. 17-19.

17. G. Muelleri, Hk. ; st. tufted, 3-4 in. 1., wiry, densely clothed with small

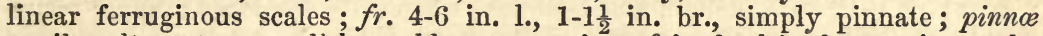
sessile, alternate, roundish or oblong, sometimes $\frac{3}{4}$ in. $1 ., \frac{1}{2}$ in. br., entire or the lower ones auricled; texture thick, coriaceous ; rachis and under surface densely matted with scales like those of the stem, upper surface pale-green, with scattered scales; veins flabellate ; sori linear.-Hk. Sp. 5. p. 143.t. 295.

Hab. N. E. Australia ; and gathered lately in Queensland by Mr. Hill.

18. G. vestita, Hk. ; st. tufted, 3-6 in. 1., wiry, more or less matted, the scales

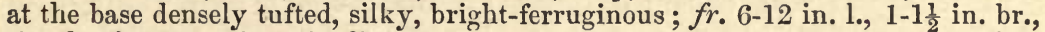
simply pinnate; pinno in distant pairs, oblong or cordate-ovate, entire, bluntish, the lower ones distinctly stalked; texture thick, but flaccid; both sides and rachis densely coated with fine velvety ferruginous hairs; veins flabellate; sori forked.-Hk. Sp. 5. p. 143. Ic. t. $11 \tilde{\text {. }}$

Hab. N. W. Himalayas (up to 8,000 ft.) and Pekin.-Veins sometimes anastomosing towards the edge.

19. G. rufa, Desv. ; st. tufted, 4-12 in. 1., firm, erect, chesnut-brown, clothed with soft spreading hairs; fr. 12-18 in. l., 3-5 in. br., simply pinnate; pinnoe

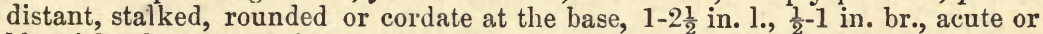
bluntish, the edge entire; texture herbaceous ; castaneous rachis pilose, and both sides slightly so; veins close, forked, or the lower ones subpinnate, the narrow sori running along all of them all over the surface.-Hk. Sp.5. $p .145$. Neurogramme, Link.

Hab. West Indies and Panama southward to the Amazon Valley and Peru.

\section{*** Frond bipinnatifid or bipinnate. Sp. 20-35.}

20. G. cordata, Schlecht ; st. tufted, 1-2 in. 1., glossy, ebeneous, more or less

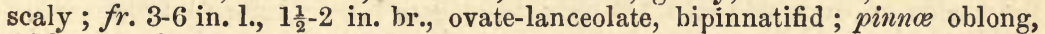
with a broad centre and suborbicular deeply-toothed lobes; texture subcoriaceous; veins flabellate; upper surface naked, lower densely coated with ovate acuminate ferruginous scales; sori linear, ultimately subconfluent.-Hk. Sp. 5. p. 131.

Hab. Cape Colony to Macalisberg and Angola.-The less-divided forms resemble Asplenium Ceterach in habit.

21. G. Pozoi, Kunze ; st. tufted, slender, clothed witl soft brownish spreading hairs ; fr. 2-3 in. l., 1 in. br., ovate-oblong, bipinnatifid ; pinnoe oblong-deltoid, unequal-sided, $\frac{1}{4}-\frac{3}{8}$ in. each way, with a few deep blunt lobes, and obliquely truncate at the base on the lower side; texture herbaceous; rachis and both sides clothed with long soft hairs like the stem; veins flabellate; sori linear.Hk. Ic. t. 935. Hemionitis, Lag. Grammitis hispanica, Cosson.- $\beta$, G. rutoefolia, $H k$. \& Gr. Ic.t. 90 ; fr. larger and stouter, some of the hairs glandular.-Hk. Sp. 5. p. 137.- - , G. papaverifolia, Kze. ; pinnoe cut down to the rachis into roundish or spathulate lobes, with a space between them, the lowest sometimes slightly toothed.-Hk. Sp. 5. p. 138.

Hab. $\boldsymbol{\alpha}$, Spain ; $\beta$, Australia and New Zealand ; $\gamma$, Chili. 
22. G. Andersoni, Beddome ; st. tufted, 1-2 in. l., densely clothed with soft golden hairs ; $f r .1-2$ in. $1 ., \frac{1}{2}$ in. br., oblong, bipinnatifid, with a terminal pinna and 4-5 lateral pairs, all sessile, roundish-oblong, bluntly lobed from $\frac{1}{4}-\frac{1}{3}$ of the way down to the rachis; texture thinly herbaceous; rachis and surfaces clothed with hairs like those of the stem; veins fine, pinnate ; sori linear.-Beddome, Fil. Brit. Ind.t. 190.

Hab. Kumaon, at 13,000 ft., Dr. Anderson.

23. G. tomentosa, Desv. ; st. tufted, 6-12 in. l., firm, erect, chesnut-brown, villose ; fr. 6-12 in. l., deltoid and bipinnate when fully developed; upper pinnce simple, stalked, rounded or cordate at the base, 1-2 in. 1., $\frac{1}{2}-1$ in. br., entire or lobed, lower pinnæ 1-4 in. 1., with several similar pinnl.; texture herbaceous; castaneous rachis pilose and both sides slightly so ; veins close, the sori running along all of them all over the surface.-HK. Sp. 5. p. 144.

Hab. S. Brazil and Peru.-Habit of $G$. rufa, but more divided. They resemble Hemionitis in habit, but the sori are not at all reticulated.

24. G. angustifrons, Baker ; st. tufted, flexuose, 2-4 in. 1., wiry, glossy, dark chesnut-brown; fr. 6-12 in. l., $\frac{1}{2}$ in. br., ligulate, bipinnatifid, enrolled at the point; pinnoe with usually a space between them, oblong-deltoid, $\frac{1}{4}-\frac{3}{8} \mathrm{in}$. l., 2-3 lin. br., with blunt rounded lobes, the lowest of which reach nearly or quite down to the rachis; texture subcoriaceous; rachis and both sides pilose; veins flabellate; sori oblong.-G. elongata, Hk. Sp. 5. p. 135. (non Swartz). Jamesonia, Fée.

Hab. Andes of Ecuador and Peru.

25. G. hirsutula, Mett. ; st. tufted, flexuose, 1-2 in. I., wiry, glossy, castaneous ; fr. $1 \mathrm{ft}$. l., $\frac{1}{2}-1$ in. br., ligulate, bipinnatifid, not enrolled at the point ; pinnce close, spreading, ovate or ovate-oblong, cut down nearly to the rachis on each side into 2-5 obovate-cuneate lobes; texture subcoriaceous; rachis and both sides slightly hairy; veins not reaching the edge.-Mett. Fil. Nov. Gran.p. 209.

Hab. New Granada, Lindig.-Differs from the preceding by being less hairy, and not circinate at the point.

26. G. Karstenii, Mett.; st. 2 in. 1., wiry, glossy, castanéous ; fr. 1 ft. l., $\frac{1}{2}$ in. br., ligulate, bipinnatifid, the apex enrolled; pinnoe numerous, lax, spreading, stalked, ovate-rhomboidal, cuneate at the base, cut down nearly to the rachis on each side into 1-3 obovate-cuneate lobes; texture subcoriaceous ; rachis and both sides nearly naked; veins seldom reaching the edge.-Mett. Fil. Nov. Gran. p. 210.

Hab. New Granada, Lindig, 15a.

27. G. incisa, Mart. \& Lind.; st. tufted, wiry, 3-4 in. 1., ebeneous, slightly pilose ; fr. 3-4 in. l., $1 \frac{1}{2}$ in. br., bipinnatifid ; pinnoe close, lanceolate, cut down to a broadly-winged centre into oblong entire or forked lobes; texture subcoriaceous ; rachis densely villose and both sides less so ; veins one to each lobe; sori linear-oblong.-Hk. Sp. 5. p. 134.

Hab. New Granada, Linden, 1044.

28. G. mohriceformis, Mett. ; st. tufted, wiry, 3-4 in. 1., dark purplish-brown, slightly villose; $f r .2-3$ in. $1 ., 1$ in. br., lanceolate-deltoid, bipinnate ; lower: pinnce the largest, $\frac{1}{2}$ in. $1 ., \frac{1}{4}-\frac{3}{8}$ in. br., cut down nearly or quite to the rachis into orbicular crenate lobes; texture coriaceous; rachis and both sides hispid; veins conspicuous, flabellate; sori small, oblong.-Hk. Sp. 5. p. 128.

Hab. Peru. 
29. G. Ottonis, Klotzsch ; st. tufted, 4-6 in. 1., glossy, wiry, eleneous ; fr. 5-8 in. 1., 1 in. br., bipinnate ; pinnoe distant, the lowest $\frac{1}{2}$ in. 1., $\frac{1}{4}$ in. br.; pinnl. suborbicular, entire or slightly cleft; texture subcoriaceous; rachis ebeneous ; both sides naked ; veins flabellate ; sori irregular, of few capsules.Hk. Sp. 5. p. 128.

Hab. Venezuela, Otto, 630.

30. G. Lindigii, Mett. ; st. 1-4 in. 1., castaneous, lispid, glossy ; fr. 4-9 in. 1., $\frac{1}{2}-1 \frac{1}{2}$ in. br., flexuose, bipinnatifid or bipinnate ; pinnoe $\frac{1}{2}-\frac{3}{4}$ in. 1., ovate-oblong or subdeltoid, cut down nearly or quite to the rachis on each side into 3-8 ovaterhomboidal or roundish imbricated lobes; texture subcoriaceous; rachis and both sides hispid; veins not reaching the edge.-Mett. Fil. Nov. Gran. p. 210.

Hab. New Granada, Lindig. - This and the six preceding are closely allied.

31. G. decipiens, Mett.; st. subtufted, 6-9 in. l., wiry, dark chesnut-brown, naked; fr. 6-9 in. 1., 2-3 in. br., deltoid, bipinnatifid; pinnoe imbricated,

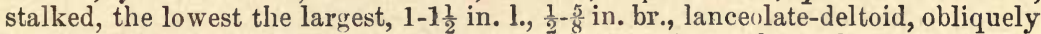
truncate at the base below, cut down nearly or quite to the rachis into cuneate or oblong entire or toothed lobes; texture herbaceous; rachis and both sides naked; veins flabellate; sori linear, conspicuous.-Hk. Sp. 5. p. 132. t. 291.

Hab. Aneiteum and New Caledonia.-Resembles Asplenium marinum in habit.

32. G. ferruginea, Kze. ; st. tufted, 6-12 in. 1., stout and densely clothed with ferruginous woolly tomentum ; fr. 1 ft. or more 1., 3-4 in. br., ovate-lanceolate, bipinnate; pinnae 2-3 in. $1 ., \frac{1}{2}-1$ in. br., cut down to the rachis below into oblong or linear-oblong entire or slightly toothed lobes; texture subcoriaceous; upper surface naked; lower and rachis densely coated with tomentum ; veins flabellate ; sori lax, simple or forked.- $\beta, G$. lanata, Klotzsch; less woolly beneath ; pinnl. larger, and the lower ones bluntly lobed halfway down.- Hk. Sp. 5. p. 130.

Hab. Peru ; and gathered also by Seeman in Panama.

33. G. Haughtoni, Hk. MSS.; st. densely tufted, 1-2 in. 1., black, glossy ; fr. 3-4 in. 1., 1-1 $\frac{1}{2}$ in. br., ovate-lanceolate, bipinnate ; pinnæe close, the central ones lanceolate-deltoid, cut down nearly or quite to the rachis below into suborbicular irregularly crenated lobes; texture subcoriaceous ; veins flabellate; colour darkgreen, only the lower surface slightly scaly; sori oblong, thick, at last often filling up nearly the whole surface.-G. cordata, Hk. Sp.5. p. 131. (in part). 2nd Cent. $t$. 7 .

Hab. St. Helena.-Perhaps should be joined with $G$. cordata, from which it differs by being more deeply cut and hardly at all scaly.

34. G. Hookeri, J. Sm.; st. tufted, 4-6 in. 1., firm, dark chesnut-brown, glossy, clothed when young with ferruginous tomentum; fr. 9-15 in. 1., 4-5 in. br., oblong-lanceolate, bipinnate ; pinno numerous, lanceolate, cut down to the rachis into entire or slightly toothed linear-oblong pinnl., the longest $\frac{1}{4}-\frac{3}{8} \mathrm{in} . \mathrm{l}$., with enrolled edges and about their own breadth between them; texture coriaceous; upper surface and castaneous rachis naked; lower clothed with ferruginous tomentum.

Hab. Andes of New Granada, Purdie, Schlim 609, and Bolivia, Mandon"1547.Habit of $G$. ochracea, but the under surface and young stems coated with ferruginous tomentum, and not powdery.

35. G. javanica, Blume; rhizome creeping ; st. naked, glossy, 1-4 ft. 1. ; fr. 1-4 ft. l., varying from 1 to 2 pinnate; pinnl. sessile or slightly stalked, 3-12 in. 1., $\frac{1}{2}-3$ in. br., oblong-lanceolate, the apex acuminate, the edge entire or finely toothed; texture firm-herbaceous; rachis stramineous, and both sides glossy, 
sometimes slightly pubescent; veins close, simple, or once forked, the sori running along all of them, but stopping a space short of the edge.-Hk. $S p .5$. p. 145. Coniogramme, Fée.

Hab. N. India (up to 8,000 ft.) and Japan to the Sandwich Isles, Fiji, Malayan Islands, and Ceylon, Fernando Po, Cameroon Mountains, and St. Thomas, West Tropical Africa. -We include here three species of Fée, C. serrulata, javanica, and serra, and G. pilosa, Brack., as a hairy form. Diplazium fraxineum, Don, appears to be the oldest name.

\section{**** Frond tripinnatifid. Sp. 36-45.}

36. G. Schomburgkiana, Kze.; st. tufted, 6-9 in. 1., naked, glossy, dark

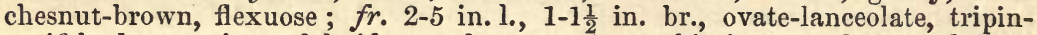
natifid; lower pinno deltoid, cut down to the rachis into spathulate cleft or pinnatifid pinnl.; texture subcoriaceous; rachis wiry like the stem; veins flabellate; upper surface with a few firm hairs on the veins ; sori irregular.Hk. Sp. 5. p. 127. 2nd Cent. t. 92.

Hab. British Guiana, Richd. Schomburgk 1196, Appun 1091.

37. G. aureo-nitens, Hk.; st. stout, densely clothed with deciduous darkferruginous tomentum; the rachis very flexuose and zigzag; pinnoe on stalks $\frac{1}{2}-1$ in. 1., lanceolate-deltoid, the largest 4-6 in. 1., 2-3 in. br., cut down to the rachis below into blunt irregular subdeltoid pinnl. with broad blunt lobes; texture thick; under surface and rachis densely matted with bright ferruginous tomentum; sori hidden, elongated, simple or forked.-Hk. Sp. 5. p. 130. Ic. $t$. 820. Eriosorus, Fée.

Hab. Peru. - A fragment from Ecuador resembles this in cutting and habit, but is much less woolly, with naked ebeneous rachises.

38. G. Matthewsii, Hk. ; st. tufted, 4-6 in. 1., glossy, dark chesnut-brown, clothed with deciduous dense brown hairs; fr. 12-15 in. 1., 4-5 in. br., oblonglanceolate, tripinnatifid ; lower pinnoe distant, lanceolate-deltoid, 2 in. $1 ., 1$ in. br., cut down to the rachis below into oblong-deltoid blunt pinnl. with broad rounded lobes, lowest pinnæ distant and reduced; texture coriaceous; rachis densely matted with brown hairs, and both sides pilose; veins conspicuous, flabellate; sori brown.-Hk. Sp. 5. p. 128. t. 290.

.Hab. Peru, Matthews, 1814.

39. G. Warcewiczii, Mett. ; st. 6-8 in. 1., reddish, slightly hairy, at last naked ; fr. 6-15 in. 1., 2-4 in. br., oblong-lanceolate, tripinnatifid; pinnoe $2 \frac{1}{2}$ in. l., lax, sessile or stalked, ovate-rhomboidal or ovate-oblong obtuse, cut down nearly or below quite to the rachis into ovate-rhomboidal obtuse pinnatifid pinnl., lower pinnæ distant, reduced; texture coriaceous, rigid; upper surface naked, the lower and reddish flexuose rachis slightly hairy; weins flabellate.-Mett. Fil. Nov. Gran. p. 211.

Hab. New Granada.

40. G. cheilanthoides, Kaulf. ; st. tufted, 3-6 in. 1., wiry, slender, glossy, dark chesnut-brown ; fr. 6-10 in. l., 1 in. br., ligulate, tripinnatifid; pinnoe close, deltoid, $\frac{1}{2}$ in. 1., nearly as broad, the upper lobes simple, linear-oblong, the lower ones forked or trifid, the largest ult. divisions 1 lin. 1., $\frac{1}{4}$ lin. br.; texture herbaceous, the glossy castaneous rachis and both sides slightly pilose; veins 1 to each ult. division; sori oblong.-Hk. Sp. 5. p. 135. Hk. \& Gr. Ic. t. 24.

Hab. Mauritius and Tristan d'Acunha.

41. G. flabellata, Hk. ; st. 3-4 in. 1, wiry, glossy, dark chesnut-brown; fr. 


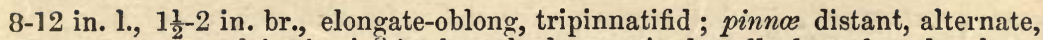
erecto-patent, 1-1 $\frac{1}{2}$ in. 1., $\frac{1}{4}-\frac{3}{8}$ in. br., the lower pinnl. stalked, as broad as long, cuneato-flabellate, deeply lobed, the lobes oblong, blunt; texture herbaceous; both sides and the castaneous raclis pilose; veins and sori one to each lobe, the latter confluent in the centre of the pinnules, - Hk. Sp. 5. p. 134.

Hab. Andes of Ecuador, Jameson.

42. G. myriophylla, Sw.; st. 6-12 in. 1., reddish-brown, more or less villose ; fr. 12-18 in. 1., 4-6 in. br., oblong-lanceolate, tripinnatifid ; pinnoe distant, lanceolate, 2-3 in. 1., 1 in. br.; pinnl. lanceolate, cut down to the rachis below into suborbicular or oblong toothed or pinnatifid segm.; texture herbaceous; rachis and both sides pubescent; veins 1 to each ult. division; sori oblong, confluent in the eentre of the segments.-Hk. Sp. 5. p. 134.

\section{Hab. Brazil.}

43. G. pedata, Kaulf. ; rhizome creeping ; st. distant, 6-12 in. l., fragile, glossy, bright chesnut-brown ; fr. 4-6 in. each way, lower pinnoe much the largest, the upper ones lanceolate, with linear-oblong entire or slightly toothed lobes $\frac{1}{2}-\frac{3}{4}$ in. 1., $\frac{1}{4}$ in. br.; lowest pinnl. 1-2 in. 1., with similar divisions ; texture herbaceous ; upper surface slightly hispid, lower pubescent, especially on the midrib; sori confluent, forming an intramarginal band.-Hk. Sp. 5. p. 131 .

Hab. Mexico and Guatemala.-Distinguished by its pedate habit.

44. G. leptophylla, Desv.; st. 1-4 in. l., tufted, slender, glossy, chesnut-brown ; fr. 2-4 in. 1., 1-1 $\frac{1}{2}$ in. br., ovate or deltoid, bi- or tripinnate, the barren ones smaller and on shorter stems; segm. cuneato-flabellate, cut from the circumference to the centre into linear or oblong lobes $\frac{1}{2}$ lin. br.; texture pellucidoherbaceous; a single vein and line of fruit carried into each ult. lobe.-Hk. Sp. 5. p. 136. B. F.t. 1. Hk. \&. Gr.t. 25.

Hab. Jersey and shores of the Mediterranean, Barbary States, Azores, Madeira, Canaries, Abyssinia, Cape Colony, Persia, Neilgherries, New South Wales, Van Diemen's Land, New Zealand, Andes of Mexico and Ecuador.-This and the two next are annual, and form the genus Anogramma of Link.

45. G. Ascensionis, Hk. ; st. 1-2 in. l., tufted, slender, almost filiform, greenish

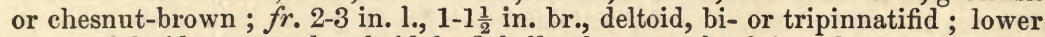
pinnoe deltoid; segm. rhomboidal, flabellately cut, the lobes short and rather acute; texture thin-herbaceous; veins and linear sori 1 to each ult. lobe.-Hk. Sp. 5. p. 137.-2nd Cent. t. 67.

Hab. Ascension Island, $D r$. Hooker, Dr. Curror.-This comes very near some of the forms of the next species.

\section{***** Fronds quadripinnatifid. Sp. 46-50.}

46. G. chorophylla, Desv.; st. tufted, slender, 3-6 in. 1., green upwards, chesnut-brown near the base ; fr. 3-6 in. 1., 2-4 in. br., ovate or deltoid, quadripinnatifid; lower pinnoe and pinnl. deltoid; segm. flabellately cut, the ult. divisions short, oblong, subacute ; texture pellucido-herbaceous, a vein and sorus. to each ult. division, the latter confluent in the centre of the segments. $-H k$. $S p$. 5. p. 131. Hk. \& Gr.t. 45 .

Hab. Cuba and Guatemala to Buenos Ayres and Paraguay.

47. G. microphylla, Hk.; st. densely tufted, 2-4 in. 1., slender, fragile, glossy, chesnut-brown ; fr. $1 \frac{1}{2}-3$ in. 1., 1-1 $\frac{1}{2}$ in. br., deltoid, quadripinnatifid ; pinnce close, the lower ones deltoid; pinnl. deltoid; ult. divisions under 1 lin. l., half as 
broad; texture pellucido-herbaceous; veins and sori one to each ult. division, the latter oblong.-Hk. Sp. 5. p. 129. 2nd Cent.t. 15.

Hab. Khasya, Griffith. - Habit of the three preceding, but not annual.

48. G. hirta, Desv.; st. tufted, 6-12 in. 1., glossy, dark chesnut-brown, slightly pilose ; fr. 6-12 in. 1., 4-8 in. br., ovate-deltoid, quadripinnatifid; lower pinnoe and pinnl. deltoid; segm. $\frac{1}{8}-\frac{1}{4}$ in. each way, cuneato-flabellate, with blunt oblong lobes; texture firm-herbaceous; rachis castaneous, often slightly flexuose, like both sides more or less pilose ; veins and sori 1 to each lohe, the latter confluent in the centre of the segments.-G. laserpitiifolia, Kze. Hk. Sp. 5. p. 133.

Hab. Columbia.-G. hispidula, Klotzsch (Jamesonia, Kze.), is apparently a reduced form. G. glandulosa, Karst., differ's from the type by being less divided and densely glandular.

49. G. flexuosa, Desv.; st. 6-18 in. 1., glossy, chesnut-brown, flexuose, slender ; fr. 3-4 ft. l., scandent, tri- or quadripinnate ; rachises zigzag, branched; pinnoe reflexed, subdeltoid in general outline; segm. flabellately branched; $u l t$. divisions linear or oblong, $\frac{1}{2}$ lin. br., with 1 vein and oblong sorus to each; texture firm-herbaceous.-Hk. Sp. 5. p. 129. G. retrofracta, Hk. \& Gr. Bot. Misc. 3.t.112.

Hab. Nicaragua to Peru.

50. G. Pearcii, Moore ; st. 6-9 in. 1., glossy, chesnut-brown; fr. about $1 \mathrm{ft}$. each way, deltoid, quadripinnatifid; lower pinnoe the largest, 4-6 in. 1., subdeltoid ; pinnl. imbricated; ult. divisions $\frac{1}{8}$ in. l., $\frac{1}{4}$ lin. br., simple or forked; texture herbaceous; rachis and both sides naked; one vein and sorus to each ult. division.-Moore, G. C. 1864, p. 340.

Hab. Peru ; discovered by Mr. Pearce.-Allied to the preceding, but the divisions much narrower, and rachis not flexuose. The crown of the root is slightly powdery.

§§§\$ Ceropteris, Link. Differs from Eugymnogramme only by the fronds being coated beneath with white or yellow powder. Sp. 51-57.

§̃1. G. (Cerop.) trifoliata, Desv. ; st.tufted, 8-12 in. 1., stout, erect, dark chesnutbrown, the lower part scaly; $f r .2-3 \mathrm{ft}$. l., 6-8 in. br., pinnate ; lower pinnce ternate, the upper ones simple, petiolate, $2-4$ in. 1., $\frac{1}{4}-\frac{3}{8}$ in. br., linear-oblong, nearly entire; texture herbaceous, the under side usually naked in the barren fronds, clothed in the fertile ones with white or yellowish powder.-Hk. sp. 5 . p. 149. G. F.t. 4 .

Hab. Cuba, southward to Peru and Brazil.-A variable plant. We include here three species of Fée,-his Trismeria argentea, aurea, and microphylla.

52. G. (Cerop.) triangu?aris, Kaulf.; st. densely tufted, 6-12 in. 1., dark chesnut-brown, glossy, nearly naked; fr. 3-4 in. each way, deltoid; lower' pinno much the largest, deltoid, unequal-sided, the other's lanceolate, deeply pinnatifid, with oblong obtuse lobes; texture subcoriaceous; powder varying from deep orange to white.-Hk. Sp. 5. p. 146. Hk. \& Gr.t. 153. Fil. Ex. t. 153 .

Hab. Vancouver's Island and Oregon southward to Ecuador.

53. G. (Cerop.) tartarea, Desv. ; st. tufted, firm, 6-12 in. 1., dark chesnutbrown, scaly towards the base; fr. 1-2 ft. l., 6-12 in. br., oblong-deltoid, bipinnatifid; pinnce lanceolate, the lowest the largest; pinnl. oblong, obtuse, entire or nearly so, united or the lower ones free ; texture subcoriaceous ; powder dense, pure white.-G. dealbata, Link. $-\beta$ G. ochracea, Presl; pinnl. very regular and 
only the lowest toothed; powder bright-yellow. $-\gamma$, G. ornithopteris, Klotzsch ; texture more coriaceous, edges of the divisions incurved ; powder white or yellow.

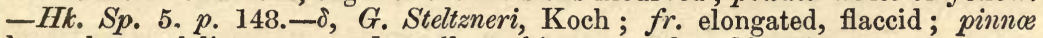
lanceolate, subdistant; powder yellow, thin; st. and rachis pubescent.

Hab. Tropical America.-There is no clear line of distinction between this and the preceding. The forms associated here differ mainly from those placed under calomelanos by being firmer in texture and less divided. G. guianensis, Klotzsch, comes between $\alpha$ and $\gamma$, and $G$. adiantoides, Karst., is said to differ from $\beta$ by its sublanceolate outline and acuminate pinnules. We cannot distinguish from $a$. ochracea a plant gathered by Gerrard in Natal.

54. G. (Cerop.) calomelanos, Kaulf. ; st. tufted, firm, 6-12 in. 1., nearly black ; fr. 1-3 ft. l., 6-12 in. br., oblong-deltoid, tripinnatifid; pinnce close, lanceolate, the lowest the largest, sometimes 6 in. $1 ., 1 \frac{1}{2}-2$ in. br.; lower pinnl. distinct, lanceolate or subdeltoid, often cut down nearly to the rachis; texture subcoriaceous or herbaceous; powder white. $-H k . G . F . t .30 .-\beta, G$. peruviana, Desv.; fr. smaller; st. and rachis castaneous; lower pinnoe deltoid ; lower pinnl. often cut down to the rachis. $-\gamma, G$. chrysophylla, Kaulf.; size and habit of $\beta$, but the rachis darker and the powder bright yellow. $-H k$. Sp. 5. p. 148.

Hab. West Indies, southward to Rio Janeiro, Peru, and Samoa; Tropical West African Islands.-We include here a wide range of forms connected by very gradual intermediate stages. G. L'Herminieri, Martensii, and Massoni of Link, and C. intermedia, Fée, are all intermediate between $\alpha$ and $\gamma$.

55. G. (Cerop.) pulchella, Linden ; st. tufted, firm, 6-9 in. l., dark chesnutbrown, powdery ; fr. 6-12 in. l., 4-6 in. br., oblong-deltoid, tripinnatifid ; lower pinnoe the largest, lanceolate-deltoid; pinnl. imbricated, the lower ones subdeltoid; segm. flabellato-cuneate, often $\frac{1}{8}$ in. br.; texture herbaceous; powder pure white.-Hk. Fil. Ex.t. 74.

Hab. Venezuela.-Joined in "Sp. Fil." to G. sulphurea, from which it differs by its more robust habit, white powder, and frond broadest at the base. It comes very near G. peruviana. Var. Wettenhalliana, Moore, is a garden variety, with pale sulphurcoloured powder.

56. G. (Cerop.) sulphurea, Desv. ; st. densely tufted, 1-6 in. l., generally short, slender, chesnut-brown, often powdery ; $f$ r. 6-12 in. 1., 3-4 in. br., ovatelanceolate, tripinnatifid; pinnoe lanceolate, the lower ones gradually reduced; pinnl. flabellately cut, with entire or cleft cuneate segm. 1-1 $\frac{1}{2}$ lin. br.; texture herbaceous; powder bright yellow.-Hk. Sp. 5. p. 147.

Hab. West Indies.-Distinguished by its cutting, small size, herbaceous texture and frond narrowed in the lower third.

57. G. (Cerop.) rosea, Desv. ; st. tufted, slender, 3-6 in. 1., dark chesnutbrown, glossy ; fr. 6-12 in. l., subdeltoid, quadripinnatifid ; pinnoe not numerous, often distant, deltoid, the lower ones 3-4 in. 1., 2 in. br.; pinnl. and segm. deltoid, the ult. divisions small, flabellato-cuneate; texture herbaceous; powder white or tinged with red; sori pale-brown.-G. conspersa, Kze. Hk. Sp. 5 . p. 147. G. farinosa, Bojer.

Hab. Mascaren Isles and Natal.-G. conspersa, Kze., appears to be a slender flaccid form of the Mascaren species. A plant from Bourbon, received from the Paris Museum under the name of $G$. aurea, is more robust in habit, with broader and closer divisions and yellow powder, and Dr. Welwitzsch has gathered similar examples in Angola. 
Series 3. Habit and mode of growth of Eupolypodium. Sp. 58-84.

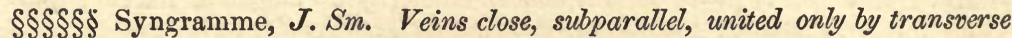
veinlets near the margin. Fig. 52. d. Sp. 58-65.

58. G. (Syn.) borneensis, Hk.; rhizome creeping, woody, densely clothed with nearly black fibrillose scales; $f r$. subsessile, $4-6$ in. 1. , $\frac{1}{4}-\frac{3}{4}$ in. br., ligulate, narrowed to both ends, the edge very slightly toothed, the barren ones the broadest; texture coriaceous; both sides naked; veins immersed, once or twice forked, connected by indistinct transverse veinlets close to the edge.- $H k$. Sp. 5 . p. 154. $t .301$.

Hab. Borneo, T. Lobb.

59. G. (Syn.) cartilagidens, Baker; rhizome slender, creeping, clothed with very small black fibrillose scales ; st. $\frac{1}{4}-\frac{1}{2}$ in. $1 . ; f r .4-6$ in. $1 ., \frac{1}{2}-\frac{5}{8}$ in. br., ligulate, the point acuminate, the lower half narrowed very gradually, the edge thickened and fringed with close small distinctly cartilaginous linear teeth; texture subcoriaceous; both sides naked; veins fine, close, very distinct when the frond is held up to the light, connected only just within the edge and the connecting vein not always distinct from the thickened border; sori fine, close, separated by a space from the midrib.

Hab. Borneo, Signor Beccari; communicated by Mrs. Lyell.-Differs from the last by its thinner texture, finer veins and sori, and very peculiar teeth.

60. G. (Syn.) obtusifolia, Hk.; rhizome creeping, fibrillose ; st. 2-3 in. 1., naked, greenish, flexuose ; fr. $6-9$ in. $1 ., \frac{1}{4}-\frac{1}{2}$ in. br., ligulate, the point blunt, the lower part narrowed very gradually; texture coriaceous; both sides naked; weins prominent, simple or forked, connected near the edge ; sori linear-oblong, medial. -Hk. Sp. 5. p. 153. t. 299.

Hab. Java, De Vriese.

61. G. (Syn.) Lobbiana, Hk. ; st. tufted, 2-3 in. 1., glossy, ebeneous ; fr. 6-10 in. $1 ., \frac{1}{2}-\frac{3}{4}$ in. br., linear-oblong, entire, the apex acuminate, the base narrowed or slightly rounded ; texture coriaceous ; both sides naked; veins parallel, simple or forked, united by a series of transverse veinlets a short distance from the edge, which bound the copious sori. $-H k$. Sp. 5. p. 153.t. 300 .

Hab. Borneo, T. Lobb.

62. G. (Syn.) vittoeformis, Hk.; st. subtufted, 12-18 in. l., naked, flexuose, dark-brown ; fr. 8-12 in. l., $1 \frac{1}{2}-2 \frac{1}{2}$ in. br., spathulate-oblong, the edge irregularly repand, the point acute ; texture subcoriaceous ; both sides naked; veins fine, parallel, forming one or two rows of distinct areolæ near the edge; sori extending from the midrib to the margin.-Hk. Sp. 5. p. 154.

Hab. Philippines, Cuming, 329.

63. G. (Syn.) Wallichii, Hk. ; st. subtufted, 6-18 in. 1., firm, glossy, chesnut-

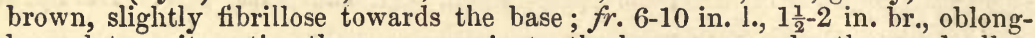
lanceolate, quite entire, the apex acuminate, the base narrowed rather gradually ; texture subcoriaceous; both sides naked; veins fine, parallel, uniting ones near the edge and indistinct beyond where they join ; sori extending on all the veins from the midrib to where they unite.-Hk. Sp. 5. p. 155.t.302.

Hab. Singapore and Borneo.

64. G. (Syn.) alismaefolia, Hk.; st. subtufted, 6-18 in. 1., firm, glossy, chesnut-brown; fr. 5-8 in. 1., 2-3 in. br., oblong, the apex acuminate, the base rounded, the edge entire; texture subcoriaceous; both sides naked; veins fine, 
parallel, uniting only near the edge, and indistinct beyond where they join ; sori extending on all the veins from the midrib to where they join.- $H k$. $S p .5$. p. 154.

Hab. Singapore and Philippines.

65. G. (Syn.) quinata, Hk.; st. 6-12 in. 1., glossy, naked, straw-coloured or chesnut-brown; fr. 6-12 in. l., 4-8 in. br., quinate, the terminal pinna the largest, 6-12 in. 1., 1 $\frac{1}{2}-2$ in. br., oblong-lanceolate acuminate, the edge entire, the lower part narrowed gradually to the base, the lowest pair deflexed and originating from the base of the lateral pair ; texture subcoriaceous; both sides naked; veins fine, parallel, uniting near the edge, with long sori upon all of them.-Hk. Sp. 5. p. 152.t. 297.

Hab. Borneo, Vanecolla, and Solomon Isles.-Frond like the leaf of a horse-chesnut.

\$§§§§§ Selliguea, Bory. Veins anastomosing variously and usually copiously. Differs from Phymatodes only by the elongated sori. Fig. 52. e. f. Sp. 66-84.

* Fronds simple. Sp. 66-79.

+ Main veins hidden. Sp. 66-70.

66. G. (Sell.) lanceolata, Hk. ; rhizome wide-creeping, the scales small, linear, dull-brown ; fr. 6-12 in. $1 ., \frac{1}{2}-\frac{3}{4}$ in. br., the point acute, the edge entire, the lower third narrowed gradually to the base or a short stem; texture thick, coriaceous but flaccid; both sides naked; veins obscure, the midrib much more slender than in G. involuta, the sori more oblique and falling considerably short of the edge.-Hk. Sp. 5. p. 156. Grammitis, Hk. \& Gr.t. 43.

Hab. Japan, China, Himalayas, Neilgherries, Ceylon, Fiji, Samoa, Mascaren Isles, Natal, Guinea Coast.

67. G. (Sell.) mexicana, Baker ; rhizome wide-creeping, the scales large, lanceolate-acuminate, dull-brown ; fr. subsessile, 6-10 in. 1., 1-1 $\frac{1}{4}$ in. br., the point acute, the lower half narrowed very gradually to the base; texture coriaceous but flaccid; both sides naked; veins obscure, the midrib broad and fleshy at the base but almost vanishing upwards; sori linear-oblong, few and not close, almost in one row on each side, not far from the midrib.-Selliguea, Fée. G. Salvinii, Hk. Sp. 5. p. 157. 2nd Cent. t. 71.

Hab. Mexico and Guatemala.

68. G. (Sell.) elongata, Hk, ; rhizome wide-creeping, tomentose ; st. distant, $\frac{1}{4}$ in. l., naked, ebeneous ; fr. 4-8 in. $1 ., \frac{1}{4}-\frac{1}{2}$ in. br., narrowed gradually to both ends, the edge entire ; texture coriaceous; both sides thinly clothed with small scales; veins obscure; midrib black in the lower part; sori linear-oblong, placed end to end in single rows midway between the midrib and edge.- $H k$. $S p$. 5. p. 157.

Hab. Cuba to Rio Janeiro and Juan Fernandez, - Habit and scales of Polyp. lanceolatum.

69. G. (Sell.) involuta, Don ; rhizome creeping, the scales large, lanceolate, dull-brown; fr. 8-12 in. $1 ., 1-2$ in. br., the point acuminate, the edge entire, the lower part narrowed very gradually to the base or a short broad compressed stem; texture thick, coriaceous but flaccid; both sides naked; areoloe obscure, without free veinlets; sori in long parallel very oblique lines reaching from the midrib nearly to the edge.-Hk. Sp. 5. p. 155. Grammitis, Hk. \& Gr.t. 53. S. Wallichiana, Hk. Ic.t. 204.

Hab. N. India, Neilgherries, Ceylon, Malaccas, Solomon Isles. 
70. G. (Sell.) avenia, Baker ; rhizome creeping, the scales linear, dull-brown; fr. 12-18 in. 1., 1-3 in. br., the point acuminate, the edge entire, the lower half narrowed gradually to the base or a short stout black stem; texture subcoriaceous; both sides naked; areoloe distinct, with free veinlets; sori in long parallel oblique lines nearly touching the midrib but falling short of the edge.Grammitis, Blume.

Hab. Malayan Peninsula and Isles.-Habit of the last, but thinner in texture, not wrinkled when dry, the areolæ finer, and furnished with free veinlets.

+ Main veins distinct nearly or quite to the edge. Sp. 71-79.

A. Main veins fine, texture of the frond papyraceous. Sp. 71-75.

71. G. (Sell.) membranacea, Hk. ; rhizome wide-creeping, the scales small, linear, nearly black ; st. $2-6$ in. 1., nearly naked ; fr. $6-12$ in. $1 ., \frac{1}{2}-1 \frac{1}{2}$ in. br., the point much acuminated, the edge entire, the lower part narrowed very gradually; texture papyraceo-herbaceous; both sides naked; primary veins distinct to the edge, but zigzag and very slender, united by similar transverse veinlets so as to form large hexagonal areolæ; sori in oblique parallel interrupted lines, one between each main vein.-Hk. Sp. 5. p. 159.

Hab. Malay Isles and Philippines.

72. G. (Sell.) Wrightii, Hk.; rhizome firm, wide-creeping, the scales small,

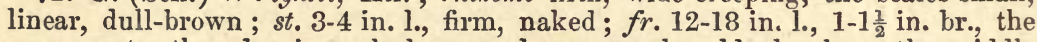
apex acute, the edge irregularly repand, narrowed suddenly about the middle and below this very gradually into the stem; texture papyraceo-herbaceous; both sides naked; main veins distinct to the edge, but zigzag and very slender; areolce copious, with free included veinlets; sori in continuous oblique parallel rows one between each main vein.- $H$ k. Sp. 5. p. 160.t. 303.

Hab. Loo Choo and Formosa.

73. G. (Sell.) regularis, Baker ; rhizome creeping, the scales $\frac{1}{8}$ in. 1. , ovatelanceolate, subferruginous; st. 1-6 in. 1.; fr. dimorphous, the barren ones 15 in. $1 ., 2 \frac{1}{2}$ in. br., elongate-oblong, narrowed gradually to both ends, the edge entire, the fertile ones 8 in. 1., 2 in. br.; texture papyraceous; both sides naked; main veins $2-3$ lin. apart, the areolæ copious, subquadrate, the main ones divided into distinct secondary ones with free veinlets; sori in single interrupted or continuous rows between the main veins.-Polyp. Mett. Fil. Ind. 2. p. 225.

Hab. Borneo, Korthals.

74. G. (Sell.) macrophylla, Hk. ; rhizome creeping, the scales lanceolate, dullbrown; st. 2.6 in. l., naked; fr. 12-18 in. l., 3-4 in. br., narrowed gradually to both ends, the edge entire; texture papyraceous ; main veins distinct but slender and zigzag, with copious uniform subquadrangular areolæ with free veinlets between them; sori in single continuous or slightly inter'upted rows between the main veins. $-H k . S p .5 . p .159$.

Hab. Malay and Philippine Isles and New Guinea.

75. G. (Sell.) spuria, Baker ; rhizome creeping, the scales ovate-acuminate, brown ; st. 9 in. 1., reddish-brown, margined upwards ; fr. 1 ft. 1., 3 in. br., ovate-oblong, the base cuneate, the point bluntish, the edge subrepand ; texture papyraceous; both sides naked; main veins straight, prominent, 3-4 lines apart; areoloe irregular, the main ones divided, and those again sometimes subdivided with free veinlets; sori in single interrupted rows.-Polyp. Mett. Fil. Ind. 2. p. 226.

Hab. Celebes, Forsten. 


\section{B. Main veins prominent, texture coriaceous. Sp. 76-79.}

76. G. (Sell.) Féei, Hk.; rhizome firm, wide-creeping, the scales bright-brown, fibrillose ; fr. dimorphous, the barren ones $3-4$ in. $1 ., 1 \frac{1}{2}-2$ in. br., ovate-oblong, on stems 1-3 in. 1., the fertile ones 3-6 in. $1 ., \frac{5}{8}-1 \frac{1}{4}$ in. br., on shorter stems, both acute and entire; texture coriaceous; both sides naked; main veins distinct, the intermediate veinlets obscure; sori linear-oblong, immersed, in single rows between the main veins, not reaching either to the midrib or edge.-Hk. $S p$. 5. p. 158.

Hab. Malay Peninsula and Isles.-P. vulcanicum, Blume, is said to be like this, but to have the barren and fertile fronds uniform.

77. G. (Sell.) hetorocarpa, Blume ; rhizome woody, wide-creeping, the scales dense, $\frac{1}{4}$ in. l., linear, full-brown ; st. 6-9 in. l., firm, erect, naked ; fr. 6-12 in. 1., 1-2 in. br., the point much acuminated, the edge entire, the lower part narrowed very gradually ; texture subcoriaceous; both sides naked, glossy; main veins distinct to the edge, the veinlets hidden; sori linear-oblong, immersed, one between each main vein, not extending either to the edge or midrib.-Hk. Sp. 5. p. 160.

Hab. Java.

78. G. (Sell.) Hamiltoniana, Hk. ; rhizome wide-creeping, woody, the scales linear, dull-brown ; fr. dimorphous, the barren ones $1 \mathrm{ft} .1$. , 3-4 in. br., spathulate, the stem 2-3 in. l., the fertile ones $4-6$ in. $1 ., 1 \frac{1}{2}$ in. br., the stems more than $1 \mathrm{ft}$. l., slender, naked; texture subcoriaceous; both sides naked; main veins distinct to the edge, with copious intermediate areolæ with free included veinlets ; sori in broad continuous rows, one between each main vein.-Hk. Sp. 5. p. 160 . Ceterach pedunculata, $H k$. \& Gr.t. 5 .

Hab. East Himalayas (subtropical region).

79. G. (Sell.) cauãiformis, Hk.; rhizome woody, creeping, the scales large, pale-brown, lanceolate ; st. 6-9 in. 1., firm, erect, glossy, pale-brown ; fr. 6-9 in. 1., ovate-oblong acuminate, the sterile ones $3-4$, the fertile ones 1-2 in. br. ; texture coriaceous ; both sides naked; main veins distinct to the edge, the veinlets obscure; sori in one continuous or interrupted row between the main veins.Hk. Sp. 5. p. 158. Bot. Mag. t. 5328.

Hab. Mergui, Moulmein, and Malayan and Polynesian Isles to Tahiti and New Caledonia.

$$
\text { * Fronds compound.-Sp. 80-84. }
$$

80. G. (Sell.) palmata, Baker ; st. 6-9 in. 1., polished, naked, ebeneous ; fr. 6-9 in. each way, cut down palmately very nearly to the base into five divisions, the central one 4-6 in. l., 1-1 $\frac{1}{2}$ in. br., oblong-lanceolate, slightly sinuated, the others similar but shorter, and often unequal-sided; texture thin-herbaceous; both sides nearly naked; main veins wavy and falling short of the edge; areoloe fine, irregular, with a few free veinlets; sori fine, irregular in shape, united on the uniting veinlets.

Hab. San Christoval, Solomon Isles, Milne, 508.

81. G. (Sell.) elliptica, Baker ; rhizome woody, wide-creeping; st. $1 \mathrm{ft}$. or more 1., firm, erect, naked, stramineous ; fr. 12-18 in. 1., 6-9 in. br., cut down nearly to the rachis in the upper and quite in the lower part into 4-6 linear-oblong pinnoe on each side, which are 6-8 in. $1 ., \frac{1}{2}-1 \frac{1}{2}$ in. br. ; texture herbaceous ; rachis and both sides naked; main veins slender, not distinct to the edge; areoloe large and unequal, with free veinlets; sori linear, oblique, reaching the midrib, but not the edge.-Polyp. Thunb. G. decurrens, Hk. Sp. 5. p. 161. 
Hab. Himalayas (up to 6,000 ft.) and Japan southward to Moulmein, the Philippines, and Queensland.-Oldham gathered in Formosa a form with the fronds quite entire.

82. G. (Sell.) pinnata, Hk. ; st. subtufted, 6-12 in. l., firm, erect, glossy ; fr. 1. ft. or more 1., nearly as br., simply pinnate; pinnoe erecto-patent, 6-9 in. 1., $\frac{1}{2}-1$ in. br., narrowed gradually to both ends, the lower ones stalked, the edge nearly entire; texture coriaceous; rachis and both sides naked; areoloe narrow, irregular, usually in two rows between the midrib and edge; sori oblong or linear, irregular, often confluent.-Hk. Sp. 5. p. 151. Dictyogramme, Moore.

Hab. Fiji and Queensland to the Malay Isles._Q. ? subtrifoliata, Hk. Sp. 5. p. 152. t. 298, from Fiji, is like this in habit and the shape of the pinnæ, but they are only three in number, and the veins join hardly at all. The fruit is not known.

83. G. (Sell.) japonica, Desv.; rhizome creeping; st. 6-12 in. 1., glossy, stramineous or chesnut-brown, naked; fr. $1 \frac{1}{2}-2 \mathrm{ft}$. l., $1 \mathrm{ft}$. br., simply pinnate or bipinnate at the base; pinnoe 6-12 in. 1., 1-2 in. br., linear-oblong, acuminate, entire, the lower ones stalked; texture herbaceous; rachis and both sides naked; veins close, usually twice forked, and joining once, the sori often on all of them and extending from the midrib to the edge.-Hk. Sp. 5. p. 151. Dictyogramme, Presl.

Hab. Japan and Formosa.-Probably not really distinct from G. javanica.

84. G. (Sell.) podophylla, Hk. ; st. tufted, 6-8 in. l., dark chesnut-brown, glossy ; fr. 4-6 in. each way, deltoid ; lower pinnoe much the largest, cut down nearly to the rachis into oblong-lanceolate lobes, the lowest only prolonged and pinnatifid ; texture herbaceous; under surface finely pubescent; veins copiously reticulated; sori in the outer half of the lobes.-Hk. Sp. 5. p. 152. t. 296.

Hab. Mexico and New Mexico.-Probably a form of $G$. pedata, with which it quite agrees in everything except venation.

\section{Gen. 53. Brainea, $H k$.}

Sori continuous along transverse veins near the midrib and also produced along the veins in the direction of the edge of the frond. A single subarborescent Indian and Chinese species resembling Blechnum in general habit, but with naked sori and the veins forming costular areolce. TAB. VI. f. 53.

1. B. insignis, Hk.; trunk 3-4 in. thick, the scales linear, ferruginous, $\frac{3}{4}-1$ in. 1.; st. firm, 3-4 in. 1., naked, scaly only at the base ; fr. 2-3 ft. 1., 8-12 in. br., simply pinnate ; pinnoe close, numerous, linear, finely serrated ; texture coriaceous; rachis and both sides naked.-Hk. Sp. 5. p. 162. Fil. Ex. t. 38.

Hab. Hong-Kong and Khasya.

\section{Gen. 54. Menisciom, Schreb.}

Sori oblong or linear, occupying the connivent transverse veinlets. Fronds simple or once pinnate. A small genus, almost confined to the tropics, with the venation of Polypodium \$ Goniopteris, from which it differs only by its elongated or confluent sori. TAB. VI. f. 54 .

\section{* Fronds simple. Sp. 1-2.}

1. M. simplex, Hk.; rhizome firm, wide-creeping; st. stramineous, slightly pubescent, of the barren frond 4-6 in., of the fertile $1 \mathrm{ft}$. or more 1.; barren 
fr. 6-9 in. 1., 2-3 in. br., oblong-lanceolate acuminate, the base cordate and sometimes auricled, the edge crenate; fertile fr. similar, but smaller; texture subcoriaceous; veins beneath pubescent, main veins $\frac{1}{8}$ in. apart; areoloe 8.12 between the midrib and edge.-Hk. Sp. 5. p. 162. Fil. Ex.t. 83.

Hab. Chusan, Hong-Kong, and Formosa.-Kunze considers this a simple form of M. triphyllum.

2. M. giganteum, Mett.; st. 1 ft. l., dark-brown, slightly pubescent; fr. $1 \frac{1}{2}-2$ ft. l., 4 in. br., elongate-oblong, narrowed rather suddenly at both ends, the edge slightly repand; texture papyraceous; veins beneatl nearly naked, main veins $\frac{1}{4}$ in. apart; areolce $30-40$ between the midrib and edge.- $\dot{H} k$. Sp. 5 . p. 163.

Hab. Peru, Lechler, 2292.

* Frond pinnate. Sp. 3-10.

3. M. triphyllum, Sw.; rhizome firm, wide-creeping; st. slender, substramineous, slightly pubescent, of the barren frond 4-6 in., of the fertile frond $1 \mathrm{ft}$.

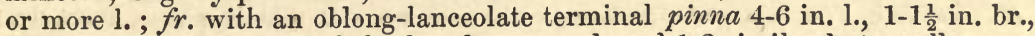
the base cuneate or rounded, the edge repand, and 1-2 similar but smaller ones on each side, the fertile ones smaller than the barren ones; texture subcoriaceous; veins beneath slightly pubescent, main veins $\frac{1}{8}$ in. apart; areoloe 6-9 between the midrib and edge.-Hk. Sp. 5. p. 163. Hk. \& Gr.t. 120.

Hab. Himalayas to Ceylon, S. China, and Malaccas.

4. M. Thwaitesii, Hk.; vhizome firm, wide-creeping; st. 9-12 in. 1., substramineous, nearly naked; $f r$. 8-10 in. l., 4-5 in. br., subdeltoid, the apex acuminate, crenato-pinnatifid, below this several blunt linear-oblong subentire pinnoe, the lowest the largest, distinctly stalked, $2-3$ in. l., $\frac{3}{4}$ in. br., the edge bluntly, not deeply, lobed, the base narrowed suddenly ; texture herbaceous; colour dark-green; midrib beneath pubescent; main veins 1 lin. apart; areoloe and sori 4-5 in the lower pinnæ between the midrib and edge.

Hab. Ceylon, C. P. 3145.

5. M. pauciflorum, Hk. ; st. tufted, 6-12 in. l., glossy, brownish ; fr. 12-18 in. 1., 6-8 in. br. ; pinnoe numerous, spreading, $\frac{1}{2}-\frac{3}{4}$ in. apart, 3-4 in. 1., 2-3 lin. br., narrowed very gradually from the middle to both ends, the edge sharply toothed; texture subcoriaceous; rachis and both sides naked; areoloe in 1-2 rows between the midrib and edge.-Hk. Sp. 5. p. 164.

Hab. Sierra del Crystal, West Tropical Africa, Mann, 1672.

6. M. salicifolium, Wall. ; st. $1 \mathrm{ft}$. or more 1., stramineous or pale-brown, glossy ; fr. 12-18 in. l., $1 \mathrm{ft}$. br.; pinno numerous, $\frac{3}{4}-1 \frac{1}{2}$ in. apart, 4-8 in. l., $\frac{1}{4}-\frac{3}{4}$ in. br., narrowed very gradually from the middle to both ends, the edge nearly entire, the lowest the largest; texture subcoriaceous ; rachis and both sides glabrous; main veins oblique, 1 lin. apart; areoloe 4-5 between the midrib and edge.-Hk. Sp. 5. p. 164. 2nd Cent.t. 90.

Hab. Penang and Singapore.

7. M. angustifolium, Will. ; st. subtufted, 6-18 in. 1., firm, erect, slightly pubescent; fr. $1 \frac{1}{2}-2$ ft. 1., 1 ft. br. ; pinnce spreading, 4-6 in. l., $\frac{1}{4-\frac{3}{4}}$ in. br., narrowed gradually to a long acuminate point, the edge subentire, the base cuneate, the lower ones often stalked; texture subcoriaceous; rachis and veins beneath pubescent; fertile pinnoe much narrower than the barren ones; main veins 1 lin. apart; areoloe 4-6 between the midrib and edge.-HK. Sp. 5. p. 164.

Hab. West Indies to Peru. 
8. M. serratum, Cav.; st. 1-3 ft. 1., stout, brownish, glossy ; fr. 3-4 ft. or more 1., $1 \mathrm{ft}$. or more br. ; pinnce 1-3 in. apart, 6-12 in. 1., $\frac{1}{2}-2$ in. br., oblonglanceolate, the base cordate or cuneate, the apex acuminate, the edge finely toothed; texture subcoriaceous; both sides naked; main veins $\frac{1}{8}$ in. apart; areola 12-20 between the midrib and edge.-Hk. Sp. 5. p. 165. M. palustre, Raddi.

Hab. Mexico and West Indies to Brazil and Peru. - Doubtfully distinct from $M$. reticulatum.

9. M. cuspidatum, Blume; st. 1-2 ft. 1 , stout, naked ; fr. 2-4 ft. $1 ., 1 \mathrm{ft}$. or more br.; pinnoe 6-9 in. 1., 1-3 in. br., the point acuminate, the edge nearly entire, the base cuneate or rounded, often slightly stalked ; texture subcoriaceous ; rachis and both sides naked or nearly so; main veins $1 \frac{1}{2}-2$ lin. apart; areoloe 6-20 between the midrib and edge.-Blume, $t .45$.

Hab. Himalayas, Malaccas, Philippines.-Very probably a Meniscioid form of Polyp. urophyllum, with which Hooker united it. M. villosum, J. Sm., and M. Parishii, Beddome, have pubescent and more herbaceous pinnæ than the form described above, and M. Cumingii, Fée, is a glabrous form, with narrower and thinner pinnæ, the lateral ones few or sometimes absent.

10. M. reticulatum, Sw. ; st. tufted, 1-3 ft. 1., stout, brownish, glossy ; fr. 2-4 ft. $1 ., 1 \mathrm{ft}$. or more br.; pinnoe 6-12 in. l., 1-4 in. br., the apex acuminate, the edge entire or subrepand, the base rounded or cuneate ; texture subcoriaceous ; rachis and both sides naked or slightly pubescent; main veins $1-1 \frac{1}{2}$ lin. apart; areolo 8-12 between the midrib and edge.-Hk. Sp. 5. p. 165.

Hab. Mexico and West Indies to Brazil and Peru.-M. macrophyllum, Kze., appears to be a form with a few large pinnæ. M. molle, Mett., gathered in New Granada by M. Triana, has the rachis and under surface softly hairy, and quite entire pinnæ $1 \mathrm{ft}$. l., $1 \mathrm{in}$. br., truncate on the upper and rounded on the lower side at the base. $M$. sorbifolium, Willd. (M. Kapplerianum, Fée), is a form with narrower pinnæ than usual, the lower ones slightly stalked.

\section{Gen. 55. Antrophyum, Kaulf.}

Sori carried along the veins, imperfectly reticulated. A small genus of closely allied species almost restricted to the tropics, all with simple fronds of firm but fleshy texture and copious uniform hexagonal areoloe. TАв. VI. fig. 55.

\section{* Sori sunk in a distinct groove. Sp. 1-8.}

1. A. lineatum, Kaulf.; fr. 6-12 in. 1., $\frac{1}{4}-\frac{1}{2}$ in. br., the point acute, the edge entire, the lower half narrowed very gradually to the base; a distinct slender raised midrib throughout; areoloe very long and narrow; sori in 2-3 almost continuous lines on each side of the midrib parallel with it, sunk in deep furrows with raised edges.-Hk. Sp. 5. p. 175. Polytænium, Desv.

Hab. Cuba and Mexico to Ecuador and Brazil.-Habit of Vittaria, but the sori multiserial.

2. A. subfalcatum, Brack. ; fr. 6-12 in. 1., $\frac{1}{4-\frac{3}{8}}$ in. br., the point acute, the edge entire, the lower part narrowed very gradually to the base or a short stem, an indistinct midrib in the lower part; areoloe vertical, about two on each side the midrib, several times longer than broad; sori moderately immersed, in 2-4 long interrupted lines, hardly uniting.-Hk. Sp. 5. p. 175. A. Brookei, Hk. 2nd Cent. t. 79.

Hab. Borneo, Fiji, and Samoa. 
3. A. immersum, Mett. MSS.; fr. 2-4 in. 1., $\frac{1}{2}-\frac{3}{4}$ in. br., narrowed gradually to an acute point and at the base to a short stem; texture thick; no distinct midrib; central areolee vertical, long and narrow; veins distinctly raised on the upper surface ; sori quite immersed, often forked.-Hemionitis, Bory. A. pumilum, Kaulf. Hk. Sp. 5. p. 170.

Hab. Mauritius and Bourbon.

4. A. coriaceum, Wall.; fr. 6-8 in. $1 ., \frac{1}{2}-\frac{3}{4}$ in. br., narrowed very gradually from the centre to the base and an acute point; texture very thick; no midrib; the areoloe very long and narrow, very distinctly raised on the upper surface; the sori quite immersed, sometimes confluent. $-H k . S p .5 . p .163$.

Hab. Himalayas, the Philippine and Malayan Isles.-A. nanum, Fée, is as coriaceous in texture, but not so plicate. In our specimens the fronds are oblong-spathulate, and only $1 \mathrm{in.}$ l., so that it is very doubtful whether the plant be not an undeveloped condition of some of the other species.

5. A. plantagineum, Kaulf. ; fr. 6-9 in. 1., $1 \frac{1}{2}-2$ in. br., broadest one-third of the way down, the point acute, the lower part narrowed gradually into a stem 1-4 in. l.; no midrib; areoloe 1-3 in. 1. , $\frac{1}{8}$ in. br.; the sori copious, deeply immersed, often uniting.- $\beta, A$. angustatum, Brack.; texture thinner ; fr. ligulate, $1 \mathrm{ft}$. 1., $\frac{3}{4}$ in. br.; st. 6 in. 1.-Hk. Sp. 5. p. 170. A. Lessoni, Bory. Hk. Sp. 5. p. 168.

Hab. Ceylon, Himalayas, and Malay ; Philippine and Polynesian Isles.-A. parvulum, Blume, looks like a small narrow-fronded form of this.

6. A. Cumingii, Fée; fr. 18 in. 1., 1-1 $\frac{1}{4}$ in. br., ligulate, about equal in width in the central half, narrowed very gradually to the base and an acute point, with a black midrib in the lower quarter, the central areoloe several inches long and not more than $\frac{1}{2}$ lin. br.; sori very slender, deep-sunk, often joining, the edge of the furrow rather raised.-Hk. Sp. 5. p. 167.

Hab. Philippines, Cuming, 416.-The Javan A. latipes, Kze., appears to be nearest to this.

7. A. reticulatum, Kaulf. ; fr. $6-15$ in. $1 ., 1 \frac{1}{2}-2$ in. br., broadest about onethird of the way down, the point blunt or acute, the lower part narrowed very gradually to the base or a short compressed stem; midrib scarcely any; areoloe several in. 1., 1-1 $\frac{1}{2}$ lin. br., very distinctly raised on the upper surface; sori copious, often joining, raised above the surface.-Hk. Sp. 5. p. 163.

Hab. Himalayas, Ceylon, and Malaccas to Aneiteum and Queensland.-A. callcefolium, Blume, does not seem to be clearly distinguishable.

8. A. semicostatum, Blume; fr. 6-18 in. 1., 2-4 in. br., broadest about onethird of the way down, narrowed to an acute point and very gradually to the base or a short stem, the edge entire, with a distinct blackish midrib in the lower half, the central areoloe often 2-3 ill. $1 ., \frac{1}{8}$ in. br. ; sori copious, often joining, rising above the surface.-H. Sp. 5. p. 168 .

Hab. Ceylon, Malaccas, Philippines and Polynesian Isles.-Species 2 to 8 come very near to one another, and cannot be regarded as clearly distinct.

** Sori superficial or but slightly immersed. Sp. 9-16.

9. A. ensiforme, Hk. ; fr. 6-12 in. 1., $\frac{1}{2}-\frac{7}{8}$ in. br., ligulate, the point acute, the edge entire, the lower part narrowed very gradually from halfway down to the base; midrib broad, obscure, lost upwards ; veins sunk, forming 3-4 rows of irregular hexagonal areolæ between the midrib and edge; sori raised above the 
surface, oblique, linear-vermiform, often forked.-Hk. Sp. 5. p. 174. Ic. t. 394. 2nd Cent. t. 70. Scoliosorus, Moore.

Hab. Mexico and Guatemala. - Connects Antrophyum with the Selliguece of the lanceolata group.

10. A. lanceolatum, Kaulf.; fr. 1 ft. or more $1 ., \frac{1}{4}-\frac{1}{2}$ in. br., the point acute, the edge entire, the lower half narrowed very gradually to the base; texture papyraceous, a distinct slender raised midrib throughout; areole vertical, hexagonal, 2-3 times as long as broad, about three rows between the midrib and edge ; sori slender, superficial, often joining.-Hk. Sp. 5. p. 176.

Hab. West Indies and Mexico to New Granada.-The Mexican A. Féei, Schaff., is a short broad variety of firmer texture, with a slightly repand margin.

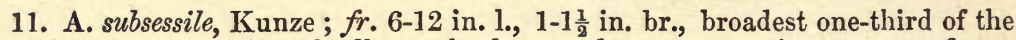
way down, narrowed gradually to the base and an acute point; texture firm ; midrib raised, distinct from the base to the apex; areolce oblique, hexagonal, about twice as long as broad; sori subsuperficial, often forked.-Hk. Sp. 5 . p. 171 .

\section{Hab. Cuba and Guatemala to Peru.}

12. A. cayennense, Kaulf. ; st. 1-4 in. 1. ; fr. 6-9 in. 1., 1-1 $\frac{1}{2}$ in. br.. lanceolateoblong, narrowed at both ends, the edge thickened, entire ; texture rather firm, a distinct prominent midrib extending from the base to the apex ; areoloe oblique, hexagonal, half as broad as long; sori subsuperficial, often forked.-Hk. Sp. 5 . p. 171.

Hab. Guiana and the Amazon Valley.-Closely allied to the preceding. The two may be readily distinguished by their raised midribs and short oblique areolæ.

13. A. latifolium, Blume; st.3-6 in. l., stout, compressed, widening into the frond gradually ; fr. 4-6 in. 1., 3-4 in. br., oblong or obovate, the apex cuspidate, the edge entire or slightly repand towards the point, the base narrowed very gradually ; texture thick ; no distinct midrib; areoloe vertical, $2-3$ in. $1 ., \frac{1}{8}$ in. br. ; sori stout, copious, rarely joining.-Hk. Sp. 5. p. 172.

Hab. Java and Bootan.

14. A. Mannianum, Hk. ; st. 6-9 in. l., slender, blackish, curved ; fr. 6-9 in. l., nearly as broad, obovate or roundish, the apex cuspidate, the edge repand, the base broad-cuneate; texture thin, no distinct midrib; the areole 1-2 in. l., $\frac{1}{8}$ in. br., radiating from the base to the circumference; sori slender, copious, often joining.-Hk. Sp. 5. p. 173. 2nd Cent. $t .73$.

Hab. Guinea Coast.

15. A. Boryanum, Kaulf. ; st. 1-4 in. 1., stout, compressed, passing into the frond gradually ; fr. 6-12 in. 1., 2-4 in. br., broadest a third or halfway down, the point acute or blunt, the edge entire, the lower part narrowed very gradually; no distinct midrib; areoloe numerous, vertical, hexagonal, $\frac{1}{2}$ in. $1 ., \frac{1}{4}$ in. br. ; sori slender, often joining. $-H k$. Sp. 5. p. 172. Hk. \& Gr.t. 74 .

Hab. Mauritius, Bourbon, and Johanna Island.-A. obtusum, Kaulf., does not appear to be clearly distinguishable.

16. A. giganteum, Bory ; fr. 12-18 in. 1., 3-4 in. br., broadest a third of the way down, narrowed very gradually to a short very stout paleaceous stem, the edge with a broad entire cartilaginous border; texture very thick ; areoloe close and fine, vertical, about $\frac{1}{4}$ in. 1., 1 lin. br. ; sori slender, often joining.-Hk. Sp. 5 . p. 174 .

Hab. Mauritius and Bourbon. 


\section{Gen. 56. Vittaria, Sm.}

Sori in continuous marginal or slightly intramarginal lines. A small genus, almost entirely tropical, with free veins and grass-like fronds of subcoriaceous texture. It has considerable claim to be placed in the Involucrate series near Lindsaya. The species are very difficult of discrimination, and we have admitted here sonsiderably fewer than M. Fee, who has published an elaborate illustrated monograph of the genus, in which he relies to a large extent upon microscopic characters (the shape of the spores and abortive capsules) to characterize them. TAB. VI. fig. 56.

\section{§ Euvittaria. Sori sunk in a two-lipped marginal groove. Sp. 1. Fig. 56. a.}

1. V. elongata, Sw. ; fr. 6-18 in. 1., $\frac{1}{8}-\frac{1}{4}$ in. br., the point acute or bluntish, the lower part narrowed very gradually to the base; texture subcoriaceous ; midrib faint or distinct; veins simple, oblique, immersed, parallel, connected by an intramarginal veinlet; sori quite sunk in a marginal groove with two nearly equal lips which open outwards.

Hab. Himalayas and Benin to Sandwich Isles, New South Wales, and Ceylon; Mascaren Isles, Seychelles, and Guinea Coast. -We cannot separate from this clearly $V$. 20stercefolia, bisulcata, isoetifolia, ovwariensis, rigida, ensiformis, intermedia, plantaginea, and anodontolepis of authors. The two first are said to have a distinct midrib, the others none.

$\$ \S$ Tæniopsis, J. S'm. Sori in a slightly intramarginal line, with the unaltered edge of the frond produced beyond and often rolled over it. Sp. 2-9. Fig. 56. b. c.

2. V. (Tæniop.) scabrida, Klotzsch ; fr. 2 in. $1 ., 1$ lin. br., the point blunt, the lower half tapering gradually to the base; texture fleshy, when dry wrinkled; midrib lost in the upper half; sori sunk in an intramarginal groove, with the flattened thick edge of the frond produced beyond it. $-H k$. Sp. 5. $p .182$.

Hab. Mexico and Brazil.

3. V. (Tæniop.) falcata, Kunze ; fr. 4-5 in. 1., $\frac{1}{8}$ in. br., the point blunt, the lower part narrowed gradually to the base ; texture leathery and very thick; a distinct raised midrib attaining the apex in the barren fronds, but lost in the fertile ones ; veins short, oblique, parallel, immersed ; sori quite sunk in slightly intramarginal grooves.-Hk. Sp. 5. $p .182$.

Hab. Malaccas and Ceylon (C. P. 3807).-The Malayan and Philippine V. minor, Fée, is like this, but smaller in size, with the habit of Polyp. australe and gramineum.

4. V. (Tæniop.) Gardneriana, Fée; $f r .1 \mathrm{ft}$ or more 1., $\frac{1}{4}$ in. br., the point acute, the lower part narrowed gradually to the base or a short slender stem; texture thin, the young fronds translucent; a slender immersed midrib extending from the base to the apex; veins fine, distant, oblique ; sori in a broad superficial slightly intramarginal line, with the edge produced beyond, but not wrapped over it. - Hk. Sp. 5. p. 178. (in part).

Hab. Organ Mountains, Brazil, Gardner, 147.

5. V. (Tæniop.) stipitata, Kunze; fr. 11 $\frac{1}{2}-2$ ft. l., 3-4 lin. br., tapering gradually below into a long slender stem ; texture firm ; midrib indistinct, except towards the base; veins distant, fine, oblique, immersed; sori sunk in a groove within the margin, with the flattened thickened edge of the frond produced beyond it. -Hk. Sp. 5. p. 179.

Hab. Columbia to Peru.-V. Moritziana, Mett., is said to have the sori less distinctly 
immersed, and the edge of the frond not thickened; V. Karsteniana, Mett., to have sessile fronds and more distant veins; and $V$. Ruiziana, Fée, superficial sori and a flattened stem.

6. V. (Tæniop.) stricta, Carm.; fr. 18 in. 1., $\frac{1}{8}$ in. br., narrowed below to a compressed stem; texture thick; midrib stout, continued to the apex; the sori occupying the whole space between it and the much reflexed edge.-Hk. Sp. 5 . p. 182.

\section{Hab. Tristan d'Acunha.}

7. V. (Tæniop.) lineata, Sw. ; fr. 6-18 in. 1., $\frac{1}{8}-\frac{2}{8}$ in. br., narrowed gradually downwards to a stout compressed stem, which passes into the frond gradually, the edge often reflexed ; texture firm, a distinct raised midrib running from the base to the apex ; veins immersed, parallel, very oblique; sori in a broad slightly intramarginal line in a slight furrow, the edge of the frond at first wrapped over it. $-H k$. Sp. 5. p. 178.

Hab. Japan, West Indies, and Florida to Peru and Brazil ; Himalayas, Neilgherries, Malaccas, Mascaren Isles, Guinea Coast, Zambesi-land, Natal, Cape Colony.-Of M. Fée's species we include here lineata and filifolia (Tropical America), flexuosa (Hindostan), tenera and sarmentosa (South Africa), and guineensis (Guinea).

8. V. (Tæniop.) remota, Fée ; fr. 12-18 in. l., $\frac{3}{8}-\frac{1}{2}$ in. br., narrowed gradually to the base or a short compressed stem; texture moderately firm ; midrib darkcoloured and distinct below, but often lost before it reaches the apex; veins immersed, very oblique ; sori in a broad superficial distinctly intramarginal line, with the edge not at all wrapped over it.-Hk. Sp. 5. p. 185.

Hab. West Indies to Ecuador.-Distinguished from the other American species by its broader flat frond and the position of the sori. It is very like Tcenitis angustifolia in general habit, but the veins are free.

9. V. (Tæniop.) scolopendrina, Thw.; fr. 12-18 in. 1., $\frac{1}{2}-\frac{3}{4}$ in. br., the point acute, the edge entire, the lower part narrowed very gradually to the base ; texture thick ; midrib thick, blackish, grooved in front below, sometimes nearly lost upwards; veins oblique, fine, simple, parallel; sori in broad continuous submarginal lines, with the firm unaltered edge of the frond at first wrapped over it.-V. Forbesii and zeylanica, Fée. Hk. Sp. 5. p. 177.

Hab. New Guinea, Philippine and Malayan Isles, Neilgherries, Ceylon, Seychelles, Mozanbique.- $V$. loricea, Fée, appears to be closely allied, but the Himalayan plant mentioned in "Sp. Fil." is referred to $\nabla$. scolopendrina by Mettenius. The largest and finest of the group.

\section{Gen. 57. Thenitis, Sw.}

Sori linear, but the line sometimes interrupted, central or submarginal. $A$ small genus of not very closely allied species, all tropical. Some of the species scarcely differ from Tæniopsis in fruit, but in all those placed here the veins anastomose. 'ТА. VI. fig. 57.

* Fronds simple. Sp. 1-3.

1. T. obtusa, Hk. ; rhizome creeping; st. 2-3 in. l., slender, glossy, naked; fr. $1 \frac{1}{2}-2$ in. l., $\frac{1}{2}-\frac{3}{4}$ in. br., ovate-oblong, the point blunt, mucronate, the edge entire, the base rounded; texture coriaceous; areoloe large, oblique; sori in a continuous line $\frac{1}{8}$ in. from the edge.-Hk. Sp. 5. p. 186. 2 2nd Cent.t. 94.

Hab. Borneo, T. Lobb.

2. T. angustifolia, R. Br. ; fr. 12-18 in. $1 ., \frac{1}{4}-\frac{1}{2}$ in. br., narrowed very gradually 
to an acute point and below to the base or a short stem ; texture subcoriaceous, flaccid; midrib distinct; veins immersed, forming 2-3 rows of vertical hexagonal areola, 3-4 times as long as broad between the midrib and edge; sori sunk in a groove a short distance from the edge.-Hk. Sp. 5. p. 187. Pteropsis, Desv.

Hab. Cuba to N. Brazil and the Galapagos.

3. T. lanceolata, R. Br. ; rhizome creeping, very stout; st. 1-2 in. l., firm, erect; fr. 6-12 in. 1., 1-2 in. br., narrowed gradually from the centre to both ends, the edge entire but often crisped; texture firm, coriaceous, naked; midrib distinct; areole immersed, copious, small, with copious free veinlets; sori in continuous or interrupted lines near the edge of the contracted upper third or quarter of the frond.-Hk. Sp. 5. p. 186. Paltonium, Presl. Neurodium, Fée.

Hab. West Indies and Guatemala.-The Javan T. marginalis, Monre (T. Blumei, Hk.), is said to be like this, but smaller in size, and without a midrib.

\section{** Fronds compound. Sp. 4-5.}

4. T. furcata, Willd.; rhizome subrepent, densely tomentose ; fr. 6-18 in. 1. , once or twice dichotomously forked or subpinnatifid, the lobes linear, erectopatent, much acuminated, entire, 4-8 in. l., $\frac{1}{4}-\frac{1}{2}$ in. br.; texture coriaceous ; under surface thinly clothed with minute scales; veins anastomosing without free veinlets; sori submarginal, continuous or interrupted.-Hk. Sp. 5. p. 188. Cuspiaria, Fée.

Hab. West Indies to Ecuador and the Amazon Valley.-T. Desvauxii, Klotzsch (C. semipinnatifida, Fée), is a small variety with narrow lobes, unbranched primary veins, and only a single row of areolæ.

5. T. blechnoides, Swz. ; rhizome creeping ; st. 8-12 in. l., firm, naked, glossy ; fr. 1-2 ft. l., 8-12 in. br., simply pinnate; pinnoe of barren frond 2-3 on eacli side, 6-9 in. l., 1-2 in. br., oblong-lanceolate, the point acuminate, the edge thickened and wavy, the base cuneate, the lower ones stalked; fertile pinnoe narrower and more numerous; texture coriaceous; areola copious, oblique, without free veinlets; sori in a continuous line about midway between the edge and midrib. $-\beta, T$. interrupta, Wall.; pinnoe smaller; sori interrupted and much nearer the edge.-Hk. \& Gr.t. 62. Hk. Sp. 5. p. 188.

Hab. Malaccas and Philippines.

\section{Gen. 58. Drymoglossum, Presl.}

Sori scarcely differing from those of Tænitis, but the fronds dimorphous. Tав. VI. fig. 58.*

1. D. carnosum, Hk. ; rhizome filiform, wide-creeping; fr. dimorphous, the barren ones suborbicular or elliptical, 1-2 in. 1., $\frac{3}{4}-1$ in. br., the fertile ones linear-spathulate, 2-3 in. 1., $\frac{1}{\mathrm{~s}}$ in. br., both narrowed to the base or a short stem; texture coriaceous; areoloe small, with copious free veinlets; sori in a line midway between the edge and midrib, when young covered with stalked peltate scales.- $\beta, D$. subcordatum, Fée; fr. smaller, the barren ones roundish, subsessile ; texture thinner ; caps. mixed with hairs, not scales.-Hk. Sp. 5. p. 189.

Hab. Japan to Formosa, Hong-Kong, and the Himalayas.

* It would be better to make two genera only out of this and the two preceding, placing in one those species in which the line in front is submarginal, and in the other those in which it is remote from the edge. 
2. D. piloselloides, Presl ; rhizome filiform, wide-creeping; fr. dimorphous, the barren ones roundish or obovate-elliptical, $\frac{1}{2}-2$ in. 1 ., $\frac{1}{2}-\frac{3}{4}$ in. br., the fertile ones linear-oblong, 2-4 in. 1., $\frac{1}{8}-\frac{1}{4}$ in. br., both narrowed to the base or a short stem; texture coriaceous; veins immersed, anastomosing, with copious free veinlets ; sori in a broad continuous submarginal line, the capsules mixed with stalked peltate scales.-Hk.Sp. 5. p. 190. G. F. t. 46 .

Hab. Himalayas, Neilgherries, Ceylon, Malaccas.

3. D. rigidum, Hk.; rhizome firm, wide-creeping ; fr. dimorphous, the barren ones 1-1 $\frac{1}{4}$ in. 1., half as br., obovate, entire, with thickened edges, on firm erect stems 1 in. 1 ., the fertile one $4-5$ in. $1 ., \frac{1}{8}$ in. br., narrowed into a stem about as long as itself ; texture very thick and rigid ; areolae copious, immersed, without free veinlets; sori in a deep groove between the broad midrib and edge.- $H k$. $S p$. 5. $p .190$.

Hab. Borneo, T. Lobb.-An anomalous species, which Moore places in Schizolepton of Fée, a genus founded on our Lindsaya cordata.

\section{Gen. 59. Hemionitis, Linn.}

Sori continuous along the veins and copiously reticulated, sometimes also developed slightly between them. A small genus, as now restricted, almost confined to the tropics. Veins anastomosing copiously. TAB. VI. fig. 59.

\section{§ Euhemionitis. Sori confined to the veins. Sp. 1-6.}

1. H. lanceolata, Hk. ; caud. stout, ascending ; st. 6-9 in. l., firm, erect, glossy, castaneous ; fr. 6-9 in. 1., $1 \frac{1}{4}-2 \frac{1}{2}$ in. br., ovate or oblong-lanceolate, the apex acuminate, the edge subentire, the base narrowed; texture coriaceous; both sides naked; areoloe copious, oblique, about $\frac{1}{2}$ in. l., 1 lin. br.-Hk. Sp. 5. p. 191. 2nd Cent. $t .55$.

Hab. Fiji, Seemann, 716, Milne.

2. H. cordata, Roxb. ; caud. erect; st. of the barren frond 2-4 in. 1., of the fertile frond often $1 \mathrm{ft}$. 1., dark chesnut-brown, glossy, densely fibrillose towards the base; fr. 2-3 in. each way, cordate-hastate, the barren ones bluntish at the point, with rounded basal lobes and a deep sinus, the fertile ones with the lobes more produced and sharper; texture herbaceous or subcoriaceous; under surface subvillose; areolae oblique, $\frac{1}{8}-\frac{1}{4}$ in. $1 ., \frac{1}{2}$ lin. br. $-H k . S p .5 . p .192$. Hk. $\& G r$. t. 64 .

Hab. Peninsular India, Ceylon, Moulmein, Philippines.

3. H. palmata, L. ; caud. erect ; st. of barren frond 2-4 in., of the fertile frond 6-12 in. l., glossy, dark chesnut-brown, clothed with soft yellowish hairs; $f r$. 2-6 in. each way, palmate, with five nearly equal lanceolate divisions, those of the fertile frond the sharpest, varying from subentire to lobed one-third of the way down, those of the barren frond shorter, blunter, and less divided; texture herbaceous; both surfaces villose; areoloe oblique, $\frac{1}{8}-\frac{1}{4}$ in. 1., $\frac{1}{2}-1$ lin. br. $-H k$. Sp. 5. p. 192. Ex. Fl. t. 53 .

Hab. West Indies and Mexico to Peru.

4. H. hedercefolia, J. Sm. ; caud. decumbent; st. nearly 1 ft. l., ebeneous, naked; fr. about 3 in. each way, palmate, with 5 lobes, the three central ones about equal, lanceolate, the lateral ones spreading, shorter and blunter, all 
entire; texture herbaceous; both surfaces densely matted with short silky yellowish-grey hairs; areolee small, oblique.-Bot. Her. p. 339.

Hab. Mexico, Liebold.

5. H. pinnatifida, Baker; st. tufted, 1-2 in. l., glossy, chesnut-brown, clothed with soft yellowish hairs; $f r .2$ in. each way, deltoid in general outline, with a large oblong-lanceolate subcrenate terminal lobe and two spreading ones on each side, which reach down within $\frac{1}{4}$ in. of the rachis, both blunt, the lowest 1 in 1 . and auricled at the base; texture subcoriaceous; both sides densely coated with yellowish hairs; areotoe small, copious.

Hab. Central America, Wendland, 438.

6. H. pinnata, J. Sm. ; st. 6-9 in. l., glossy, dark chesnut-brown, clothed with soft yellowish hairs ; fr. 5-6 in. 1., 3-4 in. br., the apex deeply pinnatifid, below this 2-3 pairs of distinct pinnoe, the upper ones oblong-lanceolate, 1-1 $\frac{1}{2}$ in. 1., $\frac{3}{8}-\frac{1}{2}$ in. br., the lowest larger and forked at the base, all repand ; texture herbaceous; both sides thinly clothed with soft yellowish hairs; veins oblique, 2-3 times dichotomously forked, anastomosing principally near the midrib. $J_{\text {. }} S_{m}$. Gen. Fil. p. 33. (name only).

Hab. Jamaica, Wiles.-This is not very far from Gymnogramma rufa, but the pinnæ are adnate, and the groups of veins join slightly. Our descriptions of this and the two preceding are taken from J. Smith's specimens, now in the British Museum.

7. H. "Griffithii, Hk. fil. \& Thoms.; st. 8-12 in. 1., scaly towards the base, villose throughout; $f r .1 \mathrm{ft}$. or more $1 ., 6-10 \mathrm{in}$. br., subdeltoid, pinnatifid or pinnate, with 2-4 distinct pinnce on each side, which are 3-4 in. 1., 1-1 $\frac{1}{2}$ in. br., entire, acuminate, the lower ones stalked; texture herbaceous, thick; rachis and both sides villose; main veins barren and pinnate, the veinlets fertile and copiously reticulated.-Hk. Sp. 5. p. 192. H. Wilfordii, Hk. Fil. Ex.t. 93. (the pinnatifid variety).

Hab. Khasya, Hk. fl. \& Thomson; Formosa, Wilford.-This differs from the foregoing by its barren main veins, and constitutes the genus Dictyocline of Moore.

$\$ \S$ Anetium, Splitg. Sori lax, placed both on the veins aud scattered also in the spaces between them. Sp. 7.

8. H. (Anet.) citrifolia, Hk.; vhizome creeping; st. $\frac{1}{2}-9$ in. l., weak, compressed ; fr. pendent, 6-24 in. l., 1-4 in. br., oblong or subspathulate, narrowed gradually to both ends, the edge entire; texture thick but flaccid; colour palegreen ; midrib often lost in the upper part, winged on the back below; areolee vertical, long-hexagonal.-Hk. Sp. 5. p. 193.

Hab. West Indies to North Brazil.-An anomalous species, with the habit of Antrophyum, in which genus it is placed by Fée, and in the fruit connecting Grammitideae with A crostichea.

\section{Tribe 13. Acrostichere.}

Sori spread in a stratum over the under surface or rarely over both surfaces of the frond, not confined to the veins only. GeN. 60-61.

\section{Gen. 60. Acrostichum, $L$.}

Sori spread over the whole surface of the frond or upper pinnæ, or occasionally over both surfaces. A large genus, almost entirely tropical, including groups with a wide range in venation and cutting. TАВ. VII. \& VIII. fig. 60. 
§ Veins free. Sp. 1-87.

* Elaphoglossum, Schott. Fronds simple. Sp. 1-65. Fig. 60. a, b.

+ Both surfaces of the barren frond nearly or quite naked, the edge not fringed. Sp. 1-19.

1. A. petiolosum, Desv.; rhizome woody, the scales dense, fibrillose, nearly black ; st. 4-6 in. l., firm, slender, erect ; barren fr. 2-3 in. l., $\frac{3}{4}-\frac{7}{8}$ in. br., ovateoblong, narrowed suddenly to a point, which is sometimes 1 in. 1. ; texture coriaceous ; both sides nearly naked ; veins immersed, subparallel ; fertile fr. smaller than the barren one.-Hk. Sp. 5. p. 207. A. caudatum, Hk. Ic.t. 215.

Hab. Ecuador and Peru.-Well marked by the small size and very distinct caudate apex of its fronds, and the rigid nearly black scales of the rhizome.

2. A.tambillense, Hk. ; rhizome stout, the scales dense, linear, crisped, chesnutbrown ; st. tufted, 2-3 in. I., firm, slender, naked ; barren fr. $2 \frac{1}{2}-3$ in. 1., 1-1 $\frac{1}{4}$ in. br., the point cuspidate, the base rounded or even slightly cordate; texture coriaceous ; both sides quite naked ; veins distant ; fertile fr. considerably smaller than the barren one.-Hk.Sp. 5. p. 207. Ic.t. 856.

Hab. Ecuador, Jameson; Guatemala, Salvin \& Godman.-Like the last, but the frond not caudate, and the scales different.

3. A. micradenium, Fée; rhizome slender, wide-creeping, the scales small, linearsubulate, squarrose, dark chesnut-brown ; st. 1 in. or more apart, 3-6 in. 1., firm, erect, naked, stramineous ; barren $f r .5-6$ in. $1 ., 1-1 \frac{1}{4}$ in. br., the point acuminate, the base narrowed gradually ; texture herbaceous; both sides naked; veins raised, conspicuous, usually once forked; barren $f r$. much smaller than the fertile ones. -Hk.Sp. 5. p. 216. E. nitidum, Brack. t. 9.

Hab. Sandwich Isles and Sumatra.

4. A. simplex, Sw.; rhizome woody, short-creeping, the scales rather large, lanceolate, dark-brown ; st. 1-4 in. l., firm, erect, naked ; barren fr. 4-12 in. l., $\frac{3}{4}-1 \frac{1}{2}$ in. br., the point very acute, the lower part narrowed very gradually ; texture coriaceous; both sides quite naked; margin distinct, cartilaginous; veins immersed, usually once forked ; barren fr. narrower than the fertile one, and on a longer stem.-Hk. Sp. 5. p. 205.- $\beta, A$. martinicense, Desv.; fronds narrower, very coriaceous, $H k$. Sp. 5. p. 218. A. durum, Kze. E. glabellum, J. Sm.

Hab. Cuba to Brazil.-Characterized by its firm fronds, narrowed very gradually to both ends. A plant gathered by Barter at Sierra Leone probably belongs here.

5. A. nigrescens, Hk. ; caud. stout, erect, not scaly ; barren fr. tufted, subsessile, $6-9$ in. 1 ., $\frac{1}{2}$ in. br., the point bluntish, the base narrowed very gradually ; texture coriaceous; both sides naked; veins simple or once forked, distant, not reaching the edge; fertile fr. 2-3 in. l., $\frac{1}{4}$ in. br., on long slender naked stems $1 \mathrm{ft} .1 .-H k$. Sp. 5. p. 214.

Hab. British Guiana, Schomburgk.

6. A. leptophyllum, Fée; rhizome firm, creeping, the scales "soft, fulvous ;" st. of barren frond 3-4 in. l., firm, erect, stramineous, nearly naked; barren fr. 6-8 in. l., $\frac{1}{2}-\frac{5}{8}$ in. br., the point bluntish, the lower part narrowed gradually ; texture subcoriaceous; both sides naked; veins fine, rather raised, simple or once forked; fertile fr. similar to the other, but the stem three or four times as long. -Hk. Sp. 5. p. 218.

Hab. Venezuela and Brazil.-Characterized by its ligulate barren frond and very longstalked similar fertile one. 
7. A. conforme, Sw.; rhizome woody, wide-creeping, densely clothed with large lanceolate brownish membranous scales sometimes $\frac{1}{4}$ in. l., 1 lin. br.; st. 1-12 in. 1., firm, erect, stramineous, naked or slightly scaly ; fr. $2-9$ in. $1 ., \frac{1}{2}-2$ in. br., the point acute or bluntish, the base cuneate or spathulate, the edge cartilaginous, entire; texture coriaceous; both sides naked or nearly so; veins subparallel, usually once forked; barren fr. usually narrower than the fertile one, the edge inflexed.-Hk. Sp. 5. p. 198.

Hab. Mexico to Chili and Brazil, Sandwich Isles, Samoa, Fiji, Java, Queensland, Himalayas (up to 6,000 ft.), Neilgherries, Ceylon, Tristan d'Acunha, Mascaren Isles, Cape Colony, St. Helena, Guinea Coast.-From this we cannot distinguish clearly A. Lepervanchii (Bory), A. didynanum (Fée), A. lauvifolium (Thouars), A. angulatum (Blume), A. impressum (Fée), A. marginatum (Wall.), A. obtusifolium (Brack.), and A. vagans (Mett.). The Polynesian A. Feejeense, Brack., is thinner and darker green than usual, and narrowed downwards more gradually ; A. alatum, Fée (Hk. Sp. 5. p. 204), has a more distinct haft to the frond; and the Sandwich Island A. cemulum, Kaulf., and Andine A. Gayanum, Fée, and A. unitum, Bory (A. affine, M. \& G.), and probably the Brazilian A. minutum, Pohl., are small narrow-fronded varieties. Vittaria acrostichoides, Hk. \& Gr. t. 186, is an abnormal form, with the fruit in two submarginal lines.

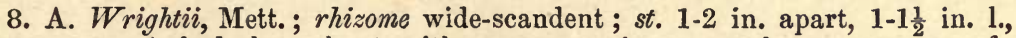
firm, erect, clothed throughout with ovate-acuminate membranous scales; fr. 6-9 in. l., 1-1 $\frac{1}{2}$ in. br., the point cuspidate, the lower part narrowed very gradually, the edge thickened, white, and crisped ; texture coriaceous ; both sides naked ; midrib scaly in the lower part; veins stout, immersed, subparallel, usually once forked; fertile fr. much smaller, the edge entire and inflexed.-Hk. Sp. 5. p. 195.

Hab. Cuba, Wright, 965.-Perhaps a form of the last.

9. A. flaccidum, Fée; rhizome short-creeping, woody, the scales small, lanceolate, dull-brown; st. tufted, those of the barren frond very short ; fr. 6-12 in. l., $\frac{1}{2}-1 \frac{1}{2}$ in. br., the point very acute, the lower part narrowed very gradually; texture subcoriaceous ; both sides quite naked, colour dark-green, edge not thickened; veins not close, simple or forked; fertile fr. smaller than the barren one, and on a distinct st. 3-4 in. 1.-Hk. Sp. 5. p. 204. A. Karstenianum, Kze.

Hab. Panama to N. Brazil.-This is thinner in texture than the preceding, and in the shape of the frond is most like $A$. simplex on a larger scale, with sessile barren fronds but long-stalked fertile ones. A. oxyphyllum, Brong., appears to be a large form ; the Peruvian $A$. Lechleri, Mett. differs only by its stout wide-scandent rhizome ; and a plant labelled by Mettenius A. pallidum, Beyr., is thinner and more glossy than the type, with the costa and long stem of the fertile frond ebeneous.

10. A. Burchellii, Baker; rhizome short, woody, the scales small, linear, darkbrown; st. 8-12 in. l., erect, nearly naked; fr. 1-2 ft. l., $\frac{3}{4}-1 \frac{1}{4}$ in. br., the point very acute, the lower part narrowed very gradually ; texture subcoriaceous ; both sides naked and glossy ; veins fine, close, usually once forked ; fertile fr. much smaller than the other.-A. punctulatum, Mett. MSS. (not L.).

Hab. Brazil, Burchell, 5155.-Very near the last, differing mainly in the finer veins and long stem of the barren frond.

11. A. Norrisii, Hk. ; caud. stout, "woody, the scales long, linear, dull-brown; barren $f r$. sessile or nearly so, tufted, $12-18$ in. l., $\frac{3}{4}-1$ in. br., the point blunt, the lower half narrowed very gradually ; texture coriaceous ; both sides nearly naked ; veins immersed, indistinct; fertile fr. much narrower than the other. $-H k$. Sp. 5. p. 215.

Hab. Penang, Sir W. Norris, Mactier.--Not unlikely identical with the Javan A. melanostictum, Blume. It is like flaccidum in the shape of the barren frond, but the texture is that of conforme and latifolium, and the fertile frond also is subsessile. 
12. A. Schlimense, Fée ; rhizome thick, woody, wide-scandent, the scales broad, ovate, dull-brown ; st. 4-8 in. l., firm, erect, slightly scaly ; barren fr. 9-12 in. l., $1 \frac{1}{4}$ in. br., the point bluntish, the lower third narrowed very gradually ; texture subcoriaceous ; both sides naked, the edge narrow, cartilaginous, quite distinct from the frond; veins fine, very close, usually once forked; fertile fr. similar to the barren one.-Hk. Sp. 5. p. 202.

Hab. N. Granada, Schlim, 622 ; Ecuador, Spruce.-Resembles flaccidum in texture, but the fronds are much less narrowed in the upper part, and distinctly stalked.

13. A. palustre, Hk.; rhizome wide-creeping, not thick but woody, the scales long, linear, bright-brown ; st. 1-2 in. 1., firm, clothed with linear scales ; barren fr. often $1 \mathrm{ft}$. l., 1-2 in. br., the point acute, the lower part narrowed very gradually ; texture herbaceous ; both sides naked ; veins raised, close, simple or once forked ; fertile fr. (in all our specimens) soriferous only in the upper part, much narrower than the others.-Hk. Sp. 5. p. 214.

Hab. Guinea Coast; gathered by Barter and Mann.-Distinguished by its herbaceous texture and very prominent veins. A plant collected in Berbice by Schomburgk is perhaps the same, but our specimens are barren only.

14. A. stenopteris, Klotzsch; rhizome woody, the scales small, ovate, dullbrown ; st. scarcely any ; barren fr. 12-18 in. $1 ., \frac{1}{2}-\frac{3}{4}$ in. br., the point acute, the lower part narrowed very gradually ; texture papyraceous ; both sides naked, except that the lower part of the midrib beneath has a few small dark-brown linear scales; veins fine, simple or forked, often 1 line apart, falling short of the edge ; fertile fr. narrower, and on a longer stem than the barren one.Hk. Sp. 5. p. 213.

Hab. Columbia, Moritz, 234; Venezuela, Fendler, 282.-Distinguished by its thin texture, long narrow frond, and distant veins. An authentic specimen of $A$. brachyneuron, Fée, from Guadeloupe, is smaller in size, but does not otherwise differ.

15. A. Herminieri, Bory ; rhizome stout, woody, short-creeping, the scales dense, linear, reddish-brown, $\frac{1}{2}-1$ in. $1 . ;$ st. tufted, very short or none; barren fr. $1 \frac{1}{2}-3 \mathrm{ft} .1 ., 1-1 \frac{1}{2}$ in. br., the point acuminate, the lower part narrowed very gradually; texture coriaceous; both sides naked, the upper one with a metallic gloss; veins immersed, indistinct, usually once forked; fertile fr. short-stalked, 3-4 in. 1., 1-1 $\frac{1}{2}$ in. br.- $H k$. Sp. 5. p. 216.

Hab. Cuba to Brazil.-Distinguished by its very large sword-shaped barren fronds of coriaceous texture, a striking contrast to its small subsessile oblong fertile ones.

16. A. Lingua, Raddi ; rhizome firm, wide-creeping, the scales small, ovate, dark-brown ; st. 6-12 in. 1., stramineous, firm, erect, nearly naked; barren fr. 6.9 in. $1 ., 2 \cdot 3$ in. br., the point acute, the base narrowed suddenly ; texture coriaceous; both sides nearly naked, the edge thickened; veins subparallel, simple or once forked; fertile $f r$. much narrower than the barren one.-A. latifolium, Hk. Sp. 5. p. 202 (in part).

Hab. West Indies to Brazil and Peru.-Differs from latifolium in the rhizome, scales, and shape of the frond. We cannot distinguish from this an authenticated specimen of A. scandens, Fée, though a plant from Linden (74) is thinner in texture, with finer veins and a sativy gloss.

17. A. luridum, Fée; rhizome woody, the scales linear, dark-brown, crisped; st. of barren frond 1-2 in., of the fertile 3-4 in. l. ; fr. 6-12 in. 1., 2-3 in. br., oblong-spathulate, blunt or subacute, the edge thickened and slightly scaly, the haft narrowed very gradually into the stem; texture very coriaceous; both sides nearly naked ; veins subparallel, usually once forked; edge of fertile frond flat or slightly inflexed.-A. Schomburgkii, Hk. Sp. 5. p. 200. (in part) \& Griseb. non Fée. 
Hab. Trinidad and Guiana.-Differs only from A. latifolium by its blunter fronds of subspathulate outline, with the edge slightly scaly.

18. A. Sieberi, Hk. \& Gr. ; rhizome stout, woody, the scales $\frac{1}{2}$ in. l., linearsubulate, nearly black; st. 3-6 in. 1., firm, erect, stramineous, hardly at all scaly; fr. 3-12 in. 1., 1-3 in. br., the lower part narrowed very gradually, the edge cartilaginous, entire; texture coriaceous; veins immersed, usually once forked; fertile fr. smaller than the barren one.-Hk. Sp.5. p. 197. H. $\& G$. t. 237.

Hab. Mauritius and Bourbon; and a similar plant, but with shorter and browner scales, gathered by Mann at Fernando Po.-This has quite the habit of the next, but the scales are different.

19. A. latifolium, Sw. ; rhizome thick, woody, often creeping, the scales lanceolate, crisped, dark or light-brown; st. 6-12 in. l., firm, erect, stramineous, naked or slightly scaly; barren fr. 9-18 in. l., 2-4 in. br., the point acute, the lower part narrowed gradually, the edge entire, thickened and cartilaginous; texture very coriaceous; both sides naked or nearly so; fertile fr. considerably narrower than the barren one.-HK. Sp. 5. p. 202.

Hab. Mexico and Cuba to Brazil and Peru.-From this we cannot distinguish clearly A. longifolium, Jacq., A. Sartorii, Liebm., A. Blanchetii and Tovarense, Mett., A. scalpellum, Mart., A. alismafolium, Schomburgkii, Funckii, and andicola, Fée, and the Javan A. calloefolium of Blume. A plant from the Seychelles is probably the same.

\section{** Both surfaces nearly or quite naked, the edge of the frond fringed.}

$$
\text { Sp. 20-24. }
$$

20. A. stramineum, Mett. ; rhizome short, stout, the scales lanceolate-subulate, often $\frac{1}{2}$ in. 1., bright-brown ; st. 5-9 in. 1., stramineous, finally naked; barren fr. $3-5$ in. $1 ., \frac{3}{4}-1 \frac{1}{2}$ in. br., narrowed gradually to both ends ; texture subcoriaceous ; the margin ciliated but the scales deciduous ; fertile fr. $1 \frac{1}{2}-2$ in. $1 ., \frac{1}{2}-\frac{3}{4}$ in. br., the st. 2-4 $\frac{1}{2}$ in. 1.-Mett. Fil. Nov. Gran. p. 200.

Hab. N. Granada, Lindig, 251.-Very near the next species.

21. A. melanopus, Kze.; rhizome short-creeping, densely clothed with small reddish-brown linear scales; st. $2-3$ in. 1 , densely clothed with linear spreading dark chesnut-brown scales ; barren fr. 5-8 in. $1 ., 2$ in. br., the apex acuminate, the base rounded or subcuneate; textuve coriaceous; veins lax, the margin ciliated with similar scales ; fertile fr. $3-4$ in. $1 ., \frac{3}{4}$ in. br., on a longer stem.Mett. Fil. H. Lips. p. 19.t. 1 .

Hab. Venezuela.-This comes near the small forms of the next, and there are a few scales on the lower part of the midrib beneath.

22. A. hybridum, Bory ; rhizome woody, the scales dense, $\frac{1}{4}-\frac{1}{2}$ in. l., linear, crisped, dark chesnut-brown ; st. subtufted, 6-9 in. 1., firm, erect, with scattered squarrose linear dark scales; barren fr. 6-12 in. $1 ., 1 \frac{1}{2}-2$ in. br., the point acuminate, the base rather rounded; texture subcoriaceous; both sides naked except the midrib beneath, the edge ciliated with linear-subulate scales; veins immersed, usually once forked; fertile $\mathrm{fr}$. much smaller than the others.$\beta, A$. Vulcani, Leperv.; fr. ovate-oblong, cuspidate, $3-4$ in. $1 ., 1 \frac{1}{2}$ in. br.- $H k$. Sp. 5. p. 231 .

Hab. Mascaren Isles, Natal, Tristan d'Acunha, Cameroon Mountains, Fernando Po, Mexico to Brazil. - The scales here are from 1 to $1 \frac{1}{2}$ line long, and often fall quite away as the frond matures. A. Lindbergii, Mett., from Brazil, appears to be identical with this.

23. A. decurrens, Desv.; rhizome woody, the scales large, ovate, dull-brown; 
st. 1-4 in. 1., firm, erect, scaly ; fr. $1 \mathrm{ft}$. or more 1., 2-3 in. br., the apex very blunt, the lower part narrowed into the stem very gradually; texture very thick; both sides naked, but the edge densely fringed with minute ovateacuminate brown scales; veins immersed, nearly hidden.-Hk. Sp. 5. p. 203.

Hab. Philippines, Cuming, 144.-This is referred by J. Smith to A, obtusifolium, Willd.

24. A. decoratum, Kze. ; caud. very stout, the scales $\frac{1}{2}-\frac{3}{4}$ in. 1., linear, brightbrown, crisped ; st. 4-8 in. l., firm, erect, densely clothed with blunt squarrose scales often $\frac{1}{4}-\frac{3}{8}$ in. l., 2 lin. br. ; barren fr. $1 \mathrm{ft}$. or more l., 3-4 in. br., the point acute, the base rounded, the edge densely fringed with scales like those of the stem, but small ; texture coriaceous; veins subparallel, usually once forked, sometimes anastomosing; fertile fr. nearly as large as the other.-Hk. Sp. 5 . p. 195 .

Hab. West Indies, Guiana, Peru.

*** Surface of the frond slightly scaly. Sp. 25-45.

A. Fronds 1-4 inches long. Sp. 25-32.

25. A. Feei, Bory; rhizome filiform, very wide-creeping, the scales linear, reddish-brown, scarcely spreading; st. $\frac{1}{2}-1 \frac{1}{2}$ in. 1 ., slightly scaly ; barren $f r .1-2$ in. $1 ., \frac{1}{4}$ in. br., the point bluntish, the edge conspicuously repand, the lower part narrowed gradually; texture subcoriaceous; both sides with a few small ovate-acuminate scales ; fertile fr. $\frac{1}{4}-\frac{1}{2}$ in. $1 ., \frac{1}{8}$ in. br., on longer stems than the others. - Hk. Sp. 5. p. 222. 2nd Cent. t. 92 .

Hab. West Indies to Ecuador.

26. A. cardiophyllum, Hk. ; rhizome wide-creeping, $\frac{1}{8}$ in. thick, densely clothed with rather large lanceolate dark-brown scales; st. 1-1 $\frac{1}{2}$ in. l., slightly scaly, the upper part winged ; barren fr. $\frac{3}{4}-1 \frac{1}{4}$ in. $1 ., \frac{3}{4}-\frac{7}{8}$ in. br., the point blunt, the base cordate, with a narrow decurrent haft; texture very thick; under side with a few small linear dark chesnut-brown scales; veins immersed; fertile fr. similar to the other, but the stem longer. $-H k$. Sp. 5. p. 229. Ic. t. 715.

Hab. Andes of Quito, Jameson, 212, 395.

27. A. squamipes, Hk.; rhizome firm, but not woody, wide-creeping, clothed with adpressed lanceolate acuminate bright-brown scales; st. 1-2 in. apart, $\frac{1}{2}-1 \frac{1}{2}$ in. 1 ., clothed with similar scales; barren fr. $\frac{1}{2}-1$ in. $1 ., \frac{3}{5}-\frac{1}{2}$ in. br., the point blunt, the base rounded to a slight haft; texture coriaceous; under side with a few small linear reddish-brown scales; veins raised beneath ; fertile fr. rather smaller than the other, and the stem much longer.-Hk. Sp. 5.p. 228. 1c.t. 197.

Hab. N. Granada and Peru.-We cannot distinguish from this the Mexican A. ovatum, Liebm., not Hk. A. humile, Mett. (N. Granada, Lindig, 167), is said to be like this, but to have an oblong fertile frond (1 $\frac{1}{4}$ in. $1 ., 4$ lin. br.) larger than the barren one.

28. A. Lindeni, Bory ; rhizome short, firm, the scales dense, fibrillose, nearly black; st. tufted, 4-9 in. 1., very slender, with a few scattered linear scales; barren fr. 1-4 in. l., $\frac{3}{4}-1 \frac{1}{2}$ in. br., the point bluntish or acute, the base rounded ; texture subcoriaceous; the edge thinly ciliated with subulate bright-brown scales, which are sometimes scattered over the under surface; veins visible, terminating within the edge; fertile fr. much smaller than the other.-Hk. Sp. 5. p. 223. A. venustum, Liebm.

Hab. Mexico to Ecuador and Brazil.-The scales of the frond are longer and more hair-like than its allies. 
29. A. squarrosum, Klotzsch ; rhizome wide-creeping, the scales dense, linear, dark chesnut-brown; st. $\frac{1}{2}-1 \frac{1}{2}$ in. l., slender, slightly scaly ; barren fr. $2-3$ in. 1 ., $\frac{1}{2}$ in. br., narrowed gradually to both ends; texture herbaceous, the under surface with scattered linear dark-chesnut scales; veins visible; fertile fr. $\frac{1}{2}$ in. $1 ., \frac{1}{4}$ in. br., the stem 2 in. 1.-Hk. $S p .5 . p .224$.

Hab. Columbia, Moritz, 319.-Most like the last, but the scales different, and the frond a different shape.

30. A. Lloense, Hk. ; rhizome slender, wide-creeping, the scales adpressed, lanceolate-acuminate, ferruginous ; st. 1-2 in. apart, 2-5 in. 1., slender, slightly scaly ; barren fr. 2-4 in. 1., $\frac{1}{2}-1 \frac{1}{2}$ in. br., the point blunt or acute, the base narrowed suddenly or rather rounded; texture subcoriaceous; under surface with a few small linear dark chesnut-brown scales; veins visible, not reaching the edge ; fertile fr. much smaller than the other, on a longer stem.- $H k$. $S p .5$. p. 229. Ic. t. 657 .

Hab. Mexico, along the Andes to Peru.

31. A. heteromorphum, Klotzsch ; rhizome filiform, wide-creeping, the scales small, scattered, lanceolate-acuminate, brown ; st. 1-3 in. 1., slender, slightly scaly; barren fr. $1 \frac{1}{2}-2$ in. $1 ., \frac{3}{4}-1$ in. br., the point bluntish, the base rounded; texture thin but firm; both sides scattered over with linear dark castaneous scales; veins conspicuous, raised and darker in colour than the rest of the frond; fertile fr. much smaller and the st. much longer.-Hk. Sp. 5. p. 224.

Hab. Columbia and Ecuador.

32. A. Huacsaro, Rinz.; rhizome woody, wide-creeping, the scales short, black, fibrillose ; st. of barren frond 1 in. 1., clothed with small furfuraceous scales ; barren fr. 3-4 in. l., $\frac{1}{4}-\frac{3}{3}$ in. br., the point very blunt, the lower part narrowed very gradually; texture coriaceous ; the lower surface viscid, the upper with scattered minute furfuraceous scales; veins fine, close, indistinct; fertile fr. narrower than the other and the st. much longer.-A. Calaguala, Klotzsch. HK. Sp. 5. p. 218. A. Ruizianum, Moore.

Hab. Columbia to Peru.-Distinguished from all the preceding by its ligulate fronds and very coriaceous texture.

\section{B. Barren fronds 6-18 inches long. Sp. 33-45.}

33. A. Gardnerianum, Fée ; caud. woody, erect, the scales large, ovate-lanceolate, pale-brown; st. tufted, 1-2 in. l., firm, erect, densely clothed with similar spreading scales ; barren fr. 4-6 in. 1., $\frac{3}{4}-1$ in. br., the point blunt, the base rather rounded; texture coriaceous; upper surfaee nearly naked, lower with small thickly scattered furfuraceous scales; veins raised beneath, fine, usually once forked; fertile fr. narrower than the other, narrowed at the base on a stem 6-8 in. l. Hk. Sp. 5. p. 233.

Hab. Brazil and Venezuela.-Texture and general habit of conforme, but the scales almost dense enough to entitle it to a place in the next group.

34. A. alpestre, Gardn.; rhizome wide-creeping, densely clothed with lanceolate acuminate bright-chesnut scales; st. of barren frond 4-5 in. l., erect, slightly scaly ; barren fr. 6 in. $1 ., \frac{5}{8}$ in. br., bluntish at both ends; texture subcoriaceous; surface rather thickly scattered over with small linear brightchesnut scales ; veins distant, prominent; barren fr. 2-3 in. 1., $\frac{1}{2}$ in. br., the st. $1 \mathrm{ft}$. 1.-Sert. Pl.t. 25. A. eximium, Mett.

Hab. Organ Mountains, Brazil, Gardner, 5924 ; N. Granada, Lindig, 318.-Differs from the next principally by its shorter fertile frond rounded at the base. 
35. A. lineare, Fée; rhizome short-creeping, the scales dense, linear, glossybrown; st. of barren frond 1-3 in. l., slender, thinly clothed with squarrose linear scales; barren fr. 8-12 in. 1 ., $\frac{1}{4}-\frac{3}{8}$ in. br., narrowed very gradually to both ends; texture thin, midrib beneath with a few linear scales and under surface slightly furfuraceous; veins distant, not reaching the edge ; fertile fr. not more than 2-3 in. 1., on a slender stem 4-8 in. 1.-Hk. Sp. 5. p. 221.

Hab. Brazil, Gardner, 98, 5927 ; and a plant from Bourbon differs only by its more distinct raised veins. - This is very likely a narrow-fronded variety of the next, with which it agrees in clothing and texture.

36. A. Aubertii, Desv.; rhizome woody, short-creeping, the scales dense, linear, bright-brown; st. of barren frond 1-6 in. 1., clothed with squarrose linear brown scales ; barren fr. $1 \mathrm{ft}$. or more l., $\frac{1}{2}-1$ in. br., the point acute, the lower part narrowed gradually, the edge entire or subrepand; texture thin; midrib and edge slightly ciliated with scales like those of the stem; veins fine, conspicuous, usually simple, 1 lin. apart ; fertile fr. 2-3 in. 1., $\frac{1}{2}-\frac{3}{4}$ in. br., narrowed suddenly at the base, the stem 6-9 in. 1.-Hk. Sp. 5. p. 219.

Hab. Bourbon, Natal, Zambesi-land, Fernando Po, Venezuela (A. Klotzschii, Moritz), Guatemala.-A well-marked species, differing from viscosum in texture, clothing, and veining.

37. A. dimorphum, Hk. \& Gr. ; rhizome stout, horizontal, the scales lanceolate, dark-brown ; st. close, 4-6 in. l., slender, erect, slightly scaly throughout; barren fr. 3-5 in. 1., $\frac{1}{2}-\frac{3}{4}$ in. br., the point bluntish, the edge deeply and irregularly crenate; texture subcoriaceous; both sides covered with minute white dots; veins subparallel, simple or forked; fertile fr. much smaller than the barren one, nearly entire.-Hk. Sp. 5. p. 208. Hk. \& Gr.t. 145. 2nd Cent.t. 90.

Hab. St. Helena. - The only Elaphoglossum that has the fronds distinctly incised or crenated.

38. A. viscosum, Sw. ; rhizome woody, short-creeping, the scales dense, fibrillose, dark chesnut-brown ; st. 3-6 in. 1., firm, erect, furfuraceous, often viscous ; barren fr. 6-12 in. $1 ., \frac{1}{2}-1$ in. br., the apex acute, the lower part narrowed gradually; texture subcoriaceous; both sides more or less viscid and minutely furfuraceous; veins close and fine; fertile fr. smaller, and on longer stems than the others.-Hk. Sp. 5. p. 220. Hk. \& Gr.t. 64.

Hab. Cuba to Brazil and Peru ; Himalayas to Ceylon, Java, and Philippines; Seychelles, Mascaren Isles, Fernando Po, Angola.-From the large forms of this we cannot distinguish clearly $A$. xanthoneuron, Karstenianum, dissimile, and curvans, Kze. The two latter are described as squamulose, but both our authentic specimens are nearly naked. The frond often becomes quite naked in an old state, and then the plant is difficult to recognize. A. stigmatolepis and falcatum, Fée, we cannot separate clearly.

39. A. ciliatum, Presl ; rhizome woody, wide-scandent, the scales short, dense, deciduous, linear, dark chesnut-brown; st. of barren frond 6-9 in. 1., firm, erect, slightly scaly; barren fr. 12-18 in. l., $\frac{3}{4}-1 \frac{1}{4}$ in. br., the point acute, the base narrowed gradually; texture subcoriaceous; both sides nearly naked; the edge deciduously furfuraceous ; veins fine, close, indistinct; fertile fr. smaller and on much longer stems than the others.-A. Preslianum, Fée. Hk. Sp. 5. p. 220. (not p. 265).

Hab. Columbia to Peru.-Probably a variety of the last, from which it differs chiefly by its woody wide-scandent rhizome and larger barren fronds.

40. A. pilosum, H. B. K. ; rhizome woody, the scales large, dense, lanceolate, pale-brown ; st. 6-8 in. l., firm, flexuose, slightly scaly ; barren fr. flexuose, 6-8 in. l., $\frac{3}{4}$ in. br., the point acute, the base narrowed gradually; texture herbaceous; both sides, especially the under one, clothed with small bright- 
brown scales, each like a tuft of stellate hairs ; veins conspicuous, very close.Hk.Sp.5. p. 241.

Hab. Mexico to Columbia.-Easily distinguished by its texture and clothing.

41. A. samoense, Baker ; rhizome short, woody, the scales long, dense, fibrillose, glossy, dark chesnut-brown; st. 4-6 in. lo, clothed with squarrose woolly

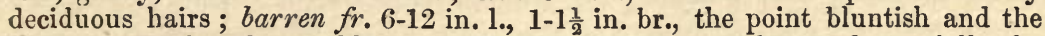
base narrowed rather suddenly ; texture herbaceous; surfaces and especially the midrib clothed with soft bright silky brownish hairs; veins sometimes twice forked ; barren fr. much smaller than the other.-Elaphoglossum, Brack.t. 9.

Hab. Polynesian Islands. - Very like the last in texture and general habit, but the scales both of the rhizome and surface are very different. Judging from the figure, the Chilian A. Webbii, Bory, may be identical with this.

42. A. apodum, Kaulf.; caud. thick, woody, the scales dense, linear, brightbrown, crisped; st. tufted, none or short, when present densely clothed with squarrose fibrillose bright-brown scales; barren fr. $1 \mathrm{ft}$. or more $1 ., 1 \frac{1}{2}-2$ in. br., the apex acuminate, the lower part narrowed very gradually; texture subcoriaceous but thin; the edge and midrib densely fringed with soft short brown hairs; veins fine, simple or once forked; fertile fr. much smaller than the barren one.-Hk. Sp. 5. p. 213. Hk. \& Gr.t. 99 .

Hab. West Indies to Brazil and Peru.-The West Indian specimens are thinner and less ciliated than the Continental ones.

43. A. scolopendrifolium, Raddi ; rhizome woody, short-creeping, the scales long, linear, dark chesnut-brown, crisped ; st. 4-12 in. 1., firm, erect, densely clothed with spreading, nearly black, long fibrillose scales; barren fr. often $1 \mathrm{ft}$. 1., $1 \frac{1}{2}-3$ in. br., the apex acute, the base narrowed gradually; texture subcoriaceous; edge and midrib more or less densely ciliated with scales like those of the stem, but smaller ; veins subparallel, usually once forked ; fertile fr. much smaller than the barren one.-Hk. Sp. 5. p. 211. A. barbatum, Karst. A. erinaceum, Fée.

Hab. Guatemala, along the Andes to Peru.-A plant from Fendler has the veins not unfrequently joining. A. Hystrix, Kze., seems nearly allied. An Ecuador plant from Jameson is densely ciliated not only on the edge, but over the surface. The scales are like those of $\boldsymbol{A}$. hybridum, but much more copious.

44. A. Cumingii, Fée; rhizome woody, the scales large, ovate, dull-brown ; st. 6-8 in. l., firm, erect, clothed in the lower part with similar scales; barren fr. 8 in. $1 ., 1 \frac{1}{2}$ in. br., the point blunt, the base narrowed gradually, the edge densely fringed with minute scales; texture very thick; the upper surface clothed all over with very minute scattered scales; veins quite hidden ; fertile fr. as long but narrower than the barren one.-F'é, Acrostich. 34 .

Hab. Philippines, Cuming, 193.-Perhaps a subfurfuraceous variety of decurrens, with which it agrees in texture and general habit.

45. A. Boryanum, Fée; rhizome woody, the scales dense, linear-subulate, nearly black ; st. tufted, 3-9 in. 1., more or less densely clothed with ovateacuminate or lanceolate pale-brown scales; barren fr. often $1 \mathrm{ft}$. l., 3 in. br., the point acute, the base rounded; texture almost papyraceous, flaccid; both sides thinly clothed with small ovate or peltate furfuraceous scales, which fringe the edge densely ; veins immersed, very distinct, simple or once forked, ending in black dots within the edge; fertile fr. much smaller and on longer st. than the barren one.-Hk. $S p .5 . p .210$.

Hab. West Indies.-The Ecuador plant mentioned in "Sp. Fil." seems to belong to A. scolopendrifolium. 
**** Surface of the frond densely scaly. Sp. 46-65.

\section{A. Fronds 1-4 inches long. Sp. 46-52.}

46. A. ovatum, Hk. ; rhizome filiform, very wide-creeping, with slender fibrillose bright-brown scales; st. distant, $\frac{1}{4}-\frac{1}{2}$ in. l., clothed with spreading scales; barren fr. $\frac{1}{2}-\frac{3}{4}$ in. $1 ., \frac{3}{8}-\frac{1}{2}$ in. br., roundish or broadly ovate; texture subcoriaceous; both sides often densely clothed with fimbriated ferruginous scales; veins hidden; fertile fr. the largest, and on longer stems. - Hk. Sp. 5. p. 228. Hk. \& Gr.t. 140.

Hab. Mexico to Ecuador and South Brazil.-Best distinguished from the small forms of spathulatum by its wide-creeping rhizome.

47. A. procurrens, Mett.; rhizome slender, wide-creeping, with squarrose linear-subulate bright-brown scales; st. 0-1 in. 1., slender, ciliated; barren fr. 1-3 in. l., $\frac{1}{2}-\frac{3}{4}$ in. br., spathulate, the point blunt, the haft narrowed very gradually ; texture subcoriaceous ; both sides scattered over and the edge ciliated with long, linear, dark chesnut-brown scales ; veins distant, slender ; fertile fr. much smaller than the others.-Hk. Sp. 5. p. 226.

Hab. Cuba, Fendler, 793.-Most likely a small form of villosum. The scales of the frond are the same, but that has the stems tufted.

48. A. spathulatum, Bory ; st. densely tufted, 1-2 in. l., firm, erect, clothed with soft spreading brown fibrillose scales; barren fr. $\frac{1}{2}-4$ in. $1 ., \frac{1}{4}-\frac{1}{2}$ in. br., obovatespathulate, the point blunt, the base tapering narrowly or gradually; texture coriaceous; both sides scattered over and the edge usually densely ciliated with small linear-subulate reddish-brown scales; veins hidden; fertile fr. smaller than the other and the stem longer.-A. piloselloides, Presl. Hk. Sp. 5. p. 227. Fil. Ex. t. 29.

Hab. Cuba and Mexico to Brazil and Peru ; Tristan d'Acunha, Ceylon, Natal, Mas. caren Isles.-A.obtusatum, Carm. Hk. \& Gr. t. 22, from Tristan d'Acunha, and A. Raddianum, Hk. \& Gr. t. 4, are forms, the latter with the stem especially densely clothed with dark-brown fibrillose scales, and the frond 3-4 in l., $\frac{1}{4}$ in. br.

49. A. Matthewsii, Fée; rhizome woody, wide-creeping, the scales small, dense, linear, nearly black; st. 2-3 in. l., wiry, clothed throughout with small lanceolate scales, nearly black in the middle, with a grey border; barren fr. 2-3 in. 1., $\frac{1}{2}-\frac{5}{8}$ in. br., both ends narrowed gradually ; texture coriaceous ; scales small, dense, peltate or uvate, brown or nearly black in the middle, with a pale sometimes silvery border; veins hidden; fertile fr. larger than the others, on longer stems.-Hk. Sp. 5. p. 230. A. Hartwegii, Fée, Hk. l. c.

Hab. Andes, from Mexico to Peru.-This should probably be regarded as a more scaly variety of $A$. Huacsaro, with which it agrees in texture and mode of growth.

50. A. acrocarpon, Mart.; rhizome woody, often 1-2 ft. 1., clothed with slender squarrose subulate dark-brown scales ; st. distant, those of the barren fr. 2-3 in. l., fibrillose throughout; barren fr. $3-4$ in. $1 ., \frac{1}{4}-\frac{3}{8}$ in. br., the point blunt, the base narrowed gradually; texture coriaceous, the edge inflexed, the upper surface clothed with minute peltate furfuraceous scales, the lower scaly on the elevated midrib throughout; veins simple; fertile fr. like the barren one, but the stem longer.-Hk. Sp. 5. p. 208.

Hab. N. Granada, Ecuador, Brazil.-The fronds of this are like those of the last in texture and shape, but are not scaly over the surface beneath.

51. A. succiscefolium, Thouars; rhizome woody, the scales dense, linearsubulate, nearly black; st. 2-3 in. l., firm, erect, densely clothed with spreading 
linear scales, dark chesnut in the centre, grey at the edge ; barren fr. $3-4$ in. 1 ., 1-1 $\frac{1}{4}$ in. br., blunt at both ends ; texture coriaceous; both sides densely clothed with pale-brown linear scales; veins hidden; fertile $f r$. smaller than the other and on a much longer stem.-Hk. Sp. 5. p. 241. Hk. \& Gr.t. 2.

Hab. Tristan d'Acunha, and reported also from Bourbon and Mauritius.-Habit of A. conforme.

\section{B. Fronds 6-18 inches long. Sp. 52-65.}

52. A. cinnamomeum, Baker ; rhizome short-creeping, the scales dense, linear, bright reddish-brown; st. 3-4 in. l., firm, densely clothed with similar but narrower squarrose scales ; barren fr. 4-6 in. 1., $\frac{3}{8}-\frac{1}{2}$ in. br., narrowed gradually to both ends; texture coriaceous; both sides, especially the lower one, densely clothed with long bright-yellow hair-like scales, which are scarcely at all flattened or ciliated; veins hidden; fertile fr. shorter and blunter than the other, the stem longer.

Hab. Cameroon Mountains and Clarence Peak, Fernando Po, G. Mann.-This agrees with the next in size and habit, but the scales are quite different.

53. A. lepidotum, Willd.; rhizome thick, woody, the scales very dense, linear, glossy, black; st. 1-3 in. l., firm, scaly throughout; barren fr. 3-6 in. 1., $\frac{3}{8}-\frac{3}{4}$ in. br., the point usually blunt, the base cuneate or rather rounded; texture coriaceous; scales furfuraceous and white on the upper surface, large, dense, ovate, ciliated, and ferruginous on the lower one, those on the midrib with a black middle; veins hidden; fertile fr. similar to the other, but the stem longer. - Hk. Sp. 5. p. 238.

Hab. Andes, from Columbia to Peru.-To this appear to belong A. Engelii, Karsten, A. Dombeyanum, Fée, the West Indian A. vestitum, Schlecht., and Mexican $A$. fulvum, M. \& G., and probably A. rufescens, Liebm. It may be a dwarf mountain variety of A. muscosum.

54. A. strictum, Raddi ; rhizome woody, short-creeping, densely clothed with small lanceolate dark chesnut-brown conspicuously ciliated scales; st. 1-2 in. I., clothed with similar scales ; barren fr. 4-6 in. l., $\frac{1}{2}-\frac{5}{8}$ in. br., narrowed to both ends; texture subcoriaceous; veins mostly simple; upper surface nearly or quite naked when old, lower densely clothed with bright reddish-brown scales, which are almost reduced to stellate tufts of hairs; fertile fr. about equal to the other, but the stem longer.-Hk. Sp. 5. p. 225.

Hab. Brazil and Columbia.-This bears the same relation to auricomum that lepidotum does to muscosum.

55. A. villosum, Sw.; rhizome woody, but not thick, densely clothed with bright-brown soft fibrillose scales ; st. tufted, 2-4 in. 1., slender, densely clothed with spreading scales like those of the base ;-barren fr. 6-9 in. 1., 1-1 $\frac{1}{2}$ in. br., the point acute, the lower part narrowed gradually; texture thin and flaccid; both sides with scattered scales like those of the stem, and the edge usually densely ciliated; veins distant, usually once forked, clubbed at the point and not reaching the edge; fertile fr. much smaller than the other. $-H k . S p .5 . p .225$. $H k$. \& Gr.t. 95 .

Hab. Mexico and Cuba to Peru.-A plant gathered by Barter at Sierra Leone is like this, but more robust and more scaly. A undulatum, Willd., Hk. Sp. 5. p. 212, is evidently a form. It is larger and thinner than the type, with main veins two lines apart. A. setosum, Liebm., is a small form, less scaly than usual, and A. Plumieri, Fée, Hk. Sp. 5. p. 226, a thin variety, with the edge of the frond repand. This may be known from all its neighbours, except cinnamomeum, by the scales, however dense, being uniform, and not at all flattened. 
56. A. tectum, Willd.; rhizome thick, woody, the scales dense, linear, rigid, black; st. 3-4 in. l., firm, erect, clothed with small furfuraceous adpressed and a few spreading scales; barren fr. 6-12 in. 1., $\frac{1}{2}-\frac{3}{4}$ in. br., narrowed gradually to both ends; texture coriaceous; lower or both sides clothed with small thin scales, which are brown, darker in the centre, ultimately bleached; veins hidden; fertile fr. narrower than the others, on longer stems.-A. rubiginosum, Fée. Hk. Sp. 5. p. 222.

Hab. Mexico and West Indies to South Brazil and Peru.-Distinguished by its long narrow frond, the upper surface of which is nearly or quite naked, with the scales beneath, though dense, thin and closely adpressed. A. Schiedei and nivosum of Kunze appear both to belong here.

57. A. Bellermanianum, Klotzsch; rhizome woody, the scales dense, linear, glossy, reddish-brown; st. 3-6 in. l., firm, erect, densely clothed with large spreading ovate-lanceolate pale-brown scales ; barren fr. $4-6$ in. $1 ., 1 \frac{1}{4}-1 \frac{1}{2}$ in. br., the point very blunt, the base cuneate or rather rounded; texture coriaceous; both sides with small scattered furfuraceous scales, those on the midrib beneath black in the middle; veins slightly raised, usually once forked; fertile fr. much narrower than the others and on longer stems.-Hk. Sp. 5. p. 236.

Hab. Columbia and Ecuador.-Habit and texture of $A$. conforme.

58. A. muscosum, Sw.; rhizoms woody, short, the scales dense, glossy, linear, bright chesnut-brown; st. 4-6 in. l., firm, clothed with large ovate spreading pale-brown ciliated scales; barren fr. 6-12 in. 1., 1-1 $\frac{1}{2}$ in. br., narrowed at both ends ; texture coriaceous ; upper surface slightly scaly, at last of ten naked, lower quite hidden by imbricated ovate-acuminate short-ciliated ferruginous scales, which are often dark chesnut-brown in the middle; barren fr. much smaller than the other, the st. longer.-Hk. Sp. 5. p. 231. A. Langsdorffi, $H$. \& $G$. t. 234 .

Firmer in texture than $A$. squamosum, and often glabrous above when mature, but even more densely scaly beneath, but the cilia of the scales much shorter. A. polylepis, Kze., A. rupestre, deorsum, caulolepia, and truncicola, Karst., are either this or closely allied.

59. A. obductum, Kaulf.; rhizome woody, the scales dense, rigid, fibrillose, black; st. 3-4 in. l., firm, erect, the scales small, peltate, and also linear, with a

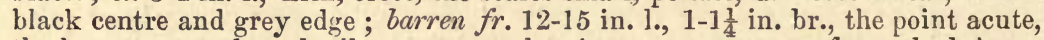
the base narrowed gradually ; texture subcoriaceous ; upper surface naked, lower thinly matted with small pale peltate scales; veins conspicuous ; fertile fr. much smaller than the other.-Hk. Sp. 5. p. 237.

Hab. Mauritius and Bourbon.-Most like the large forms of viscosum in habit and texture. The scales are altogether peltate and very minute, and the coating, though close, is very thin, and easily rubs away. The American A. elongatum, Kze., gathered in Peru by Poppig, and in Brazil by Lindberg, does not appear to be safely separable from this.

60. A. auricomum, Kunze ; caud. erect, woody, the scales linear, reddishbrown; st. 2-3 in. 1., densely clothed with spreading linear and soft fibrillose scales like those of the base; barren fr. 12-18 in. $1 ., 1 \frac{1}{2} \mathrm{in}$. br., the point acuminate, the lower part narrowed very gradually; texture subcoriaceous; upper surface naked or slightly scaly, lower thinly matted with minute brightbrown scales, densest and longest on the midrib; veins close, mostly simple; fertile fr. $1 \mathrm{ft} .1 ., \frac{3}{8}$ in. br., the st. 5 in. 1.-Hk. Sp. 5. p. 239.

Hab. Andes, from Columbia to Peru, and reported by F́e from Mexico.-Probably a variety of squamosum. The scales are bright reddish-brown, and reduced down, except on the midrib, to mere stellate tufts of hair. A. meridense, Klotzsch, is like this, except that the stem is longer, aud the scales of the stem and midrib are not so narrow or so dense. 
61. A. tomentosum, Bory ; rhizome woody, the scales dense, black, fibrillose ; st. 3-5 in. 1., rigid, erect, densely clothed with linear short-ciliated scales, of which the upper ones are quite white, the lower ones black in the middle;

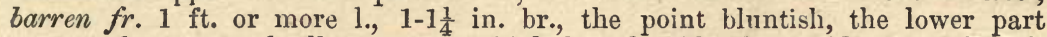
narrowed very gradually; texture thick but flaccid; both sides matted with scales like those of the stem and small adpressed white furfuraceous ones; veins distant; fertile fr. narrower than the other, on a stem $1 \mathrm{ft}$. or more $1 .-\mathrm{A}$. heterolepis, F'ée. Hk. Sp. 5. p. 234.

Hab. Bourbon.-Not unlike A. Sieberi in texture and general habit, but densely scaly, and the scales peculiar.

62. A. cuspidatum, Willd.; rhizome thick, woody, the scales dense, linearsubulate, black, or nearly so; st. 6-15 in. 1., firm, erect, clothed with deciduous adpressed dark-coloured scales; barren fr. 1-2 ft. 1., 3-4 in. br., the point cuspidate, the base not narrowed very gradually ; texture coriaceous; upper surface nearly naked, lower densely matted with small furfuraceous ciliated brown scales; veins fine and close; fertile fr. rather smaller than the other, the stem about the same.-Hk. Sp. 5. p. 235. A. Lindigii, Karst. $t .3$.

Hab. West Indies to Peru.-The representative of A. latifolium in this group. The scales, though dense, are altogether adpressed and peltate, as in obductum. A. laminarioides, Bory, seems to be closely allied.

63. A. perelegans, Fée ; rhizome woody, the scales linear, dark-brown; st. 6-8 in. 1., firm but slender, slightly scaly ; barren fr. $8-12$ in. $1 ., 1 \frac{1}{4}-1 \frac{1}{2}$ in. br., the point subacute, the base narrowed rather suddenly; texture subcoriaceous; lower surface matted all over with small bright-brown scales, which are scattered over the upper surface; veins conspicuous, usually simple; fertile fr. linear.Hk. Sp. 5. p. 232.

Hab. Dominica, Imray, 101, and reported also from Brazil and Peru.-Most like the last, but not so coriaceous. The scales beneath are not matted so densely, and though all small, as compared with those of squamosum and muscosum, are some of them lanceolate and ciliated.

64. A. Sprucei, Baker; rhizome woody, short-creeping, the scales dense, fibrillose, bright reddish-brown; st. $1 \mathrm{ft}$. or more l., rather slender, thickly clothed throughout with decurved pale-brown linear scales, some $\frac{1}{2}$ in. 1.; barren fr. $2 \mathrm{ft}$. l., 3 in. br., narrowed to both ends; texture herbaceous; veins distinct, usually simple, $\frac{1}{8}$ in. apart; upper surface thinly clothed with scales like those of the stem but smaller, the lower more thickly with pale scales, which are cordate, broad and distinctly ciliated in the lower half, then narrowed suddenly to a linear point; fertile fr. unknown.

Hab. Foot of Mount Chimborazo, Spruce.-The peculiar scales of the lower surface are enough scattered to be each seen as a distinct object.

65. A. squamosum, Sw. ; rhizome woody, the scales dense, rigid, linear, nearly black; st. 2-4 in. 1., densely clothed with unequal lanceolate ciliated pale or dark-brown scales, the lower ones often nearly black; barren fr. 6-12 in. l., 3-1 in. br., the point acute, the base narrowed gradually; texture thick but Haccid; both sides matted and the edge densely ciliated with bright reddishbrown ciliated linear or lanceolate scales; veins hidden; fertile fr. as long as the other but much narrower, the stems much longer.-Hk. Sp. 5. p. 240. A. vestitum (paleaceum on the plate), Hk. \& Gr.t. 235.

Hab. Mexico and West Indies to Ecuador and the Amazon Valley; Sandwich Isles, Sumatra, Ceylon, Neilgherries, Mascaren Isles, Guinea Coast, Madeira, Azores -Distinguished by its soft texture and copious long-ciliated scales. A. plumosum, Fée, and probably $A$. Wageneri, Kze., may be placed here with confidence. 
* Stenochlæna, J. Sim. Barren fronds simply pinnate, the pinnoe like those of Lomaria in their shape, coriaceous texture, and fine close venation. Sp. 66-70. Fig. 60. f. g.

66. A. (Steno.) sorbifolium, L.; rhizome thick, woody, often 30-40 ft. l., clasping trees like a cable, sometimes prickly ; fr. 12-18 in. 1., 6-12 in. br., simply pinnate ; barren pinnoe 4-8 in. l., $\frac{3}{4}-\frac{1}{2}$ in. br., 3 to 20 on each side, articulated at the base, the edge entire or toothed ; texture coriaceous or subcoriaceous ; both sides naked; rachis often winged; fertile pinnoe 1-2 in. apart, 2-4 in. 1., $\frac{1}{4}-\frac{3}{8}$ in. br. - Hk. Sp. 5. p. 241.

Hab. West Indies to Peru and South Brazil ; Fiji, Samoa, New Caledonia, Philippines, Malaccas, Cochin China, Seychelles, Mascaren Isles, Angola, Guinea Coast.This corresponds to the genus Lomariopsis of Fée, who makes 17 species. The type has 12 to 20 pairs of pinnæ about $2-3$ in. l., $\frac{3}{4}$ in. br., the edge slightly and irregularly crenato-serrate ; S. longifolia, J. Sm. (Lomaria, Kaulf.), fewer pinnæ, the edge more distinctly toothed, and the base cuneate ; A. yapurense, Mart. (Gard. F. t. 57), pinnæ sometimes $1 \frac{1}{2}$ in. br., 3 to 6 on a side, almost entire, the texture not so coriaceous, and the veining not so close ; $L$. fraxinea, Willd., short-stalked, entire, pinnæ often 5-6 in. l., $1-1 \frac{1}{4}$ in. br. ; L. Wrightii, Eaton, oblong-obovate pinnæ remarkably narrowed at the base, and cuspidate at the apex ; and $L$. cuspidata, F'e, long-stalked, ligulate-cuspidate pinnæ sometimes 8 in. l. Here also, as abnormal fornıs, probably belong $A$. buxifolium, Kze., pinnæ sessile, coriaceous, dark-green, oblong, very obtuse, under 1 in. l., $\frac{1}{2}$ in. br. ; L. variabilis, Fée, lower pinnæ deeply pinnatifid, with round crenated lobes ; Polyp. ? binerve, Hk., and L. Smithii, Fée, frond sessile, deltoid, tripinnatifid, the pinnules small, dichotomously forked, or with 2 ligulate lobes on each side.

67. A. (Steno.) decrescens, Baker ; rhizome woody, wide-scandent ; st. 2-3 in. l., firm, slightly scaly; barren fr. 18 in. $1 ., 4$ in. br., with about 40 pinnæ on each side, those about a third of the way down the longest, and from this narrowed very gradually down to mere auricles at the base ; pinnoe close, $\frac{3}{8} \mathrm{in} . \mathrm{br}$., the edge obscurely crenulate ; texture coriaceous ; both sides naked ; rachis slightly winged upwards ; fertile pinnoe $\frac{1}{8}$ in. br., cuneate at the base or subpetiolate.-A. polyphyllum, Hk. Sp. 5. p. 243. (not p. 269).

Hab. Cameroon Mountains, West Tropical Africa, Mann, 1391.

68. A. (Steno.) scandens, J. Sm. ; rhizome woody, wide-scandent, scaleless; st. 3-4 in. l., firm, erect, naked ; fr. 1-3 ft. l., $1 \mathrm{ft}$. or more br., simply pinnate ; barren pinnoe 4-8 in. 1., $\frac{3}{4}-1 \frac{1}{2}$ in. br., the point acuminate, the edge thickened and serrulate, the base cuneate, sessile, or slightly stalked, articulated, and with usually a gland on the upper side; texture coriaceous; rachis and both sides naked; veins fine and close; fertile pinno 6-12 in. $1 ., 1 \frac{1}{2}-2$ lin. br., the lower

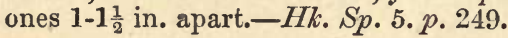

Hab. Himalayas and South China to Ceylon, Queensland, and Fiji.-The veins here spring from a line (see fig. 60. f.) which runs parallel with the midrib, either quite close to it or with a very narrow space between. Davallia achilleifolia, Wall. (Hk. Sp. 1. p. 195. t. 56. D.), seems to be a deltoid tripinnatifid abnormal form.

69. A. (Steno.) laurifolium, Hk. ; st. firm, erect, naked ; fr. 2-3 ft. 1., 12-18 in. bl., simply pinnate ; barren pinnoe 6-9 in. $1 ., 1 \frac{1}{2}-1 \frac{3}{4}$ in. br., narrowed gradually from the cordate base to the apex, the edge sharply but finely toothed, the base sessile, not articulated and without a gland; texture coriaceous ; rachis and both sides naked ; veins fine and close ; fertile pinnoe 6-10 in. 1., $\frac{1}{4}-\frac{1}{2}$ in. br., the lower ones 1-2 in. apart.-Hk. Sp. 5. p. 251.

Hab. Philippines, Cuming, 2261 ; Solomon Isles, Milne, 518. - Like the last, but larger, and the pinnæ not articulated.

70. A. (Steno.) tenuifolium, Baker; rhizome wide-scandent, woody, slightly 
scaly ; barren fr. simply pinnate, the st. 4-6 in. 1., naked, firm, erect, the fr. 3-5 ft. 1., 12-18 in. br.; pinnoe 6-12 in. $1 ., \frac{3}{4}-1 \frac{1}{2}$ in. br., the point acuminate, the edge thickened and serrulate, the base short-stalked, with a gland on the upper side, not articulated ; fertile fr. bipinnate, on a longer stem ; pinnoe long-stalked, with numerous distant pinnl. 2-3 in. 1., $\frac{1}{2}-1$ lin. br., spreading from the rachis at right angles; texture coriaceous; rachis and both sides glossy; veins fine and close.-Lomaria, Desv. A. Meyerianum, Hk.Sp. 5. p. 250. G. F.t. 16.

Hab. Mascaren Isles and Natal.-Well distinguished from all the others by its compound fertile pinnæ.

\section{** Polybotrya, H. B. K. Barren frond not lomarioid in habit, variously} pinnatifid or pinnate, with the veins, except in the first species, pinnate in the ultimate divisions of the barren frond. Fig. 60. c, d, e. Sp. 71-83.

71. A. (Polyb.) bifurcatum, Swz.; st. densely tufted, 2-4 in. 1., slender, stramineous, naked; fr. $3-4$ in. $1 ., \frac{1}{2}-\frac{3}{4}$ in. br., pinnate ; lower pinnoe of barren fr. usually 2-sometimes 3-cleft, with linear divisions, those of the barren pinnæ broader and not so deep; texture herbaceous; both sides naked; a single vein carried into each ult. division. - IIk. Sp. 5. p. 209. 2 nd Cent. t. 91. Microstaphyla, Presl.

Hab. St. Helena.

72. A. (Polyb.) articulatum, Hk.; st. firm, erect, nearly naked ; fr. ample, probably several feet long, bipinnate; barren pinnoe (in our specimens) 9 in. l., $1 \frac{1}{2}$ in. br.; pinnl. close, oblong, the point bluntish, the edge crenate, the upper side distinctly auricled, and the lower obliquely truncate at the base; texture subcoriaceous; rachis and both sides naked; fertile pinnce 3-4 in. 1., stalked, linear-cylindrical, auricled on the upper side at the base.-Hk. Sp. 5. p. 247.

Hab. Philippines, Cuming, 296.

73. A. (Polyb.) Wilkesianum, Hk.; rhizome woody, wide-scandent, naked ; st. 6-9 in. 1., firm, erect, naked, stramineous ; fr. bipinnate, 1-2 ft. 1., 8-12 in. br., upper pinnoe of the barren fr. entire in one of our specimens, usually all cut down to the rachis into numerous unequal-sided rhomboidal pinnl., which are cuneate, especially below at the base, the rest of the edge deeply toothed ; texture glossy, subcoriaceous; rachis and both sides naked; fertile pinnl. stalked, linearcylindrical or oblong-subdimidiate.-Hk. Sp. 5. p. 247.

Hab. Society Isles and New Caledonia.-This comes near the preceding, with which Mettenius unites it. Both bave the pinnæ and pinnules distinctly jointed at the base.

74. A. (Polyb.) apiiffolium, Hk. ; caud. stout, woody, erect; st. of barren fr. 2-3 in. 1., erect, densely clothed with tomentum ; barren fr. 4-6 in. each way, deltoid, tripinnate; pinnoe close, only the lowest pair with pinnatifid pinnl.; ult. divisions oblong-rhomboidal, $\frac{1}{4}-\frac{3}{8}$ in. 1 ., the base equally cuneate, the outer edge slightly toothed; texture herbaceous; rachises tomentose; fertile fr. on a slender naked st. 6-8 in. l., the fr. panicled with a few distant slender simple or compound beaded branches.- Hk. Sp. 5. p. 248.

Hab. Philippines, Cuming, 26, Lobb.-This has altogether the habit of an Anemia, with the fertile segments ball-like, with the sori all over the surface.

75. A. (Polyb.) plumbicaule, Baker ; rhizome woody, wide-scandent, scaly ; st. of barren fr. $9-10$ in. l., firm, erect, glossy, naked; barren fr. $1 \frac{1}{2}-2 \mathrm{ft}$. 1., nearly $1 \mathrm{ft}$. br., simply pinnate, with about 12 pinnoe on each side below the point, the lower ones sessile, 5-6 in. 1., 1 in. br., the point acuminate, the edge in the upper part sharply toothed, the base broadly rounded on the upper, truncate 
on the lower side; texture coriaceous; rachis and both sides naked; veins fine, in close pinnated groups, with two veinlets on each side; st. of barren fr. $1 \mathrm{ft} .1$.; barren pinnce pinnate, the lower ones 2-3 in. 1., 2-3 lin. br., the pinnl. oblong.

Hab. Tarapota, North Peru, Spruce, 4090.

76. A. (Polyb.) fractiseriale, Baker ; st. (of fertile fr.) 2 ft.l., naked; barren fr. $4 \mathrm{ft}$. l., $2 \mathrm{ft}$. br., simply pinnate, with 16 pinnoe on each side, the lower ones short-stalked, $1 \mathrm{ft}$. 1., $1 \frac{1}{2}-1 \frac{3}{4}$ in. br., the apex acuminate, the edge toothed, the base rounded on the upper, truncate on the lower side; texture coriaceous ; rachis and both sides naked; veins distinct, in pinnate groups of 3-4 on a side, with a simple vein springing from the rachis inidway between each group; fertile pinnoe distant, simply pinnate, the lower ones 6 in. l., $\frac{3}{4}$ in. br.

Hab. Monte Campana, North Peru, Spruce, 4337.-This and the preceding are two interesting novelties, easily recognisable from the other South American species by their quite simple pinnæ.

77. A. (Polyb.) aspidioides, Baker; 1 ft. high; st. densely clothed with lanceolate-acuminate scales; fr. bipinnatifid; upper pinnce united at the base, lower $2 \frac{1}{2}$ in. l., 1 in. br., cut down nearly to the rachis into blunt linear-oblong. falcate subserrulate lobes; texture subcoriaceous; surfaces naked; fertile fr. narrower, bipinnatifid, the lobes fertile on both sides,-Polybotrya, Griseb. Cat. Pl. Cub. p. 276.

Hab. Cuba, Wright, 1827.- This we have not seen, and the description is compiled from Grisebach, who compares the general habit of the plant to that of N. Filix-mas.

78. A. (Polyb.) pubens, Baker ; rhizome woody, wide-scandent, scaly ; st. 6-9 in. l., firm, erect, villose, scaly below ; barren $f r .2-3 \mathrm{ft}$. $1 ., 1 \mathrm{ft}$. or more br., the lower pinnce 5-6 in. 1., $1 \frac{1}{4}-1 \frac{1}{2}$ in. br., cut more than halfway down to the midrib into close blunt subentire oblong lobes $\frac{1}{4}-\frac{3}{8}$ in. br. ; texture subcoriaceous; all the rachises villose and the under surface slightly so; fertile pinnoe 1 in. or more apart, the upper ones simple, 3-4 in 1., $\frac{1}{8}$ in. br., the lower ones with a few short branches spreading at right angles from the lower part.-Polyb. Kze. Linnoea, 9. p. 23.

Hab. Brazil, Martius; Peru, Poppig, Spruce, 3880, 4740.-This is much less compound than the next, with which it is united in "Sp. Fil.," the lower pinnæ being not larger than the central ones and pinnatifid only.

79. A. (Polyb.) acuminatum, Hk.; rhizome thick, woody, wide-scandent, densely scaly ; st. 4-6 in. l., firm, erect, scaly throughout; barren fr. 1-2 ft. l., often $1 \mathrm{ft}$. br., deltoid, bipinnate; upper pinnoe oblong-lanceolate, slightly lobed, truncate on the lower side at the base, 2-3 in. l., $\frac{3-1}{4}-1$ in. br. ; lower pinnoe 6-8 in. 1., 4-5 in. br., with several similar pinnl. on each side; texture subcoriaceous ; rachis and both sides naked; fertile fr. $1 \mathrm{ft}$. 1., deltoid, tripinnate; segm. short, linear-oblong.- $H k$. Sp. 5. p. 245.

Hab. Brazil.-This resembles the least divided forms of the next in its barren frond, but the fertile frond is more compact and more compound, with much shorter ultimate divisions. The Peruvian $P$. nutans, Kze., seems to come near to this, but the fertile frond is said to be subquadripinnatifid at the base.

80. A. (Polyb.) caudatum, Hk.; rhizome woody, wide-scandent, often 1 in. thick; st. woody, erect, with long linear scales at the base; fr. bipinnate or tripinnatifid, $3.4 \mathrm{ft}$. l., 1-3 ft. br., the upper barren pinnoe lanceolate, pinnatifid, the lower ones sometimes 18 in. $1 ., 6-10$ in. br. ; pinnl. $3-5$ in. $1 ., \frac{3}{4}-1 \frac{1}{4}$ in. br., the edge entire, with oblong-falcate lobes reaching lialfway down to the midrib; texture subcoriaceous; rachis and both sides naked; fertile pinnl. 2-3 in. $1 ., 1$ lin. br., continuous or beaded, $\frac{1}{4}-1$ in. apart. $-H k . S p .5 . p .244$. 
Hab. Mexico and West Indies to Peru and Brazil.-This and A. pubens may be distinguished from the rest by their long dangling narrow-cylindrical fertile pinnules.

81. A. (Polyb.) osmundaceum, Hk.; rlizome woody, wide-scandent, clothed with long linear scales; st. 12-18 in. l., firm, erect, stramineous, scaly only at the base; fr. ample, tripinnatifid or tripinnate, the lower pinnoe 1-2 ft. 1., 4-8 in. br.; barren pinnl. stalked, lanceolate, cut down nearly or quite to the rachis below into close subentire lobes; texture subcoriaceous; both sides naked; fertile fr. and pinnoe nearly or quite as large as the barren ones; segm. linear, cylindrical, $\frac{1}{4}-\frac{1}{2}$ in. 1., with a space between them.-Hk.Sp.5.p.246. A. cylindricum, $H k \cdot l$. $c$.

Hab. Cuba to Ecuador and South Brazil.

82. A. (Polyb.) canaliculatum, Hk.; rhizome woody, wide-scandent, spinulose and densely clothed with linear scales; st. $1 \mathrm{ft}$. or more l., scaly throughout; fr. 2-3 ft. l., 12-18 in. br., tripinnate ; lower barren pinnoe 6-9 in. 1., 4-5 in. br.; pinnl. lanceolate, stalked, cut down to the rachis below into oblong lobes; texture subcoriaceous ; both sides naked ; fertile pinnl. close, the branches $\frac{1}{4}$ in. 1 ., spreading at right angles and bearing $3-4$ sessile balls of sori._-Hk. Sp. 5. p. 247.

Hab. Venezuela.-Very near the last, but the fertile segments moniliform.

83. A. (Polyb.) Lechlerianum, Hk. ; rhizome woody, wide-scandent, scaly ; st. 6-12 in. 1., firm, erect, scaly downwards; fr. 3-4 ft. 1., 12-18 in. br., the barren one quadripinnatifid ; lower pinno 6-9 in. 1., 4-5 in. br. ; pinnl. close, lanceolate; segm. oblong, eut down nearly to the rachis into ligulate lobes; texture subcoriaceous; rachises pubescent; fertile pinnl. narrower, distant, the segm. between oblong and cylindrical, with a space between them, the lower ones rather beaded.-Hk. Sp. 5. p. 246. 2nd Cent.t. 97.

Hab. Peru, Lechler, 2156, Spruce, 4744 ; Ecuador, Jameson.-Much more divided than any of the preceding.

**** Egenolfia, Schott. Differs from Polybotrya only by the presence of a seta in the sinus of the lobes of the uttimate divisions. Fig. $60 . \mathrm{h}, \mathrm{i}, \mathrm{j}$. Sp. 84.

84. A. (Egenol.) appendiculutum, Willd.; rhizome firm, woody; barren fr. 6-18 in. l., 4-8 in. br., simply pinnate, sometimes rooting at the apex ; st. 3-6 in. 1., erect, naked or slightly scaly ; pinnoe $2-4$ in. $1 ., \frac{3}{8}-\frac{3}{4}$ in. br., the edge varying from subentire to cut halfway down to the midrib into blunt lobes, the upper side often auricled, the lower one obliquely truncate at the base; colour dark-green ; texture papyraceous or subcoriaceous ; both sides naked ; rachis often rather scaly ; fertile fr. narrower, on a longer st., the pinnæ roundish or oblong, often distinctly stalked.- $\beta, A$. Hamiltonianum, Wall.; pinnce large, lanceolate, acuminate, equal-sided, subentire, the fertile ones with the sori in bead-like clusters without any connecting leafy membrane. $-\gamma, \boldsymbol{P}$. ludens, Wall.; barren pinnoe 1 in. or more br., equal-sided, deeply pinnatifid, with crenulate lobes, the lowest pair with several distinct pinnatifid pinnl. on the lower side; fertile pinnoe linear-oblong, blunt, entire.-Hk. Sp. 5. p.251. Ex. F. 2.t. 198.

Hab. Himalayas to Hong-Kong, Ceylon, the Malaccas, and Philippines.-Fée enumerates eight species, and makes of the forms with moniliform fertile pinnæ a sub-genus (Granulina, Bory), but the extremes appear to pass into one another quite gradually. $P$. Helferiana, Kze., is a small form with beaded fertile pinnæ and blunt slightly-lobed barren ones a little truncate at the base beneath.

***** Rhipidopteris, Schott. Venation flabellate, the fertile fronds small, suborbicular, uncut. Sp. 85. Fig. 60. k, l.

85. A. (Rhip.) flabellatum, H. B. K. ; rhizome slender, wide-creeping; st. distant, 1-3 in. l., slender, slightly scaly ; sterile fr. cuneato-flabellate, $\frac{1}{2}-\frac{3}{4}$ in. br., 
entire or cleft, the outer edge crenate or dentate; texture subcoriaceous ; fertile fr. $\frac{1}{4}$ in. br., orbicular.-Hk. Sp. 5. p. 252. Ic. t. 96.- $\beta$, A. tripartitum, Hk. ; barren fr. 2-3 times dichotomously forked, with cuneate or ligulate ult. divisions. $-H k . \& G$. t. 118.

Hab. New Granada to Peru.

86. A. (Rhip.) peltatum, Sw.; rhizome slender, wide-creeping; st. distant, slender, 1-3 in. l., scaly throughout; barren $f r$. 1-2 in. each way, repeatedly dichotomously forked, with narrow linear ultimate divisions $\frac{1}{4}-\frac{1}{2}$ lin. br. ; texture subcoriaceous ; fertile fr. $\frac{1}{4}$ in. br., often 2-lobed.-Hk. Sp. 5. p. 252.

Hab. Mexico and West Indies to Peru and Brazil.

87. A. (Rhip.) freniculaceum, Hk. ; rhizome slender, wide-creeping; st. distant, slender, 2-8 in. l., scaly throughout; sterile fr. 1-2 in. br., very often dichotomously forked, with filiform ultimate divisions ; texture subcoriaceous ; fertile $f r$. $\frac{3}{8}$ in. br., 2-lobed.-Hk. Sp. 5. p. 253. Hk. \& Gr. t. 119.

Hab. Andes of Ecuador, Jameson, Spruce.

§§ Veins anastomosing. Sp. 88-132.

* Veins united only near the margin. Sp. 88-90.

+Fronds simple. Aconiopteris, Presl. Sp. 88-89. Fig. 60.p.9.

88. A. (Acon.) subdiaphanum, Hk. \& Gr. ; caud. woody, erect ; st. tufted, 2-6 in. l., firm, erect, scaly ; barren fr. 4-8 in. 1., 1-1 $\frac{1}{2}$ in. br., both ends narrowed, the edge entire; texture subcoriaceous; veins beneath very prominent, united by a zigzag veinlet just within the edge; fertile fr. much narrower, on a longer stem.-Hk. Sp. 5. p. 256. Hk. \& Gr.t. 105.

Hab. St. Helena.

89. A. (Acon.) gorgoneum, Kaulf.; st. tufted, firm, erect, 1-2 in. 1., passing gradually into the barren fr., which is 6-15 in. 1., 2-3 in. br., the point acute, the lower two-thirds narrowed very gradually, the edge entire; texture subcoriaceous; surfaces naked; veins united by a straight veinlet just within the margin ; fertile fr. smaller, narrower, on a st. 6 in. or more l.-Hk. Sp. 5. p. 254.

Hab. Sandwich and Society Isles.-Habit of A. latifolium.

t+ Fronds pinnate. Olfersia, Raddi. Sp. 90. Fig. 60. m, n, o.

90. A. (Olf.) cervinum, Sw. ; rhizome woody, creeping, densely clothed with long linear scales; st. $1 \mathrm{ft}$. or more l., scaly downwards; barren fr. 2-4 ft. l., simply pinnate ; pinnoe 4-9 in. l., 1-2 in. br., entire or nearly so, unequal at the base ; texture coriaceous, naked; veins prominent, united just within the edge by a straight veinlet; fertile pinnoe distant, linear-lanceolate, bipinnate, with short spreading subcylindrical pinnl.-Hk. \& Gr.t. 81. Fil. Ex. t. 43.-B, O. corcovadensis, Raddi ; fertile fr. simply pinnate only, the pinnæ unbranched. -Hk. Sp. 5. p. 254.

Hab. Cuba and Mexico to South Brazil and Peru.-The extremes look very different, but are connected by intermediates. There is a forn with the barren pinnæ deeply pectinato-pinnatifid.

** Stenosemia, Presl. Veins forming one or two rows of areoloe against the midribs, the rest free. Sp. 91. Fig. 60. r, s.

91. A. (Steno.) auritum, Sw.; caud. erect, woody ; sterile fr. with a st. 6-9 in. l., deltoid, 8-12 in. each way, ternate, the central segm. deeply pinnatifid, 
with lanceolate entire lobes, the lateral ones unequal-sided, with elongated lobed lanceolate-oblong lower pinnl. not reaching down to the rachis; texture papyraceous; both sides naked; fertile fr. with a st. 12-18 in. l., deltoid, with distant linear pinnoe $\frac{1}{2}$ lin. br., the upper ones simple, the lower pinnatifid.-Hk. $S p .5$. p. 257. Fil. Ex. t. 81 .

Hab. Philippine, Malay, and Solomon Isles.-S. cicutaria, Presl, known only in a barren state, is more deeply divided, with narrower lobes and more conspicuous main veins, which are fulvo-villose on the under surface.

** Soromanes, Fée. Veins pinnate, a few of those of contiguous groups usually joining. Sp. 92. Fig. 60. t. u.

92. A. (Soro.) Conopteris, Kze. ; rhizome woody, wide-creeping, densely clothed with long linear ferruginous scales; st. 6-12 in. 1., stramineous, scaly below ; fertile $f r .1 \frac{1}{2}-3 \mathrm{ft}$. 1., $1 \mathrm{ft}$. or more br., simply pinnate; pinnce $4-8 \mathrm{in}$. $1 ., 1-1 \frac{1}{2}$ in. br., oblong-lanceolate, entire or toothed, especially towards the point, or sometimes pinnatifid; texture subcoriaceous; both sides naked; fertile fr. smaller and narrower, with pinnate pinnæ $\frac{1}{4}-1$ in. br. $-H k$. Sp. 5. p. 256. S. serratifolium and integrifolium, Fée.

Hab. Mexico to South Brazil.-The venation is that of Cyclodium, and in some of the forms the veins hardly unite at all.

\section{****Veins anastomosing copiously. Sp. 93-132.}

+ Gymnopteris, Bernh. Fronds dimorphous. Main veins distinct nearly or quite to the edge. Sp. 93-107. Fig. 60. v-x. aa. bb.

A. Barren frond entire. Sp. 93-95.

93. A. (Gym.) Linnceanum, Hk. ; rhizome wide-creeping; st. 1-2 in. 1., slightly fibrillose below ; barren fr. 4-8 in. l., $\frac{1}{2}$ in. br., narrowed gradually to both ends, sometimes rooting at the point, the edge entire ; texture papyraceous; colour dark-green ; main veins fine, rather zigzag but distinct nearly to the edge ; areola copious, without free veinlets; fertile fr. 3-4 in. 1., $\frac{1}{4}$ in. br., the st. slender, 4-5 in. 1.-Hk. Sp. 5. p. 278. 2nd Cent. t. 26.

Hab. Malay Isles.

94. A. (Gym.) gaboonense, Hk. ; rhizome firm, wide-creeping ; st. of barren fr. 4-6 in. 1., firm, erect, slightly scaly ; barren fr. $1 \mathrm{ft} .1 ., 3-4 \mathrm{in}$. br., narrowoblong, the apex sometimes proliferous, the edge subentire, the base narrowed suddenly; texture subcoriaceous; surfaces naked; main veins very distinct, reaching nearly to the edge, with transverse veinlets, with copious intermediate areola with a few free veinlets ; fertile fr. 4-6 in. $1 ., \frac{3}{4}-1$ in. br., narrowed at both ends, the edge sinuated, the st. $1 \frac{1}{2}-2 \mathrm{ft}$. 1.-Hk. Sp. 5. p. 270.

Hab. Guinea Coast, Mann 1049 ; Angola (1,000-2,400 ft.), Welwitsch.-Barren frond very like that of the next, but the fertile one not Lomarioid.

95. A. (Gym.) variabile, Hk.; rhizome wide-creeping ; st. of barren fr. 0-6 in. l.;

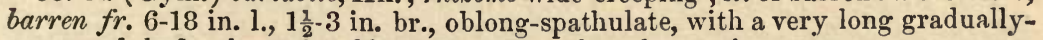
narrowed haft, the point blunt or acute, the edge entire; texture papyraceoherbaceous; surfaces naked; main veins raised, zigzag, reaching nearly to the edge, with copious fine areolce with free veinlets between them ; fertile fr. 6-12 in. l., 2-3 lin. br., the st. often $1 \mathrm{ft}$. l.-Gym. decurrens, $H k$. G. $F . t .6 .-\beta$, laciniatum, Hk.; barren fr. deeply irregularly pinnatifid; fertile fr. pinnate, with a few Lomarioid pinnæ.-Hk. $S p .5 . p .277$.

Hab. Himalayas (up to $3,000 \mathrm{ft}$.) to Ceylon and Java. 
B. Barren fronds sometimes simple, but one or two pairs of distinct pinnoe when fully developed. Sp. 96-100.

96. A.(Gym.)oligarchicum, Baker; rhizome woody, short-creeping ; st. of barren fi. 6-8 in. 1., firm, scaly; barren fr. 8-12 in. l., 3-6 in. br., broad-oblong, the edge nearly entire, the base subcuneate, simple or with a single pair of small spreading oblong pinnæ at the base ; texture herbaceous; main veins $\frac{1}{4}-\frac{3}{8}$ in. apart, raised beneath, distinct to the edge, with abundant areoloe with free veinlets between them ; fertile fr. simple, 3-4 in. l., 1 in. br., or ternate, the st. 6-12 in. 1 .

Hab. North Peru, Spruce 4737, 4636.-Most like A. panduriforme, but the veining different.

97. A. (Gym.) quercifolium, Retz. ; rhizome stout, wide-creeping ; st. of barren fr. 1-2 in. 1., clothed with soft spreading ferruginous hairs ; barren fr. 3-4 in. 1., $1 \frac{1}{2}-2$ in. br., the terminal pinna with blunt rounded lobes, reaching sometimes $\frac{1}{4}$ of the way to the rachis ; below this usually a single pair of small sessile ovate blunt auriculate lateral ones; texture thin-herbaceous; veins beneath hairy; main veins distinct to the edge, with copious areola with free veinlets between them ; fertile fr. with a terminal pinna 1-2 in. 1., 1 lin. br., and a pair of smaller lateral ones, the $s t$. slender, 6-9 in. 1., naked except at the base.- $H k$. $S p$. 5. p. 279. Ic. t. 905. Fil. Ex. t. 80.

Hab. Peninsular India, Ceylon, South China, Cochin-China.

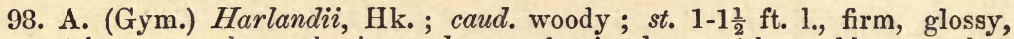
chesnut-brown, scaly at the base ; barren fr. simple or with an oblong-spathulate entire terminal pinna, sometimes $1 \mathrm{ft}$. 1., 3 in. br., and 1-2 smaller similar ones on each side, usually connected at the base, all acuminate ; texture coriaceous ; main veins distinct, connected by transverse veinlets with copious areolø with free included veinlets between them; fertile $f r$. similar, but the pinnæ much smaller.-Hk. Sp. 5. p. 274. G. decurrens, Hk. Fil. Ex. t. 94. (not G. F.t. 6).

Hab. Hong-Kong and Formosa.

99. A. (Gym.) taccofolium, Hk.; caud. woody, with copious dark reddishbrown linear scales; st. of barren fr. 1-4 in. 1., scaly downwards; barren fr. varying from simple oblong-lanceolate, entire, 1 ft. or more $1 ., 2-3$ in. br., to $1 \frac{1}{2}-2 \mathrm{ft}$. 1., more than $1 \mathrm{ft}$. br., copiously pinnate, with oblong-lanceolate pinnce 6-9 in. l., $1 \frac{1}{2}$ in. br., the upper ones narrowly decurrent, the lower ones forked at the base on the under side; texture papyraceous; rachis and surfaces naked; main veins distinct nearly to the edge, with regular transverse veinlets and copious fine areolæ with abundant free veinlets between them; fertile fr. simple, 6-12 in. l., $\frac{1}{8}$ in. br., or pinnate, with forked linear pinnæ.-Hk. Sp. 5. p. 279. Ic. $t .907$.

Hab. Philippines.-Though so variable in cutting, the forms coincide in texture and venation. The simple form is $L$. hilocarpus, Fée, and the 3-lobed form Gymn. trilobata, J. Sm.

100. A. (Gym.) flagelliferum, Wall.; rhizome woody, creeping, scaly ; st. of barren fr. 6-12 in. 1., nearly naked, the latter simple or with 1-3 pairs of pinnoe, the terminal one ovate-lanceolate, entire or repand, and often very much elongated and rooting at the point, the lateral ones 3-6 in. 1., 1-2 in. br., sometimes also prolonged; texture herbaceous; rachis and both sides naked; main veins pinnate, with copious areolae between them, with few or no free veinlets ; fertile pinnoe 2-3 in. 1., about $\frac{1}{2}$ in. br.-Hk. Sp. 5. p. 258. Hk. \&. Gr.t. 23. A. heteroclitum, Presl.

Hab. Himalayas to Java and the Philippines. 


\section{Barren fronds copiously pinnate. Sp. 101-107.}

101. A. (Gym.) repandum, Blume ; st. of barren fr. 6-12 in. 1., naked ; barren fr. 1-2 ft. 1., 8-12 in. br., sometimes elongated and rooting, with numerous pinnoe on each side, the lower ones 4-6 in.l., $\frac{3}{4}-1$ in. br., the edge with entire blunt lobes reaching a quarter of the way down; texture herbaceous; rachis and both sides naked; main veins distinct; areolo copious, without free veinlets, the sinuses often setose ; fertile pinnoe 2-3 in. 1., 2-3 lin. br., stalked, entire or repand.Hk. Sp. 5. p. 260.- $\beta, A$. Quoyanum, Gaud.; pinnce lobed halfway down or more, the lobes toothed.-Hk. Sp. 5. p. 259.

Hab. South China, Bonin, Philippine, Malay, and Polynesian Isles, New Caledonia, Queensland, Seychelles.-The two varieties seem to be connected by gradual intermediates. $N$. argutum, Fée, is probably this in an undeveloped condition.

102. A. (Gym.) punctulatum, L. ; rhizome firm, wide-creeping ; st. of barren fr. 6-12 in. l., slightly scaly, the latter 12-18 in. l., often $1 \mathrm{ft}$. br. with a terminal pinna and 1 to 8 on eacli side, which are 4-9 in. l., 1-2 in. br., lanceolate or oblong, narrowed at both ends, the edge entire or repand ; texture papyraceous ; rachis and both sides naked; main veins pinnate, with copious hexagonal areolæ between them without free veinlets ; fertile fr. on a longer slender stem with similar but much smaller pinnæ.-Hk. Sp. 5. p. 258.

Hab. Mascaren Isles, Zambesi-land, Guinea Coast, Angola.

103. A. (Gym.) subrepandum, Hk. ; rhizome woody, wide-creeping; st. of barren fr. stout, erect, nearly naked; barren fr. varying from simple, $1 \mathrm{ft}$. 1 ., $1 \frac{1}{2}-2$ in. br., to $2 \mathrm{ft}$. l., $1 \mathrm{ft}$. br., copiously pinnate, with several linear-oblong entire or subrepand pinnoe on each side, which are sometimes 6-9 in. 1., 2 in. br.; texture subcoriaceous; surfaces and rachis naked; main veins distinct nearly to the edge, with copious areolæ with free veinlets between them ; fertile fr. like the others, but smaller.-Hk. Sp. 5. p. 275.

Hab. Luzon, Cuming 225 ; Penang, Sir W. Norris, Mactier.-Very near the last, but firmer in texture.

104. A. (Gym.) alienum, Sw. ; rhizome woody, short-creeping ; st. 6-18 in. 1., scaly downwards; barren fr. 1-2 ft. l., often $1 \mathrm{ft}$. br., the upper part deeply pinnatifid, with lanceolate lobes, the lower part pinnate, with entire or deeply pinnatifid lower pinno, the lobes sometimes reaching more than halfway down to the rachis; texture papylaceous ; rachis and surfaces naked, a distinct midvein in each of the lobes; areoloe copious, irregular, with free veinlets; fertile fr. much smaller, with distant narrow linear or pinnatifid leafy pinnæ.-Hk. Sp. 5 . p. 272.- $\beta$, A. subpinnatifidum, Hk. ; areoloe with few or no free veinlets. - Hk. Sp. 5. $p .273$.

Hab. Cuba and Mexico to North Peru and the Amazon Valley.-This and the next are the American analogues of the three preceding. Mettenius (Annales, 5. ser. vol. 2. p. 204) has two closely allied species from New Granada under the names of Chrysodium opacum and pellucens.

105. A. (Gym.) nicotianofolium, Swz. ; rhizome woody, wide-creeping, scaly ;

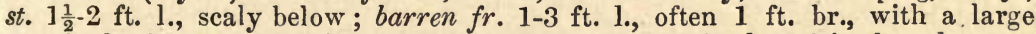
terminal pinna and 1-3 lateral pairs, which are 6-12 in. 1., 1-3 in. br., the apex acuminate, the edge entire or nearly so, the base slightly rounded or subcuneate; texture papyraceous or subcoriaceous; rachis and surfaces naked; main vcins distinct to the edge, with transverse veinlets, with copious fine areolae with free veinlets between them ; fertile pinnce distant, $3-4$ in. l., $\frac{3}{4}-1$ in. br. $-H k . S p .5$. p. 275. G. F.t. 26.

Hab. Cuba to the Amazon Valley. 
106. A. (Gym.) Preslianum, Hk.; vhizome woody, short-creeping; st. 4-8 in. l., firm, erect, naked; barren fr. $1 \mathrm{ft}$. l., 6 in. br., with numerous erectopatent pinnoe on each side, which are 2-3 in. 1., $\frac{3}{5}$ in. br., the edge entire, narrowed to both ends, the lower ones short-stalked; texture subcoriaceous; rachis and both sides naked; venation of Goniophlebium; fertile pinnoe 1 in. 1., $\frac{1}{4}$ in. br., blunt, stalked.-Hk. $S p$. 5. p. 265. (not p. 220).

Hob. Philippines, fide Presl; Concan, Mr. Law.-Habit resembling that of the narrow-leaved forns of the next, but the venation peculiar. There are two plants given under the same name in "Sp. Fil."

107. A. (Gym.) virens, Wall.; rhizome woody, short-creeping; st. of barren fr. 1-2 ft. l., firm, erect, naked, the latter 1-3 ft. l., often $1 \mathrm{ft}$. br., with numerous sessile pinnoe on each side, which are 4-8 in. $1 ., \frac{3}{4}-1$ in hr., the edge repand or bluntly lobed, the terminal one sometimes elongated and rooting at the point; texture subcoriaceous; rachis and both surfaces naked; veins pinnate, main veins distinct, the veinlets of opposite groups joining, with usually a single quadrangular areole between them, free veinlets none; fertile fr. on longer stems, the pinnæ $2-4$ in. l., $\frac{1}{8}-\frac{1}{2}$ in. br., linear or ligulate, entire or lobed.- $H k$. $\&$ Gr. t. 221. A. terminans and contaminans, $W$ all. Bolbitis, Schott.- $\beta, A$. crispatulum, Wall.; pinnoe narrow, coriaceous, crisped, the veins anastomosing principally in costal arches. $-\gamma, A$. proliferum, Hk.; pinnoe broad; main veins close, distinct, the veinlets of contiguous groups joining at an angle, as in Goniopteris, from which proceed one or in the lower areolæ two free veinlets, terminal pinna usually elongated and rooting.-Hk. Ic.t. 681-2.- $\delta, A$. costatum, Wall. ; pinnos 8-12 in. 1., 2-3 in. br., tinged with red; main veins very distinctly raised beneath, $1 \frac{1}{2}-2$ lin. apart, the transverse veins joining at an angle, with 2-3 free veinlets or areolæ between them.- $H k$. $S p$. 5. p. 262.

Hab. Himalayas to Ceylon, Formosa, and Moulmein; Angola, Fernando Po, Sierra Leone.-We cannot draw any clear line of separation between the plants here placed as varieties. There are two remarkable abnormal states,-one, Meniscium deltigerum, Wall., with the fertile pinnæ nearly as broad as the barren ones, and the sori in triangular, often confluent, patches between the main veins; and the other, Notholana undulata, Wall. (Jenkinsia, Hk. Gen. Fil. 75), with the sori in a broad band along the edge of the pinnæ, which is sometimes lobed between the main veins.

+t Chrysodium, Fée. Fronds dimorphous, or in A. aureum, the upper pinnoe like the others and fertile; main veins none or indistinct. Sp. 108-128.

\section{A. Barren fronds entire. Sp. 108-114.}

108. A. (Chrys.) minus, Mett. ; rhizome wide-creeping, firm; st. of barren fr. 1-2 in. l., naked, stramineous; barren fr. $1 \frac{1}{2}-2$ in. $1 ., \frac{3}{8}-\frac{1}{2}$ in. br., the point bluntish, the edge quite entire, the base tapering gradually ; texture herbaceous; surfaces naked; no main veins; areoloe copious, with copious free veinlets, bounded by a wavy intramarginal line ; fertile fr. $1 \frac{1}{2}-2$ in. $1 ., \frac{1}{8}$ in. br., the st. slender, naked, 3-4 in. 1.-Hk. Sp. 5. p. 277. 2 nd Cent. $t .78$.

Hab. Philippines, Cuming; Khasya (2-3,000 ft.), Hk. fil. \& Thomson.

109. A. (Chrys.) lanceolatum, Hk. ; rhizome woody, wide-creeping; st. of barren fr. 1-6 in. l.; barren fr. 6-12 in. l., $\frac{1}{2}-2$ in. br., the point blunt or acute, the edge entire, the lower part narrowed very gradually; texture herbaceous; surfaces naked; main veins raised, but falling considerably short of the edge; areole copious, with free veinlets; fertile fr. 6-12 in. $1 ., \frac{1}{8}-\frac{1}{4}$ in. br., the st. as long.- $\beta$, G. normalis, J. Sm. ; barren fr. sessile, 2-4 in. 1. - Hk. Sp. 5. p. 157.

Hab. Peninsular India, Ceylon, Malaya, Philippines.

110. A. (Chrys.) axillare, Cav.; rhizome wide-scandent; barren fr. 6-18 
in. 1., $\frac{1}{2}-1 \frac{1}{2}$ in. br., the point bluntish, the edge entire, the lower half tapering very gradually to the base or a short stem ; texture papyraceous; surfaces naked ; no main veins; areolve very copious, with abundant free veinlets; fertile fr. 6-12 in. 1., 1-3 lin. br., flexuose, on a stem 1-6 in. 1.-Hk. Sp. 5. p. 276.

Hab. Himalayas to Ceylon and the Philippine and Malay Isles.

111. A. (Chrys.) aureo-nitens, Hk. ; st. tufted, that of the barren fr. very short, the latter oblong-spathulate, $3-4 \mathrm{in.}$ l., $1 \mathrm{in}$. br. a short distance from the blunt apex, thence narrowed gradually to the base, the edye entire; texture coriaceous; under surface densely clothed with ovate-acuminate ferruginous scales; areoloe fine, copious, hexagonal, without free veinlets; st. of fertile fr. $3-5$ in. l., firm, erect, scaly ; fertile fr. pinnate, with 2-3 distant ligulate-oblong pinnæ on each side.-Hk. Sp. 5. p. 270. Ic.t.933.

Hab. Galapagos.-A very distinct species, remarkable for the combination of an entire barren with a pinnate fertile frond.

112. A. (Chrys.) reticulatum, Kaulf.; caud. erect, woody, with large narrow lanceolate ferruginous scales; st. of barren fr. 1-3 in. l., firm, erect; barren fr. 6-9 in. l., $1 \frac{1}{2}$ in. br., the point bluntish, the edge entire, the base subcuneate; texture coriaceous; surfaces naked; veins indistinct, fine, anastomosing copiously; fertile fr. like the other, but the st. 6-9 in. 1.-Hk. Sp. 5. p. 267.

Hab. Sandwich Isles.

113. A. (Chrys.) pachyphyllum, Kze.; st. nearly 1 ft. l., strong, erect; barren fr. 2 ft. l., 6 in. br., oblong-lanceolate, narrowed to both ends, the edge entire; texture very coriaceous; surfaces naked; veins fine, subparallel, anastomosing in areoloe several times as long as br.; fertile fr. 9 in. $1 ., 2 \frac{1}{2}$ in. br. $-H K . S p .5$. p. 268.

Hab. Peru, Poeppig. - This and the preceding have quite the habit and texture of Elaphoglossum.

114. A. (Chrys.) crinitum, L. ; caud. woody, erect; st. of barren fr. 4-8 in. 1., densely clothed with long, slender, squarrose fibrillose purplish-brown scales; barren fr. often 12-18 in. l., 6-9 in. br., broad-oblong, the apex blunt, the base rounded, the edge entire; texture subcoriaceous; the edge densely fringed and both sides scattered over with scales like those of the stem; areoloe large, hexagonal, without free veinlets; fertile $f r$. like the other but much smaller, the st. longer.-Hk. Sp. 5. p. 267. Hk. \& Gr. t. 1. Fil. Ex.t.6. Hymenodium, Fée.

Hab. West Indies and Mexico.

B. Barren fronds sometimes simple, but forked, or pinnatifid or pinnate at the base when fully developed. Sp. 115-118.

115. A. (Chrys.) bicuspe, Hk. ; rhizome woody, short-creeping, densely clothed with yellowish silky hairs; st. of barren fr. $1 \mathrm{ft}$. l., firm, naked ; barren fr. 5-6 in. br. in the entire portion, the base rounded, the apex consisting of two broad divaricated acuminate lobes with a broad rounded sinus between, the edge entire; texture coriaceous; surfaces naked; main veins radiating from the apex of the stem to the upper edge, with copious areolce (the larger ones distinct, the smaller ones less so) between them ; fertile fr. $6-9$ in. $1 ., \frac{1}{2}$ in. br., narrowed to both ends with 2-3 prominent subparallel ribs from the apex to the base, the st. 18 in. or more 1.- $\beta$, integrifolium, Eaton; $f$. ovate-acuminate, not forked.Hk. Sp. 5. p. 271. Cheiropleuria, Presl.

Hab. Java, Formosa, and Loo Choo Isles. 
116. A. (Chrys.) tricuspe, Hk. ; rlizome woody, wide-creeping ; st. of barren fr. nearly $1 \mathrm{ft}$. l., firm, naked; barren fr. composed of three entire oblong lobes, the terminal one 6 in. 1., 2 in. br., the lateral ones spreading, rather smaller; texture coriaceous; surfaces naked; main veins fine, not distinct to the edge, connected by transverse veinlets with copious small areoloe between them, with free veinlets ; central lobe of fertile fr. $13 \mathrm{in.} 1 ., \frac{1}{4} \mathrm{in.}$ br., the lateral ones erectopatent, rather shorter, the st. $1 \frac{1}{2} \mathrm{ft}$. 1.-Hk. Sp. 5. p. 272. $t .304$.

Hab. Sikkim, Mrs. Atkinson.-One of the specimens has the upper half of two out of the three lobes contracted and soriferous, thus connecting this group with Hymenolepis.

117. A. (Chrys.) fluviatile, Hk. ; rhizome firm, wide-creeping ; st. 12-18 in. 1. , slightly scaly ; barren fr. varying from narrow-oblong, entire, 1 ft. $1 ., 3$ in. br., to $2 \mathrm{ft}$. l., $1 \mathrm{ft}$. br., deeply pinnatifid, with aslarge lanceolate terminal lobe and 1-3 pairs of lateral ones, which are 2-6 in. 1., 1-1 $\frac{1}{2}$ in. br., the apex acuminate, the edge entire; texture papyraceous; surfaces naked; main veins not distinct more than halfway to the edge; areole copious, without free veinlets; fertile fr. like the other, but smaller, the st. $2 \mathrm{ft}$. 1.-Hk. Sp. 5. p. 274.

Hab. Guinea Coast ; gathered by Curror, Barter, and Mann.-Most like A. punctulatum, but less divided, with main veins less distinct.

118. A. (Chrys.) pandurifolium, Hk. ; rhizome firm, wide-creeping ; st. of barren fr. $6-12$ in. l., firm, slightly scaly ; barren fr. 9-12 in. 1., 3 in. br., narrow-oblong, the edge entire, and below this sometimes a pair of small round or oblong spreading sessile pinnoe; texture papyraceous ; surfaces naked ; principal veins zigzag, not distinct to the edge; areoloe copious, with abundant free veinlets; barren fr. similar, but the principal division 4-6 in. $1 ., 1$ in. br., the st. 12-18 in. 1.-Hk. Sp. 5.p. 271. Gymnopteris, Hk. 2nd Cent. $t .87$.

Hab. Andes of Peru, Spruce 4741, 5684.

\section{Barren fronds copiously pinnate. Sp. 119-127.}

119. A. (Chrys.) Heudelotii, Hk. ; rhizome firm, wide-creeping ; st. 6-9 in. 1., firm, erect, naked; barren fr. 12-18 in. 1., 6-10 in. br., with numerous erectopatent pinnoe on each side, which are 2-6 in. $1 ., \frac{1}{2}-\frac{3}{4}$ in. br., narrowed to both ends, the point blunt or acute, the edge nearly entire, all sessile; texture subcoriaceous; rachis and both sides naked; veins very fine, the main ones not straight to the edge, with copious irregular areoloe between them, with a few free veinlets ; fertile fr. similar, but the pinnæ narrower.-Hk. Sp. 5. p. 264.

Hab. Senegambia, Sierra Leone, Zambesi-land.-A plant gathered by Barter, growing under water at Sierra Leone, may be a form. The texture is pellucid, the whole plant much smaller, and the pinnæ are deeply toothed.

120. A. (Chrys.) salicinum, Hk.; rhizome stout, short-creeping ; st. of barren fr. 4-9 in. 1., firm, erect, naked, the latter $1 \mathrm{ft}$. or more 1., 6-8 in. br., with numerous erecto-patent pinnoe on each side, which are $3-4$ in. $1 ., \frac{1}{2}$ in. br., narrowed to both ends, the edge repand, the lower ones stalked; texture subcoriaceous; no distinct main veins, the areoloe in 2-3 rows between the midrib and edge, almost without free veinlets; fertile fr. similar--Hk. Sp. 5. p. 265.

Hab. Sierra Leone, Barter; Fernando Po, Mann.-Like the last in habit, but the areolæ much fewer and larger.

121. A. (Chrys.) semicordatum, Baker ; rhizome woody, short-creeping; st. of barren fr. 6-8 in. 1., erect, nearly naked; barren fr. 8-12 in. 1., 3-4 in. br., sometimes proliferous at the apex; lower pinnce $2-3$ in. $1 ., \frac{1}{2}-\frac{5}{8}$ in. br., the edge inciso-crenate throughout, the base cordate on the upper, truncate on the lower side; texture herbaceous; surfaces naked; veins fine, the main ones distinct 
about lialfway to the edge, the areolce in 3-4 rows, with free veinlets; barren

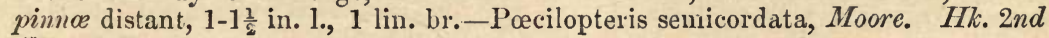
Cent. $t .88$.

Hab. Concan, Law; Neilgherries, McIvor.

122. A. (Chrys.) Blumeanum, Hk.; rhizome woody, wide-scandent; st. of barren fr. 6 in. l., deciduously scaly ; barren fr. 1-3 ft. 1., $1 \mathrm{ft}$. or more br., with numerous sessile pinnoe on each side, which are 4-6 in. 1., 1 in. br., the apex acuminate, the edge slightly toothed, the base rounded; texture membranous; rachis and midrib beneath slightly scaly; areolae hexagonal, without free veinlets ; fertile fr. with distant pinnæ 4-8 in. l., $\frac{1}{8}-\frac{1}{4}$ in. br. $-\beta$, samoense ; st. of barren fr. $1 \mathrm{ft}$. 1., the central pinno $2 \frac{1}{2}$ in. 1 ., $\frac{1}{2}$ in. br., more distinctly toothed.Hk. Sp. 5. p. 268.

Hab. Assam, Java, Philippines, and Samoa.-Lomagramme pteroides, J. Sm. Hk. Gen. Fil. t. 97 (Luzon, Cuming), is apparently an abnormal form of this, with the sori in a line along the edge of pinnæ rather narrower than the usual barren ones. A. Requienianum, Gaud., should not unlikely also be referred here.

123. A. (Chrys.) Raddianum, Kze. ; rhizome woody, wide-scandent; st. of barren fi. 4-6 in. 1., firm, naked; barren fr. 1-2 ft. 1., 8-15 in. br., with numerous pinnce on each side, which are 4-8 in. l., $\frac{1}{2}-1$ in. br., the apex acuminate, the edge toothed, especially towards the point, the base cuneate, the lower ones often stalked; texture firm-herbaceous; surfaces and rachis naked; no main veins; costal areoloe large, triangular, the others small, without free veinlets; fertile fr. like the other, but much smaller.-Hk. Sp. 5. p. 264.

Hab. Brazil and North Peru.-Near the next, but distinguished by its wide-scandent rhizome and more uniform veining.

124. A. (Chrys.) serratifolium, Mert.; rhizome woody, short-creeping; st. of barren fr. 12-18 in. 1., slightly scaly ; barren fr. 1-2 ft. l., 6-12 in. br., with numerous sessile pinnoe on each side, which are $3-8 \mathrm{in}$. l., $\frac{3}{4} \cdot 1 \frac{1}{2}$ in br., the edge inciso-crenate, the base cuneate; texture subcoriaceous; rachis and surfaces naked; main veins distinct halfway or more to the edge ; costal areoloe large, triangular, the others smaller, without free veinlets; fertile pinnoe distant, 2-3 in. 1., $\frac{1}{4}-\frac{1}{2}$ in. br., blunt, entire.-Hk. Sp. 5. p. 263.

Hab. Venezuela, Brazil, Peru.

125. A. (Chrys.) Lindigii, Baker; rhizome woody, scandent; barren fr. $2 \mathrm{ft}$. l., $1 \mathrm{ft}$. br., with about a dozen spreading subsessile pinnoe on each side, the lower ones $6-8$ in. $1 ., 1 \frac{1}{2}$ in. br., the apex acuminate, the edge crenate upwards, the hase cuneate; texture herbaceous; rachis and surfaces naked; main veins distinct more than halfway to the edge, the costal areolo shallow, all without free veinlets; fertile pinnoe distant, 4-5 in. l., $\frac{1}{4}-\frac{3}{8} \mathrm{in.}$ br., entire, narrowed gradually upwards.-Chrys. Mett. Fil. Nov. Gran. p. 204.

Hab. New Granada, Lindig 258.

126. A. (Chrys.) prostantissimum, Bory ; caud. erect; st. $1 \mathrm{ft}$. or more 1.,

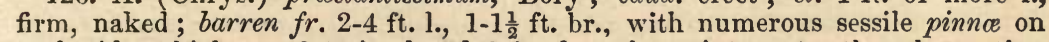
each side, which are $6-10$ in. $1 ., 1 \frac{1}{2}-2$ in. br., the point acute, the edge entire, the base rounded; texture subcoriaceous; rachis and surfaces naked; areolae copious, hexagonal, without free veinlets; fertile pinnoe 4-8 in 1. , $\frac{1}{4}-\frac{3}{8}$ in. br., distant.-Hk. Sp. 5. p. 269. G. F.t. 58. Neurocallis, Fée.

Hab. West Indies.-In this, as in A. Blumeanum, the sori are sometimes tænitoid.

127. A. (Chrys.) aurenım, L. ; caud. erect ; st. 1-2 ft. 1., tufted, strong, erect, 
glossy ; fr. 2-6 ft. 1., 1.2 ft. br., the upper pinno fertile, slightly smaller than the barren ones, which are usually stalked, ligulate-oblong, 3 in. to more than $1 \mathrm{ft} .1$., $\frac{1}{2}-3$ in. br., the point acute or blunt, sometimes retuse with a mucro, the edge quite entire, the base subcuneate ; texture coriaceous ; rachis and surfaces naked ; areoloe very small and copious, without free veinlets.-Hk. Sp. 5. p. 266.

Hab. Florida and Bermudas to Peru and South Brazil ; Polynesia ; Bengal, HongKong, and Formosa to Queensland, Seychelles, Mascaren Isles, Zambesi-land, Natal, Angola, Guinea Coast. - Includes five species of Fée.

\section{Frond bipinnate. Sp. 128.}

128. A. (Chrys.) polyphyllum, Hk. ; rhizome woody, wide-scandent ; st. 6-12 in. l., firm, naked, jointed at the base; barren $\mathrm{fr}$. sometimes simply pinnate, more usually several feet long, with pinnate pinnoe 6-12 in. l., 2 in. br. ; pinnl. numerous on each side, 1 in. l., $\frac{1}{4}-\frac{3}{8}$ in. br., sessile, lanceolate, sharply toothed ; texture herbaceous; rachis and surfaces naked; areolo hexagonal, without fiee veinlets; fertile pinnl. stalked, $\frac{3}{8}-\frac{1}{2}$ in. l., $\frac{1}{8}$ in. br.-Hk. Sp. 5. p. 269. Lomagramme, Brack.

Hab. New Hebrides and Fiji.-In general habit and in its articulated pinnæ this quite agrees with $A$. Wilkesianum. A. pteroides, R. Br., from Tropical Australia, has an ebeneous naked stem $1 \mathrm{ft}$. l., and distant Lomarioid fertile pinnæ, the lower ones again sparingly pinnate, but the barren frond is not known.

***** Hymenolepis, Kaulf. Fronds simple, uniform, bearing the fruit on the contracted apex. Sp. 129-130.

129. A. (Hymen.) spicatum, L. ; rhizome woody, short-creeping; st. 1-2 in. 1., short, firm ; fr. 6-18 in. l., $\frac{1}{2}-1$ in. br., the upper part for 4-6 in. contracted and fertile, the edge entire, the lower part narrowed very gradually ; texture subcoriaceous; surfaces naked; areolce uniform, hexagonal, with copious free veinlets; caps. mixed with peltate scales.-Hk. Sp. 5. p. 280. Fil. Ex.t.78.-

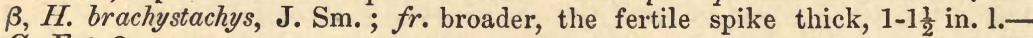
G. F.t. 3.

Hab. Himalayas (to 6,000 ft.) to Madagascar, Mascaren Isles, Ceylon, South China, Philippines, Queensland, Society Isles.-H. validinervis, Kze., is a strong broad form.

130. A. (Hymen.) platyrhynchos, Hk.; st. tufted, scarcely any ; fr. 12-16 in. $1 ., 1$ in. br., the sori in a patch at the apex 1-2 in. 1., $\frac{3}{8}$ in. br., which does not reach to the edge, the edge entire, the lower part narrowed gradually ; texture very coriaceous; surfaces naked ; areoloe copious, fine, hidden, uniform, with copious free veinlets. - Hk. Sp. 5. p. 280. Ic. t. 999. Macroplethus, Presl.

Hab. Philippines, Cuming 196.

****** Photinopteris, J. Sm. Frond pinnate or deeply pinnatifid, the fruit on the Lomarioid upper pinno. Habit and venation of Drynaria. Sp. 131-132.

131. A. (Photi.) rigidum, Wall.; rhizome woody, wide-scandent ; st. short, firm, erect; $f r$. several feet long, often $1 \mathrm{ft}$. br., the lower pinnoe several on each side, barren, stalked, jointed at the base, ovate-acuminate, entire, 3-6 in. 1., $1 \frac{1}{2}-3$ in. br.; ahove this several pair of distant fertile pinnoe 4-6 in. $1 ., \frac{1}{8}$ in. br. ; texture very coriaceous; surfaces and rachis naked; main raised veins connected by raised transverse veinlets with copious sinall areolæ between them with free veinlets. - Hk. Sp. 5. p. 281.

Hab. Philippines and Malay Peninsula and Isles.-P. simplex, J. Sm., has the fertile pinnæ reduced to one. 
132. A. (Photi.) drynarioides, Hk. ; fr. subsessile, several ft. $1 ., 1 \mathrm{ft}$. or more br., the upper part with numerous distant Lomarioid pinno, sometimes $1 \mathrm{ft} .1$., 1 lin. br., below this pinnatifid, with numerous close entire lanceolate-acuminate

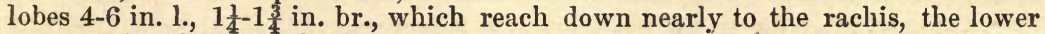
ones passing down gradually into a mere undulated wing to the rachis, which is continued to its very base ; texture very coriaceous; main veins ${ }^{2}$ raised, with transverse veinlets, and between them copious small areolæ with free veinlets. Hk. Sp. 5. p. 282.

Hab. Penang, Sir W. Norris, Mactier ; Solomon Isles, Milne.-The leafy pinnæ, though adnate to the rachis, break away from it very readily.

\section{Gen. 61. Pratycerium, Desv.}

Sori forming large patches on the upper part of the lower surface of the fertile fronds. A small widely-diffused genus, well marked by its dichotomously forked fertile fronds with stags'-horn-like divisions. 'ТA B. IX. f. 61.

1. P. alcicorne, Desv.; barren fr. rounded, convex, downy when young, the edge sinuated, the lobes spreading; fertile fr. 2-3 ft. 1., clustered, erect, 2-3 times dichotomons; ult. divisions ligulate, bluntish, the fruit in the last forks and at their base in very irregular patches; under surface covered with thin white cottony down.-Hk. Sp. 5. p. 282.

Hab. Temperate Australia, and a larger form in the Mascaren Isles and Seychelles; and a similar plant has been gathered by Dr. Spruce in Peru.

2. P. athiopicum, Hk. ; barren fr. rounded, convex, downy when young, the edge more or less lobed, the lobes spreading; fertile fr. 2-3 ft. l., clustered, pendent, twice dichotomous, the disk and first division broader than in the preceding, the patch of fruit surrounding the sinus and passing into the fork so as to be shaped like the letter $\mathrm{V}$; under surface covered with thin white cottony down.-Hk.Sp. 5. p. 283. G. F. t. 9. A. stemaria, Beauv.

Hab. Guinea Coast and Angola.-Dr. Welwitsch has furnished us with a plant (P. angolense, Welw. MSS.) which is most like this, but has a broad-cuneate fertile frond 9 in. br. at the top, without either forks or horns, and with a patch of fruit nearly as broad as the lamina.

3. P. grande, J. Sm.; barren fr. very large, suborbicular, convex, or the upper ones erect, deeply laciniated with spreading or inflexed divisions; fertile fr. 4-6 ft. 1., pendent, in pairs, the disk broad-cuneate, with the sorus against the upper edge, occupying the disk only, with an elongated dichotomously forked division beyond it at each corner; both surfaces green and smooth.-HK. Sp. 5 . p. 284. Fil. Ex. t. 86.

Hab. North Australia, Philippines, and Singapore.-There is only one soriferous patch to each frond, and it is sometimes nearly a foot broad.

4. P. Wallichii, Hk. ; barren fr. deeply lobed, with inflexed forked divisions ; fertile fr. in pairs, pendent, each in two divisions, in each of which the cuneate disk has a rounded upper edge occupied by a sorus, from each side of which a once-forked division is produced; texture thick, the under surface matted with yellowish woolly pubescence.-Hk. Sp. 5. p. 284. Fil. Ex.t.97.

Hab. Malay Peninsula.- Here the two soriferous patches are only $3.4 \mathrm{in.}$ br., and occupy a semicircular projection with the forks springing almost from its base.

5. P. biforme, Blume; barren fr. imbricated, very thick, especially towards the base, the edge sinuato-lobate; fertile $f r .6-15 \mathrm{ft}$. l., repeatedly dichotomous 
from a subcuneate disk, the harren divisions narrow-ligulate, the fertile ones quite different in shape, reniform, stalked, 6-8 in br., the outer edge rounded, entire.-Hk. Sp. 5. p. 285.

Hab. Philippines and Malay Peninsula and Isles.-The only species with a distinct uniformly ferile segment, which in a specimen from Mr. Prout is nearly a foot broad.

\section{SUB-ORd. III. OSMUNDACEA.}

Caps. two-valved, opening across the apex, furnished with a short horizontal ring. Vernation circinate. GEN. 62-63.

\section{Gen. 62. Osmunda, $L$.}

Sori quite distinct from the leafy part of the frond, forming a panicle made up of copious thyrsoid clusters. A genus of striking ferns, very clearly marked by habit, containing few species, hardly at all tropical, and only one known in South temperate regions. TAB. VIII. fig. 62.

1. O. javanica, Blume; st. tufted, 6-12 in. l., firm, erect, naked; fr. 1-3 ft. 1., 8-12 in. br., simply pinnate, the lower or central pinnæ fertile; barren pinnce 4-8 in. $1 ., \frac{2}{8}-\frac{3}{4}$ in. br., cuneate at the base, and often slightly stalked, the edge entire or sharply toothed; texture coriaceous; rachis and both sides naked; fertile pinnce shorter, made up of numerous close but distinct oblong sessile clusters.-Kunze, t. 3. O. Vachellii, Hk. Ic.t.15. O. Presliana, J. Sm.

Hab. Kamschatka to Java and Ceylon.

2. O. Claytoniana, L. ; st. tufted, $1 \mathrm{ft}$. or more l., clothed with loose woolly ferruginous tomentum when young, naked when mature; $f r .1-2 \mathrm{ft}$. l., 8-12 in. br., the upper, central, or lower pinnæ fertile ; barren pinnoe lanceolate, 4-6 in. l., 1 in. or more br., cut down nearly to the rachis into close oblong entire lobes; texture herbaceous; fertile pinnoe similar but shorter; pinnl. dense, cylindrical.-O. interrupta, Michx. U. pilosa and monticola, Wall.

Hab. Canada, Newfoundland, and throughout the United States, Himalayas up to $10,000 \mathrm{ft}$. - The station of Rio Janeiro, which rests on Wallich's authority, is perhaps given by some confusion with 0 . cinnamomea. O. glaucescens, Link, is the form with a terminal panicle.

3. O. cinnamomea, L.; st. densely tufted, the barren and fertile ones distinct, the young plants densely clothed with ferruginous tomentum; barren $\mathrm{fr}$. simply pinnate, naked when mature, the $s t .12-18$ in. l., the $f r .2-3 \mathrm{ft} .1 ., 6-9 \mathrm{in}$. br.; pinnce close, ligulate-lanceolate, $3 \cdot 4$ in. $1 ., \frac{3}{4}-1$ in br., cut down nearly to the rachis into close entire blunt oblong lobes; texture subcoriaceous ; fertile fr. much smaller, the pinnce lanceolate, with close dense cylindrical pinnl.

Hab. Canada and Newfoundland to Mexico, West Indies, Guatemala, New Granada, and Organ Mountains (O. imbricata, Kunze, Fil. 2. t. 112), Japan, Mantchuria, A murland.-There is a form (var. frondosa, A. Gray) with some of the fronds sterile below and sparingly fertile above.

4. O. bipinnata, Hk. (not Linn.); st. tufted, $1 \mathrm{ft}$. or more l., rather slender, glossy, stramineous ; $f r_{\text {. }} 1 \frac{1}{2}-2 \mathrm{ft}$. 1., 6-10 in. br., bipinnate, the upper pinnoe barren, the uppermost linear-oblong, simple, below these several pinnate, 3-4 in. l., 1 in. br., with a winged rachis and numerous entire oblong imbricated pinnl. on each side, and lowest of all, 3-4 opposite pairs of fertile pinnæ with several cylindrical pinnl. on each side, $\frac{1}{4}-\frac{3}{8}$ in. $1 ., 1 \frac{1}{2}-2$ lin. apart; texture subcoriaceous; rachis and both sides naked.-Fil. Ex.t.9.

Hab. Hong-Kong, Dr. Harland. 
5. O. lancea, Thunb. ; barren and fertile fr. distinct, the former about $1 \mathrm{ft} .1$., oblong, shortly acuminate ; pinnoe oblong-acuminate, about 5 in. 1., stalked, the lowest rather reduced; pinnl. narrowly lanceolate, $1 \frac{3}{4}$ in. $1 ., \frac{1}{4}$ in. br., narrowed at both ends, sessile, distinct, slightly toothed upwards ; texture subcoriaceous ; surfaces naked; fertile fr. ternato-decompound.-Milde. Fil. Eur. p. 311.

Hab. Japan.

6. O. regalis, L. ; st. tufted, 12-18 in. 1., firm, erect, naked ; fr. $2-4 \mathrm{ft} .1 ., 1 \mathrm{ft}$. or more br., bipinnate, the apex fertile; barren pinno $6-12$ in. $1 ., 2-4$ in. br., pinnl. sessile or slightly stalked, 1-2 in. l., $\frac{1}{2}-\frac{3}{4}$ in. br., oblong, blunt, often unequal at the base, the edge finely serrulate; texture subcoriaceous; rachis and both sides naked; fertile pinnl. cylindrical, forming a copious panicle.-Hk. B. $F . t .45^{\circ}$ O. palustris, Sturm, $t .12$.

Hab. Sweden to Siberia, Japan, Azores, Barbary, Himalayas, Bombay, Neilgherries, Cochin, and Hong-Kong ; Mascaren Isles, Zambesi-land, A ngola, Natal, Cape Colony; Canada and the Saskatchewan to Rio Janeiro.-Of Presl's species we place here without hesitation spectabilis, Willd., capensis and Hugeliana, Presl, Hilsenbergii, H. \& G., gracilis, Link, obtusifolia, Willd., and Leschnaultiana, Wall. O. japonica, Thunb. (O. speciosa, Wall.), is a curious variety from Japan and the Himalayas, with the fertile and barren fronds often quite distinct, the former being developed the earliest and soon disappearing; and it also occasionally happens that some of the lateral pinnæ become fertile, whilst the terminal ones remain barren. Mr. McKen sends a similar form from Natal.

\section{Gen. 63. Todea, Willd.}

Sori on the back of the leafy part of the frond. A small genus, almost confined to the South Temperate Zone, with the capsules of Osmunda, but the ordinary habit of Polypodiaceæ. ТАв. VIII. fig. 63.

\section{§ Eutodea. Texture of the frond coriaceous. Sp. 1. Fig. 63. a. b.}

1. T. barbara, Moore ; caud. subarborescent ; st. $1 \mathrm{ft}$. or more 1., stout, erect, quadrangular, quite naked ; fr. 3-4 ft. l., often $1 \mathrm{ft}$. br.; pinnoe close, erectopatent, 6-9 in. 1., $1 \frac{1}{2}-2$ in. br. ; pinnl. close, linear, erecto-patent, 1-1 $\frac{1}{2}$ in. 1. , $\frac{1}{8}-\frac{1}{4}$ in. br., the edge more or less distinctly toothed, the upper ones connected at the base ; texture coriaceous; both sides naked; sori dense, when mature filling up the whole under surface of the pinnules on which they are placed.-Acrostichum, L. 'T. africana, Willd. Hk. fil. Fl. Tasm.t. 168. T. rivularis, Sieb.

Hab. New Zealand, Temperate Australia, as far north as Queensland, Van Diemen's Land, Natal, Cape Colony.

$\S \S$ Leptopteris, Presl. Texture of the frond like that of Hymenophyllum. Fig. 63. c. d. Sp. 2-4.

2. T. (Lept.) Fraseri, H. \& G.; caud. erect, woody, $1 \frac{1}{2}-2$ ft. high, $1 \frac{1}{2}-2$ in. thick ; st. 6-9 in. l., firm, erect, naked; fr. 1-2 ft. l., 8-12 in. br., bipinnate; pinnoe close, lanceolate, $4-6$ in. $1 ., \frac{3}{4}-\frac{7}{8}$ in. br., with a narrowly-winged rachis, the lowest about equal to the others; pinnl. linear-oblong, $\frac{1}{2}$ in. $1 ., 1 \frac{1}{2}-2$ lin. br., sharply toothed; rachises naked.-H.\& G.t. 101.- $\beta$, T. Wilkesiana, Brack.; $f r$. larger; lower pinnoe rather shorter than the others and deflexed; rachises slightly pilose.-Brack. $t .43$.

Hab. Blue Mountains, Australia, rare ; New Caledonia, Vieillard 2152; $\beta$, Fiji.

3. T. (Lept.) hymenoplyylloides, Rich. \& Less.; st. tufted, 6-12 in. 1., firm, erect, naked; fr. 1-2 ft. l., 8-12 in. br., tripinnatifid; pinnoe close, lanceolate, $4-6$ in. $1 ., \frac{3}{4}-1 \frac{1}{4} \mathrm{in}$. br., the rachis winged only towards the apex, the lowest about equal to the others; pinnl. close, linear-oblong, $\frac{1}{2}-\frac{3}{4}$ in. l., $\frac{1}{4}$ in. br., cut down 
nearly to the rachis into erecto-patent, simple or forked linear segm.; rachises naked or slightly tomentose.-Hk. G. F.t. 54. T. pellucida, Hk. Ic.t. 8.

Hab. New Zealand.- There is a form which quite agrees with this in the size and cutting of the pinnæ, but which has the lower ones reduced very gradually, thus receding from the type in the direction of the next species.

4. T. (Lept.) superba, Col. ; caud. erect, woody, 12-18 in. high ; st. 2-3 in. 1., firm, erect, naked ; fr. 2-4 ft. l., 6-10 in. br., tripinnatifid ; pinnoe close, narrowlanceolate, the central ones $4-5$ in. $1 ., \frac{5}{8}$ in. br., the lower ones gradually reduced; pinnl. close, linear-oblong, $\frac{1}{4}-\frac{3}{8}$ in. l., $1 \frac{1}{2}-2$ lin. br., cut down nearly to the rachis into erecto-patent simple or forked linear segm.; rachises densely tomentose.Hk. Ic. t. 910.

Hab. New Zealand.-Pinnæ and pinnules more numerous and denser than in the last, often crisped.

Sub-ORd. IV. SCHIZÆACEA.

Caps. two-valved, opening down the side, crowned by a complete operculiform ring. Vernation circinate. GEN. 64-68.

\section{Gen. 64. Schizea, Smith.}

Caps. sessile, in 2-4 rows, which cover one side of close distichous spikes, which form separate fertile segments at the apex of the fronds. A small widelydiffused genus very distinct in habit. TA B. VIII. fig. 64.

§ Euschizæa. Fertile segment pinnate; frond terete or subterete. Caps.biserial. Sp. 1-9.

\section{* Fronds not forked. Sp. 1-7.}

1. S. australis, Gaud.; st. dense, very short, dark chesnut-brown, passing gradually into the wiry subterete fr., which is 1-2 in. 1. , about $\frac{1}{4}$ lin. thick, simply channelled in front ; fertile segm. suberect, $\frac{1}{4}$ in. l., unilateral, with about 6 short stout nearly spreading spikes on each side, the lowest $\frac{1}{8}$ in. 1.-S. palmata, Homb. \& Jacq. t. 43.

Hab. Falkland and Auckland Isles.

2. S. pusilla, Pursh; st. dense, the barren fr. much shorter than the fertile ones, much twisted and slightly flattened; fertile fr. 3-4 in. 1., terete, wiry, very slender; fertile segm. suberect, $\frac{1}{4}$ in. l., unilateral, with about 6 rather stout erecto-patent spikes on each side, the lowest $\frac{1}{8}$ in. 1.-Hk. $\& G r . t .48 . A$. Gray Man, $t .13$.

Hab. Pine barrens of New Jersey, U. S. A.

3. S. malaccana, Baker ; st. dense, not distinguishable from the fr., which is 4-8 in. l., weak, flexuose, subterete, simply channelled in front, not more than $\frac{1}{6}$ lin. thick, the barren and fertile ones similar; fertile segm. erect, often bilateral, $\frac{1}{4}$ in. deep, with $3-6$ slender spreading spikes on each side, the lowest $2-2 \frac{1}{2}$ lin. 1 . -S. propinqua, Presl (in part).

Hab. Philippines, Cuming 379 ; Malay Peninsula and Isles, gathered by Griffith, Lobb, \&c.

4. S. tenella, Kaulf. ; st. dense, chesnut-brown, passing gradually into the fr., which is 6-8 in. 1 ., not very rigid, subcompressed, with a broad distinct midrib and two equal wings, the whole about $\frac{1}{4}$ lin. br. ; fertile segm. suberect, $\frac{1}{4}-\frac{3}{8}$ in. 1 ., unilateral, with 4-8 rather stout erecto-patent spikes on each side, the lowest

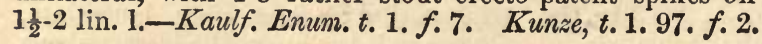

Hab. Cape Colony and Natal. 
5. S. fistulosa, Labill. ; st. dense, chesnut-brown, passing gradually into the fr., which is 4-12 in. l., rigid, rush-like, subterete, simply channelled in front ; fertile segm. suberect, unilateral, $\frac{1}{2}-1$ in. 1., with 10-20 close slender erectopatent spikes on each side, the lowest $\frac{1}{8}$ in. l. - Lab. Fl. Nov. Holl. t. 250. $f .3$. S. valdiviana, Phil. S. propinqua, A. Cunn. (in part).

Hab. Australia, Tasmania, New Zealand, New Caledonia, Chili.-S. propinqua is in part this, and in part unbranched S. bifida.

6. S. robusta, Baker ; st. not very dense, dark-chesnut, passing gradually into the $f r$., which is 6-10 in. l., rigid and rush-like in texture, with a broad central midrib and two narrow thick revolute edges, the whole under $\frac{1}{2}$ lin. thick; fertile segm. suberect, unilateral, $\frac{1}{4}-\frac{3}{8}$ in. 1., with 4-6 stout erecto-patent spikes on each side, the lowest $\frac{1}{4}$ in. 1.-S. australis, Brack. p. 302 ?

Hab. Sandwich Isles, Hillebrand. - This may be a tropical form of S. australis, as Brackenridge seems to consider it. If his plant be the same, it grows also in the Society Isles.

7. S. pectinata, Sm.; st. very dense, chesnut-brown, passing gradually into the fr., which is 4-8 in. 1 ., rigid and rush-like in texture, with a broad central midrib and two narrow thick revolute edges, the wliole under $\frac{1}{2}$ lin. thick; fertile segm. nearly horizontal, $\frac{1}{2}-\frac{5}{8}$ in. $1 ., \frac{1}{4}-\frac{3}{8}$ in. deep, with 10-15 slender vertical spikes on each side.-Schk. $t$. 136 .

Hab. Cape Colony.

\section{** Fronds forked. Sp. 8. 9.}

8. S. incurvata, Schk. ; st. dense, chesnut-brown, passing gradually into the $f r$, which is 6-18 in. l., forked below the middle and sometimes forked again, very wiry and rush-like in texture, smooth, subterete, simply channelled in front, the whole $\frac{1}{3}$ lin. thick ; fertile segm. erect, $\frac{1}{2}-1$ in. deep, with 10-20 slender spreading spikes on each side, the lowest $2-2 \frac{1}{2}$ lin. 1.-Schk. $t .137$. S. bifida, Meyer (non Sw.).

Hab. Guiana and North Brazil.-Very near the next, but more slender, with a panicle like that of S. fistulosa.

9. S. bifida, Sw.; st. dense, chesnut-brown, passing gradually into the fr., which is $6-18$ in. l., forked generally below the middle, sometimes forked again, casually simple, very wiry and rush-like in texture, with a prominent scabrous midrib and two narrow thick wings, the whole $\frac{1}{3}$ lin. thick; fertile segm. suberect or recurved, unilateral, $\frac{1}{2}-\frac{3}{4}$ in. 1., with 10-20 slender erecto-patent spikes on each side, the lowest $\frac{1}{4}-\frac{3}{8}$ in. 1 .

Hab. New Zealand and Temperate and North Australia.

§ Lophidium, Rich. Fertile segment pinnate; frond flattened; caps. biserial. Sp. 10-14.

10. S. (Loph.) rupestris, R. Br. ; st. lax, about 1 in. 1., subterete, passing gradually into the fr., which is grass-like and flattened, almost fleshy in texture, 3-4 in. 1., 1 lin. br., with a slender midrib; fertile segm. solitary, suberect, $\frac{1}{4-\frac{1}{2}}$ in. 1 , with $6-10$ slender spreading serrated spikes on each side.-Hk. $\& G r$. t. 47. G. F.t. 42 .

Hab. Temperate Australia.

11. S. (Loph.) fuminensis, Miers ; st. passing gradually into the fr., which is 4-12 in. l., slender, wiry, naked, once forked at the top, and each fork bearing usually two stalked fertile segm., which are $\frac{1}{4}-\frac{1}{2}$ in. l., the rachis slightly curved, with 6-10 close-spreading slender spikes on each side, the point either not at all 
flattened or slightly so either before or after the first fork.-Sturm in Mart. Fl. Bras. fasc. 23. p. 184. t. 13.

Hab. Guiana and Brazil.-Perhaps this should be considered a reduced variety of
elegans.

12. S. (Loph.) Sprucei, Hk. MSS. ; caud. woody, suberect; st. 9-12 in. l., firm, dense, erect, clothed, especially below, with squarrose fibrillose brownish scales; fr. 6-8 in. l., very thick in texture, naked, channelled, $\frac{3}{8}$ in. br. at the widest part, narrowed gradually downwards, bearing at the. apex 1-6 long-stalked fertile segm., which are $1 \frac{1}{2}-2$ in. l., the rachis spirally recurved, the spikes very numerous, $\frac{5}{8}-\frac{3}{8}$ in. l., tomentose beneath. - Hk. Ic. t. 1016.

Hab. Banks of the Rio Negro, Spruce 3752.-A very distinct new species.

13. S. (Loph.) dichotoma, Sw.; st. 6-18 in. 1., firm, erect, glossy, channelled on the face above ; $f r$. fanlike in general outline, 6-9 in. each way, many times dichotomously forked, the uitimate divisions $\frac{1}{2}-1$ lin. br., with 1 fertile segm. to each, $\frac{1}{4}-\frac{1}{2}$ in. 1 ., the rachis often curved, with 4-10 close, spreading spikes on each side.-Hk. \& Gr. t. 17. Beddome, t. 65. S. Forsteri, Spr. S. cristata, Willd. S. Poppigiana, Sturm.

Hab. Cuba, Venezuela, Peru, Polynesia, Australia, New Zealand, Philippines, Malaccas, Neilgherries, Mascaren Isles. - The Polynesian S. cristata, Willd., is a large form with broader divisions than usual. The American plant is S. occidentalis, Griseb., and is said to have the fertile segment twice as long as in the type; but we do not find the character to always hold good.

14. S. (Loph.) elegans, Sw.; st. 6-12 in. 1., firm, erect, naked ; fr. like the letter $\mathrm{V}$ in outline, 4-8 in. each way, dichotomously forked or cleft, the divisions varying greatly in number and breadth (1-2 in.), surface glossy; fertile segm. copious, distinctly stalked, $\frac{1}{4}-\frac{3}{8}$ in. l., the rachis often recurved witl $6-15$ close spreading linear-cylindrical spikes on each side.-Hk. G. F. t. 54.- $\beta$, S. flabellum, Mart.; fr. almost or quite undivided.-Mart. t. 55. L. latifolium, Rich. S. spectabilis, Mart. Sturm. Fl. Bras. fasc. 23. t. 14.

Hab. West Indiea and Mexico to Brazil.-S. attenuata, Beyr., appears to be a form with unusually narrow divisions. S. pacificans, Mart. Icon. Crypt. t. 56, has two entire divisions, each 6 in. br.

$\S \S \S$ Actinostachys, Wall. Fertile segment digitate rather than pinnate; caps. quadriserial. Sp. 15-16.

15. S. (Actin.) pennula, Sw. ; st. dense, 1-2 in. 1., subterete, brownish, passing gradually into the $f r$., which is $1 \mathrm{ft}$. or more l., nearly 1 lin. thick, triquetrous, with 3 sharp angles, crowned at the apex with 6-12 subtriquetrous fertile spikes, which are $\frac{1}{2}-1 \frac{1}{2}$ in. l., pilose beneath, with the caps. usually in 4 rows.S. trilateralis, Schk. Hk. \& Gr. t. 54. S. penicillata, H. B.K. S. lævigata, Mett.— $\beta, S$. subtrijuga, Mart.; fr. 6-9 in. l., much more slender, the spikes often reduced to 3 or 4.-Kunze, t. 97.f. 1. A. Germani, Fée, Fil. Ant. t. 29.

Hab. West Indies to Rio Janeiro, New Caledonia, Isle of Pines.-We cannot distinguish the Polynesian S. lavigata from the American plant. The New Caledonian S. intermedia, Mett., is intermediate between our two varieties.

16. S. (Actin.) digitata, Sw. ; st. dense, 1-2 in. l., brownish, subterete, passing gradually into the $f r$., which is $1 \mathrm{ft}$. or more l., 1-2 lin. br., flattened, the midrib beneath prominent, crowned at the apex with 6-15 subtriquetrous fertile spikes, which are $1 \frac{1}{2}$ in. l., naked beneath, with the caps. in 4 rows and the edge much inflexed. $-H k$. G. F.t. 54 .

Hab. Himalayas to Ceylon, Bonin, Philippines, Malay Isles, and Fiji. 
Gen. 65. Anemia, $S w$.

Caps. small, very abundant, forming a copiously-branched panicle quite distinct from the leafy part of the frond. $A$ well-marked genus, almost confined to Tropical America. TAB. VIII. fig. 65.

$\$$ Euanemia. Panicle and leafy portion united in the same frond; veins free. Sp. 1-18. Fig. 65a.

* Pinnoe of barren segment entire or nearly so. Sp. 1-12.

+ Barren segment lanceolate or lanceolate-oblong. Sp. 1-8.

A. Pinnce 6-8 or less on each side. Sp. 1-3.

1. A. Gardneri, Hk.; st. 3-4 in. 1., firm, erect, naked ; barren segm. shortstalked, 4 in. l., $2 \frac{1}{2}$ in. br., with 4 imbricated nearly round pinnoe on each side, the lowest 1 in. br., short-stalked, the edge crenulate ; texture coriaceous ; rachis and both sides naked; veins quite flabellate; panicle 2 in. 1. , with elongated spreading lower branches, the peduncle about equalling it.-Hk. Ic. t. 190 (not A. Gardneriana, Presl).

Hab. South Brazil, Gardner 4.

2. A. filiformis, Presl ; st. 1-3 in. l., slender, slightly villose ; barren segm. sessile, 3-4 in. 1., 1-1 i in. br., with 6-8 sessile linear-obovate pinnoe on each side, which are 2-3 lin. br., with nearly their own breadth between them, the edge rather deeply toothed ; texture almost herbaceous; rachis and surfaces finely villose ; veins flabellate; panicle 2-3 in. 1., the branches short, with a peduncle 3 or 4 times its own length.-A. dentata, Gardner.

Hab. Mexico and West Indies to Brazil.-This may be a variety of the next, with which it coincides in its short stem and very long peduncle; but the texture is much less coriaceous, and the pinnæ are narrower and distinctly toothed. - Mettenius refers the synonym of $A$. filiformis, Swartz, to our A. Breuteliana.

3. A. oblongifolia, Sw.; st. 2-4 in. 1., firm, erect, slightly villose; barren segm. sessile, 3-4 in. 1., $1 \frac{1}{2}$ in. br., simply pinnate, with 6-8 pairs of sessile pinnoe, which are oblong, blunt, subentire, the base on the upper side parallel with the stem, on the lower obliquely truncate; texture coriaceous; rachis and surfaces finely villose; veins flabellate; panicle 1-2 in. l., the lower branches short, the peduncle $5-6$ in. 1. -Schk. t. 142. $-\beta, A$. humitis, Sw. ; smaller, pinnoe close, $3-4$ only on each side. A. Seemanni, Hk. Lond. Journ. 7. t. 16.

Hab. Mexico to Brazil and Peru.-A. pilosa, Presl (A. pumila, Klotzsch), appears to be a form intermediate between our two varieties. Characterized by its close coriaceous pinnæ and barren segment nearly equal in width throughout.

\section{B. Pinnoe more than 6-8 on each side. Sp. 4-8.}

4. A. Dregeana, Kze.; st. 8-12 in. l., firm, slightly villose ; barren segm. subsessile, 8-12 in. l., 2-3 in. br., about equal in width in the lower half, with 8-12 pinnoe on each side, which are 1-1 $\frac{1}{2}$ in. 1 ., $\frac{1}{2}-\frac{3}{4}$ in. br., ovate-deltoid, unequal at he base, the upper side subcordate, the edge inciso-crenate; texture subcoriaceous; rachis and surfaces finely villose, a distinct midrib often halfway to the apex; panicle 3-4 in. l., the lower branches elongated, on a peduncle about as long as itself. $-K z e . t .20$. Hk. Ic. $t .236$.

Hab. Natal ; and a plant collected by Seemann in N. W. Mexico, referred in Bot. Herald. to A. collina, is so near this that we do not venture to separate them. 
5. A. rotundifolia, Schrad.; st. 6-9 in. l., deciduously villose; barren segm. 8-12 in. l., often prolonged and rooting at the extremity, 1-2 in. br. below, with 8-12 pairs of distant pinnoe, which are 1 in. $1 ., \frac{5}{8}-\frac{3}{4}$ in. br., very blunt, the lower side obliquely truncate at the base, the outer edge finely toothed; texture subcoriaceous; rachis and surfaces finely villose; veins flabellate; panicle 2-3 in. 1., the peduncle slender, 3-4 in. 1.-A. radicans, $\beta$ Raddi, Fil. Bras. $t .11$.

Hab. South Brazil.

6. A. caudata, Kaulf.; st. 6-9 in. l., slightly villose ; barren segm. 8-12 in. l., often prolonged and rooting at the apex, 2 in. br. at the base, narrowed very gradually upwards, with 20 or more pairs of close sessile subdimidiate pinnoe, which are $\frac{3}{4}-1 \mathrm{in} .1 ., \frac{1}{4} \mathrm{in}$. br., the point blunt, the edge finely toothed; texture subcoriaceous ; rachis and surfaces finely pilose; veins flabellate; panicle 2-3 in. l., lax, on a peduncle 3-5 in. 1.-A. radicans, Raddi, Fil. Bras. t. 10.

Hab. Brazil.

7. A. mandioccana, Raddi ; st. 6-12 in. 1., deciduously villose ; barren segm.

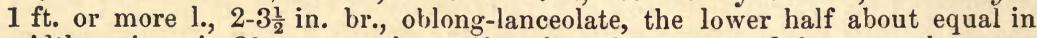
width ; pinnoe in 20 or more close pairs, the point narrowed, but scarcely acute, the edge finely serrulate, the base on the upper side parallel with the stem, on the lower obliquely truncate; texture subcoriaceous; rachis and surfaces finely pilose; veins flabellate ; panicle very compound, $3-4$ in. 1 ., with a peduncle longer than itself.-Raddi, t.9. Hk. G. F.t.36 (non Gen. Fil. t. 90).

Hab. Brazil.-Very doubtfully distinct from the preceding.

8. A. collina, Raddi ; st. 8-12 in. l., firm, erect, densely clothed with fine ferruginous spreading hairs; barren segm. sessile, 6-12 in. 1., 2-3 in. br., with about 12 sessile pinnoe on each side, which are $1-1 \frac{1}{2}$ in. $1 ., \frac{3}{8}-\frac{1}{2}$ in. br., unequal-sided, obliquely truncate below, blunt, subentire; texture subcoriaceous; rachis clothed with hairs like the stem; venation flabellate; panicle $2-3$ in. l., close, the peduncle 4-6 in. 1.-Raddi, Fil. Bras.t.12. Hk. Fil. Ex.t.1. A. vellea, Schrad. A. hirta, J. Sm. (non Sw.).

Hab. Brazil.-This comes near to the two preceding, but the stem is densely ferrugineo-tomentose, and the pinnæ are distant and less numerous.

\section{† Barren segment subdeltoid. Sp. 9-12.}

9. A. glareosa, Gardner; st. 4-5 in. 1., firm, erect, with adpressed ferruginous hairs; barren segm. sessile, under 2 in. $1 ., 1-1 \frac{1}{4}$ in. br., ovate-deltoid, with a terminal lobe and 3-4 oblong blunt pinnoc $\frac{1}{4}$ in. br. on each side, only the lowest pair, which are sometimes lohed on the lower side at the base, reaching down to the rachis; texture subcoriaceous; rachis and surfaces finely villose; veins flabellate; panicle 3-4 in. l., with dense short erecto-patent branches, the peduncle under 1 in. 1.-Gard. Sert. Pl.t. 70. A. Gardneriana, Presl.

Hab. South Brazil, Gardner 4086, Burchell 6594-2.-Most like oblongifolia in texture, but the peduncle much shorter, and remarkable for the barren segment being truly pinnate only at the base.

10. A. Breuteliana, Presl ; st. 6-12 in. l., slightly villose ; barren segm. sessile, 4-9 in. l., $1 \frac{1}{2}-4$ in. br., subdeltoid, with $6-9$ pairs of sessile pinnoe, which are oblong, obtuse, rather unequal-sided, entire or pinnatifid in the lower part, and grow smaller gradually upwards; texture subcoriaceous; rachis and both sides nearly naked; panicle $2-4 \mathrm{in}$. l., lax, the peduncles $3-6 \mathrm{in}$. 1.-A. mandioccana, $H \hat{k}$. Gen. Fil. t. 90. and Griseb. (non Raddi).

Hab. Mexico and West Indies to Brazil and Peru.-A well-marked and widely-distri- 
buted plant with a confused synonymy. Probably it is $A$. hirta, Sw. ; but Plumier's figure (t. 157) is much stronger and more hairy than any of our specimens. Mettenius refers here $A$. filiformis, Swz., but we have thought it best to drop both names. A. incisa, Schrad., and A. pallida, Gardn., are apparently a subpinnatifid variety, and $A$. hispida, Kze., and Pohliana, Sturm, either belong here or are closely allied.

11. A. Langsdorffiana, Presl ; st. 8-12 in. 1., rather densely villose ; barren segm. sessile, subdeltoid, about 6 in. 1 . by nearly as br., with 6 pairs of sessile pinnce, with nearly their own breadth between them, the lowest the largest, $2 \frac{1}{2}$ in. l., $\frac{3}{4}-\frac{7}{8}$ in. br., the two sides nearly equal at the base, the apex acuminate, the edge serrulate; texture subcoriaceous ; rachises finely pilose; a midrib nearly to the point; panicle $2-3$ in. 1 ., with a peduncle about cqualling it in length. Lang. \& Fisch. $t .28$.

Hab. South Brazil, as figured by Langsdorf.-We have a specimen gathered in Bahia by Salzmann, and a similar one, but with the lower pinnæ deeply lobed, gathered by Fendler (No. 12) in Venezuela. Probably it is a free-veined form of A. Phyllitidis, which it resembles closely in habit.

12. A. mexicana, Klotzsch ; st. 6-12 in. 1., firm, naked ; barren segm. on a stalk 1 in. or more 1., 6-9 in. 1., 4-6 in. br., with 4-6 pinnoe on eacl side, the lowest the largest, distinctly stalked, ovate-lanceolate, $2-3$ in. $1 ., \frac{5}{8}-\frac{3}{4}$ in. br., rounded on both sides at the base, the edge very slightly crenate; texture coriaceous; rachis and surfaces quite naked; a distinct midrib from the base to the apex; panicle 3-1 in. l., with dense short erecto-patent branches; peduncle 1-4 in. 1.-Hk. Ic. t. 988. Kunze, t. 131.

Hab. New Mexico and Texas to Guatemala.-A. speciosa, Presl (Hk. 2nd Cent. t. 65), is a reduced form, with only a single pair of pinnæ. This is well marked by its naked coriaceous pinnæe, with a very distinct midrib.

\section{** Pinnce of barren segment pinnatifid or bipinnatifid. Sp. 13-18.}

13. A. hirsuta, Sw.; st. 6-12 in. 1., slender, naked ; barren segm. 2-6 in. 1., 1-3 in. br., sessile, oblong-deltoid, bipinnatifid ; pinnoe in 6-8 opposite pairs, 1-1 $\frac{1}{2}$ in. $1 ., \frac{1}{4}-\frac{3}{4}$ in. br., varying from oblong, obtuse, subentire, truncate at the base on the lower side, to deeply pinnatifid with narrow divisions; texture subcoriaceous; rachis and surfaces slightly pilose ; panicle 1-2 in. 1., close, the peduncle $2-6 \mathrm{in}$. 1., slender.-Plum. t. 162. A. repens, Raddi, t.9.b. A. ciliata, Presl.- $\beta$, A. tenella, Sw. ; pinnoe cut down to the rachis into linear divisions, with a considerable space between them, the lower ones forked or trifid. A. dissecta, Presl.

Hab. Cuba and Mexico to Peru and South Brazil.-A. coriacea, Griseb. (Cuba, Wright 1798 ), is said to be like this, but naked and shining, the barren segments only $1 \frac{1}{2}$ in. 1 ., 1 in. br., with only the lower pinnæ pinnatipartite at the base. A. gracilis, Schrad. (A. humilis, Hk. Ex. Fl. t. 28. non Sw.), appears to be a reduced form with subentire pinnæ.

14. A. tomentosa, Sw. ; st. 6-12 in. 1., strong, erect, clothed with deciduous ferruginous hairs; barren segm. 6-12 in. l., half as br., ovate-deltoid, bipinnatifid or bipinnate ; lowest pinnoe the largest, the blunt lobes often $\frac{1}{2}-\frac{3}{4}$ in. $1 ., \frac{1}{4}$ in. br., nearly uncut; texture subcoriaceous; rachis and surfaces densely pilose ; veins fine, flabellate; panicle 4-9 in. l., lax, the peduncle 1-2 in. 1.-A. flexuosa, Sw. Raddi, t. 13. Hk. Fil. Ex. t. 30. A. villosa, H. B. K. A. deltoidea, Sro.$\beta, A$. fulva, Sw.; smaller, more coriaceous ; barren segm. tri- or even quadripinnatifid, the ult. divisions much smaller and sharper.-Hk. F. Exot. t. 26. A. anthriscifolia, Schrad.

Hab. Mexico and West Indies to Peru and Monte Video.-The two varieties look very different in the extreme forms, but appear to slide into one another gradually. The 
original A. tomentosa and deltoidea are the less-developed forms of the less-divided variety, with which agree the Neilgherry $A$. Wightiana, Gardn. (Beddome, t. 66), and Abyssinian A. Schimperiana, Presl. The former has an unusually strong stem, both that and the rachises densely ferrugineo-tomentose ; whilst a plant gathered by Dr. Welwitsch in Angola is like $\beta$, but nearly naked, with the divisions blunter than in the extreme form. Besides the synonyms already quoted, we appear to include the following, which are given as distinct by Sturm; viz. rubrostipes, Pohl, fervuginea, H. B. K., Raddiana, Link, oblonga and imbricata.

15. A. trichorhiza, Gardn. ; caud. with a dense tuft of bright red-brown fibrillose scales $\frac{1}{2}$ in. l. at the crown; st. 1-2 in. l., densely clothed with white woolly tomentum ; barren segm. ovate-deltoid, $2-3$ in. l., 1-i $\frac{1}{2}$ ill. br., bipinnate ; pinnoe close, spreading, lanceolate, with several close roundish or oblong pinnl.; texture coriaceous ; both sides when young completely enveloped in dense woolly tomentum ; panicle subsessile from the base of the barren segm.-Hk. Ic.t. 876 .

Hab. South Brazil, Gardner 4080, Burchell 7043, 1881.-A very distinct species.

16. A. rutaefolia, Mart. ; st. 6-9 in. 1., firm, naked ; barren segm. short-stalked, 2-3 in. l., 1-1 $\frac{1}{2}$ in. br., oblong, bi- or tripinnatifid ; pinnoe subdistant, lanceolate, cut down nearly to the rachis into narrow toothed or slightly pinnatifid divisions; texture subcoriaceous ; surfaces slightly hairy ; panicle subsessile, close, 1-1 $\frac{1}{2}$ ill. 1 . -Mart. t. 55. A. glareosa, Gard. MSS.

Hab. South Brazil, Martius, Gardner 5339.-This may be a variety of the next, from which it seems to differ principally by its subsessile panicle.

17. A. adiantifolia, Sw. ; rhizome creeping ; st. 12-18 in.1., firm, naked ; barren segm. short-stalked, 6-9 in. l., 4-6 in. br., deltoid, bi-tripinnate ; pinnoe close, lanceolate, the lowest the largest ; ult.divisions oblong or linear-cuneate, the outer edge toothed ; texture coriaceous; rachises slightly pilose; veins fine, channelled, flabellate ; panicle 3-4 in. 1., the peduncle 1-3 in. 1.-Plum. $t .158$.

Hab. Cuba, Bahamas, Florida, and Mexico to Bahia.-A asplenifolia, Sw. (Hk. \& Gr. t. 16), is a reduced bipinnate form. This forms the genus Anemirhiza of J. Smith, characterized by an elongated rhizome, from which the stems arise in a single row. A. caruifolia, Presl, is a finely-cut variety.

18. A. cuneata, Kze. ; rhizome creeping ; st. 3-4 in. 1., slender, naked ; barren segm. long-stalked, 3-4 in. l., tripinnatifid, with distant pinnæ and pinnls., the uit. divisions linear-cuneate, $\frac{1}{2}$ lin. br., cleft at the apex ; texture subcoriaceous ; rachis and surfaces naked; panicle slender, lax, the lower branches elongated, the peduncles slender, $1 \frac{1}{2}$ in. 1. $-K z e$. Anal. Pter. 8. $t$. 5 .

Hab. Cuba, Poppig.-Perhaps a small finely-cut form of the preceding.

§§ Anemidictyon, J. Sm. Panicle and leafy portion united in the same frond; veins anastomosing. Sp. 19-21. Fig. 65. e.

19. A. (Anemid.) Tweediana, Hk. ; st. 3-4 in. 1., naked or slightly pilose ; barren segm. $1 \frac{1}{2}-2$ in. l., 1 in. br., ovate-oblong, simply pinnate; pinnoe in 2-3 sessile pairs, oblong, $\frac{3}{4}$ in. $1 ., \frac{3}{8}$ in. br., the point blunt, the edge crenulate, the base rounded ; texture subcoriaceous; main vein not distinct to the apex; panicle 1-2 in. 1., dense, the lower branches short, the peduncle 1-2 in. 1.-Mk. Ic. t. 906.

Hab. Uraguay and South Brazil.

20. A. (Anemid.) Schraderiana, Mart. ; st. 6-9 in. 1., villose below ; barren segm. 3-5 in. each way, with 1-3 nearly equal pinno on each side, which are $2-2 \frac{1}{2}$ in. l., 1 in. br., ovate-acuminate, the edge subentire, the base cuneate, the terminal pinna with 2 divergent lanceolate lobes; texture subcoriaceous ; main vein 
distinct to the apex, the veinlets oblique, slightly joining; panicle 1-2 in. 1., the peduncle 1-4 in. 1.-Mart. Ic. t. 58. A. diversifolia and Vespertilio, Schrad.

Hab. South Brazil.-With this we are not acquainted. The description is compiled principally from Martius.

21. A. (Anemid.) Phyllitidis, Sw. ; st. 6-18 in. 1., stramineous, naked or fibrillose ; barren segm. sessile, 4-12 in. 1., 2-8 in. br., ovate-oblong, simply pinnate ; pinno in 4-12 sessile pairs, the lowest the largest, ovate, 1-6 in. l., $\frac{1}{2}-2$ in. br., the apex acute, the edge crenulate, the base rounded or cuneate or unequal; texture subcoriaceous; main vein distinct to the apex, the veinlets oblique, forming numerous long narrow areolæ ; rachises naked or pilose ; panicle dense, 3-9 in. 1., the branches short, the peduncle 3-8 in. l.-Plum. $t$. 156. Raddi, Fil. Bras. $t .8$.

Hab. Cuba and Mexico to Peru and South Brazil. - We appear to include here eight species of Sturm, of which A.obliqua and sorbifolia, Schrad., A. fraxinifolia, Raddi, and A. macrophylla, have the terminal pinna more or less joined to those below, whilst in his A. Phyllitidis, longifolia, Link, and densa, Raddi, it is distinctly separated. A. laciniata, Link, has the lower pinnæ inciso-lobate. Villose forms of this are often labelled A. hirta, Sw. ; but that synonym appears to belong properly to our A. Breuteliana.

\section{$\S \S \S$ Coptophyllum, Gardn. Barren and fertile fronds distinct. Sp. 22-26.}

22. A. (Copt.) aurita, Sw. ; st. of the barren frond 2-3 in. 1., firm, erect, slightly pilose ; barren fr. 3-6 in. 1., $1 \frac{1}{2}-2$ in. br., oblong-deltoid, bipinnate, the lower pinnoe the largest, stalked, simple, or with 1 or 2 roundish sessile entire or slightly toothed pinnl. on each side ; texture coriaceous; surface glossy ; veins finely channelled, flabellate; panicle 2-3 in. 1., interrupted, the lower branches short, the st. 6-8 in. 1.- HI. Ic. t. 903.

Hab. Jamaica.

23. A. (Copt.) Wrightii, Baker ; st. of barren frond 1-5 in. 1., slender, naked, stramineous ; barren fr. 2-3 in. 1., $1 \frac{1}{2}$ in. br., subdeltoid, tripinnatifid ; pinnoe few, distant, the lower ones deltoid, the upper pinnules cuneate, simple, $\frac{1}{8}$ in. br., the lower ones deeply cleft from the circumference inwards; texture subcoriaceous ; rachis and surfaces naked; veins flabellate ; panicle 2-3 in. 1., very lax and fewbranched, stem 8-12 in. 1.

Hab. Cuba, Wright 1812.-In habit not unlike A. cuneata, or a small slender form of adiantifolia.

24. A. (Copt.) bipinnata, Moore ; st. of barren frond 1-2 in. 1., slender, naked ; barren fr. 2-3 in. 1., $\frac{3}{4}-1$ in. br., oblong-deltoid, tripinnatifid; lower pinnoe the largest, subdeltoid, with cuneate pinnatifid pinnl. ; texture subcoriaceous ; veins flabellate; rachis and surfaces slightly hairy ; panicle lax, close, elongated, the st. slender, 2-3 in. 1.-Osmunda, Linn. Herb. A. cicutaria, Kze. Anal. Pter. 9. $t$. 5 .

Hab. Bahamas and West Indies.-The figure of Plumier which Linnæus quotes is evidently Osmunda cinnamomea.

25. A. (Copt.) dichotoma, Gardn. ; st. of barren frond densely tufted, firm, erect, slender, naked ; barren fr. 1-2 in. 1., about 1 in. br., oblong, tripinnate, the segments filiform, dichotomously forked, the divisions 2-3 lin. 1.; texture subcoriaceous; surfaces and rachis naked; panicle 2-3 in. 1., the lower branches elongated, the st. 3-4 in. 1.-Sturm, in Mart. Fl. Bras. fasc. 23. fig. 16. $t$. 4. Copt. buniifolium, Gard. Hk. Ic. $t .477$.

Hab. Brazil.-A. tenuifolia, Presl (Sturm, 1. c. t. 16. f. 2), is probably a smaller and more slender form of this species. Leaf in cutting resembling that of Bunium flexuosum, the divisions much longer and fewer than in the next. 


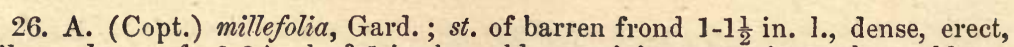
pilose ; barren fr. 2-3 in. l., $\frac{3}{4}-1$ in. br., oblong, tripinnate ; pinnoe close, oblong, the segm. slightly flattened, under 1 lin. l. ; texture subcoriaceous ; rachises pilose ; panicle 2-3 in. 1., with copious erecto-patent branches, the stem 3-4 in. 1.Sturm in Mart. Fl. Bras. fasc. 23. fig. 16. t. 4. Copt. Gardn. Hk. Ic. t. 478.

Hab. South Brazil.-Barren frond in shape and cutting resembling a leaf of Achillea millefolium.

\section{Gen. 66. Mouria, Sw.}

Caps. sessile, placed on the back of the leafy frond near the edge. A single species, combining the capsules of the sub-order with the habit of Cheilanthes. Tав. VIII. fig. 66.

1. M. caffrorum, Desv.; st. tufted, 3-4 in. 1., slightly scaly ; fr. 6-18 in. 1., 2-4 in. br., tripinnatifid ; pinnoe close, lanceolate-oblong, cut down to a narrowlywinged rachis into oblong pinnl., which are pinnatifid and deeply toothed in the barren frond, less divided in the fertile one ; texture herbaceous or subcoriaceous; rachises and under surface more or less clothed with linear subulate pale-brown scales.-Polyp. Linn. M. thurifragra, Sw.

Hab. Cape Colony to Natal, Mauritius, Bourbon, and Madagascar.-Fragrant when bruised. $M$. achilleafolia of the gardens (Lowe, N. F. t. 42. B.) is a finely-cut variety, almost quadripinnatifid, and is said to have a different scent, and grow in more open places.

\section{Gen. 67. Trochopteris, Gardn.}

Caps. small, sessile, placed irregularly round the edge on the under side of the slightly-contracted lower lobes of the leafy frond. $A$ single species, like a dwarf Anemia, but with the fertile and barren parts of the frond not distinct. TAB. VIII. fig. 67.

1. T. elegans, Gard. ; st. densely tufted, very short; fr. 1 in. $1 ., \frac{1}{2}-\frac{5}{8}$ in. br., lyrato-pinnatifid, the upper lobes rounded, not deep, the lowest pair reaching down nearly to the rachis, and bearing the sori on its laciniated edge; texture herbaceous ; venation flabellate, free; both sides villose-Gardn. in Hk. Journ. 1. p. 74. t. 74. Anemia, St. in Mart. Fl. Bras. t. 16.

Hab. South Brazil.-The fronds resemble the leaves of a Geum, and form a dense rosulate tuft.

\section{Gen. 68. Lygodium, Sw.}

Caps. solitary (or casually in pairs), in the axils of large imbricated clasping involucres, which form spiles either in separate pinnæ or in lax rows along the edge of the leafy ones. A small widely-diffused genus, well characterized by its wide-scandent twining stems. TAB. IX. f. 68.

\section{$\S$ Eulygodium. Veins free. Sp. 1-13.}

* Fully-developed barren pinnules palmate or dichotomously forked. Sp. 1-6.

1. L. palmatum, Sw. ; primary petiole slender, $\frac{1}{8}-\frac{1}{4}$ in. 1 , each fork in the lower part of the stem bearing a single cordato-palmate pinnl. $1 \frac{1}{2}-2$ in. li.e, not so deep, bluntly 4-6-lobed more than halfway down, the slender petiole $\frac{1}{2}-\frac{3}{4}$ in. 1 .; fertile pinnl. subdeltoid, 3-4-pinnatifid, formed only of winged rachises and short spike-like fertile ultimate divisions, the latter linear, 1-1 $\frac{1}{2}$ lin. 1.; surfaces naked ; texture thin-herbaceous.-Hk. Fil. Ex.t. 24. Schk.t.140. A. Gray, Man.t. 13. Gisopteris, Bernh.

Hab. Massachusetts to Florida. 
2. L. dichotomum, Sw.; primary petiole so much reduced that the fork seems almost to spring from the main rachis, secondary 1-2 in. 1., firm, naked; pinnl. digitate, with 5-6 lobes reaching nearly down to the base, or once or even twice forked; ult. barren divisions 4-8 or even 12 in. l., $\frac{1}{2}-\frac{3}{4}$ in. br., the fertile ones contracted, sometimes so much so that the lamina is nearly lost; the spikes 1-2 lin. l., in close marginal rows ; texture subcoriaceous ; surfaces naked.-Hk.\&Gr. $t$. 55. Beddome, $t$. 62. L. circinatum and pedatum, and probably flexuosum, Sw. Ugena, Cav.

Hab. Chusan, Hong-Kong, Philippines, Ceylon, Malay Peninsula and Isles,-If, as seems likely, this is L. flexuosum, Swz., that is the oldest specific name.

3. L. digitatum, Eaton (not Presl) ; primary petiole short or obsolete, secondary 1 in. or more 1. ; pinnl. palmate, cut down nearly to the base or once forked, the lobes 6-12 in. l., $\frac{3}{4}-1$ in. br., the point acute or bluntish, the base narrowed, the edge of the barren ones crenulate or finely toothed; texture subcoriaceous; surfaces glossy, naked; spikes 1-2 lin. 1., in close rows along the edge of the lobes.-Eaton, Fil. Wright \&. Fend. p. 217.

Hab. Gathered about Panama and in New Granada by Seemann, Cuming, and Hayes, and in Guatemala by Salvin and Godman. Apparently larger and less divided than the preceding, which is Presl's digitatum, but very doubtfully distinct.

4. L. semihastatum, Desv. ; primary petiole nearly or quite obsolete, secondary 1 in. or more ; pinnl. once forked, each short-stalked, divisions (in our specimen) simple, ligulate, $6-8$ in. 1 ., nearly 1 in. br. without the spikes, the base unequal, one side very cordate ; texture coriaceous ; surface naked ; spikes $\frac{1}{4}$ in. 1. in close rows along the edge of the segments.-Ugena, Cav. H. auriculatum, Cav.

Hab. Philippine and Marianne Isles, Cuming, \&c.-The sterile pinnules are described as palmate. The fertile ones, except that they are in pairs instead of being numerous and arranged pinnately, are like those of pinnatifidum.

5. L. articulatum, Rich.; primary petiole $\frac{1}{4}-\frac{1}{2}$ in. 1., secondary 1 in. or more 1. ; barren pinnl. twice forked, each bearing 4 ligulate-oblong segm., which are 2-3 in. l., about $\frac{1}{2}$ in. br., blunt at the point, very distinctly articulated at the base on a short petiole; texture sulbcoriaceous; rachis and surfaces naked; fertile pinnl. many times dichotomous, the short spikes in dense clusters, which are often almost destitute of lamina.-A. Rich. Fl.t. 15.

Hab. New Zealand.-A very well-marked species.

6. L. trifurcatum, Baker; primary petiole obsolete or very short, secondary 1-1 $\frac{1}{2}$ in. l. ; pinnl. twice dichotomously forked, and each division bipartite nearly to the base, the ult. barren divisions $4-6$ in. $1 ., \frac{3}{4}-\frac{7}{8}$ in. br., the point acute or bluntish, the edge crenulate, the petioles not articulated ; texture subcoriaceous ; rachis and surfaces naked; fertile divisions contracted, cut down nearly to the rachis, the short spikes in clusters of 3-6 upon the lobes.

Hab. Solomon Isles, Milne 511, 591, J. G. Veitch; Louisiade Archipelago, McGillivray. -This seems a very distinct species. In one of our specimens the spikes are 1 to 3 together, and the portion of the lamina that supports them is only linear.

\section{** Fully-developed barren pinnules pinnate. Sp. 7-13.}

7. L. scandens, Sw. ; primary petiole very short, secondary $\frac{1}{4-\frac{1}{2}}$ in. 1. ; pinnl. 4-8 in. 1., 2-4 in. br., with a terminal segm. and 4-5 on each side, which are very variable in shape, usually simple, ovate or ligulate-oblong, with a rounded or cordate base, sometimes hastate or even slightly pinnate below, always articulated on a short petiole, spreading from the rachis at right angles; texture firm ; sur- 
faces naked or nearly so; spikes 1-3 lin. 1., in close rows along the edge of the segments.-Beddome, $t$. 61 .

Hab. South China and Himalayas to Queensland, Malay Isles, and Ceylon; Guinea Coast. - L. microphyllum, Br., is a common form with short broad segments; L. semibipinnatum, Br., the form with the segments pinnate at the base. We do not venture to separate the Mexican $L$. mexicanum, Presl, which is quite like this in halit, but is said to be not articulated at the apex of the petiole, a character which our specimens leave in doubt.

18. L. venustum, Sw.; primary petiole very short, secondary $\frac{1}{4}-\frac{1}{2}$ in. $1 . ;$ pinnl. 6-12 in. 1., 4-6 in. br., with a terminal segm. and 4-12 on each side, which are simple, ligulate-oblong, the lower ones usually hastate, or pinnate below, all articulated at the base, bluntly lobed at the edge when barren, the upper ones sessile, the lower ones on a spreading petiole $\frac{1}{8}-\frac{1}{4}$ in. l. ; texture firm ; rachis and surfaces densely villose; spikes 1-4 lin. 1., in close rows.-L. polymorphum, H. B. K. Ugena, Cav. H. hirsutum, Willd.

Hab. West Indies and Mexico to Brazil and Peru.-Near the preceding, but larger and constantly villose, with the edge of the barren segments crenato-pinuatifid. L. cubense, H. B. K., probably belongs here.

9. L. volubile, Sw.; primary petiole nearly or quite obsolete, secondary about 1 in. l. ; pinnl. 8-12 in. l., 6-10 in. br., with a simple ligulate-oblong terminal segm. 3-6 in. 1., 1-1 $\frac{1}{4}$ in. br., and 3-5 like it on each side, truncate or subcuneate, and articulated at the base, and all distinctly stalked ; texture subcoriaceous ; rachis and surfaces naked or slightly pubescent; spikes 1-3 lin. 1., in close rows along the edge of the leafy segments.-L. scandens, Schk. $t$. 138. (non Sw.). L. hastatum, Mart. t. 57.

Hab. Cuba to Brazil.-From this we cannot separate by any clear character L. has. tatum and-expansum, Desv., hirtum and lucens, Kaulf., Poppiganum, Presl, Wrightii, Eaton, surinamense, Miquel, acuminatum, puberulum, and micans, Sturm. Segments of several of these are figured by Sturm (Mart. Fl. Bras. fasc. 23. t. 13-14). In some of the forms they have a pair of pinnæ at the base, and in others they are slightly villose.

10. L. pinnatifidum, Sw.; primary petiole none or very short, secondary often 1 in. 1. ; pinnl. 8-12 in. l., 6-12 in. br., with a ligulate-oblong terminal segm. 3-6 in. 1., $\frac{1}{2}-\frac{3}{4}$ in. br., and 3-4 like it on each side, usually rounded or cordate, all articulated at the base, the lower ones, or all, short-stalked, and sometimes hastate or pinnate below; texture subcoriaceous; rachis and surfaces naked or slightly pubescent ; spikes 1-3 lin. l., in close rows along the edge of the leafy segments. -L. flexuosum, Bedd.t. 63, but scarcely of Swartz.

Hab. Himalayas, Philippines, Malaccas, South India, Ceylon, Angola, Guinea Coast. -Here belong $L$. longifolium and pubescens, Wall., the latter a slightly pubescent form, and L. salicifolium, Presl (a form with small neat long-stalked segments), and Smith's Congo plant, called L. Smithianum by Presl.

11. L. polystachyum, Wall.; primary petiole short or obsolete, secondary $\frac{1}{4}-\frac{1}{2}$ in. 1. ; pinnl. 8-12 in. 1., 4-6 in. br.; the segm. uniform, 9-12 on each side, 2-3 in. l., $\frac{3}{4} \mathrm{in}$. br., articulated at the base, pinnatifid more than halfway down to the rachis into close entire blunt lobes $\frac{1}{8} \mathrm{in.}$ br. ; upper segm. sessile, lower ones short-stalked ; texture subcoriaceous ; rachis and surfaces pubescent; the fruit in the fertile ones occupying the back of the scarcelly modified lobes. $-H k$. $2 n d$. Cent. $t .76$.

Hab. Malay Peninsula ; gathered by Wallich, Griffth, Parish, \&c.-Well distinguished by its numerous uniform deeply and regularly pinnatifid seginents.

12. L. subalatum, Bojer; primary petiole obsolete or very short, secondary $\frac{1}{4}$ in. 1.; pinnl. 6-9 in. l., 4-6 in. br , subdeltoid, bipinnate, the apex pinnatifid; 
upper segm. sessile, ovate-deltoid, pinnatifid, lower short-stalked, deeply pinnatifid or pinnate in the lower part, the divisions pinnatifid, the base not articulated ; texture herbaceous ; surfaces naked or slightly villose ; spikes 1-2 lin.l., terminating the ultimate lobes.

Hab. Madagascar and the Comoro Isles; collected by Bojer, Kirk, and Speke.-The segments are very close, often imbricated, and in well-developed pinnules six on each side below the pinnatifid apex. This is midway between japonicum and polystachyum, and bas the pinnatifid barren segments of the latter.

13. L. japonicum, Sw.; primary petiole very short, secondary $\frac{1}{2}-1$ in. 1.; pinnl. 4-8 in. l., nearly as broad, deltoid ; the terminal segm. pinnatifid or hastate, the lateral ones 2-3 on each side, very unequal, not articulated at the base, the lower ones long-stalked and pinnate in the lower part, the divisions entire or crenulate; texture herbaceous ; surfaces naked or slightly villose ; spikes 1-2 lin. 1., the lamina of the fertile divisions often much reduced.-Beddome, $t .64$.

Hab. Japan and the Himalayas to Ceylon, Java, Philippines, Hong-Kong, and Loo Choo Isles.-L. Finlaysonianum, Wall., and $L$. tenue, Blume, both appear to be forms of this with the lamina of the fertile divisions nearly obsolete.

$\S \S$ Hydroglossum, Presl. Veins anastonosing. Sp. 14-16. Fig. 69. c. Lygodictyon, J. Smith.

14. L. (Hydro.) heterodoxum, Kze. ; primary petiole obsolete or very short, secondary $1 \frac{1}{2}$ in. l. ; pinnl. with 2-3 bipartite segm., the ult. divisions 4-6 in. l., $\frac{3}{4} \mathrm{in}$. br., the petioles not articulated, the lowest often $\frac{1}{2}$ in. 1. ; texture thin ; rachis and surfaces naked; veins joining copiously ; spikes 1 lin. l., in close rows along the edge of the leafy divisions.-Kunze, t. 113. H. spectabile, Liebm. L. Lindeni, Hort.

Hab. Mexico and Guatemala.

15. L. (Hydro.) reticulatum, Sclik. ; primary petiole $\frac{1}{8}-\frac{1}{4}$ in. 1. , secondary $\frac{1}{4}-\frac{1}{2}$ in. l. ; pinnl. 6-9 in. 1., 4-6 in. br., with a terminal segm. and 4-6 nearly uniform ones on each side, which are cordate-hastate or ligulate-oblong, rounded or cordate at the base, 2-3 in. 1., $\frac{1}{2}-\frac{3}{4}$ in. br., all articulated at the base, the lower ones shortstalked; texture subcoriaceous; rachises naked or slightly villose, sometimes ebeneous; spikes 1-3 lin. l., in close rows along the edge of the segments.-Schk. t. ]39. H. polycarpum, Willd. H. scandens, Presl. L. Schkuluri and Forsteri, J. Sm.

Hab. Polynesian Isles and East Tropical Australia.

16. L. (Hydro.) lanceolatum, Desv. ; primary petiole short or obsolete, secondary 1 in. l. ; pinnl. 8-12 in. 1., 6-10 in. br. ; segm. 3-4 on each side, uniform, 4-6 in. 1., $\frac{3}{4}-1$ in. br., all stalked, articulated at the base, the base rounded or cuneate, never cordate ; texture coriaceous ; rachis and surfaces glossy ; spikes 1-2 lin. 1., in close rows along the edge of the segments.-H. madagascariensis, Poir.

Hab. Madagascar, Bojer, Forbes, Meller, \&c.

\section{Sub-ORd. V. MARATTIACEA.}

Caps. opening by a slit down one side or a pore at the apex, without a ring, usually joined together in concrete masses (synangia). Vernation circinate.* GEN. 69-72.

* An elaborate illustrated monograph of the sub-order (excluding Dancea) was published by De Vriese and Harting at Leyden in 1853. They define altogether ninety-four 


\section{Gen. 69. Angiopteris, Hoffm.}

Caps. opening by a slit down the side, sessile, very close to one another but not concrete, arranged in linear-oblong or boat-shaped sori near the edge of the frond. TAB. IX. fig. 69.

1. A. evecta, Hoffm. ; caud. erect, 2-6 ft. high, $1 \frac{1}{2}-2 \mathrm{ft}$. thick ; st. swollen and articulated at the base, furnished with two large leathery auricles, which remain attached to the caudex after it falls ; fr. 6-15 ft. l., bipinnate; pinnoe 1-3 ft. l., spreading, the lowest the largest, the rachis swollen at the base; pinnl. 4-12 in. l., $\frac{1}{2}-1 \frac{1}{2}$ in. br., linear-oblong, sessile or short-stalked, the point acuminate, the edge entire or slightly toothed; texture subcoriaceous; both sides naked, smootl, shining; veins subparallel ; sori consisting of 8-15 caps., in close rows near the edge, almost hiding the inferior fimbriated involucre. - Hk. \& Gr. t. 36. Hk. Fil. Ex. t. 75.

Hab. Himalayas and Japan to Ceylon, Madagascar, New Caledonia, Queensland, and Society Isles.-We cannot determine more than one clearly-marked species, but Presl defines ten, and De Vriese sixty. There is a considerable range of variation in the texture of the pinnæ and closeness of the veins and sori, and the number of capsules which compose the latter; and in many of the forms there is a free veinlet, which is very variable in length and distinctness, which begins at the edge of the frond in the interspace between the veins proper. Psilodochea salicifolia, Presl, is an entirely obscure plant, supposed to have been gathered in Lahore, said to be like Angiopteris, but without an involucre.

\section{Gen. 70. Maratita, Sm.}

Caps. sessile or stalked, 4-12, concrete in boat-shaped synangia, which consist of two opposite rows of capsules, and open by slits down their inner faces. $A$ well-marked genus, extending all round the world within the Tropics, and a little beyond the southern one. 'TAB. IX. fig. 70.

\section{$\S$ Eumarattia. Synangia furnished with an obscure fimbriated inferior invo- lucre. Sp. 1-2.}

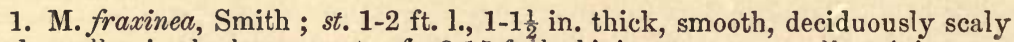
and swollen in the lower part; fr. 6-15 ft. l., bipinnate or casually tripinnate; pinnce 1-2 ft. l., often $1 \mathrm{ft}$. br. ; pinnl. oblong-lanceolate, 4-6 in. 1. , $\frac{1}{2}-1 \frac{1}{2} \mathrm{in}$. br., the apex acuminate, the edge entire or serrulate, the base cuneate or slightly rounded; texture coriaceous; surfaces naked; veins simple or forked, the rachis of the pinnæ sometimes slightly winged; synangia usually submarginal, in close rows, $\frac{1}{2}-1 \frac{1}{2}$ lin. l., the sides vertical, the receptacle linear, with $6-12$ caps. on each side.

Hab. Guinea Coast, Angola, Zambesi-land, Mascaren Isles, Natal, Cape Colony, Neilgherries, Ceylon, Philippines, Malaccas, Polynesia, New Zealand, Queensland, Norfolk Island.-The typical plant (Smith, Ic. inedit. t. 48 ; Beddome, t. 79) has pinnules 1-11 in. br., serrulate principally at the apex, numerous forked veins, and submarginal synangia, with 10-12 caps. on each side. To this belong $M$. sorbifolia, Bory, and M. elegans, Endl. From this we cannot separate clearly many plants which have been regarded as distinct; of which the principal are $M$. salicifolia, Schrad. (Kze.t. 38), including $M$. Dregiana and natalensis, Presl (South Africa), pinnules sharply toothed throughout, often only $\frac{1}{4}-\frac{3}{8}$ in. br., veins more distant, synangia with about 6 caps. on each side, not so close or so near the edge; M. salicina, Sm., De Vriese, tab. 3. fig. 18 (Society Isles),

species, and give nine large folio plates to illustrate the characters of these and the anatomical structure of the genera. In all of them the caudex is a succulent irregularly. shaped tuberous mass, upon which the stems are articulated, and the latter are furnished at the base with a pair of large flap-like auricles, which are leathery in texture when dry. 
colour dark-green, veins and synangia very close, the former all simple, the latter long, narrow, marginal ; a plant from Fiji, coriaceous in texture, colour dark-green, veins simple, much raised, $\frac{3}{4}$ line apart, synangia a third or nearly halfway from the edge to the midrib ; M. purpurascens, De Vriese, t. 3. f. 19 (M. Ascensionis, J. Sm., Hk. G. F. t. 65, from Ascension Island), a reduced fleshy form, as if grown in a very exposed situation, the fronds not more than $3-4 \mathrm{ft}$. high, lurid-purple in the wild plant, lower pinnl. often cut down to a distinctly-winged rachis, the auricles at the base of the stem sometimes producing soriferous lobes like the frond in texture; and $\boldsymbol{M}$. sambucina, Blume (Java), pinnl. $2-3$ in. $1 ., \frac{3}{8}-\frac{1}{2}$ in. br., narrowed to both ends, very pale beneath, with distant simple veins, small synangia placed half as far from the edge as from the midrib, and the rachis of the pinnæ more distinctly winged than usual. The Philippine $M$. pellucida, Presl, comes very near this last, and $M$. sylvatica, Blume (De Vriese, t. 3. f. 23), appears to differ only by having the lower pinnules again pinnatifid.

2. M. attenuata, Lab. ; st. 3-4 ft. 1., smooth ; fr. 3-4 ft. 1., tripinnate ; pinnae $1 \frac{1}{2}-2 \mathrm{ft}$. 1 , the lower ones with a stalk 6 in. l. and 2-3 pinnl. on each side, the latter with a terminal segm. and 3-4 on each side, which are 4-6 in. $1 ., 1 \mathrm{in}$. or rather more hr., the apex serrated, the base cuneate, the lower ones shortstalked ; texture subcoriaceous ; surfaces naked ; rachis not winged ; veins usually once forked ; synangia 1-1 $\frac{1}{2}$ lin. l., submarginal, the sides vertical, the receptacle linear.-Lab. Sert. Austro-Cal. p. 9. t. 13-14.

Hab. New Caledonia.-This may not be more than a more compound variety of the preceding, but examples received recently from Vieillard quite agree with Labillardière's specimens and figures.

\section{\$ Gymnotheca, Presl. Synangia sessile without an involucre.} Sp. 3-6.

3. M. (Gymno.) cicutoefolia, Kaulf. ; st. 1-2 ft. 1., 1 in. thick, smooth ; fr. 5-6 ft. l., bipinnate ; lower pinnoe 12-18 in. l., often $1 \mathrm{ft}$. br.; pinnl. oblong-lanceolate, 4-6 in. 1., $\frac{3}{4}-1$ in. br., the edge entire or serrulate, the base cuneate or slightly rounded; texture subcoriaceous; surfaces naked ; veins distant, usually in pairs that join at the base, one often forked; rachis of the pinnæ slightly winged towards the apex ; synangia a short distance from the edge, 1-1 $\frac{1}{2}$ lin. l., deep cleft, the sides ultimately spreading, the attachment linear.-Mart. Ic. $t .70$. M. fraxinea, Raddi, t. 82. (non Smith).

Hab. Brazil.-De Vriese and Sturm define six Brazilian species, which we cannot distinguish clearly,-Raddiana, polyodon, obtusidens, cicutcefolia, Verschaffeltiana, and podolepis. The latter is the most unlike the type, and has herbaceous pinnæ only 2-3 in. $1 ., \frac{3}{8}$ in. br., and very small 'synangia.

4. M. (Gymno.) laxa, Kze. ; st.1-2 ft. 1., smooth ; fr. several ft. 1., bipinnate ; lower pinnoe $1 \frac{1}{2}-2 \mathrm{ft}$. 1 ., often $1 \mathrm{ft}$. br.; pinnl. ohlong-lanceolate, 4-6 in. l., $\frac{3}{4}-1$ in. br., the edge inciso-crenate, the base cordate; texture suhcuriaceous; surfaces naked; veins in pairs that join at or near the base, both sometimes forked; rachis slightly winged towards the apex; synangia quite close to the edge, $\frac{3}{4}-1$ lin. l., the sides always erect, the attachment linear.-Kunze, $t .95$. Presl, Suppl.tent. p. 15. Lowe, 8. t. 77. M. macrophylla, Hort.

Hab. Mexico, Liebold 62.-This and the preceding bave entirely the habit of M. fraxinea.

5. M. (Gymno.) Douglasii, Baker ; st. 3-5 ft. 1., thick, smooth ; fr. 6-8 ft. 1 ., tripinnatifid, the lower pinnoe much the largest, all except the lowest pair simply pinnate, 6-8 in. $1 ., 2-3$ in. br., the rachis flattened and narrowly winged throughout, the pinnl. usually under 1 in. l., $\frac{1}{4}$ in. br., linear-ohlong, with broad blunt teeth, the base cuneate; pinnl. of the lowest pinnæ again pinnatifid ; texture thick-herbaccous ; surfaces naked ; synangia 1 to each lobe of the pinnules, sub- 
marginal, $\frac{1}{2}-\frac{3}{4}$ lin. 1., the sides ultimately spreading, the attachment oblong.Stibasia, Presl. De Vriese, tab. 3. f. 24.

Hab. Sandwich Isles.

6. M. (Gymno.) alata, Smith ; st. 1-2 ft. 1., 1 in. or more thick, deciduously scaly ; fr. 3-4 ft. l., tripinnatifid, the lower pinnoe the largest, all except the lowest pair usually simply pinnate, the ultimate divisions $\frac{1}{2}-\frac{3}{4}$ in. l., about $\frac{1}{4}$ in. br., oblong, blunt or acute, the base cuneate, the edge serrate or crenate, the rachises with a very distinct wing; texture herbaceous; under surface more or less chaffy ; synangia copious, submarginal, $\frac{1}{2}-\frac{3}{4}$ lin. 1 ., the sides erect, the attachment oblong or roundish.-Simith, Ic. inèdit. t. 46. (non Raddi). Discostegia, Presl. M. lævis, Simith, Ic. t. 47. M. weinmanniæfolia, Liebm.

Hab. West Indies, Mexico, and Guatemala.-Presl and others assign to this an involucre, which we are not able to detect. M. laevis, Sm., is a form with the rachis smooth and teeth of the segments blunt.

\section{§§§ Eupodium, J. Smm. Synangia short-stalkea without an involucre. Sp. 7.}

7. M. (Eupod.) Kau'fussii, J. Sin. ; st. 2-3 ft. 1., thick, naked ; fr. 3-4 ft. 1., quadripinnatifid, the lowest pinnce much the largest, all except the lowest pair bipinnatifid, $1 \mathrm{ft}$. or more l., 6-8 in. br.; pinnl. 3-4 in. 1., the rachis very distinctly winged; segm. oblong, deeply and bluntly toothed, those of the lowest pinnæ again pinnatifid ; texture herbaceous ; surfaces naked ; synangia $\frac{1}{2}-\frac{3}{4}$ lin. l., not marginal, deeply cleft, the sides ultimately spreading.-Hk. 2nd Cent. $t .95$. M. alata, Raddi, t. 83-4. (non Sm.)

Hab. West Indies and Columbia to Ecuador and Rio Janeiro.

\section{Gen. 71. Dandea, $S m$.}

Caps. sessile, concrete in rows, which cover the whole under surface of the pinnæ on which they are placed, opening by pores at the apex. $A$ well-marked genus restricted to Tropical America. TAB. IX. fig. 71.

1. D. simplicifolia, Rudge; st. of the barren fr. 2-12 in. 1., with 0-2 nodes, slightly scaly below; barren fr. 6-12 in. 1., 2-4 in. br., ovate-oblong, the apex acuminate, the edge entire, the base rounded or cuneate; texture subcoriaceous ; midrib beneath naked; veints close, usually once forked; fertile fr. similar but smaller, and the st. longer.-Rudge, $t$. 36 . Kunze, t. 50.

Hab. Guiana and North Brazil.-One of our specimens is partially fertile only. There are about 100 capsules in the central synangia, and 30,000 to an entire froud.

2. D. trifoliata, Reich.; st. of barren fr. about 1 in. l, with 1 node, slightly scaly below ; barren $f r$. with an oblong-lanceolate entire terminal pinna 8-12 in. l., 3 in. br., and one or two pairs of similar but smaller lateral ones ; texture coriaceous; surfaces glossy, the rachis naked, not winged, swollen at the nodes; veins close, usually once forked, casually anastomosing ; fertile fr. on a longer st., the pinnæ smaller.-Kze. Anal. 4.t.2.

Hab. Guiana ; gathered by Hostmann and Schomburgk.-Perhaps not really distinct from the preceding.

3. D. trichomanoides, Spruce, MSS.; st. of barren fr. under 1 in. l., furfuraceous, continuous; barren fr. $3-4$ in. $1 ., 1$ in. br., with about 12 pinnoe on each side, the central ones $\frac{1}{2}$ in. $1 ., 2$ lin. br., oblong, short-stalked, the base rounded ; colour dark-green; texture pellucido-herbaceous; veins simple; rachis with a 
distinct crisped wing throughout ; fertile fr. on longer st. than the barren ones, and the pinnæ more distinctly stalked and not so close.-Moore, Ind. Fil. p. 288 .

Hab. Tarapota, East Peru, Spruce 4710.

4. D. Leprieurii, Kze.; st. 6-9 in. 1., slender, nearly naked, with 3-4 distinct articulations; barren fr. $6-9$ in. $1 ., 3-4$ in. br., with about 6 sessile pinnce on each side, which are $1 \frac{1}{2}-2$ in. l., $\frac{3}{4} \mathrm{in}$. br., oblong-falcate, the edge crisped, the lowest pair nearly equalling the others; texture subcoriaceous; veins very fine and close, usually once forked; rachis slender, swollen at the nodes, slightly winged upwards; fertile fr. on a longer st. than the barren one, the pinnæ similar, but smaller.-Kze.t. 60 .

Hab. Guiana and the Amazon Valley.-This forms the section Arthrodancea of Presl, characterized by a distinctly articulated stem.

5. D. humilis, Moore ; st. of barren fr. 2-4 in. l., furfuraceous, with 0-1 node ; barren fr. about $1 \mathrm{ft} .1 ., 2-3$ in. br., with $15-25$ close pinnce on each side, the central ones $1 \frac{1}{2} \mathrm{in.}$. ., $\frac{1}{4}-\frac{3}{3}$ in. br., distinctly stalked, the point blunt, the edge slightly crisped, the base on both sides rounded or subcordate; lower pinnoe rather shorter than the others; texture fleshy-herhaceous; rachis furfuraceous, distinctly winged throughout; veins fine and close; fertile fr. like the other, but smaller.-Moore, Ind. Fil. p. 286.

Hah. El Ecuador, Seemann 996 ; and a plant gathered by Dr. Spruce in East Peru (4769) is probably the same. Some of Dr. Seemann's specimens are proliferous at the apex.

6. D. alata, Smith ; st. of barren fr. 2-6 in. 1., densely furfuraceous, with 0-1 node ; barren fr. 12-18 in. 1., 6-8 in. br., with 8-10 pinnoe on each side, the central ones shurt-stalked, $3-5$ in. $1 ., \frac{3}{4}$ in. br., the apex acuminate or cuspidate, serrated, the base rounded, the lowest pair distant and much reduced; texture subcoriaceous; rachis and midrib beneath furfuraceous, the former distinctly winged in the upper half; veins conspicuous, usually simple; fertile fr. on a longer st., the pinnæ stalked more distinctly, 1-3 in. l., acute or obtuse, 3-4 lin. br.-Plum.t. 109 . Hk. \& Gr.t. 18.

Hab. West Indies.

7. D. Augustii, Karst.; st. of barren fr. 3-4 in. 1., slender, naked, with 1-2 nodes; barren fr. about $1 \mathrm{ft} .1 ., 6-8$ in. br., with 4-5 pinnae on each side, which are 3-4 in. 1., $\frac{1}{2}-\frac{3}{4}$ in. br., the upper ones sessile, the lowest stalked and slightly reduced, all narrowed to the base, the upper part inciso-crenate; texture herlaceous; colour dark-green; veins not very close, usually once forked; rachis naked, slightly winged upwards; fertile pinnoe similar.-Sturm in MLart. Fl. Bras. fasc. 23. p. 159.

\section{Hab. Venezuela, Karsten.}

8. D. Moritziana, Presl ; st. of barren fr. 8-12 in. l., slightly furfuraceous, with 1-2 nodes; barren fr. 12-18 in. l., 6-10 in. br., with 10-12 pinnoe on each side, all sessile or nearly so, $3-5$ in. 1 ., $\frac{1}{2}-1$ in. br., the apex acuminate or cuspidate, sharply toothed, the base cuneate, the lowest pair not distant or reduced; texture subcoriaceous; veins close, mostly once forked; rachis nearly naked, slightly winged towards the apex; fertile pinnoe $1 \frac{1}{2}-2$ in. l., $\frac{1}{4}$ in. br.-Presl, Suppl.6.p.35.

Hab. Columbia to Peru.-Midway betreen alata and elliptica.

9. D. stenophylla, Kze.; st. of barren fr. about $1 \mathrm{ft}$. 1., naked, with 2-3 nodes ; barren fr. $1 \frac{1}{2} \cdot 2 \mathrm{ft} .1 ., 6-10 \mathrm{in}$. br., with $12-15$ pairs of pinnce, the upper sessile, 
the central ones short-stalked, $4-5$ in. $1 ., \frac{1}{2}$ in. br., the apex sharply toothed, the base rounded, the lowest shorter; texture subcoriaceous; veins mostly simple ; rachis furfuraceous, slightly margined towards the apex ; fertile pinno distinctly stalked, 2-4 in. 1., 2-3 lin. br.-Kze. t. 28. Heterodanæa, Presl.

Hab. Guadeloupe, L'Herminier.-Our description is taken from an authentic specimen communicated by M. Fée. Moore gives the Mexican D. cuspidata, Liebm., with which we are not acquainted, as probably the same.

10. D. elliptica, Sm.; st. about $1 \mathrm{ft}$. 1., nearly naked, with 2-5 nodes ; barren fr. $1 \frac{1}{2}-2 \mathrm{ft}$. 1., 8-12 in. br., with 6-9 pairs of pinna, the upper sessile, 4-6 in. 1., 1-1 $\frac{1}{2} \mathrm{in}$. br., the apex acuminate, entire or slightly toothed, the base cuneate or slightly rounded, the lowest stalked, not reduced; texture subcoriaceous ; veins fine and close; rachis naked, slightly winged at the top ; fertile pinnoe similar, but narrower and more distinctly stalked.- $H k$. \& $G r . t .51$. D. geniculata, Raddi, t. 5 .

Hab. West Indies to South Brazil.-The commonest species. D. Sellowiana, Presl, is probably a nodeless variety.

11. D. nodosa, Sm. ; st. $1 \frac{1}{2}-2$ in. 1., strong, erect, nodose ; barren fr. 3-4 ft. 1., $1 \frac{1}{2}-2 \mathrm{ft}$. hr., with 10-15 pairs of pinno, the upper ones sessile, the lower ones short-stalked, not reduced, 6-12 in. 1., 1-2 in. br., the apex acuininate, the edge entire or subrepand, the base cuneate or slightly rounded; texture subcoriaceous ; rachis naked, the upper part slightly winged; veins fine, close, simple or once forked ; fertile pinnoe 4-6 in. 1., $\frac{3}{4}-1$ in. br.-Plum. t. 108. Hk. \&. Gr.t. 51.

Hab. Cuba and Mexico to Brazil. $-D$. dubia, Presl, and D. longifolia, Desv. (figured by Sturm in Mart. Fl. Bras. fasc. 2. 3. t. 11), are probably nodeless varieties. Presl and Sturm make two sections of the genus, characterized by the absence or presence of those nodular sirellings of the stem, but the character seens to be a very unsafe one. The genus Danceopsis of Presl is founded upon a pinna figured by Raddi (Fil. Bras.t. 5) with jrregular anastomosing venation, under the name of $D$. paleacea.

\section{Gen. 72. Kaulfussia, Blume.}

Caps. sessile, 10-15, quite concrete in raised circular masses, which are hollow in the centre, with the oblong apertures on the inner face. 'TAB. IX. fig. 72.

1. K. aesculifolia, Blume; st. 12-18 in. l., herbaceous, auricled at the base; fr. ternate or quinato-digitate, the central pinna the largest, oblong-spathulate, 6-12 in. l., 3-4 in. br., the edge subentire, the others similar but smaller, often unequal-sided or lobed; texture fleshy-herbaceous; main veins pinnate, with copious immersed areolæ, with free included veinlets between them; sori copious, scattered.-Hk. \& Gr. t. 229. K. assamica, Griff.

Hab. Assam, Philippines, and Malay Isles.-A curious plant, with \& frond like a chesnut-leaf, and the under surface dotted over with copious stomata-like pores. De Vriese makes four species.

\section{Sub-ORD. VI. OPHIOGLOSSACEA.}

Caps. deeply two-valved, opening down the side nearly to the base, without a ring. Vernation erect. Gen. 73-75.

\section{Gen. 73. Ophioglossum, $L$.}

Caps. sessile, arrangerl in two rows so as to form a narrow close spike. TAв. IX. fig. 73 . 
\$ Euophioglossum. Fertile spike single, arising from the base of the barren segment. Sp. 1-6.

1. O. lusitanicum, L. ; rootstock slightly tuberous; fr. 1-3 in. 1., the sterile division placed below the centre, $\frac{1}{2}-1$ in. $1 ., 1 \frac{1}{2}-2$ lin. br., linear-lanceolate, the point bluntish, the base narrowed; texture thick, no midrib, and the veins indistinct ; fertile spike $\frac{1}{4}-\frac{1}{2}$ in. l., the peduncle firm, $\frac{1}{2}-1 \frac{1}{2}$ in. l. when mature. $-H k . B . F$. t. 47. O. azoricum, Presl.

Hab. Shores of the Mediterranean, and as far north as Guernsey, Azores, Madeira, Guinea Coast.-The European plant is developed in winter, whilst in Britain O. vul. gatum is not mature till June. O.gramineum, Willd., from North and Peninsular India, is probably identical, and the same may be said of the Australian and New Zealand 0 . gramineum, R. Br. The New Zealand 0 . minimum, Colenso, is not more than 1 in. high, with the barren segment 3 lin. 1 . by half as broad; and three closely-allied forms have been gathered by Dr. Welwitsch in Angola,-O. gomesianum, Welw., 1.1 $\frac{1}{2}$ in. 1., barren segm. near the base, $\frac{1}{2}-\frac{5}{8}$ in $1 ., 2$ lin. br. ; O. luso-afivicanum, W elw., 4 in. l., barren segm. central, $1 \frac{1}{2}$ in. $1 ., 2$ lin. br. ; and 0 . gracillimum, Welw., $1 \frac{1}{2}$ in. l., barren segm. central, truly livear, acute, 1 in. or less l., under 1 lin. br.

2. O. rubellum, Welw. MSS.; rootstock slightly tuherous; fr. 1-2 in. 1., the sterile division placed very near the base, roundish, $\frac{1}{4}$ in. each way, without a haft, often adpressed to the surface of the ground, thick in texture, the veining hidden; fertile spike $\frac{1}{4}-\frac{3}{8}$ in. l., the reddish peduncle $\frac{3}{4}-1$ in. l. when fully matured.

Hab. Pungo Andongo, Angola, 2,400-3,800 ft. ; Welwitsch 33.-Most like O. bulbosum but smaller, with the barren segment sub-basal.

3. O. bulbosum, Michx.; rootstock tuberous, $\frac{1}{4} \frac{3}{8}$ in. thick; fr. 2-4 in. l., the sterile division placed considerably below the middle, $\frac{1}{2}-1$ in. $1 ., \frac{1}{2}$ in. br., ovate, without a haft; texture stouter than in $O$. vulgatum, the midrib and veining quite indistinct; fertile spike $\frac{1}{4}-\frac{1}{2}$ in. 1 ., the peduncle $1 \frac{1}{2}-2$ in. when fully developed..-0. crotalophoroides, Walt. O. tuberosum, Hk. \& A. O. opacum, R. Br. Hk. \& Gr.t. 50 .

Hab. Louisiana and Florida to Chili and Tristan d'Acunha; and a Malay specimen from Prof. De Vriese agrees with the American plant.

4. O. nudicaule, L. fil.; rootstock slightly tuberous; fr. $2-4$ in. 1., the sterile division placed not far from the base, $\frac{1}{2}-1 \frac{1}{2}$ in. 1 ., $\frac{1}{4}-\frac{1}{2}$ in. br., ovate or oblong, without a haft or with only a slight one, the texture thin but the veins not distinct; fertile spike $\frac{1}{2}$ in. 1 ., the peduncle often 2-3 in. 1., very slender.Swartz, Synop. t. 4. f. 2. Kze. t. 29. fig. 29. t. 3. b. O. parvifolium, Hk."\& Gr. Beddome, $t .71$.

Hab. America from the Southern United States southward to Brazil ; New Caliedonia, Malaccas, Peninsular India, Guinea Coast, Angola. - Whether this be the original nudicaule is not quite clear, but it is the plant figured under that name by Swartz and Kunze. To the type belong $O$. ypanemense, Mart. t. $73, O$. surinamense, Reich., and O. flavicaule, Klotzseh, and probably 0 . moluccanum, Schlecht. Kunze's fig. a, O. Wightii, Hk. \& Gr., and O. ellipticum, Hk. \& Gr. t. 40, are larger in size, with the sterile segment as thin and the venation as plain as in reticulatum, 2 in. or more $1 ., \frac{5}{8} \cdot \frac{3}{4} \mathrm{in}$. br., and the stem longer. O. macrorhizum, Kze. t. 29. fig. 1 (fron Guiana and Brazil), is a much-reduced variety, not more than $1 \frac{1}{2}-2$ in. bigh, with the sterile division nut more than $\frac{1}{2}$ in. l., $\frac{1}{4}$ in. br. The Sand wich Island $O$. concinnum, Brack. t. 44 , is most like this, but the barren segment is farther from the base of the stem ; and this also appears to be the ease with the Chilian 0. melipillense, Remy.

5. O. vulgatum, L. ; rootstock not tuherous ; fr. 6-9 in. 1., the sterile division generally placed about the middle, $2-4$ in. l., $\frac{3}{4}-2$ in. br., ovate or ovate-oblong 
without a distinct haft; texture stouter than in the others, the midrib usually indistinct; fertile spike 1 in. or more 1., upon a peduncle $2-4$ in. 1. , and considerably overtopping the sterile division when the plant is fully mature.Hk. B. F. t. 46.

Hab. Lapland to Japan and the Himalayas ; Azores, Guinea Coast, Angola, St. Helena, Abyssinia, Cape Colony, Mascaren Isles, Australia, New Zealand, Sandwich Isles, Temperate North America.-From the type O. coriaceum, Hk., O. elongatum, R. Cunning. and $O$. ovatum, Bory, scarcely diverge at all. The Cape plant (O. capense, Schlecht.) has sometimes, but not always, a more distinctly-marked midrib than the European one. The Azorean 0. polyphyllum, A. Br., is a small form with often several fronds from the same root. O. costatum, R. Br. (Hk. fil. Fl. Tasm. t. 169), is also smaller, with the midrib sometimes clearly marked. There is a tropical variety (O. pedunculosum, Desv., Kze. p. 58. t. 29 ; O. petiolatum, Hk. Ex. F. t. 56, and Blume) which occurs in Peninsular India, Java, and Guiana, with the barren division like that of the type in form and size, but thinner in texture, and with a distinct baft, which is not clearly separable from the large forms of 0 . nudicaule; and near to this come O. brevipes, Beddome, t. 72, from the Neilgherries, with a stem under $1 \mathrm{in.}$., a peduncle $5 \cdot 6 \mathrm{in.}$., very distinct areolation and copious free veinlets; and the Angolan and Guinean $O$. aphrodisiacum, Welw. MSS., with a bulbous rootstock $\frac{1}{4}-\frac{8}{8}$ in. thick, and a distinct flattened midrib extending nearly to the apex of the sterile segment.

6. O. reticulatum, L. ; rootstock not tuberous ; fr. 6-12 in. 1., the sterile division placed about the middle, $2-3$ in. $1 ., 1 \frac{1}{2}-2$ in. br., with a distinct haft and distinctly cordate basal lobes, the point blunt or subacute; texture thin, the veins distinct, usually no midrib ; fertile spike 1 in. or more l., on a slender peduncle 2-4 in. l., much overtopping the sterile segment. $-H k$. \& Gr. t. 20. Beddome, t. 70.

Hab. Tropical America, from Cuba to Peru and South Brazil ; Polynesian, Malayan, and Philippine Isles ; East India, as far north as the Himalayas, Guinea Coast, Angola, Zambesi-land, Mascaren Isles, Cape Colony.-To this appear to belong O. cordifolium, Roxb., O. Cumingianum and peruvianum, Presl, and probably U. cognatum, Presl, is a form with a rudimentary midrib.

§§ Ophioderma, Endl. Fertile spikes usually single, arising from the centre of the barren segment. Sp. 7-8.

7. O. (Ophiod.) intermedium, Hk. ; fr. erect, 6-8 in. l., the flattened stem passing gradually into the leafy part, which is $\frac{3}{8}$ in. br. not far from the point; texture fleshy; veins indistinct; fertile spike $1 \frac{1}{2}$ in. 1 ., erect, on a peduncle which about equals it and just reaches to the point of the barren segment.-Hk. Ic. t. 995 .

Hab. Borneo, T. Lobb.

8. O. (Ophiod.) pendulum, L. ; fr. pendulous, ribbon-like, without a distinct stem, 1-15 ft. l., 1-3 in. br., simple or forked; texture fleshy; no midrib, and the veining not distinct; fertile spike usualiy low down, $2-6$ in. 1 ., on a peduncle shorter than itself, usually solitary.-Hk. \& Gr.t. 19. G. F.t. 33.

Hab. Polynesian Isles to N. S. Wales, Assam, Malaccas, Philippines, Ceylon, and Mascaren Isles.

$\S \S \S$ Cheiroglossa, Presl. Fertile spikes numerous, arising from the base of the barren segment. Sp. 9.

9. 0. (Cheir.) palmatum, L. ; st. 6-12 in. l., fleshy, flaccid ; fr. like the letter $\mathrm{V}, 6-12$ in. $1 ., 4-8$ in. br., more or less cut from the circumference towards the centre into deep blunt lobes; texture fleshy; fertile spikes 2-12 in number, 1-2 in. 1., arising from the stem or edge of the lower part of the frond, on short nodding or spreading peduncles.

Hab. Cuba to South Brazil ; and it has been gathered also in Bourbon. 


\section{$\S \S \S \S$ Rhizoglossum, Presl. Fertile and barren fronds distinct. Sp. 10.}

10. O. (Rhiz.) Bergianum, Schlecht; rhizome slightly tuberous, one bearing several fronds of both kinds, the barren ones $\frac{1}{2}-1$ lin. l., $\frac{1}{2}$ in. br., linear, fleshy, the fertile spike slender, $\frac{1}{4}$ in. 1 ., on a slender peduncle $1-1 \frac{1}{2}$ in. $1 .-H k$. Ic. $t .263$.

Hab. Cape Colony, rare.-A very delicate and distinct little plant.

\section{Gen. 74. Helminthostachys, Kaulf.}

Caps. in small crested clusters which form a long loose spike. TAB. IX. fig. 74 .

1. H. zeylanica, Hk. ; rhizome thick, fleshy, creeping ; st. often $1 \mathrm{ft} . \mathrm{l}$.; barren segm. palnato-pinnate, often in three principal divisions, which are stalked and again forked or pinnate, the ult. divisions linear-oblong, 3-4 in. l., $\frac{3}{4}-1 \mathrm{in}$. br., the apex acuminate; the edge slightly toothed; texture subcoriaceous ; fertile spike solitary, arising from the base of the barren segm., 3-4 in. 1., $\frac{1}{2}$ in. br., the firm peduncle about as long as itself.-Hk. 2 d Cent. $t .94 . \quad G . F . t .28$. Beddome, t. 69. Osmunda, $L$. H. dulcis, Klf.

Hab. Himalayas, Cochin and Philippines to Ceylon, New Calerlonia, and Queensland. -Presl makes three species, and published the plant from Mexico by mistake under the name of Botryopteris mexicana.

\section{Gen. 75. Botrychium, $S w$.}

Caps. sessile, arranged in two rows on the face of spikes which form a compound panicle. TAB. IX. fig. 75 .

\section{* Texture thick. Sp. 1-4.}

1. B. simplex, Hitch.; st. slender, 1-4 in. 1.; sterile segm. short-stalked, $\frac{1}{2}-1 \frac{1}{2}$ in. 1 ., $\frac{1}{4}-\frac{1}{2}$ in. br., ovate or oblong-lanceolate, cut down to a flattened rachis into 1-3 oblong or obovate pinnæ on each. side, which are toothed or pinnatifid, with usually their own breadth between them; panicle elongated, $\frac{1}{2}-1 \frac{1}{2} \mathrm{in} .1$., with a few distant branches, the lowest sometimes branched again, the peduncle about as long as itself.-Hk. \& Gr.t. 82. B. Kannenbergii, Klins.

Hab. United States and British North America; North Europe.

2. B. rutaceum, Sw. ; st. stout, 1-4 in. 1. ; sterile segm. sessile, 1-2 in. 1., ovatedeltoid, broadest at the base, cut down to a flattened rachis into several close obovate-rhomboidal pinnoe on each side, the lower ones deeply pinnatifid; fertile peduncle equalling the sterile segm. when mature; panicle close, 1-2 in. 1., lanceolate-deltoid, bipinnate.-Newm. Phyt. 5. p.133. B. matricariæfolium, A. Br. Koch. - $\beta, B$. lanccolatum, Angst. ; st. more slender; pinnoe linear-lanceolate, with a space between them, the lower ones sharply toothed, panicle smaller.B. palmatum, Presl.

Hab. Scandinavia to Unalaschka; $\beta$ also in the United States.-Figures of tho two varieties and all the other European forms will be found in a paper by Milde in vol. 26. pt. 2. of the Nova Acta N. C. Swartz seems to have confused this with the small forms of species 4. B. crassinervium and boreale, Milde, come very near to the typical form.

3. B. Lunaria, Sw.; st. stont, 1-4 in. 1. ; sterile segm. sessile or nearly so, 1-3 in. l., $\frac{1}{2}-1$ in. br., not much breader at the base than the middle, cut down to a flattened rachis into several distinct, close, entire, or notched cuneato-flabellate pinnæ on both sides; fertile peduncle equalling or exceeding the sterile segm. 
when fully developed ; panicle close, 1-2 in. 1., lanceolate-deltoid, bipinnate.$H k . B r . F . t .48$.

Hab. Arctic Europe and Iceland to Spain, Italy, Kamschatka, and the Himalayas ; South Australia, Tasmania, Patagonia, N. W. America, Greenland.

4. B. ternatum, Sw.; st. 1-2 in. 1.; petiole of the sterile segm. 2-4 in. 1., the latter 3-6 in. each way, deltoid, tri- or quadripinnatifid; lower pinnoe much the largest, and pinnl. of the lower side larger than the others, oblong or subdeltoid, stalked, the ult. divisions oblong or obovate, often $\frac{1}{4}$ in. br., blunt or acute, slightly toothed ; fertile peduncle 6-9 in. 1., considerably overtopping the sterile segm. ; panicle 1-6 in. l., deltoid, very compound. $-K$ Kunze, t. 121. Osmunda, Thbg. Fl. Jap. f. 32.

Hab. Nootka and Hudson's Bay territory southward to New Granada, Australia, Tasmania, New Zealand, Lapland, to Siberia, Japan, Pyrenees, and Hungary.-Of this the European . matricarioides, Willd. (B. rutafolium, A. Br. \& Koch), and the American B. lunarioides, Sw. (A. Gray, Man. t. 13), appear to be smaller, and the Australian $B$. australe, R. Br., and the American B. obliquum, Muhl, and B. decompositum, M. \& G., larger and more divided forms. B. silaifolium, Presl, seems also to belong here. B. dissectum, Muhl, is a curious form or variety, thinner in texture than the type, with the ultimate divisions acute and sharply inciso-serrate, which occurs both in the United States and New Zealand.

\section{* Texture thinner. Sp. 5-6.}

5. B. daucifolium, Wall. ; st. stout, 6-12 in. 1. ; petiole of sterile segm. 1-6 in. l., the latter 6-12 in. each way, deltoid, tripinnatifid or tripinnate, the lower pinnoe much the largest; segm. lanceolate-oblong, $\frac{1}{4}-\frac{3}{8}$ in. br., finely toothed; fertile peduncle about equalling the sterile segm. when mature; panicle 2-4 in. 1., tripinnate, not very close. $-H k$. \& Gr.t. 161. B. subcarnosum, Wall. Moore, Beddome, t. 78. B. subbifoliatum, Brack. t. 44.

Hab. Himalayas, Neilgherries, Ceylon, Japan, Java, Sandwich and Society Isles.Distinguished from the next by its much less finely.cut fronds and stalked sterile seg. ment. The Polynesian and Japanese specimens are forked considerably lower down than the Indian ones, and Brackenridge's plate represents a pair of barren segments to the stem.

6. B. virginianum, Sw. ; st. 3-18 in. 1. ; sterile segm. sessile, 4-12 in. each way, deltoid, quadripinnatifid ; lower pinnae much the largest; pinnl. ovate-oblong, close, cut down to a broadly-winged rachis into finely cut linear-oblong segm.; both sides naked; fertile peduncle equalling or overtopping the sterile segm. when mature, arising from its base; panicle 1-4 in. 1., lax, oblong, generally not more than bipinnate. $-H k . G$. F.t. 29. B. cicutarium, Sw. B. anthemoides, Presl. B. brachystachys, Kze. B. lanuginosum, Hk. \& Gr. t. 79.- $\beta, B$. lanuginosum, Wall.; surface slightly hairy, fertile peduncle arising from the centre of the sterile segm., which the panicle scarcely overtops.-Beddome, $t .77$.

Hab. Oregon and North United States to Ecuador and Brazil ; Norway to Austria, the Himalayas, and Tsus-Sima ; $\beta$, Himalayas (up to 6,000 ft.), Neilgherries, Ceylon.The leaf in cutting resembles that of Anthriscus sylvestris. 


\section{ADDENDA ET CORRIGENDA.}

Page 9, line 26, for Dictyoxiphipium read Dictyoxiphium.

" 12, $\S$ Mertensia $=$ Mecosorus, Hassk. The former name is preoccupied by a genus of Boraginacece.

" " species 7, glauca (Sw.), the oldest specific name.

„13, species 17. G. pallescens and rubiginosa, Mett. in Fil. Nov. Gran. p. 266, are varieties of pubescens, as the species is here understood.

„19. Cyathea equestris appears to be a synonym of divergens.

C. hirtula, Mart., appears to be a form of vestita. The species is distinguished by its ultimate segments not more than a line broad, very hairy frond and rachises, and very fragile involucre.

C. Beyrichiana appears to be Alsophila setosa, Kaulf., and a Hemitelia, and therefore should be called H. setosa, Mett. MSS.

25, species 46, for Mr. Lindsay read Mount Lindsay (in Queensland).

27, species 27. The Australian plant is probably C. medullaris.

29, species 9, Brazil, Burchell.

"species 10, for Copensis read capensis.

", second line from bottom, for A. read $\mathrm{H}$.

30, species 14. H. Moricandiana, Kze. MSS., was previously published by Presl (Die Gefass, p. 44) under the name of H. macrocarpa.

32, species 3. Two quite distinct plants are here confounded. That to which the name and diagnosis quoted from Martius refer is tripinnate, and probably identical with species 11 . The other appears to be undescribed, and may be characterized as follows :-

A. pubescens, Baker ; caud. 6-10 ft. high ; st. 15-18 in. 1., densely pubescent, not muricated, clothed below with rigid ovate-acuminate scales ; $f r$. oblong-deltoid, bipinnate, $3 \mathrm{ft}$. l., more than $1 \mathrm{ft}$. br.; lower pinnoe 6-8 in. $1 ., 1 \frac{1}{4}$ in. br., cut down nearly to the rachis into close blunt lobes $\frac{1}{4}$ in. br.; texture herbaceous; rachis and both sides densely pubescent; veinlets about 10 on a side, forked near the base; sori at the fork.

Hab. Peru, Lechler 2190, Spruce 4712 ; New Granada, Purdie.

33. Species $8 *$. A. proecincta, Kunze; st. $1 \frac{1}{2} \mathrm{ft}$. high, unarmed, glabrous, dark-castaneous ; fr. subdeltoid, 4-5 ft. l., $3 \mathrm{ft}$. br., tripinnatifid; pinnce oblong-lanceolate, $1 \frac{1}{2} \mathrm{ft}$. l., 6-7 in. br., subequal below; pinnl. linear, 3-3 $\frac{1}{2}$ in. 1., 9-10 lin. br., broadest at the base, cut down below

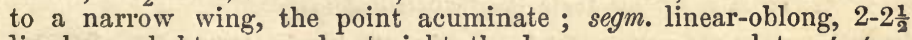
lin. br., subobtuse, nearly straight, the barren ones crenulate; texture papyraceo-herbaceous; both sides quite naked; veins 7-8 on each side 
in a segment, simple or forked at the point, all soriferous; sori submarginal ; recept. naked.

Hab. Bahia, Blanchet. - General habit of Hemitelia guianensis. Well marked in the genus by its broad segments, subsimple veins, and nearly marginal sori.

Page 33, species 10. Apparently the same as species 21, which is the original Cyathea aculeata, Willd. Herb. Spreng. ; but armata is an older name.

34, species 16. Omit the synonyms quoted from Klotzsch and Martius. Probably this is identical with species 24, and it only differs from 23 by the frond being subglabrous.

35 , line 37 , for arillare read axillare.

" species 23, for $K l f$. read Kze., the plant of Kaulfuss, according to Mettenius, being our species 16.

40, species 43. A. Macarthurii, Hk. In consequence of Sir W. Hooker's death, this sheet was in print nearly a year before it was issued, and this plant was published by Dr. F. Mueller (Fragm. 5. p. 53) under the name of $A$. Leichhardtiana, and by J. Smith (Brit. and For. Ferns, p. 245) as A. Moorei. The former of the two has priority.

Species 45*. A. Robertsiana, F. Muell. ; caud. $6 \mathrm{ft}$. high ; fr. ample, oblong-deltoid, quadripinnatifid ; lower pinnoe oblong-lanceolate, 12-18 in. 1., 4-6 in. br. ; pinnl. linear, 2-3 in. 1., $\frac{3}{4}$ in. br., cut down to a narrowly-winged rachis into deeply-pinnatifid linear-oblong segm. $\frac{1}{8}$ in. br.; texture herbaceous; rachis and both surfaces densely villose; sori 1 to each lower ult. lobe.-Fragm. 5. p. 54.

Hab. Queensland, Messrs. Dallachy \& Hill.-Nearest A. Colensoi, the segments the same size, but here deeply pinnatifid, the rachises of the pinnæ and pinnules without scales, and the whole plant more hairy.

A. Rebecco, F. Muell. ; caud. slender, $8 \mathrm{ft}$. high ; $f r$. ample, bipinnate ; lower pinnoe oblong-lanceolate, $12-15$ in. l., 4-5 in. br. ; pinnl. 20-30 on each side, the lower ones stalked, linear, 2-3 in. 1., $\frac{3}{8} \mathrm{in.}$ br., the apex acuminate, the upper part deeply, the lower less deeply incisocrenate, the base rounded on both sides, slightly auricled above; texture subcoriaceous; rachises reddish-brown, slightly fibrillose, the main one rough, with raised points; upper surface naked, lower scattered over with small membranous scales; veins fine, $4-5$ in a group ; sori principally in 2 rows midway the midrib and edge.-Fragm. 5. p. 53. Hk. Ic. t. 1015.

Hab. Rockingham Bay, Messrs. Hill \& Dallachy.-Very near A. podophylla, but the veins few, and under surface with small scattered scales.

47. Species $4^{*}$. Woodsia scopulina, Eaton; st. tufted, not articulated, castaneous at the base, stramineous upwards, 2-3 in. l., the scales brown, ovate-acuminate ; $f r$ lanceolate, bipinnate, $3-4$ in. l., 1-1 $\frac{1}{2}$ in. br.; pinnoe oblong-lanceolate, cut down to the rachis below into 6-10 narrow-oblong crenate pinnl. on each side; texture herbaceous, the whole plant pubescent and glandular ; inv. with both cup and cilia almost hidden by the sorus.-Canad. Nat. April, 1865.

Hab. Rocky Mountains and British America.

W. oregana, Eaton, is our obtusa $\beta$ Lyallii, but evidently a distinct species, with the involucre of Euwoodsia, general habit of obtusa, but smaller, and not so hairy.-Can. Nat. l.c.

Hab. Oregon and Rocky Mountains.-This and the preceding differ from species 1.4 by their inarticulated stems.

Species 7 is Dicksonia fragilis, Trev. (1816), Woodsia, Moore. See Milde, Fil. Eur. p. 167. 
Page 55. Deparia producta, Baker ; fr. ample, tripinnate ; pinnce broad-lanceolate, $1 \frac{1}{2}-2$ ft. $1 ., 8-10$ in. br.; pinnl. 3-5 in. l., $\frac{3}{4}-1$ in. br., cut dow $n$ to the rachis, except at the apex, into subquadrangular deeply incisopinnatifid segm.; texture subcoriaceous; rachis and both sides nearly naked ; sori 6-8 to a segment, quite extramarginal but sessile.-Dennstædia, Mett. Fil. Nov. Gran. p. 260.

Hab. New Granada, Lindig. -Closely allied to concinna, of which we have received better specimens since the description at page 55 was drawn up, and find to be subtripinnate. In that the segments are closer than in producta, and only reach down below to the midrib of the pinnules, and are not at all toothed.

58. Species 8*. H. microphyllum, Mett. ; st. under 1 in. 1., slender, naked ; fr. $\frac{3}{4}$ in. l., under $\frac{1}{2}$ in. br., ovate-deltoid, tripinnatifid ; main rachis winged nearly or quite down to the base; pinnoe crowded, the lower ones deltoid, only the lowest pinnl. more than forked ; the segm. linear, blunt, 1-1 $\frac{1}{2}$ lin. l. ; sori $6-12$ to a frond, cut about half down, the lip broad-oblong, entire, terminating the upper segments, the upper twothirds free.-Fil. Nov. Gran. p. 196.

\section{Hab. New Granada, Lindig 245.}

Species 8**. H. emersum, Baker ; st. 1 in. or less l., slender, naked; fr. 1-2 in. 1., $\frac{3}{4}-1$ in. br., ovate-deltoid, tripinnatifid ; main rachis winged down to the base; pinnoe close, the lowest deltoid; pinnl. simple, or the lowest forked or 3-cleft ; segm. blunt, $\frac{1}{2}$ lin. br., with a space between them ; sori 6-8 to a pinna, terminal ; invol. round, quite free and cut down to the base, the receptacle often protruded.-H. macroglossum, $V . D . B$. (in part).

Hab. Ceylon, C. P. 3360 ; Mauritius, Lady Barkly.-Nearest rarum, but erect and more compound, and the fruit different.

59, line 20, for 106 read 107.

61, line 31, for 109 read 104.

63. H. hirsutum, discovered by Dr. Meller in Madagascar.

"H. ciliatum, discovered by Capt. Bulger in Sikkim.

64, line 2, for 98 read 93 .

"line 13, for Capt. Carmichael read Dupetit Thouars.

" species 38. H. subtilissimum, Kze., oldest name.

68. Species 55*. H. japonicum, Miquel; st. hairy upwards, and narrowly winged ; fr. oblong, bipinnatifid, $1 \frac{1}{2}-1 \frac{3}{4}$ in. $1 ., \frac{3}{4}-1$ in. br. ; pinnce $3-5$ on each side, $\frac{1}{4}-\frac{1}{2}$ in. l., erecto-patent, close, ovate-oblong, with broad short close lobes, the upper simple, the lower ones bifid or trifid; rachis and veins hairy ; sori few, terminal ; invol. ovate, the lips toothed, hairy when young. - Ann. Mus. Bat. vol. 3. p. 383.

Hab. Japan, Keiske \& Buerger.

" 69. Species $63^{*}$. H. flaccidum, Baker ; st. $1 \frac{1}{2}-3$ in. l., wiry, naked ; fr. 4-6 in. l., 1 in. br., lanceolate, bipinnate, the rachis distinctly winged throughout ; pinnce deltoid ; pinnl. close, linear, strongly toothed, the lowest sometimes forked ; sori 4-6 to the lower pinnæ, terminal, quite free, the valves serrulate, roundish, reaching down nearly to the base. -Lept. V.D.B.Suppl.p. 65.

Hab. Khasi, Griffith, Hk. fl. \& Thoms.-Very near H. Smithii, but the fruit different. 
Page 76. Species 26*. Trichomanes Armstrongii, Baker; rhizome wide-creeping ; st. very slender, naked, 2-3 lin. l.; $f r . \frac{1}{2}-\frac{3}{4}$ in.l., irregular in general outline, between pinnately and flabellately divided, the divisions few, $\frac{3}{4}$ lin. br., with only a midrib in each, and a distinct strongly ciliated border similar to the midrib in texture; sori $2-4$ to a frond, terminal, obconical, ciliated.

Hab. New Zealand, Armstrong.-Branching as in T. Powellii, scarcely flabellate, but the alliance for the rest entirely with the digitatum group, from all the other species of which it may be known by its very distinct border.

85 , line 38 , omit 2 .

89. Species 6 is Adiantum repens, Linn. Suppl. p. $446=$ Davallia, Kuhn. Fil. Deck. p. 27 ; but we have a $D$. repens already (Sp. 27). It is also a plant of Japan and Queensland.

90. Species 13 should be D. hymenophylla=Acrophorus hymenophyllus, Parish, MSS. Beddome, Fil. Ind. t. 96.

92, species 20. According to Moore, this is the original D. pulchra, Don ; and if so, species 17 must be called D. pseudo-cystopteris, Kze. Probably they should both be regarded as varieties of one species.

93. Species 36 should be called D. assamica=Acrophorus assamicus, Beddome, Fil. Ind. t. 94, and should follow species 13.

„Species 40 is Adiantum denticulatum, Burm. Fl. Ind. p. 236=Davallia, Mett. MSS.

97. Species $47^{*}$. D. Lorrainei, Hance ; general habit of bullata, but the scales rigid, erect, dark-coloured, densely grey plumoso-ciliated.Ann. Sc. Nat. 5. ser. 5. p. 154.

Hab. Malaya.

98. Species 54 is D. hirsuta, Sw. Syn. p. 131, which name, of course, takes precedence of ours.

, Species 56 should be $D$. marginalis $=$ Polypodium marginale, Thunb.

105, species 8. Synonyms L. crenulata and multifrondulosa, Fée, Gen. Fil. t. 28.

106, line 8, for 287 read 206-7.

" Species 13*. L. parvula, Fée ; st. 6-8 in. l., smooth, stramineous ; $f r$. about as long, b ipinnate when fully developed, with a few distant spreading pinnoe 2-3 in. l., $\frac{3}{8}$ in. br. ; pinvl. close, not imbricated, under $\frac{1}{4}$ in. br., subrhomboidal, upper line slightly curved ; texture pellucidoherbaceous; sori continuous, the outer valve protruded beyond the inner one.-Fil. Ant. p. 17.t. 7.

Hab. Trinidad, Germain.-Near filiformis, but the rachis different, and habit more erect.

109, species 25. Probably one of the very curious abnormal forms of Acrostichum sorbifolium.

111, line 8, for 112 read 212.

112, species 41. L. lanceolata, Lab., oldest name.

114. Species 3*. Adiantum grossum, Mett. ; st. 4-9 in. 1., naked, ebeneous ;

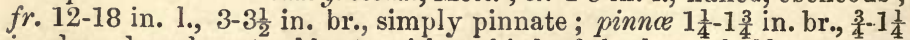
in. deep, broad-ovate, blunt, with a third of the lower half cut away, 
the lower petioles $\frac{1}{2}$ in. 1. ; veins flabellate ; texture firmer than in species 3, the sori similar.-Fil. Nov. Gran. p. 114.

Hab. New Granada, Lindig 373.

Page 114. Species 4 proves to be $A$. Capillus-junonis, Ruprecht, and that name must take precedence. See Dr. Hance's remarks in Seemann's Journ. 57. p. 261.

118, line 7 from bottom, for 43 read 45 .

119, line 4 from bottom, for 28 read 8.

126, line 5, for 55 read 28.

line 17, for 29 read 28.

131. Species $\mathbf{1}^{*}$. Cheilanthes Lindigii, Mett. ; st. densely tufted, 1-4 in. 1., castaneous, naked ; fr. 4-8 in. l., $\frac{3}{4}-1$ in. br., broadest about the middle, narrowed gradually both ways; pinnoe close, deltoid, $\frac{3}{8}-\frac{1}{2}$ in. 1 . by about half as broad, deeply pinnatifid; texture firm-herbaceous; rachis and both sides naked; sori minute, copious.-Fil. Nov. Gran. p. 218.

Hab. New Granada, Lindig 257.

132. Species 8*. C. propinqua, Mett. ; st. 3-6 in. l., firm, erect, naked, ebeneous ; fr. 8-10 in. l., 5-6 in. br., lanceolate-deltoid, tripinnatifid ; lower pinnce the longest, 3-4 in. l., 1 in. br., lanceolate ; pinnl. lanceolate, blunt, cut down to the rachis in the lower part into oblong obtuse entire segm.; texture firm-herbaceous; rachis and both sides naked; sori copious.-Fil. Nov. Gran. p. 219.

Hab. New Granada, Lindig 93.

137. Species 28*. C. Kuhnii, Milde ; rhizome suboblique, the scales broadovate ; st. $1 \frac{1}{2}-2 \frac{1}{2}$ in. l., naked, castaneous ; fr. $3 \frac{1}{2}-6$ in. $1 ., 1 \frac{1}{2}-1 \frac{3}{4}$ in. br., oblong-lanceolate, bipinnatifid ; pinnce lax, the central ones ovateoblong, obtuse, the lowest remote and rather reduced; pinnl. oblong, cut down to a narrow wing, those of the lower side not larger than the others; texture herbaceous; rachis and both sides finely glandular.Fil. Eur. p. 35.

Hab. China, Fischer.-Smaller and less divided than $C$. subvillosa, and the pubescence glandular.

141. Species 50*. C. aurea, Baker; st. tufted, $2-3$ in. 1., deep chesnut-brown, glossy, densely clothed towards the base with large ovate-acuminate reddish-brown scales ; fr. 3-4 in. l., 2-3 in. br., subdeltoid, tri-quadripinnatifid ; pinnoe deltoid, the lowest much the largest, with the pinnl. on the lower side nearly 1 in. l., cut down to the rachis into roundish or pinnatifid segm.; texture herbaceous; rachis castaneous and powdery; under side densely coated with bright-yellow powder; invol. broad, membranous, yellow.

Hab. Guatemala, Salvin \& Godman.

142, line 17, for 97 read 76 .

145. Species 4 should be P. Stelleri=Pteris Stelleri, Gmel., and Siberia added to its localities.

152, species 38, Pteris viridis, Forsk. Fl. Agypt. p. 186, oldest name.

163. Species $41 \%$. P. acclivis, Mett. ; rhizome wide-creeping ; st. 6-9 in. 1., firm, erect, naked ; fr. ample, deltoid, tripinnate; pinnoe lanceolate, the lower ones sometimes $1 \mathrm{ft}$. 1., 4-6 in. br. ; pinnl. lanceolate, 2-3 in. 1., $\frac{3}{4}-\frac{7}{8}$ in. br., cut down to the rachis into lanceolate or oblong entire or 
slightly toothed blunt or acute segm.; rachis often flexuose, naked like both surfaces; texture subcoriaceous; invol. double.-Fil. Hort. Lips. p. 59 .

Hab. Columbia and Guiana.-Habit like that of $P$. viscosa, but not at all glandular.

Page 165, line 8, for 120 read 177.

„166, last line but one, for Syn. read Sp.

"196. Species $37 \%$. A. Newmanni, C. Bolle, from the Cape Verdes, regarded as distinct both by Mettenius and Milde, is said to differ from Trichomanes by its conspicuously ribbed rachis, pinnæ sessile from a broad base, with a few adpressed linear and fibrillose scales on the under surface, and broader scales destitute of a spurious nerve.-Vide Milde, Fil. Eur. p. 69.

263, species 25. Dr. Kuhn points out the identity of this with Aspidium cirrhosum, Schum. \& Thonn. Besk. Guin. p. 457. 
Page 278, species 105, for Chinense read subtripinnatum=Aspidium, Miquel. Ann. Mus. Bat. 3. p. 179.

"305, species 7. Specimens just received from Dr. Thwaites show this to be a Nephrodium.

310 , species 37 , for platyphyllum, Hk., read polystichoides, Klotzsch, the former name being preoccupied (page 359).

307. Species 22*. Polypodium (Pheg.) Fischerianum, Baker; st. $1 \mathrm{ft}$. 1., nearly naked; $f r .1 \frac{1}{2}-2 \mathrm{ft}$. l., $1 \mathrm{ft}$. br., oblong-deltoid, bipinnatifid; lower pinnoe 6-7 in. l., $1 \frac{3}{4}$ in. br., cut down nearly to the rachis into blunt oblong slightly falcate lobes 4-5 lin. br., lowest pinnæ reduced; texture herbaceous; rachis and both sides naked; lower veins forked or subpinnate; sori medial.-Alsophila Fischeriana, Regel MSS.

Hab. Brazil, - Received at Kew from the Imperial Gardens at St. Petersburg.

315. Species $66^{*}$. P. (Goniop.) mascarense, Baker ; st. 6-8 in. 1., green, naked; $f r$. subdeltoid, 9 in. l., 6 in. br., with a lanceolate terminal pinna 1 in. br. below, with rounded lobes reaching one-quarter down, and 6 similar but rather narrower pairs, the apex acuminate, the lower part narrowed; texture herbaceous; rachis and surfaces naked; veins 4-5 on a side; sori near the main veins.

Hab. Ampassimba, Madagascar, Mrs. Higginson; received from Lady Barkly.

319. Species $90 \%$ P. (Dicty.) nicotianoefolium, Baker; rhizome creeping ; st. about $1 \mathrm{ft}$. l., brown, deeply sulcate, clothed throughout with linear brown scales; $f r .1 \frac{1}{2}-2 \mathrm{ft}$. l. by about half as broad, oblong-deltoid, with an oblong-lanceolate terminal lobe 3-4 in. br., and 3-4 similar but smaller ones on each side, which reach down nearly to the rachis, the lowest the smallest; texture papyraceous; surfaces naked; main veins distinct nearly to the edge; the transverse veins not so distinct as in species 90 and more wavy, with copious intermediate square areolæo with abundant free veinlets; sori scattered.

Hab. Mount Chimborazo, Spruce 5723 ; Chontales, Seemann.

320, species 98. Discovered in Ceylon by Dr. Thwaites.

331, species 170, for Lobbianum, Hk., read pediculatum, Baker, as the former name occurs again at p. 362 .

332-4. According to Dr. Miquel, P. papillosum and venulosum are given as Japanese in error. 



\section{N D E X.}

[Genera and Subgenera in Small Capitals, accepted Species in Italics.]

Abacjpteris, see Nephro- Acrostichom (continued). DIOM and POLYPODIUM.

Aconiopteris, see AcrostiCHUM.

Acrophorus, see Davallia. Acrostichum.

acrocarpon, 408

acuminatum, 414

æmulum, 401

alatum, 401

alienum, 419

alismæfolium, 403

alpestre, 405

andicola, 403

apiifolium, 413

apodum, 407

appendiculatum, 415

argutum, 419

articulatum, 413

A ubertii, 406

auricomum, 410

auricomum, $4 \therefore 9$

aureo-nitens, 421

aureum, 423

auritum, 410

axillave, 420

barbarum, 427

barbatum, 407

Bellermanianum, 410

bicuspe, 421

bifurcatum, 413

Blanchetii, 403

Blumeanum, 423

Boryanum, 407

brachyneuron, 402

Burchellii, 401

Coenopteris, 417

Calaguala, 405

callæfolium, 403

canaliculatum, 415

curdiophyllum, 404

caudatum, 400

candatum, 414 caulolepia, 410

cervinum, 416

cicutarium, 417

ciliatum, 406

cinnamomeum, 409

conforme, 401

coutaminans, 420

corcovadense, 411

costatum, 420

crinitum, 421

Cumingii, 407

curvans, 406

cuspidatum, 411

cylindricum, 415

decoratum, 404

decurrens, 403

decurrens, 407, 417, 418

deorsum, 410

didynanum, 401

dimorphum, 406

dissimile, 406

Dombeyanum, 409

drynarioides, 424

durum, 400

elongatum, 410

Engelii, 409

erinaceum, 407

eximium, 405

falcatum, 406

Feei, 404

feejeense, 401

flabellatum, 415

flaccidum, 401

flagelliferum, 418

fluviatile, 422

fceniculaceum, 416

fractiseriale, 414

fulvum, 409

Funckii, 403

gaboonense, 417

Gardnerianum, 405

Gayanum, 401

glabellum, 400

gorgoneum, 416
Acrostichum (continued).

Hamiltonianum, 415

Harlandii, 418

Hartwegii, 408

Helferianum, 415

Herminieri, 402

heteroclitum, 418

heterolepis, 411

heteromorphum, 405

Heudelotii, 422

hilocarpum, 418

Huacsaro, 405

Huacsaro, 408

humile, 404

hybridum, 403

Hystrix, 407

impressum, 401

integrifolium, 421

Karstenianum, 401, 406

Klotzschii, 406

lanceolatum, 420

Langsdorffii, 410

latifolium, 403

latifolium, 403

laurifolium, 401

Lechleri, 401

Lechlerianum, 415

lepidotum, 409

Lepervanchii, 401

leptophyllum, 400

Lindbergii, 403

Lindigii, 411

Lindigii, 423

Lindeni, 404

lineare, 406

Lingua, 402

Linnceanum, 417

Lloense, 405

longifolium, 403

luridum, 402

marginatum, 401

martinicense, 400

Matthewsii, 408

melanopus, 403

melanostictum, 401 
ACROSTICHUM (continued). meridense, 410 Meyerianum, 413 minus, 420 minutum, 401 muscosum, 410 muscosum, 409 nicotianaefolium, 419 nigrescens, 400 nitidum, 400 nivosum, 410 normale, 420 Norvisii, 401 obductum, 410 obtusatum, 408 obtusifolium, 401, 404 oligarchicum, 418 osmundaceum, 415 ovatum, 404 ovatum, 408 oxyphyllum, 401 pachyphyllum, 421 pallidum, 401 palustre, 402 pandurifolium, 422 peltatum, 416 perelegans, 411 pilosum, 406 piloselloides, 408 platyrhynchos, 424 plumbicaule, 413 plumosum, 411 Plumieri, 409 polyphyllum, 424 polylepis, 410 prcestantissimum, 423 Preslianum, 420 Preslianum, 406 procurrens, 408 proliferum, 420 pteroides, 424 pubens, 414 punctulatum, 401 p inctulatum, 419 quercifolium, 418 Quoyanum, 419 Raddianum, 423 Raddianum, 408 repandum, 419 Requienianum, 423 reticulatum, 426 rigidum, 424 rubiginosum, 410 rufescens, $40 \$$ Ruizianum, 405 rupestre, 410 salicinum, 422 samoense, 407 Sartorii, 403 scalpellum, 403 scandens, 402 Schiedei, 410 Schlimense, 402
Acrostranum (continued).
Schomburgkii, 402, 403 scolopendrifolium, 407 semicordatum, 422 serratifolium, 423 setosum, 409

Sieberi, 403

simplex, 400

simplex, 424

spathulatum, 408

spicatum, 424

squamipes, 404

squarnosum, 410

squamosum, 411

squarrosum, 405

stenspteris, 402

stigmatolepis, 406

stramineum, 403

strictum, 409

subdiaphxnum, 416

subiepandum, 419

subpinnatifidum, 419

succisscefolium, 408

taccefolium, 418

tambillense, 400

tectum, 410

terminans, 420

tomentosum, 411

Tovarense, 403

tricuspe, 422

trilobatum, 418

tripartitum, 416

truncicola, 410

undulatum, 409

unitum, 401

vagans, 401

validinervis, 424

variabile, 417

venustum, 406

vestitum, 409

villosum, 408

villosum, 409

virens, 420

viscosum, 406

Vulcani, 403

Wageneri, 411

Webbii, 407

Wilkesianum, 413

Wilkesianum, 424

Wrightii, 401

xan thoneuron, 406

\section{ACTINIOPTERIS.}

australis, 246

radiata, 246

Actinostachys, see Schizad.

Adenophorus, see PolypoDIUM.

Adrantopsis, see Cheilan-
Adiantum.

aethiopicum, 123

affine, 117

affine, 117

alarconianum, 122

amœnum, 126

angustatum, 126

asarifolium, 114

assimile, 123

betulinum, 116

brasiliense, 121

calcareum, 115

cantoniense, 114

Capillus-Junonis, 452

Capillus-Veneris, 123

cardiochlæna, 118

Catherinæ, 118

caudatum, 115

cay'ennense, 121

chilense, 123

colpodes, 124

concinnum, 123

crenatum, 120

cristatum, 117

cristatum, 118

cubense, 119

cultratum, 118

cuneatum, 124

Cunninghami, 117

deflectens, 114

deltoideum, 121

denticulatum, 115

diaphanum, 117

digitatum, 125

dilatatum, 123

dolabriforme, 114

dolosum, 127

Edgeworthii, 115

emarginatum, 123

excisum, 123

falcatum, 122

Farleyense, 124

Feei, 125

filiforme, 114

flabellatum, 126

flexuosum, 125

formosum, 119

fovearum, 116

fragile, 124

fructuosum, 120

fulvum, 120

Galcottianum, 116

glanduliferum, 123

glaucescens, 118

glaucophyllum, 124

gracile, 119

grossum, 452

Henslovianum, 118

Hewardia, 127

hirtum, 119

hispidulum, 126

humile, 126

incisum, 122 
ADIANTUM (continued). intermedium, 116 Kaulfussii, 115

Kunzeanum, 118

Kunzei, 119

Leprieurii, 127

Lindeni, 120

Lindsæa, 126

Lobbianum, 120

lucidum, 121

lunulatum, 114

macrocladum, 118

macrophyllum, 121

Matthewsianum, 118

microphyllum, 122

microphyllum, 125

monochlamys, 125

nigrescens, 117

obliquum, 115

obtusum, 119

olivaceum, 127

Parishii, 114

patens, 126

pectinatum, 120

pedatum, 125

pentadactylon, 118

peruvianum, 116

philippense, 114

Phyllitidis, 121

platyphyllum, 121

polyphyllum, 118

politum, 120

prionophyllum, 120

pseudo-capillus, 123

pubescens, 126

pulchellum, 120

pulverulentum, 122

pyramidale, 122

Reichenbachii, 118

reniforme, 114

rhizophorum, 115

scabrum, 123

Seemannii, 121

sessilifolium, 118

setulosum, 117

Shepherdi, 116

sinvosum, 116

soboliferum, 115

speciosum, 125

subcordatum, 116

subscandens, 123

sulphureum, 123

tenerum, 124

tetragonum, 126

tetraphyllum, 120

tomentosum, 118

trapeziforme, 118

tremulum, 114

triangulatum, 116

urophyllum, 118

Veitchii, 125

velutinum, 120

venustum, 125
Adiantum (continued). villosum, 122

Wilesianum, 120

Wilsoni, 127

Aglaomorpha, see PolyPODIUM.

Aleuritopteris, see CueiLANTHES.

Allantodia.

australis, 229

Brunoniana, 246

umbrosa, 227

Allosorus, see Pellesa.

A L

cethiopica, 44

alternans, 41

armata, 34

armata, 33, 450

armigera, 33

aspera, 33

aterrima, 38

atrovirens, 34, 450

australis, 40

blechnoides, 32

Brunoniana, 39

caudata, 42

celebica, 41

chimborazensis, 37

Colensoi, 40

comosa, 30

comosa, 41

compta, 34

conjugata, 37

contaminans, 41

crenulata, 4.1

crinita, 42

Currori, 44

decurrens, 39

elegans, 32

elongata, 34

excelsa, 40

excelsa, 32

frigida, 38

Gardneri, 33

gibtosa, 34

gigantea, 43

glabra, 43

Godmani, 36

hirta, 35

Hookeriana, 33

Humboldtii, 35

infesta, 34

intermedia, 41

Junghuhniana, 31, 41

latebrosa, 43

Leichhardtiana, 450

lepifera, 42

leucolepis, 34

lunulata, 41

luvida, 43

Macarthurii, 43, 450
Alsophila (continued).

marginalis, 32

melanopus, 37

mexicana. 38

microphylla, 36

Miersii, 32

Moorei, 450

myosuroides, 38

nigra, 35

nitens, 34

novæ-caledoniæ, 39

oblonga, 30

obtusiloba, 45

paleolata, 32

phalerata, 34

phegopteroides, 32

plagiopteris, 35

podophylla, 43

Poeppigii, 35

procincta, 449

procera, 33

pruinata, 38

pubescens, 449

pungens, 33

pycnocarpa, 36

radens, 35,450

ramispina, 42

Rebecca, 450

rigidula, 35

Robertsiana, 450

sagittifolia, 37

Salvinii, 36

samoensis, 39

Schiedeana, 33

Sellowiana, 32

senilis, 34

setosa, 449

Sprucei, 37

squamata, 36

squamulata, 43

subglandulosa, 44

talitensis, 40

tenera, 39

Tunitis, 32

tomentosa, 42

tristis, 44

truncata, 39

villosa, 35.

A mblia, see Aspidium.

Ampelopteris, see PolypoDIOM.

A mphiblestra, see Pteris.

Aмphicosmia, see Heмi TELIA.

Anapeltis, see Polypodiom.

Anchistea, see Wood. WARDIA.

ANEMIA.

adiantifolia, 434

authriscifolia, 433 
Aremra (continued). asplenifolia, 434 aurita, 435 bipinnata, 435 Breuteliana, 431 Breuteliana, 432 buniifolia, 435 caruifolia, 434 caudata, 432 cicutaria, 435 ciliata, 433 collina, 431 collina, 432 cuneata, 434 deltoidea, 433 densa, 435 dentata, 431 dichotoma, 435 dissecta, 433 diversifolia, 435 Dregeana, 431 elegans, 436 ferruginea, 434 filiformis, 431 filiformis, 433 flexuosa, 433 fraxinifolia, 435 fulva, 433 Gardneri, 431 Gardneriana, 432 glareosa, 432 glareosa, 434 glomerata, 434 gracilis, 433 hirsuta, 433 hirta, 432 hispida, 433 humilis, 431, 433 imbricata, 434 incisa, 433 laciniata, 435 Langsdorffiana, 433 longifolia, 435 macrophylla, 435 mandioccana, 432 mandioccana, 432 mexicana, 433 millefolia, 436 obliqua, 435 oblonga, 434 oblongifolia, 431 pallida, 433 Phyllitidis, 435 Phyllitidis, 433 pilosa, 431 Pohliana, 433 radicans, 432 Raddiana, 434 repens, 433 votundifolia, 432 rubrostipes, 434 "utopfolia, 434 Schimperiana, 434
Anemia (continued), Schraderiana, 434

Seemanni, 431

sorbifolia, 435

speciosa, 433

tenella, 433

tenuifolia, 435

tomentosa, 433

trichorhiza, 434

Tweediana, 434

vellea, 432

Vespertilio, 435

villosa, 433

Wightiana, 434

Wrightii, 435

A nemidictron, see A nemia.

Anemirhiza, see A nemia.

Anetium, see Hemionitrs.

ANGIOPTERIS.

evecta, 440

Anisocampium, see NepHroDIUM.

Anisogonium, see AspleNIUM.

Antigrame, see SoolopenDRIUM.

ANTROPHYUM.

angustatum, 393

Boryanum, 394

Brookei, 392

callæfolium, 393

cayennense, 394

coriaceum, 393

Cumingii, 393

ensiforme, 393

Féei, 394

giganteum, 394

immersum, 393

lanceolatum, 394

latifolium, 394

Lessoni, 393

lineatum, 392

Mannianum, 394

nanum, 393

niphoboloides, 351

parvulum, 393

plantagineum, 393

pumilum, 393

reticulatum, 393

semicostatum, 393

subfalcatum, 392

subsessile, 394

A PAlOPhlebia, see PoLYPODIUM.

Arachnomes, sce Aspidium.
ARthrobotrys, see NePhroDIUM.

Arthrodandea, see Danfen.

Arthropteris, zee NephroDIUM and NEPHROLEFIS.

AsPIDIUM.

abbreviatum, 257

abortivum, 292

abruptum, 263

acrostichoides, 250

acrocarpon, 281

aculeatum, 252

alatum, 296

alsophilaceum, 265

amabile, 254

anplum, 285

angulare, 252

angulatum, 258

anomalum, 253

apiifolium, 297

argutum, 275

aridum, 291

aristatum, 255

ascendens, 255

asperulum, 266

attenuatum, 290

auriculatum, 251

Barteri, 299

Berteroanum, 255

biaristatum, 252

caducum, 257

calcareum, 259

californicum, 253

canariense, 272

capense, 254

Capitainei, 266

caryotideum, 257.

chærophylloides, 276

cheilanthoides, 270 .

cicutarium, 299

cirrhosum, 454

correinnum, 277

coniifolium, 256

conioneuron, 289

coriaceum, 255

Cornu-Cervi, 256

Ctenitis, 265

cucullatum, 290

cystostegia, 253

decrescens, 270

decurrens, 299

decurtatum, 292

dilaceratum, 300 .

dimorpluum, 294

dissectum, 290

echinatum, 266

edentulum, 279

emarginatum, 262

extensum, 289

fulcatum, 257

falcinellum, 249 
AsPIDIUM (contínued). fimbriatum, 258

flexum, 255

foniculaceum, 256

Forsteri, 297

frondosum, 255

Funckii, 268

Germani, 266

giganteum, 259,500

glundulosum, 249

gongylodes, 289

gracilescens, 262, 267

grande, 299

grandifolium, 298

Gueintzlanum, 269

guianense, 257

Hamiltonii, 256

heracleifolium, 258

heterocarpon, 293

heterolepis, 251

hispidulum, 293

Hookeri, 257

Hookeri, 292

ilicifolium, 251

immersum, 298

insigne, 262

intermedium, $2 \pi 6$

irregulare, 298

irriguum, 297

juglandifolium, 257

Karwinskyanum, 279

Kingii, 249

Klotzschii, 287

lachenense, 250

laserpitiifolium, 254

latebrosum, 294

latifolium, 297, 300

lentum, 251

lepidocaulon, 250

leptorachis, 276

lobatum, 252

Lonchitis, 250

-longipes, 290

luctuosum, 252

Ludovicianum, 272

lugubre, 266

lutescens, 285

macrourum, 262

macrophyllum, 300

maderense, 250

marginatum, 251, 272

megaphyllum, 292

melanochlamys, 256

melanocaulon, 296

melanostictum, 256

membranaceum, 259

meniscioides, 257

Meyanthidis, 297

mohrioides, 252

molle, 289

Moritzianum, 252

mucronatum, 250

multidentatum, 91
AsPIDIOM (continued). multifidum, 256

multilineatum, 291, 292

multijugum, 291

munitum, 249

nephrodioides, 258

nitidunı, 265

obliquatum, 264

obliquum, 251

obscurum, 291

obtusum, 252

ocellatum, 251

oculatum, 253

odoratum, 280

oligocarpum, 268

ordinatum, 252

pachyphyllum, 299

pallidum, 275

paludosum, 294

palustre, 270

pauciflorum, 265

pellitum, 293

pennigerum, 292

pilosiusculum, 293

plantagineum, 258

Plaschnichianum, 249

platanifolium, 258

Plumieri, 258

Pica, 298

pilosulum, 268

polymorphum, 297

Prescottianum, 253

procurrens, 290

proliferum, 252

prolixum, 268

propinquum, 289

pteropus, 299

puberulum, 298

pungens, 252

ramosum, 301

repandum, 258

rhizophyllum, 248, 249

Richardi, 253

rivulorum, 268

sagenioides, 271

Schimperianum, 272

Schweinitzii, 250

Seemannii, 255

semicordatum, 249

semibipinnatum, 297

sesquipedale, 301

setosum, 274

Shepherdi, 281

siifolium, 299

Sikkimense, 256

Singaporianum, 296

sinuatum, 258

spinuloso cristatum, 273

squamigerum, 265

squarrosum, 252

stimulans, 251

stipitatum, 278

stipulaceum, 269
Aspidium (continued).

stipulare, 262

subglandulosum, 285

subsericeum, 281

subtriphyllum, 296

sulcatum, 265

syrmaticum, 272

Teysmannianum, 299

Thomsoni, 251

trapezioides, 251

Trianæ, 286

triangulum, 250

tridens, 251

trifoliatum, 258

trifoliatum, 298

tripteron, 254

truncatum, 294

tsus-simense, 252

uliginosum, 284

undulatum, 276

variolosum, 298

varium, 253

vastum, 296

velleum, 265

venulosum, 291

vestitum, 252

Vieillardii, 282

violascens, 293

viviparum, 251

Zollingerianum, 298

AsPIDotis, see HyPoLEPIS.

Asplenidictyon, sce AspleNIUM.

\section{AsPleniom.}

abscissum, 203

abyssinicum, 220

achillecefolium, 227

acuminatum, 218

acuminatum, 235

Adiantum-nigrum, 214

adiantoides, 213

adiantoides, 217

affine, 215

alatum, 200

alienum, 242

alismcefolium, 243

alternans, 194

alternifolium, 231

amabile, 205

anceps, 197

angustum, 191

angustifolium, 199

angustatum, 217

anisodontum, 205

anisophyllum, 204

arboreum, 233

arborescens, 240

arcuatum, 197

Arnottii, 240

asperum, 238 
ASPLENIUM (continued). aspidioides, 228 attenuatum, 194 auriculatum, 203 auvitum, 208 australasicum, 191 australe, 229

bantamense, 231

Barteri, 202

basilare, 229

Belangeri, 223

bifissum, 220

bipinnatifidum, 221

bipartitum, 212

bissectum, 211

Blakistoni, 216

Boltoni, 204

borbonicum, 222

borneense, 203

Bourgæi, 216

brachypteron, 221

Brackenridgii, 234

brevisorum, 228

bulbiferum, 218

Callipteris, 231

camptorachis, 202

caracasanum, 233

castaneum, 197

caucense, 454

caudatum, 209

celtidifolium, 282

Ceterach, 245

chimborazense, 244

chinense, 237

chocoense, 244

cicutarium, 220

cladolepton, 220

coarctatum, 233

Colensoi, 219

comorense, 240

compactum, 219

compressum, 206

conchatum, 228

concinnum, 220

concolor, 191

contiguum, 205

cordifolium, 243

coriaceum, 192

costale, 236

costale, 227

crassidens, 232

crenato-serratum, 230

crenatum, 454

crenulans, 232

crenulatum, 224, 236, 454

crenulatum, 193

crinicaule, 205

cristatum, 210

cultratum, 231

cuneatum, 214

Curvori, 192

cyathecefolium, 238
Aspueniom (continued: cyrtopteron, 205

cystopterioides, 225

Dalhousiæ, 194

davallioides, 222

decipiens, 227

decurtatum, 226

decussatum, 243

delicatulum, 219

deltoideum, 237

densum, 197

dentatum, 196

deparioides, 226

Desvauxii, 236

dicholomum, 221

difforme, 207

dilatatum, 239, 245

dimidiatum, 209

dimorphum, 223

distans, 109

dissectum, 214

divaricatum, 219

divergens, 216

diversifolium, 200, 239

divisissimum, 242

Dombeyi, 228

Doreyi, 201

Dregeanum, 221

drepanopteron, 228

dubiuni, 220, 236, 241

ebenoides, 191

ebeneum, 198

ebenum, 238

elatum, 233

elegans, 243

elegantulum, 217

elongatum, 201

emarginatum, 200

enatum, 205

ensiforme, 191

erectum, 202

erosun, 208

esculentum, 244

exiguum, 216

expansum, 241

extensum, 197

Fabianum, 218

Fadyeni, 220

falcatum, 206

falcatum, 208

fallax, 227

feejeense, 192

ferulaceum, 224

Fernandesianum, 202

firmum, 203

firmum, 206

Finlaysonianum, 245

Filix-fomina, 227

fimbriatum, 229

fi:sum, 213

flabellifolium, 195

flibellatum, 205

flaccidum, 222
Asplentum (continued).

flavescens, 232

flexuosum, 208

flexuosum, 241

founiculaceum, 216

foliolusum, 227

fontanum, 216

for'mosum, 201

fragile, 195

fragrans, 205

fragrans, $216^{\circ}$

Franconis, 235

fraxinifolium, 231

fraxilleum, 382

frondosum, 238

fuliginosum, 203, 454

furcatum, 214,221

fuscopubescens, 242

Galeottii, 197, 228

Gaudichaudianum, 214

Gautieri, 193

gemmiferum, 207

germanicum, 212

Gibertianum, 219

Gilliesianum, 193

Goringianum, 227

gracile, 202, 228

gracilescens, 242

grammitoides, 226

grandifolium, 231

Grevillei, 191

Grifithianum, 193

Griffithii, 239

gyinnogrammoides, 227

Hallii, 211

Hancei, 208

harpeodes, 202

hastatum, 205

Hermionitis, 194

Hender'soni, 198

herbaceum, 219

heterodon, 201

lieterocarpum, 210

heterophlebium, 213

Heufleri, 196

hians, 214

lirtum, 205

Hohenackerianum, 225

Hookerianum, 213

horridum, 211

humile, 230

imbricatum, 219

Imrayauum, 207

inæquilaterum, 233

incisum, 217

induratum, 205

integrum, 193

integerrimum, 200

irregulare, 222

Jamesoni, 218

japonicum, 234

juglandifolium, 232, 234

Klotzschii, 241 
Aspleniom (continued).

Kraussii, 195

Kunzei, 243

laciniatum, 211

lotum, 210

lanceslatum, 217

lanceum, 229

laserpitiifolium, 215

lasiopteris, 235

latifolium, 228

latifolium, 239

laxum, 218, 228

Lechleri, 231

lepidum, 454

Lindbergii, 236

Lindeni, 218

lineolatum, 243

Lobbianum, 232

lobulosum, 234

longifolium, 234

lucidum, 207

lugubre, 454

Lyallii, 207

macilentum, 208

macrocarpum, 227

macrophyllum, 209

macrosorum, 206

magellanicum, 213

Mannii, 221

marinum, 207

Martensi, 228

maximum, 239

medium, 225

melanochlamys, 239

melanocaulon, 240

Mertensianum, 218

Meyenianum, 238

molle, 228

montanum, 213

montverdense, 220

mucronatum, 212

multifidum, 224

multisectum, 228

muricatum, 229

mutilum, 233

myriophyllum, 220

neglectum, 232

nervosum, 237

Newmanni, 454

nicotianæfolium, 454

nigripes, 227

nigripes, 248

nigritianum, 215

nigro-paleaceum, 240

niponicum, 227

nitens, 206

nitidum, 215

nova-caledoniae, 223

obesum, 209

obliquum, 207

obovatum, 217

obtusatum, 207
Asplenium (continued).

obtusum, 214

obtusilobum, 221

officinarum, 245

Otites, 210

Ottonis, 233

oxyphyllum, 228

paleaceum, 208

pallidum, 230

paradoxum, 209

pectinatum, 228

pellucidum, 205

pinnatifido-pinnatum, 231

plantagineum, 239

planicaule, 211

platybasis, 206

polypodioides, 238

porrectum, 230

Powellii, 224

præmorsum, 215

Prescottianum, 233

Prionitis, 204

proliferum, 228, 233

prolongatum, 222

protensum, 211

pseudo-nitidum, 217

pulicosum, 240

pulchellum, 210

pumilum, 212

puncticaule, 227

Purdieanum, 245

rachirhizon, 205

radicans, 241

refractum, 216

repens, 219

resectum, 210

vhizoplcorum, 204

rhizophgllum, 220

rhœticum, 228

rhoifolium, 232

Richardi, 222

rigidum, 208

riparium, 203

rivale, 244

robustum, 244

Roemerianum, 232

rutaceum, 220

rutcefolium, 222

Ruta-muraria, 213

Sampsoni, 223

Sandwichianum, 242

sanguinolentum, 204

scandens, 224

scandicinum, 228

scandicinum, 215

Schiedei, 233

Schimperi, 228

Schkuhrii, 235

scleropium, 207

Seemannii, 231

semihastatum, 233

sepulchrale, 213
A SPLENiUM (continued). serampurense, 244

Serpentini, 214

Serra, 206

serræforme, 210

sessilifolium, 219

Shepherdi, 233

Shuttleworthianum, 218

Skinneri, 226

Smithianum, 245

solenopteris, 227

solidum, 214, 454

sororium, 239

sorzogonense, 266

spathulinum, 215

speciosum, 235

spinulosum, 225

splendens, 214

Sprucei, 234

squamosum, 218

squamigerum, 237

stans, 222

stenocarpum, 244

stramineum, 228

striatum, 233, 236

strictum, 220

subsinuatum, 229

subservatum, 230

subtriangulare, 225

sylvaticum, 232

tenellum, 228

tenerrimum, 212

tenuifolium, 220

tenuifrons, 228

ternatum, 219

ternatum, 242

thelypteroides, 226

Thunbergii, 223

Thwaitesii, 235

tomentosum, 234

Trianæ, 232

triphyllum, 219

umbrosum, 229

vagans, 195

varians, 216

variabile, 194

vastum, 241

Veitchianum, 223

venosum, 192

venulosum, 238

vestitum, 239

Vieillardii, 200

virens, 201

virescens, 237

viride, 195

vitiense, 245

viviparum, 223

vomeriforme, 206

vulcanicum, 201

Wardii, 217

Welwitschii, 235

Wichurce, 233

Wightianum, 199 
A SPLENiom (continued)

Wilsoni, 242 woodwardioides, 229

Wrightii, 204

zamioides, 209

Zenkerianum, 202

zeylanicum, 230

Astryrium, see Asplentum.

Balantidu, see Dicksonia.

Bathmiom, see Aspidiom.

Blechnidium, see Blechnum.

\section{Blechnum.}

acuminatum, 185

arcuatum, 115

asplenioides, 183

australe, 186

brasiliense, 184

campylotis, 185

cartilagineum, 184

corcovadense, 184

diversifoliuın, 181

Fendleri, 185

Finlaysonianum, 187

fraxineum, 185

gracile, 185

hastatum, 185

intermedium, 185

Lanceola, 183

lavigatum, 186

Lechleri, 179

longifolium, 185

snelanopus, 186

nitidum, 184

oocidentale, 185

opacum, 176

orientale, 186

pectinatum, 185

plantagineum, 183

polypodioides, 184

remotum, 186

scandens, 187

Schlimense, 185

seminudum, 375

serrulatum, 186

striatum, 186

triangulare, 184

unilaterale, 184

Vieillardii, 175

vittatum, 184

volubile, 187

Bolbitis, see Acrostichum

\section{BOTRYCHIUM.}

anthemoides, 448

australe, 448

boreale, 447

brachystachys, 448

cicutarium, 448

crassinervium, 447
Botrychium (continued).

daucifolium, 448

decompositum, 448

dissectum, 448

Kannenbergii, 447

lanceolatum, 447

lanuginosum, 448

Lunaria, 447

lunarioides, 448

matricariæfolium, 447

matricarioides, 448

obliquum, 448

palmatum, 448

v'utaceum, 447

rutæfolium, 448

silaifolium, 447

simplex, 447

subbifoliatum, 448

subcarnosum, 448

ternatum, 448

virginianum, 448

Botryopteris, see HelminTHOSTACHYS.

Brachysorus, see AspleNIUM.

Brainea.

insignis, 390

Calymnodon, see PolypoDruM.

CAmpteria, see Pteris.

Camptodiom, see NephroDIUM.

Camptosonus, see ScoloPENDRIUM.

Campylonedron, see PolyPODIUM.

Cassebeera.

gleichenioides, 143

pinnata, 142

triphylla, 142

Cephalomanes, see TrichoMANES.

Ceratopteris.

thalictroides, 174

Ceropteris, see GyanoGRAMME.

Ceterach, see Asplenium.

Cheilanthes.

allosuroides, 137

andina, 134

arabica, 134

argentea, 142

aspidioides, 135

Atherstonii, 150
Cheilanthes (continued). aurantiaca, 141

aurea, 453

Barklyæ, 151

Bradburii, 141

bullata, 137

capensis, 132

cheiloglyphus, 140

chlorophylla, 133

chusana, 135

chryophylla, 142

coriacea, 134

cucullans, 135

cuneata, 150

Dalhousiae, 137

dealbata, 142

Eatoni, 140

elegans, 140

elongata, 135

farinosa, 142

fasciculata, 134

Fendleri, 139

fimbriata, 139

flexuosa, 138

fragilis, 135

fragrans, 134

frigida, 141

Gardneri, 131

glandulosa, 136

gracilis, 139

gracillima, 139

hirta, 136

hispanica, 136

incisa, 133

induta, 138

Kirkii, 132

Kuhnii, 453

lanosa, 139

lanuginosa, 139

lendiger a, 141

leucopoda, 136

Lindheimeri, 140

Lindigii, 453

Mac.Leanii, 135

maderensis, 134

malaccensis, 137

marginata, 151

marsupianthes, 140

Matthewsii, 134

micromera, 135

microphylla, 135

micropteris, 134

minor, 141

monticola, 131

Moritziana, 135

multifida, 138

myriophylla, 140

mysurensis, 135

obtusata, 135

ochracea, 141

odora, 134

olivacea, 136

paleacea, 140 
Cheilanthes (continued). parviloba, 136

paupercula, 132

pedata, 132

pilosa, 135

Preissiana, 137

propinqua, 453

pruinata, 134

pulchella, 134, 136

pulveracea, 373

pygmæa, 135

pyramidalis, 151

radiata, 132

Radula, 130

regularis, 131

rufa, 140

rufa, 141

scabra, 130

scariosa, 140

Schimperi, 133

Seemanni, 133

setigera, 284

Sieberi, 137

speciosissima, 141

suaveolens, 134

subvillosa, 137

Szovitzii, 139

tenvifolia, 138

tenuis, 136

tomentosa, 140

Tweediana, 135

varians, 136

vestita, 134

vestita, 139

viscosa, 136

Welwitschii, 142

Wrightii, 138.

Cheiloplecton, see Pellea.

Cheiroglossa, see OphioGLOSSUM.

Cheiropleuria, see AcroSTICHUM.

Chnoophora, see Alsophila.

Chrysodidm, see AcrostiCHUM.

Cibotium, see Dicksonia.

Cincinalis, see NothoCHLENa.

Cionidium, see Deparia.

Cnemidaria, see Hemitelia.

Cochlidium, see MonoGRAMME.

Cerlopteris, see PolypoDIUM.

Colysis, see Polypodium.

Uoniogramme, see GrmnoGRAMME.
Cotophyllum, see Anemia.

Craspedaria, see PolypoDIUM,

Craspedoneuron, see TriCHOMANES.

Crepidomanes, see TrichoMANES.

Crypsinus, see Pouypodium.

Cryptogramme.

acrostichoides, 144

Brunoniana, 144

crispa, 144

Cryptosorus, see PolypoDIUM.

Cuspidaria, see Tanitis.

\section{Crathea.}

affinis, 27

aneitense, 26

angolensis, 22

arachnoidea, 24

arborea, 16

arborea, 24

assimilis, 24

balanocarpa, 17

Beyrichiana, 19, 449

bicrenata, 17

Brunonis, 16

Burkei, 21

camerooniana, 21

canaliculata, 23

caracasana, 34

crenulata, 23

Cunninghami, 25

cuspidata, 17

dealbata, 26

Delgadii, 19

denudans, 20

divergens, 17

Drègei, 21

ebenina, 20

elegans, 16

equestris, 19, 449

excelsa, 22

excelsa, 23

extensa, 27

frondosa, 18

Gardneri, 20

gracilis, 18

Grevilleana, 16

hirtula, 19, 449

Hookeri, 16

hymenodes, 24

Imrayana, 17

incana, 18

insignis, 17

integra, 23

javanica, 23

Kirkii, 22
Crathea (continued).

Korthalsii, 25

leucolepis, 26

Iindsayana, 25

Lobbiana, 24

Manniana, 21

medullaris, 25

Mertensiana, 41

Mettenii, 18

mexicana, 20

microphylla, 21

Milnei, 26

minor, 16

muricata, 17

nigrescens, 33

nigricans, 26

orientalis, 24

pallida, 16, 24

petiolata, 23

propinqua, 27

sarawakensis, 23

Schanscliin, 19

Sechellarum, 22

Sellowiana, 32

serra, 17

sinuata, 16

speciosa, 28

spinulosa, 23

Sprucei, 20

squamipes, 18

subnudata, 17

Tussacii, 17

vestita, 19

Vieillardii, 27

villosa, 35

Welwitschii, 21

Crclodium, see Aspidiom.

Cyclopeltis, see Aspidium.

Cyrtomium, see Aspidium.

Crrtomiphlebium, see PolyPODIUM.

Crstopteris.

alpina, 103

atomaria, 103

bulbifera, 103

dimidiata, 91

Douglasii, 103

fragilis, 103

montana, 104

sand wicensis, 103

spinulosa, 225

squamata, 92

sudetica, 103

tasmanica, 103

tristis, 44

DANAA.

alata, 443

Augustii, 443

cuspidata, 444

dubia, 444 
Danaa (continued). elliptica, 444 geniculata, 444 humilis, 443 longifolia, 444 Moritziana, 443 nodosa, 444 paleacea, 444 Sellowiana, 444 simplicifolia, 442 stenophylla, 443 trichemanoides, 442 trifoliata, 442

\section{Danmopsis, see Datean.}

Darea, see Asplentum.

\section{Davallia.}

aculeata, 102

affinis, 92

alpina, 89

amboynensis, 100

angustata, 88

assamica, 452

Belangeri, 89

bifida, 101

bipinnatifida, 90

Blumeana, 93

Boryana, 93

botrychioides, 90

bullata, 97

calvescens, 98

campyleura, 99

cunariensis, 97

caudata, 95

chcerophylla, 92, 452

chinensis, 102

ciliata, 98

clavata, 102

concinna, 100

coniifolia, 96

corniculata, 96

Cumingii, 90

decurrens, 95

Denhami, 100

denticulata, 452

divaricata, 96

elata, 95

elegans, 95,452

epiphylla, 96

falcinella, 91

ferulacea, 92

fijiensis, 97

flaccida, 96

foniculacea, 101

fumarioides, 102

gibberosa, 100

Goudotiana, 101

gracilis, 98

Griffithiana, 96

hemiptera, 93

heterophylla, 88
Dafalima (continued).

hirsuta, 452

hirta, 100

Hookeriana, 97

hymenophylla, 452

hymenophylloides, 93

immersa, 91

Imrayana, 90

incequalis, 99

jamaicensis, 100

Khasyana, 99

Lindeni, 100

Lindleyi, 95

Lobbiana, 94

lonchitidea, 99

longula, 89

Lorrainei, 452

luzonica, 98

madagascariensis, 100

marginalis, 452

mauritiana, 96

Melleri, 102

membranulosa, 91

micans, 95, 452

Moorei, 95

multidentata, 91

nigrescens, 101

nitidula, 97

nodosa, 92

Novae Zelandiae, 91

papillosa, 100

parallela, 89

Parishii, 90, 432

parvula, 92

patens, 96

pectinata, 89

pedata, 89, 452

pentaphylla, 94

pilosella, 98, 452

pinnata, 98

platyphylla, 99

polyantha, 96

polypodioides, 100

Preslii, 94

proxima, 100

pseudo-cystopteris, 452

pulchella, 93

pulchra, 91, 452

pusilla, 89

pycnocarpa, 94

pyxidata, 98

repens, 93,452

rhomboidea, 97

Saccoloma, 97

Schimperi, 100

Schlechtendahlii, 103

scoparia, 101

serrata, 98

sessitifolia, 89

solida, 95

Spelunca, 100

strigosa, 98

tenuifolia, 93
Davalira (continued).

tenuifolia, 102

thecifera, 100

Thwaitesii, 99

trichomanoides, 72

trichosticha, 100

triphylla, 94

triquetra, 93

uncinella, 102

urophylla, 99

vestita, 90

villosa, 98,452

Vogelii, 95

Davalliopsis, see TrichoMANES.

DEPARIA.

concinna, 55, 451

Macræi, 55

Moorei, 55

producta, 451

prolifera, 55

\section{Diacalpe.}

aspidioides, 45

\section{Diblejma, see Polypodium.}

\section{DICKSONIA.}

abrupta, 52

adiantoides, 52

antarctica, 50

anthriscifolia, 53

apiifolia, 53

appendiculata, 54

arborescens, 50

assamica, 49

Barometz, 49

Berteroana, 51

Blumei, 50

Chamissoi, 50

chrysotricha, 50

cicutaria, 53

coniifolia, 51

consanguinea, 52

cornuta, 53

Culcita, 51

davallioides, 54

deltoidea, 54

dissecta, 52,53

dubia, 51

erosa, 52

fibros $\alpha, 50$

flaccida, 53

glauca, 49

glaucescens, 49

lauata, 50

Lindeni, 52

magnifica, 50

Martiana, 51

Menziesii, 49

moluccana, 53 
Dicrsonia (continued). nitidula, 54

obtusa, 52 obtusifolia, 54 ordinata, 53

Pavoni, 54

Plumieri, 52 punctiloba, 54 rubiginosa, 53 scabr'a, 54 Schiedei, 50

Sellowiana, 50

Smithii, 54

sorbifolia, 52 squarrosa, 51 straminea, 52

tenera, 53

thyrsopteroides, 51

Torreyana, 52

Diclidopteris, see MonoGRAMME.

Diclosodon, see NepHroDIUM.

Dictymia, see Polypodium.

Dictyopteris, see PolypoDIUM.

\section{DIDYMOCHLANA.}

\section{lunulata, 248}

polycarpa, 248

Didymoglossum, see HyMtNOPHYLLUM.

Dielita, see Lindsaya.

Digrammaria, see AspleNIUM and GYMNOGRAMME.

Diplazidu, see Asplentum.

Dipteris, see Polypodium.

Discostegia, see Marattia.

Doodia.
aspera, 189
blechnoides, 189
caudata, 190
connexa, 190
dives, 189
linearis, 190
media, 190

\section{Doryopteris, see Pteris.}

\section{DRYMOGLOSSUM.}

carnosum, 397

piloselloides, 398

vigidum, 397

subcordatum, 397
DRYOMENIS, see AsPIDIOM.

Dryopteris, see NepHroDIUM.

Dryostachyom, see PolyPODIOM.

Egenolfia, see AcrostiCHUM.

Elaphoglossum, see adroSTICHUM.

Ertosorus, see GrmnoGRAMME.

Eupodium, see Marattia.

FADYenta. prolifera, 303

Frea, see Trichomanes.

Galeoglossa, see PolypoDIUM.

GISOPTERIS, see LygodIUM.

Gleichenta.

acutifolia, 13

alpina, 12

arachnoides, 12

bifurcata, 14

Boryi, 12

bracteata, 14

bullata, 12

circinata, 11

crassifolia, 15

cryptocarpa, 13

Cunninghami, 13

dicarpa, 12

dichotoma, 15

emarginata, 15

farinosa, 14

ferruginea, 15

flabellata, 12

flagellaris, 14

furcata, 14

gigantea, 12

glabra, 12

glauca, Sw., 11, 449

glauca, $H k ., 12$

glaucescens, 15

grandis, 14

Hawaiensis, 14

hecistophylla, 12

Hermanni, 15

hirta, 14

inmmersa, 14

Klotzschii, 15

lævigata, 14

longipinnata, 14

longissima, 12

Mathewsii, 14

microphylla, 11

moniliformis, 11
Graichenta (continued).

owhyhensis, 14

pallescens, 449

pectinata, 15

pedalis, 13

pinnata, 12

plumæformis, 14

polypodioides, 11

pruinata, 13

pteridifolia, 15

pubescens, 13

quadripartita, 13

revoluta, 13

revoluta, 15

rubiginosa, 449

rufinervis, 15

rupestris, 12

semivestita, 11

simplex, 13

Speluncæ, 11

subflabellata, 13

tenera, 12

tomentosa, 14

umbraculifera, 13

vestita, 14

vulcanica, 12

Glyphotaniom, see PolypoDIUM.

GoniophlebIUM, see PolypoDIOM.

Goniopteris, see PoLypoDIUM.

Grammitis, see Poltpodium and GYMNOGRAMME.

\section{GYMNOGRAMME.}

adiantoides, 385

alismafolia, 386

ambigua, 378

Andersoni, 380

angustifrons, 380

argentea, 384

Ascensionis, 383

aspidioides, 378

asplenioides, 376

asplenioides, 378

aurea, 384, 385

aureo-nitens, 382

aurita, 377

avenia, 388

borneensis, 386

calomelanos, 385

cartilagidens, 386

caudiformis, 389

choerophylla, 383

cheilanthoides, 382

chrysophylla, 385

consinuilis, 377

conspersa, 385

cordata, 379 
GrMnogramme (continued). corduta, 381 dealbata, 384 decipiens, 381 decurrens, 389 decurrenti-alata, 377 diplazioides, 377 elliptica, 389 elongata, 386 elongata, 387 Féei, 389 ferruginea, 381 flabellata, 382 flavens, 374 flexuosa, 384 glandulosa, 384 gracilis, 377 grandis, 377 guianensis, 385 Hamiltoniana, 389 Haughtoni, 381 heterocarpa, 389 hirsutula, 380 hirta, 384 hispanica, 379 hispidula, 384 Hookeri, 381 incisa, 380 intermedia, 385 involuta, 387 japonica, 396 javanica, 381 javanica, 382 Karstenii, 380 lanata, 381 lanceolata, 387 laserpitiifolia, 384 leptophylla, 380 L'Herminieri, 385 Lindigii, 381 Linkiana, 377 Lobbiana, 380 Lowei, 376 macrophylla, 388 marginata, 378 Martensii, 385 Massoni, 385 Matthewsii, 382 membranacea, 383 mexicana, 387 microphylla, 383 mohriceformis, 380 Muelleri, 379 myriophylla, 383 obtusata, 378 obtusifolia, 386 ochracea, 384 opaca, 378 ornithopteris, 385 Ottonis, 381 palmata, 389 papaverifolia, 379 Pearcei, 384
Grmnogramme (continued). pedata, 383 pedunculata, 389 peruviana, 385 pilosa, 376 pilosa, 382 pinnata, 389 podophylla, 390 polypodioides, 377

Pozoi, 379 pulchella, 385 pumila, 379 quinata, 387 regularis, 388 reniformis, 378 retrofracta, 384 rosea, 385

rufa, 379

rupestris, 377 rutæfolia, 379

Salvinii, 387 Schomburgkiana, 382 serra, 382 serrulata, 382 spuria, 388 Steltzneri, 385 subsimilis, 313 subtrifoliata, 390 sulphurea, 385 tartarea, 384 tomentosa, 380 Totta, 376 triangularis, 384 trifoliata, 384 vestita, 379 villosa, 376 vittceformis, 386 Wallichii, 386

Wallichiana, 387

Warcewiczii, 382

Wettenhalliana, 385

Wrightii, 388

Grmnopteris, see AcrostiCHUM.

Grmanosphera, see AlsoPHILA.

Gymotheca, see Marattia.

Gynosorium, see PolypoDIUM.

Habrodictyon, see TrichoMANES.

Haplodictyum, see NephroDIUM.

Hecistopteris, see GyMnoGRAMME.

\section{HeLminthostachYs.}

dulcis, 447

zeylanica, 447
HEMESTHEUM, see NePhRoDIUM.

Hemidictyum, see AspleNIUM.

\section{Hemionitis.}

citrifolia, 399

cordata, 398

Griffithii, 399

hedercefolia, 398

lanceolata, 398

palmata, 398

pinnata, 399

pinnatifida, 399

Wilfordii, 399

Hemiphlebium, see ThichoMANES.

\section{Hemitelia.}

alternans, 41 apiculata, 29 bella, 29 calolepis, 29 capensis, 29 crenulata, 41 denticulata, 31 grandifolia, 28 guianensis, 30 Hookeri, 28 horrida, 28

Imrayana, 28 integrifolia, 28 javavica, 31 Junghuniana, 31 Karsteniana, 27

latebrosa, 43 Lindeni, 29 macrocarpa, 449 Moricandiana, 30, 449 obtusa, 28

Parkeri, 30 petiolata, 28 platylepis, 29 servitensis, 30 setos $a, 449$ Smithii, 31 speciosa, 28 subincisa, 27 tripinnata, 31 Wulkerce, 30

Wilsoni, 30

Heterodan ala, see Danafa. Heterogonium, see GyMnoGRAMME.

Heterophlebium, see Pteris. Hewardia, see Adiantum.

Holcoohlana, see Pellata. Holcosorus, see PolypoDIUM. 
Homata, see Datallia.

Hydroglossum, see LygoDIUM.

HyMeNocystis, see WoODSIA.

Hymenodium, see AcrostiCHOM.

Hymenoglossum, see HymeNOPHYLLUM.

\section{HYMENOPHYLLUM.}

abruptum, 57

acanthoides, 71

aculeatum, 70

cruginosum, 64

affine, 69

amœnum, 59

andinum, 60

angustum, 63

antarcticum, 67

apicale, 58

asperulum, 67

asplenioides, 57

asterothrix, 66

atrovirens, 60

attenuatum, 70

axillare, 58

badium, 60 .

barbatum, 68

Bibraianum, 70

bivalve, 69

blepharodes, 70

borneense, 62

Boryanum, 63

Braunii, 71

brevifrons, 57

Bridgesii, 70

capillaceum, 58

Catherince, 67

caudatum, 61

caudiculatum, 61

chiloense, 63

ciliatum, 63, 451

corticola, 57

crispatum, 60

crispum, 59

cristatum, 70

cruentum, 56

Crugeri, 66

cubense, 66

cupressiforme, 67

dædaleum, 60

demissum, 61

dentatum, 70

denticulatum, 71

dichotomum, 70

dilatatum, 62

divaricatum, 65

Dregeanum, 67

elasticum, 64
HYMENOPHYLXUM (contd.).

elegans, 66

elegantulum, 66

emersum, 451

eriophorum, 66

erosum, 61

eximium, 62

exsertum, 58

feejeense, 69

fimbriatum, 60

flabellatum, 61, 76

flaccidum, 69, 451

flexuosum, 60

formosum, 62

Francavillei, 61

Franklinianum, 64, 451

fuciforme, 62

fucoides, 69

gracile, 58

Gunnii, 58

hirsutum, 63, 451

hirtellum, 64

holochilum, 69

intermuptum, 65

Jamesoni, 68

japonicum, 451

javanicum, 60

Junghuhnii, 62

Karstenianum, 66

lanceolatum, 64

latifrons, 63

Lindeni, 65

Lindigii, 65

lineare, 66

macroglossum, 58

magellanicum, 70

Malingii, 66

marginatum, 57

megachilum, 67

Menziesii, 67

Mettenii, 67

Meyeri, 67

micranthum, 76

microcarpum, 65

microphyllum, 451

microsorum, 59

minimum, 67

mnioides, 57

Moritzianum, 66

multifidum, 69

myriocarpum, 59

natalense, 58

Neesii, 71

nitens, 61

obtusum, 63

organense, 65

parvifolium, 56

Pastoensis, 67

pectinatum, 68

pedicellatum, 70

pendulum, 66

peruvianum, 70

platylobum, 65
HYMENOPHYLLUM (contd.).

Plumieri, 63

plumosum, 66

polyanthos, 60

Preslii, 69

procerum, 66

productum, 61

protrusum, 60

pteropodum, 65

pulcherrimum, 62

pulchellum, 67

pyriforme, 69

Raddianum, 63

rarum, 51

recurvum, 61

Reinwardtii, 61

reniforme, 59

Ruizianum, 65

sabinafolium, 71

scabrum, 61

secundum, 68

semibivalve, 58

sericeum, 66

Serra, 68

serrulatum, 69

seselifolium, 70

Simonsianum, 68

Smithii, 69

speciosum, 66

spectabile, 65

spinulosum, 70

Sprucei, 65

subtilissimum, 451

tabulare, 58

tasmanicum, 60

tenerrimum, 68

tomentosum, 66

torquescens, 70

tortuosum, 70

triangulare, 69

trichophyllum, 66

trifidum, 66

Tunbridgense, 67

undulatum, 59

unilaterale, 67

valvatum, 65

venustum, 63

Wilsoni, 67

zeelandicum, 67

Zollingerianum, 62

Hrmenostachys, see TrIChOMANES.

HyPochlaMrs, see AsPLinNIUM.

Hypodematium, see NephroDIUM.

\section{HYPODERRIS.}

Brownii, 46 


\section{HYPOLEPIS,}

alpina, 129 amaurorachis, 129 anthriscifolia, 129 aspera, 129

Bergiana, 130 californica, 131 capensis, 132 dicksonioides, 129 distans, 129 elata, 129 hostilis, 130 javanica, 129 millefolium, 130 nigrescens, 129 occidentalis, 128 pallida, 129 parallelogramma, 130 paupercula, 132 pedata, 132 polypodioides, 162 pteridioides, 129 Purdieana, 130 radiata, 132 repens, 129 resinifera, 129 resistens, 129 rudis, 129 rugulosa, 163 spectabilis, 133 stenophylla, 129 tenuifolia, 129

Isoloma, see LINDSAYA.

\section{JaMesonta.}

angustifrons, 380

canescens, 369

hispidula, 384 imbricata, 369 rotundifolia, 370 scalaris, 370 verticalis, 369

\section{KaUlfossta.}

aesculifolia, 444 assamica, 444

Lacostea, see Trichomanes. Lastrea, see Nephrodium.

Lecanium, see Tricho. MANES.

Lecanopteris, see PolypoDIUM.

Lepicystis, see PolypoDIOM.

Leptocioniom, see HrmenoPHXLLUM.

Leptogramme, see GymnoGRAMME.
|Leptopleuria, see DickSONIA.

LEPTOPTERIS, see TODEA.

Leucostegia, see Davallia.

\section{LINDSAYA.}

adiantoides, 104

alutacea, 110

arcuata, 107

borneensis, 107

botryclioides, 105, 452

Catherince, 106

caudata, 107

concinna, 105

cordata, 111

crenulata, 452

cultrata, 105

cuneata, 112

davallioides, 111

divergens, 109

dubia, 105

elegans, 108

elongata, 110

ensifolia, 112, 452

erecta, 113

falcata, 113

falcata, 107

falciformis, 104

filiformis, 106

flabellulata, 107

flabellulata, 105

Fraseri, 112

Gardneri, 107

gigantea, 107

Griffthiana, 112

Gueriniana, 111

guianensis, 117

heterophylla, 112

horizontinalis, 107

intermedia, 111

japonica, 105

Kirkii, 108

Klotzschiana, 107

lanceolata, 452

lanuginosa, 109

Lapeyrousii, 106

laxa, 107

Leprieurii, 107

Lessonii, 10

L'Herminieri, 107

linearis, 104

macrophylla, 112

media, 111

Michleriana, 113

microphylla, 110

multifrondulosa, 452

nitens, 111

oblongifolia, 106

obtusa, 111

ovata, 105

Parishii, 109, 452

parvula, 452
Lindsara (continued).

pectinata, 106

pendula, 108

pentaphylla, 112

propinqua, 111

punila, 112

quadrangularis, 107

recurvata, 111

reniformis, 109

retusa, 110

rigida, 108

sagittata, 109

scandens, 106

Seemannii, 105

Sprucei, 108

striata, 107

stricta, 108

tenera, 107

tenuifolia, 94

trapeziformis, 107

trapeziformis, 104

trichomanoides, 110

triquetra, 93

virescens, 106

Walkerce, 109

Litobrochia, see Pteris.

Llavea.

cordifolia, 144

Lomagramme, see AcrostiCHOM.

\section{LOMARIA.}

acuta, 180

adnata, 182

alpina, 178

articulata, 183

aspera, 177

attenuata, 176

Banksii, 178

blechnoides, 177

Boryana, 179

capensis, 179

caudata, 179

chilensis, 179

ciliata, 175

Colensoi, 174

Cumingiana, 174

cuspidata, 180

daneacea, 179

discolor, 175

divergens, 176

diversifolia, 181

dura, 177

elongata, 174

euphlebia, 183

filiformis, 180

Auviatilis, 181

Fraseri, 182

Germainii, 180 
LoMaria (continued). gibba, 175

gigantea, 176

Gilliesii, 179

glauca, 182

L'Herminieri, 176

lanceolata, 177

Lenormandi, 181

longifolia, 179

magellanica, 180

membranacea, 181

nigra, 181

obtusata, 178

onocleoides, 178

opaca, 176

ornifolia, 179

Patersoni, 174

pilosa, 176

Plumieri, 176

procera, 179

pumila, 178

punctulata, 179

punctata, 174

pycnophylla, 183

rigida, 177

semicordata, 182

spectabilis, 179

spicant, 178

squamulosa, 179

tuberculata, 179

vestita, 179

Vieillardii, 175

volubilis, 182

vulcanica, 176

LOMARIDIUM, see LOMARIA.

\section{LONCHITIS.}

aurita, 128

Ghiesbreghtii, 168

glabra, 128

hirsuta, 160

Lindeniana, 128

madagascariensis, 128

natalensis, 128

occidentalis, 128

pubescens, 128

LophididM, see Schizara.

Lopholepis, see Pol YPodiuM.

LORINSERIA, see WOODWARDIA.

Lotzea, see Asplenium.

Loxoscaphe, see Davallia.

Loxsoma.

Cunninghami, 56

\section{LygoDium.}

acuminatum, 438

articulatum, 437
LYGODIOM (continued). circinatum, 437

dichotomum, 437

digitatum, 437

expansum, 438

Finlaysonianum, 439

flexuosum, 437, 438

Forsteri, 439

hastatum, 438

heterodoxum, 439

hirsutum, 438

hirtum, 438

japonicum, 439

lanceolatum, 439

Lindeni, 439

longifolium, 438

lucens, 438

madagascariensis, 439

mexicanum, 438

micans, 438

microphyllum, 438

palmatum, 436

pedatum, 437

pinnatifidum, 438

Pœppiganum, 438

polycarpum, 439

polymorphum, 438

polystachyum, 438

puberulum, 438

pubescens, 438

reticulatum, 439

salicifolium, 438

scandens, 437

scandens, 438, 439

Schkuhri, 439

semibipinnatum, 438

semilhastatum, 437

Smithianum, 438

spectabile, 439

subalatum, 438

surinamense, 438

tenue, 439

trifurcatum, 437

venustum, 438

volubile, 438

Wrightii, 438

\section{Marattia.}

alata, 442

attenuata, 441

cicutcefolia, 441

cicutæfolia, 441

Douglasii, 441

Dregeana, 440

elegans, 440

fraxinea, 440

fraxinea, 441

Kaulfussii, 442

lævis, 442

laxa, 441

macrophylla 441

natalensis, $\mathbf{4 4 0}$
Maratiua (continued).

obtusidens, 441

pellucida, 441

podolepis, 441

polyodon, 441

purpurascens, 441

Raddiana, 441

salicifolia, 440

salicina, 440

sambucina, 441

sorbifolia, 440

sylvatica, 441

Verschaffeltiana, 441

weinmanniæfolia, 442

Matonia.

pectinata, 45

Mecosords, see GleicheNIA.

Melanopteris, see AspiDIUM.

\section{Meniscium.}

angustifolium, 391

Cumingii, 322

cuspidatum, 392

deltigernm, 420

giganteum, 391

Kapplerianum, 392

macrophyllum, 392

molle, 392

palustre, 392

Parishii, 392

pauciflorum, 391

veticulatum, 392

salicifolium, 391

serratum, 392

simplex, 390

sorbifolium, 392

Thwaitesii, 391

triphyllum, 391

villosum, 392

Mertensia, see Gleichenia.

Mesochlena, see DidyMOCHLXNA.

Microgonium, see TrichoMANES.

Microgramme, see PolypoDIUM.

Microlepia, see Davallia.

Microsorium, see NephroDIUM.

Microstaphyla, see AchoSTICHUM. 
MoHria.

achilleæfolia, 436

caffromum, 436

thurifragra, 436

Monachosorum, see PolyPODIUM.

\section{Monogramme.}

angustissima, 375

darececarpa, 375

furcata, 375

graminea, 375

graminoides, 375

graminifolia, 376

immersa, 376

Junghuhnii, 375

myrtillifolia, 376

rostrata, 375

seminuda, 375

subfalcata, 375

trichoidea, 375

Myriopteris, see CheillanTHES.

\section{NEPHRODIUM.}

abortivum, 292

abruptum, 263

abruptum, 294, 295

acuminatum, 281

acutum, 286

cemulum, 279

affine, 272

albicaule, 262

albo-punctatum, 264

amboinense, 292

amplissimum, 287

amplum, 285

amplum, 285

angustifrons, 283

angustifolium, 293

apiciflorum, 271

apiifolium, 300

appendiculatum, 268

arborescens, 286

Arbuscula, 292

aridum, 291

aristatum, 288

articulatum, 292

Ascensionis, 279

asperum, 292

asplenioides, 293

athamanticum, 277

atratum, 261

attenuatum, 263

augescens, 290

aureo-vestitum, 265

barbigerum, 274

Barteri, 299

Beddomei, 267
NePHRODIUM (continued).

Bergianum, 269

Berteroanum, 286

Bojeri, 280

Boottii, 275

borneense, 273

Boryanum, 280

Boryanum, 284

brachyodon, 295

Brackenridgii, 263

Braunianum, 260

Brunonianum, 274

calcaratum, 264

canescens, 290

canum, 267

caripense, 265

catocarpum, 285

catopteron, 284

caudiculatum, 263, 295

chinense, 278, 455

chrysolobum, 262

cicutarium, 282

cicutarium, 299

cirvhosum, 454

cochleatum, 272

cognatum, 279

collinum, 276

concinnum, 268

conterminum, 268

crassifolium, 266

crinipes, 294

crinitum, 265

crinibulbon, 263,454

cristatum, 273

ctenitis, 265

cucullatum, 290

cucullatum, 289

Cumingianum, 287

cuspidatum, 263

cyatheoides, 293

davallioides, 287

decipiens, 260

decompositum, 281

decurrens, 259

decurrens, 299

decursivo-pinnalun, 259

deflexum, 292, 305

deltoideum, 276

deltoideum, 270

denticulatum, 287

deparioides, 277

dilatatum, 275

diplazioides, 270

dissectum, 290

dissidens, 295

distans, 288

diversilobum, 293

divisum, 284.

Eatoni, 276

echinatum, 266

edentulum, 279

effusum, 287
NEPHRODIUM (continued).

elatum, 298

elatum, 291

elongatum, 272

eriocarpum, 280

erythrosorum, 273

excellens, 295

excultum, 287

exiguum, 267

extensum, 289

eusorum, 294

falcilobum, 264

falciculatum, 264

Falconeri, 277

Fendleri, 295

ferox, 294

ferrugineum, 283

figiense, 280

filix-mas, 272

flaccidum, 274

floridanum, 273

Fœnisecii, 279

fragrans, 275

funestum, 281

furcatum, 285

giganteum, 300

glabellum, 281

glabrum, 278

glanduligerum, 262

glandulosum, 276, 288

glandulosum, 291

globuliferum, 269

Goldieanum, 272

gracilescens, 262

Griffithii, 300

Grisebachii, 285

griseum, 271

Haenkeanum, 290

heterocarpum, 297

heterocarpon, 293

heterophyllum, 295

Hilsenbergii, 293

hirsutum, 291

hirsutun, 280

hirtipes, 261

hirtum, 278

hispidum, 286

Hudsonianum, 294

immersum, 263

incequale, 277

incequilaterale, 454

incisum, 288

insigne, 262

intermedium, 283

invisum, 263

irregulare, 298

irviguum, 297

Jamesoni, 293

javanicum, 248

Karstenianum, 286

Karwinskyanum, 279

Kaulfussii, 268

lacerum, 273 
NePHRODIUM (continucd).

latifolium, 297

latifrons, 282

latipinna, 292

lepidotum, 276

lepigerum, 284

Leprieurii, 266

Leuzeanum, 295

limbatum, 269

lineatum, 292

lonchodes, 270

longipes, 290

macrophyllum, 300

macrotis, 261

macrostegium, 287

macrourum, 262

macrourum, 263

marginale, 273

melanocaulon, 296

melanopus, 271

membranifolium, 282

membranifolium, 272

mexicanum, 276

Meyanthidis, 297

microsorum, 271

molle, 293

monostichum, 266

montanum, 271

Motleyanum, 266

multijugum, 291

Napoleonis, 279

noveboracense, 267

obliquatum, 264

obtusilobum, 284

ochthodes, 268

odoratum, 280

odoratum, 284

oppositum, 283

Oreopteris, 270

Otaria, 288

pachyphyllum, 299

pachyrachis, 270

Palatanganum, 285

pallidivenium, 290

palustre, 270

Parishii, 280

patens, 262

pedatum, 259

pennigerum, 292

Pica, 298

pilosissimum, 281

piloso-hispidum, 307

pilosulum, 262

platypus, 286

podophyllum, 260

polymor-phum, 297

Preslii, 272

procurvens, 290

prolixum, 268

propinquum, 272

pteroides, 289

pubescens, 280

punctulalum, 261
Nephrodium (continued).

purpurascens, 276

pusillum, 260

Raddianum, 265

recedens, 281

recurvum, 279

refractum, 292

remotum, 275

resino-foetidum, 269

rigidum, 275

rubiginosum, 280

sagenioides, 271

sagittofolium, 294

Salvini, 274

sanctum, 267

scabrosum, 283

schizotis, 262

Schottianum, 262

sclerophyllum, 293

scolopendrioides, 288

semibipinnatum, 297

semiliastatum, 260

Serva, 289

Serra, 263

setigerum, 284

setosum, 274

Sieboldii, 261

siifolium, 299

simplicifolium, 313

singaporianum, 296

Skinneri, 287

sophoroides, 289

sparsum, 276

spectabile, 272

Spekei, 263

sphoerocargum, 277

spinulosum, 275

spinulosum, 279

splendens, 282

Sprengelii, 268

Sprucei, 269

squamisetum, 278

squamigerum, 278

squamulosum, 271

stenopteris, 288

stipellatum, 294

stipitatum, 278

subbiauvitum, 261

subfuscum, 267

subglandulosum, 285

subincisum, 286

subobliquatum, 261

subquinquefidum, 281

subsericcum, 281

subtripinnatum, 455

syrmaticum, 272

tarapotense, 265

tenericaule, 284

tenuifolium, 278

ternatum, 296

terminans, 289

tetragonum, 266

thelypteroides, 269

30
Nephrodium (continued).

Thelypteris, 271

Thom:oni, 256

Thwaitesii, 277

tomentosum, 269

Trianæe, 286

trichophorum, 265

trifidum, 297

triste, 266

truncatum, 294

tylodes, 268

uliginosum, 273

undulatum, 276

unitum, 289

unitum, 290

varians, 288

variabile, 281

variolosum, 298

vastum, 296

velatum, 270

velleum, 265

velutinum, 281

venustum, 294

vestitum, 265, 286

Vieillardii, 282

villosum, 286

viridescens, 275

viscosum, 264

Vogelii, 281

Walkerce, 455

Webbianum, 264

Welwitschii, 274

Wrightii, 288

Zollingerianum, 293

\section{NEPHROLEPIS.}

acuta, 301

altescandens, 301

biserrata, 301

cordifolia, 300

davallioides, 302

delicatula, 301

ensifolia, 301

exaltata, 301

floccigera, 302

hirsutula, 301

imbricata, 301

veglecta, 301

obliterata, 301

obtusifolia, 301

occidentalis, 301

pectinata, 301

pendula, 301

pilosa, 301

platyotis, 301

punctulata, 301

ramosa, 302

rufescens, 301

splendens, 301

tenuis, 302

trichomanoides, 301

tuberosa, 301 
INDEX.

NePHROLEPIS (continued). valida, 301

volubilis, 301

Neurocallis, see AcrostiCHUM.

Neurodium, see Tanitis.

Neurogramme, see GymnoGRAMME.

Neuromanes, see TrichoMANES.

Neurophylium, see TriChomanes.

Niphobolus, see PolypoDIUM.

NIPHopsis, see Polypodium.

\section{Nothochl一NA.}

affinis, 373

Aschentorniana, 371

Borsigiana, 374

brachypus, 371

Brackenridgii, 371

Buchanani, 373

candida, 373

chilensis, 374

cretacea, 374

dealbata, 374

densa, 372

distans, 372

Eckloniana, 371

eriphora, 372

Fendleri, 374

ferruginea, 370

flavens, 374

fragilis, 372

glabra, 372

hirsuta, 372

hypoleuca, 372

incequalis, 371

lanuginosa, 370

Maranto, 371

mollis, 372

monosticha, 374

nivea, 374

nudiuscula, 372

persica, 139

peruviana, 371

Pohliana, 372

Rawsoni, 370

semiglabra, 372

sinuata, 370

sinuata, 371

squamosa, 371

sulphurea, 373

tenera, 373

trichomanoides, 373

undulata, 420
OCHROPTERIS.

pallens, 127

Odontoljma, see Davalita.

Oleandra.

articulata, 302

Cumingii, 303

hirta, 302

hirtella, 302

micans, 302

mollis, 302

Moritzii, 302

muscefolia, 302

neriiformis, 302

nodosa, 303

phyllarthron, 302

pilosa, 302

Sibbaldi, 303

trujulensis, 302

Wallichii, 303

Welwitchii, 303

OlfERsia, see ACROSTICHUM.

ONOCLEA.

germaroica, 46

orientalis, 46

sensibilis, 46

\section{ONYCHIUM.}

auratum, 143

japonicum, 143

lucidum, 144

melanolepis, 143

strictum, 143

Oochlamys, see Nephro. DIUM.

Ophioderma, see OphioGLOSSUM.

\section{OPHIOGLOSSUM.}

acuninatum, 302

aphrodisiacum, 446

azoricum, 445

Boryanum, 447

brevipes, 446

bulbosum, 445

capense, 446

cognatum, 446

concinnum, 445

cordifolium, 446

coriaceum, 446

costatum, 446

crotalophoroides, 445

Cumingianum, 446

ellipticum, 445

elongatum, 446

flavicaule, 445

gomesianum, 445
OpHIoglossum (continued). gracillimum, 445 gramineum, 445 intermedium, 446 lusitonicum, 445 luso africanum, 445 macrorhizum, 445 melipillense, 445 minimum, 445 moluccanum, 445 nudicaule, 445 nudicaule, 446 opacum, 445 ovatum, 446 palmatum, 446 parvifolium, 445 pedunculosum, 446 pendulum, 446 peruvianum, 446 petiolatum, 446 polyphyllum, 446 reticulatum, 446 rubellum, 445 surinamense, 445 tuberosum, 445 vulgatum, 445 Wightii, 445 ypanamense, 445

\section{OSMUNDA.}

bipinnata, 426

capensis, 427 cinnamomea, 426 Claytoniana, 42 frondosa, 426 glaucescens, 426 gracilis, 427 Hilsenbergii, 427 Hugeliana, 427 imbricata, 426 interrupta, 426 japonica, 427 javanica, 426 lancea, 427

Leschnaultiana, 427 monticola, 426 obtusifolia, 427 palustris, 427 pilosa, 426 Presliana, 426 regalis, 426

speciosa, 427 spectabilis, 427

Vachellii, 426

Pachyderis, see NephroDIUM.

Pachiloma, see HymenoPHYLLUM.

Paragramma, see PolypoDIUM. 
Parkeria, see Ceratopte- Pellasa (continued). RIS.

Patania, see Dicksonia.

\section{Pellida.}

alabamensis, 148

alteruifolia, 152

ambigua, 147

andromedoefolia, 150

angustifolia, 150

articulata, 153

aspera, 148

atropurpurea, 147

auriculata, 145

Barklyo, 151

Boivini, 149

Bojeri, 150

Bieweri, 145

Bridgesii, 151

Burkeana, 153

calomelanos, 152

columbina, 146

consobrina, 150

cordata, 152

cuneata, 150

decomposita, 150

deltoidea, 146

densa, 149

Doniana, 152

dura, 147

falcata, 151

flexuosa, 153

geraniafolia, 146

glauca, 150

gracilis, 145,453

hastata, 152, 453

hastæfolia, 152

hirsuta, 151

intramarginalis, 148

lomariacea, 146

longimucronata, 148

macrophylla, 152

marginata, 151

mucronata, 148

mucronata, 148

nitidula, 149

ornithopus, 149

paradoxa, 152

pilosa, 145

profusa, 148

pubescens, 150

pulchella, 150

rigida, 147

robusta, 149

rotundifolia, 151

Scemanni, 145

seticaulis, 152

Skinneri, 147

Stelleri, 453

Tamburii, 146

ternifolia, 148

vestita, 146 viridis, 453

Wrightiana, 148

Phanerophlebia, see AspiDIUM.

Phegopteris, see PolypoDIUM.

Phlebjgonium, see NephroDIUM.

Phlebiophyllum, see TriCHOMANES.

Phlebodiug see PolypoDIUM.

Photinopteris, see AcroSTICHUM.

Phymatodes, see PolypoDIUM.

Physapteris, see CheimanTHES.

Physematiom, see Woodsia.

Plagiogrria, see Lomaria.

Platycerium.

athiopicum, 425

alcicorne, 425

angolense, 425

biforme, 425

grande, 425

stemaria, 425

Wallichii, 425

Platrloma, see Pellea.

Platrzoma.

micropliyllum, 11

Plecosorts, see CheillanTHES.

Pleocnemia, see NephroDIUM.

Podopeltis, see NephroDIUM.

Pcesia, see Pteris.

Polybotrya, see AcrostiCHUM.

Polycampium, see PolypoDIUM.

\section{PoLypodium.}

A bitaguce, 333

accedens, 353

achillexefolium, 338

acrostichoides, 356

acrostichoides, 350

aculeatum, 34

acuminatum, 345
PoLYPODIUM (continued).

adenochrysum, 268

Adenophorus, 328

adnascens, 349

adnatum, 345

adnata, 325

adspersum, 319, 320

affine, 364

africanum, 351

alatum, 365

albicans, 352

albo-punctatissimum, 360

albo-squamatum, 369

alleopterum, 305

alpestre, 311

alternans, 41

alternifolium, 335

amboynense, 306

americanum, 352

ammifolium, 311

amcenum, 341

amphostemon, 348

andinum, 323

androgynum, 317

anfractuosum, 326

angustifolium, 347

angustatum, 356

angustum, 363

anocarpum, 360

apiculatum, 332

appendiculatum, 343

appendiculatum, 306

aquilinum, 311

areolatum, 347

argyratum, 331

argutum, 344

armatum, 33

arthrothrix, 315

asperulum, 311

asplenifolium, 329

asplenioides, 316

asterothrix, 316

athyrioides, 339

atro-virens, 34

attenuatum, 345

attenuatum, 354, 355

aureum, 347

auriculatum, 306

aurisetum, 340

australe, 334

australe, 322

axillare, 35

barbatum, 294

barbatum, 323

Barberi, 317

Barterianum, 309

Beaumonti, 319

Beckleri, 301

Bergianum, 269

biauriculatum, 336

bifrons, 331

Billardieri, 364 
Polypodium (continued).

binerve, 323

biseriale, 309

bisulcatum, 321

blechnoides, 331

Bojeri, 311

Boothii, 352

borneense, 314

brasiliense, 345

Brongniartii, 318

Brownii, 355

cæspitosum, 321

caffrorum, 436

Calaguala, 343

californicum, 341

cambricum, 334

cameroonianum, 318

capitellatum, 368

carnosum, 365

Catharinæ, 343

Catharince, 343

caudatum, 309

cclebicum, 329

chacapoyense, 343

chnoodes, 344

chrysolepis, 321

cicutarium, 299

ciliatum, 323, 340

clavifer, 334

coarctatum, 348

cocbleatum, 316

comptoniæfolium, 323

concinnum, 268

confiuens, 349

conforme, 319

conjugatum, 366

conjugatum, 362

connexum, 312

cordatum, 304, 345

cordifolium, 300

coronans, 365

costatum, 350

costatum, 350

crassifolium, 360

crassifions, 325

crassinervium, 360

crenatum, 315

crenato-dentatum, 315

crenulatum, 368

crincle, 311

crispatum, 361

ctenoides, 306

cubense, 348

cucullatum, 324

cultrafum, 327

Cumingianum, 318

Cumingianum, 354

curvans, 329

curvatum, 329

cuspidatum, 344

cyrtolobum, 363

Dalhousianum, 315

dareaforme, 339
Polxpodium (continued).

dasypleuron, 343

davallioides, 340

debile, 313

decipiens, 329

decorum, 331

decumanum, 347

decurrens, 348

decursivo - pinnatum, 259

decussatum, 306

defiexum, 305

delicatulum, 326

deltoideum, 270

dependens, 335

Deplanchei, 322

detergibile, 351

Dianæ, 309

dictyocallis, 347

difforme, 318

dilatatum, 287

dilatatum, 365

discalor, 326

dissectum, 290

dissimile, 344

distans, 308

distichocarpum, 352

divergens, 287

diversifolium, 314, 368

draconopterum, 319

drepanum, 310

Dryopteris 309

dubium, 313

ebenipes, 365

Eckloni, 346

effusum, 287

Ehrenbergianum, 334

elasticum, 327,363

elatum, 337

eleutherophlebium, 343

ellipsoideum, 333

ellipticum, 389

elongatum, 260

ensatum, 361

ensifolium, 347,356

ensiforme, 341

eriophorum, 372

erubescens, 306

excrvatum, 354

excultum, 287

exiguum, 326

extensum, 323

Falcaria, 343

falcatum, 334

fallax, 337

farinosum, 329

fasciale, 348

fasciatum, 322

faucium, 315

Féei, 317

Fendleri, 348

ferox, 294

ferrugineum, 318
Pouypodidm (continued).

ferrugineum, 332

fibrillosum, 307

firmum, 335

Fischerianum, 455

fissum, 351

flabelliforme, 326

Alabelliverium, 322

flavo-puinctatum, 304

flexile, 311

floccigerum, 351

flocculosum, 351

Forsteri, 317

Fortunei, 367

fragrans, 134

fraternum, 337

fraxinifolium, 314

fraxinifolium, 346

Friedrichsthalianum,339

funiculum, 338

furcatum, 332

fuifuraceum, 332

fuscatum, 331

fusco-punctatum, 357

Gardneri, 352

geminatum, 353

Germanianum, 306

Gheisbreghtii, 315

glabrum, 356

gladiatum, 345

glanduliferum, 310

glandulosum, 327

glauscophyllum, 340

glaucum, 365

glycyrhiza, 334

gracile, 338

gracilis, 316

grammitidis, 327

gramineum, 321

grandidens, 344

grandifolium, 300

Griffithii, 308

Griffthianum, 359

griseum, 330

griseun, 38

guatemalense, 345

harpeodes, 343

harpophyllum, 337

Hartwegianum, 336

Hasseltii, 309

hastatum, 317

hastatum, 361

hastoefolium, 304

hemionitideum, 360

Henchmanni,' 337

Heracleum, 366

heterocarpum, 360

heteromorphum, 334

hexagonopterum, 309

Hillebrandii, 339

himalayense, 369

hirtellum, 320

hirtum, 320 
POLYPodiom (continued).

Hookeri, 319

Horsfieldii, 362

humile, 325

hydrophilum, 306

hymenophylloides, 337

incequale, 325

incanum, 346

inconspicuum, 327

incurvatum, 363

insigne, 363

intermedium, 342,345

irioides, 360

Jamesoni, 323

jubaeforme, 327

juglandifolium, 368

jungermanioides, 320

Kennedyi, 314

Keraudrenianum, 313

Khasyanum, 325

Kœnigi, 350

Korthalsii, 345

Labv'usca, 361

lacerum, 273

lachnopus, 342

laciviatum, 365

lætum, 343

lampongense, 345

lanceola, 358

lanceolatum, 354

lanceolatum, 356

lanigerum, 335

lapathifolium, 348

lasiosorum, 320

lasiopus, 343

lasiostipes, 327

latipes, 343

latifolium, 297

latum, 349

legionarium, 337

Lehmanni, 369

leiorhizon, 369

lepidotum, 356

lepidopteris, 346

leptoclidium, 317

leucosorum, 324

leucosporum, 362

L'Herminieri, 332

ligulatum, 320

Lindbergii, 358

lineare, 354

linearifolium, 356

liniatum, 316

lingua, 350

linguoeforme, 558

Linncei, 368

lividum, 328

Lobbianum, 294

Lobbianum, 331, 362

lomarioides, 365

lomariæforme, 333

longifolium, 355

longifrons, 358
Polrpodium (continued).

longipes, 364

longisetosum, 338

longissimum, 366

loriceum, 343

loriforme, 354

lucidum, 348

lunulatum, 41

lycopodioides, 357

Mackenii, 357

macrocarpum, 330

macrodon, 318, 337

macrophyllum, 308

macrothecum, 306

madrense, 330

magnificum, 349

malacodon, 363

Mannianum, 310

marginatum, 355

marginellum, 321

Martensii, 333

mascarene, 455

Matthewsii, 341

maximum, 364

megalocarpum, 318

megalodus, 317

melanopus, 329

Melleri, 357

membranaceum, 360

menisciicarpon, 297, 299

menisciifolium, 346

meniscioides, 314

meridense, 333

Meyenianum, 366

microphyllinum, 339

microstegium, 308

Milnei, 282

millefolium, 339

minus, 348

minutum, 328

molle, 308

molle, 344

mollis, 315

mollissimum, 329

molliusculum, 293

monilifor'me, 325

montanum, 271

monticolum, 326

Moritzianum, 333

moulmeinensis, 368

multifidum, 322

multilineatum, 316

muricatum, 252

murorum, 339

musøfolium, 360

myosuroides, 323

myriocarpum, 334

myriophyllum, 338

nemorale, 285

neriifolium, 345

nicotiancefolium, 455

nigrescens, 364
PoLyPodiom (continued).

nigvitianum, 313

nigripes, 347

niponicum, 341

nitidissimum, 349

nitidum, 348

normale, 358

nudum, 354

nummularium, 340

nummulariaefolium, 351

obliquatum, 328

obliquatum, 328

obovatum, 350

obscurum, 308

obtusum, 322

oblusilobum, 305

Oldhami, 311

onustum, 339

oodes, 354

oppositifolium, 316

organense, 324

ornatum, 285

Otites, 334

ovatum, 359

oxylobum, 363

pachyphyllum, 342

paleaceum, 285

pallidum, 285

pallidivenium, 290

palmatum, 368

paludosum, 308

papillosum, 328

papillosum, 332

parasiticum, 293

parasiticum, 319

parvulum, 326

patens, 342

pauciflorum, 305

pectinatum, 333

pectinatum, 343

pediculatum, 455

pellucidum, 333

peltideum, 364

penangianum, 352

penangianum, 316

pendulum, 329

pennigerum, 317

pentagonum, 321

percussum, 356

persicoefolium, 344

persicavicefolium, 358

peruvianum, 326

petrophyum, 319

Phegopteris, 308

Phyllitidis, 348

phymatodes, 364

pilipes, 330

pilipes, 329

pilosiusculum, 319

piloselloides, 340

pilosissimum, 327

pilosum, 367

platylobum, 306 . 
Polypodiom (continued). platyphyllum, 313,455 platyphyllum, 310, 359 plebeium, 335

plectolepis, 344

plesiosorum, 342

Plumula, 332

pœcilophlebium, 314

polylepis, 356

polystichoides, 455

Poppigianum, 321

porosum, 351

portoricensis, 280

Powellii, 364

prasinum, 312

princeps, 351

Prionitis, 304

procerum, 313

procurrens, 301

proliferum, 315

propinquum, 367

pteroideum, 308

pteropus, 329

puberulum, 336

pubescens, 342

pulchrum, 332

pulvinatum, 347

punctatum, 312

punctulatum, 343

pustulatum, 363

pycnolepis, 310

quadrangularis, 317

quercifolium, 367

vadicale, 332

reclinatum, 355

recurvatum, 332

refulgens, 307

regularis, 388

Reinwardtii, 320, 344

repandum, 315

repandulum, 328

repens, 348

reptans, 316

retroflexum, 292

revertens, 337

rhizocaulon, 346

rhynchophyllum, 359

Richardi, 346

rigescens, 331

rigidulum, 368

rigidum, 310

rigidum, 252

rivale, 367

Rivoirei, 315

Robertianum, 309

rostratum, 353

rotuudatum, 307

rubidum, 314

rude, 307

rufescens, 309

rufulum, 346

rupestre, 349,356

rupestre, 359
Polypodium (continued).

rusticum, 306

salicifolium, 316, 357

samarense, 356

samoense, 321

Sancta-Gabrieli, 304

sanctum, 267

sandvicense, 312

sand vicense, 317

sar'mentosum, 327

saxatile, 359

Schiedeanum, 33

Schkuhrii, 333

Schomburghianum, 355

Schraderi, 354

scolopendrioides, 288, 323

Scouleri, 342

sectifrons, 363

Seemanni, 295, 331

semiadnatum, 335

semipinnatifidum, 341

sepultum, 346

sericeo-lanatum, 335

sericeun, 280

serpens, 349

serpens, 357

serratifolium, 344

serrulatum, 323

sessilifolium, 311

sessilifolium, 322

setigerum, 320

setigerum, 319

setosum, 323

Sieberianum, 306

siifolium, 299

simplicifolium, 313

sinuosum, 355

sinuosum, 365

Skinneri, 331

Sloanei, 285

solidum, 324

solutum, 348

sophoroides, 289

soridens, 355

sororinum, 337

sparsiflorum, 319

sparsisorum, 368

spectabile, 286

spectrum, 361

sphenodes, 348

spissum, 350

splendidum, 312

splendens, 353

Spixianum, 333

sporadocarpum, 347

sporadolcpis, 336

Sprucei, 319

spurium, 388

squamatum, 346

stegnogr'ammoides, 317

stenoloma, 363

stenophyllum, 354
PolyPodiom (continued).

stigmaticum, 357

stigmosum, 350

stramineum, 316

subauriculatum, 344

subcrenatum, 325

subdimidiatum, 326

subecostatum, 353

subevenosum, 320

subfalcatum, 328

subfurfuraceum, 350

subdigitatum, 340

sublanosum, 330

subpetiolatum, 336

subpinnatifidum, 324

subscabrum, 326

subsecundo-dissectum, 328

subsessile, 329

subserratum, 337

subservatum, 325

subspathulatum, 320

subtile, 326

superficiale, 355

surrucuchense, 343

suspensum, 329

Swartzii, 357

sylvaticum, 252

tamariscinum, 338

taxifolium, 332

tenellum, 337

tenerifrons, 318

tenerum, 317

tenuicauda, 368

tenuifolium, 334

tenuilore, 354

tenuisectum, 338

terminale, 364

tetragonum, 317

Thwaitesii, 328

tomentosum, 269

translucens, 342

trichomanoides, 326

trichosorum, 323

tricuspe, 350

tridactylon, 362

tridens, 246

trifidum, 363

trifurcatum, 323

trilobatum, 347

trilobum, 341

tripinnatifidum, 338

triquetrum, 359

truncicola, 326

Tweedianum, 330

unitum, 289

vacciniifolium, 340

vacillans, 343

varians, 369

varium, 350

venosum, 357

venulosum, 334

venustum, 369 
Polypodium (continued). verrucosum, 344 Vieillardii, 364 villosissimum, 324 violascens, 365 vittaria, 360 Vogelii, 313 vulcanicum, 389 vulgare, 334

Walkeræ, 305, 455

Wallichii, 362

Willdenovii, 367

Willdenovii, 367

xiphophoron, 345

zeylavicum, 321

Zippellii, 360

Zollingerianum, 360

zosteraforme, 357

Polystichum, see Aspidium.

Polytenium, see AntroPHYUM.

Profera, see Nephrodium.

Prosaptia, see Fatallia.

Psedathyrium, see PolyPODIUM.

Psilopdoohra, see AngioPTERIS.

\section{Pteris.}

acclivis, 453

aculeata, 171

alternif lia, 168

anamallayensis, 164

angusta, 159

aquilina, 162

arachnoidea, 163

arguta, 160

argyræa, 158

articulata, $] 53$

asceusionis, 161

asperula, 158

aurantiaca, 141

aurita, 172

Barteri, 168

Beecheyana, 171

biaurita, 164

borbonica, 170

brasiliensis, 169

brevisora, 162

camptocarpa, 173

catoptera, 158

caudata, 163

chilensis, 161

ciliaris, 170

collina, 166

comans, 171

cordata, 152

coriacea, 162
Pteris (continued).

crenata, 155

cretica, 154

Currori, 168

dactylina, 155

Dalhousice, 157

decipiens, 166

decora, 167

decurrens, 171

decussata, 165

deflexa, 162

deltea, 158

denticulata, 159

digitata, 154

dispar, 157

distans, 156

edentula, 159

elata, 173

Endlicheriana, 178

esculenta, 162

euchlora, 166

excelsa, 159

fallax, 149

Felicienna, 167

felosma, 158

flabellata, $] 61$

flexuosa, 157

Gaudichaudii, 162

Ghiesbreghtii, 160

gigantea, 173

gracilis, 160

grandifolia, 164

Griffithii, 156

heteromorpha, 156

heterophlebia, 172

hetcrophylla, 160

Honkeana, 169

Hookeriana, 155

incisa, 172

irregularis, 158

Jamesoni, 162

Junghuhnii, 170

Kingiana, 161

Kleiniana, 164

Kunzeana, 173

laciniata, 160

lanceæfolia, 168

latifolia, 173

laurea, 168

leptophylla, 171

leptophylla, 160

litobrochioides, 157

lomariacea, 164

lomariacea, 166

lonchophora, 166

longibracteata, 173

longifolia, 153

longipinnula, 158

ludens, 166

Luschnathiana, 172

macilenta, 171

macroptera, 169

madagascarica, 156
Pteris (continued).

Mannii, 167

maratticefolia, 157

melanocaulon, 154

Melleri, 165

Milneana, 170

moluccana, 154

montbrisonis, 170

mutilata, 156

nobilis, 166

nova-caledonia, 159

opaca, 154

ornithopus, 166

paleacea, 159

palmata, 166

patens, 165

paucinervata, 157

pedata, 167

pedata, 167

pellucens, 161

pellucida, 154

podophylla, 172

polita, 171

propinqua, 171

pulchra, 169

pungens, 159

pyrophylla, 158

quadriaurita, 158

э"ugulosa, 163

sagittifolia, 166

sagittata, 153

scabra, 159

scabripes, 154

scaberula, 163

scalaris, 163

semiadnata, 157

semidentata, 160

semipinnata, 157

serrulata, 155

setifera, 173

sinuata, 172

spinulifera, 170

splendens, 168

stenophylla, 154

stridens, 162

subquinata, 158

subserrata, 156

sulcata, 158

sulphurea, 373

Swartziana, 158

tremula, 161

tricolor, 158

tripartita, 170

tripartita, 172

triplicata, 164

triphylla, 168

umbrosa, 155

vespertilionis, 172

vestita, 169

Vieillardi, 167

viscosn, 163

Wallichiana, 165

woodwardioides, 170 
Pterogonivm, see GrmnoGRAMME.

Pteroneuron, see DatalLIA.

Prcnodoria, see Pteris.

Pycnopteris, see NephroDIUM.

RHIPIDOPTERIS, see AcroSTICHUM.

Rhizoglossum, see OphioGLOSSUM.

Saccoloma, see Davalita.

\section{SADLERIA.}

cyatheoides, 187

Kaulfussiana, 187

pallida, 187

Souleytiana, 187

squarrosa, 187

SAGENIA, see NePHRODIUM.

SALPICHLANA, see BlechNUM.

SchaffNeria, see ScolopenDRIUM.

Schellolepis, see PolypoDIUM.

\section{Schizera.}

attenuata, 430

australis, 428

bifida, 429

cristata, 430

dichotoma, 430

digitata, 430

clegans, 430

fistulosa, 429

flabellum, 430

fluminensis, 429

Forsteri, 430

Germani, 430

incurvata, 429

intermedia, 430

lævigata, 430

latifolia, 430

malaccana, 428

occidentalis, 430

pacificans, 430

pectinata, 429

penicillata, 430

pennula, 430

propinqua, 428,429

pusilla, 428

robusta, 429

rupestris, 429

spectabilis, 430

Spruicei, 430

subtrijuga, 430

tenella, 428
Schizsa (continued)

trilateralis, 430

valdiviana, 429

Schizoloma, sce LindsaYa.

Scoliosorus, see AntroPHYUM.

\section{SCOLOPENDRIUM.}

brasiliense, 247

Douglasii, 247

Durvillei, 247

Hemionitis, 247

Lindeni, 247

micropodium, 247

nigripes, 247

pinnatum, 247

plantagineum, 247

rlizophyllum, 248

sibiricum, 248

subsessile, 247

vulgare, 246

Scyphularia, see Datallia.

Selliguea, see GrmnoGRAMME.

Serpyllopsis, see Tricho. MANES.

Sitolobiom, see Dicksonia.

Soromanes, see Acrosti CHUM.

Spherocionium, see HymeNOPHYLLUM.

SPHAROPTERIS.

barbata, 49

Spharostephanos, see DIDYMOCHLENA.

Stegnograme, see PolypoDIUM.

Stenochlana, see Lomaria.

Stenoloma, see Davalita.

Stenosemia, see AcrostiCHOM.

Stiblsia, see Marattia.

Stromatopteris, see GleiCHENIA.

Struthiopteris, see OnoCLEA.

Synaphlebium, see Dafal. LIA and LINDSAYA.

Syngramme, see GrmnoGRAMME.

Thanicpsis, see VitTaRia.
T.ENITIS.

angustifolia, 396

blechnoides, 397

Blumei, 397

Desvauxii, 397

furcata, 397

intermedia, 395

interrupta, 397

isoetifolia, 395

lanceolata, 397

margiualis, 397

obtusa, 396

sagittifera, 186

semipinnatifida, 397

Thylacopteris, see PolyPODIOM.

ThyrsOPTERIS.

elegans, 16

TODEA.

africana, 427

barbara, 427

Fraseri, 427

hymenophylloides, 427

pellucida, 428

rivularis, 427

superba, 428

Wilkesiana, 427

Triblemma, see Aspleniom.

Trichocarpa, see Deparia.

Trichomanes.

abruptum, 84

achilleæfolium, 86

ærugineum, 75

alatum, 79

album, 80

angustatum, 85

antillarum, 81

apiifolium, 86

apodum, 75

Armstrongii, 452

Asæ-Grayi, 87

attenuatum, 79

auriculatum, 82

Bancroftii, 78

Barklianum, 74

Bauerianum, 86

bicorne, 79

bimarginatum, 75

Boivini, 86

Bojeri, 73

borbonicum, 81

botryoïdes, 72

brasiliense, 81

brevipes, 84

coespitosum, 83

calvescens, 77

capillatum, 81 
Trichomanes (continued). caudatum, 85 cavifolium, 81 cellulosum, 87 Colensoi, 85 coriaceum, 78 crinitum, 82 crispulum, 75 crispum, 82 cuspidatum, 73 delicatuin, 79 dentatum, 86 denticulatum, 82 diffusum, 76 digitatum, 76 dilatatum, 81 dissectum, 82 Draytonianum, 81

Dregei, 86 elegans, 72 elongatum, 86 Endlicherianum, 80 emarginatum, 81 erectum, 80 erosuin, 75 exaltatum, 86 eximium, 81 exsectum, 85 Filicula, 81 filiforme, 87 flabellatum, 76 flavo-fuscescens, 86 floribundum, 84 fœniculaceum, 87 foniculaceum, 88 gemmatum, 87 giganteum, 87 glauco-fuscum, 80 Godmani, 74

Griffithii, 81

Henzaianum, 75

heterophyllum, 72

holopterum, 78

Hookeri, 75

Hostmannianum, 84 humile, 80

hymenophylloides, 81 incisum, 78 insigne, 81 intermedium, 86 intramarginale, 79 javanicum, 83

Kapplerianum, 75

Kaulfussii, 79

Kirkii, 78

Krausii, 77

Kunzeanum, 81

Lambertianum, 83

late-alatum, 81

latemarginale, 79

Lechleri, 81

Lenormandi, 75

Leprieurii, 87
Trichomanes (continued).

Lindeni, 86

lineare, 79

lineolatum, 73

longicollum, 86

longisetum, 87

Jucens, 79

lucens, 83

Luschnatianum, 81

Lyallii, 77

macilentum, 78

macroclados, 86

Malingii, 66

mandioccanum, 86

Mannii, 75

Martinsii, 82

maximum, 86

meifolium, 86

melanorhizon, 84

membranaceum, 73

Milnei, 81

minutum, 75

Motleyi, 73

muscoides, 75

nanum, 77

nanum, 72

neilgheriense, 74

nitidulum, 76

obscurum, 86

olivaceum, 81

opacum, 87

Pabstianum, 75

pallidum, 80

palmatnm, 76

palmatifidum, 76

parvulum, 75

pellucens, 82

peltatum, 73

Petersii, 74

pinnatum, 84

pinnatifidum, 78

plicatum, 81

Plumula, 82

polyanthos, 86

Powellii, 76

Prieurii, 86

proliferum, 76

ptilodes, 79

pumilum, 86

punctatum, 74

pusillum, 77

pyxidiferum, 81

quercifolium, 77

racemulosum, 81

radicans, 81

reniforme, 73

reptans, 74

rigidum, 86

Robinsoni, 77

saxifragoides, 75

scandens, 85

Schaffneri, 75

Schmidtianum, 81

$$
3 \mathrm{P}
$$

Trichomanes (continued).

serratulum, 8

sinuosum, 78

Smithii, 84

speciosum, 81

sphenoides, 74

spicatum, 72

splendidum, 83

Sprucei, 87

sublimbatum, 75

superbum, 78

tamarisciforme, 86

tenerum, 85

tenue, 84

Teysmanni, 76

Thouarsianum, 76

trichoideum, 85

umbrosum, 81

venosum, 82

Vieillardi, 81

vitiense, 74

Vittaria, 84

Weddellii, 87

Trichopteris, see Also. PHILA.

Trichosorus, see AlsoPHILA.

Trismeria, see GymnoGRAMME.

TROCHOPTERIS. elegans, 436

UgENA, see Lygodidm.

Vaginularia, see MonoGRAMME.

\section{VITTARIA.}

acrostichoides, 401

anodontolepis, 395

bisulcata, 395

elongata, 395

ensiformis, 395

falcata, 395

Féei, 395

filifolia, 396

flexuosa, 396

Forbesii, 396

Gar'dneriana, 395

guineensis, 396

intermedia, 395

isoetifolia, 395

Karsteniana, 396

lineata, 396

loricea, 396

minor, 395

Moritziana, 395

o wariensis, 395

plantaginea, 395 
VitTaria (continued).

remota, 396

rigida, 395

Ruiziana, 396

sarmentosa, 396

scabrida, 395

scolopendrina, 396

stipitata, 395

stricta, 396

tenera, 396

zeylanica, 396

zosteræfolia, 395

\section{WoodsIA.}

andina, 48

Burgessiana, 48

caucasica, 47, 450
Woodsia (continued).

elongata, 47

fragilis, 47,450

glabella, 47

guatemalensis, 47

hyperborea, 46

ilvensis, 46

incisa, 48

lanosa, 47

Lyallii, 48

manchuriensis, 48

mollis, 47

obtusa, 48

oregana, 450

Perriniana, 48

peruviana, 48

polystichoides, 48
Woopsid (continued). scopulina, 450

sinuata, 48

Veitchii, 48

WOODWARDIA.

angustifolia, 189

areolata, 189

Harlandii, 189

japonica, 188

orientalis, 188

radicans, 188

virginica, 188

Xiphopteris, see PolypoDIUM.

As botanical names take precedence according to the date of their publication, we give, in accordance with the suggestion made in De Candolle's recently published "Laws of Botanical Nomenclature," the precise dates at which the different parts of this work have been issued :-

$$
\begin{aligned}
& \text { Part } 1 \text { page } 1 \text { to 32, July 24, } 1865 . \\
& \text { " } 2 \text { " } 33 \text { - 64, Dec. 11, } 1866 . \\
& \text { " } 3 \text { " } 65 \text { - 112, Jan. 22, } 1867 . \\
& \text { " } 4 \text { " } 113-160 \text { ditto. } \\
& \text { " } \\
& \text { " } 6 \text { " } 209-256 \text { ditto. } \\
& \text { " } 7 \text { " } 257 \text { - 304, Oct. 4, } 1867 . \\
& \text { " } 8 \text { " } 305-352 \text {, Nov. 8, } 1867 . \\
& \text { " } 9 \text { " } 353-402 \text {, Jan. 29, } 1868 . \\
& \text { " } 10 \text { " } 403 \text { - } 482 \text {, A pril, } 1868 .
\end{aligned}
$$



TAB. I.

Fig. 1. Platyzoma - $a$, portion of a frond ; $b$, pinnæ (underside); $c$, fertile pinna laid open, showing veins and a sorus ; $d$, capsule.

Fig. 2. Gleichenia. - $a$, $\S$ Eugleichenia ; $b$, sorus of ditto; $c$, $\S$ Mertensia ; $d$, sorus ; e, capsule.

Fig. 3. Thyrsopteris. - $a$, sterile, and $b$, fertile pinnules ; $c$, sorus and involucre; $d$, the same cut through vertically; $e$, capsule.

Fig. 4. Cyathea. - $a$, fertile pinnule; $b$, sorus and involucre; $c$, involucre from which the capsules have fallen.

Fig. 5. Hemitelia.— $a$, $\S$ Amphicosmia ; $b$, $\S$ Euhemitelia ; $c$, sorus, with the scale-like involucre.

Fig. 6. Alsophila. $-a$, fertile segment; $b$, sorus cut through vertically ; $c$, capsule.

Fig. 7. Diacalpe.- $a$, fertile pinnule; $b$, sorus, with perfect involucre; $c$, the same, with the involucre bursting open ; $d$, capsule.

Fig. 8. Matonia.—a, segments, with 2 sori; $b, c$, single sori, covered with the involucre; $d$, involucre laid open, showing the sorus ; $e$, ditto, the sorus removed ; $f$, capsule.

Fig. 9. ONocLea. - $a, b$, sterile segment of $\S$ Struthiopteris; $c$, fertile pinna of ditto; $d$, single fertile pinnule, enclosing the sori and involucres. ( $\$$ Euonoclea has free venation.)

Fig. 10. Hypoderris. - $a$, portion of a fertile frond ; $b$, sorus and involucre.

Fig. 11. WoodsIA. - $a$, § Euwoodsia ; $b$, involucre ; $c$, § Physematium; $d$, sorus and involucre of the same.

Fig. 12. Sphжropteris.- $a$, fertile pinnule; $b$, sorus and stalked involucre; $c$, ditto, seen from the underside. 
Tab. I.

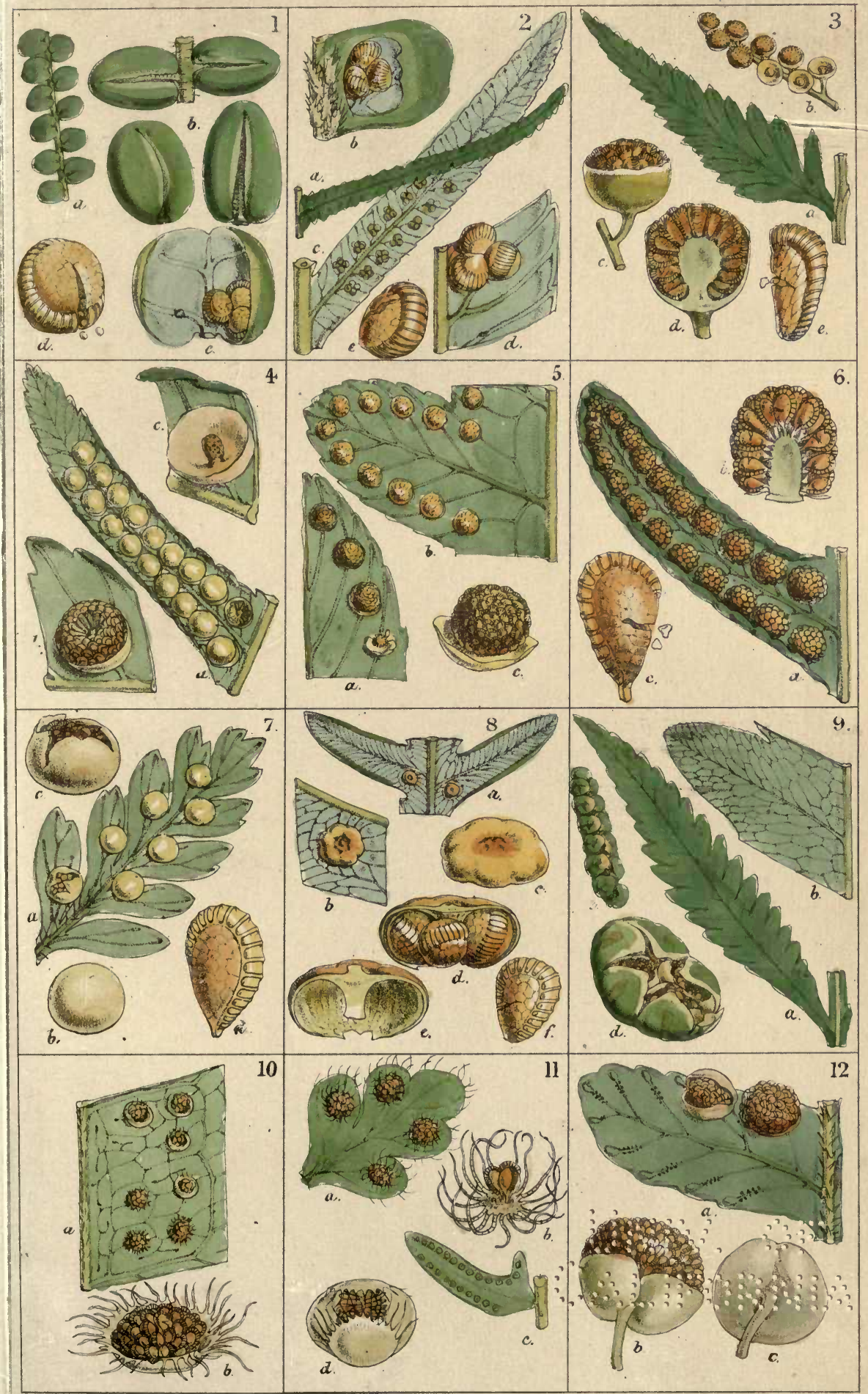




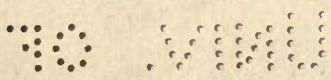

$\therefore: \vdots: \vdots: \because \because \because \vdots \vdots \vdots \cdots$ 

TAB. II.

Fig. 13. Dicksonia — $a, b, \S$ Balantium ; $c$, $\S$ Patania.

Fig. 14. Deparia. - $a$, fertile segment; $b$, single sorus and involucre; $c$, ditto cut through vertically.

Fig. 15. Loxsoma. - $a$, fertile segment; $b$, sorus and involucre; $c$, ditto cut through vertically; $d$, capsule and accompanying hairs.

Fig. 16. Hyмenophyllum. - $a$, fertile portion; $b$, sorus and involucre; $c$, ditto cut through vertically ; $d$, capsule.

Fig. 17. Trichomanes. $-a$, fertile portion; $b$, $c$, sori, involucres, and columella or receptacle ; $d$, capsule.

Fig. 18. Davaluia. - $a, a, \S$ Humata ; $b$, sorus, the involucre forced back ; $c$, $\S$ Eudavallia ; $d, \S$ Microlepia ; $e, \S$ Loxoscaphe.

Fig. 19. Cystopteris. $-a$, fertile pinnule; $b$, sorus covered by the involucre; $c$, sorus with the involucre forced back.

Fig. 20. Lindsaya. - a, § Eulindsaya. - Gen. 20 bis. Fig. 20. b. c. Dictyoxiphium, upper side, the sorus forced back showing the onelipped involucre ; $c$, small portion of the same, the sorus removed.

Fig. 21. Adiantum. - $a$, fertile pinnule (in a few species the venation anastomoses); $b$, involucre forced back to show the sorus situated on the involucre.

Fig. 22. Ochropteris. - $a$, fertile portion; $b$, involucre forced back to show the sorus at the base of the involucre.

Fig. 23. Lonchiris. $-a$, fertile portion; $b$, single sorus.

Fig. 24. Hypouepis. $-a$, fertile portion; $b$, single pinnule, with sori. 
Tab.II.

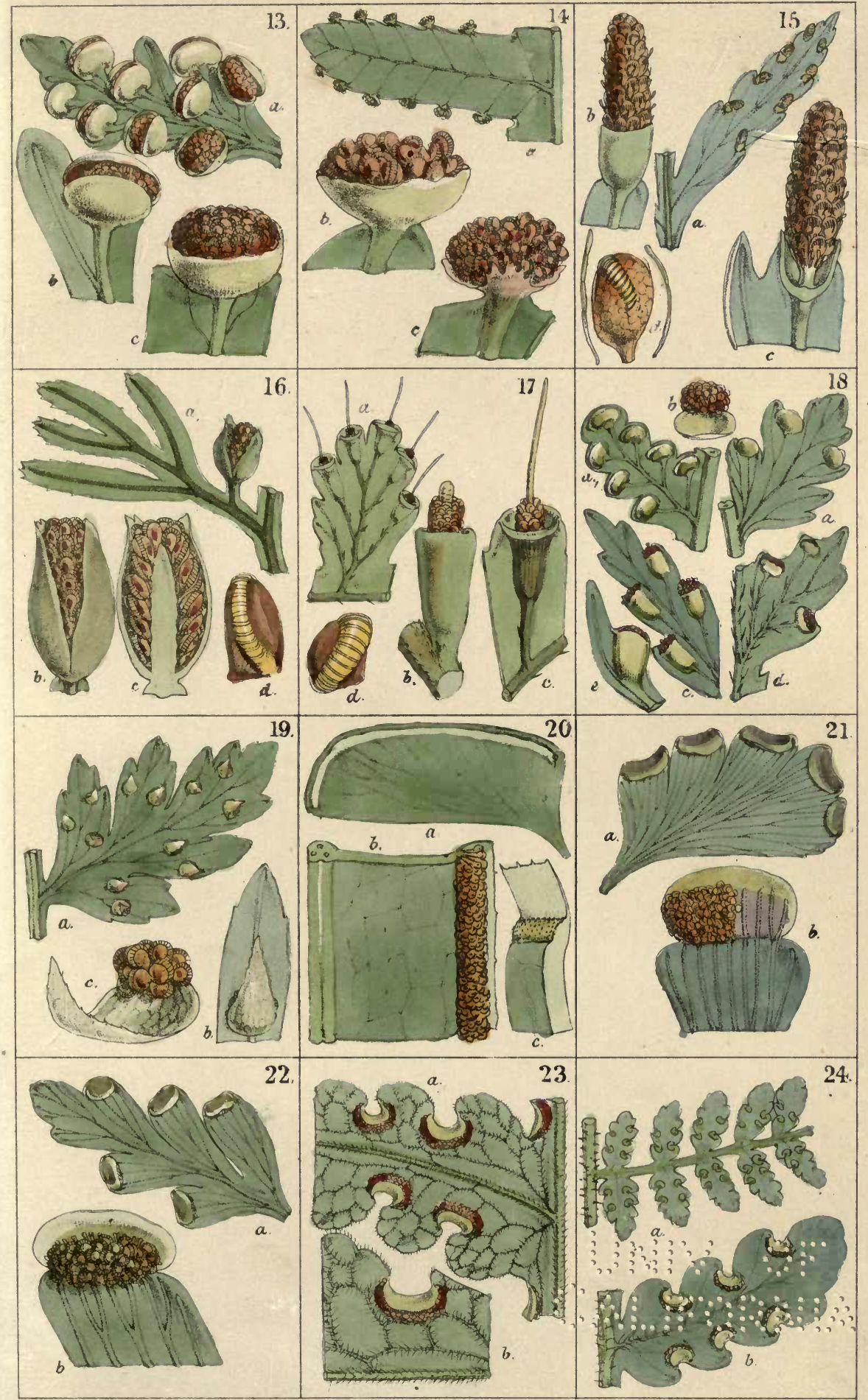

Fitch, lith

Vincent Brooks, Inp 


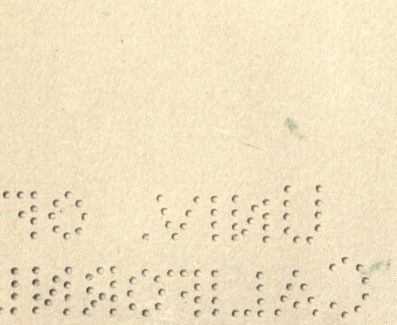





\section{TAB. III.}

Fig. 25. Cheilantues. - $a$, fertile pinna ; $b$, portion of the same, one involucre turned back.

Fig. 26. Cassebeera. $-a$, fertile pinna ; $b$, portion of the same. with sorus.

Fig. 27. Onychium.- $a$, fertile segment; $b$, portion of the same, with involucre turned back.

Fig. 28. Illavea. $-a$, barren segment ; $b$, portion of the fertile frond ; $c$, the same, unrolled.

Fig. 29. Cryptogramme. - $a$, segment of barren frond; $b$, segment of fertile frond ; $c$, section of the same, unrolled.

Fig. 30. Peluea. - $a$, pinnule of $\S$ Platyloma; $b$, portion of the same.

Fig. 31. Pteris.- $a, b, \S$ Eupteris ; $c$, $\S$ Heterophlehium ; $d$, $e$, $\S$ Poesia ; $f$, occasional double involucre of the same ; $g$, $\S$ Campteria; $h$, $\S$ Litobrochia ; $i, \S$ Amphiblestra : all, portions of the frond selected to show both fructification and venation.

Fig. 32. Ceratopteris - $a, b$, portion of the fertile frond; $c$, section of the same, unrolled; $d$, e, capsules ; $f$, spores.

Fig. 33 . Lomaria. - $a$, barren pinna ; $b$, fertile pinna ; $c$, the same, with the involucre partially unrolled. 
Tab.III.

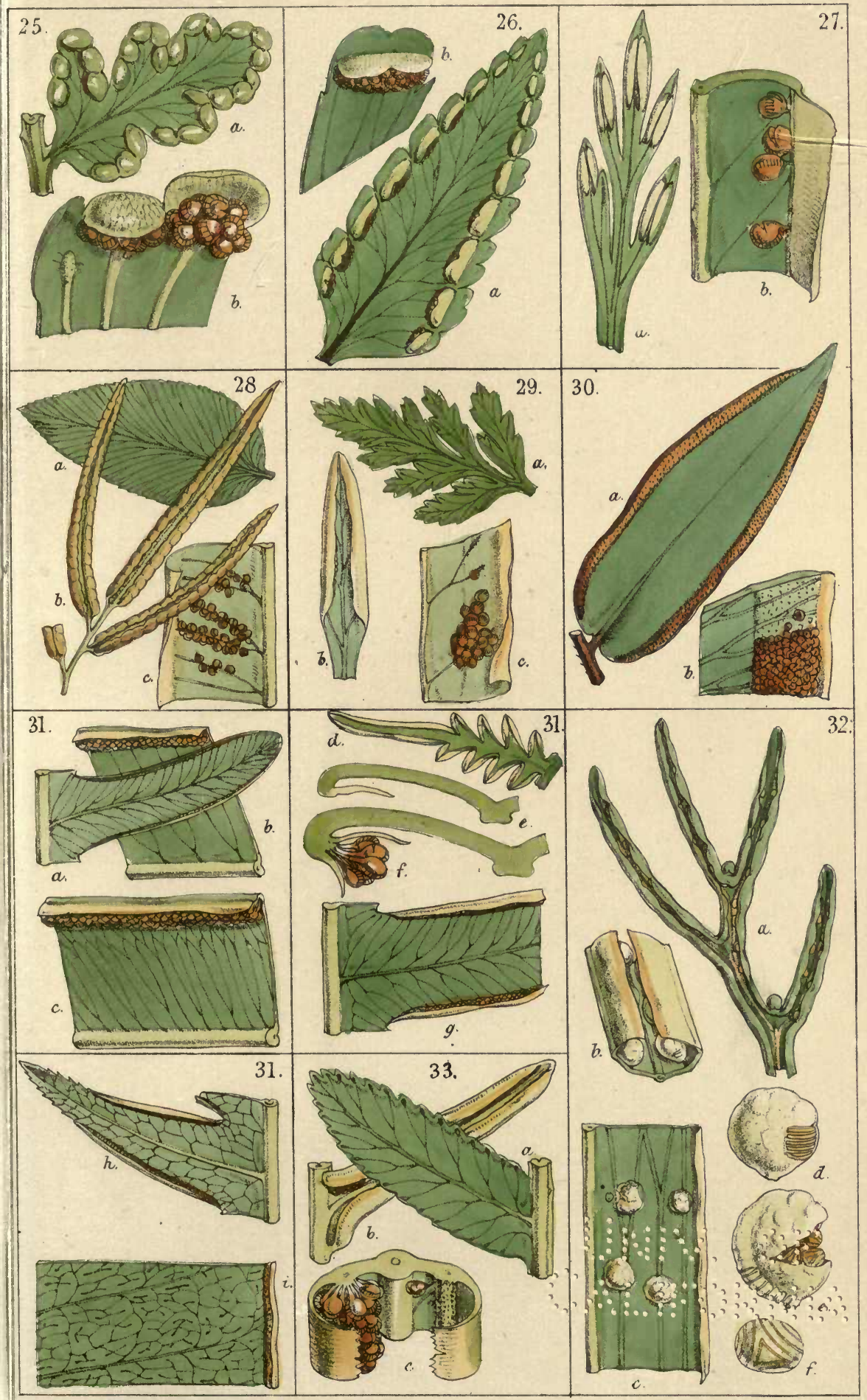

Fitch, ]ith.

Vincent Brocks, Imp. 


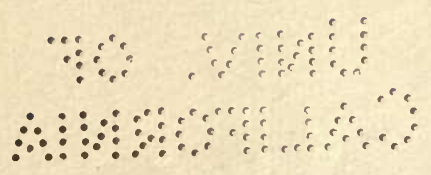



TAB. IV.

Fig. 34. Blechnum.-a, fertile pinna, with sori remaining on one side, cleared away from the receptacle on the other.

Fig. 35. SAdLERIA. $-a$, fertile pinnule; $b$, portion of the same enlarged.

Fig. 36. WoodWARdia - $a$, fertile pinnule; $b$, portion of pinnule of $\S$ Lorinseria.

Fig. 37. Doodia. $-a, b$, portions of fertile pinnæ.

Fig. 38. Asplenium. - $a$, $\S$ Euasplenium ; $b, c, \S$ Darea ; $e, \S$ Athyrium ; $d, f, \S$ Diplazium ; $g, \S$ Anisogonium ; $h$, $\S$ Hemidictyum : all, portions of the frond to show the fructification and venation.

Fig. 39. Allantodia. - $a$, portion of fertile pinna, with outer veins; $b$, inner half of the same enlarged.

Fig. 40. Actiniopteris. - $a$, entire frond ; $b$, fertile segment ; $c$, the same, with the involucres rolled back.

Fig. 41. Scolopendrium. - $a$, $\S$ Euscolopendrium; $b$, $\S$ Antigramme ; $c$, $\S$ Schaffneria ; $d, \S$ Camptosorus ; portions of the frond, to show fructification and venation.

Fig. 42. DidymochL ana. - $a$, fertile pinnule ; $b$, single sorus, enlarged. 
Tab.IV.

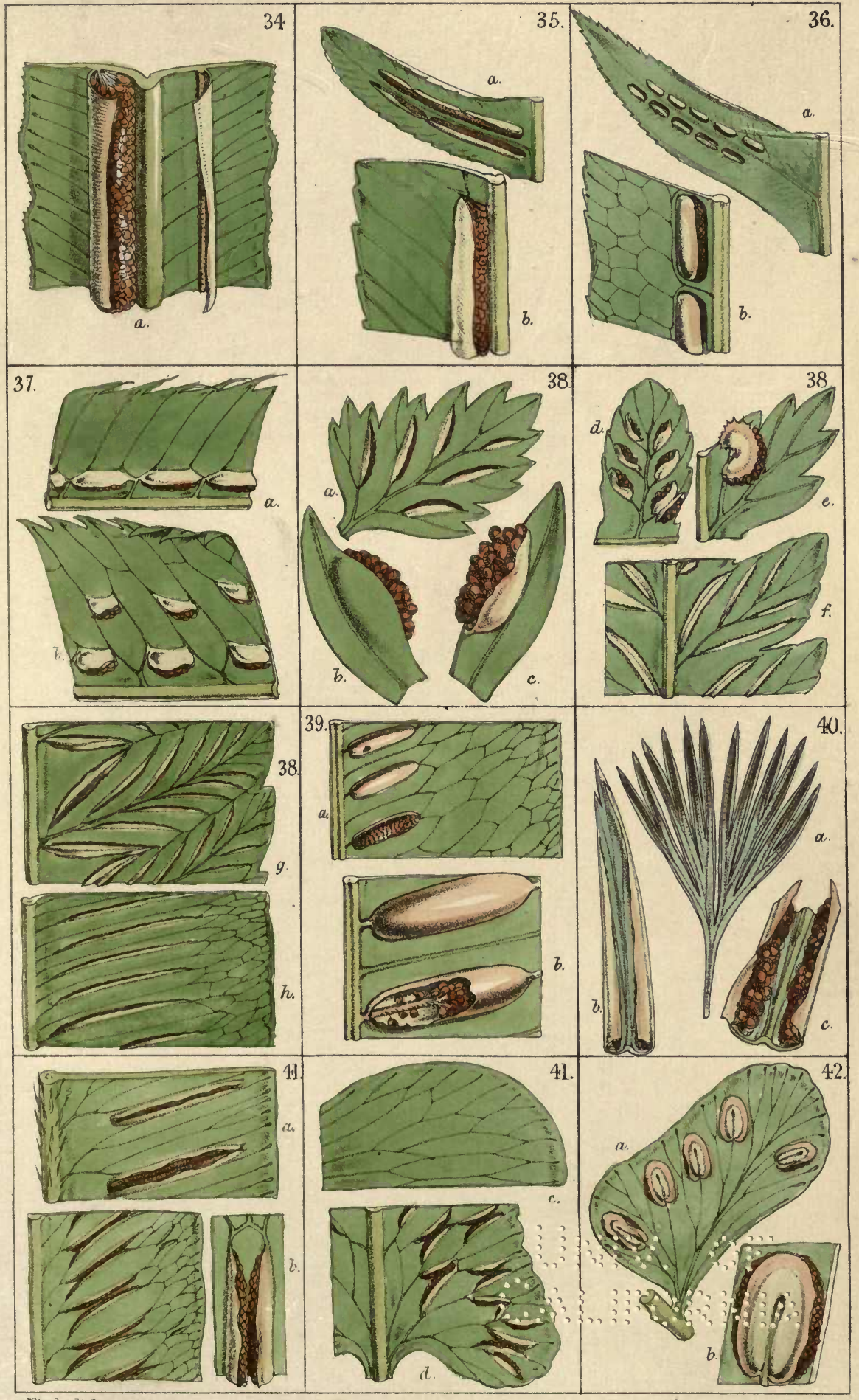




TAB. V.

Fig. 43. Aspidium. - $a, b, \S$ Polystichum, fertile pinna and sorus; $c$, $\S$ Cyrtomium, portion with sori ; $d, \S$ Euaspidium, with sori.

Fig. 44. Nephrodium.- $a, b, \S$ Eunephrodium, fertile portions; $c, d, \S$ Lastrea, fertile portions.

Fig. 45. NePhrolepis.— $a$, fertile pinna ; $b$, sorus ; $c$, portion of a fertile pinna, showing the venation.

Fig. 46. Oleandra. $-a$, fertile portion of a frond.

Fig. 47. Fadyenia. - a, sterile (but proliferous frond), much reduced; $b$, venation of the same; $c$, fertile frond, much reduced; $d$, portion of the same, magnified.

Fig. 48. PolyPodium.- $a$, § Eupolypodium, fertile segment, and $b$, small portion of the same magnified; $c, \S$ Phegopteris, portion of fertile pinnule, and $d$, smaller portion of the same magnified; $\theta$, $\S$ Goniopteris, fertile portion ; $f$, $\S$ Cyrtomiphlebium, fertile portion; $g$, $\S$ Phlehodium, fertile portion ; $h$, § Goniophlebium, fertile portion; $i$. $\S$ Craspedaria, fertile portion ; $j$, Campyloneuron, fertile portion ; $k$, $\S$ Niphobolus, fertile portion, and $l$, branched and stellated hairs from the same; $m$, $\S$ Phymatodes, fertile portion; $n$, Dipteris, fertile portion ; $o, \S$ Dictyopteris, fertile portion. 


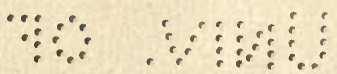

$\therefore: \vdots \because \because \because \because \vdots \vdots \cdots \cdots$ 

TAB. VI.

Fig. 49. Jamesonia. - a, portion of a frond, seen from above; $b$, fertile pinna, seen frorn beneath; $c$, jointed hair from among the sori.

Fig. 50. NотноснцаNA.- $a, b$, fertile portions ; $c$, smaller portion of $a$ more magnified.

Fig. 51. Monogramme. - a, $\S$ Eumonogramme, fertile portion; $b$, transverse section of the same through the sorus; $c, \S$ Pleurogramme, fertile portion; $d$, small portion of the same magnified, and showing the venation.

Fig. 52. Gymnogramme.- $a$, § Eugymnogramme, fertile pinnule; $b, \S$ Stegnogramme, fertile portion ; $c, \S$ Dictyogramme, fertile portion; $d$, § Syngramme, fertile portion ; $e, f$, $\S$ Syngramme, sterile and fertile portions.

Fig. 53. Brainea. $-a, b$, sterile and fertile portions.

Fig. 54. Meniscium. - $a, b$, fertile portions.

Fig. 55. ANTrophyum. $a, b$, fertile portions, showing the sori sunk in a groove; $c$, fertile portion, with the sori not sunk in a groove.

Fig. 56. VitTaRia. - $a, \S$ Euvittaria, fertile portion; $b, c$, $\S$ Tæniopsis.

Fig. 57. T正NIris.- $a$, fertile pinna ; $b$, magnified portion, showing the venation.

Fig. 58. Drymoglossum. - $a$, sterile and fertile frond; $b$, portion of the fertile, and $c$, portion of the sterile frond magnified.

Fig. 59. Hemrontris. - $a$, $\S$ Euhemionitis, fertile portion; $b$, $\S$ Anetium, fertile portion. 


TAB. VII.

Fig. 60. Acrostichum.-Portions selected to show venation and fructification of

\author{
$\S$ Elaphoglossum, $a, b$. \\ $\S$ Polybotrya, $c, d, e$. \\ $\S$ Stenochlæna, $f, g$. \\ $\S$ Egenolfia, $h, i, j$. \\ $\S$ Rhipidopteris, $k, l$. \\ $\S$ Olfersia, $m, n, o$. \\ $\S$ Aconiopteris, $p, q$. \\ $\S$ Stenosemia, $t, u$. \\ $\S$ Soromanes, $r, s$. \\ § Chrysodium, $y$, z. \\ $\S$ Gymnopteris, $\boldsymbol{v}-x, a a, b b$.
}


$\because{ }^{c}$

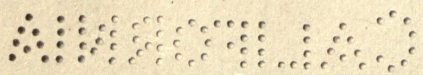





\section{TAB. VIII.}

Fig. 60. Acrostichum. - $\S$ Hymenolepis, $c c$, portion of barren frond ; $d d$, ee, portions of fertile frond. $\$$ Photinopteris, $f f$, portion of barren frond; $g g, h h$, fertile portions.

Fig. 61. Platycerium. - $a$, barren portion; $b$, section, showing part of patch of fructification.

Fig. 62. Osmunda. - $a$, pinna in part barren and in part fertile; $b$, pinna entirely fertile; $c$, detached capsules; $d$, spores.

Fig. 63. TodeA. - $a, b, \S$ Eutodea, portion of fertile and detached capsule ; $c, d$, the same of $\S$ Leptopteris.

Fig. 64. SchizжA. - $a$, fertile segment; $c$, fertile pinna; $b, d$, detached capsules ; $e$, spore.

Fig. 65. ANemia. - $b$, entire frond; $a$, portion of barren frond, with simple venation; $c$, fertile portion; $d$, detached capsule; $e, \S$ Anemidictyon, barren portion.

Fig. 66. MoHria. - $a$, barren portion ; $b$, fertile portion; $c$, detached capsule.

Fig. 67. Trochopteris. - $a$, entire tuft ; $b$, entire frond ; $c$, fertile portion ; $d$; detached capsule. 
Tab.VIII.
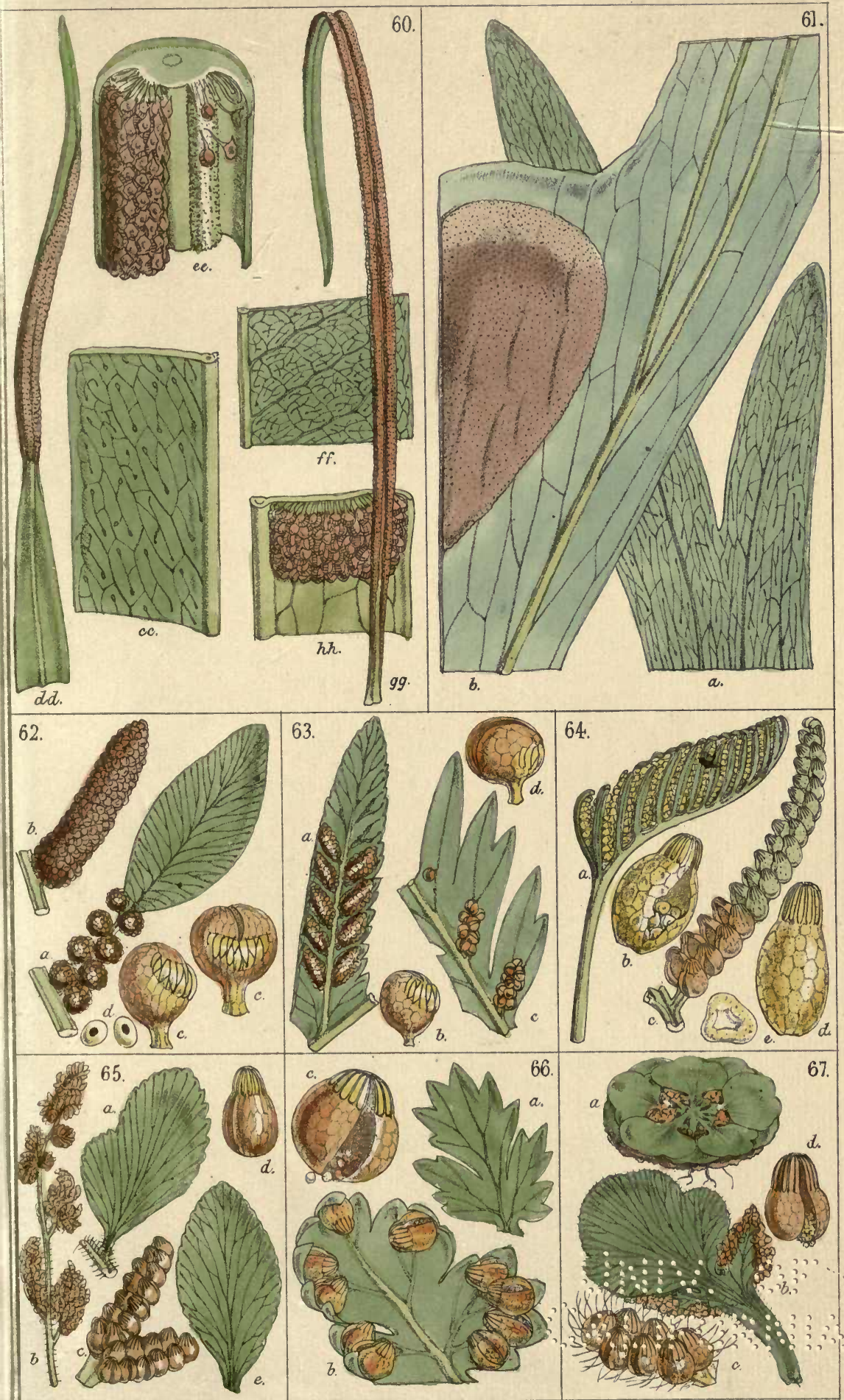


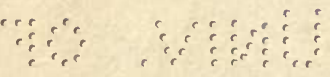

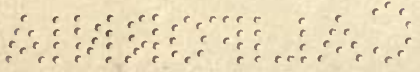



TAB. IX.

Fig. 68. Lygodium.- $a$, portion of barren frond ; $b, d$, portions of fertile frond ; $c$, Lygodictyon, barren portion.

Fig. 69. Angiopteris.- $a$, cluster of capsules; $b$, pair of capsules and section of frond ; $c$, single detached capsule.

Fig. 70. Marattia.- $a, b$, portions of frond, with a single multilocular receptacle ; $c$, vertical section of receptacle.

Fig. 71. DankA. $-a$, portion of fertile frond ; $b$, section of receptacle ; $c$, spores.

Fig. 72. KaUlfussia.- $a$, portion of fertile frond ; $b, c$, detached receptacles; $d$, spores.

Fig. 73. Ophioglossum.- $a$, complete plant; $b$, barren portion; $c$, fertile portion ; $d$, spores.

Fig. 74. Helminthostachys. $-a$, nearly complete plant ; $b$, portion of barren frond ; $c, d$, portions of fertile frond.

Fig. 75. Botrychium.- $a$, complete plant; $b$, barren portion; $c$, fertile portion ; $d$, spores. 
Tab. IX.

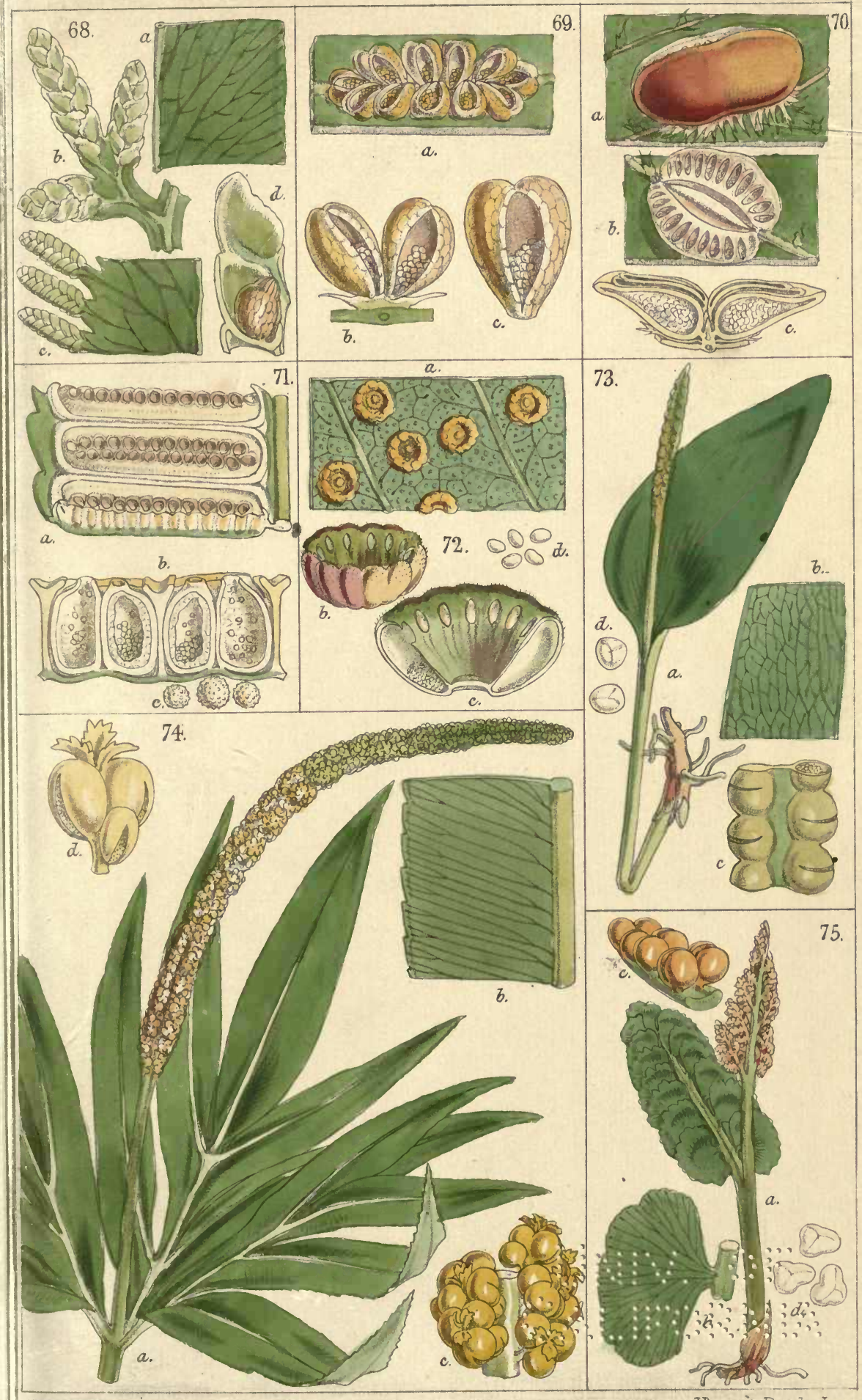

Fitch, lith.

Vincent Brooks, Imp. 


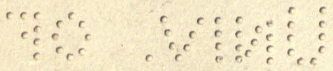

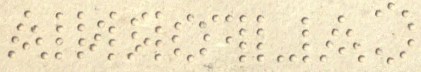





RETURN BIOSCIENCE \& NATURAL RESOURCES LIBRARY

TO $\longrightarrow 2101$ VALLEY LIFE SCIENCES BLDG. 642-2531 LOAN PERIOD

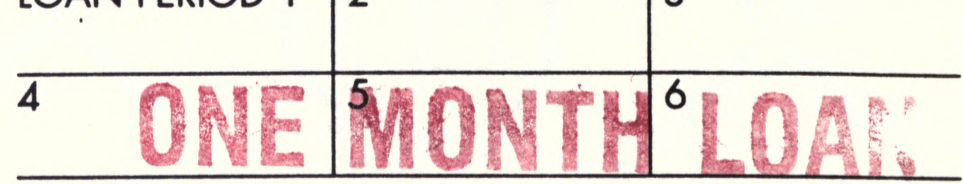

ALL BOOKS MAY BE RECALLED AFTER 7 DAYS

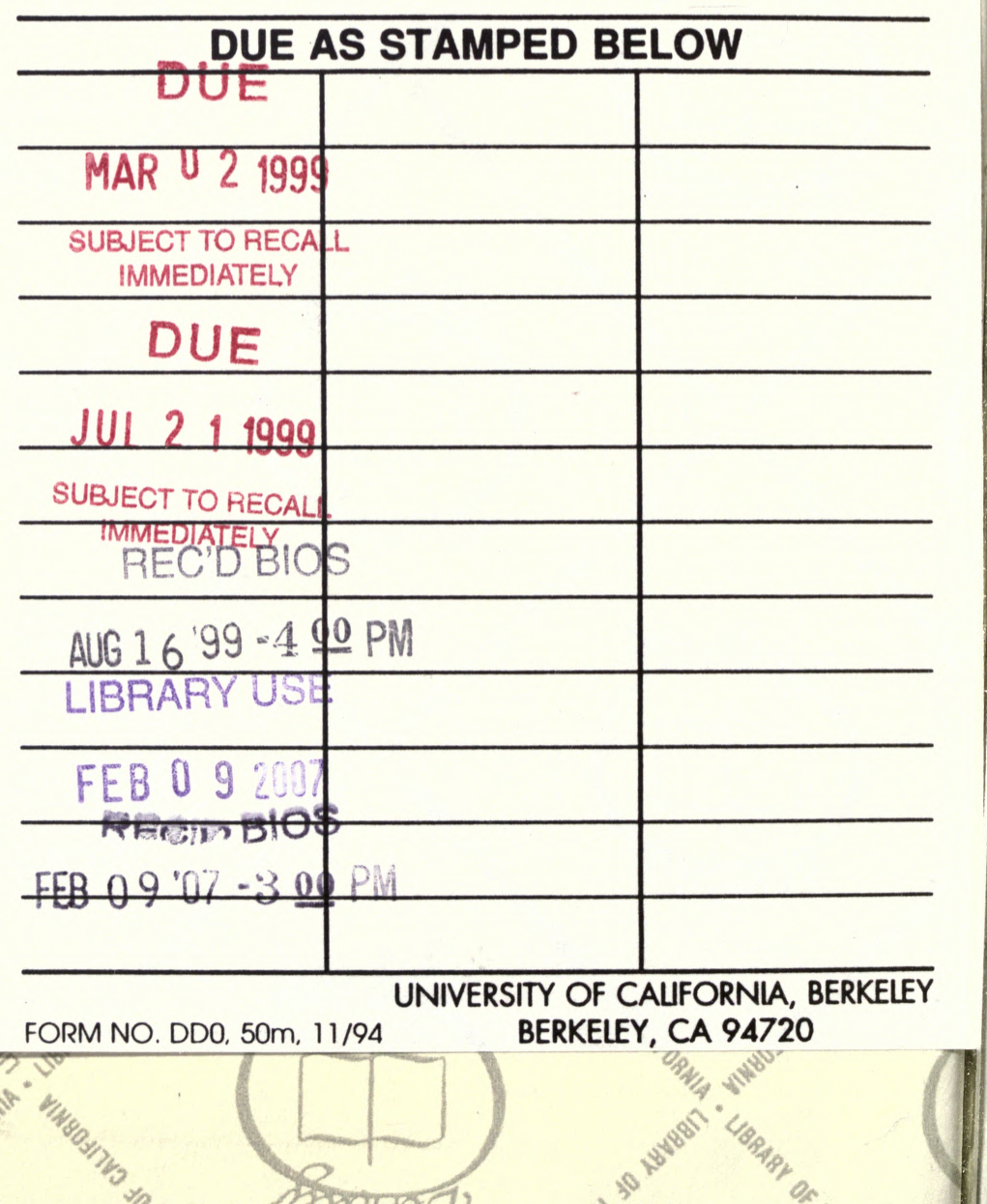


Berferses

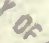

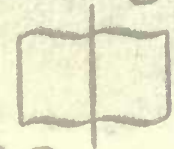

अभुक्षण 
